
REYNOLDS HSTOSICAL
GEMEALOYY COLLECTION 


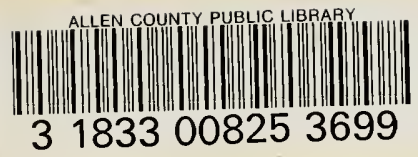







\section{HISTORY OF PASADENA}

COMPRISING

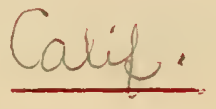

An Account of the Native Indian, the Early Spanish, the Mexican, the American, the Colony, and THE INCORPORATED CITY

OCCUPANCIES OF THE

Rancho San Pasgual, and its adjacent Mountains, Canyons, Waterfalis, and Othfr Objects of Natural, Artificial, Old

HISTORIC, OR MODERN INTERHST:

Being a Complete and Comprehensive Histo-cyclopedia of ali, Matters PERTAINING TO THIS REgION; With Copious

INDEX FOR REFERENCH.

By HiRam A. REID, A. M., M. D.

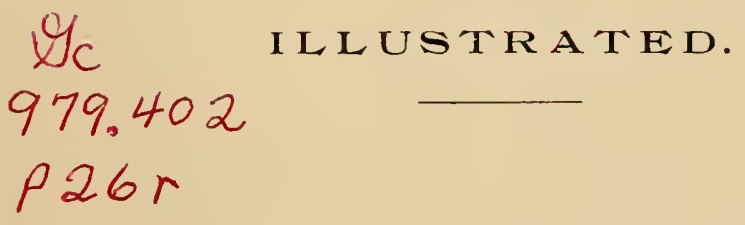

PASADENA, CAL:

Pasadena History Company, PUblishers. 1895. 
Copyright 1595,

BY HIRAM A. KEID.

Press of

KINGSLEY-BARNES \& NIUNER CO. Los Angeles, Cal. 


\section{7}

\section{THRESHOLD REMARKS.}

GENESIS. - How it came about that this History was written.- List of books specially examined.-The Bicycle Episode.-Friendly favors acknowledged.

THE START.

Before entering the Hahamog-na doorway to this Pantheon of Pasadena history, the reader will please take a cosy rustic seat in the roseshaded sunshinyness of our front porch for a few minutes, while I relate the history of the History-or how this history project originated, and how this book came to be written.

January I4, I894, I went to Los Angeles to deliver before the Science Association of Southern California my report on the Geology of the Pasadena Monntains. In the same car with me was W. H. Knight, Esq., president of the Association, and auditor of the Mount Lowe Electric Railway Co., who was then also secretary of the Pasadena Board of Trade. In conversation as we rode together I pointed out from the car window some places and objects which had interesting historic associations, and some places of scientific interest. These things enlisted his earnest attention; and finally he said:

"There must be a great deal of interesting history connected with Pasadena and its vicinity which ought to be preserved. It is passing away, and in a few years will be lost beyond recovery; somebody ought to collect it and write it up in a book."

"Yes," I answered, "that is true; but it would require so much time and painstaking labor to do the work reliably that no publisher could afford to undertake the enterprise. The work would necessarily be local in its scope, and hence of sucl limited sale that he would certainly lose money on it."

But Mr. Knight thought the financial difficulty could be met by a subscription plan, and continued: "Why can't you do it? You're just the man for it."

To this I replied, that I probably knew better than any one else here what a protracted and arduous undertaking it would be, if done with such thoroughness as to make it worth the doing; and my health was too feeble and precarions for me to think of entering upon so great a task. But he was still earnest, and urged that it ought to be done, and that I could do it better than anybody else.

On returning home I told my wife about this conversation with $\mathrm{Mr}$. Knight. She chimed right in with Mr. Knight's suggestion; said there wasn't anybody else here who could do it as well as I could. "Yes, and I can help you with the typewriter," she added quite enthusiastically.

In order to show her how much greater a task it would be than she 
thought of, I penciled a schedule of points and topics that would have to be covered, data to be gathered, old books and records to be hunted up, pioneer settlers and old Spanish people interviewed, scientific research in and about Pasadena pushed much farther than had ever yet been done, etc. But, nothing daunted, she still said that I could do it all better than anybody else; and she'd help me; she'd take care of the chickens herself, and do all the housework, and look after the yard, and attend to the grandchildren alone, etc., so I could have my time ; and I could have the east bedroom for an office ; and so on, and so on - oh, so easy seems such a job to one who has not delved in its trenches of difficulty.

A few days later I saw my intimate friend, H. N. Farey, who has more practical knowledge on the details of book-printing than any other man in this community, and in course of conversation I told him what had been said by Mr. Knight and Mrs. Reid on this matter. He studied a bit, and then said energetically, "It's a go! you're the very man to do it! Why, you've made a good start on it already! that schedule of what would have to be done is a first-rate beginning of the work! Why, you have commenced the thing already! And you have more material already on hand, or know where and how to find it, than any half-dozen other men in Pasadena! Yes, SIR-k-R, it's a Go!"

Mr. Farey knew' of my poor health, but said I was tough, and could work along by laying off a day or two at a time when specially severe sick spells overtook me. And the financial part, he thought, could be worked up all right.

Next, I talked with Hon. P. M. Green and B. I'. Ball about it. Mr. Green's first thought was that Pasadena was too young a city to have much of a history yet. Then, as he thought of the Indian occupation here, and the Spanish occupation, and the American occupation prior to the "Indiana Colony," and the many features of scientific interest, and the rapid succession of notable events here since Pasadena commenced to be a village - he exclaimed, "Why, yes! it grows upon me as I think of it! There is, indeed, a great field of history here." And they two concurred in the idea that a book of history to cover all the ground ought to be written now, while some of the oldest settlers are still living; and I was the right man to do it. Then I talked with F. R. Harris, and Henry G. Bennett, and James Cambell, and others about it, and they were very heartily of the same opinion.

I still feared that on account of failing liealth I would not be able to carry the work to completion. Nevertheless, trusted friends advised the effort, and offered helpful assistance. A stock company was suggested. But I felt that if anybody took stock in it as a financial renture, there would be a pressure upon me to hurry it through - and this would sacrifice the method of slow, plodding, persevering, patient, steady search and research, 
writing and re-writing, to the mere commercial idea of getting our money back with profits, as soon as possible. This latter plan is what has made so many of the "county histories" gotten up all over the country prove to be a fraud, and brought the local history business into disrepute. I said I must be perfectly free and untrammeled to take all the time I may find necessary to do and undo and re-do the work, till I feel sure that bedrock facts have been reached, on the different matters of historic interest to be set forth for there will be mistakes enough, even after the best endeavor has heen made to avoid them. And if thirty or forty citizens would aid me a little for the necessary incidental expenses, such as explanatory circulars, inquiry blanks, postage, stationery, horse hire for research trips, etc., I would undertake the task. The question was raised, suppose I should not live to complete it? I replied that those who aided me would have whatever manuscript and material I had accumulated, and could probably then get some one else to complete it. Accordingly, an advance pledge note was prepared, payable in 20 per cent. installments, to aid me in the matters mentioned; and these notes were signed by P. M. Green, B. F. Ball, F. R. Harris, H. G. Bennett, Henry N. Farey, W. U. Masters, Wm. R. Staats, R. H. Pinney, J. A. Jacobs, T. J. Martin, M. D. Painter, P. G. Wooster, James Smith, Benj. M. Page, James Cambell, T. P. Lukens, W. J. Barcus, C: C. Brown, Geo. T. Downing, Geo. F. Kernaghan, Oscar Freeman, Delos Arnold, John McDonald, C. M. Simpson, Wm. H. Knight, F. J. Woodbury, W. E. Arthur, G. Roscoe Thomas, A. K. McQuilling, D. J. Macpherson, Lucy F. Wilson, Jeanne C. Carr, J. W. Wood. All amounts thus prepaid were to apply on the price of one or more copies of the book when printed.

So that was the origin of this History of PASADENA, and how it came about that I undertook the preparation of the volume. In pursuance of the work I have examined with care the following books which contained more or less points of incidental linkage with Pasadena history:

\section{LIST OF WORKS CONSULTED.}

Centennial History of Los Angeles County. By Col. J. J. Warner, Judge Hayes, and Dr. J. P. Widney. 1876.

Publications of the Los Angeles County Historical Society.

Lewis's History Los Angeles County and Biographical Register. I889.

Southern California. By T. S. Van Dyke of San Diego. Fords, Howard \& Hurlbert, N. Y. I 886.

Califoruia of the South. By Drs. Widney and Lindley of Los Angeles. D. Appleton \& Co., N. Y. I 888.

A Southern California Paradise. By Rev. R. W. C. Farnsworth. 1883. All About Pasadena. By C. F. Holder. I 888.

The Highlands of Pasadena. By C. F. Holder. H. S. Crocker \& Co., San Francisco. 1889. 
To and Fro, Up and Down, in Southern California. By Emma H. Adams. 1888. [Specially full of errors on historical matters.]

Reminiscences of a Ranger. By Maj. Horace Bell of Los Angeles. $188 \mathrm{I}$.

Mediterranean Slores of America; Southern California Climatology, etc. By P. C. Redondino, M. D. 1872. [A good work.]

A Tour of Duty in California. By Joseph Revere. Published in Boston. I 849. [Grandson of the famous Paul Revere.]

Two Years Before the Mast. By R. H. Dana. Published in Boston. I846. [Experiences in California in $1835-36$.]

Native Races of the Pacific Coast. By H. H. Bancroft. 1883.

History of California-witl .Pioneer Register. By H. H. Bancroft. Seven volumes. Published in 1883 to I 886 .

California Geological Reports, Vol. I. Prof. J. D. Whitney. Published in 1865 .

Elements of Geology. By Prof. Joseph LeConte, of the State University of California.

Reports of State Mineralogist. Successive years.

California Blue Book. Edition of r 89 I.

Archæological Reports of the Smithsonian Institute. I880.

The Mountains of California. By John Muir. Century Co., N.Y. I 894. Our Switzerland-Italy. By Prof. G. Wharton James. I 892.

Fremont's Memoirs, Vol. I. I887.

Man and the Glacial Period. By Prof. Geo. Frederick Wright. D. Appleton \& Co., N. Y. I892.

Life in California. [1829 to 1845.] By Alfred Robinson. Published in New York, 1846.

Annals of San Francisco and History of California. D. Appleton \& . Co., New York. I854.

Life of Col. Fremont. By Bigelow. Derby \& Jackson, New' York. I 856 .

Early Days and Men of California. By W. F. Swasey. San Francisco. i 89i. [Capt. Swasey was a member of Col. Fremont's famous California Battalion, and he shows up the meanness, injustice and misrepresentation of Bancroft's history toward Fremont.]

Occidental Sketches. By Maj. Ben C. Truman. San Francisco. I88 I. [Major Truman was for some years an editor and news reporter in Los Angeles, then in San Francisco; but in 1895 he is editing a weekly paper called The Capital at Los Angeles.]

Old Californian Days. By James Steele. Chicago. 1889. [Uses the term South California instead of Southern California. Right.]

History of California. By John Frost. Hurst \& Co., New York.

Sixty Years in California. [ 1831 to I889.] By Wm. Heath Davis. San Francisco. I 889. 
History of Los Angeles County. By J. Albert Wilson. Published by Thompson \& West. I 880. [This is altogether the best "County History" yet gotten up here.]

California. By Josiah Royce. Houghton, Miflin \& Co., Boston. I886. [Partisan against Col. Fremont.]

History of California. Two volumes. By Theodore H. Hittell. San Francisco. I885. [This is on the whole the fairest and best history of the State yet published.]

Tourists' Guide Book to Sonthern California. By G. Wharton James, F. R. A. S. Baumgardt \& Co., Los Angeles. I895. [This work uses the name South California instead of Southern California, all the way through - a new feature which I heartily commend.]

Board of Trade pamphlets. Different years.

Bound volumes of the weekly Pasadena Union, I884-85-86.

Bound volumes of the Pasadena Daily Star.

Stitched volumes of the Pasadena Standard.

Record Books of the City Clerk.

Record Books of the City Recorder.

Record Books of the San Gabriel Orange Grove Association, the original Pasadena colony, or "Indiana colony," as it was commonly called.

Record Books of the Pasadena Land and Water Co.

Special articles local to California, in leading magazines of both the Atlantic and Pacific coast; bound volumes of the Overland Monthly, Atlantic Monthly, Harper's Monthly, Popular Science Monthly, Illustrated Californian, the Century Magazine, and others of lesser note.

Notes of a Military Reconnoissance," etc., by Major W. H. Emory, of U. S. topographical engineers, 1846-47. Washington: 3oth congress, ist session. Senate. Executive document No. 7. [This gives maps, diagrams, descriptions, etc., of three battles in California ; but I did not find this work until Stephen Foster showed it to me, after my Chapter IV. was printed. [See page 1021/2.] Maj. Emory says: "We saw the Mexicans place four pieces of artillery on the hill, so as to command the passage "' [at San Gabriel river.] See forward, page 93 .

THE BICYCLE EPISODE.

In pursuance of my work I found it necessary to go many times to exanine natural objects, to consult old settlers, to procure documents or books, to authenticate localities by name, and for many points and particulars which it was needful I should know from personal investigation and not merely from hearsay, in order to write understandingly about them. I could not afford to keep a horse for making such trips; and walking proved very soon that it was too slow and tiresome for me. I was past sixty years old, and had never strode a bicycle in my life--but now I needed to learn the new trick. 
It was "business." So I procured a bicycle--and then the "wild west" circus commenced. But I conquered the thing in due time, and the following article from the Laily. Star of May I2, I894, I quote both for the humor of it and because it is a part of the "history of the History" :

"The Star reporter who has been watching Dr. Reid's sexagenarian experiments with a fiery, untamed bicycle says "it's a go," at last; and he won't tell of the hundred or more throws the new rider got-nor of the trees, fences and gutters that might have brought an action for assault and battery; nor how he ran into a horse and buggy with three ladies in it, when nobody could tell whether the horse, the ladies or the flopped-over doctor were most frightened; nor how he ran into Arnold's milk wagon and scared the milk into curd cheese. Final success wipes out all the little erraticisms of cranky inexperience, even for a man over sixty years old; and as a conclusion of the whole matter, our reporter captured the following humorous document recently read before the Fortnightly Club :

\section{SPINNING WHEELS.}

BY DR. H. A. REID.

II was in sone doubt as to whether this poem should go to the Historical Society. the Science Association, of the Bicycle Club, but I fiually concluded that the Thror p Po ytechuist- would probably classify it as an evolutional sport in Biocyclology-sub-class Pedo economics. This wonld account for the Dazly Star's recent squib about my bicycle experiments; hence I present it here.]

Our grandmas had their spinuing wheels And made them spin like fun,

With treadle going up and down

To make the spindle run.

But this was in "yeolden time," Before the factories came

With patent spinning-jacks to beat The women's fast-work fame.

Each spin-wheel then was stored away In dingy garret room,

To wait some new fad of the world Which might unseal its doom.

And it has come; for now our girls Go spinning through the street

With wheels that run as Grandma's did, By treadles for the feet.

On two wheels now instead of one The spinning whirl is done ;

'Their grandmas did it for day's work; They do it just for fun.
And likervise, even gray old men Have caught up this new prank;

From grandma's spin-wheel made a "bike," And learned to pump the crank.

Our grandma's spinned at home, the yarn From their deft fingers twirled:

But now the biker boys and girls Go spinning round the world.

The problem next is, how to save The waste force thus evolved ?-

Put wind-up springs upon the wheels, And 1o, the problem's solved.

For when you've springs enough wound up, Gear them in gangs, and run

A motor street car at less cost Than ever yet $t$ 'was done.

Or start a plant to generate Electric light and heat

To serve for evening lamps at home, And cook your bread and neat.

This scheme will prove our spinuing wheels

In true worth not unlike

The wheels our grandmas used to tread,

And so commend the "bike."

I found the bicycle wonderfully lelpful in my work, and also of some benefit to my health by the exhilarating exercise it gave me.

On January 24, I 895, Mrs. Reid had the misfortune to get her arm broken. This of course was unavoidably a great hiudrance and drawback to our history work-stopping it entirely for a while, and embarrassing it in some measure all the rest of the time. Howvever, we lost no time lamenting, but went on with the task as best we could, to its final conclusion. 
ACKNOWLEDGMENT OF FAVORS.

I am under obligation for special favors and assistance to many persons in getting my work as complete as it is, and I wish to make open acknowledgment in the case. Judge B. S. Eaton has very kindly and generously written out for me many matters of early history which 110 other living person could tell about. Dr. J. W. Wood loaned me a whole year of his bound volumes of the Pasadena and Valley Union of 1884-85-86the only copies in existence; and it being the only local newspaper here in those years, was the prime authority for dates and data on many historical matters of the transition time from colony to city, that could not to be found elsewhere. I am indebted to $H$. N. Farey for the valuable table of Pasadena corporations, which he carefully compiled for me from the county records; besides many other matters in which he generously aided me. Arturo Bandini and wife, and Mrs. Bandini's mother, Mrs. Dr. Elliott, have aided me with loan of books; with suggestion of books and magazine articles that I needed to see; with translation of Spanish documents and Spanish terms ; with documents and data of the original "Indiana colony," and of the true origin of the name Pasadena-documents not obtainable but from them. Prof. A. J. McClatchie furnishes me the results of his years of research on the native flora of this region. [See chapter 32, on Botany.] Young Joseph Grinnell gives me the first publication of his complete list of native Pasadena birds. [See chapter 3I, on Zoology.] J. B. French has assisted me very much in my researches on the glaciology of this region. James H. Cambell furnished me early in I 894 , one of his official record maps of Pasadena city, with all her sub-divisions, streets, city lots, adjacent lands, etc., - a favor exceedingly helpful for identifying streets, land tracts, and other lncal points. And Byron O. Kendall, from his extensive real estate, insurance, loan and collection agency at $49 \mathrm{E}$. Colorado street, has furnished as his contribution to the book the very convenient reference map folded in at page 16 . P. G. Wooster, Wesley Bunnell and Thomas F. Croft have taken special pains to furnish me with memoranda of events in the colony time, from their diaries; and Mr. Croft loaned me for citation the only complete abstract of title of Rancho San Pasqual [after the Garfias patent of 1863 ] known to be in existence. Mrs. J. De Barth Shorb loaned me the unpublished MSS. autobiography of her father, Hon. B. D. Wilson, which he dictated the year before his death; besides other historic documents and information furnished by herself and husband. Chas. A. Gardner, Esq., kindly gave me "the freedom of his bailiwick" for frequent research in the bound volumes of the Pasadena Daily Star-a favor of great value. Messrs. Wood \& Church, from their real estate office in the Masonic Temple, furnished me with 300 copies of their valuable and interesting copyright birdseye map of Pasadena, showing buildings, streets, R. R. lines, fields, mountains, canyons, toll road, etc., as folded in at page 4 ro. 
The publishers of the "Land of Sunshine" generously allowed me the use of many of their half-tones and other plates, some of which they held in special reserve and would neither lend or hire to anybody else for the present. Photographer Geo. L. Rose of Pasadena and engraver Herve Friend of Los Angeles made for me without charge the frontispiece picture, showing myself and wife going to church on our wheels. Heman Dyer, city clerk, and Judge J. G. Rossiter, city recorder, gave me every facility and convenience. for examining the city records and archives. Prof. T. S. C. Lowe furnished free transportation for myself and wife over his mountain railroads, for any further investigations we might wish to make in that region during the years i 894-95. And many others kindly and cordially loaned me books or documents I needed ; or carried me on trips to visit canyons, mines, mills, springs, ancient dams, etc. ; also to visit the aged Spanish women at Linda Vista bluff and San Gabriel village. These of course were extra long or difficult trips, beyond my strength for bicycle travel; but for any ordinary run of one, two or three miles, I could go on my wheel.

Everybody seemed pleased to learn of the work I had undertaken and glad if they could aid me in some way. It was at once pleasant, encouraging and helpful to find such a general feeling of confidence and trust that I would do the work well; and at the same time it bore in upon me a deeper sense of responsibility, and a keener pressure of obligation to spare no pains for making my work of permanent value - the standard reference book and authority on Pasadena matters, for all the years and interests covered by it. Friends, I have done what I could. And now I respectfully submit my work, which will reveal to you how truly Pasadena is a veritable surprisegarden of local history:*

$$
\begin{gathered}
\text { Pasadena, Cal., I } 33 \text { Mary street, } \\
\text { October i 2, I } 895 .
\end{gathered}
$$

H. A. R.

* The following from the Daily Star of September 9, 1895, I thought worth preserving as a rare coincidence in the "history of the History:" "The printing is being done by the Kingsley-Barnes \& Neuner Co., and there are some curious incidents of Pasadenian associations connected with the job. Mr. Davis, president and financier of the printing company, resides in Pasadena! and his son officiates as copyholder for the proof-reading-while the foreman and proof-reader $\mathbf{M r}$. H. E. Moles, formerly resided in Des Moines, Iowa, and knew Dr. Re1d there. Mr. Barnes, secretary of the company, is an old-tine Pasadena boy, and nephew to Thomas F. Croft. Mr. Fred Lang, vice-president of the company, and who holds high rank as an embossing artist, was formerly a printer with H. N. Farey \& Co. of Pasadena. Mr. Blankenhorn, of Pasadena, has his photo-engraving busiuess in the same building; and Wood $\&$ Church have their Los Angeles branch real estate office there also. Mr. H. C. O'Bleness. the assistant foreman, or "make-up," as printers say, who has the responsible task of arranging the type-pages ready for press, is the same man who set the type of the first paper ever published in Pasadeua - The Chronicle-started and edited by Ben E. Ward in 1883. and printed at the Los Angeles Times office. Mr. O'Bleness also formerly knew Dr. Reid in Des Moines, Iowa-as did also Mr. Al. Binkard, the master pressman in cliarge of the press-work on this Pasadena History. And youug Walter Clapp, son of I. B. Clapp, is in charge of the stock room of this great printing house. Yet when Dr. Reid first planued to go there to get his work done lie was not aware of any of these coincidences, except that Mr. Lang was a nember of the printing company." 


\section{N DEX.}

A

PAGE

Abbreviations for Botany localities (footnote) . 608 A hila, Dona Encarnacion...........................63, 97 Aborigines, Pre-Pasadenian.

A cademy of Sciences...

. 21 I

A cademy, The Pasadena.............................. I90

Accident, Rall road, fatal................................ I50

Adventist Church, 7 th day ......................... 493

Advent Church, ist day............................... 494

African M. E. Church ................................. 482

Aftermath of "first thiugs" "............................ 659

Alhambra and Pasadena Railway.................. 439

Allendale Tract........................................ 344

Alpine Division, Mt. Lowe R. R. .................... 453

Alpine Falls ....................................... $3^{85}$

Altadena, origin of the name ...................... 342

Altadena Railroad $\ldots . . . \ldots \ldots \ldots \ldots \ldots \ldots \ldots \ldots \ldots \ldots \ldots \ldots . . \ldots \ldots, 432$ Altitudes......................................28, $363,400,453$ Altruria Association................................... 516 A mphibian Insect..................................... $60_{3}$ Ancient Animals ............................................. $5^{8} 5$ Ancient Townsite on Reservoir Hill.................. 529 A nimals here with Prehistoric Man.........533, 542-3 Annals of the Schools................................ 168 Antelope .................................................... $5^{84}$ Anti-saloon Agreement................................... ${ }_{243}$

A. O. U. W. ........................................ 508

A. P. A. ............................................ 505

A pplied Christianity....................................... 494

A rchæology Collection .................................... 213

Architecture, Pasadenian............................ 226

Army Flag made from Children's Clothes...... 88

Arnold, Hon. Delos, Collection...................... 212

Arroyo Fire, A notable............................ 153

Arroyo Seco Canyon .................................. $3^{87}$

Artesian Well Borings ................................... 568

Astronomical Banquet.................................. 325

Athletic Club ......................................... 526

A ththorities on Plants of California................... 606

Authors, Pasadenian ................................. 223

B

Bacon Spring, The

Bacteria

Badger.

Baker's Bear.

Baker's Spring

Banbury, Col.'s Deer.......................................... 148

Bandini, Dona Refugio's Flag........................ 88

Bandini Family, 91 ; Bandini Avenue.............. 353

Band of Hope.............................................. 508

Banks.......................................................... 296

Baptist Churches .................................................... $48_{5}, 486$

Barley Flats............................................ 404

Bassaris, Ring-tailed............................................ 57

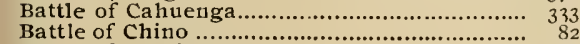

Battle of Dominguez

Battle of Los Angeles

Battles in Los Angeles County, schedule of..... r... ro4

Battle of San Gabriel Ford................................

Battle of San Pasqual.................................. 87

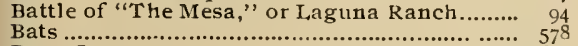

Bear Canyon

Bears

Benefits paid by I. O. O. F., table..................... 510

Bennett, Henry G........................................... Ii

Berry, D M......................................... II

Bicycle Cluh................................................ 527

Bicycle Episode, Poetry, E.tc......................... and 8

Bitds, native, 587 ; Bird list............................... 595

Black Jack Peak .................................... 370

Board of Trade................................305, 308, 309

Boom, The Story of.............................301, 307, 314

Boulder Clay...................................................558, 570

Breaking Ground for Great Iucline.................. 409

Bridges at Devil's Gate.................................. 666
PAGE

Brick making .................................... 460

Brigden, A., killed by winery explosion......... $\quad$ I59

Brown's Canyon, 387 ; Trail ....................... 373, 671

Brown. Owe11's, funeral, 322 ; grave............... 373

Brown's Peak...................................369-70, 373, 671

Builder's Fixchange.

Building and Loan Associations..................... 300

Bulletin, The Daily and Weekly....................... 220

Business College, Wrllians's........................... 200

Butcher Bird ............................................. 594

Buzzard Cliff............................................. 374

\section{C}

Califoruia Entomology [book].................... 604

Cannery burned........................................... 152

Caunon, The Historic old ................... $84,102 \frac{1}{2}, 335$

Cahuenga, Capitulation of............................. 99

Carlton Hotel............................................... 471

Cariton Hotel Liquor Case.............................. 264

Cart, Mrs. Jeanne C., old Mission mill stoue for doorstep.

Carson's Trail.

Carpenter's Union.

in top................................ 402

Castle Canyon................................................. 383

Catholic Church......................................... 492

Cenletery Association.................................. 465

Centenuial Inauguration Day ........................... 326

Centipede

Chauge of climate...................................... 562

Chapman's Glen........................................ ${ }_{3}^{8} 5$

Chapman, Pirate Prisoner in Millard Canyon. 45

Chapman, night fight with Indians................. 48

Chapman, Mill at San Gabriel....................... 5I

Chapmau, Ship built at San Gabriel....... .52, 54, 56

Chapparal Cock ............................................. 591

Charity Organization Society.............................. 519

Chautauqua Circles.................................5I 7,518

Children's homes.....................................521, 522

Children, three burned to death........................ 155

Chiquito Canyoll................................................... 384

Chinamen mobbed................................. 153

Chosen Friends, Ordet of.................................... 5 II

Christian Alliance........................................... 50 5

Christian Church .............................................. 487

Christian Endeavor Union........................... 500

Churches, four blown dow 1 ............................. 165

Citrus Fair, The first..................................... 112,318

Citrus Fair, The second,.............................. 319

City Expense Account............................28 to 290

City Officers in Successive years....................... 285

City Officers repel false reports.......................... 265

City Property and Values. 288

City Railway Co. [Painter Line]..................... 436

City of South Pasadena................................... 650

Civet Cats........................................................... $57^{8}$

Clapp, I. B............................................ I19

Classical Schools.................................................. 200

Coal Mine, Beaudry's..................................... 8 8, 550

Collamet, Miss, School...................................... 670

College, The Sierra Madre.......................... 188

Colony Farms as first chosen......................... 108

Colony Work, how commenced ......................... 124

Colored People's Baptist Church....................... 486

Colorado Street R. ‥ Line........................... 435

Columbia Hill ............................................. 390

Columbus Day .............................................. 331

Committee disbands..................................252, 274

Com modore Peak, The ............................. 37 I

Company B, N. G. C...................................... 525

Condensed Vegetables Factory......................... 456

Condor Shot [foot note]... ............................... I29

Concert Extraordinary [jocose]..................... I4 143

Conchology Collection................................. 212

Conger, Dr. O. H....................................... 119

Congregational Church, ist.................................. 488

Coon..................................................... 579 
Co-operative Kitchen [jocose].

\section{$\mathrm{D}$}

Daily Evening Nervs.

Daily Pasadeva standard.

Daily Star...

Daily Union.

Daily Uniou and Johin Gur

Day, Arthur $\mathrm{H}$.

Deadman's Canyou.

Degree of Honor, A. O U. W

Democratic Meeting.

Detectives Assaulted.................................... 20́

Devil's Gate...

Devil's Slide.

Dog Poetry

Dreadful night in Eaton Canyon......................... I5I

Dr. Reid's Geological Chart............................. 54

Drunken mob.

Dry Canyon

Dummy R. R. Project.

\section{E}

Eagle Rock

Eagles

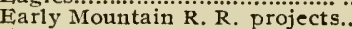

Eaton Canyon, Eaton Falls

Eaton, Judge's biography [footnote] ................. 378

Eaton. Judge's narrative ...............................

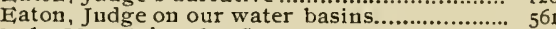

Echo Mountain, 369 ; Canyou........................ 382

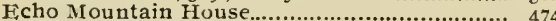

Echo Mountain Postoffice................................... 446

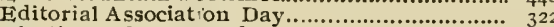

Elections, [see Votes] ..........................227 to 232

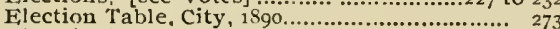

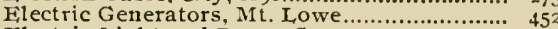

Electric Light and Power Co........................ 463

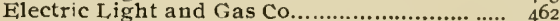

E1 Molino Ranch....................................... 345

E,Ims's Canyon............................................. $38,{ }_{3}$

Emendations.

Encampmeut, I. O. O. F

Enforcement Committee, The

E,11forcement Committee Chairman slandered ' 262

Enforcement Conimittee disbands................. 274

Enforcement Fund Notes, siguers................. 258

Episcopal Church .................................... 486

Fithical Culture Society................................ 516

Eulalia Perez, first owner Ro. San Pasqual.......

Exchange Block

\section{$\mathrm{F}$}

Fair Oaks.....

Fair Oaks Avenue straightened

I20, 346, 355

(1) 356

Father Throop Day .................................... 193

Favors Acknowledged...................................

Fern Canyon.....

Fertilizer Works.................. 462

Fire Departinent........................................... 290

First City Election...................................... 282

First City Council Meeting ........................282, 284

First Citrus Fair ............................... 112

First Civil Officers at Pasadena........................ 278

First-class Hotel Cla use .................................. 48,255

First Electric Car......................................248,

First National Bank

First Newspaper, "The Reservoir".................. I37

First Reunion Colony Picnic........................ 11 I First Saloon Case .................................. I 52

First Street R. R. in Pasadena...................... 434

First Thungs lan aftermath of ]....................... 659

First White Race Boys Born Here.................. 65

First White Man on Pasadena Soil................... 57

First Women on San Gabriel Peak [footnote].. 372

Floral E,mblem of Pasadena........................ 16

Flora of Pasadena and Vicinity............................. to 646

Flora of Pasadena, Index to.......................647 to 650

Flutterwheel springs............................... 351

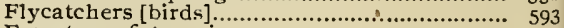

Foresters of America...................................

Fortuightly Club...................................519. 674

Fossil Fish Ledge....................

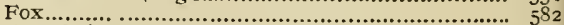

Frauds in High I.

Fraternal Aid Association.......................... 512

Fraternal Mystic Circle.............................. 512

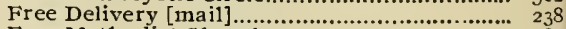

Free Methodist Church .................................. 482

Freewill Ch 1drel1's Home...................... 522

Fremont's Headquarters.........................101, 1021/2

Freniont's Negotiations............................... 98

Fremont's Redont.................................... $02.1021 / 2$

Fremont's 'Tra1l [?]..................................68, 406

Frien is Church......................................... $48_{3}$

Friends, Society of........................................ $4^{\mathrm{x}} 4$

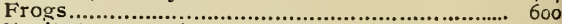

Fruit Crystallizing Works........................... 455

Fruit $\mathrm{D}$ ileries.......................................... 455

Fruit Growers' Association............................ 457

Fut in the Colony .................................... 137

Funeral of Owed Brown.............................. 322

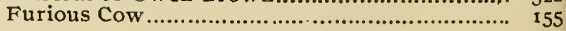

\section{$\mathrm{G}$}

G. A. R., John F. Godfrey Post.................. 502 Garfias Adobe Mansion ................................ 66

Garfias Family, The

Garfias, Mrs., Visit to Pasadeua ........................ 97

Garfias Ownership, The................................. 63

Garfias spring.................................. 350

Gas and Electric Light Co........................... 462

Geological Chart............................................ 541

Geological Section [from borings]..................552, 571

Geology ................................................ 539

Geology Collection.............................................. 21 212

Gen. Sherman's Visit....................................... 315

German M. E. Church........................................ 48 i

German I utheran Church............................ 494

Giddings, E. W.................. I28

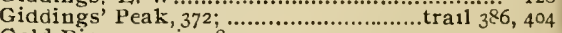

Gold Discovery in $1842 \ldots \ldots \ldots \ldots \ldots \ldots \ldots \ldots \ldots \ldots . . . \ldots \ldots, 52$

Gold Vein and Mines................................. 457

Gopher.................. 576

Gopher Snake................................................

Gospel Union, Pacific..................................... 50I

Glacial Enamelings.

Glacial Drift, Glacial Meadows....................... 559

Glacial Period, How Long Ago..................... 534

Glacial Terrace........................................... $55^{\text {m }}$

Glacial Terrace Canyons............................ 374

Glacial Till............................................. 557

Glaciers in Pasadenalaud ................................. 55.5

Glacier Marks at Devil's Gate...................... 554

Grace Hill. 390

Grahain, D. M.............................................. $\$ 30$

Grand Canyou, Graud Canyon Falls................. 385

Grand Opera House....................................... 463

Grasshopper Talk.................................144, 603

Great Incline Cable R. R................................ 446

Green, Hotel.............................................. 473

Grinuell, Jos. Account of Native Birds .......... 587

Grinnell. J. List of Native Birds..................... 595

Grizzly Bear shot...................................... 129

Grogain 'Tract.................................................... 342

\section{H}

Hahamovic Chief of Pasadenaland I9 to 2 I Harrison, President, Wine Episode. 329 Harvard Telescope Point.

Hawks

Hawk Moths.. 
PAGE

Helen Hunt Jackson's Work.......................

Hen wiger's Flat.

Hermi age Water $\mathrm{C} O$.

Highland Railroad

High School Graduates.

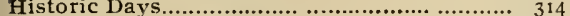

History of the History ................................. 3 to 15

Hodge's Peak, Hodge's Trail...................... 374

Holder, Professor, List of Native Animals....... 585

Holiness Church

Holland's Blinds Factory.

Hollingsworth Store, The.

Hollingsworth Syndicate, The.

Hospital

Hotel Green.

How Tbese Mountains Were Made.

Humane Society.

Hummingbirds

Hurlbut's Artesian Well

Hydrology.

Indiana Colony, The

Incorporation of Pasadena

Incorporating the Mountains

Indemuity Pledge Notes, Signers

Index of Plants in Pasadenaland

Indian Association, Woman's.

Indian Chief baptized as "Pascual",.............. 49

Indian Graves, Why None Found

Indians After Mission Rule Abolished.................

Indian Horse Eaters Kill Two Men.

Indian Native Food.

Indian Native Government

Indian Native Medical Practice..................2 I, 22, 26

Indian Native Religion................................. 23

Indian Native Villages, Locations, Etc ........... I9, 20

Indian Relics, H. N. Rust's......................... I $_{31}$

Indian Relics on Giddings Farni.................... 28

Indian Sweat House at sheep Corral Spriugs. 26

Indian Trades at San Gabriel Mission...........26, 35

Insects............................ 601

Iowans in Pasadena.......................................... 3I9, 666

Irish Colony and British Protectorate............ 99

Iron Ore, Bog Iron, Etc........................... 551

Ivy Springs.......................................... 35 I

\section{J.}

Jack Rabbit

Jason Brown Kissed Her.

575

Johnston, Gen. Albert Sidney ........................ 75

Jumbo Knob.......................................... 374

Juvenile Templars ............................................. 508

\section{$\mathrm{K}$}

Kangaroo Rat

Kinds of Rocks.

Kingbirds

King's Daughter Circles............................. 520

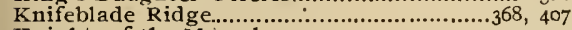

Kuights of the Maccabees..................................... 512

Knights of Labor

Knights of Pythias..................................... 509

Knights Templar, Masonic............................. 506

\section{L}

La Canyada Rancho

Ladies Aid Society to Sons of Veterans.

L,adies of the Maccabees............................... 512

Ladies Union Prayer Meeting.............................. 496

I,adies Visit the Saloonkeeper........................... 215

Lake Vineyard Ranch..................................... 345

Lake Vineyard Colony Tract............................... II

Lake Vin eyard House.......................... 466

Land Grants, Old Spanish, Confirm ed............. 349

Land Tracts by Name.................................. 342

Las Casitas Tract................................................. 348

Las Flores Can yon ..................................... 383,549

Las Flores Ranch........................................ 344

Las Flores Water Co......................................... 424
PAGE

Leighton's Canyon.

Leontine Falls, How Named.......................... 382

Letter from London A. D. $2000 \ldots \ldots \ldots \ldots \ldots \ldots \ldots . .137$

Liorary Art Loan Exhibition.......... 207

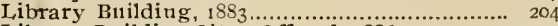

Library Building Sites Offered, 1886................ 205

Library Citrus Fair.................................. 204

Library Fixpenses in $1893 \ldots \ldots \ldots \ldots \ldots \ldots \ldots \ldots \ldots .2 \mathrm{I} 1$

Library Syndicate, $\$ 6,000$ Note....................... 207

Libraty, The Public......................................... 202

Lightniug Strikes a Barn ........... I66

Linda Vista Gold Mines.............................. 550

Linda Vista Peak and Trail............................. 374

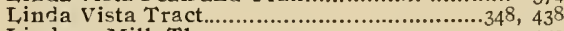

I, indsay Mill, The.................. 459

I,iquor Attorneys Fight shy........................... 25I

L, iquor Cases, First Trials............................... 254

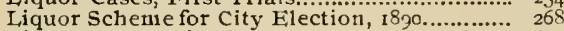

Liquor Sellers Fined ........................276, 277, 670

Literary People of Pa:adena .......................... 223

Literary Societies.......................................... 517

Local Poetry ............................................. 667

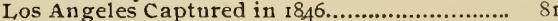

Los Robles Canyon.................................. 375

Los Robles Ranch, Gov. Stoneman's............... 344

Lopez Claudio, Major Domo at San Gabriel.2I, 40

Lopez, Claudio's, Descendants....................... 43

Lost in the Mountains....................................... 156

Lowe, Mrs., Collection................................... 213

Lowe, Prof., His Inventions........................ 450

Lowe, Prof., Ovation to...................................3

Loyal Temperance I,egion .................................. 496

Lugo, Don Antonio, and Joe Chapman.......... 44

I, utheran Church, German......................... 494

Lynx .......................................................... 58

\section{MC}

McClatchie, Prof. A. J., Botany................. $60_{5}$

McQuilling, A. K................................... 130

McQuilling's Collection.............................. 535

\section{M}

Maccabees, Knights and Ladies of.

Macpherson Mountain R. R Survey............ 442

Macpherson Trestle, The............................. 451

Marengo Tract........................................ 343

Markham for Congressman........................ 228

Markham, Gov.'s, bear story.......................... 451

Martin's Camp............................................ 402

Mammals, List of Native............................. 585

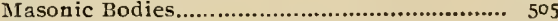

Masonic Temple...................................... 507

Mass Meeting against saloons.............242, 246,255

Mass Meeting resolutions, Aug. $6,1888 \ldots \ldots \ldots . . . .256$

Mechanics Mill.

M. E. Church South.................................... 45

Medical Association....................................... 519

Men chosen to high office............................... 232

Methodist Churches....... 478

Millard Canyon and Falls............................. 384

Millard Catiyon Water Co.............................. 425

Mill Canyon........................................... 375

Mill No. 2, or "Chapman's mill" "................... 43

Mill, The Old Stone, or "El Molino"...............42, 39 I

Mineralogy Collection.................................. 212

Miner's inch, 414 ; footnote........................... 42 I

$M$ ines and Mining...................................547 to 550

Miscellaneous................................................ 664

MIissionary Union, Woman's.......................... 497

Mission Caryon ........................................ 377

Mocking Bird............................................. 594

Moles...................................................... 577

Monks Hill Tract...................................... 343

Montclair Children's Home...................... 521

Monuments to the founders of the colony...... I $_{3} 8$

Moraines, Terminal and Lateral................. 558

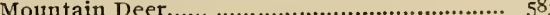

Mountain Iion

Mountain Peaks by mame.............................. 363

Monntain R. R. celebration ......................... 447

Mountain View Cemetery ............................ 465

Mount Disappointment ............................. 370

Mont $\mathrm{t}$ Harvard......................................... 364 
PAGE

Mount Lowe

Mount Lowe Fcho, The

Mount Lowe Electric Railway........................ 440

Mount Mark ham ......................................... 372

Mount Vesuvius.......................................... 369

Mount Wilson ............................................. 366

$\begin{array}{lll}\text { Mount Wilson Toll Road................................... } & 397 \\ \text { Muir's Peak, } 369 \text {; Muir's climb................... } & 406\end{array}$

Mule Deer............................................. 583

Mutual Protection Association .......................... 243

Mystic Circle, Order of.................................. 5 t2

\section{$\mathrm{N}$}

Name of Mountain Railroad.

Naming of Mount Lowe.

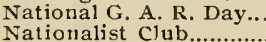

Nativity of School Pupils.

Negto Canyon...

New Charter? - "No"

New Education, The

Newspapers.

Newspaper Suspeusions.

Night Birds...

"Nine Nobby Niggers"...........

(147)

North Pasadena M. E. Church ....................... $48 \mathrm{t}$

"No Saloon in the Valley "........................... 218

\section{$\mathrm{O}$}

Oak Knoli Canyon.

Oak Knoll 'Tract.

Oak Knoll Water co

Observatory Casino

Observatory Peak [?] [San Gabriel Yeak]........ 37t

Observatory, The Mount Lowe...................... 454

Odd Fellows, Orders.................................... 509

Ode to "Father Throop" ".................................. 196

Office, men chosen to high ................................ 232

Old Settlers' Association.................................... I

Old Settler Experiences ..................................... If

Old Settlers, where from ................................... 136

Oil Company, Southern.................................. 464,552

Olive Industry ............................................... 456

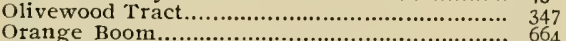

Orange Grove Association organized................. 107

Orange Grove Colony Day............................. 314

Oraige Packing, Shipping, Ftc......................... 664

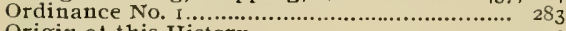

Origin of this History .......................................

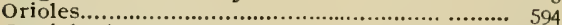

Ostrich Farm...................................................... 494

Ovation to Capt. Cross........................................... 327

Owls ........................................................... 590

\section{$\mathrm{P}$}

Pacific Gospel Union

Painter \& Ball Tract.

Painter Hotel Trac

Painter Hotel............................................... 472

Painters and Decorator's Union..................... 514

Partridges.

Pasadena Capitalists.

Pasadena Chapter, () E 5.

Pasadena Chronicle, The................................ 214

Pasadena City School District............................ 180

Pasadena City Incorporated........................278, 281

Pasadena and Valley Union.............................. 215

Pasadena's Floral Émblem ............................. i6

Pasadena Fruit Growers' Association................ 457

Pasadena Highlands Water Co...................... 425

Pasadena and Los Angeles Filectric R. R......... 439

Pasadena Commandery Knights 'Templar...... 506

Pasadena in Politics ....................................... 227

Pasadena I,ake Vineyard L. \& W.Co............... 416

Pasadena I, and and Water Co........................ 4I

Pasadenaland fitst called San Pascual............. 59

Pasadenaland, why this term is used.............. $34 \mathrm{I}$

Pasadena 1,odge, F. and A. M........................ 505

Pasadena Lodge I. O. G. 'T........................... 507

Pasadena Lodge, I. O. O. F.......................... 509

Pasadena's I iterary People .......................... 223
Pasadeua, Maj, Bonebrake's fun t:

(alk

Pasadena National Bank..................................... 298

Pasadena, Origin of the name........................... 348 , 340

Pasadena's part in Mexican war................... 80

Pasadena People of Mexican war connection.. 103

Pasadena Standard.... .................................. 118

Pasadena Star..

Pasadena Street RailwayCo

Pasadena Students in Pompora College........

Pasadena Students in Stanford University...... 202

Pasadena Students in State University........... 20I

Pasadena Students in State Normal School..... 200

Pasadena's very first name.

Yasadena Weekly Journal..

Patents to Pasadena Geniuses [fun]............... 22

Petitioners against saloon.............................. 247

Petition for "high license",............................. 26r

Picnic, first colony reunion............................... In

Pickwick Club. ......................................... 526

Pigeon ............................................................... $5_{589}$

Pine Canyon ..................................................... 379

Pine Flats........................................................... 404

Pipeclay ............................. 559

Pirate Prisoner in Pasadena Mountains.......... 43

Poem by Chas. A. Gardner.............................. 667

Peoples convention and city nominations, $1890 \quad 27 \mathrm{I}$

Poet ry, first ever written in Pasadena........... 140

Poetry ............................ 8, 140, 196, 382, 428, 667

Politics, Pasadena in .............................. 227

Pomological Society …..................................... 517

Poorwills [night bird]............................ 592

Portola, Gov., in Pasadenaland in $1770 \ldots . . . \ldots \ldots . .557$

Postoffice, Story of the................................. 2.34

Poultry Farm, The................................... 464

Powder made at San Gabriel, $1846 \ldots \ldots \ldots \ldots \ldots \ldots . . . \ldots 57$

Power (ienerators for Mount Lowe.................. $45^{2}$

Precipice Canyon Water Co............................. 424

Precipicio Peak........................................... 368

Prehistoric Man in Pasadena......................... 528

Presbyterian Cluturches....................................... 475,478

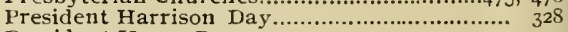

President Hayes Day..................................... 314

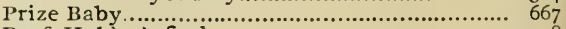

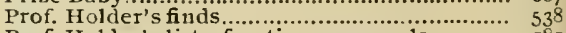

Prof. Holder's list of native mammals............... 585

Prof, Lowe Day....................................... 44

Prof. Lowe's Inventions................................ 450

Prof Lowe takes hold...................................... 444

Progressive League.................................... 265

Prohibition E, nacted .........................

Prohibitory Ordinance changed..................... 276

Prohibitory Ordinance mull, till re-enacted..... 260

Punchhowl Canyon and Falls ....................... 384

Puzzles on Calvin Filetcher........................... $\quad$ i 26

Pyrain $d$ Peak.......................................... 365

\section{Q}

Qt1a1s ................................................. 587

Quaker Churches................................................. 83,484

\section{$\mathrm{R}$}

Rabbit Inuts................................... 149

Rabbits................................................... 575

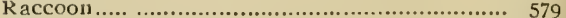

Ramabai Circle........................... 500

Raniona and Pasarlena R. R............................ 440

Rancho San Pasqual bonded for oil................. $7_{76}$

Ro. San Pasqual, complete cluain of title....... 69

Ro. San Pasqual's first louse......................... 7 I
Ro. San Pasqual's first owner..................6. 6 t

Rathbone Sisters, Order of ........................... 509

Rattlestiakes .......................................600, 674

Rattlesnake Spring................................. $37 \mathrm{I}$

Rats....................................................... 575,576

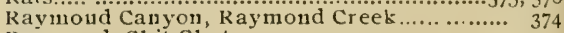

Raymond Chit-Chat................................. 222

Raymond Hill......................................... 290

Raymond Hotel Day..................................... ${ }_{322}$

Raymond Hotel, 467 ; Burned down ................. 47 r

Real Estate Excliange................................. 304

Rebekah Lodge, I. O. O. F.........................

Red Racer [sriake].................................... 600

Reid, Iugo, aud Indian wife.......................... 17 
Reid, Hugo writings Removal of San Gabriel Mission .................. Republican Club........................................228, 231 Republican anti-saloon convention, 1890 ......... 269 Republican Party's anti-saloon plank, I $894 \ldots . . .277$ Reptiles. Resolutions, The [anti-saloon] ......................... 25 Revenue Law Violators........... 259 Richardson Spring, The.............................. 35 Rifle Team, The Pasadena........ 146, 148, 45t-2, 523 Road runner [bird] ........................................ 591 Rock Lizards.

Roller Skating Rink........................................319, 665 Royal Arcanum, Order of............................. 513 Rubio Canyon L. \& W. Co............................. 425 Rubio Canyon, with nine waterfalls............379, 38 Rubio

Rubio Water Trail

Ruse de guerre at San Pedro.

Rust, Maj. H. N.

Saloon started

Salvation Army.

San Gabriel Mission, Successive Padres............ to 43 San Gabriel Mission, secular Officers............40 to 55

San Gabriel Peak....

San Gabriel Valley Bank.................................... 297

San Gabriel Valley Railroad ............................. 426

San Gabriel Valley Railroad Day [opening] 320, 428

San Pasqual, How First Named so................ 25

San Rafael Canyon, [Johnson's Creek).............. ${ }_{3} \delta 8$

San Rafael Ranch, 346; Springs......................... 350

San Marino Ranch, 346; Can yon.................. 377

Santa Anita Ranch.......................................17, I

Santa Anita Avenue.......................................... 36 I

Saucer Falls..

Savings Banks.

School District below California Street, i $877 \ldots$ i... School House Subscription List, $1878 \ldots \ldots \ldots \ldots \ldots . . . .170$

School Lots, Auction Sale of......................... 174

School Statistics ..................

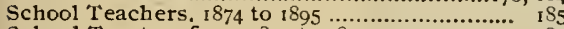

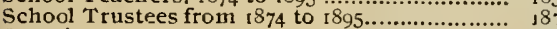

Scorpions ......................... 60 r

Secularization of the Mission .............................

Sexton, Dan's, Old Adobe Mili............................

Sierra Madre College.......................................... ${ }_{1} 88$

Signa1 Peak...................................... 368

Simons, Joe's Historic Cart Ride....................... 402

Shakspeare Club................................................. 518

Shale Beds......................................................... 550

Sheep Corral Springs.................................. 350

Shorb's Artesian Well ....................................... $57 \mathrm{I}$

Shorb Water Scare, The.............................. 668

slickensides.

Scciological Society

Soldier Guards at Mission.....................

Sons of St. George, Order of............................ 113

sons of Temperance........................................... 508

Sons of Veterans................................... 504

Southern Oil Co...........................................464, 552

Southern Pacific Rail road.................................. 440

South Pasadena Beer Garden.......................... 658

South Pasadena Churches............................ 656

South Pasadena City ..................................... 650

South Pasadena Industries............................. 657

South Pasadena Library and Reading Room.. 654

south Pasadena Literary Societies................. 655

Sout b Pasadena Newspapers............................. 654

Soutb Pasadena Post-office................................. 655

South Pasadena Schools.................................... 653

Spanish Land Grants Confirmed.................... 349

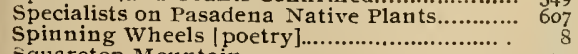

squaretop Mountain ................................... 372

Squirrels .............................................. 577

Stage Talent in the Colony............................... 145

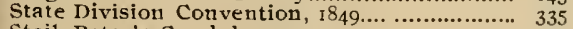

Stei1, Peter's Candidacy...................................
Stockton, Commodore's Headquarters..........97, I00 Stoneman, Gen. [footnote] ........................... 75 Stove Implements found at Reservoit Hill...... 535 Storms, Floods, Etc. 186i to i $895 \ldots \ldots \ldots \ldots \ldots \ldots$.......... to i 67 Strain's Camp. 401 Strawberry Peak [?] .................................... 370 Street Altitudes......................................... 363 Street Car Smash-up............................... ${ }^{156}$ Summary of Plants Listed................................ 645 Swedenborgian Preaching.................................... 494 Switzer's Trail........................................... 403

\section{$\mathrm{T}$}

Tabernacle, The.................................480, 48 Table of City Property and Expenses............... 288

Table of Successive City Officers................... 285 Tarantulas............................. 602

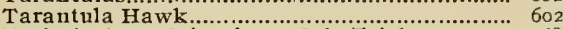
Technical Catch in Liquor Sale Trial................ 2f

Telescope Episode...................................... 396 Temperance Orders....................................... 507 Temperance Question, The............................... 240 Terminal Railroad Day............................. 327

Terminal Railroad, The Los Angeles............... 432

Thibbets Springs, The................................ 35I

Throop, Hon. A. G., Biography..................... Ig

Throop, Hon. A. G., I)eath and Funera1......... I 98

Throop Institute Scholarships...................... 195

Throop Museum Collection ............................... 536

Throop Polytechnic Institute................19o, 193, 197

Throop University............ 191

Titus's Artesian Well................................. 569

Toll Road, The Mt. Wilson............................. 397

Tree Rat................................................ 576

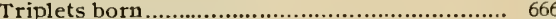

$\begin{array}{lll}\text { Tuunel, The Beaudry................................... } & 389 \\ \text { Twins, Col. Banbury's-[girls] :..................... } & 168\end{array}$

Twins, Col. Banbury's-[girls] ..................... 168
Twins, Mayor Cox's-[boys]......................

\section{$\mathrm{U}$}

Uncle Bob's Trail.

Union Prayer Meeting

uiform rank $\mathrm{K}$ of $\mathrm{P}$................................ 509

United Samaritans..................................... 520

Universalist Cburch......................................... 492

\section{$\mathrm{V}$}

Vaccination of School Children ..................... I 80

Valley Hunt Club..................................... 524

Vasquez, The Robber................................... 150

Vegetables, Condensed, factory ......................... 456

Verdugo Ranch............................................. 346

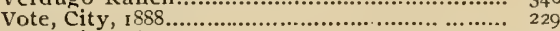

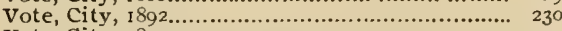

Vote, City, $1894 \ldots \ldots \ldots \ldots \ldots \ldots \ldots . . . \ldots . . .232$

Vote, Colony, Presidential, $1876 \ldots \ldots \ldots \ldots \ldots \ldots \ldots .227$

Vote, Presidential, I880, not foind................... 228

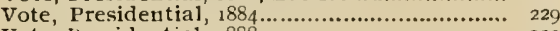

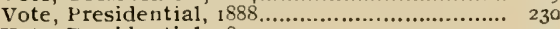

Vote, Presidential, $1892 \ldots \ldots \ldots \ldots \ldots \ldots \ldots \ldots \ldots \ldots \ldots . . \ldots \ldots$

Vulture................................................... 589

W

Wages, mechanics............. 306

Wakeley's Bird Specimens................................ 598

Wakeley's Novelty Works................................ 460

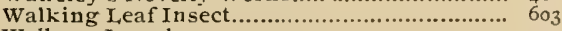

wallace, Joseph..................................... I3

Wallace's Cannery .................................... 152,454

washington School................................... I73

Water Beetle................................................... 603

Water Carvings...................................... 556

Water Measure [state engineer] ..................... 414

Water Meter Trial ...................................... 423

Water Question Settled...................................... 420

Water Rates ..................... 416

Water Supply, The first............................ 410

Water Supply, Total for Pasadena................... 573

Water 'runnels..................................... 572

IVater Works, Expense, Etc.................. 415, 416 


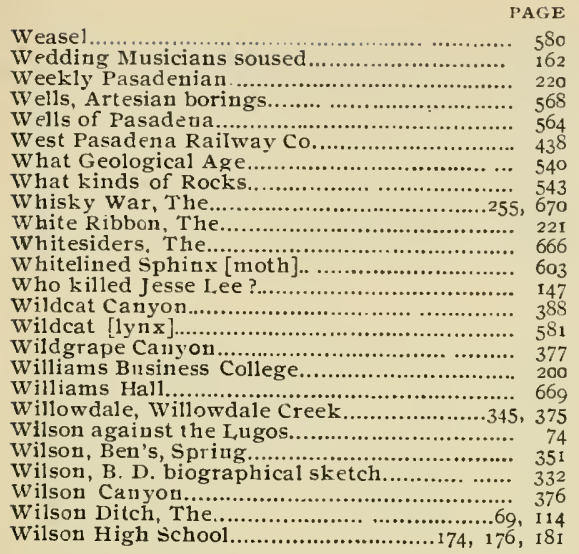

Wilson Lake.

PAGE

(n.......... 394

Wilson's Peak........................................... 366

Wilson's report as U.S. Indian agent [footnote] 336

Wilson's Trail.....................................395, 441

Wilson's wine and the preacher........................ 145

Wineglass, The inverted................................. 329

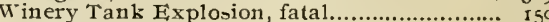

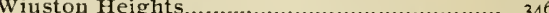

Winston, L. C., lost in mountain snow storm.. I56

Woman's Christian Temperance Union......... 495

Woman's Relief Corps..................... 503

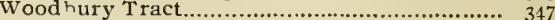

Woodpeckers........................................... 592

woolly Spider. ............................................... 604

Wooster, P. G.....................................13 I, 228

Works consulted in preparing this History ... 5, 6, 7

Worms, Visitation of................................ I 164

Y

Young Men's Christian Association............... 499 Z

Zalvidea, Padre, 26 years at San Gabriel Mis-

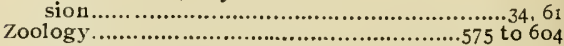

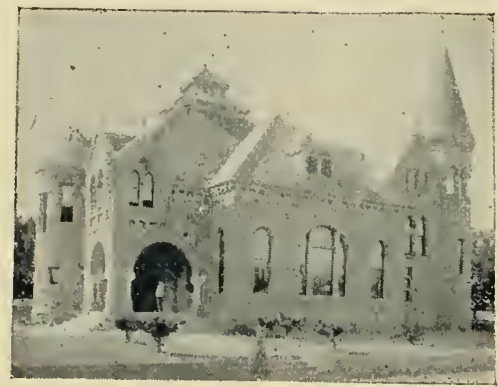

From "Laud of sunshine."

CITY LIBRARY - SOUTH-BY-WEST VIEW

[See page 206.]

Pasadena's Floral kimblam. - On pages 57 and 59 I have explained how the notably conspicuous profusion of wild poppies on our highland slopes first suggested the idea of "San Pascual " as a descriptive term for the Pasadena region, in Apri1, 1770-over 125 years ago. This poppy is therefore historically and distinctively the floral emblen of Pasadena, and is so represented by Mr. I ang in the artistic embossing stamp which he made for the covers of this IIistory volume. 



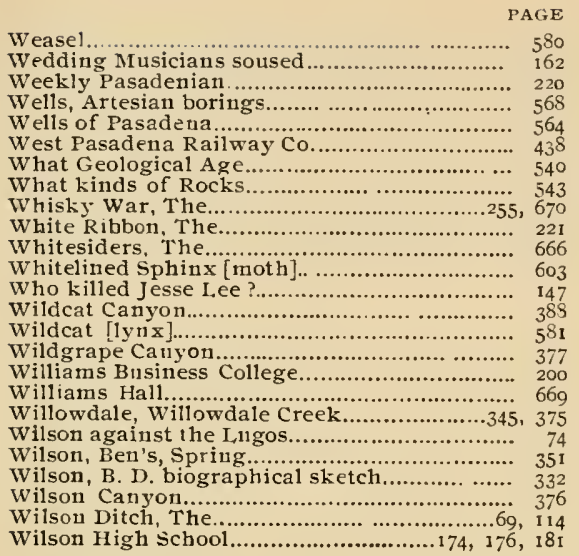

Wilson Lake.

PAGE

Wilson's report as $U$.S. Indian agent [footuote] 336 Wilson's Trail

395,44 I

Wilson's wine and the preacher................... 145

Wineglass, The inverted............................. 329

Winery Tank Explosion, fatal........................ 159

Winston Heights.................................... 346

Winston, L. C., lost in mountain snow storm.. 156

Woman's Christian Temperance Union......... 495

Woman's Relief Corps................................. 503

Wood hury 'Tract........................................ 347

Woodpeckers.................. 592

Woolly Spider. ............................................ 604

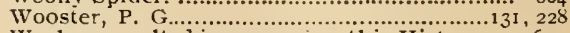

Works consulted in preparing th is History... $5,6,7$

Worms, Visitation of................................. 164

\section{Y}

Young Men's Christian Association................ 499

Z

Zalvidea, Padre, 26 years at San Gabriel Mis-

sion ................................................... 34,61

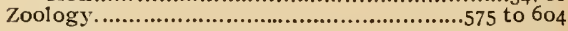

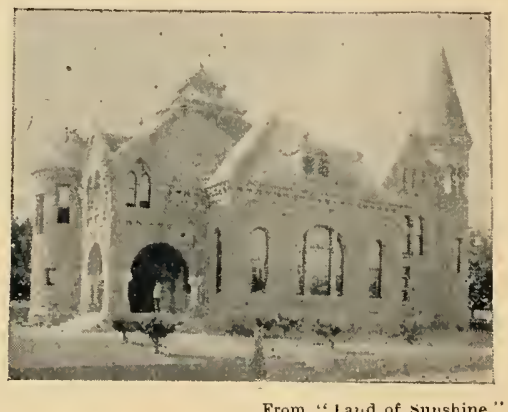

CITY LIBRARY - SOUTH-BY-WEST VIEW.

[See page 206.]

PASAdena's Floral Fimbla. - On pages 57 and 59 I have explained how the notably conspicuous profusion of wild poppies on our highland slopes first suggested the idea of "San Pascial " as a descriptive term for the Pasadena region, in April, 1770-over 125 years ago. This poppy is therefore historically and distinctively the floral emblem of Pasadena, and is so represented by Mr. I,ang in the artistic embossing stamp which he made for the covers of this History volume. 


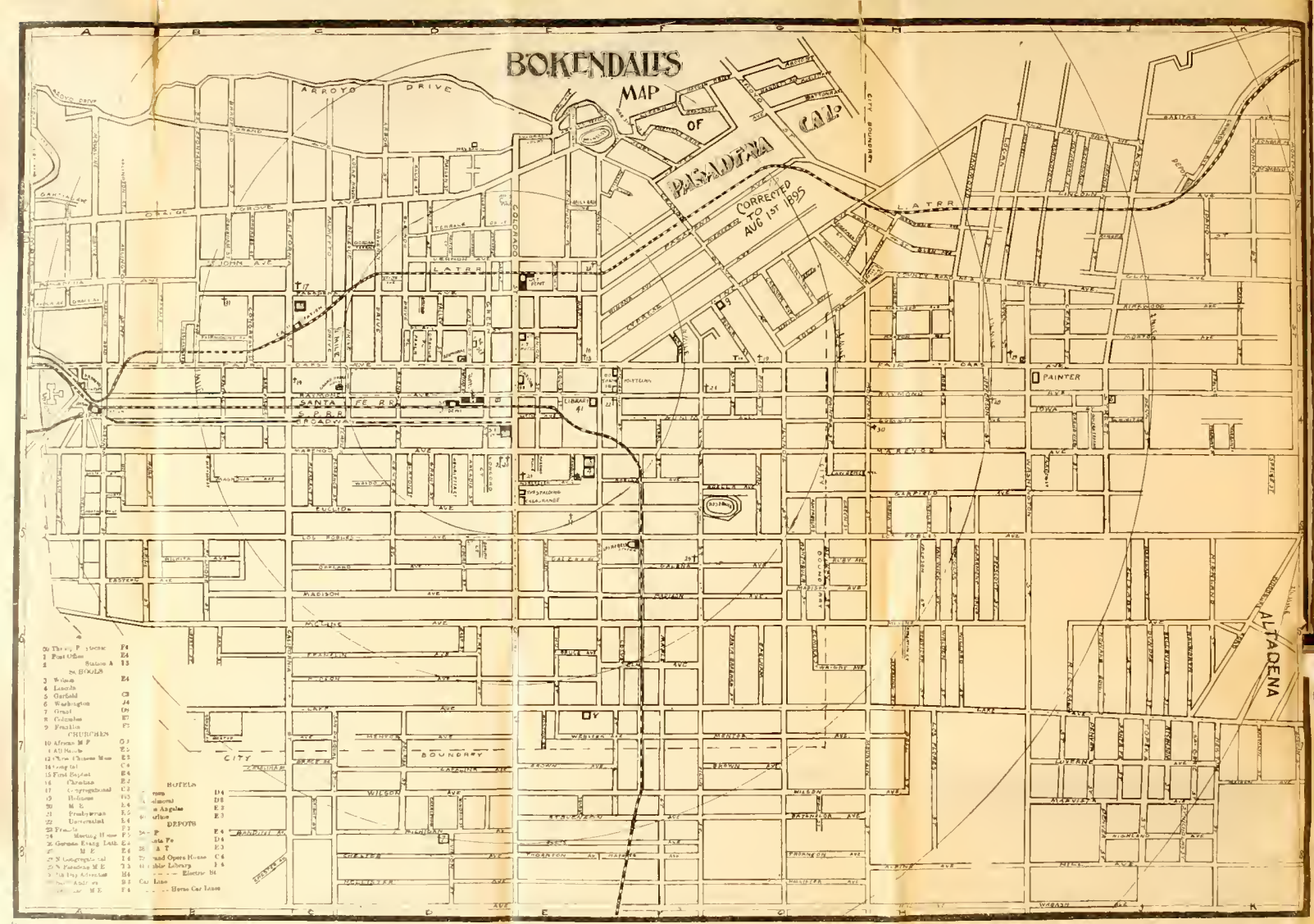

$\mathrm{K}$ Nodelise Rond A 3 Nountnin ave $\mathrm{H}+$ Prom at

J. 4 Sit l'sul at

L 1 Wababl ave

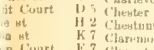

Freubint

lway

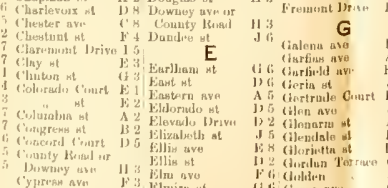

c

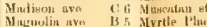

is Perpterint

I 3 Si Nicbulas at H is Waldea

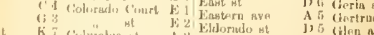

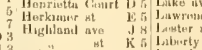

(Alugder

li? Myrte

$\mathrm{R}$

Shev

J 5 Wuluat
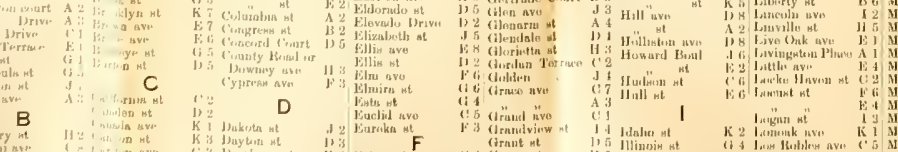

Marengo ave Ua New York 0

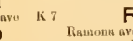

Anplu ot

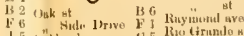

$32 \quad T$

Willis ot
4 Winlwith

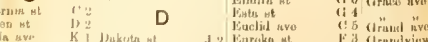

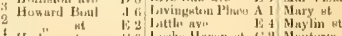

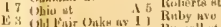

"1T2ve D2 Weliater ave 


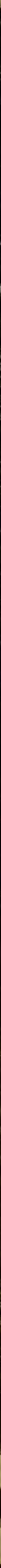




\section{DIVISION ONE - PRE-PASADENIAN.}

\section{CHAPTER I.}

The PRE-PASAdenian A boRigines. Early writers.-Hugo Reid, the Scotchman, and his Indian wife.-Sixteen Indian villages by name and location.-Pasadena's very first name and people-their government, medicine, food, etc. -The Indian religion.-Mission incidents.-Pascual el Capitan and the Pascual Indians. - Indian Sweat House at Sheep Corral Springs.-Indians after the Mission days.-Indian horse-eaters kill two white men in the Arroyn.-Helen Hunt Jackson's work.-Why no Indian graves found.

\section{INDIAN EVENTS IN PASADENALAND.}

When the Spaniards first took possession of this region of country, which was in $1769-70$, they found it occupied by native Indians who then had twenty-seven or more village settlements within what is now Los Angeles county, and the Spaniards called them rancherias.* Each village had its local chief; and some clans had a group of villages with one hereditary or patriarchal chief over all, he bearing the clan name with the suffix "ic" to indicate his office. The writings of padres Crespi, Junipero Serra, Boscana, and others of the earliest missionaries here, besides records left by Governor Fages and many officers and soldiers of the first occupancy, give us information of the Indians of South California in general; but the one writer who devoted himself to local details concerning the Indians of Los Angeles county was Hugo Reid. He wrote from his own studies and investigations, made over sixty years after the Spaniards commenced their rule here, and of course did not get everything-yet he is the chief authority, and most often quoted by later writers in this particular field. Hence I give here a condensed sketch of his life, as a part of the local history of Pasadenaland.

\section{HUGO REID AND HIS INDIAN WIFE.}

Hugo Reid was born in Scotland in $\mathrm{r} 8 \mathrm{I}$; ; came to New Mexico in 1828 and resided there six years. Came to California in 1834 and engaged in mercantile business at Los Angeles. In 1839 he became naturalized as a Mexican citizen, having married a native Indian woman at San Gabriel and settled on the rancho Santa Anita comprising three leagues of land, which was finally granted to him by Mexican authority in I84 I and $1845 . \dagger$ Tiburcio Lopez (a son of the historic Claudio Lopez of San Gabriel) had lived upon it and claimed it before, but somehow Reid got it; and in 1847 he sold it to Henry Dalton for $\$ 2,000$. [The same land was sold in 1874

*In July, I769, Father Junipero Serra wrote: "We found vines of a large size [wild] and in some cases quite loaded with grapes. $* *$ We have seen Indians in immense numbers.........they contrive to make a good subsistence on various seeds, and by fishing. The latter they carry on by means of rafts or canoes made of tule (bulrush)................... All the males go naked; but the women and temale children are decently covered from their breasts downward."

f"Hartnell aided him |Reid] in getting the land, against the efforts of J. A. Carrillo in behalf of the Lopez family."-Hist. Cal. Vol. 5. p.69I. This Hartnell was visitador geveral of Missions, under Governor Alvarado. 
for $\$ 200,000$.] Its original west line ran from the mouth of Eaton canyon southwesterly to the corner of Wilson avenue and San Pasqual street, thence back east along that street to Santa Anita avenue, thence south on that avenue nearly to the Mission. In California he was always known as Hugo Reid. Just when he was married I did not learn, but it appears that in 1839, when he took the oath of Mexican citizenship, he already had his Indian wife, Victoria, and two children. His wife was an excellent woman, much respected at San Gabriel,* and a cottage which she built and lived in is still pointed out as one of the historic buildings there, since her case was dimly woven into the famous story of "Ramona". In 1838 a piece of land I $281 / 4$ acres called Huerta [garden] de Cuati was granted to her by Mexican authority, and confirmed by U. S. patent of June 30 , I 858 ; but as early as I 852 she had sold it to B. D. Wilson, and it became his Lake Vineyard home place, so intimately associated with Pasadena's early history. In I 843 Hugo Reid was justice of the peace at San Gabriel; in 1846 he was auxiliary administrator in closing up the business of secularizing the Mission property; the Mission was heavily in debt, and in June of that year Governor Pico sold out the whole business-buildings, lands, water rights, and all, to Hugo Reid and Wm. Workman-Reid being then in possession. But in August of same year the country was captured by Stockton and Fremont, and they annulled this sale as not valid under Mexican law. In I849 Reid was elected to and served as a member of the convention which gave California her first constitution, under which she entered the Union as a sovereign state. He died in Los Angeles December I 2, I 852.

A pioneer merchant and coast trader of San Francisco named Wm. Heath Davis published in 1889 a book entitled "Sixty Years in California"; and on pages $196-7$ I find this narrative:

"In November, r 844, James McKinlay and myself left San Diego and went overland to Santa Anita. Hugo Reid, a Scotchman, lived at Santa Anita. He was a skillful acconntant, and we brought along with us, on a pack animal, a large pile of account books belonging to the business of Paty, McKinlay and Fitch, who were about dissolving their partnership. We remained at Reid's house most of the months of November and December, adjusting and settling the books, with his aid. Reid had been disappointed in love in his own country, his intended bride having 'throwil him over', so to speak; and he left the country in disgust, vowing he would marry some one of the same name as she who had slighted him, even though an Indian woman. He came to California and fell in with a woman of pure Indian blood, named Victoria, the name of his former love, and married her. Upon our visit at Reid's house we found that they were living very happily together. We were surprised and delighted with the excellence and neatness of the housekeeping of the Indian wife, which could not have been excelled. The beds which were furnished us to sleep in were exquis-

* "There are striking examples of Indian women married to foreigners and native Californians, exemplary wives and mothers." Hon. B. D. Wilson's report as U.S. Indian Agent 1852.

"The Indian women of California were far better stock than those of Mexico." -Davis' "Sixty Years in Cal.," p. 196 . 
quisitely neat, with coverlids of satin, the sheets and pillow cases trimmed with lace and highly ornamented."*

\section{THE INDIAN VII,LAGES.}

Among Hugo Reid's writings is a list more or less complete of the original native Indian names of their villages or clan settlements in Los Angeles county. Usually a clan had only one village, a central settlement; but sometimes the same clan had several villages, with an hereditary clanchief over all, and an elected sub-chief in each village, thus forming a sort of patriarchal confederacy in government; and this seems to have been the case with our Arroyo Seco Indians when Governor Portola, the first white man here, was treated kindly by them and their head chief, Hahamovic, in January, $\mathbf{7 7 0}$, at their village near the Garfias spring in South Pasadena. Reid's writings in regard to the Indians were first published in the Los Angeles Star in 1852, and republished in the California Farmer in January, I86I. A copy of the MSS. was furnished by Judge Hayes, to H. H. Bancroft while preparing his volume on "Native Races of the Pacific Coast", in I88I-82. Considerable portions of the matter were reprinted in Lewis's "History of Los Angeles Co." published in I889. And from Reid's account of the Indian villages I select a few of the localities best known to Pasadena people, or with which they have some special interest, citing the Indian name, and its location as given by Reid, with my own notes of explanation as to present identity. The suffix "na" was equivalent to our word clan, but was also used in a sense the same as our suffixes "ville" or "burg".
Name of Indian
village.
Location as given by Hugo Reid.
Present occupancy or identity of the site.

Acurag-na-La Presa. [A large tule bog or cienega on the L. J. Rose place, above the winery, where the padres built a stone dam in $182 \mathrm{I}$ and conveyed the water in a ditch to their flouring mill No. 2, across the street in front of the church. The stone dam stands yet; and the foundation walls, cement flumes, wheel pit, etc., of the mill are still visible as ruins.]

Ahupquig-na-Santa Anita ranch, where Hugo Reid lived in I844. Azrig-na-La Puente.

Azucsag-na-Azusa.

Cucomog-na-Cucamonga.

Hahamog-na-Verdugo ranch. [From other sources and circumstances, I find that this clan occupied both sides of the Arroyo Seco from Garvanza ford northward; and when Reid wrote his account the Arroyo hills were called promiscuously the "Verdugo hills", or "San Rafael" hills, all lumped off as pertaining to Don Jose Maria Verdugo's ranch. These were the Indians who occupied Pasadena's location when white men first visited the country in $1769-70$.]

*This Indian woman had been one of the "neophytes" under the training of old Eulalia Perez at the San Gabriel Mission. See Chap. 2 and 3. 
Isanthcog-na-Mission Vieja. [The place called "Old Mission," at the San Gabriel river-the site where San Gabriel Mission was at first established (September 8, I77I), but afterwards moved to its present location. Some fragments of the adobe walls of the old first church, and other structures, may be seen yet (I895), at "Old Mission."]

Pasinog-na-Chino ranch.

Pubug-na-Alamitos ranch. [The shores of Alamitos bay.]

Sibag-na-San Gabriel. [This was at a great alluvial marsh which formerly existed in the washway southwest of the present village, and furnished rich crops of vegetables and grain to the Mission while its buildings were going up at the new location. But that body of rich marsh land has all been washed away, leaving only fields of sand and gravel.]

Sisit Canog-na-Pear Orchard. [The old Mission pear orchard, below the mouth of Wilson, Mission and San Marino canyons-now called the Cooper Place, where Isaac and Thomas Cooper live.]

Sonag-na-Mr. White's place. [Irving A. White of the Sierra Madre colony, near, or a part of the present village of Sierra Madre.]

Suang-na-Wilmington. [This was the largest or most populous of the Indian villages in the county, on account of the abundance of food, and so easily obtained from the great estuary or bay there-fish and clams, and such roots, berries and native plant seeds as they used for food.]

Tibahag-na-Cerritos ranch. [Site near Clearwater.]

Toybipet-na-San Jose. [Spadra.]

Yang-na-Los Angeles.

PASADENA'S VERY FIRS'T NAME AND PEOPLE.

The Hahamog-na clan occupied our Arroyo Seco region, and therefore "Hahamog-na" may be set down as the first name by which Pasadena territory was ever designated in human speech; and Hahamovic* was the name or title of the old native chief who smoked the peace-pipe with Governor Portola at South Pasadena, January $17, x 770$. In regard to tribal headship among the Indians, Bancroft's "Native Races," p. 409, says :

"Each tribe acknowledged one head, whose province it was to settle disputes, levy war, make peace, appoint feasts, and give good advice. Beyond this he had little power. He was assisted in his duties by a council of elders. The office of chief was hereditary, and in the absence of a male heir devolved upon the female nearest of kin. She could marry whom she pleased, but her husband obtained no authority through the alliance, all the power remaining in his wife's hands until their eldest boy attained his majority, when the latter at once assumed command."

This old chief, Hahamovic [called by the Spaniards " Pascual el Capitan"], was head chief, and his tribe or clan had several villages at points

*"'The chief of each lodge took its name, followed by ic, with sometimes the alteration of one or more finalletters. For instance, the chief of Azucsag-na was called Azucsavic; that of Sibag-11a, Sibapic; etc." - Hugo Reid's Records: Letter 1. 
convenient to water-one near the Garfias spring which now supplies Lincoln Park with water; one on banks of the brook east of Raymond hill; one on C. M. Phillips's place, near the head springs of Los Robles brook and Oak Knoll brook; one near the Ben Wilson and Richardson springs; one on the Giddings place near the mouth of Millard canyon, far up whose mountain course the tribe obtained their finest and fattest acorns for food; and perhaps others. Each village had its sub-chief, and these formed the "council of elders " referred to-a sort of cabinet or board of directors, with Hahamovic presiding. After the old chief was baptized and named Pascual, his tribe were called the "Pascual Indians;" but later all tribal distinctions were broken up by the Mission authorities and all were blended or mixed together as "neophytes," or "Mission Indians "-and finally called Gabrielenos, to distinguish this populace from those of other Missions-the term "Mission Indians" having come to be applied to any body of natives who had come under the rule of the padres. Our Pasadena chief, Hahamovic or Pascual, finally married a Spanish white woman named Angelina Sysa, resided at San Gabriel, and lived to be very old. Senora Maria Guillen de Lopez, aged 83 , and still living at San Gabriel, knew him as a very old man when she was a little girl. Her mother was the famous Eulalia Perez de Guillen, first grantee of the Rancho San Pasqual; and her husband was a son of the historic Claudio Lopez who served as major domo (chief overseer) at San Gabriel before and through the masterful administrations of Father Zalvidea and Father Sanchez-or a total period of about thirty-six years, as I was informed by his grandsons Felipe and Theodore Lopez of San Gabriel. Their grandmother, Eulalia Perez de Guillen, was living at San Gabriel and attended as midwife upon the mother of Governor Pio Pico when he was born, May 5, r8or; and it was the family tradition that Claudio Lopez was already serving as major domo at that time. Hence he was overseer of Indian laborers for a longer period and in greater numbers probably than any other man in California, and was the first man who ever started any civilized industries on the land now occupied and known as Pasadena. He used it as a Mission stock range.

These primitive people do not appear to have had any sort of domestic animals-not even dogs or cats-nor any sort of agriculture;* but subsisted wholly upon the natural products of the land, both vegetable and animal, including the eggs of quails and other birds in their season. Nevertheless, in some respects they seem to have made real advances toward a semi-civilization, as in matters of civil polity, literature, treatment of diseases, etc. Their medical practice was combined with a good deal of superstitious mummery by the "doctor," such as noise of rattles, smoking [incense] to the Great Spirit, singing of songs or incantations, and other

*The native inhabitants found on some of the Santa Barbara islands did have a domesticated variety of coyote or wild dog; but the early Spanish writers do not mention any such creatures in the Pasadena region. 
ceremonial antics; yet withal they did have some practical and efficient knowledge of the use of sweating or steam baths, of numerous herb decoctions, of lobelia emetics, of counter-irritation by nettle blisters and by burning or "moxa," and of blood-letting, etc. Among the herbs which they used medicinally were Nicotiana or wild tobacco, thornapple [jimson weed], marshmallow, tansy, mustard, southernwood ["old man," as it is sometimes called], wild sage, nettles, and some others. They also had knowledge and skill to prepare poisons for making their arrow points more deadly. In regard to civil regulations among them I quote this brief extract from Hugo Reid's work :

"The government of the people was in the hands of the chiefs, each captain commanding his own lodge. The command was hereditary in a family, descending from father to son, and from brother to brother. If the right line of descent ran out, they immediately elected one of the same kin nearest in blood. Iaws in general were made as they were required, with the exception of some few standing ones. Robbery and thieving were unknown among them; and murder, which was of rare occurence, was punished by shooting the delinquent with arrows until dead. Incest was held in great abhorrence and punished with death ; even marriages between kinsfolk were not allowed. The manner of death was by shooting with arrows. All prisoners of war were invariably put to death, after being tormented in a most cruel manner."

Those occupying the San Gabriel valley he designates by the general name "Gabrielenos," and the mountain Indians he calls " Serranos." Of their native articles of food he says :

"The animal food used by the Gabrielenos consisted of deer meat, young coyotes, squirrels, badgers, rats, gophers, skunks, raccoons, rabbits, wild cats, small crow, blackbirds, hawks, and snakes, with the exception of the rattlesnake.* A few ate of the bear, but in general it was rejected, on superstitious grounds. A large locust or a grasshopper was a favorite morsel, roasted on a stick at the fire. Fish, quails, seals, sea-otter, and shellfish formed the principal subsistance of the immediate coast range lodges and Islanders. Acorns, after being divested of the shell, were dried and pounded in stone mortars, put into filterers of willow twigs, worked into a conical form and raised on little sand mounds, which were lined inside with two inches of sand; water added and mixed up, filled up again and again with more water, at first hot and then cold, until all the bitter principle was extracted; the residue was then collected and washed free of any sand particles it might contain; on settling, the water was poured off; on being boiled it became a sort of mush, and was eaten when cold. $\dagger$ The next

\footnotetext{
*Davis, "Sixty Years in Cal," p. 526, tells of a notable trip which he and others made in $\mathbf{r} 850-5 \mathrm{r}$, when Don Ramon Arguello (uncle to Arturo Bandiui, of Pasadena,) officiated as guide. Rattlesnakes were very abundant and Don Ramon was wonderlully expert in killing them ; and Davis says : "He would eat a portion of their bodies after it was broiled over a hot fire, and often remarked to me that it was more nutritious than the meat of a tat chicken."

†Fremont speaks of the Indians bringing him "bread made of acorns to trade," aud adds that they "live principally on acorns aud the roots of the tule, of which also their huts are made."-Memoirs, page 360. The "tule" is Scirpus lacustris, variety occidentalis.

Another writer who has lived amoug these Indians, says: "Pine-nuts, acorns and roots are all pounded up together in a mortar. The flour is then made into a paste and thrown into a hole scooped out amongst the ashes of a hot fire," etc. * * * In case of birds, rabbits, fish, etc., "without removing feathers, hair or scales, they are plasteted over with mud, then buried in the fire. When the cook thinks the meat done it is raked ont, the baked mud easily dropping off and taking the feathers or hair and skin with it." - Tourists' Guide lo S. Cal., p. 192. By G. Wharton James.
} 
favorite food was the kernel of a species of plum, which grows in the mountains and islands. It is sometimes called the mountain cherry, although it partook little of either, having a large stone wrapped in fiber and possessing little pulp.* Chia, which is a small, gray, oblong seed, was procured from a plant apparently of the thistle kind, having a number of seed vessels on a straight stalk, one above the other, like sage. $\dagger$ This, roasted and ground, made a meal which was eaten, mixed with cold water, being of a glutinous consistence and very cooling. Pepper seed (chilis) were also used ; likewise the tender tops of wild sage. Salt was used sparingly, as they considered it as having a tendency to turn the hair gray. All their food was eaten cold or nearly so."

In addition to what Hugo Reid says above, it appears from other writers that they also used prickly pears (fruit of the broad-leaved cactus), the succulent water cress, the root of some species of flag, wild barley (or wild oats, avena fatua) and various kinds of grass seeds - besides birds' eggs, of which a healthy quail usually lays from twelve to twenty in a season; and thus it will be seen that the range of their dietary was not so very limited after all. They also used the native wild berries, some varieties of which are passably edible, as I have myself tested. These are, blackberries; one species of gooseberries; nightshade berries; some portions of the elderberry crop; manzanita berries; grapes ; canyon bush cherries.

The next historic point in regard to these Pasadenaland Indians is the founding of a Mission among them.

\section{THE INDIAN RELIGION.}

The native Indians of Pasadenaland were very religious, in their rude way, and that accounts for their being so early and so easily brought under the religious influence of the Mission Fathers. Several of the pioneer missionaries, as Junipero Serra, Crespi, Boscana, and others have left some accounts of the religious ideas and customs of these aborigines, besides such secular writers as Gov. Fages, Hugo Reid, etc. In the Thompson \& West "History of Los Angeles County," on page i 5, J. Albert Wilson summarizes the matter in perhaps as fair shape as it can well be done in so brief a space ; and as this summary applies in particular to the Indian predecessors 125 years ago of the church-going people of Pasadena to-day, I make free to quote it :

"They believed in one God, the Creator, whose name - "Qua-o-ar," was rarely spoken, and never save in a low and reverend voice. They usually referred to him by one of his attributes, "Y-yo-ha-ring-nain" "The Giver of Life." They had but one word for life and soul. Their theology knew no devil, and no hell, prior to the advent of the missionaries; and they have ever since maintained that these, being a foreign innovation,

\footnotetext{
*This wild cherry grows abundantly in the West San Gabriel and intramontane Arroyo Seco canyons; and during the last week of October, I $89 \mathrm{I}$, myself and wife and $\mathrm{H}$. N. Farey and wife camping there, ate freely of it, both stewed and raw, and found it quite palatable, with a distinct cherryish flavor wheu fully ripe.

†This "shafted-ball thistle" I have seen growing abundantly near Monrovia and through the valley eastward; it is also found about Pasadena. It is the Salvia columbariae of botany, a species of sage, although prickly like a thistle.
} 
concerned the foreigners only. They looked for no resurrection of the body, but firmly believed in a spiritual existence after death. The souls of wizards were supposed to enter animals - especially bears.-[Hence they would not eat bear meat.-E.D.] And eagles, owls, crows, and porpoises were held sacred. * * * Each village had its church [worship place], woven of basket-work, and circular in form. This building was sacred ever, yet was consecrated anew whenever used. A similar but unconsecrated building served for rehearsal, and the religious education of youth designed for the priesthood. Only seers and captains, male dancers and female singers (all of whom took part in the service) were permitted to enter the consecrated church except on funeral occasions, when near relatives of the deceased were also admitted. The services consisted in asking vengeance on enemies, returuing thanks for victory, and rehearsing the merits of dead heroes; together with the appropriate dances, songs, and gesticulations."

\section{MISSION INCIDENTS.}

The original San Gabriel Mission ["Old Mission"] was founded September 8th, I 77I, The first baptism was that of a child, November 27 th ; and the whole number of baptisms during the first two years was only 73 . This was deemed poor success ; and in reporting on it Father Junipero Serra attributed it largely to the bad conduct of the soldiers. He complained that " the soldiers refused to work, paid no attention to the orders of their worthless corporal, drove away the natives by their insolence, and even pursued them to their rancherias [villages], where they lassoed women for their lust and killed such males as dared to interfere." [See Bancroft, Hist. Cal., Vo1. I, p. I 8r.] And Hugo Reid says of these Indians: "Women used by the soldiers were obliged to undergo a long purification; and for a long time every child born with white blood in its veins was strangled." * They refused to eat any food given them by white men but buried it in the earth. Brown sugar they thought to be the excrement of these new comers; and cheese they thought was dead men's brains. The padres wanted to convert the Indians to Christianity as they viewed it, while the soldiers wanted to conquer and enslave them.

Another report at the end of I773, says: "At San Gabriel the native population is larger than elsewhere - so large in fact that more than one Mission will be needed in that region. [Hence the San Fernando Mission, which was established September 8th, I 797.-E.D.] The different rancherias [villages] are unfortunately at war with each other, and that near the Mission [San Gabriel] being prevented from going to the sea for fish, is often in great distress for food. $\dagger$ Here the conduct of the soldiers causes most trouble; but the natives are rapidly being conciliated."-[Hist. Cal., Vol. I, p. 202.]

*It is related that during Friar Zalvidea's incumbency, from r8o6 to $r 826$, every woman who liad the misfortune to have a miscarriage, or bring forth a still-born child, was presumed to have destroyed it on purpose because it had a white man as its father, and slie was therefore severely punished for infanticide. Her head was shaved, she was flogged once a day for fifteen days, compelled to wear iron on her feet, and to sit on the altar steps at church every sunday for three months holdiug in her arms a hideously painted wooden image of a child. "rlis was "doing penance" for her sin.-See Hisl. Los A. Co., p. 35. Lewis's, 1889 .

† "“The A hapchingas were a clan or ancheria between Los Angeles and San Juan Capistrano, and enemies of the Gabrielenos or those of San Gabriel."-Cal. Farmer, May 11, IS60: ciled in "Native Races," p. 460 . 
That word "conciliated" simply means that the male Indians who had spirit enough to resist the outrages of the soldiers had either been killed or had fled to the mountains ; those remaining were cowed down and passively submitting to their fate. There was indeed an occasional revolt; and the old records abound in accounts of floggings, shootings, banishments, sentence to exceptionally hard labor, recapture of fugitive Indians, shaving of heads, iron on feet, men (and sometimes a man and woman) chained together by the leg, etc. Hence it would appear that these natives were not so tame and unspirited a race as is commonly supposed,* for they did make all the resistance that was possible for them to make with their crude resources against the superior discipline, weapons and intelligence of the Spaniards.

\section{THE NAMING OF SAN PASQUAL RANCHO.}

Some time during $1774-75$ the San Gabriel Mission was moved from the original site on the banks of the river to its present location ; but sometime before the removal one of the "conversions" or baptisms was that of the old chief, Hahamovic, who had furnished food to Governor Portola's famished party in January, 1770 . He was christened by the name of Pascual [spelled with a "c" in Spanish but "q" in English]. This was a name of common occurrence in Spanish usage; but its special adaptation to him is supposed to have been suggested from the vast and brilliant poppy fields within or bordering on his tribal territory, and which the Spaniards had poetically termed the glorious altar cloth of Holy Easter [San Pascual]. At any rate, he was christened "Pascual," and being the hereditary chief of his clan, he was known to the Spaniards as "Pascual el Capitan," and his people as the "Pascual Indians." Nevertheless, the Rancho San Pascual in its distinctive character as a rancho, did not take its name from him, as some writers have supposed - but, as I have narrated elsewhere, it was given as a land grant by the Mission authorities to Eulalia Perez de Guillen; and as the formal assignment of the land to her occurred on Easter Day [San Pascual in Spanish] therefore this body of land or rancho was called the San Pascual or Easter Day ranch. This was atter the Mission lands were threatened to be secularized and Mission rule broken up, in I 826-27; but as her claim became forfeited, it does not appear in the official records of title to the ranch. [For full account see Chap. 3.]

The "Tourists' Guide to South California," page 19-20, gives a pretty complete list of civilized occupations in which our San Pasqual Indians, along with others, were trained, many of them becoming very skillful workmen. This list has a special historic interest as relating to the intelligence and tractability of these Indians, and is at the same time useful to the English reader for explaining the Spanish terms ; hence I quote it here :

"Of this rude, ignorant, useless, savage population the padres made

*'This will explain why the old stone mill below foot of Lake avenue was built to serve as a fortress, in case of a possible revolt and siege by the Indians. 
silleros (saddlers), herreros (blacksmitlis), sastres (tailors), molineros (millers), panaderos (bakers), plateros (silversmiths), toneleros (coopers), cargadores (freighters), valeros (candle makers), vendemiadores (vintagers), caldereros (coppersmiths), zapateros (shoemakers), sombrereros (hatters), comfeleros de panocha (makers of panocha), guitareros (guitar makers), arrieros (muleteers), alcaldes (judges), mayordomos (overseers), rancheros (ranchmen), medicos (doctors), pastores (shepherds), cordileros (ropemakers), lenyadores (woodcutters), pentores (painters), esculores (sculptors), albanilos (masons), toreadores (toreadors), acolitos (acolytes), canteros (stonecutters), sacristanos (sacristans), campaneros (bellingers), cocineros (cooks), cantores (singers), musicos (musicians), cazadores (hunters), jaboneros (soapmakers), curtidores (tanners), tegidores (weavers), tigeros (tile makers), bordodores (embroiderers), piscatores (fishermen), marineros (sailors), vinteros (winemakers), caporales (corporals), habradores (farmers), vaqueros (cattle herders), llaveros (turnkeys), domadores (horse tamers), barberos (barbers), cesteros (basket makers), and carpenteros (carpenters). * * * Such a host of skilled workers and producers were developed by the sagacious training of the savages by the padres."

\section{INDIAN SWEAT HOUSE.}

Pasadena's "Sheep Corral Springs" seem to have been a favorite point and place of resort among the Indians. When our colonists first came here there were some remains of a small old adobe house on the flat a short distance above the springs, at the foot of Hanaford's bluff, and an old water ditch ran from the Arroyo bed out toward the house and down through the same rich bottom land that is now in use there by Byron O. Clark as a blackberry orchard, but the ancient adobe and ditch have entirely disappeared. At that time (I874) there were some pumpkin vines and other vegetables still occupying the ground, from seed of former cultivation. John W. Wilson, I. N. Mundell, and others remember noticing the old adobe walls and water ditch, but had no idea when or by whom they were made. And Mr. Wilson says when he first came here, in $187 \mathrm{I}$, there was a similar water ditch on the west side of the Arroyo bottom a short distance above Devil's Gate, and another one a little way above his adobe ranch house opposite the end of Logan street, where he resided about twenty years. These ditches, however, were long ago filled up and obliterated by vegetable growths and by sand wash from rains or overflow. They were only remnants of the improvements made by Carlos Hanewald and John Pine in I850-5I, who had bought from Don Manuel Garfias a mile square of land for $\$ 2,000$, at 48 per cent interest. [See article on "Complete Chain of Title of the Ranch."]

A man known as Don Geo. Walter, who was orderly sergeant in Capt. B. D. Wilson's U. S. company of California soldiers in the Mexican war, (all captured and made prisoners in a fight at the Chino ranch house in September, I846,) told some of our colony people that the Indians formerly had a "sweat house" or Temescal here at the Sheep Corral springs. This was 
a sort of aboriginal Turkish-bath process, peculiar to the South California Indians, for the cure of rheumatism and sundry other ailments, and was undoubtedly the pioneer sanitarium of Pasadena, which has been so prolific of such institutions in these later years. 'This native sweat-house or hot bath was operated thus: A hole was dug in the ground deep and large enough for a man to sit there in the squat posture and have it filled with water up to his waist. Over this was built a booth or hut of tules, having a small doorway that could be closed with a mat of woven rushes or some animal skin. This hole was filled with water, and from a fire outside hot stones were put into it until it was just as hot as the human body could endure, then the patient sat down in it and the door was closed, but an occasional hot stone was added to the water to produce steam and make him sweat freely. The patient was kept there about an hour. After he had been thoroughly sweated and almost par-boiled, he must rush out and dive head foremost into a ditch filled with cold water deep enough for him to go entirely under, then get out and take a lively run for a mile or two, when the blood would go rushing through the system like a race horse and the patient would feel as fine as a fresh-tuned piano. Sergeant Walter said he once went through the process there himself with the Indians; but once was enough for him. This adventure of Walter's was probably before I 846 ; and the Indians may have had a ditch or sluice there for their sweat-house business which was atterward utilized by Hanewald and Pine in $185^{\circ}$, in their search for placer gold deposits in this Arroyo sandwash.

\section{THE INDIANS AFTER MISSION RULE WAS BROKEN UP.}

When the Missions were broken up and their lands sold by the Mexican government in I835-36-37. most of these Indians were left landless and helpless, notwithstanding some grants made to them. Some of them worked for white people, and had some sort of a dwelling place and familyhood on the ranch where they worked; while others huddled together in fragments of tribes among the canyons and mountains, gaining a scant livelihood by stealing, begging, chopping wood, grubbing greasewood, etc. Even as late as I 884-85 the fine body of land now known as Linda Vista was called "Indian Flat" because it had been for many years occupied by one of these fragmental Indian settlements; and there was another one in a little nook or canyon up between Ia Canyada* and Crescenta Canyada; besides single families occasionally found in out-of-the-way places; and all living in rude huts made of sticks, bushes, tule stalks, rushes, and perhaps some fragments of boards, old matting, bits of threadbare carpet, and other rubbish which they had picked up.

*An old Spanish Mexican at Pasadena was asked what "Canyada" meant. He put his hands together, then opened them a little at their thumb side, making a narrow trough shape, and said-" canyone! canyone!" Then opening the trough much wider, he said "canyada! canyada!" So canyada is simply a large wide canyon. 
Farnsworth's book entitled "A Southern California Paradise," page i 7, in speaking of results when the Mission lands were secularized and the civil rule of the priests broken up, says :

"The Indians were given certain portions of land, and remained at the Mission, working for the white settlers, until $1862-63$, when the small-pox broke out and spread rapidly among them. The few Indians that escaped were so effectually frightened that they betook themselves to the mountains near San Bernardino, where they have since continued."

As to their peculiar skill in basket work, the American Naturalist, I 875 , p. 598 , says :

"In Utah, Arizona, Southern California, and New Mexico the Indians depend solely on the Rhus Aromatica, var. tribola (squawberry) for material out of which to make their baskets. It is far more durable and tougher than the willow, which is not used by these Indians. * * Baskets made thus are very durable, will hold water, and are often used to cook in."

Hugo Reid mentions twenty-four principal ranches which had formerly been lands belonging to the San Gabriel Mission, and among them are San Pasqual, Santa Anita, Azusa, Cucamonga, Chino, San Jose and Puente. The domain of this Mission extended from the Arroyo Seco eastward to the desert, and from the mountains to the sea.

Prof. C. F. Holder, in "All About Pasadena," says :

"In $\mathrm{I} 852$ a report was made by the Hon. B. D. Wilson to the Department of the Interior, to the effect that there was then in Santa Barbara, Tulare, Los Angeles, and San Diego counties, about fifteen thousand Indians, comprising the Tularenos, Cahuillas, San Luisenos, and Diegenos. Thirty years later another report was made showing a decrease of ten thousand; the remaining five thousand are fast disappearing." **

In the same work, page 68-69, Prof. Holder again says:

"The Giddings ranch [at mouth of Millard canyon] is the site of an extremely old settlement; and for years objects of various kinds, mostly old and broken, have been plowed up. They were generally flat, shallow mortars, [metates] of a dark stone, with short, flat grinding or mealing stones. In following the plow of Mr. Giddings I have seen pieces of mortars or pestles thrown up every few moments, showing that large numbers must have been left here; and as they were buried a foot or more below the surface, it is evident that they were older than many others found upon the surface. The old town was situated at what is now the beginning of the road leading down into Millard canyon; $\dagger$ and the assumption is that the women went up into the canyon to collect acorns, which were brought down to the village to be ground. Every year at plowing time, which comes between November and Christmas, specimens are unearthed. $* * *$ Also on the San Rafael ranch, opposite the west end of California street, many interesting specimens have been found; and the author has picked them up in various parts of the city. Few of the older residents but possess a collection of some size."

*In some streets of this little city [L,os Angeles, 1852] almost every house is a grog shop for Indians." - B. D. Wilson's Report as Indian Agent.

†See article entitled "A pirate prisoner in the Pasadeua mountains." 
INDIAN HORSE-EATERS IN PASADENA. TWO WHITE MEN KILLED.

Judge Eaton has narrated for this History the following incidents:

"When I first came out here Don Manuel Garfias told me that I would be exposed to incursions during the spring, from the Pah ute Indians, who were in the habit of coming in through the mountain passes to steal horses to eat. They employed no skill in catching them, but relied upon such animals as they might find at the end of a picket rope; or slipping quietly upon a band when lying down in the night, and lassoing one while sleeping. I had been at Fair Oaks only long enough to get a pair of bronchos trained to drive in a buggy, when without any notice whatever, their picket ropes were cut close to the pickets and the horses taken. They were within a hundred yards of my house, but the thing was done so still and sly that they did not alarm the household. I started out a couple of Mexican boys on their trail and in an hour they returned with one animal that they caught by the picket rope. After breakfast I despatched a boy to B. D. Wilson's but on his way down he saw the other three horses coming from the Santa Anita ranch full tilt, with their picket ropes trailing behind them. They did not stop until they got into one of the ranch bands, and the boy drove them all up to my corral. This was Monday. On Wednesday night I took them out after dark and hid them in a belt of oak timber, back of the house. The next morning two of them, a. pair of handsome grays, were gone. I mounted one of the Mexicans on a horse and sent him in pursuit. $\mathrm{He}$ traced them into Santa Anita canyon, but having no arms he was afraid to go farther and returned. After a lapse of so much time it was useless to prosecute the search, as the Indians had probably killed the horses when they got fairly into the mountains, and packed off the meat on their backs, [This was in I 865.-ED.] The summer following there came onto the ranch a band of desert Cahuillas, ten bucks and one squaw. They made headquarters near the base of the mountains, never showing themselves in the daytime, and making nightly raids on the neighboring settlers, carrying off calves that they found in the corrals. I saw their tracks occasionally, but apprehended no danger from them, though I felt a little anxiety about my family during the day, when I was absent in the canyon, and not a soul nearer than three miles upon whom they could call for assistance. At that time an old man, Sam Kramer, had charge of Dr. Griffin's stock of brood mares and colts, and lived in the old ranch house. One day, I think it was in May, the man who at the time had charge of the Stoneman place, came along accompanied by a friend of his from Los Angeles, and asked Kramer if he would not join them in a bee-hunt up the Arroyo Seco. As he could not join them they rode on, and that was the last time they were seen alive. The next day as Kramer was riding over the ranch looking after his stock, he discovered in one of the bands a horse with saddle and bridle on. Driving the band to the corral he fonnd that the horse was the same one ridden by his neighbor the day before, and the saddle was covered with blood. Immediately notifying the family and summoning assistance, they commenced a search for the body of the missing man. Following the tracks of the beehunters up the bed of the Arroyo, to a point opposite the west end of California street, they found a deserted Indian camp. The occupants had apparently left in haste, dropping an old soldier coat, and a small bag of panole, (parched corn ground or pounded into meal.)

"Following the horse tracks which indicated that their riders were 
making all possible speed, they were led up into the thick brush upon the eastern bank of the Arroyo. Half way up the hill they encountered the body of one of the victims, stark dead. An arrow pierced his heart to the center. Upon withdrawing it they found the arrow head was of glass. They then remembered that they had seen at the camp just left, the remnants of a black bottle out of which the Indians had been constructing arrow heads. The body had not been molested in any way. The dead man had a Derringer pistol in his hand which had been recently discharged. The other man could not be found, but on the following day his horse and bloody saddle entered one of the ranch herds, and the search was continued, with the result that not far from the spot where the first man was found lay the body of his companion. He had been killed by a single arrow piercing the heart, but entering at the back. This arrow was also pointed with a head made of black glass. These are two of the most remarkable arrow shots ever heard of. The body of this man had not been disturbed either. In his hand was a revolver with one barrel freshly discharged, and in his pocket was found nearly $\$ 40$. It was evident therefore that the object was not robbery. The mystery attending this tragedy was never thoroughly explained. The theory was that these men, coming suddenly upon the band of apparently wild Indians, (for they wore no clothes but breechclouts, no hats, and were armed with bows and arrows, ) attacked them with their pistols. The Indians returned the fire with the results already told. They suddenly left for their homes in the mountains of the desert country. Only one man ever saw them, and from him I obtained a description of the band but too late to pursue them:

"Two years after the above occurrence the people around the outskirts of San Bernardino were annoyed by frequent thefts of calves from their corrals. A party started in pursuit of the marauders, and overtaking them before they reached their mountain home, captured them and gave them a drum-head court-martial and executed them on the spot. Indians, after they find there is no escape from death, boast of the scalps they have taken, so now did the chief of this party boast of having killed two white men in the Arroyo Seco a couple of years before. And that is all we ever learned of this remarkable event."

HELEN HUN'T JACKSON'S WORK.

Hon. Abbott Kinney, in the Pasadena Valley Union of September 5, I 885, speaking of the then recent death of Mrs. Helen Hunt Jackson, who was associated with him on the U. S. Indian Commission, says :

"Helen Hunt Jackson was a woman of warm heart, poetic insight, and large cultivation. Her sympathies were wide enough to have a place for every one in distress whom she knew. She was as much at home and as welcome at the scanty fireside of the hovel as in the palace of the rich. The Mission Indians of Southern California, for the most part an industrious and much injured people, have much to thank Mrs. Jackson for in the improved condition of their land tenures, their good schools, and the more intelligent course of the government toward them. Her poems, novels and essays have been widely read; many of them are of a high order of merit, and some of her poems are gems, true to nature, simple and touching, that have in them the qualities of perpetual endurance. "Ramona" is her last great work. It has been well said that it is by far the best novel ever written 
with the scene laid in California, and it is properly a California novel. It is a poem in prose, and is of universal interest, as it deals with the true and simple feelings of humanity. Every incident in this book is founded on fact. From the ejectment at Temecula to the killing of the husband and acquittal of his murderer, the basis of every statement is susceptible of proof."

\section{WHY NO INDIAN GRAVES AT PASADENA?}

In a letter to me July I I, I894, Prof. C. F. Holder raised this question, and I quote his remarks :

"One question has interested me greatly - where did the San Gabriel Indians bury their dead? I have never found a skeleton, nor heard of one being found. Graves are common at Catalina and Santa Barbara; but a Pasadena place of Indian burial has not been found."

The answer is that cremation was practised by our Indians. Taylor's Indianology, cited in the California Farmer of June 8, 1860, says: "From north to south in the present California up to the Columbia river, they burnt the dead in some tribes and in others buried them."

In Schoolcraft's Archæology, Vol. 3, page I12, Gibbs reports from the Pacific coast Indians : "The body is consumed upon a scaffold built over a hole, into which the ashes are thrown and covered."

Father Geronimo Boscana, who served as a missionary among the Indians of Southern California nearly 30 years, and died at San Gabriel July 5, 1831, left a MSS. account of these Indians in Spanish, which was translated by Alfred Robinson, a Boston man, who was in California as a trade manager and traveler from February, 1829, until I 845 ; and it was published by Wiley \& Putnam, New York, in I846, as an appendix to Robinson's own work, entitled "Life in California." On the matter in question Father Boscana, at page 239, says: "The bodies of their dead were immediately burnt." Again, page 268: "The parents of the deceased were permitted afterwards to take possession of the body and perform the accustomed ceremony of burning it." And yet again, page 3I4, he says : "Preparations were made for his sepulture or the burning of his body; $* * *$ they bore the corpse to the place of sacrifice, where it was laid upon the faggots. Then the friends of the deceased retired, and the "burner" set fire to the pile, and remained near the spot until all was consumed to ashes."

\section{Hugo Reid gives a somewhat different account. He says :}

"When a person died all the kin collected to lament his or her loss. * * * This was continued until the body showed signs of decay, when it was wrapped up in its covering with the hands across the breast and tied from head to foot. A grave having been dug in their burial place, the body was interred according to the means of the family, etc. If deceased was the head of a family or a favorite son, the hut was set fire to, in which he died, and all of his goods and chattels burned with it." 
Father Boscana was a pioneer missionary among these Indians, while Reid wrote from hearsay long after they had become partly Christianized.

Governor Fages $[\mathrm{I} 77 \mathrm{I}]$ and various other writers, give varying accounts of burial practice. But taking all the testimony in the case, and the circumstantial evidence besides, I am safe in stating that our Pasadena aborigines burned their dead; and so that is why no graves or skeletons have ever been found, nor any general place of sepulture. 'The fact is, when the "hut" was burned the body was burned with it. And in other cases the body was laid on a hurdle of sticks and brush over a hole in the ground, as Gibbs reports, and as the body and brushwood consumed together they dropped into the hole, and things belonging to the deceased were then thrown in also, and the cavity filled up. This. was the grave, and this is how it happens that a metate or some other stone relic is occasionally found "three or four feet down," as Prof. Holder says in his letter given in another chapter, while ordinarily these things are covered so shallow with vegetable mould, or drifted sand and dust, that they are turned up by the farmer's plow, which usually cuts only from six to ten inches deep.

"Old Francesca," who was born at Los Nietos in I794, and is still living as a resident of Pasadena, told me on September 23rd, 1894, that she had always understood that "the Indians here burned their dead, before they became Christians ;" but she had never seen it done herself.

Senora Lopez also related an incident of an Indian coming to life again in the San Gabriel church while they were preparing to bury him, some time during Father Sanchez's administration. He was an old man, a woodchopper; his body had been prepared for burial and left in the church over night. The next day at the hour set for the funeral his relatives and the people and priest went in to complete the burial service and lay him away in the graveyard north of the church. But now to their astonishment and fright he raised up, and said faintly in the Indian language, "Mamma, I want some water." He recovered and lived several years afterward. Senora Lopez and old Francesca, then young women together at San Gabriel, once asked him what he saw while he was dead, and he replied, "Lights, lights - up high — and a pretty road! — high, too high! - I was so tired - I couldn't go up, — so I had to come back ! - so tired !'”

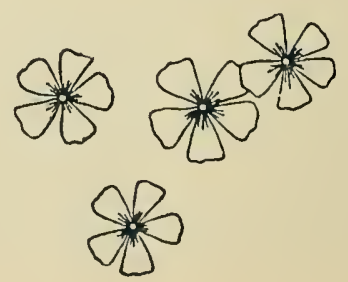


In September, 1775, padre Francisco Miguel Sanchez took Paterna's place, and remained until July 27, I803, when he died. Padre Calzada was also here until 792 .

1792-93: Padre Cristobal Oramas.

1794-96: Padre Juan Martin.

1798-99: Padre Juan Lope Cortes.

July, 1797 to October, I 802 : Padre Pedro de San Jose Esteban.

In $1775-76$ the Mission was removed to its present location, the Indian village of Sibag-na being near this site. An adobe structure was built here for a church at first, but its walls cracked and became unsafe, and the project of building a stone church was commenced. The records are strangely and stupidly meager ; but it appears that in 1794 the stone church was about half completed: and in $\mathrm{I} 800$ it was still unfinished. (Hist. Cal., Vol. $I, p$. 667.) Of the present location J. Albert Wilson writes:

"The site now occupied by the San Gabriel Mission buildings and the adjacent village, was a complete forest of oaks, with considerable underwood. The water composing the lagoon of the mill (one and a half miles distant) then lodged in a hollow near the Mission on the Los Angeles road. This hollow was a complete thicket of sycamores, cottonwood, larch, ash, and willow; and was almost impassable from the dense undergrowth of brambles, nettles, palmacristi, wild rose and wild vines. Cleared of these encumbrances, this land (which then possessed a rich black soil, though now a sandy waste) served to grow the first crops ever produced in Los Angeles county. [NOTE.-This is a mistake, for some corn, beans, barley, and garden stuff had been raised at Old Mission, before the removal-ED.] Near by stood the Indian village Sibag-na. Bears innumerable [?] prowled about the dwellings, and deer sported in the neighborhood."--Thompson $\mathcal{E}$ West Hist. Los A. Co., p. 20.

I 802 to I 804 : Padre Isidoro Barcenilla.

In $1803-04$, and again from 1806 to January I4, 181 r, when he died, padre Francisco Dumetz was here. He had been forty years a missionary, and was the last survivor in California of the original band that came here with Father Junipero Serra.

I 803 to I8I3: Padre Jose de Miguel. Then he went to San Fernando Mission, and died there June 2, I8I4.

From August, 1804, to September, r806: Padre Jose Antonio Urresti.

In 1806 Padre Jose Maria Zalvidea was placed in charge of this Mission; and for twenty years he pushed its development and managed its affairs with vigor and rigor and masterful ability. He was a severe and rigid disciplinarian; he worked hard himself and made everybody else work hard; some of his regulations, both religious and secular, were diabolically harsh, cruel and torturous; the Indians both male and female were reduced to a condition of virtual slavery, under taskmasters armed with bullwhips made from strips of rawhide. Any show of resistance was punished with ruthless 
severity, until all Indians who had pluck and grit enough to rebel were either killed, or escaped to the mountains or broken in spirit--for it must be remembered that the Indians had only clubs, wooden spears, bows and arrows, or stones for weapons, while the Spanish soldiers on guard duty at the Missions had muskets ; and this is why so few could overcome and hold in servitude so many. In fact the Indians at the Mission were not allowed to keep in possession weapons of any sort. Nevertheless, Zalvidea's ironhanded harshness of rule here was no worse than had been carried on by Spanish ecclesiastics against heretics or heathens in Europe and Mexico and South America, or by Americans in the slave-holding portions of the United States prior to $\mathrm{r} 860$. Hence it is not for us to throw stones at this austere padre. His policy resulted in a most brilliant and famous commercial success for this particular Mission; the blood and sweat of his enslaved "neophytes" (the "converted" Indians were always thus called) was veritably coined into money. He finished the stone church; built the great dam, saw mill and stone grist mill at Wilson lake ; brought water in ditches from the San Gabriel river beyond Monrovia to irrigate field crops, orchards and vineyards; established numerous distinct mechanical trades to manufacture or prepare for market the products of flocks, herds, fields, and the chase, and assigned Indians to each kind of work, with a taskmaster over them; carried on a large trade with ships at San Pedro from Mexico, Sonth America, Spain, United States and other countries, selling them hides, tallow, soap, candles, wines, grain, peltries, shoes, etc. But the settlers at Los Angeles, and the ranch people of the region round about, and the people of other Missions, were also large purchasers from the San Gabriel workshops.* To give an idea of the extent of the business carried on by Zalvidea (with the very efficient aid of his famous major domo. Claydio Lphez),

Butchers-Slaughter men, who killed, skinned and dressed beeves, sheep, etc., separating the hides, tallow and meat to the different workers in each article. Theodore Lopez pointed out to me the place on the banks of the Arroyo west of the village where one hundred cattle were slaughtered every Saturday as rations for the 3,000 to 4,000 Indians during the ensuing week, when his grandfather was major domo there.

Hide-dressers - who prepared hides, sheepskins, deerskins, etc., for sale or shipment.

Tallow-workers - who operated vast iron cauldrons procured from whaling ships, for trying out tallow by the ton and running it into underground brick vaults, some of which would hold a shipload of it in one solid mass, keeping it there safe from becoming rancid or being stolen until some ship

* "The town of I os Angeles was formally founded September 4, $178 \mathrm{I}$-just ten years (less four days)

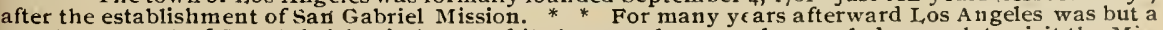
country outpost of San Gabriel Mission: and its tew people were always glad enough to visit the Mission, there to purchase its weekly supplies, and witness the Sunday festivities." -7 , $\circlearrowleft W$. Hist Los $A$. Co.,p. 23 . 
was ready to take a cargo of it; then it was cut out in great blocks and hauled on carts to San Pedro.* This work was carried on for many years a few rods south of the present old Mission church just below the S. P. R. R. track. In August, I 894, I found some remaining ruins of these ancient tallow vaults still visible in the Bishop's orange orchard which is enclosed by a high picket fence below the railroad.

Meatdriers - who prepared jerked beef, sun-dried, for local use and to sell or trade. $\dagger$ The Indians preserved their meat in this way before the Spaniards came.

Candlemakers-who made tallow dips for selling to ships and in the general market. These were the staple articles for household or ship-lighting purposes at that time.

Soapmakers-Hogs were raised chiefly to furnish soap fat, as the Indians refused to eat hog meat, though the padres ate it, + and the same cauldrons and furnaces were used alternately for tallow rendering and soap boiling. The ashes from these furnaces and from the brick and tile works, and bake ovens, were used to leech lye for the soapmakers.

Tanners-who made dressed leather, and also tanned skins and peltries with hair or fur on.

Saddlers - The ranches furnished an immense market for these products and it became an important industry; for horse-back riding was then the chief method of travel or movement in California.

Shoemakers - Shoes were made for the Mission people, although the Indiaus mostly went barefooted; and some were sold to the ranches and town settlements, and to ships at San Pedro.

Sawmill Men-Prior to about I 8 Io or I 8 I2, such lumber as was absolutely necessary was provided either by hewing or splitting with axe, or sawing by hand, with two men above and two in a pit below the log to work the saw up and down; s but now Zalvidea had the great dam built at Wilson lake and a water-power sawmill erected below the dam, to provide lumber for buildings, fences, carts, wine vats, candle and soap boxes, cooperage, etc., etc. And the labor of cutting and fetching logs, operating the mill and delivering the lumber employed many men.

Grist Mill Men - Following or in connection with the building of the

* The tallow he had laid down in large, arched stone vaults, of sufficient capacity to contain several cargoes."-Robinson's "Life in California" p. 35. This was at San Fernando Old Mission, in April, 1829 and it had to be quarried out and hauled to San Pedro, the same as the San Gabriel stock. Davis in his book. "Sixty Years in California," says the tallow was sometimes run into bags made of hides that would hold from 500 to 1000 pounds each.

f "The best part of the bullock was preserved by drying, for future consumption. "-Sixty Years in California p. 36 . Auother writer of date November 23, 1818, says: "My good mother was in a wagou [cart] which had two hides for a floor and two more for a roof, where after supping ou half-roasted strips of dried meat without salt, she gathered around her her whole family," etc.

"The Indians, with few exceptions, refuse to eat pork, alleging tlie whole hog family to be transformed Spaniards. I find this belief current through every nation of Irdians in Mexico."-Hugo Reid.

3" Old men rejoicing in the fame of witchcraft, he made sawyers of them all, keeping them like hou dis in couples [chained], and so they worked, two above and two below in the pit." -Hugo Reid.

Santa Anita Canyon derived its old nickname of "Saw-pit canyon," from this early practice. 
dam and sawmill at the lake, the stone grist mill was erected. Prior to this, the Spanish people of the Mission had depended for their breadstuff on Indians who still used their old primitive metate and mealing-stone implements to supply meal for the entire Mission populace. But now, with a water-power grist mill of their own, the first one ever built in California,* they would be independent of the uncertain ship supplies from Lower California or Mexico, and would make breadstuff for their own use and some to sell. So hauling and handling the grain, operating the mill and delivering the flour employed a distinct lot of both men and women. The mill produced only coarse unbolted meal, whether of wheat, corn, or barley, and this was carried to store-rooms where Indian women put it through a rude process of sifting, and so furnished some "sifted flour" for the Mission bakers. [See article entitled "The Story of the Mills," farther on.] General John Bidwell, a California pioneer of $184 \mathrm{I}$, writing in the Century Magazine of December, I890, describes an Indian harvesting scene thus:

"Imagine three or four hundred wild Indians in a grain field, armed, some with sickles, some with butcher knives, some with pieces of hoop iron roughly fashioned into shapes like sickles, but many having only their hands with which to gather by small handfuls the dry, brittle grain, and as their hands would soon become sore, they resorted to dry willow sticks, which were split to afford a sharper edge with which to sever the straw. But the wildest part was the threshing. The harvest of weeks, sometimes of a month, was piled up in the straw in the form of a mound in the middle of a high, strong, round corral; then three or four hundred wild horses were turned in to thresh it by treading, the Indians whooping to make them run faster. Suddenly they would dash in before the band at full speed, when the motion became reversed, with the effect of plowing up the trampled straw to the very bottom. In an hour the straw would be thoroughly threshed and the dry straw broken almost into chaff. In this manner I have seen two thousand bushels of wheat threshed in a single hour. Next came the winnowing, which would often take another month. It could only be done when the wind was blowing, by throwing high into the air shovelfuls of the grain, straw and chaff, the lighter materials being wafted to one side while the grain, comparatively clean, would descend and form a heap by itself. In this manner all the grain in California was cleaned. At that day no such thing as a fanning mill had ever been brought to this coast."

Such scenes as the above were yearly enacted in the grain fields of San Gabriel Mission, under padres Zalvidea and Sanchez.

Carpenters - This trade comprised wheelwrights, cartmakers, boxmakers and fence builders, as well as those who did such woodwork as was necessary about their buildings-laying floors, joists and rafters, putting in doors and windows, making bench seats, and the like. Their "carretas" were great clumsy ox carts with wheels made of blocks sawed or chopped off from the end of a large round $\log$, then a big hole bored, chiseled and burned through

*Davis, "Sixty Years in California," tells of a grist mill built at Yerba Buena [San Francisco] in 1839 , and calls it the first one in California. Big mistake, by twenty-five years at least. 
its center, enabling it to turn on a rude wooden axle, soap or tallow being sometimes used for lubricants.* The making and repairing of these carts for themselves and ranchers made work for many men, besides the wheelwright work for the mills.

Blacksmiths-California native horses were tough hoofed, and horseshoeing was scarcely known at the Mission; but carts and mill gears, and plows, harrows, hoes, picks, shovels, etc., made business enough for this trade. The blacksmiths had to provide their own coal, and hence this trade included charcoal burners.

Brickyard Men-Making bricks and tiles was an important trade. I found four arched chambers in the old stone mill, besides other parts, where large square bricks were used of their ow11 manufacture; and also in the ruins of the tallow vaults in the Bishop's orange orchard. The church was originally roofed with thatch; then with tiles,- - but these proved too heavy, broke down the rafters, and had to be changed for shingles; and the stone mill had a tile roof until Col. Kewen changed it in $1859 . \dagger$ In I 831 there were in Los Angeles four houses roofed with tiles made by the Indians at San Gabriel.

Masons - This included both brick and stone masons, and cement or artificial stone artisans. Much of their artificial stone or cement work stands yet, as hard as bed rock; and there is a tradition that the old cemen $n_{t}$ ditch south of the church was made by mixing it with beeves' blood, which is said to account for its extraordinary hardness as found by the railroad graders when they had to cut through it. The Spanish, Irish and Chinese workmen on the railroad grade all believed this bloody fable.

Limeburners - This trade was carried on quite extensively at the cement quarry where the Lincoln Park reservoir in South Pasadena is now built, right in the ancient lime pit of Father Zalvidea's "converted " Indian limeburners. The cement for the Mission church, and for the stone dams at Wilson lake and on Rose's ranch, and for the stone mill, the later cement ditch and mill-pit ruins south of the church, and for other works, was all obtained at this Lincoln Park quarry.

Spinners and Weavers - The women were almost entirely assigned to this trade, taking the raw wool and carrying it by hand methods through all the stages of carding, spinning, dyeing, weaving, until it came out as cloth or shawls from the looms.

Tailors and Dressmakers - This was also a trade for women. They

*' The wheels of these carts were a foot wide, made of sections of oak logs, never quite round or of uniform thickness, running on equally clumsy axles which were never in the center of the wheel, nor at right angles with the sides. Age and wear added to these imperfections, and the wheels when in motion made a tortuous track. As for some reason, or perhaps for no reason at all, these wheels were never lubricated, they made a wonderfully plaintive noise as they rolled along. This was the only wheeled conveyance seen on the coast as late as 1840."-()verland Monthly, March, 1897, p. 266.

tSome portion of the old roof was asphalt. The early Spaniards had some kn=wledge of the uses of this material; and its existence here is mentioned in the reports of Gov. Portola's first visit, 1769-70. 
made all the garments for men, women and children of the work people;* for it must be borne in mind all the time that all these Indian people, numbering at one period as high as 4,00o, were dependent on Father Zalvidea or Father Sanchez, for all their clothing and food, and could only have what he allowed them. This Mission was at this time a perfect ecclesiastical monarchy, or padrearchy.

Vintners - This included vinedressers and winemakers.

Coopers - This trade alone was kept in the hands of white men (just why, I do not know), while all the others were carried on by Indians under taskmasters.

Woodsmen-These were wood-choppers, and those who made shakes [split shingles], rived out the undressed staves for wine casks and barrels, hewed building timbers, worked in the sawpits, and all such work as was done in the mountains or canyons where the timber grew.

In addition to the foregoing, there were task classes of cattle herders, horse herders, sheep herders, agriculturists, orchardists, teamsters, besides bakers, cooks, pages, poulterers and other domestic trades. And thus it will be seen that the man who could systematically develop and supervise all these works, govern the entire Mission territory, acquire the Indian language so as to write and preach in it, and at the same time attend to his daily and weekly duties as a priest, was a man of real genius and extraordinary executive talent. And such was Father Zalvidea, who ruled at San Gabriel from I 806 to I826; then he was sent to San Juan Capistrano where he remained until 1842 , when he was sent to San Luis Rey Mission, and died there early in 1846 -probably in February.

I 813-I4: Padre Luis Gil y Taboada, commonly known as "Father Gil." $\mathrm{He}$ is mentioned as going from San Gabriel to dedicate the new church at the Plaza in Los Angeles, December 8, r822; but whether he had been at San Gabriel all this time I did not find out. (Father Gil, in August, 1814, laid the corner stone for a church at Los Angeles; but that building never was erected any farther.)

From March, 1814, to December 30, 1821 (the date of his death), padre Joaquin Pascual Nuez.

I 82 I to 1826 , thence to I 833 , padre Jose Bernardo Sanchez.

From 1826 to July, 5, 183 , when he died, padre Geronimo Boscana, who wrote the account of Indian myths, traditions and religious beliefs that was translated by Alfred Robinson and published under the title of "Chinigchinich," as an appendix to Robinson's own chapters on "Life in California," published in 1846 .

*The spinning, weaving and tailoring women were in charge of Eulalia Perez de Guillen, the first owner of Rancho San Pasqual. She instructed them, cut out the garments, and had a general oversight of their work. She was cashier or paymaster of the Mission; she kept the keys of the storehouses and dealt out the weekly rations. She also had charge of the money room where little bags of silver dollars were piled up all around as high as she could reach; and all disbursements of money were made by her on order of the chief padre; and she kept the accounts. 
From I 826 to 1833 the Friar Superior at San Gabriel was padre Jose Bernardo Sanchez, a friend of Zalvidea, who had been his colleague since the death of padre Nuez in December, I82I; and he continued the system of task work, of manufactures and trade already established; and up to r830 or ' 3 I he sustained the business prestige and prosperity of the Mission quite to the full-but by this time the disintegrating and demoralizing effects of prospective secularization had begun its work among the Indians. They gradually found out that they were not to be slaves any longer, but free men-and so they would work less and less; get drunk, gamble, or stray off more and more; and thus the whole great business steadily declined, and at last went out altogether.*

\section{832 to ' 36 : Padre Alexis Bachelot.}

January 15, 1833 Padre Sanchez died at San Gabriel, and he was succeeded by Padre Tomas Eleuterio Estenega. In 1843 the entire business of the Mission was put into Estenega's hands, there being no income to support a major domo any more; and in $\mathrm{r} 844$ he was assisted by the presbyter, Antonio M. Jimenez.

June $8, \mathrm{x} 846$, the Mission property was all sold by Governor Pio Pico to Hugo Reid and Wm. Workman. Reid was then justice of the peace, and also auxiliary administrator of the Mission estate, which was heavily in debt; they bought it subject to debts and other encumbering stipulations, and Reid as administrator already had possession. But when Stockton and Fremont took possession of the country for the United States, in August, I846, they declared Governor Pico's sale of the property not in accordance with Mexican law and equity in such cases, and thereupon ousted Reid and Workman, and put Manuel Olvera in charge of the property, the same as he had been from October, 1845 , to the time of the purchase above mentioned.

In February or March, ' I847, Padre Estenega died; and he was succeeded by Padre Ordaz, who remained, but only as curate or parish priest, until 1850 ; and I follow the clerical line of officials no further.

\section{SECULAR OFFICERS OF THE MISSION.}

But now, to go back again: From the founding of the Mission up to 1798, Jose Maria Verdugo (he of Verdugo ranch fame) was corporal of the guard here; and he was then succeeded by Pedro Poyorena-but there seems to be no further record on this line. [Records lost.]

The first imajor domo [general overseer] was Jose Miguel Flores. $\mathrm{He}$ died in 1796 . And the records so far as found do not seem to show by name any successor until Claudio Lopez is named as major domo from i 821 until February, 1836. But I am informed by his daughter-in-law, Senora Maria

*The fatal defect of this whole Spanish system was that no effort was made to educate the Indians, or teach them to read, and think and act tor themselves. Hence, as soon as the Mission authority over them was broken they fell back into barbarism again. 
Guillen de Lopez, who is still living at San Gabriel, and also by her son Theodore Lopez, that Claudio Lopez served there as major domo thirty-six years or thereabouts-that is, both before and after and all through the administration of Padre Zalvidea and Padre Sanchez. This seems hard to believe, yet no records have been found to show anybody else there in that office; and "old Francesca," the hundred-year-old Spanish woman, still living here at Pasadena, told me substantially the same as to Claudio Lopez's wonderfully long service at San Gabriel.* Hence I conclude that he was probably the successor of major domo Flores, with perhaps some temporary appointee in between for two or three years. The History of California, vol. $4, p .7 I 7$, says he settled in Los Angeles in $\mathrm{I} 8 \mathrm{I} \mathrm{I}$, and that he was alcalde [judge] there in $\mathrm{I} 826$; but all this would not hinder his being major domo at San Gabriel at the same time. Rancho San Pasqual was part of the Mission lands; Major Claudio was the overseer or head "boss" of all the agricultural, stock-raising, herding and other industries of the Missionand thus he was the first man who ever made any civilized use or occupancy of these acres where Pasadena now stands.

In February, I836, Lopez was succeeded by Juan Jose Rocha; and in I 837 Rocha was succeeded by Juan Perez $\dagger$ who served until March I, I843, when he turned everything over to Padre Estenega. Yet in 1845 Crispin Perez's name occurs as major domo ; and in October in this year he is succeeded by Manuel Olvera, who served until the property was taken in possession by Hugo Reid for himself and Workman as purchasers, July 8, 1846. Then in August or September of this year Stockton and Fremont annulled Reid's purchase and put Olvera in charge again.

The United States Land Commission abrogated all sales that had been made of the church building and its garden and cemetery grounds, and restored them to the church authorities; but sales of outlying lands were confirmed. However, in 1875 , the Commission also confirmed to Bishop Alemany as church property $55^{1 / 2}$ acres south of the church, where the Chapman mill, and tallow works and other industries formerly stood, and now known as the "Bishop's orchard, or garden," it having a fine orange grove on it, all fenced in.

In 1885 considerable repairs were made on the old Mission church. Its original heavy doors of iron and wood had decayed much, and were renewed, besides other patching and mending, which gave the structure less of the ancientness of appearance than it had before. It is still in regular use every Sunday as a Catholic church.

*Governor Pio Pico was born at San Gabriel May 5, 180r. Eulalia Perez de Guillen officiated as midwife at his birth; and her family say that Claudio Lopez was there as major domo then.

†ancroft gives this name erroveously as "Jose" Perez. I find that there were four of these Perez brothers, to-wit: Eranio Perez, whose wife was Vicente L,ugo, one of the four daughters of Don Antonio L,ugo. Juan Perez, father of our Pasadena 100-year old woman, old Francesca L, ugo, whose husband, Don Felipe Lugo, was brother to Eranio Perez's wife. Esteban Perez, whose son Jose was the first white man who ever made a howe ou Rancho San Pasqual, this Jose's wife being Merced Lugo, sister to his uncle Eranio's wife, but atterwards wife of Stephen C. Foster, a Yankee from New England. Crispin Perez, who was major domo at San Gabriel in I845. And these four Perez brothers were cousins to Eulalia Perez de Guillen, the first owner of Rancho San Pasqual. 
THE STORY OF THE MILLS.

"The Old Mill" is one of the historic spots near Pasadena for romantic people and history hunters to visit, as a relic of the old Spanish Mission days. But it is a fact, though little known, that there are really two old Mission mills partly remaining, besides a private one built by Daniel Sexton at East San Gabriel. The history of the two Mission mills has been woefully mixed, confused, transposed ; and I found it necessary to expend a vast deal of time, patience, perseverance, research, personal inquiry of living witnesses, and personal examination of the remaining parts of the structures, before I could unravel the tangled threads of error running through every account of "the old mill" that has appeared in print hitherto. Even some of the attempts at sober history in the matter have been little better than romantic fancy. It is so much easier and pleasanter to imagine how it "might have been" than it is to hunt up facts as to how it really was.

MII, NO. I-THE OLD STONE MILI.

This was the first grist mill to be run by water power ever attempted to be built in California, and was erected under the administration of Padre Zalvidea, with Claudio Lopez as major domo-in about i810 to 1812.* Very little grain had been raised on the Mission lands until after Zalvidea took charge, in $\mathrm{I} 806$; and the small amount of corn, wheat and barley produced was made into meal by the Indian women with their old native metates and mealing stones, while the men were kept busy at heavier work, mostly of the building sort, besides looking after the flocks and herds which furnished their principal food supply. But now Zalvidea pushed horticulture, viniculture and agriculture forward, and in a short time had large crops of grain to ship away. Then he wanted a mill and built this one. [See full account of its dimensions, structure, and other particulars in Chapter 19; articles on "The Old Mill," "Mill Canyon," "Wilson Lake," etc.] But after all their hard toil and zeal and hope in building it, this mill proved a failure because of dampness. It was built in the hillside. Its west main wall was also the wall of the deep, funnel-shaped cisterns or forebays which furnished the water head. The basement arch or water wheel chamber was so low that the powerful jet of water striking the horizontal wheel would splash all over the walls and work up through the shaft hole to the mill stones on the upper floor. So that as fast as the meal was made it had to be carried away to dry store rooms at the Mission, where Indian women bolted or sifted it by a hand process of their own devising. The distance of the mill from the business center at the Mission was also a great drawback. And from this combination of adverse conditions, the mill had

*Wm. Heath Davis in his book, "Sixty Years in California", p. 251, tells of a mill built where is now Clay street, in San Francisco, in 1839 , and adds: "This was the first grist mill in California. It was operated by six mules." Yet Pasadena's old stone mill, run by water power, was built more than a quarter century before that; and the one in front of the San Grbriel Mission church was built at least 17 years before the "mule mill "which he claims to have been first. And Joseph Chapman built one at Santa Ynez in $1820-21$. So Davis is widely in error as to "first grist mill in California." 
been abandoned and lay idle some time before Maria de Guillen (afterward Mrs. Lopez) came to San Gabriel to live, which was about I 82 I, she being then nine years old; and for several years the grain grinding for the Mission had been again done by Indian women on their metates; though it seems that occasionally a little was still done at the old mill in the way of gristing for Los Angeles and other points, where the meal was taken direct from the millstone.

The little girl above mentioned, Maria de Guillen, was a daughter of Eulalia Perez de Guillen, the first owner of Rancho San Pasqual or Pasadenaland, who died June 8,1878 -aged 143 (?) years. [See article headed "Complete Chain of Title," Chap. 3.] And Maria was married in I829 to Tiburico Lopez, son of Claudio Lopez who served about thirty-six years as major domo at San Gabriel, according to the traditions of the family ; hence, as general overseer of the old Mission business, he was the first white man who ever utilized the lands which afterwards became Rancho San Pasqual, and Pasadena. And I have found descendants of Major Claudio still living in this county, as follows :

Theodore Lopez, San Gabriel-grandson.

Felipe Lopez, San Gabriel--grandson.

Romaldo Lopez, Old Mission-grandson.

Geronimo Lopez, San Fernando-grandson.

Francisco E. Lopez, Los Angeles-great grandson.

Jose Lopez, San Gabriel-great grandson.

Valentine Lopez, San Fernando-great grandson.

Luis Lopez, La Ballona-great grandson.

Jose Lopez, La Ballona-great grandson.

All these, besides their families; while some of the descendants reside out of the county, and some out of the state. [There were fifty-two voters named Lopez in our "great register" of I892-94.]* Tiburcio Lopez died in 1857 ; but his wife and her two sons, Theodore and Felipe, are still living at San Gabriel, and they have kindly assisted me in correcting the many published errors about the old mill. Old Francesca Perez, who was born at Los Nietos [near Whittier] in I 794, and is still living in Pasadena [June, r895], was godmother to Theodore Lopez and second cousin to Eulalia Perez de Guillen; and she too has furnished me some points about the old mills.

\section{A PIRATE PRISONER IN OUR PASADENA MOUNTAINS.}

The old Mission Mill No. 2 was commonly called "Chapman's mill"; and therefore I must tell about Chapman. In 1818 a Buenos Ayres privateer landed some men on the Ortega ranch above Santa Barbara to plunder it, and the family fled in terror, one of them being a young daughter named *Bancroft, Hist. Cal., lists forty persons named Lopez who had figured in some way in Californa history. 
Guadalupe. The Mission soldiers from Santa Barbara and Los Angeles succeeded in capturing some of these men, one of whom was Joseph Chapman, a sailor, from the state of Maine.* Corporal Don Antonio Maria Lugo of Los Angeles became surety for Chapman so that he need not be executed, and brought him to Los Angeles as a prisoner, riding behind him on the same horse, for the sailor chap couldn't keep his balance on a horse without somebody to hold onto. $\dagger$ Chapman was a tall, strong, bright fellow, with a good deal of Yankee ingenuity, and skillful with tools. He didn't know a word of Spanish, nor Lugo a word of English ; yet in a few days the prisoner had picked up enough Spanish so that with the addition of signs he could make himself understood, and now he went with Lugo to the mountains to help get out timber for building the church, the one which still stands there near the plaza in Los Angeles. $\ddagger$

Stephen Foster, writing from his father-in-law Lugo's statements, says the timbers were being cut in "church canyon, away in the mountains," but gives no hint or clue as to whereabouts this particular "church canyon' was located, and I found no written record to help me. However, I remembered that in July, I893, I had noticed in Grand Canyon, about a mile below Crystal Springs of the Mount Lowe itinerary, some evidences of timber work done there long ago. There were some large old pine stumps, much decayed; one big tree chopped down, but never trimmed or hewed; and some graded spaces that looked like remnants of an old wagon road. Duncan Cameron and Alex. McDonald were with me. $\$$ And taking this for a clue, I followed it steadily for eight months, as a possible chapter in the lost record of the Los Angeles "church canyon," before the links of evidence were all found which made a chain of circumstantial proof strong enough to affirm. I inquired of the oldest living settlers, both Spanish and American, but they were as blank as the empty records. Old Francesca only knew that

*A row boat in whicl chapman and others were rowing ashore was capsized in the surf. Commandante Lugo had his men concealed in a clump of willows near by, and shouted to them, "Now's our time!" "They all rushed out and fired their blunderbusses at the struggling men in the water, killing two or three; then sone swam back to a second row boat and returned to ship. while Chapman and a West Indies negro came ashore through the surf. A vaquero now ran down on the beach and lassoed him; but he, half drowned though be was, jumped up and commenced hauling in the riata hand-overhand, in sailor fashion, pulling the vaqueroalong, who yelled with fright and terror, for he had no horse now to help him out; and two others ran to his rescue, throwing two more lassoes over Chapman before they could hold him. He was a tall, muscular and dextrous man, and pushed the vaqueros around like puppets, which greatly astonished and pleased old Lugo, and made him admire the lusty Yankee.

J. Albert Wilson, Hist. Los A. Co. I880, calls him a native of Pennsylvania; but Hon. Stephen C. Foster, who knew Chapman personally, says he was from New England; and Bancroft and J. D. Mason say from Maine.

†The History of Santa Barbara county says: "Lngo, the grandfather of Senora de la Torreand Senora Pico, was the Lugo who assisted in beating off the pirate ship commanded by Bonchard, which made an attack on the Refitgio rancho in 1818 , and carried Johu [Joe] Chapman (who was one of the pirates) on his horse behind him as a prisoner-he being the same tnan who subsequently married one of the noted beauties of the Ortega family."

†To aid in building this church, there were donated by citizens, 500 cattle; by friars, seven bbls. brandy. worth $\$ 575$ The labor was done by neophytes from san Gabriel and San Luis Rey, at oue real $\left[12 \frac{1}{2}\right.$ cents] per day as their wages.-Hist. Cal. Vol. II, $p .35 I$.

2"I was with Dr. Reid and Alex. McDonald in July, 1893, when we saw some remains of grading or terracing which looked like an ancient road, in Grand Canyon, a short distance below Crystal springs.-We also saw some very old and decayed large pine stumps where trees had been chopped down; and one large old tree chopped down and leftlying. And it was a great mystery to us how these things came to be in such a out of the way place. DUNCAN CAMERON.

Eicho Mountain, May 28, $1895 . "$ 
the place was "somewhere up in these mountains," but as to just which canyon it was she had no idea; and the venerable Senora Lopez at San Gabriel could tell me no more; yet they both knew Chapman. Jose Lugo, old Francesca's son, thought it was Santa Anita Canyon [it was also called "church canyon" while timbers were being gotten out there for the church at San Gabriel]. Arturo Bandini didn't know anything about it. Theodore Lopez believed it was in Canyon el Blanco-now called Millard Canyon.

At last I learned from E. W. Giddings that in $1877-78$, when his father and family settled on their Millard Canyon farm, they found up the canyon some broken pieces and chunks of hewed pine timber, all decayed so that only the shell remained to show the axe-marks; they were from eight to twelve inches square in size, and had been washed down over Millard Falls from some place above. It was a great mystery to them at the time, for neither they nor any of their old-settler neighbors had ever heard even a tradition of any timber work so far up in the mountains; and no one could offer any explanation as to how, why, when, or by whom such work should have been done in a place so remote and difficult of access as that above the Falls. And when I told him about Joe Chapman's prisonership in "church canyon", and what I had noticed up in Grand Canyon in I893, and my surmise that this was the "church canyon" of the Los Angeles padres, it was the first inkling of a solution of the hewed drift-wond mystery he had ever heard. He then mentioned that at a place perhaps a mile lower down the canyon than where I had noticed the signs of timber working, there were more very old stumps, now all rotted away, and more graded spaces like remnants of an old road, when he first knew this canyon twenty years ago. $\mathrm{He}$ also mentioned that when Mr. Millard first settled in this canyon, in I862 [See article, "Millard Canyon"], there were remnants of a rude old road or dragway up into it along the stream to the Millard Falls, but all signs of that road have since been washed away. J. Reed Giddings also remembered about their finding fragments of hewed timber among old driftwood below Millard Falls; and likewise about the very old stumps and the graded spaces like parts of an old road far up toward the head of the canyon. And our conclusion was that Chapman and his Indians had dragged their timbers with rawhide ropes down the upper canyon course, and along the mountain sides, and across the spurs, till they reached this old road below the falls which was probably only an ox-trail; and here oxen were hitched to them by means of rawhide ropes lashed around their horns-for the Spaniards had not yet learned or taught the Indians how to hitch up oxen with a yoke on the neck. The hewed fragments which the Giddings people found had most likely been used as blocks for the great logs to rest upon while being hewed, and also as skids on which to slide their hewed timbers over difficult places on the way down. This canyon was the nearest poin $t$ where suitable trees could be reached; and it gave the most direct and con- 
tinuous down slope for dragging the hewed timbers to Los Angeles. The oxtrail, then, led from Millard Canyon down toward Monks Hill, and then nearly on the present line of Fair Oaks avenue clear down to the old Spanish road from San Gabriel to Los Angeles, where the Southern Pacific Railroad now runs. On reaching the public road the timbers would be loaded onto heavy carts made with wheels that were simply round blocks sawed or chopped off from the butt end of a $\log$, and thus they would be conveyed across the Los Angeles river and up to the plaza. And in all this work Chapman managed better and accomplished more, and got more work out of the Indians than anyone had ever done before-all of which greatly endeared him to the padres, and also to the old Don who had sturdily withstood the demand for his ignominious execution only one year before.

The graded spaces in Grand Canyon that have been mistaken for remnants of a mysterious ancient wagon road were made by Chapman to get enough straight and level ground for the timber hewers to stand on at their work, with the $\log$ resting on blocks. The Indians themselves could only hack a tree down and let it fall where it happened to-and then haggle it into imperfect square shape just where it lay, thus working very slowly and at great disadvantage. But Chapman could chop a tree down and make it fall whichever way he wanted to, which was a marvelous thing to most of the Spaniards as well as the Indians. In their ignorant and superstitious minds it was magic or " black art," and they called him "Diablo Chapman." Then by getting his logs up onto blocks along these leveled places, and marking with a bit of burnt wood and a stretched string the lines for the hewers to work by, the work went on easier and better and faster than before. And these were Chapman's Yankee improvements to expedite the work, which won him so much favor with Don Antonio and the padresfor anything that helped along their church enterprises touched their hearts in the tenderest spot; and all this service was credited to him for pious "good works" - so that on one occasion when others were denouncing and contemning the gringo heretic, old Don Antonio made in his defense this argument: "As to his being a heretic, has not all of his work gone into the church? How can he get away from that? * * I know that they [the padres] consider him a good Christian, and a very useful one, too. And then, who can manage the Indians as he can?"

It was also objected that Chapman couldn't ride a horse, which was an unpardonable deficiency in Spanish eyes. But Lugo replied; "Yes, he can ride a horse now, without falling off more than twice in one day."

The logs having been hewed square up in the mountains, were dragged on different faces alternately so that all sides might be scoured and smoothed alike. And the special necessity for such heavy pine timbers, that would not sag, was to support the great weight of the tile roofs then in use.* And

*"The rafters, after being cut in the mountain forests many miles away, were dragged here by Indians and oxen, each log being occasionally turned upon the way, that all sides might be planed 
the term "church canyon" was applied to any such place where timbers were being cut for a church, no matter what other name the place might have borne, if any, before or afterward. So I find that our present Grand Canyon and Millard Canyon was really the "Church Canyon" of the old Los Angeles Spanish Mission records, and this was the first name the place ever bore in white men's speech, though they afterward called it Canyon el Blanco - the white canyon - from the conspicuous walls of white feldspathic rocks in some of its upper branches.

In the Overland Monthly of March, i 894, J. D. Mason writes a sketch of our Joe Chapman's romantic adventures, and from his article I here quote a few points. Mason says :

"He was quite as much of a curiosity to the Los Angelenos as he was to the rancheros. * * The captured Yankee was watched with fear and trembling, much as a grizzly bear would be if turned loose. The question of what to do with him was necessarily prominent. Some openly asserted that he ought to have been executed; and that it was not too late yet to remedy the mistake. Lugo, however, proved his fast friend.

"At that time quite a number of men and Indians were employed in the pine woods forty miles away [only about twenty miles], getting out timbers for the church. There was no road leading to the place, only a rough trail over the mountains and through rocky canyons. If he was set to work there, he could not communicate with any enemies nor escape, for the mountains beyond were considered impassable; he would be lost if he attempted to climb them. So he was sent to the pine woods. Now, Chapman knew all about timber. Though he could not ride a horse, he could chop down a tree, and make it tall just where he chose. He could line, score and hew it, for he had worked at ship-building; and when that was done he could hitch a drove of long-horned cattle to it and move it off. * * A year passed, and he became sole manager of the timber squad, and was in high favor not only with Lugo, but with the church fathers as well. He had really become indispensible. Many consultations unknown to Chapman had been held as to the policy of identifying him with the colony by marrying him into some Spanish family, and holding him to the coast, as it were, by domestic ties. * * * There was talk of Castilian superiority - noble blood, and all that sort of stuff. * * They finally agreed to state the case to the padre of the Los Angeles Mission. In an hour they received a terse letter, written in a plain hand, on strong paper, as follows :

'My ChILdREN : - Lugo's advice is sensible. Let the man Chapman marry.'

"This ended the discussion, as to the propriety of his marrying." **

[scoured] alike. They are as as smooth as though really plaued,"-J. Albert Wilson, Hisl. Los Ang. Co. [1880], page 105. This was written of the San Fernando old Mission, built in 1795-96.97. But the same plan was used in building the church in Los Angeles, in 1818-19-20-2I-22. I learned from the old Spanish people that pine timbers were brought down the same way from big Santa Anita canyon for building the chirch at San Gabriel.

* See Overland Monthly, March, 1894 ; article, "One Way to Get a Rancho," by J. D. Mason. He represents events that really extended over four years of time as all occurring within oue year; he represents the pirate ship as plundering San Gabriel Mission by mistake for San Juan Capistrano; he makes Chapman's wedding occur at Santa Barbara instead of Santa Ynez; and overstates distances sometimes; yet his story of Chapman and his lovely Spanish bride is in the main correct. Mason seems to have had some points from Chapman's descendants in Ventura county, in addition to what Stephen Foster received from old Don Antonio Lugo, and what $H$. H. Bancroft had found in the old Mission and Pueblo records. 
In another place Mason relates how Chapman "whipped a thousand Indians" with a club, in a night attack they made on his corral at mouth of Millard Canyon;

"The time for the rainy season was near, and Chapman was preparing for his last haul of timber.* The cattle that had been pastured on small patches of grass were lying in the adobe corrals, which had been built to keep them together at night, and secure them from the raids of the wild Indians. Sometimes a dozen or more of "converted Indians," that were not satisfied with their allotted work or rations, or social relations with the females, would break away from the missions, and unite with the wild Indians to plunder the padres' storehouses or drive off their stock. This was a standing danger to the colonists as well as to the missions. During the night mentioned one of the Indian cattle-drivers awoke Chapman, saying, 'Senor, Senor! 'The wild Indians are cutting the cattle out.' As Chapman awoke the man urged him to listen. He could distinctly hear a grating sound produced by moving something forward and backward like a saw. The noise was new to Chapman, but the Indian explained that it was the cutting down of the adobe walls, by drawing a rawhide riata across them; that when a section was cut that way it could be pushed over, making an opening through which to stampede the cattle with firebrands and a great noise.

"' How many Indians ?' said Chapman to the vaquero.

“" Oh! thousand, Senor!' said the Indian excitedly.

"Some Indians had deserted a day or two before, and probably had induced others to join them in a raid; but Chapman knew that a thousand was an impossibility. He had learned that an Indian's estimate of numbers was of little value; that scarcely one in a hundred could count more than twenty. More than that was a thousand or a million to their weak mints. So he concluded that there might be a dozen, the bulk of them stationed near the outer wall, opposite the bars, ready to break over with a wild hurrah when the bisected portion of the wall fell. He knew he could easily drive away the four or five that were sawing the wall with riatas, but the others might attack his men with their bows and arrows, and in the confusion kill some of them. He planned a daring way of discomfiting the Indians by a dash among them alone, while the others of the camp should make a great noise; for noise is a potent factor in all savage warfare. The wild Indians generally ran away at the first explosion of fire-arms, but Chapman chose rather to teach them a lesson. He passed out quietly, and as he expected, saw a number of firebrands ready to be blown into a flame as soon as the wall fell. He rushed into the midst of the lights, his club describing wide circles as it went around his head, occasionally hitting something with a sickening thud. About the same time the others rushed out with loud shouts and the firing of guns.

"The besiegers, when the club began to whack their heads, shouted 'Diablo Chapman! Diablo Chapman!' They were too astonished to make any resistance, and fled with the others as the outcry and firing commenced

*This was in 1819 ; and during that winter (1819-20) he went to Santa Ynez, and there built a flouring mill for the padres. Lugo had often joked Chapman about the pretty girl who saved his life, and hinted that she loved him; and this was probably the secret of Joe's going to Santa Ynez at this time, for the Ortega fanily came there to church by a bridle ruad only ro miles over the mountains, while it was 30 miles to Santa Barbara; aud thus he could see her and perhaps exchange glances with her almost every Sunday, although they conld not speak together. In September the next year, he was ordered by the governor to build another mill at San Gabriel. 
the custom then was, the old people attended to the business of matchmaking, although the lady in the case had the reserved right to say "No" if she wished to, and that would end it ; for the suitor must then try his luck somewhere else. Lugo introduced Chapman among his Barbareno friends, and vouched for his good character, his skill in useful arts, and his worthiness to mate with the best Spanish blood in the province; so in a short time he and old Captain Ortega arranged that Chapman might marry Ortega's pretty daughter, Guadalupe.* The young lady at first rebelled, but finally consented; and in proper time the wedding was duly celebrated -and thus she became the Spanish bride of the down-east Yankee, who had only four years before, as a Buenos Ayrean buccaneer, frightened her and the whole family in hasty alarm from their home; and the first time she ever saw him was that same day, in sailor's garb, a bound and pinioned prisoner subject to death penalty. The men were going to tie Chapman's feet to a wild horse's tail and then turn it loose to drag him to death; but Guadalupe plead passionately against it as a barbarism unworthy of Christians, or brave soldiers, or Spanish gentlemen, and so saved his life.

After the wedding ceremony and feasting were done with, which lasted some days, he took off his red silk sash, an essential part of the Spanish horseman's costume which he now wore, and made a loop of it to hang over the pommel of his saddle for a stirrup, for a lady to ride sidewise; and on this he seated his bride, then sat himself on the crupper or pillion behind, and thus the two made the journey from Santa Barbara to Los Angeles, stopping over night, however, at the old Mission San Buena Ventura, where he had a few weeks before been baptized. His cognomen in Spanish was Jose el Ingles (Joseph the Englishman). He was the first English-speaking bona fide settler in the State of California, as claimed by Col. J. J. Warner and Hon. Stephen C. Foster. In his Historical Sketches, Foster says :

"In I 822, when the first American adventurers, trappers and mariners found their way to California, they found Jose Chapman at the Mission San Gabriel (with fair-haired children playing around him), carpenter, millwright, and general factotim of good old Father Sanchez.",

Foster must be a little " too previous " with his " fair-haired children," for Chapman was not married until after June, 1822. I have gathered the following date points in his romantic career: Captured i11 1SIS; got out timbers for church at plaza in Los Angeles, I 8 I8-I9 [this was in the Mount Lowe "Grand Canyon"'] ; I820-2 I, built mill at Santa Ynez; in December, I 820 , was pardoned by Gov. Sola, under the king's decree of annesty ; in

*Don Jose Maria Ortega was one of the wealthiest rancheros on the coast. He had 48 ,ooo acres of land along the coast above Santa Barbara [Raucho Neustra Senora del Refugiol granted to inin by the viceroy of Mexico in 1797 . His second son. Jose Vicente Ottega, who developed and occupied the Refugio ranch, was father of the girl. Guadalupe. Mr. F,lwood Cooper informs me that their old ranch house is still stauding, near the beach about six miles east of Gaviota landing. There were five sons and two daughters of the original Ortega fanily who all married and raised families of their own, so that the name has become very numerous. The Bandinis of Pasadena have a family connection with the Ortegas. Sautiago and Itis Arguello, two brothers of Arturo Bandini's mother, both married Ortega wonen wliowere cousins to the oue that married Joseph Chapman. 
I82I-22, built mill at San Gabriel [the one in front of the church]; on June 24, I 822, he was baptized at San Buena Ventura ; and the same year, probably soon after, he was married at Santa Ynez old Mission to Senorita Guadalupe Ortega, and came to San Gabriel again ; in I 824 he bought a house and land from Agustin Machado, in Los Angeles, and planted 4,00o vines; in I 829 he applied for naturalization as a Mexican citizen, and got it in 1831 ; this same year he built his 60-ton schooner at San Gabriel ; in 1836 , lived in Santa Barbara, and by this time had five children;* in 1838 , received grant of a sobrante or "remainder" of 5,000 acres of land in the Santa Barbara district; in I 845 to ' 47 , he lived near San Buena Ventura, and died there in I 849 . Some of his descendents reside in that region yet. And a grandson of his, John Chapman, now resides on the Aguirre ranch at Ballona, in Los Angeles county, his wife being a daughter of Francisco Aguirre. This man, John, is said to resemble his grandfather, "Jose el Ingles,' in his large stature and great strength.

THE OLD MILL NO. 2, OR CHAPMAN'S MILL.

The old stone mill had proved a failure, as before explained (see page 42 ), and the following citation is here in point :

"September 25, r82 I, governor orders that the 'pilot prisoner' (Jose Chapman) be sent to build a mill at San Gabriel like that he had built at Santa Ynez."-Hist. Cal., Vol. 2., p. 568.†

So Chapman came to carry out this order. The site chosen was just south of the old Mission church, where the cement ditch forebay, the sluices, the wheel pit, the foundation walls, and other ruins can still be seen [r 894]. Water in abundance for domestic uses had been brought by ditch long before, from a stone dam at mouth of Wilson Canyon; $\$$ and the waters of Mission Canyon, San Marino Canyon and the Winston Springs were also trained into the ditch without need of dam. [They were then all three called "Mission Canyon."] But now they wanted more water ; and to meet this need, a stone dam was built at the cienega where the old Indian village of Acurag-na had stood- [the dam and lagoon are still there and still in use, about a quarter of a mile north of the "Sunny Slope " great winery]and the accumulated waters from this place, afterward called La Presa, were also led by a ditch down to the Mission; this stream and the one from Wilson Canyon being then both run into the cemented head-storage ditch above the mill.

*'The History of Santa Barbara County says: "Joseph Chapman, the hero of the pirate ship, and of the romantic affair with the daughter of the Ortega family, built a house, still standing in the rear of the Episcopal church." Mrs. Reid went and examined this historic old house for me, May 2, 1895.

fChapman's own statement, as recorded in state documents, was that "he remained here as a prisoner because he was forced. with other persons at the Sandwich Islands, on the expedition of Bonchard;" sailing as a privateer of Buenos Ayres, then in revolt against Spain. He had been on a New England whaling ship.

f"The Mission Fathers built a stone dam at the mouth of the Wilson Canyon, near where the barn stands now, but the earth dain at the head of the Canyon was built by J. De Barth shorb; afterwards was rebuilt by Mr. George S. Patton."-Mr. Shorb, in Letter to Dr. Reid, Mrarch 29, 1894. 
Chapman got his wheel pit as low as he could to advantage, then carried his foundation walls high enough and off to one side enough so that the framed superstructure for grinding room, etc., should be clear from dampness. Col. Warner in his "Historical Sketches," says this mill was built first, and had a horizontal water wheel on the lower end of a vertical shaft and the revolving mill-stone on the upper end, the same as in the stone mill. On both these points he was mistaken. My Spanish informants in telling me about this one called it an "overshot wheel." They knew how it was different from the horizontal wheel in the old stone mill, but of course did not understand the technical terms for different styles of water wheels; and from my examination and measurements, and tracing of flumes, forebay and tailrace in the ruins, I know it must have been what is called a "breast wheel," as there was not fall enough for an overshot. [Theodore Lopez, who had seen it when a boy, says it was a breast wheelor at any rate the water went out under the wheel and not over it.] Chapman made some wooden cogged miter gears to convert horizontal into vertical motion; and this was Mission Mill No. 2, as built in I82 I-22.

[NOTE-The grinding stones of this mill were made from great boulders of gray granite or syenite near the mouth of Santa Anita Canyon, and were laboriously pecked into shape by the Indians. The stones were three feet six inches in diameter and about one foot thick. One of them was broken in two and lay there with the ruins in the Bishop's orchard or garden for many years. In 1889 Mrs. Jeanne C. Carr of Pasadena procured one of the broken halves, and now has it for a doorstep at the west front of her unique residence on Kensington place. The crest of her roof is also laid with tiles made at San Gabriel by the Indians during Padre Zalvidea's administration. I did not learn what became of the other half of the broken mill-stone. Theodore Lopez said the stone that was not broken was taken away to use in a mill somewhere else, but he did not know the place. The grinding stones of the first Mission mill, and also of the Dan Sexton mill, were made from volcanic tufa instead of granite.]

In I83 I Chapman also built a ship (schooner) at San Gabriel, hauled it in parts to San Pedro on ox-carts, then put it together and launched it there.* He died in 1849 , and in 1876 his descendants were living in Ventura county; but in 1895 his grandson, John Chapman, lives at Ballona, Los Angeles county.

\section{GOLD DISCOVERY IN I 842 .}

In March, I 842, Francisco Lopez, a grandson of Claudio Lopez, discovered gold in a canyon about thirty-five miles northeast from Los Angeles,

*"A launch was to take place at St. Pedro of the second vessel ever constructed in California. She was a schooner of about sixty tons, that had been entirely franed at St. Gabriel and fitted for subsequent completion at St. Pedro. Fvery piece of timber had been hewn and fitted thirty miles from the place, and brought down to the beach upon carts," - Robinson's "Life in California," $133^{2}, p$. 100. 
the first that had ever been found by white men in California.* It was in the San Fernando valley, on land owned by Ignacio del Valle. And by December, I $843,2,000$ ounces of gold dust had been taken from these mines. Then in 1853-54 gold was found in the foot-hills of the Santa Anita ranch, and in the San Gabriel Canyon, and in our own Eaton, Rubio and Arroyo Seco Canyons. In crossing the old flood-plain of the Eaton Canyon outwash above Lamanda Park, many mysterious-looking deep pits in the sand will be noticed. These were made by the gold-hunters of that period and later time. These were all placer diggings. A quartz mill was put in far up the San Gabriel Canyon some years later. And statistics show that during a period of eighteen years over $\$ 2,000,000$ worth of gold dust was sold from these San Gabriel, Santa Anita and Eaton Canyon diggings. [Thompson \&o West Hist. Los A. Co., p. 67.]

\section{DAN SEXTON'S OLD ADOBE MILL.}

On May I6, I87 I, a patent for 2273/4 acres of the San Gabriel Mission lands were granted to Daniel Sexton. This man came to California in I84I in the same company with B. D. Wilson, John Rowland, Wm. Workman Wade Hampton [afterward a famous Confederate General in the war of the Rebellion], and others. $\dagger$ Sexton married one of the Mission Indian women, thus gaining the right under Mexican law to acquire land, and settled at San Gabriel before the United States took California. The old Mission mills were now in ruins, and he thought a mill was needed and might do a good paying business here; so he put up an adobe structure $17 \times 50$ feet, with asphaltum roof, expecting to use water from the La Presa ditch to drive his mill machinery. His right to this water service was contested; lawsuits were undertaken; and finally he lost both the water and the land-and his mill never turned a wheel. $\ddagger$ The building still stands, being now used for a dwelling, about one-fourth mile northeast from the East San Gabriel hotel; the land now belongs to Gov. H. H. Markham, and was occupied in 1894 by Mr. C. M. Smith, as tenant. The millstones had been quarried out from volcanic tufa, the same as those in the old stone mill, and

*Davis, "Sixty Years in Calif.," page 222, credits this discovery to "some Mexicans frum Sonora who were passing through going north," in 1840 . This is a mistake. Lopez showed them some of the dirt in Los Angeles, and they confirmed it as gold-bearing-that is all; and this was in 1842 . Davis also mentions two priests who told him as early as $1843-14$ that they had knowledge of gold in the Sacramento valley from Indians long ago, but they had charged the Indians upon " peril of the wrath of God" not to reveal the secret. Theit idea was that if the existence of gold here became known, foreigners would rush in to hunt for it, and would overrun and take the country. The same charge was made by the priests at San Diego and San Gabriel to Indians who brought them gold dust long before white men had discovered it. And Davis, p. 257-59, relates how in 1850-51 the old chief Zapaje rejected the most tempting bribes that could be offered to an Indian, rather than lead them to a gold mine which he had told the priest about 70 years before. In this adventure Davis was accompanied by three Arguellos of San Diego, uncles to our Arturo Bandini, and by Gen. Manuel Castro.

fIn the official list of the party as recorded at I,os Angeles, Feb. 29, 1842, his name is written "Daniel Sinton, carpenter," or at least it has been printed that way from those records. It should be "Sexton" instead of Sinton.' In 1894 he was still living at San Bernardino but died during the year.

ISexton was one of the original owners of the old Orizaba tract, which was not marked on any map that I found, but it included Winston Heights, part of San Marino, and some other lands. He built on his part the very substantial adobe house, now occupied by Mr. N. A. Strain, foreman of Hon. J. De Barth Shorb's San Marino ranch. 
were lying there in the house yard when I visited it on August 30, I894, one of them being still unfinished.

NOTE.-I have taken pains to explain about this " old adobe mill " at San Gabriel, in order to prevent further confusion and misunderstanding from its being confounded with the two old Mission mills.

SECULARIZATION OF THE MISSION.

On January 6, I83 , Governor Echeandia had issued a final decree for secularizing the Missions, and forming them into towns, in accordance with the old Mexican law of September 13, I823. Elections were ordered to be held on the third and fourth Sundays of January. The twenty-eighth article of this decree said: "With all possible haste a school is to be established at San Gabriel, in which reading, writing and arithmetic will be taught, as well as the best morals and politics."* Article 32 said: "Teachers to have $\$ 40$ or $\$ 50$, according to skill, and to have also $\$$ i 5 for each proficient pupil produced in six months." [See Bancroft, Hist. Cal., Vol. 3 , p. 306.]

In 1832 there was much civil strife between factions; and now for the first time Indians were armed, to take part as soldiers in these public quarrels. In April, Governor Echeandia had a force of soldiers and Indians encamped at Paso de Bartolo on the San Gabriel river, under Captain Barroso. They marched to Los Angeles; then in a day or two they went to San Gabriel; and here they borrowed $\$ 20,000$ from the Mission treasury, $\dagger$ besides forced loans of supplies for men and horses-all which was very galling to the padres, for this was the faction that they were opposed to. Several writers say there were I, ooo mounted Indians, besides white men.

In I83I-32, while Padre Sanchez was still in control, a schooner of sixty tous burden was framed here at San Gabriel by Joseph Chapman, assisted by an Englishmen named William Antonio Richardson, who claimed to be a carpenter, a shipwright and a pilot. The vessel was hauled in sections on carts to San Pedro, - there put together and launched in I832, and used in the otter and seal fur trade among the channel islands. A man named Yount was part owner and became captain of this small ship; and different accounts have credited each of the three men, Chapman, Richardson and Yount as the builders. But it was Chapman who projected, planned and superintended its building at San Gabriel and cartage to San Pedro. $\mathrm{He}$ was the real head and hero of the whole affair until the owners took charge of it at anchor in San Pedro bay.

* This hall been the hottest question in Mexican politics for about tiventy years, between the Liberal party and the clerical or conservative party. Sometimes one and sometimes the other was in power, so that the padres had never obeyed either the spanish or the Mexican law in regard to the matter, but held their grip of ecclesiastical doninasce till Echeandia finally forced them to obey.

tEulalia Perez hid the keys of the money room and refused to give them np, as she was the Mission treasure-keeper; but the room was broken open, and the $\$ 20,000$ thus "borrowed" from the padres. was never returned-for it took all of it and nore, too, to pay costs of entorcing the law which they had so long disregarded. 
In I 8.32-33-34 the Mission cattle were slaughtered in droves by contract, just to sell the hides-the Mission treasury to receive half and the contractors half.* And Mofras, a French consul here at the time and who wrote a book about this country, says that in 1834, I00,000 hides, 2,500 centals of tallow and several cargoes of soap from San Gabriel were shipped at San Pedro. The fact was simply this: the Mission Fathers were rushing all their portable products into market before the government officers should arrive to take it from them. $\dagger$

In 1834 Colonel Nicolas Gutierrez was sent to San Gabriel as administrator, to take charge of all the property and secular business on behalf of the government, and rëadjust its affairs.

In 1838 Don Juan Bandini succeeded Gutierrez as administrator. And it is recorded that in June, I 839 , the government visitador general, Hartnell, reported Bandini's accounts all right, and authorized him to "buy $\$ 2,000$ worth of clothing, to be paid for in brandy." Then on December 3 I of same year it appears that Bandini distributed \$I,6 I 5 worth of clothing among 233 Indians-this being the number then still remaining as neophytes and work people at the Mission. In March, r840, Bandini reports that he had added Ioo trees to the Mission orange orchard, the only one then existing in California. August I, of this year [1840] Bandini retired, the secularization business being about completed; $\$$ and all that was left of the Mission property was placed in charge of the curate, Padre Estenega-but Juan Perez had been major domo since 1837 , and he continued to serve under Estenega's direction until March I, I843, when he dropped out, and the padre attended to everything himself for a year or so.

While Don Juan Bandini was administrator his home was at his great Jurupa ranch of seven square leagues which had been granted to him September 28 , I 838 ; but part of the time he lived at San Gabriel, occupying one of the padre cottages, as Senora Lopez informs me. In r84 I, during his term of office, his father, Captain Jose Bandini died, and was buried under the flagstones of the old church. Then in a few weeks (or months) his daughter Arcadia was married in the church to Don Abel Stearns of Los

*Gen. M. G. Vallejo, a Mexican commandante, wrote: "In the Missions of San Gabriel, Sun Fernando, San Juan Capistrano, and San Luis Rey, they killed by contract with private individuals, during the yoars 1830-31-32, more than 60,000 head of cattle, from which they only saved the hides."

IIn his MSS. Hist. Southern Cal., Bandini says: "2,00ocattle were killed in a single day at one Mission. [San Gabriel,] the meat and fat being left in the fields" Pio Pico, in his MSs. Hist. Cal., says he" had a contract at San Gabriel, employing ten vaqueros and thirty Indians, and killing over 5,000 cattle." Mrs. Ord, MSs. Occurances, says she "understood that 30,000 cattle were killed at San Gabriel, and remembers that there were fears of a pestilence from the rotting carcasses."

At that time, as the reader will bear in mind, the rancho San Pasqual or Pasadenaland was a part of San Gabriel. The cattle were killed for their hides only, these being mostly shipped around cape Horn to Boston; they were Mission live stock, and this occurred in the process of secularizing the Mis. sions. Father Gonzales, one of the pioneer missionaries, writing of the Missions as they were in 1833 , says: "The richest in population was that of San Luis Rey [in San Diego Co.]: in temporal thiugs, that of San Gabriel. *** Twice a year a new dress was given to the neophytes ;" etc.

IIn August or September, 184r, Bandini was appointed to manage the temporal affairs of San Juan Capistrano, and to superintend the founding of the pueblo, San Juan de Arguello, as a hone place for the now secularized Mission Indians. But on March 7,1342 , he put the whole business into Padre Zalvidea's hands, and on May 30 resigned this commissionership. 
Angeles, the bride being dressed in mourning, * and having ridden in on horseback from Jurupa [now Riverside], while Don Abel came with his friends from Los Angeles. And after the nuptial ceremony the whole wedding party went to Los Angeles for the usual social festivities. The youthful bride of this occasion, then only sixteen, is now Mrs. Col. R. S. Baker (widow) of Los Angeles, the wealthiest woman in Southern California. $\dagger$

SOME SAN GABRIEL ITEMS.

"The earthquake of December 8, I8I2, at sunrise, overthrew the main altar, breaking the St. Joseph, the St. Dominic, the St. Francis, and the Christ, damaging the church considerably, bringing down the top of the steeple, and badly cracking the sacristy walls, and injured the friars' houses and other buildings." - Hist. Cal., Vol. 2, p. 356.

The wall of the north forebay or water-head cistern at the old stone mill was cracked by this earthquake before a wheel was put in for its spout, and hence the mill never had but one wheel, although built for two. The walls were built so massively solid as they are, in order to withstand earthquakes, in addition to their possible need as a fortress.

The first orange culture ever attempted in California, was at San Gabriel, from i 820 to ' 25 .

In 1829 the Mission sheep were estimated at 54,000.

Robinson's book, "Life in California," written mostly in 1829 to I 835 , and published in 1846 , gives a picture of this old Mission church as he saw it, and it had a high pointed steeple on it. This was afterward blown down, and the unique five-groined stone belfry, as now seen there, was built in its place. On page 32 Robinson says [1829]:

"There are several extensive gardens attached to this Mission, where may be found oranges, citrons, limes, apples, pears, peaches pomegranates, figs and grapes in abundance. From the latter they make yearly from four to six hundred barrels of wine, and two hundred of brandy; the sale of which produces an income of more than $\$ 12,000$. The storehouses and granaries are kept well supplied, and the corridor in the square is usually heaped up with piles of hides and tallow. Besides the resources of the vineyard, the Mission derives considerable revenue from the sale of grain; and the weekly slaughter of cattle produces a sufficient sum for clothing and supporting the Indians."

In I 831 Col. J. J. Warner estimated the Mission hogs at I, ooo head"used chiefly for making soap," he says. The same year the Mission's grape vines were reported to be 50,000 . It was this year also that Chapman built a ship here in parts and hauled it to San Pedro in ox-carts. Alfred Robinson, who saw it launched, calls it the Refugio, a schooner of sixty tons burden; but Bancroft calls it the Guadalupe. This discrepancy is easily explained.

*A Spanish woman who was there at the time told me that the bride not only stood up in mourningattire, but iu going to the altar she walked over the flagstone under which her grandfather was buried, and it was talked of as a bad omen for the girl's future, in social gossip.

H Abel Stearns owned six great ranches in 1868 - total 140,000 acres.-Hist. Los Angeles Co., p. 153.Mrs. Baker was assessed in 1894 on $\$ 264,255$ valuation in L os Angeles county. 
Guadalupe was the name of Chapman's wife ; and Refugio was the name of her home ranch where he had been captured by the Spanish soldiers, and captivated by the Spanish maiden. This ship was his greatest mechanical achievement; and it bore both names, in romantic commemoration of his wife and her early home.

In December, I831, Governor Victoria was brought to San Gabriel after being wounded in a battle with insurgents near Cahuenga; and he was nursed by Eulalia Perez, with Joseph Chapman, the Yankee "pilot prisoner," serving as surgeon pro tem.

In October, I846, powder was manufactured at San Gabriel for General Flores' army, after Gillespie's U. S. troops had been driven out of Los Angeles. The powder was poor stuff, but it was all they had in the battles of January, i847. It was made in an adobe guard-house that stood right where Mr. Silverstein's store is now-i 895 .

August 7, I85I, the court of sessions at Los Angeles divided the county into six townships, San Gabriel being one, and Rancho San Pasqual was included in its territory.

July I I, I855, an earthquake made cracks or fissures in the ground at San Gabriel, and threw down the church bells. This accounts for the patched cracks now seen in the belfry walls.

\section{CHAPTER III.}

Rancho SAN PASQUAL - Gov. Portolo's visit in I770.-How the ranch was named.-Its first owner a woman in 1827 . - The Garfias ownership from I843. - The Wilson and Griffin ownership, from 1858 ; and sale to the colonists, 1873.-Complete Chain of Title-1769 to 1874 ; being the first complete schedule of its various occupancies and ownerships ever written.

FIRST WHITE MAN ON PASADENA SOII.

The initial point of the modern history of Pasadenaland is in January, I770; and in April of the same year comes the first inkling of the name "San Pascual," as applied to this particular section. In 1769 Gov. Gaspar de Portola, marched overland with an expedition from Loreto in Lower California (the peninsula) to find Monterey bay, then only known from reports made by the navigator Vizcayno, who had discovered it in 1603 - or 166 years previously. Portola's march was made with a total of 64 persons, including two priests, Crespi and Gomez. Crespi kept a diary. Lieut. Fages, afterward governor of California, was also along, and he wrote accounts of the country and people. On their up trip they crossed the Los Angeles river August Ist, I769, and camped where Los Angeles city now stands. The Indian village of Yang-na was there. Angust 2d, they staid there to rest, and to prospect their route ahead. In the church calendar it was the 
day of "Saint Mary, Queen of the Angels"; the two priests celebrated it in due form, and in their diaries they designated that camp by the calendar day. This is how and when the place got its name of "Reina de Los Angeles." The river they called Rio Porciuncula. August 3d, they marched through the Cahuenga pass to the Indian village of Cabueg-na; thence on up the south border of the upper Los Angeles valley through Calabasas, and over to Hueneme which was then an Indian village on the beach.* And so on westward. As the company was partly on foot and partly on saddle beasts, they could readily follow the Indian paths from one village to another. All this was of course before any of the California Missions had been established.

In January, I770, Portola made the return trip eastward over the same route; but after crossing the Santa Clara river he mistook the trail and wandered farther away from the coast than was intended, finally coming through the Simi pass into the San Fernando valley, near where the village of Chatsworth now stands, and thence across the valley to the region of Pacoima or Dundee on the Southern Pacific R. R., vainly searching for the Rio Porciuncula [Los Angeles river]. He was literally "lost," not knowing how to find his way back to the trail of his outward march; but he pushed on eastward by way of Glendale and the lower part of Eagle Rock valley, and found the fording place across the Arroyo Seco at Garvanza. The stream was swollen with the winter rains; he supposed it to be the Rio Porciuncula again, and the priests so recorded it in their diaries. They marched up across the lands where Lincoln Park and South Pasadena are now located, and found there some Indian villages. His men were worn out with hardships of roadless and trackless mountain travel; their food supply was exhausted; and they were indeed in a sorry condition. The Indians here were the Hahamog-na clan and proved to be friendly; so from them they obtained some dried meat and meal of dried acorns, and halted there a few hours for rest and recuperation. The old chief of this clan, Hahamovic, gave the governor some of their native tobacco [Nicotiana Begelovii] and smoked the "peace pipe" with him. $\dagger$

In referring to this part of Portola's return march, Bancroft's Hist. Cal., Vol. $I$, page $I 63$, foot-note, says : "They finally crossed by the modern stage route via Simi. January I6th to I 8th their route through the Los Angeles region was also different but not very clear. On the 17 th they crossed the Rio Por-

*" Isligua, or Ishguaget, was a rancheria /village] near the mouth of the Saticoy river and not far from the beach. Ineneme was a rancheria on the ocean coast a few iniles south of saticoy river."Ventura Mission records, quoted in Bancrofl's "Native Races," p. 459.

†This was on January 17th, 1770. "The Capitan, filling his long stemned pipe with leaves of the wild tobacco, presented it to the Spanish officer, whose supply of the foreign weed had been long exhausted. Thus the consoling 'Pespihuta,' the Indian name of this plant, became the foundation of a lively traffic between the aborigines and spaniards, who paid for it in trinkets and beads." --Mrs.Jeanne C.Carr, in Hist. Los Ang. Co. (1,ervis's), p. 313.

"A species of tobacco is found on the sandy heaches which the Indians prepare and smoke." - Com. Wilkes's U. S. Exploring Expd.. Vol. V. p. 202.

"They 11 se a species of native tobacco of nauseons and sickening odor." - Schoolcrafl's Archaeology, Vol. $I 11$, p. 107 . 
ciuncula [they thought so at the time but learned better afterward-ED.], and went on to a valley which they called San Miguel, where San Gabriel Mission afterward stood."

After this rest and refreshment he marched on eastward along the north side of the Mission hills till he came to the Rio San Miguel [the present San Gabriel river], at the point now called Mission Vieja or "Old Mission," where then stood the Indian village of Isanthoog-na, and where the San Gabriel Mission was at first established, about a year and a half later. Here the San Gabriel river makes passage from its upper valley through between the monticle ranges called "Mission hills" westward and "Puente hills" eastward; and from this point he followed down the river to the place where he had crossed it on his outward march, some distance south of the Mission hills, and so found his lost "old trail" again. Thence southeastward to El Rio Jesus de los Temblores [the Santa Ana river], and so on to San Diego, where the famous Father Junipero Serra was then engaged in starting the San Diego Mission, the first one of the "old Missions" in our California.

In April, I770, Portola again marched up the coast in search of Monterey bay, which he had failed to find [or rather failed to recognize] the year before, but had discovered San Francisco bay instead. This time he went partly over his return route of January, by the line which afterward became the Spanish governmet road from San Diego via San Juan Capistrano, San Gabriel, San Fernando (old Mission), San Buenaventura, Santa Barbara and San Luis Obispo to Monterey, and crossing the Arroyo Seco at Lincoln Park or the old Garvanza ford. The poppy fields of Altadena were now all aflame with their redolence of rich golden color spread over thousands of acres; Easter Sunday was fresh in mind [April], and the pious soldiers called this wonderful poppy field La Sabanilla de San Pascual - the great altar cloth of Holy Easter.*

The original or "Old Mission" San Gabriel was formally commenced Sept. 8th, 177r. This was at the place still known as "Old Mission," or Mission Vieja, near where the San Gabriel river passes through the line of Mission Hills that form the southern boundry of what is called in general terms the "San Gabriel Valley." There was already an Indian village at this place, called in their language Isanthog-na. The river had before been called Rio San Miguel by the Spaniards, but from this time it was called Rio San Gabriel, and the Indians of the region began to be called the San Gabriel Indians. In 775 the Mission was removed to the Indian village of Sibag-na, $\dagger$ where the famous old church still stands, surrounded by the modern village of San Gabriel. The church building erected at the

* "La Sabanila de San Pascual was the name given by Spanish sailors to the vast fields of poppies seen from far out at sea, the same glorious altar cloth, or bridal veil, which adorns the foot-hills of North Pasadena with the returu of every spring."-Mrs. Jeanne C. Carr, in Hist. Los Ang. Co.

$\dagger$ "The village of Sisit Canog-na was only a mile and a half further north, where the Mis,ion pear orchard afterward stood, and now kuown as the Cooper place, occupied by Isaac and Thomas Cooper. Two of these old Mission pear trees are bearing yet. I saw them Ioaded with blossoms April 7 th, 1895 . 
orignal site was of adobe bricks, and some fragments of its walls may be seen there yet. The first church built at the new site was also adobe, a short distance north of the present stone edifice; but its walls were cracked by an earthquake and made unsafe; and about $179 \mathrm{I}$ work was commenced on the stone church. In I 797 the stone church was about half finished and partly occupied. In 1800 it was still unfinished. In 1804 foundation was laid for some additional portion of the great structure. These various changes of site, and the long slow progress of work on the present stone edifice, with occasional change of plan and change of priest, gave rise to conflicting reports as to dates in the matter, so that I found variations anong different authors amounting to a difference of over twenty years as to when this stone church was built. It was about fifteen or sixteen years being built. Now, the point I was coming at is, that sometime while the Mission remained at the old site, the Indian chief, Hahamovic, who had befriended Gov. Portola and his famished men at South Pasadena [their village being near the Garfias Spring], was baptized at this Old Mission and given the name "Pascual," from the fanciful name "La Sabanilla de San Pascual," which had been given to the vast cloth-of-gold poppy fields within or bordering, his tribal domain, that comprised both sides of the Arroyo Seco from South Pasadena to the mountains; and his tribe were thenceforth known as the Pascual Indians. [Chief Pascual afterward married a white woman named Angela Seise, and lived at San Gabriel to a very old age.] Then, after the Mission was removed to its present site, and the old Mill erected [about I 8 IO to 18 I 2 ], and the Wilson Lake dammed up for irrigation purposes and to run a saw mill, etc., these Indians were reduced to heavy servitude, and proved a very important factor in producing the wealth for which the San Gabriel Mission became famous, even exceeding all others in California ; but they also specially served as herders and shepherds.* This mill was intended to be the source of breadstuff for the San Fernando, San Buenaventura and Santa Barbara Missions, and all the outlying settlements; and the main road leading to the Mill and the Mission from these western localities is still called the Monterey road. It crossed the Arroy Seco at Lincoln Park or Garvanza, where there was always a good fording place, just below the present county bridge at that point. The cement quarry in the Lincoln Park hills, where the reservoir is now, was then worked by Indians and its product hauled in heavy ox-carts [carretas], to the other Missions - even as far as Monterey, away up the coast almost to San Francisco.

RANCHO SAN PASQUAL'S FIRST OWNER.

In 1806 Father Jose Maria Zalvidea was removed from San Fernando to the San Gabriel Mission and placed at the head of its affairs, a position

* "After the removal of Mission San Gabriel to its present site, the San Pascnal Indians were employed as herders; the 'bell mare,' fleetest and most beautiful of the padres' stock, ranged in the glades aud led the band of wild horses to crop the grasses of the Altadeua uplands."-Mirs. Jeanne C Carr, Hist. Los Ang. Co., p. 314 . 
which he held with distinguished success for twenty years. It was during his administration that the old stone mill and the great stone dam at Wilson's lake were built ; saw mill, tannery, tallow chandlery, spinniug rooms, weaving works, saddle factory, and other industries were established and pushed to success; large orchards and vineyards planted, and water brought in ditches from long distances to irrigate extensive field crops as well as fruits. All this in addition to what had been done by his predecessors; and thus he brought the Mission to the highest degree of industrial and commercial success ever reached by any Mission in California. But in the height of his career, and when he had plans under way for a still farther increase of business and pretige for this Mission, he was in 1826 removed by order of the Friar President to San Juan Capistrano;* and Friar Jose Bernardo Sanchez was placed in charge of the San Gabriel Mission.

During Zalvidea's administration there had resided at San Gabriel a devout, motherly woman named Eulalia Perez de Guillen, a Spanish lady of purest blood, who had won high repute as a midwife and nurse, and was in attendance upon Senora Pico when her son Pio Pico [afterward twice made Governor of California], was born May 5th, I80 I. Eulalia Perez had taken an earnest and practical interest in the welfare of the Indians, especially the women - teaching them the arts, decencies and religious sentiments of civilized life as best she could, and was a sort of Mother Superior to them in her devotion and zeal for the church. For several years before Zalvidea's removal from San Gabriel in 1826 , the matter of secularizing the Mission lands had been agitated; for as early as Sept. I3th, I823, the Mexican Congress had passed a law for this purpose, which however was repealed and reenacted, ordered enforced and then countermanded several times, and was not finally enforced until about ten years later. Eulalia had been so helpful and faithful in works of the church $\dagger$ that Father Zalvidea wished to provide for her in her old age by securing to her a large body of land, before the Mission authority should be entirely broken up; $\ddagger$ accordingly he prepared a deed to her of $3 \mathrm{x} / 2$ square leagues of land in the northwest portion of lands belonging to the San Gabriel Mission. This deed was sent to Father Sanchez, who also knew right well of Senora Eulalia's life-long labors for the good of others; and he approved and ratified it on Easter Day [called "San in 1846

* Zalvidea served here until $\mathbf{1 8 4 2}$, when he was sent to San Luis Rey Mission, and died there early

tEulalia's husband, Antonio Guillen, was one of the King's soldiers stationed at San Diego when that Mission was first lounded. But later he was sent to San Gabriel, and was there with his family in 180t. Then, some time before 1812 he was sent back to San Diego, and his daughter Maria de Los Angeles was born there in that year. Later he fell sick; his son Theodore took his place as soldier of the Mission guard; and about 1821 he returned with his family to San Gabriel [the daughter above mentioned tells me she was nine years old when they came], and died here. Eulalia had eleven children, as follows:

Petra-daughter. Josefa-daughter [died young]. Josefa again-daughter. Tomas-sou. Domingoson. Theodorp-son. Laureta-daughter. Maria Antonio-daughter. Maria de los Angeles-daughter [still living, the widow Lopez of Sau Gabriel]. Maria del Rosario-daughter. Rita-daughter, still living, Senora de la Ossa, at San Gabriel,- and her son Fabricio de la Ossa is deputy sheriff there-1895.

f "To secure lands for farming purposes, it was in former years necessary to get the written consent of the Missionary under whose control they were, ere the government could give legitimate possession, therefore their acquisition depended entirely upon the good will of the Friar." -Life in California; Robinson, $p$. 218. 
Pascual" in the Spanish language], 1827 ; and the ranch thus took its name from the name of the day in the church calendar on which it was first formally deeded to individual ownership. Thus Eulalia Perez de Guillen became the first person who ever held civil tenure of the land where Pasadena now stands; and of this worthy woman, Dr. J. P. Widney, in "California of the South," page I54, says :

"In 1878 [June 8] Eulalia Perez de Guillen died here [San Gabriel Mission], aged one hundred and forty-three years, she having been born at Loreto in Lower California, in 1735. The age of Senora de Guillen has been established beyond a doubt."

In May. I890, Mrs. Jeanne C. Carr wrote a strong article in the Sacramento Record-Union advocating state division; and in it she says incidentally, that she spent the winter of $1869-70$ in Los Angeles, and sometimes rode out across the rancho San Pasqual to visit B. D. Wilson's place, and the old San Gabriel Mission, - and adds: "I found Eulalia Perez, the first owner of rancho San Pasqual, where Pasadena now stands, who had, in the practice of her profession (midwifery) brought Gov. Pio Pico, and nearly all the venerable persons of local distinction, into the world; waiting for the hand which should preserve the interesting story of her life."*

She waited in vain for an earthly biog-

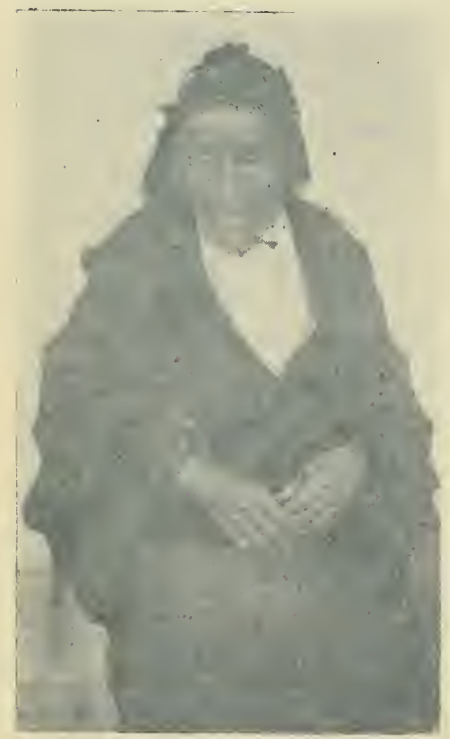

EULALIA PEREZ DE GUILLEN Photo taken in 1877 , less than a year before she died rapher; but the recording angel's book of life tells how unselfishly she worked more than a bundred years for the good of others.

A daughter of this woman, Senora Maria Guillen de Lopez, is still living at San Gabriel, a widow aged eighty-three years. She was born at San Diego in $1812, \dagger$ but was raised at San Gabriel. Her husband was a son of the historic Claudio Lopez who held the office of major domo at San Gabriel for thirtysix years, and superintended the building of the stone mill and the stone dam at Wilson's lake, as well as the stone ditch and water walls of the later one called "Chapman's mill," which are still visible across the street south from the old Mission church. Her son, Mr. Theodore Lopez, aged fortyfive, also resides at San Gabriel-an intelligent and well-informed gentleman, who speaks the English language well, although

* "Another old lady, Senora Fulalia Perez de Guillen, died bere [San Gabriel] in 1578 , at the ripe old age of one hundred and forty [143] years. She was born below San Diego, in Lower California, in 1735, three years after the birth of George Washington; in 1854 she married Francisco Villabobas de Zavia. who died aged one hundred and twelve years."-Prof. C. F. Holder, in "All About Posadena." p. 4.1 .

This is all a mistake as to her marrying Villabobas in 1854 , or any other time. Her second hus. 
Spanish is his mothers tongue. On August 30,1894 , and five or six times afterward, I had long interviews with him and his mother in regard to old matters of the Mission. They are frank-hearted, candid people, telling things to the best of their recollection; and I gathered from them particulars about the historic old mills and other information nowhere found in print.

\section{THE GARFIAS OWNERSHIP.}

In 1844 Dona Encarnacion, widow of Don Francisco Abila, took the ranch; put on to it the number of horses, horned cattle and sheep which the Mexican law required to make a claim valid; built an adobe house at the historic spring on the Arroyo bluff, which had aforetime supplied the aborigines, and now supplies Lincoln Park with pure water; sent her major domo there to superintend the ranch; paid Jose Perez's family for their improvements, and used the adobe house which Perez had built for her vaqueros to live in. Thus Dona Encarnacion was the real founder of the rancho, as an industrial enterprise. It had been granted to her new sonin-law, Lieut.-Col. Garfias, November 28, I843, by Gov. Micheltorena ; and she took it in hand to manage it, while he attended to his soldier business. The Pasadena titles all trace to Garfias's U. S. patent, I 863.

\section{THE GARFIAS FAMILY.}

Don Manuel Garfias first came to California in August, I842, as a young Lieut.-Colonel in Gov. Micheltorena's army, which stopped at San Diego awhile, but came to Los Angeles in September. Here they remained three months, the Governor's staff and army officers enjoying almost a continual round of feasting and dancing, with bull fights, bear baiting, cockfighting, and other national sports. And in the midst of it all, young Garfias fell in love with Senorita Luisa, the beautiful daughter of Dona Encarnacion Abila, she being then a belle in the highest circles of Spanish society. And the young couple were married in January or February, i 843 . In November, a girl baby was born to Lieut.-Col. Garfias; and as he was a favorite with the fatherly old governor, Micheltorena, that dignitary now gave him a grant of rancho San Pasqual, which would make a "Don" of him, and put him on a social footing with the family and relatives of his wife. This grant bears date of November 28, I 843 , a few months before Garfias's mother-in-law, Dona Encarnacion, took possession of the ranch and stocked

band was Juan Marina, a gentleman from Spain-married about 1832. Eulalia's daughters and grandsons at San Gabriel had never heard of this Villabobas story until I asked them about it, and they were quite indignant that such a misstatement had been published.

†According to Dr. Widney's dates, Eulalia was seventy-seven years old when this daughter was boru; and she had another daughter [now Senora Rita de la Ossa of San Gabriel] born still later; hence I thought Dr. Willney's statement as to Eulalia's age could not be correct. But Mr. T. F. Barnes, of the great printing house of Kingsley-Barnes \& Neuner Co, Los Angeles, assures me that he knew a SpanishMexican woman at Phoenix. Arizona, who had an eight-pound daughter born when she was reputed to be eighty years old. He weighed the baby himself; then took pains to investigate as to the woman's age, and found that she was really seventy-four years old, instead of eighty. So we thought Southern California climate might easily beat Arizona by four or five years on the baby question, without straining the record. 
it. On February 20-2I, I845, occurred the battle of Cahuenga, which resulted in Micheltorena being forced to return to Mexico, with all his imported troops, and Pio Pico being again made governor of California. [For account of this battle, see Chap. 17.] Garfias, however, did not return, but remained here with his family. And on May 7, 1846, Gov. Micheltorena's grant to him of rancho San Pasqual was confirmed by the departmental assembly, then in session at Los Angeles, and by Gov. Pio Pico; for by this time Dona Encarnacion had fully complied with the law as to live stock and improvements on the land.

During the military operations of the Mexican war period, i 846-47, Garfias took horses from this ranch to mount the soldiers of his own command. And after the defeats of January 8 and 9,1847 , it was from their camp on this ranch that he and Gen. Flores started back to old Mexico, while Gen. Andres Pico made the capitulation with Col. Fremont. When Gen. Scott finally captured the City of Mexico, in September, 1847 , the whole Mexican army became prisoners of war, Garfias included. The prisoners were of course paroled; and Garfias returned to L,os Angeles, where he became an American citizen under the treaty of peace between Mexico and the United States. In 1850 he was one of the regidores [councilmen] of Los Angeles; and in $185^{-}-51$ he served as county treasurer. In $185^{2-53}$ he built his great and costly adobe house or hacienda on rancho San Pasquala sort of country palace according to the fashion of the time-near by where Dona Encarnacion had built a house for her major domo in I844. In I 853 his son Manuel E. was born here; and in I 855 his son Mariano Jose also - the first white race children ever born on the ranch. In $185^{8-59} \cdot 60$ he was in Mexico and took part in the contests between Gen. Miramon's faction and President Juarez, for he seems to have still held the rank of Lieut.-Col. in the Mexican army. In 1869 or '70 President Grant appointed him U. S. consul at Tepic, in Mexico; and the Centennial History of Los Angeles, county [1876] speaks of him as then living at Tepic. In 1895 he is living in the City of Mexico, as I learn from his brother-in-law, Theodore Rimpau, of Anaheim.

Mrs. Garfias was a woman of superior mind, like her mother before her, the latter being a Sepulveda, and aunt to Hon. Ignacio Sepulveda, who served with honor, ability and good repute as judge of the Los Angeles district and county courts from 1870 to $1884-$ and had also been assemblyman

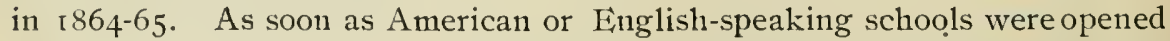
in Los Angeles she sent her boys to them. This was protested against by her Spanish friends, and especially by the church influence ; but she replied that it was plain enough the Americans were going to fill up and occupy this country; its business would be done in the English language ; and she did not want her boys to come up with the disadvantage of not being able to both read and speak the business language of the country. This was at once a moth- 
erly and stateswomanly view of the case, and she had the force of character to carry it out. While Don Manuel Garfias was serving as U. S. consul in Mexico she put her boys into college there, and lived in the City of Mexico herself for some years to give them her motherly oversight. Wm. Heath Davis of San Francisco in his book "Sixty Years in California," p. 3r2-I3, gives the following narrative:

"Dona Luisa Abila de Garfias, a California lady, born in the city of Los Angeles, a relative of two noted families there of great wealth and married to a citizen of Mexico, - was attractive for her remarkably fine personal appearance and superior conversational powers. On Christmas, I 880, she was visiting in San Diego, and I was interested in her account of her life in the City of Mexico, where she had lived for a number of years. Although fiftysix years of age she had not a gray hair in her head. The lady relates that when Juarez was elected president of the Mexican Republic, Miramon with his forces opposed him, and designed effecting his capture, so as to prevent him taking the office. [ $185^{8}$.] Dona Luisa, having large estates in Los Angeles county, plenty of resources and ready money (as had her husband also), proposed to Juarez to furnish him with means, horses, escort, funds everything needed for him and his family to make a safe retreat to the mountains, where he could remain until such time as his friends should organize a sufficient force to defeat Miramon and his schemes, after which he could safely take the position of president of the Republic. Juarez accepted her proposal, and she actually carried the plans into effect, with entire success. Subsequently, during the administration of Juarez, her friendly services in his behalt were duly recognized, and appreciation accorded from Mrs. Juarez also. Don Garfias, the husband, distinguished himself in the engagements of the Californians against Commodore Stockton at San Gabriel [ford] in the winter of $1846-47$, having then a command in the native forces. In that fight he behaved bravely. Subsequently he acted as United States consul at Tepic, Mexico."'*

\section{PASADENA'S FIRST BOYS.}

I will now give a sketch of Mrs. Garfias' two sons - the first white race children ever born on Pasadena soil. In I 869-70 Byron O. Clark, now of Pasadena, and his father-in-law, B. F. E. Kellogg, bought a 640-acre farm at Anaheim, and the first man they hired to work for them was Manuel $\mathrm{E}$. Garfias, + then [spring of I 870 ] about seventeen years old, having been born at the Garfias hacienda of Rancho San Pasqual in IS53. On October 29, I870, the Anaheim Gazette newspaper was started by a man named G. W. Barter, and young Garfias went there to learn the printer's trade; and he was at work in the office when Chas. A. Gardner [now of the Pasadena

*It is interesting to note that our Pasadenaland Garfias family was on the right side in this contest. Miramonl led the antiliberal or clerical party in rebellion against Juarez, the law ful President, in 1858 to 1860. But he was utterly defeated and made his escape to Europe; there he aided in working up the Maxinilian scheme of Empire, under patronage of Louis Napoleon; he came back to Mexico as one of Maximilian's chief officers, and was captured and shot with that misguided prince in 1867 . So our Pasadena fanily bore a part in stirring historic events in Mexico as well as here. By collating some documents which I specially obtained from the City of Mexico, with other records in California. I gather that Garfias was a Lieut.-Colonel in the regular Mexican army when he first came to Los Angeles in 1842 ; and he had a brother who was a Colonel in the army in Mexico. Garfias.

†He was then living in the family : $\mathrm{f}$ Theodore Rimpau, whose wife, Francisca, was sister to Mrs. 
Daily Star] bought it in I871. Young Garfias had attended English schools both in Los Angeles and Anaheim, and was reckoned the smartest boy in school to "speak a piece"-hence he was much in demand for entertainment occasions, and naturally enough was somewhat proud of it. Subsequently he attended St. Vincent's college in Los Angeles, and graduated there. Then he went back to Mexico and studied law--but at last drifted into military life, won his way step by step, and finally reached the rank of General. He was killed in battle in Honduras in April, 1893, while commanding troops in defense of the lawful government of that republic to which he had offered his services against insurgents.

In my researches upon this family I procured documents from the City of Mexico; and in a Mexican publication called El Universal, dated February 2 I, I89I, there was a sketch of this Pasadena boy which Arturo Bandini kindly translated for me, and from it I quote this passage:

"The love of country and the career of arms is traditional in the Garfias family; valor also is a hereditary trait. The father of our young Colonel [afterward General] was Lieut.-Col. Manuel Garfias who fought bravely in upper California against the Americans till the end of that war. Another Col. Garfias, an uncle of Don Mariano and his brother our present subject, is well known in our history as having occupied military positions above any other one of equal rank, his probity, valor and talents in military affairs being fully recognized. Worthy son and nephew of these military chieftains is young Col. Garfias, born in the flourishing city of Los Angeles [on rancho San Pasqual-now Pasadena], upper California, thirty-nine years ago [1852]. He was educated in the colleges of that state, receiving his diploma therefrom.* In early youth he devoted himself for some time to the study of law ; but he had missed his vocation ; his love and destiny was the military profession. He had ancestors from whom to inherit it ; and as his father and uncle were called to fill distinguished careers of arms, he determined to follow in their footsteps."

Mariano Jose Garfias, the second boy born on Pasadena soil, is now a reputable lawyer in the City of Mexico; and he had the distinguished honor of being secretary and sub-delegate of the Mexican Commission to the great Columbian World's Fair at Chicago in 1893 .

JUDGE, EATON'S ACCOUNT OF THE GARFIAS HOUSE.

"I came onto the San Pasqual Rancho, the present site of Pasadena, in December, 1858. This Rancho was a Spanish grant made to Don Manuel Garfias, a Captain [Lieut.-Col.] in the Mexican army who served in the defense of his country when the Americans under Commodore Stockton and Fremont invaded this section. The Mexican grant, which called for three and a half square leagues (about $\mathrm{I}_{4}, 000$ acres), was issued during Governor Pico's administration in I 846-only two years before the treaty of Hidalgo. The only house on the rancho was the hacienda, located on the east bank of

*St. Vincent's college at Los Angeles was started in 1867 ; and Manuel E. Garfias and Arturo Bandini were students there together. 
the Arroyo Seco, on land now owned by G. W. Glover in South Pasadena, and was occupied by the grantee, together with his wite, Dona Luisa, and a large family of children.* Mrs. Garfias was a niece [sister's daughter] of Don Jose Sepulveda who was the father of Hon. Ignacio Sepulveda, for some years presiding judge of this district.

"The Garfias hacienda was at that time one of the finest country establishments in Souther1 California. It was a one-and-a-half story adobe building, with walls two feet thick, all nicely plastered inside and out, and had an ample corridor extending all around. It had board floors, and boasted of green blinds-a rare thing in those days. This structure cost $\$ 5,000$-in fact, it cost Garfias his ranch, for he had to borrow money to build it, and the prevailing rates of interest were four per cent per monthto be compounded if not paid when due. $\uparrow$ The title of the property passed into the hands of Dr. John S. Griffin of Los Angeles, by purchase just before I first came out here; and as my wife's health seemed to be failing in Los Angeles and the change was recommended, I determined to take up my residence here To prepare for this step I left my wife and two children (Mary, now Mrs. H. M. Johnston, and Fred, late city engineer of Los Angeles) with her sister, Mrs. Dr. Griffin, and came out myself with stock, etc., taking possession of the premises just before Christmas, $185^{8}$. [It was in $185^{8}$ that Dr. Griffin loaned Garfias $\$ 8,000$, as he told me.-E.D.]

"No attempt had ever been made to divert the waters of the Arroyo upon the ranch lands, so that cultivation of them was impracticable except for such crops as would mature with the winter rains-chiefly wheat and barley. I had brought with me quite a little herd of American cows which I had been gathering and raising for years, and I did not at that time turn my attention to anything but stock, and dairy produce. My wife did not live to join me here, but lingered until the following May. Her death broke up my plans, and in July following I rented my dairy stock and left the ranch-not returning again until February, I865."

Some further historic incidents connected with the original San Pasqual ranch house (the "Garfias adobe" as it was familiarly called by Pasadena's early settlers) may here be noted. On the brink of the Arroyo bluff a few rods from the house a bountifui spring gurgled out under a great spreading oak tree, and this spring was the determining cause for locating the house here. The Indians had one of their villages near here when the Spaniards first came in January, and again in April, r770. This spring is now closely boxed up and its waters piped to Lincoln Park, where it furnishes the supply for domestic and irrigation purposes in that oak-embowered settlement.

*The Garfias children were six : three boys-Enrque, born at Los Angeles, was sheriff at Phœnix, Arizona, in $1894-95$, and had been deputy U.S. marshal before. Manuel E., the General. and Mariano Jose, the lawyer, as before explained. Three girls, Angelina Salome-now Mrs Lambeck of San Diego. Manuelita-now Mrs. Alejandro Sabin of Tia Juana. Laura-now Mrs. Lainesse of San Francisco. The girls were all born at L,os Angeles.

†'In I 851 a common interest of money was five percent. permonth often ten per cent.; a rate that commenced in 1848 -' 49 , with the loans of John Temple to the hundreds eager to share in the 'bonanza' at auy sacrifice." - $[$ Centennial Hist. Los A. Co., p. 73 . 
During the boom days of $1886-87$, G. W. Glover, Sr., laid off his land, which included the site of the old Garfias hacienda, into town lots, and this made it necessary to pull down all that remained of the heavy adobe walls and grade the ground. This was done in November, 1888. Cottages have been built on each side of it, but the lot where the historic old hacienda stood is still vacant (1894) and now owned by Geo. W. Glover, Jr., editor of the South Pasadenan.

While engaged in building his ranch house, Senor Garfias made a road up over the Arroyo hills nearly opposite the head of Colorado street, to get timber from a fine sycamore grove which then grew on what is now known as the Campbell-Johnson ranch. That old road was quite a conspicuous object, in plain view from Pasadena for nearly twenty years, and had been facetiously dubbed "Fremont's Trail" by D. M. Berry, the colony secretary ; the name stuck, and the majority of early Pasadenians really believed that Gen. Fremont had made that road; but Fremont never saw nor heard of it. Garfias made it, and the rafters for his house and timbers for the rear veranda, besides poles and posts for corrals and various other uses were all hauled or dragged down that miscalled "Fremunt's trail." It is now (1895) almost entirely obliterated by the grading and improvements made by Mr. J. W. Scoville on those Arroyo hills. As this "Garfias adobe" was the one historic manor house of Pasadenaland, I quote here another account of it published some years ago:

"The wood work was mostly of Oregon pine. The posts which supported the projecting roof were of redwood. The interior was plastered and nicely finished throughout. It was the finest country house in Los Angeles county, but it cost Garfias the ranch. When interest on the borrowed money amounted to $\$ 1,000$, and he saw no way to pay it, he went to Dr. Griffin and told him that if he would give him $\$ 2,000$ more he would make him a deed for the ranch. Griffin did not want the place, $*$ and he would never have foreclosed the mortgage ; but to oblige Garfias the $\$ 2,000$ additional was paid over, and the Doctor received the deed for the ranch, which contained nearly i 4,000 acres."

Dr. Griffin informed me in July, I895, that Garfias built his hacienda in about 1853 , and it was not till 1858 that he [Griffin] loaned Garfias $\$ 8,000$ (not $\$ 3,000$ as has been commonly reported), taking security on the land. And when the additional $\$ 2,000$ was furnished Garfias, it was to pay for the personal property-the farm implements, tools, work horses, oxen, etc., that were then on the ranch. It was thought at the time by business men of Los Angeles that he had paid a great price for the place.

*Ex-Mayor Spence of Los Angeles in a public speech at Pasadena's great Citrus Fair in 1885 , said that when he first rode over rancho San Pasqual in the early ' 60 's he would not have given twenty-five cents an acre for it -in fact he would have hesitated to take it as a free gift and agree to pay taxes on it. And in 1874, when B. D. Wilson made a free gift to the Orange Grove colony of 4000 acres up where A1tadena now lies, the colony men generally felt that they could not afford to accept it; but on learuing that the taxes were all paid they ventured to risk its acceptance. 


\section{THE WILSON AND GRIFFIN OWNERSHIP.}

The next step in the evolutional progress of San Pasqual Rancho was in I867, when B. D. Wilson and Dr. Griffin as joint owners had a ditch made to convey the waters of the Arroyo Seco from Devil's Gate up onto the second bottom, with a view to irrigate the land and raise alfalfa hay for summer feeding of their ranch stock.* Judge Eaton had the job of making the ditch, which was at first only a small dirt-bed channel, and extended down to the knoll or rise of ground east of the old Tirrell house where John W. Wilson resided from i87I till i89o. Judge Eaton also "bossed the job" of building this adobe tenant house, which was for the use of a man named Tirrell, who was then engaged in working the land, while a man named Sam Kramer had charge of the stock ranging on the ranch. The alfalfa land, to keep the stock off from it, was fenced with pickets and posts brought down over the old trail from Wilson's Peak; and the house was roofed with shakes from the same source, some of which can be seen there yet [I894]. This Wilson ditch was the first attempt made to lead the waters of the Arroyo Seco out upon the summer-desert mesa lands and make them habitable by civilized man; and it presented to the eye in a most striking manner the famous California illusion of "water running up hill."

COMPLETE CHAIN OF TITLE OF RANCHO SAN PASQUAL, FROM I 769 TO I 874.

There has been some variance of opinion and an occasional dispute as to who originally owned the Rancho San Pasqual; and semi-occasionally a rumor is whispered around that somebody, somehow, somewhere, is going to rip up the title, and play smash generally with the conveyance tenures of its present occupants. I have therefore taken pains to collect and prepare a succinct schedule of dates, names and conveyance of title from the first-a body of most valuable historical matter which has never before been collect. ed or made public.

In 1769 the Spanish crown first took formal possession and made occupancy of Upper California, under Gov. Portola, although certain navigators had claimed the country for Spain nearly a century before. (See Chap I.)

In I77 I the Mission San Gabriel was established, and it took possession of the territory now comprised in Los Angeles, San Bernardino, Riverside and Orange counties. Its tenure and jurisdiction of this territory was in accordance with Spanish law, and had the special sanction, confirmation and support of the Spanish sovereign.

In March, I826, Father Zalvidea was removed from his position as Friar Superior of San Gabriel, which he had held for twenty years, and sent to San Juan Capistrano. He had overworked himself and everybody else at

*In the county assessment of 1858 B. D. Wilson is taxed on $\$ 20,648$ valuation ; Dr. J. S. Griffin on $\$ 15,000$; and Abel Stearns on $\$ 1 \$ 6,586$. But Stearus' assessment included property which rightly belonged to his father-in-law, Don Juan Bandini, who had trusted him to manage his estates. 
San Gabriel, in his zeal to make it a great success, till he had fallen into a state of exploitive monomania ; for he was then negotiating for an enormous purchase of iron to build iron fences around the gardens and orchards of the Mission-a preposterous and crazy project.* These were reasons enough for his removal, without imagining "jealousy," as Bancroft and other writers have done. $\dagger$

At San Juan Capistrano he prepared a deed for three and a half square leagues of land to Eulalia Perez de Guillen and sent it to Father Sanchez, his friend and successor at San Gabriel. The Mexican government having become independent of Spain in I 822, had already twice passed decrees for secularizing the Missions; and although these decrees were not enforced, the work of disintegration and gradual breaking up had commenced-and these two priests wished to provide for this faithful and devoted woman in her old age, for her life had been "full of good works." Zalvidea had verbally promised or given her the ranch some time before, but no deed of it was made out until after he went to San Juan Capistrano. Then he sent it to Padre Sanchez, who accordingly [as the story goes] on Easter Day ("San Pasqual" in Spanish), I826, $\$$ confirmed and ratified at San Gabriel the deed to Eulalia Perez de Guillen, of the body of land thenceforth known as "Rancho San Pasqual." This was in due accord with Spanish and Mexican law at the time, and was thus a valid title as far as it went; but Eulalia was old, and had no skill or knowledge in matters of law and had no one to act for her who knew any more as to what further steps were necessary on her part than she did herself; and the result was that her deed was never entered on the civil records. Likewise the law required certain buildings to be erected on such land grants, and a prescribed amount of horses, sheep and cattle to be maintained there, etc., in order to complete the title ; but she and her family failed to fulfill these conditions, and consequently of course her claim became forfeited. I did not succeed in finding this original deed nor any copy of it, but I did find and talk with people who had seen it while it was preserved in the family, for her death did not occur until June 8, 1878, at San Gabriel. Her grandson, Theodore Lopez, told me

* "He purchased large quantities of iron with the intention of railing in all of the rineyards and gardens." - Hugo Reid.

†"Two aged missionary friars resided here [San Juan Capistrano, April, 1829], Padre Geronimo Boscana, and Padre Jose Maria Zalvidea-the latter thongh at this time secluded and apparently weak in mind, once took an active aud laborious part in the maugement of the Missious."-Robinson's "Life in Califorma," p. 28.

Boscana was afterward sent to San Gabriel, and died there July 5, IS 3 I. Padre Zalvidea was still living in $1840-41$, in active service amoug the Mission Indians of San Juan Capistrano and viciuity. He died at San Lnis Rey early in 1846 , while still on duty as a missionary to the Indians, especially those of Sin Paspual village.

†alvidea was transferred in March, only two or three weeks before Laster Sunday, and he sent the deed up to San Gabriel in time to have it officially ratified by Sanchez on that day, $1826(1827$, in top line of page 62 , is a misprint).

I At that lime Monterey was the capital, and the deed would have to be taken there for record, a transaction which of course would involve considerable expense; and she was very poor, besides being then already verv old. Also, slie had no money to buy stock for the ranch, nor to build a house and live there. This explains how it happened that she failed to complete her title and hold the ranch. 
that the last he heard of the deed was that Felipe Lugo had it. Don Felipe was justice of the peace in 1840 (when the ranch was granted to Enrique Sepulveda and Jose Perez), and again in 1850.

Some years after the ranch had been given to old Eulalia, there came to San Gabriel a fine appearing gentleman of straight Castilian blood, recently from Spain, Juan Marine by name, who had held for a while some public office at San Diego. He wooed the aged Eulalia and married her. But they did not get along well together ; so they agreed to divide their property and go apart. Eulalia took his bit of land and house where the San Gabriel public school now stands, for her portion, and gave to Marine the Rancho San Pasqual, which was solely hers.

[NOTE.--I made nine unsuccessful trips hunting for documents on this Marine case, to E. Sorabjee, and the district court, and the federal court, and to G. W. Hughes, and to Hervey Lindley ; but a tenth effort proved successful after this chapter was in type, ready for press. And I find that in 1833, Don Juan Marine [pronounced Mar-e-nay] was in possession of "Rancho el Rincon de San Pascual." December 27, 1833, the governor" made inquiry about it of the City Council of Los Angeles. They replied : "Juan Marine has all the requisites required by law to be heard in his petition." In February, I835, Governor Figueroa granted the ranch to Marine. In I838 Marine died. April I, I839, Fruto Marine, his son, sold his interest in the ranch to Jose Perez for "six horses and ten head of cattle." In July of same year Antonio Silva and Deciderio Belardi (sonsin-law of Marine) and his two other sons, Filomeno and Rafaela Marine, sold their interests to Jose Perez,--but as to Chino Silvas, another son-inlaw, I did not find whether he sold or not. The Marine family had some crops on the ranch, but apparently never built any permanent house on it, nor stocked it according to law. Jose Perez built the adobe house which still stands, and lived there in $\mathrm{r} 839-40$. His heirs finally sold their interest to Dona Encarnacion Abila ; she stocked the place as the law required, being the first person to do this ; and her rights all passed over to her son-in-law, Don Manuel Garfias. - ED.]

The first white man who ever made a home on Rancho San Pasqual was Jose Perez, a son of Eulalia's cousin, Esteban Perez. Jose's wife was Merced Lugo, sister to his uncle Eranio Perez's wife; but after Jose's death she married the American, Stephen C. Foster, who was the first alcalde [mayor and judge] of Los Angeles under American rule - 1847-48-49, and was a member and secretary of the first State Constitutional convention of California, being a graduate of Yale College and a proficient scholar in the Spanish language. Jose Perez built the west $L$ of the old adobe house recently occupied by $\mathrm{E}$. Sorabjee, as manager of the Raymond Improvement Company's large tract south of Raymond Hill, and lived there in I839. 


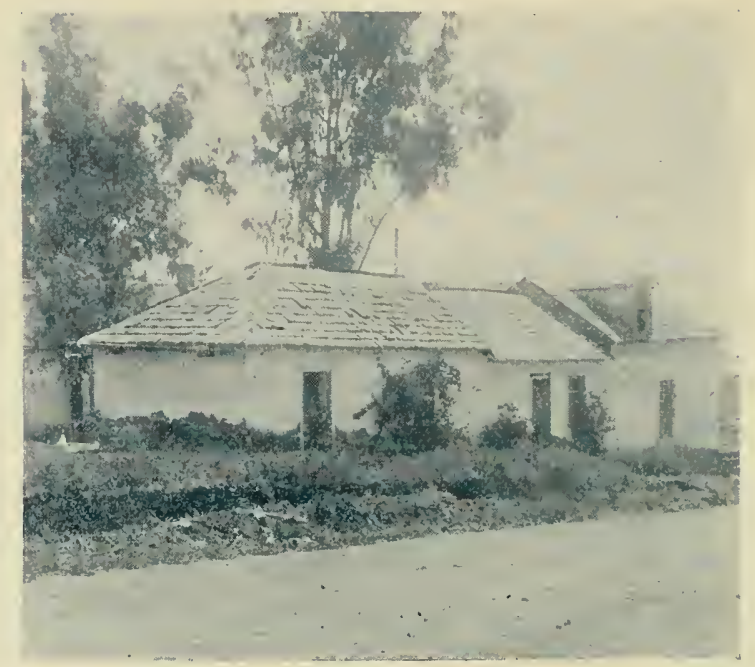

HOUSE BUILT BY JOSE PEREZ ON RANCHO SAN PASQUAL IN 1839. Still standing, 1895 .

Senora Maria Lopez told me that he was a favorite violin player for the young people to dance. He was now sick - thought he was going to die, and sent word to her to come up to his house and hear him play on his violin for the last time; so she walked from San Gabriel up there to visit him. She could not tell what year it was. I asked which one of her children was a baby at that time, and in this way she made out that this incident occurred in 1839 . He removed to Los Angeles for medical treatment soon after, and did not die at once - for in r840 Gov. Alvarado made a grant of Rancho San Pasqual to Jose Perez and Enrique Sepulveda. But neither of them ever stocked the ranch with horses, sheep and cattle, as the law required hence their claim was "abandoned" and the ranch was still public land, open for somebody else to take.

On November 28, I843, this rauch was granted by Gov. Manuel Micheltorena to Don Manuel Garfias, a young officer of the Mexican army who had come here with the governor. And this grant was confirmed to him by the Departmental Assembly and Gov. Pio Pico on May 7 th, i 846. [See Los Angeles records, Book I, page I4, of Patents.]

March 9, I850, Manual Garfias conveyed to Carlos Hanewald a body of land "one mile square," with no boundaries given, but simply this vague description: "Commencing where the Arroyo turns upward on the tillable lands there." For this he was to pay $\$ 2000$; but he failed to pay - and on December 3, 1850 , one John Pine appears with Hanewald in a new contract for the purchase. They were to pay $\$ 600$ down, and the balance of purchase money was to draw 4 per cent. per month, (or $4^{8}$ per cent. 
annual interest!) - all to be paid within one year ; or, failing of this, they were to forfeit all payments and improvements they had made, without recourse. It was an iron-clad contract. Their plans failed; and all their claims, interests and improvements reverted to Garfias.* Thus the Spanish Don was nearly forty years ahead of the Yankees as a "boomer" of these lands. His prices (according to the times) and his rate of interest beat any record of Pasadena's famous "boom" period - so the "boom class" will have to let this historic old Spaniard go up head.

On April 25, I854, the United States Board of Land Commissioners passed judgment on the validity of the Garfias claim above mentioned, and confirmed it - and thus the Rancho San Pasqual entered upon its first legal status and recognition under the United States law. $\dagger$

On September 18, I858, a document was issued at San Francisco and signed by I. W. Mandeville, United States Surveyor General for California, from which I quote the following points of historic record in regard to this ranch. [Book I, p. I4 of Patents, Los Angeles Co.]

"Whereas, it appears from a duly authenticated transcript, filed in the General Land Office of the United States that, pursuant to the provisions of the Act of Congress, approved the third of March, one thousand eight hundred and fifty-one, entitled, "An Act to ascertain and settle the Private Land Claims in the State of California, Manuel Garfias, as claimant, filed his petition on the sixteenth day of September, I 852, with the commisioners to ascertain and settle the Private Land Claims in the State of California, sitting as a Board in the City of Los Angeles, in which petition he claimed the confirmation of his title to a tract of land called San Pasqual, containing three and one-half square leagues, a little more or less, situated in the County of Los Angeles and State aforesaid: said claim being founded on a Mexican Grant to the petitioner, made on the 28th day of November, I 843, by Manuel Micheltorena, then Governor of the Department of the Californias, and approved by the Departmental Assembly on the 7 th day of May, r846. And, Whereas, the Board of Land Commissioners aforesaid, on the 25th day of April, I854, rendered a Decree of Confirmation in favor of the claimant, which Decree or Decision was on appeal affirmed by the District Court of the United States for the Southern District of California. And the said Court further adjudged and decreed that the claim of the above mentioned Appellee is good and valid, and the same is confirmed to him, to the exent of three and one-half square leagues within the bound-

* Some of our pioneer settlers in 1870.74 noticed the crumbling walls of au adobe house on the Arroyo bottom at foot of Hanaford's bluff, a short distance above Sheep Corral Springs ; also rentains of old water ditches there and at other places along up the Arroyo. It has always been a great inystery who made them. They were simply relics of work done by Hanewald and Pine, who believed they could wash gold from these Arroyo sand beds.

fAugust 27th, 1852, the United States Land Comıissioners reached Los Angeles. September i6th Garfias filed his petítion on his San Pasqual claim. September 23rd, says the CentenuiaI IIistory, p. 44, "there was a grand ball at the dwelling of Don Manuel Garfias, in honor of the Land Commissioners." This of course was a socjal affair at the very top of the scale in Los Angeles society. The Garfias mansion was a spacious structure of adobe, and fronted on Main street at corner of First street, where the Lichtenberger block now stands. Mr. G. W. Robinson, now 86 years old, and his wife (of 441 Conmercial street), then lived in a part of the Garfias house and were at this grand ball. The commissioners had rooms in the same buildiug. Mr. Robinson was deputy sheriff several years; and at anotler time had a lot of his own stock on Rancho San Pasqual, and juilt tor himself a house made of tules, up against Dona Encarnacion Abila's adobe house, before Garfias ever lived on the ranch. Mr. and Mirs. Robinson were the parents of the first child ever born in Southern California whose parents were both Americans. 
aries described in the grant and the Map to whish the grant refers, to-wit: On the east of the Rancho of "Santa Anita," on the west by the bluff of the Arroyo Seco, on the north the Sierra, and on the south the range of hills near the road to Los Angeles, these the said hills being included in the said described premises, provided that should there be a less quautity than three and a half square leagues within the said boundaries, then confirmation is hereby made of said less quantity.

"And, Whereas, it further appears from a duly certified transcript, filed in the General I and Office, that the Attorney General of the United States having given notice that it was not the intention of the United States to prosecute the appeal heretofore taken in this cause, the aforesaid District Court, at the December term, I 856 , ordered that the order of appeal heretofore granted in this cause be and the same hereby is vacated, and the Appellee has leave to proceed under the Decree of this Court heretofore rendered in his favor as a final Decree.

"The said tract has been surveyed in conformity with the grant thereof and the said decision. And I do hereby certify the annexed map to be a true and accurate plat of the said tract of land as appears by the field notes of the survey thereof made by Henry Hancock, Deputy Surveyor, in the month of August, A. D. I 858 , under the direction of this office, which having been examined and approved, are now on file therein. And I do further certify that under and by virtue of the said confirmation and Survey, the said Manuel Garfias is entitled to a Patent from the United States upon the presentation hereof to the General Land Office for the said tract of land.

Surveyor Hancock's field notes showed 28 different courses in the boundary line of the ranch, which illustrates the curiously irregular shape of the body of land described; and this was equally true of nearly all of the old Mission or Spanish land grants.

On January i 5th, I 859, Manuel Garfias and Luisa Abila, his wife, executed a deed to Benjamin D. Wilson, * of " all right, title, interest, claim and demand, both at law and in equity, as well in possession as in expecttancy of, in and to the real property * * known as the Rancho de San Yasqual," etc. Consideration, \$I,800. 'This deed is recorded in Book 4, page 3 ro of Deeds, Los Angeles County. That was four years before Garfias had obtained his United States patent for the land, and said patent was the "expectancy" referred to in the above quoted recital of what interests were conveyed. In fact, besides monetary interests, Wilson had a special reason of a personal nature for aiding the Garfias claim before the U. S. Land Commissioners. The rival claim, based on the prior grant of I840, had become a sort of Lugo family affairt-and the Lugos were

*'There is a biography of B. D. Wilson ir the History of Los Angeles Connty, published by Thompson \& West in I 880 , on pages $36-37$.

† As this is au interesting historic episode touching Pasadenland, I will make it more clear. Old Don Antonio Lugo originally owned the San Antonio ranch, 29,513 acres, and the Chimo ranch, I6,000 acres. In 1835 to 1840 he was listed as owning 37,000 head of cattle. and 2,400 horses. He had five sons, as follows : Jose Maria Lugo. Felipe Lugo. Jose del Curmen l.ugo, Vicente Lugo, Jose Antonio l.ugo; and four daughters-Vicenle. wife of Eranio Perez and aunt of Jose Perez to whom (with Enrique Sepulveda) the ranch had been granted in s 40 ; Mlerced, wife of Jose Perez, and after his death wife of Stephen C. Foster, and claimant of the ranch before the U. S. Commission; Maria Antonio, wife of - Yorba: Maria Jesus, wife of Isaac Willians whom B. D. Wilson believed had betrayed him at the battle of 
specially obnoxious to Wilson. In the affair at Chino, in September, I 846 , when Wilson and his company of U. S. soldiers were all captured, he always believed that Isaac Williams betrayed him; and Williams's wife was one of the Lugo women. Then when they were being marched to Los Angeles as prisoners, it was Capt. Jose del Carmen Lugo who wanted to shoot Wilson and all the rest; and they were only saved trom this fate by the heroic and soldierly honor of Capt. Serbulo Barelas. Mrs. Merced Lugo de Perez de Foster, the rival claimant of the ranch against Garfias, was sister to Mrs. Williams and to Jose del Carmen and Felipe Lugowhile Mrs. Garfias was cousin to Wilson's first wife, * so here was a call for him to take a hand in the fight for the ranch, and bring discomfiture upon his old enemies the Lugos. He therefore went into the contest, aided in its management, and won the case.

On December I I, I862, John S. Griffin and Louisa, his wife, deeded to Benjamin D. Wilson and Margaret S. Wilson, his wife, for the consideration of $\$ 500$ a tract of 640 acres " on the Rancho San Pasqual, out of which said Rancho the herein described lot of land is carved." [Book 6, p. 5I.] This conveyance included what was afterward known as the "Fair Oaks" and the Allen property; and the same day, to-wit :

On December I I, I862, Benjamin D. Wilson and Margaret S. Wilson his wife made a deed to Eliza G. Johnston of 262 acres of which the document says: "The said tract hereby conveyed being part of the San Pasqual Ranch, and the southwesterly half of the land this day conveyed by John S. Griffin and Louisa his wife, to the parties of the first part herein ;' etc. The consideration was $\$ \mathrm{I}$, ooo. [Book 6, p. 53.]

This Mrs. Johnston was sister to Dr. Griffin, and wife of Gen. Albert Sidney Johnston, who was in command of the Department of California when the war of I86I commenced. Unionists at San Francisco reported to Washington that Gen. Johnston was planning to turn the resources of his command over to the confederate cause, as Gen. Twigg had done in Texas $; \dagger$ and he was thereupon superseded by Gen. Sumner.+ Johnston re-

Chino. Don Felipe Lugo, justice of the peace, had the original deed that was made of the land to Eulalia Perez de Guillen by the padres, and was trying to aid his sister Merced Foster, widow of his nephew Jose Perez, in her case. However, their claim had the fatal defect of failure to pnt such buildings and such live stock on the ranch as the Mexican law of land grants required, this failure being due to the death of Jose Perez before he could complete his undertaking.

* Dona Vicenta Yorba, widow of Don Tomas Yorba, and then managing the great Santa Ana ranch herself, [January, 1847], "was the aunt of Mr. Garfias, wite of the American Consul at Tepic, Mexico."-See "Sixty years in California, pp 432-3-4.

fGeo. Stoneman was a captain in command of Fort Brown, Texas, and was ordered by Gen. Twigg to surrender the Fort to the secessionists. He refused to obey this order of the commanding General but marched out with his own troops under the old flag and took steamer for New York, and afterward became famons as a Union cavalry officer. And this was our Pasadenaland Gen. Stoneman, Governor of California from 1883 to 1887 . Gen. Stonenan first came to California in 1847 , arriving at San Diego January 29 th of that year as Lieut. in ist U. S. dragoons and quartermaster of the Mormon battalion.

IGen. Sumner was sent from Washington to San Francisco so secretly that the newspaper men did not get hold of it. He went by steamer to the isthmus, then by steamer up the coast The vessel arrived off Golden Gate in the daytime but the General held her from running in until after vightfall; then instead of going directly to her own dock she lauded him and his staff at another wharf a mile nearer the Presidio or fort where Gen. Johnston had his headquarters. Gen. sumner was met by the U. 
signed instead of reporting at Washington as ordered; went south and joined the confederacy ; and was in joint command with Gen. Beauregard of the confederate army at the battle of Shiloh or Pittsburg Landing, where he was killed April 6, I 862. Mrs. Johnston occupied the land above mentioned, built a house on it, and named it "Fair Oaks," after the old plantation home of her childhood in Virginia. April 27, I863, her oldest son, Albert Sidney, was killed in the historic steamboat explosion at San Pedro, his body not being recovered until the 29th. This sad event affected her mind and plans so disastrously that in a few weeks she left the place and never returned to it. Dr. Griffin's wife and Judge B. S. Eaton's first wife were sisters; and Mrs. Johnston's son Hancock married Judge Faton's daughter Mary; and out of this interblending familyhood came the fact of Judge Eaton's settling on this "Fair Oaks" place in I866, where he still resided (and owned it) when the Orange Grove colony settlement was made in $1873-74$.

On April 3, I863, a United States patent for the land comprised in Rancho San Pasqual, was issued to Manuel Garfias, with Abraham Lincoln's signature attached. [Book I p. I 4 of Patents.]

On March 27, I865, B. D. Wilson and John S. Griffin conveyed to Phineas Banning, John G. Downey, Matthew Keller, George Hansen, and R. W. Heath, trustees of the Los Angeles Pioneer Oil Co., "all their riglit, title and interest to any and all brea, petroleum, rock oil or other oleaginous substances in the Rancho San Pasqual." But it was stipulated that they must "commence boring or sinking wells for the extraction of oil within six months ;" and the Oil Company was to pay Wilson and Griffin " a roy-

S. naval officer and the postmaster, and a few others known to be loyal unionists, besides a squad of local militia in citizens' dress, with sidearms only, in command of Capt. D. M. Greene, now of Pasadena. These formed his escort to the fort, where they arrived after midnight. Gen. Sumner weut in alone, and had Johnston called up out of bed. The two Generals had been classmates at West Point, were intimately acquainted, shook hands cordially, then Sumner delivered the sealed documents from Washincton directing Johnston immediately upon the receipt of these orders to turn over his command to Gen. Sumuer. Johnston opened and read the papers, and then with a forced smile said. "Geueral, the command is yours." Sumner spent the rest of the night in preparing orders, putting his own staff iu command, etc., so that when daylight arose California was saved to the union instead of being (as it would have been in three days more) held in control by open adherents of the pro-slavery rebellion - for this element was strong, boastful and bullying in California at that time. R. H. Williams of Pasadena lived in Sa francisco then, and was a member of Co. D Washington Light Infantry-a local militia organization, and also vouches for these events. Mr. Williams afterward served in the Califoruia Battal. ion of $2 \mathrm{~d}$ Mass. cavalry. He is adjutant of John F. Godfrey Post G. A. R., in I895.

Capt. Greene has a copy of the Mesilia, Arizona, Times [a secession ist paper] of A ugist 3, 1861, from which I quote this: "The followiug named gentlemen under command of Capt. Alonzo Ridley, arrived in our city on the $3 i s t$ ult.. from Ios Angeles, Cal. : GEN.A.S. JoHnston, a uative of Kentucky, late in command of the Department of California," etc. Then follows a list of seven lieutenants with him who had resigned from the U.S. army : and twenty-six volunteer recruits-all on their way to join the con. federate arny. The same paper names nine companies of confederate soldiers then holding Arizona and publishes the proclamation of John I. Baylor as acting governor on behalf of the Confederate States of America Capt. Greene's force of union troops afterward captured Mesilla, and used the same printing office to issue a union paper.

Judge Waltet Van Dyke of the superior court, Los Angeles, was a Douglas democrat in 1860 ; then in 861 he was elected to the state senate on the "Union Ticket" by the close majority of fourteen, and bore an important part in saving California from secession. He kuew Gen. Johnston; says lie was a man with a fine setse of personal houor; and he thinks that Johuston, like Gen. I,ee, was struggliug with his conscience as to whether his present duty was to the general governmeut, or first to his native state (Kentucky) according to the state rights doctriue which then prevailed in the Sonth-hence he did] not take any decisive stand either for or against the secession novement. But meanwhile some army officers under him, and certain politicians, presuming on lis southern sympathies, were plotting and planuing to give California over to the Confederacy, -thus implicating him without any direct participation or purpose on his part, yet naking his prompt and quiet removal a prime uecessity for the Union cause. I make this explanation as due to the feelings of Gen. Johnston's family and relatives who still reside amongst us. 
alty of ten per cent. net of all the crude oil extracted from these lands," free of all expense to them except that they must "furnish their own casks." -Wilson and Griffin were themselves members of this Oil Company. The consideration for this grant was only One Dollar, besides the "royalty," and the grant was "limited to the term of twenty-five years." [Book 9 p. 490 of Deeds.] But I have found no evidence that any oil wells or even prospective borings were ever made on the ranch, though "smelling committees" have several times sniffed over the ground and thought they found oil "odor" down around Columbia hill.

September I 2, I866, Eliza G. Johnston conveyed to John S. Griffin all her right of pasturing, herding and grazing 500 head of live stock on the Rancho San Pasqual which had been granted in her deed from B. D. Wilson and wife on December I I, I862. Consideration, $\$ 2,500$. [Book 8, p. 213 , of Deeds.]

On March 3, I869, B. D. Wilson deeded to Phineas Banning all his right, title, interest, share, claim or demand whatsoever in the Rancho San Pasqual. Consideration, $\$ 35,000$. [Book I2, p. 237.]

On March Io, I869, Phineas Banning deeded to John S. Griffin, [Book I 2, p. 3I I] all his right and interest acquired by deed from B. D. Wilson, only seven days before. Consideration, $\$ 30,000$.

On October I 3 , I 869, Phineas Banning deeded to Benjamin D. Wilson [Book I3, p. 628] the same property rights and interests described in Wilson's conveyance to Banning on March 3, and in Banning's conveyance to Griffin on March IO, as above given. But this time it is described as "the Rancho de San Pasqual, in the township of San Gabriel "- - this being the first mention of San Gabriel township in any of the deeds. Consideration, $\$ 35,000$. The explanation of these last three peculiar and apparently conflicting transactions is this: Banning, Griffin and Wilson were intimate friends and all engaged in very large trading, speculative or business enterprises. They often borrowed large sums of money or credit from each other, giving a deed or mortgage as "collateral" security-sometimes put on record and sometimes not.

On September 23, I870, John S. Griffin deeded and quit-claimed to B. D. Wilson [Book I 5, p. 482] an undivided half interest in all of the Rancho San Pasqual that had not before this date been sold by deed or contract to third parties. Consideration, \$I. It seems that prior to this the Monks tract of 2,000 acres, the Grogan tract of 5,000 acres, and the Raab tract of 30 acres had been sold, besides the "Fair Oaks" tract conveyed to Griffin's sister, and some lesser parcels to relatives of Wilson. There was also a parcel occasionally mentioned as the "Widney tract," but not found of record.

On June 20, I872, Griffin and Wilson deeded to Prudent Beaudry [Book 2 I, p. 26] a parcel of hilly land on the west bank of the Arroyo Seco, 
estimated as 30 acres, opposite what is now the junction of West Columbia street and Arroyo Drive. There, in $1875^{-7} 6$, Beaudry, and a man named Carson (son of Gen. Fremont's famous and faithful scout, Kit Carson), worked a shaft into the hill or Arroyo bank 200 feet, seeking for a coal mine. They found carbonaceous shale and a few pockets of lignite, or possibly indurated asphaltum, but no true vein of coal.

In October, 1873, Griffin and Wilson employed Wm. P. Reynolds to survey the remainder of the Rancho into four separate parcels marked as tracts Nos. I, 2, 3 and 4 , and to make a map of the whole. Tract No. I contained 2,576.35 ácres. No. 2 contained $1,366.03$ acres. No. 3 contained 693 acres. No. 4 contained also 693 acres. Total 5,328.38 acres.

On December i 8, i873, Griffin and Wilson made an agreement of partition, with said Reynolds' map attached as a part of the agreement [Book 27, p. 229], by which Griffin took tracts Nos. I, 3 and 4 for his share, and Wilson took tract No. 2 for his share of the now completely broken up old ranch. The right to burn lime at the kilns on tract No. I (Lincoln Park region) was reserved to Wilson, and an equal share of the waters of the Thibbet's Springs on tract No. 2 was allotted to each party. Thus it exhibits that Wilson took I, 366 acres for his share, and left Griffin 3,962.35 acres. But this apparent disproportion was made up in the deed by Griffin to Wilson, September 23, I870, of a body of choice oak timber land, surveyed by J. M. Baldwin, in August, 1870, lying east of this latter tract No. 2 (Fair Oaks avenue being now on its line), and south of the Grogan tract.

On December 26, 1873, John S. Griffin deeded to Thomas F. Croft [Book 27, p. 25I] all of the partition tract No. I as marked on the Reynolds' map, containing 2,576.35 acres ; and another parcel of land described by metes and bounds, and containing 1.357 acres ; total, 3,933.35 acres, with all waters arising on these lands, or otherwise pertaining to them. Consideration, $\$ 25,000$.

The San Gabriel Orange Grove Association (commonly called "Indiana colony") had been organized Nov. 13, 1873, and had been negotiating for the purchase of this body of land from Dr. Griffin, with Judge Eaton acting as his agent. At this time [November I3] Griffin and Wilson still owned the land jointly. Griffin was anxions to sell out, but Wilson was not, and some difficulty arose between them in regard to it. This caused delay, and for awhile threatened to break up the colony project entirely. Mr. Croft was one of the original incorporators and trustees of the colony association; and at this critical time he went to Wilmington [December 13 ] to confer with Phineas Banning and B. D. Wilson, and succeeded in bringing about an understanding which finally resulted in the agreement of partition between Wilson and Griffin, dated December 18, г873, as above cited. This enabled Griffin to go on and complete the sale which he desired to make. But now the colony people could not at once raise the amount of money necessary to 
meet his terms. Mr. Croft then privately, at his own expense, procured a complete abstract of title which covered every transaction affecting the ownership or any auxiliary rights comnected with this body of land, from November, I 843 , to December, 1873 ; and upon this he purchased the land himself under the above cited deed of December 26, in order to secure it beyond further delay or difficulty for the colony association. The abstract referred to is a voluminous document, comprising nineteen sheets of heaviest grade abstract paper, $81 / 2 \times 13$ inches, printed in close lines of small type, and cost Mr. Croft over $\$ 50$. He preserves it yet as a valued relic of the colony's cradle-bed time, and I am indebted to him for its use in preparing this schedule of the many changes of ownership and other rights which have occurred in the history of Rancho San Pasqual.

Mr. Croft's diary shows that he first visited the ranch on October I 3 , I 873, in company with D. M. Berry and J. H. Baker. Reynolds was then making the tract survey for Griffin and Wilson, and Croft and Berry came out from Los Angeles frequently to note the progress of the survey and study the lay of the land. Mr. Berry was negotiating on behalf of the colony for the land they wanted, and he insisted on having their strip project eastward along where East California street now runs, instead of northward along the Arroyo Seco. Wilson wouldn't have it that way, because it would leave his own land in very inconvenient shape; and the efforts to coerce him in this matter brought about the anger and hot blood between Wilson and Griffin above referred to, and delayed the colony purchase all through November. Mr. Croft saw Mrs. Griffin and got an understanding with her; then on December 13 , he went to Wilmington as a peacemaker and colony land-buyer himself, and gained his case successively with Mr. Banning, Mrs. Wilson, and finally Mr. Wilson. Then on December I5, his diary says: "This day, determined stakes and points of satisfactory division of Rancho San Pasqual with B. D. Wilson on the grounds." On December 16, he met Wilson at surveyor Reynold's office in Los Angeles, and arranged details of boundary to be recited in the conveyance. December 17 , lawyers were at work preparing the articles of agreement on segregation of interests between Wilson and Griffin. December I 8 , Wilson and Griffin signed these articles, without which the colony purchase from Griffin could not be consummated. The question of colony funds, spot cash, now made another balk. So, on December 26, Mr. Croft paid Griffin $\$ 6,250$ cash himself, and gave his note for the balance, $\$ 18,750$, in one year, and received the deed as above mentioned.

On December 29, 1873, three days after Griffin's conveyance of the entire colony tract to Croft, Thomas F. Croft deeded all his right, title and interest therein to the "San Gabriel Orange Grove Association, a corporation duly organized under the laws of California," etc. Consideration, $\$ 25,000$ [Book 27, p. 267], the same as he paid. The association then 
assumed all of Mr. Croft's notes and obligations, according to an agreement which he had made with Dr. Griffin beforehand, and paid them by quarterly assessments on the shareholders, or by sale of lands when it could be done.

On January 27,1874 , the colonists assembled on Reservoir Hill, and each made selection of his own choice of lots in the tract as platted by the colony's surveyor, equal to his number of shares of stock in the association. A complete list of these original selections is given in another place, with explanation of where each one lies now [1894] in the present sity of Pasadena. [See Chap. 5.]

\section{CHAPTER IV.}

Pasadena's Part in the Mexican War.-Capture of Los Angeles in in 846.-Lieut. Gillespie driven out. - Battle of Chino. - Battle of Los Angeles. - Battle of Domingnez ranch. - Carrillo's hippodrome strategy at San Pedro.-Army flag made from children's dresses. - Battle of San Gabriel ford.-Battle of Laguna ranch.Mexican army encamped at South Pasadena.-Plans made there for their final surrender to Col. Fremont.-List of Pasadena families correlated with these notable events.

HOW PASADENA FIGURES IN THE CALIFORNIA BATTLES.

Don Manuel Garfias, the first patentee owner of Rancho San Pasqual, and B. D. Wilson its second recorded owner, and Dr. John S. Griffin its third owner, all bore a part or had deep concern in the battles of San Gabriel and the Mesa, or Laguna Ranch, fought between the American and Mexican forces on January 8 and 9, 1847. A portion of the Mexican troops under Garfias' command took horses and cattle from this ranch for their march back to Mexico. And from his camp on this ranch Gen. Andres Pico appointed commissioners who made and signed the final terms of surrender to Col. Fremont, known in history as the "capitulation of Cahuenga," and which was the last official act, and in fact the only one, of MexicCalifornian authorities for turning the vast territory of California over to the United States. But besides these, there are other Pasadenian families that have historic association with the stirring events, battles and marches of I $846-47$; and therefore I devote a chapter to this part of our local history.

The name of note in Pasadena history which first appears in connection with the military movements for securing California to the United States is that of Don Juan Bandini, after whom Bandini avenue was named (miscalled "Michigan" avenue in part of its course.) This man's son, Arturo Bandini, married a daughter of Dr. T. B. Elliott, the first president of the original "Indiana colony," out of the ashes of which Pasadena arose, and 
he gave to the world the now famous name of "Pasadena." Mr. and Mrs. Arturo Bandini have been prominently identified with Pasadena's sporting, social and literary life for twenty years. Every book written about California by any citizen of the United States prior to the Mexican war, such as Dana's "Two Years Before the Mast," Robinson's "Life in California," Davis' "Sixty Years in California," etc., make frequent mention of Don Juan Bandini, because he was a man of note and influence at San Diego, Los Angeles and Santa Barbara. But his first connection with U. S. military affairs is explained in Gen. Fremont's "Memoirs," pages $563^{-64}-65$, as follows:

THE: TAKING OF LOS ANGELES IN I 846.

"The ship [sloop Cyane] entered the land-locked bay of San Diego, where the still waters reflected the quiet of the town. Here no enemy was found. On the contrary, we were received on the footing of friends by Don Juan Bandini, the chief citizen of the place, and by Don Santiago Arguello [father to Mrs. Bandini], the Captain of the port. [This was July 27, I 846.-Ed.] Senor Bandini was a native of Spain; of slight and thin person, sarcastic and cynical of speech, often the shape in which a keen intelligence, morbid because without outlet, expresses itself. * * * One of Don Juan's daughters was married to Don Abel Stearns, whose residence was at Los Angeles."

Fremont's troops could not move a mile from their ship withont horses and beef cattle for their subsistence and transportation; and speaking of this matter, he writes :

"There were not enough horses at hand to mount a party to send after animals to distant places through an enemy's conntry. In the midst of these difficulties, the aid which Bandini and Arguello were willing to give us was most fortunate. * * * After little more than a week occupied in this way [collecting horses and beef cattle] with the aid of Don Juan, a sufficient number of animals were obtained to enable me to move ; and on the 8th of the month [August] we moved out on the road to Los Angeles. * * Just before leaving the town an uncommonly beautiful sorrel horse, thoroughly trained, was brought me from Senor Bandini. * * It was a gift from the family."

With Fremont on this march was his famous scout, Kit Carson, whose son Sam, nicknamed "Kit," afterward lived a while at Pasadena, and in 1876-77 dug the entrance shaft for the Beaudry coal mine opposite the foot of Columbia street. He had formerly worked for Don Juan Bandini at San Diego.

While Fremont was in San Diego, in r 846 , Commodore Stockton had arrived at San Pedro, and on Aug. I Ith he commenced his march from there towards Los Angeles, being joined on the r $3^{\text {th }}$ by Fremont's troops, and they marched into the city together without any armed resistance, hoisted the America flag and took possesion of the country in the name of the 
United States.* August 28th, Stockton sent Kit Carson as bearer of despatches to Washington, reporting all his proceedings here, and Carson started on horseback across the country to Santa Fe. Lieutenant A. H. Gillespie with about fifty men was left in command at Los Angeles; Fremont marched north overland to Sacramento, and Stockton returned to his ship and sailed north. But before leaving, Commodore Stockton had commissioned B. D. Wilson as a Captain in the U. S. Army, and authorized him to raise a company to guard the frontier. At this time Wilson owned the great Jurupa ranch which he had bought from Don Juan Bandini, and his ranch house, with gardens, orchards, etc., was located near where the City of Riverside now stands.t Gillespie proved entirely incompetent for the position he was placed in. He exercised his authority in a way to exasperate the intelligent Spanish citizens who were peacefully disposed. He arrested some of the Spanish "Dons", and held them responsible for a drunken mob attack on his quarters on the night of September 16, Mexican "Independence Day," when in fact his own men were as much to blame for the carouse as the Mexican revelers, and over half of his soldiers were lying locked up in the guard-house for drunkenness at the very moment when the drunken Mexicans assailed the barracks. His unwise course in the matter so outraged and incensed the better class of citizens that they raised a revolt to drive him out of the country. He then sent a courier to Captain Wilson for help.

THE BATTLE OF CHINO.

Wilson got twelve of his company together as quickly as possible and started for Los Angeles. They went to the Chino ranch house, a large adobe structure, in hope to find a supply of powder there for them, and while there they were surrounded and attacked by a body of Mexicans in command of Serbulo Barelas of Los Angeles, and Jose del Carmen Lugo of San Bernardino. A sharp battle ensued here at daylight of September 27, 1846. The Americans were sheltered in the adobe house of Isaac Williams;

* Governor Pio Pico and Gen. Castro fled the conntry, and have been accused of cowardice for it. $T t_{a}$ at is a mistake. Pico had issued a patriotic address appealing to the Mexicausto rise iu arms and repel the Anerican invaders. But Gen. Castro reported to the Governor, and to the L,egislative Assembly then in session at Los Angeles, that from lack of powder aud firearms he was utterly unable to cope with the well armed, well equipped and disciplined American troops. Governor Pico then advised that the legislature adjourn sine die, and that he and the commanding general should get away, so that the Americans should not find any man or body of men in authority to transfer the government to them. 'This was "good politics" on their part and the plan was followed out; and this was why he fled. Fremont tried hard to entice Pico back bist he was too shrewd to come, still hoping that either Mexico or Fngland would yet overturn the American occupancy. Don Juan Bandini and his brother-in-law, Santiago E. Arguello were members of this legislative assembly, though not present at the adjournment. They were auti-Pico men. Governor Pico died at Los Angeles, September 11, 1894, aged 93.

†From Robinson's "L,ife in California," pp. 203, 204, I quote a few passages that have a Pasadena interest. They were written in early spring time of 1842 .

"We resunied our saddles and soon reached Santa Ana. plains of the Rancho de San * At sunset entered upon the plains of the Rancho de San Juan del Rio, the dwelling place of Senor Bandini. We found our friend Yorba [grandfather of Mrs. J. de Barth Shorb/ here. * * We visited the planting grounds of Bandini, which were beautifully laid out on the side of the river. [Hence the name, Riverside.] On our route back to the Pueblo [Los Augeles] we passed through a long valley [San Gabriel Valley] which was the scene of destruction during the slaughter of the Missinn cattle in 1835 . Its devastation was still visible, for skulls and bones were lying about in every direction." 
but it had an asphaltum roof, and the Mexicans succeeded in setting this on fire, so that Wilson and his men were now at their mercy; and on promise of protection as prisoners of war they surrendered. They were marched to Los Angeles and turned over to Gen. Jose Maria Flores, who had been chosen commander-in-chief of the Mexican troops. While on their march to Los Angeles, some of the victors, led, as B. D. Wilson afterward claimed, by Capt. Jose del Carmen Lugo, concluded to end all this trouble at once by shooting the prisoners right there.* And of this episode the $1880-H i s t o r y$ of Los Angeles County, page 43, says: "The treacherous Mexicans had drawn their prisoners up in file on one side of the road, and were about to massacre the whole lot. Barelas bravely dashed between, and swore he would run his sword through the first of his command who dared to fire a shot. He said he had pledged his honor as a man and as a commander for the safety of the prisoners, and only over his dead body might they suffer harm."

\section{THE BATTLE OF LOS ANGELES.}

When Gillespie sent to Capt. Wilson for help, the latter was off in the mountains with most of his company, on a bear hunt, and there was a delay of some days in finding him. Meanwhile, as Hittell's History relates, the Mexicans made a dushing assault on Gillespie's barracks, September 23 ; $\dagger$ but as the Americans were well armed, had plenty of ammunition, and were sheltered within adobe walls, the assailants were defeated with a loss of eight killed and many wounded. [See J. G. Parson's "Life of John W. Marshall.'] This was four or five days before the Mexicans had found their own hidden-away cannon which afterward became famous as the "Woman's Gun." Notwithstanding their defeat the Mexicans kept Gillespie in a state of siege and he probably could not hold out another week. September $27-28$ the Chino prisoners were turned over to Gen. Flores. There had been a sort of guerilla fight going on every day. And on the 29 th, Flores, with a view to save further bloodshed, sent B. D. Wilson to tell Gillespie that he might march out unmolested if he would go to San Pedro and there embark his troops. Now, before Stockton and Fremont left in August, Gillespie had dug up and brought into his barracks some old Mexican cast-iron cannon which had been spiked and buried in a field east of Boyle Heights, when Gen. Castro and Gov. Pico fled the country on Stockton and Fremont's approach; and now, to shade off the ignominy of retreat, he asked permission to take these cannon along on his march. This was *Bancroft says there was "a young man named Sepulveda" who joined with Lugo in this scheme
to shoot the prisoners. I learn from Jesus Rubio and E. S. Hereford that the man referred to was Enrique Sepulveda, who with Jose Perez had received a grant of Rancho San Pasqual in 1840.

†'"The assailants, according to Marshall's biographer, were forced to retreat, with a loss of eight

killed."-Lewis' Hist, Los A. Co. p. 72. [Pub. 1889.] beseiged Gillespie and his handful of men. ${ }_{*}$ He, however, made a determined resistance, until finally on September 30 , finding the odds too great against him, he capitulated." - Hitlell's History
Cal., 2, p. 599 . 
finally agreed to, on his promising to restore the guns to them at San Pedro. [John Marshall, he of gold discovery fane, who was one of Gillespie's soldiers in Los Angeles, had unspiked one of the cannon and used it against the Mexicans on Fort Hill, after their unsuccessful assault on the barracks below.] But when Gillespie reached San Pedro, instead of restoring these guns as he had promised to do, he broke off all their breech knobs, had them packed tight with small gravel stones, and then rolled into the surf at low tide.*

This act of bad faith and over-smart strategy further incensed the Mexicans against him, and greatly increased the peril of B. D. Wilson and his fellow-prisoners; and they would have been killed but for the faithful watch kept over them by Serbulo Barelas, who had at the battle of Chino given his word of honor to protect them as prisoners of war, which he repeatedly did at the risk of his own life. The next January B. D. Wilson learned from Gen. Andres Pico just where these cannon were; and as they were of no use to the government, Commodore Stockton gave him permission to secure them as relics. Three of them were old Mexican guns which Gov. Micheltorena had hauled down from Monterey and used against the Los Angeles revolutionists at the battle of Cahuenga, February 2O-2I, I845. Micheltorena sent them back to Los Angeles by Mauricio Gonzalez, after his embarkation at San Pedro to return to Mexico.

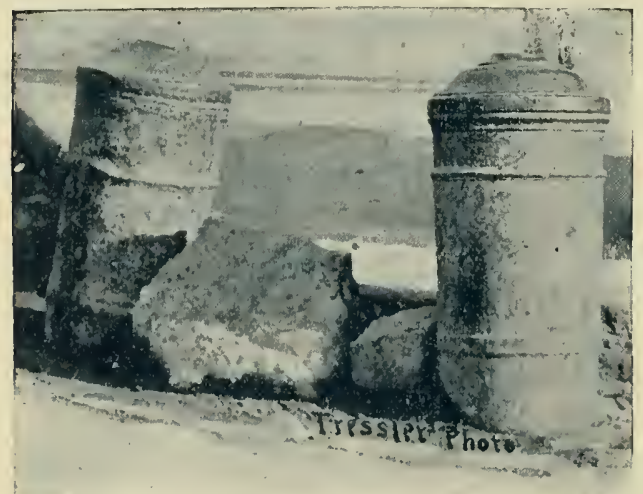

The historic cannon at corner of Main and Commercial streets. - Photo 1895 .

Wilson eventually hired some Mexican cartimen [in 1849 or '50] to haul them up from San Pedro, where they had lain in the salt water until that time and were badly "pock-marked." He planted them, muzzles down, in front of his store on corner of Main and Commercial streets, and two of them remain there yet, just as he put them; but at the centennial celebration of the founding of Los Angeles city (I88I) two of them were placed on corners at the old court house; and in 1892 these two were removed to west front of the new court house, where they may now be seen.

As soon as Gillespie had been driven out, as above noted, Don Manuel Garfias (our Pasadena first patentee) was sent with a small troop of mounted ment to retake Santa Barbara, where a garrison of ten men had been

* "There is a general agreement that Gillespie promised to deliver his field pieces at San l'edro, but broke his promise." - Hisl. Cal., Vol. $5, p .315$.

f" Manuel Garfias, one of the Californian leaders, marched with two hundred nen to Santa Barhara," etc.-Hillell's Hist. Cal.. Vol. 2, p. 6oo. This is a big exaggeration, for Garfias had not to exceed fifty men-but nearly all our Americau writers magnify the Mexican uumbers. 
left by Commodore Stockton or Fremont to hold the place. They heard of his approach, and escaped in the night. Garfias left a small Mexican garrison there, and one also at San Buena Ventura, and then returned to Los Angeles with forty or fifty recruits for Genl. Flores' army, but did not arrive until after the battle of Dominguez. He brought in as a prisoner from Santa Barbara an American named George Nidever, who refused to give his parole; but Nidever escaped from Garfias at Los Angeles, succeeded in reaching Stockton's army, and was in the battles of January 8 and 9, r847. This Nidever was the same man who afterward in 1853 discovered and rescued the native Indian woman who had lived on San Nicholas island entirely alone for cighteen years. He was offered $\$ I, 000$ to sell her for a traveling show; but he was opposed to slavery, and refusing the golden bribe, he gave her protection and a home in his own family till she died.

THE BATTLE OF DOMINGUEZ.

On reaching San Pedro, Lieut. Gillespie embarked with his troops October 4, for safety, on the merchant ship Vandalia, which chanced to be lying there. October 6 Capt. Mervine arrived there from San Francisco with the U. S. frigate Savannah. On the 7 th he landed 350 of his men, who were then joined by Gillespie's men, but without horses or cannon, for Gillespie told Mervine that the Mexicans had no artillery, as he had brought away and destroyed all their cannon, and therefore he wonld need none. This force of 400 men marched to the Dominguez ranch house and camped there for the night. The next morning, October 8, they formed in marching order and started for Los Angeles, but were immediately attacked by a force of ninety men uinder Don Jose Antonio Carrillo, one of the Spaniards whom Gillespie had so indiscreetly arrested only three weeks before. Carrillo had a small brass cannon, [the historic "Woman's gun"], which his men manœuvered by hauling it about with rawhide ropes tied to the pommels of their saddles. They would dash forward and fire it at Mervine's marching column, then gallop off with it out of musket range and reload, then back to the front, discharge it, and off again. They fired four times in this way during a running fight of about three miles, and had loaded again with their last ball; but by this time six Americans had been killed and six or seven wounded, and Mervine retreated to San Pedro, buried his dead on Deadman's Island, and re-embarked his crestfallen troops.

On his retreat, Mervine stopped at the ranch house again, and compelled an old workman there to hitch up an ox-cart and haul the dead bodies to the beach at San Pedro. During these operations some accoutrements of killed or wounded men and a flag were carelessly left behind. These were gathered up by Carrillo's men as trophies of their victory. During the next month, November, Don Antonio F. Coronel started as a commissioner to Mexico to obtain funds and other aid for Gen. Flores' 
army ; and carried with him the American flag captured at Dominguez as a progf of their patriotic prowess. But he did not succeed in reaching Mexico.

Different writers have given somewhat varying accounts of this battle, but I have relied chiefly on that written by Stephen C. Foster, who came to Los Angeles with the Mormon Battalion, (as did also our Gen. Stoneman,) in March, I 847, and served as government interpreter two years there, and also as alcalde or district judge ; then was elected to the first constitutional convention, where his services were exceedingly valuable, because he was a proficient Spanish scholar and familiar with the old Spanish archives. * From various writers I gather that no Mexicans were killed or seriously wounded in the battle of Dominguez. They had no cannon balls, only some rude ones that were hammered ont by a blacksmith, and no powder except some very inferior stuff which they made themselves at San Gabriel. After his account of this battle, Foster continues :

\section{RUSE DE GUERRE AT SAN PEDRO.}

"The next day Commodore Stockton arrived [from Monterey] with the remainder of his ships, [another writer says, October 23, on the ship Congress.-ED.] and landed 800 men and six light guns, to march on the town [Los Angeles] next day. $\dagger$ But Carrillo manœuvered his force of 400 men [he had been reinforced by ranchmen and others from Temple's ranch, Sepu1veda's ranch, and other points.-E. E.] by forming them in a circle in columns of fonrs, so that some eighty men could be seen at once from the ships' mast-heads marching toward the beach and disappearing in a hollow. The middies were in the topmasts with their spy-glasses, counting the enemy's force, and by dark they had counted more than two thousand; and they were still marching when night fell. Stockton re-embarked the next day and proceeded to San Diego. ' +

Stockton had found that there was no chance for him to get a supply of horses at San Pedro necessary to mount a portion of his troops and haul the artillery; and he knew of the friendly aid Don Juan Bandini had given to Fremont six months before. These were reasons for his going to San Diego, where there was also safe harborage for his ships-which there was not at San Pedro at that time of year; and he arrived there about November I. Bandini was away at his Guadalupe Rancho in Lower California, and the Mexican adherents had driven all cattle and horses to inland points

*Foster married Jose Perez's widow, who was the first white womau that ever lived on Rancho San Pasqual. [See Chap. 3.]

$\dagger$ 'Carrillo now assembled a vast cavalcade of wild horses from the plains, and dispersing his mounted troop: anong them, the whole body was kept constantly in motion, passing and repassiog a gap in the foothills plainly discernible from the roadstead. Owing to the clust raised by this cavalcade it was impossible to discern that all the horses had not riders, when it was seen that some liad." - Hist. L. A.Co., (1980) p. 13 .

†B. D. Wilson was then at 'Temple's ranch (Cerritos) as a prisoner, and saw Carrillo's strategic display of men and horses; and he wrote in his memoirs that Stockton did not land any troops; hut stockton himself made official report that he did land them. And I explain Wilson's nistake in this way: While Carrillo was performing his hippodrone strateg», Gillespie was trying to land fifty marines but was signaled back, aucl all returned to ship; and this part wilson saw, but dicl not see the rest. Yet the next day stockton himself put 800 wet and six cannon ashore; but not beiug able to get any horses or oxen to haul the artillery, nor any horses to monnt skirmishers or sconts, he re-embarked and sailed to San Diego. 
beyond the reach of the Americans.* While awaiting events here, Stockton learned that Gen. S. W. Kearny was marching overland from Santa Fe.

THE BATTI.E OF SAN PASQUAL.

On December 6, I846, Gen. Kearny had reached the Indian village of San Pasqual in San Diego county, $\dagger$ with 160 men and three cannon; and here he attacked a force of eighty Mexicans who had no cannon, under Don Andres Pico, another of the Spaniards whom Gillespie had unwarrantably arrested and locked up in his guard house at Los Angeles on September I7. A hot battle was fought, in which Kearny himself was wounded, and also Lieut. Gillespie who had been sent by Stockton to join him. Dr. John S. Griffin of Pasadena fame, was surgeon on Gen. Kearny's staff; and in his journal he reported the American loss as eighteen killed, three mortally wounded, sixteen wounded who recovered, one missing and never accounted for. In addition to this, three were taken prisoners by the Mexicans; and they also captured one brass cannon. The Mexicans had none killed, but eleven were slightly wounded, and one of them had to have a leg amputated.+ One of their men was taken prisoner. Commodore Stockton got word of the affair the next day, and immediately dispatched a force of 200 men to Kearny's relief. By this aid Kearny arrived at San Diego December 12, with his wounded and the remnant of his command. The San Diego residence of Don Juan Bandini was Commodore Stockton's headquarters, and that of Bandini's brother-in-law, Santiago E. Arguello, was used for a hospital.s Dr. Griffin of course had charge of the wounded in their improvised hospitals at San Diego. Another man in the battle was Kit Carson, whose son afterward figured in Pasadena, and whose cousins and a nephew reside here yet.

Bandini was a man of superior intelligence and culture. He had become heartily tired of the continual revolutions and changes of government in Mexico and California; he had always been friendly to Americans as traders here; he believed the United States could give them a stable gov-

*"Rancheros must at once remove their live stock from the coast beyond reach of the naval forces ; whoever refuses is a traitor."-Order of Gov.-Gen. Flores, October 17, 1846.

$f$ "San Pasqual of battle memory is thirty-four miles northeast from the city of San Diego, close to the foot of the mountains."-Tourists' Guide to S. Cal., p. 6r.

IIn his report to the Secretary of War, Gen. Kearny said: "The enemy succeeded in carrying off all their dead except six" "This was such a brazen and ludicrons false pretense on his part that the soldiers dubbed him "Fxcept-Six Kearny" - and this nickname stuck to him through life. Sergeant Falls, who was in the battle, spoke at a meeting of Mexican War Veterans at Sau Francisco in J11ne, iS85, and said the Mexicans captured the cannon by lassoing its lead horses; but Kearny had tried to belitile the prowess of the Mexicans by claiming that his artillery horses merely took fright and ran awav into the enemy's lines. I have learned that the man who did that historic job of lassoing was Mannel Rubio of San Gabriel, nncle to onr Jesis Rubio; aud Manuel's uncle Casiniro was wounded at the same time, as mentioned by Bancroft. Then Manuel's brother, Francisco Rubio, was fatally wounded in the battle at I aguna ranch, was hauled home from the battle field in a cart by his nephew, Jesus Rubio of ubio canyou fame, and died the next day at San Gabriel.

3Stockton had taken Baudini's house for army nse. His headquarters mess was there, and the band from his flag-ship "Congress"; and the commodore would often invite the Bandini family and others to dine with him, and would have the band play during the dinner hour. See Davis' "Sixty Years in Cal.," p. 418. This Davis's wife was niece to Baudini's first wife, and cousin to MIs. Col. Baker of Los Angeles, owner of the Baker block, the Laguna ranch, and other great properties. 
ernment, and he preferred it to any English protectorate. With these views, he and his brother-in-law, Arguello, had esponsed the American cause. The Mexican government had ordered all the ranchers to drive their cattle, horses, hogs and sheep to the mountains, beyond reach of any American troops that might land along the coast. Bandini then owned two great ranches, Guadalupe and Tecate, in Lower California,* and he refused to obey this order, but instead had armed all his tenants and employes, ready to fight if any Mexican troops attempted to enforce that order on his lands. This was the situation in November and December. Stockton's army was literally "out of meat ;" and now he sent an expedition down into Lower California, which became very famous by reason of " a woman in the case," Dona Refugio Bandini, who made from her children's garments the first American flag ever made on the Pacific coast, and thus at the time met a serious emergency for an American army officer marching without a flag.

\section{THE ARMY FIAG MADE FROM CHILDREN'S DRESSES.}

During the winter of $1882-83 \mathrm{Mr}$. H. C. Dane learned from Col. R. S. Baker and wife, and Dona Refugio Bandini and her daughters, Mrs. Dr. Winston and Mrs. Charles R. Johnson the particulars of the first American flag ever made on the Pacific coast. Mr. Dane wrote out the story and it was published in The Home Guardian magazine of Boston, for April, i 883. And from its pages, I54 to 157 , (Vol XLV, No. 4,) I make the following extracts : $\dagger$

"Cut off from all other sources of supplies, the Commodore despatched a vessel down to Todos Santos Bay, [now called Ensenada] opposite the San Guadalupe rancho, with 200 men under command of Major Hensly, with orders to land and proceed to Guadalupe, and there obtain the necessary supplies of Don Juan Bandini. When the vessel arrived at Todos Santos Bay, Don Juan was there, secreted among the rocks, awaiting them. With Major Hensly and his men Don Juan returned to his rancho. where he gave to him 500 cattle, 200 horses, and eight carretas, or long, narrow carts, usually drawn by four, six, or eight yokes of oxen each.

"As the Mexican forces were hovering about Bandini's ranches, especially about the San Guadalupe, in great numbers, and realizing that he and his fanily wonld no longer be safe in their vicinity, Don Juan, with all his family, left the rancho with Major Hensly and started overland for San Diego, where he had a very large house - a kind of Spanish palace.+

"In due time the party arrived at La Punta, fifteen niles below San Dicgo, where they went into camp for the last night. In the morning Major Hensly, wishing for a flag to head his coltunn, to his chagrin and disgust discovered that none had been brought with them from the vessel.

\footnotetext{
*He had previonsly owned the Jurupa ranch [Riverside] and the Rincon de Santa Ana ranch in the San Gabriel district.

In the Centennial I istory of I,os Angeles Co., pp. 32-33, Col. J. J. Warner gives some account of this Bandini flag incident; but there is no other account of it so full and authentic as this one by Mr. Dane.

f"Onr administrador, hon Juan Banlini's mansion, then in an unfinished state, bade fair when completed to surpass any other in the cumtry." "Life in California." p. IS, March, iSzg. By Alfred Rabinson, who is still living (1894), and now a banker in San Francisco, althongh blind.
} 
This placed him in a very unpleasant condition, for to enter the town with no colors flying, would seem to denote that he dared to carry none; and a still more distressing consideration was that Commodore Stockton, upon seeing a heavy column entering the town with such an array, and displaying no flag, might very naturally take them as a band of the enemy, and open his broadsides on them.

"In his distress, Major Hensly made known his mortifying condition to Don Juan, and very naturally that gentleman communicated the fact to his devoted wife. And now occurred a wonderful display of woman's wit, and but for the attending circumstances, it might also be denominated humor. A pproaching the crest-fallen Major, the smiling lady said:

"'Why, Major, I will furnish you with a flag.'

"'You will furnish me with a flag? Pray tell me how!' replied the surprised officer.

"'Oh, leave that to me,' rejoined the lady. 'When the column is ready to move there shall be a United States flag at its head, to guide and herald our entree to San Diego, my home by the sea.'

"Dona Refugio immediately called to her side her three children, Dolorosa, aged ten, who was dressed in red satin; little Margarite, aged eight, clad in spotless white; and tiny Juan de la Cruz, seven years of age, who wore a suit of navy blue. The three suits were exchanged for others; and while the stock was feeding and breakfast being served, the garments from her little ones were cut into stripes and stars, and by the mother's cunning fingers formed into as perfect a star-spangled banner as ever was kissed by the breath of heaven sweeping in from the broad Pacific; and when Major Hensly was ready to take up his line of march, Dona Refugio presented to him the first starry flag that ever floated over lower California, or the city of San Diego, and with it at the head of the column, they marched proudly and safely into the town, while the vessels at anchor roared their hearty salutes of welcome.

"That same evening the bands of the frigates Congress and Savannah came on shore and gave the beautiful Dona Refugio a grand serenade in honor of her kind devotion to the glorious flag ; and the following evening Commodore Stockton, attended by his officers, waited upon the fair Dona to tender his thanks in person for her marked attention to his command. And when the gallant Commodore was presented to Dona Refugio, he took her right hand into both of his, saying with deep emotion: 'And this is the hand that made that flag. In the name of my country and my government, I say to you, madam, that whatever the owner of this hand sball ever ask of them shall promptly be granted. I shall take that flag to Washington, and tell my Government that it was the first American flag to wave over California and was made by a native lady.'

"When the war was over, and peace between Mexico and the United States restored, Don Juan Bandini fotnd himself deprived of his five ranchos in Lower California, because he was listed as a traitor to Mexico. And today his widow and children are deprived of them because of the kindness of himself and family to our officers.

"During all that war, and long after, the house of Don Juan, in San Diego was a constant hotel and hospital for our naval and military officers, where his beautiful wife and lovely daughters* served and ministered unto

* "The ladies were mostly quite haudsome, particularly those of the families of our friends, Bandini and Carrillo. 'The daughters of the former were, though very joung, yet very beautiful "-Life in Californi, p. 20 , by A. Robinson, March, 1829 . 
them more as mothers and sisters than as strangers. Of this many officers bear witness.

"To that house Gen. S. W. Kearny was taken from the battle-field when struck down, and he found in Dona Refugio the kindest and most attentive nurse. Within that lome Generals Sherman, Sheridan, Grant, Hancock, Stevenson, Stoneman, Magruder, Johnston, Lee, Stuart, and many others who subsequently wrote their mames high on the pillar of fame, ever found a warm-hearted welcome and free-hearted hospitality.

"Years have passed; and now Dona Refugio in her old age finds herself dependent upon her relatives, and simply because of the self-sacrificing devotion of herself and husband to the American flag.* The fingers that made the first flag in the growing dawn of that far-off day have lost their cumning, but the noble heart that inspired the act has lost none of its love for the starry banner. As Dona Refugio and her two daughters, Dolorosa and Margarite, both mothers now, related to me the incidents of those days, the eyes that had so often greeted with sparkling smiles the great chieftains, when they were young officers winning for us the Golden I and, filled with blinding tears, and the lips that had so often cheered them on to heroic deeds, quivered with pain and sorrow as they spoke of the neglected vow, and the matron's dependency in her old age. [1882-83.]

"When the Walker filibustering expedition passed through California on their way to Central America, $\dagger$ they robbed the store of Don Juan Bandini, literally clearing it ont of $\$ 60,000$ worth of property, leaving him and his family penniless. After the death of her noble husband, remembering the solemn vow of Commodore Stockton to her, Dona Refugio prayed the United States Government to recompense her, at least, in part for her loss sustained at the hands of American citizens ; but to that prayer no reply has ever been made." +

This is the story of the flag, as gathered from three of the women themselves, besides other members of the family, by Mr. Dane. And from various sources I learn that Commodore Stockton deposited that flag among the historic relics of the Navy Department, and it is preserved there yet. He did what he could to have Bandini reimbursed, as did also Col. Fremont, and his father-in-law, Senator Benton of Missouri; and at a later period Gen. Beale, and also Gen. Sherman tried to have justice done in the matter. The claim was lumped in with many others, and has been several times before Congress, with favorable recommendation; and yet the family say to this day [1894] even the cattle and horses which Bandini furnished to Commo-

* When Bandini was in the Mexican Congress he opposed the State-church party and supported the final and mandatory act to secularize the Missions, which was passed Angust 17, 1833 . This act was simply to separate church and state, and establish religious freedom, the same as in the United statesa contest which had been going on hotly in Mexico tor ten years. He steadity and faithfully favored the United States, as against the State-church party of Mexico, and against any scheme for turning Calitornia over to England. I take pains to mention these matters here, because he was "black listect" bv the State-church party as a traitor to Mexico, and his large estates thus confiscated; and because of this partizan record aganst him in Mexico, many superficial or careless American writers have done him gross injustice. And even in Pasadena a street that was first naned Bandini avenue in honor of this worthy man and wife as true-hearted and original Spanish-Americans, was perversely changed to Michigan aveuue. Such a historic disgrace onght not any longer to stand against Pasadena's fair vame.

†Mr. Dane was mistaken here. Walker had taken Lower California ; and theu with some recruits from San Francisco in March, 1854 , lie set out to march a round the head of the gnlf of California into Sonora and capture that province also, and this was the time his men lcoted Bandini's store. His Central America expedition was later-1856-57. Sep Cyclopedia Americana, Arlirle "Walker, $\mathrm{W}$ 'm."

tThe robbing of the store might ke grounds for a claim against the local anthorities of county or state, but could not be against the United states. 
dore Stockton at this time, and to Fremont in July previous, and without which they could not have reached Los Angeles at all, have never been paid for.*

Wm. Heath Davis, who was an intimate friend of the Arguello and Bandini families, in his book, "Sixty Years in California," p. 438, says :

"Don Santiaguito Arguello furnished large quantities of army supplies to Stockton from his extensive rancho eleven or twelve miles from San Diego - several hundred head of cattle and horses, and for which he had a claim against the government amounting to $\$ I 4,000$. The claim was sent to Washington by Major Lee, commissary-general for the Pacific coast. Stockton's attention being called to it he was then U.S. Senator from New Jersey] he exerted himself effectually in its settlement, and in a few months Arguello received his money."

The ranch referred to by Davis was that of Tia Juana, which had been granted to Arguello's father in I829.

Of this Bandini family, Don Juan died at Los Angeles, November 2, 1859. Do1ra Refugio died there Jine 28, r89r. The little Dolorosa whose dress furnislied the red for that historic flag, is now [1894] Mrs. Charles Robinson Johnson of 433 South Main street, Los Angeles ; little Margarite whose dress furnished the white for that flag, is now Mrs. Dr. James B. Winston (widow) of Los Angeles : and little Juan de la Cruz, whose 7-year old boy suit furnished the blue for the flag, is now engaged in the cattle trade between the United States and Mexico. Mrs. Co!. R. S. Baker, (widow) of L,os Angeles, was an older sister, and not with the family on that occasion ; and Arturo, so well known in Pasadena, was a younger brother, not born until i 853.† Three of the Bandini girls married American husbands; and one of the boys, Arturo, married an American wife.

\section{BATTLES OF SAN GABRIEI, FORD, AND "THE MESA."}

On December 29, I846, Commodore Stockton marched out from San Diego with an army numbering in all 607 men, six cannon, 87 mounted riflemen, ten ox carts to carry the baggage, and a band of beef cattle from Bandini for army rations. Among Stockton's officers were Capt. Santiago E. Arguello and Lieut. Iuis Arguello, brothers of Dona Refugio Bandini who made the famous flag, and therefore uncles to our Pasadena Bandini family. Kit Carson, though not an officer, had charge of a squad of mounted riflemen who served as scouts and skirmishers. [For full list of

*August 31,1852 , Congress finally authorized the appointment of three army officers as a board ot commissioners, to examine and report on the California war claims; and their final report was made April 19. 1855. In this I find that Arguello, [Bandini's brother-in-1aw,] made claim for $\$ 21,685$. and was allowed $\$ 6,800$. The total of these California claims before the conmission was $\$ 987,1 \$ 5 ;$ aud $\$ 28,570$ more were filed after April 19, making over a million in all. The commission allowed a total of $\$ 157,365$ of these claims, and Congress provided for their payment. A total of $\$ 157,317$ were rejected; and the rest were suspended, to wait further evidence. One claim of $\$ 10,000$ was cut down 200 per cent, and just $\$ 50$ was allowed the man.-See Baucroft, Hist. Cal., lol. 5, p. 767 .

†Mr. Arturo Bandini has now [1894] a silver cup presented to his father, and bearing the following inscription: "To Don Juan Bandini, fronn Captains H. Day, S. Casey, H. W. Wessels, H. S. Burton, and G. C. Westcott. C S. Army, as a token of friendship and high esteem." "These were officers with Commudore Stockton. They procured the cup and had their names engraved upou it in Washington, aud then shipped it around Cape Horn to Don Juan, in 1850. 
officers and troops, see Bancroft, Hist. Cal., Vol.5, p. 385-86.] The main public road leading to Los Angeles was followed. The niarch was slow, at ox-cart pace only; and although they met with no armed resistance until they reached the San Gabriel river, it was not till January 8, I847, - ten days-when they arrived there. And now they were confronted by the Mexican army under Gen. Jose Maria Flores,* another of the honorable Spanish Dons whom Lieut. Gillespie had rashly imprisoned because of a drunken mob with which Flores had no more to do than father Adan. Gov. Pio Pico and Gen. Castro had fled the country rather than surrender or be captured wlien Stockton and Fremont took possession of Los Angeles in August, r 846. Gillespie's wrongful imprisonments occurred on September I 7. The men he arrested had been put on parole of honor by Commodore Stockton; and the Lewis History says: "The Californians arrested were furious at their seizure, and at the attempt to hold them responsible for the acts of a few drunken vagabonds ; and as Gillespie had violated the promise made them of personal liberty when they gave their parole, they declared they would be no longer bound by it." This was the view of the matter taken by the intelligent and cultivated portion of the Spanish citizens; and on October 26 , 1846 , the remaining members of their former legislature assembled in special session and elected Gen. Flores to be Governor ad interim and commander-in-chief. Stockton knew nothing of these reasonable views of the Spanish-Mexican citizens. He only knew of Gillespie's expulsion from Los Angeles; of Mervine's severe defeat at Dominguez ranch ; of his own discomfiture by Carrillo's shrewd and successful strategic display of imaginary troops at San Pedro; of Kearny's disastrous battle at San Pasqual. He was here to conquer and take possession of the country, and was attending strictly to business. The foregoing digression was necessary, as a clue for the reader in understanding some later events.

On his march, January 4, Stockton was met by three commissionersWm. Workman representing the American settlers; Charles Flugge representing the foreigners; and Domingo Olivast representing the Spanish or Mexican citizens-asking terms of conciliation. B11t he was smarting 111der the defeats above mentioned, was in no mood to conciliate anything, and would hear to nothing but unconditional surrender-asserting at the same time that Flores and others who had violated their parole would he shot it captured.

Stockton's army reached the San Gabriel river on January 8, and at-

*: "They are formed between the American army and the Rio San Gabriel, apparently waiting to give battle, and are estiuted at 1,000 to 1,200-almost wholly cavalry." - Report of Commodore Stockton's Scouts and Spy, on night of January 7.

One of Stockton's officers wrote: "The enemy had fortified themselves to the number of five hundred men, with four pieces of artillery," etc. "I'his was a mistake, for the Mexicans liad only two suall cannon, while Stockton had six cannon and plenty of good anmunition. The same writer speaking of the battle of the Mesa tlie next day, says: "They made a bold and resolute stand; tried our lines on every side; and mancuvered their artillery with inuch skill."

tThis was the grandfather of Jose D. Olivas, who resides on Cypress avenue in Pasadena. 
tempted to cross it at the ford on the old stage road leading out by Aliso street from Los Angeles. But here he was attacked by troops under Gen. Flores, Gen. Andres Pico, Capt. Carrillo, and Lieut.-Col. Manuel Garfias-all of whom the American commander had foredoomed to be shot if captured. The Mexicans had two small brass cannon, one of which is known in history as the "Woman's gun;"* it bore a part in six battles of the Mexican war, and is still preserved in Washington as a relic, marked "Trophy 53, No. 63, Class 7." Their other cannon was the mountain howitzer which Pico had captured from Gen. Kearny at San Pasqual. A battle ensued in the afternoon which lasted about two hours and resulted in the Americans crossing the stream and driving the Mexicans from their position. $\dagger$

Dr. John S. Griffin [still living, July, I\$95, on Downey avenue, East Los Angeles,] was chief Medical officer. American loss, two men killed and eight wounded. The Los Angeles County History says : "The chief reason that the loss of life was so small appears to have been the poor quality of the Mexican home-made gunpowder."

It was made at San Gabriel in an old adobe guard house that stood where Mr. Silverstein's store is now [1 S95], and was a very inferior article. The Spanish writers never mentioned but three killed and two severely wounded

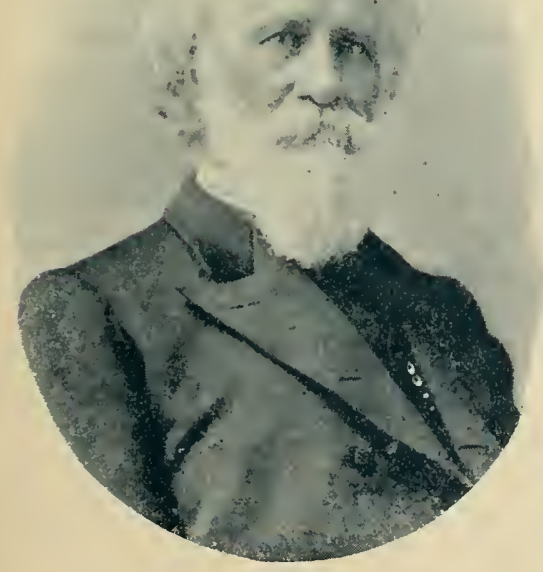

DR. JOHN S. GRIFFIN -1895 on their side; but Stockton reported their loss as between seventy and eighty, besides many horses. Of course he could only guess at it. One of the three Spaniards killed was Francisco Rubio, a brother to the mother of Jesus Rubio, after whom our Rubio canyon was named. The Mexican troops in this battle have been variously estimated from 350 to 500 men. [Some exaggerate it up to I 200.] They withdrew up the Los Angeles road to Aliso canyon and took position again. The Americans did not pursue, but camped for the night

*'This was a brass cannon which had long been kept at the oid church near the plaza in Los Angeles for use on certain festival days. When Stockton and Fremont took the city, in August, Is46, 1 inis gun was hidden by the Mexicansiua patch of canes growing in the garden of Dona Clara Cota de Reyes Then when Stockton learned where the four old iron cannon had been buried and sent Lient. Gillespie to dig them up, Mrs Reyes and her danghter dragged the brass caunon out from the canes, and buried it themselves, to keep the Americans from finding it ; and thus it got its historic name of the "Wonan's gun."

f"Half way across, Kearny sent a message to Stockton that it would be impossible to cross on account of the quicksands; but Stuckton jumped off his horse and seized the ropes, sayın. "Quicksands be danned.! " Kearny suppressed his anger; and the two nine-pounders, drawn by officers and men as well as by mules, soon reached the opposite bank, where they were immediately placed in battery." Lewis' Hist. Los A. Co., p. 76 . 
on the battle ground. If a passenger on the Santa Fe railroad going from Los Angeles toward Orange and San Diego, will look out of the car window on the north side as the train approaches and crosses the San Gabriel river, he will be gazing on the ground where this battle of January 8 was fought.

\section{BATTLE OF THE MESA, OR "IAGUNA RANCH.'}

The next morning, January 9, Stocktou learned where the Mexican army had taken position, and then he moved by the left flank away from the main road and ont across the open plain toward the city, on what is now known as the Laguna ranch, owned by Mrs. Col. R. S. Baker, a daughter of Don Juan Bandini. But at the time of the battle it was owned by Don Felipe Lugo. Here Gen.. Flores again opposed his advance; and another battle was fought, resulting in defeat for the Mexicans and their retreat to Rancho San Pasqual [Pasadena]. Wm Heath Davis in his "Sixty Years in California," says: "Twenty-five or thirty of the Californians were killed and a great many wounded; while Stockton's loss did not exceed ten killed, with a few wounded." In this I understand Davis to include the battles of both days. Again he says :

"Forcing their horses forward, in approaching Stockton's line, every horseman in their ranks threw himself over to one side, bending far down, so that no part of his body, except one leg, appeared above the saddle. When the columns met and the horseman was required to use the lance or do other effective service, he remained but a few seconds in the saddle, and in the retreat he threw himself over along the side of the horse, and rode rapidky in that position, guiding the steed skillfully at the same time. By these tactics the cavalry of the enemy avoided presenting themselves as conspicuous marks for the American riflemen."

Lieutenant Joseph W. Revere* of the troop-ship Congress, was in this battle; and in 1873 a book of his entitled "Keel and Saddle" was publshed by James R. Osgood \& Co., of Boston. In his chapter I 8 he describes the battle, and I quote from page 145 to $147 \mathrm{his}$ graphic account of the opposing forces and the action:

"Commodore Stockton, having completed his preparations, set forth towards the Pueblo at the head of four hundred seamen, sixty dismounted dragoons of Kearny's escort, fifty California volunteers, and a light battery. He first encountered the enemy-about five hundred cavalry, with artillery - at the ford of the river San Gabriel, not far from the Angelic capital, on the Sth of Jannary, and celebrated the day by a spirited little fight. Having forced the passage of the San Gabriel, our little column debonched upon the "Mesa," a table-land some four leagues in extent, through which runs the road from San Diego to the Pueblo de Los Angeles. As we came in sight of its white walls in the afternoon [January 9,] we saw a long procession of horsemen issuing from the town, and directing their march towards us. It soon became evident they meant to oppose our progress; and our jolly tars were in high spirits as they formed in square, the artillery at the

* Grandson of Pan1 Revere, the famous Boston hero who helped to tirow the British tea into Boston harbor, and whom Longfellow has immortalized in his poem of "Panl Revere's Ride." 
angles, to receive them. The ground was a perfectly level, treeless plain, and thus admirably fitted for the evolutions of both infantry and cavalry. The enemy's cavaliers were about two thousand strong [?] principally rancheros, and the best horsemen probably in the world. [Stockton estimated them at I,OOO to I,200; but the Mexicans say they never had more than 400 to 500 men, though their extra horses, amounting to something over IOo, made the troop look larger.-Eע.]* They were dressed in the Mexican costume, in gay serapes of all colors, and divided into bands, or squadrons, each of which had some kind of music,-trumpets, bugles, and even guitars and fiddles. They were armed with the escopeta (a clumsy carbine,) a few with pistols and rifles, and some with sabres, and machetes; but by far the larger part had only a short lance, with a long blade, that could be used with one hand. Many flags streamed over the column; some troopers having gaily colored handkerchiefs fixed to their lances, which, fluttering in the breeze, gave a festal aspect to the concourse. Confidently approaching our little force, they sent their led horses to the rear under charge of their vaqueros, and began their dispositions for an assured victory, forming in two columns with a squadron front, opposed to two faces of our square.

"Meanwhile, our men stood firm, as it had been thought best to withhold our fire until the charge was made. Orders were issued to wait until the enemy came within pistol-shot; but our sailors, seeing a tumultuous, noisy crowd of men and horses rushing upon them with cries and waving flags, opened fire at half-musket range rather prematurely. Our cartridges, being an ounce ball and three buck-shot, proved very destructive. Men and horses tumbled over in considerable numbers, and the six-pound field-guns completed their discomfiture. They retired, however, in tolerable order, carrying off the wounded-those who had lost their horses hanging by the stirrups of the more fortunate-and again formed for another charge. Three times they essayed to shake our square; but, being steadily met with the same withering fire, they at last desisted, and rode off towards the mountains, leaving open to us the road to their capital, which we entered on the same evening. The force which attacked us on this occasion consisted of native Californians, superior to Mexicans in physical power and military spirit, and far better horsemen; while all the conditions of the action were favorable for cavalry in attacking infantry. These men were not only finely mounted on well-trained horses, but had also remounts on the field. Yet not one of them got within twenty yards of our square, in the face of that steady rolling file-firing; nor was a single bayonet or lance on either side reddened with the blood of horse or man. It was a fair test of the respective merits of fiery and chivalrous cavalry opposed to steady and disciplined infantry ; and the former was, as the sportsmen say, "nowhere."

"Their leader, Flores, attacked our sailor battalion in preference to the volunteer force of Fremont, which had the prestige of long frontier experience that had habituated them to Indian warfare, and made them unerring marksmen. I think he committed a serious blunder; and that had he engaged Fremont's force-which had no knowledge of infantry drill, or discipline, and no bayonets-he must have been successful. This affair ended

*In a private letter to Fremont. dated Jan. 1oth, the very next day after the battle. Gen. Kearny wrote: "Their force does not exceed four bundred-perhaps not more than three hundred." And again on the $r 2$ th he wrote: "We met and defeated the whole force of the Californians on the 8 th and 9 th. They have not now to exceed 300 men concentrated." -Bigelow's "Life of Fremont," p. 265. 
the struggle for the possession of Upper California, and our squadron sailed soon after for the coast of Mexico, where a part of it was employed in blockading Mazatlan and San Blas, while my ship [sloop Cyane] was sent with the frigate Congress to Guaymas."

In regard to Flores' attacking the "sailor battalion " in preference to Fremont's troops, Revere was greatly mistaken; for the Mexican army had waited at Cahuenga and San Fernando Old Mission to intercept Fremont and give him battle there, till they heard on January 7 that Stockton was advancing from San Diego.* Then they moved hastily down the Monterey road across Rancho San Pasqual to the San Gabriel river, and Garfias supplied his company with extra horses as they passed through his ranch ; and some food supplies for the army were obtained at San Gabriel while passing through that village. A woman who has resided in Pasadena for nine or ten years past, and known as "Old Francesca," galloped about the country on horseback gathering provisions for the Mexican troops, although she was then 53 years of age, having been born at Los Nietos in November or December, I794. ${ }^{\dagger}$ (I visited her September 23, I 894, [also three other times,] and her grandsons, Frank Lugo and Jose Lugo, Jr., acted as interpreters for me.) When Col. Fremont marched into Los Angeles after the capitulation of Cahuenga, he took Gov. Pico's house for his quarters. This Pasadena woman, Francesca de Luga, was then occupying the house to take care of it: and she delivered its keys to Fremont.

The battle of the Mesa (Laguna ranch) closed about 4 o'clock P. M., when the Mexicans "rode off toward the mountains," as Revere puts it. They had made three brave but unsuccessful charges upon the American artillery, it being supported by a hollow square of well-armed, well-drilled and well-officered marines. The California Spaniards showed as much dash and bravery and skill in mancuvering and charging as the Americans ever did ; but the advantage of good powder, good firearms, good training and actual fighting numbers, was all against them; and the fact that they maintained this unequal contest for two days, or that they engaged in it at all, showed a degree of patriotic devotion in fighting for their own flag and

*B. D. Wilson used to tell with much humor, an incident of this time. He and other Antericans were held as prisoners of war, and Don Andres Pico, the General, had always been very kind to them, so that they really felt a friendly concern for his safety. When he was staring out with the expectation of neeting Col. Fremont in battle, Mr. Wilson, Wn. Workn1an, and others, told him of their feeling toward him-told him that Fremont's men were all expert riflemen, and they feared if Ion Andresexposed hinself on the field he would be shot. 'The General naively replied: "Don't be anxions about me, gentlemen. I would rather have history record where Don Audres ran than where Don Andres fcll." "This I have from Hou. J. De Barth Shorb.

†The I,os Nietos [or Santa Gertrudis] ranch was granted to Mannel Nieto by Gov. Fages in $\mathrm{r}_{7} 84-$ the first land grant ever made in L,os Angeles county

†"I lived alone, after a short time, in the ancient capital of the governors general of Los Angeles, without guards or military protection; the cavalry having been sent off niue nilies to the Mission San Gabriel. I lived in the midst of the people in their ancient capital, administering the government as a governor lives in the capital of a ny of our states." -Extract fiom Ficmont's answer to "Specification 7." in General Kearny's disgraceful conspiracy to ruin Fremont through a preprejudiced court martial at Washington, in $1847-48$. This kearny gained military prestige by falsifying records within his control, and claiming aclievements which were none of his. He died at St. Lonis, Oct. 31, 1848. Gen. Phil. Kearny, who won lionorable distinction in the war of the rebellion, and after whoun "Phil Kearny Canp $S$. of V.; in Pasadena was named, was a very different sort of man. 
country which nearly all American writers have unjustly ignored. After the battle they retreated to Rancho San Pasqual, making their camp on the solith slope of what is now Raymond hill; this hill was then 34 feet higher than at present, and had a stream of water, and Jose Perez's old adobe house [still standing, 1895,] and a fine oak grove on its south slope, extending down to and beyond the Monterey road. Sentinel horsemen were kept posted on the peak of that hill; and also on the hills below South Pasadena, to watch for an expected pursuit by the American cavalry.* But Stockton paid no further attention to the Mexican army; it was Los Angeles city he was after, and there he went, marching in with flags flying and bands playing, and took formal possession again on the morning of January ro.

On September 6, 1894, Dona Luisa Garfias, who now resides at San Diego, visited Arturo Bandini's family.

It was the first time she had been

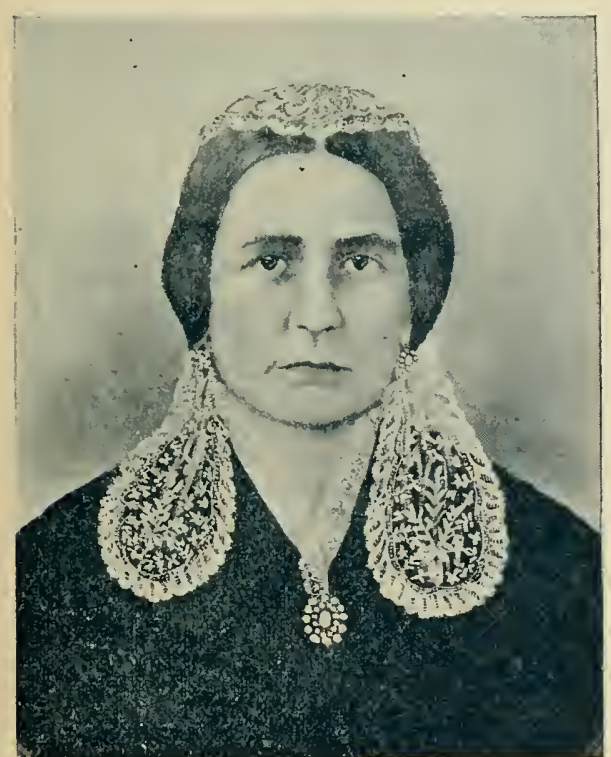

DONA ENCARNACION SEPULVEDA DE ABILA on the old ranch since it was sold from her, about thirty years ago; and as soon as she came in sight of it, on the cars at South Pasadena, her feelings overcame her and she wept until she reached Bandini's house. In conrse of conversation she told Mrs. Bandini how she remembered seeing the Mexican horsemen on top of Raymond hill, and on the South Pasadena hills, watching for the American cavalry to pursue them, after the battles of January 8, and 9, r 847 . She was then at the house of her mother's major domo, Camacho, near the Garfias spring.

Commodore Stockton took and used as his headquarters the adobe house which is still standing, Nos. 14, I6, IS, Olvera street, north of the plaza. It was the city home of

*"The insurgent force under Flores, failing to make any impression upon the Americans in an attack upon the marching colum 11 on the gth, was moved to San Pasqual, some five or six [8] miles northeast of Los Angeles. * * On the night of the ith, about miduight, Don Jose Jesus Pico came unto the camp of the Californians, at San Pasqual, and gave them the in formation that Col. Fremont had reached San Feruando. * * After having met Col. Fremont at San Fernando, Messrs. Rico and De la Guerra returned to San Pasqual early in the morning of the 12th. [About noon.] Immediately after their return to camp. Don Jose Antonio Carrillo and Don Augustin Olvera were appointed and commissioned by General Pico, to meet and negotiate terms of capitulation with commissioners to be appointed by Col. Fremont. Gen. Pico immediately broke up his camp at San Pasqual, and with his entire command accompanied his commissioners to Providencia." - [Col.J.J. Warner, in Centennial History of Los Angeles County, p. 16.

Providencia was a southwest portion of the San Rafiel or Verilugo ranch, on the Monterey road, where Flores and Pico had stationed a small force to watch and report Fremont's movements. 
Dona Encarncion Abila (Mrs. Garfias's mother,) who had fled with her family to the home of the old Frenchman, Louis Vignes, for safety.

FREMONT'S NEGOTIATIONS.

Colonel Fremont, after a stormy winter march of extraordinary hardship down the mountainous coast from Monterey, * arrived at old Mission San Fernando, on the evening of January i $t+$ With him was Don Jesus Pico, [a cousin of Governor Pio Pico and Gen. Andres Pico] whose life Fremont had saved after he was condemmed by a court-martial to be shot for violating his parole. Don Jesus immediately rode down to the Mexican canıp at Raymond hill, and reached it a little before midnight, having been detained awhile at the picket camp on Verdugo ranch. He informed them of Fremont's arrival and of his fighting strength, which made their cause evidently hopeless; and he urged them to seek terms of capitulation or surrender from Fremont. A council was at once called, of such leading men as Gen. Flores, Andres Pico, Carrillo, Garfias, Olvera, La Guerra, Manuel Castro, etc., and the surrender plan was agreed upon. Gen. Flores and Lieut. Col. Garfias approved of it, though they would not themselves remain but would depart for Mexico, as they were commissioned officers in the regular Mexican army. Flores had been elected Governor and commander-inchief of California by the Legislature in special session at Los Angeles in the October previous; and he now formally appointed Don Andres Pico to the chief command. Gen. Pico then appointed Francisco de la Guerra and Francisco Rico (two more of the Dons whom Gillespie had imprisoned) to go with Don Jesus and see what terms, if any, Fremont would make. By daylight they set off on this errand. And about the same time Flores and Garfias, with forty or fifty men, started for Mexico by way of San Gabriel, San Bernardino, San Gorgonio pass and Sonora. The two men who had been sent as a preliminary committee to see Fremont returned about 110011 with a favorable report. Fremont had ordered a suspension of hostilities for the day, and given the Mexicans permission to bring their wounded to San Fernando Mission for care and treatment. Upon this, Gen. Pico appointed Captain J. A. Carrillo, who had defeated Mervine at the battle of Dominguez ranch, and Hon. Agustin Olvera who was a nember and secretary of the last legislative session, to be commissioners representing the people of California, and who would meet a similar commission to be ap-

*The start was made in the winter. The weather being very severe, mamy hardships were suffered by the troops on the march, and when they arrived at Santa Barbara many of them were in a rery weak condition. * * I told Col Fremont I could slpplv them with flour, tea, coffee, sugar, and clothing. * * Upou order of his quartermaster and commissary, goods amounting to about $\$ 6,000$ were landed for them from my vessel the next day." - Wm. Heath Davis, "Sixly Years in California," pp. $115-16$.

"The passage was made with great diffinlty. Both men and horses suffered exceedingly. Between I50 and 200 horses were lost. The men were obliged to pull the cannon over the rougliest places by hand."-Hillell's Hist. Cal., Vol. 2, p.603. Our B. F. F. Kellogg was one of these nien. This was the same severe winter in which the terrible Donner I,ake disaster occurred.

tWhile Fremout was encamped in the willows just across the creek west of veutura, after marching down the beach road fron Carpenteria which is only passable at low tide, he was met by a inessenger with despatches from Stockton: and this messenget. who had reached Fremont's camp through hardship and peril was Dan Sextou. [See Article "Dan Sexton's Old Adobe Mill," in Chap. 3.] 
pointed by Col. Fremont. All these stirring, historic events occurred within a few hours, in the Mexican camp within the borders of South Pasadena, on the South slope of Raymond hill; and now Gen. Pico moved his camp about six miles over on the Verdugo [San Rafael] ranch* along the old Monterey road toward San Fernando Mission, which place was then his own property† but occupied by Fremont's troops. In Fremont's Memoirs, page 60I, he says: "The next morning, [I $3^{\text {th }}$ ] accompanied only by Don Jesus, I rode over to the camp of the Californians, and in a conference with Don Andres the important features of a treaty of capitulation were agreed upon."

The same day both armies marched to the old Cahuenga ranch house, on the most direct road to Los Angeles.t There the terms of surrender were completed in form, and signed by the conmissioners and commanders on both sides. The Mexicans agreed to turn over all arms, equipments and war materials in their possession, and to assist in restoring peace and order among the people of California, under United States authority ; and on complying with this, they were "guaranteed protection of life and property, whether on parole or otheruise." Here was the vital point ; for Stockton had doomed Flores, Carrillo, Pico, Garfias, and others to be shot, who had violated their parole after Gillespie had, as they thought, violated the terms on which they had given such parole, but which they had scrupulously observed up to that time. Fremont's idea and mission had not been to "conquer " and subdue the Californians; but to secure the territory to the United States before England could take it under her protectorate control in accordance with Rev. M'Namara's great Irish Catholic colonizing scheme-a project which came within a few days of being consummated. The plan had been favored by President Santa Ana and his council in Mexico ; and on July 7, I 846 , the Departmental Assembly of California at Los Angeles, under Gov. Pio Pico, had formally granted to M'Namara one square league apiece for 8, ooo Irish Catholic immigrant families, to be colonized in Californias - that meastre of land being equal to $\mathrm{I} 3,500$, ooo acres. [Fremont's Memoirs, p. 553.] M'Namara was then at Santa Barbara, fresh from Mexico; and on the I6th

*The Mexicans had a small force encamped here before to watch Fremont's movements. And because of these two camps, ald because Geu. Pico was visited by Gen. Fremont here, much confusion has arisen, and many erroneous statements have been published in regard to the whole matter of Fremont's negotiations. Hence I have taken extra pains to identify localities and to trace the rapidly occurring incidents in their chronological order. That sub-camp was near the old verdugo ranch house, about where the village of Glendale now stands.

†In December, 1845, Andres Pico and Juan Manso had leased San Fernando old Mission and ranch for $\$ 1,120$ per year.

†en. Pico's camp at Providencia [near Glendale] was only five or six miles from Cahuenga ; but Fremont's troops had to march sixteen or seventeen miles, as the road then ran by way of rancho Eil Encino to a ford and thence down the west bank of the I,os Angeies river to Cahuenga pass.

?Gov Pico and the Spanish consul both urged the assembiy to make the grant. On July 6 it was referred to Bandini and his brother-in-law Arguello as a committee, They put in "stipulations" chich scheme, or a British goverument scheme, and then recommended its passage. And it was passed without noticing that Banditit had sawed off its teeth so it couldn't feed itself or anybody else. However, if the British had sncceeded in getting a protectotate foothold under that grant, they would have found a way to make it stick. 
of that month the British Admiral, Geo. F. Seymour sailed into Monterey Bay for the purpose of hoisting the British flag and proclaiming a British protectorate.* But the Americans had got ahead of him and had hoisted their flag and taken possession on the 7 th of the month. (For official documents, debates in congress. etc., on this matter, see Fremont's Memoirs, Vol. I, pages 547 to 549 , and on to 559). The initial and preparatory steps which resulted in the country being thus taken before the British got hold of it were distinctly those of Fremont. And here from Pasadena commenced the negotiations with him which secured to the Spaniards an honororable treaty of peace instead of a galling submission to mere brute force, when he thus wisely pacified the country by the terms given in the only formal surrender of California that was ever made by any California officials to any United States officer. It was the white hand of Destiny enforcing the law of poetic justice, by awarding to Fremont this indefeasible seal to

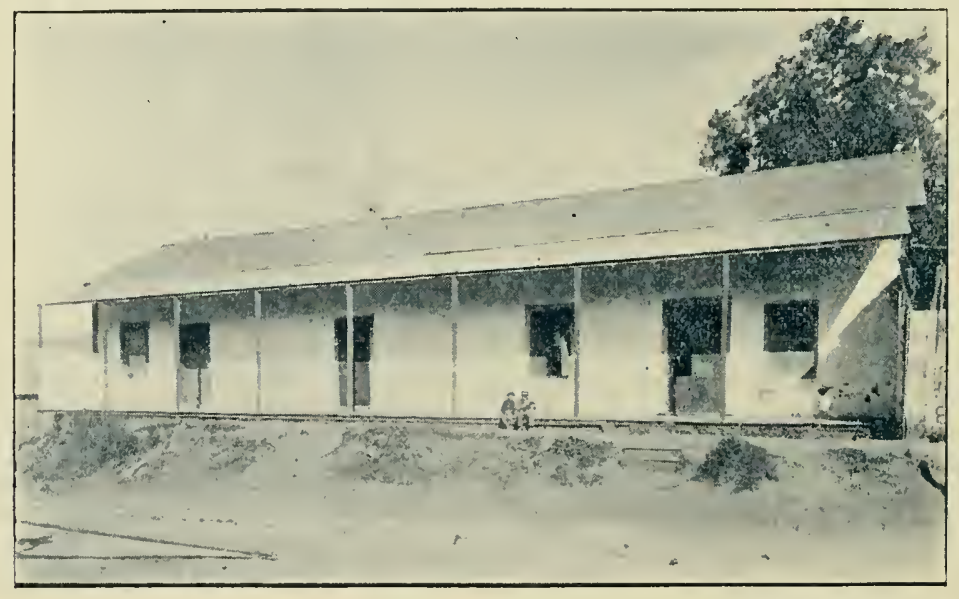

"Land of Sunshine" Photo, 1st:

HOUSE TAKEN BY COMMODORE STOCKTON FOR HIS HEADQUARTERS, JAN. 10, 1847.

himself as the one central figure of the California conquest, but which in later years narrow-minded, envious men most persistently sought to pluck from his plume of honors all heroically and worthily won. $t$ When other men stood halting and haggling about precedents, he made a precedcnt by going ahead and doing the thing which needed to be done, right now. Fremont recognized that these Spanish soldiers had fought bravely, with patriotic devotion to their own flag, and should not be treated as outlaw mis-

* Rodmau Price, afterward governor of New Jersey, was purser of Commodore sloat's squadron at this time, and lie wrote: "The Fuglish admiral arrived a few days afterward, and the first thing he said on meeting the conmodore was, "Sloat, if your flag was not flying on shore, I sliould have hoisterl mine there.'

† Lieut. Walpole of the Finglish flag ship Collingwood, who saw Fremont's troops at Monterey, wrote about them, and among other things said: "They are allowed no liquor tea and sugar only. This no doubt has much to do with their good couduct." - See "Early Days and Men of California," $p$. $1 ; 1$. 
creants. They appreciated this chivalric sentiment and courtesy on his part, and became true and loyal citizens of the United States, many of them afterward holding important offices under the new order of government.

In his report to the Navy Department at Washington, Commodore Stockton wrote: "By the capitulation we have recovered the gun taken by the insurgents at the sad defeat of Gen. Kearny at San Pasqual." The other historic cannon called the "Won1an's gun," was also delivered up to Fremont at this time, and afterward used in three other battles of the United States against Mexico to-wit: Mazatlan, Urios Palos Prietos, and San Jose in Lower California. A document produced in evidence at the trial of Fremont in Washington, in November, December, Jan11ary, i $847-48$, spoke of Fremont arriving at Los Angeles Jantury I3, I847, "with 400 mounted riflemen, and six pieces of artillery, including among the latter two pieces lately in possession of the Californians." These were the only cannon the Californians had for use in any of the battles, while Stockton had six and Fremont four to use against them. These two cannon were with the Mexicans in their camp at South Pasadena; and in the ensuing month of March Fremont's battalion was on duty at San Gabriel, occupied the old Mission court as barracks, and had their six cannon, including these two, there. [See Bigelow's Life of Fremont, pp. 3 I I-I 2-I3].

While Fremont served as Governor of California under Commodore Stockton's appointment, lie occupied Gov. Pio Pico's residence fronting the plaza; and in regard to this I have a letter from Mrs. Fremont dated Los Angeles, November 14, I894, in which she says :

"Don Abel Stearns had his lien on that Pico mansion used by Gen. Fremont as headquarters. I wish you could identify and fix the place; for other houses in a then unbuilt part of the town, southwest, have been photographed and sold to tourists as the old 'headquarters'-especially one on Main street, a one-story adobe with a fine pepper tree, a kind of tree unknown here forty years ago.* Gen. Fremont himself had trouble identifying the old Pico house when he showed it to me in r888. But it was then converted into a great granary and its upper floor built out over what had been a surrounding gallery. It was almost in line with the old church at the plaza ; in line with his fort on the hill ;' etc.

As Mrs. Fremont requested, I have learned positively from old Spanish people who were here at the time, and also from Americans who have lived here ever since I 847 , just where Gov. Pico's residence was. It stood on the south side of the Plaza, fronting north, and extended from Los Angeles street west to Sanchez street, at rear of the old Pico hotel, now called "National." The fire engine house there occupies part of the ground, the old Pico adobe having been torn away. All that still remains of the old walls occupied by Pico as the last Mexican governor, and by Col. Fremont as the

*The house referred to was away out at Thirteenth street, nearly two miles "out of town " at that time-a house that Fremont probably never saw at all. I have seen those pictures inyself, with their false label, and denounced it as a fraud. 
first American governor, is a few feet of adobe frontage occupied by a Chinese store; and adjoining this on the west is a board shanty occupied as Chinese lodgings. [See plate.]

The "Fort," which was a mere earthwork, and after I 847 was generally called "Fremont's redout,"* was commenced by Gov. Micheltorena in 1844 ; was occupied and improved a little by Lieut. Gillespie in September, I 846 ; was occupied and further improved by Col. Fremont's troops in January 1847 ; was enlarged and further strengthened by Col. Stevenson in $1847-48$, after Fremont had been taken east for court martial under Gen. Kearny's infamous conspiracy. $\dagger$ Among the soldiers in Fremont's battalion in 1847

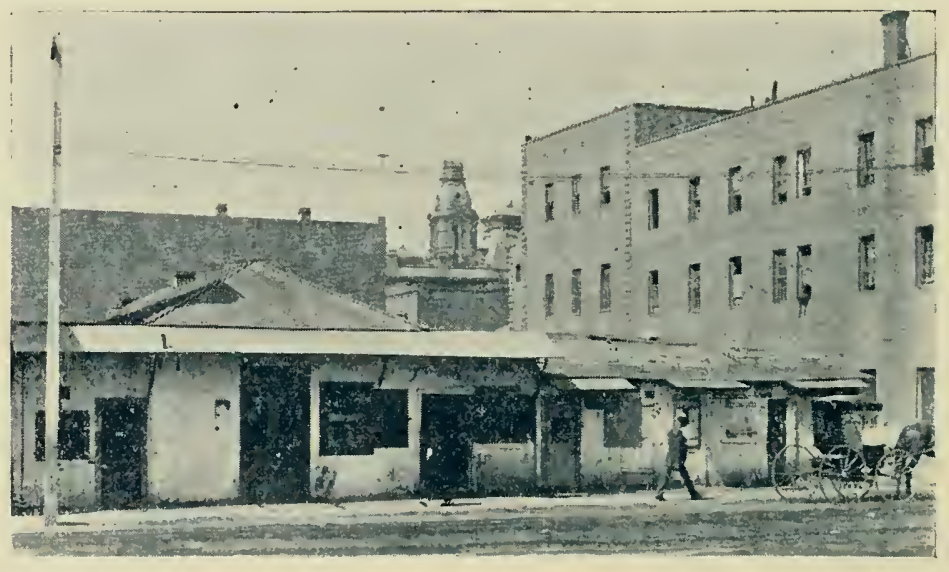

"Land of Sunshine" Photo, 1895.

SITE OF COL. FREMONT'S HEADQUARTERS AS MILITARY GOVERNOR OF CALIFORNIA, IN JANUARY AND FEBRUARY, 1847.

was B. F. E. Kellogg, father of Mrs. Byron O. Clark of Pasadena. Mr. Kellogg and a brother had the contract and built the United States fort at Fort Laramie, Nebraska, in 1844 . Then in 1846 he came across the monntains with ox teams to California, arriving in Napa connty in November. Fremont was then recruiting his battalion at Monterey for the march to Los Angeles, and Mr. Kellogg immediately joined it. He was with them on the march, and at San Fernando, and the capitulation of Cahuenga, and in Los Angeles, and at San Gabriel where they waited some weeks to be finally discharged. Mr. Kellogg died at Anaheim December 16, 1890, but was buried at Mountain View cemetery, Pasadena; and his grave is one of those that are annually decorated there on Memorial day.

*Iu vecember, $1 S_{3}$, I several times visited this old fort or redont, examining its barlsettes, its salieut angles, rampart walls, sally ports, etc., some parts of which were then still traceable; but it lias all since been obliterated by street gracling and other inprovements.

†'One of the howitzers which Owens was ordered to give up had heen captured from Kearney at San Pasqual and given up to Fremont at Cahuenga."-Hist. Cal., Vol. $5, p .140$.

This order occurred at San (iahriel, white our B. I' Kellogg was there with Frenont's battalion under Capt. Oweus. Kearny had alway's cliafed nuder what had happened with his howitzer, and hated Fremont accordingly: aud this was one step in his plot to insult and aggravate Fremont into some technical insulordiuation. He refused to let Capt. Owens obey the sinister order, and that refusal was one of the trumped-11p charges against thin for court martial. 


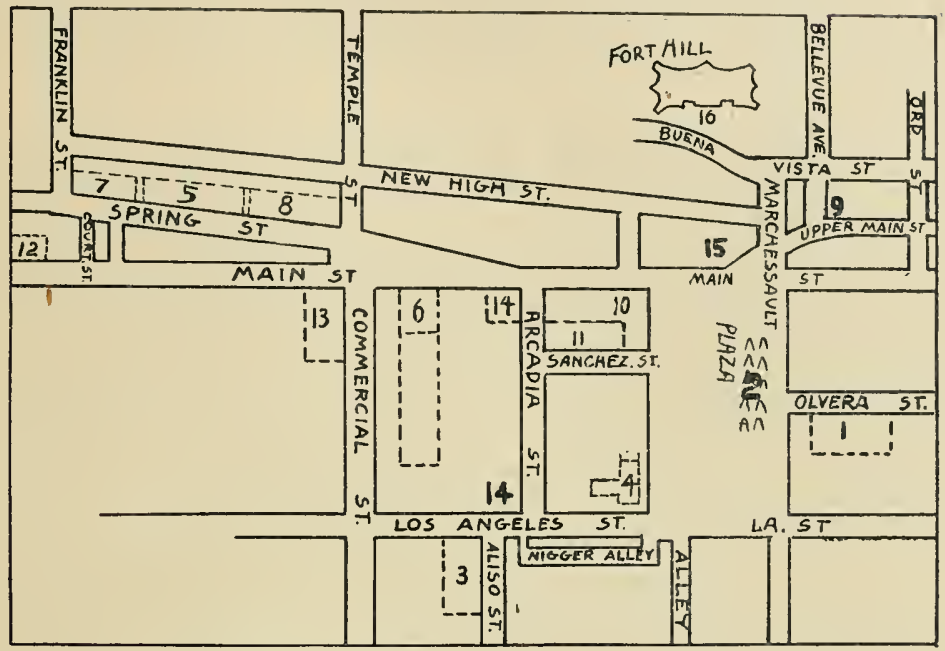

1.-Commodore Stockton's headquarters, January 10 to 14, 1847. [See page 100.]

2.-Stockton's troops encamped on the plaza.

3.-Col. Fremont's headquarters while Governor of California, in a two-story adobe house owned by Alexander Bell, unele to Maj. Horac e Bell, editor of the Los Angeles "Porcunine."

4.-An old one-story adobe house owned by Pio Pico, whose son-in-law, Jose Moreno, lived there. House still standing. Pico himself had lodgings and an office there in later years, and bence many supposed that that was where he lived when he was governor. He had bought this place from the heirs of Don Juan Marine, who died in 1839 . [See page 71. ]

5.-Residence of Pio Pico while he was Governor. Mrs. Picostill held and occupied this mansion in 1846-17, while her husband was absent in Mexico. Steyhen Foster tried to rent her house for the government, for use as army bospital, but she would not consent, fearing if she did it would be held as "surrendered," and so taken from her: then be secured the building on Upper 11 ain near ord street, marked 9.

6.-Headquarters and barracks of Lieut. Gillespie, where the "battle of Los Angeles " was fought. September 23, 1846. [See p. 83.] The same buildings were occupied by Col. Fremont's troops, Jan'y and Feb' $\mathrm{y}, 1847$.

7.-Adobe buildings occupied by Col. Stevenson's troops, 1847. This structure was afterward used as county and city jail.

8.-A dobe building occupied hy Quartermaster's department, 1847.

9.-Adobe building used as military hospital-now all torn away. [The figure 9 should be nearer to Ord st.]

10.-Residence of Jose Antonio Carrillo.

11.-Residence of Jose Sepu1veda. The present Pico hotel stands on these two lots.

12. -Residence of Manuel Garfias, a Mexican Lieut. Col. in the battles of January 8, 9, 1847, and owner of Rancho San Pascual. [See page 73, footnote.]

13. -B. D. Wilson's store ; the two old iron cannon were planted there in 1849 , and are there yet. [See 1.84; 335.]

14.-Ahel Stearns's corners, where were planted in 1849 the two old iron cannon which now lie at west front of court house.

15.-Old church at the plaza, for which the original roof-timbers were gotten out by the Yankee "pirate prisoner," Joe Chapman in 1818-19, from Millard's and frand canyon, within a mile down from the Alpine Tavern on Alpine section of the Mt. Lowe Rall way. [See pages 43 to 52 , and page 385 .)

16.-The "Fort," which was commenced by Gov. Miclieltorena in 1844; used by Lieut. Gillespie in September, 1846 ; built in proper military form by Col. Fremont in January, 1847 : further improved by Col. Steven son the same year. Now entirely obliterated.

I prepared the above diagram from information furnished me at different times by the following old-time Californians, who are still living: Hon. Stephen C. Foster, aged 74; Francisco Garcia, 114 on May 1,1895 G. W. Robinson, 86; Elijah Moulton, 74; Thedore Rimpau, 69; Jose Perez, 63: Pio Zabaleta, 62 ; Judge B. S Eaton, 72 ; Dr. John S. Griffin, 79 ; besides printed records, and my own examination of "Fremont's Redout" in December, 1883 .

For six weeks before this chapter IV was printed I had been trying to find Hon. Stephen C. Foster, to obtain his verdict on some matters which I had written here, upon information received from four old Spanish and two old American residents. Mr. Foster had served as government interpreter at Los Angeles in I847, and all its business with Spanish people was done through him; then in I848-49 he was the "alcalde" or mayor and civil judge of Los Angeles; and on these old historic matters he is the best posted man living. My letters to him at Downey failed; and many inquiries for him at the court house, and at the City Clerk's office, and at the City Library failed, until after the matter as then written had to go to press. But three days afterward I found him, and learned that my previous informants were in error on several points; and I

* The cut on page 102 was made for the "Land of Sunshine," but was first printed in my pages. Then I discovered its error before they were ready to print it, and hence prepared and furnished them this Correction Map instead. See "Land of Sunshine" for October, I895; page 222. 
stop the reader right here, to make correction. I have since also seen old Senor Francisco Garcia, who was with Gov. Micheltorena in the battle of Cahennga in 1845, and Elijah Moulton who was with Col. Fremont on his wintry march down the coast, and into Los Angeles, January I3, I847. And from the new and authentic information thus obtained I have prepared the above correction map of the chief historic points in Los Angeles in 1847 :

The popular story that Fremont as first American governor occupied the same house that Pico lived in, as the last Mexican goveruor, is entirely a fiction. Neither Fremont nor his troops occupied any house owned by Don Pio Pico, although Mrs. Fremont herself thonght he did. [See her letter on page IoI.] Hence, old Francesca's story about "delivering the keys of Pico's house to Col. Fremont," as I have it on pages 96 and 103, is a fiction. Neither Foster, Garcia or Mouiton had ever heard of it. They say she then lived at San Gabriel, not at Los Angeles. [She may have passed the keys of some house at San Gabriel to some officer of Fremont's battallion while they were stationed at the Mission, and the incident been misreported and magnified; for I talked with old people there who thought it was true. And "one of Frenont's officers" could easily grow into "Fremont himself."] 'The building on which Abel Stearns had a mortgage, as mentioned by Mrs. Fremont [page IOI], was the one called the "government building" occupied as barracks by Lieutenant Gillespie in 1846 , and by Fremont's battallion in January, I847 ; but it never belonged to Pico.

My statement ori pages 93 , IOI, and footnote to 335 , that the Mexicans had only two cannon, is an error. Mr. Foster showed me Maj. Emory's official report, with a military map or diagram of the two days battlefields, made at the time, giving relative positions and movements of the opposing armies at different stages of the contest; and it seems that the Mexicans had two "common, short, heavy cast iron guns," as B. D. Wilson says, besides the two brass ones. Foster says that after the battle of Dominguez they managed in some way to get two iron cannon, but he could never find out just how or where. They were the very old style of guns called carronades, one or more of which were almost always carried on merchant ships. When Gen. Andres Pico marched from Rancho San Pasqual to Providencia, after deciding on surrender to Fremont, the iron guns were too heavy to haul along, so he hid them in the Arroyo Seco, somewhere near the Garvanza ford at the old Monterey road crossing. These were the guns which Gen. Pico toid Commodore Stockton about, as mentioned by B. D. Wilson [page 335]; and Wilson evidently, when he wrote, had them in his mind as the same ones which he got from the surf at San Pedro and planted at his store on Commercial street. This mistake of Wilson's misled me as to the Mexicans having any others but the two brass guns. Foster says these Arroyo Seco guns were brouglit into Los Angeles, and fired on holidays year after year until Fourtli-of-July, I860, when one of them burst into three pieces while being fired by a man named Moore (nobody hurt). The other one he had lost track of, but thinks it was burst also.

Jose Perez died in $\mathrm{IS}_{4} \mathrm{O}$, and Stephen Foster married his widow in August, 1848. [See pages 7 I-72.] She is still living, September, 1895, at their home place near Downey: aged 79 .

My footnote on page $8_{3}$ is wrong. Foster says it was Diego Sepulveda, a nephew of Enrique, who was with Del Carmen Lugo at the battle of Chino. Enrique Sepulveda died at Monterey in 1844 .

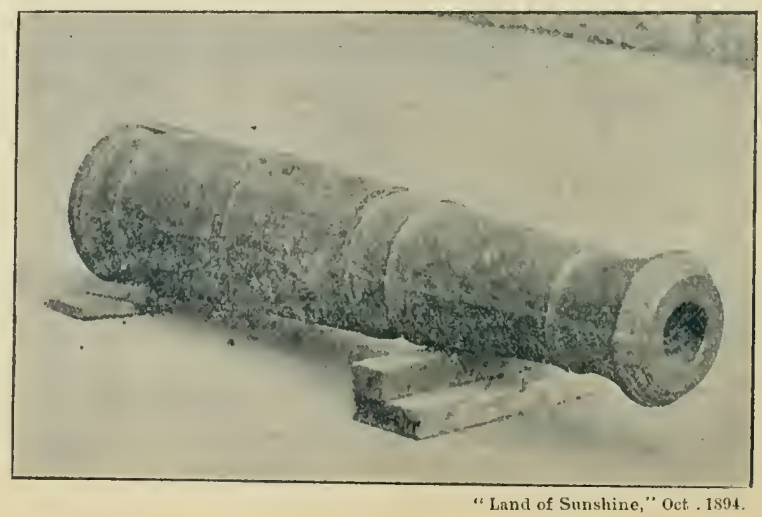


And now, to recapitulate: Pasadena has the following living links of direct connection with persons who took part in the struggle within easy cannon sound of our streets, which resulted in making California an English-speaking American state, instead of a Spanish-speaking Mexican province :

ARTURo BANDINI: His father and mother, his maternal grandfather and two uncles all bore some goodly part on the American side, as fully narrated in preceding pages.

Hon. B. D. Wilson : See article, "Battle of Chino." Mrs. Wilson and her daughters, Mrs. Ruth W. Patton and Miss Annie Wilson, and Mr. Wilson's older daughter, Mrs. J. De Barth Shorb, are still with us-I 895 .

Don Manuei, Garfias: The first U. S. patentee owner of Pasadena soil was a Mexican Lieut.-Col. of cavalry, and took part in the battles of San Gabriel Ford and Laguna ranch January 8-9, t847. From these defeats he went to Mexico, and was among the prisoners taken by Gen. Scott when his army finally captured the City of Mexico.

Dr. John S. GRIFFin : From whom the Orange Grove Colony bought their land and started the Pasadena settlement. He was chief medical officer of the American troops in the battles of San Pasqual [San Diego county, December 6, 1846], San Gabriel ford, and Laguna ranch. He was brother-in-law to our Judge Eaton, and brother to Mrs. Gen. Albert Sidney Johuston. [See page 76 , foot note].

Kit Carson: Col. Fremont's famous Rocky Mountain guide and scout was with Fremont's troops in their march from San Diego to Los Angeles in July-August, I 846; was sent as special envoy with despatches to Washington from Stockton and Fremont; was stripped of his despatches and forced to turn back by Gen. Kearny on the road from Santa Fe; he was thus in the battle of San Pasqual, and also in the battles of January 8 and 9, r847. His brother Apollos Carson was in Fremont's battalion also; and his son Sam afterward lived a while in Pasadena. John V. Carson and his son Eugene, well known building contractors of Pasadena, are cousins of Kit Carson ; and J. C. Studebaker is a nephew - son of Kit's sister Sarah.

Old Francesca Lugo: Don Felipe Lugo owned the great Laguna ranch, then called "La Mesa," at the time the battle of January 9, I 847 , was fought there in plain sight of the whitewashed adobe walls of Los Angeles; and she herself acted as supply agent and commissary for the Mexican troops during the two days' battles. Then when Col. Fremont marched into the city and became the first American governor of California, she delivered to him the keys of Gov. Pio Pico's house. She has resided in Pasadena with her son Jose Lugo, on the Arroyo flat under the Linda Vista bluff, for nine or ten years past, and claimed to be 100 years old about December $\mathrm{t}, \mathrm{I} 894$. 
B. F. E. KELLOGG: Member of Fremont's California battalion, fatherin-law to Byron O. Clark, one of our best known citizens for ten or twelve years past.

Jisus Rubio, the original owner of Rubio Canyon, brought his uncle, Francisco Rubio, to San Gabriel from the Laguna ranch battle field where he was fatally wounded and died next day. His uncle, Manuel Rubio, was slightly wounded while lassoing Gen. Kearny's artillery horses in the battle of San Pasqual. [Jesus Rubio now lives at Duarte-IS95.]

JOSE D. OrIVAS: grandson of Domingo Olivas, who was one of the three peace commissioners who met Commodore Stockton on his second march against Los Angeles. Olivas represented the Spanish people.

Other citizens of Pasadena who took part in the Mexican war were: J. A. Buchanan, $4^{\text {th }}$ Regt. Indiana Volunteers; Charles Everett, teanster ; Parley S. Tubbs, 6th U. S. Inf.; A. Wakely, Co. D 7 th U. S. Inf. In the war of the rebellion, 1861-65, Wakely was a captain in the 98th N. Y. Inf. Mr. Everett was a member of F troop in Brig.-Gen. Kit Carson's Ist. Regt. New Mexico mounted infantry. Buchanan was purchasing agent in quartermaster department.

\section{SCHFDULE OF BATTIES IN LOS ANGELES COUNTY.}

The battles or memorable actions locally near to Pasadena were:

Capture of L,os Angeles, without battle, August I3, I846, by Commodore Stockton and Col. Fremont.

Night attack on American lieadquarters by Serbulo Barrelas and his drunken revellers celebrating the Mexican "Independence Day," September I6, 1846.

Arrest and imprisonment of leading Spanish citizens by Licut. Gillespie, September I 7 th and I 8 th, on account of the drunken mob.

Siege of Gillespie's barracks and headquarters by Mexicans in revolt, September I9, 20, 21, etc., and he sent to Capt. B. D. Wilson at Jurupa, [now Riversicle] for reinforcenents.

Battle of Chino, September 27, I846. Anericans under Capt. B. D. Wilson all captured, and held as prisoners of war by the Mexicans until January io, i 847 .

Battle of Los Angeles, September 23, I846.* The Mexicans made a dashing assault on Gillespie's barracks, which were inside of ligh adobe walls [about where the St. Charles hotel now stands,] and were repulsed witl a reported loss of eight killed and many wonnded.

\footnotetext{
*Some accomts say this battle accurred on the $16 \mathrm{th}$, some say the 23 , some say the $28 t h$ of Septem. ber. Some say four Mexicans were killed, some say eight, and some say none. I aceonnt fot these discrepancies thus: Some narrators tell of the night assault on Gillespie's barracks by tlie drunken mob celebrating Mexican "Inpependence Day," Sent. r6, in which none were killed, and called that "the battle." Others tell of the open, dashing assault made against the barracks on the 23 , which was repulsed and the four men killed. "rhis was really "the butlle," and the proper date, as Hittell has it. "The other four were killed on different days in the desultory fighting that was kept up, but have been lumpel into one day's report. "Then on the 28 th the Mexicans had fomnd their "Woman's Gun" and were hauling it up onto fort IIIl; but John Marshall unspiked one of the old Mexiean cannon in Gillespie's harracks, and a crew of his men dragged it quickly mp the steep east face of Fort Iill, got in posilion and opened fire one minute aliead of the Mexicans, drove them off, and "beld the fort." Aud some call this "the battle of I, os Augeles."
} 
Evacuation of Los Angeles, September 30, by Lieut. Gillespie, and retreat to ship at San Pedro.

Battle of Dominguez ranch, October 8, i 846 , Americans under Capt. Mervine and Lieut. Gillespie defeated, with six killed and seven wounded.

Ruse de guerre at San Pedro, October 23. Commodore Stockton landed 800 men and six cannon at San Pedro, to march on Los Angeles, but could not get any horses or beef cattle; and the Mexican Captain, Carrillo, inanœuvered his 400 men, mostly raw ranchmen leading one or two extra horses, so skillfully that Stockton was made to believe there were over 2,000 Mexican troops in line to oppose his advance. So he re-embarked, and sailed to San Diego. [He had to go there anyway to find safe harborage for his ships at that time of year.]

Battle of San Pasqual, (an Indian village in San Diego county,) December 6, 1846. Gen. Kearny attacked Mexican troops, and was disastrously defeated, with i 8 killed, 19 wounded (three mortally), one missing, and one cannon captured from him.

Battle of San Gabriel ford, Jantury 8, I847. Mexicans defeated.

Battle of Laguna ranch (called "The Mesa " in Stockton's and other reports), January 9, I848. Mexicans defeated.

Re-occupation of Los Angeles by Commodore Stockton, Jannary 10, 1847, and Mexican army encamped at South Pasadena.

Capitulation of Cahuenga, January I3, 1847 . This practically ended the Mexican war so far as California was concerned.

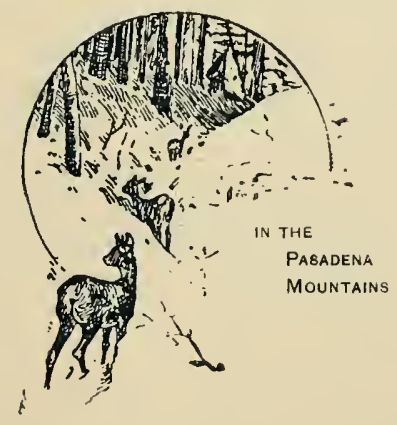




\section{DIVISION TWO-COLONIAL.}

\section{CHAPTER V.}

ORIGIN OF PASADENA - The "Indiana Colony" scheme, and its collapse.-D. M. Berry "spies out" Rancho San Pasqual,-Origin of the "San Gabriel Orange Grove Association."-How its members chose their lots, and where--Success of the colony.-Anniversary picnic.-First Citrus Fair.-First preminms won twice at Los Angeles.-The Lake Vineyard Colony started.-Its lands and first settlers. - The colony water ditch.

\section{THE INDIANA COLONY.}

Sometime in the winter of $1872-73$, some friends were together one Sunday at the home of Dr. T. B. Elliott, in Indianapolis, Ind. It had been a severe winter, and as usual the rigors and hardships of the season were among the topics of conversation. Mrs. Elliott remarked that they had better all emigrate to California, and said, "I'm going, anyway. if nobody else does." This was taken as a joke at first ; but it seemed to stick like a seed of burr clover, for it very soon thereafter became a matter of serious consideration among those friends; and by May they had matured a scheme to form an association called the "California Colony of Indiana." The first formal meeting in regard to the matter was held at the office of Berry \& Eilliott in Indianapolis, there being present Dr. T. B. Elliott, D. M. Berry, John H. Baker, J. M. Matthews, and Gen. Nathan Kimball. A circular was issued, giving elahorate details of the plan, which was to send certain pioneers to "spy out the land," select a tract " well timbered, well watered, and adapted to the culture of citrus fruits "-and which could be bought for about \$3 per acre. These pioneers were to go ahead and sow wheat, Iooo acres, plant hedge fences, start 11urseries, plant vineyards, set out orange groves and other fruits, provide irrigation facilities, etc, - all so easily done on paper, and so hard to do on land. And where were the funds to carry forward all this magnitude of rugged endeavor? 'The circular makes answer tintis :

"To create a fund to mect these expenses, assessments will be made on each nuember, as follows: June I, I873, \$1 ; July I, I873, \$Io; August I, $1873, \$ 10$; September I, 1873, \$IO -total \$40; and thereafter, on the first day of each month an asscssment of like amonnt, or if found necessary, \$12.50 per month will be made."

The circular was signed

T. B. ELLIOTT, President.

J. M. MATTHEWS, Secretary. Hon. J. H. RuDmini, 'Treasurer.
Calvin Fletcher, Genl. Agent. JOHN H. BAKER. D. M. BERRY.

In Angust, a committee consisting of Gen. Nathan Kimball, Berry, Baker, and a surveyor named Albert Ruxton, were dispatched to California 
to select and purchase land and start the colony work as laid out in the printed circular. But soon thereafter came the great financial crisis and panic of that year, which followed the failure of Jay Cooke, the Wall street king of the hour, and his gigantic Northern Pacific Railroad scheme. Partly owing to this money panic, and partly from its natural weakness as a prompt cash resource, the financial plan of the colony enterprise proved a sorry failure; for D. M. Berry, its purchasing agent, reported in December from Los Angeles to treasurer Ruddell at Indianapolis that he had only \$I 30.80 on hand. However, this Mr. Berry became the "connecting link" between the extinct colony creation of Indianapolis and the living Pasadena of today, which happened in this wise :

One day very early in November, I873, Judge Eaton was in Los Angeles and happened to meet Mr. Berry. In the course of conversation Mr. Berry stated his business in California ; and when asked by the Judge with what success he had met, he replied in a comical but rather lugubrious tone: "Well, I have worn my shoes out, and have worn my clothes out, and I am about worn ont myself ; but I have failed to find the desired "well timbered, well watered tract." Mr. Eaton then invited Berry to accompany him to his home on the San Pasqual ranch, out a few miles in the country. Mr. Berry accepted, and was driven up the Arroyo to the Garfias mansion, and on up to "Fair Oaks," now J. F. Crank's place, near Eaton Canyon. The following morning when Mr. Berry got up he made the remark that he felt fine, and had passed the night in sonnd, unbroken slumber for the first time in three years. He looked down over the beatiful valley and was enchanted. He said, "this is the place I have been looking for."

Mr. Berry had opened an office under the name of Berry \& Elliott, in Los Angeles, in a small adobe building on the southwest corner of land where the Baker block now stands, on North Main street. After returning from his visit at Judge Eaton's, he and J. H. Baker and Calvin Fletcher, being all that was then left of the "Indiana Colony," went to work trying to get other eastern people in and abont Los Angeles to join them as colonists and buy the San Pasqual lands. They succeeded so well that the first formal meeting was held in Berry \& Elliot's office Nov. I3, at which were present in person or by legal representative-B. S. Eaton, T. F. Croft, D. M. Berry, T. B. Elliott by proxy, P. M. Green, A. O. Porter, W. T. Clapp, John H. Baker, A. O. Bristol, Jabez Banbury, H. G. Bennett, Calvin Fletcher, E. J. Vawter, H. J. Holmes, J. M. Mattlews, Nathan Kimball, Jesse Yarnell, Mrs. C. A. Vawter, N. R. Gibson. And they then and there voted to organize themselves into a corporate body called the "San Gabriel Orange Grove Association," to exist ten years, and have a capital stock of $\$ 25,000$, divided into roo shares of \$250 each.

It took a month to get the articles of incorporation prepared, signed and recorded in due and legal form, with certificate from the Secretary of 
State, etc., and on December I3. I873, the "San Gabriel Orange Grove Association" first breathed the breath of full legal existence. Its first Board of Directors were B. S. Faton, A. O. Porter, D. M. Berry, Thomas F. Croft, W. T. Clapp, A. O. Bristol, Calvin Fletcher: and they elected Eaton for president, Croft vice president, Clapp treasurer, Berry secretary.

In an article written by Hon. P. M. Green for the Farnsworth pamphlet published in $\mathrm{I}_{83}$, he says .

"The Association purchased in December, i 873 , the interest of Dr. J.. S. Griffin in the San Pasqual Ranch, consisting of abont 4,00o acres of land, and their Civil Engineer, N. R. Gibson, * was directed, under the efficient supervision of Calvin Fletcher, to subdivide I,500 acres of the choicest part of the land into tracts, varying in size from fifteen to sixty acres, for distribution among the stockholders. In this work ample provision was made for parks, wide and convenient streets, and sites for school-houses and reservoirs. The plan for parks was subsequently abandoned on account of the garden-like appearance which the entire place assumed. Active work was also begun in carrying the water from its source near the mountains, by a system of iron pipes, to each subdivision and to within a short distance of every man's door.

"The work of the engineer in subdividing the lands having been completed, the stockholders met on the 27 th day of January, 1874 , and by mutual agreement each made his selection of a tract proportionate to his interest in the corporation and suited to his taste and judgment. And such was the diversity of soil, location, and topography of the land that each of the then twenty-seven stockholders was able to secure his own choice without conflict with the choice of any other stockloolder. The chief instrument in bringing about this happy consummation was Calvin Fletcher, a resident of Indiana, who was then temporarily residing in Los Angeles."

Mr. Fletcher gave his valuable services in the matter gratuitously, for which the settlers were very thankful. He was himself the largest shareholder, yet he voluntarily took his choice of land last, saying, "Any of it is good enough for me!' and chose I 80 acres in the vicinity of South Pasadena; and afterward purchased sixty acres more from the Ward Leavitt place.

\section{THE, ORIGINAL, COLONY FARMS.}

From a careful inspection of Secretary Berry's records and the original colony map preserved in the Pasadena I. \& W. Company's office, I have compiled the following schedule of names, acres, and location of land selected by the several colonists on that memorable and historic day, January 27 , 1874. One share equaled fifteen acres, and it had been agreed that the oneshare and two-share men might first take their choice out of all the lands.

J. H. BAKER, fifteen acres. Fair Oaks to Vernon Avenue, and Walnut to Mary street-now known as the Mosher Tract. The Christian church

*Ion, P. M. Green, A. O. Bristol and W. T. Clapp served as chain men in this surveying work. They were all living in Los Angeles-Mr. Fletcher at the Pico house-and Mr. Bristol's buckskin ponies brought the party out every morning and back at uight. 
and the Lutheran church are on this selection. Baker's was the second house built in the colony.

W. J. BARcus, fifteen acres. South Pasadena-West Columbia to Hermosa street, and Palm Avenue to Arroyo Drive. He resides there yetI 895 .

AlF. W. DANA, fifteen acres. Fair Oaks to Vernon Avenue on south side of Mary street-afterward the B. F. Ball home place, and on which Mr. Ball built the first brick house ever erected in Pasadena.

JeSSE YARNELL, fifteen acres. Orange Grove Avenue and Kensington street-now W. U. Masters's home place.

A. O. BRISTOL, thirty acres. Lincoln Avenue [Old Fair Oaks] and Cypress Avenue, and from North Orange Grove Avenue down to Walnut street. Mr. Bristol built the first house in Pasadena, 20x22, one-story, and it stands there yet, near his present dwelling, at S. W. corner of North Orange Grove and Lincoln Avenue. He had by general consent chosen his lot several days previously and planned work on it, so that was really the first choice amnounced. [This special favor was a "thank you" for his buckskin ponies' services in the surveying work.]

I. N. MUNDelL, thirty acres. N. E. corner North Orange Grove and Walnut street, where he resided till $\mathrm{i} 894$, then moved to Orange county. This was the second choice announced.

A. W. Hu'TTON, thirty acres. Each side of Arlington Drive from Orange Grove to Fair Oaks Avenue. This was Judge Hutton of Los Angeles.

T. J. AND L. J. LockharT, thirty acres. Orange Grove Avenue and Arlington Court down to Arroyo Drive. (Now the McGregory place.)

E. J. VAWTER, per D. M. Berry, sixty acres. North of Reservoir Hill and west of North Orange Grove Avenue down into the Arroyn.

T. E. LippincoTT, per D. M. Berry, sixty acres. From Walnut street to North Orange Grove Avenue where the Terminal railroad now runs, and also Pasadena and Winona Avenues running northwest. He also took another lot north of North Orange Grove Avenue.

NEY STRICKLAND, sixty acres. West of Lincoln Avente and north of North Orange Grove Avenue-the Joseph Wallace place. Mr. Wallace started here the first fruit canning enterprise in Pasadena, in I88I, and continues it yet.

Mrs. C. A. VAw'ter, per D. M. Berry, sixty acres. North side of Colorado street from Fair Oaks to Orange Grove Avenue-afterward the Dr. Carr place.* The First National Bank, the Arcade building, the City Hall [White's block], the Los Angeles House, the Terminal R. R. clepot, etc., are on this tract,

EiLitotT AND Berry (Dr. T. B. EliliotT, D. M. BERRY), per D. M. Berry, I 80 acres. (Dr. Elliot had not arrived yet from Indianapolis.) From 
Fair Oaks Avenue to Arroyo Drive, and from Colorado street south to Elevado Drive.

Col. J. Banbury, sixty acres. From Fair Oaks Avenue to Arroyo Drive, and from Elevado to Waverly Drive. He built the third house in the settlement-the one where Mrs. I. M. Hill now resides, on Orange Grove Avenue - IS94.

N. R. Gibson, 6o acres. From Fair Oaks to Arroyo, and from Waverly to Palmetto street. (The James Smith tract.)

Thomas F. Croft, 6o acres. From Fair Oaks to Arroyo, and from Palmetto to California street. The first plow that ever turned a sod in Pasadena was run by Mr. Croft on his land, along where the 1st Congregational church and Rev. D. D. Hill's residence now stand-1894. The Garfield school is also on the Croft farm.

W. T. ClapP, 60 acres. From Fair Oaks to Arroyo, and from California to Congress street. The first colony school house and the first church (Presbyterian) were erected on this body of land.

H. J. HoLmes, per W. T. Clapp, 60 acres. From Fair Oaks to Arroyo, on each side of Bradford street and Markham street. Gov. Markham's residence, fronting east on Pasadena Avenue, is on this selection.

HENRY G. BenNETT, 60 acres. From Fair Oaks to Arroyo on each side of Bellefontaine street. The Catholic church now stands on this land.

J. M. MatThis, per Thos. F. Croft, 60 acres. From Fair Oaks to Arroyo Drive, next south of Mr. Bennett's choice. On this farm are now located the fine residences of E. F. Hurlbut, Prof. T. S. C. Lowe, and Mrs. Col. Baker.

B. S. EATON, 60 acres. His present home place named "Hillcrest," on the south Pasadena bluff; also from Fair Oaks to Orange Grove Avenue, and on down the west bluff, next north of the Porter \& Green selection which lay along the north side of Columbia street. "Grace Hill" is on Judge Eaton's selection.

PORTER \& GREEN, 120 acres. From Fair Oaks to Arroyo Drive on north side of Columbia street; and also on south side of same street to Sylvan Drive-Columbia Hill being then reserved for school, church and reservoir sites.

WARD LEAYI'T, per D. M. Berry, 6o acres. South Pasadena.

CALVin FLETCHER, ISo acres. South Pasadena. II $2 \frac{1}{2}$ acres of his lands are marked "Mayhew" on the original colony map.

The colony map was prepared by N. R. Gibson, engineer, and was $23 \times 52$ inches in size. A photograph copy of it was made for record, and was recorded June 25, 1874, in Book 2, pages 556 to 559 of Miscellaneous Records of L os Angeles county. J. W. Gillette, county recorder.

The amount of land bought was $3,933 \frac{1}{3}$ acres, for $\$ 25$,ooo. About I, 400 acres which lay detached, up toward the mountains, was donated to 
the colony by B. D. Wilson. This was sold off in parcels; and finally the last 900 acres of it (without water) was sold in I 882 to Woodbury Brothers from Marshalltown, Iowa, for $\$ 5$ per acre. It is now known as Altadena. I 800 acres of the water-rights land were subdivided; and 800 acres were Arroyo and hill lauds, including reserved water-bearing lands, reservoir sites, etc.

The name Pasadena was officially adopted April 22, 1875. See full account of it in chapter 18 .

Mrs. Jeannie C. Carr in her contribution to the Lewis "History of Los Angeles County," published in I889, speaking of the first apportionment of the colony lands, says :

"Nearly all had a choice spot in view, and it was an anxious noment when, the lovely landscape at their feet, and the maps outspread, the bictding was about to begin. Mr. Fletcher moved that the owners of a single share be first invited to make their selections. And such was the diversity of soil, location and topography that each of the twenty-seven stockholders secured his chosen homestead, without interfering with that of his neighbor. * * It was a singular fact that there was not a professional and hardly a practical horticulturist or farmer among them ; but the spell of the neighboring orchards and vineyards soon transformed them into enthusiastic culturists of the orange and the vine. The worn-out physician found the fonntain of youth in the pure California sunshine, which turned his grapes into delicious raisins. In the first nine years of the history of the settlement, not a single criminal prosecution occurred among a population of a thousand souls, and quarrels were unknown. Lawyers issued writs of ejectment to gophers and burrowing squirrels, of which there was no lack."

\section{FIRS'T REUNION PIC-NIC OF THE COLONY.}

On their second anniversary, January 27, I 876 , the colonists held a general reunion pic-nic in what they called Live Oak Park-now the Lincoln Park portion of South Pasadena. The entire population was theremen, women and children. Among the guests of the occasion was the venerable C. F. Clarkson, a pioneer agricultural editor and publisher of Iowa, and father of J. S. Clarkson, editor of the Iowa State Register, the leading republican paper of the state, who afterward became famous as chairman of the Republican National Committee, and First Assistant Postmaster-General in President Harrison's administration [1889]. Father Clarkson paid a glowing tribute to the location, and complimented in the highest terms the wisdom and foresight of those who had selected the situation for the settlement, and had laid so broad and deep the foundations of its success; and he predicted in eloquent words the bright and prosperous future before it, such as the most sanguine of its projectors had not conceived of. Mr. Clarkson and his wife spent the winter here and at Los Angeles; and with Col. Banbury and other friends they made a trip up Eaton canyon to the Falls, which was a notable event at the time, for Mrs. Clarkson was a woman of such large and fleshy proportions, that it was only with extreme difficulty, 
patience, perseverance, and frequent assistance that she was able to accomplish the canyon trip. Father Clarkson then and for many years until his death, edited the Agricultural Department of the Iowa State Registcr; and he wrote rapturously of Pasadena and all this region of country even to the year of his death, thus making himself its chief apostle and missionary throughout lowa-a circumstance which accounts for so many Iowa people coming here.

Another guest and speaker on that anniversary occasion was Col. John F. Godfrey of Los Angeles, after whom the John F. Godfrey Post, G. A. R., and Woman's Relief Corps of Pasadena were named. Calvin Fletcher, Dr. T. B. Elliott, and other colony members also made appropriate speeches.

FIRST CI'TRUS FAIR.

The next important stage in the evolution of the colony, as to its material interests and its guerdon of stability, was when its orchards and vineyards began to yield their fruit. And here I quote again from Hon. P. M. Green's well written sketch. Mr. Green says :

"The year 1880 being the first in which the orchards and vineyards began to be productive, the society decided to hold its first Citrus Fair, at which the products of the locality might be placed on exhibition. March 24 was the date fixed for the Fair, and when the time came the display of fruits of all kinds was greatly in excess of the most sanguine expectations. The exhibition was a grand success, and a surprise to all in attendance. The public prints of the day-all the Los Angeles newspapers being represented at the Fair-abounded in praises of the exhibition, and of the energy and enterprise of its projectors.

"The success of the society at its local exhibition encouraged it to make another display of the products of the place at the Citrus Fair held under the auspices of the Southern California Horticultural Society at the city of Los Angeles, in March, 188I. This was intended as an exhibition strictly of the citrus products of every part of the State where citrus fruits can be produced, and every section was represented. The exhibition of Pasadena at this Fair was grand and imposing. A huge pyramid of oranges, lemons, and limes was erected, which attracted marked attention. and was the admiration of the thousands in attendance. The exhibit was awarded the first premium over all competitors, and bore off in triumph the blue ribbon and the one hundred dollars awarded to it as the largest and best exhibit of the kind ever made in the State.

"At the regular Annual Fair of the Sonthern California Horticultural Society, held in the fall of $188 \mathrm{I}$, at which a general exhibit of all the fruits produced in California was made, the Pasadena exhibit again took the first preminm. Thus, at two successive tairs [in Los Angeles] Pasadena was able to carry off the first premium for the quality and display of its fruits, against the competition of the very best fruit-growing districts of the State."

THE IAAE VINEYYRD COLONY TRAC'T.

The foregoing account has followed apparently the founding and progress of the San Gabriel Orange Grove Association only, whose territory was bounded on the east by Fair Oaks Avenue. But another colony sub- 
division of lands was made by Hon. B. D. Wilson in 1876 , because by that time the Orange Grove Association had only two or three small lots left for sale, so rapidly had its lands been taken up and improved. This new colony tract comprised about 2,500 acres of land, eastward, with Fair Oaks Avenue as the line of separation from the original plat; and it was named the "Lake Vineyard Land and Water Company," from the name of Mr. Wilson's home place, he being himselt the "Company," with his son-inlaw, J. DeBarth Shorb, as general manager. Wilson and Griffin had sold the Grogan tract in 1868, and Wilson now repurchased a portion of it for his new colony scheme, so that the plat extended eastward a few rods beyond Wilson Avenue to what is now Bandini Avenue. This colony tract was laid out in five and ten acre lots, and water to be piped to each lot from a reservoir at the end of the original "Wilson Ditch" before described as made by Judge Eaton in $\mathrm{x} 867$, for Wilson and Griffin.

Thomas Banbury was here from Canada without his family. He was working for B. D. Wilson on the San Pasqual ranch, and knew of his plan for making a new subdivision of colony lands, so he bargained for a ten acre lot and staked it off himself before any survey had been made. This was in December, 1875 . Mr. Banbury planted a patch of potatoes on his lot, just about where the Pasadena Manufacturing Co.'s big planing mill is now located, and on December 27 started back east to bring his family. His was the first lot ever taken in the Lake Vineyard Colony tract. On his return he took three nore ten-acre lots, making a 40 -acre block extending from Fair Oaks Avenue to Marengo Avenue. In i 877 he sold the south 20 acres of his land to W O. Swan, Sr., which was the first sale from the Lake Vineyard Tract made to second parties. Glendale street now runs through this 20 , and the Santa Fe freight depot stands upon it.

These new colony lands, with water, were held at $\$ 75$ per acre, in small lots, in I876. But L. D. Hollingsworth, just arrived from Iowa, sought better terms, on condition that he would induce a number of Iowa families to come and settle here and so give the newly opened lands a good start for settlement and sale. Upon this, Mr. Wilson agreed that if he and his friends would take onie hundred acres at once they might have it at $\$ 55$ per acre. Then Mr. Hollingsworth made up a syndicate of buyers, as follows :

L. D. Hollingsworth [in the family] - - $\quad 50$ acres.

Charles Legge - $\quad$ - $\quad$ - $\quad$ - 20 "

Solomon Dunton (by his son-in-law, Col. J. Banbury) ro "

Col. Jabez Banbury - - - - - - 5 - 5 "

S. Washburn

This made 90 acres [the other ten being guaranteed], and was the original purchase and start for the new colony except ' $T$. Banbury's lot. But Mr. Hollingsworth had obtained a special concession that any of his Iowa friends who should come here to settle within a year should have land 
at the same price. This concession, however, was afterward extended to others, and under it lands were bought the same year at the same price by David Townsend, 30 acres; John Lowe, 20 acres; A. Ninde, 20 acres; P. G. Wooster, io acres.

Thomas Banbury gives a little different version of the matter from the Hollingsworth people. He says the low price of the lands sold in 1876 was conditioned on their "making up a pot," as Mr. Wilson expressed it. of 200 acres; and that the total sales that year, including his first ro taken in December, 1875, amounted to 2 Io acres-so Mr. Wilson was satisfied, as the " full pot" had been made up.

These purchases, and the occupancy and improvements which went forward in rapid succession, had now given the "east side colony" as it was called, a good start; and the price of Company lands, with water, was thereafter held at $\$ 75, \$ 80$ and $\$$ I 00 per acre.

The work of getting a water supply down to these lots now had to be pushed as rapidly as possible. The original ditch was enlarged and extended down to Reservoir No. I, and finally cemented from Devil's Gate to the reservoir. Of course all this took time; and for several months the "eastsiders" had no water supply but what flowed in a plow-furrow ditch from the reservoir site down through the body of land they lad chosen. Then the gophers would often push fresh loose dirt into the stream and muddy it, or make their holes where the water would all run into them and disappear, leaving none for the new comers above ground; and occasionally hogs were found wallowing in the ditch where it crossed the old ranch lands up near the Arroyo. These were some of the tribulations of pioneer life in Pasadena. It was the daily business of the settlers to go with their canteens, buckets, barrels, tubs, etc., to the ditch and secure a supply of water for the day, or longer. Dr. Allen tells that, having no horse, he had to roll his water barrel back and forth by hand, a distance of half a mile from house to ditch.

The construction and cementing of the permanent main ditch was done by 'Thomas Banbury under contract, superintended by Hon. J. De Barth Shorb, who relates with much satisfaction that two distinguished U.S. army engineers, Gen. B. S. Alexander and Col. Geo. H. Mendel, estinated that it would cost at least $\$ 5$ per runuing foot, but he built it at a cost a little under \$2.75 per runuing foot. The cement or lime for this job was dug out of the hillside at Lincoln Park by Thomas Baubury, and burned there, where the Mission Fathers had done the same thing asearly as $1780-8$ I. In constructing this cement ditch there was a certain point where a pike or causeway had to be made some distance across a depression in the land. Mr. Shorb and his engineer, named E. T. Wright, had set the stakes for this fill, and A. O. Bristol had charge of a gang of Chinamen doing the grade work. One day John W. Wilson reported to his uncle B. D. Wilson down at his Lake Vineyard home, that there was something not right about that ditch 
work. The old man called Mr. Shorb in from the winery above the house for some explanation, and they took the buggy and drove in haste up to where the work was going on. Seeing the bungle of it at once, the old man was deeply vexed, and reproached Bristol for making such a blunder. Bristol very calmly replied that he was following the stakes just as they had been set and marked by the engineer. Mr. Shorb thought this could not be so. Mr. Bristol replied, "Well, here are the stakes; I have saved them from being covered up or broke11 ; You can see for yourselves." Mr. Wilson looked at them sharply a few seconds and then burst out - "Well, I never did depend on any of these scientific fellows but what I got fooled. Here, Bristol, bring your old crooked level-stick and make this thing right."'

And Bristol with his "old crooked level-stick" made the line right. The trouble with the engineer was that he had drank wine freely and it made him see crooked.

The first house on the Lake Vineyard side was a rough board cottage built by L. D. Hollingsworth, on one of his ro acre lots, early in 1876 . It was afterward improved and a neat front added - and it still stands in the same place, being the third house on west side of Marengo Avenue south of Kansas street.

The lots selected by the original Hollingsworth syndicate have all become points of historic interest. Mr. Legge chose his twenty acres on the south side of Walnut street from Fair Oaks to Marengo Avenues; and on it are located the Baptist church, the Crown Villa Hotel, the Public Library, and his home place where he still resides.

Col. Banbury selected for his father-in-law, Rev. S. Dunton, the ten acres on north side of Walnut street and east of Fair Oaks. During the "boom " lays (I 885 to I 888 ), Chestnut street and Raymond Avenue were opened through it ; and the Universalist church, besides the East Hall and West Hall of Throop Polytechnic Institute are now located on the original Dunton purchase.

Mr. Hollingsworth's son, Henry, had chosen ten acres south of Walnut and east of Marengo (which was included in his father's fifty), and the Wilson High School and Lincoln School are both now on this land.

L. D. Hollingsworth took three Io-acre lots on north side of Colorado street, from Fair Oaks Avenue eastward, which reached a little beyond Worcester Avenue, and built his own home on the east lot, just about where the Presbyterian church now stands. He also proposed to put up a building, and open a store and get a postoffice located in it, at the corner of Colorado street and Marengo Avenue, because he thought that elevated site would be the finest point for the colony village or business center. But the "west siders," as the Orange Grove people were then called, pulled so hard for a location at least on the street line between the two settlements that he yielded the point, and built his store near the corner of Fair Oaks Avenue 
and Colorado street, where McDonald, Brooks \& Co.'s real estate office now stands. Then J. H. Baker moved his original colony blacksmith shop from Walnut street, west of where Rev. W. C. Mosher now resides, down to a location just east of the new store. A man named Watson started a meat market just north of the store. O. R. Dougherty started a shoe shop. And thus the trading center became established. Then, in August, 1876, Mr. Wilson donated five acres on the south side of Colorado, eastward from Fair Oaks Avente to where the Santa Fe railroad now runs, to the colony for school purposes. [See Chapter 9, "Annals of the Schools."] The district voted a tax to erect a school-house there, large enough to accommodate 200 pupils. And this was the final nail which clinched the town center, and fastened it so firmly that half-a-dozen or more strong efforts to change it since, in the interest of some speculative scheme, have proved disastrous and memorable failures.

The five acres chosen by Col. Banbury for himself was that where the M. E. church and parsonage and "The Tabernacle" now stand. And the five chosen by S. Washburn was on the opposite side of Marengo Avenue, the Brockway block being the only important building on it as yet, I 895 .

The ten acres which P. G. Wooster bought about the same time, but not in the syndicate, comprised the ground now occupied by the Santa Fe R. R. depot, the Hotel Green, the Post Office or Morgan block, and the Wooster block. The Townsend, Lowe and Ninde purchases of that year were farther out in different directions and have not won any special historic prominence, up to 1895 .

\section{CHAP'TER VI.}

OLD SETTIER EXPERIENCES.-Eleven personal narratives of first experiences in Pasadena, in response to questions sent out.-Who the "Old Settlers" were, and where they were from.

\section{OLD SETTLER EXPERIENCES.}

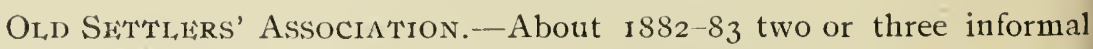
meetings were held to talk up the matter of organizing an Old Settlers' Association; and A. O. Porter served as chairman. [Mr. Porter died January 17, 1888.] But the same difficulty that occurs in all such cases came up here also-that of agreeing upon a time limit for determining who should be reckoned as "old settlers" and who should not. No agreement was reached, and the whole matter gradually dropped out; so that no such organization was ever really effected, although I found some who thought there had been. It is true that at these "talks" on the matter a preliminary list was made up to see who were here and when they came, etc., but 
that was all; and Rev. Farnsworth used it in making up the Pasadena Directory part of his book, a "Southern California Paradise," published in I 883 .

On commencing the preparation of this History of Pasadena, I gave out by mail or personal delivery to about 130 different persons a blank prepared for noting down such items of their first experiences here as might form an interesting little historical sketch. Only eleven of them ever took the trouble to fill out the blanks and return them to me; and to these eleven I devote this chapter, taking the names in alphabetical order.

HENRT G. BENNETT.

Came from Ann Arbor, Michigan, by way of Union Pacific and Central Pacific Railroads to San Francisco, thence by boat to San Pedro, and reached Los Angeles October 23, I873. Settled in Pasadena in February, 1874. Built a two-room cottage on west side of Orange Grove Avenue, where Bellefontaine Avenue now runs westward, and this pioneer house is still in use at the west end of that street. It was the fourth house built in the colony. Building material, fiel and provisions all had to be brought up from Los Angeles. My first crop was barley; then wheat, corn, vegetables, and fruits. i $876-$ 77 were dry or drouth years; wheat and barley grew only one foot high; yet during the following summer we had fruit of finest quality. [It is curious to note that the first four houses built in the colony were by B-men : I-Bristol ; 2-Baker ; 3-Col. Banbury ; 4-Bennett.--ED.]

D. M. BERRY.

In Chapter 5 will be found a full account of Mr. Berry's first visit to Rancho San Pasqual, and the part he bore in deciding the colony settlement here. Mr. Berry died at San Fernando, December 22, 1887. His daughter, Mrs. Jessie Berry Waite, resides there ; and in a letter of September 16, I874, she says of her father: "He selected the location [Pasadena] from the garden spots of Southern California. He was at first much pleased with Santa Barbara, but let its sleepy beauty go by, feeling assured that there would be greater things yet in store for Pasadena, with her large valley and fine climate."

Mrs. Waite loaned me a scrap book which she had made when a little girl at their old home in Indianapolis ; and in it I found the following account of our new colony, written by Mr. Berry from Los Angeles, May 30, 1874 , to the Indianapolis Daily Journal:

"In this valley of beauty the cabin of the writer had been built, and a gallant hunter from Indianapolis, with another from Chicago, started in the morning for the valley to gather venison, rabbit and quail, to inaugurate the ranch house with a sumptuous feast, while the 'Secretary' himself was to arrive at sunset to join in the opening feast. But -

"'In vain! alas! in vain, ye gallent few!

From rank to rank your volleyed thunder flew." 
"It is sad to say, the game flew too, and at the sunset hour when the hopeful party gathered for the feast, the disconsolate hunters unpacked their stores, consisting of one ancient owl. Finding nothing in Nordhoff, Blackstone or Euclid, by which we could adapt the bird of wisdom to our necessities, it was left to the culinary skill of the coyotes, and all tried their skill at cooking on an alcohol fire. The bill of fare was brief and the cooking susceptible of criticism.

"Owing to a disappearance of the carpenter, the roof of the house had been omitted, so the building was well ventilated, and there was no necessity of putting in a sky-light. But as the season of rain was supposed to be gone on a summer vacation along the Mississippi, no inconvenience was anticipated from the absence of a roof. The first attempt at sleeping was interrupted by a company of owls that perched on the rafters, to hiss their indignation at the sleepy sinners beneath, for shooting their venerable comrade. The shooters devoutly wished the defunct bird re-animated and back in the canyon with all his noisy tribe. On the third night, during the most slumberous hours, a heavy rainstorm put in an unexpected appearance. The agility and zeal displayed in improvising a shelter in midnight darkness was worthy of a good cause. It was then discovered that even so trifling a thing as a roof to a house was not to be despised at all times. As soon as the spring rains were apparently passed, the carpenter appeared and the roof was put on, to lie in idleness during all the summer time.

"In the few weeks since the Hoosiers took possession of their lands great activity has prevailed. Three miles of flume and ditch have been made; three miles of large iron pipe made, laid, and covered below the depth of a plow; a reservoir with the capacity of three million gallons has been constructed on the highest land of the settlement, and the water has been let in. An occasional mountain brook trout takes an unexpected trip through three miles of darkness, and is hurried into the reservoir at the speed of a railway train. Eighty acres of grain have been raised for hay, roo, 000 grape cuttings have been planted, and a large quantity of orange and lime seed; about ten thousand small trees for nursery planting have been purchased; and a large area of land prepared for corn and semi-tropical fruits.

"Potatoes and other garden products, planted in February and March, are now yielding a good return without irrigation. Our company has been recently re-enforced by Major Frie Locke, who is actively at work as a ranclero, and seems to enjoy the business as a pleasure. Tree planting will be conmenced in a few days."

In a letter published in the Los Angeles Herald, Nov. -, I874, Mr. Berry again wrote:

"Major Tirie Locke has just completed his residence at San Pasqual, (Orange Grove Association) and gave a house warming last night to celebrate the event. * * Within the past month Dr. Conger of Salt Lake, Mr. Cooley of Marysville, Mr. Weldon of Truckee, and Mundell of Los Angeles, liave built comfortable residences, and Messrs. Porter and Green are preparing to build. Messrs. Berry, Elliott and Conger have constructed private reservoirs to hold from 75,000 to 100,000 gallons, and Messrs. Berry, Locke, Banbury, and Bennett have planted out a considerable number of orange, lemon and lime trees." 
When the opening of the S. G. V. railroad to Pasadena occurred, September I6, I885, Mr. Berry was city editor of the Los Angeles Daily Herald, and of course came ont to report the great historic event. And from an interview with him the Pasadena Union gave a graphic account of his first experiences in the colony, which I here condense :

"As soon as the colony was started I hired a man to go out from I,os Angeles and build me a little house. He got the walls up, floor laid, etc., but no roof, then he got dry, and went to Los Angeles and got drunk - and forgot to come back and get my roof on. Meanwhile I came out, supposing my house was all ready for me, but found it roofless and no carpenter at work. I rolled in my blankets, lay down on some shavings, and dreamed that I slept. Before morning there was a pouring rain and I was soaked to the marrow. It seemed as if my house would become the first reservoir of the colony, from the amount of wetness that filled up around me."

\section{B. CIAPP.}

I arrived here in September, I 876, by railroad to San Francisco, and boat thence to San Pedro. Came from Hartford, Conn. The first of the colony men I met was Dr. T. B. Elliott, who brought meout from Los Angeles. My first lodging was on top of a pine box, softened a little with some hay borrowed from a neighbor's stack. I bought a 23 -acre lot and built on it the first two-story plastered house that had a solid concrete foundation in Pasadena. It was located on Orange Grove Avenue south of California street-now owned by James North. Building stone and fuel we hauled up from our Arroyo lot ; but lumber, provisions, hardware, etc., had to be procured from Los Angeles. The eatable wild game was deer, ducks, rabbits, and quail ; and for want of turkeys or chickens, we made our Thanksgiving dinner of rabbits that year. There was no rain until Jannary, I877, and my household goods had lain out doors until then. The first crops we raised were corn, wheat and barley. A year or two after we built our house a rattlesnake attempted to crawl in at the back door : but we captured him, and found that he was an older settler than we were, for he had seven rattles and a button. None have been seen thereabouts, however, for many years.

\section{DR. O. H. CONGER.}

Mrs. Conger writes: "We arrived here August 24, I874, by steamer from San Francisco. We had lived two years in Salt Lake City, but formerly in New York City. The first colony people we met were Judge Eaton and D. M. Berry; and we first lodged in Mr. Berry's board shanty on Orange Grove Avenue. Fuel was hauled from the mountains [canyons]; but provisions, building material, laundry work and mail, were procured from Los Angeles. Our first house was on the site of our present home, and consisted of one long room built of matched redwood boards, with a sash door in each end; and we moved into it on September 28, I 874 . The first crops we raised were potatoes, white beans, lettuce and onions. The 
following June we set out 300 two-year-old orange trees west of the house. A few months later grasshoppers came. We bought a lot of muslin and Doctor and I covered every tree and saved them. Our thirty acres were all set to oranges, grapes, and a full variety of deciduous fruits. Our first raisins were cured by hanging the large bunches of grapes on nails driven along the south side of the house and covering them with mosquito netting. Our daughter, Lulu N. Conger, born August 4, I875, was the second child born in Pasadena-the first one being a daughter of the Wentworth family then living on the Joseph Wallace place. Mr. Wentworth went back east soou after the grasshopper raid, saying he was tired of wearing old clothes with no money in his pocket. He had formerly been a railroad conductor.

\section{JUDGE EATON'S NARRATIVE.}

I arrived in California in August, I850, coming across the plains on horseback, with ox teams to haul our provisions. Came to Los Angeles in the autumn of $185 \mathrm{I}$, by sea, on a little tug boat called the "Ohio," from San Francisco.* It took four days to steam down the coast. Came onto the San Pasqual ranch, the present site of Pasadena, in December, i858. [A part of this narrative, pertaining to his temporary occupancy of the old Garfias adobe ranch house, from December, is 58 , till July, I 859 , is embodied in Chapter IV., Division 1 , which see. He left the ranch in 1859 , and did not return to it until February, I865.-ED.]

I must here recur to a little history foreign to myself personally, as it involves the incipient steps toward turning this ranch from a stock range into the thriving, beautiful city that it now is.

After the death of General Albert Sidney Johnston [Confederate General], his widow determined to remain here ; and her brother Dr. Griffin requested her to visit San Pasqual ranch and select a spot for her future home. She fixed upon the spot now known as "Fair Oaks" - the property of J. F. Crank [1894]. Accordingly a square mile of the ranch, including that spot, was segregated and a partition made of the lands (for in the meantime B. D. Wilson had become the owner of an undivided one-half interest), $\dagger$ Mrs. Jolnston thereby becoming the owner of the Fair Oaks property, and B. D. Wilson owner of what is now the Allen estate. Mrs. Johnston immediately built a comfortable but unpretentious cottage for her home. This was the second house built on the ranch.+ She first occupied it with lier family aboit Christmas, 1862. The following May the loss of her oldest son, Albert, $s$ a young man of splendid promise, destroyed her plans, and in a

\footnotetext{
*In 1851 there was seemingly some clanger of a general revolt of Mcxicans against American rule, and a company of volunteer troops was formed, nnder Gen J. H. Bean. B. S. Iiaton was one of the corporals in this company. - [See Cenlennial History of Los Angeles County.]

+ It was in 1858 that Dr. (iriffin had loaned Garfias $\$ 5,000$, but this transaction did not appear of record; hence (iarfias's first deed of the entire ranch was made to B. D. Wilson, Jan. 15,1859 , as shown in uy sketcl of the "Chain of Titie." on page 74. But just when and how wilson aud Griffin arranged their undivided joint ownership I failed to find.- ED.

$\ddagger T h i s$ is a mistake. The Jose Perez adobe house ou south slope of Raymond hill was built in 1839 . Dona lincarnacion Abila built an adobe house for Camacho, her major domo, in is 44 , near the Garfias spring. carlos llanawald and John Pine, the gold hunters, built their adobe ca hin at foot of IIanaford's bluff, in 1850-59. Garfias built his great adolre ranch honse in 1853. Mrs. Jolnston's house came next, in 1862 .

2. In the explosion of the little stcamer, Ada IJancock, Apri! 20, 1863, near Wilmington, among many lost were, of our merchants, Wm. 'r. B. Sanford, Dr. Henry R. Miles, Loeb Schlessinger; with capt. Tliomas Workman, the young ALBFRT SIDNEY Jounston, son of General Albert Siduey Johnston. Miss Melora Ifereford. sister-in-liaw of $11011 \mathrm{~B}$ W Wilion, died soon after of injuries receivid in this deplorable cillamity. - Centennial llist. Lus . Angeles County, p. 57 .
} 
few weeks she left the ranch never to return. [NoTE.-Mrs. Johnston's husband was killed in the battle of Shiloh or Pittsburg Landing in April, 1862. Her brother Dr. Griffin's wife was sister to Judge Eaton's first wife ; and her son, Hancock M. Johnston, married Judge Eaton's daughter Mary. When Mrs. Johnston sold the Fair Oaks ranch and gave a deed of it, she made special reservation of the space occupied by the grave of her son, Albert Sidney Johnston, who had been buried there.-ED.]

About two years after she left I entered into a contract (I865) to bring the waters of Eaton Canyon ont, and moved with my family into the Johnston house. The terrible drouth of I $864-65$ had swept away my stock and I turned my attention to agricultural pursuits. Cleaning off the sagebrush and cactus, I planted 5,000 grape vines as an experiment-for no one in Southern California had ever tried to carry a vineyard through the summer without flooding it with water from three to five times, and I knew from the small supply of water that I had I could not give my vines a drop. In fact, for the first two years of my residence there, I had to haul all $\mathrm{my}$ water for stock and domestic use from Wilson's and Rose's, a distance of three miles and a half. When the Savans and older inhabitants heard of my reckless undertaking, they unanimously voted me a leather medal for being the greatest fool that ever struck this country. But my vines did so well that the year following I planted 30,000 more, and in two years (it had always taken four years before this) produced a wine that made old manufacturers open their eyes, for it brought prices that they had never before heard of.

During these first years my greatest anxiety was where the next sack of flour was coming from to feed the hearty kids that were constantly putting in an appearance in the family circle.

The ranch abounded in jack-rabbits, cotton-tails, quail, and some deer. Of wild fruits there were none except a few cherries that grew on a brilliant green shrub near the base of the mountains. This production hardly deserved the name of fruit, as it consisted principally of a pit about the size of a cherry, with a very light veneering of flesh. [See foot-note, p. 23.]

Bears were frequent visitors in early days; not grizzlys, perhaps, but the brown bear, very much like them but not so large. One of these "varmints" had the audacity to enter Mrs. Johnston's door yard in the daytime, tip over a bee-hive and help himself to honey. He was discovered by Sid Johnston, then a lad of seventeen, who in the absence of fire arms, drove him off with rocks, at the same time denouncing him as a "dog-gon thief." The first visit I received from the gentry was in the spring of 1865 , when a big fellow whose tracks measured eleven inches, came within fifty yards of the house in the night, and slaughtered a calf. Being disturbed by my dogs and men before he had finished his feast he beat a retreat. I tracked him into Rubio Canyon, where I set a big trap, hanging a part of the calf on a tree above. He sprung the trap, but escaped only to find his death by eating anotlier piece of the slaughtered calf, which I had loaded with strychnine. The following summer I was engaged most of the time building a dam up in the canyon. In going up mornings I frequently saw the tracks of a large California Lion, or puma, and on one occasion he waded through my mortar bed and left the impress of his great foot-prints upon many a boulder, from which I concluded he was a big fellow. One morning later I went to the creek to get a bucket of water. A Mexican boy accompanied me. It was very warm and we sat on the edge of the streanl close to a big 
clump of bushes and slaked our thirst from the clear, beautiful stream. A few moments elapsed when the Mexican, who sat next to the bush, suddenly jumped up, and turning around, exclaimed "What animal is that ?" I had also risen to my feet, and turning, saw within reach of a buggy whip, the biggest lion I have ever seen. He did not seem a bit scared, and walked off leisurely, keeping his head turned so that he could watch us. I had nothing but a tin cup to defend myself with in the event he had felt aggressive. I even held my hands behind me to convince him I was a non-combatant. But this interview did not end our acquaintance. Some days later one of my gentle driving horses was missing, and after a brief search, I found her not far from where the Allen house now stands, dead-the body still warm. There were evidences in the disturbed earth around that there had been a violent struggle. He had evidently sprung upon her while sleeping, sunk his teeth in her flank, and never relaxed his hold until she surrendered. There was no question as to the cause of her death; for the lion, as is their custom, had dragged up grass and rubbish in an attempt to cover up the carcass. Knowing full well that he would return at night to finish his feast, I seasoned the body with strychnine. He did not come back but once. I saw no more of his tracks in the canyon; and six months afterward one of my boys discovered his carcass about a half mile distant from where lie took his last supper.

The next year I had quite a lot of hogs and a litter of fine shoats that I kept in a pen not far from the house, and they began to disappear one by one. Of course I knew pretty well where they had gone; and considering them an insectre piece of property in that region, I disposed of all but one fine, fat animal that I had reserved to put into liam and sansage about Christmas time. I had thought that as she would weigh about 250 or 300 pounds, she would be too much of a load for the wild animals to pack away, and was therefore safe. I reckoned without my host, for one morning she was gone and had not even given a squeal.

I learned from some Mexican wood choppers about that time that there was a she-lion with two cubs living in one of the deep ravines that lead np to where the Sierra Madre Villa Hotel now stands. After cleaning me ont of my hog-meat, she turned her attention to horse-flesh, first killing a colt, and afterward a lame mule belonging to Mr. Wilson. She also caught one of my horses and wounded three of his legs, but he was young and strong and escaped from her. I finally disposed of her by dosing that dead mule's carcass with strychnine.

That was abont the last of bear and lion on the ranch, unless I mention a laughable incident which occurred about i 870 . A man by the name of Orr had a bee ranch on what is now the Elms place, above Altadena. Absenting himself for awhile from hone, he found on his return that bears had been there and upset eleven stands of bees, robbing them of all the lioney. Hot for revenge, he went over to old man Seabury's (now Kinneloa) and got the old gent to go with him and kill the thieves. They hunted three or four days through the mountains, and finally returned worn out, and slept at Orr's ranch. That same niglit the bears came in silently and lielped themselves to the contents of three more stands, and retired withont alarming the hunters. 'This impudent behavior so disgusted Orr that lie abandoned the place and never returned.

One year after my vineyard conmenced bearing, the bears ate off all the grapes from a reninte corner of it. T'he coyotes were formerly abundant 
here, and were also destructive on the grape crop. Mr. Wilson once told me that discovering that the ranch abounded in jack-rabbits, he bred a lot of gray-hounds, and anticipated great sport in the chase; but he had no sooner got his dogs ready than the eagles discovered the game, gathered about and caught the jacks in such numbers that they were greatly thinned out, and the sport was spoiled.

Along the base of the mountains rattlesnakes were quite plentiful, but they do not increase rapidly and soon disappear upon occupation and culture of the territory. The first year at "Fair Oaks" I killed eleven, three of them having eleven rattles each. Fvery year the number killed became less, and the last year we encountered but one, and he a little fellow with but one rattle.

Of tarantulas, scorpions and centipedes there were enough for family use, but as they are harmless, they are only proper subjects for natural history. I have never known any one injured by them.

\section{HOW "A CASE OF ASTHMA" DECIDED THE LOCATION OF PASADENA.}

Judge Eaton furnishes the following graphic account of D. M. Berry's first night at his house, and how it proved the turning point which led ultimately to the settlement of Pasadena-a story now for the first time told in print. Also a sketchy narrative of the beginnings of colony work :

Dr. Griffin wishing to dispose of his remaining interest in Rancho San Pasqual, for two years I made a business of bringing out prospective buyers, but met with no one who could see anything in it. At last, happening into a real estate office in Los Angeles, I was introduced to a slender, pale, weaklooking, round-shouldered man, with a stove-pipe hat, and other characteristic features that proclaimed him a "tender-foot." He told me that he was one of a pioneer committee of three who were in search of a tract of land on which to establish a colony of "Hoosiers," already organized in Indianapolis. I invited him to go out home with me. * * * It was a long, dry and dusty drive to my home, and the ranch, which had been pastured very closely with sheep, showed not a vestige of green. Arriving at Fair Oaks about sundown a different scene greeted his eyes. Broad live oaks surrounded the little cottage, affording a grateful shade, and in front a vineyard of 60,000 vines presented a sea of verdure. On either side of the house were groves of orange, lemon and lime trees. The following morning he looked two inches taller, and upon my asking him how he rested, he straightened up, and striking himself heroically upon the breast replied, "Gloriously! Do you know, sir, that last night is the first night. in three years that I have remained in bed all night?"

"Why so?" I inquired. "Don't you go to bed and sleep nights, like a good Christian?"

"Yes, I go to bed all right, but by midnight I am obliged to get up and sit in a chair until morning, for I can't breathe lying down."

This circumstance has led me to remark sometimes, "that it was a case of ast!lma that determined the location of the Indiana Colony."

I kept Mr. D. M. Berry, for my guest was none other, for two or three days, during which I drove liim around the neighboring country. I showed him the waters of the various springs in the Arroyo ; and knowing well the topography of the country, I explained to him how the waters could be 
brought out and distributed over the plains. Then we visited Wilson's and Rose's to see places that had been improved long before I broke ground on my place.

Mr. Berry was so certain that he had found the desired spot that he immediately sent back a description of the property and what it would cost. Negotiations began, and steps were taken for a partition of interests between Wilson and Griffin, the former not wishing to dispose of his. It was three months before a satisfactory partition was effected. Meanwliile the Indiana Colony Association failed; but those who had embarked in it were determined not to give it up, and commenced immediately to canvass the city of Los Angeles to fill the places of the delinquent subscribers. Their efforts were crowned with success, and a new organization was formed and incorporated under the name of the "San Gabriel Orange Grove Association." Messrs. Porter, Green, W. T. Clapp, Barcus, Mundell, Bristol and Col. Banbury were Los Angeles recruits. In the meantime the partition of the Griffin and Wilson interest was completed, and about 4,000 acres were allotted to Dr. Griffin, who sold it to the colony, and the balance, I,600 acres, to B. D. Wilson. [Wilson's allotment included the original water ditch from Devil's Gate.-Fin.]

\section{HOW THF, COLONY WORK COMMENCED.}

One of the first acts of the Board of Directors was to appoint a committee consisting of Messrs. A. O. Porter, Calvin Fletcher, and B. S. Eaton to superintend the subdivision of the lands and devise the construction of water-works. At the first meeting of the committee, business opened about this way: Mr. Fletcher stated that he had had a good deal of experience in laying ont towns, planning streets, etc., and if it was agreeable to the other members of the committee he would take charge of that part of the business, and direct our engineer in his work. "But," he added, "Judge, you will have to look out for the distribution of the water, for I don't know anything about that."

Mr. Porter, in his modest, conservative manner, said, "I know a little something about land, and a little something about water, for I owned a grist mill once. But I am satisfied with your arrangement, and I will act as umpire; and if I see you going astray will call you off." Accordingly this was the understanding, and each one set about his special task.

Mr. Fletcher was a thorough-going energetic man, and he immediately commenced planning for a convenient and equitable subdivision. He traveled on foot from one side of the 1,500 acres which was to be subdivided to the other, and from end to end, studying the topography and the general features of the tract, and in his own judgment determining the character and value of the lands. He so contrived the laying off of lots that oneshare stockholders (fifteen acres) had the same chance of obtaining desirable situations and good lands as those who represented twelve shares (iso acres). This obviated a difficulty which had very much perplexed the company - that was, how were selections to be made so that all would be satisfied?

At a meeting one Saturday night, our engineer announced that his survey was completed-all the lots-( IOO of them)-were staked off and numbered. Several of the subscribers were living in a temporary way in Los Angeles with their families and were impatient to get onto their newly acquired lands. But how were they to be assigned - that was the momentous 
question. Histories of other colonies were ransacked for precedents and methods of division. Several were suggested, only to be voted down. Arguments waxed warm, and a trifle of acerbity was creeping in, when the chair [Judge Eaton himself.-E,D.] proposed that every stockholder appear on the ground at an appointed time and we would have a sham fight over the business.

This was apparently showing levity about a serious matter, and was promptly opposed, for the reason that it would probably end in a row, and we would be no nearer an amicable settlement of the question than we were now. Mr. Fletcher had sat back in a corner listening. He was one of the largest stockholders. It was nearing midnight and all were anxious to get avay, yet nothing had been accomplished. Finally Mr. Fletcher arose and said, "Gentlemen, as we have not succeeded in adopting any of the plans proposed, suppose that we try the suggestion made by the chair, and all go out there and see how many of us can get just the spot we want. I would suggest that next 'Tuesday-that will give us one day to look over the ground-we all meet at the foot of what I have named Orange Grove Avenue, and try and settle this matter to everybody's satisfaction." 'That proposition was adopted, and we met as proposed.

It was as lovely a day in the month of January (27th) as a California sun ever shone upon. Early rains had fallen and the hills were dressed in living green, while the earth was a carpet of flowers of every hue. By ten o'clock people began to arrive. Men with their wives and children, men with their sweethearts and men without them, and not a few of the neighboring settlers attended, as they said "to see the fun." Everybody was happy, surrounded as they were by everything beautiful in nature.

I was then living at "Fair Oaks," but was taking as much, if not more interest in the establishment of the colony than in my personal affairs. As I came in sight of the grounds I saw men on horseback, men in buggies, and men on foot rushing from one side of the plain to the other, occasionally stopping to note the number of some lot that they thought might be desirable. When I alighted at the ground where the group had gathered, joy and pleasure beamed in every face, and I deemed it an auspicious omen. The children scattered about gathering flowers and full of mirth, lent cheerfulness to the scene. Bountiful lunch baskets were brought out, and everybody seemed disposed to a merry-making time. After lunch, which the ladies had provided in the most liberal style, the men began sauntering along in twos and fours and squads toward the point where the Orange Grove reservoir is located, as this afforded the best outlook over the tract to be divided. When all had gathered there the President directed Secretary Berry to call the roll of subscribers, and requested those stockholders present to announce, when their names were called, the number of the lot or lots they would prefer. (The committee on subdivision [Porter, Fletcher and Eaton] had agreed that they would make no selections themselves until all the others had chosen, and they represented twenty-eight out of the roo shares.) There had been some apprehension felt by the small shareholders that they would be crowded out into some corner, or be obliged to take what was left after the "heavy men" had made their selections. Mr. Fletcher, knowing what was apprehended, had cut some of the most desirable sections of the tract into one-share and two-share lots, and the oneshare men were called on to select first. After things had proceeded in this way for a time, the secretary was requested to call the names of some of the 
absent stockholders, and if any one present represented them they were called on to make their choice. In about twenty minutes the whole business was settled without a clash, and every man had secured just what he wanted. Everybody seemed happy and a general love feast ensued. [For names of members and lots chosen, see page I08.]

Mr. L. H. Titus, a neighbor who had been an interested witness of the whole affair, remarked, "Let me tell you, Judge, this colony is going to be a success. When I see men act as they have today success will surely follow." How well that prophesy has been verified the Pasadena of I894 can testify.

\section{PUZZLES ON MR. FLETCHER.}

Mr. Fletcher strove hard to preserve some of the old landmarks on the ranch. He laid off Orange Grove Avenue so as to save two noble oaks, which stand today as mementoes of his careful labors. But he was perfectly at sea about how the levels rum in this country. He was so positive that water would run toward the mountains that he spent one of the rainiest days I ever saw in California, wandering over the ranch to see which way the water would actually run in a flood. On his first visit to the ranch I had taken him onto the hill where the Orange Grove reservoir is now located, and explained that that was the spot from which the waters would be distributed over the colony lands.

"But where is its source?" he asked.

"Yonder, where that spur comes down into the Arroyo from the west," said I, pointing to "Devil's Gate."

"And do you pretend to say that water will flow from there up here?" feet."

"No, sir, it will flow from there down here, with a fall of sixty-two

"Judge," he replied, in a half-doubting tone, "I s'pose you know ; but I an a railroad bnilder, and if I wanted to run a line of road between these two points I would bring 1ny engineer right onto this spot and tell him he must wind around and try to get down to that place the best way he could."

California took him at a disadvantage when he went to measuring lands with his eye ; for on the same occasion and from the same standpoint he inquired, "Where are the 1,300 acres situated that we got in the deal ?"

I well knew what inspired the inquiry; for before he started for California, and while negotiations were pending, some malicions fellow wrote an anonymous letter to Indianapolis, telling the colonists that their pioneer committee was being imposed upon, or had entered into a conspiracy with the owners of the ranch, and were bribing the surveyors to make false surveys and give enlarged areas; in fact, that the Indianians were being swindled. This caused some trouble for a while ; but as there was 110 fonndation whatever for such a story, things came around all right. In reply to his question I pointed out to him a strip along the base of the mountain, bordered on the sonth by a dark line representing the Monks ditch.

"Why, Judge," says Fletcher, "I can take a couple of yoke of Indiana 4-year-old steers and plow up your I,300 acres in a week."

I made no reply, but bided my time. Soon after that, Fletcher, Berry and myself drove over the I,30o-acre tract to the west end, next to the Arroyo Seco. Fletcher alighted, and began kicking up the dust and examining the soil, as was his custom. Giving Berry a significant wink, I said, 
"Let's go over to the southeast corner and see if we can find that stake which Reynolds said he had driven there."

"Go on! go on!" says Fletcher; "I'll walk."

We drove over to the stake. It was a very warm day; and after we had waited an hour, Mr. Fletcher, who carried a good deal of extra flesh, came up with his coat off, puffing and wiping the perspiration from his cheeks, and exclaimed, "Gentlemen, it's all here! it's all here!"

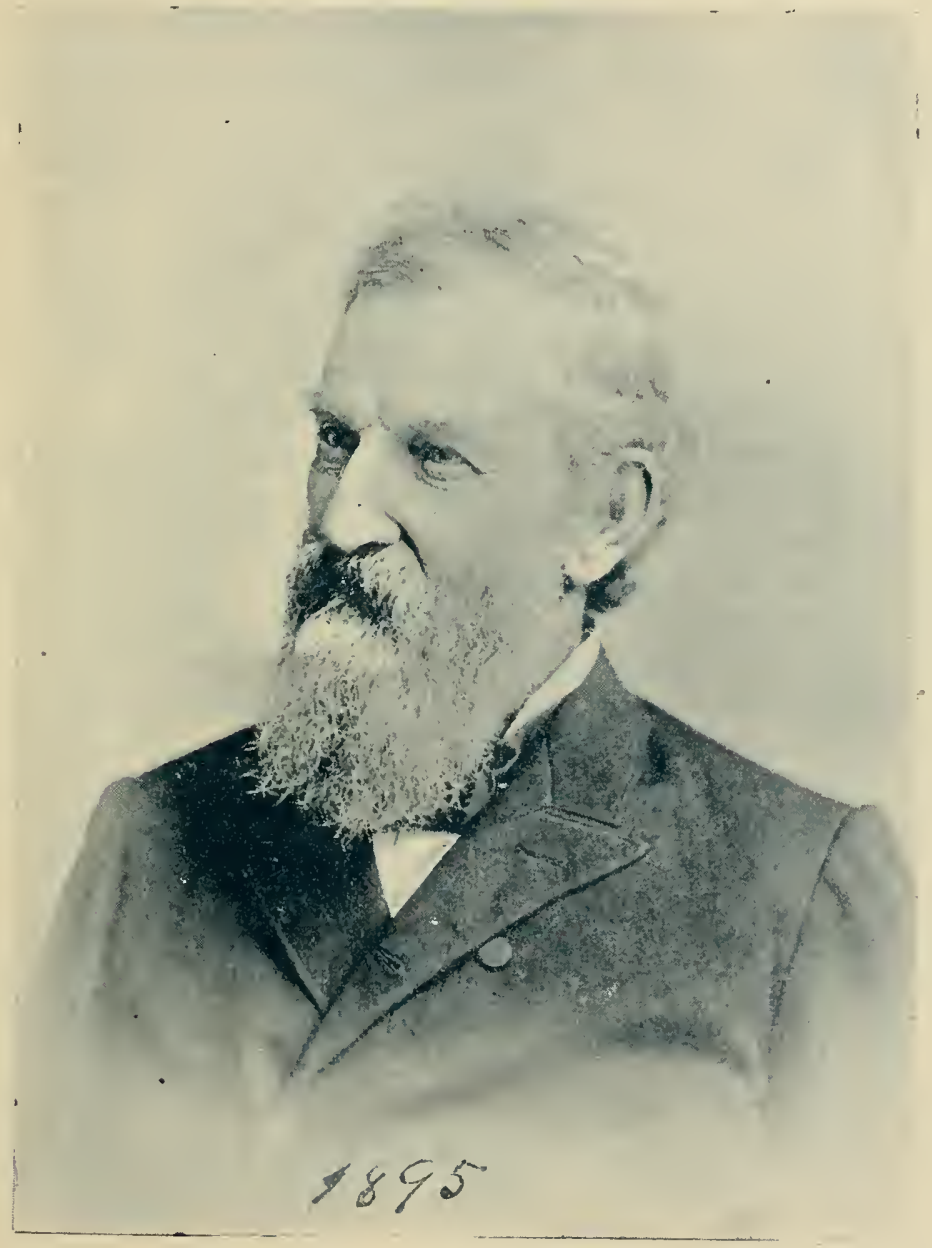

JUDGE B. S. EATON, 1895.

See foot-note, page 328 .

"You won't plow it up, then, in a week with your Hoosier steers!" I said, latughing.

"'Well! well!" he answered, "who ever saw a country so deceiving in its appearances!"

At another time the same party were coming up the Arroyo Seco road from Los Angeles, when Fletcher, who was always inclined to chaff 
Berry, good naturedly said to him, "Berry, you will never be able to make a corner on sand and boulders in your settlement, as you and Elliott used to make on corn and wheat back East."

When our local paper noticed the fact that this same sand and boulders of which he had spoken so derisively was worth twenty-five cents per load, "as it lay," Mr. Fletcher was reminded of his little joke by the report of the totally unexpected rise in the value of these waste-land commodities.*

\section{E. W. GIDDINGS.}

Our families consisted of L. W. Giddings and wife, with their children, married and nnmarried, as follows: Oldest daughter Elsie, and her husband E. H. Royce, with their daughters Jennie and Florence Royce. Eugene W. Giddings; Mary, and her husband Calvin Hartwell. Laura Giddings, J. Reed Giddings, Jr., and Grotius L. Giddings.

We all came with our own teams from Sacramento, and arrived at Pasadena November 4, i 874 . We did the breaking or first plowing on much of the colony land; but finally settled on the bench of land at mouth of Millard canyon, commonly called " Giddings Heights.' '†

As to wild game, I have taken all sorts, from rabbits or quail to grizzly bears. I have always kept hounds-have six on the ranch now, and scarcely a week passes that I don't get at least one or two foxes. Once I was hunting near Devil's Gate, when my hound treed four big wildcats in one tree. I shot two of them; the third one jumped and the dog grabbed him - then the fourth one sprang on the dog, but he never let loose his grip. One got away after being wounded, but "Cash," the dog, and I got three to carry home as trophies-though he was laid up for some time with the bites and scratches the cats gave him. This was the same dog with which I got thirty-seven deer within two miles of home, one year. Once I shot a young buck; he fell, and I ran to him, laid down my gun and grasped his

*From a biography of Judge Faton prepared by Mrs. Carr for the I.os Angeles Co. Iristorical Society, I gather a few nain points, as follows: BENJ. S. FiATON-bor11 December 20, 1823, at Plainfield, Conn. Both of his grandfathers were soldiers in the revolutionary war: and his father was in connuand of Fort Trumbull in the war of 1812 . Youttg Benjamin taught district school in Southbridge. Conn.. and Oxford, Mass. Studied law at Newbury, N. Y., and Ellington, Conu. Graduated from Harvard I,aw School in July, 1846 In spring of 1847 was 111artied at Liberty. Missouri, to Miss Helen Hayes of Baltimore. Md., sister to Benjanin Hayes who afterward served twelve years as Judge of I,os Angeles conity, Cal. In $1847-48$ published a newspaper at Weston, Mo. In 1850 came to California with ox teans via Salt I,ake to sacranento, and engaged in newspaper work. In 1851 went gold digging. In 1852 canle to Los Angeles because his brother-in-law. Judge Hayes, was living there. In 1853 was elected I)istrict Attorney. ISee Chapter 11 for list of public offices held by hin1. In December this vear his family came here via Isthmus of Panama. In December, IS58, he cane onto Rancho San Pasqual with live stock. In May, 1859, his wife died $i n$ L,os Angeles. In 1860 he went hack overland to Plainfield, Conn., to visit his mother, then eighty-four years old. In February, 186t, was married to Miss Alice Taylor Clarke, at Plainfield, and returned to Los Angeles about Mav ist. In February, 1865 , settled at Fair Oaks, on Rancho San Pasqual; hut while residing here was employed in superintcnding construction of ditches, flumes, canals, reservoirs for supplying water to the liill portions of Los Angeles. His work on the Rancho, and his part in the original colony settlement are given elsewliere. State Engineer W1n. H. IHall, in his official report for 1858, p, 502. says: "The Orange Grove Association's origiual works, planned and carried out under the supervision of IIon. B. S. Haton, were the first constructed in Sonthern California wherein water was conducted and distributed for general horticultural irrigation by means of iron pipes and under pressure." [This is a unistake, for B. D. Wilson and J. De Barth Shorb had done the same thing at Alhanbra two years eartier.-Iitn.]

tI. W. Giddings died September 23, 1Sgr; and the Daily Slar of next day said: "He had been sick about a year. He is of a historic fanily, being a nephew of the great abolitionist, Joshula R. Giddings. He was born in Ashtabula county, Olio, sixty five years ago last June; and seventeen years ago he came to Pasadena, settling on the mesa near the foot of the mountaius, wlience he was only removed two and a half months ago to Ellis street in this city for convenience of treatment." 
fore foot to bleed him-then he jumped up and started down the canyon, I holding on with all my might, and for about a hundred feet on the slope there was a mixed up mess of deer and man, each on top by turns. However, I finally triumphed, and had venison for supper; but ever after that I

\section{CORRECTION SUIP [to face page I28].}

On page 128,6 th and 7 th lines from bottom [footnotes] there is an editorial note in brackets at which Judge Eaton felt aggrieved, and thought it erroneous, and also unjust toward him upon a matter in which he had taken a good deal of pride. Hence I "rise to explain." Now, that "NoTE" was based on what I had written, as printed on pages 336-37, about B. D. Wilson's operations at Alhambra, upon information gathered from Mr. and Mrs. Shorb, and from Mr. Wilson's MSS autobiography, and from his step-son, E. S. Hereford, Esq., of San Gabriel. Mr. Wilson knew of Shorb having iron-piped water from a canyon at Camulos in 1864 to supply the boiler for his steam engine, and then extending it to his house fir domestic uses and also to irrigate the trees, flowers and shrubbery growing there; and it was because he fully believed the same thing could be profitably done on a large scale that he ventured to buy in $I 87 \mathrm{I}$ the waterless and worthless block of school lands now called Alhambra. His plan and purpose to pipe water onto that land was talked over and well understood in the family when the purchase was made; but on account of various other large enterprises in which Mr. Wilson was then engaged, the subdividing and water-piping project was not carrierl out until two or three years later, although I had understood at first that it was done within a year or so after the purchase of the land, and hence so wrote in I 894. But now, October 2I, I 895, I learn from J. F. Holbrook of Los Angeles that in I 873 his firm of Miles \& Holbrook made a lot of riveted sheet-iron piping for Dr. John S. Griffin and piped water under ground from two large elevated pump-tanks to irrigate a ten-acre orange orchard, the same land now known as the Schieffelin Tract in East Los Angeles. Then in the spring and summer of 1874 they furnished the same sort of pipe for the work that Judge Eaton was superintending in the "Indiana Colony." And also at the same time they were laying the same sort of pipe for B. D. Wilson, to convey water from Mission Canyon near the old distillery to irrigate his large Lake Vineyard urange orchard; then the next year they extended this piping on down to the Alhambra Tract. I find in county records that the original Alhambra Tract was surveyed and platted by G. Hansen, in June, I874. Mr. James M. 'Tiernan, business manager of The Capital [a weekly newspaper at Los Angeles] assisted as chainman on this survey, and has kindly aided me in these special investigations.

ADDITIONAL ERRATA: discovered after those given on page 675 were printed.

Page $338,2 \mathrm{~d}$ line from bottom: i 884 should be 1894 .

Page 408, I 8 th line from bottom: "northwestwardly" should be northeastwardly.

Page 416,3 d line from buttom: i 886 should be 1876 .

Page 610, 4th line below the plate of illustrations: "stages of division" should read, stages of germination.

Ars Each purchaser is requested to mark at the proper place in his own copy the corrections noted here, and also those on page 675 , so that the errors shall not be quoted, nor stand to mislead any one. There are doubtless other misprints in the book which I have not yet detected.

The general Index, pages II to I6, contains 963 page references.

The Floral Index, pages 647 to 649 , contains 709 page references.

The street Map, at page 16 , contains 310 references by figures and letters.

The bird's-eye Map, at page 4 IO, contains 80 references by numbers.

The plant names commencing with $O$ were accidentally omitted from the Floral Index, at page 648 , and I give them here:

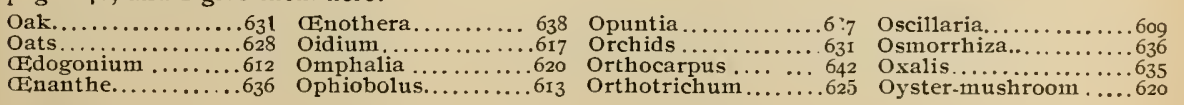


Berry, good naturedly said to him, "Berry, you will never be able to make a corner on sand and boulders in your settlenent, as you and Elliott used to make on corn and wheat back East."

When our local paper noticed the fact that this same sand and boulders of which he had spoken so derisively was worth twenty-five cents per load, 
fore foot to bleed him-then he jumped up and started down the canyon, I holding on with all my might, and for about a hundred feet on the slope there was a mixed up mess of deer and man, each on top by turns. However, I finally triumphed, and had venison for supper; but ever after that I made sure that the game was dead before venturing too near.

On Thanksgiving Day, I878, my brothers Reed and Grotius and I went hunting up the canyon; and espying an eagle, we followed it and, after a hard climb and lots of work, succeeded in killing it. His tip feathers measured nearly twenty-four inches, and the total spread of wings was ten feet three inches.* We left the body where we killed it, for it was too heavy to carry home. The place was the mountain wall on eastern side of Punchbowl canyon, a branch of Millard canyon which comes in from the north, half a mile above Millard Falls.

\section{A PASADENA GRIZZLY BEAR.}

During the winter of 1879 -8o, bears kept robbing our bee stands, a lot of which we had in the opening now called Elms's Canyon. One night in January or February I had a howling toothache and couldn't sleep, so I told the boys I would go over to the apiary and "kill a bear for them." They were too sleepy to go. Before I got started of course the tooth stopped aching ; but I wouldn't back out then. So I took my old Sharp's musket50-70, single shot, and went. About 2 o'clock in the morning, just as the moon was going out of sight, I heard a noise among the bees and started out to investigate. Creeping slowly and cantiously along and peering right and left among the hives, I finally espied a bear beyond one of the tall hives-and he wasn't a baby, either. I took aim and fired, and over he tumbled-but was up again in a second, hitting his right shoulder where the bullet had entered vigorously with his left paw ; and he gave one of the most terrific batks or grunts I ever heard: it was like the rage and fury noise of a mad hog and dog combined. Then he spied me, reared on his hind legs and came toward me. I fired again, this time hitting him in the left hip. He turned, started off, went about i25 yards and fell dead. 'The first shot had passed through his lungs and liver. I didn't find him till morning. Then four of us carried him up to the road, loaded him into a wagon and drove down to Pasadena. In a few moments it seemed as if the whole population of Pasadena was gathered at Williams's store to see the bear; and the public school opposite the store was dismissed so the children could have a chance to see it. The animal measured 7 feet io inches from tip to tip, but only weighed about 500 pounds, for he was very poor-almost nothing but skin and bones. Some men fancy they could face a bear and be perfectly calm ; but with a big grizzly within less than thirty feet, coming

*This was not an eagle, but a California coudor, the largest bird known in North America No eagle reaches that dimension. And Reed Giddings tells me that he remembers they were puzzled to tell what kind of an eagle it was, but finally concluded that it was a "bald eagle." "They didn't know about the condor, and it was perfectly natural that they should think it an eagle of some sort. 
at you, you feel as if your hair all stood up as stiff as hazel brush. It was less than ten short paces from where the empty shell fell from my shoulder to where the bear stood when I gave him the second shot. This was the only genuine "grizzly" killed at Pasadena since the town commenced. I killed or helped to kill three other bears that same year.

As to Indian relics, I have found no stone axes nor arrow heads, but have found old mortars [metates] and pestles [mealing stones] - small ones, only $3 \times 5$ inches, and larger round ones 6 to 7 inches through, or mostly about 5 inches long, $1 / 2$ inches thick and 3 inches wide; also some 6 to 7 inches through, round, and about 2 inches thick. All show extreme age, and were from 2 to 15 inches below the surface. The mortars are nearly all worn through. They were found mostly on the banks of the Arroyo or Millard creek. [See page 49.]

\section{M. GRAHAM.}

By Mrs. Graham: We came to Pasadena in October, 1876 , with our own conveyance from Anaheim, but were originally from Bloomington, Ill. We boarded at Mrs. Locke's for awhile, then rented a part of Mr. Cooley's cottage; but built our own house in 1877 . The first crop we raised was strawberries. My sister, Jennie E. Collier, was with us. Pasadena was just getting a postoffice; and Mr. Graham had a two-horse carriage and wanted to drive out every day for his health anyway; so he took the contract and became the first mail-carrier from Los Angeles to Pasadena, doing also a passenger and package business at the same time. [See "Story of the Postoffice," Chap. Ir.]

A. K. M'QUILLING.

Came to Pasadena with my family in July, I875, from Mercer County, I11. Came by railroad to Sacramento, then to San Francisco and San Pedro by steamer. The first man we met in Pasadena was A. O. Porter, who was irrigating a bed of orange seed, on Orange Grove Avenue. We first lodged in D. M. Berry's house. Our fuel was procured from wood lots in the Arroyo. I bought ten acres in the Berry \& Elliott tract on Colorado street, where Pasadena Avenue and Kansas [Green] street are now. Hauled lumber from L,os Angeles and built a house there. My first crop was corn. As to snow, hail, destructive wind storms, excessive rains, and drouth, we have had them all; but came through them in good shape.

HORATIO N. RUST.

My family came from Chicago to Pasadena by Southern Pacific railroad, arriving here January 23, 1882. The party consisted of myself and wife, our son, Frank N. Rust and wife ; our children, Nellie F., Edward H., and Elizabeth E. Rust, and Ernest H. Lockwood. We first met here Wm. T. Clapp, and obtained lodgings at his house and Thomas Nelmes's (the boys 
lodging in Mr. Clapp's barn), until we could prepare a shelter on my own land. I purchased the last piece of colony land on Monterey road (the same where I now reside), paying \$So per acre. We all worked, and homemaking improvements went on rapidly.

[Mr. Rust was a member of the board of directors of the public library, from its beginning as a colony blossom down to the time when it was transferred to the city as one of the municipal institutions. See full account in Chapter 10.]

Being commissioner of immigration for Southern California, I originated and helped carry through the first Citrus Exxhibit sent from here to Chicago. This was in $\mathbf{1 8 8 6}$, and gave our navel orange a prominence in Eastern markets which it never had before. Again, in September, 1887, I was general superintendent of the Southern California Horticultural Exhibit, at Armory Hall, St. Louis.

Indian Relics. - I brought with me to Pasadena a collection of prehistoric and modern Indian relics which I had been gathering ever since my boyhood from many states and territories, besides Canada and Mexico; and I soon began collecting specimens of the same sort in Pasadena and vicinity. I also made the first special art-collections of Indian baskets in Southern California. And my archæological collections formed a prominent feature of the first Art-Loan Exhibition, held for the benefit of the public library in 1884 . In $1890-9 \mathrm{I}-92$ I was United States Indian Agent, under President Harrison's administration. In I 892 my archrological collection was purchased by Frank G. Logan of Chicago, and I exhibited it for him at the World's Columbian Exposition, I893, being nyself a member and secretary of the board of judges for the Ethnological Department there. Mr. Logan finally donated the entire collection to Beloit College, Wisconsin, where it is now carefully preserved.

JOSEPH WALLACE.

Arrived in Pasadena in June, 1875 , coming by rail and stage from Titsanburg, Ontario, Canada. The first resident we met here was Mrs. Dr. Elliott, and we boarded with their family at first.

[This is all that Mr. Wallace gave of his "old settler" experience. But his good work for the colony will be found in the historic sketch of his pioneer cannery enterprise, Chapter 24.- - ED.]

\section{P. G. WOOSTER.}

Late in April, 1875, I came down the coast from San Francisco to Santa Monica. Some thought that place was to be the great city and shipping port for the Los Angeles and San Gabriel valleys. From Santa Monica to Los Angeles I came by the old Independence Railroad. Stopped at the United States hotel for a while, but soon took a room at Dr. McKee's cottage, corner Third and Fort street (now Broadway). I must have looked 
and acted very sick; for as I walked about the streets of the city I overheard such remarks as these: "There's another poor consumptive. He's come out here to die. He's too far gone. This climate won't do him any good. He'd better have staid at home with his friends," etc., etc. One said, "He ought to drink buttermilk; that will cure him. When I came here I had the consumption ; and I drank buttermilk and it cured me." I looked at the fellow, and thonght him a pretty poor specimen to be sent back East as an advertisement of this country-for his cheeks were sunken like the hollows on a New England coast map, and his eyes looked like buttons in a washtub. Seeing things thus, I decided not to diet on buttermilk.

In May I got acquainted with surveyor E. T. Wright of Los Angeles. He invited me one day to ride with him out to the "Indiana Colony." We went by the Arroyo road. On what is now called Highland Park, and near the Arroyo where the Potts residence now stands, there was a low old adobe building - a relic of the old Spanish or Mexican days; and Wright told me, with solemn tone and countenance, that the man living in that house had killed six men, and was waiting for the seventh to come along. I felt very uncomfortable till we got well past the place. (We returned to the city by the east or adobe road, and I was very glad of it.) We reached the colony settlement at what was called "Porter's Hill," where A. O. Porter and P. M. Green had pretty cottages - the prettiest in the place, I thought, because the others were mostly unpainted. At this time there were no houses on the Lake Vineyard Tract-that is, none east of Fair Oaks Avenue.

In June I bought ro acres on the Lake Vineyard side at \$\$5 per acre, less 12 per cent. for cash down - the land where Hotel Green, and the Santa Fe depot, and the Post Office building, and the Wooster block all now stand. I came to pitch my tent here July 8, i 875. My lumber, my stove and other kitchein utensils, my provisions and myself were hauled out from Los Angeles by a Mr. Higgins with his 6-horse team that day. I lodged awhile at Dr. Elliott's, nearly where the Arroyo Vista house (Mrs. Bangs's) now stands; theu a week or two at Rev. W. C. Mosher's home; then moved into my own less than half-completed shanty. While at Mosher's, and also in my own shanty alone, I suffered terribly and nearly died with rheumatism. I lived in my shanty several months before I got a roof on it, for I was too sick to work, and had but little means. But I needed a horse; and I bought from a man who had just came from Arizona, an Indian pony, a fine saddle, bridle and tether, all for \$40. The boys called my pony "Rosinante," after Don Quixote's famous steed. I rigged up for my pony a two-wheeled cart, the thills of which were fastened to the saddle; and when I hauled wood, or water, or anything, I rode in the saddle myself instead of the cart. The pony was Injin bred and I was Yankee bred, and 
we compromised on this new trick style of express wagon. I wore cowhide shoes, usually run down at the heel; a checked cotton shirt; and blue jeans pants that were rather short, so that my ankles and cotton socks were exposed. These were badges of bachhood and wifeless independence. One day I begged a dog from a shepherd going by with his flock, named him "Watch," and he stuck to me closer than a brother.

My shanty was one of the very first put up on the Lake Vineyard side. At the same time old Mr. Hollingsworth built his house; and Mr. Lowe built the Roger Plant house on Marengo Avenue; Mr. Vore built a board cottage; and Mrs. R. H. Martin built a board cottage of two or three rooms on the E. C. Webster place. One moonlight night in the month of July, 1875, I slept in the Martin cottage, with only a grass hammock and a thick traveling shawl for bedding, and I nearly froze to death before morning. How the coyotes did howl that night! and other nights, too, when I slept in my own shanty there where the big pepper tree is, in front of Hotel Green. By the way, my wife planted that pepper tree there in I880.

I came to Southern California for wy health. In the East I was much afflicted with catarrh, and my bronchial tubes were badly clogged. Life was a burden; I had no ambition and was not able to work. After coming here I had a severe siege with rheumatism, then began to improve rapidly and soon was able to labor hard every day. And have enjoyed pretty good health ever since.

\section{WHERE THE OLD SETTLERS CAME FROM.}

A few months ago a San Francisco paper spoke of Pasadena as a place "originally settled by a lot of Puritans from New England" - a statement, widely incorrect, as my following syllabus will show. When an Old Settlers' Association was talked of, twelve or thirteen years ago, it was commonly agreed that persons wlo came here prior to and during the year I 880, should be reckoned as "Old Settlers," anyway, whether later arrivals were counted in or not; and upon that basis I have compiled the following list of names, years and places, both for its own historic interest, and as a guide list for a Pasadena Pioneer Society which may possibly spring up some day yet. For convenience of reference I give the names in alphabetical order rather than the order of successive years, and have marked with a star those who were members of the original Orange Grove Colony Association :

PASADENA OLD SETTTIERS-I 870 TO I 880 .

Alle1, Lyman, M. D.......... I880...Missouri, formerly Ohio.

Allen, Wm.................. $879 \ldots$ England.

Baker, Edwin ................ I 874...Pennsylvania.

*Baker, John H............... $873 \ldots$ Indiana.

Ball, Benjamin F............ I878... Iowa, formerly Ohio.

*Banbury, Jabez............. I874...Iowa. 
Banbury, John W............. I 876...Canada.

Banbury, Thomas.............. I 874...Canada.

Bangs, Mrs. Emma C......... I 880... New York State.

*Barcus, Wm. J ................ 874 ...Indiana.

Beebe, Jerome................. $876 \ldots$ Chicago.

Bell, Charles W.............. I $877 \ldots$ New York State.

*Bennett, Henry G............ I 874... Michigan.

Bennett, Will J................ $875 \ldots$ Michigan.

*Berry, D. M.................. I 873...Indiana.

Bishop, Miss Cynthia M....... I876...Vermont.

Blatenburg, James ............. I $877 \ldots$. Iowa.

Brigden, Albert................ I877...Chicago.

*Bristol, A. O................. I873 ... Iowa.

Brown, C. C.................. I 879... Michigan.

Bryant, S. D................ I876... Iowa.

Bryant, H. L................. I 876...Iowa.

Cambell, James................1877... New York State.

Carr, Ezra S., M. D., etc.... 1880... New York State.

Case, Cyrus C................. I 878...Michigan, formerly Maine.

Case, H. R.................. I 880...Massachussets.

Case, Chas. H............... I 880...Maine.

Chapman, Fred E............ I880...Illinois.

*Clapp, Wm. T................. I 873...Massachusetts.

Clapp, Wm. B............... $874 \ldots$ Massachusetts.

Clapp, I. B................. I876...Connecticut.

Clapp, Ed. C.................. I880...Connecticut.

Clark, Geo. P.............. I $874 \ldots$ Connecticut, formerly Rhode Island.

Cobb, Mrs. Rebecca A........ I876... Iowa.

Conger, O. H., M. D.......... I874... New York State.

Cooley, Walter E.............. I874... Massachussetts.

Craig, James ................. $869 \ldots$...ngland.

Crank, James F.............. 877 ... New York State.

*Croft, Thomas F.............. I873...Indiana.

*Dana, Alfred W............... I874... Massachussetts.

Dougherty, O. R............. I $877 \ldots$ Indiana.

Dunsmoor, A. V.............. I 878...Minnesota.

Dunton, Rev. S.............. 1876... Iowa.

Dyer, R. B................. I 876...Connecticut.

*Eaton, Benj. S................ I858... Missouri.

Edwards, Alex ............... I 874...Indiana.

*Elliott, 'T. B., M. D........... I 875 ... Indiana.

Farnsworth, Rev. R. W. C..... I880...Vermont.

*Fletcher, Calvin .............. I 8 74 ... Indiana.

Foote, Chas. R............... I 879... Massachusetts.

Foote, Misses Mary H. and

Catherine L ............. I879...Massachusetts.

Freeman, Wm ................ r 880...W isconsin.

Gano, Peter................... I880...Ohio.

*Gibson, N. R................. 874...Indiana.

Giddings, I,evi W............. I874... Iowa.

Giddings, Grotius L ........... I $874 \ldots$... Iowa.

Giddings, Eugene W..........I874...Iowa. 
Giddings, J. Reed............. I 874... Iowa.

Gilchrist, James D.

I $879 \ldots$... Chicago.

Gilmore, Mrs. Lucy .

I 876 ... Massachusetts.

*Green, Peryr M.

1874...Indiana.

Greene, Frank W

I $874 \ldots$ Massachusetts.

Goodwin, H. F. r 880 ...W Wisconsin.

Hannaford, Wm. S........... r880...England.

Harry, Wm ................. $874 \ldots$ Indiana.

Hartwell, John L ............. $879 \ldots$ Iowa.

Heald, F. H................. $878 \ldots$ Iowa.

Heydenreich, F. H. ........... $877 \ldots$ New York City.

Hollingsworth, L. D.......... $876 \ldots$ Iowa.

*Holmes, H.J............ I874-1882...San Francisco, formerly Michigan.

Hovey, F. M

i $880 .$. Vermont.

Hurlbut, Edwin F ........... r 875 ... Chicago.

*Hutton, A. W................ $874 \ldots$ Alabama.

Jewett, S. P.

I 878 ... Ohio.

Kinney, Abbott................. 880...Maryland.

*Leavitt, Ward ................ 879 .... Indiana.

Legge, Charles ............... 876 ... Iowa.

*Lippincott, T. E.............. I 874...Philadelphia.

Locke, Mrs. R. C.............. I $874 \ldots$ Indiana.

*Lockliart, T. J. and L. J....... I 874... Indiana.

Lord, I. S. P., M. D........... I879...Chicago.

Lowe, John.................. I $876 \ldots$.... Salt Lake City.

Lukens, 'T. P............... I880...Illinois.

Markham, H. H............. 8 879...Wisconsin.

* Matthews, J. M...............1874...Ohio.

McQuilling, A. K............. I875 ... Illinois.

Meharry, Geo. E.............. r $880 . .$. Indiana.

Michener, L. H............. r877... Iowa.

Millard, Ellisha ................. I $875 \ldots$ Indiana.

Mills, A. F................. 878 ...Canada.

Mills, John S................ I $877 \ldots$ Canada.

Martin, Mrs. R. H........... $876 \ldots$ Massachusetts.

Martin, C. S.................. 876 .. Massachusetts.

Martin, Wm. D............ r $876 \ldots$ Massachusetts.

Maudlin, Solomon .............r878... Iowa.

McLean, Edward.............. $888 . .$. Oakland, Cal., formerly Connecticut.

Mosher, Rev. W. C.............1874...New York State.

* Mundell, I. N.

874 ...Ohio.

Nelson, Joseph A .. ..........1876...New Orleans.

Ninde, Albert ............... I $877 \ldots$ Salt Lake City.

Painter, John H............. r880... Iowa.

*Porter, A. O.................. 875 ...Indiana.

Printz, Dennis................ 1876... Iowa.

Raab, David.................. $870 .$. Illinois.

Rice, B. A ..................... $880 .$. Kansas.

Richardson, Geo. A ........... $875 \ldots$ Massachusetts.

Ridgway, Harry ............... i $878 \ldots$ Canada.

Riegle, Henry H............... I 879... New York State.

Ripley, C. B.................. $876 \ldots$ Maine. 


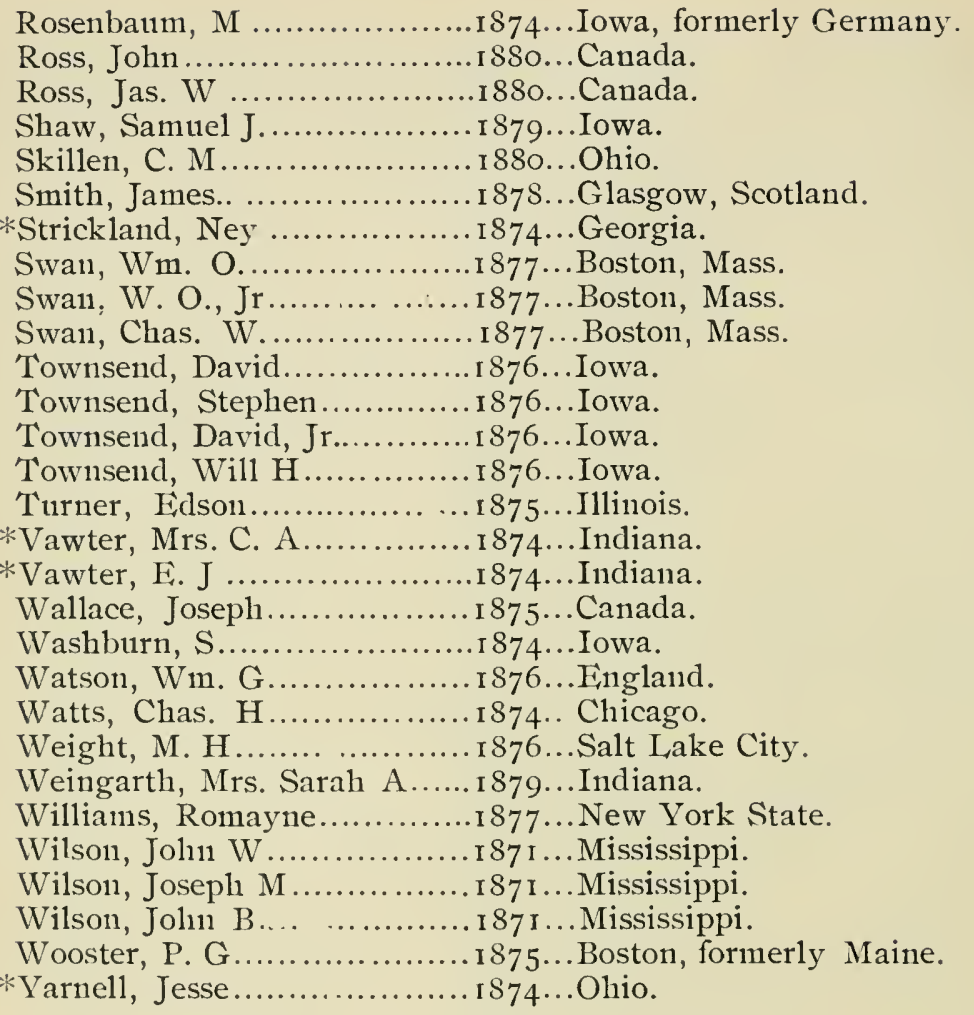

The first Directory of Pasadena ever published gave names and former home of all permanent residents of the place, up to May r, IS83; and the following summary shows from what diverse portions of our own and other conntries these people had gathered to form an ideal and polyethnic settlement (Chinamen not counted) at this "crown of the valley":

From Iowa 62, Illinois 29, Massachusetts 26, Indiana is, N. Y. State 17, Missouri Ir, Canada Ir, Ohio 9, England 9, California 8, Connecticut 7, Minnesota 6, Wisconsin 6, Maine 5, Michigan 5, Pennsylvania 5, Vermont 5. Colorado 3, Kansas 3, Mississippi 3, Utah 3, Germany 3, Scotland 3, Nebraska 2, Arkansas I, Delaware I, Lonisiana I, Maryland I, Montana I, Rhode Island r, Texas I, Washington Territory I, Manitoba I, New Brunswick I, Sweden I. These represent about 200 fanilies, not counting bachelors.

The twenty-seven members of the original colony association stood thuss: From Alabania i [Judge A. W. Hutton now of Los Angeles], from Georgia I, Indiana I4, Iowa 2, Massachusetts 2, Michigan 2, Missouri I, Ohio 3, Pennsylvani i - total, 27. 


\section{CHAPTER VII.}

FUn In THE Colony.-A witty newspaper, The Reservoir.-Some Dog-gerel poetry.Grasshopper Talk.-The Preacher, and Wilson's wine.-Stage talent in the colony.-Baker's Bear.-The "Nine Nobby Niggers."-Who killed Jesse Lee?-Col. Banbury's Deer.-The "rifle team" saw a bear.-Rabbit Hunts.

FUN IN THF, COLONY.

The first colony settlers of Pasadena were very largely of the class who keep school-houses and churches in the foreground wherever they go, yet they were neither morose nor long-visaged people. The spirit of fun and funmaking cropped out very soon, even amidst the most arduous cares and labors of their pioneer life. D. M. Berry was notably a joker; Calvin Fletcher had a keen vein of humor; Judge Eaton could see the ludicrous side of a thing, and laugh as easily as any one; and in fact the American tendency of the age to give serious things a humorous turn was not at all lacking in this sober and very earnest community. But the first distinctive historic manifestation of this spirit is found in the first number of The Reservoir, Pasadena's first newspaper.

THE FIRST NEWSPAPER.

This was a pen-and-ink paper, prepared by Arthur H. Day, and read before the literary society in the up-and-down board shanty school-house of the colony, December 28, 1876 . It was entitled "The Reservoir"; and the following extracts from the leading editorial article will serve to show the spicy flavor of the entire first number. The editor says :

" To carefully conserve the results of this experiment we have prepared this 'Reservoir,' small in size to be sure, and plain in construction, but we do not assess yon for its making, and its water is free.

"That an undercurrent of literary genius does exist in this fertile ranch has been satisfactorily proved - not artesian in its nature, forcing a profuse current into the upper atmosphere; neither, on the other hand, has one to bore severely for results. A judicious removal of the upper crust of modesty and excuses will give rise to many a gentle flow.

"As your appointed 'zanjero,' having filled the 'Reservoir,' we continue our official duties by apportioning its contents out to you. This is 'service-water' only, and only your small pipes are to be used - large ones we conld not fill, and you will only be disappointed if you prepare to receive our effusions in that way. You may complain of lack of head, and that feature we acknowledge and justify - a part of a tale, , at least will appear."

Under the head of "Foreign Correspondence," the following humorous and witty "letter from London" was given :

\section{LoNDon, December 25, A. D. 2000.}

MosT Venerable Doctor Day - The High and Mighty Editor of the "Reservoir": In looking over the mouldy archives of the past I came

*This "tale" refers to a story entitled, "Perdita," written by Mrs. Margaret Collier Graham, which was commenced in "The Reservoir" and afterward completed by Mrs. Graham and published in The Argonaul at San Francisco. And also in a volume of her writings issued in 1894. 
across an account of a settlement of a city in California named "PASADENA." Said city was founded in the year of grace 1873 , by some devout pilgrims from the country of Indiana and other Indian countries of North America, because the stock of quinine on which they lived and moved and had their being had become exhausted. * * * The land was appointed to the pilgrims by choice, and all fell to work to develop some pet hobby. Among the first settlers were found the names of Porter, Green, Croft, Bennett, Barcus, Elliott, Rosenbaum, Clapp, Newton, Locke, Banbury, Berry, Conger, Cooley, Mundell, Watts, Bristol, Washburn - these ancient names indicating distinguished tribes to which they belonged. * * * In time the people extended all over the great valley of San Gabriel, but the original settlement of Pasadena remained the center of attraction and a sacred place to all the descendants. And now in all parts of that beantiful place are conspicuous monuments to the memory of the pioneers, with characteristic inscriptions.

'To the memory of Green there is a tablet with a copy of Blackstone and Whateley's Logic and Rhetoric, with an orange grove in the distance.

In the memory of Porter is a marble shaft with a bust of John Wesley and a Methodist church surrounded by orange trees in bas-relief on the pedestal.

On the monument to Croft was a span of mules driven at full speed by himself and carrying a load of provisions and some books of music and poetry - all for the benefit of some family in distress.*

Over the ashes of Bennett rose a monument representing two hachelors cooking Christmas turkey and labeled "Par nobile fratrum, Ann Arbor, Michigan.,"

The monwment to Elder Clapp represented that venerable father in Israel marching at the head of his tribe to Sunday school, carrying a banner with the inscription, "I consider this the proper thing to do."

Jndge Locke is represented as the presiding magistrate of the people, and has just blown counsel, sheriff and jury ont of doors by exploding a pun in the conrt-room about the size of a barrel of cider. Some thought it was an earthquake; but his son who could Sey-mour, said it was pure Lock-jaw, and was sent to the Lock-up for contempt of court.

Colonel Banbury was represented on one side of his monument leading a regiment of "Hawk-eyes" to battle; on the reverse he had come home and beaten his sword into a pruning hook, while lis wife had given him "Jessie." +

Watts is embalmed as the publisher of a book of hymns and a ruddyhaired son named Harvey. In his wed-Locke he joined the cliurch Millietant. $t$

In memory of the Conger tribe was a large tablet representing " spirits of just men made perfect" ascending and descending wpon the earth, with a philosopher and cliemist seeking after the source of motion and life. In the group were the busts of Tyndall, Darwin, Herbert Spencer and Ralph Waldo Emerson conversing with Dr. Conger about the infinitesimal elements of existence.

* Mr. Croft had a pair of stont mules which wonld get up or lie down at his word of command at any time, whether in harness or not; and heing a hachelor then, he often hitched up lis hig wagon and took the young people on a moonliglit ride to some social gathering or surprise party, or just for the fun of a ride. IIence "Croft's mules" were a listoric part of the colony population.

†The Colonel had twin danghters, and the one named Jessie is now Mrs. Dr. Crank of Pomona.

$\ddagger$ Chas. Watts had married Miss Millie Locke-the first wedding in the colony. 
Bristol had the keys of the first "Zanjero" of the settlement, and was intent on irrigating a span of buck-skin horses, the first in the colony.

Mosher carried a Westminister catechism on his shoulders, and was surrounded by olive branches.

Newton had a microscope in one hand, while holding the Scriptures in the other ; he was reading, "A good wife is from the Lord.'

Over a grand mausoleum to Fletcher were the startling words, "He could but he wouldn't." While over Vawter there were the words, "He would but he couldn't."

To the memory of Gibson was written, "Blessings brighten as they take their flight." Barcus was smiling among the bees of Hymettus ; and Vulcan stood over the sepulcher of Baker.*

There were many other ancient relics of this singular people, showing their means of locomotion and system of cultivation.

The present city of Pasadena covers the entire valley of San Gabriel and is watered throughout by artesian wells whose source is in the mountains. When more nountain showers are needed a gigantic explosion of dynamite or vigorite is made between the mountain ranges, and in a short time copious thunder showers gather and drench the mountain forests, and thus keep a good supply of water perpetually for the use of this great and beautiful city, which now numbers 500,000 people.

Signed, TRUTH.

Further specimens of the exuberant wit and humor of this first Pasadena paper appear in a "List of Patents granted to Pasadena inventors during the week ending November 3I, I 876," as follows :

To P. G. Wooster - Bachelor's Button, covering improvement in pants and shirt buttons, and method of attachment. This improved button, in addition to eyes, has hands with which to hold on, and instead of sewing the button to the garment the garment is sewed to the button, so that even if the former is lost the button remains.

To A. H. Day - Patent Hecl and Toe for Stockings. The same being detachable from the body of the sock, so that when worn through they can be removed and replaced by new. Every pair of socks accompanied by seven extra heels and toes; being small and light can also be sent East for darning and returned at slight cost.

To H. G. Bennett - Improved Copper-Toed Collars and Cuffs. Being a light metallic binding applied to the edges of shirt collars and wrist-bands, having the appearance of linen and not noticeable; saves all trimming of edges on Sunday morning. Proof against Chinamen. Can also be applied to the bottoms of pants.

To W. O. Moody - New Method of Raising Bread. Being a small mechanical toy resembling a gopher; when wound up and placed in a pan of thick sponge it will move rapidly around under and through the dough and go-pher the whole until the pan is "raised" full. 'The process can be completed while one is heating the oven.

The following appear under the head of

\section{ADVERTISFMENTS.}

Lime Trees For Sale-B Buy some and raise your own lime for whitewashing. A few slacked lime trees at half price. Seymour Locke- "Locke Harem.", 
Church Lots For Sale - Three corners left. Can be returned if they don't suit. Frank W. Greene - "Old Adobe."

\section{FIRST PASADENA POE'TRY.}

The first poetry ever written in Pasadena also appeared in this first number of the first paper, and ran as follows:

\section{A CHURCH DOG-MA, IN DOGGEREL, METER. \\ BY PROF. SHORTFELLOW.}

Our Mr. Porter had a dog; its given name was Fido;

IVhen Mr. Porter went to town it always said "can't I go ?"

At Dr. Newton's lived a dog ; its hair was long and yellow ;

And when the Doctor went away, Bob was quite sure to follow.

And Mrs. Barcus had her dog ; it wouldn't stay at home ;

When Mrs. Barcus came up town, Carlo would likewise come.

Then Mrs. Mundell had one, too ; 'twas socially inclined;

If told to stay at home alone, sonetimes it would not mind.

Now all these folks were church-going folk, and went to church each Sunday ;

So all the dogs they followed on, the same as though 'twas Monday.

Now this was wrong, for dogs should learn the difference in days ;

Their special fort it is to walch; they cannot pray or praise.

And so they should not go to church; and if they try to follow,

Their master shonld turn right about, and whip them till they holler;

For folks will laugh and look distressed to see a dog at service;

And when it goes up towards the desk, it makes the preacher nervous.

And when four dogs together come, they make such a commotion,

'Tis very likely to disturb the spirit of devotion.

But not long since the Methodist another church began ;

And now there is but one dog left at the Preshyterian.

"Boh" Newton now comes all alone; all others on the list

Now go just where their masters go, and have turned Methodist.

And now we hope, before 'tis time that clurch to dedicate,

A pledge to leave all dogs at hotne, some one will circulate.

The precedent is very bad, when dogs do so increase,

And by and by, if all shonld go, we could not meet in peace.

This market is getting stocked with pups, of every kind and size,

And if the old logs go to church, the pups will go, likewise.

The Moody boys a puppy liave, and Charley Watts, another;

And Seymour Locke is keeping one, besides "Ivy," their mother ;

Anrl Mrs. Barcus, not content with her nice Black and Tan,

Has gone and got a puppy, too; and now she has a span.

Then John11y Nelson got one too, before it was too late;

And Mr. Wallace spoke in time to make sure of its mate.

The Martin boys have also two, and Banbury a third,

And Doctor Filwarits several more; from some we have not heard.

Now, if each pup when it's grown up, should go to church each week,

We could not sing, or hear a thing our Minister might speak;

So let each n11an who has a dog help cur-tail this abuse ;

But if our dogs must go to church, let's build one for their use.

The Mr. Day who wrote the above poem and prepared the entire paper, was a newspaper man connected with The Advance of Chicago, the organ of the Congregational denomination in the Mississippi Valley States. He was here for his healtlı; his name was Arthur Henry; he kept some hens ; and so he was facetiously called "A. Hennery Day." He and Frank W. Greene 
and a Mr. Fleming "kept bach" in a shanty near where the Garfias house then stood. Mr. Day was afterward the hero and victim of a fearful, calamitous adventure in Eaton Canyon, related by Judge Eaton in Chapter 8; but he recovered, and finally returned to his newspaper work in Chicago. Frank Greene afterward married a daughter of John Werner on Columbia street; he moved from Pasadena to Eagle Rock valley; but in 1894 was residing at Garvanza.

The second number of The Reservoir was edited by Miss Jenuie Collier ; and from its leading editorial I quote this excellent bit of facetia:

"We hope in another issue to give the exact number of pounds of Muscat grapes the Moody brothers raised to the square inch, as well as the exact number of turkeys the coyotes raised from Mr. Watts' barn-yard. We trust that the notice taken by The Reservoir of the triumphs of the colonists in agriculture, literature, poultry-ture, dogra-ture, and bachelor-ture may excite our readers to a laudable emulation in these worthy pursuits ; and in order to stir up an interest in some of these departments we propose to offer two handsome preniums in the next three months. One will be a fine chromo of Mr. Berry's house, taken from the southwest corner, so as to bring out in all their beanty the five varieties of architecture displayed in its construction, with the lean-tos both west and south standing out in beautiful relief. The picture can be obtained with or without the fluted columned porch, as desired. The hen-ranch on the slope can be dimly seen circulating in the distance. This exquisitely colored chromo will be presented to anyone who will in the next three months send us the names of six regular contributors to The Reservoir, accompanied with the written promise of the same over their own signature. We also offer a life-size chromo of Mr. Croft's mules to anyone who will bring to our table an orange raised from a three-year-old seedling, planted on unmortgaged ground and raised without irrigation. It is unnecessary for us to expatiate on the beauties of this far-famed chromo. The graceful attitude of these noble creatures as they stand with ears erect, waiting the word of command from their master, is so life-like and pathetic that all men praise it and children cry for it. Who among you will be the happy possessors of these lovely chromos?"

From The Reservoir No. 2 I also copy this dash of wit played off by Miss Collier on the unmarried men of the colony who were "keeping bach" as it was called.

CO-OPERATIVE KITCHEN.

On a chill January day in 1877 the following circular was quietly distributed among the male inhabitants of the colony, by one whose visage was lean and hungry, and whose sunken eyes told a touching story of destitution.

"There will be a meeting of the male housekeepers of Pasadena at the school-house, Friday evening, January —, I 877, to discuss culinary matters with a view to the establishment of a co-operative kitchen. A full attendance is desired, and gentlemen are requested to make any suggestions which may help to lighten the burdens now crushing. us. - No refreshments.

"(Signed)

"T. F. Croft and forty others." 
The proceedings of this wonderful meeting might have been lost to future generations had not the younger Mr. Martin, who applied for admission on the ground of having been at one time a culinary artist of high stand$i_{n g}$, been refused, and retiring to the seclusion of the ante-room, by means of a crack in the door and two inches of lead pencil furnished us with the following report:

"'The meeting was called to order at seven o'clock, Mr.' Berry in the chair. Mr. A. Hennery Day moved that the Bennett brothers be expelled, as he had been credibly informed that they put potatoes in their bread. Evidently the Messrs. Bennett had been notified of this attack for they hastened to display their credentials in the shape of a letter which the secretary proceeded to read as follows :

" "We, the undersigned, cheerfully certify that we have eaten some of the bread made with potatoes by the Messrs. Bennett, and were able to attend to our household duties at the expiration of a week after partaking of the same. Yours respectfully,

Mrs. Errie Locke, Mrs. Jimmie Banbury, Mr. Donnie Pike." "

"The president decided, after some deliberation, that the Bennetts should be retained on promise of reform, and the payment of a fine consisting of one loaf of bread to each bachelor present. Fred Berry moved that a committee be appointed to submit the names of ladies in Pasadena who were willing to loan yeast. Mercer Moody objected, on the ground that this was calculated to interfere with the sale of his patented gopherated bread-raiser; whereupon one P. G. Wooster arose with indignation in his mien and fury in his eye, and said in broken accents: 'I stand here, Mr. Chairman, the victim of base deception-in the gentleness of my unsuspecting nature I traded one of my duplex-elliptic button attachments to the gentleman from Boston for one of his gopherated bread-raisers, and the first batch of bread rose like a volcano to the tremendous height of two feet and seven inches, thereby taking the roof from my stately edifice and leaving me a homeless wanderer upon the face of the earth.' 'The gentleman commenced to sit down, and a death-like stillness pervaded the solemn assembly, broken only by a deep sob from Mr. Berry. When the emotion had somewhat subsided Mr. Cooley arose and told the chair how he and Dr. Baker cooked rice-'only a small quantity, Mr. President,--a quart or so,'- and how the stuff swelled and swelled and swelled until they were obliged to turn on the hose to get water enough, and how they filled seven milk-pans, one churn, two wash boilers, three hats, two pairs of boots and one pillow slip. A solemn silence followed this painful recital, broken only by a deep groan from $\mathrm{Mr}$. Berry. Mr. Croft arose, and bending his earnest gaze upon the chairman, said in a voice heavy with emotion: 'My suffering brothers, the remedy for all your evils-incleed, for all the evils of the Pacific Slope, lies in the one word gems. When will humanity learn that saw-dust and water baked in the lids of yeast powder cans and served liot on the dust pan, will cure dyspepsia, even in a male? I know, Mr. President, for I have tested it-even in two males. And I have mentioned these things before, with no effect. My friend Berry still frics beans for his Sunday dinner, and Day continues to bake buckwheat cakes on a shovel, just as of yore. I leave you to your fate.' The speaker 
burst into a flood of tears and rushed from the house, while Mr. Berry wept aloud. Mr. Mitchell arose and said, 'Brethern, I have learned the beauties of co-operation. I roll my clothes down the hill to Mrs. Watson and she throws me a dozen eggs in return. This is sweet to me, but sweet potatoes fried in butter are sweeter.'" *

"Here Mr. Berry's feelings so overcame him that Fred, thinking him threatened with an attack of horizontal parallellaries, thought best to remove him ; so he retired leaning on the arm of his dutiful son, while the remainder of the lank assembly dispersed with a dejected air."

Reservoir No. 5 was edited by Mrs. Margaret Collier Graham, and from its pages I quote the following humorous announcement :

\section{CONCERT EXTRAORDINARY.}

We are authorized to announce a grand concert to be given by the ladies and gentlemen of Pasadena at an early date, the proceeds to be equally divided between the Pomological Society and the Base Ball Club. The program comprises the most brilliant vocal and instrumental talent of the place, and the mention of performers' names will be sufficient to insure a large and breathlessly appreciative audience.

The entertainment will be held in Mr. Moody's barn, which has been secured at great expense and is being fitted up in the most dazzling style. The program is as follows:

Grand opening chorus extraordinary- "I am dying, Egypt, dying," in B flat, by the Pomological Society.

Solo, "Betsy and I are out," John Pease Babcock. This gentleman is the only artist on the slope who can sing with a meerschaum in his mouth.

Boarding-house trio, "When the tourists homeward fly," by Mrs. Locke, Mrs. Banbury, and Mrs. Graham, accompanied by Miss Collier.

Bass solo, "When the cows come home," by Seymour Locke. If encored, Mr. Locke will give that charming ballad, "What is home without a Moody."

Chorus by the Gilmore family, "Out of the old house into the new."

PART II.

Mendelssohn's 59th symphony, "Dead March in Saul," by the Base Ball Club.

Solo, "Hush, my babe," from Italian opera of "Nothing to do," by Mrs. Conger. $\dagger$

Duet, "Almost persuaded." Miss Annie Clapp and Miss Gilmore.

The performance will conclude with that tearfully pathetic ballad, "No one to love,"' by Mr. D. M. Berry.

The services of Mr. P. G. Wooster of Puckechechuck, Skehowtan county, Maine, have been secured as pianist. Of this musical phenomenon the Boston Globe says: "He has the most unprecedented genuinity of artistic feeling, and extraordinary excessiveness of manual dexterity. Especially was this noticeable in the difficult double run of thirds which occurred in the presto of Gordigiani's aria from orchestral suite in 'D.',

We bespeak for this gentleman the most tunultuously enthusiastic reception. Admittance $2 \frac{1}{2}$ bits. Children, three for $\$ I$. Tickets for sale at

*This joke was on Rev. J. A. Mitchell, the bachelor pastor of the Preshyterian church.

†Mrs. Dr. Conger then had in arms her baby Lulu, the second child born in the colony. 
Post-office, Watson's meat market, and the laundry of John C. Yuen, Esq., lately from China.

Other numbers of The Reservoir were prepared by D. M. Berry, Clarence Martin, and Mrs. Dr. Conger. I found no copy of Berry's or Martin's numbers, and only some fragments of Mrs. Conger's. 'These latter were essays of a high order of merit-but not humorous, and not comprising any special points of Pasadena history-hence not quoted. (Mrs. Conger prepared No. 4, dated February 24, 1877, and also No. 8, dated August 3, I878.)

\section{GRASSHOPPER TALK.}

Charles A. Gardner wrote up a conversation which he heard among "old settlers" about the grasshopper trouble in the colony days [1876], and I quote the gist of his article from Pasadena Star of May i 5, I 889:

Some one started the question of grasshoppers and a visitation which the colony had endured from them long ago, before Prof. Holder came to scare them away with hard Latin names.

Says one, "I've seen the time when I would have left Pasadena if I could have got away." jug ?",

"No?" says the tenderfoot; "when was that - when you were in the

"No, when the grasshoppers got us, ten or twelve years ago. They were as big as blackbirds and ate everything from the ground up."

"Do you remember," says another, "the fire we built to kill them, and how it got away from us and burned over the sheepherder's land?"

"Yes," responded a bald-headed reprobate, who is generally not far off when a pioneer yarn is in the stocks, "and how mad he got about it and threatened to sue us ; kept sending us threatening letters for six months."

"We started the fire down in Baker's place," resumed the first sinner, "with the expectation that the road would stop it from the pasture lands above; but it jumped two roads and we had only one more to go. Finally, by plowing ahead of it we got it stopped, and some of the furrows are there yet. It roasted the grasshoppers, you bet, and I remember one day while we were looking at the wreck, Doctor —_said, 'I've often heard of the Indians eating them; I've a notion to see how they taste.' So he reached down and hauled up a fat one out of the cinders, pulled off a hind leg and gave it a bite. It was pretty good, and I'm inclined to think they'd make good eating. Well, these fellows were the occasion of my wanting to leave. It seems that it was only a local visitation. They didn't extend down into the lower valley, and if I could have sold out that year I should have gone down to Alhambra. As it was, they destroyed every green thing that was not in some way protected. Hollingsworth had just opened his store then (I876), and I got of him a lot of paper sacks which I put over my trees, first cutting off the tops of the trees and tying the sack down close around the trunks. But the worst joke happened to Dr. - - . He got some cheese-cloth and wrapped it around his trees, sewing it with long stitches. The stitches were too long, however, for on examination one day he found these tree-covers full of the hoppers, which had crawled through the stitches and were eating up his trees in the very shelter of the covers he had made to keep them off. 'The Doctor's rage at this knew no bounds. 'Oh, you sons-of-guns!' said 
be, 'didn't I fix it nice for you in there? Don't those covers keep the sun off of you and make it cool and comfortable? Wouldn't you like a fan, now, and some ice cream (with sarcasm)? If you don't see what you want, ask for it. I'm not the man to be backward in the matter of hospitality.' And then language failed him and he gave it up.'”

THE PREACHER ANU WIISON'S WINE.

John W. Wilson relates the following "old settler" incident. Some time in the Sixties a clergyman from the East was spending a season at Los Angeles; and being strongly "American" in his sentiments, he thought it a good idea to introduce East the pure California native American wines for sacramental purposes, instead of the imported French, Spanish or Italian brands usually obtained for that purpose. Accordingly he hired a horse and buggy and drove out to B. D. Wilson's Lake Vineyard home-place, which had the only large winery then in this section, to sample the wines, "purely for sacramental purposes." He introduced himself and made known his errand to Mr. Wilson, who invited him to stay for dinner. He took the man into the house to wait, while he himself went to give his workmen some directions. When dinner was ready the stranger was seated at table as a guest of the family; and Mr. Wilson opening a bottle of wine poured out a glass for the visitor first, which he gulped down at once; then after it had passed around the table, Wilson set the bottle down near the man. He took it $u p$, filled his own glass again and drank it off greedily, smacking his lips, and remarked with an air of self-importance, "I like that, Mr. Wilson; I like that!"

"You do, eh?" said Wilson, with a twinkle in his eye.

"Yes, really, I like that! It's a good article, Mr. Wilson! a good article!"

"Well, you stay with it, and it'll play hell with you before long," came the quick response-Wilson having entirely forgotten that his guest was a preacher.

\section{STAGE TALENT IN THE COLONY.}

The Daily Star of May 24, I889, reports a sketch of a little casual gossip between two or three "old settlers " which the reporter heard one day in a private office; and it contains some historic reminiscences of Pasadena's teething period which are worth preserving:

"Speaking of social matters," remarked the first gentleman, "I remember how readily we all mixed in those early days; there were no cliques, but all joined in getting up entertainments and having a good time, and the whole colony went. After the school-house was established on the square - the first school-house, that now does duty as a dwelling on Adella Avenue-we used to meet there for everything, whether it was a minstrel show, a play, a dance, or a church entertainment; and what jolly times we had!",

"Yes," chimed in another old timer, "I remember the first performance of a dramatic kind we had there."

"Let's see; I can give you the characters from memory; there were Miss Ella Gilmore (afterwards Mrs. C. S. Martin), Miss Annie Swan (now Mrs. Wm. Martin), Chas. Bell, Will. Martin, Seymour Locke, Will. Swan, Miss Annie Clapp, Miss Wallace (now Mrs. Croft), and George Clapp. 
They were members of our literary club, and the drama did not exhaust their intellectual repertoire by any means." '*

"Yes, and there was our minstrel troupe," remarked the first speaker. "The Pasadena minstrels were known throughout the county. There was Col. Banbury, now the worthy money-bags of the county. He did not disdain to play the flute in said orchestra, no more than the proprietor of the Acme, J. H. Baker, stood on his dignity in the matter of twanging the tuneful guitar. 'Then there was Judge Eaton. One wouldn't think he, too, could blow witching strains from the flute, but in those days he used to do it with the greatest eclat and all that sort of thing possible. C. P. Brown played the viola, and a violinist from Alhambra, whose name I have forgotten [John Burus], gave us first-rate music on the violin. Whatever reputation Charlie Bell enjoys as a singer and cliaracter delineator he mostly gained as 'end man' in the company of distinguished artists who were wont to delight the entire population of Pasadena in the old school-house. Local gags and songs were generally entrusted to him, and I happen to remember a verse or two of one of the latter that he got off to a rollicking plantation tune in commemoration of a certain hunting episode. It doesn't read very smoothly in cold-blooded print, but as a song with chorus it used to bring down the house. It ran about this way :

"Have you seen our rifle team!

Have you seen them shooting!

Markham and Watts make very good shots,

But Gilchrist he makes nothing."

cHORUS.

"Then Baker went to the mountain side,

And when he got there-

'Hush! hush! tell no one else, And I will kill that bear.' ",

BAKER'S BEAR.

Many of the colonists had such a keen relish for fun that they were much given to turning jokes upon one another. One time it was reported that bears were making nightly visits to a bee ranch up near the mountains. Now, to shoot a bear was the crowning ambition of every man who conld hit a barn door at forty paces; so here was a chance to go on a night hunt, loaded for bear, and a company of three or four was soon made 1 p, with J. H. Baker as one of them. They found shelter in a little cabin near the bee hives and lay down to rest until Mr. Bear should begin to disturb a hive, or they should hear his sniffs and footsteps. The rest of the boys had got an idea that Baker was braver in talk than he would be in action, and they planned to have a little fun on that line. So after waiting quietly for some time, and all were apparently dropping into a doze, there was a noise outside, as the boys had planned, and Baker raised up, moving and stepping as softly as a cat, and said in a muffled whisper, " H'sh! li'sh! I'll kill the bear!"

*Other performers in dramatic and minstrel entertainments not named in this list were: $\mathrm{F}$. M. I.ippincott. A. L. Carr, W. I. Keith. Jerome Beehe, Geo. and Fred Mnelner, F. H. Heidenreich, C. Swan, those days, and one of her popular songs was "What do birdies dream of?" 
No bear appeared that night, and the hunters returned without their game. But they told the story of Baker's cautious " $\mathrm{H}$ 'sh! h'sh! I'll kill the bear!" and from that time it became a local by-word, applied in all sorts of jocular ways-some of the old settlers using it even yet occasionally as an illustrative figure of speech. And this is the incident referred to in the chorus of Charlie Bell's negro minstrel song quoted above.

THE N. N. N.'S.

These cabalistic letters being interpreted meant "Nine Nobby Niggers," which was the title of the minstrel troupe formed by the colony boys, just for the fun of it, in $1875^{-76}$, some months before Charlie Bell's arrival in 1877 . The original N. N. N.'s were: Clarence Martin, Will Martin, Mercer Moody, Will Moody, Arthur Day, Mr. Breand, Fred Muehler, Seymour Locke, Fred Lippincott. This feature and resource of colony fun was kept up for several years, and others took part in it from time to time ; but it was alway's the "N. N. N.'s" or the minstrel troupe. It is related that even Judge Eaton, Col. Banbury, J. H. Baker, and C. P. Brown occasionally helped the boys out by adding their special skill with instrumental music.

"WHO KILLED JESSE LEE?"

This burlesque murder trial occurred in the old original school-house on lower Orange Grove Avenue (where Mrs. Sarah Ware now resides) before its removal up to Fair Oaks and Colorado, and was a "put-up-job," as the boys say-really the most striking piece of grim drollery that occurred in all the colony annals of fun-making. It was a local farce, well contrived, and enacted with excellent dramatic skill. A youth named Jesse Lee was supposed to have been murdered by Mart. Weight; and he was arrested for this breach of civil order by Frank Lowe, acting as sheriff, with Seymour Locke as deputy. B. S. Eaton sat as judge; P. M. Green appeared as attorney for the State, and Dr. O. H. Conger as attorney for the accused. The jury was Dr. T. B. Elliott, foreman; A. O. Porter, John Lowe, Will Martin (other names not learned). The principal witness was young Morton Banbury, who had found in the Arroyo the skull of some animal. This he produced in court from a bag, and identified it as the skull of Jesse Lee. Dr. J. C. Newton was called as a medical expert; and he cane with wig and gown and solemn face, using a long section or tube of sheet-iron water pipe for a microscope to examine the skull, and determine by the molecular structure of its ultimate particles whether it was veritably bone of man or beast, that question having been vigorously raised by Dr. Conger, the attorney for the defense. Young Clarence Martin was also dressed with wig and spectacles, and some foreign-looking garments, and was introduced as the eminent savant, Dr. Brown-Sequard. He was sworn as a medical expert, too, and gave a learned disquisition on "the polariscopistic intussuscep- 
titude of all anthropomorphous sanguineous fluids; wherefore their inflammatory or semi-tropical exoticity, with non-irrigability in the citrus belt, might depolarize the red corpuscles and become the protoplasmic injectiverator of bloody deeds like this" ; etc., etc.

That may not be the exact language, but it is the substance and style of it. The circumstantial evidence seemed to be winding up tightly about the prisoner at the bar. Dr. Conger made a strong plea for the defense. Then P. M. Green, in closing his argument for the State, exclaimed in eloquent diction: "As a star falls from heaven and is seen no more, so fell Jesse Lee!" (And after that he was sent to the legislature.)

The jury reported through their foreman, Dr. Elliott, that they could not hang the culprit on the evidence, but he ought to be hung anyzoy, on general principles, and they gave a verdict accordingly. 'The prisoner was pronounced "guilty." The sheriff had his noose and black cap ready, and was about to proceed with the hanging. Bui now Jesse Lee came bounding into court-declared that that wasn't his skull at all; that his blood corpuscles were all right; his citrus belt was perfectly well irrigated; and there was no bloody deed for all this fuss; etc., etc. So the case was dismissed, and the court adjourned.

The part of Jesse Lee was played by Perry Kewen, son of Col. E. J. C. Kewen, who then lived in the historic old stone mill, below the foot of Lake Avenue, which he had fixed up at great cost for a dwelling. Mrs. Kewen was also present. 'This burlesque trial was the most notable and longest remembered of the many entertainments given by the colony's original "literary society," except perhaps the reading of their first paper, The Reservoir No. I, in which occurred the famous "dog poetry."

\section{COLONEL, BANBURY'S DEER.}

The story they tell on the Colonel is this. One day word was brought in that there was a deer browsing in the chapparal up toward the monntains. Colonel Banbury made up a party to go in pursuit, and with his trusty rifle in hand and seated in a wagon he took the lead. In due time they reached the place, and sure enough a deer was there; thc Colonel saw it and jumped up and shouted, "There it goes!" but entirely forgot his gun and didn't shoot at all. So this incident became a standing joke on the "Pasadena Rifle Team."

\section{THE “RIFLE TEAM" SAW A BE $\Lambda$ R.}

Another of the colony bear stories is thus related. It was learned that bears were nightly stealing honey from the bee ranches up near the nountains and a party was gathered to go up there and bring down some bear steak for breakfast. Uncle David Townsend and Charley Watts were of the party, besides others not learned. They reached a bee ranch cabin after dark and climbed onto its roof to lie in wait and watch for bruin's arrival. 
In due time a great shaggy grizzly came, and went to turning over the hives and feasting himself on the honey. When our donghty hunters saw his formidable size they wilted - kept as still as mice, watched him rob the hives, and let him depart without their ever firing a gin. The fact was, that if they shot the bear and did not succeed in killing him at once but only wounded him, the chances were that he would tear and claw the shanty down and kill or mangle every man of them. But the jokers (those who had never faced a wild bear themselves) would have their fin abont the "rifle team " watching a bear while he robbed a bee ranch, and not daring to fire a shot at him. It was said facetionsly, they didn't want to hurt the bear; they only wanted to see the bear and bee circus, which beat anything Barnum ever got up.

See article on the Mount Lowe Railway, chapter 23, for another "bear story " told by Governor Markham on the "Rifle Team," with himself in the stampede.

\section{RABBIT HUNTS.}

In $1876-77-78$, rabbit hunts were among the sporting events of the colony, in which W. O. Swan, Joseph Wallace, A1. Carr, Charley Watts, Charlie Bell, Will Clapp, Whit. Elliott, and others are mentioned as participants, with Arturo Bandini as chief director. A sketch in the Star of May 29, I889, speaks thus of this matter :

"As to hunting," exclaimed another veteran, "I wish you could have enjoyed some of our rabbit coursing. There was no such organization then as the 'Valley Hunt,' but every man kept a hound or other dog, and when our meets occurred, you would see crowds of Los Angeles people on hand to enjoy the sport. We used to assemble at the twin oaks west of Romayne Williams's present home [Hill Avenue north of Mountain street], and the whole country was then open to us.

"Fifteen rabbits a day was no uncommon catch ; and we used to stimulate the hunters, not by offering such trifling prizes as the animal's tail or a wreath, but something useful, as well as ornamental. For instance, Charley Watts once carried off in triumph a set of harness won as a trophy of his hound's fleetness. Things were run on a substantial basis in those days. Colonel Winston and Arturo Bandini led the heavy hunting squad by bagging the large game - wild cats, foxes, coyotes, bear, etc."

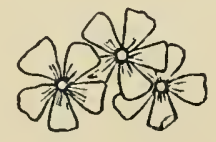




\section{CHAP'TER VIII.}

Hor Rors.-Notable Crimes, Calamities, Accidents, Storms, Floods, etc., within Pasadenaland.

\section{VASQUEZ, THE ROBBER.}

The first thing to record for Pasadena under this head is the visit here of Tiburcio Vasquez, one of the most noted bandits of California history. In April, 1874, the colony men were hard at work getting their water pipe laid from Devil's Gate down to the Orange Grove reservoir, having contracted with Miles \& Holbrook of Los Angeles to furnish a supply of I r-inch iron pipe for the purpose, while Judge Eaton took charge of the spring-heads, the sand-box and the pipe-lining and ditching part of the work. Just after dinner on April I6th Mr. Miles and his teamster George Osborne were returning down the Arroyo bottom road to Los Angeles, after delivering a load of pipe to Judge Eaton's workmen up toward Devil's Gate ; and when they had got down in the vicinity of Sheep Corral springs where the old road began to wind through the oak park by a steep grade up to Orange Grove Avenue (just below Wm. S. Hanaford's place - I 894), they were met by Vasquez and four of his gang, all well mounted, and all armed with rifles, pistols and kuives, in the most approved and ferocious style of their craft. The men in the wagon were required to halt and throw up their hands; then to deliver their money. Osborne had none, and Miles had only a little loose change-less than a dollar ; so Vasquez said very politely, "Then, if you please, sir, I will take that watch." Miles hesitated, or pretended he had none. Vasquez cocked his Winchester rifle, saying, "No foolishness! I can't parley with you. Billy Workman's only a few rods down the road after me!" And he began to draw a bead on Miles, who then handed over his watch. ['This he recovered after the bandit's final capture.] And at this time the Deputy Sheriff Albert Johnston (not the sheriff, Wm. H. Workman) and his posse were on their trail, less than a mile behind.

The outlaws now rode leisurely on up to where Judge Eaton had fifteen or twenty men at work on the colony ditch and pipe-line, near the Richardson springs; and here were A. O. Porter, P. M. Green, Col. J. Banbury, A. O. Bristol, W. T. Clapp and D. M. Berry, besides Judge Faton and others -all unarmed, so that the robbers conld have taken every watch and every dollar in the crowd. The workmen were sitting or lying around taking their nooning or after-dinner rest. Eaton, Porter and Green were just coming down afoot from the sand-box, in their shirt-sleeves, and were thus supposed by the robbers to be workmen like the rest and probably had nothing worth taking. As Vasquez drew near he called out to the workmen and told them who he was; and one of his men who could speak English well introduced hin, assiring them that he was "a gentleman ! a 
perfect gentleman!' On Orange Grove Avenue they had found two horses tethered and took one of them, which they were leading. They scarcely stopped but rode slowly along the old road up the Richardson gully, then across the Arroyo at Devil's Gate, and up the old Soledad Trail, securely beyond reach of any pursuing sheriff; but here one of their horses fell from the trail down a precipice and was killed. That same night they rode back through Pasadena down to Sycamore Grove, and compelled the man living there, who had a flock of goats, to dress a kid and get up a good supper for them.

When Eaton, Porter and Green put their coats on to start home, and congratulated themselves on their lucky escape from being robbed, they found that among them all there were three watches and $\$ 48$ in money which made so close a shave from falling into the robber's hands.

This was the same day that Vasquez had committed what became famous as the Repetto robbery. He was finally captured a few weeks later at an out-of-the-way house in the mountains near Santa Monica, had a trial, and was hung at Los Angeles.

\section{A DREADFUL NIGHT IN EATON CANYON.}

Judge Eaton has kindly written out for me the following historic incident :

"The principal accident that occurred in Colonial days happened in this way: Mr. Arthur H. Day, an employe of The Advance, the Congregationalist paper of Chicago, conceived the idea of a trip up Eaton Canyon, with two companions as inexperienced as himself.* They started off on foot, packing their grub and blankets on their backs. It was all easy going until they reached "The Falls," distant about three-fourths of a mile from the month of the canyon. Here they found a barrier to all farther progress up the bed of the stream. Depositing their packs on the banks they commenced the ascent of the right bank upon their hands and knees. Arriving on top, a height of 250 feet, they thonght to descend again into the creek above the falls. This was a difficult and dangerous task for men not used to scaling mountains. But they persevered till poor Day made a mis-step and was precipitated to the bottom, spraining his ankle, and breaking one leg square off. After many times trying, his cumpanions succeeded in reaching him. Finding that he was utterly helpless, they began a reconnoisance to see low they were going to get him out. Down the canyon fifty or a hundred yards was the falls-a precipice 40 feet in height over which the water was tumbling into a pool 20 feet in width and 6 or 8 feet deep. Over the falls was the only mode of egress in that direction ; turning about, they followed up the canyon where they were soon brought to a stand still by another precipice about 80 feet in height. Either side was bounded by an almost perpendicular wall several hundred feet high. There was nothing to do but contrive some way of letting Day down over the Falls. Fortunately they had along with them some pieces of fence rope. With these and some long slender poles they had cut, a ladder was constructed; but

*His companions were Eilio Brenna, a young Italian then living at W. J. Barcus's, and another young man named L,alyạ-both dead now. 
when dropped down it did not reach the surface of the pool below by 5 or 6 feet. It was a frail thing for a man with a broken leg to trust himself to ; but Day had "grit." 'Dropping himself over, he clutched the rounds, while his companions held the ladder above, and thus let himself down as far as the ladder reached, and then dropped into the pool. He swam and paddled until he reached the shore. By this time it had become so dark that the mountaineers were unable to find their way out till morning.

"The provisions and blankets had been left here. Day was able to crawl to them, and there he spent the night alone. Early in the morning one of the boys came down to my house and told of their mishap. I immediately dispatched a couple of strong men and a spring wagon to the canyon. Leaving the wagon at the mouth of the canyon, the men proceeded to the falls. There they constructed a rough litter upon which they stretched the unfortunate man and carried him to the wagon, and thence to his home. He must have been suffering a great deal of pain, but not a groan escaped his lips as he was jolted over the boulders and down the rough mountain road. It was six months before he could walk again."

For more about Mr. Day, see Chapter 7.

First Saloon Cask. - March 30, 1885, Jerome Beebe, who had opened the first liquor saloon in Pasadena, was tried in justice's court for making threats of bodily violence against L. H. Michener. District Attorney Geo. M. Holton of Los Angeles and H. W. Magee of Pasadena were attorneys for the prosecution; and Geo. W. Knox of Los Angeles was attorney for Beebe; and T. P. Lukens was justice of the peace. The result was that Beebe was found guilty, and required to give bonds in the sum of $\$ 2,500$ for six months to keep the peace. Mr. Knox tried hard to get the bond reduced, claiming that it was exorbitant, etc.; but justice Lukens was inflexible and the amount had to stand. Kn1ox afterward laughed over it, and said privately, " $\mathrm{O}$, it's all right. I was told by the wholesale liquor men of Los Angeles to tell Beebe not to worry. He could have any amount of bail he required. They'd back him." I heard Knox say it minself.

CANNERY BURNED. - The first fire calamity of importance in the Colony was the burning of Joseph Wallace's Cannery on the night of September 2, I 885. ('Thomas Banbury's house had burned down a few years before.) The following points showing the disastrous nature of the Cannery fire I quote from the report published in the Valley Union at the time :

"The building was of wood and consisted of a two-story part, 20x50, and a one-story part $16 \times 30$. The contents were 10,000 cans of fruit in tins, one and one-half gross cans in glass, 6o cases of last year's pack, three tons of evaporated fruit; and two tons green peaches, besides the evaporator and tools of the cannery. 'The fruit includes all of this year's pack and part of last. Mr. Wallace roughly estimates the loss on fruit at $\$ 5,000$; insured for $\$ 3,000$. There is also $\$ 1,000$ insurance on the building. Work was nearly through for the season, the cannery being engaged on late peaches. As to the canse of the fire none is known, thougl incendiarism is suspected. * * * The ten thousand cans of tinned fruit made a novel feature 
of the ruins; and they exploded with the heat with low, dull booms, that were still going on at the time of our visit, twelve hours after the fire."

\section{A NOTABLE ARROYO FIRE.}

The Union of October 9, I885, reported :

"A fire started in the Arroyo Saturday morning. 3rd inst., by the carelessness of parties living in the Arroyo below Wallace's, and spread thence up the Arroyo, carrying destruction in its wake. It extended $11 \mathrm{p}$ as far as Devil's Gate and above, killing timber and destroying some of the flumes and trestle work of the water companies. It also spread up the mountain side, burning over most of Mr. Yocum's timber land, and miles of the adjacent mountains, including the water-bearing lands of Painter \& Ball, and others. The loss amounts to thousands of dollars, and includes, besides growing timber, mucl wood already cut, among which are thirty cords belonging to J. W. Wilson, and fifteen cords of Painter \& Ball's. The damage to growing timber is immense, and the resultant effects upon the water supply is still more serious. J. D. Yocum lost $\$ 200$ worth of cord-wood by the fire, besides much standing timber; his total loss estimated over $\$ \mathrm{r}, \infty 00$. It came within ten rods of his dwelling, and had to be fought off his buildings."

\section{CHINAMEN MOBBED.}

In 1885 there was a Chinese wash-house on Fair Oaks Avenue below Colorado street, in a rough board building owned by Jacob Hisey; and one or two houses back of it on Mills street, owned by A. F. Mills, were rented to Chinamen for a store, employment office, lodging-rooms, etc. There were then a great many transient day-laborers in Pasadena, and a good deal of rough talk was indulged in against Chinamen. During the evening of November 6, a large number of men and boys were loafing, smoking, and talking "Chinaman" along the street in front of the wash-house. Three or four Chinamen were at work ironing, with kerosene lamps for light. Finally two of the crowd outside threw stones in at the door or window, one of which hit an ironer at his work, and one struck a lamp, breaking it. The oil was thus spattered over the clothes piled up on the ironing table, and instantly the room was all ablaze with flame. The Chinamen fled for their lives out the back way to Mills street, being pursued by a mob hurling stones and sticks and vile imprecations after them. The building was then looted from the rear before the flames got entire control; and threats were freely made of setting fire to the Mills street building also, into which the Chinamen had fled for refuge and locked the doors and windows. Demand was made that every Chinaman in town should leave that night or be hung ; and some even began trying to tear down the buildings they were in, so as to get at them. For the rest of the story I liere quote from the Union of November I3:

"After the fire, November 6, a number of men and boys went to the China houses on Mills street, and considerable talk was made of raiding them, but cooler-headed citizens succeeded in quieting the crowd and in giving the Chinese twenty-four hours to leave town. Chief among those 
whose efforts were valuable in preserving order and averting acts of violence were Deputy Sheriff Thomas Banbury, B. F. Ball, George A. Greeley, and I. N. Mundell, who exerted themselves manfully and courageously in favor of law and order, and happily with success. No buildings were torn down, other than the one referred to, to save the Mullins Block. Of the buildings destroyed Mr. Mills owned only one, and that was the meat market. All these Chinese tenants, both of Mr. Mills and Mr. Hisey, were soon to leave anyway, having made arrangements to go by December r. Mr. Banbury had, ten days before the fire, leased them ground for a store and a wash-house, these premises being away outside the town center, and out of the way ot annoying anyone. Mr. Clark, the carpenter, had made arrangements with the other Chinese tenants to erect places for them immediately in the same neighborhood; thus removing the entire lot of Chinamen from the center of the town. Next morning a citizens meeting was held at T. P. Lukens, office, at which C. B. Ripley presided and Charles A. Gardner was Secretary. The following resolutions were adopted :

"Resolved, That it is the sentiment of this community that no Chinese quarters be allowed within the following limits of Pasadena: Orange Grove and Lake Avenues, California street and Mountain Avenue.

"Resolved, That the Chinamen now within said limits be given reasonable time to depart; and that if any have paid rent' in advance for premises within said limits, the persons receiving such advance payments be requested to refund same.

"Resolved, That it is the sentiment of this meeting that no mob-law be allowed in Pasadena, but that everything be done decently and in order; that the good name of our community depends upon its law-abiding character, and that we will use all necessary ineans to preserve such character.

"Signed by P. M. Green, R. Williams, A. Cruickshank, E. C. Webster, W. O. Swan, Jr., James Clark, T. P. Lłtkens, A K. McQuilling, Byron O. Clark, T. Banbury, I. S. Goldman, Charles A. Gardner, W. E. Cooley, C. B. Ripley, J. W. Wood, Thomas Rigg, M. D., C. Ehrenfeld, S. H. Doolittle, Wm. Pierce, A. F. Mills, W. P. McCoy, T. H. Arthur, J. Hisey, M. Mullins, J. H. Fleming, E. T. Dearth, G. A. Greeley, W. W. Doolittle, Wesley Bunnell, Charles Legge, John Ball, D. Galbraith, E. Turner, S. H. Lowe, J. C. Kerr, M. D. reigus.'

"The above were fully carried out, the Chinamen have gone, and order RAILROAD ACCIDENT.

In September, I886, freight conductor M. E. Griffith was thrown from his train in the Raymond cut and four cars passed over hin. The Union of September r r, said :

"The head was severed completely from the body, all but a small piece of skin at the back of the neck; the left arm also severed from the body, all but a small piece of skin above the elbow; the right leg below the knee the same; the left leg crushed through the thigh, rather than severed. As for the face, it was calm and serene, not in the least disfigured, showing conclusively how terribly sudden his agony was over. The jury rendered their verdict that the deceased came to his death 'by reason of striking a water pipe across the line of the L. A. \& S. G. V. R. R. accidentally.'" 
A Furious Cow.-The Star of May I8, I889, says:

"A cow having a calf broke away from a band that was being driven to the Union market slaughter-house, and charged eastward at full speed, bent on mischief. On Summit Avenue a child was saved from being run down by runuing into the house, and on reaching Marengo Avenue the maddened animal saw a crowd coming from the firiends church, where a meeting had been held. She first made for Wilson Kirk (whose wife was hurt by another cow a short time ago), knocked him down, then directed her fury against Mrs. Williams, a lady of Modena who was attending the meeting, catching her on her horns and throwing her high in the air. Mr. Kirk was but slightly hurt, but Mrs. Williams was cut in the face and injured about the limbs. The next person in the path of the bovine happened to be Jonathan $W$. Bailey, one of our venerable and well-known citizens, whom she knocked down and gored, breaking his collar bone, bruising his face, and probably injuring him internally. Mr. Kirk and others beat off the cow with clubs, when she made for a buggy, but was stopped by a shot fired by the herder. Two charges of shot and a bullet from a Winchester were required to bring the animal down. Mr. Bailey was taken into O. Burlingame's residence, and Drs. Grinnell and Dixon called, who dressed his wonnds."

THREE CHIIDREN BURNED TO DFATH.

The Pasadena Standard of September 2 I, I889, reports :

"Wednesclay night about half after ten o'clock a house occupied by Mrs. Beaton on Orange Grove Avenue below California street caught fire and burned to the ground. Three little boys, aged three, five and ten years, were burned to death.

"Little Johnny and his sister Mary were asleep in one room, while Willie and the baby were in their mother's bed in the adjoining room. The children had all retired about half past seven o'clock. The mother sat up sewing till after ten, then went up-stairs with a large kerosene lamp, nearly full of oil. She set it down on a box, and went to see if the children were all right in the other room, when somehow not known the lamp fell to the floor and broke, sprearling the oil, and instantly the room was all ablaze. She grasped a quilt from the bed and tried in vain to smother the fire with it, getting badly burned herself in the effort. Little Mary, only seven years old, jumped up, called to Johnny, then ran to the window and broke it out with her bare feet and hands, getting them severely cut, climbed out on the little porch roof, and from there into an orange tree and down to the ground. The up-stairs rooms were low, half-story attics, and the blaze of the oil reached to the roof slopes, and caught quickly into curtains, bedclothes, and hanging-garments. Mrs. Beaton finding it impossible to reach the younger children through the doorway, got out on the porch roof to try to break through the other window and so get to them; but the room was a mass of flame, and she was in extreme agony both from having drawn flame and smoke into her throat and lungs, and mental anguish for her children, so that she sank powerless, and jumped or fell from the roof into Mr. John Withiel's arms, he being the only person who had yet reached the scene. In a few minutes Rev. Geo. P. Kimball got there, then Rev. D. D. Hill and others. But ere this the three little boys were suffocated, and entirely beyond reach of lhuman aid, the whole up-stairs of the house being 
one volume of intense flame. Mrs. Beaton was carried to Rev. Kimball's temporary residence and has had to have night and day watchers continually. At last accounts she was not expected to live."

However, the woman did recover. The children had been members of the Congregational Sunday School, and were there in their classes the Sunday before. The Sunday after, a funeral service was held for them at the church, their charred remains, burnt and crisped beyond all possible recognition, having been buried on Saturday. Much censure and reproach was vented upon the fire company in connection with this calamitous fire. The city council therefore appointed a day and sat as a court of inquiry upon the case. It was then proved that the fire company had done all that they possibly could under the circumstances, and were in nowise at fault or justly blamable for any part of the dreadful affair. However, it resulted in some additional facilities being provided for fire protection.

\section{STREET CAR SMASH-UP.}

May 30, 1892 , the street car line up Fair Oaks Avenue to Mountain View Cemetery engaged to carry the G. A. R. men and their friends attending the decoration ceremonies of Memorial Day. In the afternoon two cars were loaded full of people at the cemetery, then coupled together and started to run as far down as the Painter Hotel by gravity, without any horses attached. But when about half way down the cars jumped the track, the forward one rolling over down the embankment westward, while the other one was smashed and racked but not turned over. Yet, marvelous to tell, while nearly every man, woman and child on the two cars were hurt in some way, none were killed, and only two cases of broken bones or serious injury occurred.

\section{LOST IN THE MIOUNTAINS.}

November 18, I893, L. C. Winston, Esq., was lost in the mountains north of Pasadena during a snow storm, and perished alone, his body not being fonnd, nothwithstanding the best efforts of experienced search parties, until by merest accident about nine months afterward. Mr. Winston was one of the earliest settlers here, even before the colony, and had been a lawyer and notary public in Pasadena for many years; while his wife had been a teacher in the public schools much longer than any other person. Hence his loss and death in the monntains was perhaps the most notable calamity in the entire history of the settlement; and I glean from newspaper reports at the time a resumé of particulars of the dreadful case. He was out on a hunting and liealth trip, in company with Charles Brown of Pasadena and Palmer Reed of Sierra Madre. And now I quote from the Pasadena Star of November 23, I893:

"The facts regarding the affair, as related by Messrs. Brown and Reed, are as follows: Abont three weeks ago these two gentlemen and Mr. Winston went over into the mountains on a hunting and pleasure trip, taking 
along plenty of provisions and other supplies, packed on three burros. They made their main camp in a cabin at a point about six miles east of Pine Flats, called Chillao, but after a time moved on six miles farther eastward and camped in Buckhorn Canyon, one of the tributaries of Rock creek, which runs into the desert north of the Sierra Madre range. Mr. Reed, who is a resident of Sierra Madre, took one or two carrier pigeons with him and one of thein arrived home a week ago to-day, bearing the message that all the party were in camp in Buckhorn Canyon, and all well.

"The next morning (Friday) it began to snow and blow, and the three men immediately made preparations to pack up and start for home. While Reed got breakfast, Winston and Brown went out to hunt up the burros. They kept together for a short distance and then separated, the former going west and the latter southeast. Brown soon found the animals and according to agreement gave a signal by hallooing. He kept this up until he came back to camp, but there was no response. The two men then fired their guns and blew a tin horn they carried, keeping the signals going until about eleven o'clock, but getting no response.

"They then concluded that Mr. Winston had kept on in the direction he had started, expecting to find the burros at Chillao cabin, so they packed up and left for that point, arriving about six o'clock in the evening. When they pulled out of Buckhorn Canyon the snow was still falling and had already attained a depth of nearly two feet. Farther west, however, the fall had been lighter and did not obscure the trail.

"No signs of Winston were found at the cabin and the two men spent an anxious night. Saturday and Sunday they spent in searching for their lost companion, but to no avail, and Monday morning they packed up and started for home, arriving at Sierra Madre Tuesday night at I I o'clock, all worn out and distressed. Brown was hardly able to return this morning with the rescuing party, but he did go.

"Mr. Brow11 says that on Tuesday night last Mr. Winston became confused as to his location while out hunting and was obliged to remain out all night and wait for daylight to get his bearings. It is a very rough country, and in a blinding storm it is easy to lose all ideas of place and distance. Mr. Winston had a narrow escape some years ago not far from the same camp, when he was out two days and two nights without food.'

That was Thursday. Then Friday's paper said:

"Two of the best mountaineers in town, Jud Blick and Lew Newcome, started up the toll trail immediately upon the return of Mr. Winston's companions, Messrs. Brown and Reed, yesterday morning; and this morning another party composed of Palmer Reed, Charley Winston, Charley Brown, Cal Hartwell, Mart. Weight and Frank Grant, left for the summit in one of Wiley \& Greely's teams, proposing to take pack animals at the foot of the trail."

The next week the paper reported:

"Two of the men who have been in the mountains since last Wednesday and Thursday hunting for L. C. Winston returned about noon today after more provisions. They are Charley Winston, a half brother of Lang, and Jud Blick. The returned men bring no tidings of Winston that affords the least reliable clue as to his whereabouts or his condition. Charley Winston went on home soon after arriving, to prepare several pack loads of 
supplies, with which he will start back tonight. Jud will go back in a couple of days with another supply."

Then the Star of December 14, said:

"Messrs. Chas. Brown, Jos. and Grant Griswold, John Hartwell, A. Leffler and Reney returned yesterday afternoon from their expedition up the Arroyo Seco in quest of L. C. Winston, bringing no encouraging news whatever. They made a very thorough search of the main and tributary canyons as far up as the divide between the headwaters of the Arroyo and the Tejunga, with side trips down the Tejunga and west branch of the San Gabriel, but absolutely no trace of the missing man could be found. The region about Barley Flats was explored also Another small party, headed by one of Mr. Winston's brothers, has gone over to Chillao and beyond, and they will continue the search in that direction."

The next report is of date December 20 , and says :

"Another party has been made up to go in search of L. C. Winston, consisting of John Hartwell, Joe and Grant Grisivold and Charley Brown. I ou Newcombe is already over on the 'Tejunga and the others will join him there and all will establish a camp at Chillao, where there is a cabin. They have all been in former searching parties and know the mountains thoroughly. 'They will go well prepared with provisions and clothing, so that they can weather storms. Those who are not familiar with the trails and canyons of the range should by 110 means venture into the mountains at this time of year. It is dangerous work for experienced mountaineers, and for others the danger is vastly increased."

These brief quotations from long articles will show what deep interest was felt and great effort made to find the missing man, dead or alive. Yet not the least clue was found, or heard of him, until the following account appeared, dated Los Angeles; August 16, 1894:

"On Tuesday a young man who was liunting in the Little Rock Creek Canyon found the body of the lost man, L. C. Winston. I,ittle Rock Creek Canyon runs into the Sierra Madre mountains up to Mount Waterman, which is the divide between the San Gabriel Canyon and the Iittle Rock Creek Canyon. A party consisting of J. B. Martin, W. A. Pallette, R. B. Burns; C. E. Meiggs, Fred Lees and Charles Brossart were camping; and on Tuesday Meiggs took his rifle and went up a little tributary canyon looking for deer. Losing his bearings, he climbed upon a high rock and looked about. As he clambered down he saw wliat appeared to be a man in an overcoat sleeping alongside a $\log$. As he approached he was horrified to see that the man was dead, the legs being detached from the body, both being some distance away. The bones of the feet were still encased in the slioes. The trunk was wrapped in a heavy overcoat, which was closely buttoned and belted. 'The hat was on the skull, the hair and beard still clinging to the tightly drawn parchment-like skin. An investigation showed that the remains were undoubtedly those of Winston, for a cob pipe bearing lis name, a bowie knife, also engraved, his watch, a match box and other articles were found in the pockets of the clothes. The body is twelve miles from the nearest house and can only be reached by pack-train in about two days' travel. 'The campers left the body wliere it was found, marking the locality so that it could be easily found again, and started at once for the city, 
arriving early this morning and going at once to Pasadena, where the Winston family was notified. A party of friends of the dead man started at once for the Little Rock Creek Canyon, and will bring back the remains as soon as possible."

On Tuesday morning, August i6, about eight o'clock, policeman A. O. Bristol was informed by Ernest Meiggs of East Los Angeles that he had found Winston's body, and had come to report the matter. Bristol at once went with him to the residence of W. S. Wright, Esq., and Mrs. Winston with the information. And by noon train Mr. Wright, Mr. Meiggs and Peter Steil started to recover and bring in the body. They had to go by S. P. Railroad to Palmdale, thence by team twenty-two miles to Pallette ranch on the north side of the mountains, thence by pack mules about twenty miles up Rock Creek Canyon. The spot where the body lay was five or six miles from the camp that Winston had started from, when he got bewildered and lost in the snow storm; and it is likely that some of the search parties sent out eight or nine months before had passed within fifty yards of the body without discovering it. August 20, Messrs. Wright and Steil returned to Pasadena with the remains. August 2I, Coroner Cates held an inquest, with the following jurymen : Ed. Lockett, Thos. Banbury, Samuel Weight, E. A. Mote, B. A. Sparks, Thos. Grimes, Geo. Swerdfiger, S. O. McGrew, and G. W. Benedict, foreman. In his testimony before the jury, W. S. Wright said: "The range on which the body was found is estimated to be next highest to Baldy in the Sierra Madre range. It is two or three miles north of Waterman range, and is in section 18 , township 3 , north, of range ro west." They buill a cairn or monument of stones to mark the place, and named it Winston mountain.

Mr. Wiuston had long been an honored member of the Ancient Order of United Workmen, and they conducted his burial. They also paid his life certificate of $\$ 2,000$ to his widow.

\section{WINERY TANK EXPLOSION.}

October 8, i 894, occurred at Lamada Park one of the most horrible catastrophes that fall within the province of this history to record. Workmen were engaged at re-arranging some old and putting in some new apparatus at the winery there. The manager, Albert Brigden, was standiug on an old tank, three of which had just been newly placed, testing a stop-cock while the engineer was letting in steam. Adam Schumann, the company's cooper, had warned Brigden that those tanks were not safe; but he insisted that they were all right, and must be tested to adjust the gauge points for the uses they were to serve. So both men were on the tanks at four o'clock p. m. when the explosion occurred. The Los Angeles Times report of the event said :

"Brigden and Schumann were upon a platform over a series of three large wooden casks, or tanks, used in the process of distilling, situated in a 
new building which the company had just erected. Mr. Brigden was directly over the first of these tanks, engaged in trying some stop-cocks, the cooper standing some feet away, nearer the central cask. The engineer, on the ground below, was engaged in turning into the cask a pressure of stean, indicated on the boiler's gauge as fifty pounds, for the purpose of heating the water in the vessel. Suddenly, with a loud report, the upper end of the cask blew upward in a cloud of steam and a deluge of boiling water, striking and enveloping both the men on the platform, carrying them to the roof, Mr. Brigden falling to the ground, a distance of something like twenty feet, and Mr. Schumann lodging on the staging. Mr. Brigden, scalded all over and stunned by his terrific fall, had yet sufficient strength to run to the office, where he called for help to take off his clothing. When this was finally done, and by his direction he had been bathed in oil and wrapped in blankets, the flesh falling from his hands and back, he was carried to his home, over a mile away, where physicians ministered to him up to the hour of his death."

Mr. Brigden was a member of John F. Godfrey Post G. A. R. of Pasadena, and his burial was conducted by the Post, at Mountain View cemetery. He had resided here about fifteen years, and was brother-in-law to, and business partner in the winery with, Hon. J. F. Crank.

The other man, Adam Schumann, suffered great agony from his injuries and lay in a critical condition several weeks, but finally recovered.

A long list of minor accidents, shootings, fires, etc., I had to onit, because they would overload my pages with their numerousness.

STORMS, FLOODS, CLIMIATE, ETC.

There have been some storm periods, and incidents connected with them, besides occasional extremes of weather, which form historic waymarks in the course of years. And I have gleaned what I could that seemed of enough celebrity at the time to be worth preserving for reference when similar freaks of weather shall occur hereafter. The Centennial History of Los Angeles County, page 52, says :

\section{86 I -62 .}

"At Los Angeles, the flood of $186 \mathrm{I}-62$ began with the rain on Christmas eve, I86r, and continued almost without intermission until January 17 , I 862, on which last day, 3 o'clock p. m., fell tremendous torrents of water, accompanied by loud claps of thunder and vivid lightning."

The Historical Society's pamphlet, published in 1890 , page 36 , makes mention of the same storm, thus :

"The Arroyo Seco, swollen to a mighty river, brought down from the mountains and canyons great rafts of drift-wood that, lodging here and there in the channel of the Los Angeles, formed dams that turued the current hither and thither, tearing away the low banks, and spreading the waters still further over the valley, then, hreaking away, the drift was carried down and spread over the plains below the city. The drift-wood brought down by that flood funished fuel for the poor people of the city for 
several years. It began raining on December 24, I86 I, and continued for thirty days, with but two slight interruptions."

I 865.

Of a severe storm this year Judge Eaton writes:

"About once a year-generally in the month of February, but certainly during the winter months-we are visited with an electric storm that comes directly over the mountains, but loses its force rapidly as it leaves the base and spreads over the plains. The first of these I ever saw came the day I arrived at Fair Oaks, February 3, r865. It commenced at sundown, at the close of one of the most perfect days I ever saw. There had been heavy rains and the earth was thoroughly soaked with water. The result was, many of the stalwart old oaks scattered about the ranch were prostrated. This storm lasted about 48 hours and was the worst one I have ever seen in this section. Once since then the storm has repeated itself on the same day and date, but was not so violent. Since the settlement of Pasadena, twenty years ago, there have been but one or two storms that did enough damage to be worthy of notice.

I $880-8 \mathrm{I}-82$.

For the Farnsworth pamphlet, published in r883, Dr. I. S. P. Lord furnished a valuable article on "Disease and Climate," based on his own weather records and notes as a practicing physician; and from this I quote, p. I05:

"January 27, r888, we had a snow storm, and snow lay on the ground several hours before melting, and was seen on the foothills south in patches the next day. Again, January I2, r 882, it snowed till the ground was white. On the 8th of December, I88I, it blew a gale all night and injured some buildings, etc. There were three hot, sultry nights in 1879 , such as they have at the East. * * Ice in the winter of 1882 and ' 83 attained the thickness of three-fourths of an inch under very favorable circumstances, as direct exposure and shallow water."

Of the wind storm above noted on December 8, i88 I, P. G. Wooster writes: "Although our cottage was well braced and built in the form of a $\mathrm{T}, \mathrm{my}$ wife did not dare remain indoors, but went out and sat down in the barley patch and held on to the stubble."

$$
\text { I } 884 \text {. }
$$

I 882 and I 883 were "dry years," but I 884 gave destructive floods. The Pasadena Valley Union of February 23 [Saturday], 1884, says :

"Never in the history of Los Angeles county has been recorded so great a storm nor so destructive a one as that just passed, and for many years to come the "rain of ' 84 " will figure as an epoch from which to date important events in our meteorological history. As we went to press last Saturday, our record for the three weeks past shows $19.5 \mathrm{I}$ inches for that period, and all Saturday it continued. After dark the fall increased in force and came down in torrents which continued without intermission until the afternoon of Sunday, when a little rest was had; but only for a short period, for it was collecting renewed energy for another downpour, continu- 
ing until midnight, when it cleared. No great damage was sustained in and around Pasadena beyond some heavy washes upon the steeper slopes and mesas, although some complain of owning an acre or two of real estate that had been transported from their neighbor's orchards by heavy washing. The most serious damage was done to the main cement ditch beyond John W. Wilson's ranch, about a mile of which was buried in the sand and debris, and about fifty feet destroyed. In the valley everything was flooded. At San Gabriel culverts were partially destroyed, and the plain beyond, embracing the Eil Monte and Savanuah districts were covered with water. * * * The Pasadena Central School has been closed during the past week on account of the storm, but will re-open as usual on Monday." [Several items through the paper show extensive rainfall, mudholes, washouts, impassable roads and streets at this time.]

The same paper of March 8th says: "On Monday morning [March 3] began another rain storm that for damage done surpasses the one last recorded." The storm continued till Thursday, accompanied at intervals with sharp thunder and lightning. The local report continues: "A heavy and deep wash, beginning south of Mountain Avenue, near Lake Avenue, extended into one corner of the Mutual Orchard Co.'s orange grove, but beyond that shallowing out over a large area, then again cutting heavily wherever the ground has been recently plowed. Farther up the slope, crossing the Crank property, another large wash occurs, extending down through the lands of Clark Maudlin, Henry Wood and Samuel Bundy. On the Gano, Banbury and Woodbury estates, the damages have been very great, and will require thousands of dollars to repair. It is said a double harrow was carried bodily from somewhere about Swartwout's ranch down to near Villa street. [Over a mile.] This will give an idea of the force of the torrent."

"Later: About 250 feet of the main ditch on the Lake Vineyard Co.'s lands was washed ont by the late storm."

Again, March 15, the Union says: "This season will certainly exceed any previonsly recorded one, for rainfall. The wet season of I 862 gave this county 36 inches of rain, and not since then has it reached 30 inches. Now we have 35.I 8, with two or three good months to hear from; so we can predict from 40 to 45 inches with almost a certainty."

I remember myself that during I $8 S_{4}$ rain fell sometime during every calendar month of that year except September. The Union of October I I, says :

"A light rain accompanied by thunder and lightning, visited Pasadena on 'Thursday. At Los Angeles and along the Sierra Madre motntains it rained quite heavily, and an old-fashioned thunderstorm seemed to be raging in the mountains."

The paper also mentioned generons, showers on December 7,8 and II.

WEDDING MUSICIANS SOUSED IN THE ARROYO.

Wednesday evening, April 9, 1885, a notable and historic wedding occurred at the residence of E. F. Hurlbut on Orange Grove Avenne. Miss Jessie Banbury, daughter of Col. J. Banbury, was married to Dr. F. De W. Crank, brother of J. F. Crank, who was President of the first railroad into 
Pasadena, and afterward built the great system of cableroads in Los Angeles. It had been planned to have the marriage ceremony at the M. E. Church, and then a reception at Mr. Hurlbut's, which was the largest and most commodious residence then in the colony and was freely offered for the occasion, Col. Banbury's family being old friends and neighbors. But a great rainstorm compelled the entire proceedings to be held at the house. The marriage service was performed by Rev. Solomon Dunton, grandfather of the bride. A string band had been engaged to come out from Los Angeles and play, for the wedding guests to enjoy a little dancing. And here is where the romance of history comes into the case. The Pasadena and Valley Union of April 12, I884, says :

"When Wangeman's string band, who were en route for the CrankBanbury wedding, attempted to cross the Arroyo Seco on Wednesday evening, the vehicle was upset and the bold musicians were incontinently dumped into the 'raging main.' Being swimmers, they 'swam for the shore' with a will, but minus a valuable violin and a cornet, which they lost in the stream. A city hack happening along opportunely, conveyed them to their destination, their own team being badly damaged. Mr. Hurlbut's old clothes were in demand; and it was a little funny to observe the musical gentlemen wearing pants twelve inches too long, and coats with the waist seam where the tails should end."

$$
\text { I } 885 \text {. }
$$

The Valley Union of Saturday, November 20, said:

"The flumes of the Pasadena Lake Vineyard Land and Water Company at Devil's Gate were washed away by the high waters Wednesday night, and will be immediately re-built at a cost of about $\$$ r 50 to $\$ 200$."

I 886.

The Union of January 22, I886, gives this report:

"The experience of November is was repeated January is-with a singular coincidence, just two months to a day. Rain had been falling with little intermission for several days, and Monday night there came a crisis. On that day and night fell over four inches of water, and everything was afloat. Great streams rushed through the streets, and at every available point miniature lakes formed, though thanks to the good natural drainage of Pasadena, the chances for the latter were very limited. The storm was severe and Eastern in its character. Good, old-fashioned, orthodox thunder and lightning, such as they wore in our grandmother's days, was startlingly frequent, and reminded the hearer of 'artillery of heaven' that used to be so favorite an accompaniment of western eloquence. Next morning the trains of our local road, which have become a pleasant feature of Pasadena life, were conspicuous for their absence. They did, indeed, toot a whistle afar off-away up toward Lamanda Park-but it was a case of 'thus far shalt thou come, and no farther'- they remained afar off and did not approach Pasadena. The cause was a big vacuum where there ought to have been a road-bed across the 'wash' about Hill Avenue. This was repaired, but on the same day ('Tuesday) washed out again and had to be rebuilt. There was also a washout of the culvert at Marengo Avenue. This did 
not amount to much. Further down the damages were, a cave on the track at the Raymond cut, a similar one at the east end of the upper Arroyo bridge, a washout under the track opposite Sycamore Grove, a big washout at the lower Arroyo bridge, and extensive damage at Los Angeles. The bridge over the river at that place stood, but the approaches to it at both ends were washed away, the largest break being at the north end. From here the turn-table was carried and swept down the river against the Downey Avenue bridge, which it weakened so that a part of that structure also gave way and was carried down the stream. In Los Angeles the track in the yard was washed out and the passenger station undermined and carried down stream, it going against the S. P. bridge, where it had to be broken up to save the latter structure. The loss to the railroad we do not know, but judge that $\$ 5$, ooo would not be far out of the way.

"Next to the railroad loss, perhaps the greatest injury about Pasadena is to the water companies, whose works in the Arroyo were all at the mercy of the torrent. The flumes of the Pasadena I. V. L. \& W. Company, which were carried away in November, were taken again this time, and will cause the same expense over again that it did before to replace them. The Orange Grove Company also lost some of their iron piping about Devil's Gate. The reservoir near the college broke away, and perhaps others that we have not heard of. Railroad communication with Los Angeles is thus far suspended, only a construction train running to carry the workmen repairing the breaks. They take passengers for the first time today, leaving them at the river. Regular trains will not be resumed until the Los Angeles river bridge is made passable, which it is hoped to do tomorrow. No mail came Tuesday, but the stage has since supplied the deficiency."

January 29, the paper said :

"The mail came up by cars Friday evening, for the first time since Monday (Wednesday and Thursday it came by stage), and was a big one-thirteen bags, the largest ever received here."

December 14, I 887 , a wind storm occurred which blew down Mr. Gould's residence at North Pasadena, then unfinished, although occupied by the family, and some its members were slightly injured. Other damage was done hereabouts, but nothing serious.

P. G. Wooster reports from his memorandum of February 29, 1888: "It hailed just at night. The heavy rain last night did much damage to streets." I 889.

This year was marked by a grievous visitation of worms; and the Pasadena Standard of May I I, reported about it thus :

"They destroyed the tomato, squash and pea vines in our own garden, besides roses, geraniums, verbenas, fuchias and other things in our front yard. It is the California cutworm or W-marked cutworm - Agrotis clandestina-described in Matthew Cooke's work as "a naked, greasy looking, I6-legged caterpillar or worm. Order Lepidoptera; family Noctuidae. Do their devonring mostly by night." 
GREAT STORM - FOUR CHURCHES BLOWN DOWN.

I 89 I .

The Pasadena Daily Star of December I I, I89I, said :

"Four years ago yesterday there was a storm of exceptional violence. Houses were unroofed and trees blown down, but no great destruction was wrought. Last night this section was visited by the hardest blow it has experienced within the memory of the oldest resident. It was the culmination of the storm which began the night before, and it appeared to reach its height between three and four o'clock this morning. The wind came from the north and northwest at hurricane speed, rocking houses, taking off tin roofs and chimneys, threshing the fruit off from trees, bending and breaking dowll shade trees, driving through the streets and into the houses clouds of fine dust gathered on the wings of the storm as it came swooping down through the Canyada and the mesa at the foot of the mountains."

The paper then goes on to give a full account in detail of the destruction wrought; and I have compiled from its report the following table of principal losses :

Presbyterian church on East Colorado street ; tall, elegant round steeple blown over into the street.

First Methodist church, corner Marengo Avenue and Colorado street; tall, square steeple with bell in it, blown over on the church roof and crushing it down. wreck.

Christian church on South De Lacy street; all blown down-a total

North Congregational church, corner North Raymond Avenue and Jefferson street; total wreck.

Raymond hotel, tin roof blown off from tower, eight or nine brick chimneys blown down, crashing through veranda roofs, and many windows broken.

Arcade block, tin roofing torn off, chimneys and iron cornice blown down, and $\$ \mathrm{I}, 000$ worth of heavy plate glass broken.

Brockway block, corner Marengo Avenue and Colorado street; chimneys, roofing, skylights, cornices whisked and hurled away into the street, and five great lights of plate glass worth $\$ \mathrm{I}$, ooo broken.

E. S. Frost's two-story frame building near the corner of Broadway and Colorado street totally demolished, killing a horse and smashing up two buggies and a valuable bicycle.

Williams Hall, tin roof torn off.

Haskins's two-story brick blacksmith and carriage building on West Union street unroofed.

The Steam Laundry, two-story building on Wilson Avenue and Villa street, a total wreck. Machinery not much damaged.

Capt. Thornton's two-story frame block on South Fair Oaks Avenue went to smash, down across the sidewalk.

Nine or ten cottages or dwellings were mentioned as blown down, besides many more residences and business houses more or less severely damaged; and yet nobody seriously hurt within Pasadena. 
The telephone and telegraph service was of course in a state of wreckage; but the railroads did not miss a train. As the damage to buildings and personal property was caused by wind and not by fire, there was no insurance to recoup any of these losses.

March 2I, 1894, icicles eight inches long were reported at Rev. Mr. Northrop's, 330 North Lake Avenue, and frost spray all around on the shrubbery, guavas, etc. This was deemed remarkable enough at the time to give it publicity.

Mr. Harold S. Channing, our young meteorologist, grandson of the eminent Wm. Ellery Channing, D. D., of Boston, prepared the following valuable tables for the Pasadena Star in October, I894, and I copy them here for permanent reference :

RECORD OF RAINFALL AT PASADENA.

\begin{tabular}{|c|c|c|c|c|c|c|c|c|c|c|c|c|c|}
\hline YEAR & JAN. & FEB. & MAR. & APR. & MI A Y & JUNE & JULY & AUG. & SEPT. & ост. & NOV. & DEC. & THE YR, \\
\hline & & & & & & & & & & .80 & I.7 & .00 & \\
\hline & .93 & 4.45 & I.80 & & 2.36 & .05 & .00 & .00 & & 1.30 & & & \\
\hline ........ & 6.10 & I 3.21 & 12.99 & 5.93 & .77 & 1.90 & .0 & & & .25 & & & \\
\hline 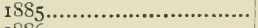 & 1.22 & .00 & .05 & 3.00 & $\cdot 3$ & .II & .0 &. $\mathrm{I}$ & & .00 & & & \\
\hline …....................... & $7 \cdot 40$ & 2.32 & 2.43 & 4.11 & & .0 & .0 & .2 & & . Io & & & \\
\hline 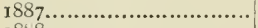 & . 9 & 10.66 & .27 & 2.33 & .28 & .0 & .17 & .00 & .3 & .12 & & & \\
\hline (n........................ & $7 \cdot 40$ & 1.57 & 5.62 & .46 & .00 & .0 & .0 & .00 & & .45 & & & \\
\hline ….. & .09 & 1.08 & $8.8_{3}$ & .41 & .95 & .00 & .00 & .62 & .00 & $.9 \cdot 3 I$ & & & \\
\hline & $7 \cdot 92$ & 2.66 & .90 & .60 & .20 & .06 & .00 & .00 & .26 & .07 & & & \\
\hline ....... & .34 & 10.75 & .68 & 1.84 & .73 & .00 & .00 & $.0 c$ & & .00 & & & \\
\hline & 1.54 & 3.40 & 4.23 & .25 & 394 & .0 & .00 & .00 & & .62 & & & \\
\hline ......... & 7.65 & 2.78 & 9.84 & .47 & .70 & .00 & .00 & .00 & .00 & .80 & .20 & $4 \cdot 77$ & 27.21 \\
\hline I $894 \ldots \ldots \ldots \ldots \ldots \ldots \ldots \ldots \ldots \ldots \ldots \ldots \ldots \ldots$ & I. 51 & .82 & .96 & .13 & $.6 \mathrm{I}$ & .00 & .00 & .09 & .85 & & (.......... & .......... & $\ldots \ldots \ldots$ \\
\hline Mean.. & 3.51 & $4 \cdot 32$ & 4.05 & I. 67 & .91 & .18 & .02 & .II & .13 & I. I 5 & 1.98 & $4 \cdot 3^{8}$ & 23.95 \\
\hline
\end{tabular}

Data furuished by Thos. Nelmes. Computed by H. S. ChanNing.

COMPARISON OF THE AVERAGE MONTHLY RAINFALL OF PASADENA AND LOS ANGELES FOR THE PAST TWELVE YEARS, BEGINNING OCTOBER, I882.

\begin{tabular}{|c|c|c|c|c|c|c|c|c|c|c|c|c|c|}
\hline & JAN. & FEB. & MAR. & APR. & MAY & JUNE: & JULY & A UG. & SEPT. & OCT. & Nov. & DEC. & THE YR. \\
\hline & 3.0 & 3.7 & $3.4^{2}-1-x-1$ & 1.15 & $\cdot 5^{0}$ & & .04 & .06 & .13 & .90 & $\mathrm{I} .7 \mathrm{I}$ & 84 & 8.67 \\
\hline 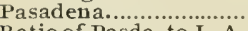 & $3.5 \mathrm{I}$ & 4.42 & 405 & I. 67 & $.9 \mathrm{r}$ & .18 & .02 &. $\mathrm{II}$ & .13 & I. 15 & I. 98 & 4.38 & 22.4 I \\
\hline Ratio of Pasda. to L. A. & $*_{\text {II } 6}$ & *II5 & $*_{118} 8$ & ${ }^{*}{ }_{140}$ & $* 182$ & $* 129$ & ${ }^{*} 55$ & ${ }^{*} \mathrm{I}_{3}$ & ${ }^{*} 100$ & ${ }^{*}{ }_{128} 8$ & *116 & * I I I & * 120 \\
\hline
\end{tabular}

* Per cent.

H. S. Channing, Voluutary Observer.

The record for I884 shows the largest rainfall for any one year of the duodecade; and December, I889, shows the largest amount in one month.

I,IGHTNING STRIKES A BARN.

I 893 .

The first and only record or report of damage done by lightning in Pasadenaland that I found was the case of Banning Bros.' barn, December 27, I893. The Daily Star of that date said:

"About 4 o'clock this morning, during the sharp thunder storm that was prevailing, an alarm of fire was rung in from the center of town and the department turned out in the driving and copious rain to find that the large barn of Banning Bros. on Walnut street near the Terminal R. R. track was on fire. $* * *$ The fire was caused by lightning striking the corrugated iron roof. A resident of that section of town says he saw the bolt strike and that it appeared to split the roof in two parts, and to send up 


\section{DIVISION THREE - BRAINS.}

\section{CHAP'TER IX.}

ANNALS OF THE SCHOOLS.-First schoolteacher and first pupils.-School buildings from I874 to I894.- Successive teachers for twenty years.- Successive trustees for twenty years.-The central school lot's public sale, I886.- Graduates of High School.Tables of School statistics.

Our Colleges, etc.-Sierra Madre College.-Pasadena Academy.-Throop Polytechnic Institute.-Father Throop Day.-Classical Schools.-Business College.

List of Pasadena Graduates or Stndents at State Normal School, State University, Stanford University, and Pomona College.

\section{ANNALS OF THE SCHOOLS.}

The colony settlers of Pasadena were of that class of people who regard puplic schools not as a mere ornamental appendage, but as one of the prime necessities of a civilized community. They were connected with San Gabriel for school purposes; but measures were taken at once to have a new school district, to be called San Pasqual, created by the County Board of Supervisors. This was effected in August, I874, and J. Banbury and H. G. Bennett were appointed as the first trustees of the new district, and Thos. F. Croft as school census marshal. They held their first meeting August 27, I 874, and organized for business by making J. Banbury chairman, and $\mathrm{H}$. G. Bennett clerk. On September 7, they met again and employed Miss Jennie H. Clapp to teach a school for one month. On Saturday, September I2, r874, the first school election was held, at which Col. J. Banbury, H. G. Bennett and Dr. W. W. Edwards, received each ten votes - all that were cast - and thus the people had a full board of school trustees of their own choosing. Meanwhile, on September ro, the first school in Pasadena had commenced its work, with only two pupils the first day, Jennie and Jessie, the twin daughters of Col. J. Banbury; but in about a week the attendance had increased to sixteen. This first school was held in the house of $\mathrm{Wm}$. T. Clapp, on Orange Grove Avenue near California street, being taught by his daughter Jennie - now Mrs. Rev. F. J. Culver. At the end of the month the school had grown so large as to require more room, and in October it was closed to wait until a school-house could be erected. A rough board structure was built at a cost of about $\$ 300$, on the west side of Orange Grove Avenue a few rods below California street, where Mrs. Sarah Ware's residence now stands. 'Thos. F. Croft with his historic mules donated the hauling of the lumber. The house stood by a great spreading live-oak tree which was afterward unwisely grubbed up by the roots to "clear the land." Miss Clapp re-opened the school in this rough pioneer building on January 28,1875 , and continued it through that school year. The pupils of that first school were: Jennie Mosher, Charlie Mosher, Lavinia Mosher, Olive 
Eaton, Belle Eaton, Will Eaton, George Eaton, Ben. Eaton, Jennie Banbury, Jessie Banbury, Agnes Elliott, Whit. Elliott, Howard Conger, Florence Edwards, Forest Edwards; Joseph M. Wilson, Belle B. Wilson, children of John W. Wilson ; and Charles and Maggie Wilson, children of John Bunyan Wilson. The Eaton children then resided at Fair Oaks (now Hon. J. F. Crank's place), over three miles from the school-house; and the Wilson children resided about two and half miles up the Arroyo on the La Canyada road.

For the school year of $1875^{-76}$ a Mrs. Rodgers was engaged; but after two weeks' work her health failed, and Miss Eugenia Rudisill conducted the school through this and the next year-1876-77. Meanwhile, in the winter of $1875^{-76}$ a neighborhood literary society had been formed. These colonists had come together mostly as strangers to each other, from many different sections of the country, and needed some common center for both social and intellectual intercourse and cultivation of acquaintanceship; and the literary society furnished such a gregarian center for the neighborhood by holding meetings once a month in the school-house. Very soon more room was needed, and the young men of the colony took the matter in hand and built an additional room to the school building. The literary society's meetings were made up of formal debates; topical papers with discussion following ; recitations, essays, music ; mock trials ; a local paper called "The Reservoir," written up to suit the occasion [See Chapter 7]; etc.; and there was thus brought out an amount of talent for writing and speaking that astonished the people themselves.

In 1876 the Lake Vineyard Colony was commenced on the west side of Fair Oaks Avenue, with L. D. Hollingsworth as the leading figure in the movement for its settlement, as is fully explained in Chapter 5. He intended to build a store and start a trading center or village on the high ground at the corner of Colorado street and Marengo Avenue, because that was the most sightly place for it, but the west side people made earnest appeal to have it not so far from them, but at least on the line between the two colonies; and as the population was then mostly on the west side, Mr. Hollingsworth yielded the point, and built his store near the corner of Fair Oaks and Colorado street. It was in April, I 875, that the name Pasadena had been officially adopted; but even before that a petition was forwarded to Washington for a new postoffice by that name, which was granted March I 5, I875, with Josiah Locke named as postmaster. He declined to serve on the small salary of twelve dollars per year. Then Henry T. Hollingsworth was appointed to the place, and he thus became Pasadena's first bona fide postmaster. This settled the postoffice to be kept in the Hollingsworth store; then J. H. Baker moved his colony blacksmith shop from west Walnut street down here; and a Mr. Watson started a meat market; and other kinds of business began to gather around this point. 
The same year, August 8, i 876, Hon. B. D. Wilson donated five acres, right across the street south from the store, to the San Pasqual School District for school purposes. The gift was accepted by the district; and to confirm title and make the acceptance conclusive, the school-house on Orange Grove Avenue was, after some natural friction between the two sections, moved November io, I876, onto the five-acre lot; and during the school year of $1877-78 \mathrm{Mr}$. Newell Matthews officiated as principal teacher, with Miss Florence Royce as assistant; they also held the same positions for I 878-79. During the summer vacation of $1878 \mathrm{P}$. G. Wooster taught a private school in the public school-house. Among his pupils were Sherman Washburn (nephew of S. Washburn, Esq.), Will H. Townsend, Olive Eaton, Nellie Richards, Jennie and Jessie Banbury.

Meanwhile the settlement had grown so rapidly that the old schoolhouse was entirely inadequate for its purpose; and on March 30, r 878, a proposition to levy a special tax on the property of the district for $\$ 3,500$ to erect a new and larger school building was submitted to a popular vote, and was carried almost unanimously, 44 for and only 3 against. Yet it was plain that the tax levy would not provide enough funds to put up a building of size and style and character of rooms suitable for a place that was growing so rapidly in population, and also in outside repute as a place of superior intelligence, culture and good taste. To meet this emergency, a subscription paper was started for voluntary increase of resources at command of the school board; and here is a copy which I made from the original paper as still preserved by S. Washburn :

The undersigned hereby agree to pay to the Trustees of the San Pasqual School District, within sixty days after date, the sum set opposite our names, for the purpose of building a more commodious school-house than can be built by the tax levied.

Dated Pasadena, California, June roth, i 878.

S. Washburn ...........................................\$100.00

M. H. Weight ........................Labor............... 25.00

J. F. Crank...Will raise tax to........................... 100.00

J. Smith...I will make my tax up to...................... 100.00

J. Banbury...In work $\$ 30$, or cash ..................... 20.00

H. T. Hollingsworth .................................. 25.00

Charles Legge...In work .............................. 25.00

Mills Bros...Will raise tax to............(Labor)............. 20.00

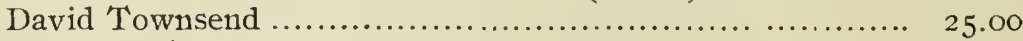

L. D. Hollingsworth.................................. I 5.00

P. W. Hollingsworth ..................Work............... 15.00

J. H. Baker........................................... 10.00

T. Banbury...Raise tax to .............................. 20.00

S. E. Locke...............................Work ................. 20.00

F. Lowe.................................. Labor ................. 20.00

O. H. Conger...Will raise tax to.......................... 50.00

P. G. Wooster.......................Work .............. 15.00 


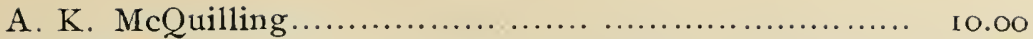

E. Turner .............................. Labur or money...... I0.00

Jos. Nelson ........................................... 10.00

Newell Matthews.........................Cash \$25, Bills $\$ 5 \ldots$ 30.00

E. Millard ............................Labor ............... 10.00

Newell Matthews........................Cash. .............. 20.00

R. Williams..........................Labor .............. I0.00

F. M. Lippincott .................... Labor ............. 10.00

Geo. Miller ...........................Labor............... 10.00

Frank Heydenreich....................Labor ............... 10.00

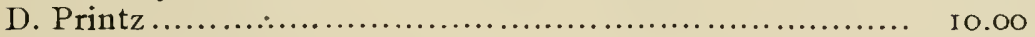

Capt. S. Jones......................................... 10.00

James Blattenberg .......................Labor ............... 10.00

Geo. P. Clark .........................Labor ............... 15.00

Arthur A. Knox.........................Labor ............... $\quad 5.00$

J. R. Giddings .......................... Labor ............... $\quad 5.00$

C. W. Bell...........................Labor .............. 5.00

J. Beebe..................................

Joseph Wallace ......................... Labor .............. I I5.00

The good work went forward, and by the end of the year a handsome two-story building with rooms separate for different grades, and crowned with a suitable bell, was ready for, use. And Mr. Matthews and Miss Royce had the honor of inaugurating the new temple of learning.* The historic little old original school-house was sold and moved off the grounds; it served various uses till finally most of it was incorporated in a cottage built by R. Williams on South Fair Oaks avenue-and in the "boom time," [1886], this cottage was sold and moved to a lot on Adella Avenue, where it still stands as No. 407-the residence of Joseph Yates, in 1894. But another portion of it forms the main body of a cheap cottage, now No. 20, on Mills street. $\dagger$

Meanwhile, during the fall of 1877 , the people at the south end of Pasadena, thinking the San Pasqual School at too great a distance, and desiring to have more immediate control in their own school matters, began to agitate the question of having a new district. The movement succeeded, and in January, 1878, the "Pasadena School District" was formed, including that portion of the settlement south of California street and west of Fair Oaks Avenue, to the north line of Los Angeles city. On March 5, I 878 , the first school was opened in a building owned by C. B. Ripley, and standing at the summit of the grade, or hill on west Columbia street, now the Charles Foote place. A five-acre lot at the corner of Sylvan Avenue and Columbia street was soon purchased of A. O. Porter, for school purposes.

* May 2I, Iźg4, J. W. Vandevort presented the City Council with a photograph of our First City Hall (the old Central School building), and S. Washburn presented the original subscription list which enabled that building to be erected, in 1876 . The relics were properly cased and hung on the wall of the Council room.

tAfter this chapter was written, J. A. De Hay bought this part of the old colony school-house and moved it down to his home place on Waverly Drive. 
The first term of the school was taught by Miss Bessie Harris, of San Jose. The next term by Miss Fannie Carroll, of Pasadena. During the summer of 1879 a small building was erected near the above lot, as a temporary school-house. Miss Lucy Newell, of Santa Clara, taught that year. In the fall of I880 Miss Minnie Joslyn, of Orange, began the term, Mr. C. H. Case, of Pasadena, continuing it till Christmas, when Mr. R. B. Warren, of Orange, took the school for the remainder of the year. He was succeeded again by Mr. Case. [For further history of this school, see Chapter 35.]

On the Ist of January, 1883 , a new postoffice called Hermosa was granted to these South Orange Grove people," with F. M. Glover as postmaster-the office being located at northeast corner of the school lot; and in $1884 \mathrm{Mr}$. Glover was succeeded by C. H. Case as postmaster. [See Chapter 35.]

In $r 883-84$ a large, fine school building was erected on the summit of their school lot, now known as "Columbia Hill," at a cost of about $\$ 4,000$. In 1885 this building and its magnificent grounds were given by the district to the "Sierra Madre College," the people hoping thereby to secure permanently in their midst a higher institution of learning. The college struggled along in hard straits for two years and finally failed, with heavy debts encumbering all its property, and to pay which it was at last sold. The place was bought, and building altered, enlarged and reconstructed by its present owner, making the fine and sightly residence of Chas. D. Daggett, Esq., on Columbia Hill.

In 1884 the population had increased to such numbers that two new school-houses were built at a cost of $\$ 4,300$ for the two-one at Monks Hill, and the other on East Colorado street, corner of Hill Avenue. An article in the Valley Union of March 8, I884, said: "The school census of Pasadena for 1883 showed an increase of over fifty per cent on the census of I882, and the attendance for this school year (I883-84) shows the same increase over last year, so that we have in October, when our schools are fairly commenced, about one-fourth more pupils than we have funds provided for, and at the close of the school year we have three pupils to provide for with the funds designed for two."* 'To meet these necessities for the time, a special tax was voted by the district. School grounds at Monks Hill were donated by Painter \& Ball, and a small building was erected thereon. These grounds were afterward exchanged for the present more suitable location, where the nine-room "Washington School" now stands. But a lot for the Colorado street school had to be bought outright, and cost \$175. Each building was planned to accomodate about eighty pupils, from first to sixth grade, although seats for only half that number were put in at first.

*An official report showed 222 pupils in school during the year, with 160 as the average attendance per mouth. 
Miss Elma Ball [now Mrs. H. I. Stuart of Pasadena] was teacher at Colorado street, and Miss Hannah Ball [now Mrs. F. R. Harris of Pasadena] at the Monks Hill school. These two houses were designed and built by Ridgway \& Ripley, and were first occupied in January, 1885 , after the holiday vacation, the schools having been opened a few months previously in temporary rooms.

All through this year, and for two years following, the teachers were embarrassed with difficulties of a peculiar nature; for in addition to the rapid increase of population, there was a large contingent of winter visitor pupils. And the new-comers, both permanent and transient, were of all sorts and grades, from all sorts of schools-ranging in quality from the poorest of remote country districts in the mountains or in the South, up to the highest type of graded schools in the great eastern cities ; and thus it was extremel $r$

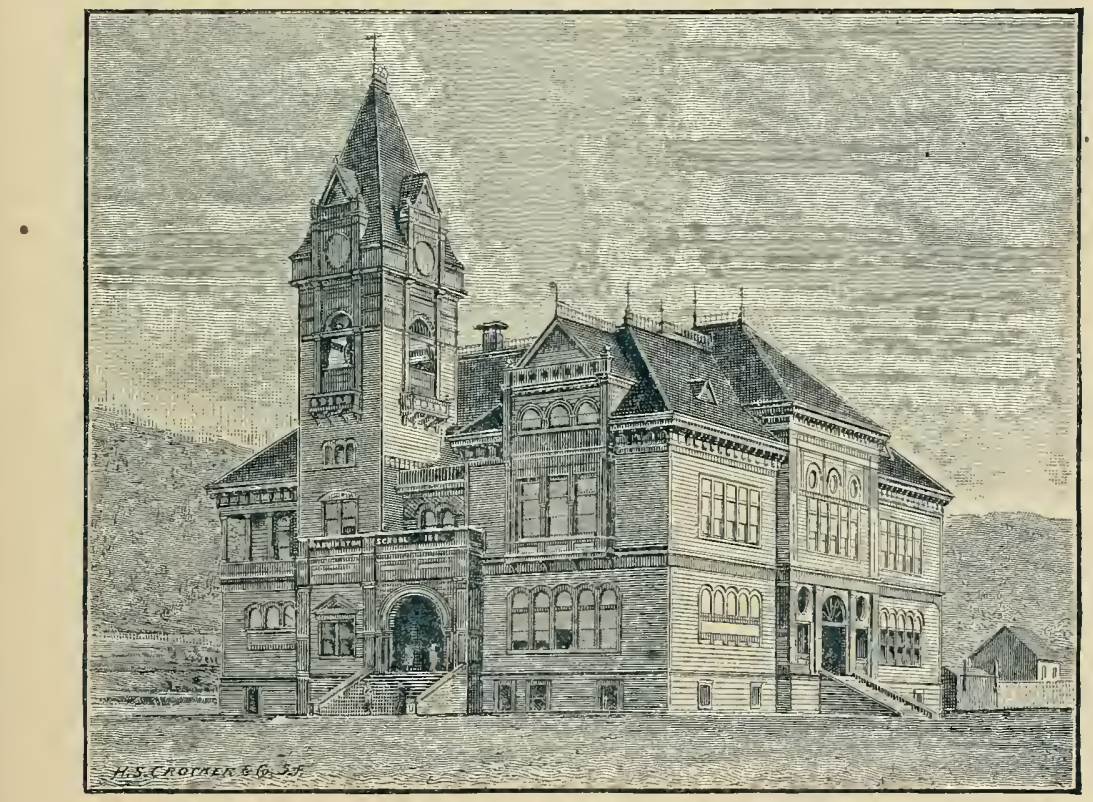

WASHINGTON SCHOOL.

Architecture, American. Erected 1888. Cost $\$ 25,000 ; 9$ rooms; 450 seats.

hard to grade them satisfactorily to pupils or parents. Also, the rooms were overcrowded, the teachers overworked, the apparatus and supplies, such as globes, wall-maps, blackbøards, reference books, charts, etc., greatly short of what were daily needed. Such were some of the difficulties which E. T. Pierce had to struggle with continually during the last three years of his arduous administration; yet he laid the foundations good and firm for better things in after years, the credit of which has often been mistakenly given to others. In May, I884, he published a statement showing 
what the school law called for that was impossible for him and his coteachers to fulfill, and made this appeal : "We must, however, have more than eight months in which to accomplish the work that is given for ten months."

In 1885 Chas. Turner and Maria Vischer gained the highest percentage in scholarship of any pupils in Los Angeles county. And in I886 Ernest Byram gained first, and Agnes Elliott second, rank in the county.

In May, I885, Edward S. Mosher took the school census of the district, and reported as follows: Number of white children between five and seventeen years of age, 459 ; number of census children, 460 ; number under five years of age, I 47 ; number attending private school, 23 ; not attending any school I 46 ; native born children (all ages), 559 ; births during the year, 13 ; foreign born children, 27 ; negro children, $\mathrm{r}$.

July 9, r886, principal Pierce published in the Valley Union a school report, giving grade and class rank of each pupil in the several schools.

During this year the matter of removing the school building to some point less exposed to the stir and confusion of a business center was decided upon. And besides, the original school grounds donated by Hon. B. D. Wilson, had become so valuable for business lots that their sale would certainly yield funds to buy a more eligible site and erect a much larger and better arranged building. It was necessary, however, to get written consent from the heirs of Mr. Wilson, before any sale of these lands could be made with good title, as they had been given to the district specifically "for school purposes." This consent was readily obtained ; and the district agreed that the large new school building to be erected from proceeds of the sale should be named the "Wilson School," as a perpetual memorial to the original donor of the lands. This matter being settled, the school-house was moved eastward a few hundred feet to a west frontage on Raymond Avenue; $*$ the grounds surveyed and staked off into 35 business lots, with convenient alleyways running through, and arrangement made for a public sale of the lots on March 12, I886. The following table shows the buyers of lots and the price paid for each, at this great sale:

\section{AUCTION SALE OF SCHOOL LOTS, MARCH I2, IS86.}

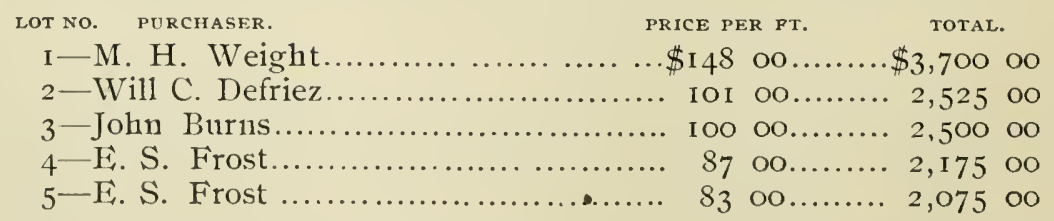

*This building was still used for school purposes until the new "Wilson School" was ready. But the Union of Aug. 26, 1886 , said: "School opeving is delayed till the 20 th of September by the moving of the building." It was afterward leased by the city as a City Hall for a term of years. Its next use was as a colored people's church. Then it was leased and fitted up for a gymnasium by the Athletic Club. But in 1894 it was sold to Thomas Banbury and moved away to make room for a fine brick block; and it now stands at the cormer of Fair Oaks Avenue and Glendale street, where it has been shorn of its bell tower and made over into a nice dwelling-house. 
LOT NO. PURCHASER.

PRICE PER FT.

TOTAL.

6-M. Fish

80 oo........\$2,000 oo

7 - M, Fish

$7000 \ldots \ldots \ldots$ I, 750 oO

8 - J. Hisey

$6600 \ldots \ldots \ldots 1,650$ oo

9-D. Parker

$5500 \ldots \ldots \ldots$ I, 375 OO

Io-Adam Becker.

$5 \mathrm{I} \quad 00 \ldots \ldots \ldots$ I, 275 OO

I I-C. A. Gardner

5 I $50 \ldots \ldots \ldots$ I, $287 \quad 50$

I2-W. W. Mills

$5000 \ldots \ldots \ldots$ I, 250 OO

I 3 -W. G. McCaldin

$4900 \ldots \ldots$ I, 22500

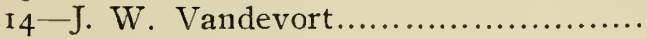

$5000 \ldots \ldots \ldots$ I, 250 oO

I $5-\mathrm{J}$. G. Miller

$5000 . \ldots \ldots$ I, 250 OO

I6-J. G. Miller

6 I $50 \ldots \ldots \ldots 1,537 \quad 50$

I7-J. G. Miller.

67 Oo........ 1,675 OO

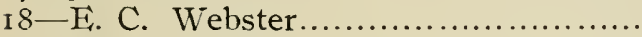

$5500 \ldots \ldots \ldots$ I, 375 OO

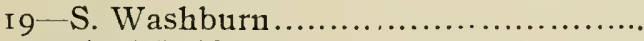

$5000 \ldots \ldots \ldots$ I, 250 OO

20-Fred Swift.

$4400 \ldots \ldots \ldots$ I, 100 OO

2 I-C. A. Steele

$4300 \ldots \ldots \ldots$ I,075 00

22 -C. A. Steele

$3700 \ldots \ldots . .93700$

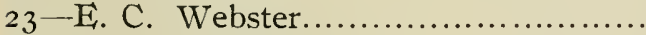

$3300 \ldots \ldots \ldots$

825 oo

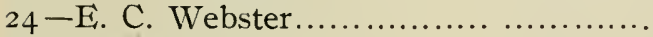

$2600 \ldots \ldots .650$ oo

25-A. Tower.

$2450 \ldots \ldots \ldots 6$ i 250

26-A. Tower.

$2450 \ldots \ldots \ldots 6$ 6 2 2 50

27-A. Tower

$2450 \ldots \ldots \ldots$

6 ז 250

28-A. Tower.

$2450 \ldots \ldots \ldots$

61250

$2500 \ldots \ldots .62500$

29-Edwin Ward..

6 I $50 \ldots \ldots$ I, 53750

3 I-Tom Hoag

$4650 \ldots \ldots \ldots$ I, I $62 \quad 50$

32-Tom Hoag.

$4500 \ldots \ldots \ldots$ I, I 2500

33 Reserved for Town Hall purposes, and the

34 school-house was moved onto them.

35-Free Library (by Abbot Kinney, president; this was where the original Library

building then stood)

17000

Total $. \$ 44,772$ oo

This was a great historic day in our school history. Among these lots was the entire frontage on the south side of Colorado street from Fair Oaks to the Santa Fe railroad, and on both sides of Raymond Avenue as far south as the north line of the present postoffice building-lots where some of the best business blocks of the city now stand.

The school trustees at this time were H. W. Magee, A. O. Bristol and S. Washburn, with E. T. Pierce as school principal and superintendent and clerk of the board; and these changes of school site, choice of new grounds, planning for new buildings, etc., imposed an immense amount of labor and care upon them. In a few weeks they called for competitive plans and specifications for the new Wilson school building. Nine different architects sent in plans under fictitious names, with their real names in sealed envelopes. These different plans were all exposed for public inspection and opinion two days (May 4-5, 1886) in a large vacant room over the Valley 
Union printing office-the frame building on alley opposite rear of the Natural History store, and famed in later years as the "Cheap John restaurant," or "blind pig," with illicit whisky kept hidden under the floor, etc. The estimated cost by the competitors varied from $\$ 15$, ooo to $\$ 30$, 000 . When the trustees came to vote on their preference among the nine different plans submitted. Magee and Bristol favored the one signed "Justitia," which proved afterward to be Harry Ridgway of Pasadena, but Washburn preferred the one signed "A point within a circle," which on opening the

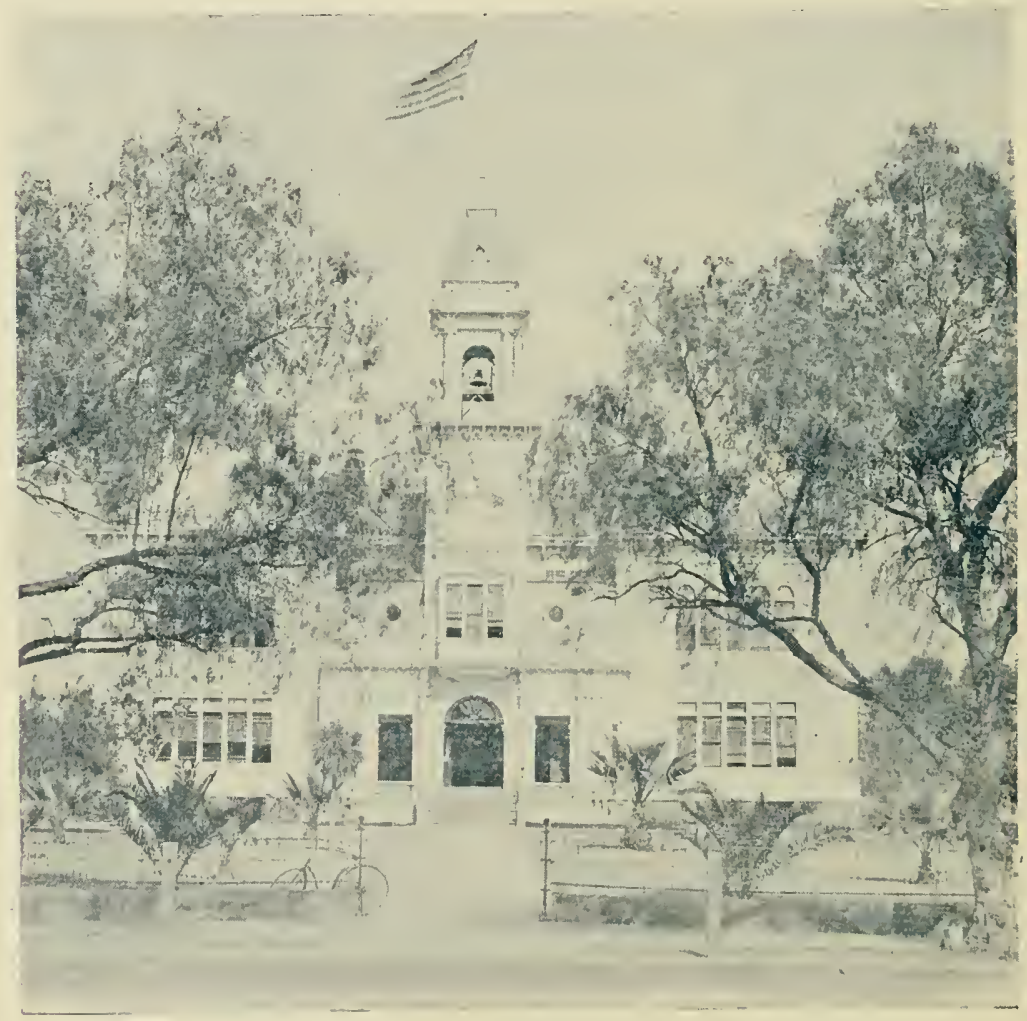

WILSON HIGH SCHOOL.

Architecture, Italian. Firected I887. Cost $\$ 30,000$; Io rooms; 425 seats.

sealed envelopes proved to be J. M. Stewart of San Diego. However, no action could be final in the matter until approved by the county superintendent, who was at this time J. W. Hinton. He examined the plans carefully in detail, and decided that as a whole-for size and style of building, size and placing of rooms, arrangement for ventilation and light, for egress in case of fire, the chaste and elegant external appearance, etc.the plan by Mr. Stewart was the preferable one: The trustees finally concurred in this view, and steps were taken at once to erect such a buildingthe one now known as the Wilson High School. 
It will be seen from the foregoing narrative that the years I886-87 were crowded with difficulties, transitions and changes in the school interests of Pasadena. In the autumn of 1887 the fine, new Wilson School building was first occupied. At the close of the school year $1887-88$, the trustees, for the first time in Pasadena, ventured to authorize the expense of a full printed report, in pamphlet form, on the school work and business of the year. This report is signed, H. H. Markham, president; A. O. Bristol, clerk; Z. Decker,-school trustees; and E. T. Pierce, city superintendent. And from it $I$ here quote some passages of permanent historic interest :

"The past year, that of $1887-8$, has doubtless been the most trying in the history of our schools. At the opening of the fall term it was evident that our school facilities, though much more ample than ever before,

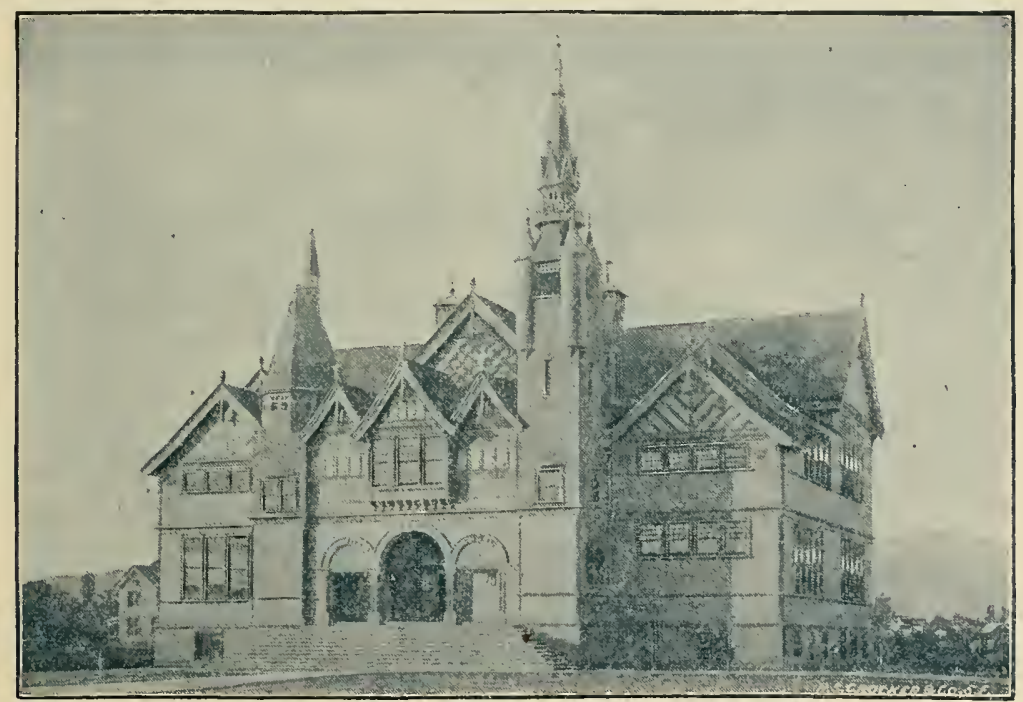

GARFIELD SCHOOL.

Architecture, Anglo-Teutonic. Erected, 1888 ; cost $\$ 22,000 ; 7$ rooms ; 375 seats.

were entirely insufficient to accommodate the great increase in attendance incident to our rapid growth as a city.* A vacant store on South Fair Oaks Avenue was rented and two teachers were employed to take charge of the primary pupils living in that vicinity. The corps of teachers at Monks Hill was doubled, and thirty-six more seats were placed in the main room of the Wilson School. Thus all the available space at the command of the school officers was utilized. Nevertheless, after the winter holidays, it was found necessary to hold 'double sessions ' in no less than ten departments.' School Report, page 3 .

"At the close of last year it became evident that, in view of our rapid growth, to be Superintendent of Schools, act as Principal of the largest

*When the Wilson school building, with 10 rooms, and to cost $\$ 30,000$, was being planned for, some citizens talked vehemently against it as a piece of extravagance and folly-and said, "We won't need so big a school house for ten years yet." 
building, visit the teachers in their rooms and direct their work, teach the graduating class, receive parents and visitors, examine and grade the large number of new pupils, act as Clerk of the School Board, and perform such other duties as that Board might direct, exceeded the powers of any one man. It was therefore thought by the board wiser and more economical to employ a Principal for the Wilson School, and leave the Superintendent free to attend to the many duties incident to his office. Mr. Herbert Pinckney was the Principal employed." - School Report, page 4.

"By the completion of handsome and commodious buildings in the northern and southern parts of our city, each of which will be thoroughly graded, and managed by an experienced Principal, with an able corps of teachers, our schools will assume the character properly befitting a well organized city system." -School Report, page 9.

[This refers to the "Washington School" in North Pasadena, and the "Garfield School" on California street.]

Some of the statistics of that year I thought worthy of preservation here for future reference and comparison:

\section{SUMMARY.}

I Eurollment for the year $\{$ Boys ...................................... 698

1 Eirls .................................. 656

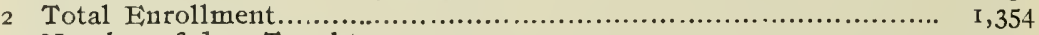

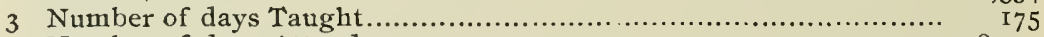

4 Number of days Attendance............................................ 148,472

5 Number of days Absence............................................. 10,667

6 Number of days Tardinesses ........................................... 2,960

7 Average Number Belonging ............................................. 909

S Average Daily Attendance.............................................. 849

9 Percentage of Attendance on Average Eurollment......................... 93

ro Average Number of Pupils Enrolled by each Teacher.................. 85

I I Average Daily Attendance per Teacher.............................. 53

SOME COMPARISONS WITH LAST YEAR.

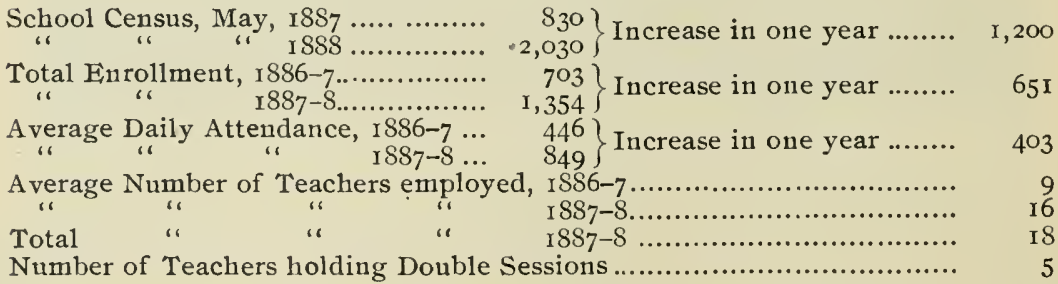

The total amount of funds in control of the school board that year was $\$ 1$ I 8,234.04. Their total expenditures, including new buildings, etc., were $\$ 63,965.48$; leaving on hand a balance of $\$ 54,268.56$. Five pages of itemized details are given, to show how the money was used; and a comparative summary of the regular school service expenses is given, thus:

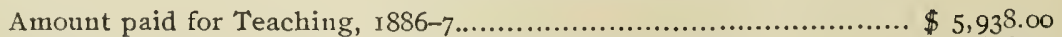

Amount paid for Teaching and Superintendence, r887-8................ $12,696.09$

Amount paid for Janitors, Fuel, Supplies, and Incidental Expenses,

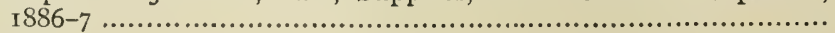

Amonnt paid for Janitors, Fuel, Supplies, and Incidental Expenses, $1887-8$

I, 300.00

2,02699 
This showed an increase of $\$ 7,481.08$ for running expenses in one year; and hence parties who took little pains to investigate the matter accused the school board and superintendent of folly, extravagance, peculation and mismanagement. These accusers even went so far the next year as to circulate a paper demanding an investigation, naming a committee to conduct the same, and agreeing to contribute \$100 for expenses thereof. But only three signatures were obtained to it, and the whole thing fell flat, although the much talk about it at the time did a good deal of mischief. [See school report for I 889-90, pages I 8 and I 9 , for further particulars in this matter.] In view of these things, the school board published a table showing that Pasadena's school expense per pupil in attendance was only $\$ 10.50$, while in ten other cities named it averaged $\$ 27.83$ per pupil. And many facts about increase of district, with new buildings required, etc., were given, to show how and why the expense account had to be rapidly increased.

The year I888-89 was a sort of breaking-up and transitional period. Z. Decker, R. Williams and C. W. Buchanan were the trustees. The city of Pasadena became incorporated in I886, and there was an undecided question of law as to whether the territory included within the city limits must be regarded and administered as a new and separate school district, or whether there was still only one district the same as before. Heavy school expenditures were necessarily going on both inside and outside of city limits, the validity of which was called in question ; and also an unfortunate public strife grew up over the retention of certain principal teachers. These things together made this really the most trying and worrying year, to those in charge of the school, of any one year in our school history; and personal animosities were engendered which have in some cases hardly worn away yet. The streets were filled with rumors and accusations of bad management or wrong-doing by the school officers; and yet, in every instance where such charges were made specific enough to be met, they were shown to be based upon the most frivolous and sometimes ridiculous misapprehension of what had been done or what had not been done, and the reasons therefor in either case. There was no printed pamphlet report this year. Prof. Pierce had engaged to take the principalship of the State Normal school at Chico the succeeding year, and would therefore retire from the Pasadena work at the close of this school year; and with the many cares and special difficulties of the situation at this time, he found it wholly impossible to do the clerical and literary and press-overseeing work necessary for such a publication. I mention this, because he has been misjudged and unjustly blamed in the matter. His successor, Will S. Monroe, bore this testimony: "When I took charge of the schools one year ago, I found them in good condition. Efficient work had been done by my predecessor, and the foundation had been laid on a broad, practical basis."

The Annual School Report for year I889-90 gives some account of the double-district case, thus : 


\section{PASADENA CITY SCHOOL, DISTRICT.}

This district was originally a part of the San Pasqual school district, which covered the city of Pasadena and left outside of the city limits the remainder of the San Pasqual district. When the city was incorporated in I 886, that part of the territory which comprised the city should have been set off as a separate school district, as provided by law ; but no steps were taken in that direction. In I 889, when it was discovered that a mistake had been made and that two districts had been voting for one set of trustees, the District Attorney and the Attorney-General decided that a set of trustees must be appointed for each district. These two boards of trustees met in joint session and conducted the school business so that no trouble was experienced. Special teachers were employed by both districts, and their salaries equitably divided between the two; and thus affairs went on until the San Pasqual district was added to the Pasadena city district, which was the only legal consolidation that could take place. The school district is now identical with the old San Pasqual district, but called the Pasadena City School District.

From various parts of the same document I gather a few items. It is mentioned that Ior visits to class-rooms were made by trustees during this year, whereas a total of only I3 I similar visits had been made during the preceding fifteen school years. In regard to the State law which requires school children to be vaccinated the report says : four physicians of the city donated their service as inspectors, and reported 426 pupils examined by them who bore evidence of previous successful vaccination; 727 pupils presented lawful certificates of vaccination; 43 presented physicians' certificates stating that after due effort it was found that successful vaccination could not be produced; and two or three pupils whose parents opposed vaccination were withdrawn from school because it was required, The school census of I89o showed a decrease of 387 from that of 1889 [the "boom" had collapsed]; and the total number enrolled was only thirtynine less than the full census report. "The average daily attendance of pupils for the year ending June $30 t h$, I 889 , was i 136 , and the total expenditures the past year, $\$ 32,507.00$, thus making the cost of educating each pupil \$31.37 12 ." The financial report of this year for the first and only time, gave the accounts of the Pasadena City District and the San Pasqual District separately. Geo. F. Kernaghan served as clerk or secretary and made up the reports this year.

From the School reports for 1890-9I, I glean sundry matters to preserve for future reference, or comparison :

\section{THE PASADENA CITY SCHOOL DISTRIC'T.}

The boundaries of this district comprise not only the city of Pasadena in its entirety, but extend on the west to the Linda Vista hills, on the north to and some distance into the mountains, on the east to Allen Averue, and on the south to the boundaries of the city, where they join those of South Pasadena, and thence eastward a little south of San Pasqual street to Allen Avenue. The district contains a population of about 7,000 people. [I 89 I.] 
Nativity of Pupils.-As showing the character of this population, the appended statistics of the nativity of the pupils in attendance upon our schools will be read with interest as well as pleasure: Arizona, 3 ; Arkansas, 2 ; California, I8I ; Colorado, 7 ; Connecticut, 9 ; Delaware, I ; Illinois, I24 ; Indiana, 42 ; Iowa, 208 ; Kansas, 72 ; Kentucky, 2; Louisiana, 5 ; Maine, 15; Maryland, 4; Massachusetts, 43; Michigan, 40; Minnesota, 21 : Missouri, 33; Mississippi, 3 ; Nebraska, 30 ; Nevada, 7 ; New Hampshire, 5 ; New Jersey, 6 ; New York, 49 ; North Carolina, 2 ; North Dakota, 2; Ohio, 74; Pennsylvania, 83; Rhode Island, 3; South Dakota, 6; Tennessee, 1 ; Texas, 2 I ; Vermont, 9 ; Virginia, 5 ; Washington, 4; West Virginia, 5; Wisconsin, 34; Wyoming, I ; Idaho, I; Indian Territory, I; New Mexico, 2; Canada, 39; England, 19; Scotland, 9; Germany 7 ; Italy, I ; Switzerland, 2 ; Australia, I.

High ScHoOI.- - On June 24, 189 I, the electors of the district by an almost unanimous vote, adopted the high-school provision submitted by the last legislature. During the year five different professors in the State University visited the Pasadena schools ; and near the close of the year notice was received that Pasadena had been placed on the accredited list. Hence, from this time forward graduates of the Pasadena High School would be admitted to the State University, or the Stanford University, without preliminary examination. Hon. Delos Arnold donated to the High School a classified collection of 200 Pacific coast marine shells, a starter for a scientific museum. As this was the first year of the High School, I give a list of its teachers :

Will S. Monroe, City Superintendent.........................Science. James D. Graham .......................... Mathematics and Science. Mrs. Theo. Coleman......................... English and History. Ellen F. Thompson ............................. Latin and English. I. I. Eivans................................. German and French. W. P. Hammond....................Book-keeping and Penmanship. Hattie C. Stacey. ........................................ Music. Marie A. Ney ......................................... Drawing.

A special effort was made this year to raise the standard of scholarship among the teachers; and to show what had been reached in this line the following table is given in the year's report :

Number teachers employed, including Superintendent .......... 34 " graduates California State Normal Schools ............. 6

" " " of other State Normal Schools ............. I6

" " $"$ of special Professional Schools ............... 3

" " " of Colleges ................................. 5

" who have taught from I to 5 years .................... 4

" " " " 5 to ro years ................... I3

" " $\quad$ " $\quad$ " 10 to I 5 years .................. I2

" " " $"$ I 5 to $\mathrm{I} 8$ years .................. 5

" holding High School certificates.... ................... 4

" " " Grammar Grade certificates ...................... 23

" " "

" " $\quad$ Special certificates............................ 3 
The following is a summary of current expenses for the year :

Insurance [on $\$ 66,500$ valuation] $\ldots \ldots \ldots \ldots \ldots \ldots \ldots \ldots \ldots . . \$$

Repairs

Labor [including for election board, $\$ 45$, and for washing towels, $\$ 74.70]$......................................

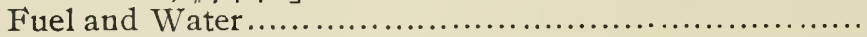

Rent [Opera House for graduating exercises] ..............

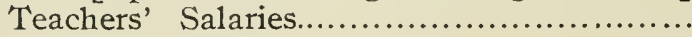

Janitors' Wages..........................................

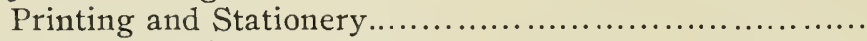

School Supplies, Books, etc............................

J. W. Wood served as secretary this year, and also during I89I-92. The school year of 189I-92 was one of unusually quiet; easy-going smoothness. There were no strifes or contentions to mar the harmony of the work, although the problem of how to reduce expenses without impairing the efficiency of the school service was deeply pondered by the board of trustees and others who took a lively interest in educational matters; and some reduction of salaries was made. The school census this year showed an increase of 339 over the previous year. On April I $5^{\text {th }}$, I892, a special tax of $\$ 10,000$ was voted by the district, and this was expected to supply the deficiency from State and county funds for the ensuing three years. The total of teachers' salaries and general expenses for the year was $\$ 32,783.82$, being $\$ 530.30$ more than the previous year. An item worth mentioning is, that out of twelve High School graduates of I89I, eleven, were already enrolled in higher institutions of learning. At the close of this school year Superintendent Will S. Monroe retired by resignation; the office of city superintendent was abolished, and James D. Graham was employed to take charge as "supervising principal" for the ensuing year.

The year 1892-93 had some points of note, and I quote from the official report: "The year of $1892-93$ marks a new era in the workings of the public schools of this city. The lines along which it was decided to retrench were the offices of superintendent and special instructors in music and drawing, the duties of supervision being transferred to the principal of the High School, and the work of music and drawing being done by the regular teachers."

The schools this year prepared an exhibit of their work for the great Columbian World's Fair at Chicago. The national program for Columbus Day was observed in all the schools, with a detail of old soldiers from John F. Godfrey Post, G. A. R., taking part in the flag-raising and other exercises at each school. And in the observance of Memorial Day this year the children for the first time took part in decorating the soldiers' graves. It is noted in the report that the number of tardinesses had been reduced by nearly 300 , and corporeal punishment had been almost entirely abolished. 
The High School had 123 enrolled (ten more than any previous year) and graduated a class of sixteen-and this, notwithstanding that many former pupils had gone to the Throop Polytechnic Institute. [W. U. Masters made up the secretary's report for this year, Mr. Wood being absent.

\section{HIGH SCHOOL GRADUATES.}

Class OF r 890 -Efffe Bye, Walter Carrothers, Florence Hay, Eudora Kirk, Bertha Landreth, Fred Seares.

Class of r $89 \mathrm{I}-\mathrm{Hal}$ F. Bishop, Annie L. Brush, Winifred C. Caldwell, Rennie W. Doane, Carlton E. Durrell, Roy D. Ely, Katherine Gardner, William H. Linney, Alva D. McCoy, Kate Louise Nash, Leonora Schopbach, Carl C. Thomas.

Class OF I892-Ethel W. Bishop, L. L. Chambers, Ida M. Hampton, M. Mae Henderson, Eunice Hazel Hodgson, J. Paull Fife, Roy M. Gray, Ida M. Mellish, Dora E. Moody, Kate A. Mosher, Mary S. Mosher, Frank G. H. Stevens, Winifred Webb.

CLASS OF I893-George H. Baldwin, Volney H. Craig, John W. Craig, Ruth Daggett, Harold W. Durrell, Harry D. Gaylord, Ralph A. Gould, Joseph E. Grinnell, Ina Goodwin, Maud F. Jones, E. Louise Kernaghan, J. Emmett Louthian, Abbie Louise Marston, Gale McCoy, Mabel E. Prentiss, Anna M. Reid.

Class of r 894-Literary-Eugenia Boynton Henderson, Edith Louise Hill, Grace Longley, Alice Palmer Marston, Marie Markham, Mary Scott Ogden, Mary Moulton Parker, Nettie Underwood, Lillian Eva Whiton, Bessie Horton Yocum, Marcia Jessie York. Scientific-Irving Cowan Allen, Ralph Arnold, Charles Frederick Buchanan, Charles Edward Groesbeck, Archelaus Price, Wacil Randall, John Speer Stevenson, May Wright.

CLASS of I895-Literary-Mary Louise Fish, Edna Gearhart, Myrtie Luella Hamilton, Grace Elizabeth Machin, Mabel Schopbach, John Calvin Kelso, Wallace Sprague Woodworth, Elbert Hubbell Shults, Fred Chaffee Nash, Alexander Craig, Benjamin Edwin Page, Charles Harold Briggs, Joseph Grant Yocum, Edward Burton Dwight, Neal Keely Traylor, Frank M. Wellington. Scientific-Ada Emma Palmateer, Bertha Annette Smith, Laura Edith Higley, Frances Leah Wadey, Lulu Augusta Bixby, Ruby Louise Breed, Sara Anne White, Leon Caryl Brockway, Henry Aaron Doty, Frank B. Coleman, Herbert Forest Brown, William Charles Doane, Donald McGilvray, Archibald McClure Strong, Joseph Marx, Lewis Freeman, Charles Matthew Coleman, Percy Nicholas Gibbings, Benjamin Overfield Lacey.

The following tables of school statistics, expenditures, etc., in successive years are valuable for reference :

\begin{tabular}{|c|c|c|c|c|}
\hline YEAR & RESOURCES & EXPENDITURES & $\begin{array}{l}\text { AVERAGE DAILY } \\
\text { ATTENDANCE }\end{array}$ & $\begin{array}{l}\text { AVERAGE } \cos T \\
\text { PER PUPIL }\end{array}$ \\
\hline I $889-90 . .$. & $\$ 35,599$ O3 & $\$ 32,5 \circ 7$ oo & 1,036 & $\$ 31 \quad 37$ \\
\hline I89o-9ז.......... & 33,041 o9 & 32,24752 & 1,059 & 3045 \\
\hline I $891-92 \ldots \ldots \ldots \ldots$ & $33,745 \quad 59$ & $32,783 \quad 82$ & I, IOS & 2959 \\
\hline $1892-93 \ldots \ldots \ldots \ldots \ldots \ldots$ & $40,527 \quad 21$ & 30,77080 & $\mathrm{I}, 167$ & 2636 \\
\hline I $893-94 \ldots \ldots \ldots \ldots \ldots \ldots \ldots$ & $33,270 \quad 26$ & 34,12948 & 1,352 & $25 \quad 25$ \\
\hline
\end{tabular}




\begin{tabular}{|c|c|c|c|c|c|}
\hline \multirow{2}{*}{ YEAR } & \multirow{2}{*}{$\begin{array}{l}\text { SCHOOL } \\
\text { CENSUS }\end{array}$} & \multirow{2}{*}{ ENROLLMENT } & \multirow{2}{*}{$\begin{array}{c}\text { AVERAGE } \\
\text { DAILY } \\
\text { ATTENDANCE }\end{array}$} & \multicolumn{2}{|c|}{ VISITS. } \\
\hline & & & & TRUSTEES & PATRONS \\
\hline $1880 \ldots . . . . . . . . . . . . . .$. & 133 & $6 I$ & 40 & 0 & 30 \\
\hline ISSI ......................... & I.39 & 85 & 54 & 6 & 60 \\
\hline IS82 $\ldots \ldots \ldots \ldots \ldots \ldots \ldots \ldots$ & 160 & II 7 & 76 & 6 & 52 \\
\hline ISS $3 \ldots \ldots \ldots \ldots \ldots \ldots \ldots \ldots$ & 274 & 165 & 100 & 4 & 50 \\
\hline 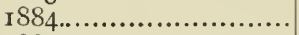 & 363 & 222 & I 55 & 5 & 46 \\
\hline I $885 \ldots \ldots \ldots \ldots \ldots \ldots \ldots \ldots$ & 460 & 278 & 205 & I0 & I6I \\
\hline ISS6........................ & 527 & 394 & 254 & 5 & I $2 \mathrm{I}$ \\
\hline I $887 \ldots \ldots \ldots \ldots \ldots \ldots \ldots \ldots$ & $\mathrm{S}_{44}$ & 703 & 446 & 4 & I $2 S$ \\
\hline I $888 . \ldots \ldots \ldots \ldots \ldots \ldots \ldots \ldots$ & 2033 & I 354 & 849 & 4 & 800 \\
\hline I $889 . . . . \ldots \ldots \ldots \ldots \ldots \ldots . . . . . . . .$. & 1776 & 1687 & I I 33 & 70 & 700 \\
\hline ISgo... ................... & 1388 & I427 & 1036 & IOI & 1840 \\
\hline I891.......................... & I4 I 2 & I 437 & 1059 & II 3 & 978 \\
\hline 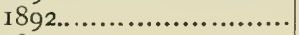 & 1739 & 1469 & I 108 & I I 2 & I I IO \\
\hline I $893 \ldots \ldots \ldots \ldots \ldots \ldots \ldots \ldots \ldots \ldots \ldots$ & I 835 & 1644 & I 167 & I 54 & I 243 \\
\hline $1894 \ldots \ldots \ldots \ldots \ldots \ldots \ldots \ldots \ldots \ldots \ldots$ & 2043 & IS62 & 1352 & I 58 & 648 \\
\hline I $895^{*} \ldots \ldots \ldots \ldots \ldots \ldots \ldots$ & $24 I 3$ & ........ & . & ................ & n............. \\
\hline
\end{tabular}

SCHOOL BUILDINGS.

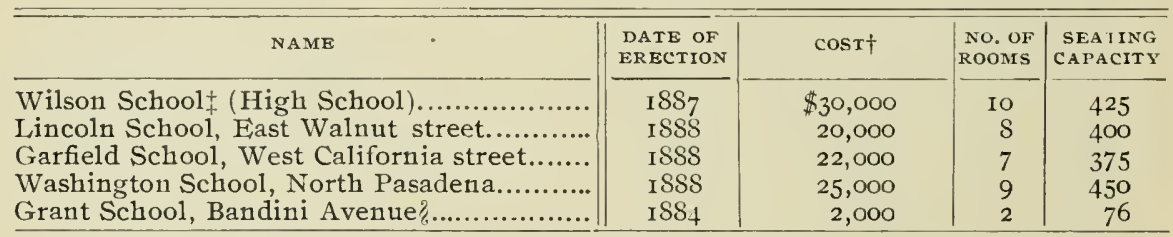

The Grant school was originally built at the corner of Colorado street and Allen Avenue, and afterward moved to its present location on Bandini Avenue. In I884 the first school building was erected at North Pasadena, with two rooms, and seating capacity for seventy-four pupils, at a cost of $\$ \mathrm{r}, 200$ - and was called the "Lincoln School"'; but when the present fine nine-room building superseded it and was named "Washington School," the name "Lincoln" was transferred to the eight-room building on Walnut street which had previously been called the "Wilson Primary School." In I888 a one-room school building costing $\$ 700$, with capacity for twenty-five pupils, was erected at Linda Vista by the Land Company operating there, and named the "Jackson School." For two years it was provided with a teacher by the district board, but in I89 a special tax for it was voted down, and no teacher has been sent there since.

The school census for I894, as compiled by Secretary F. P. Boynton, shows a remarkable increase over the preceding year, as follows:

No. of white children between 5 and $\mathrm{r} 7$, I98I; same last year, I8I 1 . No. of negro children between 5 and 17,62 ; same last year, 24 ; total number of children between 5 and 17,2043 ; same last year, 1835. No. of

*The school census of 1895 showed 3068 native-born children; i17 foreign-born; and 591 children who had not attended any school, either public or private, during the school year.

†'The furnishing is not included in these figures.

f" The fine new flag purchased by the pupils of the Wilson School was hoisted to the flag-staff for the first time on Wednesday, by Miss Mame 'Thompson, granddanghter of "old John Brown, Ossawatamie Brown."-Pasadena Standard, June 1, 1889 . Avenue.

"See article on "Bandini Aventc" tor explanation of how it happens to be called Michigan 
children under 5, 806; same last year, 78I. No. of children between 5 and I 7 who attended public school during the year, I 520 ; same last year, I 368 . No. of children between 5 and I 7 who attended private school, I 6 ; same last year, 95. No. of children between 5 and 17 who have not attended any school, 407 ; same last year, 372. No. of native-born children, 2763 ; same last year, 2500. No. of foreign-born children, 86; same last year, i 6. Total No. of children in district, 2849 ; same last year, 26 I6.

The increased number of census children (a gain of 208 over that of last year) entitles the district to three more teachers.

A report at Christmas time, I894, said :

"There are now I97 enrolled in the High School, forty-seven in the senior class, of whom thirty are young men, and seventeen young ladies, a condition unusual in High Schools. The five buildings now occupied by

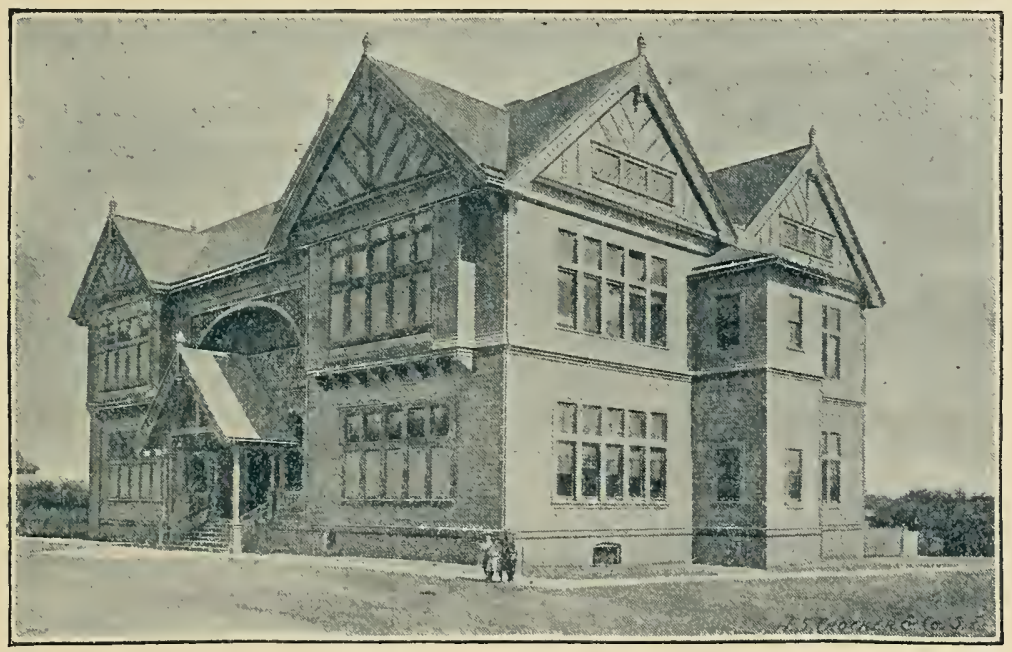

LINCOLN SCHOOL.

Architecture, Old English-Elizabethan type. Cost $\$ 20,000 ; 8$ rooms ; 400 seats.

the Public Schools are fine specimens of architecture and are capable of seating about eighteen hundred pupils ; but with the exception of the Washington, are filled to their highest capacity. The entire enrollment is 1765. '

School Years.

\section{LIST OF SUCCESSIVE HEAD TEACHERS.}

I 874-75. Miss Jennie H. Clapp, now Mrs. Rev. F. J. Culver of Pasadena. I 875-76. Mrs. Rodgers two weeks [fell sick]; Miss Eugenia Rudisill.

I 876-77. Miss Eugenia Rudisill. [Returned east.]

1877-78. Newell Matthews and Miss Florence Royce, in new Central School building. [See pages I70, I7 r, I72.]

1878-79. The same teachers. [Mr. Matthews is now one of the firm of

Matthews \& Bosbyshell, hardware and implement dealers of Los

Angeles.]

I 879-80, G. C. Hall* and Miss Royce.

*Present place not learned. 
I880-81. Mrs. Jeanne C. Carr, principal, with Miss Royce and Mrs. Elizabeth M. Winston as assistants. [Mrs. Carr still resides in Pasadenaretired.]

1881-82. Mrs. Elizabeth M. Winston [same as Mrs. L. C. Winston], principal, and Miss Royce, assistant.

1882-83. Orin N. Raney, principal, with Mrs. Winston and Miss Royce as assistants. [Mr. Raney is now secretary of the Security Title Insurance and Abstract Company of Southern California, at Los Angeles.]

1883-84. Edward T. Pierce, principal, with Mrs. Winston and Miss Royce for assistants. [At the close of the year Miss Royce retired and became Mrs. H. R. Case, now of Westminster. Mrs. Winston also retired, for domestic reasons.]

1884-85. E. 'T. Pierce, principal ; Mrs. E. T. Pierce, assistant.

I885-86. E. T. Pierce, principal; Mrs. E. T. Pierce, assistant.

I886-87. E. T. Pierce, principal; Mrs. E. T. Pierce, assistant.

r887-88. E. T. Pierce, superintendent of schools; Herbert Pinckney, principal of the Wilson Grammar School.

1888-89. Pierce and Pinckney, same. [Prof. Pierce is now (1895) principal of the State Normal School at Los Angeles, and member of State Board of Education. Mr. Pinckney got married and went back East.]

I 889-90. Will S. Monroe, superintendent of schools ; Chas. E. Tebbetts, principal of High School.

I 890-9I. Will S. Monroe, superintendent; James D. Graham, principal of High School.

I89i-92. Monroe and Graham same. [At the close of this year Prof. Monroe resigned and entered for an undergraduate course of study at Stanford University.]

I 992-93. James D. Graham, principal of the High School and supervising principal for the district.

I 893-94. James D. Graham, same.

I 89495 James D. Graham, same.

SUCCESSIVE; PRINCIPALS OF THE, DIFFERENT SCHOOLS.

Wilson Grammar School.-Herbert Pinckney, I887-88-89. Chas. E. Tebbetts, I 889-90. James D. Graham, I 890-91-92-93-94-95.

Wilson High School.-Chas. E. Tebbetts, 1889-90. James D. Graham, I 890-91-92-93-94-95. Mrs. Theodore Coleman, vice-principal, I 893-94-95. (Mrs. Coleman had been vice-principal of the Wilson Grammar School in I 888-89-90.)

Lincoln School.-- [Formerly called Wilson Primary School.] Mrs. Clara A. Burr, I889 90. C. W. Hodgson, I890-9I-92-93 [then went to take a course of nudergraduate study at Stanford University]. G. W. Strominger, I 893-94. Mrs. Frances S. Burt, 1 894-95.

Garfield School.-A. L. Hamilton, principal from is8s till i893. William W. Payne, I893-94. [Mr. Hamilton, in fall of 1893 , took the department of mathematics in Throop Polytechnic Institute.] G. W. Strominger, I $894-95$.

Washington School.-Miss Hannah Ball [now Mrs. F. R. Harris of Pasadena], I 884-85. Miss Carrie Hill, I885-86-87-88. B. V. Garwood, 
I888-89. W. H. Housh, I889-90-91-92. Luther G. Brown, 1892-93$94-95$ * $^{*}$

Grant School.-Miss Elma Ball [now Mrs. H. I. Stuart of Pasadena], I 88485. Miss Pauline Wright, I $885^{-86}-87$. Miss Helen Crittenden, I 887-88. Caspar W. Hodgson, 1888-89-90. L. L. Evans, 1890-91. Charles C. Hill, I 89 I-92. Wm. B. Frackleton, I 892-93-94-95.

Jackson School.-[Linda Vista] Lydia A. Burson, I889-90. Ella G. Wood, I890-9I. [In June, I89I, a proposition for a special tax of $\$ 6000$ to buy the school-house property at Linda Vista and for other purposes, was rejected by a popular vote ; and thereafter no teacher was sent by the school board to that point.]

\section{TABLE OF SCHOOL TRUSTEES BY SUCCESSIVE YEARS.}

1874-75. Col. J. Banbury, Henry G. Bennett, Dr. W. W. Edwards.

I 875-76. P. M. Green, Banbury, Bennet.

I876-77. P. M. Green, Edson Turner, A. O. Porter.

[After the removal of the original school-house from Orange Grove Avenue and California sireet, up to Colorado and Fair Oaks, in November, I 876, Green and Porter resigned, and on June 30, i 877 , L. D. Hollingsworth and I. B. Clapp were elected to fill the vacancy. Meanwhile a movement was in progress to have a new district created south of California street, and I. B. Clapp resigned, S. Washburn being appointed, November I 5, I 877, to fill the vacancy; and the new district was duly authorized by the county board in January, 1878.$]$

I 877-78. Edson Turner, L. D. Hollingsworth, S. Washburn.

I $878-79$. Turner, Hollingsworth, Washburn.

I 879-80. Washburn, Hollingsworth, Col. J. Banbury.

I 880-8I. Washburn, Banbury, B. F. Ball.

I 88 I-82. Washburn, Ball, Banbury.

I882-83. Washburn, A. K. McQuilling, Dr. Lyman Allen.

I883-84. Washburn, McQuilling, Allen.

I 884-85. Washburn, McQuilling, H. W. Magee.

1885-86. Washburn, Magee, A. O. Bristol.

1886-87. Washburn, Magee, Bristol.

I887-88. Bristol, Hon. H. H. Markham, Z. Decker.

I888-89. Decker, R. Williams, C. W. Buchanan.

I889-9o. Buchanan, C. F. Holder, George F. Kernaghan.

[In the spring of $\mathrm{I} 890$ it was discovered that by the creation of the city of Pasadena in I886, carved out from the old San Pasqual school district, a new school district was thereby created, comprising the same territory as the city; but this was not understood at the time, and hence the proper legal steps were not taken to comply with the law until a judicial ruling was had in I8go upon some unsettled points. At that time two of the trustees resided within the city, and the third, C. W. Buchanan, outside. The county superintendent therefore appointed W. S. Wright as the third man within the city district; and R. Williams and M. D. Painter for the outside

\footnotetext{
*Mrs. E. M. Wiuston, of the Washington School, taught in our public school in I8So-8I, and was herself the principal in $1881-82$. In 1884 she retired for a season; but as she held a life certificate she was called in occasionally to fill transient vacancies. In 189I-92-93 she was ready for regular service again, and taught those two years in the Wilson Grammar school. In $1893-94-95$ she was in the Washington School, and was here when the dreadful calamity occurred of her husband perishing in a snowstorm in the mountains. Another teacher in this school in 1893-94-95 was Mary E. Thompson, a granddaughter of the historic "Old John Brown" of Kansas and Harper's Ferry fame.
} 
district. The two boards worked together to keep all the schools going on without any break or jar, the same as before; and in a few months the legal consolidation of the two districts was again effected, under the name of "Pasadena City School District." Then Trustees Wright, Williams, Painter and Holder resigned, leaving one vacancy for the consolidated district; this was filled by the appointment of E. E. Spalding; so Buchanan, Kernaghan and Spalding constituted the full board for the time.]

r89o-9r. C. W. Buchanan, Hon. A. G. Throop, J. W. Wood.

I 89I-92. Buchanan, Wood, W. U. Masters.

I892-93. Buchanan, Masters, F. P. Boynton.

I 893-94. Masters, Boynton, Calvin Hartwell.

1894-95. Hartwell, Boynton, Hon. Delos Arnold.

1895-96. Hartwell, Arnold, E. A. Walker.

During the school year $1894-95$, the school attendance was so large that it was found necessary to divide the primary schools into half-day sections, so that one section could be in school during the forenoon only, and the other section during the afternoon-and even then the rooms were crowded, especially at the Iincoln School. To provide for this difficulty it was decided to erect two more school-houses, one in the northeast and one in the northwest portion of the district. And accordingly on May 27, I 895 , $\$ 40,000$ of school district bonds were voted for this purpose. The vote stood : For the bonds, 302 ; against, 22. For the east school a lot $300 \times 400$ feet, at corner of Lake Avenue and Walnut street, was bought for $\$ 4$, ooo. For the east school a lot $200 \times 220$ feet, at corner of Lincoln Avenue and Peoria street was bought for $\$ 3,850$. It is a historic incident that " bicycle racks " are to be provided in these new school-houses-the first instance on record.

\section{SIERRA MADRE COLIEGE.}

Although this College enterprise failed and at last went out entirely, leaving no sign of its existence, yet it did during the few years of its struggle for life cut quite a figure in Passadena history; and hence it must be reported.

The first public or formal action in regard to it was at a convivial gathering or banquet of about forty persons, held at the Sierra Madre Villa Hotel on January 20, I884, and reported in the Pasadena Chronicle of January 24. There a board of Trustees was appointed, as follows: Rev. J. W. Ellis and Dr. Cochran of Los Angeles; Abbot Kinney of Kinneloa ; C. C. Hastings of Sierra Madre; Gov. Samuel Merrill of Des Moines, Iowa; D. H. Newton of Holyoke, Mass.; Hon. P. M. Green, Judge B. S. Eaton, Rev. Williel Thompson, and H. W. Magee, Esq., of Pasadena.

A call was made for competing offers of land for a building site, and other aid, to determine where the college should be located. Offers came from Los Angeles, from Sierra Madre, from Santa Anita, from citizens of Pasadena, from Painter \& Ball, and from South Pasadena school district. 
Painter \& Ball offered the Monks hill site, comprising fifty acres of land with water, and $\$ 2,425$ in cash. [I at the time advised the acceptance of this offer as the best.] South Pasadena offered her Columbia Hill school grounds, comprising six acres with water, and the public school building already there, and which had cost nearly $\$ 4,000$, upon the college paying to the school district $\$ 1,000$. This offer was accepted, and the College was started there. Its formal opening took place September I7, I884, with an elaborate program of thirty-two numbers, and speeches in nineteen different responses to "toasts" or sentiments proposed. The faculty then consisted of Rev. J. W. Healy, D. D., president, mental and moral philosophy; M. M. Parker, A. M., classics ; Prof. F. D, Bullard, mathematics; Rev. Williel Thomson, engineering; Mrs. Vernam, art department; Mrs. E. A. Nims, music. A local item in the Union of October i I said the College had 25 pupils enrolled and was making good progress.

"The new faculty will be as follows: Rev. W. Thomson, A. M., president and professor of mathematics and civil engineering; Rev. M. M. Parker, A. M., professor of ancient languages and instructor in natural sciences; Mrs. C. T. Thompson, A. M., instructor in English and German languages; W. G. Cochran, M. D., medical supervisor; Mrs. E. A. Nims, teacher of vocal and instrumental music; Mrs. L. G. McKee, teacher of oil painting."

\section{Again, on April 24, I885, the same paper reports :}

"The Presbytery of Los Angeles met in Pasadena on Thursday evening, I6th inst., and was opened with a sermon by Prof. Ward of Sierra Madre College. On Saturday the subject of the Sierra Madre College was taken up. A financial report was made by the president, Rev. Williel Thomson, stating that the College held property valued at about $\$ 18,000$, and that the income of the College during the past year had been about $\$ 400$; that three teachers had been employed, who had faithfully done their work, and that the examination showed the instruction to have been of a high order.

"The number of students in attendance during the past year has been twenty-five, which number was diminished toward the close of the last term from sickness and other causes.

"A new board of eleven trustees was elected, consisting of the following gentlemen: Rev. M. N. Cornelius, Hon. P. M. Green, Geo. A. Swartwout, Abbot Kinney, of Pasadena ; Rev. Mr. Wells, Dr. Cochran, Howard Mills, of Los Angeles; Rev. Alexander Parker, of Orange; O. C. Johnson, Esq., of Riverside ; D. H. Newton, of Boston, Mass. ; Mr. Hughes, of Tustin."

The local newspaper did everything it could to aid the enterprise. But the fact was, this college was mislocated, was premature, was not on a plan in touch with the spirit of the times, and had no money behind it-hence it was born with failure in its bones. After two years of hard struggle, continually running in debt, its property was all heavily encumbered, was sold under mortgage, and eventually bought by C. D. Daggett; and the building which had served successively as public school-house, college hall, Congre- 
gational church, was at last changed and reconstructed into Mr. Daggett's Columbia Hill residence as it now stands.

THE PASADENA ACADEMY.

In I 883-84 Prof. M. M. Parker and wife, assisted by his brother, Prof. C. M. Parker, opened an academic school at his home place on east California street. But when the Sierra Madre college was started he merged his private ente.prise into that. After failure of the college he.reopened his Academy in September, I886, in Williams Hall, occupying the large main hall and two adjunct rooms. The school soon outgrew these close quarters, and early in November it was removed to the old Central School building, then standing on Raymond Avenue where the Vandevort block now stands, and he occupied the entire two stories except one room used for meetings of the city trustees. Thus passed the academic year of 1886-87. After that the offices of city clerk, marshal, surveyor, recorder or police judge, etc., were located in this building, which had been leased by the city for three years. The Academy was next opened in the second-floor rooms of the Grand Opera House, and its school years of I887-88 and 1888-89 were spent here. But a more central location seemed desirable; and on September 9, I889, it opened in the second-floor rooms of our present City Hall building. This Academy won a good name, reached an enrollment of as high as I 50 pupils, and employed nine teachers.

The Pasadena Standard of September 14, 1889, mentions the annual opening of the Academy, and at the same time names other private schools then in the city, as follows :

"Prof. Parker's Academy opened its fourth year last Monday, corner Fair Oaks Avenue and Union street. Miss Sarah Hay's Kindergarten on Herkimer street, opens its third year next Monday. Miss Collamer's select school, on Valley street, opens its fourth year next Monday. St. Margaret's school (Episcopal) for girls, on East Colorado street, opens next Monday for its third year. Prof. S. C. Clark's classical school for boys, on South Los Robles Avenue, opens its first year, October 2. Mrs. Graham's Kindergarten on Euclid Avenue (formerly Miss Curtis') will open next Monday. Mr. Coggswell's mechanical training school for boys, on West Colorado street, is open for the formation of classes at any time."

In I89i Prof. Parker, at Father Throop's earnest desire and request, co-operated with him in founding the Polytechnic Institute, and merged his Academy into that.

THE THROOP POLYTECHNIC INSTITUTE.

Hon. A. G. Throop came from Chicago and settled in Los Angeles in I 880 ; but in I 886 he removed to Pasadena and made his permanent home here. In April, 1888 , he was elected a member of the city council; and on October 5, I889, he was chosen president of the board, or "Mayor."

By successful business enterprises in Chicago he had acquired a considerable fortune. He had always been an ardent advocate of education in its 
highest and best phases, although his own early advantages in this respect had been very meager; and now he purposed to devote his money and the remainder of his life to the founding in Pasadena of an institution of learning, on the most approved plan that educational experts could suggest. After several conferences and consultations with friends upon the subject during the spring and summer of 1891 , a special meeting was held at his house on August 31, at which were present Rev. Dr. E. L. Conger; Prof. John Dickinson of the University of Southern California, Los Angeles; Prof. C. H. Keyes, superintendent of schools, Riverside; Prof. Will S. Monroe, superintendent of schools, Pasadena; Prof. James D. Graham, principal of High School, Pasadena. The result of this meeting was a decision to proceed at once to open the college; and in a few days Father Throop had leased for five years the great four-story Wooster block, corner of Fair Oaks Avenue and Kansas street, and commenced fitting it up for school uses; and a circular was issued announcing that the new college would open and begin its scholastic year on November 2. I quote :

"On September 23d, articles of incorporation were filed with the secretary of state, with the following named persons as a board of incorporation : Gov. H. H. Markham, H. W. Magee, Esq., J. C. Michener, M. D., W. U. Masters, J. S. Hodge, M. D., Major Geo. H. Bonebrake, Hon. Delos Arnold, Hon. T. P. Lukens, E. F. Hurlbut, Prof. 'T. S. C. Lowe, Hon. P. M. Green, F. C. Howes, Milton D. Painter, Hon. A. G. Throop, Ex-Gov. Lionel A. Sheldon.

"The first meeting of the board of trustees was held October $2 \mathrm{~d}$, at which time officers were elected as follows: Hon. A. G. Throop, president ; L. W. Andrews, secretary; Hon. P. M. Green. treasurer.

"On October 8th the by-laws of the corporation were by the trustees discussed and adopted, and an executive committee elected, consisting of Hon. A. G. Throop, Rev. E. L. Conger, W. E. Arthur, Mrs. L. T. W. Conger and E. E. Spalding.

"“ Throop University' was the name that had been adopted, and it was announced to embrace the following departments: College of Letters and Science: (a) Classical Course, (b) Philosophical Course, (c) Scientific Course, (d) English Course. Preparatory Department, Law School, Musical Institute, Art Studio, Elocution, Stenography and Typewriting, Physical Culture-Gymnasium. Prof. M. M. Parker was elected vice president of the University. A list of ten instructors was announced for the first year."

The Daily Star of November I I, said:

"Prof. M. M. Parker is in receipt of a letter from Hon. Delos Arnold offering to Throop University a valuable collection of 150 varieties of quaternary and pliocene fossils from this [Los Angeles] county. The gift has been accepted by Prof. Parker on behalf of the University, with thanks. A duplicate of this collection was recently sent by Mr. Arnold to the curator of the national museum at Washington, by whom it is considered of especial value."

\section{OPENING DAY.}

The University classes commenced their regular sessions on Monday, November 2, I87I; and on the previous Saturday the friends of the enter- 
prise took occasion to express their sentiments in a public reception to Father Throop. From the Star's report of this event I make a few extracts of pertinent and historic interest :

The commodious room set apart for the chapel and assembly hall of Throop University was filled Saturday afternoon by a concourse of ladies and gentlemen who fairly represented the culture and intelligence of the community. Prof. M. M. Parker, vice-president of the University, filled the chair. He stated that the objects of the gathering were to afford the citizens of the city an opportunity of congratulating Father Throop upon the success of his plans thus far, and to express their appreciation of his efforts in behalf of the cause of education.

A. R. Metcalfe, Esq., said : "The founding of such an institution in Passadena is cause for general congratulation among the people of the community. * * Every home and every citizen will be the better and the happier and the richer for the victories to be won in Throop University; and in behalf of the people of Pasadena, Mr. Metcalfe said, he thanked Father Throop for his noble work-for what he had done and what he intended to do. To found such an institution was the act of one of the noblest of God's creatures, one whose love for the people dominates all his acts. In their hearts Father Throop has a very warm spot which could be hardly filled by any other (applause)."

Mrs. Jeanne C. Carr said : "If such an institution had been opened 50 years ago, all girls would have been left out in planning for the reception of students, and she desired to thank Father Throop for making no discrimination in the matter of sex in opening the doors of the University. * * * Fifty years ago only eleven of the great rancheros who owned the five southern counties of California, could read or sign their names. The nearest boarding school was at Honolulu in the Sandwich Islands. We congratulate ourselves upon the birth of this University; not only for the obvious advantages it will bring to our city, but because each new institution is another step in advance in the recognition it gives to the value of practical education."

Rev. C. E. Harris, pastor of the Baptist church, was introduced as a representative of the local ministers. Mr. Harris made one of his happy responses, saying that he wished to adopt as his sentiments everything that had so far been said in commendation of Father Throop, and to add that Mrs. Throop is entitled to share in the praise for the work done in founding this college. Its establishment marks a significant crisis in the history of the city.

Prof. Parker called upon Father Throop to speak, and the venerable founder of the college came upon the platform amidst loud and long-continued applause. He said that in the course of his long life he had had many happy days, and that this was one of the happiest. After a life of economy and industry he had devoted such means as he had to the endowment of the college. He had himself felt the need of such education as it will afford, which perhaps fitted him better to appreciate its needs, and had stimulated his ambition to do something in the cause of higher learning. In all his plans he had the good-will and co-operation of Mrs. Throop, of his dlaughter, Mrs. Vaughan, of his niece (Miss Waite), and other relatives, many of whom were liappily present with him on this happy occasion. Father 'Throop said it was his ambition to make the college what the times 
demand, which was a school of the best. Aside from all politics and sectarianism he desired to make its instruction broad and high and pure, under which its pupils may learn what is best and most useful.

In 1892 a body of land was secured at the corner of Fair Oaks Avenue and Chestnut street, where two street-car lines passed, and the building now known as "West Hall" was erected. It stands 140 feet frontage on Fair Oaks by 80 feet on Chestnut, two stories high. Its ultimate design was for the departments of Mechanics and Physics chiefly, as the institution should progress in its evolutional development; but in October, I892, all the school work was transferred from Wooster Hall to this new building, which had been equipped with gas engines and machinery for wood work, iron work and electric work ; also for cooking school, sewing school, chemical laboratory, biological laboratory, and type-writing.

\section{CHANGE OF TITLE.}

Before the opening of the college year of 1892 it had been decided to drop the ambitious and incorrect title of "University"; to make manual and industrial education the characteristic feature of the school ; and to call it "Throop Polytechnic Institute." And the motto "learn to do by doing" was adopted, to express tersely the plan and aim of its curriculum.

By I893 an additional block of ground had been secured, extending from West Hall eastward to Raymond Avenue; and here was erected the main building - $\mathrm{I} 50$ feet frontage on Chestnut street by 68 on Raymond three stories high, besides a full basement - and cost nearly $\$ 40,000$.

During the summer of $1894 \$ 12,000$ worth of new machinery, steam power, and other mechanical apparatus was added to the West Hall equipment; and all the literary and fine arts class-work was established in East Hall.

In I893, when East Hall had been completed, the permanent character of the institution and its great value to the general interests of Pasadena became more apparent. The matter was talked up in the Board of Trade meetings and elsewhere, and finally, December $2 \mathrm{I}$, was settled upon to be observed as

\section{FATHER THROOP DAY.}

The necessary committees were appointed, and arrangements made for a testimonial meeting and public ovation during the day, in the Tabernacle, and a banquet at Hotel Green in the evening. The forenoon, from 9 to 12 o'clock, was devoted to visiting and inspecting the Institute buildings, the machinery being all in motion and students at work. Then from 12:15 till I:45 lunch was served by the cooking school in West Hall, limited to visitors from outside the city. And at 2:I 5 the program of exercises at the Tabernacle commenced. Here W. E. Arthur, Esq., city attorney, served as president of the day, and Hon. W. A. Cheney of Los Angeles delivered the testimonial oration, which was a most brilliant effort. 
Mr. Arthur, on behalf of the citizens of Pasadena, presented to the trustees of the Throop Institute, a very fine life-size oil portrait of Father Throop, elegantly framed, which was unveiled to the audience by two young lady students while he spoke. And it was accepted in a fitting speech on behalf of the trustees by President Keyes, who spoke for Mr. Throop, president of the board.

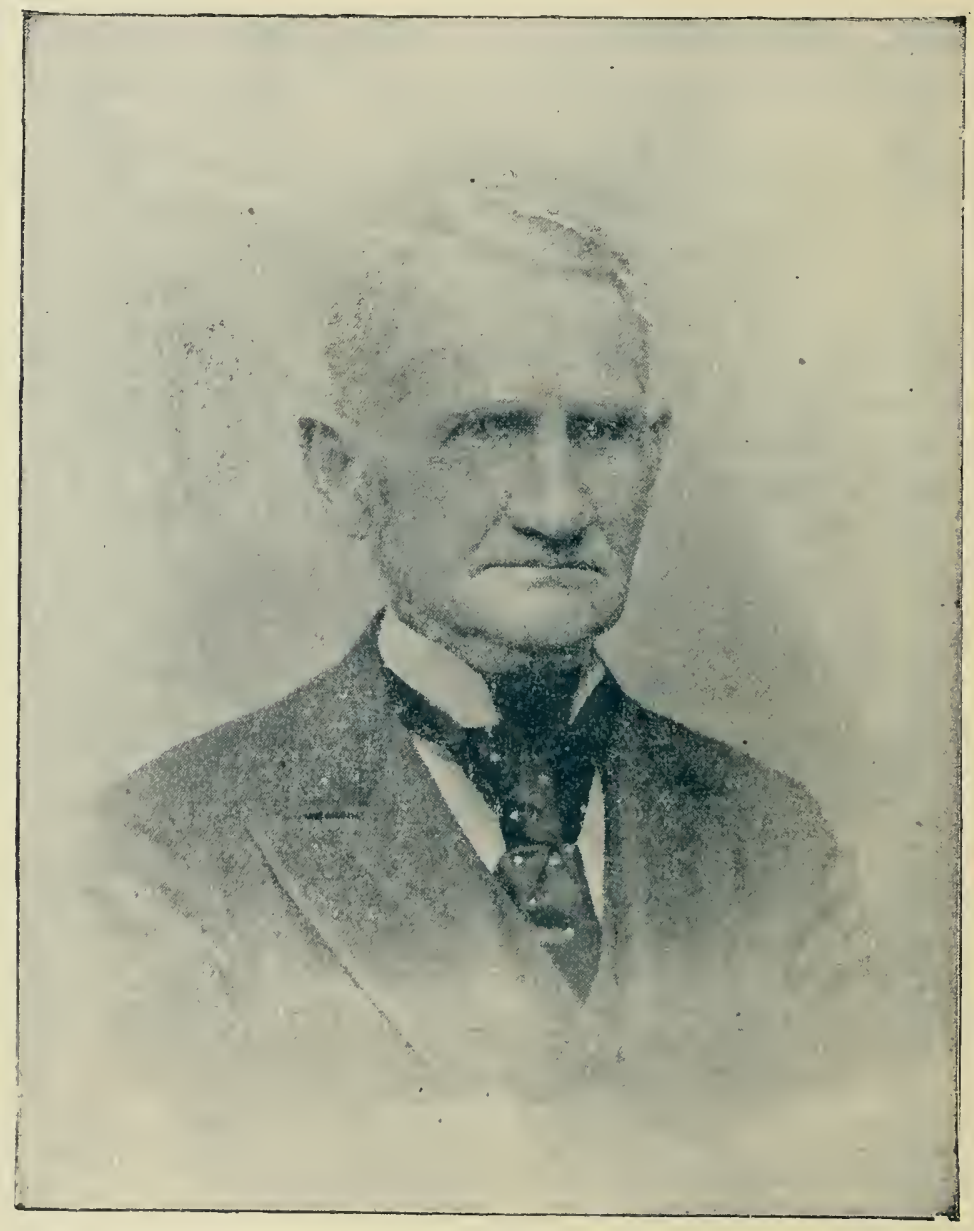

HON. A. G. THROOP - "FATHER THROOP."

Following this, Father Throop himself, in a speech of deep earnestness and pathos, made formal presentation of the Throop Polytechnic Institute, with all its lands, buildings, equipments and endowments, as a free gift to the City of Pasadena and her people. He bequeathed it to them as a sacred trust, to be fostered and sustained, and made to subserve the highest and noblest uses of a thorough-going, practical, moral, self-helpful, unsectarian 
education, for boys and girls alike, and at the lowest possible cost. His feelings had been deeply hurt by his having heard several times of testy oppusition to his school from a few persons of extra stiff devotion to so-called "Orthodox" theology, because he was a prominent member of the Universalist church; and upon this point he said :

"I want to disabuse anyone of the idea that this is a sectarian school. This is a school for the public, and $\mathrm{I}$ am not here today to forfeit my honor and my character to build up any sectarian institution. I have property here unincumbered worth $\$ 60,000$ which will be used as an endowment fund for this school, provided the directors keep it what it now is, non-partisan and non-sectarian. I am here to offer you this property for the benefit of Pasadena, Los Angeles county, Southern California, humanity. I want you to leave me my character, worth more to me than anything. I did not do this for public applause, but to return the means God has given me to the one to whom it belongs. I offer this as a Christmas donation, and if it is worth anything to you, take it, and help me make it what it ought to be."

His speech was received with enthusiastic and long-continued applause.

To this munificent and noble offer Mayor O. F. Weed responded on behalf of the city authorities and the people, accepting the gift, and promising that the high aims of the venerable and beloved founder of the institution should be carried out. He said :

"The people of Pasadena have much to be thankful for - for their climate and soil, for the culture and refinement of the community, for our magnificent hotels and other buildings, for Prof. Lowe's unique mountain railroad, for our schools and churches. But Father Throop's gift of the Polytechnic Institute surpasses all others, and it will bear his name along the line of coming generations yet unborn. Pasadena accepts the gift, and will ever hold the giver in grateful veneration. Other men have achieved fame, but Father Throop has achieved a glory that is immortal."

An appeal was made for scholarships to aid the Institute in providing free tuition for worthy pupils who need a little help. In response a number of pledges were announced, some of which were never paid. The following is a complete list of bona fide scholarship pledges $(\$ \mathrm{I}, \infty 00)$ up to January. I, I895:

B. F. Ball $\$ 1,000$ W. C. Stewart.................. I,000 F. J. Woodbury (land).......... 1,000 Prof. T. S. C. Lowe................ 2,000 Mrs. Prof. Lowe ................. 2,000

Mary E. McGee..............\$I,O0O Mrs. Thos. F. Croft..........., I, 000 Citizens Subscription pledge... I,000 Adelia M. Callender............ I, E. F. Hurlbut ................ r,ooo

Some other persons also, have given lesser amounts to the scholarship fund.

THE BANQUET.

In the evening the largest assemblage ever seated at a banquet in Pasadena gathered at Hotel Green, 260 plates being served. Hon. P. M. Green presided, sitting with Father Throop at his right hand and Gov. Markham at his left. By Father Throop's special request, the evil custom of serving 
wines and liquors on banquet occasions was entirely dispensed with here. The sentiments or "toasts" and responses were as follows:

"California." Response by Gov. H. H. Markham.

"Give the American Boy a Chance." Response by Dr. Walter Lindley, superintendent of the State School at Whittier.

"Woman's Influence." Response by Rev. Florence E. Kollock.

"The Ladies." Response by J. G. Rossiter, Esq.

"The Tramp." Response by Prest. C. H. Keyes.

"Physical Culture." Response by Dr. Norman Bridge.

" Our Duty to Posterity." Response by Hon. A. G. Throop.

Here I quote a passage from the Daily Star's report :

"The announcement of Father Throop as the next speaker was received with great applause. He spoke to the text, "Our Duty to Posterity." There is one great lack in our system of education, he thought, and he hoped Throop Polytechnic Institute would insist upon supplying it, and that is, moral training. We must teach our children to be honest. He would also teach our young people to be patriotic, and to this end he hoped the flags on the buildings of the Institute would never be taken down (applause). Moral honesty and patriotism were the two great lessons he wanted to insist upon tonight."

Following this, Mrs. Elizabeth Grinnell read an original poem of $3^{2}$ stanzas, entitled "An Ode to Father Throop," from which I quote a few pertinent lines :

Men unveil statues of the world's great heroes; Cold statues, soulless marble, unresponsive stone;

Carved images within whose empty chambers Sits no brave spirit on its royal throne.

Not so today; with heads uncovered, waiting Before the One Great Master's work of art,

Behold we, not a silent piece of marble, While with a tender touch we draw the veil apart.

Chiseled in warm flesh, see the figure standing; His pedestal God's truth, the love of human kind

Cementing each to each in perfect union; Lo, here the living form, and in the form the mind.

I saw a dude pass by you yester morning Wheu you were raking builders' trash away ;

He glanced with silly scorn upon your rubbish And asked, "What do such workmen get per day?"

Ask, ye who will, the hoary-headed ages If love e'er bargained for its price in gold;

Or stipulated for its wage in silver, As if its ministrations could be sold.

The man who grasps a tool with honest motive, And stoops hinself to help the laborer rise,

Doubles the gift his charity would tenderHe gives his wealth, his toil, his enterprise.

Oh, Father Throop, your form we love and honor. You teach that "Industry is Fortune's maid."

Long may you live to show the generations That Purpose builds, where Prudence is afraid. 
This concluded the exercises of one of Pasadena's most notable and far-reachino historic days, which had set her noblest institution before the EODARS ARE - low of wholesome and heartsome interest that had erto. It was the first thoroughly-equipped Polyining College established west of the Mississippi 1ery, apparatus, and facilities for highest grade insrfect and complete of their kind that money could ature the latest and best improvements had been ison it really excels any of the older schools on the Eastern cities.

minated Yule Trees, vay steadily from the first.

Himalaya Cedars

ANTED IN 1885 IN ALTADENA

80 Feet in Height, 200 in Number

ADENA Dec. 31. - The deodai's inta Rosa avenue, which are viewed nightly by thousands ople, are Himalayan cedars, $s$ of the cedrus deodora 1 of the cedar family, accord. a bulletin issued by AltaChamber of Commerce. name "deodar" means "tree 1." They border both sides highway from Footh ard to Woodbury road, apately a mile in length. Hidthem and bordering the are many beautiful home landscaped with green exof lawn, terraces, trees, and flowers.

leodars, nearly 200 in numre planted fifty years ago,

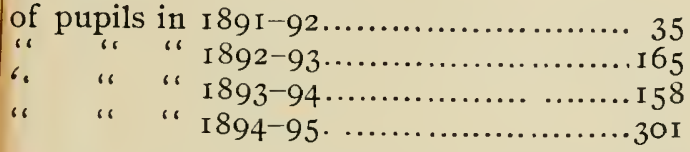

[891, to April I9, I893, there had been paid out and current expenses of the school, by Father ie current expenses for I893-94 were \$I9,591.25.

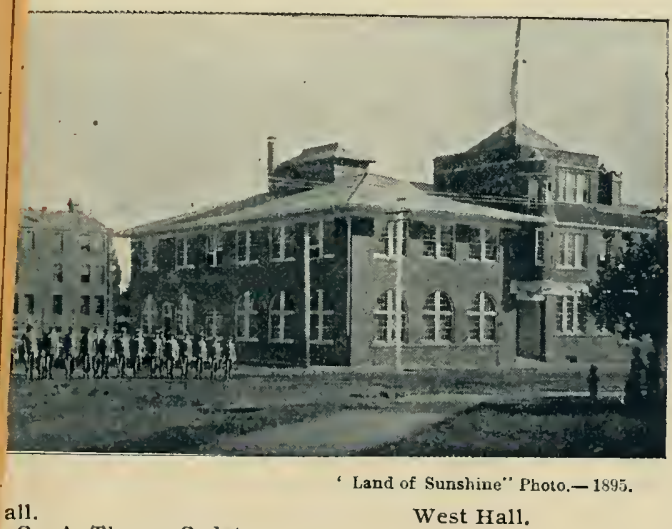

Co. A, Throop Cadets.

THROOP POLYTECHNIC INSTITUTE. says :

A report printed in the New Year Edition of the Pasadena Star, I895,

"It has accomodations for over 400 pupils. The growth for I $894-95$ has been rapid and gratifying. Seven members were added to the faculty, making a total of twenty-five teachers engaged in the work of the Institute. Prof. M. M. Parker was chosen Dean of the faculty. During the summer \$1 2,000 worth of new machinery and apparatus has been purchased and installed. This includes additions to chemical, physical, electrical and biological equipment, a new steam plant, complete pattern shop outfit, a complete machine shop outfit, and a Sloyd school equipment. The total value of the equipment at present amounts to about $\$ 100,000$. The officers 
wines and liquors on banquet occasions was entirely dispensed with here. The sentiments or "toasts" and responses were as follows :

"California." Response by Gov. H. H. Mark" -eurpezit jo 7red e

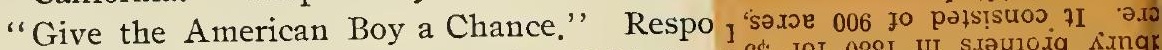

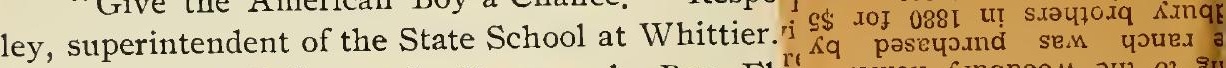

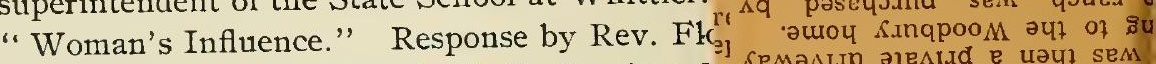

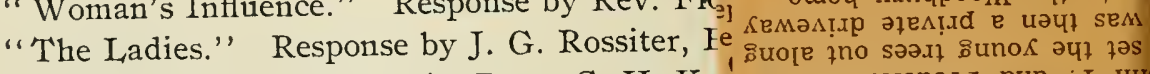

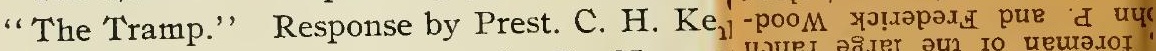

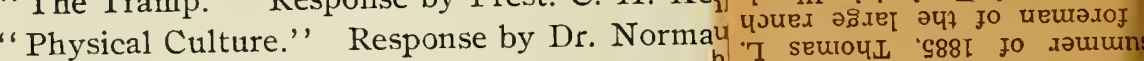

"Physical Culture." Response by Dr. Norma "T seuroy I 'C88I jo dəuums

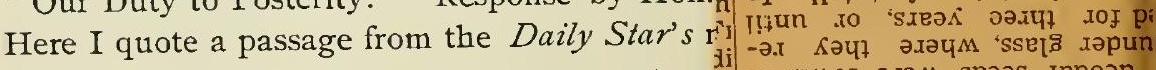

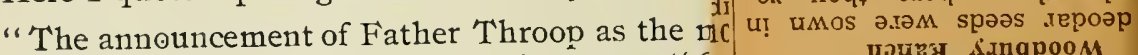
with great applause. He spoke to the text, "( $(\mathrm{m}$ There is one great lack in our system of educat le hoped Throop Polytechnic Institute would insist up is, moral training. We must teach our children $t \leqslant$ also teach our young people to be patriotic, and to flags on the buildings of the Institute would ne plause). Moral honesty and patriotism were th wanted to insist upon tonight."

Following this, Mrs. Elizabeth Grinnell read stanzas, entitled "An Ode to Father Throop," fro I pertinent lines :

Men unveil statues of the world's great 1 a Cold statues, soulless marble, unrespon $k$

Carved images within whose empty chan Sits no brave spirit on its royal throne.

Not so today; with heads uncovered, wai 1 Before the One Great Master's work of

Behold we, not a silent piece of marble, While with a tender touch we draw the

Chiseled in warm flesh, see the figure star His pedestal God's truth, the love of ht

Cementing each to each in perfect union; Lo, here the living form, and in the for

I saw a dude pass by you yester morning When you were raking builders' trash a

He glanced with silly scorn upon your rub чวนชя isnqpooM

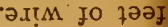

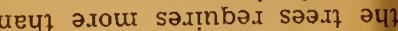

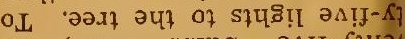

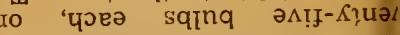

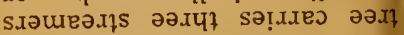

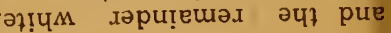

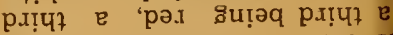

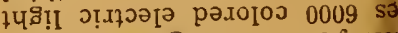

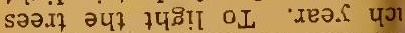

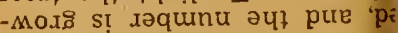

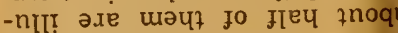

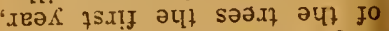

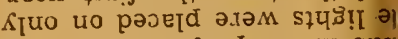

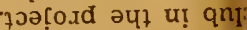
-esed әчt प1!

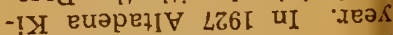

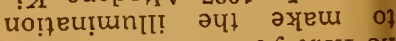

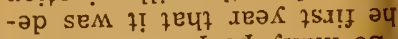

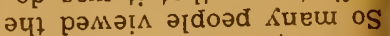

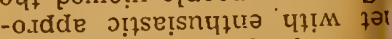

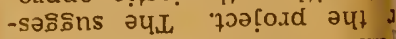

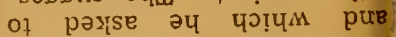
stuen!y euəpesed jo 20 SeM әч นәчм әшा? әчҰ 78

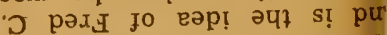

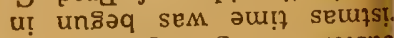

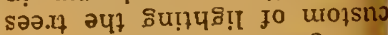

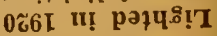
And asked, "What do such workmen get per day?"

Ask, ye who will, the hoary-headed ages If love e'er bargained for its price in gold;

Or stipulated for its wage in silver, As if its ministrations could be sold.

The man who grasps a tool with honest motive, And stoops himself to help the laborer rise,

Doubles the gift his charity would tenderHe gives his wealth, lis toil, his enterprise.

Oh, Father Throop, your form we love and honor. You teach that "Industry is Fortune's maid."

Long may you live to show the generations That Purpose builds, where Prudence is afraid. 
This concluded the exercises of one of Pasadena's most notable and far-reaching historic days, which had set her noblest institution before the public in a fresh, warm glow of wholesome and heartsome interest that had not been manifested hitherto. It was the first thoroughly-equipped Polytechnic or Manual Training College established west of the Mississippi river, and all its machinery, apparatus, and facilities for highest grade instruction are the most perfect and complete of their kind that money could purchase. In every feature the latest and best improvements had been sought; and for this reason it really excels any of the older schools on the same plan in the largest Eastern cities.

The school won its way steadily from the first.

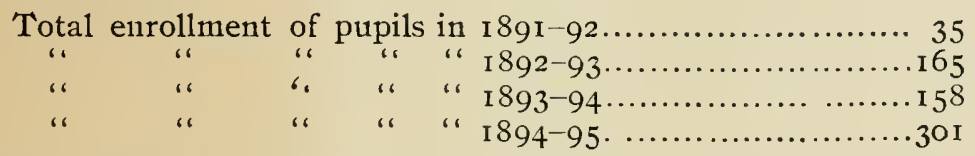

From September I, I891, to April 19, I893, there had been paid out for buildings, grounds, and current expenses of the school, by Father Throop, $\$ 57,628.70$. The current expenses for I 893-94 were $\$ 19,591.25$.

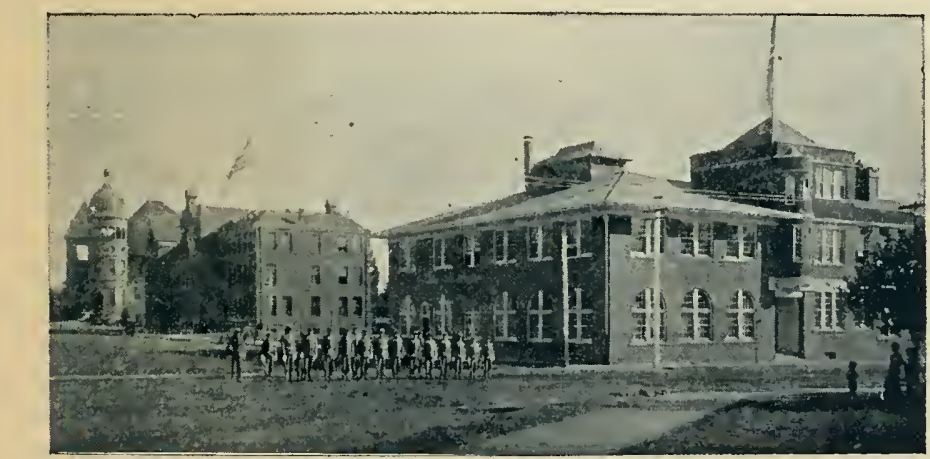

"Land of Sunshine" Photo.-1895.

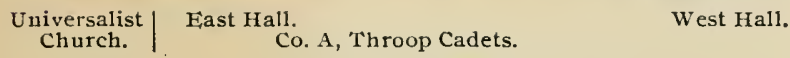

THROOP POLYTECHNIC INSTITUTE.

A report printed in the New Year Edition of the Pasadena Star, I895, says :

"It has accomodations for over 400 pupils. The growth for I $894-95$ has been rapid and gratifying. Seven members were added to the faculty. making a total of twenty-five teachers engaged in the work of the Institute. Prof. M. M. Parker was chosen Dean of the faculty. During the summer $\$ 12,000$ worth of new machinery and apparatus has been purchased and installed. This includes additions to chemical, physical, electrical and biological equipment, a new steam plant, complete pattern shop outfit, a complete machine shop outfit, and a Sloyd school equipment. The total value of the equipment at present amounts to about $\$ 100,000$. The officers 
of the board of Trustees for I894-95, are: Hon. P. M. Green, President ; E. L. Conger, D. D., Vice-President ; Frank J. Polley, Secretary ; C. B. Scoville, Teasurer.

"The members of the Board of Trustees are: Hon. P. M. Green, E. E. Spalding, Mrs. Ellen I. Stanton, Mrs. Louise T. W. Conger, Hon. Enoch Knight, Hon. T. P. Iukens, W. E. Arthur, Esq., John Wadsworth, C. B. Scoville, Esq., President C. H. Keyes, Norman Bridge, M. D., Hon. W. L. Hardison, E. L. Conger, D. D., C. D. Daggett."

Executive Board for I895-96: Hon. P. M. Green, chairman; C. D. Daggett, John Wadsworth, W. E. Arthur, Rev. Dr. Conger.

\section{LIFE OF FATHER T'HROOP.}

As a fitting addition to this historical sketch of the Throop Polytechnic Institute, I give here a brief biography of its founder, who is more truly loved by the people of Pasadena than any other man who has ever lived here. Prof. Lowe is honored and admired; "Father Throop" is loved and revered with an affectionate tenderness born in us from his own great love toward his fellow-men.

Hon. Amos G. Throop was born in De Ruyter, Madison county, New York, July 22, I8Ir. The most of his boyhood was spent in Courtland and Chenango counties, New York. In May, 1832 , he left Chenango county for Michigan, the then far west, settling in St. Clair county. In I 838 he returned to his native State, and at Preston was united in marriage with Miss Eliza V. Waite. He and his wife returned to his home in Michigan, where they remained until I 843 , in which year they removed to Chicago, where they resided until 1880 . He was one of the organizers of the Chicago Board of Trade, and a member of it for many years. In r $849 \mathrm{Mr}$. Throop was elected an alderman of the city of Chicago, serving four years. In 1854 and 1855 he was appointed assessor for West Chicago. In i 855 he was elected city treasurer for a term of two years, during which time he handled over $\$ 5,000,000$ of the city funds. Mr. Throop served five years as a member of the Board of Supervisors of Cook county, and for two years was a member of the state legislature of Illinois. In 1876 he was again elected alderman, and served the city in that capacity for four years.

He came to California in I880, locating in Los Angeles, where he remained until i 886, when he removed to Pasadena. In I888 Mr. and Mrs. Throop celebrated their golden wedding. From I 888 to 1892 he served Pasadena as a member of her city council, being also Mayor of the city for the last two years of his term.

\section{PASSED AWAY.}

On Thursday, March 22, I 894, he worked until about noon setting out some flowering plants at the Polytechnic grounds. Then he went home, feeling sick from a chronic ulceration of the stomach with which he had long been a sufferer; and at 8:10 in the evening he passed away as quietly and peacefully as a child falls asleep. His wife and daughter [Mrs. J. C. Vaughan] were in Chicago, and his brother, John Throop, at his own home below Los Angeles, and they were summoned by telegraph. The next day 
all flags in the city were displayed at half mast. Awaiting the arrival of absent members of his family, the funeral did not take place until March 28th, when, as the Daily Star said, occurred "the most impressive demonstration of popular sorrow that ever occurred in Pasadena." Mrs. Throop was sick in Chicago and not able to come, but the daughter came. Places of business were generally closed during the funeral hour, and nearly all were draped with emblems of mourning. The public services occurred at the Universalist church; and as an historic indication of the esteem in which he was held by all classes and sects, I note that the following clergymen sat in the pulpit area as participants in the commemorative exercises:

Rev. Dr. J. B. Stewart, Rev. N. H. G. Fife and Rev. L. P. Crawford, Presbyterians.

Rev. Clark Crawford and Rev. W. G. Cowan, Methodists.

Rev. H. 'T. Staats, Congregationalist.

Rev. C. E. Harris, Baptist.

Rev. T. D. Garvin, Christian or Disciples.

Rev. C. E. Tebbetts, Friends.

Rev. Dr. E. I. Conger, Rev. Dr. Deere, and Rev. Florence E. Kollock, Universalists.

The pall-bearers were: Prof. T. S. C. Lowe, W. U. Masters, Thomas F. Croft, Hon. P. M. Green, T. P. Lukens, and Elisha Millard.

Marshals and assistant marshals of the funeral procession were Col. L. P. Hansen, city marshal John 'T. Buchanan, Capt. A. C. Drake of G. A. R., Capt. N. S. Bangham of Sons of Veterans, and Geo Mahler. Escorts were Co. B. of the National Guards, Co. A of Throop Polytechnic Cadets, and the Pasadena Band. The church was crowded to its uttermost capacity, besides many comers who could not gain entrance ; and there were few who did not shed tears. It was as if every one felt it a personal bereavementthe loss of a beloved friend. The fine memorial window in the east wall of the church to his only son, George Throop, who died as a soldier in the Union army, was appropriately draped with national flags, and bore witness now to the devoted patriotism of both father and son in the days when the nation's life was in peril.* Mr. Higinbotham, late president of the World's Fair managers, who had known and loved both Father Throop and his soldier son from thirty-four years back, was present, and spoke most feelingly his tribute of praise. Gov. H. H. Markham also spoke; and others. And James G. Clark, the venerable poet, music composer and singer, known to fame for nearly forty years past, sang his own well-known song, "The Evergreen Mountains of Life." Rev. Dr. Conger related his last interview

* An elegant memorial window occupies the east wall of the Universalist church, to the memory of George Throop, son of our venerable city councilman, Hon. A. G. Throop. The young man belonged to the Chicago Mercantile Battery, and took part in the battles of Black River Bridge, Champion's Hill, Port Gibson, Arkansas Post, Mausfield, siege of Jackson, Siege of Vicksburg. "-Pasadena Standard, March 12 , 1889. He was mortally wounded in the disastrous Red River expedition in April, I864, and his body never found. 
with Father Throop, when with almost his last breath he said: "My journey is almost ended; and I am ready, if it is my Heavenly Father's will. But what will become of my school?" I answered, "You have done your whole duty nobly ; and Pasadena will take care of your school."

He had already expended for the Institute a total sum of $\$ 97,874$. His will gives $\$ 20,000$ more, or whatever remains of the estate after the death of his wife.

CLASSICAL, SCHOOL, FOR BOYS.

Established in October, I889. Stephen Cutter Clark, A. B., principal ; Mrs. Grace Miller Clark, A. B. and A. M., Greek and Latin; Mary Louisa French, A. B., primary; Jean Trebáol, French; Wm. P. Hammond, penmanship; Wm. Wallis, drillmaster. Object : To fit and prepare boys for admission to any college or university in the country. The enterprise succeeded from the first. In the spring of I89 I Mr. Clark erected a building purposely for his school, at No. 59 South Euclid Avenue, with six recitation rooms. The number of pupils averaged about 30 , the highest enrollment being 37 .

CLASSICAL SCHOOL, FOR GIRLS.

Established in 1890 , by Anna B. Orton, principal, and instructor in Mathematics and in Greek and Latin; May A. Morrison, French and History; Isa Cranston Pirret, English branches ; Mabel L. Merriman, Science ; Fraulein A. Werner, German; Wm. P. Hammond, penmanship; Mrs. L. E. Garden-Macleod, drawing and painting, this department being a branch of the Los Angeles School of Art and Design. The music department has Herr Thilo Becker and Susan R. Orton, as instructors on the piano; and Josef and Johanna Rubo, teachers of voice culture and chorus singing. The object is to give girls a thorough school culture, and to prepare those who wish it for entrance to any college or university where women are admitted. In the summer of 1892 Miss Orton erected a fine building in old Spanish style of architecture, designed and planned purposely for her school, with five recitation rooms - No. I24 South Euclid Avenue. She had 16 pupils the first year, and about 60 in all departments the past year.

WILIIAMS BUSINESS COLLEGE.

Commenced September I 7, I 894, in Strong's Block on Colorado street: T. J. Williams, principal; Miss Bertha Buckingham, teacher of English branches; Chas. A. Miles, business agent. Full courses in all branches of book-keeping, penmanship, pen drawing, shorthand, typewriting, etc. Furniture and apparatus, about $\$ 800$. Publish a paper called The New Education.

PASADENA'S STATE NORMAI, GRADUATES.

Prof. E. T. Pierce, now principal of the State Normal School at Los Angeles, has kindly furnished me the following list of all the young people from Pasadena who have graduated at that institution: 
Crass of r 884 - Elma Ball, Hannah P. Ball.

Class of I 886 - Henry A. Fisk.

ClasS OF I 887 - Mary M. Baker.

Crass OF 1889-Agnes Elliott (now a teacher in the Normal-I895).

Crass OF 1890 - Ida Robinson, Ella G. Wood.

Crass OF I891 - Imelda Brooks, Jessie A. Fisher, Frances H. Gearhart, May Gearhart, Caroline E. Harris, Charles C. Hill, Edith M. Kellogg, Sarah L. Prentiss.

ClASS OF I892-Lizzie E. Batchelder, Mary E. Johnston, Eitta V. Neibel, Mary E. Thompson [grand-daughter of the historic "Old John Brown"'].

Class Of 1893-Aura M. Beach, Grace E. Bosley, Agnes E. Daniels, Esther C. Daniels, Anna M. Dilworth, Agnes Fushia, Grace Johnston, Herbert C. Mosher, James W. Mosher, Marion Van Slyck.

Total, 29-4 gentlemen and 25 ladies.

TABLE OF ENROLLMENT IN THE UNIVERSITY OF CALIFORNIA OF STUDENTS REGISTERED FROM PASADENA.

\begin{tabular}{|c|c|c|c|c|}
\hline NAME & $\begin{array}{l}\text { DATE OF } \\
\text { ENROLL- } \\
\text { MENT }\end{array}$ & $\begin{array}{l}\text { DEGREE } \\
\text { OBTAINED }\end{array}$ & $\begin{array}{l}\text { COURSE } \\
\text { PURSUED }\end{array}$ & REMARKS \\
\hline 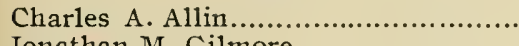 & 1887 & Ph. B., ' 94 & & \\
\hline Jonathan M. Gilmo & I890 & B. L., ' 94 & ....... & \\
\hline Mary H. Gilmore.. & I889 & B. L., ' 94 & & \\
\hline y W. Rhodes.. & 1890 & B. S., ' 94 & & \\
\hline s L. Turner... & ISSS & A. B., ' 92 & & \\
\hline O. Dow & 1890 & & $\mathrm{Cl}$. & In residence. \\
\hline et $\mathrm{H}$. Godfrey & I89 I & B. L., '95 & L. P.S. & \\
\hline $\mathrm{Ra}$ & 1893 & & Chem. & \\
\hline William H. Linney..... & $189 \mathrm{I}$ & B. S., '95 & Min. & \\
\hline Alva D. S. I & I89 I & & Chem. & " \\
\hline Fred H. Seares... & I89I & B. S., '95 & C. E. & \\
\hline & I88́6 & …................. & Lit. & Withdrew, I887. \\
\hline Clifford W. B & $188_{5}$ & .................. & $\mathrm{Cl}$. & \\
\hline George F. Duncan................. & I8S9 & (.................. & L. P. S. & \\
\hline
\end{tabular}

Attest: James SutTon, Recorder of the Faculties.

PASADENIANS IN STANFORD UNIVERSITY-I 894 .

The following students from Pasadena were on the rolls at Leland Stanford, Jr., University, Palo Alto, California, in 1894, and the list was kindly furnished me by Prof. Monroe:

Will S. Monroe, formerly city superintendent of schools.

Caspar W. Hodgson, formerly principal Lincoln school.

Charles C. Hill, formerly principal Grant school.

Agnes Stowell, formerly teacher in Washington school.

Ella G. Wood, formerly teacher in Lincoln school.

Ellen F. Thompson, formerly teacher in High school.

Hattie Mason Willard, * formerly teacher in Pasadena Academy [graduate of Chicago Law School.]

Clara Winifred Caldwell, * formerly student in Pasadena High school.

Kate L. Nash, * formerly student in Pasadena High school.

Lenora Schopbach, formerly student in Pasadena High school.

*Graduated in June, I8y5. 
George H. Baldwin, formerly student in Pasadena High school. Ethel W. Bishop, formerly student in Pasadena High school. Carleton E. Durrell, * formerly student in Pasadena High school. LeRoy D. Ely, formerly student in Pasadena High school. Chas. A. Fife, formerly student in Pasadena High school. J. Paull Fife, formerly student in Pasadena High school. Lyman Woodworth, formerly student in Pasadena High school. Carl C. Thomas, formerly student in Pasadena High school. Winifred Webb, formerly student in Pasadena High school. Rennie W. Doane, formerly student in Pasadena High school. Will A Strong, formerly student in Pasadena High school. Roland H. Manahan, * formerly student in Pasadena High school. Frances M. Rand, formerly student in Pasadena High school. Erma Rand, formerly student in Pasadena High school. Harriet Nichols, formerly student in Pasadena High school. Mrs. May Caldwell Ray, formerly resident of Pasadena.

Errnest B. Hoag, B. S., special course.

Total 26, out of a total of 44 from Los Angeles county. PASADENA STUDENTS AT POMONA COLLEGE.

Claremont, Cal., May 2 I, 1894.

DR. H. A. REID, Pasadena, Cal.: Dear Sir:-In the absence of president Baldwin, your communication asking for names of those who have attended our institution, has been handed me for reply. None have graduated from the College course, but the following have been connected with the school from Pasadena :

Edwin F. Hahn, [graduated from preparatory school in I894.]

Lucy 'Traylor, special student, ' 94.

Emma Parker, freshman, '94.

Abba L. Marston, freshman, '94.

Charles C. Knight, junior preparatory, '94.

Alfred Erskine, middle preparatory, '94.

Very truly yours, E. C. NorTon.

I wrote the University of Southern California for a similar report, but received no answer.

\section{CHAPTER X.}

Literary: The Public Library.-The Library Building.-The Library Citrus Fair.The Library Syndicate.-The Library's purchase by the City.-Academy of Science and Scientific Collections.-Pasadena's Newspapers.- $\mathrm{I}_{3} 8 \mathrm{~S}_{3}$ to $\mathrm{r} 895$. - Pasadena's Literary People.-Pasadena Architecture.

\section{THE PUBLIC LIBRARY.}

In I882, while Pasadena was still merely a fruit colony, Abbot Kinney suggested the starting of a public free library. Some thought the colony settlers too much scattered and too poor to make or use sucl a library; but the more cultivated and progressive people grew more in favor of the under- 
taking as they kept on talking about it; and the lugubrious "lions in the way " proved to be empty air bubbles whenever punched with a pointed argument or a living purpose. I find special credit accorded to $\mathrm{S}$. Washburn for his public-spiritedness and attention in working up subscriptions for the enterprise; and to H. N. Rust, Dr. O. H. Conger, Dr. Lyman Allen, T. P. Lukens, and F. F. Hurlbut for active assistance in the preliminary work necessary to complete the organization. Mr. Kinney had planned it to be a popular movement in which all could take part; there were to be Io, 000 shares at $\$ 5$ each; and on this basis it was incorporated December 26, I882, under the name of "Pasadena Library and Village Improvement Society." A circular was at once issued, setting forth its objects, and that $\$ \mathrm{r}, \mathrm{OOO}$ of the stock had already been subscribed and paid in; that $\$ 700$ had been pledged by the A. O. U. W. and I. O. G. T. fraternal orders; and soliciting further contributions of money, books, periodicals, etc. This first document ever issued by the Association bears no date, but is signed by the Board of Directors: Abbot Kinney, president; Jeanne C. Carr, corresponding secretary ; S. Washburn, A. R. Hanna, W. H. Wakeley, H. N. Rust, E. F. Hurlbut, Lyman Allen. Up to February I, I885, there had been 348 shares of the stock subscribed and paid, which with funds from other sources made a total of $\$ 2,374.04$ received; while the expenditures had been $\$ 3,063.70$. In reporting the sources of the Library funds a list is printed of I 49 individual contributors, among whom Abbot Kinney is credited with $\$ 300, \mathrm{H}$. D. Bacon $\$ 250, \mathrm{E}$ F. Hurlbut $\$ 60$; J. F. Crank and H. H. Markham $\$ 50$ each; T. P. Lukens, James Craig and James Smith \$25 each; H. H. Vischer, H. Ridgway, W. W. McGee, E. S. Frost, \$20 each; Mrs. Gov. Stoneman, \$I 5 ; and others in \$Io and \$5 sums. The Art Loan Society is credited with $\$ 272.46$; Entertainment at Hall, $\$ 92.05$; Cash from Concert $\$ 5^{8}$; Col. Howard's lecture $\$ 30 ;$ H. N. Rust's lecture $\$ 2 \mathrm{I} .50$; Horticultural Society $\$$ I 9 ; and so on. These will indicate some of the methods used to raise money, outside of stock share subscriptions. Public concerts were given on the evening of Memorial Day, I884, and on November I, I884, under the management of Mrs. S. E. Merritt, the librarian, * which netted \$I I8, and the Trustees assigned this to her to provide needful furnishings for the Library parlor and reading room. A book social was held at Library Hall in January, I 884 , each guest bringing some sort of a book suitable for the Library. And Mr. Kinney planned an Art Loan Exhibition, in which H. N. Rust's large and rare collection of stone implements and Indian relics was a prominent feature; this Loan Exhibition proved the most successful of anything, and brought $\$ 272.46$ into the Library fund. Other persons who are specially credited with good

*Mrs. Merritt was librarian from the first; and on November 7, 1884 , she was elected secretary, vice $W$. W. Doyle, resigned, and held the office until 1889 , wben L. C. Winston was elected (after one Otto Froelich had served a few months). The Decoration Day concert gotten 'up by Mrs. Merritt in Williams Hall this year was the first public observance of the day ever made in Pasadea. It cleared $\$ 50$ for the Library. 
service in the various ways for raising funds were: Mrs. Jeanne C. Carr, Mrs. Dr. O. H. Conger, Mrs. Belle M. Jewett, Mrs. L. C. Winston, Mrs. Rosenbaum, Miss Anna Picher, Miss Alice Freeman.

THE IIBRARY BUII,DING.

B. D. Wilson had donated the central five-acre school lot to the colony for school purposes only. From these grounds the school trustees leased a lot $100 x_{306}$ feet in size to the Library Association for a term of twenty years; but in order to validate this lease it was necessary to get the Wilson deed changed-and this change was granted by Mrs. J. De Barth Shorb and the two younger daughters of Mr. Wilson, his surviving heirs, for which favor the Association was very grateful. Then during $1883^{-84}$ a substantial frame building $22 \times 40$ and two stories high was erected on their lot, next east of where the Masonic Temple block now stands and close to the Santa Fe railroad line. The building cost about $\$ 2,300$. Of this amount the Independent Order of Good Templars and the Ancient Order of United Workmen furnished $\$ 700$, and owned the upper story, which they fitted up for their Lodge meetings. The lower story was the Library part, and was opened to the public by Mrs. Merritt on February 26, I884, with 329 volumes in place, besides magazines and newspapers on the reading-room tables. The rooms were to be open daily except Sunday, from Io to I 2 , from 2 to 5 , and from 7 to 9 . From the opening day until August $\mathrm{I}$ there had been $\mathrm{I}, 835$ drawings of volumes, entirely free. But it was found necessary to provide some source of income for necessary current expenses, and after August I, I884, a fee of twenty-five cents per month was charged for loan of books, although the reading room remained free to all; and under this rule, up to February I, 1885 , there had been 2,036 drawings of books, and $\$ 124.03$ received as Library fees.

THE LIBRARY CITRUS FAIR.

The next notable incident in the Library's history was the great Citrus Fair held in the Roller Skating Rink (a large frame building which then stood on the northwest corner of Fair Oaks Avenue and Dayton street), on March 3, 4, 5 and 6, r 885. The special committee to work up and manage this undertaking, the most extensive of anything yet attempted, was $T$. P. Lukens, Dr. O. H. Conger and H. N. Rust. To advertise this Fair, and advertise Pasadena at the same time, Mr. Rust and others got out a pamphlet of 96 pages [2,000 copies of it], receiving enough advertisements from business firms in Pasadena and Los Angeles to pay the cost of printing it. Seventeen pages of this first "boom " pamphlet were devoted to a catalogue of the Library, the first ever printed. The Fair proved a great success and turned $\$ 53 \mathrm{r}$ into the Library treasury. [For some additional particulars, see article entitled "Second Great Citrus Fair," in chapter I6].

In the spring of I 886 , when the "boom" tide was flushing its phe- 
nomenal rise, the School Trustees subdivided their central five acres into city lots and sold them at auction. [For particulars of this event see chapter 9]. The Library lot had I 7 years of its leasehold yet to run,* and hence the society was allowed to bid it in for $\$ 170-$ and within a year thereafter they sold it for $\$ 10,000$, not including the building, it being removed to a small lot on Dayton street for which they paid $\$ 1,496$ cash. And this year the first classified catalogue of the Library was issued.

From the annual report of the Library trustees, made in December of this year, I quote here a few points :

"Taking charge of its affairs in January 1886 , we found the Library out of debt but with only $\$ 23.30$ in the treasury, and no assured income from any source. A series of entertainments was at once inaugurated, with the following results :

In January [I886] a parlor theatrical given by Dr. W. F.

Channing and family yielded net to the library.......... \$ 65 oo

In February, Mrs. S. E. Merritt's concert at Williams Hall i 60 oo

In March, the net receipts from the floral and citrus fair in

Williams' Hall were................................... $477 \quad 05$

Total ........................................\$702 05

The funds thus obtained, together with the monthly dues from subscribers, have paid the monthly expenses ever since, besides enabling us to add by purchase over 300 volumes to our collection of books. We have now on our shelves about I,700 volumes, and their use is steadily increasing with their number.

About six months ago, by the aid of both of our enterprising local newspapers, we asked for offers of lots for future use of the library. Four excellent offers were made to us - all without price. They were as follows :

r. From Messrs. Painter \& Thomas, a lot on the corner of Fair Oaks Avenue and the new extension of the same. We deemed this too far from the center of the town, [junction of Fair Oaks and Lincoln Avenue].

2. From Dr. E. S. Carr, a lot on the east side of Pasadena Avenue north of Colorado street. This also we feared would be liable to the same objection.

3. From E. C. Webster, of the free privilege of building above the one-story walls he proposed erecting on two lots [50xioo feet], on the south side of Colorado street, opposite the Exchange Block [Carlton hotel].

4. Offer made by Charles Legge, who after frequent consultations with our Committee in charge of this matter, has executed in favor of our Society a heavy bond for the conveyance to it, on or before January I, I888, of that centrally located and spacious lot fronting roo feet on the east side of the new. Raymond Avenue by I 50 feet on the south line of Walnut street; provided, that meantime our Society shall have erected thereon, and paid for, without incurring any debt, a brick or stone building, to cost not less than $\$ 25,000$; and that the property shall not be alienated, or incumbered, or used for other than library purposes during the life of the grantor.

* When the railroad was built it took a strip is feet wide by 306 feet long off from this lot and never paid a cent for it. The whole right-of-way through the city was donated, the people were so anxious to get their first railroad. 
At the annual meeting of the Library Association, June 13, 1888 , there were I6 IO shares represented, out of a total of ig9o shares of stock that had been issued. The officers then elected were C. T. Hopkins, president; Abbot Kinney, vice-president; Mrs. S. E. Merritt, secretary and librarian; L. C. Winston, assistant secretary ; Otto Froelich, treasurer; H. N. Rust, Dr. W. F. Channing, Charles M. Parker, and Chas. Legge, additional directors. Enoch Knight, attorney. President Hopkins in his annual report said: "We had made all arrangements for the external completion of the building during the past year at a total cost of $\$ 17,604$, leaving the interior finish and painting to be provided for hereafter. * * * But the contractor for the brick and stone work failed after completing half the walls." This failure caused much embarrassment and delay, for this contract was to have been completed by October $3 \mathrm{I}, \mathrm{I} 887$, and now they had to enforce continuance of the work by the bondsmen for the contractor, the Tehachipi Building Stone Co. of Los Angeles; but the delays and troubles with other contracts caused by this delinquent one proved disastrous.

A later report, in 1888 , says the lot was valued at $\$ 16,000$; and that in default of the conditions being fulfilled by the Library society, the property should revert to the grantor or his representatives. And after reciting these conditions of the grant as made and accepted in 1886 , this 1888 report further says :

"Plans were then obtained and contracts let for the construction of a beautiful stone edifice in the Romanesque style.* The internal finishing was not contracted for, the entire available resources of the Society being exhausted in paying for the walls and roof, which as the building now stands, have cost $\$ 20,000$. This cost has been defrayed out of the proceeds of the two lots owned successively by the Society, and by individual subscriptions. The hard times following the reaction from our late "boom" made it utterly impossible to obtain further contributions from the residents of Pasadena, and Mr. Legge has kindly extended the time for another year, ending December $3 \mathrm{I}, \mathrm{I} 889$. About $\$ 5,000$ is required to finish the building -in default whereof it will become the property of Mr. Legge, should he see fit to assert his rights, and the Society will then be stripped of all its property except the books upon its shelves."

The Library managers, by counting on "boom" pledges that had been given for their building fund, represented that $\$ 6,000$ would finish the building and pay up all outstanding obligations, and secure the whole property, worth $\$ 36,000$, as a permanent Public Library belonging to the whole community. And upon this assurance and belief a few public spirited citizens came to the rescue by raising the money on their joint note, which I here give as a notable historic document:

*The green stoue and the buff stone in this building are from quarries only half a mile apart in the Tehachipi inountains; while the marble pillars are from the quarry at Colton. 
$\$ 6,000$.

Pasadena, Cal., Oct. $31, \mathrm{r} 888$.

Two years after date, without grace, for value received, we, or either of us promise to pay to the order of "The Pasadena Public Library and Village Improvement Society,' at the First National Bank of Pasadena, the sum of Six Thousand Dollars-with interest at the rate of ten (Io) per cent. per annum. Interest payable semi-annually.
W. Aug. Ray,
J. Banbury.
R. Williams,
James Smith,
Wm. T. Clapp,
M. Rosenbaum,
Joseph Wallace,
J. M. Radebaugh,
B. 'Talmadge,
Thos. F. Croft,
S. Washburn,
W. T. Vore,
J. B. Young,
O. S. Picher,
J. B. Corson
C. E. Langford,
H. H. Markham,
C. H. Rhodes,
T. P. Lukens,
C. M. Skillen.

This syndicate appointed Col. W. A. Ray, who was then President of the San Gabriel Valley Bank, as its Trustee, with J. B. Corson, J. B. Young and Thos. F. Croft, as an Advisory Committee; and the next day, November I, the Library Society deeded their property on Dayton street in trust to the makers of the note. Its managers then went on with their building work and other matters until the $\$ 6,000$ was all used up - and now, instead of having the building completed and all clear of incumbrance, they were still about $\$ 3,000$ behind yet, and debts still accumulating, because so many of the boom-time pledges to their building fund utterly failed to be paid, besides increased cost of building and other matters.

To aid the struggling Society in raising funds, Miss Anna Picher and a few others worked up an Art Loan Exhibition, to be held for ten days in the unfinished new Library building. This was the most ambitious and elaborate Art Loan show that had yet been attempted on the Pacific coast; and having been in some sort repeated yearly ever since, it became an historic event which has won fame to Pasadena in literary and art circles both East and West, through illustrated periodicals and descriptive pens, and therefore calls for some account here. The Exhibition commenced February 9, 1889, * with the following daily order of events as announced :

"Senor Arturo Bandini will daily conduct a Spanish conversazione upon suggested subjects of interest to strangers."

I. OPENING DAX.-W. U. Masters, master of ceremonies. Formal opening of the Exhibition, by Hon. J. DeBarth Shorb.

2. FORESTRY DAY.- Under the patronage of Mrs. Eliza A. Otis of the Los Angeles Times. Mrs. Jessie Benton Fremont, special guest of the Association on this day; and an address by Hon. Abbot Kinney, State Forestry Commissioner.

3. Childiren's DAy.

4. Russian Day. - With exhibits from Alaska by T. P. Lukens, Capt.

* On Jan. 8, I889, occured the sixth annual election of the Library Society, and ont of a total of 1763 shares, 1303 were voted. The trustees than elected were H. N. Rust, L. C. Wiuston, Dr. W. F. Channing, S. Washburn, Prof. C. F. Holder, J. W. Vandevort, B. M. Wotkyns. And the officers chosen by this board were Rust, President; Channing, Vice-President; Otto Froelich, Secretary and Treasurer; Mrs. Merritt. Librarian. So these were the people put forward to wrestle with the "busted boom " of the 11nfinished new Library building. 
Chittenden and Mrs. Belle M. Jewett, and Russian tea served by Mrs. Jewett in genuine Russian costume.

5. Mexican Day. - With reception to Don Antonio F. Coronel of Los Angeles, and exhibit of his rare collection of Mexican relics.*

6. Spanish Day.-With reception to Senator Del Valle, and an exhibit of relics from his hacienda of Camulos, the reputed home of "Ramona."

7. Orientai, Day.

8. California Day.-Mrs. Margaret Wilson, widow of Hon. B. D. Wilson, former owner of the Rancho San Pasqual, will pour tea; and Mrs. J. De Barth Shorb, his daughter, loans a chair carved from wood of the old San Gabriel Mission.

9. ChINESE DAY, or "Feast of Lilies."-The Chinese candle-maker will give a receipted bill in his own language.

Io. Carnival, Day, or "Feast of Lanterns." - Pageant conducted by C. M. Stetson, the portrait painter, and Mr. Benchley of Los Angeles.

There were many other special exhibits, and persons engaged; but the above includes all that were of such distinctive historic quality as to call for record here. The ten days' proceedings showed a vast resource of ingenuity, enterprise, skill, working energy and steadfastness on the part of the lady managers and their assistants; yet the incidental expenses of so large and varied and picturesque an undertaking ate up the proceeds and left nothing for the Library fund. Therefore, on the last day, February I8, I889, C. T. Hopkins, who had been president of the Library Association when this new building was undertaken, and had himself given liberally toward it, $\dagger$ made a strong appeal for aid in a public address, preceded by a talk from Prof. Pickering of Harvard University. After setting forth briefly the previous history, present condition and prospective outlook for the Library interest, Mr. Hopkins said :

"Pasadena has put $\$ 36,000$ into this beatutiful building, as its highest expression of reverence for literature and art. Times are very hard with us, and we can do no more. For want of $\$ 5,000$ we stand in jeopardy of losing the whole. Can there not now be found among you one liberal soul who can and will advance that $\$ 5,000$, and so save to the institution the $\$ 36$, ooo now at stake? If not one such, cannot two be found who will contribute $\$ 2,500$ each, or five of $\$ 1,000$ each, or ten of $\$ 500$ each ?"

The "liberal souls" called for by President Hopkins failed to show up ; and court judgments, mechanic's lien attachments, delinquent taxes, professional fees, etc., continued to accumulate against the new building until it was finally sold at sheriff's sale, and Mr. Legge had to buy it in to save himself. The whole property was now lawfully his own; nevertheless, he was still willing to donate the land for Public Library purposes, in accord* This Don Antow io was the man who made the unsuccessful effort to carry to the city of Mrexico a
flag captured from the American troops in their disastrous defeat at the battle of Dominguez ranch, San Pedro, Oct. 8, 1846 . He was the special friend and helper of Mrs. H. H. Jackson in gathering material for her famous story of "Ramona."

†Mr. Hopkins gave $\$ 1,000$ in money, and 300 books. 
ance with his original agreement; and with this understanding Mr. J. B. Corson set about to see if the city would not buy it, and support the Library as a public institution. He consulted several lawyers about the matter, and they said, under the very limited powers of a "city of the Sixth class," as Pasadena was, there was no law or authority by which the city trustees could appropriate funds for such a purpose. But W. E. Arthur took issue with the older attorneys on this, and gave a written opinion that there was law and authority for it. Frank J. Polley was then the city attorney, and he concurred with Mr. Arthur's opinion. Upon this, Hon. A. G. Throop, "Father Throop," who was then a member of the city board, said, "It is a good thing, a right thing for the city to secure the Library property, and make it a free public institution." Some other members, under adverse advice of other lawyers, were afraid it was not good law - and the times were too hard, anyway - the city expenses were already burdensome - the city's management of the library would become a political job - and various other "lions in the way" loomed up through the fog. But "Father Throop " championed the cause both in public and private until he had won every member of the city board to his view. Thereupon they submitted to public vote a proposition to issue $\$ 8,5$ oo of city bonds to purchase the Library property, finish the building, etc.; and this was carried by a large majority on January I 4, I 890.

Meanwhile, Col. Ray, as trustee for the syndicate, was buying up the outstanding small debts of the old society; and on January 23, r89o, his attorney, W. E. Arthur, filed in court these assigned claims amounting in the aggregate to $\$ 979.55$. On March 26 , I890, J. B. Corson was made trustee of the syndicate in place of Col. Ray, who was removing back east ; in fact, Mr. Corson had done most of the work, anyway, toward getting things into shape to save the Library from being broken up, scattered, and wiped out entirely by bankruptcy.* April 4, r89o, the Library Society, by W. F. Channing as acting president, and L. C. Winston as secretary, made to Mr. Corson as trustee of the syndicate a quitclaim deed of all the Library Society's property on Dayton street-consideration, $\$ 1$. Also a friendly suit was entered in the Superior court, with Arthur as attorney for the Syndicate trustee, and M. C. Hester attorney for the Library Society ; and on August 3, I89o, the latter allowed the case to go by default, so that the title of the Library, lot, books, fixtures, etc., on Dayton street was by decree of court vested in J. B. Corson as trustee. All this was to enable him to convey the books, etc., to the city, and to sell the lot for benefit of the makers of that $\$ 6,000$ note. They paid Mr. Legge the costs which he had necessarily incurred in redeeming the new building at sheriff's sale, and he engaged to convey it to the city as soon as the building should

*March 16,1888 , the Library property was sold to the state for delinquent taxes amounting to $\$ 46.32$ But it was redeemed by the Society on October 26 of the same year at a cost of $\$ 65.68$. 
be completed without incumbrance, in accordance with his original offer to the now defunct Library Society.

On December I I, I889, a special committee consisting of city trustees A. G. Throop, and W. W. Mills, and city attorney F. J. Polley, reported to the council that they had invoiced the books, fixtures, etc., of the Library and valued them at $\$ 3,042$. Then on April I9, I890, the city council purchased this property from the syndicate trustee, J. B. Corson, for $\$ 3,000$, payable in city bonds. The post of librarian now became a city office; and on April 2r, Mrs. S. E. Merritt was duly appointed by city authority to the same place she had filled ever since the library was started in I883, and which she holds yet, I 895 .

The syndicate had paid out, besides the original $\$ 6,000$, about $\$ 1,100$ to meet outstanding liens, judgments, and other legal claims against the Library property, and about $\$ \mathrm{I}, 000$ of interest on their note-making a total of $\$ 8,100$. And in return they received $\$ 3,000$ of bonds from the city, and finally $\$ 950$ for the old Library lot on Dayton street*-a total of $\$ 3,95^{\circ}$; so that these twenty citizens had thus contributed $\$ 4,150$ outright, in their public spirited work to save and firmly establish the free Public Library. $\dagger$ Charles Legge also generously co-operated with them and is entitled to equal credit. The city clerk in February, I894, reported the Library property valued thus: lot and building, $\$ 25,000 ;$ books, maps, documents, etc., $\$ 6,500$; furniture, $\$ 300$. Total, $\$ 3$ I, 800 .

On April 29, I890, the first board of City Library Trustees was appointed, consisting of J. W. Vandevort, C. T. Hopkins, Mrs. Jeanne C. Carr, W. U. Masters, Geo. F. Kernaghan. The new Library building was completed by the city, and fitted, furnished, and books moved into it, so that on Admission day, September 9, r 89o, its doors were first officially opened to the people of the city, with speeches by Abbot Kinney, T. P. Lukens, "Father Throop," and others.

The only historic episode in Library history during I 891 , was on October 23, when the eastern members of the National Librarians Congress at San Francisco visited Pasadena on their return trip. They had a special train of five Pullman cars. The Daily Star of October 23, gave a full list of their names, places of residence, and official positions. The Board of Trade and City Library officers gave them a ride through the city, a floral reception in the Library building, and a bauquet at Hotel Green.

The city clerk's annual report for the year ending February 28, I894, gives some statistiç which will serve to show how the Library is managed and its expenses met by the city. The library officers for I 894 were: S.

*C. E. Langford bought their interest in the lot aud building for $\$ 950$ only a few weeks before his death. The two secret Orders of A. O. U. W. and I. O. G. T. owned the second story of the building for Lodge rooms.

†March 20, 1895 , T. F. Croft, T. P. Lukens and J. B. Corsou met as a committee to make a final closing up of the affairs of the library syndicate, and fond a balance of $\$ 2.25$ remaining for each one of the original twenty signers of the $\$ 6,000$ uote which saved the library in i 888 . 
Washburn, president of board; Geo. A. Gibbs, secretary; C. M. Parker, O. S. Picher, J. W. Vandevort, trustees. Mrs. S. E. Merritt, librarian, Miss Laura B. Packard, assistant librarian. The following table I take bodily from the city clerk's report above referred to:

LIBRARY DEPARTMENT.

Salary of Librarian, $\$ 50.00$ per month . ...

$\$ 60000$

300 oo

I 80 oo

17569

10300

$\mathrm{r}, 20867$

I8 33

I59 10

8260

$403 \mathrm{I}$

24 I5

220

Broom

Notary fees

Repairs on building, painting, etc

The total amount of Library bonds issued in I890, was $\$ 8,500$, at 7 per cent. interest. And at the date of the above report there were $\$ 6,800$ of these bonds still outstanding.

In August, I894, the librarian made her annual report to the board of trustees, and from it I glean a few points of historic interest for preservation. She says :

"The support of the library is derived from a tax levy on all taxable property within the city limits, the assessment being 5 cents on each $\$ 100$, two-fifths of which goes to the library sinking fund and three-fifths to the maintenance of the library. The apportionment to the library department for I $893-94$ was $\$ 2,736.92 . "$

The total number of books then in the library was 7,044. The total number of card-memberships for drawing out books was $2,78 \mathrm{I}$. The library had been open to the public on 360 days during the year, and 43,982 books had been drawn out by card, while 8,273 had been drawn for use in the library reading rooms. A charge of 50 cents per month or \$I.25 per quarter, in advance, is made for membership cards to persons residing outside the city limits. During the year.90 books had been rebound, i 2 discarded, and 207 repaired in the library workroom. Eighty-two periodicals were regularly received; and the total outlay for supplying the literature tables for the year was $\$$ I 54.40. The fees from non-resident borrowers had amounted to $\$ 43.75$; and fines for keeping books out over time were $\$$ I 79.65 .

\section{ACADEMY OF SCIENCES AND SCIENTIFIC COLLECTIONS.}

President C. T. Hopkins of the Pasadena Library Association delivered a public address February I8, 1889, on the early history and pressing needs of the Library enterprise. And in this address he said:

"We have in private hands four large collections-in Mineralogy, Geology, Conchology and Archæology - ready to be placed on exhibition in 
our museum as soon as it is finished. We have an Academy of Sciences ready to arrange and utilize them."

The Academy of Sciences referred to was organized in Jantuary, I886, at the residence of Hon. Delos Arnold, on Kansas [now Green] street between Fair Oaks and Raymond Avenues. Mr. Arnold was elected president of the society. Other members were: Prof. C. F. Holder, Dr. Wm. F. Channing, Dr. N. D. Van Slyck, Mrs. Jeanne C. Carr, Maj. H. N. Rust, Frank J. Polley, Esq., J. R. Greer, C. T. Hopkins, and others. The "museum" mentioned by Mr. Hopkins was never provided for in the Library building. The Academy of Sciences, however, has never disbanded, but holds a nominal existence yet, although in a state of quiescent dormancy. And the "collections" mentioned have become historic, giving prestige and fame to Pasadena, as follows :

Mineralogy ColieCtion.-This belongs to Hon. T. P. Lukens, and comprises specimens of every sort of mineral that has any commercial value, ever found in Los Angeles County, besides others from all over California and the other mineral bearing states of our own country, and many other parts of the world. There are also specimens of fossil wood found in excavations at Los Angeles city, and from other places; and fossil fish and leaves from our local "fossil hill," down the adobe road toward Los Angeles. Mr. Lukens had a complete catalogue of his collection made in June, I895.

Geology Collection. - This was Dr. Ezra Carr's, which amounted to some tons weight and had lain in their shipping boxes, unshelved, ever since they were brought to Pasadena in $\mathrm{r} 880$. In $\mathrm{r} 894$ this valuable accumulation of specimen fossils, minerals and rock types was donated to Throop Polytechnic Institute.

Conchology Collection.- Hon. Delos Arnold has the largest and finest accumulation of scientific material in this line of any man in the State, I suppose - and all systematically arranged and classified - a total of about 25,000 specimens. Among these are some 1,500 different living species or varieties of mollusca, about 400 species of which are found on the Pacific coast, and at least half of these occur in Los Angeles county. More varieties are found at San Pedro Bay and vicinity than at any other one point from Alaska to San Diego. Also about 300 species of fossil shells have been found at San Pedro and Deadman's Island. In Mr. Arnold's collection as a whole, there are specimens representative of every age in the geological scale, from the lower Silurian up to the living present. And some 25 or 30 specimens from this Pasadena collection were illustrated in Vol. 8, of the State Geological Reports of Illinois, published in July, I890 - one of them being Actinocrinus Arnoldii, which Mr. Arnold himself discovered in a quarry near Marshalltown, Iowa; it was named by the professional experts, and pronounced the only specimen of its species known in the world. These illustrations were borrowed and used in "North American Geology and 
Paleontology," by S. A. Miller, Cincinnati, Ohio, I889- this work being issued some months before the Illinois State Report was gotten through the press. Mr. Arnold made generous donations from his collection to the State Normal School at Chico ; to the Smithsonian Institution at Washington, D. C. ; to the Pasadena High School; and to the Throop Polytechnic Institute. In addition to his wonderful collection of shells and crinoids, mostly the gatherings of his own hands, Mr. Arnold has made canes from about one hundred different kinds of rare woods, shrubs and plants that grow in this semi-tropic clime, but not in the more northerly portions of our country, and hence have a fascinating interest to our Eastern visitors, as well as a scientific value in themselves.

ARChal,ogy ColiLetion.- Maj. H. N. Rust had what was deemed the finest collection in this branch of science on the Pacific coast at the time President Hopkins referred to it, as above quoted. In 1892 it was sold to Frank G. Logan of Chicago, and was exhibited in the great World's Fair there in I893. Mr. Logan afterward donated it to the Congregationalist college at Beloit, Wisconsin, and it there abides.

Mrs. Lowe's Colinction.- Since the date when President Hopkins alluded to the four collections then here, another one has been brought to Pasadena which quite overtops them all in the comprehensive magnitude and marvelry of its completeness both as to number and quality of the specimens, nine-tenths of them being the choicest of their kind. It comprises thirty-one distinct and different collections, made by Mrs. Leontine Augustine Lowe herself (wife of Prof. T. S. C. Lowe) during the past forty years - and she is still adding to it. The collection of curios alone has cost \$150,000, and comprises some of the rarest old paintings, old laces, tapestries and costumes-relics of rank and royalty; carvings, sculptures,

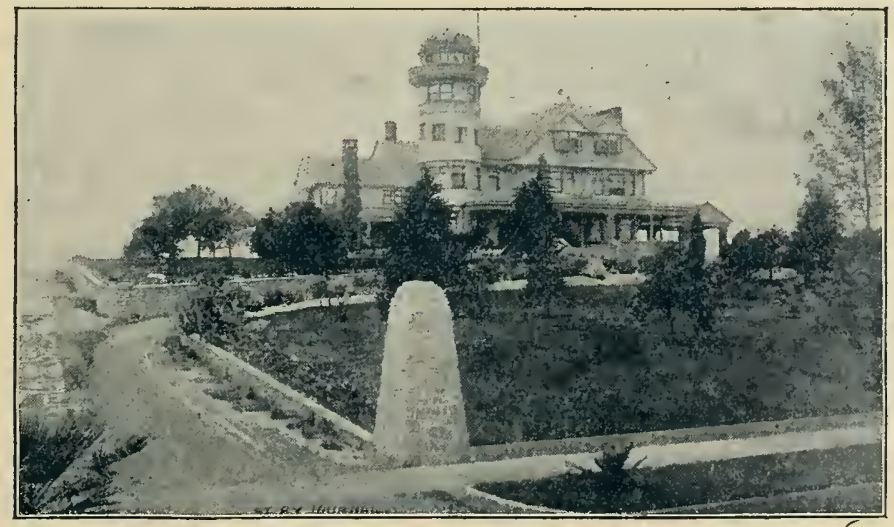

RESIDENCE OF PROF. T. S. C. LOWE.

There are basement rooms under the entire building, and all occupied by Mrs. Lowe's unique collection. 
coins, mosaics, and other relics of classic antiquity. In the department of Mineralogy alone there are 80,000 specimens, comprising every known metal or its ores, and every species of precious stones, both cut and uncut ; every species of marble, onyx, agate, alabaster, etc., etc. Rare old bookssome made by hand about A.D. I 430, before the art of printing was in vogue, and others along up the far-away centuries. In Ceramics there are rare vases and table ware of ancient royalty; Venetian porcelains of most exquisite quality and in great variety; a set of table ware used by George Washington while he was President; etc. In fact, all branches of natural science, all phases of artistic skill, and all zones of the earth are liberally represented in this unique collection, which is estimated to contain over 300,000 specimens. Of Indian baskets alone there are 547 , and no two alike. In the field of Ethnology the exhibits are most extensive, comprehensive, versatile and instructive. Mrs. Lowe had a passion for making collections, from her early childhood; and this great Museum represents her life-work and life-play, besides raising a family of seven girls and three boys - all still living, and all vigorous, healthy and bright people. The collection is to be placed in a fire-proof building erected purposely for it on Echo Mountain. In her search for rare specimens Mrs. Lowe has traveled around the world. She enlisted the co-operation of scientists, travelers, mine-managers, art collectors, antiquarians, curio dealers, high officials in different countries, missionaries, etc., thus levying tribute on all lands. Her collection is said to be the largest one now in private hands in the United States, and is without doubt the largest one ever made by a woman in the world - hence its prominence as a living incident in Pasadena history.

NEWSPAPERS.

The Pasadena Chronicle.-D - During the spring of 1883 it began to be talked that Pasadena ought to have a newspaper of her own. Most of the talkers, however, thought the place was not big enough yet, and were not willing to put money into such a dubious enterprise. In July a printer named C. M. Daley offered to start a paper here if some of the citizens would lend him their credit so he could get his type-setting and press-work done at the Los Angeles Times office.* Ben E. Ward was the only Pasadena man who had faith and grit enough to make the venture, and he became Daley's surety for the printing contract. So, on August 8, I883, the first number of the Pasadena Chronicle came forth, and was the first printed newspaper for the place. It went in Daley's name, but Ben E. Ward, assisted by his brothers Frank and Walter, did the editing and the Pasadena business for it, and at the end of two months he had to pay the printing bills himself. Daley was no help in the matter at all, and Ben then took

* Mr. H. C. O'Bleness set the type and printed the Pasadena Chronicle from its first number until February, I884, when types and press were first brought to Pasadena. The same man is now with the Kingsley-Barnes \& Neuner Co, and was assistant foreman on the work of printing this History. 
full charge and ran it in his own name as editor, with Frank and Walter Ward as associate editors.

In November, I883, H. W. Magee and J. W. Wood bought the paper and tried their 'prentice hand as editorial helmsmen. In Jantuary, 1884, Magee sold his interest to J. E. Clarke; and the only copy of the Chronicle that I have been able to find, bore date "Thursday, January 24, I884. Vol. I, No. 24. J. E. Clarke and J. W. Wood, editors and proprietors." It contained a report of a meeting of about forty persons, just held at the Sierra Madre Villa hotel, to talk up a College project for Pasadena. It mentioned that the Public Library was open only on Wednesdays and Saturdays from 2 till 4:30 p. m.; Wm. Doyle, acting librarian. It gave only four churches - the Methodist, then meeting in Williams Hall; the Presbyterian, in their own house down on California street; the Episcopal and the Baptist societies met in Library Hall. It gave as a local item of note, that on Monday, January 21, I884, 517 letters were received at the Pasadena postoffice, and two sacks of papers. Its printing was still done at Los Angeles. But in February, a practical printer named E. N. Sullivan was added to the firm; a stock of type and a hand press were bought; the paper was enlarged to eight columns per page, it having had only six before; and the name was changed to

Pasadena and VAlley Union. - The first issue was on Saturday, February 16, 1884, by the three-headed firm of Clarke, Wood \& Sullivan. And as an historic incident of this time, Mr. Wood writes me:

" J. W. Hugus kindly lent his assistance to put 'in case' the first supply of type ever brought to Pasadena. He worked a week gratis, ' just to get his hand in,' as he expressed it then, for he was an old printer.'

Sullivan soon dropped out, leaving the firm as Clarke \& Wood again. Then on November 22, I884, Mr. Clarke, on account of continued illness, sold his interest to Mr. Wood and retired, and the plucky J. W. W. carried it alone till about Christmas week, when he met with an accident by which a leg was broken and his back severely injured, so that he had to give up all business for the time. And on January io, I885, he sold the establishment to Charles A. Gardner, an old experienced editor, who at once took hold of the concern with vim and enterprise.

April Io, I885, J. E. Clarke comes on deck again, having bought from Gardner a half interest in the paper; and from this date the firm was Gardner \& Clarke. In April, I 886, during Citrus Fair week, a small daily called Union Junior was issued, and the Los Angeles Times of April 15, said :

"The latest addition to the family of Southern California journalism is the Pasadena Union Junior. The "Gem's" little, but a lively daily. Mother and child are doing well, and "the old man" - - Br'er Gardner-is likely to pull through." 
This was the first daily ever published in Pasadena;* but after Fair week the Union Junior dropped down to a semi-weekly instead of a daily issue.

June 25, I886, a practical printer named Athel B. Bennett became a partner, and the paper once more had a three-headed firm to devour its revenues. On August 6, they issued a great commercial and industrial edition of eight pages - a sort of "boom" sheet.

September I, I886, J. E. Clarke bought Gardner out, so the firm was now Clarke \& Bennett. They suspended the Union Junior, but on September 26 they enlarged the weekly, making it nine columns instead of eight to the page. Bennett soon retired, and Clarke became sole proprietor.

The next move was to form a stock company, which was accomplished, and the "Union Publishing Co." was incorporated June $16, \mathrm{I} 887$, the incorporators being P. M. Green, J. E. Clarke, J. E. Howard, R. M. Furlong, W. U. Masters, J. W. Wood, and Bayard T. Smith. The business flourished and went on well until the real estate boom collapsed; then every kind of business fell into a sort of sickly decline. Clarke and Howard sold their stock to Dr. John McCoy; and in April, I887, he became its editor. Its decline was now more rapid, and bankruptcy both in business and prestige soon followed. The Publishing Company made assignment to J. W. Wood, who became manager and editor. $\dagger \mathrm{Mr}$. Wood is a man of grit and pluck; and he held his grip and kept the paper going for nearly a year longer, in spite of very embarrassing adverse conditions. The owners of the plant were now J. W. Wood, W. U. Masters and R. M. Furlong, the two latter being leading democrats, while Mr. Wood, the editor, was a republican. The Union's business and good will were finally sold August 3I, I888, to the Daily Star; but the plant, which was leased to the weekly Joumal during its short struggle for existence without survival as the fittest, was at last sold off in detached lots as opportunity offered. And Mr. Wood writes pathetically: "The poor Union died of too much 'management;' but it was on an expense-paying basis when I sold it to the Star."

The Pasadena Star.-This paper was first issued on Wednesday, February 9, 1887 , as a weekly, 8-column folio, edited and published by H. J. Vail. Mr. Vail had formerly published a paper called the Star at New Sharon, Iowa, and thus brought the name here. Ou August i 8 of the same year it was enlarged to 9-column folio. Next, in October it was changed to octavo form, and has retained that form ever since. The paper was professedly Republican in politics, but it was also pro-liquor,-for the editor in a lengthy editorial

*" The Pasadena Star says it was the first daily of Pasadena. Not so: The Union was the first, as the writer hereof has painful occasion to remember, haviug beeu ass enough to start it himself."-East Los Angeles Exponent (Chas. A. Gardner then its editor .- September $18,1889$.

"Correct; and the writer hereof did some pencil pushing for that first Daily Union, but kept at a safe distance from the heels of the "ass!"-Pasadena Standard, September 21,1889 .

$\dagger \mathrm{J}$. W. Wood, the druggist, is now editor of the Daily Union. Don't know if there is fire enough in that Wood to give more light than the evening Star.-Pasadena Standard, Feb, wary 2, 1889. 
condemned and opposed the unanimous decision of the United States Stpreme Court that the brewers and distillers of Kansas were not entitled to payment for their liquor factories, etc., by the State when it enacted prohibition. The entire eight judges of the highest court in our country con. curred on this point, December 5, I887; but the Pasadena Star's editor said they were all wrong (Daily Star, December I7, 1887), and boasted that he had maintained the same brewery "compensation" doctrine while he was an editor in Iowa. This "compensation" theory was the docirine of almost the entire democratic party and press, as well as of all the liquor organizations in the country, the latter having spent over $\$ 50$, ooo in their great contest against the State of Kansas on this issue. [So much of explanation was necessary, to show what sort of a Republican paper the Star was, under its first administration, and to throw an important sidelight on sundry matters of evil import in Pasadena's history, up to April 7, i89o].

The Star was first issued as a daily paper on Wednesday, February 9, 1887 , in 7 -column folio form. On Saturday, June 25 , same year, it was enlarged to a 9-column folio. Then on Monday, November 7 , it was changed to 7 -column octavo form - and has retained that form ever since, though eventually reduced to a 6-column page.

August 3, I889, the Star purchased the business and good will of the Union; and on the next Monday, September 2, the paper carried the double head of Daily Star and Daily Union-this being necessary to make valid the completion of some advertising contracts belonging to the Union. In an editorial on the long struggle of both papers for bare existence, the Star said :

"Both papers remained in the field; both fought for existence; each preferred that the other should die. * * Thus the life-and-death struggle continued until more than $\$ 25,000$ had been lost in the newspaper business in Pasadena."

Pasadena was always strongly republican in its political character, but the Star was never a satisfactory representative of the better element of its party ; and when financial embarrassments thickened around it they would not come to its rescue without an entire change of administration - it must sell out to better men, or go down. And that is how it happened that the paper appeared on Saturday, April 5, I 89o, bearing at its head the old names, H. J. Vail, editor; W. I. Vail, manager : then on the ensuing Monday bore the names, "Star Publishing Co., Geo. F. Kernaghan, manager." The new company was represented by Hon. P. M. Green, B. F. Ball, Geo. F. Kernaghan, Prof. T. S. C. Lowe and T. P. Lukens, as a board of directors, Mr. Kernaghan being in charge of the property, under full warrant of power

*Among the books, papers and documents turned over to the Star office when the Union sold out to it were the unbound files of the latter, after Jauuary, 1887 , rolled and tied in bundles. And when I was trying to find these files for my history research I was told that they had been thrown into a heap with old exchanges and sold off for waste paper-hence destroyed beyond recovery. 
to oversee and direct the editorial conduct of the paper, as well as the mechanical and business affairs connected with it. Messrs. Green, Ball and Kernaghan were each signers of \$100 notes for the prohibitory Enforcement Fund; and Mr. Lukens had made a similar note for the original enactment or "Indemnity Pledge" fund; hence, it will be seen, the conduct and course of the paper would be very different, both in its general political quality and in its local bearings.

On May 27, I 890, the Star first appeared with this formula at its head: "Geo. F. Kernaghan, president and manager; J. S. Glasscock, secretary ; First National Bank, treasurer."

On May 19, I891, Charles A. Gardner* bought out Mr. Kernaghan's interest, and became manager and editor in his stead. Mr. Gardner then gradually bought out the other shareholders until he became sole proprietor ; and that was the situation on January $\mathrm{r}, \mathrm{1} 895$, when the business had been worked up by diligent, patient and perservering effort through the years of business depression to a good paying basis-and a great 16-page New Year edition was issued in good heart.

Theodore Coleman became city editor of the Star in June, I886, and has held the place ever since. His natural aptitude for the work, and his uniform courtesy and fairness as a reporter, have given him a prestige and a staying hold which few men can reach in that field.

The Pasadena STANDard.-This paper was started in 1888 , to sustain Pasadena's anti-saloon ordinance and policy, for an account of which see Chapter I3. The first number appeared on Saturday, December 22, I888, with Dr. H. A. Reid as principal editor, and H. N. Farey as business manager. The editorial salutatory was only two lines, thus: "Folks, we're here; and hereof you'll hear more herein and hereafter."

Heading the first column on its first page was the following original poem :

"NO SALOON IN THE VALLEY."

Rise, Pasadena! march and drill

To this your bugle's rally-

"A church or school on every hill, And NO SALOON IN THE VALI,EY."

Stand firm in rank, but do not boast Too soon your victory's tally ;

You "hold the fort" for all the coast For NO SALOON IN THE VALLEY.

The seige is on, the bombs aflight! Let no true soldier dally :

For truth and right, for HOME we fight, And NO SALOON IN THE VALLEY.

Then let your STANDARD, full unfurled

On every street and alley,

Pledge Pasadena round world

For NO SALOON IN THE, VALILEY.

*Mr. Garduer was editor of the Anaheim Gazette in $187 \mathbf{x}-72$; of the daily and weekly Napa Register, 1873 to 1875 ; of the Helena Star, 1875 to 1884 ; of the Pasadena Union, $1885-86$; of the Rural Californian, Los Angeles, I 886 to 1888 . 
The paper was issued in six-column quarto form five weeks, and then for want of financial support was suspended; but every dollar of its indebtedness was paid. Next, after conference with friends of the cause, Dr. Reid and wife decided to reduce the size, reduce its cost as much as possible, and continue it themselves, purely as a missionary work. Accordingly, on January 26, I889, their first number was issued, in size of page that could be printed on a job press - and the presswork was contributed by $\mathrm{H}$. N. Farey \& Co., job printers, for more than a year, as their part in aid of the good work. Mrs. Reid, although over sixty years old, did canvassing, collecting, type-setting, folding, mailing - anything to help. Another woman over sixty-six years old, who had never touched a type before, learned to set type, and gave her time occasionally for several months to help get out the paper. Two men who were carpenters by trade did the same thing. Three different boys did the same thing. And six different practical printers [type-setters], both men and women, sometimes lent a hand. The Standard of November 9, I889, said :

"Last Saturday Mrs. Reid was absent, and four ladies came and helped us about our mailing-day work-pasting, folding and wrapping The Standard. Three of them were past sixty years old - and 'the old lady' being away, we 'young folks' just had a picnic."

On August 24, 1889, in reply to a correspondent who wanted the paper enlarged, the editor said :

"The suggestion is very clever, but is not practicable. Small as The Standard is, we are issuing every week a better paper than the income pays for. In fact, we could not issue it at all but for the mechanical help which has been donated more or less every week thus far since about February I."

An Anti-Saloon Republican city convention was held March 29, 1890, to nominate candidates for the city offices. [For an account of this, see Chapter I3.] Then arrangements were made to issue The Standard as a daily during the campaign ; and the first number of its "Daily Edition" bears date April 3, I890; and eight numbers were issued, or until Saturday, April I2, the election occurring on Monday, the I4th. The paper was finally suspended, its debts all paid, and its printing outfit offered for sale, on May 3, 1890, being Vol. III, No. 19. Among his closing statements the editor said :

"The recent change in the management and control of the Daily Star makes the special work of The Standard no longer necessary. The new City Trustees have given their pledge of honor not to permit any sort of liquor saloon business within the city limits. The NEW Daily Star will co-operate with them in this and every other good work that is right and proper for the city's general welfare. $* *$ We gladly retire to private life again, feeling that OUR FLAG IS S'TILL, THERE."

AlL-SainTs RECORD.-In February, i889, Rev. G. A. Ottman, rector of All-Saints Episcopal church, started a monthly paper in three-column 
octavo form, with above name. It was devoted entirely to the local interests of the Episcopal parish and denomination. Mr. Ottman resigned his rectorship here and returned east in April, I89I ; the paper was then suspended five months, or until October, I89I, when its publication was resumed by the new rector, Rev. Wyllys Hall, D. D., and has been continued regularly since. It is sustained by business men using it as an advertising medium.

The CRITIC.-In February, I888, J. M. Shawhan started a paper under this name, devoted to "society gossip, criticism, literature, music, the drama," etc. Shawhan was a drinking fellow, and in a few months his paper became a special organ of the liquor interest in Pasadena, and then rapidly declined. By December 8 it ceased to be a Pasadena publication, but was dated at Los Angeles. Then Shawhan couldn't pay his printing bills, and gave it up to a firm who changed its name to Life, and continued it a while. Mr. Shawhan had some dramatic talent, and went touring as a member of a traveling theater company.

WeEkly YASAdenian.- In October, 1885, Major J. D. Gilchrist, brother-in-law to Gov. H. H. Markham, started a paper here; and the Union of October 23, said :

"The Weekly Pasadenian made its appearance on Thursday, and we now have a contemporary in very truth. Mr. Gilchrist, the editor and publisher, extends to us the courtesies of the fraternity in a spirit of good will. We are pleased to return the compliment, and shall aim to prove that with its success the Union is not selfish."

I could not learn of any but the one number of this paper ever being issued. It was printed at Los Angeles, where Major Gilchrist owned a large printing establishment himself.

Daily and Wekkly Bulletin.-In August, I887, the Pasadena Real Estate Exchange was organized with a purported capital stock of $\$ 100,000$, and opened its doors for business on September I, in the Eldridge block in rooms fronting on Raymond Avenue. One of its rules was, that all transactions "shall be recorded, bulletined and PUBLISHED, for the information of members." This of course made necessity for a daily paper of some sort to be issued to its members; and accordingly the real estate BuLLETIN commenced its regular issue on September 4, I887. I found with Dr. Lyman Allen one copy of the Daily and one of the Weekly Bulletin, preserved as historic relics of the "boom" time. 'This copy of the Weekly is dated February 20, I888, is marked Vol. I, No. 25, and contains 64 pages of printed matter $21 / 8 \times 71 / 8$ inches in form. In it is a list of 142 Real Estate firms, 6 I of which are only one man, 47 have two members, and 34 have three or more members of the firm or company. All but the first two pages are filled with classified list- 
ings of lots for sale, each one being listed by number, and the highest number in this edition is 2, I 7I. The copy of the Daily which I found is also dated February 20, I888, and is marked Vol. I, No. I28. It says, "Office hours 8:30 a.m. to $5 \mathrm{p}$. m." Listing of property for the day closes at 2 p. m. Notice of change of price or of sale made closes at 4:30 p. m. E. D. Hough was the Exchange "manager," and editor of the Bulletin. The Association had its own type and press there in the office, and these were its principal assets when the "boom" bursted. The expenses of the Exchange office, including the printing of the paper, were met by quarterly dues from the members, and this number of the Daily contains an urgent call for the members to "pay up" their quarterage which fell due in January. The boom was already feeling a little sick.

The White Ribbon.-The Pasadena Standard of February 2, 1889, contained the following item :

"The White Ribbon is the name of a new paper just issued by the State Womans Christian Temperance Union, from the press of H. N. Farey \& Co. Mrs. M. C. Lord edits it. The new paper is our little twin sister, being the same size of page as the "little" STANDARD. It goes to every member of the W. C. T. U. in South California, and 3,00o copies were printed. It is monthly, and it is sprightly, at 25 cents a year."

The "Ribbon" was continued till I 894 with the same editor and printers ; then it was removed to Los Angeles and edited and printed there.

The Pasadena Weekly Journal made its first issue on October 5, 1889. By the suspension of the Daily Union, and other newspaper failures, a number of Pasadena printers found themselves out of work - stranded on the desert beach of a "busted boom," with no bread-and-butter croppage in sight ; to meet this emergency, three of them, C. W. Jackson, F. S. Hearn and W. H. Korstian, leased the material of the defunct Union and started the JOURNAL, hoping that, as they would do the work themseves it would yield them at least a living. It was a neat paper, 7 columns to the page, devoted to general news and the local interests of Pasadena. They issued 23 numbers, the last one bearing date of March 8, I89o. And the Pasadena Standard of March ${ }_{15}$, said :

"The Pasadena Journal suspended publication last Saturday. The young men who started it made a good paper; but the field was too full already. They held on remarkably well, as it was, and retired with honor and respect to their good intentions."

THE CROwn VisTA.- Sometime in I $888 \mathrm{H}$. E. Lawrence started a paper at the village of Sierra Madre, called The Vista. But about November I, I 89 I, he moved his printing office to Pasadena, and on November I 4 issued the first number of the Crown Vista, in pasted journal form, $12 \times 18$ inch page. It gave much attention to local matters of Sierra Madre and Lamanda Park, as well as Pasadena; and varied in size - being 8, Io or 12 
pages, as occasion required. Suspended about May I, I895, for want of support. Then the office was sold to Ralph W. Strong of Monrovia (formerly Chicago) who revived the paper, making his first issue of it on May 25, 1895. June 22, I895, he changed the name to Current Topics.

Raymond Chiт-Сhat.-This paper seems to have been started in I 893, or perhaps earlier-but no particulars were furnished me. The Daiiy Star of December 30, 1894, said :

"The first number for the season of Chit-Chat, the Raymond hotel organ, is to appear next Sunday morning under Mr. Cooper's editorial management. The little paper was a decided success last year."

The Mount Lowe Echo.-On March I I, I894, was issued the first number of the Daily Mount Lowe Echo, with Prof. G. Wharton James as editor. Its opening announcement said :

"Let the birth-bells ring! Another child is born to the family of California newspapers. As its name implies, the Mount Lowe Echo will be an echo of the doings on and about Mount Lowe."

Its form is that of a wide 2-column folio, printed on heavy, calendered book paper, in highest style of job printing art, and illustrated about twice a week with full page and first-class photogravure plates. It is devoted to the interests of the Echo Mountain and Mount Lowe region, with all its connected enterprises, and people who visit or sojourn there. On March i 7, the first weekly edition was issued. Subscription price, $\$ 2.50$ per year ; and on sale at news stands at ro cents per copy. The Mount Lowe R. R. Co. has a complete printing office of its own in the Rubio pavilion, with presses run by water power, and its printing is all done here. [See Chapter 23.] On April 27, I 895, the Echo suspended publication till January I, I 896 , when the tourist season should be open again.

The Daily Evening News.--Early in October, I894, W. S. Gilmore, who had served long as the Pasadena local reporter of the Los Angeles Times, conceived the project of starting a new daily paper in Pasadena. His scheme matured rapidly, so that the "News Publishing Company" was incorporated October I2, by W. S. Gilmore, W. C. Stuart, Isabel Bates Winslow, C. Ornbanm, L. P. Hansen, J. W. Wood. The first board of directors consisted of Gilmore, Stuart, Hansen, Wood, and F. C. Bolt, and its officers were-Gilmore, president; Stuart, vice-president; Mrs. I. B. Winslow, secretary; San Gabrie! Valley Bank, treasurer. The amount of capital was $\$ 15,000$. A complete newspaper and job printing outfit was purchased; the entire first floor of the Hopkins block, formerly occupied by city officers, cortuer Fair Oaks avenue and Union street, was leased; and the Pasadena Daily Evening News, 7-column quarto form, made its first issue on November I, I894. In politics, Republican. Number of employes, twelve. The day before Christmas it was issued as a special 
" charity edition," edited by thirty-four of Pasadena's well known citizens and literary people, and resulted in furnishing \$107.95 to the Charity Organization Society funds, as special income from this day's edition.

ThE New Education.-This paper was first issued December I, I894. It is an 8-page folio, published monthly in the interest of the Williams Business College; and edited by Prof. J. T. Williams, the founder and managing principal of this institution.

PASADENA'S IITERARY PEOPLE.

Hon. Delos Arnold : public addresses, published articles, etc., on Paleontology and kindred sciences. Has himself collected and classified more original specimens than any other man in Southern California.

I YMan AlLEN, M. D. : Author of "Political Problems" - I892; and other writings on national economics.

Arturo Bandini: Magazine articles; stories of the chase, etc.

MRS. HELEN ELIIOTT BANDINI : Local correspondence ; stories, poems; varied contributions to periodical literature.

Dr. KATE ShEPARDSON Bhack: Topical papers; public addresses; current literature.

Norman W. Camp, D. D. : Author of "Ritual Hand-Book of Praise and Prayer." Washington, D. C., I 884.

Ezra S. CARR, M.D., LL. D.: Agricultural economics; geology ; public lectures. Edducational science; large volume history of the Grange movement. Author of works on "Child Culture," "Genesis of Crime," "Claims and Conditions of Industrial Education," etc. [Died I894].

Mrs. Jeanne C. Carr : Letters; reminiscences; botany; horticulture ; historical writings; varied contributions to published volumes and to periodical literature.

Wm. F. Channing, M. D. : Author of "Manual of Magnetism," I 847 ; "Medical Application of Electricity," I 849 ; original patentee of Fire Alarm Telegraph; also of Inter-Oceanic Ship Railway; assistant geologist in U.S. survey of $\mathrm{I}_{4}$ ake Superior mineral lands; member of advisory council World's Congress of Electricians; contributor to leading magazines and scientific journals.

Mrs. Lou V. Chapin: Author of History for Children; long time editress of the Chicago Graphic; magazine writer ; etc.

Mrs. Julia Clarke Chase: Author of "Driftwood," a volume of poem. published at Milwaukee, Wis., I878. Was a frequent contributor to leading journals and magazines. She and her sister, Medora Clarke, were at one time famed in the middle west as " the poet sisters." She is preparing another volume of her poems for publication in I896-and this will be a Pasadena production.

JAMES G. CLARKE: Author of many popular poems and songs ; music composer ; magazine writer ; editor.

Mrs. C. D. DAGGETT : Short stories; sketches; dramatic pieces; etc.

JUDGE B.S. EATON : Magazine literature ; reminiscences ; local pioneer history. [Judge Eaton wrote many narratives of local history for this volume]. 
Rev. Eli Fay, D. D. : Contributor to the North American Review, and others of the most scholarly eastern periodicals. Author of "Reason in Religion" $-\mathrm{I} 895$.

Chas. A. GARDNER: Humorous poetry; magazine literature; editor.

Mrs. Margaret Collier Graham; Stories and periodical literature. "Stories of the Foothills," a volume published by Houghton, Miflin \& Co., N. Y., I894. Stories mostly located in Southern California. A writer for the Overland Monthly, Scribner's Monthly, Atlantic Monthly, etc.

MRS. ELIZABETH GRINNELL : Poems ; periodical literature ; author of "How John and I Brought up the Child;"--a $\$ 400$ prize story published by the American Sunday School Union in 1894.

CHARLES FREDERICK HOLDER, LL. D.: author of numerous volumes in science, and a prolific contributor to literary and scientific journals, and the newspaper press. Author of "The Ivory King." "Marvels of Animal Life," and "Living Lights," all published by Scribner's Sons, New York and London. "Along the Florida Reef," D. Appleton \& Co., New York. "Elements of Zoology:" American Book Co., New York. "A Strange Company :" D. Lathrop \& Co., Bostou. "Pasadena and Vicinity:" Lee \& Shepard, Boston. "Life of Darwin," "Life of Agassiz," Putnam's Sons, New York. "A Frozen Dragon."

CASPAR T. Hopkins, A. M.: author of "Manual of American Ideas," - San Francisco, I872-a text book on civil government which went through eight editions; and he was negotiating with a Boston publishing house for its re-issue when his death occurred, in I893. He was for many years a contributor to the Overland Monthly, and other Pacific Coast periodicals, chiefly on economic questions.

G. Wharton James, F. R. A. S., etc.: Author of "Tourists' Guide Book to South California," I 895: and other works. Also, lectures on Astronomy, and other topics; and the extensive and profusely illustrated Mount Lowe literature. Editor of the Mount Lowe Echo.

PRESIDENT C. H. KEYES, of Throop Polytechnic Institute: Educational Science; public lectures and addresses; contributor to educational journals.

Авво'T KinNEy: Author of "Protection vs. Free Trade"- I884. Forestry reports ; travels ; essays ; public addresses; magazine articles.

REv. Solon Lauer: Author of "Life and Light from Above:" Lee \& Shepard, Boston-I895. And other works.

Eirias LONGLEY: Author of "American Manual of Phonography," and nine other works or text books on Phonography, 'Typewriting, etc. He was the pioneer of phonography and phonotopy in America, commencing his publications in this field of art at Cincinnati, O., in 1849.

Mrs. M. V. LoNGLEY: Author of standard text books on Typewriting; public lectures on Woman Suffrage ; etc.

MrS. MARY CASE LORD: Author of published work on "Bible Wines," and other writings ; editor "Southern California White Ribbon."

W. U. MASTERS : contributor to periodicals; topical addresses ; public lectures.

Prof. A. J. McClatchie, A. M.: Author of "A Guide in the Study of Plants" - I893; contributor to scientific periodicals on Botany, Biology, and kindred topics. [See chapter on Botany in this volume.] 
Chester Gore Milifer: Author of a book entitled "Father Junipero Serra," a dramatic poem ; and other poems. 1894.

Miss Anna Picher : Author of Pasadena Art Loan Souvenir pamphlets, in successive years from $\mathrm{I} 889$ to $\mathrm{I} 895$.

Prof. Frank J. Polley : Antiquarian researches; early history of California; topical papers, reports, public lectures, etc.

H. A. REID, A. M., M. D.: Author of "The Heart Lace," Davenport, Iowa, 1856 - the first volume of poems ever printed in Iowa; also "Harp of the West," same place, 1858. Author of History of the State of Missouri, I88I ; and History of Lafayette County and City of Lexington, Mo. Author of History of Johnson County and Iowa City, the first state capital, and the State University town of Iowa-r883. History of Montgomery County and city of Red Oak, Iowa, I880. Author of "Calendars of Creation," showing the steps and stages of creational progress on four different lines of evolution-1879. Contributions to "Review of Science," Kansas City, Mo. Topical papers, public lectures, etc., on Evolution and kindred topics.

Mrs. RAChel F. Reid, M.D. : Stories; poetry ; lectures to women ; topical papers and addresses.*

Maj. Horatio N. Rus'r: Magazine articles; antiquarian research; Indian Life.

Gov. Lionel, A. Shýldon: Magazine contributor; civil economics ; political questions ; etc.

EliAS Snith, M. D.: Author of "Atlas of Surgical Operations," Peoria Ill. - r889. "Regional Anatomy for Beginners"; same date. Various anatomical and surgical charts for physicians. Invented and published in I889 a school mannikin that dissects into over thirty different pieces, showing internal parts of the human body in their proportionate size and proper place. In 1860 he made some new discoveries in the polar phenomena of electro-magnets, and invented electric batteries for use of physicians.

Mrs. Grace Elilery Channing Stetson: Stories; poems ; travels ; magazine literature.

Mrs. LAURA G. STUnTz: Some of her poems are printed in a volume entitled "Poets of America," published in Chicago in r89r. Also in a volume entitled "Woman in Sacred Song," edited by a Mrs. Smith of Springfield, Ill.

Mrs. Hannah E. Taylor: Poems; dramatic pieces; music.

Timothy B. Taylor, A. M., M. D: Author of "The Inebriate"Montpelier, Vt., I865. "Old Theology Turned Upside Down or Right Side Up, by a Methodist Minister,"-Fort Scott, Kansas, I87 I ; but published now by the "Banner of Light Co.," Boston. "Text Book on Psychology" - to be published in I 895-96. This latter is a Pasadena production. Author of sundry pamphlets and other writings on religious and science topics.

JUdGE A. J. UtLex: Author of "Free Coinage,"-I893; and other works on Economic questions.

*Mrs. Reid was one among the first twelve women ever graduated from medical colleges in the United States; and as an Army Nurse she was the first woman mustered into the service west of Washington, this being at St. Louis in September, 186r, when Gen. Fremont was in command there. 
IsAaC N. VAIL: Author of "The Earth's Aqueous Ring"; Westtown College, Pa.-1874. "The Origin of Coal,"-1884. "The Earth's Annular System "-Cleveland, Ohio, I885. "The Great Red Dragon,"I893. Editor "Vail's Annular World"; magazine, Los Angeles, I 895.

MrS. Eilizabe'TH A. VORE: Stories; poems; treatises; periodical literature.

John W. Wood, Ph. G.: Author of prize report on Pharmacy; poetry ; periodical literature.

\section{PASADENA ARCHITECTURE.}

Pasadena is justly famed for the tasteful elegance, the high-art styles and the picturesque diversity of types of its architecture, alike in public buildings, in business blocks and in private residences. There is no architectural rut of sameness or monotony to be found here. And this historic fact and feature is largely due to Harry Ridgway, the first man who ever opened an architect office and established the business as a regular profession in Pasadena, which he did in 1878 , and holds the field yet - i 895 . His

Delos Arzold

B. F. Ball

Allen Dodsworth.

Mrs, Louse T Conger.

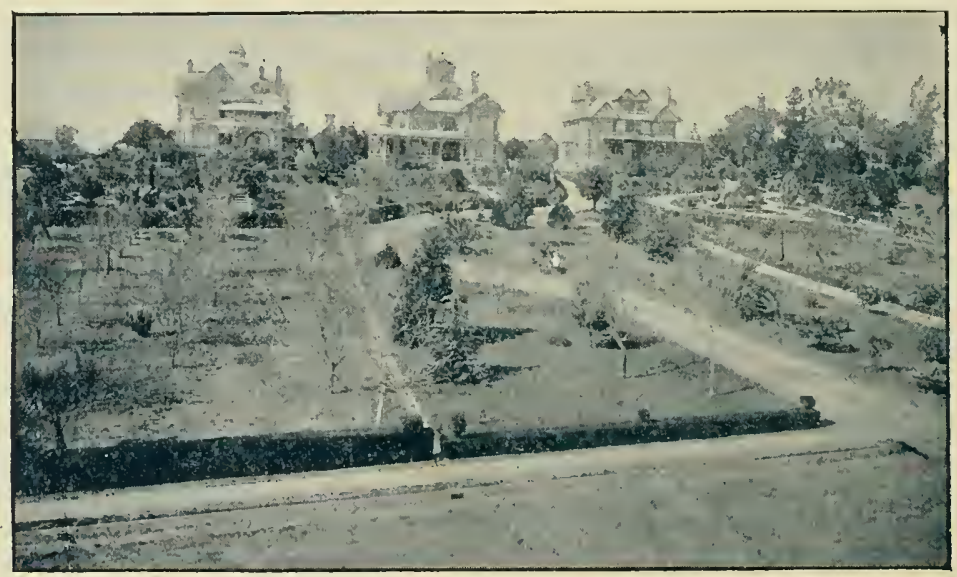

FOUR SIGHTLY HOMES.

idea was never to make two buildings exactly alike, but to utilize all the styles known to architectural science, ancient, mediæval and modern, in new combinations of artistic beauty and perspicuous variety. $\mathrm{He}$ never wanted any man to be able to point out any structure and say, " that's one of Ridgway's designs-it shows the earmarks of his style." He rather sought and achieved that ideal freedom from "style" called the artlessness of art. And others coming later brought additional novelties. Hence there are many original and diverse combinations of Venetians, Normans, Eastlakes, Old Spanish, Old Plantation, Italian, Firench Mansards, English and Colonial Dormers, Old English Queen Annes, Old English Elizabethans, multi- 
gables of many styles; villa combinations, haciendas, bays and towers in great variety. In fact most of our local architects have seemed to catch the spirit of the field as stamped by Mr. Ridgway, and tried to produce something distinctly and worthily Pasadenian in architecture, in which a few have succeeded. [A list of Ioo buildings showing architectural types I was obliged to omit for want of space].

\section{CHAP'TER XI.}

Pasadena in Politics.-Political Clubs and Party Representatives. - National and City Election Tables.-Pasadena Men in High Office.- Story of the Postoffice for twenty years.

PASADENA IN POLITICS.

There were twenty-seven members of the original San Gabriel Orange Grove Association who selected and took possession of their several proportions of the colony lands on Jan. 27, I874. Of these twenty-seven founders of Pasadena five were democrats, namely, Judge B. S. Eaton the president, A. O. Bristo1, A. W. Hutton, Ney Strickland and Henry G. Bennett ; all the rest were republicans. But these five were not necessarily lonesome, for nearly all the old settlers around were democrats, such as Gen. Stoneman, Col. Kewen, Hon. B. D. Wilson, J. DeBarth Shorb, Col. Winston, John W. Wilson, Jesus Rubio, etc. For all political or voting purposes the Rancho San Pasqual was only a part of San Gabriel township.* Our colonists, however; took measures at once to be formed into a new school district; and the first election ever held in Pasadena was for school directors, on Saturday, September I 2, I874. Ten votes were cast, and unanimous choice was made of Col. J. Banbury, H. G. Bennett and Dr. W. W. Edwards. No voting except school elections occured here until i 876, when the San Pasqual school district was allowed to vote as a separate election precinct of San Gabriel township. And at the presidential election that year the polling place was at the original colony school-house on lower Orange Grove Avenue, only a few days before its removal to the central school lot, this latter event taking place November I0, I876. This was the year of Hayes's election as president; and out of a dozen old settlers whom I consulted only J. H. Baker remembered how the vote stood. He gives it as Republican, 60; Democrat, 5 ; Greenbacker, 2 . Total, 67.

Early in 1875 I. N. Mundell was appointed road overseer for the school district; and in 1876 he was succeeded by A. O. Bristol.

In March, I 877 , Henry G. Bennett was appointed deputy county as-

* On Aug. 7. 1851, San Gabriel township was created by order of the Court of Sessions, and was to include besides the Mission, "the Ranchos San Pasqual, Santa Auita, Andres Duarte, Azusa, I, Puente, Las Coyotes, Nietos with all its lines of boundary, Cienega, Mission Vieja with all its lines of boundary. The residence of the authorities is in San Gabriel." - Old records, as cited by Bancroft. 
sessor, and served continuously for nine years. At the fall election this year Maj. Erie Locke was elected justice of the peace for San Gabriel township; and A. O. Bristol was elected constable, but declined to serve.

In I878 Dr. T. B. Elliott and P. M. Green were delegates from Pasadena to the republican congressional district convention; and Mr. Green here made his maiden effort in politics by offering a resolution in favor of civil service reform, which was adopted by the convention.

In 1879 P. G. Wooster was appointed deputy sheriff for Pasadena, under county sheriff H. M. Mitchell, and was thus the first constabulary officer of the new settlement. He was re-appointed deputy by sheriff W. R. Rowland in 1880 .

In 1879 (special election) P. M. Green was nominated and elected assemblyman; and this was Pasadena's first elective achievement in the political field. The voting this year was at the Central School-house. Mr. Green received 109 votes, and the democratic candidate received six.

In r882 J. F. Crank, another Pasadena republican, was elected to the assembly ; and Gen. Geo. Stoneman, democrat, was elected governor. But I still found no record or report of any political club here. The Pasadena vote in 1882 was, republican I 36 ; democrat 30 . The vote of San Gabriel was, 73 republican and 119 democrat.

On March 29, I884, a republican club was organized, with Col. J. Banbury as president, and Ben E. Ward secretary; and Banbury, Ward, and H. W. Magee were appointed delegates to a convention at Los Angeles for choosing delegates to the State convention, and to decide on who Los Angeles county would support for nomination as the republican candidate for congress in the Sixth District. On this latter question four ballots were had at Los Angeles, the last of which stood : for H. H. Markham, 78 ; for Judge W. A. Cheney, 40 ; for E. F. Spence, I6. Then it was made unanimous for Markham; and Spence, Cheney, Magee, and others were appointed a committee to inform him of the result. Magee was appointed one of the delegates to the State convention at Sacramento; and there on July 23, 1884, Markham was nominated by the sixth district caucus, and ratified by the convention.

September ig the Pasadena republican club or caucus appointed delegates to the county nominating convention, as follows: H. W. Magee, J. Banbury,. J. W. Wood, O. R. Dougherty, T. P. Lukens. The convention was in session two days, September 24 and 25 . J. W. Wood was one of its secretaries. Magee was nominated for assemblyman. He went on making the canvass; but the last week in October he discovered that it required a three years' residence in the State to be eligible for this office, and he had only come here in $\mathrm{r} 883$ - hence was ineligible. He at once resigned the candidacy, and Col. J. Banbury was put on the ticket in his place, and was elected. 
This is the first year that I found any published election returns from Pasadena, and its vote on November 4,1884 , was : FOR PRESIDENT.

Blaine, rep.

Cleveland, dem........ 59

St. John, prohib., *.. 32

Butler, labor party*.. 4
FOR CONGRESS.

Markham, rep.

Del Valle, dem.
FOR LEGISLATURE.

298 Col. J. Banbury, rep., 275

49 Abbot Kinney, dem. 56

Thus Pasadena precinct cast 365 votes for presidential candidates in I884. But the vote for precinct officers ran up to 38 I on justice of the peace, as follows :

For Justice-'T. P. Lukens, rep., 239 ; 'T. K. Bufkin, prohib., SI ; E. S. Hereford, dem. 6I For Constable-H. C. Price, rep., 224 ; Geo. H. Little, prohib., I Io.

April 14, I884, the first Prohibition club was organized, as a result of lectures by the famous Mrs. J. Ellen Foster of Iowa. The officers wereStephen Townsend, president; Dr. Lyman Allen, secretary; S. D. Bryant, treasurer. And the votes for St. John, Bufkin and Little, as given above, showed their voting strength that year.

The first mention of any democratic political move in Pasadena is a report of a meeting called by L. C. Winston at the Roller Skating Rink, October 29, I884, and presided over by John W. Wilson. It was a mixed affair, in which some republicans from San Gabriel took part, in opposition to $\mathrm{O}$. A. Stevens, a republican candidate for justice of the peace ; but the real object of the meeting seemed to be in interest of the democratic candidate, E. S. Hereford, step-son of Hon. B. D. Wilson, who received 61 votes in Pasadena precinct, as above noted.

In June, I 885, T. P. Lukens resigned as justice of the peace, and Charles A. Gardner was appointed by the county board of supervisors to fill the vacancy. Hence Gardner was the incumbent when in 1886 the city was incorporated, and he was then appointed Pasadena's first city recorder or police judge.

The next electional event was the first vote for city trustees, which took place June 7 , I886, the incorporation having been officially granted on May 13. For particulars of this election, see Chapter I4; also Chapter I2.

This year affords the first formal notice that I found of a democratic party meeting in Pasadena, and I quote it from the Union of June I8, I886, to show who were the leading democrats here at that time. The notice read :

"A meeting will be held at 8 P. M. Saturday, June 26, in the schoolhouse, Pasadena. All who are in sympathy with the great principles held by the Democracy are invited to be present. Abbot Kinney, E. C. Webster, Bayard 'T. Smith, H. G. Bennett, R. M. Furlong, L. C. Winston, A. O. Bristol."

April I6, I888, the city trustees canvassed the votes polled at the election held on April 9, and found the following officers elected :

*The votes for Bntler and st. Joln were never published in Pasadena, and I had to hunt up old records in Los Angeles to find them. St. John had 343 votes in the county. 
NAME.

M. M. Parker,

Edson Turner,

Stephen Townsend,

W. W. Webster,

A. G. Throop,

City Clerk, James H. Cambell.

City 'Treasurer, Jabez Banbury.

City Marshal, I. N. Mundell. city trustee, 2 years.

city trustee, 4 years.

city trustee, 4 years.

city trustee, 2 years.

city trustee, 2 years.

PASADENA'S PRESIDENTIAL, VOTE IN I 888.

\begin{tabular}{|c|c|c|c|c|c|}
\hline For President : & $\begin{array}{l}\text { FIRST } \\
\text { WARD }\end{array}$ & $\begin{array}{l}\text { SECOND } \\
\text { WARD }\end{array}$ & $\begin{array}{l}\text { THIRD } \\
\text { WARD }\end{array}$ & $\begin{array}{l}\text { FOURTH } \\
\text { WARD }\end{array}$ & TOTALS \\
\hline Harrison, Republican............ & $35^{\circ}$ & $2 \mathrm{I} 5$ & $2 \mathrm{I} 5$ & 288 & 1,068 \\
\hline Cleveland, Democrat ............ & 73 & 89 & 87 & IOO & 349 \\
\hline Fisk, Prohibition ............... & 63 & 18 & I 8 & 33 & 132 \\
\hline Counts & 486 & 322 & 320 & $42 \mathrm{I}$ & I, 549 \\
\hline Col. Banbury, Republican...... & 359 & 233 & 226 & 308 & I, 126 \\
\hline Hewitt, Democrat.............. & 64 & 77 & 80 & 98 & 319 \\
\hline
\end{tabular}

[The most remarkable local contest was on Col. Banbury's candidacy at this time, and hence I preserve the vote, for its historic interest.]

The city election in April, I890, had the maintenance of the city's antisaloon ordinance distinctly in issue; and for particulars of that campaign and the vote in the case, see Chapter I 3 .

In the county election A. J. McLachlan won the race for district attorney; and Col. Banbury was re-elected county treasurer.

At City election April I I, I892, the vote stood:

For City Trustee-John S. Cox, Republican.................... 509

Oscar F. Weed, Republican.................. 485

Samuel H. Doolittle, Independent ............. 9

For five others, one vote each.

For City Clerk - Heman Dyer, Republican. ..................... 532

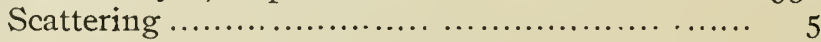

For City Marshal -John T. Buchanan, Republican ............... 506

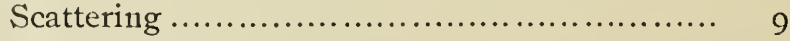

For City Treasurer-W. U. Masters, Democrat.................... 320

W. T. Vore, Republican................. 29 I

VOTE ON I,IBRARY TRUSTEES.

Chas. M. Parker, 525; O. S. Picher, 522; Sherman Washburn, 523; B. M. Wotkyns, 5 I 5 ; John W. Vandevort, 52 r.

This year C. M. Simpson, republican, of Pasadena was nominated and elected to the legislature; and J. DeBarth Shorb, democrat, was elected county treasurer.

I found published reports this year of two political meetings, republican on October 4, and democratic October 5, with lists of the men who were 
deemed sufficiently prominent and representative members of the two parties to be called to sit on the platform as vice-presidents; and I give these lists here as historic memoranda of accredited party leaders at that time.

\section{REPUBLICAN - OCTOBER 4, I 892.}

The meeting was called to order by J. A. Buchanan, president of the Pasadena Harrison club; and after music by the band, the following list of vice-presidents was read by the secretary of the club, Theo. Coleman :

Arturo Bandini, J. W. Scoville, J. W. Hugus, John McDonald, Prof. T. S. C. Lowe, B. M. Wotkyns, W. B. Rowland, Calvin Hartwell, Col. O. S. Picher, Mayor O. F. Weed, T. P. Lukens, M. H. Weight, Capt. A. Wakeley, Col. Chase, Capt. Geo. T. Downing, B. F. Ball, P. M. Green, Judge H. W. Magee, W. E. Arthur, M. D. Painter, Governor L. A. Sheldon, C. C. Brown, A. H. Conger, J. S. Cox, Thomas Banbury, Frank C. Bolt, S. Washburn, W. L. McAllister, J. W. Wood, H. J. Vail, M. L. Clark, H. H. Rose, W. H. Wiley, Wesley Bunnell, J. R. Greer, Jr., Rev. L. P. Crawford, James H. Cambell, Ben W. Hahn, C. A. Gardner, Col. J. M. Irvin, Geo. D. Patten, R. H. Williams, R. H. Knight, Fred Swift, Heman Dyer, N. S. Bangham, John T. Buchanan, W. S. Wright, W. R. Staats, W. S. Gilmore.

\section{DEMOCRATIC - OC'TOBER 5, I 892 .}

The meeting was called to order by W. U. Masters, president of the Democratic club, upon whose request W. D. McGilvray, secretary, read the following list of vice-presidents [Pasadena names only given] :

R. M. Furlong, W. C. Stuart, A. R. Metcalfe, Judge Enoch Knight, W. D. McGilvray, L. C. Winston, A. O. Bristol, Jas. Clarke, Dr. H. S. Slaughter, Dr. R. J. Mohr, J. B. Stoutenburgh, W. L. Wotkyns, A. J. Wright, Hon. J. DeBarth Shorb of San Gabriel, Hon. Geo. S. Patton of San Gabriel, Bayard T. Smith, George Hermann, C. F. Harris, Joseph Simons, Lucien E. Walker, H. C. Allen, Saml. Palmateer, Jas. Blatenburg, C. H. Ryan, A. Thorns, John Simons, Judge B. S. Eaton of South Pasadena, A.W. Armstrong, Ed. Kennedy, Peter Steil, Prof. C. H. Keyes, Dr. H. Sherk, L. C. Torrance, H. G. Bennett, W. T. Grimes, H. B. Belt, F. B. Colver, W. B. Scarborough, R. C. Guirado, A. R. Stoed, J. R. Matthews, J. C. Kays, M. P. Snyder, W. T. Martin, J. R. Pitts.

The presidential vote of Pasadena this year, I892, stood:

\begin{tabular}{|c|c|c|c|}
\hline $\begin{array}{c}\text { HARRISON } \\
\text { Rep. }\end{array}$ & $\begin{array}{l}\text { CLEVELAND } \\
\text { DEm. }\end{array}$ & $\begin{array}{l}\text { WEAVER } \\
\text { Popul't }\end{array}$ & $\begin{array}{l}\text { BIDWELL } \\
\text { Prohib. }\end{array}$ \\
\hline Precinct No. I :.................. 98 & 20 & IO & 38 \\
\hline Precinct No. 2 .................... 45 & 36 & 30 & 53 \\
\hline Precinct No. 3 .................. 103 & 45 & 32 & I 4 \\
\hline Precinct No. 4 .................. 84 & $3 I$ & I 4 & 12 \\
\hline Precinct No. 5 .................. I06 & 45 & $3 \mathrm{I}$ & 13 \\
\hline Precinct No. 6 .................... I 50 & 46 & I 8 & 28 \\
\hline Totals in city ................. & & - & - \\
\hline 686 & 223 & 134 & I $5^{8}$ \\
\hline North Pasadena..................... I I 6 & 32 & 25 & 32 \\
\hline South Pasadena.................... 64 & 37 & 14 & I 8 \\
\hline Alhambra .......................... I 24 & 68 & I 6 & 7 \\
\hline San Gabriel ....................... 66 & 83 & 4 & 2 \\
\hline Lamanda......................... 66 & 27 & 22 & 9 \\
\hline Sierra Madire..................... 67 & 29 & 8 & 4 \\
\hline
\end{tabular}


[I have given the vote of these six adjacent precincts also, because they are settlements historically within Pasadenaland, and the figures were ready at hand.]

At the city election on April 9, I 894, the vote stood as follows .

For City Trustee-John B. Cahill, prohibitionist................ I I 3

James Clarke, democrat.....................379

H. M. Hamilton, republican................693*

T. P. Lukens, republican...................762*

Peter Steil, democrat....................... I9I

Andrew J. Utley, populist.................. 53

Sherman Washburn, republican.............856*

For City Clerk - Heman Dyer, republican................ I054*

No other candidate for this office.

For City Treasurer-Henry C. Hotaling, republican...........846*

Philander G. Wooster, prohibitionist....2 10

For City Marshal-John T. Buchanan, republican...............905*

John S. Withiel, populist................... 62

The new officers took their places on Monday, April I6, I894; and T. P. Lukens was elected President of the Board of Trustees, or "Mayor" as commonly spoken of. [ January 2, I895, John S. Cox was elected president - then, in July a pair of twin boys were born to him!]

\section{MEN CHOSEN TO HIGH OFFICE.}

List of Pasadena men who have held State, County or National offices, or other public positions of high responsibility and trust: I 892 .

Col. J. BANBURY : assemblyman, I $885^{-86}$; county treasurer, i 888 to

ThOMAS BANBURY: director for sixth congressional district of the state agricultural commission. Appointed May 5, I891.

CHAS. W. BELL: representative of Los Angeles county at the World's Fair in New Orleans, September to December, I 884.

DR. EZRA S, CARR: state superintendent of schools from December I, I 875 , to January 5 , I 880 .

Mrs. Jeanne C. CarR: deputy state superintendent-same time. Member of state silk commission, I 884 to I 894 .

Dr. Wm. F. Channing: member administrative council of the World's Congress of Electricians - I892.

J. F. CRANK: assemblyman, I $88 \mathrm{r}-82$.

Z. DECKER: public administrator, I886 to I 888 .

BENJAMIN S. EATON. associate justice of Los Angeles county court of sessions, I854-55; district attorney, I855-56; associate justice again I 862-63. $\dagger$ [Judge Eaton was also city assessor of Los Angeles in I857, and city clerk, $x 863^{-64 .]}$

\section{*Elected.}

f"From the organization of the county in 1850 to the creation of the board of supervisors in 1852 , the court of sessions (consisting of the connty judge and two associate justices) administered the civil af fairs of the county, in addition to their ordiuary judicial functions." -Hisl. Los Angeles Co. I880, p.50. Ou January $\mathrm{I}, \mathrm{I} 880$, the court of sessious was supplanted by the superior court, as now in vogue. 
Thomas J. Fleming: county treasurer, i 893 to I 895 .

MANUEl, Garfias : county treasurer, $1850-51$.

P. M. GREEN : assemblyman, I879 to '8I.

Dr. John S. GRIFFIN : county superintendent of schools, elected June 7 , I856 ; coroner, I862 to ' 65 ,

C. F. HolDER : trustee of State Normal School at Los Angeles, 1890 to ' 92 .

COL. E. J. C. KEWEN : district attorney, I860-6I ; assemblyman I 863 to '65. [Col. Kewen had been attorney general of the State from December 22, I849, to August 13, I850, before he came to Los Angeles county and settled at our Pasadena "Old Mill.' ']

Prof. C. H. KeYES : president Throop Polytechnic Institute; member Advisory Council National Educational Association. I895.

Аввот Kinney : U. S. Indian Commissioner, I88 I to '83; State Forestry Commissioner, from May, I 886 to I 890.

ENoch KNIGHT: Register U.S. Land office at Los Angeles, I893-4-5, during President Cleveland's second term.

T. S. C. LowE: State Commissioner of Yosemite Park, I 892-94.

T. P. Lukens: trustee of State Normal School at Los Angeles, I 892-94.

H. W. MAGEE: state inspector of banking institutions, I $894-95$.

A. J. MCLACHLAN : district attorney, I890-92 ; congressman I895-96.

H. H. MARKHAM ; congressman, I884-1886; governor, I 8yo-94.

John MCDonaLD : commissioner of deeds at Pasadena for the States of Arizona, Illinois, Iowa, Massachusetts, Michigan, New Jersey, New York, Ohio, Pennsylvania, Washington.

E. T. Pience : principal State Normal School at Chico, I889-92; principal State Normal School at Los Angeles, I892-95.

DR. H. A. REID : member for Wisconsin of United States Sanitary Commission, I $86 \mathrm{I}-64$.

CAPT. D. R. Risi,EY: U. S. Marshal, 1884 to '88, during President Cleveland's first term.

H. N. RUST: Commissioner of Immigration, I886; U. S. Indian agent, I891-93; member and secretary of board of judges in department of Ethnology at World's Columbian Exposition, Chicago, I893.

J. DEBARTH SHORB : member at large of State Viticultural Commission. I 890-94; county treasurer, 1892-93. [Resigned, and Fleming appointed to fill vacancy].

C. M. Simpson: assemblyman, 1892-94; state senator, 1895 .

Gen. George Stoneman : governor, January, i 883 to January, i 887.

W. H. WILEY : State Agricultural Commissioner for 6th Congressional district, I892-94.

B. D. Wilson: U. S. Indian agent, $185^{2-53}$; member of county board of supervisors, I853, and I86I to I865; state senator, I855-57; and again 1869 to 1872 . to ' 95 .

John W. Wood, Ph. G.: member State Board of Pharmacy, I89i

WALDO M. YORK : judge of superior court, Los Angeles county, I 893 and r895. 
THE STORY OF THE POSTOFFICE.

For ten years after Pasadena's settlement by Americans it was commonly called the "Indiana Colony; " and it was more than two years after the date of settlement before a local postoffice was obtained; but none of the old settlers could tell with any certainty just when they began to have a postoffice of their own. I pursued the inquiry among them for nearly a year, and the nearest to any definite date I could get was, that Miss Jennie Hollingsworth (now Mrs. J. R. Giddings) remembered that she wrote a letter during the colony picnic in the old oak grove at Lincoln park on July 4 , I 876 , and there was no postoffice here then, for she had to send her letter to Los Angeles for mailing. For several months before a local office was finally obtained, young Morton Banbury, son of Col. J. Banbury, kept up a sort of "free delivery" service for all the lower portion of the colony. He was attending school in Los Angeles and rode back and forth every day on his own pony. The mail for these people all came to Los Angeles; and every day after school he called at the postoffice there for the colony mail, and distributed it on his way home to such families as lived on the line of his ride. He did this merely as a neighborly accommodation; and was as careful and anxious and painstaking to do it satisfactorily to the people served as if he had been getting a good salary for it. As the months wore on and the mail matter increased, the little kindness which he had set out to do for the neighbors became a serious burden of care and overtaxing labor, in addition to his daily ride of eighteen miles on horseback and his daily work to keep up with his classes; and he broke down under the strain, took sick, and died September 4, I877.

I did get a few random points in regard to the first efforts at securing a postoffice, but nothing definite enough to call "history" ; and at last I wrote to Washington explaining my dilemma and appealing for reliable information. In reply I received the following :

POST OFFICE DEPARTMENT,

OFFice of THE FOURTH ASSISTANT POSTMASTER GENERAL.

Washington, D. C., February 9, I895.

Respectfully returned to the writer, with the desired information attached :

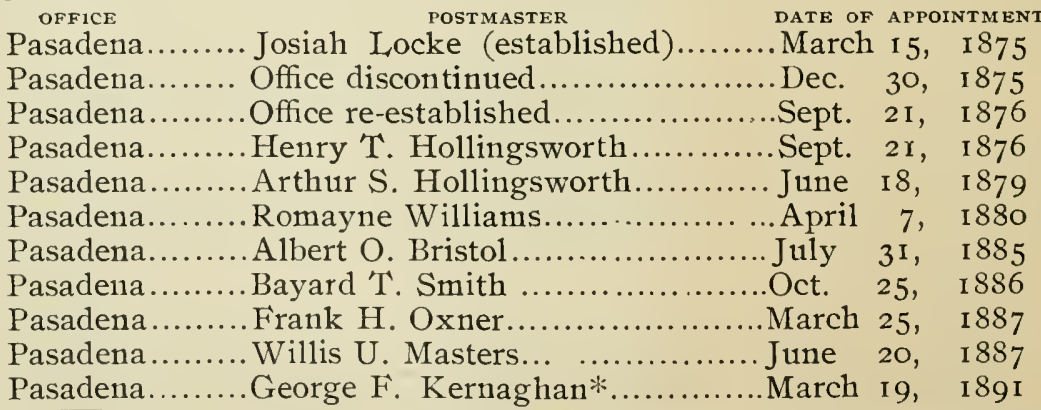


From the records, as will be seen, the office of Pasadena was first established March I 5, I875, and was afterward on December 30, I 875, Discontinued; and was re-established September 21, I876. The office was made third-class [appointment vested in the President] on the appointment of Albert O. Bristol, July 31, I885.

R. A. MAXWELL, 4th Asst. P. M. General.

The original colonists had set out to establish their business center in the vicinity of Orange Grove Avenue amd California street. [See oak tree cut, page 167.] The school-house was first built there, and the first two churches were in that vicinity. The name Pasadena was formally adopted by the colony Association on April 22, I875; but it seems to have been agreed upon in the petition for a postoffice prior to this action, for the date March 15,1875 , is given when the name first appears in the records at Washington. Josiah Locke (uncle to Seymour Locke, now a well-known business man of Pasadena), who was first named as postmaster, then owned and occupied thirty-five acres along the north side of California street where the Garfield school and Congregational church now stand, and up to Orange Grove Avenue. The postmaster's salary was set at twelve dollars per year. Mr. Locke declined to serve.*. No reports were made to the Department, for nobody else seemed willing to incur so much care and responsibility for so little pay; and accordingly the whole record at Washington was canceled, and Pasadena as a postoffice name was snuffed out.

Meanwhile the new settlement east of Fair Oaks Avenue had been developing rapidly; and L. D. Hollingsworth had erected a small building of up-and-down rough boards, making a room $20 \times 30$ feet, where McDonald, Brooks \& Co.'s office now stands-No. 7 East Colorado street. Here he opened a small store to accommodate the settlers, so they would not have to go or send to Los Angeles for every little purchase of family supplies. But a postoffice? Where was the self-sacrificing individual who would be willing to serve as postmaster for One Dollar per month? Young Henry T. Hollingsworth finally came to the rescue, threw himself in the breach and "filled a long-felt want." He was going to open a watchmaker and jeweler's window in his father's store, and so he consented to act as postmaster. Accordingly a new petition for mail service was sent to Washington, and Pasadena was revived or re-established as a postoffice, with H. T. Hollingsworth as postmaster, September 21, I876. D. M. Graham was then here as an invalid, and had taken to driving his two-horse buggy daily between the colony and Los Angeles, partly as an out-door recreation for his own health, and partly as an accommodation for the settlers and their winter visitors. And he took the contract to carry the mail on this new route, thus becoming the first official who ever made a mail delivery in Pasadena. Yet I

*Mr. Locke died at Indianapolis, Ind., March 5,1885 . He had been connected with several newspaper enterprises in his life; and in a biographical sketch of him the Indianapolis fournal said: "He spent a couple of years in California and planted an orange grove at Pasadena, which he sold but a few weeks ago [to $H$. W. Magee], the grove costing him $\$ 2,500$ and selling for $\$ 17,500$. He was for about a year in Chicago, as manager of The Advance [the Congregationalist paper]." 
found it impossible to learn the exact date or any particulars of this first delivery. Mr. Graham died in 1893 ; and Mr. Hollingsworth in 1895, is keeping a large jewelry store in Los Angeles

The postoffice being finally established at the Colorado and Fair Oaks corner instead of the California and Orange Grove corner, was a grievance to the original colony people in the latter vicinage.* Then in November of the same year [1876] the original colony school-house on lower Orange Grove Avenue was moved up to the new five-acre school lot given by B. D. Wilson just across the street from the Hollingsworth store. And this was another grievance to the Orange Grove people. [For fuller particulars, see chapter 9: "Annals of the schools".]

S. Washburn afterward owned the Hollingsworth store for awhile but was not postmaster. Romayne Williams clerked for Washburn, and became postmaster April 7, 1880; then he bought out the store business himself and put up a new building of his own - since known as the Williams Hall block, and itself a pantheon of historic associations. On February 27,1883 , he moved the store into his new building, and of course the postoffice went with it. In the old place there were only 27 postoffice boxes; in the new place there were 360 boxes. Pasadena had grown so rapidly as to justify this large increase; and Mr. Williams was always a man to keep full up to the front line of the procession - in fact generally a little ahead. In August, I 882, this had been made a money order office, while yet in the old building. When Cleveland became president, in 1885 , of course it was "innings" for the democrats. Pasadena had always had a republican postmaster; but now the time for a change had come, and A. O. Bristol, one of the only five democrats in the original colony Association, was commissioned postmaster July 3I, and took possession of the office September I, I885. During I 886 the business increased so much that it was found necessary to seek larger and better quarters for it. The Union of March 5, 1886, said :

"The Pasadena postoffice is doing a big business. Its money orders are over $\$ 60,000$ a year; its supplies for this quarter amount to $\$ 1,000$; about $\mathbf{I}, 000$ letters daily are received ; registry business last quarter, 234 packages sent and 258 received. 'The fine new quarters provided last Fall are already too small for the public, though large enough inside for the postal work ; and the 420 boxes (253 "call" and 167 lock) are insufficient for the demand."

March 15, 1886, the San Gabriel Valley Railroad first contracted to carry the mail between Los Angeles and Pasadena, this service having before been done by W. 'T. Vore's hack line, after D. M. Graham gave it up.

The estimates and allowances for postal service are made annually one year in advance; and hence there is no provision at Washington for such mail-bag booms in local postoffices as Pasadena experienced early in 1886. The allowance for clerk hire at Pasadena proved utterly inadequate to meet

*A new ipostoffice called "Hermosa" was established at corner of Columbia street and Sylvan Drive, Jan. 3,1883 , but afterward had the name changed to South Pasadena. [See Chap. 35.] 
the emergency. Bristol was a man of good grit; and he held on till he was completely snowed under with accumulations of mail impossible to be distributed, even with the extra help he had hired out of his own pocket; and his requests and bills for extra help were rejected at Washington. Then he quit - resigned suddenly by telegraph, and got out with a big fund of "experience ' in his head but some hundreds of dollars less funds in his pocket. The Washington authorities telegraped back, October 25, I 886, that Bayard T. Smith had been appointed postmaster, vice Bristol, resigned; so Smith took hold to win his spurs as a democratic official. But criticism and complaints filled the air, and there was a clamor for better mail service - many persons, as I often heard them myself, foolishly claiming that the trouble was all because the democrats had got into power again. Mr. Smith soon got tired of the "honors of office" ; and in self-defense he published in the Union of February 5, I 887 , an official statement, from which I make a few extracts :

"Funds availabie

Monthly

Salary at \$I, 400 per annum \$I I 667

Private contributions toward rent of office................. 4000

Money order commissions (available about six months after

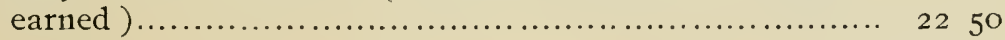

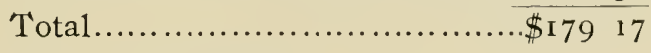

AVERAGE, EXPENSES.

Clerks' hire....................................\$I 7623

Rent for December and January................. 50 oo

Lights and fuel................................. I 8 oo

Sundry expenses............................... $6 \quad 33 \quad \$ 250 \quad 58$

Monthly deficit $\$ 7 \mathrm{I} .4 \mathrm{I}$. The public can hardly expect the postmaster to do more, under the circumstances."

But alas, the unfeeling public did expect more, and continued to upbraid the postmaster until the sweets of office soured and palled upon his taste; and on February 29, I887-only three weeks after publishing his financial dilemma and personal defense, as above, he resigned in favor of Frank H. Oxner, who had served as his deputy. So Oxner was appointed to fill the vacancy March 25, I887-but he died before his commission arrived.

Next, Willis U. Masters was appointed June 20, I 887 - the fourth democratic postmaster within two years. The new man went in with resolute zeal to redeem the credit of his party and administration, and give Pasadena such a mail service as her necessities and amount of business would justify. With Jacksonian grit he took the responsibility, and hired enough help to keep the office in good running order for a few months. But when the winter tide of tourist business rolled in, he too was swamped, and the breakers of mail matter rolled over him as ruthlessly as they had over his predecessors. And the Daily Star of December I3, I887, gave a report of the situation, from which I summarize the main facts : 
"The postoffice was not opened to-day. Back mail is piled all over the floor two feet deep. It is utterly impossible to do the postoffice work of Pasadena with the number of clerks allowed by the Postoffice Department. Since July I Mr. Masters had paid for clerk hire \$2,055 out of his own pocket to keep the work going on right, but could get no allowance for it at Washington, nor increase of clerks, and hence had discharged all his extra help - and here was the result."

As soon as the situation became known an impromptu meeting sent out a committee to raise funds to assist the postmaster, consisting of $\mathrm{T}$. P. Lukens, Geo. E. Meharry, B. W. Bates, A. F. Mills, I. F. Miller. They raised $\$ 350$ in two hours, which was increased to $\$ 500$ the next day. A vacant store-room was secured, piles of mail bags dumped into it, both hired and volunteer assistants were set at work, and in about a week the vast accumulation of back mail was assorted and distributed to its proper owners.

During December I 2 and I3, Washington was besieged with telegrams calling for the authorization of more postoffice clerks at Pasadena. Excongressman H. H. Markhan telegraphed to the Postmaster General about it. Col. W. A. Ray, chairman of Citizens committee, also telegraphed the Postmaster General. Prof. M. M. Parker, president of the city council, telegraphed to Gen. Wm. Vandever, then our member of congress. And Rev. E. I. Conger telegraphed to his brother, a member of congress, to aid us in the matter. Out of all this effort came at last some relief, and more clerical help was provided for the office.

In March 1888, the office was removed from its place on Fair Oaks Avenue into a larger and more commodious room in the Morgan block on south Raymond Avenue, where it still remains - I895. And at that time the extensive and improved box system, with Yale locks, and passage way or lobby on two sides, were put in nearly the same as now.

FREF DELIVERY.

The Pasadena Standard of July 6, I889, said :

"Free delivery of mail commenced Monday, July r. The carriers are : Capt. A. C. Drake, business portion of city north of Colorado street. L. T. Lincoln, business portion south of Colorado street. A. L. Petrie, mounted, northern outlying district. C. R. Dillman, mounted, eastern district. E. Watson, mounted, southern district. Drake and Petrie are old soldiers. 'The other three have been clerks in the postoffice."

The same paper in October said:

"During the month of September our free mail carriers delivered $38, s_{3} 8$ pieces of mail matter, and collected from the street boxes r r,62 r pieces."

And February 8, 1890 , it said again:

"The total receipts of the Pasadena postoffice in 1889 were $\$ 13,5$ r 9.28 . Total expenses $\$ 1$ I, O2 I.88. Leaving $\$ 2,497.40$ net revenue to the government."

During I 890 our postoff,ce matters went on smoothly under W. U. Masters headship, without any marked historic event to note. 
On April 23-24, I89I, occurred the visit of President Harrison and Postmaster General John Wanamaker to Pasadena. And Mr. Masters being both postmaster and president of the Board of Trade at the time, stood at the forefront of all the reception ceremonies in honor of the distinguished visitors. For full particulars of this event, see Chapter 16: "President Harrison Day."

Mr. Kernaghan had been appointed postmaster as Masters's successor, but had not yet taken formal possession of the office, and thus he stood as adjunct host of the Postmaster General. Very soon thereafter Mr. Kernaghan came into his kingdom, and during the year had occasion to make sundry changes. The Star of September 23, gave the following report:

"The improved postoffice is a wonderful advance over the old one and its neat appearance is a pleasant surprise to those who have not been keeping track of the progress of work there. The walls of the whole interior have been rekalsomined, the working room has been entirely partitioned off by glass frames extending from the top of the boxes to the ceiling; the departments have been rearranged, with a neatly enclosed corner for the $m$ oneyorder and stamp business; speaking tubes and call bells have beenr unfrom the postmaster's desk to different parts of the room; and the woodwork of the outer and inner divisions of the office have been revarnished. These improvements are made by the owner of the building, Mr. Morgan, under the superintendence of Mr. Staats.'

October I9, the paper again reported thus:

"By reference to the annual report of the postmaster-general for the year ending June 30 , I 890 , it will be seen that only two offices of the presidential class were not self-sustaining--the gross receipts did not pay the expenses. Of these two the Pasadena office was one. We are informed that no change for the better has taken place in receipts and expenses for the year ending June 30, I891"

It then goes on to mention that the free delivery district had been reduced, two carriers had been dismissed, and clerkhire cut down until the remaining clerks were "overworked and underpaid," in the efforts of the P. O. Department at Washington to get itself onto a paying basis. The Star of December 24, contained some statistics furnished by postmaster Kernaghan which are worth preserving for future reference and comparison, hence I quote them here :

Receipts from sale of stamps, stamped envelopes, etc.,

for the fiscal year ending June 30 , '9I I............ \$I I , 540.83

Total number of pieces of mail matter handled by the carriers during the fiscal year ending June 30 , I89I,

Total handled during year ending June 30 , $1890 \ldots \ldots . . .$.

Number of letters dispatched from this office during the month of July, I89I, 29,7 II. During the month of October, I89I, 35, I 7 I.

The receipts of the office for the months of September and October of this year, as compared with the corresponding months of last year, show an increase of $33^{1 / 3}$ per cent. 
The mounted carriers of this office travel upwards of 9,400 miles each per year, while the foot carriers each cover a distance of about 4,000 miles in the same time.

In January, I 895, the Los Angeles Times published a tabular exhibit of the business of the Los Angeles postoffice for the years i 890-91-92-9394, showing the steady annual increase. Mr. Kernaghan made a corresponding exhibit of the Pasadena postal business for the same years, and the result showed our annual increase to be 17 4-5 per cent. greater than theirs. From some private memoranda in the office I gleaned the following statistics worth preserving:

Stamps sold in December, I $892 \ldots \ldots \ldots \ldots \ldots \ldots \ldots \ldots \ldots$ II,7 6 to to

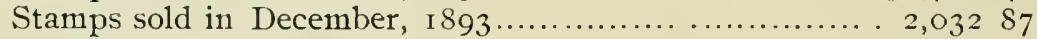

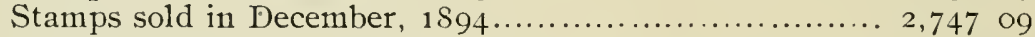

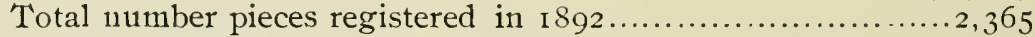

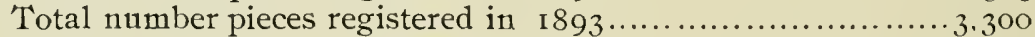

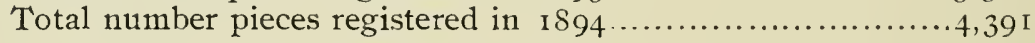

As an illustration of how the registered package business inundates the postal service for a week or two before the Christmas holidays each year, Mr. Kernaghan gave me a footing of this business during six working days, from December 16 to 22 inclusive, for three successive years, as follows :

Pieces registered from December I 6 to 22 , in $1892 \ldots \ldots \ldots \ldots \ldots . \ldots 290$

Pieces registered from December i 6 to 22 , in I $893 \ldots \ldots \ldots \ldots \ldots . \ldots . \ldots 62$

Pieces registered from December 16 to 22 , in $1894 \ldots \ldots \ldots \ldots \ldots . . . .335$

August I 5, I 894, a branch office called Station A was established at North Pasadena, with David McLeod as chief clerk in charge.

The Pasadena postoffice service in 1895, Geo. F. Kernaghan being still postmaster, has 744 lock boxes and thirty-six drawers. There are five carriers, two afont and three mounted; and four inside clerks. The foot carriers traverse from fifteen to eighteen miles per day, and the mounted ones about thirty miles. The total allowance for salaries is now $\$ 3$, ooo per annum.

\section{CHAPTER XII.}

THE TEMPERANCE QUESTION-First Saloon in the colony.-The historic anti-saloon agreement.-The city's prohibitory ordinance.

\section{THE TEMPERANCE QUESTION.}

The original colony settlers of Pasadena were mostly of a class who wished to establish the moralities and decencies of a Christian civilization as the dominant sentiment and practice in their community ; and they considered a saloon or any place for the beverage sale of liquors, as wholly inconsistent with and contrary to that purpose. But in spite of this sentiment, some time in 1875, M. Rosenbaum, a native of Hamburg, Germany, started a little store on Orange Grove Avenue, about where J. W. Wood's 
pretty cottage now stands, and along with other goods kept liquors for sale. This aroused such a storm of indignation and energetic protest that he was soon compelled to give up the business; and the building was afterward used for a number of years as a Chinese wash house. That first attempt to establish the liquor trade here brought forth the formal and official action of the colonists, as reported in Hon. P. M. Green's sketch of Pasadena history written for the Farnsworth pamphlet of 1883 , from which I quote :

"The San Gabriel Orange Grove Association, at a meeting of the stockholders held on the I 7 th day of February, 1876 , by a unanimous vote adopted the following resolution :

"Resolved, That the members of this Association are opposed to the sale of liquors upon the Association's grounds,"

thus placing the seal of its condemnation on the traffic, and doing all that it could, in its corporate capacity, to mould public sentiment and give character to the community on this subject."

There was no further trouble on the saloon question until i 884 . During this year one Jerome Beebe, erected a two story frame building on E. Colorado street (now No. 47 and occupied by E. H. Lockwood and others), professedly only for a billiard hall, with tobacco and cigar counter included. But in a few weeks after opening up for business he put in a stock of liquors also, in spite of the fact that T. P. Lukens had gotten up a respectful request, and every business man in town had signed it, that he would not start a liquor saloon in Pasadena. He said his business wouldn't pay without a stock of liquors, and he had got a license and was going to do a lawful business. The matter soon became notorious; and the liquor interest of Los Angeles for awhile took special pains to send their tourist friends out this way, to patronize the Pasadena saloon and help Beebe to hold his grip here, in spite of the strong local sentiment against it. This was the state of affairs in October and November, when H. R. Case went to Los Angeles and got some large handbills printed calling a mass meeting at Pasadena on November IO, I884, to consider what should be done or could be done to get rid of the liquor saloon recently started there. These bills were posted up through Pasadena and vicinity; and by the time the day arrived the matter had warmed up so much that Beebe was pretty badly scared, and kept himself armed with two loaded revolvers, swearing that he would shoot on sight anybody who should attempt to interfere with his business. He also procured a deputy sheriff to be sent up from Los Angeles for his special protection on that mass meeting day; and, to guard against a night raid of those wicked temperance people to destroy his stock of liquors, he kept an armed companion to sleep with him in his saloon building. At last the day arrived and a large gathering of people took place, whose proceedings I here quote from a report published in the Valley Union of November I5, 
I 884 , then edited by J. E. Clarke and J. W. Wood; but I have added some explanatory remarks in brackets :

"A saloon having been started in Pasadena, against the unanimous protest of every business man or firm in the place, a mass meeting was held on the subject November IO, 1884 , in the public school grounds [nearly where the Eldridge block now stands]. B. F. Ball was made chairman, and C. B. Ripley secretary. Rev. S. S. Fisk, pastor of the Baptist church was called for, who responded by brief remarks, and moved that the sentiment of the people of Pasadena here assembled be taken in regard to the saloon question. Pending a vote upon the question as to whether the people of Pasadena desire a liquor saloon in their midst, speeches were made by Rev. J. B. Britton, Rev. L. W. Hayhurst, Calvin Abbott, Rev. A. W. Bunker, Hon. P. M. Green, Mr. C. C. Thompson, Col. J. Banbury, Rev. Williel Thompson, J. W. Wood; also a letter was read from H. W. Magee, who could not be present.

"The following set of resolutions were offered by Rev. A. W. Bunker, and unanimously adopted, and a copy ordered to be furnished to the Valley Union for publication; also that the editor of the Union forward a copy to the Board of Supervisors of Los Angeles county ; also voted that a copy of the resolutions be taken to the proprietor of the saloon with a demand that he stop the sale of liquor in Pasadena at once. It was voted that a committee, consisting of Rev. S. S. Fisk, Rev. A. W. Bunker, and Col. J. Banbury, and as many ladies as would accompany them, take the resolutions to the saloon-keeper at once, and report to the meeting his response. Mrs. Russell Case, Mrs. Mary C. Lord, Mrs. O. S. Barber, Dr. Rachel F. Reid, and others accompanied the committee.

" WhEREAS, Many of us citizens of Pasadena, procured land and built our homes in this settlement because it was a temperance community and we were led to believe that it would always continue thus ; therefore,

"RESOLVED, That we regard the opening of this liquor saloon, under the circumstances, as a base injustice and an unmitigated insult to us, the citizens of Pasadena. That words utterly fail to express our contempt for, and righteous indignation against the party or parties who have so deeply wronged us in disregarding our desires and trampling upon our rights, and for all who assist or support them in their nefarious work. That, as lawabiding citizens, we demand of this State such a change in the laws of the commonwealth as will protect us and other communities from the curse of the liquor traffic, where this traffic is not desired by a majority of the people of that community. That we will use our influence and cast our ballots only for such men, irrespective of party, who favor and will work for the enactment of such laws.'

"While the committee were absent, H. N. Rust, Mrs. Sigler and others addressed the meeting. It was voted that the sense of the meeting was in favor of incorporation; and it was also voted that a committee of five be appointed by the chairman to take steps toward incorporation.

The chairman appointed H. W. Magee, Col. J. Banbury, H. N. Rust, S. Washburn, and J. W. Wood as such committee.

"The chairman of the committee to wait upon the proprietor of the saloon reported that the resolutions were read as directed: and that he replied that he was selling liquor according to the laws of the land, and that he should continue to do so; he would, however, sell his whole property 
and not engage in the saloon business again, for the sum of $\$ 7,000$. It was voted that the meeting did not want to buy saloons at any price. It was voted that a committee be appointed to wait upon Mr. Stamm and Mr. Nay and request them to discontinue the sale of wines, beer and liquors, as the people of Pasadena were opposed to their sale in any form. It was voted that the people organize for mutual protection. Mr. B. F. Ball was elected president of such organization, Dr. Rachel F. Reid vice-president, and Mrs. Russell Case secretary." [Mrs. Case is better known as Miss Florence Royce, who was for seven years a favorite teacher in the Central school of Pasadena.--Eiv.]

The Mutual Protection Association mentioned in the above report appointed an executive council of thirty business men, with a committee from the Woman's Christian Temperance Union as co-laborers. For several months meetings were held twice a month in the Library Hall, to confer on ways and means. Committees were appointed from time to time to ascertain from lawyers in Los Angeles what possible legal process could be taken to rid Pasadena of its saloon pest. C. B. Ripley, Geo. A. Swartwout, C. W. Abbott, Dr. H. A. Reid, Martin Mullins, and Dr. Lyman Allen served in this special work at different times. And Mr. Swartwout especially procured citations of law enough to make a book of themselves; but there was nothing found in California law to help Pasadena a particle in her desired riddance until she should become an incorporated city. After making all these efforts, and finding no resource at law, a document was prepared in March, eventually signed by 272 voters and taxpayers, [ten more names were added later] sixty-three of them being business men or firms of the village, and published with all the names attached, both in the Valley Union and in a circular, June I2, I 885 , reading as follows :

\section{AGREEMENT.}

"We, the undersigned, citizens of Pasadena, realizing that the indiscriminate sale of intoxicating liquors in our midst depreciates the value of our homes, retards immigration, injures our business interests, endangers our lives and property, leads our young men and boys into habits of vice and crime, and lowers the moral tone of our society.

"THEREFORE, We declare ourselves opposed to this traffic in our midst, and in favor of using all lawful means for its suppression; and to this end

"We agree that we will not patronize or in any way give support to any person who is engaged in the indiscriminate sale of liquors in Pasadena, and that we will not, knowingly, employ, or retain in our employ, or in any, manner lend support to any person who patronizes such traffic in our midst."

Copies of the agreement were circulated by a committee consisting of Mrs. Mary Case, Mrs. S. Townsend, Dr. Rachel F. Reid, Mrs. M. C. Lord, Dr. Lyman Allen, Amos Wright and C. M. Skillen. Copies of it were also kept for signature at the Valley Union office, at the Pasadena Bank, [now First National], and at the Free Library. While the work of procuring signatures was going on, the Valley Union of March 27th published the following statement with regard to it : 
"For ten years this colony had no liquor saloon, no criminal record, and no paupers. And the practical business object of this anti-saloon agreement is to keep out of our midst that class of men who would spend their earnings at the saloon, thus sustaining the nuisance here, with all the crimes and other evils that naturally occur at such a place or by reason of it, and leave their families to be supported by their industrious and sober neighbors. One hundred and sixty-two of our well-known citizens and leading business men have already signed this anti-saloon agreement, and it is desirable that every man among us who is willing to stand with them on this matter should add his name to the list. All who refuse to sign it will, of course, be understood to stand in favor of having a saloon here."

For a while this seemed to be effective; but Beebe was sustained by his Los Angeles backers, * and also by a few men in Pasadena, probably twenty in all, who pretended that he was being persecuted, or for various reasons had refused to sign the "Agreement," and who began to decry it as a boycott." Some who signed it entirely disregarded its practical application, while others lived up to it in good faith; $\dagger$ though population was changing and increasing so rapidly that the matter became every week more difficult, for the great historic " boom" was then already beginning to blow up a few preliminary bladders. Col. Banbury was this year elected to the legislature; and a local option bill was prepared here by T. P. Lukens and others and sent to him. He introduced it in the Assembly, so as to have a law by which communities that were strongly opposed to saloons, like Pasadena, might vote them out; but it was received with levity, referred to committee on public morals, and never heard of again. This was February I3, I885; and it was entitled "A bill to prohibit the sale of liquors within 2000 feet of any school-house or church in California outside of any incorporated town or city." Penalty, fine from $\$ 50$ to $\$ 500$, or imprisonment twentyfive to 250 days, or both.

Meanwhile the "boom" crowded along and swept everything else into its rushing stream. In August, I885, a duly framed, legally signed and formal petition for Pasadena to be incorporated as a city was laid before the county board of supervisors; yet it was not until May I3, r886, after nine months of dickerings and bickerings and technical delays, that the order for incorporation was finally granted, and June 7 th, set for an election to be held within the prescribed city boundaries on the question of incorporation, and choosing of city officers. And all this time the saloon had been gaining a stronger foothold by the great influx of a drinking class of mechanics and laboring men who flocked to Pasadena in swarms-drawn by the high wages paid, and the great demand for labor in the booming rush of new buildings, street gradings, water and gas pipe layings, cement walk construction, etc.

* "It is claimed by the proprietor's mouth-pieces that he is well backed by the whisky interests of Los Angeles and elsewhere."-Editorial in Valley Union of November 15, 1884 .

$\dagger$ "It is said that more than fifty workmen have been discharged from the Raymond hotel job at difterent times for drinking liquor or patronizing liquor saloons." - Valley Union, February 5, ISS4. 
When the election took place, incorporation carried by 29 majority. There were eight candidates for city trustees, and the five who received the highest number of votes were the ones elected, which proved to be two democrats and three republicans. When the time came to act on the saloon matter they licensed it, but fixed the fee at the highest rate which they thought would be paid without making a legal contest $-\$ 100$ per month. And thus a full-fledged dramshop went on in Pasadena, with the formal consent of its city authorities. The original saloonkeeper, Beebe, having been engaged to be married, his prospective wife refused to marry him while he remained in that disreputable business (so I was informed), and therefore he sold out to a man named E. I. Campbell, who paid his \$Ioo license promptly each month, and pushed the business for all the money there was in it. He employed two sets of bar men and kept the thing open continuously, days and nights and Sundays. It became rumored that he was the son of a Baptist preacher; and a committee of W. C. T. U. ladies went to labor with him, appeal to his moral nature, etc., and show him what an evil business it was, and so persuade him to give it up. He received them most politely, listened with gracious composure to their plea, and then replied: "Ladies, you cannot tell me anything new about the evils of this business. I know all about it. I could give you blacker points in it than you ever dreamed of. But I am doing a laweful business. I have both a city and county license, and United States tax permit. I am not in the business for the fun of it, nor because I like it, but because I can make more money at it than anything else." The ladies retired, with some new ideas about "moral suasion" for saloon keepers.

Much talk was indulged in, in a loose way, against the saloon. But no definite action was taken again until January 23, I887, when I find the following record in the Y. M. C. A. secretary's book which is still preserved:

"A meeting was held this Sunday afternoon in Williams Hall, at the close of the Y. M. C. A. meeting. C. B. Ripley was chosen chairman and Geo. Taylor, secretary. Remarks were made on the temperance work by several speakers; and 56 of those present signed a petition to the city council, offered by Stephen Townsend, to abolish the saloon. Voted that a mass meeting be held in Williams Hall next 'Thursday evening, at 7:30 o'clock (January 27). The chair appointed Frank Wallace, S. Townsend and P. G. Wooster, a committee to arrange for this meeting. On motion it was voted that the following committee be appointed to ascertain and report what can be lawfully done towards the suppression of liquor saloons in our city * * and to report at the mass meeting :

Dr. H. A. Reid, of the Congregational Church.

Stephen Townsend, of the Methodist Church.

C. W. Abbott, of the Friends Church.

Geo. Taylor, of the Baptist Church.

Geo. A. Swartwout, of the Presbyterian Church.

The Valley Union of January 26, made a brief report of this meeting, 
and from it I quote a few additional points: "Remarks were made by perhaps a dozen different persons on various phases of the problem, and finally a committee was appointed to ascertain and report what can be lawfully done toward the suppression of liquor saloons in our city, and to counsel and cooperate with our city authorities for the abatement of this great public evil. * * A general mass meeting was called for Thursday (to-morrow) evening, at Williams' Hall, to hear a report from the committee. 'They have already in hand the result of test cases in the supreme court from Los Angeles, Riverside, Butte county and other places, besides opinions from high legal authority on other points. Also, Mr. Hardy, mayor of the city of I,incoln, Nebraska, will be at the meeting and give the experience of Lincoln, Omaha and other cities with the famous 'high license law' of that state."

['The fact was, Dr. Reid had been already at work on the matter, collecting court decisions, copies of ordinances, lawyers' opinions, etc., with the knowledge and co-operation of F. J. Culver, general secretary of the Y. M. C. A.]

The mass meeting was held as proposed, and the hall packed full, Col. O. S. Picher acting as chairman. A full report was published in the Union of January 29. Dr. Reid for the committee presented the results of legal contests with the saloons in Butte county, and city of Los Angeles, and at Riverside-all showing that the courts were against them, and that they could be outlawed. Yet this meeting resulted chiefly in talk, and an enlarged sanction to the continuance of the Anti-Saloon Committee, for whose aid a collection was taken, amounting to $\$ 44.65$. The chairman of the committee had prepared a schedule of five specific inquiries, covering every possible method of dealing with the liquor traffic under California law; his intention being to secure eminent legal counsel upon all these points, as the basis of the future work of the committee.

On the ensuing Sunday evening [January 30] a vast congregation assembled at the Methodist church to hear a temperance discourse which had become somewhat famed as "Dr. Bresee's hyena sermon." At its close some resolutions were adopted, and a committee was named, consisting of Dr. Reid, S. Townsend, Dr. Wm. Converse, Chas M. Parker and Rev. A. W. Bunker, to carry out the purpose of the resolutions. Before leaving the church this committee held a meeting and formally consolidated with the committee appointed at the Williams Hall meetings on Sunday and Thursday previously, and named Dr. Reid chairman of the joint committee.

Now it should be noted that the city attorney, N. P. Conrey, in common with a majority of lawyers at that time, held the opinion, and so advised the city council, that there was no law in California under which they could enact a prohibitory ordinance in Pasadena; and the Pasadena Star [H. J. Vail, editor] thrust this doctrine continually into the face of its readers, thus prejudicing them against the efforts of the Anti-Saloon committee. Dr. Reid took his five questions to ex-Lieut. Gov. Mansfield, who had been a 
member of the State convention which framed the present constitution of California. He said there was no doubt as to the city's right, under Article I I, Sec. I I of the constitution, to abolish saloons or any other evil thing, by a proper exercise of the city's police power; but as he could not take time then to prepare a brief on the questions of law submitted, he recommended Williams \& McKinley, who he said, were the best posted on that subject of any law firm in California. Dr. Reid then went to them, got points of instruction, and engaged them to prepare a full professional brief on the five inquiries submitted. These things he reported at the second mass meeting in Williams Hall. The next historic step in the case will best be seen by the following extract from the Pasadena Union's report as published at the time :

"At a very large meeting in the new Methodist Church on Sunday night, January 30 , a committee was appointed to take measures for bringing the saloon question before our city trustees in the best way possible to secure their prompt action. Monday morning the chairman of the committee went to Los Angeles and prepared under advise of good legal counsel a form of petition which covered only such ground as is within the recognized and established police powers of municipal incorporations. At $2 \mathrm{p} . \mathrm{m}$. the committee met, and by 9 o'clock 'Tuesday morning the petition headings were in the hands of canvassers to solicit names.

"Saturday morning, February 5, the committee waited on the City Fathers with the following documents:

\section{To the City Board of Trustees of Pasadena, in regular session, February 5, I887:}

GENTLEMEN :-We appear before you as a committee duly appointed at a mass meeting of citizens of Pasadena, and bearing a petition properly signed by over 500 adult male citizens or taxpayers of this city. We also present herewith the legal opinion, with full citation of cases, court rulings, standard legal authorities, constitutional powers and statute law upon which our petition is based. And we respectfully request that you refer the matter of this petition, together with the legal opinion and authorities accompanying it, to your city attorney, with instructions to prepare an ordinance in accordance with the prayer of petitioners and lawful procedure in the case, and report the same at your next regular meeting.
H. A. REID,
WM. CONVERSE,
Chas. M. PARKER,
A. W. Bunker,
G. A. SWARTwOU', $\}$ Committee.

"The list of petitioners made a roll measuring fourteen and a half feet in length, mostly with double column of names as signed. At the head of the roll was a paper containing twenty or thirty names which had been taken from a canvasser by a saloon man and torn into shreds. It looked like a reliquary battle-flag of the G. A. R.'"

The list of 540 signatures was a!l printed in double column alphabetical order, so that every man stood up to be counted. The petition was received, placed on file, and Saturday, February 12, at 9 o'clock, set for a further hearing. Meanwhile a subscription paper pledging funds to meet litigation 
expenses if the ordinance should be contested, was signed to the amount of $\$ 6,680$; and at the next hearing this was presented. But the council refused this, and required that the actual cash, or legal and collectible promissory notes, should be deposited in bank as a guaranty of funds, before they would venture to pass such an ordinance.

The committee next prepared promissory notes, payable in ro per cent. installments, and went resolutely at work to comply with the requirement of the council. February 16 , a meeting was held in the parlor of the Pasadena National Bank (Mr. Swartwout, the cashier, being a member of that committee), and Dr. Wm. Converse, a director of the bank and member of the committee, was elected treasurer, to hold the committee's funds and pledge-notes in trust, subject to its order. February 19, they again appeared before the council, exhibiting lawful promissory notes amounting to $\$ 5,935$, with Io per cent. of the amount already in bank subject to the committee's order. It seemed then, that with 540 voters and taxpayers petitioning for such an ordinance, and nearly six thousand dollars of cash or notes in bank to relieve the city from any costs of litigation arising from it, there could be no further excuse for refusing to pass the ordinance as prayed for. But no, it was not so. Two members of the council, E. C. Webster and R. M. Furlong, both "anti-sumptuary" democrats, were somehow interested in the then new Carlton Hotel, which was to be a "first-class" hotel, very high toned, etc., and they must have a clause granting this "first-class" hotel the right to serve wine or beer with meals. So here was another hitch. But Dr. Reid had already submitted this very point to Williams \& McKinley; and they had replied :

"Do not put in a clause permitting hotels or restaurants to furnish liquors at table. That would leave the way so open and easy for evasion that it would be impossible to carry a case to conviction in the courts, on account of the endless technical questions that could be raised. It would thus defeat the whole object and intent of the law."

They had said, however, that " there was as yet no ruling of California courts on this point; and it would probably be impossible to get a California jury to convict on it. Hence they would not be willing as attorneys to take a case into court that was based merely upon such a violation as the furnishing of wine or beer when called for with a meal at a hotel. Nevertheless, if you put in a clause giving this privilege, you might just as well abandon your whole project of prohibiting the liquor trade, for you never could enforce it."

The full board of city trustees, with city clerk, city marshal, city attorney, and the committee authorized to represent the 540 petitioners, were all present; and after considerable further questioning and discussion on this matter it was finally agreed upon by all that the ordinance should be passed just as prayed for, without any excepting clause for hotels; but that no 
arrests should be made for the furnishing of wine or beer with meals at the Carlton hotel. This was all and the only "concession" ever made or agreed upon in regard to this matter, although contrary assertions were publicly made through all the years later by parties seeking to break down the law ; for this special agreement was not made public at the time, being only known to those present and a few others who happened to be in some way personally interested in it. It should be noted that this was on February I9, r887; and it was not until October $3 \mathrm{I}$-nearly nine months later-that the California Supreme Court decision was rendered, fully sustaining the ordinance just as it read when passed. And then, December 5, of same year, the United States Supreme Court rendered its decision in the celebrated Kansas cases, sustaining most explicitly and to the fullest extent every point of prohibition contained in the Pasadena ordinance.*

The committee urged the immediate passage of the ordinance, because they had knowledge of three additional saloons already planned for in Pasadena, and it was earnestly desired to let these parties know that if they did start such places they were buying a law suit in advance. But objection was raised that E. I. Campbell already had a license from the city which did not expire until May I,-over two months yet; and if the ordinance was passed now, he could sue the city for breach of contract, loss of trade, depreciation of property, etc., and recover damages from the city-[for the "compensation" doctrine was now boldly affirmed by the liquor interest everywhere, although it was completely overruled by the United States Supreme Court, December 5, 1887.] H However, the council was finally prevailed upon to pass the ordinance, but have it not take effect until 6 o'clock A. M. on the first Monday in May, as Campbell's license would then have expired. So this was done, and the three new saloon projects were thus headed off.

When the ordinance went on record as duly and lawfully enacted, little Pasadena had boldly bearded the great whisky lion of California in his den ; and soon the air was full of ominous growlings, and threats of what direful things would happen to the youthful city. The newspaper articles and other documents on the subject would make a law-library volume of themselves. The law's delays and uncertainties from the time of enactment of the ordinance in February till the decision upon it by the Supreme Court on October $3 \mathrm{I}$, gave an open field for controversy; and the chairman of the committee found it necessary every two or three weeks to publish a report of the progress being made, in order to satisfy the friends of the ordinance, and to keep some from being disheartened by the confusing fallacies, soph-

*See Mugler vs. State of Kansas, printed in SuPreme Court Reporter Vol. 8, No. ro, January 23, 1888. Pages 273 to 306.

tThe Pasadena Star of December 17, 1887, took issue with the U. S. Supreme Court on this matter, just as every liquor trade journal throughout the United States had done; and the editor boasted that he had maintained the "compensution" doctrine in Iowa, as he did also now, in spite of the contrary rulings of both State and United States Supreme Courts. 
istries, and predictions of failure cast against it both openly and covertly by its enemies. From one of these reports dated April 5, 1887, and published in the Pasadena Union, I quote the following passages which show something of the situation then .

"But sundry special threats have been circulated which it may be well to report.

"While the ordinance was pending a threat was reported as coming directly from the Los Angeles Liquor Association's attorney, that he would break down our city charter - show in open court that Pasadena had never been lawfully incorporated - that all her municipal acts were null and void - and thus remand her to the sovereignty of the county board of supervisors again. This, he said, "would knock the stuffing out of all her damned foolishness on the liquor question." This idle boast fell flat and limp, as a drunk man falleth.

"2d. They would prosecute those who pledged money in the case for offering a bribe to the city trustees. This little threat was a child of beermug wisdom, and died of froth on the brain.

" $3 \mathrm{~d}$. They would prosecute for damages every man who signed a pledge of money to enforce that ordinance, as being engaged in a conspiracy to destroy the business of a fellow citizen and drive him out of town. This threat got up a little scare for one or two days; but six men who had signed for $\$ 100$ each, said they would make their pledges $\$ 500$ right away if the liquor men would only start in on that game. They didn't start.

" 4 th. They will keep on selling liquor in spite of the ordinance against it, and then see what the city will do. This is the latest word from the whisky camp, and is probably just about what they will do.

"Of course it does not rest with the saloon keeper here. He is a mere figure-head, and will have to do whatever the liquor organization at Los Angeles decides they had better do in this particular case. We know full well the David-and-Goliah nature of the conflict. It is little Pasadena against the entire liquor interest of California; for if Pasadena can drive the dram shop out of her limits, there are a hundred other towns in the State ready to take the same step at once. Our people are not going it blind. They have counted the cost; they have planted their battle-flag, and stand firm and steady in solid square around it, ready for the enemy's attack in front, flank, or rear."

Of course, when the first Monday of May arrived, Mr. Campbell went on with his saloon, in defiance of the law. He was arrested, tried in the Pasadena police court, convicted, and sentenced to $\$ 100$ fine, or imprisonment roo days. C. N. Terry, judge. He appealed his case to the superior court at Los Angeles, and there it hung for several weeks. The committee had engaged Williams \& McKinley to carry the case, as attorneys for the people, through the superior court and supreme court for $\$ 1,000$; and after this was all agreed upon, they showed their faith in the case, in opposition to the opinions of a large majority of the Los Angeles lawyers, by voluntarily giving Dr. Reid a written agreement, that if their position on the right of the city trustees to prohibit liquor saloons was not sustained by the 
supreme court, they would relinquish $\$ 500$ of their fee. Reardon \& Daly were attorneys for the saloon-keeper. They talked of great confidence in their case, and other lawyers freely expressed the opinion that "the prohibitionists would get beaten out of their boots ;" yet in spite of this they fought shy and pursued a dallying policy, as the following correspondence shows :

Dr. H. A. RËID,

Los Angeles, CAlı, May 26, I887.

Dear Sir :-We presume you think we are making slow progress, and you are certainly right in that presumption. We have been camping with those fellows from day to day until we are out of patience. They keep promising to go into court, but always have some little thing which they want done yet. We have notified Reardon \& Daly that unless they take the matter into Court by to-morrow noon we will consider all stipulations at an end and take our course in the matter. If they do not proceed we will notify you and the marshal, and let the war go on. Our idea will be to put him into jail and keep him there until released by legal process. We will write you as soon as we know result.

Yours,

WILLIAMS \& MCKINLEY.

But the very next day the following note was sent: "We got our habeas corpus case disposed of pro forma in the Superior Court this morning. We have had a great amount of trouble and annoyance in getting those people to do anything, but they came to time at last.

W. \& McK."

The case now went to the Superior Court ; but that court refused to act upon it until it had had a full hearing in the Los Angeles Superior Court, and so sent it back with an order for Judge Wm. A. Cheney to hear the case. His decision, rendered July 7,1887 , * fully sustained the law. The case then went to the supreme court again ; and this body waited their full limit of time, ninety days after hearing, before rendering their decision. But when it came [October 31, I887], the whisky lion of California siunk back into his den with a very large flea in his ear, for six out of seven of the supreme judges agreed that the Pasadena ordinance was good bed-rock law under the constitution of California, and also of the United States.

The Pasadena saloon had been running in full glare all this time, pending the decision; but when the result was reported by telegraph the proprietor did not wait for official notice to be served upon him. He closed the saloon at once, packed up his outlawed liquors and bar fixtures and moved out of town before the order of the supreme court could reach the city officers. A great mass meeting to give thanks and rejoice over this signal victory was held in the Methodist Church ; and Pasadena then stood as the first and only town in California which had driven the liquor trade out of its borders by legal process, fought and sustained through all the courts. The committee now deemed its work done; and from a brief running sketch of the whole matter in the editorial columns of the Valley Union, I quote a few paragraphs worthy of permanent historic record :

* The arguments on the case were heard June 27 , and again June 30 . 
"The Executive Committee which had charge of the work on behalf of the citizens of Pasadena of outlawing liquor saloons has finished its work and formally disbanded, as shown by the following resolutions adopted at their meeting on November i 8, I887:

WHEREAS, The special object and purpose for which we were constituted an Executive Committee on behalf of the citizens of Pasadena has been fully and successfully accomplished, and funds enough to meet all financial obligations incurred by us in carrying on our work have been collected, therefore,

Resolved, That the chairman is instructed to pay the balance of all claims by proper draft on the treasurer, and to return the Indemnity Pledge notes to their respective signers. [See list below.]

Resolved, That all funds remaining in our hands as a committee be left in charge of $\mathrm{C}$. W. Abbott, to co-operate with the city officers in securing the enforcement of the anti-saloon ordinance.

Resolved, That we now formally dissolve our organization and cease to exist or be any further in vogue as such committee.

\section{LIST OF THE INDEMNITY NOTE SIGNERS.}

$\begin{array}{lll}\text { NAME. } & \text { NO. OF AM'T. NOTE. AME. } \\ \text { NOTE. }\end{array}$

A $\mathbf{M}^{\prime} \mathrm{T}$.

Abbott, C. W ............... 2

Allen, Lyman.............. 3

Allen, E. B …........... 72

Allin, John................. 47

Arnold, Delos.............. 7

Ball, B. F............... I 8

Barnes, Joseph............ 52

Barber, O. S ............... 46

Beach, Will................ 37

Bennett, H. G............. 5

Bresee, Rev. P. F......... 73

Brown, A. J ............... 62

Cambell, James............ 40

Case, H. R............... $6_{3}$

Cooley, W. E............... 36

Converse, Wm............ 4

Conger, O. H ................ 56

Craig Bros................. 32

Clarke, J. E................ 39

Clapp, W. T............ I I

$\$ 100$

Galbraith, D

100

IOO

Glass, J. M .

Green, P. M

IOO

Harris, F. R

20

100

IOO

Healy, E. A

25

25

Hopkins, C.

IO

Ioo Lukens, T. P............. I6

100

100

I 00

Lyman, G. P..

100

IOO

50

I,egge, Charles

30

$\$ 100$

100

Lewis, H. C...

100

100

Machin, F. W

25

IOO

Macomber, H. K .

I 00

25

Magee, H. W.

IOO

IOO

Mills, A. F.

50

I OO

Miller, L. F

100

Meharry, G. E............. $5^{8}$

$5 \circ$

100

McGrew, S. O............. 53

I 00

IOO

Ioo Painter, M. D .............. I 7

50

IO

Cole, J. .I................ 7 I

Chaplin, S............... 29

Davis, Milton ............. 48

Decker, Z............. 59

Ehrenfeld, C.............. 55

Evans, L. A ............. 33

Evans, W. P.............. 76

Farey, H. N............. 2 I

Farris, Ed. L.............. 57

Fisher, D. J ................ 74

Fleming, J. H. ........... $3^{8}$

50 Palmateer, S................. 9

25 Parker, Chas. M.......... 54

IO Proudfit, Rob't R......... 75

IOO Reid H. A................ 60

25 Rice, B. A................. I3

25 Riggins \& Clark............ 27

25 Riggins, P. A............ 35

I 00 Ripley, C. B .............. 6

5 Skillen, C. M ............. I2

Ioo Smith, James............... 28

100

IOO

100

100

I $O O$

IOO

IO

100 


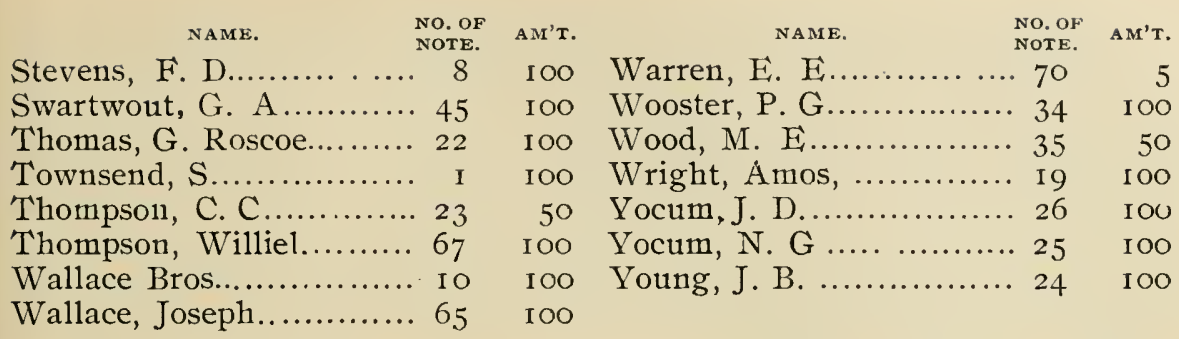

The total amount thus pledged "was $\$ 5,935$, of which Io per cent. was paid when note signed.

"A good many who had signed subscription papers refused to sign individual notes, and many others could not be found ; so that the above are the true historic names who stepped to the front and made our legal contest and victory against saloons possible.

"Those signers expected to pay ten installments, but instead of that have only had to pay two. This result was gained by Dr. Reid collecting a total of \$109.50 for the cause from the following persons who did not sign notes but who sympathized with the work: Peter Sumstine, C. E. Daily, Dr. J. C. Michener, James Clarke, W. C. Carpenter. J. F. Steen, R. E. Pinney, I. B. Lambert, L. H. Michener, W. J. Barcus, W. J. Goss, A. O. Porter, James Hewitt, J. F. Church, R. B. Hubbard, and the \$I 7 from the Williams' Hall meeting."

Several of the above signers when their notes were returned to them had them framed to preserve as heirlooms in the family. The Union's article, speaking of the Supreme Court decision, further says :

"The opinion of the court was delivered by Justice Patterson, a republican, and concurred in by Seärles, (C. J.) Sharpstein, McKinstry, Temple, Thornton, all democrats, while McFarland, republican, filed a dissenting opinion."

\section{HOW WAS IT ACCOMPLISHED?}

"The result exceeded the most sanguine hopes of the committee and their friends, for they had expected the court would stand four to three, or possibly five to two, but six to one was not dreamed of. This happy result was due to the fact that, by the most watchful and painstaking care from the very inception of the movement, the case was gotten into court free from any technical questions or side issues, so that the court had nothing before it but the one plain question of law-has Pasadena a lawful right to prohibit liquor saloons, or has she not? It took a vast deal of discreet consultation, skillful management, patience, forbearance, faith and forecast to secure and hold the case in this shape; but it won at last, and so settled the matter for the whole State."

\section{HOW MUCH MONEY?}

"January 23, I887, the first committee was appointed, with Dr. H. A. Reid as chairman, to carry on this work ; and from that time until now the citizens of Pasadena have contributed a total of $\$ 1310.80$ for this special cause. Every item of the expense account was carefully audited by the committee in quorum session, before being paid. It has been a hard battle, well fought and nobly won." 
So much for the Valley Union newspaper at the time. But the Pasadena Star had from the first cast slurs and contempt on the movement, and predicted failure; hence it had nothing to say except "we are surprised at the result." And that was not the only "result ;" for the San Francisco Chronicle reports, up to July r, I894, five counties that have carried the Pasadena ordinance, namely: Modoc, Sutter, Lake, Riverside and Humboldt-and nine others which had already made strong moves in that direction-all as a historic following of the pioneer work done by Pasadena in I887. In fact, that contest and its outcome gave Pasadena a more widespread fame and permanent historic prestige than anything else which has ever occurred in her history except the building of the Mount Lowe Electric Railroad.

So Pasadena waked up one morning and found herself without any saloon, and was happy. But this did not last long; for very soon certain restanrants and drug stores began doing a saloon business "on the sly" at first, but finally in open, bold defiance of the law ; and it began to appear also that some men who had signed the petition for the ordinance were, at heart, opposed to it-but believing it would be beaten in the courts, anyway, had joined in the call for it; and now that it was fully sustained as good California law, they were ready and hot to break it down and make it prove a failure after all. And I find on the police court records the following liquor cases :*

November 2, I887, John Senich. Jury trial. Found guilty. Fined \$roo. Paid fine. [The same day three other cases against the same man were dismissed. The law makes the sales of one day one offence; and he had been charged with selling liquor on four different days-but the one conviction was deemed sufficient at that time.--ED.]

April 30, I888, John B. Dolan. Jury trial. Case Dismissed. [It was proved that it was Dolan's wife, not himself, who sold the liquor-although with his connivance and that of his mother-in-law and a certain negro man. A warrant was issued the next morning for Mrs. Dolan; but the whole family, negro and all, had fled the city during the night, and never came back.-ED.]

May 23 to 25, I888. Peter Steil. Jury trial. Found guily. Fined \$5 50. Case appealed. [But it was never carried up to a higher court.]†

The liquor element was now fairly aroused to try and break down the ordinance. Peter Steil, by advice of certain lawyers, went on selling liquor

*'The city police court record from April 25 to Nov. 25. 14.57, shows a total of 134 cases tried within that time; and of these cases 121 were arrests for being "drunk and disorderly," and seven were various violations of city ordinances by liquor sellers-leaving ouly six cases in the seven moutlis, or only $4 \frac{1}{2}$ per ceut. of the criminal business of the city that was not directly caused by liquor sellers.

tThis case presented a very curions and a nomalous state of affairs. Pasadena as a voting precinct was strongly Republican. There were two daily papers, both claiming to be Republican, yet the Union was at this time chiefly owned by three leading Denocrats, W. U. Masters, R. M. Furlong and Bayard $T$. Smith, and edited by Dr. John MicCoy; and all four of them were proved to have bought and drank beer which Mr. Steil suld in violation of the law, be heing also a strong Democrat, aud a believer in his party's distinctive doctrine, known as the "anti-sumptuary" plank. The daily Star also, although pretending to be a Republican paper, supported this Democratic party doctrine, in opposition to the courts. 
at his restaurant, under pretense of his "appeal " case in court still pending, and also that restaurants had a right to serve liquors with meals, anyway. The original private "agreement" as to the Carlton Hotel [see pages 243-44] now came up with a barb on it ; for the claim was made, and rightly too, that if a "first-class" hotel might furnish liquor with meals, anybody else selling meals might do the same thing. The law could not discriminate in favor of any particular "class" of houses or price of meals. And thus things went on from bad to worse until August 6, I888, when another great mass meeting was held to consider the situation and decide what should be done. The gauntlet which had been thrown down by violators of the law was taken up with vim and earnestness; an enforcement campaign was here started, which met with organized resistance from those who favored legalizing for a high price the sale of liquors; the conflict went on for months, and thus came to be characterized as the "Whisky War" period.

\section{CHAPTER XIII.}

The WhISKy WAR.-Enforcement Committee. - Progressive League - Petition for Licensed Saloons. - City Election Contest.-Ordinance Changed.-Violations Continue.-Cases in Court.

THE WHISKY WAR.

With the appointment of an Enforcement Committee at the great mass meeting in the Tabernacle commenced the period historically known as "The Whisky War in Pasadena." Those in favor of maintaining and enforcing the city's prohibitory ordinance now organized for vigorous action, and moved at once on the enemy's works, where the law had been violated either openly or secretly for several months. In regard to this historic Tabernacle meeting and its work, I here quote from a public document entitled "The Whisky War in Pasadina," which was published in September - an edition of 2,000 copies:

THE MASS MEETING.

On Monday evening, August 6, I888, a mass meeting of about r,000 citizens of Pasadena assembled in the Tabernacle to take action against the liquor outlawry in this city. The meeting was called to order by Col. W. A. Ray, chairman of the committee of arrangements. On motion of Dr. O. H. Conger, Hon. P. M. Green was elected chairman of the meeting. Theo. Coleman, city editor of the Daily Star, was elected secretary. On motion of Dr. Lyman Allen, it was voted that a committee of five be appointed by the chair to prepare resolutions expressing the sense of this meeting, and to nominate a committee of substantial business men to carry them into effect. The chair appointed Rev. D. D. Hill, pastor of the First Congregational church, J. M. Glass, president Pasadena Eilectric Light Co.. T. J. Martin, Dr. H. A. Reid, and H. N. Farey as such committee. 
After a long absence (during which speeches were made in the meeting by prominent citizens), the committee reported as follows :

THE RESOLUTIONS.

WHEREAS, Our city's anti-saloon ordinance is being violated both openly and covertly. and also one or more wholesale liquor stores are preparing to force themselves upon us, contrary to the spirit and intent and plain purport of our law, therefore,

I. Resolved, That we are emphatically in favor of maintaining and enforcing Pasadena's anti-saloon ordinance without change, just as it was when passed upon and sustained by the supreme court of California.

2. Resolved, That we pledge our influence and moral support, and financial aid if necessary, to the trustees and officers of the city in their efforts to enforce the law against all violators, and that we urge them to proceed at once with such enforcement.

3. Resolved, That this is not a question of any political party's doctrines or methods, but purely a question of whether a lawful majority of the people shall be permitted to make and enforce the laws in Pasadena, or whether a few shall be allowed to set the laws at defiance and bring republican government into contempt.

4. Resolved, That we regard every place in Pasadena where intoxicating liquors are dispensed contrary to law, as an infamous invasion of our territory by a foreign foe : as a nesting-place of anarchy and outlawry ; as in flagrant defiance of the very ground principles of republican government. And against any and all such we declare unremitting war.

5. Resolved, That the aiders, abettors and supporters of such places, whether openly or secretly, are allies of the common enemy, and are helping to destroy the peace and safety of our homes, the value of our property, the good name of our city, and the rights of local government.

6. Resolved, That we regard the threatened opening of wholesale liquor houses in Pasadena as an open declaration of purpose to break down the moral prestige of Pasadena as an anti-saloon city, and that we organize at once for a resolute resistance.

7. Resolved. That as Monrovia, Riverside, Elsinore, Compton, Long Beach, South Pasadena, Lompoc, Orange, and other cities have adopted the Pasadena anti-saloon law, and are sharers with us in the common danger, therefore we signal to these sister towns that we are "holding the fort," and by God's help we propose to hold it till the last rum hole is driven from our borders; and we call upon them to never let their anti-saloon standard be lowered.

We would also nominate the following committee, with the recommendation that they be empowered to raise, hold and disburse a fund to be known as the "Enforcement Fund," and to co-operate with the city authorities in the enforcement of our prohibitory ordinance: Dr. H. A. Reid, Hon. P. M. Green, Geo. A. Swartwout, Col. W. A. Ray, Prof. C. M. Parker, I. B. Clapp, C. H. Converse, F. D. Stevens, Joseph Barnes, P. G. Wooster, C. C. Reynolds, Geo. C. Hubbard.

DEXTER D. HILL.
J. M. GLASS.
H. N. FAREY.

T. J. MARTIN.

H. A. REID. Committee.

The report was adopted by a unanimous rising vote, amid rounds of 
applause. And in about ten minutes canvassing, names were signed for various sums amounting in all to over $\$ 2,000$, payable in ten per cent installments, as an "Enforcement Fund." Much more has been added by persons who were not at the meeting.

\section{THE ENFORCEMENT COMMITTEE.}

This committee is constituted as follows:

DR. H. A. REID, representing the W. C. T. U. at their special request.* Hon. P. M. GREEN, President First National Bank.

GEO. A. Swar'TwouT, Manager Pasadena National Bank.

Col. W. A. RAy, President San Gabriel Valley Bank.

Prof. Chas. M. Parker, President Y. M. C. A.

I. B. ClAPP, orange grower, representing the Congregational Church.

C. H. ConversE, capitalist, representing the Presbyterian Church.

F. D. STEvens, of Stevens Hardware Co., representing the M. E. Church. JOSEPH BARNES, grocer, representing the Baptist Church.

P. G. WOOSTER, capitalist, representing the Universalist Church. Church.

C. C. Reynolds, Reynolds Bros., undertakers, representing the Friends

Gé. C. Hubbard, of H. N. Farey \& Co. printing house, representing the Christian Church.

[These men have all been formally approved and authorized by the several churches to represent them in the work of this committee.]

\section{EXECUTIVE BOARD.}

The committee organized by electing Dr. H. A. Reid, chairman; C. C. Reynolds, secretary, and Col. W. A. Ray, treasurer. The board of officers, with the addition of F. D. Stevens and Joseph Barnes, were appointed to act as an Executive Board, on behalf of the general committee and the several churches and other organizations which they represent.

The battle was now fairly joined. A series of promissory notes was prepared, which recited on their face these words:

"WhEREAS, A certain 'Ordinance for Police Regulation' within the City of Pasadena, which excludes liquor saloons, and other things of vicious, immoral, or dangerous character, is being violated, and contested at law ;

AND WHEREAS, A Fund has been pledged for the purpose of aiding the City Authorities in the enforcement of said law, to which I subscribed the sum of $\$ \ldots . . . . . . .$. , therefore, in consideration of said pledge, and that the funds so raised shall be used as may be found necessary, to defray expenses of such enforcement,

I promise to pay, on demand, to the duly authorized Treasurer of said Enforcement Fund, ten per cent of my subscription; and also in like manner an additional ten per cent from time to time as necessity may arise, to carry out the object and intent of said pledge."

\footnotetext{
* Note.
}

DR. H. A. REID - Dear Sir and Brother:

The Philistines are upon us. The liquor men are moving with a strong hand to force their dreadful traffic upon unwilling Pasadena. Fervent Prayer, strong Faith, and bold, prompt Work, are the call of the hour. With God's help, you led the work and won success in Pasadena's former struggle against the saloons, and now we prayerfully and trustfully ask you and appoint you to act for the Woman's Christian Temperance Union, in the same work again, for God and home and native land. MRS. O. S. BARBER, Pres't.

MRS. C. M. PARKER, Sec'y.

Mrs. Katie H. KeEse, Treas.

MRS. RACHEL F. REID, Vice-Pres't-at-large.

MRS. C. N. TERRY, Sup't Evangelistic Work. MRs. C. H. DURANT, Ass't Supt. Evangelistic Work. MRS. M. C. LORD, Press Sup't.

JENNIE G. MONFORT, Pres't Y. W. C. 'T. U.

FVA I,ANDRETH, Rec. Sec'y Y. W. C. T. U.

FANNIE I, BRENT, Cor. Sec'y Y. W. C. T. U. 
The following is a list of the signers, and amounts of these notesninety-six in all, and amounting to a total sum of $\$ 2,770$ :

Name. No. of Note. Amt.

Abbott, C. W.

Allen, Lyman............... $\mathrm{x}_{7}$

Allin, John ................ 33

Ball, B. F................ 48

Baldwin, A. E............. 66

Barber, O. S.............. 43

Barnes, Joseph ............ 26

Band of Hope (by C. B.

Gray, supt.)............ 96

Bennett, H. G............. 8

Bent, H. K. W. ............ 9

Blakeslee, Elizabeth........ 74

Burdick, F. H............ 70

Caldwell, R. M. ........... 69

Cambell, James............. 35

Carnahan, D. S............ 27

Carpenter, W. C............ 50

Carter, W. I. .............. 67

Case, C. I. .............. 82

Chapin, E. P.............. 53

Church, J. F............... 68

Clapp, W. T............... 84

Clark, F. E............... 54

Clark, Fredk. K, .......... 44

Clark, S. A. D............ 6

Conger, Dr. O. H......... I

Conger, H. M., prest...... 24

Curtis, Delia............... 85

Dagman, E. P............. 80

Daily, Carmi E............ 55

Dilworth, Benj............ 93

Doolittle, Mrs. S. H....... 72

Dyer, H. ................ 46

Evans, E. D.............. 57

Evans, IVm. Penn......... 6 6

Farey, H. N.............. I 5

Fleming, J. H. ........... 32

Furlong, Thos. W........ 79

Galbraith, D.............. 2 I

Glass, J. M................ 20

Goodwin, Mrs. H. F. ..... 87

Goodwin, H. F............ 88

Gray, C. B............... 8 I

Green, P. M.............. 39

Griffith, E................ 78

Habbick, John............. 77

Harris, C. E.............. 45

Harris, F. R.............. 7

Hazzard, Geo................ 25

Houlahan, D. J............ 7 I

50 Hubbard, Geo. C........... 28 IO

I 00 Hubbard, R. B.............. 63 Io

25 I. O. G. T. (by J. W. Sed-

IOO wick)................... I $8 \quad 25$

5 James, Smith.............. $91 \quad 25$

20 Keese, S. I................. 92 IO

25 Kernaghan, Geo. F....... 65 roo

Ladies' Un. Prayer Meet-

5 ing (by Mrs. F. H.

25 Burdick) .............. $73 \quad 25$

25 Martin, T. J............... 30 I 5

IO McGrew, S. O.............. 3 I 25

50 McLean, D. R............. I9 20

5 Meharry, Geo. E............ 350

25 Meyers, M. M............. 37 I0

IO Michener, L. H............ $3^{8}$ Iо

20 Mills, A. F.............. I4 100

25 Mundell, I. N............. $83 \quad 25$

50 Nelmes, Thos.............. $64 \quad 5$

Io Nichols, A. E. ............ 5 I IO

IO Palmateer, S................ $34 \quad 50$

25 Parker, C. M............. 4 I 50

Io Pierce, E. T.............. 86 Io

Io Pinney, H. J. .............. 94 54

5 Raymond, W. H......... $62 \quad 25$

IOO Reid, H. A................ I I 25

50 Reynolds Bros.............. 56 56

Io Rice, Benj. A............. $29 \quad 25$

5 Ripley, C. B.............. $52 \quad 50$

5 Shoup, J. G............... $4 \quad 50$

25 Smith, James............... I3 IOO

IO Stackhouse, J. B.......... 5 IO

IO Stevens, F. D.............. $5^{8} \quad 25$

5 Strong, A. F. M........... I6 50

25 Sturdevant, C. V........... I0 25

50 Taylor, George.............. $76 \quad 5$

25 Tebbetts, C. E............. 60 25

5 Thomas, G. Roscoe........ 2 100

50 Vesper, A. E............... $95 \quad 5$

Io Wallace, Joseph ........ .. 59 I00

20 Wallace, Bros.............. $47 \quad 50$

$20 \mathrm{~W}$. C. T. U. (by Katie

5 Keese, treas.)............. 3ó 25

IoO Wood, Henry ............... $40 \quad 25$

I 5 Wooster, P. G............. 75 I

5 Wright, Amos............. $22 \quad 5$

IO Wright, Lulu .............. $23 \quad 5$

25 Yocum, J. D.............. 90 90 I0

IO Young, J. B............... 89 25 
August 15 a meeting of the committee was held, to hear a report from its chairman, who had been specially appointed and instructed to go ahead and carry out the resolutions adopted at the mass meeting of August 6, and the openly declared purpose of the Enforcement Fund Notes. He said to the committee :

"Eight days ago you appointed me chairman of your committee to enforce City Ordinance No. 45. I laid out our plan of campaign to whip these liquor outlaws so thoroughly that we will have no further trouble with them, except as we do with sneak thieves, blacklegs, prostitutes, and other sly and scaly law-breakers. And I have called you together this morning to report progress."

He then stated that he had been to Los Angeles and consulted 'with the U. S. district attorney, Geo. Dennis, Esq., and the U. S. revenue collector, Mr. Ed. Gibson; and under the latter's instructions he had filed in the revenue office on August i4 a statement as to violators of the United States law in Pasadena, as follows :

Henry Beeste - Been selling beer. No U. S. revenue license.

Arthur Allen - Been selling malt beer under name of "birch beer." No revenue license [U. S. tax receipt] shown.

Terry \& Hepburn, lessees of the Carlton Hotel-Been selling wine and whisky. No U. S. revenue license stamp shown in their place of business, ${ }^{*}$ and they refused to show any when asked to do so.

John Senich-Been selling wine, whisky and beer. No revenue license shown.

Mrs. John Ziegler-Been selling beer. No revenue license.

Peter Steil - Selling beer. No revenue license shown.

Webb \& Sawyer - Selling beer. No revenue license shown.

The chairman further reported that upon consultation and agreement with the city trustees, in accordance with resolutions No. 2 and No. 7 , and the Enforcement Fund Notes, he had employed the city attorney, F. J. Polley, Esq., to act also as attorney for this committee. $\dagger$ He had engaged the services of a regular and lawfully established detective agency. He had engaged Williams \& McKinley of Los Angeles (the original attorneys on this ordinance) to counsel with our attorney and detectives. He had engaged the professor of chemistry at the University of Southern California, Prof. E. R. Shrader, to make a legal test analysis of any falsely-named liquors that might be contested in court as non-alcoholic. And he closed with this sentence :

"Gentlemen, we are now ready to move on the enemy's works all along

*He had shown to the committee that if any liquor seller had a U. S. revenue tax receipt, but did as the city law.

†August 8. I888. "Moved and supported that the city attorney be and is hereby instructed to prosecute all violations of ordinance No. 45 , when in his judgment there is evidence enough to warrant such prosecution."-|City clerk's records.] 
the line; and if any of them want to appeal to higher courts we are ready to go right along with them, clear through to the United States supreme court if necessary."

The report was formally received, adopted, and ordered placed on file. After the committee adjourned, the newspaper men got wind of this report and went to the secretary demanding a copy. It was furnished, and they published the whole business. Then there was fire and fury and bloody vengeance in the air, around all the liquor camps. Dr. O. H. Conger, who had signed an Enforcement Note for \$IOO, said facetiously, "I guess hell's broke loose! I think I can smell brimstone along the streets!"

Within a week the committee had evidence and witnesses ready to prosecute twenty-three cases of violation of the ordinance. But now the attorney discovered that the ordinance was utterly null - wasn't worth the paper it was written on ; for in its original enactment four specific requirements of the state law in regard to such procedure had not been properly complied with. It had not been formally put upon its passage and then waited the "legal" time before being finally passed. It had not been "legally" enrolled in the Ordinance Book. Printer's affidavit to its publication had not been "legally" made and placed on file. It had not been "legally" signed by the President of the City Board of Trustees. The city attorney and city clerk then in service were unfriendly to the ordinance; yet it is generous to presume that it was ignorance, carelessness and indifference combined, rather than design on their part, that caused these fatal omissions in details which it was their official duty to look after. At any rate, the committee and its attorney were now obliged to stop all proceedings, abandon their accumulated evidence, wait till the ordinance conld be re-enacted, and then commence anew by getting new evidence after the ordinance had been passed again in manner as required by the state law. However, they met the emergency without flinching, and submitted the following document to the city council:

\section{To the Honorable, the Board of Trustees of the City of Pasadena:}

GENTLEMEN: We, the undersigned committee duly appointed by the people of Pasadena to act for them, find that the violators of ordinance 45 claim they can defeat it in court on some technical informality in its original enactment - a point of law on which attorneys differ, and which might lead to long and fruitless litigation. We therefore request, in order to place this matter beyond a peradventure or the hair's-breadth of a doubt, that you have said ordinance re-introduced and put upon its course of re-enactment, whenever in your judgment you think best; so that this last possible hope of those who have set themselves to violate the law may be deprived of the least vestige of even a technical quibble to stand upon.

September 3, I888.

Signed,

H. A. REID (acting by appointment for the W. C. T. U.).

JOSEPH BARNES (acting by appointment for the Baptist church).

FRANE D. STEVENS(acting by appointment for the M. E. church). 
P. M. GREEN (president First National Bank).

W. Aug. Ray (president San Gabriel Valley Bank).

I. B. ClaPP (acting by appointment for the Congregational church).

I. J. REYNOLDS (for C. C. Reynolds; acting by appointment of the Friends church).

GEo. C. Hubbard (acting by appointment for the Christian church).

P. G. WOOSTER (acting by appointment for the Universalist church).

C. M. PARKER (acting by appointment for the Y. M. C. A.).

G. A. SwarTwou' (manager Pasadena National Bank).

C. H. ConVERSE (acting by appointment for the Presbyterian church).

The council was not averse to re-enacting the ordinance, word for word, as it had been sustained by the supreme court ; yet it was not until September 15 that this could be properly effected. And the liquor men, not knowing of the defectiveness of the ordinance, had already gotten up a petition which claimed to have $5^{1} 3$ lawful signers to it, and reading thus:

"We, the undersigned citizens of Pasadena, county of Los Angeles, and State of California, believing the present ordinance No. 45 to be detrimental to the best interests of this city, do respectfully petition your honorable body to call an election at an early day, of the voters of this city to vote on the question of the repeal of said ordinance No. 45, and the adoption in the piace thereof of an ordinance to regulate the sale of intoxicating liquors by the high license system "; etc.

This petition had been referred to the judiciary committee of the City Council - and while it was held under consideration, the Enforcement Committee by its chairman made the following points or suggestions, during various personal interviews with regard to it :

Ist. The petition and its signers' names ought to be published so that all citizens concerned may see whether the signers are all voters and taxpayers here or 11ot. The original petitioners for the ordinance did this at their own expense; and these petitioners against it ought to be put to the same test.

2d. The original petitioners for the ordinance pledged money in bank to indemnify the city against any expense which might arise from the granting of their petition. These high license petitioners had asked the city to incur the expense of a special election. 'They should be required to put up the money themselves, just as the other petitioners were.

3d. Such an election would be a non-statutory affair, not governed by any law of the state; and hence any amount of fraudulent voting could be practiced, without any recourse at law to prevent or punish it.

4th. The question of maintaining ordinance No. 45 was distinctly in issue at the last city election, and the present council was elected on a platform in favor of its maintenance. Hence, by our republican system of government, that policy has a right to stand in full force until the next lawful city election. 
In accordance with the first point, the petition and appended names was published at city's expense [the getters up of it were strongly opposed to its publication] in the Daily Union of September 8, I888-the Union being at that time the official paper of the city. It was then discovered that the names of $\mathrm{O} . \mathrm{H}$. Conger and James Smith were on it, although both of them had signed notes of $\$ 100$ for the enforcement fund-yet these names had been shown around by solicitors for this petition as proof that the original supporters of the ordinance had changed in favor of "high license ;" and thereby some were influenced to sign it who otherwise would not have done so. Dr. Conger and Mr. Smith took prompt measures to investigate this outrage upon their names and personal honor ;* and it was found that a Los Angeles carpenter named James Smith, who happened to be in Pasadena on a three weeks' job, had signed his name to it. $\dagger$ 'The other case was another Conger whose initials happened to be so nearly the same as the Doctor's that they were easily mistaken and misprinted for his.

These frauds becoming known, led two men, T. J. Martin and Merritt Allen, without any knowledge of each other, to go through the whole list of names and carefully compare them with the Great Register; and they found signed to this liquor license petition I60 names that were not lawful voters in Pasadena-most of them not even in the county, although a few names were found belonging to other precincts and to Los Angeles city. The petition was finally reported from the judiciary committee to committee of the whole. On November I3, the committee of the whole reported adversely to calling any such election, and this report was duly adopted in regular session that day. Meanwhile, however, on September I 5, i 888, the anti-saloon ordinance had been re-enacted as No. 125, "by the votes of Trustees M. M. Parker, A. G. Throop, Stephen Townsend, Edson Turner, and J. B. Young-unanimous."

During these weeks there was a concentrated effort to break down the chairman of the committee in his personal character and good name, so that he was frequently obliged to make reply through the press, in denial of some false report published. There were then five papers here pitted against the ordinance - theDaily Star, Daily Union, and Weekly Critic of Pasadena; and the Daily Times and Daily Tribune of Los Angeles which both had regular staff reporters here. Thus every foolish, malicious or false imputation against him which was concocted in the drinking places, billiard rooms and cigar stands, was eagerly caught up by the reporters, in their zeal each to get into print first with the latest sensation ; and thus it cane about, that no matter what the committee did do, or did not do, their position and action and purposes were constantly misrepresented and falsified and sensationalized

* In the Daily Star of Sept. 11, 1888, Dr. Conger offered a reward of $\$ 100$ for evidence to convict the forger of his name to this document.

†The city records show that twice afterward this same James Smith was arrested as "drunk and disorderly," plead guilty, and paid a fine of $\$ 5$. See Recorder's Book No. I, cases 76 and 206. 
to the reading public - and this had much to do with the number of names signed to the "high license" petition. This vicious policy culminated at last in a boldly slanderous article by W. H. Storms, city editor of the Daily Union, against Dr. Reid as chairman of the committee. Dr. Reid went directly to Mr. Storms in person, assuring him of the falsity of the accusations, and asked on whose authority he made the statements. Mr. Storms declined to give any name. And the next day the following document was formally served upon the "Union Publishing Co. :"

To the Proprietors or Stockholders of the "Union Publishing Company" of Pasadena, California:

Gentlemen : - Your paper, the Pasadena Daily Union, of date September 4 , I888, makes certain grave accusations against me as chairman of the "Enforcement Committee," with this declaration - "and which, if necessary, we are prepared to prove."

Gentlemen, that article is libelous, is slanderous, is scandalously false. It is injurious and damaging to me in person. And it is due to myself - it is due to the twelve reputable business men who constitute the "Enforcement Committee" and made me their chairman - it is due to the seven large churches and other organizations which that committee represents that your editor's pretended proofs should be produced to us at once, or else that the slanderous article be retracted through your editorial columns in as broad, unqualified and public a manner as the accusations were made.

This I require, both on my own behalf and on behalf of the churches and people whom I represent.

Dated September 6, r888. Respectfully,

We consider Dr. Reid's requirement above to be reasonable and just that the proofs which the editor of the Union claims to have, should be produced at once, or else the accusations be retracted as unqualifiedly and publicly as they were made.

Signed :
Reynolds Bros.,
O. H. Conger,
B. F. Ball,
Delos Arnold,
F. R. Harris \& Co.,
G. E. Meharry,
Stevens Hardware Co.
Lyman Allen,
A. K. McQuilling,
J. M. Glass,
D. Galbraith,
W. Aug. Ray,
H. G. Bennett,
H. D. Bennett,

G. A. Swartwout,

J. H. Fleming,

P. M. Green,

W. T. Clapp,

M. D. Painter,

Henry N. Farey,

L. C. Winston.

The name of informant was still withheld, but ample proof promised very soon; so that evening's paper contained an affidavit from one John Gorthy, a drunken loafer then temporarily in the city, who had reported an interview, false in every detail, which he pretended to have had with Dr. Reid. The next morning Dr. Reid got L. C. Winston, notary public, to go and procure statements under oath from E. H. Hyde and A. A. Chubb, who were present all of the time on the only occasion that said Reid had ever seen John Gorthy. [The statement of Geo. Hazzard, who had also been present, was procured some days later.] And the result was that John 
Gorthy was proved to be a liar, a slanderer and a perjurer-and he left the city forthwith. The same paper which contained Gorthy's drunken imaginings, sworn to as fact, contained also a lot of falsehoods about the Carlton hotel case, in which the committee had been the means of detecting its lessees in selling whisky by the bottle and sent to private rooms, besides other outlawry going on there. The lessee had given a bond agreeing to get all his liquors out of town within three days, and not sell any more liquors during the life of this bond (six months), under penalty of five hundred dollars. The city attorney had granted him his own free choice, to sign this bond, or go on trial and take the chances of what the court and jury would give him ; and he chose the bond. The committee was thus prevented trom making public its evidence, and this left the field open for the most unconscionable falsehoods to be put forth about the case. This open field was industriously worked for months afterwards; and these falsehoods were publicly repeated on the liquor side in the city campaign of 1890 -nineteen months later. But at that time, in a public meeting in Williams Hall, April 8, I890, A. R. Metcalfe, Esq., being called out, made an able speech defending the city council then in office, in reply to false accusations against them; and incidentally he alluded to this Carlton hotel case. The Los Angeles Tribune and the Pasadena Star both reported his speech, and I quote from them the passage referring to this particular case. Tribune's report:

"The trouble is not with the law. I understand that great stress has been laid on the fact that the Carlton hotel was closed under the provisions of this ordinance. I say boldly, the Carlton hotel should have been closed. It would cause the blush of shame to mount the cheek of any gentleman in this room if he knew all that went on there; and if the Webster or Acme should have such scenes enacted in them, I would favor closing them also."

Star's report: "The prosecution of the Carlton hotel proprietors was referred to as having been one of the best things ever done in the city, for it would bring the blush of shame to any man's cheek to know what scandalous things went on in that hotel."

This was the first recognition or acknowledgement ever made in a public way of the good work done by the enforcement committee in that case; while on the other hand they had borne for nineteen months the grossest misrepresentation and most vindictive contumely both at home and abroad, on account of it. And the lives of nembers of the detective agency were so virulently threatened that they had to leave town. One very prominent citizen said, "They ought to have been tarred and feathered!" Another said of the chairman, "O, we'll make it so $d-d$ red hot for that fellow that he can't stay in this country!"* Another, shaking a fist in bis face, said, "We can put up ten thousand dollars to beat you! We have plenty of backing in Los Angeles and San Francisco!" Another said,

*This man was a foreigner; had then been only six years naturalized. 
"We're going to see to it that you shan't enforce it." Another said, "We'll show you up to be the d-C dest liar in all this country!" Another said, "He helped to ruin Iowa, and now he's come here to ruin this country!" These were all prominent, well-known citizens at that time, and members of the "Progressive League," but it would not be proper to give the names here. Yet these are only a few sample instances of what that committee had to undergo. Nevertheless, it went right on with its work of aiding the city officers in detecting and prosecuting liquor selling outlaws.

In September, I888, a strong effort was made to commit the Board of Trade as an organized body in opposition to the prohibitory ordinance; but this did not succeed; and the next historic move was the organization of a "Progressive League," so-called, to fight the ordinance and all its supporters, on the basis of the high license saloon petition, an account of which I have already given. On Octoher 20, I888, a mass meeting of this "League" was held on an out-door public assembly ground then known as Haymarket Square. Justus Brockway served as chairman; W. P. Hyatt, then democratic deputy district attorney, was secretary ; and there were called to the platform a list of twenty-seven vice-presidents. A series of resolutions was adopted, misrepresenting the action of the city council in regard to the saloon petition, and denouncing it as "an arbitrary and tyrannical exercise of power and in derogation of the right of petition." Numerous speeches were made in virulent denunciation of the city council and the Enforcement Committee. But the whole situation was summed up in a brief speech toward the last by B. A. O'Neil, one of the most active and earnest workers of the League, who boldly and frankly said:

" There is no need of long speeches. It's saloons we want, and saloons we're going to have ; and we're going to have good ones, too."

Full reports of the meeting, with its array of vice-presidents, officers, speakers, resolutions, committees, etc., were published in the daily papers the next day; and if the reader wishes to see further about it he can find it in their files for that year. On October 27 , a committee from the League, consisting of B. A. O'Neil, W. U. Masters, and M. H. Weight, visited the city council, with complaints and demands in regard to their petition for licensed saloons. I was present, and heard the whole proceedings. Their claims and grievances were heard respectfully, and on every point were shown to be erroneous. The city council then consisted of Prof. M. M. Parker, Hon. A. G. Throop, Edson Turner, Stephen Townsend, and J. B. Young, who severally showed that the petition had been referred to the judiciary committee, and had in every respect taken the regular and lawful course customary and proper in all such cases. There were legal questions as to the validity of such an election; and a new Great Register for the county was being frepared; and other points to investigate, which made 
more time necessary; and final action was not taken on the matter until November I3. At this date I find in the city clerk's records that Committee of the Whole made a formal report on the petition for saloon license election, reciting at considerable length reasons for denying petition. The report was unanimously adopted and made of record. The points covered were in substance as follows:

rst. Present board elected on pledges to maintain ordinance No. 45 .

2 d. The claim that public sentiment has changed on the saloon question since April 9 last, is not warranted by facts.

3 d. Not advisable to engage in another election so soon after the strife, contention and excitement of a national election.

4th. It is the purpose of the board in proper time to submit the question of change of city charter; and the saloon question would then be one of the questions involved.

The next historic move on this line was the starting of the Pasadena Standard, December 22, I888, by Dr. Reid. The work of the committee which he headed was so constantly misrepresented, falsified and traduced both at home and abroad by the daily newspapers, that he was compelled in self-defense to start a paper of his own. This he did, and kept it up for seventeen months - or until May 3, I89o, after the city election of that year. [See page 218.]

There is abundant material pertaining to Pasadena's "Whisky War," from I 875 to I 894 , to make a large and interesting volume of itself. But I could give in this work only a few of the more prominent historic waymarks along the line of years, or within the most active months of the long campaign. However, I give names, dates, references, documents, newspaper citations, etc., so that any one wishing to investigate the matter more critically can know where to find information at first hand.

The misrepresentations of the newspapers, both at home and abroad, in regard to the situation in Yasadena were kept up so persistently, and became so annoying to the council and other officers, that they at last put forth this document, each point of which was necessary to officially controvert some widely published falsehood:

Pasadena, Cal., March I4, I889.

WHEREAS, False reports have been circulated by the Los Angeles and other newspapers in regard to the prohibitory or anti-saloon law of Pasadena, we hereby state, for the information of all people who care to know, the following facts in the case:

Ist. There is no open saloon within the city limits of Pasadena, though there probably are a few places where liquor is sold "on the sly."

$2 \mathrm{~d}$. The law against saloons is as well enforced as the laws against other forms of vice.

3 d. The city authorities have never given permission to any hotel to keep a bar or sell liquor; and there is no hotel in the city keeping a bar.

4th. If any persons in the city are selling liquors otherwise than in accordance with the provision made for legitimate drug stores, they are doing 
it as outlaws, and are liable at any time to be detected and dealt with as outlaws.

5th. Our last city election was a very decided majority expression in favor of the law as it is, for every officer elected was pledged to maintain it; and there is general satisfaction with the law among our best citizens. There is no intention of repealing it.

Signed,

M. M. PARKER, president city council.

A. G. Throop, member city council.

S. TOWNSEND, member city council.

A. MCL,EAN, member city council.

J. B. Young, member city council.

JAMES H. CAMBELL, city clerk.

I. N. MunderL, city marshal.

P. A. V. VAN DoREN, city recorder [police judge].

FRANK J. POLLEY, city attorney.

- The Enforcement Committee continued its work in strict accordance with the resolutions of August 6, I888, and the object set forth in the Enforcement Fund notes. More than a dozen cases of violation of the law reported by the regular police officers had to be dismissed without prosecution, for want of such precise and exact evidence regarding date, place, time of day, who sold, who bought, how dispensed, proof as to name or kind of liquor, etc., as was necessary to meet and withstand the technical catchpoints raised by attorneys in defense of the parties arrested. This made it necessary to employ detectives. The men of the regularly established detective agency, as I explained before, and also one regular policeman who made the case against John Dolan, had been driven out of town by the hoodlum element; but others came forward from time to time [ten in all] to meet the emergency.* One of these was beaten, gouged, seriously injured, and driven away. Another's life was threatened; and once a pistol was drawn upon him, but he also whisked a revolver out from his hip pocket and got an aim first, and his assailant wilted - afterward plead guilty to whisky selling, paid a fine, and left town. Two of the detectives were arraigned on fallacious charges, and compelled to stand trial at some other place, on pretense of the liquor men that a fair trial could not be had in Pasadena. So a jury trial of the case was held at Garvanza; and the two

* Nov. ro, I888; "Moved and supported that the marshal and the attorney be instructed to use all due vigilance to enforce ordinance No. I25 [same as orignal No. 45], and every violation of said ordinance to be prosecuted to the full extent of the law. Carried."-City Clerk's record

Aug. 3, 1889. The question of detective police service was before the council, on a bill of $\$ 25$ due C. L. Case in the whisky selling case against Fred Frechette. The service had been rendered under sanction of the city marshal, and bill "O. K'd." by him. 'The clerk's record says :

"City attorney stated that the city had the right to appropriate money for the use of the police de. partment in detective and similar work, etc." Whereupon the board unanimously voted "that the action of the city marshal in his endeavor to enforce the law be fully endorsed by this board." And so the bill was ordered paid.

A rankling and furious hostility was worked up against the employment of detective service in these cases, during all the months of this "Whisky War" period. Yet I find that city attorney W. E. Arthur, in some similar cases during the first week in February, I895, sustained such service. From the Weekly Star of Feb. 6 I quote: "Judge Rose's speech in support of his case [attoruey for the liquor sel-; ler] was for the most part a bitter invective against detective Vinnell and the slimy ways of detectives." * * "City attorney Arthur stated that evidence in these cases cannot be procured in any other way that the men who commonly violate the law will not testify against the violators." Thus the city council of $1888-89$ stands vindicated. 
men were acquitted and released in three minutes by the jury. Another case is worthy of mention. A man was convicted of unlawful whisky selling here, after a jury trial, and appealed his case to the superior court at Los Angeles. During the re-trial there the liquor attorney demanded that the printer's certificate as to this ordinance having been published in accordance with state law when enacted should be produced in court. That document was filed away in some pigeon hole in the city clerk's office in Pasadena, and of course could not be then and there produced. The city clerk had been in court with the ordinance book, had sworn to the due and lawful enactment of the ordinance in question, and then at his request he had been excused by the judge [McKinley] and had returned home. But now, because the printer's certificate was not produced right there, this sharp criminal lawyer claimed that it had not been proved to the court that any such law as his client was accused of violating did validly exist in Pasadena ; and therefore it was not proven that his client had violated any law. And on this the Los Angeles jury brought in a verdict of " not guilty," in spite of the fact that whisky which the defendant had sold for dram-drinking was produced and verified in court by two witnesses.

The "Progressive League," with the principal newspapers at its service, continued its fight against the city council and the Enforcement Committee ; and its managers especially planned and manœuvered for carrying the next city election in their interest. Of course I can only give a few main points, with dates and references, so that anyone wishing to pursue the matter further can find what he wants on either side. My present business as historian is only to cite a few of the more prominent historic facts, impartially and without comment.

The city election was to occur on Monday, April I4, I89o. During the preceding November, December and January, the Daily Times and Daily Star both advocated the nomination of a straight republican ticket for that election. But early in February [Feb. 8] a plan of campaign was made up privately for a so-called Citizens ticket, and a platform was put forth which was in substance a repetition of the Progressive League's resolutions adopted October 20, I889, against the city council, though with a few additional points of wrongful and grossly unjust accusation; and on the liquor question . it declared :

"Resolved, That we are in favor of our hotels being ALLOWED TO FURNISH WINES AND LIQUORS TO THEIR GUESTS."

The platform was not signed by anybody, and no report given as to its origin; yet the Times and Star [of February I2 and following] both came out in support of this non-republican scheme and its unfathered platform. And the Los Angeles Daily' Tribune, then edited by ex-Gov. L. A. Sheldon of Pasadena, in an editorial 11pon this strange state of affairs said: 
"The people of Pasadena are noted for their good order and sobriety, and they have got along without drunkenness and disorder. The place is overwhelmingly republican. We do not see why there cannot be nominated and elected a straight party ticket. Certainly our friends have plenty of good men. It seems unwise for republicans to break ranks for the purpose of giving the saloonists a chance."

And again at a later date, February 20, the Tribune again said concerning this matter:

"A petition is being circulated requesting voters to bind themselves to stand by the Citizens' ticket, whoever the nominees of the caucus may be. * * When in a strong republican community there is an effort to run a "non-partisan" ticket, it would be well to inquire if there is not a democrat at the bottom of it." **

The liquor interest movement went on, however, with the daily Times [Los Angeles], daily Star and daily Union, all advocating it. Then about February 24 a call was circulated for a counter convention, reading as follows.

"We, the undersigned, who are opposed to boss rule, to the return of saloons to Pasadena, and in favor of the maintenance of Ordinance I25, and of an economical administration of the city government, request the people of the city of Pasarena to meet in mass convention at Williams Hall, on Saturday, the 29 th day of March. I 890 , at $7.30 \mathrm{p}$. m., for the purpose of adopting a platform and nominating candidates for the several city offices to be chosen at the next municipal election.'

This was signed by such prominent republicans as Gov. L. A. Sheldon, Ho1. Delos Arnold, B. F. Ball, Hon. Alex. M'Lean, Judge E. J. Millay, Dr. G. Roscoe Thomas, Hon. A. G. Throop, and over two hundred other names. But while waiting for the time to arrive, still another call was issued for a mass meeting of all republicans in Pasadena who were in favor of maintaining ordinance I25 unchanged. This meeting was held in Williams Hall, March 22 ; and from the reports of different papers at the time I here quote a few of the main points most directly bearing upon the history topic of this chapter. From the Standard's report:

"Hon. Delos Arnold, who served two terms in the Iowa state senate, was elected chairman, and Major J. D. Gilchrist, secretary. The following vice-presidents were nominated and called to the platform: Gov. I. A. Sheldon, Mayor A. G. Throop, Col. O. S. Picher, Rev. L. P. Crawford, Dr. G. Roscoe Thomas, ex-Mayor H. J. Holmes, B. F. Ball and W. T. Knight.

"A committee of five was then appointed on resolutions, consisting of Hon. Alex. Mclean, formerly member of the legislature from Santa Barbara county, Col. O. S. Picher, B. F. Ball, Dr. Thomas, and J. B. Corson, all of them men well known as party republicans."

Gov. Sheldon was loudly called for, and made a speech of some length. One or two points specially pertinent to this chapter I quote from the Tribune's report of his speech :

*It was an open secret, that W. U. Masters, the keenest democratic politiciau in the county was "at the bottom" of this whole "non-partisan" scheme for driving "republicans to break ranks." Of course it was fair game for his party, and great big fun, also. 
"Those who know me know that I am a very decided republican. I believe in the party, and the men who represent it. I started out in the advocacy of a republican ticket for our city government. I found that party lines were to be thrown down and a new issue taken. Shall we maintain ordinance No. I 25 ? 'They want to modify this ordinance so hotels can serve wine to their guests. If this law is made we will have hotels on every corner. Do you think any one would come to Pasadena to get a drink? Where one would come hundreds would stay away. Our grand scenery, beautiful lawns and grand orange groves are not the chief glory of Pasadena. It is the order and sobriety of our city. The modification of ordinance No. I 25 was likened to the crevasses which cut breaches in river levees, caused at first by crawfish, which perforate the banks with small holes, but which end in inundation. Let there be no crawfish holes in Pasadena. I beg of you, my friends, that you see to it that the flood-gates of intemperance shall not be opened on this city."

"Judge E. J. Millay, formerly judge of Sagadahoc county, Maine, was called for, being one of the prominent republicans of the city; and some of the principal points of his speech were : We have assembled here to discuss the issue of the coming election. The issue is, "Shall we maintain the prohibition ordinance or shall we license liquor sellers?' Let me say to you tonight, if you change that ordinance you will take a backward step. There are more than four times the guests in Pasadena than Los Angeles, in proportion to the population. Our prosperity depends on the maintenance of our ordinance.

"Rev. D. D. Hill, pastor of the Congregational church was next called, and he gave a rousing short talk of no uncertain sound. He made the point in particular that Pasadena has her freedom from saloons as her one crowning advantage which no other city on the coast has, in combination with the same other attractions, and this will draw to us the best sort of families to reside here, for their children's sake. Pluck that crown from our fair Pasadena's brow and you ruin her good name and destroy her prosperity."

Rev. E. L. Conger, D. D., pastor of the Universalist church, was called, and from his speech as reported in the Standard I quote this passage :

"Ever since I cast my first vote for Abraham Lincoln I have been a republican. I believe the people should rule. I am for this city, for its government and its laws. Is there any other issue before this city than the one embodied in ordinance I25? The gentlemen on the other side say, "'There is no issue; we don't want saloons-neither do you. We want an economical government-so do you. 'There is no issue." But there is an issue. We all understand that-and out of the whole column of the socalled Citizens' platform, the issue is all centered in three lines-

"Resolved, That we are in favor of our hotels being ALLOWED TO FURNISH WINES AND LIQUORS TO THEIR GUESTS."

"This is the issue and the only issue. All the rest of the Citizens' platform is an unjust attack upon the ability and integrity of our city councilmen, who are entitled to thanks instead of censures, for they liave served the city gratuitously and faithfully.'

From the resolutions adopted as the sense of this meeting I quote only the portion covering the special topic of this chapter: 
"Resolved, That we are in favor of a strictly economical policy in the administration of the affairs of our city government, and that we are in favor of the maintenance of ordinance 125 as a police regulation.

"Resolved, That we denounce the reckless and untruthful resolutions of the so-called Citizens' platform, and their continued publication as detrimental to the best interests of Pasadena. and a subtle attempt to introduce the nefarious retail whisky traffic into our city.
A. MCLEAN,
O. S. PICHER,
B. F. BALL,
G. Roscoe Thomas,
J. B. CORSON,
Committee."

The next historic event in this anti-liquor campaign was the People's convention, the call for which I have already given. The Pasadena Standard had hitherto been published only once a week, but on April 3 it commenced a daily edition; and from its report of this convention I quote a few paragraphs :

"Last Saturday evening, March 29, the grandest city convention ever held in Pasadena assembled in Williams Hall to nominate candidates for the city offices. The hall was packed from stage to stairways, and the gallery running over. Many came late and could not force themselves in. A good many ladies were present, and others came but could not get in.

"The assemblage was called to order by Hon. Delos Arnold; and on motion A. R. Metcalfe, Esq., was elected president of the convention with rousing enthusiasm, and J. G. Shoup, secretary. On taking the chair Mr. Metcalfe made a speech, clear-cut, ringing, forcible - and showed that if the so-called Citizens' platform should prevail, it means an open liquor traffic in Pasadena-it cannot mean nor be made to mean anything else, as every lawyer knows perfectly well. He also stated that in the committee which framed that platform a resolution was presented declaring that they were opposed to the retail liquor traffic in Pasadena, and it was voted down.

"On motion the chair appointed F. S. Wallace, B. F. Ball and J. B. Corson a committee on order of business; and they retired for consultation.

" On motion, J. D. Gilchrist, M. M. Parker and W. 'T. Clapp were appointed a committee on resolutions. John Allin was appointed sergeant-atarms.

" Committee on order of business reported; report adopted; and the good work then went on by rule. Spaces were assigned in the hall for the electors from the several wards to get together and nominate each their own choice for city trustee; and a recess of fifteen minutes was taken for that purpose."

Omitting long details of procedure, the final result was the nomination of candidates as follows: For city trustees-First ward, A. F. M. Strong ; second ward, Elisha Millard; third ward, B. F. Ball; fourth ward, Charles M. Parker; at-large, Hon. Delos Arnold. For city marshal, D. R. McLean; clerk, James Cambell; treasurer, W. T. Vore.

The whereases and resolutions reported by the committee were unanimously adopted without change. I quote only these two:

"2. Resolved, That we are in favor of maintaining what is known as ordinance I25, as a measure indispensable to the best interests of Pasadena, now and hereafter. 
" 3 Resolved, That we believe the resolutions in the so-called Citizens' platform are in part untrue; that their continued publication in our daily paper is detrimental to the interests of our city ; and that the so-called citizens' movement would in fact, if successful, lead to the introduction of the retail liquor traffic into our midst.

J. D. GILCHRIST, chairman, M. M. PARKER, secretary, W. T. Cla PP, Committee.

"On motion, a central committee was appointed, consisting of C. C. Thompson, J. G. Shoup, R. H. Pinney, G. Roscoe Thomas and A. F. Keyes."

This was on Saturday evening. On the next Tuesday evening a great ratification meeting was held in the Tabernacle; and from reports published the following day, I quote the main points specially pertinent to this narrative :

"C. C. Thompson, chairman of the central committee, presided. The nominees were all called to seats on the platform, and also the following gentlemen to sit as vice-presidents: Gov. L. A. Sheldon, Hon. A. G. Throop, D. Galbraith, Rev. Dr. Ormiston, A. R. Metcalfe, Jason Brown, Geo. F. Kernaghan, L. F. Miller, Dr. Davis, James Cambell, W. T. Clapp, A. F. Keyes, P. G. Wooster, Rev. Solomon Dunton, M. M. Parker, T. J. Martin, John Allin, Rev. L. P. Crawford, John Habbick. The first speaker called was Senator Delos Arnold, candidate for trustee-at-large, who spoke briefly of the points of agreement and of disagreement between the two parties now contending for the control of our city government. As to the question of economy and discreet management, there was no division. But the so-called Citizens' ticket stood for a policy which must in the very nature of things open the way to the liquor traffic being re-established in Pasadena, while the People's ticket stands for A POLICY WHICH WILL PREVENT THAT THING."

Other candidates were called in turn, and made brief responses, Then A. R. Metcalfe, Eisq., who was city attorney at the time, and had been attacked in the daily Star, was urgently called for; and from the published reports of his speech I quote, because it is one of the waymark points in the history of this whole matter. Mr. Metcalfe said:

"The editor of the Star had advised a search of the records, and he had done so, with the result that he had found a petition on file in the city clerk's office (presented in September, I 888), expressing the belief that ordinance 45 (since changed to 125 ) was detrimental to the best interests of the city, and asked the council to call an election for its repeal and the adoption in lieu thereof of a high license system. He glanced at the names signed to it, and the third name to it was Webster Wotkyns, now the candidate on that side for city clerk. He found also the names of C. M. Simpson, their candidate for trustee from the first ward; T. Banbury, their candidate from the second ward; Jas. Clarke, their candidate from the fourth ward; S. Washburn, their candidate for city treasurer; A. Wakeley, their candidate for city marshal. The names of two of their candidates, Lukens and M'Quilling, were not signed to it; but six out of the eight men on that ticket had signed their own names to a declaration that ordinance i 25 was in their belief "detrimental to the best interests of the city," and they 
wanted it repealed, and a "high license system" adopted instead. This shows plainly what the aim and purpose of that party is."

Rev. Dr. Ormiston, pastor of the Presbyterian church, was called for. He plead for the fathers and mothers, the young men and maidens, the boys and girls, the children of our hope and our love, that ordinance 125 be maintained and liquor selling kept out of our city.

"Gov. Sheldon was called for; and although quite hoarse he made a short speech. He said he was a very decided republican, but he believed in his party going forward and not backward. The marching line of this People's movement is forward-that of the other side is backward. If the opposition policy should prevail, it means flooding the city with liquor-selling and all its evil results. He endorsed the People's ticket and platform. He also expressed himself in favor of woman's equality in social affairs, business affairs, and political affairs."

On the next day the following document was published :

"WHEREAS, The position of the candidates for city trustees upon the Citizen's ticket, on the temperance question, has been grossly and persistently misrepresented; therefore we, the undersigned, nominees, do declare that we are unalterably opposed to a saloon, bar or tippling house of any form or description in our city, and promise, if elected, that we will do no official act that will permit or encourage the promiscuous sale or use of intoxicating liquors.

(Signed,)
T. P. LUKEN,
C. M. Simpson,
A. K. MCQUILLING,
T. BANBURY, JAMES ClaRKE."

This was Wednesday. The next Monday was election day; and the vote resulted as follows :

\begin{tabular}{|c|c|c|c|c|c|c|}
\hline & \multicolumn{4}{|c|}{ WARDS } & \multirow{2}{*}{ Total } & \multirow{2}{*}{ Majority } \\
\hline & I & 2 & 3 & 4 & & \\
\hline For Trustees: & & & & & & \\
\hline 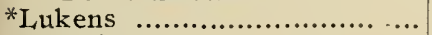 & 107 & 154 & I 75 & I5O & 586 & 43 \\
\hline * McQuilling ............................. & IIO & 156 & I $8_{3}$ & 148 & 598 & 70 \\
\hline 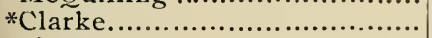 & 106 & 150 & 169 & 149 & 574 & 38 \\
\hline * Simpson.............................. & 108 & I53 & I 76 & 149 & 586 & 54 \\
\hline${ }^{*}$ Banbury ............................. & 107 & I52 & I74 & I47 & 5 so & \\
\hline †Arnold............................... & I87 & IO4 & I 35 & II 7 & 543 & \\
\hline †Strong........................... & 183 & 100 & 130 & II 5 & 528 & \\
\hline 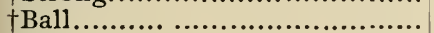 & 185 & 98 & I33 & II 9 & 535 & \\
\hline †Parker................................ & I 86 & IOI & 132 & II 3 & 532 & \\
\hline †Millard................................ & 183 & 103 & I 30 & I I I & 527 & \\
\hline *Wotkyns ........................... & 95 & I 33 & I59 & I35 & $52 \mathrm{I}$ & \\
\hline 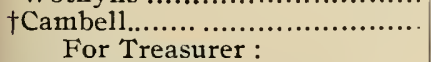 & 197 & 124 & 150 & 126 & 597 & 76 \\
\hline *Washburn. ......................... & ro6 & I 46 & I66 & I 35 & 553 & \\
\hline 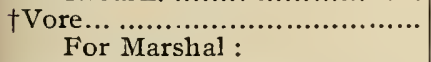 & I 87 & IIO & I 43 & 129 & 569 & 16 \\
\hline *Wakeley........................... & 103 & I 35 & 166 & I42 & 546 & \\
\hline †McLean............................ & 188 & I $2 \mathrm{I}$ & I 4.3 & I 2 I & 573 & 27 \\
\hline
\end{tabular}

* Citizens' ticket (against ordinance).

† People's ticket (to maintain ordinance).

That night after the result was announced, a drunken mob went around yelling and howling as if pandemonium had broke loose. Old tin pans and 
empty oil cans were pounded on, fishhorns blown, and every other device used to make a hideous racket. A mob of men and boys thus equipped, and variously estimated at 40 to 70 in numbers, went to the residence of Rev. Dr. Bresee, pastor of the M. E. church; went into the archway between the church and parsonage, and got close up to doors and windows, yelling like savages bent on a cannibal feast; hooting, howling, groaning; making mock prayers; banging their pans and tooting their fishhorns. Next they went to the residence of A. F. M. Strong, president of the Young Men's Christian Association, on Herkimer street, and performed the same drunken and riotous antics there, although Mrs. Strong was lying very sick at the time. The same mob, or another just like it, went to the residence of Dr. Reid, on Mary street, with the same sort of demonstrations ; crowded into the front yard and along the walk to the back door, and added to their tin can and horn noises some banging or pounding against the house. The residence of Rev. D. D. Hill, pastor of the First Congregational church, was also visited, with similar drunken mob performances.

\section{NEWSPAPER SUSPENSION AND OTHER CHANGES.}

The space of a few months along about this period was a general breaking up time-a sort of cyclonish and earthquake tumbling of Pasadena newspaper enterprises. Some weeks before this election the Laily Union had suspended publication. A company of printers leased the material and started the Pasadena Weekly' Journal - continued it nineteen weeks and then stopped. Within a day or two of this election the Daily Star printing establishment [being swamped with debts] passed into the hands of a joint stock company whose board of directors were Hon. P. M. Green, B. F. Ball, T. P. Lukens, Geo. F. Kernaghan and Prof. T. S. C. Lowe ; and Mr. Kernaghan was put in charge as general manager. Messrs. Kernaghan, Ball and Green had each given their notes for \$IOO toward the Enforcement Fund,* and of course the former vicious position of the paper on this and connected matters was at once changed to fairness and decency. On May 3, three weeks after the election, the Pasadena Standard suspended publication; and a few months later the Los Angeles Tribune went down. Then on May 5,1890 , the following historic document was issued to the signers of the Finforcement Fund notes :

\section{RHASONS FOR DISBANDMHNT.}

By the Pasadena 'Enforcement Conmittee, appointed August 6, I888, at mass meeting in the Tabernacle-

Resolved, Ist, That the objects and purposes of our appointment have been accomplished, in particulars as follows, towit :

1-In the re-enactment on September 15, r 888 , of the prohibitory ordinance by the City Trustees, upon our representation that its original enactment had not been signed, published and certified in manner required by the State law. 
2-In the decision rendered by Judge Lucien Shaw of the Los Angeles county superior court, April 27, 1889, sustaining the validity of the ordinance, and defining its legal force and effect as to liquors sold in restaurants and other places, either with or without meals. Decision in our favor.-(Case of The People vs. John Senich).

3-In that seventeen places where illicit liquor selling was carried on have been closed by enforcement of the law since our work commencedonly four cases having ever been made previously.*

4-In that the newly elected City Trustees installed April 21, 1890, have publicly pledged themselves to "do no official act that will permit or encourage the promiscuous sale or use of intoxicating liquors."

Resolved, $2 d$, That all funds at our disposal have been used in lawful manner to further the objects for which they were pledged; and that there is now nothing remaining in our treasury.

Resolved, $3 d$, That in view of the foregoing facts and results, we do now disband, and cease to exist as a committee ; and that we instruct the chairman to return all promissory notes of the "Enforcement Fund" to the makers thereof-or cancel them for signers who cannot now be found.

Pasadena, Cal., May 5, I 890. Union.

H. A. REID, chairman, member for the Woman's Christian Temperance

C. C. Reynolds, secretary, member for Friends church (proxy I. J. R.).

GEO. TAYLOR, member for Baptist church.

P. G. WoosTER, member for Universalist church.

A. F. M. Strong, member for Y. M. C. A.

FRANK D. STEVENS, member for M. E. church.

I. B. CLAPP, member for Congregational church.

P. M. GREEN, president ist National Bank.

G. A. SwarTwout (of Pasadena National Bank).

W. A. RAy, treasurer of San Gabriel Valley Bank (proxy H. A. R.).

Géo. C. Hubbard, member for Christian church.

These are all the names of the committee except the member for the Presbyterian church; he declined to sign this paper.

During the ensuing two years no change was made in the ordinance; yet hotels and restaurants were allowed to furnish liquors with meals, notwithstanding the adverse decision of the superior court [Judge Lucien Shaw, April 27, r889] upon the matter; and under cover of this lenience a semi-saloon business was done at several places, even to the extent of furnishing glasses of liquor to people in carriages from Los Angeles, to drink in front of a restaurant openly in the streets of Pasadena. I give this on the authority of responsible parties who saw it, and also saw other open violations of the law. Some of these parties boasted in my hearing that they had got liquor there, and could get it any time they wanted it ; "And we don't have to go behind a screen to drink it, cither!" they said. Yet others of my informants regretted the situation, but said it was useless for them to file a complaint, for they knew nothing would be done.

* Names and particulars of all the twenty-one cases here referred to were published in the Pasadena Standurd of April 19, 1890 . Five of the cases were against firms, thus making twenty-six persons in all; and ouly two of them were still residents of Pasadena in 1894 . 
However, it seems that the city marshal tried to do a little enforcing of the law, after a five months' rest, for on September I 5 and 'I 7 , I890, he had Thos. Twaits, a colored man known as " Cheap John," in court for violating ordinance I 25 - but the record does not show any penalty adjudged. And there is no case again until January 3 and 5, I89I, a rest of four months, when Geo. C. Monfort is in court on a similar charge. He plead guilty, agreed to close his place or quit selling liquor there - and no penalty was imposed. Then for five months the liquor sellers had a rest again. But in June lightning struck them for the first time under the new regime; and I find in the police court records the following cases:

June 10, I89I. Charles Berry-liquor selling. Fined \$100. Paid.

June 9-10, I89r. Geo. B. Hogin, druggist-liquor selling. Sentence suspended during good behavior.

June 9-Io, I89I. G. A ussen - liquor selling. Fined \$Ioo. Paid.

June 9-13, I891. Thomas Twaits-liquor selling. Fined \$25. Paid.

Then a six months' rest followed, till December 8, i89i, when Frank Becker is fined $\$ 25$ for liquor selling. And the next cases occur February 2, I 892, when Charles Berry is in court again for liquor selling, and deposited \$IOO bail; but the record fails to show anything further in regard to this case. And Frank Becker is also in court again on the same charge; he plead guilty, and sentence was suspended during good behavior.

The next step was taken by the city council on March 5, 1892, by the enactment of Ordinance No. 195, which expressly provided that prohibition "shall not apply to the sale of vinous or malt liquors at any" hotel, restaurant, or boarding house, when sold with and as a part of a regular meal." From this time the records do not show any further attempt to suppress liquor selling for more than a year. The city election occurred in April, and the liquor men had it all their own way. Men were nominated who were in favor of "high license," and there was no opposition ticket put into the field. So the liquor sellers had a long rest from "persecution," and the violation of the law went on more and more boldly.

The city clerk's records of May 8, I893, say: "Trustee Clarke called the attention of the Board to the violation of Ordinance No. 195 by the proprietors of most of the restaurants." Yet no action was taken upon the matter. And I find in the records again the following:

June 5, I 893 . "Geo. A. Gibbs presented a petition signed by a large number of citizens, asking that Ordinance No. I95 be enforced; also called the attention of the Board to alleged violations of said ordinance. Voted, that petition be referred back to the petitioners, with the information that the council were doing what they conld to enforce the ordinance."

Then, on June I9, Ordinance No. 220 was enacted, which provided that prohibition shall not apply to sale of vinous or malt liquors "when sold with and as a part of a regular meal costing not less than twenty cents exclusive of the vinous or malt liquors, and sold and consumed between the hours of II:30 o'clock a. m., and I:30 p. m., or between the hours of 5:30 p. m. and 7:30 p. m." 
After the first concession was made to the liquor sellers by Ordinance No. 195, they went on disregarding and violating the law just the same as before; and also when No. 220 was enacted they evaded or defied its restrictions. It was thus made evident that no matter whether the law was straight prohibition, or liberal concession, or restrictive regulation, this class of men would violate it, anyway. But there was a storm gathering; and lightning struck them presently from a clear sky - for I find in the police records the following cases:

July 6, I 893 . George Worthen-liquor selling. Fined \$250. Fine paid. August 17, r 893 . Peter Steil - liquor selling. Fined $\$ 175$. Fine paid.

August 19, IS93. Herman Garmshausen - liquor selling. Fined \$250. Fine paid. (This was the H. W. Stoll soda-water-factory case.)

In these cases some of the ablest lawyers of the city were employed to defend the outlaws. They claimed the fines were exorbitant, unprecedented, etc. But the court [J. G. Rossiter] stood firm, and the culprits had to pay or go to jail. Since that time they have not boasted so much, and have done the unlawful part of their liquor selling so secretly that probably nothing short of detective service could bring them to conviction again.*

One of the curious episodes in this part of Pasadena's history is the fact that Peter Steil, who had been arraigned for unlawful liquor selling oftener than any other man in the city, and had violated the law more openly and persistently than any other one, came out as an independent candidate for member of the city council at the city election in April, r 894, and received $I 7 I$ votes. Peter was a democrat, and honestly believed in the theory so often put forth in his party's platforms against what they called "sumptuary legislation"; hence he resented any law against liquor selling as an infringement on " personal liberty," and acted accordingly, in spite of the adverse rulings of the State and United States supreme courts. Apart from this error of theory and practice, he was a generous, kind-hearted, enterprising and capable man.

A1l city elections previous to 1894 had been what are called "nonpartisan " contests, because the suppression or permission of liquor selling was the dominant issue, and upon that question both republicans and democrats were divided. However, the liquor license element within the republican party were this year overborne, the "non-partisan" device was abandoned, and a straight republican convention was held in Williams Hall on Friday evening, March 2, at which a full city ticket was nominated, and the following plank adopted in the platform :

"We are opposed to the licensing of saloons, and refuse to be a party to any act that will foster or encourage a saloon business in our midst. It is the duty of all good citizens to promote sobriety."

Of course their candidates were all elected by large majorities; but as no other feature of the election concerns this chapter, no more is given here. A table of the entire vote will be found in page 232 .

*I,ATER.-Several cases of fiues from $\$ 100$ up to $\$ 250$ occurred after this search of the records was made; but some were reheard at Los Angeles, by appeal, and were there reversed on mere technicalities [See foot-note, page 267.7 


\section{DIVISION FOUR - вOOM}

\section{CHAPTER XIV.}

THE MUNICIPAL CORPORATION.-Early steps and stages of Pasadena's growth as a civil jurisdiction.-Different efforts for incorporation.-Successive city hall buildings. - Table of all city officers from date of incorporation to r894.-City expenditures one year.-List of city property.

History of the City Fire Department.

\section{CITY INCORPORATION.}

The territory now comprised within the city of Pasadena was from the earliest Spanish occupation a part of the San Gabriel Mission lands. And after the church rule was brokeis up by the Mexican government, and the lands segregated and parceled out to individual ownership as ranchos, this land still remained within the civil jurisdiction of San Gabriel. This status also continued through the American occupation of the land as a territory and as a state, $11 \mathrm{p}$ to August, 1874 , when the first civil separation from San Gabriel was made by the creation of the San Pasqual school district. This new departure was brought about by the original colonists of the San Gabriel Orange Grove Association, commonly known then as the "Indiana Colony," so that they might have a school within their own borders instead of having to send their children five miles away to the old San Gabriel village, or else to Los Angeles. I. N. Mundell settled on his original colony lot in October, 1874 - and in 1875 he was appointed road overseer, being thus the actual first civil officer belonging to Pasadena. And when his time expired A. O. Bristol served next.

In 1877 A. O. Bristol was elected constable; but he did not want the office, did not qualify, and so never actually served. And Harry Price in I 883-84 seems to have been the first Pasadena constable in real service by election.

In Marcl, I877, Henry G. Bennett was appointed deputy county assessor, and served until March, 1886 - nine years. His district included San Gabriel, Alhambra, La Canyada, etc., besides Pasadena.

Pasadena was at this time dependent on Los Angeles for notarial business, till Major Erie Locke obtained a commission as Notary Public; and his first official act was the acknowledgment of a deed from the San Gabriel Orange Grove Association to L. J. and T. J. Lockhart, of the land now known as the McGregory place - this act of his as notary being dated March 29, 1877. At the fall election that year Mr. Locke was elected one of the justices of the peace for San Gabriel township, and thus Pasadena first acquired a civil tribunal of her owı. During is78 Mr. Locke, by reason of sickness, became unable to administer the office, and Col. J. Ban- 
bury was appointed to serve ont the unexpired term; and his first official act that appears of record was the acknowledgnient of a deed, on December I I, I878. For the next term Thomas Banbury was elected. Next, R. Williams. Then in I884 T. P. Lukens was elected justice of the peace. After a few months he resigned, and Chas. A. Gardner was appointed to fill the vacancy; then before his time expired the city was incorporated, and he was appointed city recorder [police judge]. And thus the apostolic succession of judicial honors and duties trickled along down the increment of years with virtue unabated, from old Spanish San Gabriel to new American Pasadena.

In 1879 , and again in $1880, P . G$. Wooster was appointed deputy sheriff, being the first constabulary officer here. In I 885 Thomas Banbury was appointed deputy sheriff. When his term expired John R. Slater was appointed, and has held the office continuously ever since.

The first formal move made toward seeking incorporation as a city was some time in January, 1884 , but I found no record or printed report of its proceedings. The Valley Union of February 16, I884, reports an "adjourned meeting" held in Williams' Hall on Saturday evening, February 2; the weather was stormy and few were present. Dr. O. H. Conger was appointed chairman and M. E. Emery secretary. H. W. Magee, as chairman of a committee appointed at a previous meeting, made a verbal report. While a good many citizens were in favor of incorporation, there was great difficulty in agreeing on the boundaries, and the territory to be included; and those who feared greatly increased taxation to run a city government, opposed the project. However, a new committee was appointed to carry on the movement, consisting of Stephen Townsend, Col. J. Banbury, B. F. Ball, James Cambell, Dr. Lyman Allen.

I found nothing further until April I8, i 884, when a meeting was held at same place to hear a report of the committee. Rev. W. C. Mosher was made chairman of the meeting and J. W. Wood secretary. The committee reported South Pasadena unanimously opposed to the movement and refusing to be included. This committee was discharged, and a new one appointed with instructions to prepare a petition and procure signatures, praying the county board of supervisors to make Pasadena a city incorporation. Dr. O. H. Conger, T. E. Martin and James Cambell were named for this work.

Nothing appears on the subject except an occasional newspaper squib "punching up" the committee, until November IO, I884, when a great mass meeting was held on the public school grounds to consider what could be done to get rid of the liquor saloon then recently opened on East Coloradu street, in the two story frame building now No. 47, and occupied [1 894] by E. H. Lockwood, Kendall \& Howe, and others. [See page 24r, etc., in Chapter I2.] This meeting voted strongly in favor of incorpora- 
tion, and instructed its chairman, B. F. Ball, to appoint a committee of five to take measures for accomplishing that end-the committee appointed on April 18 having entirely failed of its purpose; and accordingly $\mathrm{H}$. W. Magee, Col. J. Banbury, H. N. Rust, S. Washburn and J. W. Wood were appointed to take up the burden. But this committee also wearied of the task, and accomplished nothing.

The next public move for incorporation was at a meeting in Williams' Hall on Saturday evening, May 23, I885. At this time the white scale was ravaging the country and seemed likely to destroy the entire citrus industry of California. The meeting in question was called especially to consider this subject, and see what if anything could be done to avert the threatened disaster-and also to consider any matters of general local interest. The incorporation problem very soon became the chief topic before the meeting, for at every step proposed to remedy that or any other evil, it was found that nothing could be done, for want of police authority; and as a result a committee of five was appointed to take the matter under consideration, and make out papers of incorporation, to be submitted to a public meeting of the citizens at the earliest possible time. This committee consisted of Col. J. Banbury, Dr. O. H. Conger, H. W. Magee, Esq., J. P. Woodbury and George W. Wilson.

On July i I a meeting was held to hear and consider a report of the committee. Col. Banbury called the meeting to order and J. E. Ciarke was made chairman. The petition as prepared included all the territory from Lincoln Park or the old Monterey road to the foot of the mountains, and from the Arroyo Seco eastward to Santa Anita Avenue. There was some warm debate on this extensive grasp of territory for a city ; but it was finally decided to lay it before the county board just as it was, for they had the right to change it, anyway, and those who objected to it could appear there with their reasons and arguments - and then the county board could fix the boundaries as they thought best. Thereupon a committee was appointed to lay the matter before the county board at once and have a day of hearing appointed. H. W. Magee, J. Banbury, S. Townsend, J. E. Clarke and C. B. Ripley were appointed for this duty, and they did it promptly. The Valley Union of August I4, I 885, published the petition, with names attached, a total of I I qualified electors.

The next stage of the movement is thus reported in the Union of September II, I885:

"On Thursday the petition for incorporating the Town of Pasadena was taken up by the Board of Supervisors and a hearing given to the petitioners. It was found that no less than four remonstrances had been filed from different sections of the territory embraced within the proposed incorporation linits, besides several protests from individuals. The places remonstrating were Soith Pasadena, the Highlands, all that territory east of Los Robles Avenue, and the Craig tract, including the Allen, Crank and other ranches. 
H. W. Magee, Esq., and J. E. Clarke appeared for the petitioners. Messrs. Dougherty, Risley, Porter, Glover, Eaton, I. B. Clapp and others were present in the interest of South Pasadena, which was represented by Stephen M. White, Esq.; as legal counselor. On behalf of the Craig district, James Craig, with his attorney, F. H. Howard, Esq., appeared. C. C. Brown advocated the claims of those remonstrating from the eastern portion of the colony."

After this the whole subject seems have taken a long rest, for nothing appears again until May 14, I886, when the Union said:

"Hurrah! We are incorporated! The petition was granted yesterday. In support of the petition arguments were made by Messrs. Hopkins, Brockway, Ward, Ball, Col. Picher, Drs. Thomas and Allen, and others. 'The remonstrants were represented by Messrs. Dougherty, Furlong, Painter, Arnold, Woodward and Brown."

The following is the official order, dated May I3, 1886:

"Ordered, that the petition for the incorporation of Pasadena be granted and houndaries be fixed as follows: Beginning at a point on the west bank of the Arroyo Seco due west from the south end of reservoir No. I, of the Lake Vineyard Land and Water Association, and thence running east to the south end of said reservoir, thence running southeast by the west line of the Painter \& Ball tract, to a point forty rods south of south line of Mountain street, thence running east by a line parallel with and forty rods south of the south line of Mountain street to a point forty rods east of east line of Lake Avenue, thence running south by a line parallel with and forty rods east of the east line of Lake Avenue, to the B. D. Wilson estate, thence running west and south by the north and west lines of said Wilson estate, thence running south-west by lands of B. T. Smith and land of George Stoneman, and by the Marengo ranch to the south line of Columbia street, thence running west by the south line of Columbia street, and by a direct extension of the same to the west bank of the Arroyo Seco, thence running north by the west bank of the Arroyo Seco to the point of beginning. From the evidence taken the Board finds that the population in said limits approximates 2,700 .

Ordered that June 7 th be fixed for holding the election to determine whether the town of Pasadena shall be incorporated, and that said election be held at the Williams building, Fair Oaks Avenue; and that at said election persons be chosen to fill the following offices: Five trustees, a clerk, a treasurer and a marshal ; and that Edson Turner be appointed inspector, and R. Williams and C. C. Brown be appointed judges of such election ; and that notice of said election be published for two weeks."

The next historic record is the Union's report of the election, printed in its issue of June II, I 886, from which I quote:

"The child is born who will make his fame by writing the history of Pasadena ; and we of today are making that history. Monday was another landmark - a historic day, being the first city election, and making choice of the men who should first wield corporate authority.

The "Citizen's Ticket," which was nominated by a meeting held at the Union office on Friday evening, was every man of them elected, although there were four varieties of tickets in the field. The contest was quite spirited, although entirely good-natured throughout, and the friends of the successful candidates indulged in a little jubilation after the result was finally made 
known. A bonfire was lighted on school-house square, the bell rang out a jubilee, some cannon firing was improvised, and the band played some of the liveliest tunes in their repertoire.

C. C. Brown and John O. Lowe were the judges of election, and F. H. Heydenreich and Will T. Holmes, clerks. It took them about three hours to complete the count, the result being as follows: 'Total vote, 229.

For City Trustees : R. M. Furlong........................... 222

E. Turner.............................. 219

E. C. Webster $\ldots \ldots \ldots \ldots \ldots \ldots \ldots \ldots \ldots \ldots \ldots \ldots \ldots$ 1 30

H. J. Holmes............................. I 30

M. M. Parker ............................. I I 2

James Clarke ............................. I I

R. Williams ........................... I0 104

I. M. Hill ........................... 83

The first five are elected, and will constitute the first City Council of the City of Pasadena.

For City Treasurer: Col. J. Banbury ....................... I 40

W. E. Cooley …....................... 85

For City Clerk : C. A. Sawtelle............................... 220

Scattering................................. 6

For City Marshal : I. N. Mundell ......................... 158

M. H. Weight........................ 68

For incorporation, I79; against, 50 ; majority for, I29.

The result was officially ratified by the county board of supervisors on June 14,1886 , and so recorded in Book 9, at page 16 and following.

After the vote for city officers had been duly canvassed by the county board of supervisors, Mr. Sawtelle went before the county clerk, subscribed the oath of office. and was thus qualified to swear in the other officers elect. On June 23, 1886, at $20^{\prime}$ 'clock P. M., the parties elected all met in a frame building then known as the Wakeley block, on E. Colorado street. The several trustees presented their certificates of election to Mr. Sawtelle, whereupon he administered the oath of office to them. Then R. M. Furlong was chosen as president pro tem.; after which a formal election was held by ballot, and $\mathrm{H}$. J. Holmes was duly chosen as president of the city board of trustees - bence he stands in history as the first "mayor" of the city.

The Valley' Union newspaper was at this time publishing two issues during the week, one being a small sheet called the "Union Junior," and this issue of date June 29, says :

"The Board of Trustees met yesterday, at Mr. Webster's office, over F. D. Stevens' hardware store, and deliberated over and passed the ordinances for the future government of our young and growing city. Ordinance No. 2 provides for the publication once in some newspaper in the city of said ordinances, before going into effect at noon of the following day. Necessarily they, being published in today's Junior Union, are legal from tomorrow at noon. Ordinance No. 3 provides for the filing of bonds by certain of the city officials elect, as follows: City clerk (as ex-officio city assessor) in the sum of $\$ 5,000$; marshal (as ex-officio tax collector) also 
$\$ 5,000$; city treasurer, $\$ 10,000$; and that these respecive officers are required to submit their bonds within five days, to the board of trustees. Ordinance No. 4 adopts forthwith a common seal the design of which is a key resting within a crown, and the words "City of Pasadena, incorporated June, A. D. I886," within its rim. Ordinance No. 5 provides for the imposing and collection of a street poll tax of $\$ 2$ for each male inhabitant of the city, to be due and payable by the I $5^{\text {th }}$ instant. The board will meet at Mr. Webster's office until the necessary furniture can be obtained for meeting in the rear of A. Cruickshank's store on Fair Oaks avenue."

Ordinance No. I is not mentioned in the above article, and this requires historic explanation. Chas. A. Gardner was at this time editor of the Valley Union; he was also justice of the peace for San Gabriel township. Now, the first ordinance ever enacted by a Pasadena city council was one making said Chas. A. Gardner city recorder - that is, police "judge." And if I had merely copied the newspaper report and not hunted up the why and wherefore of this remarkable omission, the readers of Pasadena history would have been left in a state of perpetual quandary as to "what was the matter with Ordinance No. I," that it had so quickly slipped out of reckoning, " unhonored and unsung." It was a case of editorial modesty that beat all previous records.

Business now pressed hard upon the board, to get proper ordinances prepared and enacted, and all the machinery of city government set in motion; and to meet these conditions they were obliged to meet often in formal session, and to be in informal session almost continuously. Their next official meetings were held July I, July 2, July 6, July 8, July io, July I 2, July I3, July I 9, July 24, July 27, July 29; August 2, August 9, August I4, August 2 I, August 24, August 31. In September only four meetings were held; and the same in October; etc.

On July ro they appointed Geo. W. Dunmore as the first city policeman who ever wore the official star in Pasadena.

By August they had enacted all the first necessary ordinances to regulate their own proceedings, provide for bonds and salaries of city clerk, marshal, treasurer, recorder, attorney, policemen, surveyor, printer, etc., so that the business of the city was all going on under lawful procedure, and all necessary appointive offices had been filled. But there was no city treasury as yet, and no funds with which to pay the necessary current expenses ; hence they were obliged to negotiate a loan until such time as the city revenues could be gathered in. And accordingly on July 2, I886, they voted to borrow $\$ 500$ for ninety days, thus providing for this financial emptiness. *

The first city council room was E. C. Webster's office, over Stevens's hardware store in a frame building on ground where the Carlton Hotel

* The city recorder paid into the city treasury on Wednesday $\$ 50$ in fines collected. A $\$ 20$ fine was the first money the city ever owned."-Valley Union, Angust $27,1686$.

I tried ny best to find out who paid this historic fine, and what it was for, but records and menories were all empty of the knowledge. 
block now stands. But in August they rented and fitted up the second story of James Smith's building on southwest corner of Fair Oaks Avenue and Kansas [now Green] street, over A. Cruickshank's dry goods store. Next, when the Exchange block was completed, Mr. Webster had a

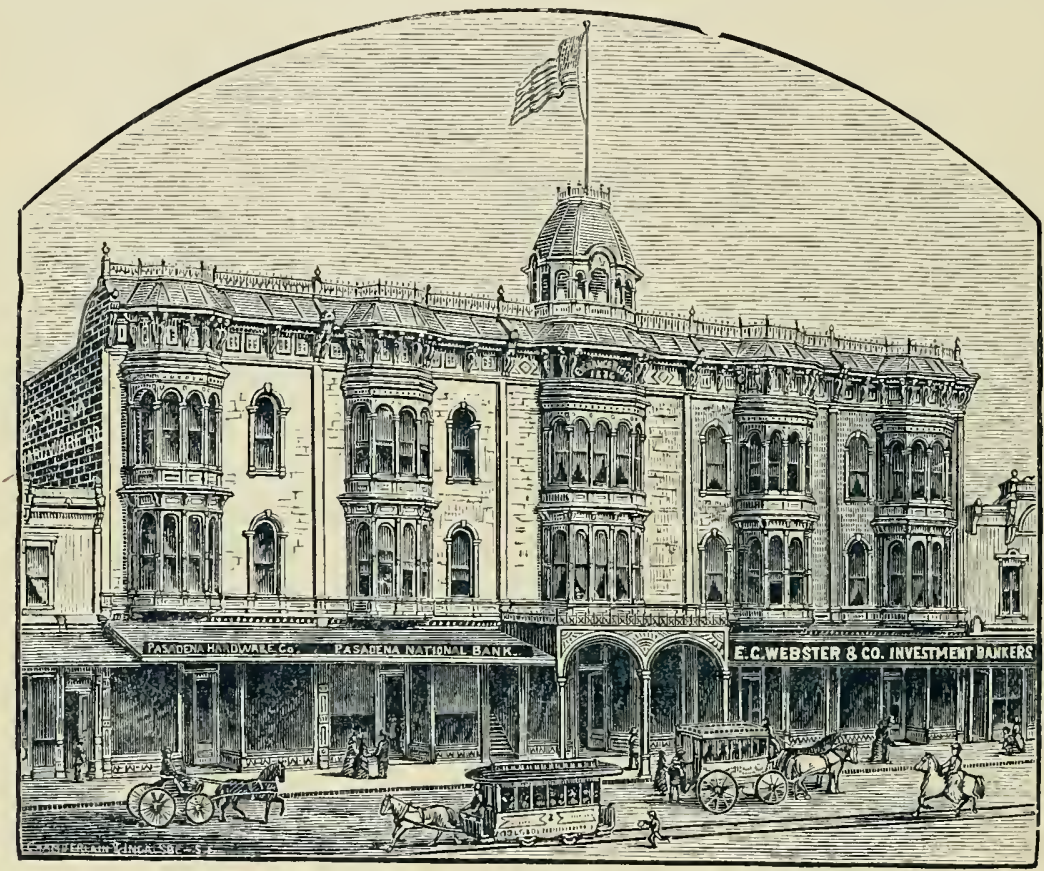

EXCHANGE BLOCK [CARLTON HOTEL], 1886-7.

The first city bench-mark was here; also, the enactment of the famous prohibitory ordinance was here; and the National G. A. R. reception; and the Astronomical Banquet; and the first editorial convention; and other historic events.

spacious double office in it, on the ground floor, and on January 3 , 1887 , they commenced using the rear room of these apartments as the city council room.* Meanwhile, they were on the lookout for a building that would serve for their meetings, and also for all of the city offices and business. And for this purpose they leased, on February 26, I887, the old Central School building, then owned by J. W. Vandevort, and located on Raymond Avenue, where Mr. Vandevort's terra-cotta block now stands. The lease was for three years, at $\$ 1,000$ per year, with option of renewal or purchase, etc., and the first meeting of the council in this building was held March 2I, I 887. An adjoining vacant lot on the south was also leased, and a city jail built there.

*July 27 , I886, a bench mark from which to reckon all city levels was established at "top of the stone pedestal or sill upon which rests the third iron column trom the west side of the Colorado street front of the Exchange block, the elevation of which is 833 and 451 -10oo feet above sea level." -Valley
Unzon.

The L'nion of July 16, 1886, gives the following altitudes as official: Front of Baker Block, Los Angeles - 282.955; Pasadena, at P. O. door-885.206; Sierra Madre, Lipiscopal chuich, 899.5 1 I. 
As the time approached for expiration of this Vandevort lease, an effort was made to purchase grounds and buildings that would serve all of the city's uses, including quarters for the fire department. But so much public strife and contention arose over the matter of location, price, choice of premises, etc., that the whole project was abandoned; and on December I I, I889, they leased for three years, for city hall purposes, C. T. Hopkins's brick block on the northwest corner of Fair Oaks Avenue and Union street, at \$I,O0O per year - with privilege to occupy it at once, but lease date and payment not to commence until March I, I890, when the Vandevort lease would expire. However, out of the agitation for a central and permanent place for all city offices and city business finally came the purchase of grounds and erection of building for exclusive use of the fire department, on Dayton street. [See article "Fire Department.']

The next historic move as to city hall premises occurred October 24, I 892, when rooms enough for all the offices, besides a council room and a police court room, were leased for five years at $\$ 600$ per year, in Geo. W. White's brick block on southwest corner of Fair Oaks Avenue and Union street, some necessary changes and refitting were made, and this building was formally occupied on February 27, I893, being the present City Hall.

The following table gives a complete register of all persons who have served the city in any important official capacity :

\section{TABULAR EXHIBIT OF PASADENA CITY OFFICERS IN SUCCESSIVE YEARS.}

City Trustees [commonly called councilmen] :

I 886 to i $888:-\mathrm{H}$. J. Holmes, president [Mayor] ; R. M. Furlong, E. Turner; M. M. Parker, chosen president June 15, I 887 , vice Holmes, resigned ; E. C. Webster ; G. Roscoe Thomas, appointed June I8, I887, vice Holmes, resigned.

I888 to I890:- M. M. Parker, president; Edson Turner; Stephen Townsend; W. W. Webster; A. G. Throop, chosen president October 5, i889, vice Parker, resigned; J. B. Young, appointed September I 5, I888, vice Webster, resigned ; Alex McLean,* appointed February 9, I889, vice Turner, deceased $\dagger$; Wm. W. Mills, appointed October I2, I889, vice Parker, resigned; Elisha Millard, appointed December 7, i889, vice Young, resigned; John Allin, appointed February i 5, I89o, vice Townsend, resigned.

I 890 to I892:-T. P. Lukens, president; A. K. McQuilling; James Clarke; C. M. Simpson; Thomas Banbury.

I 892 to I 894 :-Oscar F. Weed, president; John S. Cox; T. P. Lukens; A. K. McQuilling ; James Clarke.

I 894 to i 896 :- T. P. Lukens, president; S. Washburn ; H. M. Hamilton; O. F. Weed; J. S. Cox, elected president January 2, I 895.

* Mr. Mclean resides on Mountain Avenue; he was formely editor of the Lompoc Record: he was in the state legislature from Santa Clara County at the same time Col. Banbury was there from this county, and worked with the colonel in trying to get a local option law passed. '-Pasadena Standard, Feb. 16,1889 .

† Jan. 14, 1889, Mr. Turner's horse took fright at a steam pimp which was then working in a wellhouse at foot of the north drive up Raymond Hill; he was thrown from his buggy so that his head struck un a rail of the Santa Fe R. R. track; he lived a few hours but never recovered consciousnessagain. 


\section{City Clerk:}

I 886 to i 888 :-C. A. Sawtelle, elected.

I 888 to I 892 :- James H. Cambell, elected.

I 892 to I 896 :- - Heman Dyer, elected.

\section{City Marshal :}

I 886 to I $890:-$ I. N. Mundell;* D. R. McLean appointed March 25, 1889, vice Mundell, resigned.

I 890 to I $892:-D$. R. McLean, elected.

r 892 to $1896:-$ John 'T. Buchanan, elected.

\section{City Treasurer:}

I 886 to I 896 :- Jabez Banbury; M. E. Wood, appointed March 25, I 889, vice Banbury, resigned, but did not qualify until June 8 ; Hon. P. M. Green, the deputy treasurer officiating meanwhile.

I 890 to I $892:-W$. T. Vore, elected.

I 892 to I $894:-W$. U. Masters, elected.

1894 to 1896 :- - Henry C. Hotaling, elected.

City Recorder [police judge] :

I 886 to I 895 :- Charles A. Gardner; C. N. Terry appointed April 9, I887, vice Gardner, resigned; P. A. V. VanDoren, appointed January I9, I889, vice Terry, resigned; H. H. Rose, appointed December 6, I89o, vice VanDoren, term as justice of peace expired ; J. G. Rossiter appointed April IO, I894, vice Rose, resigned, and still holds the office, July, I 895.

\section{City Attorney' :}

1886 to 1895 :-E. J. Hueston, employed July 6, I886, for one month, at salary of $\$ 150$. Had done some work before this date. N. P. Conrey, employed July 27, I886, at salary of $\$ 75$ per month. John C. Winslow, employed September 2 I, 1887, vice Conrey, relieved at his own request, to take effect October I. Frank J. Polley, appointed April 24, I888, vice Winslow, deceased; salary \$IOO per month. A. R. Metcalfe, appointed Fehruary 15, I 890, vice Polley, dismissed; salary \$150 per month. W. E. Arthur, appointed April 2I, I 89o, vice Metcalfe, resigned, and still holds the office, July, 1895.

\section{City Engineer:}

I 886 to I $895:-$ J. M. Willard, appointed July 8, 1886 . Salary $\$ 5.00$ per day. On May 25, I887, August Meyer was employed as sanitary engineer to manage the public sewer work. Salary $\$ 25^{\circ}$ per month. October 8 , 1887, Meyer was made sewer commissioner. On May 8, 1888, the two offices of city engineer and sanitary engineer were consolidated, and $\mathrm{Mr}$. Meyer appointed to the double duty. On May 17, 1890, James E. Place was appointed, to date from June $\mathrm{I}$, at $\$ 5.00$ per day for actual time required in city service. John W. Sedwick, appointed January 17, 1891, vice Place, deceased. Wm. B. Clapp, appointed April 23, 1894, vice Sedwick, resigned.

* Dec. 3,1887 , the office of captain of police was created, and Geo. R. Shaw appointed to fill it, at a salary of $\$ 85$ per month. But somehow it seemed to infringe ou the statutory prerogatives of the marslial; and after a month or more of tromble over it the new office was dropped. 


\section{Street Superintendent:}

I886 to 1895 : - The first street superintendent was E. Turner, appointed November Io, I886. May I4, I887, Turner resigned and J. W. Vore was appointed. April 26, i890, C. C. Brown was appointed, vice Vore resigned. April I3, $1894, \mathrm{~J}$. A. Buchanan was appointed, vice Brown, resigned. Buchanan still holds, July, 1895 .

\section{Health Officer:}

I 887 to $1895:-D r$. Theron Nichols, first incumbent, appointed February I9, I887; no salary. Dr. W. L. McAllister, appointed August 27, I 887 , vice Nichols, resigned; salary $\$ 50.00$ per month. Dr. H. H. Sherk, appointed April 26, I890, vice McAllister, term expired. October 6, 1892, a cit, board of health was created by ordinance, and Drs. H. H. Sherk, J. M. Radebaugh, R. J. Mohr, and H. K. Macomber were appointed as such board. Dr. Sherk was thus continued as health officer; and on October 24 he was appointed to serve also as building and plumbing inspector. Dr. F. F. Rowland, appointed April 23, 1894, vice Sherk, resigned, and still holds, July, I 895 .

\section{Official Newspaper, or City Printer:}

1886 to 1895 : - The Union Junior of June 29, I886, contained the first official publication of city ordinances, and they took effect the next day at noon. Hence it was the first official newspaper. The Pasadena Star, appointed July 8, I 886. [For printing city ordinances, resolutions, etc., the Star had bid 24 cents per square and the Valley Union bid 50 cents per square. Hence the choice.] The Daily Union was appointed to the same service on June 2, 1888, having now made the lowest bid. But when in I 889 the Union suspended publication, this business went to the Daily Star again; and the Star still holds it, 1895.

\section{Chief of Fire Department:}

I 887 to I $895:-$ On October 8, I887, a city fire department was authorized and the office of "Chief" created. Robert Hentig was appointed to fill it; salary \$10.00 per month. On June 9, I889, Hentig tendered his resignation. On August I6, i 888, J. D. Jones appears in the records as Foreman and Acting. Chief of the Fire Department. Then on September ro, I 889, Jones is discharged, and Hentig reappointed. A. S. Turbett was appointed November 30, 1889 , vice Hentig, resigned, and still holds the place - July, I 895 .

\section{City Librarian :}

On January 14, 1890, a public vote was carried to issue bonds for the purchase by the city of the public library property. This made the post of librarian a city office; and on April 2 I, I890, Mrs. S. E. Merritt was appointed to fill it - as she does yet, I 895. [For Library Trustees, sce page $210]$.

In I 894 the city clerk published a full and exhaustive tabulation of city finances, including debts, salaries, current expenditures of every sort, tax levies, etc., etc. This was printed in a neat manual of thirty pages, which contained also a complete directory of all city officers, departments, etc. And from it I compile the following exhibit of current expenses of the city during the fiscal year ending February 28, I 894: 
DISBURSEMENTS IN ONE YEAR.

Clerk and Assessor's De-

partment ................\$2,389 30

Fire Department........... 6,478 o6

Street Department.......... 6,0 o 382

Police Department.......... 2,671 50

Engineer's Department..... I,35 I 35

Tax Collector's Dep't...... 644 io

Recorder's Dep't............. 22960

Attorney's Dep't........... r ז,027 25

Treasurer's Dep't.......... 98072

Poundmaster's Dep't....... 20985
Building and Plumbing

Inspector's Dep't ......... 30050

Street-sprinkling Dep't..... 7,077 48

Street-lighting Dep't........ 6,296 3I

Rent Dep't ................ $733 \quad 32$

Public Printing Dep't...... 1,374 or

Sewer Dep't................ $434 \quad 04$

Sewer Farm Dep't........... 3,607 04

Library Dep't.............. 3,047 60

Miscellaneous Dep't......... I,753 85

Soup house department, providing temporarily for "the unemployed :" [As this is an historic episode, I give the items in full.]

Salary of Special Officer @

$\$ 50$ per mo..................\$50 oo

Repairs on building............. 672

Shovels and rakes.............. 660

Coal......
Stove, dishes, and cooking utensils ....................... $46 \quad 04$

Groceries and provisions....... 9493

Total.....................\$209.79

Interest on Fire and Sewer Bonds*...................\$7,075 00

Interest on Library Bonds................................. 50575

Interest on Deferred Payment of Bills.................... 740 i 8

Total this year for interest on borrowed money, $\$ 8,320.93$. A total of $\$ 10,025$ was also paid out for redemption of bonds.

The following is a complete inventory of property belonging to the city on February 28, 1894:

Sewer System*

Sewer Farm and buildings, 300

acres @ \$250 per acre....................

Horses and Implements on Sewer Farm.

Fire Engine House and Lot..............

Fire Department Horses .................

Fire Engine

$\$ 160,000$ oo

$\$ 160,000$ oo

Hook and Ladder Truck ...................

Hose Cart and Reel........................

Harriess

I,900 feet of Hose.

Furniture, etc., in Engine House..........

Fire Alarm System.

Public Library Building and Lot..........

Books in Library ............................

Furniture in Library .........................

Instruments, Engineer's Dep't............

Furniture in City Hall....................

Two Safes in City Hall......................

Street Sprinkler

Street Sweeper

\begin{tabular}{|c|c|c|c|}
\hline 75,000 & OO & & \\
\hline 875 & OO & 75,875 & $\mathrm{OO}$ \\
\hline I O, OOO & OO & & \\
\hline I, 275 & OO & & \\
\hline 4,400 & $\mathrm{OO}$ & & \\
\hline 1,600 & $\mathrm{OO}$ & & \\
\hline 475 & OO & & \\
\hline I 75 & $\mathrm{OO}$ & & \\
\hline 1,425 & OO & & \\
\hline 200 & OO & & \\
\hline 3,975 & OO & $23,5^{25}$ & $\mathrm{OO}$ \\
\hline 25,000 & OO & & \\
\hline 6,500 & 00 & & \\
\hline 300 & oo & 31,800 & OO \\
\hline 300 & OO & 300 & $\mathrm{OO}$ \\
\hline 300 & OO & & \\
\hline 500 & OO & 800 & $\mathrm{OO}$ \\
\hline 400 & OO & & \\
\hline $55^{\circ}$ & OO & & \\
\hline
\end{tabular}

*On July 19. 1887, a puhlic vote to authorize the issue of \$192.000 of City Improvement Bonds was carried by 197 for, aud only two against the measure. Five per cent interest. 
Road Machine

IOO 00

Carts, Scrapers and Implements...........

Cart Horse

City Jail.

I 5000

2500

I, 22500

Supplies, Police Dep't

60000

Cash subject to warrant...................

Total Assets......

2500

62500

8,22959

$\$ 302,37959$

The city had at the same date a total bonded indebtednees of $\$ 138,700$.

CITY ASSESSMENTS AND TAX LEVY IN SUCCESSIVE YEARS.

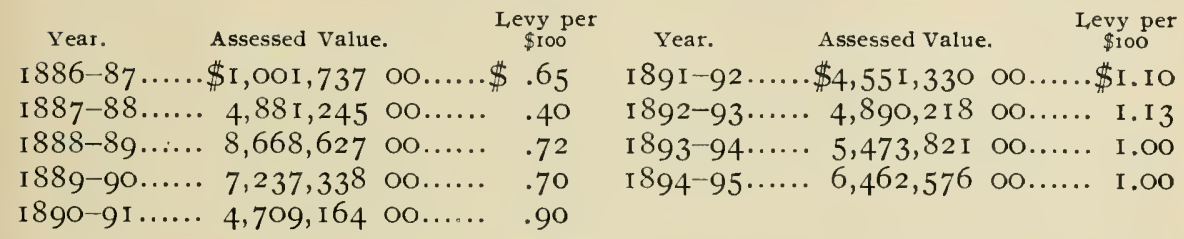

November 10, 1893, the Board of Trade issued a circular prepared by its secretary, Wm. H. Knight, from which I glean a few points to preserve, as showing the condition of certain matters at that time:

"Pasadena, with a city population of 8,000 , and an adjacent population 3,000 more, probably has a larger number of beautiful homes than any other city of equal size in the world. [See page 226.] * * * Building improvements now under way amount in value to $\$ 552,400$. Among them are dwellings ranging from $\$ 1,000$ to $\$ 30,000$. * * * Between January and September, I 893 , there were 9,5 19 lineal feet of streets graded, $26,45^{8}$ feet of curbing built, and 99,335 square feet of sidewalks laid, at a total cost of $\$ 40,000$. The principal business streets are now being paved with asphalt. $* * *$ Within and adjacent to the corporate limits of Pasadena are I55,000 orange and lemon trees from three to fifteen years old, and there are 2,500 acres planted to walnuts, olives, prunes, figs, apricots, and other deciduous fruits."

\section{NEW CHARTER - "NO!"}

In 1894 a plan was set on foot to provide the city with a bran new homemade charter, instead of accepting the one for a city of the Fifth Class, or the one for Fourth Class, as already provided by the State Code. A committee of fifteen freeholders was formed to prepare the new document. They spent several months in wrestling and worrying with the manifold points necessary to be covered. At last the completed thing came to a public vote on Saturday, February 23, I895, and was overwhelmingly rejected, by the following vote :

First precinct-yeas 5 , noes 63 ; second-yeas 6 , noes 66 ; third-yeas 2 , noes 56 ; fourth-yeas 5 , noes 33 ; fifth-yeas 10 , noes 42 ; sixth-yeas 6 , noes 51 . Total, yeas 34 , NOKS 3 II. The total cost to the city of this " new charter " fiasco footed up \$I,325.06.

*"In our city's effort to secure r1ght-of-way for laying pipe under ground to reach its sewage farm eighty different resisting property owners along the line are made co-defendants in a suit of the city for legal process to secure the desired right-of-way." - Pasadena Standard, September 21, 1859. 
NOTE.-After this chapter was ready for press, the city clerk's annual report for 1894-95 was published in pamphlet form ; and from it I glean a few additional points of historic interest.

$$
\text { APPORTIONMENT OF TAXES FOR I } 894-5 \text {. }
$$

General Fund...

Sewer Fund... $\$ 0.50$

\section{Fire and Sewer Sinking Fund ..... 0.24}

Library Sinking Fund ............... .0125

Library Fund....

Total ......................... \$ I oo per $\$ 100$ oo produced $\$ 32,312 \quad 88$ " 100 oO " $\quad 9,69387$ " 100 " " IOO OO " 10000 " 80782 6,301 o I "\$100 00

$$
\text { 6 }
$$

For current expenses of the city, \$23,484 3I of interest-bearing (8 per cent) certificates were issued for claims which could not be paid on demand because the treasury was empty: then when they were paid, (after the year's taxes had been collected,) the interest on them amounted to \$1,03I 83 . Among the items of cash receipts by the city, these odd ones occur: Fines collected by recorder [police judge], mostly from violations of restrictions in the liquor permitting ordinance, \$1,0r9.50. Dog licenses, \$7I. Sale of street sweepings, $\$ 130.35$. Sale of pumpkins and hay from sewer farm, \$I,288.7I. Library collections, \$3II.10.

Some of the expense accounts in $1894-5$, worthy of special note, were: Fire department, $\$ 6,241.76$; street work, repairing, sweeping, etc., $\$ 8,822.87$; street sprinkling, $\$ 8,969$. I 8 ; street lighting, $\$ 7,803.01$; total expense for street interests, $\$ 25,595$.06. Police department, $\$ 3,447.17$; soup house department, $\$ 825.83$; printing department, $\$ 1,768.87$; sewer farm department, $\$ 3,054.66$; library department, $\$ 3,170.91$.

Some of the valuations of city property in 1895 are: Sewer department, $\$ 235,668$; fire department, $\$ 23,525$; library department, $\$ 30,500$. The total value of all property belonging to the city corporation is given as $\$ 293,969.80$.

The city's debts, March I, I 895, were: Fire and sewer bonds, $\$$ I22,300 , at 5 per cent interest; library bonds, $\$ 6,375$, at 7 per cent interest. And at that date there was $\$ 4,966.77$ cash in the city treasury.

The street work done by the city in I894, was I 29,479 square feet of paving; 6I,2I 8 square feet of sidewalk; 22,05I lineal feet of grading; 49,535 lineal feet of curbing ; 53,026 lineal feet of guttering; 14,365 lineal feet of sewer construction.

THE FIRE DEPARTMENT.

The first effort ever made toward organizing a Fire Company in Pasadena occurred in Jannary, i 885 . Meetings were held on the $15^{\text {th }}, 2$ Ist and $27^{\text {th }}$ of that month, and on February $5^{\text {th }}$ and $\mathrm{I} 2$ th, at all of which Dr. H. A. Reid presided. Of the first meeting the Valley Union said:

"At a public meeting held at the reading room of the Webster Hotel 
Friday evening, at 8 P. M., agreeably to notice, Dr. H. A. Reid was elected chairman and Martin Mullins secretary. Mr. F. B. Wetherby read a list of names of twenty persons who volunteered to act as firemen. On motion the chairman was authorized to appoint a committee of three to learn what articles would be needed for extinguishing fires, and the cost of same. Messrs. T. E. Martin, H. W. Magee and M. Mullins were appointed as such committee ; and 'T. P. Lukens, Esq., was appointed to learn and report as to the cost of articles needed."

The hotel "reading room " referred to was the same that is now No. I6 west Colorado street, occupied by W. T. Clapp's real estate office and J. A. McIntyre's shoe store and shop. The Union of January 3 oth reported the first actual organization of a Fire Company, and I quote from it :

"Pursuant to a call, the citizens of Pasadena met Tuesday evening, $27^{\text {th }}$ inst., at the reading room of the Webster Hotel to organize a Fire Company, to be called the "Pasadena Fire Brigade." F. B. Wetherby was nominated and unanimously elected president of the Company. T. E. Martin was then put in nomination and elected secretary. W. B. Loughery was next nominated and without a dissenting voice declared treasurer. Charles Rose and John Ripley were then put in nomination for Foreman. Mr. Ripley withdrew in favor of Mr. Rose, and the latter was then elected by acclamation. John Ripley was then called to fill the position of Assistant Foreman, and was declared elected by a full vote of all present. Next in order was the appointment of a committee to draft a Constitution and ByLaws for said company, and the chair appointed Messrs. H. Phillips and C. Rose to draft the same and report to the next meeting."

No report of this committee was ever published; but the Union of February 13 , publishes the following:

"Another fire meeting was held last evening at the reading room of the Webster Hotel, Dr. Reid presiding. Mr. Wetherby read a proposition from the Harper \& Reynolds Company, for the furnishing of certain apparatus for $\$ 450$, to which Mr. Lukens supplemented a list of other articles swelling the amount to $\$ 76$ I.80."

The report then goes on to relate at length that $\mathrm{R}$. Williams raised the question whether the forming of a fire company and procuring apparatus would reduce the exorbitant insurance rates; also, what arrangement could be made with the water companies; - both of which points gave rise to much discussion, and were finally referred to committees. Then Frank M. Ward [as agent for Gen. Edwin Ward] subscribed \$10o on behalf of the General, and $\$ 20$ for his own firm of Ward Bros.; and Mr. Wetherby was appointed to solicit further subscriptions. But I could not find that any of the committees ever made report; and the whole project seems to have died and left no sign. There were then very serious difficulties as to water supply for any sort of engine, the water mains being only the original small caliber sheet iron colony pipes. Geo. A. Greeley and Dr. Reid urged the formation of a hook and ladder company, and that our own blacksmith and wagon shops be employed to make some s'itable ladders, some fire hooks, with 
poles, chains and rope, and a truck to carry them, besides a supply of buckets, etc. But the young men who had given their names to form a fire company were not willing to do anything about it unless money enough was subscribed to procure fire hats and belts for them, and a nice engine of some sort. And as nearly as I can learn, only about \$I 50 was ever actually subscribed in this first movement. The next mention of this matter in print was an item in the Union of November 27, 1885, which says:

"Last spring six or eight meetings were held, endeavoring to organize a Pasadena Fire Company and procure suitable fire apparatus and water facilities. It was found that it would take at least $\$ \mathrm{I}, 000$ ready money to provide what was necessary, and less than $\$ 200$ was ever subscribed. - Mr. Greeley proposed that they organize a hook and ladder company, and procure such tools for their use as could be made right here-one or two scaling ladders; perhaps two 24 -foot pole-hooks, and one grappling hook, with chain and suitable ropes. This was really the most practicable thing proposed, and our late fire showed pretty plainly how useful they would have been."

I found nothing more of record in regard to this interest until August 25, I887, when it appears that the First National Bank was appointed as the city's financial agent to negotiate bonds for sewer, fire protection and other improvements. Then the city clerk's book shows that on October 8, I887, resolution No. 52 was adopted, establishing a City Fire Department, comprising a Hook and Ladder Company and a Hose Company, with Robert Hentig as Chief, at a salary of \$IO per month. And there were to be I 2 men to each company, with salaries of $\$ 20$ per year each. On December Io, Chief Hentig reported the organization of these two companies completed. On December 17, I887, the city council accepted and confirmed the following list of first firemen enrolled under the ordinance creating a city fire department: Peter Steil, J. W. Buttner, J. D. Johns, E. P. Dickey, Geo. Draper, W. B. Mosher, Norman Henderson, L. Crosby, C. A. Hughes, A. S: Butterworth, Ed. Brown, C. A. Russell, John McCracken, A. W. Lewis, W. Keys, F. L. Johnston, S. McDaniels, J. S. Mills, Geo. C. Johnston, G. F. Farrer, C. Russell, Harry Haskins, Geo. Brown, T. W. Jeffers. Total, 24 .

Along in January or February the business men of the city subscribed in small sums a loan to the city of $\$ \mathrm{I}, \mathrm{I}$ IO to purchase fire apparatus. The outfit arrived about May I, and on May 8, I888, the fire committee of the city council reported a satisfactory test and public exhibit of the same.

June 4, 1888, the fire company elected John S. Mills president, C. Russell, vice-president, D. J. Jones, secretary, H. F. Cogswell, treasurer ; C. Russell, foreman, J. D. Jones, first assistant, W. H. Mowers, second assistant. On June I9, the city council approved and confirmed these officers; but meanwhile, on June 16 , eighteen members had withdrawn from the company, and 
the council appointed nineteen others to take their places.* On August i6, another break occurred, and twelve names were dropped from membership in the fire company, and the same number of new names were added by the city council.

March 9, I 889, the council voted to purchase a No.2 Silsby steam fire engine, to be naid for with municipal improvement bonds. July 6,M.M. Parker, then president of the city council, reported that the engine had arrived; and Geo. L. Sanborn was appointed as engineer to take charge of it. $\mathrm{He}$ did so temporarily, but declined to continue, and on July $20 \mathrm{H}$. H. Hillier was appointed to the place. However, in the meantime, on July I3, president [mayor] Parker had reported two satisfactory public tests of the machine, and thereupon the purchase was completed by ordering the bonds delivered to its manufacturers. This first fire engine in the city bears the name "M. M. Parker."

August 22, Mr. Hillier resigned his place as engineer, and Geo. L. Sanborn was appointed; and the salary was fixed at $\$ 75$ per month.

September IO, I889, the city council adopted a series of 29 rules and regulations to govern the fire department. One rule said: "Intoxicating liquors must not be kept nor allowed to be drank in any of the houses of the department. And gambling is strictly prohibited."

Rule 26 reads : "The foreman of the engine, hose, or hook and ladder company, shall report promptly to the chief engineer any member of his company who at any time may be unfitted for momentary service by reason of the use of intoxicating drinks; and any member of the department so reported shall be suspended at once by the chief engineer. And any foreman neglecting or refusing to enforce this rule shall be subject to removal."

In this connection occurs an historic episode to be here noted. The minutes of fire company meetings from May 2 I to September 24, I888, show J. D. Jones as secretary ; but the minutes of October 30, say: "The meeting was called to order by chief engineer Jones;" and J. W. Mosher's name is signed as secretary. And the minutes continue to name Jones as chief, up to September 7, I889. On August 14, I889, F. V. Hovey was elected secretary, and continues to hold that office yet, I894. I found nothing in the city clerk's records to show how or when Jones became fire chief; but they mention that on September I0, I889, J. D. Jones was discharged as such chief, and Robert Hentig appointed instead. And this is explained by the fire company's minutes of September 7 , from which I quote :

"Voted, that the resignation of the Pasadena fire department as a body be tendered the chief, to be handed in by him to the city council of Pasadena

*This wholesale withdrawal of old members seens to have been caused by the fact that they had electer Peter Steil to be chief of the fire department, and the city council refused to confirm him-hence he and his special friends went out. Mr. Steil was at this time in open antagonism with the council on the liquor selling question, for he was arrested, had a jury trial, was found guilty, and adjudged a fine of $\$ 150$ only a month previously-to-wit : on May 19,1888 . 
at their next meeting, September 10, if the question of salaries is not settled at that meeting, - 13 for the motion and 2 against."

This is said to have been a kick against the rules or constitution established by the city council quite as much or more than on the salary question. At any rate, the result was that for a day or two Pasadena was at the mercy of the fire fiend, as she had no fire department. But by September 15, chief Hentig had the department fully manned again, reported his list of members to the council, and they ratified and confirmed them, besides fixing the salaries. The old company had gone out; this was an entirely new organization, based on the twenty-nine rules laid down by the council, and is the organization which continues to serve the city yet.

September I8, I889, a night fire occurred, in which three of Mrs. Beaton's children were burned to death. [See page i 55.] The fire company was in nowise blamable for this terrible calamity; yet it did fail to reach the scene of the fire as soon as it ought, and a good deal of unreasonable blame was cast upon it. A public investigation of the whole matter was made by the council on September 28 , resulting in a verdict of censure upon the department; then new instructions were given to the company, and a fire alarm bell was ordered. Prior to this the Baptist church bell had been used for fire alarm purposes; and of course there was no electric alarm system. The fire engine and other apparatus was kept in a temporary structure on DeLacy street below Colorado, and horses were brought over from Wiley \& Greeley's livery stable to hitch on when required. Things were not in shape yet for either very prompt or very efficient service. The water mains, fire plugs, hose supply, and alarm system were all inadequate for any urgent emergency. But this most calamitous fire that had ever occurred here, in which three children were entirely consumed and their mother seriously injured in her frantic efforts to save them, led to vigorous measures toward improving and perfecting the fire department.

On December 3, 1889, the fire engine house on Dayton street was accepted from the contractors who built it, and was occupied at once. Robert Hentig resigned as chief, and A. S. Turbett was appointed to the place, which he has filled ever since. January 4, I890, Geo. A. Greeley was appointed assistant chief. January 25 the city bought from Richard Gird of Chino five horses for the fire department, at a total cost of $\$ 1,235.30$ - paid in municipal bonds.

The work of the department now went on in pretty good shape. The old hook-and-ladder apparatus proved unequal to our needs. and a new outfit was ordered, which was received and accepted by the council on December 20, I 890 . On January 24, I 891 , the old truck, etc., was sold to the city of Santa Monica tor $\$ 400$. The old hose cart was sold there also.

In February, 189I, an electric fire alarm system was constructed 
throughout the city; and on March 7 A. M. Clifford, who then had charge of the steam fire engine, was ordered by the city council to take charge also of the fire alarm system - and his salary was therefore raised to $\$ 90$ per month. This position Mr. Clifford holds yet- 1894 .

LIST OF FIRE DEPARTMENT ON AUGUST I, I894.

NAME. POSITION. SALARY PER MO.

A. S. Turbett, chief of fire department..................\$1 1500

F. V. Hovey, assistant chief and secretary ................. 800

A. M. Clifford, steam engineer and electrician............... 90 oo

S. W. Fancher, stoker, and driver of hose cart............. 50 oo

J. O. Reynolds, driver of engine..........................6 600

A. B. Case, foreman of hose company .. .................. 500

F. M'Afee, Wm. Barto, Lewis Allen, Geo. E Furman,

A. E. Bisbee, callmen, each.......................... 5 oo

J. A. McIntyre, foreman Hook and Ladder Co. (treasurer). 8 oo

Henry Hutchinson, driver of hook and ladder truck.........6 600

Edward Fouke, S. B. Beers, Gus. Banbury, Geo. Clayter,

Harry Porter, callmen, each........................... 500

The boiler of the fire engine is kept full of water at the boiling point, continuously night and day, by means of a coke furnace and water heater under the. floor and connected with the engine by pipes with antomatic valves, cut-offs, etc. The engine's fire-box is kept always primed with quick-blaze kindling. The harnesses remain permanently attached to the engine, but suspended and held open by slip-hooks. The horses stand loose in their stalls hehind the engine, with only a swing-bar before them ; and they are trained when the electric gong in the room sounds an alarm, to leap to their places, the harnesses drop down on them, three spring snaps for each horse complete their attachment, and thus ordinarily in about ten seconds from instant of alarm the engine begins to roll and plunge out, the horses being trained to go on a tearing gallop at once and until the scene of fire is reached. The engine weighs 7,725 pounds. If the alarm comes from a station anywhere near the business center, the fixed match is immediately struck in the fire-box, the blaze roars up, and inside of five minutes from instant of alarm the hose could be attached, and the engine throwing water on top of the First National Bank, or the Carlton Block, or Hotel Green, etc. The horses and harnesses for the hose cart and the hook-and-ladder truck have the same arrangements for quick, prompt work, the horses being all trained to leap to their own proper places when the alarm sounds, and to go at their utmost speed through the streets. Everything else - even the Salvation Army! - must give way for them.

August I, I894, there are in the city sixty fire-plugs, and eighteen electric fire alarm stations or boxes. There are $\mathrm{r}, 900$ feet of two-and-a-half inch hose, warranted to withstand a water pressure of 400 pounds per square inch, while the ordinary pressure in service is only from I 25 to I 75 pounds per square inch. The hose cart as it runs to a fire, loaded for ser- 
vice, weighs 3,I35 pounds. The hook-and-ladder truck carries one fiftyfoot and one thirty-foot extension ladder, besides fire-wall hook ladders, and others. It also carries tour three-gallon Babcock chemical extinguishers. Then there is the usual complement of hooks, chains, ropes, axes, etc., for tearing down buildings to check the spread of a fire; and a supply of leather buckets. This truck and its outfit weigh 3,640 pounds, and eight firemen are entitled to ride on it besides.

\section{CHAPTER XV.}

A Chapter of THREE Bs. - The Banks. - The "Boom."-The Board of Trade.

Table of Incorporations.

BANKS.

The First National.--The first public mention of any bank project in Pasadena occurred in the Valley Union of November 22, I884, which said :

"Yesterday an organization was effected by electing the following gentlemen a board of directors: P. M. Green, Henry G. Bennett, George H. Bonebrake, J. Banbury. John Allin, D. Galbraith, and B. F. Ball. The following officers were also elected: President, P. M. Green ; vice-president, B. F. Ball ; cashier, D. Galbraith."

It was called simply the Pasadena Bank, and November 2I, I884,

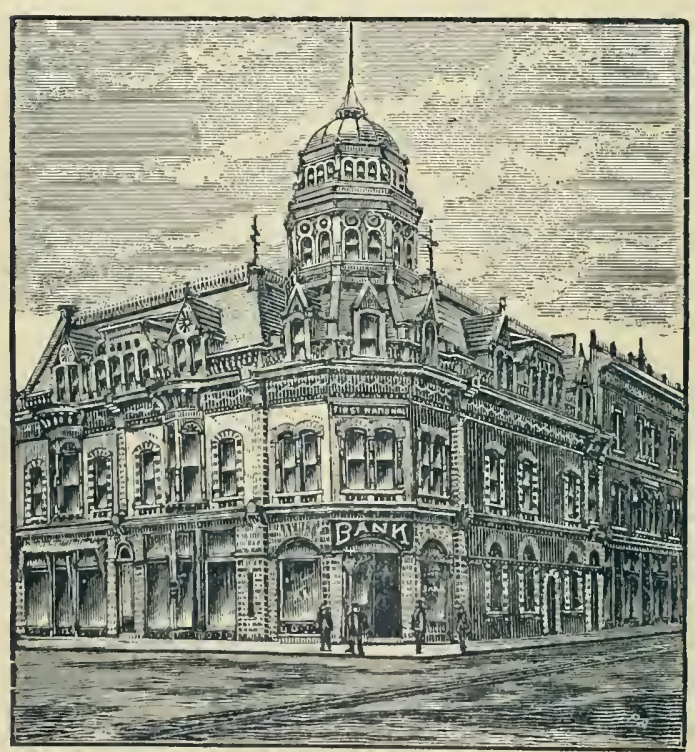

FIRST NATIONAL BANK BLOCK, 1886. Architecture, Classic. appears as the date of its incorporation under the state laws. But on May Ioth, I886, it was chartered under United States law as the "First National Bank of Pasadena," its registry number being 3,499. A few days before this date the Union contained the following as a real estate item :

"The Los Angeles House property, corner Fair Oaks Avenue and Colorado street, was sold for $\$ 25,000$ to a syndicate of capitalists composed of Geo. H. Bonebrake, P. M. Green, H. W. Magee, B. F. Ball, J. H. Painter, R. Williams, H. G. Bennett and John Allin. The property is 
363 feet on Colorado street by $293 \frac{1}{2}$ on Fair Oaks, containing within a fraction of three acres of land. It also includes the well-known and popular "Los Angeles House" hotel with all its furuiture. The Pasadena bank is now being reorganized as the First National Bank of Pasadena, and will have its quarters on this property, taking the corner lot $45 \times 120$ feet, on which a thoroughly fire-proof building will be erected."

The Board of Trade pamphlet of I 888 said, on page 2 I :

"One year ago there was practically but one bank in Pasadena, the second having just opened its doors. [The S. G. V. Bank.] The total deposits then were $\$ 4$ I $2,924.46$. The loans and discounts amounted to $\$ 268$, 209.77. As this work goes to press the deposits in the banks of Pasadena amount to $\$ \mathrm{r}, 682,339.49$, and the total loans $\$ 984,322.83$. The total bank capital a year ago was $\$ 50,000$; today it amounts to $\$ 300,000 . "$

The following chronological exhibit was prepared by H. I. Stuart, a bookkeeper in this bank, at my request, especially for this sketch, and forms a most valuable and interesting table for future reference and comparison :

\begin{tabular}{|c|c|c|c|c|}
\hline YEAR. & DEPOSITS. & $\begin{array}{l}\text { IOANS AND } \\
\text { DISCOUNTS }\end{array}$ & $\begin{array}{l}\text { TOTAL, VOLUME, } \\
\text { OF BUSINESS. }\end{array}$ & REMARKS. \\
\hline I S85 & $\begin{array}{l}\text { December } 3 I \text {. } \\
\$ \text { I } 48,96675\end{array}$ & $\begin{array}{l}\text { December } 3 \mathrm{I} \\
\$ 88, \mathrm{I} 9 \mathrm{I} \text { I I }\end{array}$ & $\$ 5,200,000$ OO & \\
\hline IS86 & $\begin{array}{l}140,900 \\
583,719 \text { I8 }\end{array}$ & 343,64750 & $30,900,000$ 00 & \\
\hline I 887 & $1,039,05772$ & 618,25564 & $46,920,084$ oo & 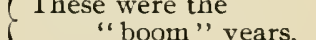 \\
\hline I88S & 5 I 4, I 9473 & $35 \mathrm{I}, \mathrm{I} 8226$ & $3 \mathrm{I}, \mathrm{I} 84, \mathrm{I} 66$ oo & ) poom years. \\
\hline 1889 & 341,840 oo & $268,9662 \mathrm{I}$ & I6, 627,000 oo & \\
\hline I89o & $382,0798 I$ & $286,987: 3$ & $\mathrm{I} 4,944,754$ OO & Boom collapsed. \\
\hline 1891 & 417,106 I 6 & 332,26042 & I9,530,000 OO & 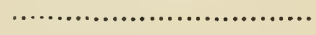 \\
\hline 1892 & 484,02704 & 304,84536 & $26,530,00000$ & ................... \\
\hline I893 & 403,52239 & 289,66055 & $23,464,000$ oO & \\
\hline IS94 & 550,97064 & 382,40999 & $26,125,00000$ & 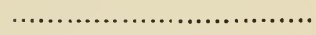 \\
\hline
\end{tabular}

The Daily Star of June 9, I895, reports the annual meeting of this bank on the 8 th, and says :

"The following directors were elected for the ensuing year: P. M. Green, B. F. Ball, Geo. H. Bonebrake, H. G. Bennett, H. M. Hamilton, A. K. McQuilling, O. S. Picher. This is a re-election of the entire board. The same officers were also elected to-wit : P. M. Green, president; B. F. Ball, vice-president; A. H. Conger, cashier ; Ernest H. May, assistant cashier.

The reports of the officers show that the volume of deposits, loans and discounts done by the bank for $\mathbf{1} 894$ was the largest since the most prosperous year of the boom. Its capital is $\$ 100,000$; its surplus $\$ 60,000$, and at the close of business October 2 last, it had resources to the amount of $\$ 735,691.51$. At that date its deposits amounted to $\$ 555,942.62$. Hon. P. M. Green has been president of this bank continuously since its first organization."

ThE SAN GABRIEL VALIEY BANK.-This bank was organized under the state law, and its articles of incorporation filed February 6, I886, the Ward Brothers having been prime movers in the matter. Capital stock, $\$ 50,000-$ all paid in. The Union of May 2I, said :

"The San Gabriel Valley Bank will open for business in its elegant quarters in the Ward Block Monday. The capital stock of $\$ 50,000$ has all 
been subscribed by citizens of Pasadena. Frank M. Ward has been elected president; Alonzo Tower, vice-president, and B. W. Bates, cashier. The directors are F. M. Ward, Alonzo Tower, B. W. Bates, C. S. Martin, Lyman Craig, J. G. Miller, Walter R. E. Ward."

In September, I886, Mr. Bates bought for the bank a lot $25 \times 75$ feet, at the corner of Fair Oaks Avenue and Colorado street, from Charles A. Gardner for $\$ 4,500$. The bank put up a building for its own use on this lot, moved into it, and remains there yet. About October Ist this year the bank was reorganized, electing H. W. Magee, president; J. W. Hugus, vicepresident ; Bates, cashier. And the following notice was officially published:

"The individual property both real and personal of the stockholders of this bank is pledged as security to its patrons for the bank's transactions."

In 1887 Col. W. A. Ray was elected president. He resigned in April, I 890, and H. W. Magee was elected again to fill the vacancy. Then in I89 I Frank C: Bolt was elected president, and still continues. The officers in 1895 are: F. C. Bolt, president; S. Washburn, vice-president; Geo. B. Post, cashier. Directors: Bolt, Washburn, W. S. Wright, J. W. Hugus, Webster Wotkyns, C. S. Cristy, H. C. Allen. At my request the following table was furnished of business done by this bank in successive years .

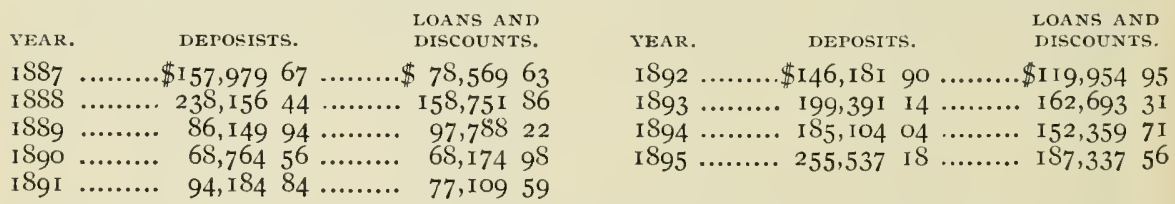

In February, I 89I, a Savings Department was opened, this right having been granted in the orignal charter of the bank, with individual liability of the stockholders the same as provided in security for other depositors. And in January, 1895, it had about six hundred savings depositors recorded.

The Pasadena Natronal, Bank. -The Pasaderia Union of Oct. i6, I 886, gave a report of the founding of this bank, from which I quote the points of chief historic interest :

"This bank was organized February I 5, I 886, under the laws governing National banks, with a paid up capital of $\$ 50,000$. The directors are : I. W. Hellman, of the Farmers and Merchants bank of Los Angeles ; E. F. Spence, of the First National bank of Los Angeles; Dr. Wm. Converse, president of the Dime Savings bank of Chicago ; Geo. A. Swartwout of the Pasadena Hardware Co.; and C. $\mathrm{H}$. Converse, late a business man of Clicago. Officers: Hellma11, president; Spence, vice-president ; Swartwout, cashier."

Mr. Swartwout was one of the owners of the new Exchange block (Carlton hotel), and therefore elegant quarters for the bank had been provided therein while the block was being erected. Here the bank first opened its doors for business on Monday, October 18, 1886; and \$25,000 deposits were made during the first day. 
This bank was custodian of the $\$ 6,061.5^{\circ}$ indemnity pledge fund put up by business men of Pasadena in $\mathbf{I} 887$, to secure their prohibitory ordinance and sustain it through the courts. [See page 248.]

In January, i889, Mr. Swartwout retired and was succeeded by A. H. Conger, as cashier. Then in January, I89 I, Mr. Conger resigned, in order to take the position of cashier in the First National bank; and he was succeeded by T. P. Lukens as cashier. In I 888 the capital had been increased from $\$ 50$, 000 to $\$ 100,000$.

In January, 1895 , this bank moved into its magnificent new rooms in the Masonic temple, corner Raymond avenue and Colorado street; and on Saturday, January 26, the officers and directors received their friends there for the first time, to inspect the very complete provision they had made of every known device for burglar-proof safety of vaults, and for comfort, expedition and accuracy in carrying on the business. The Los Angeles Times reported that the vault foundation was of concrete five feet thick, with 5,000 interlinked old horseshoes worked into the mixture. At my request the following chronological exhibit was furnished from the bank records to accompany this historical sketch:

Pasadena National Bank, Incorporated October $11,1886$.

\begin{tabular}{|c|c|c|c|}
\hline & $\begin{array}{l}\text { AVERAGE } \\
\text { DEPOSITS. }\end{array}$ & $\begin{array}{l}\text { AVERAGE } \\
\text { LOANS. }\end{array}$ & REMARKS. \\
\hline I 887 & $\$ 248,500$ & $\$$ I69,800 & \multirow{8}{*}{$\begin{array}{l}\text { OFFICERs : President, Hon. T. P. I,ukens ; } \\
\text { Vice-president, Wm. Stanton; Cashier, E. } \\
\text { F. Jones. } \\
\text { BoArD of Directors : G. Roscoe Thomas, } \\
\text { L. P. Hansen, Wm. Stanton, James Cam- } \\
\text { bell, E. E. Jones, Hon. T. P. Lukens. }\end{array}$} \\
\hline I 888 & I 84,800 & 163,000 & \\
\hline I 889 & 98, I00 & 147,100 & \\
\hline I 890 & 63,000 & $8 \mathrm{r}, 800$ & \\
\hline I $89 \mathrm{I}$ & 63,600 & IOI, 700 & \\
\hline I 892 & I 36,600 & I 24,800 & \\
\hline 1893 & I6I, IOO & I 33,900 & \\
\hline I 894 & 176,900 & I 48,800 & \\
\hline
\end{tabular}

Savings Banks.- In 1887 C. T. Hopkins opened the first Savings Bank attempted in Pasadena, in his then new block, corner of Fair Oaks Avenue and Union street, with Otto Froelich as cashier or manager; but it did not succeed, and was given up after a few months, and the building leased to the city for its offices, council room, court room, etc.

Savings Departuent of San Gabriel Valley Bank. [See page 298.]

Union Savings Bank.-The next Savings Bank venture is thus set forth in the Weekly Star of February 6, 1895:

"The proposed new savings bank to be established here, with offices in the Masonic Temple block, filed its articles of incorporation February I, under the name of the Union Savings bank. Its purpose is to do a general and exclnsive savings bank business, under the laws of California, and its capital stock is placed at $\$ 50,000$; shares $\$$ Ioo each. The directors named are H. C. Durand, Dr. Norman Bridge, Robt. Eason, H. M. Gabriel, A. R. 
Metcalfe. All the stock is subscribed, some of the principal stockholders being the directors above named, and Rev. Dr. Eli Fay, Dr. G. R. Thomas, Dr. R. J. Mohr, J. S. Torrance, John Allin, Thos. Earley, T. J. Martin, Dr. N. A. Dalrymple, H. M. Lutz, H. M. Singer, Gardner \& Webster, F. D. Stevens, J. R. Greer, E. C. Griffith, J. C. Maguire, Conrad \& Hotaling, Dr. E. E. Gaylord, Rev. Dr. E. L. Conger.'

This bank opened its doors for business in the Masonic Temple, Raymond Avenue front, March 6, i 895, with H. M. Gabriel, president; Robert Eason, vice-president; Chas. A. Smith, cashier.

\section{BUILDING AND LOANS.}

Pasadena Building and Loan Association.- Organized on Tuesday evening, June 8, I886, at a meeting in the Valley Union printing office. The capital stock was fixed at $\$ 250,000$, in shares of $\$ 200$ each, payable in monthly installments of \$I each. Articles of incorporation were adopted and signed, with the following board of directors: E. C. Webster, J. W. Wood, Edson Turner, B. S. Eaton, P. M. Green, B. F. Ball, Thos. Banbury. Mr. Green was appointed treasurer; R. W. Abbott, secretary ; N. P. Conrey, attorney; and $\$ 20,000$ was subscribed on the spot. July 5 was set for the next regular business meeting. The Union of June i 8 printed a list of fifty-six persons who had subscribed for a total of 525 shares of stock in this Association. The same paper of July 16 contained an official notice by the secretary that the said business meeting would be held July 17 , the first appointment having failed. Then the paper of July 23 contained notice that the meeting had been deferred till July 24. And this was the last living whisper that I could catch of this particular "Building Association." It was swamped in the surf-tide of the rising "boom."

Mutual Building and Loan Association.--This body was incorporated July 20, I892, with the following board of directors:

DIRECTORS. NO. SHARES. AM'T. DIRECTORS. NO. SHARES. AM'T.

T. P. Lukens ................ $35 \$ 3,500$ oo W. R. Staats................. 70 7,000 oo

J. D. Lincoln.................. Io ${ }_{1,000}$ oo B. W. Hahn.................... I0 1,000 oo

F. H. Vallette................ I00 10,000 oo A. L. Hamilton................ 30 30 3,000 oo

C. W. Mann..................... $5 \quad 500$ oo 5

The capital stock is fixed at $\$ 2,000,000$, in 20,000 shares of $\$ 100$ each. A report made June 30,1893 , showed loans on real estate, $\$ 4,100$; loans on mortgages, $\$ 4,900$. Receipts from monthly dues, $\$ 3,970.75$. T. P. Lukens, president, and Benj. W. Hahn, secretary.

The annual report of June 30, 1894, gave the following figures: Total of loans on real estate, $\$ 10,400$; dues paid by members, $\$ 4,967.50$. Number of members, 62. Number borrowing, I 2. Number shares in force, 878. A semi-annual report, January 2, I895, gave. Dues paid in, to date, $\$ 10,080$. Undivided profits, July I, I884, \$8II.75. Money on hand subject to call of borrowers, $\$$ I.890. C. E. Getchell is now the secretary July, I895. 
PASADENA SECURITy InVeSTMent Company.-Organized September I, I894. State certificate of incorporation dated February 23, 1835. Capital stock, $\$ 50,000$, in 500 shares of roo each. Board of directors: Geo. H. Coffin, Edwin Stearns, E. T. Howe, C. E. Getchell, J. K. Urmston. Officers: Coffin, president; Howe, vice-president; Getchell, secretary ; Stearns, treasurer.

\section{PASADENA'S CAPITALISTS.}

Here, in connection with the story of our banks, is the proper place to give the list of Pasadena people whose property was assessed in I 894 at $\$ 10,000$ or over. The list was compiled and published by the Los Angeles Daily Journal of February 19, r 895, for the whole county. The assessment of course was only for property in Los Angeles county; and I have compiled from the entire list those who reside in or adjoining Pasadena, or have their property here :

Allen, Wm. (heirs of).

Baker, P. C. (heirs of)

Ball, B. F.

Banbury, Thomas.

Banta, Mary G

Bartlett, J. S.....

Bennett, $\mathrm{H}$.

Brigden, A...

Brockway, Justus

Brown, Annie M

Brown, Calvin W

Callender, A. M....

Carlton Block Co

Carter, J. M.

Cristy, Charles $\mathrm{S}$

Crank, J. F

Dobbins, Mrs. C. W

Fish, Milford.

Foster, Charles.

Frost, E. S.

Gilchrist, Mrs. J. D

Goodwin, A. A.

Green, P. M

Green, George G.

Hansen, L. P.

Hastings, C. H.........................

Hugus, J. W.

Hull, Mrs. A. V. B

Hurlbut, E. F.

Kernaghan, G. F.

Kinney, Abbot.

Legge, Charles........

Lordsburg Land Co.

Lowe, T. S. C.

McArthur, John.

McGee, Mary E
$\$ 53,420$

23,000

36,575

12,150

15,550

15,270

13,000

I 2,910

15 , İo

I 3,000

I I, SoO

I0,860

36,000

24,000

I8. 250

43,000

I5.100

25,840

10,360

$26,5^{85}$

$13,75^{\circ}$

I I 400

13,500

146,550

I 7,553

76,988

I 3,000

IO, 100

I 9,125

IO, 300

98,785

I9,5 I 5

I I, 985

58,970

I 2,435

I8, 535
McQuilling, A. K.

McNally, A

Mabury, H.

Macomber, H. K

Magee, H. W.

Markham, H. H.

Markham, H. H.

Newton, J. C

Painter, M. D.

Pasadena \& Mt. W.

Pasadena \& Mt. W. R. R. Co........

Pasadena L. V. L. \& W. Co.

Pasadena L. \& W. Co..

Patton, Geo. S

Patton, Ruth, et al.

Raymond, Walter.

Reed, S. G

Rowan, G. D.

San Gabriel Wine Co

Scoville, Mary A.

Skillen, C. M

Singer, H. M

Smith, James.

Stanton, William.

Stevens, F. D.

Stimson, G. W.

Stonemian, Mary O

Stuart, W. C

Talcott, Ellen $\mathrm{H}$

Tebbetts, C. E

Thomas, G. Roscoe.

Torrance, J. S.

Turner, Esther.

Vandevort, J. W.

Wilson, Margaret S.

Woodbury, F. J.

Wooster, P. G.
$\$$ II, 190

IO, I 30

10,400

I 4,000

I I, 600

24,365

I6,425

I 5,815

29,095

14,100

21,855

15,880

I 2,035

3I, 106

30,840

$2 \mathrm{I}, 500$

52,510

43,895

I0, 645

12,455

I5,795

25.823

20,950

II.970

26,475

13,905

20,270

I I , 335

I I, 9 I 5

I 7,680

I 2,550

27,046

23,880

12,140

27,600

23,100

E. J. Baldwin, of the great Baldwin ranch, $\$ 393,950$. Mrs. Arcadia Bandini de Baker, $\$ 264,255$.

\section{THE STORY OF THE BOOM.}

Just when the "boom" commenced it is difficult to determine. The 
truth rather is that it grew spontaneously out of occasional spurts of speculative adventure. Nevertheless, of course there were beginnings of these things; and I have gathered some instances to illustrate how it grew little by little from small beginnings, until it became an epidemic mania of gambling in land values, by which a few made fortunes, and many lost their all.

In 1875 P. G. Wooster bought ten acres at $\$ 55$ per acre, less I 2 per cent for spot cash. On April 14,1887 , he sold $1 \frac{1}{7}$ acres of this same land for $\$ 36,300$ [exclusive of the buildings then on it], and got the money. This was the land now known as Hotel Green park. The next day he sold the land where Hotel Green stands for $\$ 35,000$; but before he got his pay the boom bursted, and he had trouble and loss in the matter.

In November, 1877 , A. F. Mills bought 15 acres at the southwest corner of Fair Oaks Avenue and Colorado street, out of the original Berry \& Elliott tract, and paid $\$$ I 00 per acre for it ; and he says this was the first time that so high a price had been paid for any land in the colony.

P. G. Wooster reports that in 1878 the taxes on his ten-acre home lot were $\$ 7.68$, and adds: "In 1893 , on 3,060 square feet less than one acre of the same ground I paid \$I54 county and state tax, and about the same amount as city tax."

February I, I882, Wesley Bunnell bought five acres from E. P. Little for $\$ 2,000$. In 1884 he sold a $3 / 4$-acre strip on the west side of Little Avenue from Colorado to Union street to Frank Lowe for $\$ I, 500$. In I 885 Lowe sold this lot to H. J. Woollacott of Los Angeles for $\$ 3,200$; and Woollacott built on it the row of one-story frame store rooms which stand there yet I 895. In I 886 Woollacott sold the same land in separate lots for \$1 2,800.

During the winter of $188_{3-4}$ Charles Legge bought from a man named Chapman ten acres of the land now known as "Grace Hill." His friends marveled at his foolish purchase- wondered what in the world Charley wanted of it, or could ever do with it, for he couldn't get water up onto it, and they didn't believe fruit would grow well there! But when in five weeks he sold it for $\$ \tau$, ,oo more than he had paid for it, he was not "foolish" any more, but became the hero of the hour. The "boom" had fairly struck Pasadena, and this was its biggest gun, up to that date. Then other men all over the colony began to itch for a spell of the same sort of "foolishness" which less than two months before they had twitted Charley Legge of. [See article "Grace Hill." ]

In 1885 the boom began to swell in volume and force; and a case in point I here quote from the Valley Union of October 30, I 895 :

"Real estate has boomed in Pasadena the past week. Among some of the leading transactions are the following: E. C. Webster has bought of Col. J. Banbury the two lots on Colorado street where Ridgway \& Ripley's office and the planing mill stands, 48 feet front by 150 feet deep, for $\$ 2,000$. On the same day Mr. Webster sold one of these lots to Gen. Edwin Ward for $\$ 1,250$, a clean profit of $\$ 250$ in one day. 
"On Saturday Mr. Webster made the purchase from Gen. Ward for Mr. A. Cruickshank, our dry goods merchant, of the lot adjoining the Harper \& Reynolds store, known as the "Boss Forge" lot, 37 $1 / 2$ feet front, for $\$ 3,500$; and on the same day Mr. Webster bought of Gen. Ward, also for Mr. Cruickshank, a lot fronting on Fair Oaks Avenue, between Williams' block and Hentig's plumbing shop, 25 feet front and extending back to the "Boss Forge" lot. The price of this was $\$ I, 000$, and it is purchased as an outlet to the lots fronting on Colorado. On the following Monday evening Mr. Webster also purchased of Dr. Radebaugh the latter's fine lot 50 feet front by 208 deep, on Colorado street, adjoining the "Boss Forge" lot, for $\$ 4,500$.* On the two Colorado street lots - the "Boss Forge" and the Radebaugh lot - having an aggregate frontage of 9I feet, there is now to be erected by a company consisting of A. Cruickshank, G. A. Swartwout, Gen. Edwin Ward and E. C. Webster, a magnificent brick block, three stories high and divided into four stores."

These latter transactions all pertain to land where the Carlton Hotel now stands.

The Pasadena Union of March I2, I886, footed up real estate sales amounting to \$IOI, OOO which had been made within the three days-March Ioth, I Ith, I2th. As a time-bubble, this beat the record.

The first boom sale of lots in Pasadena, with "grand excursion, brassband and free-lunch attachments," was worked up by the real estate firm of Ward Bros., early in I886; and as a prelude to the sensational novelty the Valley Union of February $5^{\text {th }}$ reported thus :

"Ward Brothers have made a big sale this week, being 20 acres of Dr. O. H. Conger's land on Colorado street and Pasadena Avenue, for \$ 5,000 cash.t The purchasers are a syndicate, seven in number, as follows : B. W. Bates (late of New York city, now occupying Ward Brothers' dwelling here), Frank M. Ward, Walter R. E. Ward, P. M. Green, A. O. Porter, C. S. Martin and H. G. Bennett. The purchase does not include Dr. Conger's dwelling property but lies east of the orange orchard. The tract is I. shaped, the longer stem of which has 363 feet frontage on Colorado street, adjoining A. K. McQuilling's. At this width, 363 feet, it runs back I, 200 feet to the rear of McQuilling's land, and thence for 600 feet further, widens sufficiently to reach Pasadena Avenue. The purchase is for purpose of subdivision."

The syndicate opened up through this tract Vernon Avenue, Grove street, and an extension of Kansas [now Green] street. The auction took place on Tuesday, February 23, I 886. A trainload of people came up from Los Angeles to see the fun, hear the brass band, and eat the free lunch, which latter consisted of beef sandwiches, bread and butter, oranges and lemonade. Out of eighty-four lots offered, seventy-seven were sold, the prices ranging all along from $\$ 520$, paid by $\mathrm{J}$. W. Wood, down to \$rso paid by J.S. Mills for one out of six lots bought by him - the others being at higher

* Dr. Radebaugh had bought this lot four years before for $\$ 250$.

$\dagger$ Dr. Conger had paid only $\$ 2,000$ for his whole 30 acres. 
figures. The first lot sold was struck off to Rev. Dr. J. G. Miller, at $\$ 5$ Io ; and he bought nine lots in all. Twenty-five different persons made purchases. The sales footed up a total of $\$ 22,140$. This set the fashion for the boom era; and brass-band free-lunch excursion land sales followed in quick succession all over South California. During this historic sale a spirit level was set on a tripod on the ground for everybody to take a sight on, and see that these lots were just on a level with the Raymond Hotel kitchen, and with Marengo Avenue at Colorado street. This rectified some of our Californian optical illusions of altitude, and was a puzzle and mystery of great interest to many of the visitors, especially the newcomers.

September 10, I886, a lot 25x75 feet, where the San Gabriel Valley bank now stands, was sold to the bank company for $\$ 4,500$. And in December of the same year Wallace Bros. and C. S. Martin bought from M. Rosenbaum about three acres at corner of Orange Grove Avenue and Colorado Court for $\$ 17,000$. They laid it out in residence lots, and opened Grand Avenue through it.

It was in March, I886, that occurred the great boom sale of the subdivided five acres known as the "Central School lot." This was one of the most notable historic events in our city's career. [See full particulars of it on pages 16465 .

"Less than four years ago A. F. Mills sold to Jacob Hisey fifty feet frontage on Fair Oaks Avenue for \$150; and Mr. Hisey sold the same lot last week for $\$ 3,100$ to Dr. Henderson of Los Angeles. "-Union, June I I, I 886.

In January, I 887, Thos. R. Hayes owned thirteen acres at the corner of Lake Avenue and Villa street, for which he had paid \$II,Ooo, and he sold it to Dr. R. K. Janes and B. W. Bates for $\$ 18,000$.

THE REAI, ESTATE EXCHANGE.

The most conspicuous boom event of 1887 was the organization and brief career of the Real Estate Exchange, which commenced business September I, 1887. Some of its objects as set forth to the public were:

"To maintain principles of honesty and fair dealing in the operations of licensed real estate brokers."

"To stimulate greater activity in real estate," etc.

"To give the business 'a position of dignity and responsibility,' " etc.

"To devise, encourage and foster schemes of public improvement and benefit to the city at large." [This feature developed later into the "Board of Trade" organization.] etc.

"To throw safeguards around inexperienced owners or purchasers,"

"To make contracts, deeds, conveyances, etc., in proper form to secure the rights of both seller and buyer, under the laws of California," etc.

And on page $\delta$ of the association's pamphlet this passage occurs : 
"The following schedule of legal points as to the rights of women in buying or selling real estate was originally prepared by Dr. H. A. Reid for the use of his own firm, the Lyman Allen Land Co., and is now permitted to be published for general information." Then follows an explanation of how contracts or deeds must be worded when there is a woman in the case, either married, single, or widow, to guard her separate property rights.

Commissions were 5 per cent. on sales up to $\$ \mathrm{I}, 000$, and $2 \mathrm{I} / 2$ per cent. on amounts over $\$ \mathrm{I}, \mathrm{OOO}$. For renting property the charge was io per cent. of first month's rent, and 5 per cent. for collections thereafter.

The officers of the exchange were: W. L. Carter, president; Col. J. Banbury, vice-president: Hon. P. M. Green, treasurer; J. R. Riggins, secretary; E. D. Hough, office manager, and editor of the Daily Bulletin. Directors: Carter, Banbury, Riggins, H. W. Ogden and J. C. Studebaker. Then there were standing committees on finance, on exchange and membership, on arbitration, on public enterprises and information. A list of members published in September, showed I 49 real estate firms then in Pasadena. A revised list published February 20, I888, showed 142 -so 7 had dropped out of the ranks. A daily and weekly paper called The Bulletin, was published. [See page 220.]

Many of the firms had two, three, or four members, so that a total of at least two hundred men were engaged in the real estate business for a few months. A large proportion of them were men without literary culture or skill, and with no experience as conveyancers-yet all making out papers for their own customers. And this accounts for the many defective papers in real estate transactions which so often resulted in lawsuits or other troubles in later months.

\section{BOARD OF TRADE PAMPHLETS.}

Early in I 888 the Board of Trade issued a pamphlet of 40 pages, beautifully illustrated, and on page 22 this statement was made:

“The extraordinary migration to Pasadena of homeseekers has resulted in a sudden rise in real estate values, and in two years property has increased in the business center from $\$ 40$ per front foot to $\$ 800$, and the actual values of land for the purposes for which it is required are far from being reached yet. Probably more fortunes have been made in real estate here in the past two years than in any city in the country, and the transactions for the year past amount to $\$ 12,786,263$. The sales have been the result of what in the East is known as a "boom."

This was a boom pamphlet, well written, neatly printed, and artistically illustrated and embellished. And it is both sad and amusing now to look it over and see how many boom projects and enterprises mentioned, pictured or described in its pages fell dead when "the boom bursted." On page $I 8$ it gives $\$ I, 987,800$ as the cost of buildings erected within the fifteen months preceding January I, 1888. And on page 34 there is a schedule of wages paid during that period, as follows : 
"Skilled masons, \$6 per day; carpenters (foremen), $\$ 5$; ordinary carpenters, $\$ 3.50$ to $\$ 4$; laborers, $\$ 2$ to $\$ 2.50$; men for ranch work, $\$ 30$ per month with board and lodging; plasterers, $\$ 4$ to $\$ 5$ per day or 36 cents per yard; lathers, $\$ 4$ to $\$ 4.50$; painters, $\$ 3.50$ to $\$ 4$; plumbers, $\$ 4.50$; tinners, $\$ 3.50$ to $\$ 4$; car drivers, $\$ 2$; blacksmiths, $\$ 2.50$ to $\$ 3.50$; bookkeepers, $\$ 75$ to $\$$ I 50 per month; clerks, $\$ 50$ to $\$ 75$; house-servants, $\$ 25$ to $\$ 35$ per month; nurse girls, $\$ 20$ to $\$ 25$; housekeepers, $\$ 25$ to $\$ 40$; harnessmakers, $\$ 3$ to $\$ 4$ per day; bakers, $\$ 30$ to $\$ 40$ per month; butchers, $\$ 30$ to $\$ 50 . "$

I thought this list of wages rates worth preserving for historic interest and future reference. And I find that a slip, dated October I, I888, was pasted into the pamphlets at this point after that date, which stated: "When the matter for this pamphlet was written the representations on the subject of mechanics' wages were strictly true. Since that time, however, the wages of skilled mechanics have declined 25 per cent." Of course that meant that the boom had passed its climax and was now on the decline.

One of the curiosities of this boom time was a petition signed by seventy qualified electors which was presented to the city council on May 2, I888. It asked to have the city boundaries extended northward one mile beyond the foot of the Sierra Madre mountains, eastward to Hill Avenue, westward to west bank of the Arroyo, but south line to remain as it was. [This would have taken in Echo Mountain and the summit crests of the front range - would have incorporated the mountains.] Some persons wanted this extension as a means to boom certain lands, water-rights, etc.; while others wanted it to get their homes under protection of Pasadena's prohibitory law, for the Board of Trade pamphlet had said of the board of city trustees (page 25) "to its intelligent action and good judgment Pasadena owes the suppression of saloons, making Pasadena a temperance city." Lamanda Park was a saloon town, and under an erroneous impression that the proposed new boundaries took in their village (althougl it did not come within a mile of it), they sent in the same day a vigorous protest against the extension. The saloon men had smelled danger a great way off, and rushed to the rescue. Both documents were referred to a special committee.

Pending further action by the council, the city attorney was called to attend a mass meeting at North Pasadena and stand up as a well-spring of legal wisdom, to be worked like a town pump, ad libitum, on questions of corporate extension, legal procedure, boundary description, representation in city council, increased taxation, benefits accruing, etc., etc., etc. It was a trying ordeal for a young man [F. J. Polley]; but every pull of the pump handle bronght up pure juice of the law, and every man's little cup of inquiry was filled.

May 22 the matter came before the city council again in regular course. The attorney showed that the boundary descriptions were too indefinite for any legal procedure to rest upon; and they were referred back to petitioners 
for correction. In a few weeks the petition came again, with boundaries properly described by official survey points, also taking in Linda Vista, and having 172 signers. But there were three different remonstrances filed against it ; and the whole matter was dropped.

By 1889 the boom was pretty well on the down grade. As early as about April I, I888, Prof. J. D. Yocum had occasion to make public reply to accusations against himself and son in regard to a great land-booming scheme at Lucerne, in San Diego county, in which a number of Pasadena men were concerned. And he said :

"I am sorry for Mr. H.. and for ourselves, and for all who suffer because of the collapse of everything at Lucerne. We go down with $\$ 100,000, \mathrm{Mr}$. H. with $\$ 20,000$, as he reckons; a number of others with as much or more in proportion to their means; and who could have avoided the collapse? Who can indemnify?"

E. C. Webster commenced without capital in 1885 , and became one of the most extensive real estate operators and successful "boomers" in Pasadena. Yet when the collapse came he went into insolvency, with the following statement of assets and liabilities, which I quote as an item of our boom history, from the Star of April 24, 1889:

"The following showing is made in the petition: Value of real estate, $\$ 169,500$; value of personal property, $\$ 35,054$; amount of debts due, $\$ 50,561$; amount of incumbrances on real estate, \$15I,448; amount of incumbrances on personal property, $\$ 64,892$. His creditors number 156 , of whom I 30 are unsecured. Fifty-two hold Mr. Webster's notes for various amounts."

Of course there were many other cases analagous to these which did not come into newspaper publicity; these did, and therefore I could cite them as illustrative instances in the great collapse, without being subject to the charge of trenching upon private affairs.

\section{AFTER THE BOOM.}

When the fever-height of the land-gambling mania had passed, there was still some real estate business going on - largely of cases where people were trying to crawl out from under the wreck and unload their holdings at any price. Hence the market went down very low. But here is a case that came through the breakers with colors all flying:

"Last week Geo. W. Stimson sold the fine building site known as Grace Hill, near the Raymond, for $\$ 25,000$. It was in the market at same price three years ago, at height of the boom. 'The purchaser; Wm. Stanton of Pittsburg, Pa., will build a residence there worthy of the site."-Pasadena Standard, March 29, 1890 .

However, the real estate business of 1890 was mostly a clearing up of wreckage. But I89I began to show up business again. The Star of August 26, I891, printed a list of $55^{\circ}$ transfers during the year, from Jan- 
uary ist to August $\mathrm{I}$, as found in the county records, which made a total sale record of $\$ I, 244,585$. And the same paper of December 24 th said:

"Today we supplement the record for those seven months by that for the remaining five months of I89I, making the record for the year complete - a total of $\$$ I , 7 I 4, I 95 .

The Board of trade pamphlet of 1892 summarized the boom period and its outcome in this fashion :

"Pasadena was enveloped in the very center of the greatest boom in improvements and land speculation known in America; the location, water, soil and climate were the causes. Pasadena has emerged from the fearful shock more beautiful than ever-a clean, well-kept, orderly municipality. A sound, healthful growth is again in progress. $* *$ The temporary check that was put upon the progress of the city by the reaction from the speculative fever, was not accompanied by disastrous and panicky interruptions to the course of legitimate business. There were no bank failures or serious embarrassments. Today the condition of our banks is better than it ever was ; merchants, manufacturers, railway companies, professional men and other classes of the community have done a better business during the past year than for any similar period since i888. During I89 I the two National banks and the State bank established here, which are capitalized to the amount of $\$ 250,000$, did a volume of business amounting to about \$40,000,000."

A table of real estate transactions in Pasadena during I 894, compiled from the county records, gave the following exhibit of values:

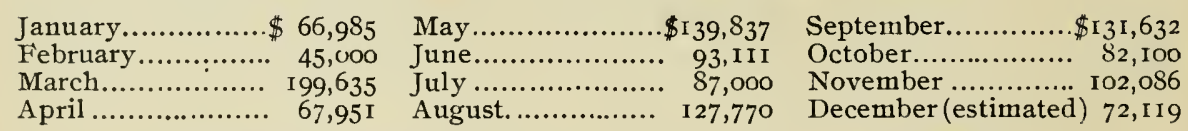

Total for the year. $\$ 1,214,726$

THE BOARD OF TRAUE.

The real estate exchange was organized in August, 1887 , and comprised a large proportion of the most enterprising and public-spirited business men of the city, for nearly everybody went dabbling in real estate ventures in some way. One of the declared objects of that real estate organization was, "To devise, encourage and foster schemes of public improvement and benefit to the city at large," etc. Under this the business men learned to confer and work together as an organized body on matters of public concern,- -whereas, before it had always depended on some one man to voluntarily stir about and get up an interest in any such matter, when the occasion arose. However, it became very evident in a few months that something larger and more comprehensive was needed on this line; and after being talked over in a general way for some weeks, a public meeting was held in Williams hall to take practical action thereon. The meeting was called to order by Col. J. Banbury, vice-president of the real estate exchange. Col. W. A. Ray, then president of the San Gabriel Valley bank, was made chairman and E. E. Fordhan, secretary. Steps were then 
taken and committee appointed to complete the organization of a BOARD OF TRADE; and the county records give March 22, I888, as the date of its incorporation. The board of directors named were W. A. Ray, Enoch Knight, J. Banbury, W. U. Masters, J. H. Painter, B. A. O'Neil, and G. A. Swartwout. At a meeting on April I2, I888, the first permanent organization was effected by electing W. U. Masters, president; W. A. Ray, vice-president; E. E. Fordham, secretary; G. A. Swartwout, treasurer. The objects and purposes of the organization were thus stated to the public:

"To arouse and concentrate public opinion upon all matters of vital importance to Pasadena. To gather and disseminate information concerning the resources of Pasadena for the benefit of immigrants, capitalists, and business men seeking homes or investments therein; to aid and encourage the establishment of such manufactories as may be essential to utilize the various products of the soil ; and to stimulate the establishment of such other industries as may be requisite and necessary for the wants or necessities of the people; and to aid and encourage the same by securing, when practicable the donation of lands for building and yard. To procure for the city of Pasadena such privileges and concessions from railway and other corporations or individuals as may from time to time be suggested by the wants and necessities of the people, and the business interests of the city. To watch over and aid the business of the city government ; to petition for all needed legislation; and to bring to bear the true sentiments of the people on behalf of wise and energetic and comprehensive municipal administration."

After one year of work a reckoning was made, and I quote results :

THINGS THE BOARD OF TRADE DID.

The following is a summary of President W. U. Masters' report at the annual meeting in April, 1889, showing what matters of public interest the Board of Trade has dealt with during the preceding year:

"The board was organized April I 2, I 888, and the first point given attention was a proposition to establish an iron foundry, which came to nothing. Then followed the entertainment of the delegates to the State Democratic convention; a proposition to establish a fruit cannery made by L. J. Bennett; appointment of a committee to secure reduction of assessment values; proposition of M. W. McGee to bore for gas or oil; distribution of real estate exchange pamphlets; celebration of Memorial Day by invitation of the G. A. R.; proposition to establish a watch factory; celebration of the Fourth of July; exhibition of stereopticon views in Columbus, O., to several thousand people; advertising in the Phillips railway guide; recommendation to the city council to appoint a local board of forestry and to encourage the planting of trees; the writing of letters to the eastern press by Prof. Holder; the entertainment of I5O school teachers from the east; entertainment of delegates to the Sovereign Lodge of Odd Fellows; agitation of the water question and reading of Judge Eaton's address on the subject; recommendation to the city council to amend ordinance 45 ; the appointment of a committee to devise a system of water supply for the city, and secure better defense from fire; the obtainment of improved train service to Los Angeles; 
the effort to secure a better cemetery site for the city; the distribution in the east of photographic views of this city; the suppression of damaging rumors as to the prevalence of typhoid fever in this city; the tender of aid to the suffering poor of Dakota; entertainment of the Editorial Association of Southern California; the efforts to secure the establishment of an astronomical observatory on Mt. Wilson; co-operation in the effort to obtain relief of debtors under real estate contracts; memorial to the Legislature for the better protection of fruits; placing the Harvard telescope on the summit of Mt. Wilson; work of committee on our agricultural resources who state that \$I 50,000 goes out of Pasadena yearly for fruits, vegetables, etc.; calling upon the cily fathers for a financial statement of the city; the recent work of the board in aid of the construction of a boulevard to Los Angeles; petition to the city council for rapid transit ; recommendations for a city park, and for a cannery; action in giving the cantata; in observing arbor day, and inauguration centennial.",

It must be kept in mind that. I 888 was a "boom" year, in order to better understand the many grand business projects above mentioned which never existed except in talk or on paper.

The Pasadena Standard of January I2, i 889, gave a few additional points, thus :

"The president of the Board of Trade reports that out of I54 who originally signed for membership, onl $\dddot{y}$ fifty have become members. The board sent photograph views to fifteen eastern cities to be put up in frames and publicly exhibited. The views selected were: The public library, Wilson grammar school, Monks Hill school, Universalist church, E. F. Hurlbut's residence, Colorado street (looking west), Colorado street (looking east), Richardson villa, Pickwick club rooms, Y. M. C. A. building, H. H. Markham's residence, Marengo avenue, Raymond Hotel, Sierra Madre mountains, Devil's Gate, Painter Hotel, Cascade in Millard canyon.'”

May 15, I 889, United States Senators Hoar of Massachusetts, Pugh of Alabama, Allison of Iowa, and Dolph of Oregon, visited Pasadena, and were driven about the city, under auspices of Board of Trade. And in all public interests of this nature, or any matter coming properly within its purview, the Board of Trade continued to be active, energetic, prompt and useful.

In 1892 the board again issued a 40-page pamphlet with close print on large sized page, and many photogravure illustrations. The text was written by Theodore Coleman, city editor of the Daily Star. At this time the officers were: W. U. Masters, president; J. A. Buchanan, vice-president; M. F. Wood, treasurer; Webster Wotkyns, secretary. And standing committees of five members each were maintained on manufactures, on education and publications, on public meetings, on railroads and transportation, on streets and parks, on health and sanitation, on advertising and fairs, on receptions. This will show what a field of volunteer endeavor for the public welfare this organization aimed to fill. In this 1892 pamphlet was a list of its members - I 48 in all. 
Its officers in I 894 were: President, Prof. C. H. Keyes, president of Throop Polytechnic Institute; vice-president, Prof. T. S. C. Lowe; treasurer, P. M. Green; secretary, W. H. Knight; directors, Keyes, A. G. Throop, Lowe, M. D. Painter, Theo. Coleman, Herman R. Hertel, M. H. Weight. [Later - Knight resigned, and M. E. Wood was elected secretary, I 894-95.]

TABLE OF CORPORATE ASSOCIATIONS.

By the kindness of Mr. H. N. Farey, who searched the records for me, I am able to present here a complete alphabetical list of all associations which have ever been incorporated with Pasadena as their recorded place of business, up to July I, r895. However, the original colony, or "San Gabriel Orange Grove Association,' was incorporated before there was any Pasadena, and it named Los Angeles as its place of business. And the Mutual Orchard Company, whose plant was here, named Oakland as its place of business, its members mostly residing there. Our two National Banks do not appear on the county records, their registry being in the national archives at Washington.

TITLE OF ASSOCIATION.

DATE WHEN INCORPORATED.

Almondale Company ..................................January 28, I 892

All Saints Church...................................... June 2 I, I 886

Arroyo Seco Water Company ...........................ebruary i $8, \quad$ r 887

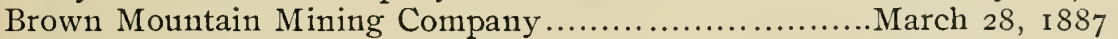

California Commercial Company ......................... November r 8 , r 888

California Olive Company .................................. I 5, r 885

California Universalist Convention........................ebruary 4, I 889

Calvary Presbyterian Church of Pasadena................. November 9, I 888.

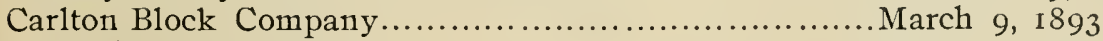

Champion Mining and Milling Company ................... 22, 1885

Christian Church of Pasadena............................... I $7,1886$.

City of Pasadena [as a city of the sixth class]............June I4, I 886

City Railway Company of Pasadena.......................November I 7, I 886

City of South Pasadena [as a city of the sixth class]..... February ... I 888

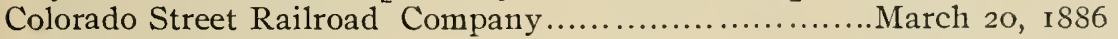

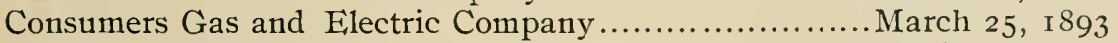

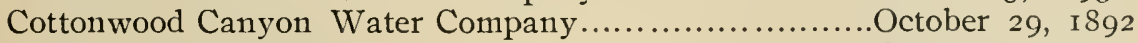

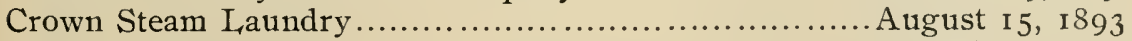

Davis Dental Manufacturing Company................... December 3I, I 894

Emanuel Methodist Episcopal Church.................. December 23, I 886

Exchange Block Company [Carlton Hotel]................ June 2, i 886

Fairmont Land and Water Company......................arch I2, I 888

First African Methodist Church.......................August 24, I 892

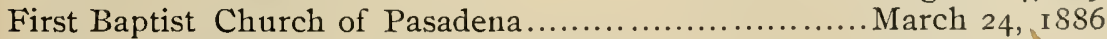

First Congregational Church of Pasadena.................December I0, I 885

First Free Methodist Church of Pasadena.................September 6, I 888

First German Baptist Church of Pasadena................ December 27, 1877

First Methodist Episcopal Church of Pasadena............December 31, 1883

First National Bank of Pasadena, No. 3,499. [Successot

to Pasadena Bank.] National charter dated................. I o, I 886

First Universalist Parish of Pasadena...................January 22, I 887 
Hermosa Land and Water Company ....................January 7, I 882

Highland Railroad Company..............................arch 2, I 888

Holland Manufacturing Company .......................April 27, I 888

Hotel Green Company.....................................

Kansas Street Improvement Company ....................March I 8, I 888

La Canyada I and and Water Company.....................November 9, I887

Lake Vineyard Land and Water Association................May 7, 1876

Lake View Land Company............................. May I 3, I 894

Las Flores Water Company ............................ June Io, I 885

Linda Vista Improvement Company ..................... November 25, I 887

Lordsburg Land Company ..................................

Loris Gold Mining Company...........................June 9, I 894

Los Angeles and Pasadena Tulare Improvement Co......September IO, I 887

Mechanics' Association of Pasadena.......................July 23, I 887

Memorial Baptist Church of South Pasadena.............. December 20, I89o

Millard Canyon Water Company ..........................April I 4, I 887

Montclair Children's Home.............................. December 20, I 893

Mountain View Water Company ........................November I, 1887

Munger \& Griffith Company............................January 3, I895.

Mutual Building and Loan Association of Pasadena...... July i 8, I 892

Mutual Orchard Company [Office at Oakland, Cal.]......June I 5, I 877

News Publishing Company .............................. October 6, I 894

North Congregational Church of Pasadena.................July 23, I889

North Pasadena Land and Water Company................January 1 5, I 885

North Pasadena Methodist Episcopal Church..............June I 7, I891

Occidental Mutual Aid Association........................ December I 5, I 888

Park Nursery Company...............................April I 8, I 887

Pasadena Bank [afterward First National] .................November 2 I, I 884

Pasadena Board of Trade .................................arch 22, I 888

Pasadena Building and Loan Association.................June 8, I 886

Pasadena Cemetery Association.......................... December I 3, I 882

Pasadena Contracting and Building Company................September 29, I 893

Pasadena Electric Light and Power Company............... Jannary 3I, I 888

Pasadena Fruit and Crystalizing Company .................. November r 3, I 886

Pasadena Fruit Growers Association....................... December 6, I 893

Pasadena Gas Company ............................... March 26, 1 886

Pasadena Gas and Electric Company.......................ay 8, 1886

Pasadena Gardening Company...........................January I6, I 890

Pasadena Gold Mining Company.......................... November 23, I888

Pasadena Grand Opera House Company ....................March 2 I, I 887

Pasadena Highland Fruit Association...................... May 1 2, 1894

Pasadena Highland Water Company ........................ November I, I 890

Pasadena Improvement Company ......................... February 9, I 887

Pasadena Investment Association ............................August 3, I 887

Pasadena and Kern County Land and Water Company...December I 2, I 887

Pasadena Lake Vineyard Land and Water Company...... January 29, I 884

Pasadena Land and Water Company [successor to the original colony or "San Gabriel Orange Grove Ass'n"']..March . I 8, I 882

Pasadena Library and Village Improvement Society...... December 26, I 882 Pasadena Lodge I 73, Independent Order Good Templars.. November 2 I, I 88 I Pasadena, Los Angeles \& Long Beach Railroad Co.........September I 2, i 887

Pasadena \& Los Angeles Railway Company ................. January 21, I 888 
Pasadena Lumber Company.. ............................ December 20, I883 Pasadena Manufacturing Company .................... .December IO, I 886 Pasadena Mining and Developing Company.............. August 7, I 888 Pasadena Monthly Meeting of the Religious Society of

Friends

Pasadena and Mount Wilson Railway Company ........... June 3, I 89 I

Pasadena and Mount Wilson Toll Road Company.........June 22, I 889

Pasadena Mutual Burial Association....................... October 1 2, I 892

Pasadena National Bank, No. 3,568-National charter...October I I, I 886

Pasadena Packing Company.............................. May 7, I89 I

Pasadena Park Tract Land and Water Company...........July 7, I 887

Pasadena Patent Improvement Company..................July 23, I 890

Pasadena Presbyterian Church ......................... November 20, 1876

Pasadena Quarterly Meeting Society of Friends [Whittier], May I6, I89 I

Pasadena Railway Company ............................ November 27 , I 886

Pasadena, Ramona \& Long Beach Railway Company.....March 2I, I887

Pasadena Real Estate Exchange........................... Iay I , I 887

Pasadena Rincon Land and Water Company...............August I6, I 887

Pasadena Savings Bank................................ May I 8,1887

Pasadena Security Investment Company................. February 9, I 895

Pasadena Steam Laundry .............................. February 9, I 887

Pasadena Street Railroad Company $\ldots . . \ldots \ldots \ldots \ldots \ldots \ldots \ldots \ldots$ February I 8 , I 886

Pasadena \& Wilson Peak Railroad Company ............. June I I, I 887

Raynor Springs Water Company.........................June 21, I 893

Rubio Canyon Land and Water Company................. February 24, 1886

San Gabriel Orange Grove Association [the original

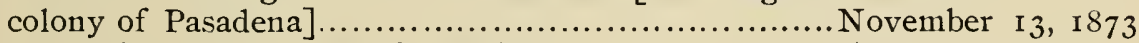

San Gabriel Valley Bank of Pasadena....................February 6, is 886

San Gabriel Valley Fruit Company.....................April 27, 1893

San Rafael Water Company .............................February 15, I 887

Sierra Madre College...................................April I, I 884

Southern Oil Company.................................March 23, I 89.5

South Pasarlena 'Bus and Transfer Company ................March 2 I, I 888

South Pasadena Hotel Company .........................April 24, I 888

South Pasadena Methodist Episcopal Church.............April 25, I 887

Star Publishing Company...............................Aprii 22, I 890

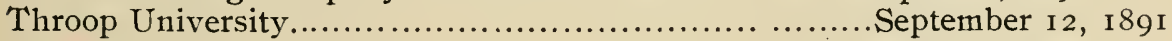

Union Club of Pasadena..............................July 8, I 887

Union Publishing Company........................... June 16, r 887

Union Savings Bank...................................January 30, I895

Valley Hunt Club.................................... November 23,1892

Waukena, Tulare and Mammoth Forest R. R. Company, January 23, I888.

West Pasadena Railroad Company .........................January I4, I 888.

William R. Staats Company................................ October 4, I 894 .

Willamette Lumber Company.............................August 25, I 894 .

Wilson Peak Mining Company...........................August I6, r 887.

Young Men's Christian Association...................... October 20, I 886.

Of the incorporations above noted there were :

Religious organizations..............25

Land and Water Companies.......... I9

Water companies.

Railroad companies.
Municipal incorporations............ 2

Mining companies ................. 6

Miscellaneous bodies...............53

Total....................... $\overline{25}$ 
The following table of the number of incorporations formed in successive years makes a curious exhibit of the culmination and decline of Pasadena's great historic “'boom," I 886 to 1888 :

\begin{tabular}{|c|c|c|c|c|}
\hline$n \quad 1873-1$ & In $1882-4$ & In $1886-20$ & In $1890-5$ & In I $894-6$ \\
\hline $1876-2$ & I $883-2$ & $1887-24$ & $189 I-6$ & I $895-4$ \\
\hline $1877-\mathrm{I}$ & $1884-3$ & I 888 -I 8 & I $892-6$ & \\
\hline $188 \mathrm{I}-\mathrm{I}$ & I $885-5$ & $1889-4$ & I $893-8$ & \\
\hline
\end{tabular}

\section{CHAPTER XVI.}

Pasadena's Chief Historic Days.-Orange Grove Colony Day.-President Hayes Day.-Citrus Fair Days.-Railroad Opening Days.-National G. A. R. Day.-President Harrison Day.-Prof. Lowe Day.-Father Throop Day; and sundry others.

HISTORIC DAYS.

This chapter is devoted chiefly to a record of such days as form distinctive waymarks in the progress of Pasadena's wonderful growth. It also includes some days on which occurred events of more than ordinary historic interest or association. But it would require a whole volume by itself to attempt an account of all the tournaments, fairs, Fourth of Julys, memorial day parades, torchlight processions, ratification meetings, jollifications, state conventions, notable excursion visits, distinguished guest receptions, and other such exceptional public affairs as have flooded Pasadena with excitement for a day, at frequent intervals all through the passing years. They are so numerous as to have become quite commonplace; yet a few of them stand out with features of prominence as public events that do call for historic recognition.

ORANGE GROVE COLONY DAY.

Pasadena's first distinctively historic day was January 27, I 874 , when the twenty-seven original shareholders of the colony lands made selection and took formal possession of their several plats of ground. [See pages ro8 and 125.$]$

\section{FIRST RE-UNION PICNIC DAY.}

On January 27,1876 , the colonists held their first general re-union picnic, in their fine grove of native oaks, now known as Lincoln Park. This was the colony's anniversary day, and they had for speakers Hon. Coker F. Clarkson of Iowa, Col. John F. Godfrey of Los Angeles, and others. [See page III.]

\section{PRESIDENT HAYES DAY.}

In October, I 880 , president Rutherford B. Hayes and wife visited Los Angeles and were made the guests of the Southern California Horticultural Society, which was then holding its annual Fair in the great pavilion erected in 1878 on Temple street, where a grand public reception was given 
them. One of the original colonists of Pasadena was J. M. Matthews, brother of Hon. Stanley Matthews, U. S. Senator from Ohio, and maternal half-brother to Mrs. Hayes. Mr. Matthews' colony tract was 60 acres, extending from Fair Oaks Avenue to Arroyo drive, and included the ground now occupied by the fine residences of E. F. Hurlbut, Prof. T. S. C. Lowe and Mrs. Col. Baker. He built a house on the hill where Mrs. Baker's elegant mansion now stands (1895) and he and Thomas F. Croft "kept bach" there together. Mr. Matthews was a man of superior talent, but was wrecked by strong drink. He had been a prominent editor at Indianapolis ; and in order to get him away from drinking influences his friends had induced him to join the Pasadena colony, hoping that by these better associations and surroundings he might be imfroved. This hope proved vain, for he continued to drink here, and had fits of delirium tremens, from which Dr. O. H. Conger twice saved his life; and most of the colony families were kind to him, for he was an excellent man apart from his drink habit. When Hayes received the nomination for president in I875, Matthews was possessed to go back and take part in the campaign; and he determined to sell his place and go. Mrs. Hayes had kept up a sisterly interest in and care for this inebriate brother-in fact seemed to have a special oversight of his affairs, and had been in correspondence with Mr. Croft for some months about the matter. Mr. Croft finally bought Matthews' place, upon an understanding with Mrs. Hayes and other friends ; but instead of letting him take part in the campaign for his brother-in-law's election to the presidency, they sent him to an inebriate asylum. Mrs. Hayes had a strong desire to see the place where her poor wreck of a brother had lived, and the people who had been so kind to him; and this desire of hers was the real ground and incentive of the presidential visit to Pasadena.

The families of Messrs. A. O. Porter and P. M. Green had only a few hours notice that the president was coming, and they sent word around as well as they could to their colony neighbors within reach, a number of whom came to assist them in making preparations for the great occasion. They talked of putting up a floral arch across the driveway leading from Sylvan Avenue up to Mr. Green's house, but the time was too short for this. And all they could do was to send a mounted escort to meet the party, besides having some little girls ready to present them with Pasadena flowers and fruits, and give the guests a warm greeting, for they were expected any minute for two hours before they did finally arrive.

J. DeBarth Shorb, being president of the Agricultural Society that year, had the president and wife in charge as guests of the society, and brought them out to Pasadena in his carriage, heading the procession. In the next carriage was Gen. Geo. Stoneman and Gov. Geo. C. Perkins, accompanied by Gen. W. T. Sherman and his daughter Rachel; and there were several other carriages following, but by whom occupied I could not learn. They 
were all engaged to take dinner at General Stoneman's house on his Los Robles ranch, and get back to Los Angeles by nightfall. Mrs. Stoneman was at home keeping the victuals hot; and the general was full of anxiety and hurry to shorten all ceremonies and hasten movements. The galloping instincts of a cavalry officer were still strong upon him. The visitors were met on Mission street in South Pasadena by Masters Whit. Elliott, Morton Banbury and Will. Clapp, all on horseback to escort them up to Columbia street. But when the dust of the carriages signaled their approach Mr. Green ran down his picturesque private driveway to Sylvan Avenue, and there meeting the president's carriage, which was much in advance of the others, he led them up to the lawn at the north front of his house. Here they were met and welcomed in a very brief speech by A. O. Porter, who was president of the colony association that year. Three little girls, Lulu Porter, Agnes Elliott and Winnie Farnsworth, dressed in white and bearing baskets of fresh flowers and fruits, were lifted up to the carriage to present their tokens of welcome, and were kissed by President and Mrs. Hayes, the latter being especially cordial and pleasant to the children. The president was then introduced to each of the gentlemen, and Mrs. Hayes to the ladies present. Of the colony people there, I have only been able to ascertain certainly the names of A. O. Porter and wife; P. M. Green and wife; Maj. Erie Locke and wife; Thomas F. Croft; Mrs. Dr. Elliott; Mrs. Rosenbaum; James Cambell, with his two sons, Samuel St. John and James H.; and Charles $\mathrm{H}$. Watts.

Meanwhile the rest of the party, with Gen. Stoneman, Gov. Perkins,* and Gen. Sherman and daughter in first carriage, instead of turning up Mr. Green's driveway continued on Sylvan Avenue up to Columbia street near Mr. Porter's house, where two old soldiers of Sherman's army saluted him, one of whom the general recognized, calling him familiarly by name, and stopped to have a little talk. This was Alexander Edwards, who had been a company officer under Sherman, but at this time resided on his I2-acre lot at corner of Columbia street and Fair Oaks Avenue - now the Rev. Dr. Miller estate. The other man, Enio Brenna, Gen. Sherman did not remember by face or name (although he had served as a cavalryman in the famous " marching through Georgia"), but of course greeted him cordially as an old soldier. Mr. Brenna was then living in a shanty at J. F. Barcus's place. [See footnote, page I 5I.]

While Gens. Sherman and Stoneman were engaged with this little episode, the President's carriage had driven rapidly up Orange Grove Avenue to about where Bellefontaine Avenue now crosses it, so that Mrs. Hayes might see the place where her brother had lived - a frame house then owned by Thos. F. Croft, where Mrs. Col. Baker's elegant residence on the hill now stands; and here Mr. Croft had a brief talk with Mrs.

*Geo. C. Perkius was governor of California from 1880 to $188_{3}$, then succeeded by Stoneman. 
Hayes about her brother's affairs, he having been Mr. Matthews's agent in the original selection of the place, lived with him there, and finally took it off his hands when he was determined to go back east during Hayes' candidacy. Meanwhile Gen. Sherman suddenly missed the president's carriage - it was nowhere in sight, and he showed considerable excitement, almost alarm, for a few moments, about the president's sudden and mysterious disappearance, for he knew nothing of Mrs. Hayes' special interest in persons and places here, and supposed their carriage was close by. The General, however, soon learned where they had gone, and drove up the avenue to join them. Mr. Cambell's home was then on the south part of the same hill, or what is now the McGregory place, next south of Prof. T. S. C. Lowe's magnificent dwelling, and he hastened home to tell his wife about the visiting party, as she had not been able to go to the reception; so they stood out on their veranda fronting Orange Grove Avenue and saluted the whole party as they returned down the avenue under Gen. Stoneman's lead, making haste to that waiting dinner at his ranch house.

The reason why so few of the colony people were at this historic reception was, that many of them were in Los Angeles at the time, attending the Agricultural Fair. Miss Jennie Clapp (now Mrs. Culver) was there, and assisted in waiting on the tables at the banquet given to the presidential party. And others of the colonists resided so far from Mr. Porter's place that word could not be sent to them in time, hence they did not know of the notable visitation until it was all past.

On the same day Gen. Sherman had called upon and paid his respects to Dona Refugio Bandini, who then resided in Los Angeles; for he had been a favored guest at her house in San Diego in the days when he was only a young lieutenant (1847) and she was the queen of society in San Diego city and all that part of the state.

The work of collecting data and writing a history sometimes becomes itself a part of the history, and I have here a case in point, sufficiently curious and interesting to be worthy of mention. During a period of five weeks I made diligent inquiry for facts about the visit of President Hayes to Pasadena, having during those weeks consulted 33 different persons who resided here at the time; but not one of them could give me the day of the month, nor even the year, nor could they be certain whether it was in September or October. However, a clue was given me in regard to the Horticultural Fair and its new building on Temple street, and by following this clue through some old records I settled on October, I878, [?] as the time of the visit. No one of the 33 persons I had seen remembered that Gov. Perkins was one of the visiting party; and the great bulky "History of Los Angeles County," pretending to give a table of notable events year by year, utterly fails to mention this visit of President Hayes and Gen. Sherman to Los Angeles, notwithstanding they had a great public reception and banquet 
there - but it does mention a visit of Gen. Butler there the same year. After I had got my story of "President Hayes Day" all written out, supposing it to embody the bottom facts, I learned that the old soldier, Alex. Edwards, who had been named to me as a "teamster" in Sherman's army, was still living at San Jacinto; and I wrote to him asking for some particulars of the affair. From him I received the following letter:

\section{San Jacinto, Cal., October 19, 1894.}

Dear Comrade:- Gen. Sherman, Gov. Perkins, and President Hayes and wife drove through Pasadena in the last week in October, I880 (not in I 878 , as you have it). Indiana was an October state then [for state election], and President Hayes was congratulating Mr. A. O. Porter on the election of his brother for Governor of Indiana. The president was anxious to get home in time to vote for Garfield.

I was in the war four years - three fights to one eat - and commanded the company for three years. I also served two terms in the Mexican war. I served under Sherman at Vicksburg ; and also knew him before the war, while he lived in Louisiana.*

AlEX. EDWARDS.

\section{FIRST CITRUS FAIR DAY.}

The next historic day of special mark was March 24, I880, when the colony held its first Citrus Fair, in the central school building, and made public exhibit of such fruit products as were already matured. It was a marvellous success, was reported extensively in the newspapers, and gave the colony a widespread fame. D. M. Graham, who died in I893, wrote an account of it for L. M. Holt's agricultural paper then published at Riverside, and from his report I gather, that papers were read at the Fair, on Pasadena's past history and future prospects, and on various horticultural topics, by Judge B. S. Eaton, Col. J. Banbury, Hon. J. F. Crank, Dr. O. H. Conger, Mrs. Jeanne C. Carr, D. M. Berry and D. M. Graham. Mr. Graham stated that Mrs. Locke had shipped to San Francisco some limes which averaged 900 to the orange box, and sold for $\$ 8$ per box. As to future prospects he remarked: "Our I 25 families must swell to 2,000." And he lived to see the swell reach twice that number. From Mr. Graham's paper I make the following extract, which gives some idea of how the colony appeared at that time:

"To a cluster of homes about eight miles northeast of Los Angeles, the name Pasadena was given by earlier settlers. Its short history of six years has made those homes beautiful beyond the most sanguine hopes of its founders. The streets are clear of weeds; the five to sixty acre lots are enclosed by neat hedges of limes and Monterey cypress ; the tasteful houses are generally set far back from the street and reached by a well-kept drive through the orange orchard, whose soil is kept scrupulously clean and mel-

* Gen. Sherman came to California in 1847 , as a Lieut. in 3 d U. S. Artillery ; came by ship around Cape Horn, to San Diego. Gen. Stonemai came two or three months earlier, overland, as Lieut. in First U. S. dragoons, but acting quartermaster of the Mormon Battalion. Sherman served here until 1850, most of the time as acting Adjt. General under the military governors, and of course he and stoneman were army comrades then. In $1859-60$ he was superintendent of the State Military Academy at New Orleans, Lousiana, where Mr. Edwards first knew hin ; and that is how it liappened that he recognized Edwards so faniliarly, but did not know the old cavalryman, Eino Brenna. 
low; further back thrive all the fruits of the temperate and many of the torrid zone; a team of horses, a carriage, a cow, sometimes a pig and chickens complete the picture. We have ceased to be an experiment. We are an acknowledged success. To have failed would have been the basest ingratitude to Nature."

See some further account of this first Fair, written by Hon. P. M. Green. page II 2 .

\section{SECOND GREAT CITRUS FAIR.}

The next eventful day that seems to call for special historic recognition was the second general Citrus Fair, which was held on March 3, 4, 5, 6, 1885, in the roller skating rink on the corner of Fair Oakes Avenue and Dayton street, where the large three-story Doty block now stands. The principal address was a learned presentation of the history and quality of all the citrus fruits, by Abbot Kinney. Mayor E. F. Spence of Los Angeles presented the greeting of that city, and from his brief address I quote the following passages :

"A few years ago, on my way to the Mission San Gabriel, I traveled over the rancho, a part of which we now stand upon; and had it then been tendered to me as a gift with the obligation on my part that I should pay all the taxes, I verily believe I should have rejected the offer, and charged the would-be donor with considering me a tender-foot. I am almost ashamed to make the statement, as it is a confession of my own lack of foresight, and inability to comprehend the immediate coming greatness of our Southern country.

The old San Pasqual Rancho is transformed; the Major Domo and his subordinates are dead; the vaquero, the shepherd and his dogs are seen and heard no more, for the old things have passed away and behold all things have become new.

Pasadena! The city of Los Angeles is proud of her little sister.

Pasadena! The county of Los Angeles ought to be proud to have such a jewel in her setting.

Pasadena! The happy home of cultured men and women, intelligent and well-trained men and maidens.

Pasadena! Protected by the rugged Sierra from the desert blasts and northern winds, who can foretell thy greatness?

Is it too much to expect that ere long Los Angeles city will extend her boundaries and capture this golden prize and make it a part of her rich municipality?

What a grand boulevard would then be constructed through Lincoln Park and the Arroyo Seco !

It takes not the ken of a prophet to tell that the habitations of both places will soon spread out and touch each other.

Pasadena! In the name of Los Angeles city, I greet thee again!"

This Fair was gotten up by the officers of the Public Library, and all profits from admission fees went to the Library fund. The Fair was held four days, the third (March 5th) being "IOWA DAY," when 195 settlers here from Iowa registered their names and the county in Iowa from which 
they came to California. On this day Dr. J. P. Widney of Los Angeles gave an able and philosophical address on the workings of climate as a factor in human history, or as he styled it, "The Climatic Belts of Civilization."

There were over twenty varieties of oranges on exhibition, seventeen of which were mentioned by name in a report for the Valley Union made by Byron O. Clark. And Bayard T. Smith exhibited an orange just picked from the tree where it had remained since $\mathrm{I} 88 \mathrm{I}$ - four years.

On March $17^{\text {th }}$ the Fair committee made the following report to the Library trustees: Receipts from the Fair, \$489. Receipts from the play, $\$ 207$. Total, $\$ 696$. Expenses, \$165. Balance turned into Library treasury, \$531. [See page 204.]

\section{S. G. V. RAILROAD DAY.}

Next comes the opening day of the San Gabriel Valley Railroad (now the Santa Fe), on September I I, I885, which was at that time considered the greatest event that had yet transpired in Pasadena's history, and everybody turned out with zeal and enthusiasm to celebrate the grand occasion. [See chapter 22.]

\section{NATTONAL G. A. R. DAY.}

August I7, I886, witnessed the visit to Pasadena of the National G. A. R. Encampment, which met that year in San Francisco. This visitation was one of Pasadena's great historic days, and I quote some particulars in regard to it from a report in the Pasadena Union of August 20 :

"August 17 was 'Pasadena Day' in the program of G. A. R. festivities, and right royally did queen Pasadena prepare for the occasion. . She sprinkled her streets far and wide, and laid the dust so thoroughly that none enjoyed it more than the inhabitants themselves, who were so well pleased with it that they wished it could be done all the time. The city was decorated. The Exchange block, Wetherby \& Harris' store, Cruickshank \& Co.'s store, Ward Bros.' block, Mills block, the Union office, Star office, Wooster's building, the Grand Hotel, and the Los Angeles House, were notable instances; while to a lesser degree the good work was very generally carried out.

"Over the entrance to the stores in Exchange block, where the banquet was spread, was a huge sign, "A cordial welcome to the Grand Army of the Republic and visitors," painted in fine style by Stewart; while over the entrance was a portrait of Grant, by the same artist, with the motto: "The Nation's Hero - He is not dead." The banquet halls themselves were handsomely ornamented with festoons of the national colors, photographs by Frost of notable views in the vicinity; and, best of all, some beautiful banana plants.

"The eatables were there in profusion-melons, fruits, meats, breadstuffs, jellies and sweet-meats, provided with lavish hand, and ready to be served on four long tables seating seventy-five persons each, or 300 at a sitting, and served by the fair hands of Pasadena's ladies, who rallied with a will to do honor to the country's defenders. The guests came in force, twelve car- 
loads, and numbering fully a thousand, for that many railroad tickets were sold, and nearly as many more must have come by other conveyances, as fully r 800 people must have been fed at the banquet tables; and many sought food elsewhere when they got tired of waiting for their turns in the endless procession that for hours filed in and out of the banqueting halls.

"The visitors were met at the station by the Pasadena band and escorted to Williams' hall - that is, as many of them as could get inwhere the preliminary exercises of the day were had. Mayor Holmes called the multitude to order and introduced Major J. D. Gilchrist, commander of the G. A. R. Post here, who in stirring words welcomed the visitors to Pasadena, and cordially invited them to remain and make homes here. Response was made with three rousing cheers for Pasadena.

"Major Bell, editor of the Porcupine, gave a stirring and characteristic address, in which he recalled the interesting fact - highly creditable to himself - that he was one of the only two soldiers furnished to the Union cause by Los Angeles during the war. Los Angeles was then excessively pro-slavery; and while she had soldiers ad lib. for the rebel army, furnished only two fighting men for the Union.

"The company were then dismissed to dinner, which had long been waiting, and were served as rapidly as possible, by the numerous citizens on hand to assist. Gen. Bennett, department commander of Indiana, Col. Robinson of Ohio, and Sheriff Gard of Los Angeles, vice-commander of the department of California, were among the distinguished visitors of the day.

"A floral wreath and bells in the banquet hall were made by Dr. Rachel F. Reid of this place, an old Army Nurse. She was the first woman ever mustered into the army hospital service west of Washington, having enlisted in St. Louis in September, I86r, under Gen. Fremont.

"An event that will live in history is the hauling in a carriage by enthusiastic 'vets' of four members of the 'Old John Brown' family, who live here. Jason and Owen Brown, Mrs. Ruth Brown Thompson and her husband, Henry Thompson, have long been residents here, and were objects of the enthusiastic admiration of the boys-in-blue, so much so that in the course of the afternoon they were got into C. C. Brown's fine carriage, the horses taken off and a long rope attached, and for a half hour or more they were hatled up and down the streets by the soldiers, singing, 'John Brown's body lies mouldering in the grave; His soul is marching on!" Jason Brown is exceedingly modest, even to bashfulness, and he protested with all his power against the embarrassing publicity thus given them, while Mrs. Thompson's womanly heart broke down at the starting of the historic song, and she wept during almost the entire time. However, it was all meant in kindness, and they will doubtless forgive the old soldier friends whose enthusiasm thus constrained them to trespass upon their privacy.*

"Among the historic incidents of the day, Dr. H. A. Reid of Pasadena, wore the identical badge (first division sixth army corps) which he wore in the battles of the Wilderness, Spottsylvania, Cold Harbor, Petersburg, etc. He was then chaplain of the fifth regiment Wisconsin volunteers, and also member for Wisconsin of the U. S. Sanitary Commission, and was within a few rods of Gen. Sedgwick, when that noble officer was killed in the battle of Spottsylvania.

*In the Union of August 27, 1886 , a card was published, signed by Jason and Owen Brown, Ruth and Henty Thom pson, thanking the old soldiers for their kind remembrance. 
"'There was in the procession and in Williams' hall the old battle flag of the 85th Missouri regiment, which was carried in the bloody battle of Pea Ridge and sixteen other fights in Missouri. This old battle-torn and tattered flag is now owned by Frank Bartlett Post G. A. R., of Los Angeles."

\section{RAYMOND HOTEL, DAY.}

November I 7, I886, was opening day of the great Raymond hotel, which was an affair of local importance second only to the building of the S. G. V. railroad, and was therefore a notable event in Pasadena's history. [See Chapter 24.]

EDITORIAL ASSOCIATION-DAY.

December I9, I888, the parlors of the Carlton hotel in Pasadena were occupied by an assemblage of editors, who made the day historic by organizing here an association, which still continues. A brief report of the natter I quote from the Pasadena Standard of December 22 :

"About thirty newspaper men assembled in Pasadena last Wednesday and organized the Editorial Association of Southern California. L. M. Holt of the San Bernardino Times was elected president, and W. L. Vail of the Pasadena Star, secretary. On motion the chair appointed Dr. H. A. Reid of Pasadena, O. A. Stevens of Los Angeles, George Rice of Alhambra, Scipio Craig of Redlands, and D. M. Baker of Santa Ana, a committee on organization. Committee's report adopted. H. J. Vail of Pasadena, Scipio Craig of Redlands, W. H. Nixon of Santa Barbara, H. E. Boothby of Fresno, and Warren Wilson of San Diego were appointed committee on Constitution and By-Laws, to report at first annual meeting, at Chamber of Commerce in Los Angeles, the second Tuesday of January, I 889. Thirtythree names were enrolled for membership. The Pasadena Board of Trade gave them a banquet at the Carlton hotel. A free excursion over the Altadena railroad, and free seats at the Pickwick Club minstrel entertainment were also accepted."

\section{OWEN BROWN'S FUNERAL DAY.}

January IO, I889, was a day of pre-eminent historic associations in Pasadena, as connected with the funeral of Owen Brown. Of all the newspaper reports published at that time, that of the Pasadena Standard of January 2 contained much the greatest embodiment of history points pertinent to the notable occasion, and hence I quote from it :

FUNERAL OF OWEN BROWN, THE LAST SURVIVOR OF JOHN BROWN'S HISTORIC RAID ON HARPER'S FERRY, VA., IN I859.

Died, at the residence of his brother-in-law, Henry Thompson, in this city, on January 8, I889, Owen Brown, aged 64 years, 2 months and 4 days.

Owen Brown was born at Hudson, Ohio, November 4, I824, and was the third son of Joln Brown's first family, there being twenty children in all.

Owen was with his father all through the struggle between the free state men and border ruffians in Kansas in I 856 and following years, and took part in the first pitched battle at Black Jack on the Missouri and Kansas border, and also at Ossawatomie where his younger brother, an unarmed lad, was deliberately shot down in the street. Jason was also in these battles. 
Owen was with his father at Harper's Ferry, a participant in that memorable raid which struck the death knell of slavery, not only in the United States but throughout the civilized world. $\mathrm{He}$ was one of seven who escaped from there through mountain fastnesses and swamps and forests and farms and streams, in rain and snow and storms, living on raw corn, acorns, sassafras leaves, and such things as they could possibly devour without making a fire to cook. For they were pursued by soldiers and citizens with dogs and guns, and a price was set on their heads. The Atlantic Monthly some 15 or 20 years ago published a narrative of their escape, which excels in thrilling pathos, and in plain matter-of-fact incidents of hardship, endurance, and apparently supernatural deliverances from discovery and capture, the most vivid conceptions of fiction. Two of them made reckless ventures to get food and were captured and hung. The remaining five escaped, Owen finally reaching his brother John's home on an island in Lake Erie.

About five years ago Jason and Owen Brown took a homestead on a bench of mountain land five or six miles north of Pasadena, at the settlement now called Las Casitas. This they subsequently sold and took land higher up the mountain side, built a cabin, cleared and worked a few acres, and lived there - - two feeble old men, alone. (Jason was with his father in the Kansas struggle, but was not at Harper's Ferry.) They were much visited by tourists and citizens, some from mere curiosity and others from a warm sympathy with the historic career of the family. They had made a good wagon trail up to their mountain hermitage, and were continuing it as a donkey path to the top of the mountain known as Brown's peak, but it is not completed yet. Owen had a desire to be buried on the top of Brown's peak; and if Jason ever succeeds in finishing the trail he will try to have his brother's grave up there as he desired. But meanwhile he is buried on a lesser peak on their mountain homestead.*

Owen Brown was never married.

LAST DAYS.-December 3oth the aged brothers came down to the city to attend Col. Woodford's gospel temperance meeting in the tabernacle. We met them there both Sunday and Monday nights. But Owen was taken sick and had a chill after going to his sister Ruth's home from the meeting, and in a week he died of typhoid pneumonia. He had been failing for some months; this had been noticed by his relatives and friends. Monday he had worked pretty hard, then lay down in the bright sunshine on the banks of the Arroyo and slept. In the evening he went to the great temperance meeting, and being very deeply and ardently interested in the cause, he put his last cent of money into the collection; had nothing to pay street car fare with, and so walked over two miles to his sister's house, after the meeting. These over-exertions were probably the immediate cause of his last sickness, although he was out some on several days after the first attack, but was not able to attend the meetings any more.

At the women's meeting on 'Tuesday he and Jason were elected honorary members of the W. C. T. U. He was much pleased with this, and said there was no cause he would more gladly contribute his \$I.00 membership

*Jason was never able to do anything more with the mountain trail. He finally lost this home place by debt, and Owen Brown's grave remains at Las Casitas, as one of Pasadena's notable historic points. Their first place was not a "homestead," but land bought from Painter \& Ball, where the Las Casitas Sanitarium now stands. 
fee to aid. So he was buried with the W. C. T. U. white ribbon on his breast.

The last words he uttered that could be distinguished were: "It is better-to be-in a place-and suffer wrong-than to do wrong."

The FunERAL. - The last rites were paid to his mortal remains on 'Thursday, January I0. It was a historic day in Pasadena. The tabernacle was well filled-about 2000 people in attendance. The exercises were conducted by Rev. R. H. Hartley, pastor of the Friends church. The great choristry was filled with singers who sang appropriate hymns with a fervor and pathos as if the very spirit of the Browns had woven itself into heavenly music.

Prayer was offered by Rev. Dr. Bresee, pastor of the M. E. Church, which went to the heart of the historic occasion and was an uplift of soul in all noble aspirations. Remarks were made by Rev. Mr. Hartley; also by Rev. D. D. Hill, pastor of the Congregational church; Rev. E. L. Conger, pastor of the Universalist church ; Col. George Woodford, the gospel temperance evangelist; and by H. N. Rust, a life-long friend and neighbor of John Brown and his family.

The city trustees, who are all old-time republicans, attended in a body and took seats on the platform, as a token of respect for the memory of John Brown and his sons.

The students of the Pasadena Academy attended in a body. And members of the G. A. R. and Sons of Veterans who could leave their business places attended the funeral.

On conclusion of the services the casket was removed to the corridor and the face cover removed. Then the vast audience passed out in columns by each aisle on each side of the bier and thus all had an opportunity to view the face of Owen Brown. It was perfectly natural-a little paler than in life, and looked as though he was only lying asleep.

The bier was covered with floral emblems and tokens of love. A cross, a wreath, and boquets, composed of calla lillies, roses, violets, marguerites, sweet elyssum, geraniums, smilax, and feather palms.

RELATIVES PRESENT.-Jason Brown, brother of the deceased.

Ruth Brown Thompson, sister of the deceased, with her husband, Henry Thompson and their youngest daughter, Mamie. Mr. Thompson was one of John Brown's soldiers in Kansas.

Mrs. Grace Simmons, daughter of Mr. and Mrs. Thompson, with her husband and son, who reside at Las Casitas.

Mrs. Town, (another daughter) with her husband and son, who also reside at Las Casitas.

Mrs. Hand, from Wellington, Ohio, a sister of John Brown, aunt to the deceased, and now visiting her daughter in Los Angeles, formerly Mrs. Hood of Pasadeña.

Mrs. Hopson, cousin of the deceased, from Sacramento.

Mrs. Quinn, a cousin, from Saratoga Springs, N. Y.

THE PALL BEARERS. - It is quite remarkable that there should be found in Pasadena so many men who were associated with John Brown in his mighty work, which up-lheaved the nation and proved the entering wedge for the overthrow of slavery, thirty years ago. In charge of the pall bearers was H. N. Rust, president of the Pasadena Library Association, who was an old-time friend and neighbor of the John Brown family at East Hampton, Massachusetts, and also for many years in this city. 
James Townsend of Spring Dale, Cedar county, Iowa, who was John Brown's intimate and confidential friend; and at his house Brown took his last meal before starting from West Liberty to Chicago with his men and twelve escaped slaves. This was a marvelous event, in which John Brown, with $\$ 2,000$ reward offered for him, dead or alive, took a lot of slaves in a car on the C. R. I. and P. railroad through the cities of Davenport, La Salle, Joliet, Chicago, and on to freedom on the soil of Canada. And from thence moved on to his final operations at Harper's Ferry, Va. In Dr. H. A. Reid's "History of Johnson County, Iowa," a volume of 966 pages, at page 466 mention is made of James Townsend's "'Travelers Rest," the tavern at West Branch (near Spring Dale) where John Brown, and his mule captured from the border ruffians at the battle of Black Jack on the Kansas and Missouri line, were always on the "free list." On page 467 , of the same work, we read: "Brown himself had his quarters at the home of Mr. John H. Painter."

John H. Painter, who was justice of the peace at Spring Dale, and Brown's intimate and confidential friend. He boxed up the guns, sabres, pikes, etc., that Brown had gathered for his anticipated army of liberation, and shipped them to him at Harper's Ferry, labeled "carpenter's tools." For this he was unchurched by the Friends Yearly Meeting to which he belonged; but he believed he was doing God's service for the rights of man, and history since has fully vindicated the act. He is father to our prominent citizens M. D. Painter, A. J. Painter, Mrs. L. H. Michener, and Mrs. Dr. J. C. Michener.

Wm. H. Coffin, was associated with John Brown and his sons in the Kansas struggle for a free state against the slave-hunting border ruffians, in I $856-7-8-9$.

Benjamin A. Rice, was taken prisoner by the border ruffians in Kansas, and was released by John Brown after hair-breadth escapes from the murderous vengeance of the ruffians. Mr. Rice served through the war of the rebellion, is an old citizen of Pasadena, and is now chaplain of the G. A. R. Post here.

Wilson T. Kirk, a nephew of James Townsend above mentioned, resided at Spring Dale, Iowa, and was intimate with John Brown and his men in the days when it was perilous to be known as their friend.

W. B. VanKirk is commander of the G. A. R. post in this city, and took part as the special representative of that patriotic order of men who marched to the music of "John Brown's soul is marching on."

These were the historic men who bore Owen Brown to his grave.* The hearse was followed by a long procession of vehicles, and four photographic instruments were trained upon the scene to take views of different incidents in the course of the day.

\section{ASTRONOMICAL BANQUET DAY.}

January 28, I889, was made memorable by the astronomical banquet, because of what followed from it as the focal center of incentive and cooperation, with results that made Pasadena and Mount Wilson famous in the scientific world. The Pasadena Standard of February 2 contained a summary of facts and points in the case, from which I quote:

* It was Dr. H. A. Reid's plan, and by his special effort, that these particular men were gotten together for this duty, and their historic relations to the deceased or his father made known to the public 


\section{ASTRONOMY AND THINGS IN PASADENA.}

Monday was a notable day. A body of eminent men were in Pasadena. In the evening a banquet was given them at the Carlton hotel, and I 32 plates were served. The proposed astronomical observatory on the top of Mount Wilson, 5,80o feet above sea level, was the topic of all the afterdinner speeches. Everything centered on Wilson's peak. The speakers were: Rev. E. L. Conger, pastor of the Universalist church. Prof. W. H. Pickering, astronomer of Harvard University. Alvan G. Clark, the worldfamed telescopic lens manufacturer of Cambridgeport, Mass. Dr. W. F. Channing of Pasadena, formerly of Boston. Capt. Thomas F. Fraser, superintendent of construction of the great Lick observatory on Mount Hamilton, Cal. Rev. S. C. Bartlett, D. D., president of Dartmouth college. Prof. Brascher, astronomer and glass expert, of Pittsburg, Pa.

W. U. Masters, president of the Board of Trade, presided, and conducted the exercises in a prompt and sensible manner.

The outcome of it all is, that if Pasadena will proceed at once to construct a road to Wilson's peak, Prof. Pickering will locate a corps of observers there with a 23 -inch telescope, and conduct observations on behalf of Harvard University, to determine some scientific problems of this Pacific coast region.

On Tuesday the Board of Trade appointed a committee to see what can be done toward securing the Wilson's peak road to be made at once. The committee are: Col. O. S. Picher, H. W. Magee, Dr. W. F. Channing, T. P. Lukens, and C. S. Martin. Mr. Martin has a claim of 160 acres of land where the observatory is to be located.

It is stated at Los Angeles that the order was given Mr. Clark to go ahead and make his proposed 44-inch lens, the largest ever yet attempted, and Southern California will take it. It will require about two years of lathe and hand work to finish this marvelous glass; and Mr. Clark has gone home to commence the work.*

LATER.- It is arranged for Judge Eaton and N. C. Carter to make the trail passable and pack-horseable to the peak, at once, so the photo-telescope can go up.

The 23-inch photographing telescope was conveyed up the old Wilson Trail in April, I889, one portion of its iron base alone weighing 600 pounds. [See chapter 20 ; article, "The Telescope Episode." Also, chapter I9; article, "Harvard Telescope Point."]

\section{CENTENNIAL INAUGURATION DAY,}

Was observed in Pasadena on May 7th, I888; and from the Daily Star's report published May 8th, I condense the following particulars:

The Tabernacle was elaborately decorated with flags, pictures, flowers, etc. The members of the city council, city officers, veterans of the Grand Army, and a detachment of the Sons of Veterans occupied the front seats on the floor. "A Hundred Years" was sung by Miss Peck and the choir. Rev. W. A. Wright offered prayer. Rev. A. W. Bunker read the passage of Scripture upon which George Washington placed his hand in taking the inaugural oath one hundred years ago - the 4oth chapter of Genesis. The

*Sonthern California failed to raise the money for this biggest lens in the world; and it was finally purchased in 1892 by Mr. Yerkes, for the Chicago observatory. 
President's proclamation of the act of Congress fixing the 3 oth of April as a national holiday was read by J. A. Buchanan.

A tableau of the thirteen original States was represented by pupils of the Washington school, as follows: Columbia, Cora Humphrey; Delaware, Mabel Overmier ; Pennsylvania, Lena Seaman ; New Jersey, Maud Thornton; Georgia, Blanche Allen; Connecticut, Bessie Cook; Massachusetts, Edith Hough; Maryland, Flora Weimar ; South Carolina, Florence Coffin ; New Hampshire, Alice Lambert; Virginia, Abbie Mohn; New York, Helen Forbes; North Carolina, Aggie Petrie; Rhode Island, Lydia Hiatt. All were dressed in white, with red-white-and-blue sashes, upon which was lettered the name of each State represented. In their hands the girls carried small flags, and all were gathered about the Goddess of Liberty, who bore a handsome American standard. Each girl read in turn a scrap of Colonial history appropriate to the State represented; and all concluded with a patriotic song, the "Star Spangled Banner," sung by Miss Peck and chorus, with orchestral accompaniment.

Rev. Dr. Bresee's address was preceded by a few introductory remarks by Judge Magee, who referred to the great event of one hundred years ago, showing that the inauguration really took place on the 3 oth of April, rather than the 4th of March, because Congress had no quorum until the April date. The key note to Rev. Bresee's address was, that true love of country is drawn from the altar. The past history of this country teaches above everything else, he said, that God has been over all. In closing, the speaker aroused great enthusiasm by stirring allusions to Washington, Lincoln, and other dead leaders, and asking if it is too much to expect that their spirits are with the people in the services of this day.

The program closed with the singing of America by the choir and the audience.

TERMINAL RAILROAD DAY.

March I2, I890, was opening day of what was then known as "the Cross railroad," but now the Los Angeles Terminal railroad; and it was celebrated with extraordinary vim and enthusiasm by the entire populace. The city official records show that all officers and employes of the city except police and firemen were excused from duty in order to take part in the public festivities. The daily papers of Pasadena and Los Angeles vied with each other to see which should give the most elaborate and gushing report of the affair. The Pasadena Standard of March I 5 contained in brief space the chief historic points, and from it I quote:

Grand Ovation to Capt. Cross. - The opening of our new Rapid Transit railroad has taken place. The celebration of the event was a triumphal ovation to Capt. Cross, who showed such splendid pluck and tenacity in overcoming obstacles both natural and artificial, and finally won the day. It is not in our line to give any detailed report of the proceedings. Suffice to say, the city was full of holiday display. Four trainloads of visitors and invited guests came up from Los Angeles - three arriving at one o'clock, and one about four o'clock. A grand civic and military procession marched through Colorado street, where the stores and other buildings were all jubilantly decorated, and the sidewalks and balconies and open windows filled with thousands - probably not less than 5,000 people in procession and along the line 
of march. Gov. Waterman and wife were in the procession; also Mayor Hazard of Los Angeles, Judges Van Dyke and McKinley of the superior court, and about twenty-five other prominent men of the county. Free lunch, races and games were given at sportsman's park.

An historic episode of this historic day was a public protest by Rev. E. I. Conger, D. D., pastor of the Universalist church, which he published in the Daily Star, and from which I quote :

EDITOR STAR :- Is it fair for the committee on reception to compel the majority of our citizens to stay away from the Cross banquet, or else seem to put at defiance ordinance I25, which they have helped to make a law ? We do not want to do either. We are deeply interested in the effort to honor Mr. Cross for what he has done, and we want to do our part; but if we help to buy the wine for the banquet (which we do when we pay $\$ 3$ for a ticket) do we not defy the law of our city, at least by implication? The majority have sanctioned ordinance I25. Is it "square " to put so many of our public-spirited citizens in such an attitude as to compel them to stay away, simply to please some who want wine served at the banquet? If it were a question of "turning down the glasses" by those who did not want wine, that would be easy enough; but when a citizen pays $\$ 3$, knowing that the money goes to help buy wine for the banquet, is he not "particeps criminis" if the question is ever raised? Will my neighbor, just for a glass of wine, force me into this attitude or compel me to stay at home?

E. L. CONGER.

Dr. Conger represented a large proportion of the citizens of Pasadena, (doubtless a vast majority of them, if women were counted) - but the liquor folks had their way, all the same.

\section{PRESIDENT HARRISON DAY.}

April 23-24, I89I, were made memorable by the visit of President Benjamin Harrison and some members of his cabinet to Pasa. dena. A reception committee of about 200 persons had been appointed; and the city turned out en masse to do honor to the distinguished visitors. Besides the president and his wife, and Mr. Halford, his secretary, the party consisted of Postmaster-General John Wanamaker; Gen. Rusk, secretary of agriculture; Major Sanger, U. S. A., aid de camp to the president; Mr. Russell Harrison and wife; United States Marshal, D. M. Ransdell; Mr. Geo. W. Boyd, excursion manager, and wife; Messrs. Tibbetts and DeLong, stenographers; Mrs. McKee, the president's daughter; Mrs. Dimmick, Carter B. Harrison, Lieut. Baker, James Horsburg ; and the official agents of the United Press, the Associated Press, and the Press News, three great news-gathering associations for the daily papers.

A grand arch of calla lilies spanned Marengo Avenue a little below Kansas street; and a gate of flowers was erected down near California street to be swung open by the children as the president's carriage approached. From Colorado to California street the avenue was filled two lines deep on each side with school children, besides thousands of people 
packed in behind them. And as the presidential party and the grand procession moved slowly down the avenue between the double lines of crowded, eager humanity, handfuls of flowers, bouquets, wreaths and floral designs were tossed toward and into the vehicles until the roadway was literally carpeted with flowers. Near the lower end of this ovational line was located the Garfield school, Prof. A. I. Hamilton, principal ; and when the president's carriage arrived here it was halted for a moment to receive a large and exquisitely-prepared floral design representing an inverted wine glass - for it had been currently reported that at the banquet during the previous evening the president had turned down his glass and refused to allow wine poured into it; and this supposed action of his met the school sentiment, and the best popular sentiment of Pasadena, on its warmest side - hence this special and particular thank token in flowers. This incident, and the banquet malventure which led to it, became matters of warm dispute and of wide celebrity at the time. A correspondent of the Los Angeles daily Evening Express gave the fullest and fairest account of the whole matter that was anywhere published; and as a famous episode in Pasadena history, I quote the entire article:

EDITOR EVENING Express : Pasadena is a good deal stirred up over a wine banquet which was thrust upon our Presidential guests, thus shutting off 2,000 citizens who were not admitted to the small dining room of the hotel, but had gathered outside the building, hoping to see the President and hear him speak a few minutes. If the banquet "bore" had not been forced upon him, he could have spoken ten minutes to the masses assembled to express their hearty and loyal good will, and then retired for rest - for he was much worn and wearied with the tax and strain upon his energies by responding to the continual popular ovations night and day for four days.

Last Sunday, Rev. D. D. Hill, pastor of the First Congregational church, publicly denounced the whole affair as a public insult to our distinguished and noble visitors, and also an outrage upon Pasadena's fair name, for a wine banquet is in open violation of the city's police law, and has been fully and forcibly so declared by the courts; and Mr. Hill said, after the chief guests had excused themselves and got away from the witless weariness of the thing, the "banquet" still went on and ended in a regular drunken debauch. Preacher Hill is a great friend of President Harrison, Secretary Wanamaker and Governor Markham. 'The governor's wife and three daughters, also a brother-in-law and wife, are all members of his church. His denunciation of the affair was bold, vehement, clear cut and powerful, like some of the ancient apostolic and pulpit orators whom we read about in history, so of course it made much talk. I found there was a report current that the President did drink wine at this banquet, and so gave his sanction to it. - But others said he did not. I set out to find authentic and reliable information, with responsible names to back up what I should say about it.' B. F. Ball, vice-president of the First National Bank, and Rev. J. IV. Phelps, pastor of the First M. E. church, were present, and said decidedly the President did not drink any wine.

Dr. G. Roscoe Thomas, a former member of the City Council, was there, but did not know about the matter. At last, however, I got reliable 
particulars from Postmaster W. U Masters, who sat near Mr. Wanamaker. He says a waiter came along behind President Harrison and poured wine into his glass, but as soon as he noticed it the President took hold of the glass and with a very emphatic and decisive motion pushed or set it away from him, and did not touch or taste a drop of it. The waiter came to Mr. Wanamaker the same way, and that gentleman decisively kept his glass turned down, refusing to allow any wine poured into it. Mr. Masters did the same thing, as a courtesy due to the temperance sentiments of the guests. (As a member of the committee he had objected to the wine feature, for the same reason, as did others also, for they knew that the President and Wanamaker were church members, and did not approve of liquor drinking; but the wine service was decided on when he [Masters] was absent.) The waiter next went to Secretary Rusk and tipped the wine bottle down to Mr. Rusk's glass, when that gentleman threw up his hand against the bottle, tilting it back and pushing it away. Thus each of the three chief guests were compelled to resist a discourtesy thrust upon them in the house of their friends, the Republican stronghold of Pasadena.*

But the next day when the people, free from the manipulations of any clique, had a chance to show their loyal regard for our chief magistrate, nearly every store in the city was closed, the people turned out by hundreds and thousands, and 2,000 school children in line literally strewed his pathway with flowers. They also presented him with an unusually attractive floral piece on which the chief emblem, richly wrought in fresh flowers, was an inverted wine glass. True, there was some other floral pieces; but in view of what had transpired the night before, this one alone touched the climacteric nerve of the occasion and became historic. It sent the visitors away with a much better opinion of Pasadena than they had been able to get from previous experience.

Pasadena, April 27.

The Pasadena Star of $23 \mathrm{~d}$ and 24 th gave an eight-column report of the honors to the President, without any hint of tribulation: but on the $25^{\text {th }}$ it came out with an editorial, scoring the banquet as " a flat failure," "a fizzle," "most wretched," etc., laying some of the blame to drunken colored waiters imported from Los Angeles, and making sundry excuses for other shortcomings in that part of the overstrained program. It seems that five kinds of wine, besides Roman punch, had been lavishly provided, but was little used ; and the waiters, with a few others, undertook to "save it" by drinking it themselves.

The Pasadena reporter for the Los Angeles Times told me personally that "the President did drink wine, for $I$ saw him drinking, just like the rest." But on further inquiry I learned that after the incident related by Mr. Masters to the Evening Express correspondent, the President and Mr. Wanamaker and Mr. Rusk each had a glass of Apollinaris water; and the Times man and others seeing them drink this, supposed it was wine they were "drinking just like the rest." These facts explain how it could

*Mr. Masters was the Democratic postmaster, still in office, but his successor, Geo. F. Kernaghan, had been appointed though not yet installed. Mr. Masters was also president of the Board of Trade, and was master of cerenonies for this hanquet occasion. Hence he had President Harrison sitting at his right hand and Governor Markham next; and at his left hand sat Postmaster-General Wanamaker, with the new appointee for Pasadena, Mr, Kernaghan, next. 
happen that such positive and yet so different statements were made in regard to the matter by different persons.

\section{COLUMBUS DAY.}

October 21, I892, was elaborately celebrated as Discovery day, or Columbus day, it being the four hundredth anniversary of the discovery of America. The five different public schools of the city each had a program of literary exercises, tableaux, etc., appropriate to the day. The Grand Army of the Republic had detailed a squad of old soldiers for each school, to visit it in the forenoon and join in the ceremony of raising the national flag on the school building, then take some part with the children by short addresses, etc., in their program. An exceptional incident worth recording was this: In making a detail of old Union soldiers for the Wilson High School building, the G. A. R. unanimously agreed to tender the post of honor as flag-bearer to an ex-Confederate soldier, T. J. Martin, as a token of peace and good will now between soldiers who wore the blue and those who wore the gray in the great war of the rebellion. Mr. Martin accepted the gallant courtesy and took his place in the line-but being in poor health at the time, he found himself too feeble to carry the flag, and a comrade of the G. A. R. walked by his side carrying it for him. (This was I. N. Stevenson, of the ${ }^{5}$ th Pennsylvania infantry regiment.)

During the afternoon a general grand parade of school children, civic societies, and citizens generally, was indulged in. They marched to the Tabernacle, which was packed to the last inch of space, and a short speech was made by Mayor O. F. Weed, president of the day. Prof. C. H. Keyes, president of Throop Polytechnic Institute, gave the principal address ; and it was a learned and brilliant pictograph of great drift currents in the world's history which took their initial flow or their historic trend from the new-world discovery made by Columbus. Short speeches were also made by Rev. E. L. Conger, D. D., Judge Waldo M. York, Rev. O. D. Crawford, and W. U. Masters. The Pasadena Daily Star devoted seven columns to a report of this day's doings in Pasadena.

\section{MOUNT LOWE ELECTRIC RAILROAD DAY.}

August 23, 1893, was the first day ever formally and officially set apart by the city council of Pasadena as a public holiday of their very own. And the festivities indulged in were like Fourth of July, Thanksgiving day, and Tournament of Roses, all combined in one superlative ovation to Prof. T.S. C. Lowe, as a commemorative testimonial on the completion of the Mount Lowe electric railway to its half-way halt at the top of the "great incline " or cable section on Echo Mountain. [See Chapter 23.]

\section{FATHER THROOP DAY.}

December 21, 1893, was made historic as "Father Throop Day," by a great testimonial celebration in honor of the founder and the founding of 
the Throop Polytechnic Institute in Pasadena-the first educational institution of its type west of the Mississippi river, and equipped in all respects equal to the best in the largest eastern cities. [See pages 193 to 197.]

In addition to the foregoing, there have been many days in the city when great parades, with band music and song, speeches, floral displays, etc, were indulged in o11 a liberal scale-such as Fourth of July, Decoration Day, Tournament of Roses, etc. ; but these occur annually in regular course, and do not have the exceptional historic quality which pertains to the notable days recorded in this chapter.

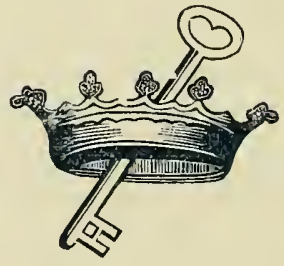

\section{DIVISION FIVE - NAMES.}

\section{CHAP'TER XVII.}

THF, NAMF, “WILSON."-Sketch of life of Hon. B. D. Wilson, after whom were named so many historic places and things within our borders.

THE NAME, WILSON.

Pasadenaland has a Wilson Ditch, a Wilson School, a Wilson Arenue, a Wilson Lake, a Wilson Canyon, a Wilson Trail, a Mount Wilson or Wilson's Peak, a Mount Wilson Toll-Road, and a Wilson Ranch, the old Lake Vineyard place. It therefore becomes a necessary part of Yasadena History to give a brief sketch of Hon. Benjamin Davis Wilsou, from whom all these local "Wilson" names are derived.

Mr. Wilson was born at Nashville, Tenn., December I, I8I I. From 1833 to 1840 he was engaged in trading and trapping in New Mexico, and all that vast region of country tributary to Santa Fe. In I 84 I he came to Los Angeles with a company of 25 men who crossed the mountains and desert from New Mexico. In 1843 he bought for $\$ \mathbf{I}$, ooo per league from Don Juan Bandini,* the Jurupa Ranch, where the city of Riverside is now located. $t$ In $\mathrm{I} 844$ he married a Spanish lady, Miss Ramona Yorba,

* Don Juan Bandini was a leading Spanish resident of San Diego, For his aid to the United States, see pages $80,88,91$, etc.

t"Riverside was founded in 1870 ; name changed from Jurupa."-Hist. Cal., Vol. 6, p. 52I. 
daughter of Don Bernardo Yorba, owner of the great rancho Santa Ana. [Miss Anna Picher, in her Pasadena Art Loan writings, says that Helen Hunt Jackson first met the title name of her famous story, "Ramona," while visiting Hon. J. DeBarth Shorb's family at San Marino, whose little daughter was named Ramona, after her grandmother, Dona Ramona Yorba deWilson ; and Mrs. Jackson then took a fancy to the name.] In the fall of $1844 \mathrm{Mr}$. Wilson went with a party in pursuit of a large bear that had destroyed many cattle on his ranch; and in the final encounter the bear leaped upon him and bit him so that its tush penetrated clear into his lung. But the bear was killed, and he recovered, although he carried life-long scars from that bear's teeth. In 1845 the Mojave and other Indians made frequent raids upon the white settlers; and Mr. Wilson, under authority of Governor Pio Pico, organized a mounted force to pursue and punish them. In this expedition he was shot with a poisoned flint arrow, the point of which broke off and remained in his body all his life. A faithful Indian neophyte among his soldiers sucked the poison out and saved his life. In the same year, I 845 , occurred the march of the Mexican governor, Micheltorena, down from Monterey, with a force largely composed of released convicts and outlaws from old Mexico, to subdue Los Angeles; for the southern district had rebelled against his rule, because of his using such troops to dominate them, and supported Pio Pico as still their rightful governor. Mr. Wilson was the Alcalde [Justice of the Peace, or Sub-Prefect] of his bailiwick, and as such raised a company and marched to Los Angeles, there joining the Pico army under Generals Jose Castro and Andres Pico.* They marched out to Cahuenga and took position to await the enemy's approach. About noon the next day the Micheltorena army came in sight, and the rest of the day was spent in an artillery duel at long range. This was renewed for a short time the next morning, before Micheltorena accepted terms of capitulation. Don Manuel Garfias was in this battle as a Lient. Col. in Micheltorena's army, but did not go with them back to Mexico. $\dagger$ Micheltorena had three iron cannon in the fight, and two of them are now lying at the west front of the new court house in Los Angeles. The Pico army had one iron and one brass cannon, the latter afterward becoming famous as the "Woman's Gun." [See pages $84,85,93$, Iог.]

Along with Micheltorena's ex-convicts and other Mexican troops was a company of Americans who had been induced to join him, under the famous John Sutter as captain, by false representations, and by giving them deeds for land which were not in accordance with the Mexican law - hence utterly worthless. Mr. Wilson was personally acquainted with some of the

* One member of Wilson's conpany was Dan. Sexton. About him and his adobe mill, see page 53 . † Another of Micheltorena's better men was Don Ignacio Francisco de la Cruz Garcia, a native of Spain, who remained and settled in Los Angeles. I visited this old man myself on Angust 19, 1895, and examined official docnments which showed that he was that day 114 years, 3 months and 18 days old - yet he was able to see, hear, talk, and answer questions readily. G. W. Robinson, aged 86, was with me as interpreter. 
leading men of this American company; and he managed early the next morning to approach their camp by crawling up a ravine with a flag of truce, accompanied by one James McKinley. They were discovered and fired upon with grape shot from Micheltorena's camp, but escaped unhurt; and when the Americans saw the white flag, three leaders came to them one of these being Gen. John Bidwell of Chico, who was the Prohibition candidate for president in $1892 . *$ Wilson soon succeeded in showing them that they were on the wrong side of this fight; and after this better understanding they withdrew from Micheltorena's support. Later in the day, or the next day, he accepted terms of capitulation. $\dagger$ His offensive troops were required to march to San Pedro without passing through Los Angeles at all, and be shipped at once back to old Mexico.

In 1846 , when the war occurred between the United States and Mexico, and American troops were on their way to capture Los Angeles, Gov. Pico called upon Mr. Wilson to raise a company of men to help repel the invaders; but Wilson was still a citizen of the United States, not of Mexico, and declined to obey the summons, though at the same time assuring the governor that he would remain quietly on his ranch, and not take part in any movement to oust Pico from the governorship. He therefore remained unmolested; and he was resolved and ready to resist if the governor should make any attempt to arrest him. But after Commodore Stockton had captured Los Angeles, in this same year, and established Lieut. Gillespie there with a small force to maintain the United States authority, the Commodore urged upon Mr. Wilson a commission as captain in the U.S. army, with power to raise and equip a company of any number he might think best to guard the frontier. For account of the battle of Chino, and Wilson's capture, and other adventures, see page 82, and following.

Mr. Wilson watched the battle of San Gabriel ford [see page 9r] with intense anxiety from the hills of the Coyote ranch, where he had gone for the purpose - for he was still a prisoner on parole, and had spent the previous night at his father-in-law Yorba's place in Santa Ana, his wife then being there. Of course the American prisoners were free after Stockton entered Los Angeles.

* "On his way back to Micheltorena's position he [Capt. John Sutter] and Bidwell, his aide, were captured, and after a brief detention were sent as prisoners under parole to Los Angeles." - Hisl. Los Ang. Co., p. 66.

† Baucroft, Hist Cal., Vol 4, p. 503, says: "Not a drop of human blood was spilled on the battlefield of Cahuenga." This brusque and reckless assertion has been accepted by other writers, and used to cast ridicule on the Mexic-Californians as fighters. The improbability of its being true is shown by his own statement in regard to the battle, for he savs: "It was kept up all the afternoon on both sides, Micheltorena's gunners using grape, and firing over a hundred times: while the others fired less shots, using ball, and in some cases perhaps snall stones." This was on Friday afternoon; and on Saturday forenoon there was thore fighting. Gen. Vallejo gave a report that "twelve cliolos [convict soldiers]. one foreigner, one Indian, and one officer were killed." And eight others make varying reports of numbers of men and horses killed.

¥W11. Heath Davis, in his book, "Sixty Years in California," says these troops were not so bad as they are represented in history. Stealing chickens was their chief rascality; but all sorts of evil re. ports were made up against thein lyy the Californians." Davis was part owner of the ship that carried them away, and he accompanied them on the voyage. 
THE FOUR OLD CANNON.

In I877, less than a year before his death, Mr. Wison prepared a sketch of his life, which has never been published in full. In this he mentions that he was present when Don Andres Pico, the Mexican general, first met Commodore Stockton after having surrendered to Fremont, and remarks :

"Don Andres Pico manifested his good faith by telling the Commodore where the cannon were concealed with which he had fought at the action of the 8th and 9th. The Commodore asked me what kind of cannon they were. I told him they were common short heavy cast-iron guns; to which he answered, they were not worth looking after, and he would not send for them.* I told him then that if he would give them to me I would make of them posts to keep the carretas [clumsy Mexican ox-carts] off from the entrance to my store $\dagger$ He therefore gave them to me; and being told by Don Andres just where they were, I hired a man with a carreta [nearly three years afterward] to bring them in, and placed them at the head of Commercial street in Los Angeles." [See page 84.]

When the centennial of Los Angeles city was celebrated, in I88I, two of these historic old cannon were placed on trucks at the north corners of the old court house; but now, I 895 , they are preserved at the west main entrance to the magnificent new court house.

In $1849 \mathrm{Mr}$. Wilson was a delegate to a convention of South Californians at Santa Barbara which petitioned Congress that the southern part of the proposed new state might be made a territory by itself, and not be included in the state of California as planned by the politicians of San Francisco. [A mass meeting for the same purpose was held at Los Angeles in February, i850.] Their plea was not heeded; but it is interesting to note that the struggle for "state division" commenced thus early - and it ought never to cease until accomplished. The state was admitted to the Union the same year [September 9, I850], and Mr. Wilson was elected the first county clerk and clerk of the courts of Los Angeles county, April I, is 50 . From January $2 \mathrm{~d}$ to July $3 \mathrm{~d}$, I 850 , he was a leading member of the city council, still under Mexican law; but on the latter date a new and full board of city officers was installed under the American charter passed and approved April $4^{\text {th }}$ of the same year. The "Centennial History" says Mr. Wilson was mayor of Los Angeles in I 854, and adds: "Mayors Hodges and Wilson through tempestuous times held the helm with firmness and foresight."

September I, I 852, he was appointed U. S. Indian Agent for the southern district, his commission being signed by Millard Fillmore, presi-

* Mr. Wilson wrote this sketch 30 years after the events, and his memory failed him as to the particular cannon in question. The only cannon which the Mexicans had in the battles of the 8 th and 9 th were the two brass howitzers which Gen Pico had surrendered to Col. Frenont at Caluenga on the I th ; and the ones that Pico told Commodore Stockton about were the four old guns lving in the surf at San Pedro, utterly unserviceable, but the only pieces of artillery remaining within reach of the Mexicans. See page 84. At the battle of Cahuenga, in 1845, Micheltorena's troops had three of these old iron cannons, and Pico's men had the other one.

†"During all this time he [Wilson] had been heavily engaged in merchandising in Los Angeles, as well as in cattle ranching at Jurupa."-Lewis's Hist. L. A. Co., p. 118. 
dent, and Daniel Webster, secretary of state.* In I 855 he was elected state senator and served the term. Also again in I869-70.

In 1853 he married for his second wife Mrs. Margaret Hereford, widow of Dr. Hereford of San Pedro. His first wife, Ramona Yorba, had died March 21, I 849.

In I852 Mr. Wilson bought the Lake Vineyard property from the Indian wife of Hugo Reid, and in 1854 he built there a dwelling house with a vast wine cellar under it and a very costly roof of tiles-the total cost of the structure and appurtenances being reported over $\$ 20,000$, the roof alone taking nearly half of it. His widow, Mrs. Margaret Wilson, resides there in the same house yet- 1895 .

In 1864 he constructed the historic and famous burro path to the top of the mountains, known as "Wilson's Trail," and this is reported to have cost him about $\$ 6,000$ before he finally dropped it. His object was to have shakes, pickets, barrel staves, orange boxes, etc., made from the cedar, oak and pine trees which grew so plentifully on the mountain top, and then transport them down on burros, for which purpose he collected a band of about sixty of these hardy little animals. But the timber proved unfit for wine barrels, which was the most important item; pickets and other lumber to fence in his orchards were brought down, besides shakes for roofing purposes, till he had enough and quit. [See Chapter 20; article "Wilson's Trail.' ']

In I867 Mr. Wilson and Dr. Griffin built the open ditch which first brought the waters of the Arroyo Seco from Devil's Gate out onto the alfalfa lands of the Rancho San Pasqual. The job was done by Judge B. S. Eaton; and this was the waterway know in colony days as the "Wilson ditch."

In r $869 \mathrm{Mr}$. Wilson was sent to Washington by the winegrowers of Los Angeles county, to ask from the revenue department some concession or relief in regard to the internal revenue tax on California wines. But it availed nothing. The law was general, and must apply in all states, counties and territories equally.

In I87 I Mr. Wilson laid out the original Alhambra tract of about 300 acres, with water piped to each five-acre lot - the first subdivision ever made

* "In 1852 the late Hon. B. I. Wilson, an old resident of I,os Angeles county, made a report to the United States government, showing the great injustice which had been done the Indians by the Americans. In 1881 Mrs. Melen I I unt Jacksou had her attention specially directed toward these longsuffering people, aud that winter she made a visit to their reservation and spent several weeks anong them." Califormia of the Sonth, p. 19.5 .

Mr. Wilson's report Was printed in the Los Angeles Star of 1852 , and again in same paper in 1868 ; and much of it is copied in J.Albert Wilson's Hist. Los Ang. Co., $1880, p p$. 87 to 90 . This report is a monnment to Mr. Wilson's painstaking fidelity as a public officer and to his good sense andkind. heartedness toward the Indians. He does not palliate their faults and vices as a class; but he plainly sets forth the wrongs, aluses, injustice and evil examples to which they had heen subject ed by white people, and then remarks: "What marvel that eighteen years of neglect, misrule, oppression, slavery and injustice, and every opportnnity and temptation to gratify their natural vices withal, should have given them a fatal teudency downward to the very lowest degradation. **** In some streets of this little city almost every other house is a grog-shop for Indians." Tet he gives many instances of true nobleness of character and sterling fidelity annong then! ; and in this official report alone Mrs. Jackson found ample warrant for all that slie pictured of Indian life, and wrongs done them, in her famous story of "Ramona." 
in California with water conveyed in iron pipes ready for use at each colony settler's own door. Before that only open ditches had been used, or wooden pipes. This scheme was projected and superintended by Mr. Wilson's son-in-law, J. DeBarth Shorb, who had done the first iron piping of water for irrigation purposes ever done in California, at Camulos in I864, while he was superintendent of the oil works started there by Col. Thomas Scott, the great railroad king of that time. And Mr. Shorb further extended and developed the same idea in the HON. B. D. WILSON. Alhambra and the PasadenaLake-Vineyard colony tracts. The Alhambra tract was school land without water, and Mr. Wilson bought it from the State for $\$ 2.50$ per acre. It was commonly deemed worthless, but the water-piping scheme jumped it at once into great value and ready sale - and a large addition was soon made to the original colony tract.

In I $876 \mathrm{Mr}$. Wilson and Mr. Shorb projected the "Lake Vineyard Land and Water Company," and laid out 2,500 acres* into 5- and ro-acre lots, east of Fair Oaks Avenue, and piped water to the lots from the reservoir (now known as No. I) at the end of the original Wilson and Griffin ditch. This land was sold at first for $\$ 55$ per acre; but very soon the price advanced to $\$ 65, \$ 75, \$ 80, \$ 100$ per acre. In I 877 an association called the Mutual Orchard Company bought 200 acres from the east part of this Lake Vineyard Company, and planted on it 14,000 orange trees, the largest orange orchard in the world. This was an Oakland, Cal., company.

March I I, I878, Mr. Wilson died, at his Lake Vineyard home place, in the 67 th year of his age. He had done more to develop and improve and open up for American settlement the region now known as Pasadenaland than any other man before or since his time; and that is why there are so many different points and objects hereabouts that bear his name.

*It was $\mathrm{I}, 500$ acres at first, and then $\mathrm{Mr}$. Wilson repurchased 1,000 acres from the Grogan tract. 


\section{CHAP'TER XVIII.}

NAMES.-The name Pasadena.-The name Altadena._Large Land Tracts by name.Old Spanish Land Grants.--Springs and Water Sources by name.-Who named the Streets, and why.

THE NAME PASADENA.

Much misrepresentation and idle guesswork has been printed and sent abroad concerning the origin of the name or word "Pasadena." Paso de Eden (Gateway of Paradise) is often given as the original form of the word, Anglicised into its present enphonious nsage. But the climax of absurdity in this matter is reached by "Bancroft's Railway Guide," San Francisco, for August, I89o. On page 48, under the head of "Spanish Words," it says :

"PASA DENA (pas-ah-day-nah). A Spanish phrase pronounced "Pah-so-deh-dain" would mean "Gate of Eden," poetically. Many Spanish words have been contracted, wrongly spelled, mispronounced and misunderstood as badly or worse than this, supposing this to be the real meaning of a nanie very probably first used by the California padres, and afterwards mispronounced, by ear, by the Americans."

Now, the fact is, "the California padres" never heard of the word, for it is a Chippewa Indian word, and not a Spanish word or phrase at all.* Neither is it an Algonquin word, as is so commonly stated, only in so far as the Chippewa tribe of Indians was a branch or offshoot of the great Algonlquin family. Upon my inquiry as to the real origin of the name "Pasadena," Judge B. S. Eaton writes :

"It came about in this way. The winter of $1875-76$ found the Indiana colony so far advanced as to require mail facilities. Thus far, Los Angeles had been the address of the colonists ; but this community was assuming importance; and as the Washington authorities would never consent to such a name as "Indiana Colony" for a postoffice, Calvin Fletcher, one of the largest stockholders, and the man who laid out the plan of the settlement and directed the subdivision of the lands, appealed to me to know if there was not some Spanish name that had been applied to the ranch, descriptive of its location or general characteristics. He thought a name that smacked a little of the language of the country wonld sound better than any name imported from the Eastern States. All the good and pretty names had already been monopolized, and he would like something that was a little out of the common. I could remember but one thing that could possibly fill the bill for him, and that was found in the answer given me by Don Mannel Garfias when I asked him why lie located lis house in such (as seemed to me) an impractical place. It afforded hinin no aventue to overlook his vast domain, or see what his flocks and herds were doing. His reply was, "Porque es la llave del Rancho."

"Yavvy what?" says Fletcher, catching on to the main word [1lave].

"Oh, that gives no clue to a name," I said, "for no Yankee would ever try to pronounce a name that commenced with two consonants."

"Well," he said, "what does it mean? Give it to us in English."

*In 1884 a pamphlet was issued from a new town and health resort in Texas named "Pasadena," and pretending to derive the name from some mongrel combination of Spanish words or parts of words. 
I gave the translation, "Because it is the Key of the Ranch." "You see," said Garfias, "the south side of the ranch from here to the Santa Anita is all improved property, and enclosed with fences. On the north side is the Sierra, and on the west is the Arroyo Seco. The little stretch between my house and the Marengo (the Bacon tract) is the gateway through which outside stock must come, to ever get on my range, or my own stock to escape ; and that is why I call this the 'Key of the Rancho.'",

So far, Judge Eaton's account.

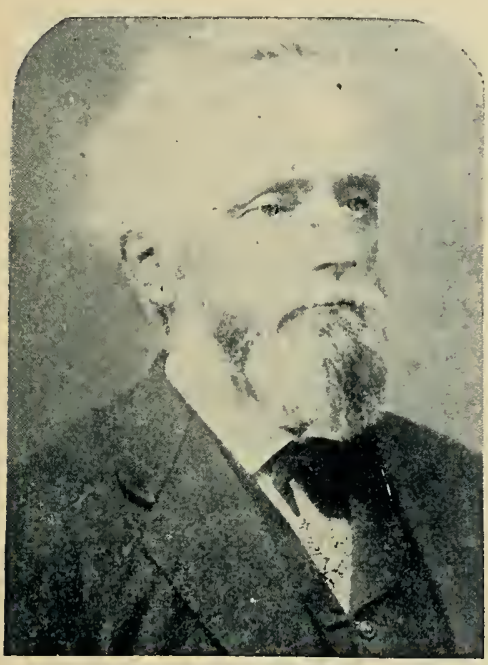

DR. T. B. ELLIOTT.

Dr. T. B. Elliott, the original projector and president of the "Indiana Colony" scheme as organized at Indianapolis, was a man of books, and of some general scholarship beyond the technical field of medicine. He now took the matter up with a good deal of zeal to carry out Mr. Fletcher's idea, as the latter was also one of the original Indiana Colony men. Dr. Elliott searched all his own books to find something which would fit the case, but without success. He then remembered that when he was a student in Hamilton College, New York, he had an intimate friend and college mate who afterward went west as a missionary among the Indians; and to him he wrote, explaining what Mr. Fletcher wanted, and what Judge Eaton had told about the "key of the ranch" or entrance to the upper part of the valley - and asking the missionary for some Indian word of pleasant sound which would serve as an appropriate and significant name for the new settlement. In reply he received the following list of words which I have copied verbatim from the original slip as written by the missionary himself, and never before published :

"Weoquân Pâ sâ de ná - Crown of the valley.

Gish kâ de ná Pâ sê de ná - Peak of the Valley.

Tape Dâegun Pâ sâ de ná-Key of the Valley.

Pe quâ de na Pâ sâ dena-Hill of the Valley.

Accent last syllable of each compound word. Chippewa dialect." *

* After writing this article I showed it to Theodore Coleman, who has been city editor of the Daily Star ever since June, 1886. He formerly lived at Chippewa Falls, Wis., had some knowledge of the language of those Indians, and thus becoming deeply interested in this matter, he wrote there for further information; and in reply received letters from Chas. Allen, Esq., of Chippewa Falls, and Rev. Casimir Vogt, a Catholic priest of Bayfield, Wis., long time missionary among the Ojibway [same as Chippewa] Indians. Mr. Allen is a half-blood of that race, and a reputable lawyer in his town. Rev. Vogt says : "The root for Pasadena can be found in passa-an-I split something. Passadena is a space formed by intersecting a range of hills or mountains"; etc. The letters received contain flfteen or twenty different words and explanations; and from it all Mr. Coleman writes in regard to the different words preceding Pasadena in Dr. Elliott's document: "One of these was weo-quan [hat]; another was gish-ka-dena [peak in a valley]; a third was tape-da-egun [key]; and the fourth was pequa-dena [hill in a valley]. The word for hat is the nearest synonym for crown the language contains; and the tern for key signifies nothing but the metal article. The Chippewa word for valley, or plain, is passa-ka-miga; that for hill is pig-wa-dena. Pasadena was therefore formed by combining the first half of one of these words with the last half of the other, giving to it the signification of valley in the hills, or between the hills. Another Chippewa word "wanadena" is also used to signify a valley between mountains, but "passadena' bears almost exactly the same interpretation." 


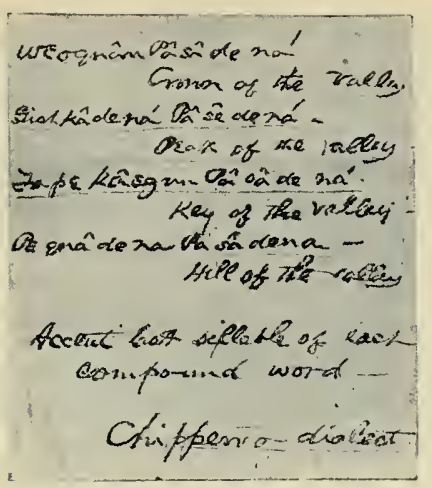

Original Notes for name Pasadena.
The friendly personal letter accompanying this document was accidentally destroyed since Dr. Elliott's death, but this historic slip chanced to be preserved. Mrs. Elliott had never seen or known personally the man who wrote it, and cannot recall his name, nor the place where he was then located; but she vouches for this document as the original slip or memorandum which came enclosed in the missing letter. Hence, here we have the true genesis of the name "Pasadena." '* And now arises the question of how the name came to be formally adopted.

Hon. P. M. Green wrote a brief historic sketch for the Farnsworth pamphlet entitled "A Southern California Paradise," which was printed at Oakland, Cal., in $\mathrm{r} 883$; and in this $\mathrm{Mr}$. Green relates :

"At a meeting of the stockholders of the San Gabriel Orange Grove Association held on the $22 \mathrm{~d}$ day of April, I875, the question of selecting a permanent name came up for consideration. A number of names were suggested, and among them Indianola, Granada, and Pasadena. A lengthy discussion ensued as to which should be adopted. Those in favor of Indianola argued that the change from "Indiana Colony" to Indianola would be most easily effected, and that the name would retain a hint of the origin of the settlement. Those in favor of Granada argued that our productions and climatic conditions were similar to those of the region of that Granada which the genius of an Irving had immortalized, and therefore would be appropriate.

"The late Dr. T. B. Elliott presented the name Pasadena, and stated that it was an Indian name, the meaning of which was 'Crown of the Valley,' and argued its appropriateness for the reason that our location was at the extreme end, and in the most beautiful and romantic portion, of the famous San Gabriel valley, and therefore was entitled to assume a name which was so descriptive of the locality, besides being beautiful, musical, and euphonious. A motion to adopt the name 'Pasadena' prevailed by a vote of more than four to one of those present. So, to Dr. Elliott the community is indebted for the name Pasadena, so dear to every inhabitant of these peopled valleys, slopes, and plains which now bear that name."

Dr. Elliott died August I3, I88 I.

The name Pasadena has heretofore been used in a comprehensive way to include all the territory from the Arroyo Seco to Eaton canyon, and from Lincoln park to the numerous mountain resorts which are connected by trail, toll-road or railroad with Pasadena. But now, in order to distinguish this

* "In family conclave we discussed the list, but my father at once settled upon the Chippewa name of Pasadena as his choice, it being euphonious, of fitting length, and easily spelled, so Pasadena it was decided should be the one name of the list pnt before the meeting. It seemed to please the majority, and being put to a rote, became the choice. 'Thus 'Pasadena' came into legal existence among civilized peoples."-Mrs.Helen Ellioll Bandini, in Pasadena Daily News, Dec. 24, 1894. 
larger district from the corporation limits of Pasadena city: I have adopted the term Pasadenaland, and used it throughout this volume.*

MuscaT.-As early as October, I873, D. M. Berry had named the colony tract "Muscat," because raising muscat grapes was then expected to be the chief industry of the colonists ; and Mr. Croft's diary all through October, November and December speaks of it by the name of "Muscat." But when the name "Orange Grove Association" was adopted, that put oranges ahead of grapes, and "Muscat" as a name for the settlement went out entirely.

\section{MAJOR BONEBRAKE'S "GENESIS OF PASADENA."}

In 1885 a great Citrus Fair was beld in the roller skating rink, for the benefit of the public library, for an account of which see Chapter I6. Then on March 23, 24, 25, 26, 1886, another similar Fair was held in Williams hall for the same object ; and on the 25th Major Bonebrake of Los Angeles, just purely as a matter of fun, gave a learned discussion on the genesis of Pasadena's location and name, which I myself reported for the Valley Union of March 26, I886, and from which I here quote :

"Major Geo. H. Bonebrake, president of the Los Angeles Board of Trade, next spoke. He showed from several points of argument that Pasadena is the veritable site of the original garden of Eden.

Ist. Philological argument: Pasadena is a euphemistic modernizing of the term Pas d'Eden, or Pass of Paradise of some ancient and lost language.

2nd. The geological argument : When our globe in its gasiform state began to cool and solidify, it commenced at the poles and worked gradually toward the equator; hence vegetable and animal life commenced in the lowest forms at the north pole and increased and improved as time advanced, so that by the sixth day of creational progress the advance line had progressed as far south as Pasadena, or ancient "Pas d'Eden," and here man was made. "Adam" means red earth, and plenty of this material was found on the Painter \& Ball hill. [Monks hill was also called "the red hill.']

3rd. The Bible argument: Sundry quotations from scripture were given in confirmation of this view.

4th. The æsthetic argument: Eden or Paradise was a place of all perfection in beauty and loveliness, including women and flowers and all manner of fruits-and here we have them all, in excellent completeness.

5th. The argument by exclusion: Nobody can show or prove that any other place on earth absolutely is the original Pas d'Eden ; hence nobody can prove that this is not the place, and therefore our proofs stand, that this must be the very spot.

This fine piece of humor seems to have been taken in owlish earnest-

*'The first instance of the name Pasadena being used elsewhere is mentioned in the Star of September 2, r89I, which says: "A friend hands us a copy of the Stamford, Conn., Herald, which contains an advertisement of town lots for sale in Pasadena, New Jersey. It is a health resort near the sea shore. It was so named, doubtless, because of the fame of our own Pasadena as a healthful city."

In November, 1894 , there was a new health-resort town in Florida named Pasadena.

In July, I894, a pamphlet was issued by Mrs. Cora Bacon Foster, advertising Pasadena, Texas, on Cotton Patch creek, about eight miles from Houston. 
ness for the solemn truth by Bancroft of San Francisco (Railway Guide), Mrs. Cora B. Foster of Texas, and others, and made the basis of their strained efforts to derive the name from the Spanish language, instead of from "some ancient and lost language," as the witty Major did.

Altadena.- The name "Altadena" was coined and first used by Byron O. Clark, to designate his 40 -acre nursery and home place at the upper stretch of the Lincoln Avenue flat. This was in the spring of 1886 ; and the first time the name appeared formally in print was on a stock of envelopes for his nursery business which he procured about that time. The meaning attached to it was, "the higher Pasadena"; and in regard to its later and larger application Mr. Clark in respouse to my inquiries, wrote me January 28, I895, thus :

"When the Pasadena Improvement Company was organized [incorporated February 9, I887], its president, J. P. Woodbury, asked my permission to use the name for the lands which they were laying out, and which now bear the name of Altadena. He said he liked the name very much and thought it especially suited for their villa sites. I consented, as I had sold my home place to which it was originally applied, and was willing that the name should have a more extended use."

The name Altadena has been borrowed and applied to a tract at Redlands. And Col. G. G. Green of Woodbury, New Jersey (owner of Hotel Green, Pasadena), had a little daughter born at his elegant winter home in our Altadena, May I 5, I 888, and named her Altadena Green.

LARGE LAND TRACTS BY NAME.

Within Pasadenaland there are several large tracts of land bearing some local designation, and with which, both as to name and land, there are some interesting historic associations that call for record.

The Grogan Tract.-Judge Eaton furnishes me the following account :

“'This tract was purchased by James Craig for Alexander B. Grogan, a wealthy capitalist of San Francisco, about 1869, from Griffin and Wilson. It contained 5,000 acres, and was bought for $\$ 30$,000. No water right went with this sale; and as Mr. Craig wished to make a home for himself on the tract. he entered into negotiations with B. S. Eaton, then owner of the "Fair Oaks" ranch and of three-fourths of the waters of Eaton canyon, for a supply from that source, and at once commenced the improvement of eighty acres - the place where he still resides. From that time onward portions of the tract were occasionally acquired by residents of Pasadena, until now [1894] nearly the whole 5,000 acres are under cultivation."

Mr. Grogan was born in Ireland; came to California in 1848 ; and died in San Francisco September 19, 1886.

The following article from the Valley Union of April 23, 1886, is of historic interest :

“'The Painter \& Ball, Tract has been for five years past so import- 
ant a factor of Pasadena as to be little less known than the town itself. Its management has contributed so largely to our growth and prosperity that a brief history of it is in order. J. H. Painter and B. F. Ball, the owners of the tract, are gentlemen whose lives have been intimately blended throughout. Both originally residents of the same town, (Salem, Columbiana county, Ohio,) they both left there long ago and emigrated to the same county, (Cedar,) in Iowa. Mr. Ball left Iowa in '7 fand Mr. Painter in '8I, both coming direct to Pasadena. A tract of 2,000 acres of land adjoining Pasadena on the north was then owned by Henry G. Monks, of New York city, a former resident here, and from whom Monks hill was named. Mr. Painter and Mr. Ball wanted about 500 acres of this land, and negotiated for it; but found that they were likely to lose it through the determination of the owner to sell it " all or none," and that there were parties in the field willing to buy it all. Mr. Painter reflected upon the situation. Something must be done. Dropping his head upon his breast, he said, "If I had a man to go in with me I'd buy the whole tract." This appealed to $\mathrm{Mr}$. Ball personally. The old friends who had been together so long in Ohio and Iowa, ought not to be separated in interest in California. So he says : "I'll take a third of it, if you will find some man for the other third." "All right," says Mr. Painter; "I will take two-thirds myself." They immediately bought the whole tract, 2,ooo acres, at \$I5 an acre, aggregating $\$ 30,000$. They spent about $\$ 20,000$ more in watering it; and they have sold it to 50 or 60 different purchasers for about $\$ 150,000$, netting a handsome profit on their venture. The tract with its water supply, has been incorporated as the North Pasadena Land and Water Company. It adjoins the old Pasadena tract on the north, and is now bounded by Villa street on the south and the Woodbury, Banbury and Giddings tracts on the north, while its east and west lines are Lake Avenne and the Arroyo."

Monks Hill TRACT.-Of this Judge Eaton writes:

"Mr. Monks, a young Bostonian [or New Yorker (?)] came here about I 868 , and purchased from Griffin \& Wilson about two thousand acres of land, including the "red hill" [Monks Hill] as it used to be called. With this tract he also acquired all the waters flowing in the canyon [Millard's] above its mouth. Griffin \& Wilson had already constructed a ditch from the water source to a point back of Monks Hill, with a view of imponnding a large supply of storm water there. 'The work was done by a Frenchman named Dargue, who had previously been tunneling into the hills at Lincoln Park for hydraulic lime - the same place where the old Padres obtained all their lime for their cement masonry at the different Missions. It had such virtues as a cement plaster that it is said the missionaries lianled it in Mexican carretas with ox teams even as far north as Monterey."

MARENGo TrACT.-Called also "the Bacon ranch," 800 acres, comprised what is now the Raymond Hotel grounds, the Raymond Improvement Company's lands, and the oak timber lands south of Monterey road and east of lower Fair Oaks Avenue. Its chain of title is a long story, it being parts of Ranchos San Pasqual and San Pasqualita. It was bonght in 1855 by J. L. Brent, afterward a General in the Confederate army* and who was

*"At a place called Big Cane [Louisana, February, 1865, ] a former citizen of Los Angeles, a Confederate brigadier, J. I. Brent, commanded a small force of Confederate cavalry," etc. - See "Reminiscences of a Ranger," by Mijor Horace Bell, page 372. 
still living (at Baltimore, Md.,) in 1894. Brent was a warm admirer of Napoleon Bonaparte, and named the ranch from Napoleon's great battlefield of "Marengo." Brent sold it to B. D. Wilson, October 31, I870. Wilson sold it to H. D. Bacon. [For some earlier points, see pages $7 \mathrm{I}, 72$. ]

OAK KNOLI, TRACT. - This was formed into a home place by Mr. Wilson and Mr. Shorb in $\mathrm{I} 872$, and named from a large, far-spreading oak tree standing on a very sightly residence spot. The tree is there yet. They sold it as a farm of 100 acres to Bayard T. Smith and brother, in 1883 . Then, during the winter of $1886-87$ the Smiths sold it to a Mr. Rosenbaum of New York city, chief of a syndicate of real estate speculators, * who subdivided the place, laying out and grading the winding streets as they stand today, with lots in all sorts of shapes, and varying from one-half acre to seven acres in size. Oak Knoll canyon rises on the west side of this tract and Mill canyon on its northeast border; and the water from these two canyons was led by ditches into the old stone mill built by the San Gabriel Mission Fathers in I 8 Io to I8 I 2. [See Chap. 19, article "Old Mill."]

ALLENDALE TRACT, adjoining Oak Knoll on the southwest, where $\mathrm{H}$. C. Allen bought 20 acres from Mrs. Gov. Stoneman in August. I89I, and improved it in a highly picturesque and artistic manner for choice residence sites.

LOS ROBLES, or the Stoneman Ranch.-This was a tract of about 400 acres, a portion of it being from the old San Pasqualita or "Little San Pasqual" ranch. It formerly belonged to B. D. Wilson's son John, who died. It was then sold to a Dr. Miles, who was killed in the steamboat explosion at San Pedro, April 29, I863. In 1872 Gen. George Stoneman bought it from Hon. B. D. Wilson and Ex-Gov. Downey. Stoneman made considerable improvements on the place, and named it Los Robles [the Oaks]. $\dagger$ Its north line forms a part of the south line of Pasadena city, at the end of Los Robles Avenue which took its name from this ranch. Mrs. Stoneman was one of the original members of the Presbyterian church of Pasadena, organized March 21, I875. Gen. Stoneman was Governor of California from 1883 to 1887 . He went east for medical treatment in I89o; and died at Buffalo, N. Y., September 5, I894. Mrs. Stoneman has sold nearly all the land in small tracts, retaining to herself all underground rights of water, minerals, etc., and has during the past year, is $83^{-4}$, done a large amount of tumneling and piping of water in Los Robles canyon and at foot of Oak Knoll canyon.

LAS Flores RANCH, better known as "the Richardson place." This comprises 70 acres, mostly from the old San Pasqualita or "Little San Pas-

* The Union reported in April, 1884, that Bayard $T$. Smith had sold his Oak Knoll place for $\$ 75,000$ to W. H. and H. E. Weston of New York. I found no other inention of the Westons, but suppose they were members of the Rosenbaum syndicate.

$\dagger$ About Gen. Stoneman, see footnote page 75. 
qual " ranch, with some fractional government lots. It was originally owned or worked as private land by a Frenchman named Flores - hence was called the Flores place. In $185^{8}$ a Mr. Hutchinson bought it and went to raising strawberries, for which he soon built up a good paying demand. In I867 Mr. S. Richardson, a native of New Hampshire, bought an interest in the place, ultimately securing the whole of it, and resides there yet. In order to retain the old name by which it was known 25 or 30 years ago, he calls it "Las Flores," the flowers, or place of flowers. This tract lies next east of the Los Robles or Stoneman place; and the old ditch by which the Mission Fathers conveyed the waters of Los Robles canyon [or Mill spring creek] along the bluff to their old stone grist mill, crossed the upper end of this Las Flores ranch; and on its land just below the ditch the priests had a garden of very rich soil, easily irrigated from the ditch. Mr. Richardson himself filled up parts of the old mill ditch; and some portions of it are discernible there yet, especially on the east side of the road that leads down Oak Knoll canyon between the Oak Knoll and Allendale tracts, nearly at the foot of the hill. There is a row of Encalyptus trees growing along where the old ditch was, on the east bank of the roadway; and a few rods below this the road crosses Mill spring creek or Willowdale creek, which is formed by the junction a little way above of the Los Robles and Oak Knoll brooks.

WILLOWDALE was a I 7 -acre lot at the northwest corner of the Richardson place on Mill spring creek, owned and named by Capt. J. Elwood Ellis, and as "Willowdale" it is mentioned in early Pasadena history. It was later owned and occupied by the widow of Will J. Bennett of Pasadena, daughter of Mr. Richardson, but is now comprised in the Richardson farm. A dense copse or jungle of willows growing along the creek on the place gave it its name of "Willowdale." [See article on "Oak Knoll canyon." ]

EL Molino (the Mill). - This is the historic Spanish name of the ranch now owned by E. L. Mayberry, and from which Pasadena's Moline Avenue was named. It was originally E1 Molino Avenue, but has been anglicized into the shorter and easier form of Moline, whence many people erroneously think the name was taken from the great manufacturing city of Moline on the Mississippi river, in Illinois. See articles on "The Old Mill," and "The Lake," for further history of this tract.

LAKE Vineyard Ranch.-This is the old home place of Hon. B. D. Wilson, who gave it this name from the old Mission lake which was partly on his place, and also the extensive vineyards which he himself planted, in addition to what had been planted there during the rule of the Padres. Mr. Wilson's widow still resides here. This was the so-called "Cuati" grant, made by Mexico in I 830 , and confirmed by the U. S. commissioners in 1859 to Victoria Reid, the Indian wife of the erudite Scotchman, Hugo Reid. [See page 17.] Mr. Wilson bought it from Mrs. Reid. Lake Ave- 
nue in Pasadena, which was originally "Lake Vineyard Avenue," was named from this ranch. But the original name was too long for this fast age.

San Marino.- This is Hon. J. De Barth Shorb's home place, next east of the old Lake Vineyard home of his father-in-law, Wilson. Mr. Shorb's childhood home, his father's old plantation in Maryland, bore the name San Marino, and he filially applied it to his elegant new home here in California.

Winston Heights. - This is the old Col. W. H. Winston farm of iso acres, bought from B. D. Wilson in $\mathrm{I} 868$, and lying east of San Marino, along the Santa Anita Avenue road to San Gabriel. The Winston place is specially associated with Pasadena because of the long residence of L. C. Winston, one of the sons, in the city - and the fact that his wife, Mrs. Elizabeth Winston, has been a prominent teacher in the Pasadena public schools from 1880 till the present time-I895. [See page 156 , and foot-note to page 187.$]$ The Winston farm was a portion of the original Orizaba tract; and San Marino was, also. [See third foot-note, page 53.] Mrs. M. E. Winston, the aged widow, still owns the old farm, and her son, P. H. Winston, resides on it - I 894 ; but its superintendent is $\mathrm{T}$. S. White, who came to California in $185_{2}$ and to Los Angeles county in 1863 . Mrs. Winston herself resides in Los Angeles.

FAIR OAKS RANCH.-Judge Eaton writes: "This name was given to it by its first occupant, Mrs. Gen. Albert Sidney Johnston, after a place of that name, her childhood home, in Virginia." [See page I 20.]

Verdugo Ranch, same as Rancho San Rafael, and joined Rancho La Canyada, both of which belonged to Mariano de la Lu1z Verdugo, who was in active service as a Spanish soldier and officer from i 766 to 1787 , and was with Gov. Portola's expedition to Monterey in $1769-70$, therefore crossed this land from west to east in Jantary, r 770 [See page 57], on their return trip. Verdugo is mentioned in the Spanish records as "the retired corporal of the San Diego company." This land was granted to him by Gov. Fages, October $20, \mathrm{I} 784$, and the title was reaffirmed to him or to his son Jose Maria Verdugo,* by Gov. Diego de Borcia, January i 2, I 798. 'The San Rafael ranch comprised upwards of 50,000 acres and extended nearly to the Buena Vista-street bridge in Los Angeles. It was also called by the Spaniards "La Zanja, across the river four leagues from Los Angeles." This great total of 50,000 acres of land was described in the Spanish records as "bounded on the north by a sycamore tree." The hacienda or patrimonial ranch house was located at the mouth of Verdugo canyon, where the village of Glendale now stands. Verdugo continually borrowed money,

* Jose Maria Verdugo was corporal of the guard at San Gabriel most of the time from its founding till 1798 . His father was sergeant in command at Monterey from 1780 to 1787 , then retired as an invalid. He had served also at San Diego and other points. 
giving liens on his land for security, until it was nearly all held by the following creditors : Dreyfuss, Beaudry, Glassell, Chapman, Capt. Hunter, Jose Ramirez, Tomas Sanchez, and others. A court commission consisting of Judge B. S. Eaton, Judge A. W. Hutton and Jas. Lander, Esq., was appointed in $I 87 \mathrm{I}$ to apportion the land equally among these men, according to their several claims. And thus it was that Beaudry received the hills opposite Pasadena now known as the Johnson ranch; Dreyfuss received the hills and "Indian Flat" now known as Linda Vista ; Glassell received the Eagle Rock and Garvanza region; Capt. Hunter received the Highland Park land; and so on. According to law the court commission had to meet on the land for each day's business; and every time when they came, the old man Verdugo would strike a military attitude and declaim in purest Spanish, with dramatic gestures, "I'm a soldier of the king! All these hills are mine! All these valleys and mesas are mine! All these cattle are mine! I' $m$ a soldier of the king!" After this regular prolog tue the court commissioners could go on with their business, but not before.

The Rancho La Canyada was the long, narrow valley lying between the Sierra Madre mountains and the Verdugo hills, from Arroyo Seco up westward to its junction with the San Fernando valley. This grant amounted to 5,000 acres of land, and included what are now called La Canyada and La Crescenta; but Monte Vista and Glorieta Heights were in the Rancho Tejunga.

'THE WoodBury 'Tract. - This was an odd remnant of B. D. Wilson's land up near the mountains, without water, and considered of little worth, which he gave as a present to the original colony association, - in token of his friendly good will, and of his satisfaction with the way they had divided their lands and gone to work making improvements. The colony (San Gabriel Orange Grove Association) sold about 900 acres of this mountain slope body of land, in I882, to F. J. and John Woodbury for $\$ 5$ per acre; but by the time these men had secured a water supply and got it developed and distributed to the land, it had cost them about $\$ 35$ per acre. Other portions of the I, 400 acres were sold to S. P. Jewett and others. F. J. Woodbury had in I88 I bought of Dr. Hall's widow the original Rubio canyon farm and was living there in the same house now owned by the Mount Lowe Railway Company and occupied by their farming tenants. With this farm Mr. Woodbury had acquired the water rights of the Rubio canyon, and ultimately piped this water down over the lands bought from the colony association, where the brothers each built a fine residence, planted vineyards, orange groves and other fruits, and made extensive improvements. It is now the village of Altadena, and junction of the Los Angeles Terminal railroad and of the Pasadena and Pacific Electric railway with the Mount Lowe Electric railway.

OlivewOOD TRACT. - This was eighty acres lying between Colorado 
and Villa streets, and between E1 Molino and Lake Avenues, and a few acres east of Lake Avenue along where the Santa Fe railroad now runs. It was bought in I 880 by C. T. Hopkins of San Francisco, the founder and president of the California Insurance company of that city. He employed C. C. Brown to manage the property and plant it with trees and vines, a large proportion of the land being devoted to olive trees- hence the name. Olivewood station of the Santa Fe railroad is on this tract; and in $1886-87$ a strong effort was made to establish a permanent business and trading center here; but it failed at last, leaving several empty store-rooms as cenotaphs to the dead "boom." In 1894 three of these store buildings were sold and moved up to Colorado street east of Marengo Avenue.

Linda Vista TRACT.-In 1883 Prof. J. D. Yocum purchased a body of wild land on the west bank of the Arroyo Seco which had long been known as "Indian flat," where a few families of native Mexicans lived in their miserable shiftless and thriftless way. This tract extended from the foot of Jumbo Knob opposite Reservoir hill up to the Verdugo hills near Devil's Gate, and comprised arroyo bottom and bluff lands, mesa land and mountain land, all densely covered with greasewood and other native chapparal growths. It was a part of the original Rancho San Rafael. Mr. Yocum cleared the land, developed water upon it, opened streets, planted orchards, and made his home there ; and eventually sold portions of it to other parties who likewise made homes there. The West Pasadena street railway, with its $\$ 8,000$ suspension bridge across the arroyo, was built and operated several years to connect Linda Vista with Pasadena; but it failed to pay expenses, was finally sold for debt, torn up, and partly used in constructing the Mt. Lowe Electric railroad.

LAS CASITAS TRACT.- The land bearing this name is a small bench or plateau forming a tongue between the Arroyo Seco and Millard canyon at their confluence. It was first taken as a 160 -acre homestead claim in I 875 by J. H. Gifford, afterward son-in-law to John W. Wilson; and about i88o, Mr. Wilson filed a claim on water in Negro canyon and made a small ditch to bring water around from the canyon to Gifford's homestead house, who with his young wife then lived there. Gifford afterward sold his land to Thomas Banbury. Banbury traded the land to Preston Hollingsworth; he sold it to John L. Hartwell, who, assisted by his brother Calvin, piped the water from Negro canyon down to it. Then in i 885-86 Hartwell sold it to James Cambell, H. N. Rust and a Mr. Doyle, and they commenced making further improvements there. Next, John R. Niles bought out the Rust and Doyle interests, and he with Cambell laid it out in lots, graded streets, piped water through them, named it Las Casitas, and put it on the market. The name is Spanish-La Casa, the home; Las Casitas, the little homes. But Mr. Niles became deranged and had to be sent away to the insane asylum ; this greatly embarrassed the business of giving titles to the lots, 
which could all have been sold at good prices during the "boom" but for this difficulty. Meanwhile Jason Brown had bought from Painter \& Ball 80 acres on the Arroyo bluff adjoining the Las Casitas plat on the west, for $\$ 400$.* He divided this up and sold it in parcels, making about $\$ 2,000$ clear, but it took nearly all of it to pay his debts. Then he and his brother Owen took as a homestead some rough mountain land just north of Las Casitas, where they lived several years, and where Owen lies buried.

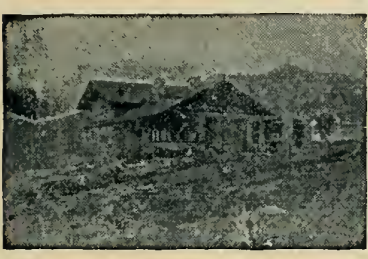

MISS DR. GLEASON'S STRUCTURE. Among those who bought lots from Jason Brown was Miss Adele Gleason, M. D., of Elmira, N. Y., who erected there in $1886-87$ a quaint and picturesque sanitarium building, and opened it for guests. But it proved a losing venture; and in 1890 , she offered it to the State Teachers' Association of California as a "home" for sick or disabled teachers. They had no funds to sustain such a place, and could not accept the gift. Then in r894, Dr. O. S. Barnum of Pasadena, re-opened the sanitarium there; and Las Casitas is now one of Pasadena's established foot-mountain resorts-five miles distant, and I, 8oo feet above sea level.

\section{OLD SPANISH LAND GRANTS CONFIRMED.}

The Spanish and Mexican method of describing boundaries of the large land estates was, by so many leagues along some stream, or some range of hills, or to some rock, tree, canyon, spring, or other object, without any idea at all of the definite number of acres included. But when after 1849, the American method of measuring lands by townships, sections, quarters, and definite acreage, began to come into use, there was a flood of confusion about the old land grants, and the later titles acquired under them. To remedy this, Congress in I852, passed an act creating a commission to settle private land claims in California. This commission sat in Los Angeles part of the time, and adjusted seventy-three individual claims in this county alone-these ranging from $19 \frac{1}{2}$ acres up to $116,85^{1} \mathrm{I} / 2$ acres to one person. From the official reports on these decisions I have culled the following cases within or near Pasadenaland :

\section{NAME OF GRANT. \\ NAME, OF PERSON WHOSE TITLE WAS CONFIRMED. NO. OF ACRES. \\ DATE OF PATENT.}

Mission San Gabriel Bishop J S Alemany

Huerta de Cuati. Victoria Reid

San Pascual Manuel Garfias.... I $90.69 \ldots \ldots . . .$. Nov. 19, I859.

La Canyada J. R. Scott et al. I $28.26 \ldots \ldots . .$. June 30,1859 .

Santa Anita. Henry Dalton...

Mission San Gabriel, out lot... Bishop J. S. Alemany.

San Pascual. B. D. Wilson

San Rafael. Julio Verdugo et al. 3,69393 . April 3. 3863 .

San Pascual Juan Gallardo. 5.832.10..........Aug. I, I866. Mission San Gabriel Daniel Sexton. Aug. 9, I866. $55.23 \ldots \ldots . .$. . Dec. 4,1875 . $708.57 \ldots \ldots \ldots . . . . F e b .12$, IS81. $.36,403 \cdot 32 \ldots . . .$. Jan, 28 , IS82. $700.00 . . . . . . .$. (No date.)

* Painter \& Ball had bought from a man named Taylor, his unperfected homestead clain here, in order to hold their own right of way from their water rights farther up the Arroyo, down to their great Tract about Monks hill. 
FLOWING SPRINGS BY NAME.

The Garfias or "Old Adobe" Spring.-This was a fine outgush of water at the top of the Arroyo bank, a few rods below the foot of Hermosa street, and near where the original Garfias adobe ranch house stood,* the walls of which were finally destroyed by Geo. W. Glover, Sr., in November, 1886 . The spring pool was in the shade of a great spreading liveoak tree, and is now all boxed up, the water being piped down to Lincoln Park for its domestic water supply. The Indians had a village near this spring before the Spaniards came.

BAKER's SPRING.-At Edwin Baker's place, on Grand avenue above West Columbia street, he has a natural flowing spring, with a stone milkhouse built over it.

SAN RAFAel SpRings, or Johnson's spring.--In the west bank of the Arroyo, nearly opposite the foot of California street, there is a bog or cienega which yields a continuous supply of water, and from a well here the water is pumped up into cisterns at the Johnson ranch house on top of the arroyo hill.

Shemp Corral Springs. - During the old Mission occupancy of these lands a sheep corral was maintained on Reservoir Hill, because of its good outlook against approach of coyotes, foxes, bears, etc.; and at the foot of its north slope was the great bog of water-bearing land for their drink supply. Hon. Stephen C. Foster tells me that the padres kept all their black sheep in flocks by themselves on rancho San Pasqual, and their white sheep on rancho San Antonio, along the San Gabriel river above Downey. To save expense of dying, the wools were cleaned and spun separately, then mixed in the weaving, making salt-and-pepper cloth, and sometimes black and white barred or striped goods, etc. This sheep corral was kept up in the earlier years of the Garfias occupancy ; but was improved and better utilized while Griffin and Wilson owned the ranch and were getting in some Yankee push and enterprise to make the thing "pay." So when our Pasadena colonists took the land they found remnants of sheep-corral fences, and bottom timbers of the rude huts of the herders and booths of the shearers; and they hauled away tons of sheep manure to fertilize their young orange trees. The name "sheep corral," therefore, applied to a thirty- or forty-acre body of hill-top and slope and bottom land all around and above the springs where the pumping works are now located. I have noticed that some eastern people, not understanding our western word "corral," have written this spring up gushingly as the "coral springs." That would do very well for Florida, but not for California. $\dagger$

*Mrs. G. W. Robiuson, whose husband was jailor at Los Angeles in the early 5os. tells me that they lived in a part of the Garfias house in I, os Angeles, corner of Main and First streets, and she and Mrs. Garfias used to take their family washings out to this spring and have the work done there. 'The major domo of Mrs. Garfias's mother lived there then, in charge of the ranch.

tThe blunder of a misprint of this name occurred in the Farnsworth pamphlet of $: 88_{3}$, on page $49-$ "coral." It was printed at Oakland. 
The Ben Wilson Spring.--In 1874, J. Benjamin Wilson, son of John W. Wilson, secured a tract of land which extended down over the Arroyo bluff near the west end of Logan street; and toward the bottom of the high bank or bluff there was an issue of water which he developed somewhat himself. Then in October and November, 1884, W. F. Gowie, run a tunnel in 200 feet for him and claimed a flowage of 7 inches of water. The same property in $\mathbf{1 8 9 4}$, is owned by P. W. Lloyd.

The Richardson Spring.-In I877, Geo. A. Richardson bought 37 acres of land next north of Wilson's, and opened a spring in the bluff portion of it. This spring was a few years ago purchased by the Painter Brothers, and the water was pumped up to irrigate lands which they owned on the arable flat above. In I 894 the spring was bought by the Pasadena Land and Water Co., and also the Wilson spring and tunnel.

FLUTTERWHEEL SPRINGS. - Just below the rocky point on east side of Devil's Gate there was formerly a great body of bog soil reaching perhaps twelve feet above the Arroyo bed; but it is all tapped or underdrained, and entirely changed in appearance and character now, by the water company's tunnels. At an early day, about $\mathrm{I}_{872}$, a man named Chesley Cawthon improved the water flowage on top of this bog-bank so as to gather its many ripples into one stream and guide it by a plunge flume upon a wooden water wheel which he had constructed. To this wheel he attached some light machinery for boring, sawing, etc., and manufactured rustic chairs from alder, sycamore, willow, and other light woods of the Arroyo. One day B. D. Wilson was up there looking at it and playfully called the "flutterwheel mill." The name stuck, and that place is called "flutterwheel springs " to this day. Some fragments of Cawthon's old wheel were there yet when our colonists took possession. Mr. Cawthon also built an adobe house nearly where Yolo Avenue and Mountain street now join, at Reservoir No. I. About I8so-81 L. H. Michener lived in this Cawthon adobe house, the land on which it stood having been bought by his fatherin-law, John H. Painter.

ThiBbeTs Springs. - A Mr. 'Thibbets held a squatter's right on the land next north of Devil's Gate on the east side, where there is perhaps an acre of boggy or waterbearing soil, and lived there some years as its first white-man occupant. Hence Judge Eaton called it by Thibbets's name, and it so remains.

Ivy Springs. - A man named Silas Ivy first claimed a body of land on the west side above Devil's Gate, where the La Canyada creek enters the Arroyo. Here were numerous trickles of water coming out of an extensive sandbed, and on being led into a common channel they formed a nice little stream, the entire sandbed being called "Ivy Springs," from Mr. Ivy, and not from the poison oak or "ivy" growing there, as many have supposed. 
The BAcon Spring.-As late as i 884 there was a spring with a large barrel set down into it for a curb, under a sycamore tree at the head of the - Raymond brook, a few rods southeast from Raymond station. But its water supply was tapped first by the building of the city sewer down across its head source; then by the digging and walling up of a large spring or well at the foot of the north driveway up Raymond hill, where a steam pump stood for a year or two ; then by the grading or deep cut of the Los Angeles, Ramona and Pasadena R. R., now the Southern Pacific, a little way east and south from the old spring place. This spring was also called the "sycamore spring," and the "Marengo spring."

There are also some developed springs in Los Robles canyon which rises at the foot of Los Robles avenue. Also water trenches and tunnels in the springs at head of Oak Knoll canyon-foot of Moline avenue.

WHO NAMED THE STREETS, AND WHY.

Names that are given to streets from some well-known historic personage, or some state, or some favorite tree, etc., are obvious enough as to their intent and meaning; and $I$ have not included such in this record. But those which were named for some special personal or private reason, or had some special historic association in their naming, are here recorded in alphabetical order, with such explanations as I have been able to gather in each case. There are undoubtedly others that should be included in this list, but in regard to which I did not get bold of the necessary data. The reader who wishes to find the particular location of any of these streets is referred to the city directory or city map; to give local details of that sort is the business of a directory, and not of a liistory volume.

Adella Avenue.-Opened first by A. Ninde, in I 886 , through his land, and named after his daughter, Mrs. A. V. Dunsmore.

Adena Street.- Opened by Dr. R. K. Janes (dentist), and named after his wife.

Allen Avenue.-- Opened when the Grogan tract was subdivided; and it was named in honor of Wm. Alle11, who owned a ranch of 474 acres called "The Sphinx," up near the mountains, and this avenue formed the west line of his land. Mr. Allen bad come from England and settled here in I 869 .

Arbor Street.- Opened by I. M. Hill, and named from the cypress arbor leading from the front of his house to Orange Grove Avenue. This house was the third one built in the original colony settlement - built by Col. J. Banbury, who also planted and trained the arbor in front, and it was a notable thing in the early colony days, as a cool and shady place for the family meals in warm weather, and the scene of many delightful social gatherings. [The arbor was cut away in I895.]

Arcadia Street.-O Opened in October, I 886, by Revs. A. W. Bunker and 
I. G. Sigler, two Methodist preachers. Named from Washington Irving's "Arcadia."

Arlington Drive.- Opened and named by C. H. Richardson of Pasadena and Dr. W. G. Cochran of Los Angeles, in November, I885. But just why this name was given I failed to learn.

Ashtabula Street.-Mr. Elon Hart first opened this street and was going to name it in honor of Joshua R. Giddings of Ohio. Then I suggested that as there were so many people named Giddings residing here, the name would miss of its historic intent. But if he would name it Ashtabula, after the county and district in northeastern Ohio [the historic "Western Reserve"'] which sent Giddings to congress continuously for seventeen years as an anti-slavery champion, between $I 840$ and $\mathrm{I} 860$, I thought this special historic association would cling to it for all time. So he named it Ashtabula street. This was, I think, in I 887.

Arroyo Drive.--This street or roadway was laid out by the original colonists, and so named because it followed the meander line of the Arroyo's east bank ; and also because it was the road they must follow to get down to their wood lots - these being narrow strips or allotments of timbered land which stretched from this Arroyo Drive on the east down the steep, high bank, thence across the wash, thence up the wooded hill-slopes west of the Arroyo.

Bandini Avenue.-Opened first by D. W. Shelhamer, and named in honor of the historic family represented by Arturo Bandini, a native Spaniard, whose land it passed through, and whose father was a historic personage. [See pages 80,87 , etc.] ${ }^{*}$ (Arturo Bandini married the daughter of Dr. T. B. Elliott, president of the original "Indiana Colony," and has taken a leading part in the hunting and field sports of Pasadena from its foundation.) Bayard T. Smith, J. A. Wood and others opened it as Bandini Avenue south of California street. Other parties opened a northward extension of this avenue, but ignored the local historic fitness of the name with which Mr. Shelhamer, Bayard Smith, Mr. Wood and Mr. Bandini had started it, and dubbed their portion "Michigan Avenue," in direct violation of the uniform custom in Pasadena, by which any extension of a street always carried the name applied at its first opening - probably through ignorance of the relations of Mr. Bandini's father and mother to the American acquisition and occupancy of this country. And if that perversion of

* Col. R. S. Baker, of Baker block fame in Los Angeles, came to California in 1849, and died May 26,1894 . And in a brief sketch of his life the Los Angeles Herald gave this bit of history: "In 1874 lie married the widow of Don Abel Stearns, daughter of Don Juan Bandini, who was half owner [with Stearns] at one time of nearly the whole of Southern California" Don Juan Bandini's father is buried under the flag stones at San Gabriel : and his grandfather was captain of the Spanish war ship Reina in the great historic battle of Trafalgar, October $2 \mathrm{r}, 1805$. He was at work writing a history of Soutliern California when he died in Los Angeles, November 2, 1859. The "Centenuial History of Los Angeles County" p. 32, says: "He was a profound thinker and a clear, forcible writer." After his death the family loaned his manuscrints to the Bancroft History Company at San Francisco, trusting its agent's word of honor to return them; but they have never been able to get back a sheet of it since. 
street name continues, it will be a lasting shame and disgrace to Pasadena. It ought to be Bandini Avenue clear through.

Benefit Court.- Opened in I 887 by A. F. Keyes, and named from Benefit street in Worcester, Mass., his former home.

Bellevue Drive.- Opened by James Smith in 1885 . Bellevue is French for beautiful or lovely view, and is a smooth, easy, pleasant-sounding word; and for these reasons it was applied as a name for this street.

Bradford Street.-Opened by H. J. Holmes. He had a favorite son who graduated in the Naval Academy at Anapolis, Maryland, and held an official position in the U. S. navy. This son married a Miss Bradford; they had a boy baby named Bradford Holmes, and Mr. Holmes named his new street after this little grandson.

Buckeye Street.- Opened by Elon Hart, and named from Ohio, the Buckeye state, from whence he came.

Burton Street.-Opened by Mrs. Mary A. Burton, and named for her husband. (1887.)

Camden Street. - Opened by Hon. Delos Arnold and Dr. O. H. Conger, and named that way by Mr. Arnold just because he fancied the name.

Carlton Street. - Opened by F. B. Wetherby, in 1886, and named from the Carlton hotel, which was just at that time the most notable project under way at Pasadena's business center.

Conter Street.-Opened and named by M. H. Weight, in August, I 885 , through the "center" of his land.

Champlain Street.-Opened by, W. S. Holland, in 1886 . His birthplace was Penton, Vermont, on Lake Champlain, and this was why he so named his new street.

Chestnut Street.-Opened by H. F. Goodwin, I886; named from Chestiut street, Philadelphia.

Concord Strect (Court). - - In in $886-87$ some New England people opened this small extension opposite the east end of Kansas street; and in February, 1887 , they started a movement to have the name of Kansas street changed to Concord street, notwithstanding that for a length of six squares (from Marengo to Vernon avenue) it had been duly entered on the county records as Kansas street. Against this presumptuous move a storm of indignation and vehement protest was raised by the settlers and lot-owners on Kansas street; and the project failed. [In I 894 the City Conncil changed the name to Green street, in deference to Hotel Green and its owner.]

Congress Strect.-The H. H. Markham tract was platted and put upon the market by a real estate firm while Mr. Markhan was in congress from this district, and the street was named by them in honor of the public place which he then held-I885. This was five years before he reached the higher distinction of Governor of California. 
Craig Avenue.-This was laid out when the Grogan tract was surveyed for subdivision, in 1876 , and named for James Craig, an Englishman who came here in I 869 as agent for Mr. Grogan of San Francisco, and bought from Griffin and Wilson 5,00o acres of land without any water right attached. This land became historic as the "Grogan Tract," and Mr. Craig acquired I50 acres of it himself, building a home there which he called "The Hermitage." This Mr. Craig made the first brave, strong effort to secure artesian water in Pasadena, sinking a well with that object 490 feet deep, on East Villa street, but which never outflowed a drop.

Dayton Street.-Opened by J. H. Baker, in I884, and named in commeration of his wife's birthplace, Dayton, Ohio.

Delmar Street.- Opened in I 885, by Will Defriez and his mother Mrs. Susan A. Defriez. It was named from Delmar Avenue, St. Louis, their former home; and in St. Louis it was an old French family name.

DeLacy Street.-First opened by Alex. F. Mills, in I884, and named after his father-in-law, R. W. Lacy. Mr. Lacy's original family name had the French form, DeLacy, but his father had dropped the De, and in naming his street Mr. Mills used the old original family name.

Douglas Street.-Opened by a land syndicate under the management of Dr. Lyman Allen, in 1887. A Mrs. Flynn and her sister were large shareholders, and the street was named after Mrs. Flynn's son, Douglas.

Eldorado Street.-Opened by Justus Brockway, in 1886 , and named from Eldorado county, Cal., where he had formerly resided.

Elevado Drive. - This street was first opened by Charles R. Foote, in October, I886, and named Berkshire street, in memory of his old home, Berkshire county, Massachusetts. The real estate firm of D. Galbraith and G. Roscoe Thomas then bought Mr. Foote's land, divided it up into smaller lots and pushed their sale. But they said, "In all the country west of New York the name Berkshire is so thoroughly identified with a certain favorite breed of hogs that everybody who sees the name of this street will at once think 'hog!' and we don't want people to think hog on our street." So they changed the name to "Elevado," which is Spanish for elevated, or " "way up" - but whether this applied most to the upness of the lots or the upness of the prices, history fails to tell.

Esther Street.-Opened by L. H. Michener, in I886, and named after his wife, Esther Painter, daughter of John H. Painter.

Euclid Avenue.-First opened by C. M. Skillen, who came here from Ohio in 1880 , and named his new street after the famous Euclid Avenue of Cleveland, Ohio. This was in September, 1885.

Fair Oaks Avenue.-- When the original San Gabriel Orange Grove Association's colony lands were platted, this street formed their east boundary, and was named after the "Fair Oaks" farm (then owned by Judge 
Eaton, who was also president of the Association) - the only spot on the whole San Pasqual ranch which had been put under proper cultivation to show what the land would produce. The Fair Oaks farm is now owned by Hon. J. F. Crank. What is now called Lincoln Avenue, running diagonally northwest, was at first a part of Fair Oaks Avenue and was the boundary line of the colony lands. The Valley Union of June 4, r886, gives an account of the straightening of this avenue, which is a good illustration of how things went in the boom time, and I quote:

"The awkward bend in Fair Oaks Avenne where it bore off northwestward from the foot of the Dunton place has been an eyesore to good Pasadenians for many years. But now a syndicate, headed by the brothers M. D. and A. J. Painter, has bought or negotiated for all of the lands necessary to open a street through on a straight line from the Raymond hotel to Mountain View cemetery and the mountains The first acquisition necessary was a small triangle on the old Dunton home-place now belonging to Mrs. Dr. Thomas, and for this triangle the syndicate paid \$I,200. Next north is the Dr. Sheldon property, now owned by the Hon. Delos Arnold of Marshalltown, Iowa, who is all right on streets. Next are the twenty acres owned by the three Misses Stowell and their companion, for which $\$ 25,500$ was paid. Next, the Carey place of five acres, owned by Dr. J. S. Baker, the heaith officer of Los Angeles, and $\$ 5,000$ was paid for this tract. Next is the Miller place of about four acres-price not given. Next, J. S. Hearn's place, four and one-half acres, $\$ 5,000$. Then a small triangle belonging to Carter \& Miller, which was bought for $\$ 500$. This lets them through to Mountain Avenue at its junction with north Fair Oaks, at what is known as the John Allin place, and from there Fair Oaks runs straight by an easy grade to the cemetery, and beyond."

After the job was done, the same paper on July 9, I886, said: "The straightened part of Fair Oaks Avenue is about half a mile long and seventy feet wide, and has cost for property to cut it through about $\$ 38$, ooo."

First Strcet.- A short street opened by the real estate firm of Wallace Bros., and so named because it was at that point the first street south of Colorado.

Florence Street.- Opened by Milford Fish, in the antumn of 1887, and named after his daughter, Florence.

Galena Avenue.-First part opened and named by James Hewitt from Chicago, when he laid out Hewitt's subdivision. Street named after Galena, Illinois.

Garfias Avenue. - Opened by Wotkyns Bros. and Scharff Bros. through their respective subdivisions. Other parties had agreed to continue it on down to the old Garfias adobe ranch house, the ruins of which were then still remaining, 1887 , and this gave the name; but that extension, and another one promised northward, were not made. [For Garfias occupancy, see page 63 , and following.]

Gertrude Court.- Opened by Dr. L. A. Wright, and named after his little daughter, in 1886. 
Glenarm Street.- Named by Thomas Banbury, from his wife's childhood home place in Ontario, Canada.

Glendale Street.- In I 885 M. W. McGee from Kansas City, Mo., bought the well-improved colony home of W. O. Swan, Sr. The orchard extended through from Fair Oaks to Marengo Avenue, with the family mansion about midway, and a private drive passing through from one avenue to another in front of the vine-trellised house and amply shaded front yard, where flowers, shrubbery, and a fountain added to the rural beauty of the place. Mr. McGee named it Glendale, and placed a sign bearing this name over the driveway entrance on each avenue. In 1887 he sold to a real estate syndicate that portion of his land lying between Fair Oaks Avenue and the railroad track, and they made his private driveway into a street, naming it Glendale. Then he extended it on up to Marengo Avenue.

Glorieta Street.-This name used to be laughed at as rather fantastical, for it was supposed to be a bit of superlative boom gush, meaning only "glorious," or something of that sort. But there is a Glorieta postoffice in Santa Fe county, New Mexico; and there is a large tract called Glorieta Heights away up northwest above La Canyada; and the Santa Fe railroad crosses the Glorieta mountains in New Mexico at an altitude of 7,453 feet.

Gordon Terrace.-Opened by James Smith, in i 885 . He had a son named James Gordon Smith; and about this time the English army in India, under Gen. Gordon, was cooped up in Khartoum by the rebellious natives, and the General was killed before re-inforcements could reach him. This was an event of world-wide celebrity at the time, and really decided the naming of this street.

Grand Avenue.-One day some time in $188_{5}$, Thomas Nelmes and Mrs. R. F. Burnham chanced to make a social call at I. M. Hill's residence on the same evening. The great real estate boom was then rising to its flushtide, and, of course, became the topic of conversation. They all owned land reaching from Orange Grove Avenue to the bluff declivity. The idea was broached that a wide street with trees on both sides and in the middle might be opened, following the meander line of the bluff, with one tier of lots having the Arroyo view. Mrs. Hill exclaimed, "O, wouldn't that be grand!" Mr. Nelmes responded, "And that shall be its name-Grand Aven11e!" Thins the project was started; however, some owners wonld not give land enongh for the wideness desired; and so the grandness was somewhat deplumed; but the name stuck.

Grant Street.- Opened by Dr. Thomas Rigg and W. O. Swan, Sr., in October, 1885 , and naned, of course, in honor of Gen. Grant.

Green Street.-- See Kansas street.

Henrietla Court.-Opened by A. Cruickshank, and named for his wife. Howard Street.- Opened by Dr. O. H. Conger, and named after his only son, Howard Conger. 
Hudson Avenue. - Opened by Wetherby and Kayser, in 1886, and named by Mr. Wetherby from the Hudson river, the scene of his boyhood days.

Herkimer Street.- Opened by S. D. Bryant, first through his own land on Los Robles Avenue, then he had to buy enough of a strip to extend it through to Moline Avenue, rather than have it stand as a mere court. $\mathrm{He}$ naned it from Herkimer county, New York, his native place.

Holliston Avenue.-First opened in 1887 by H. R. Case, and named from Holliston, Mass., his old home.

Hull Street.-Opened in I 886 by a syndicate, and named after E. R. Hull.

Hurlbut Street.- Named after E. F. Hurlbut. It stops at the stone wall which encloses the east side of his fine home place. It was first called "Terrace Avenue," and is so named on some old maps ; but that name had no sense or fitness in that locality, and was changed to Hurlbut.

Ipswich Street.-Opened in I 885 , by Henry A. Wallis, who was born at Ipswich, Mass., in a house that was erected there in 1630 , and is still standing.

Kansas Street.-Opened first by Martin Mullins, through the Mullins tract, and named for the State he came from. This tract was the first regularly platted and recorded block of village lots ever made in Pasadena, the small lots previously sold having been described by metes and bounds. Mr. Mullins had bought from John S. Mills seven acres, "being the $\mathrm{s} 1 / 2$ of lot 6 in Berry \& Elliott's subdivision in the subdivided lands of the San Gabriel Orange Grove Association, in the Rancho San Pasqual, Los Angeles county, California-47 lots." Plat recorded November 24, I883-only six days ahead of Wesley Bunnell's plat of his lots on Union street and Little avenue. The first dwelling house on Kansas street was built by Dr. H. A. Reid, at corner of Pasadena Avenue and Kansas street, early in 1884 . February $\mathrm{I} 9, \mathrm{I} 887$, an attempt was made to change the name to Concord street, but was defeated. But in 1894 the city council changed the name to Green street, in deference to Col. G. G. Green and his great hotel.

Kensington Place.-Opened by W. U. Masters, and named by the lady members of his family, after Kensington, England (London).

Kirkwood Avenue.-Named after ex-Gov. Samuel Kirkwood of Iowa. He served also as United States senator; and as secretary of the Interior in President Garfield's cabinet. After all these high honors he settled down quietly at his family home in the outskirts of Iowa City; and just for a joke his neiglibors elected him road overseer. He took the office, and made the jokers work, so that at the end of the year the township had better roads than it ever knew before.

Lake Avenue.-This was originally called Lake Vineyard Avenue, laid out by Hon. B. D. Wilson and named after his Lake Vineyard 
home place. In the boom time an extension of this thoroughfare was ofened up to Las Flores canyon, and an effort made to call this new part "Prospect Avenue,". as a name more likely to attract buyers. But that name did not stick, for it is now called Lake Avenue all the way up.

Little Avenue. - Opened by Wesley Bunnell, and plat recorded November 30,1883 , six days after Martin Mullins had his Kansas street tract recorded. Mr. Bunnell had joined with Williams and O'Hara in opening Union street, then he opened this avenue from the end of Union street as it then was, out through his own land south to Colorado street. He had bought this land from an old bachelor named E. P. Little, who went back east ; and as it was only a little short street, these two facts settled the name of it as "Little Avenue."

Livingston Place.-Opened and named by Wotkyns Bros. They were all New Yorkers. Livingston Place in New York city was familiar to them ; and one of the brothers who was very tall, -6 feet $1 / 2$ inches-had Livingston for his middle name; and so they named it.

Lockehaven Street.-Opened by Mrs. R. C. Locke, through 30 acres which she bought in I874. Named after her colony home place there, "Locke Haven."

Los Robles Avenue.--Opened by Hon. B. D. Wilson, in 1876, and named from Gov. Stoneman's place at the lower end of the street, which was called the "Los Robles ranch," or home. The street ended at Stoneman's fence, which still stands there and forms the south line of the city. Los Robles is Spanish for " the oaks."

Madeline Road.-Opened by Gen. Edwin Ward, and named for his daughter Madeline, now Mrs. Kirk of Chicago.

Madison Avenue.-First opened by Ed. I. Farris and Dr. Wm. Converse, in I885. Dr. Converse was from Chicago, and he named their new street from Madison avenue in that city.

Marengo Avenue.-Also opened by B. D. Wilson; and named from the "Marengo ranch" at its south end, then owned by H. D. Bacon, but now much divided up.

Mary Street.-Messrs. W. C. Mosher and B. F. Ball owned colony tracts adjoining each other and extending from Fair Oaks Avenue west to Vernon Avenue. In the boom time they wanted to open a street along their joint line, and were for some time in a quandary about what name to give it. But finally Mr. Mosher spoke up with a sudden impulse, "Frank, your wife's name is Mary, isn't it ?",

"Yes, her name's Mary," replied Ball.

"Well, my wife's name is Mary, too. We'll call it Mary Street," said Mosher. And that settled the matter. Mary street it went, - though "Two Marys street" would fit the case more historically.

Maylen Street.-Opened by Mrs. R. E. Burnham, in I 886. Her father's 
mother's maiden name was Maylen, and she was a direct descendant from Lord Maylen Chamberlain of Coventry, England, and inherited property from him. Mrs. Burnham's only daughter, now deceased, was named Mary Maylen Burnham; and from these facts came the name of this street.

Mentor Avenue.-Opened in I 886 by Ed. Farris and Dr. G. Roscoe Thomas. Their wives were both born at Mentor, Ohio, and were schoolmates there in their girlhood; and this was the reason for so naming the street. But Mentor had also become famous as the home place of President Garfield; and Mrs. Thomas's father was a member of the state legislature with Garfield when the latter commenced his remarkable and noble political career.

Mercer Strcet.-Opened by J. H. Fleming, and named from his native town, Mercer, in Mercer county, Pennsylvania. From there also he enlisted as a Union soldier in the $5^{\text {th }}$ Pennsylvania infantry regiment.

Millard Avenue.- Opened and named by E. Millard, one of the early city councilmen.

Mill Street. - This was originally only a private driveway from Colorado street to A. F. Mills's cottage, which he had built in part from the original colony school house that had been moved from below California street on Orange Grove Avenue up to the 5 -acre school lot donated by B. D. Wilson at the business center. In I 884, when Martin Mullins opened Kansas street through the middle of his 7 -acre tract, he opened an alley for rear access to his business lots fronting on Fair Oaks Avenue, and this connected with Mr. Mills's private driveway, so that there was a passage clear through from Colorado to Kansas street, and it was commonly called Mills's drive or Mills street. But in January, I886, Messrs. A. Pickard and H. M. Porter started a feed mill in a rough frame building on the east side of this alley or driveway; and Mr. Mills says it took its record name of "Mill street" from this pioneer mill, and not from his name.

Moline Avenue.-Opened by Hon. B. D. Wilson, and originally called El Molino [the Mill] Avenue, from the El Molino ranch or home place of Col. E. J. C. Kewen, now owned by E. L. Mayberry,-where the historic old mill built by the Mission Fathers is still standing, and much visited by relic hunting tourists. [See page 42.]

Mulberry Street.- Opened by A. Ninde, in I 886, and named from Mulberry street in Baltimore, Maryland, his boyhood home.

Mundell Drive.-Opened and named by I. N. Mundell, the first city marshal of Pasadena.

Oakland Avenue.-This street was named at a meeting held in the office of the Lyman Allen Land Co., in 1886, of parties interested in getting it opened clear through from Colorado to California street, but which was not accomplished. There were some fine old oak trees along its line, and as a compromise tie-up between these and Oakland, California, the name was adopted. [Finally opened through in $\mathrm{I} 895$. ] 
Olcott Place.-Opened by Geo. F. Kernaghan and Hon. Delos Arnold, and named by irr. Kernaghan after George M. Olcott of New York, his former business partner.

Orange Grove Avenue.-Laid out and named by Calvin Fletcher, who superintended the platting and subdivision of the original colony lands of the San Gabriel Orange Grove Association, in December and January, I $873-74$. He took pains to bring two large live-oak trees into the middle of the street so that they might be preserved, and not destroyed by private cupidity or stupidity, as many other such trees were afterward. And those two trees still remain - I 895. [See page I67.]

Painter Street.-Opened by $\mathrm{I}_{1}$. H. Michener, and named in honor of his father-in-law, John H. Painter, the head man of the great Painter \& Ball tract enterprise. The north line of the city runs along this street. Mr. Painter was father of the Painter brothers, M. D. and J. A., who built the Painter Hotel, opened Fair Oaks Avenue through on a straight line, built and owned the City Railroad Company's street car lines up to and beyond North Pasadena, and other public enterprises. [For Father Painter's connection with "Old John Brown," see page 325.]

F'almetto Street.--Opened by H. W. Magee in I885. Named from palmetto trees planted along its borders.

Pearl Street.-First opened by A. Ninde, and named from Pearl street in Baltimore, Md., his early home.

Peoria Street.-Opened in I 886 by Miller and Carpenter, and named from Peoria, Ill. The same parties had previously opened and named Illinois street.

Ramona Street.-Named by Mrs. Cordelia A. Boynton and Miss E. L. Ogden, from Helen Hunt Jackson's famous Southern California story of "Ramona."

Raymond Avenue. - This thoroughfare starts near the Raymond depot at the great hotel from which it takes its name, and runs in straight line four miles, to Mountain View Cemetery. It was first opened at the lower part, and name agreed upon, by eight or ten different land owners who subdivided their lands into city lots, in 1887.

San Pasqual Street.-Opened by Hon. B. D. Wilson, in 1876 , and named from the San Pasqual ranch, as it then formed the bonndary line between that ranch and his home place called the Lake Vineyard ranch.

Santa Anita Avenue.-Opened in 1868 by Wilson and Griffin when they sold the Grogan tract and other lands out of their San Pasqual ranch. It was the east boundary of the Grogan and Winston tracts, and extends in a straight line from the mouth of Eaton canyon down to California street, or below it to the cienega in the Craig Avenue swale, where Ford Bros. sunk the first successful artesian well in this region. The west line of the orignal "Rancho Santa Anita" extended from Eaton canyon diagonally southwest- 
ward to about the junction of Hill Avente and California street; this new, straight north-and-south avenue was therefore on land from that ranch, and hence its name. What is now known as the Santa Anita ranch, or "Lucky Baldwin's" place, is only a fraction of the original body of land covered by that Spanish title; but Baldwin still holds the old name.

Shorb Avenue.-Opened and named by Hon. J. DeBarth Shorb.

St. John Avenue.-Opened by James Cambell, and named after Ex-Gov. John P. St. John of Kansas, the prohibition candidate for president in 1884 . Mr. Cambell and his wife were much devoted to the cause of state and national prohibition, and thus testified their regard for the great leader of that cause.

Summit Avenue.-First opened by Stephen Townsend, in 1886 , and so named because it lay along the summit of a ridge at his place between Fair Oaks and Marengo Avenues.

Terrace Drive. - First opened by Hannah R. Arnold, Delos Arnold, Mary A. Bartlett and Dr. O. H. Conger. They named it Terrace Drive because it was cut along the hill slope in terrace fashion.

Union Street.-Opened in November, 1883 , by R. Williams, Thomas O'Hara and Wesley Bunnell, and named Union street because they "united" in opening it. At this time it only extended from Fair Oaks Avenue east to Little Avenue. Of course there was then no Raymond Avenue nor railroad.

Valley Street.-Opened by S. Washburn and J. H. Baker, in r $884-5$. At this time the word "valley" was much in vogue. Pasadena was rapidly winning fame as the "crown of the valley"; the local paper was called "Valley Union" ; the San Gabriel Valley Railroad [now Santa Fe route] was then struggling with difficulties and pushing its way forward, Mr. Washburn being its treasurer and one of its three chief promoters. So he named his new street Valley street.

Villa Street.- Opened by Hon. B. D. Wilson, and named from the "Sierra Madre Villa" hotel, which was at that time the most noted hostelry and invalid tourist resort in all this region of country. And this street was expected to become the direct ronte from Pasadena to that place; but it was too saudy, and Colorado street gained and held the preference for travel.

Vineyard Street.-Opened by P. G. Wooster, and named from Martha's Vineyard, Mass., his wife's childhood home.

Wallis Street.-Opened and named by Henry A. Wallis, who owned the land and lived there.

Waverly Drive.- Opened by James Smith, in 1885 , and named from Sir Walter Scott's "Waverly" novels.

Wilson Avenue.--Opened by Hon. B. D. Wilson in his Lake Vineyard Colony tract, in 1876 , and given his own name.

Winona Avenue.-Opened and named by Wm. Heiss, of Heiss Bros., clothing merchants, in 1887 . 'The family formerly resided in Minnesota, 
and he commemorated that bit of family history by naming the new street after the city of Winona, Minn., becatise he liked that Indian name.

Worcester Avenue.-Opened by Ed. L. Farris, in I886. Mrs. Cordelia A. Boynton and Miss E. L. Ogden owned land needed for the opening, and Mr. Farris gave them the privilege of naming the new street; and accordingly the name of Mrs. Boynton's birthplace, Worcester, Mass., was decided upon. An effort was made to.get it opened clear through to Walnut street; but the school directors refused to let a public street run so close to the Lincoln school-house as would be necessary, and also would not let that school's playground be lessened or marred even by a ten-foot driveway across it. Then Mrs. Boynton and Miss Ogden opened Ramona street to give the north end of their new avenue an outlet to Marengo Avenue.

Yolo Avenue.-Opened by the Patten brothers in 1888 , and named by Engineer Piper, who surveyed it, because he came from Yolo county, California. The word means "region of tules" or rushes, and is from the ancient Aztec language.

\section{STREET ALTITUDES.}

While Surveyor J. M. Willard was locating the street car line along Colorado street, in $\mathrm{I} 886$, he recorded the altitude above sea level at all the principal street crossings, as follows :

$$
\begin{aligned}
& \text { PLACE. } \\
& \text { FEET. }
\end{aligned}
$$

Fair Oaks Avente at Colorado street crossing ............... 997.00

Marengo Avenue at Colorado street crossing ............... I, or6. I 3

Euclid Avenue at Colorado street crossing ................... I,005.6 I

Los Robles Avenue at Colorado street crossing ............... I,002.08

Moline Avenue at Colorado street crossing .................. 980.93

Lake Avenue at Colorado street crossing .................. 969.72

Wilson Avenue at Colorado street crossing.................. 964.7 I

Hill Avenue at Colorado street crossing.................. 950.47

Santa Fe elevations are :

\section{CHAPTER XIX.}

Mountain Praks, Canyons, Water Falls, Hills, and other Natural Objects; with their several Names, and when, why and by whom these Names were given.

The Old Mill; the Mission Lake [or Wilson's lake]; etc.

\section{MOUNTAIN PEAKS OF PASADENALAND.}

Our local mountain peaks vary very much in appearance as viewed from different standpoints in the $4 \times 7$ miles extent of Pasadena residences, from the Arroyo bluff to Santa Anita Avenue, and from Lincoln Park to Giddings Heights ; hence I have taken the corner of Colorado street and Marengo Ave- 
nue as a convenient central point from which to designate the different peaks by name. But the view would be nearly the same from the Presbyterian church, the Wilson High School, the Throop Polytechnic Institute, the Hotel Green, etc.

MOUNT HARVARD. - Looking north-by-east from our chosen standpoint, the most striking object toward the mountain top is a prominent detached spur forming a tangent ridge by itself, with its crest running north and south and a pretty well defined gable-end facing southward. During the days of Spanish and Mexican rule this promontory was called El Picacho, "the peak." As seen from Anaheim or Los Nietos, or any of that oldsettled sontheasterly region, only its end came into view, and it seemed verily "The Peak"; and it was so nearly due north that it served the

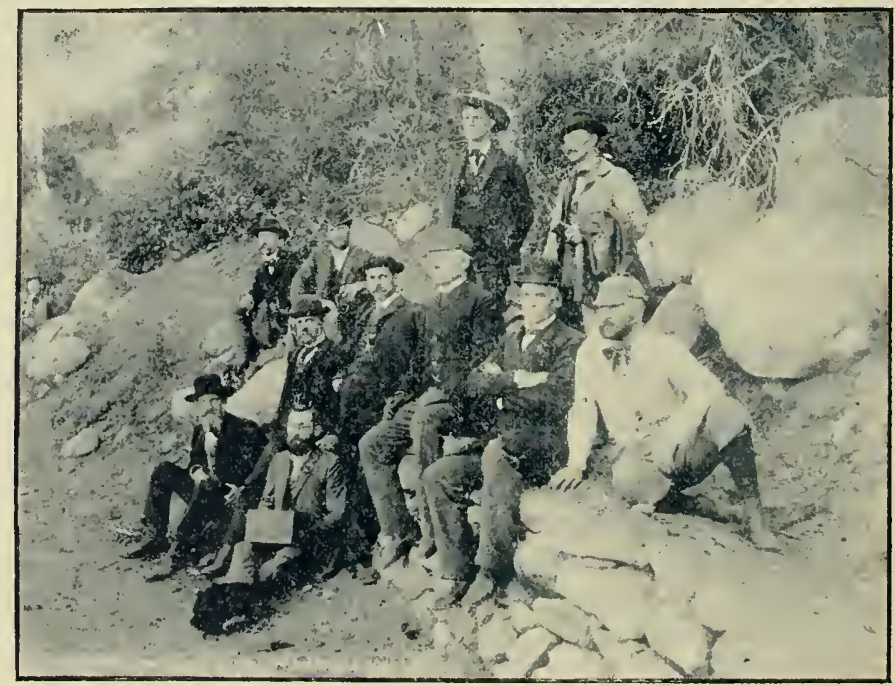

GODFATHERS AT CHRISTENING OF MOUNT HARVARD, APRIL 7, 1892.

President Elliot of IIarvard College; Prof. 'I. S. C. Lowe of Monnt Lowe fame; Prof. Will s. MIonroe, city superintendent of Pasadena schools; Prof. Winship of Boston ; Waiter Raymond of Raymond hotel; Judge B. S. Faton; II. W. Magee, Esq.; Chas. A. Gardner, editor Pasadena Daily Slar; W. S. Gilmore of I,os Angeles Daily Times staff; Clarences. Martiu of Martin's can1p; Mr. Severance.

Spanish workmen a noon-mark by the sun. Byron O. Clark relates that when Manuel E. Garfias, the first European cliild ever born in Pasadenaland, worked for him at Anaheim in 187o, he always looked at this "Peak" to see when it was dinner time. The first name that I heard it called by (winter of i $883-4$ ) was "The Hogback." From Pasadena this promontory appears to be the highest part of the mountain, but Judge Eaton says it is 250 feet lower than Wilson's peak. I called it Sonth Gable Promontory, a name which explains itself at sight. On April 7, r892, President Elliot of Harvard University accompanied a party up the Toll Road to visit the site where the Harvard photographing telescope had done its special work. 
From Martin's camp the party walked up to the summit outlook of the promontory, which affords a wonderfully fine view of the valley below, and a less obstructed view of the settlements along the foot of the range eastward than any other point, on account of its jutting out almost at a right angle from the main range; and at this time, as a compliment to Presidrnt Elliot, it was christened "Mount Harvard."* At its base lies the ranch of Abbot Kinney (known to old settlers before 1880 as the Seabury place), which he has named "Kinneloa,"- (an Anglo-Sandwich-Island word modeled after Maunaloa and other "loas" in the region of Honolulu - and meaning Kinney's home). Mr. Kinney tried to get this conspicuous mountain spur named Kinneloa by government authority, but was frustrated in it by Pasadena parties.

PYRAMID PEAK. - In front of the promontory, or a little eastward, and a little lower down is a small pyramidal peak, so distinct in its outline as to name itself.

HENNIGER'S FLAT. - About half way down the west slope of Mount Harvard there is a very distinct mountain terrace known as "Henniger's Flat." This body of land was taken as a squatter's claim in I 880 or '8 I by an old-time Californian named Wm. K. Henniger, residing at San Gabriel and known as "Capt. Henniger," who went up there to stay for the benefit of his health. He was the first sheriff of Santa Clara county; and gained his title of Captain by service in some of the local expeditions of white settlers against Indians, which were very common in California thirty to forty years ago. During the "clry" season of $1882-83$ his water supply failed, and he left the place for a few months. But the copions rains of I884 made the water supply good again; and he returned, built a house, developed water, made a storage cistern, cleared and cultivated some of the land, and established liimself as a permanent resident there. Henniger had made only the rudest sort of a footpath up the mountain, over which himself and a mule could pass. In $1885-86$, E. L. Mayberry had a mind to build a house up there as a health home for his invalid wife; and with this idea he made a briclle road so that lie conld go up and down on horseback, but intended if he did finally build a house there to make a carriage road up to it. However, the complete isolation of the place and its difficulty of access was too much, and Mayberry dropped the project after making his bridle road and riding over it a few times; and Henniger continued his hermit life, with only an occasional mountain climbing visitor to break the monotony, until the Mount Wilson Toll Road was constructed in $1890-9 \mathrm{r}$. This road extends ahout a mile along the east edge of Henniger's Flat, and at a point near the farm house there is a watering place for man and beast making the ascent. Capt. Henniger claimed to have from 30 to 40 acres of

*.' At Martin \& Lynch's the visitors never tire of sitting under the awnings or out on the promontory of Mount Harvard (Kinneloa), watching the glorious prospect," etc.-Pasadena Star, Sepl. 22.1892. 
land under cultivation, with more that might be cleared and utilized. He raised hay, grain, fruits, vegetables, poultry. In October, I89I, with a party of four, I procured there from him a supply of most excellent watermelons, peaches, plums, etc. The old man stuck to his mountain home, for he could not live in a lower altitude, and finally died there May 4, 1894 -aged 75. Peter Steil of Pasadena furnished the old mau with groceries and other supplies during his last lingering illness, and attended to his burial when he died. July 3, I895, H. C. Allen bought the Henniger property, I 20 acres, at administrator's sale, for $\$ 2,600$, and made it adjunct to the Mount Wilson 'Toll Road Company's plans of development.

WiLSON'S PEAK-MOUNT WILsON.-Back of or north from Mount Harvard lies Wilson's Peak, which is not a peak at all, but a great body of mountain, from which Harvard and Pyramid are projecting spurs. The summit of Mount Wilson has plowable land enough for two or three good farms, no more rough, hilly or stony than farms I have seen cultivated in Ohio, Pennsylvania, Virginia, New York, Northern California, and several New England states. Mr. A. G. Strain raised barley, pumpkins, potatoes, and some other vegetables successfully up there on the very summit, where a wild barley field had flourished aforetime and been a favorite pasture ground for deer; but generally the rains cease and leave the ground dry too early in the season to make the tillage profitable; and there is no chance to reach the field crop lands by irrigation except with pumping works, which would be too expensive, as the permanent springs are from 100 to 300 feet lower altitude than these lands. The top of Mount Wilson varies from onequarter to a mile in width north and south and about two miles east and west - and that is why I say there is no distinct peak. It takes its name from Hon. B. D. Wilson, who, in I 864 , built the original trail to its summit. See article, "Wilson's 'Trail."

The north slope of Mount Wilson forms the south wall of west San Gabriel canyon, the flowage of this branch of the famous river being from west to east. An old burro trail of fearful and perilous character led from the Wilson summit down into this canyon, a distance of four or five miles, to Pasadena camp. In June, I89I, a party of Pasadena young folks were encamped there, consisting of Misses Jessie R. Mitchell, Louise Kerr, Alice Glass, Ella Knight, Winnifred Webb; also Charles C. Glass, Linu Freeman, Rhoden Scudder, Alva McCoy. June 2oth Carlton Durrell and Will Linney started from Pasadena with a horse named "Jerry" loaded with camp supplies, to join their friends in the canyon. They reached Wilson's peak the first day; and on the 21 st (it being Sunday) they started down the adventurous trail. But at a certain extra perilous passage called "Devil's slide,"* their horse lost his footing, and went rolling, tumbling, grinding

* In October, 1891, Dr. H. A. Reid and wife worked hard two days making a new and safertrail right over the moutain spur instead of along its steep and crumbly side called "Devil's slide." While they were at work the second day, and before they had got the new route entirely opened, $P$. $T$. Reed of Sierra Madre came along with a luuting party, just returning from Barley Flats, and wasthe first to ride over it, pronouncing it "a mighty sight better" than the old one. It is in use yet, and is called "Reid's trail." 
helplessly down the steep, rocky declivity 800 feet to the bottom - of course being killed, his pack torn into tatters, and the provisions scattered all along the slope, as food for mountain animals and insects. Fortunately, the young men themselves managed.to get safely across the danger-stretch, and hastened on down to their comrades. Four of the party returned to try and reach the horse to see if he was killed, and to recover what they could of the lost baggage and supplies. It was a climb for life, perilous at every step. The horse was dead. They recovered a few things, and returned to camp very sad and very tired. They stayed in camp all next day to rest; then the whole company went to Barley Flats, these being the first women who had ever climbed to that long-famed mountain hunting ground. They all returned home by way of Switzer's trail, the girls having walked the entire round - about sixty miles in all.

Harvard Telescope Point, or "Signal Peak."-Directly back from Mount Harvard, and a little westward, at the summit of the range, there is a slight elevation above the main ridge line, and here is where the Harvard 23-inch photographing telescope stood from May 1, 1889, until late in 1890: hence the name. The instrument was in constant use both night and day, when there was no obscuring clouds, taking photographic views one foot square, which, when properly placed together, formed a complete and accurate map of all planets, satellites, stars or nebulae visible from that point during one entire year. And some objects in the star-world were there brought to view and recorded which had never been seen by mortal eye before. This work was conducted by Prof. - King. Up to January I, 1890 , there had been taken 1155 of these photographs. The same instru-

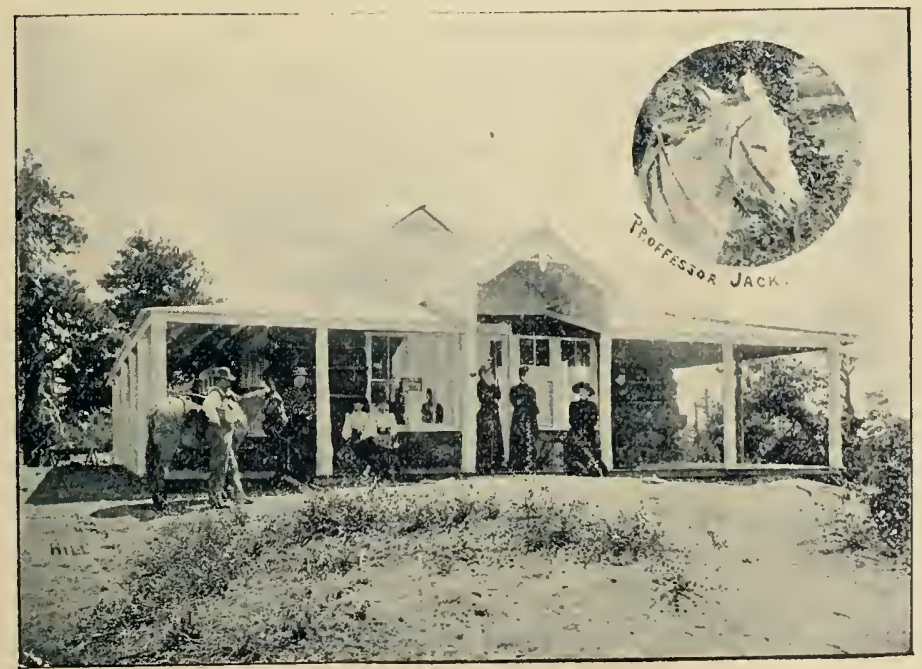

OBSERVATORY CASINO - 1894. 
ment is now, I894, doing a similar work at Arequipa, Peru, at a station 8,050 feet above sea level-over 2,000 feet higher than Mount Wilson. [See article "Wilson's Trail" for account of how the instrument was trundled up to Mount Wilson.] 'This point was often spoken of as Wilson's Peak: but the highest part of Mount Wilson lies about a mile farther east, toward a crag called Echo Rock, which looks down a tremendous precipice into a branch of Santa Anita canyon. The telescope site was formerly called "Signal Peak," as I find it described in the Pasadena Valley Union of May 21, I886, which says:

"'The high point or peak of mountain visible from Pasadena which forms the summit at the head of the ord Wilson trail is known as 'Signal Peak,' from its long use by parties who had climed that trail making a fire there in the evening to signal their friends below that they had arrived safely at the top."

The Mount Wilson 'Toll Road Company has converted the observatory building into a series of guest rooms called "Observatory Casino," which forms an Annex to their Mount Wilson Camp resort for invalids and tourists.

Precipicio Peak.-From the summit of Mount Wilson, or Harvard Point, there extends westward a long, narrow stretch of mountain crest, including what is called "Knife-Blade Ridge," and terminating at Precipicio Peak, from whose top the visitor looks down southwardly into a gulf of steep, precipitous and terrifying depth called "Eaton Canyon," although its official or recorded name is Precipicio Canyon, which was its old Spanish name. On the north side he looks down a more gradual and wooded slope, though quite as deep, into the west fork of the great San Gabriel canyon and its historic river. And on the west side he looks down into a heavily wooded deep valley or mountain gap which forms a sort of pass from Eaton canyon through to West San Gabriel canyon, and is the great gulf of separation between the Mount Wilson and the Mount Lowe systems of adjunct peaks, ridges, spurs, etc. The Precipicio peak and the sharp ridge leading to it are plainly seen from Pasadena, and have a little historic association which I quote from a document of the time, October, r89 r :

"Dr. and Mrs. Reid clambered all day over craggy peaks, and along spaces thickly strewn with sharp, angular fragments of rocks, and through thorny chapparal, and throngh a small but grand pine grove, and for several rods along the crest of a dividing ridge [the "Knife-Blade," as John Muir called it] so narrow that they could stand erect and from either hand on opposite sides drop a stone that would plunge down 2,00o feet before it could strike any thing which might stop its downward course. Mrs. Reid [then over 65 years old] went nearly two miles farther on this difficult line than any woman had ever gone before."

Since Echo Mountain and Mt. Lowe came into such pre-eminent fame, men have crossed a few times between them and Mt. Wilson, following 
this ridge to the Eaton gap, thence by way of Grand Basin to the Mt. Lowe bridle road at Castle canyon summit.*

MUIR'S PEAK.- This is the next peak west, and is the sunrise point seen from Echo Mountain during June and July. This peak is the summit of the great sloping ridge which forms the east wall of Rubio canyon and west wall of Pine canyon. The first white man ever known to have stood on this peak was the famous John Muir, who, in August, I875, climbed up here from below Eaton canyon falls. [See article on "John Muir's Mountain Climb in Pasadenaland," Chapter 20.]

EсHo Mountain, takes its name from a wonderful echo that booms and rolls and reverberates from the mountain walls that form a sort of semicircle around and above it, westward, north, and eastward. Directly northwest from Echo Mountain, and plainly visible from Pasadena, is a bold facing of white rocks [feldspathic syenite] that extends up to the crest or summit ridge, along which pine trees are seen; this mountain facing or wall of white rocks is semi-circular in form, and constitutes distinctively the "Echo Ampitheater."

Mount Vesuvius. - A detached spur of the front range a little north and east from Echo Mountain, and perhaps I,ooo feet higher, has been given this name, because for several months in 1893 fireworks were displayed from its summit every Saturday night at nine o'clock, and always ending with a piece that represented in miniature a volcanic eruption of Mount Vesuvius. These luminous displays were visible not only at Rubio Pavilion and Echo Mountain, but also at Pasadena, Los Angeles, Santa Monica, Redondo, Long Beach, etc.

MOUN'T LOWE. - This is the boldest and most bulkish mountain mass seen north of Pasadena, and lies, with its three-wave outline, like some extinct monster of past ages basking lazily on the mountain top. It is the highest one of the Pasadena mountains which can be seen from Pasadena, and is commonly spoken of as 6,000 feet altitude; but Wm. H. Knight, president of the Science Association of Southern California, informs me that according to reckonings of the U.S. Geodetic survey, its highest point is 6, Ioo feet above sea level. It was called "Oak Mountain" by hunters, and the early settlers of Pasadena ; but on September 24, I892, it was for good and sufficient reasons formally christened " Mount Lowe," and has since become world-famed under that name. Full particulars of this christening will be found in the chapter on the Mount Lowe Electric Railway. On October I I, ז887, Owen and Jason Brown, assisted by Calvin Hartwell, erected a stone monument and flag pole on this summit, and left a

* As early as 1883-84 Byron O. Clark and H. C. Kellogg had crossed over, and then projected a wagon road up the entire length of Millard and Grand Cauyons, thence across to Wilson's Peak. It's "awfully easy" to build mountain roads - on paper. 
written record claiming it as Brown's Peak.* But afterward the Browns claimed another peak west of Millard canyon for their name, and commenced building a bridle road up to it from Las Casitas.

Strawberry Peak [?] - The top of this can be seen like a little old New England haystack peeping over the west shoulder slope of Mount Lowe. It was named by some wags at Switzer's camp in 1886 , from its fancied resemblance to a strawberry standing with its blossom end up; but one of them said, "We called it Strawberry peak because there weren't any strawberries on it." The joke took ; and that burlesque name has been commonly used by the old settlers ; but the peak is waiting some worthy occasion for a worthy name. $\dagger$ This lofty peak is really back in the third range of Pasadena Mountain summits - and in front of it is seen a smaller portion of a lower and smaller cone called

BhACK JACK PfAK.- [It was also called "Little Strawberry peak."] This is simply a spur from the foregoing, but has a distinct pinnacle of its own, very steep, rugged, sharp, and difficult of ascent, and composed entirely of a.porphyritic rock called "black spar" by the miners. In 1887 Owen and Jason Brown climbed to the top of this flinty, hard, barren pinnacle, but I doubt if any other men have ever been venturously persistent and hardy enough to do it. They called it "Black Jack," as a perfectly natural and fitting name from the color and hardness of its rock substance ; but this name had likewise very vivid historic associations to them, from Black Jack in Kansas, where they with their father fought in June, 1856 , what was in fact the first actual battle in our great national struggle against the lawless encroachments of the slave power. [The battle of Osawatomie occurred August 30, I856 - two months later.]

Mount DisappoinTMENT, - Next westward is a long stretch of mountain crest or ridge, not a peak, which obtained its name in this way: The United States surveyors were working their way eastward along the mountain ranges; and from San Fernando range they sighted this mountain as their next highest point on which to establish the government record - but on coming here and testing its altitude they were "disappointed" to find that San Gabriel peak, a few miles farther east, was still higher. Accordingly they named it "Mount Disappointment," and went along to the higher peak to build their monument and deposit their official records. July 4, I889, Mr. Herve Friend, the photogravure artist of Los Angeles, took views from the summit of Mount Disappointment, the first ever taken there.

San Gabriel Peak.-Called also "The Commodore;" and in the Mount Lowe literature called "Observatory Peak." Only the tip of it can be seen, as a small ridge extending eastwardly from a point low down on the

* In July, $188_{3}$, I saw this monument or cairn standing there yet ; but the written paper had long before been destroyed by wetness or insects; and the flag-pole had gone to make some hunter's campfire.

† Prof. Lowe informs me that he has governnent authority to give names to any peaks within the itinerary of his great mountain raiiroad resort. 
east slope of the Mount Lowe tri-crest. Of course as seen from Pasadena it looks lower than Mount Lowe, and seems a part of the same, although being several miles farther north. But when there happens to be snow on its summit and not on the front range, then it shows its separateness very distinctly. 'The United States surveyors ignored the old Spanish name of "Sierra Madre" for these mountains, and called them San Gabriel mountains, because they are so extensively ramified with canyons and creeks tributary to the San Gabriel river; and this peak being the highest of all6,723 feet - they put it on record as "San Gabriel peak," the chief of the range; hence this is its name as given upon all official maps or documents. The name "Commodore" was given to it by some wags at Switzer's camp, 'which was a favorite resort far up in the Arroyo Seco canyon some eight or ten years ago,' in facetious honor of Mr. C. P. Switzer who had built the famous trail and tourist-resort camp which bore his name. They humorously dubbed him "Commodore" of the fleet of burros which navigated the intra-montane Arroyo Seco by way of Switzer's trail-and then dubbed this highest peak "The Commodore," after him ; and that burlesque name was quite commonly used for it. Big and little Strawberry peak, Walker's peak, Lucky camp, and various other points were named in this same spirit of fun and waggery, and given currency through newspaper reports. The name " Observatory Peak " was applied to it by Prof: Lowe, as being the grandest " observation" point in all these mountains. And the Mount Lowe Railway company promises in due time to make this peak accessible to their guests, and provide it with instruments for observing the wonderful scope of mundane things-of monntains, plains, deserts, valleys, cities, beaches, harbors, coast line, ocean expanse, dotting islands, etc., which can be seen from its lofty summit.

The first and only woman who had ever achieved the ascent of San Gabriel peak, up to January 1, 1895, was Mrs. Herve Friend of Los Angeles, whose husband, a prominent photogravure artist, made the first photographic views ever taken on this loftiest point of our Pasadena mountains. This occurred on August 26, I 893. The party had to camp over night on the wooded ridge which connects Mount Markham and San Gabriel peak, in order to be able to make the ascent and their return to Echo mountain the same day. There was no path, trail or waymark beyond Rattlesnake spring; * and as they had to carry their lunch and water supply, besides a heavy 8xio photogravure camera, with its adjustable and stout tripod stand and a stock of exposure plates, and find their own way just as if no

\footnotetext{
* August 4th, 1893, Jason Brown went afoot from Eicho mountain to Black Jack peak, to find for me the date wlien he and owen climbed to its snmmit and gave it the name. He tlionglit he could get back as far as Crystal Springs cabin the same niglit, but found it inpossible to do so, and had to lie out all night, without food, blankets or shelter, on the northwest slope of San Gabriel peak. Harly in the morning he made his way to where he knew of a trickle of water from a crack in the solid rock. A large rattlesnake lay coiled right at the spring. He killed it, and I now have the rattles in my collection. And thus came the name, "Rattlesnake spring." Our party obtained water there when making this ascent, August 26. That silake had eleven rattles.
} 
human foot had ever been there before, it was an arduous climb-requiring over three hours of steady hard work to reach the summit. The party consisted of Herve Friend and wife, Dr. H. A. Reid, Jason Brown, and a young man named Mahlon. They found the monument or cairn built by the men of the U.S. Geodetic survey; also the tin canister or safe for containing their official records, but the most important of these were missing-had been stolen away. When all had fairly reached the top, and were full of the sublimity and wonder of it, Jason Brown suddenly spoke: "Now I'm going to kiss the first woman who ever stood on the highest point of the San Gabriel mountains." And with that the grizzled old man put his bare bronzed arm around Mrs. Friend and kissed her, as gracefully as a French dancing master. She was taken by surprise, and stood in a sort of dazed amazement, blushing all over, but offered no resistance or resentment. A brisk cold shower of rain came on while the party were eating their lunch; and being wholly unprepared for such a phenomenon in Pasadenaland in the month of August, they could only tip their heads to the wind and take the cold wetting as it came. But fortunately it soon passed over. The descent to camp where their burros had been left occupied two hours of careful, cautious and sometimes perilous clamber work.*

Mount MarkhaM. - This is a peak somewhat higher than Mount Lowe but not visible from Pasadena. It is connected with the main body of Mount Lowe by a narrow neck or ridge perhaps a hundred rods long, and also with San Gabriel peak by a similar but much shorter ridge - and these ridges are the divide whose east-slope waters flow into Eaton canyon and thence to the San Gabriel river, while their west-slope waters flow into the Arroyo Seco and thence to the Los Angeles river. It was named in honor of H. H. Markham, who first as congressman and then as governor, had wort the highest public distinction of any Pasadenian.

SquARE-Top [also called Table mountain] is a lesser peak between San Gabriel and Strawberry peaks; and takes its name from the striking and peculiar flatness of its summit. It also is not visible from Pasadena.

Giddings Peak.-June i8, i886, the Valley Union said: "Mr. E. W. Giddings [he was assisted by Calvin Hartwell.-ED.] has planted an immense white flag on a mountain summit next east of Millard canyon which is hereafter to be known as Giddings Peak, in honor of the famous old antislavery statesman of Ohio." The point referred to does not show as a distinct peak from Pasadena, but is the westerumost monticle of the Echo wall-crest that forms the northwesterly white-rock wall of Echo ampitheater.

*After this chapter was all ready for the press, I learned that a statement was published in the Weekly Star of August 5, 18:1, signed by C. P. Switzer, to the effect that Mrs. J. D. Hooker of L,os Angeles, and leer sister Miss Bessie Putnan of San lirancisco, made the clinb from "L, incky camp," to the summit of Commodore [San Gabriel] peak on July '-1, 1891, with Will H. Hibbie as guide; and that no woman had ever ascended that peak before. He also said that Mrs. Hooker had five years previously made the climb from his camp) to the top of Monnt Disappointment, being the first woman who ever set foot on its lofty crest. This was before any burro trail had been made there. 
It is marked "Grizzly Point" on the map of these mountains published by the Mount Lowe Railway Co. in 1893 , the author of which probably did not know that this point had ever been named before. But the Giddings family had made a burro trail up to it from Millard canyon six years before the mountain railroad company's advent. However, they had not kept it open; it was much overgrown, had lapsed into fragmentary hunting trails, and their claiming and naming of it remained only as a reminiscent scrap of history. As seen from the Giddings farm it looks like a distinct mountain peak.

BROWN'S PEAK.--In front of Mount Disappointment as we look from

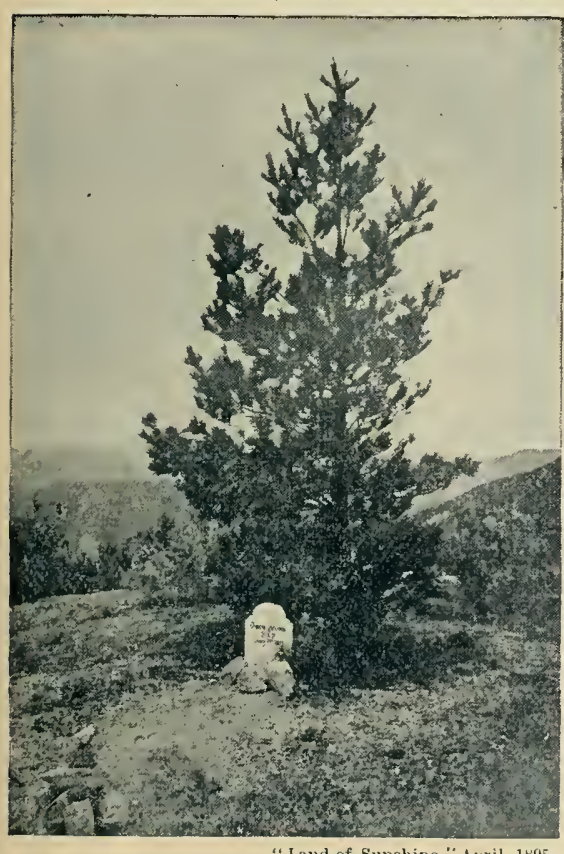

OWEN BROWN'S GRAVE.

[See page 322.$]$ Pasadena there is a stretch of front range summit ridge, with four or five slightly elevated knobs, and one of these (perhaps the middle one) was called Brown's peak. The Valley Union of Deceunber 4, I88 I, said: "Owen Brown, son of 'Old John,' arrived here Monday, November $3 \mathrm{O}$, from Put-in-Bay, Ohio, to join his brother Jason, and sister (Mrs. Ruth B. Thompson), already here. He is a man nearly 60 years of age." Again, June I8, I886, the same paper said :

"Owen Brown, residing with his brother Jason on the Mountain Home tract, has made claim and mounted his flag on a monntain summit above Prieta canyon (the same that has been called "Negro canyon"). Owen Brown is the only man now living who was with John Brown, his father, at Harper's Ferry, and his mountain sumunit will be known as the "John Brown Peak." $\mathrm{He}$ is building a horseback trail to carry visitors to the mountain top, and many persons will go there from historic sympathy or curiosity. Jason Brown has eighty acres of mesa land and also a timber claim in same vicinity."

And still again, Jantuary 29, 1887, the Union reported that Brown's trail was completed about half way up. But this ended it. They had no funds, were obliged to earn their daily bread, and never built their trail any farther. Owen died January 8, I 889, and lies buried on top of a foot-hill spur above Las Casitas. Jason was employed a year or two on Echo Mountain, but finally in March, r894, he went back to his old home at Akron, Ohio.

The other mountain summits seen still farther westward in the same 
range are beyond the Arroyo Seco; and hence, not being within the borders of Pasadenaland, are not matters for record in this volume.

HODGE'S PEAK.-Looking across the Arroyo to the great hills back of Linda Vista, the most conspicuous one northward is on a 45 -acre tract which Dr. J. S. Hodge purchased from J. D. Yocum in 1888 , and built a wagon road twelve feet wide to its summit. This site is 1,800 feet above sea level; there is a well on it ten feet deep which yields water not less than two feet in depth even in the dryest time of the year; the view from here las free scope east and west, and from mountain to sea - a landscape of more surpassing extent and grandeur than from any other point accessible by carriage road.

LindA VISTA PEAk. - This is the next highest point south and a little west from Hodge's peak, and back of Linda Vista. There is a bridle road to its summit; and it was in the east slope of this sub-mountain that some gold mining was done by J. W. Wilson and son in $\mathrm{I} 887$.

Jumbo Knob.- This is the great, bold terminal knob of the Linda Vista crescent of hills, which juts out toward the Arroyo Seco, opposite reservoir hill on Orange Grove Avenue. It was so named in I 884, from a fancied resemblance to the head of Barnum's famous and historic but illfated monster elephant, Jumbo - the protruded ridge in front representing his trunk reaching down for water.

Buzzard ClifF.-This was a jutting spur or crag of the San Rafael hills, and the Scoville road now winds across its terminal point. In the early days this was a notable roosting and nesting place for turkey buzzards; and I remember of once, in 1884 , counting twenty-seven of these scavenger birds circling around and over it at one time.

CANYONS, WATERFALI,S, ETC.

The Glacial Terracf Canyons. - From Raymond Hill eastward to San Marino there is a line of bluffs, perfectly corrugated with sulall canyons which are perennial water courses, and all of them have historic association with the days and doings of the San Gabriel Mission regime. For reasons fully set forth in the chapters on Geology, Hydrology, and Prehistoric Man in Pasadena, I designate this line of bluffs (and also westward to Columbia Hill) as the "Glacial Terrace." The Garfias spring, Ed Baker's spring, and others on the Arroyo Seco, are parts of the same general system of glacial terrace leak-spots; but those from Raymond to San Marino form a distinctive and characteristic group.

RAYMond CANyon. - The Raymond brook from the springs near Raymond station on the Santa Fe railroad flows down this canyon, and finally makes a great, troublesome ontwash on the line between the Raymond Improvement Co.'s land and the Gov. Stoneman place. During the Spanish or Mexican occupancy, this stream and outwash were known as the "Ar- 
royo San Pasqual." The Pasadena, Ramona and Los Angeles railroad (now the Southern Pacific) partly cuts the course of this Raymond canyon. Los Robles Canyon.- - At the foot of Los Robles Avenue, where it ends blunt against the Los Robies ranch fence [Stoneman's], which is the south line of Pasadena city, there is a body of springy land which gives rise to the east branch of the stream that forms this canyon - its first spring being on the south side of Wallis street. Then a few rods westward there is another spring brook, which is the outlet of another body of boggy or marsh land that extends northward to and above the junction of Euclid Avenue and Maine street, and thence diagonally across Los Robles Avenue northeastward nearly to California street. These two brooks come together and form Los Robles creek and canyon near the upper line of J. E. Jardine's picturesque and beautiful five-acre home place on its west bank. Below this place it turns eastward and joins

OAK KNOLL, Canyon.- - This takes its rise in some water-bearing land on the west side of Oak Knoll tract on line with the foot of Moline [E] Molino] Avenue. Here the O. K. company has sunk wells, water trenches, and tunnels to provide pipe water for their subdivision; but the original streamway or canyon extends down between Oak Knoll and Allendale to the head of Willowdale creek, where it is joined by Los Robles creek.* And it was near this point that the Mission Fathers started their ancient ditch which led these waters along on the side of the bluff down to their stone flouring mill. This stream has been called "Mill Spring creek," because of the padres' use of it ; also "Willowdale creek," from the name "Willowdale" given to his place by Capt. J. Elwood Ellis, who resided here during the early years of the Pasadena colony settlement; also "Hutchinson's creek," from a Mr. Hutchinson, who commenced in x $85^{8-} 59$ to raise strawberries, vegetables, etc., on its banks; also "Richardson's creek," from Solomon Richardson, who became a partner with Hutchinson in 1868 , and resides there yet. Of course the first name has the historic preference.

Mill, Canyon.- This canyon rises at the foot of Lake Avenue, and debouches at the historic "Old Mill" built by Father Zalvidea of the San Gabriel Mission about I8Io to 1812 , and the mill was run by water from this and Los Robles canyon. In $\mathrm{I}_{92} \mathrm{Mr}$. Shorb bored an artesian well in this canyon, 259 feet deep, and made a geological sample case showing depth and kinds of formations successively passed through - the only instance I have found of this being done. The Alhambra Water Company has some tunnels in the upper part of this canyon from which water is piped down to their main reservoir. And from this canyon E. L. Mayberry has

*. Capt. J. E. Ellis owued an eighteen-acre place called "Willowdale," lying south of Bayard T. ". Capt. J. E. Ellis owued an eighteen-acre place called "Willowdale," Stomeman's. This tract has much spring land upon it, and was bought last week by $\mathrm{S}$. Richardson for $\$ 18,500$. Mr. Richardson owns fitty acres just below it, and wanted to secure the bountiful water supply which it affords." - Pusadena Union, June II, 1886. 
water pumped by a hydraulic ram up into an elevated cistern at his sightly dwelling on the bluff above the Mill.

Our native Mexican people have traditions of hidden treasure in this and others of the canyons along this range of bluffs. The old-time Mexicans of wealth repudiated paper money, and hoarded great chests of silver and gold coin. In $1844-45$ occurred the rebellion of Los Angeles against Gov. Micheltorena, when he was driven back to Mexico; and in I 846-47 occurred the war between Mexico and the United States. During these troublous and lawless times the wealthy Mexicans often buried their coin in secret places known only to one or two living souls, with some particular rock, or spring, or tree as a mnemonic landmark by which to find the place again. Sometimes these persons were killed, or driven away, or forgot the exact hiding place-and thus the field was opened wide for all sorts of fabulous stories of hidden treasure. Numerous holes have been dug by Mexicans on the Stoneman place in search of buried money-pots, kegs or chests. And similar search has been made in some of these historic canyons ; but I find no reliable account of any such hidden wealth having ever been dug up in this region.

Mill canyon is easily reached by carriage road, and is a very interesting place to visit, because it furnishes a fine stream, and has been more extensively developed than any other one of the series of Glacial Terrace springs and brooks. A small unnamed canyon and brook joins it from the northwest near its upper end.

WiLson's CANYON.-This is one of the largest of the canyons that form an outlet in the lower lip of the great geological basin over which Pasadena is built. When the Pasadena settlement was commenced $\mathrm{Mr}$. Wilson made a private roadway from his Lake Vineyard ranch house,* winding up through the perennial oaks and pasture lands of this charming brookside to the colony lands north of San Pasqual street and west of Wilson Avenue ; and for many years this IVilson canyon road was the short cut and romantic route for a carriage drive from Pasadena to San Gabriel, although four gates had to be opened and shut within a mile, on account of fenced-in pasture lands and orchards on the ranch. Early in I884 I made this trip in forty minutes with ex-Gov. Merrill and Hon. Delos Arnold of Iowa, who wished to catch an east-bound train at San Gabriel. This canyon or picturesque little valley abounded in far-spreading live oak trees, in many of which the curious tree rats of California had their arborial nests or colonies; and the place was a favorite pic-nic resort for the people of Los Angeles as well as of Pasadena. 'The head of Wilson's lake is perhaps a quarter mile west from the mouth of this canyon, and its brook originally ran into the lake. For two years past the Biology department of Throop

* "The wilson homestead is a large, roomy house, of brick and adobe, costing in 1854 \&bout $\$ 20000$ nearly half of which, according to Miss Adams, was spent on the roof. Beneath the house is a large wine cellar."-[Prof. Holder's "All About Pasadena," p. 63.] 
which forms the east abutment of this canyon stands "San Marino," Hon. J. De Barth Shorb's elegant and sightly home place; and Shorb Avenue leads from San Pasqual street into the head of this picturesque canyon, and past the lagoon, then turns southeasterly up the ridge to Mr. Shorb's house. Wilson's, Mission, and San Marino canyons used to be all lumped together as "Mission canyon," by the old Mission populace.

This completes the list of those outlets of the Pasadena geological basin which have received special names as water-bearing canyons, so far as I have been able to learn. And I now pass north to the mountains for larger specimens of the canyon species, and commence at the great Eaton canyon, taking the rest in their successive order from this point westward.

Eaton Canyon.-Officially recorded as "Precipicio canyon," its old Spanish name; but as the Spaniards never did anything to invest it with a living human interest by developing or improving it in any way, their name for it would not "stick" in the popular mind, and it persists in being known only as Eaton canyon, because Judge Eaton first developed and utilized its waters. [See page I 20.] In I 865 Judge Eaton, having lost his dairy stock by the terrible drouth of $1864-5$, engaged to bring out the waters of the big canyon onto the "Fair Oaks" farm, clear the land and plant it with trees, vines, etc. This he did; and he so stamped his strong personality upon the great gorge and its water supply that it is called "Eaton Canyon " to this day, in spite of a different name in the corporate title of its present water company. The starting station of the Mount Wilson Toll Road is at the mouth of this canyon, and up to this point vehicles can go,

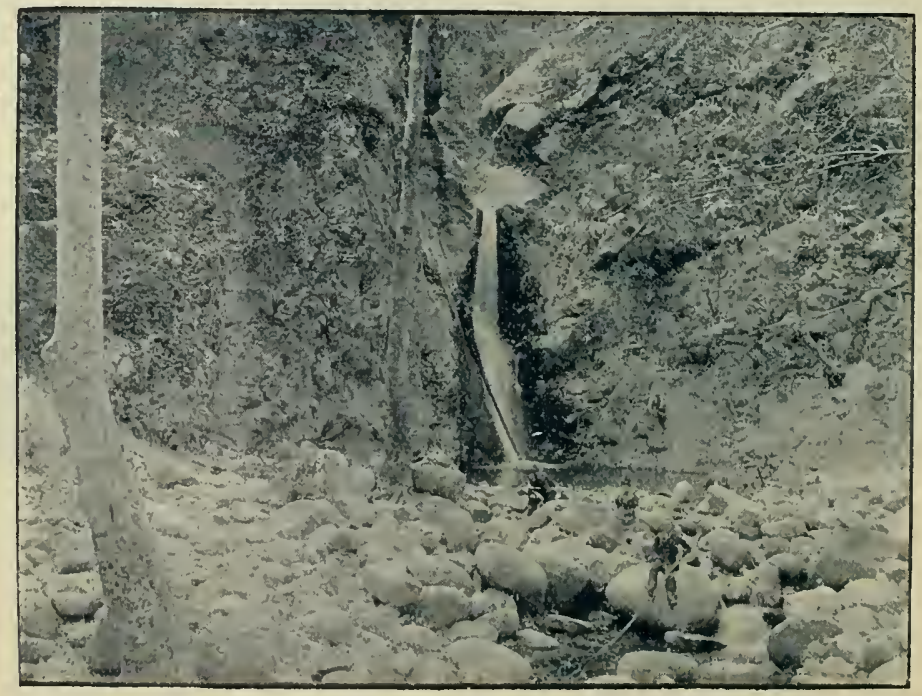

EATON CANYON FALLS-40 FEET HIGH. 
but no farther; $*$ then about a mile farther up the water course, which can be followed by footpath through the narrow cleft between mountainous perpendicular walls of rock, EATON FAL,LS is reached-a beautiful cascade about forty feet high. Waters from the north and east side of Muir's peak, from the east side of Mount Lowe, Mount Markham and San Gabriel peak, from the sonth side of Precipicio peak and Knife-Blade ridge, from the west side of Mount Wilson and Mount Harvard promontory, and from Henniger's flat, all flow into Eaton Canyon. These several peaks and ridges form the great mountain horseshoe rim of what is called in a large, comprehensive way "Grand Basin" in the vast body of literature that has grown up around the wonderful Mount Lowe Electric Railway enterprise. Grand Basin includes the entire watershed of which Eaton canyon is the outlet.

Pine CAnyon.--Next westward is a smaller gap in the mountain declivity, which is characterized by having more pine trees growing in it, and at lower altitude, than any other opening on the south side of Pasadena mountains, thus writing its own name so plainly on its breast that no man has ever attempted to write a substitute. This canyon came into celebrity in I 893-4 from gold mining operations carried on there by Carson \& Dickey in its west wall. [See chapter on geology.]

Dry CANyon. - This is a smaller break in the lower part of the great mountainous ridge between Pine and Rubio canyons. At.its outflow is a tunnel 3,000 feet long, which was made in search of water in $1884^{-} 5^{-6}$, and was reported at the time as the longest water tunnel in Los Angeles county.

The Union of June 4, I886, said of it. "It costs a mint of money and a vast deal of pluck to make such a colossal experiment." True ; and sad to say, it was an entire failure at last-a dry tunnel, waterless and worthless; yet the persistence in pushing it to a finish was truly heroic, and no man could have told in advance that little or no water would be found. It was made by David Dolben for I. M. Hill, S. L. Porter and Dr. George M. Bergen, owners of land there. A few inches of water flow in the upper section, but all sinks away long before reaching the month of the tunnel.

Rubio Canyon.-In I 867 Jesus Rubio, a native Californian, born in I826, and who had become an American citizen by the treaty of peace in r 847 between Mexico and the United States, made a squatter's claim at the mouth of this canyon, built the little farm house which still stands there, and made a start toward the improvements that now constitute "Rubio farm." The Americans called him Rubio, or "Old Man Rubio" - and his water source was called Rubio's canyon. [His name as given in the Great Register is Jesus Marron, his father's name; but Rubio was his mother's old historic family name. See third footnote, page 87.] He now resides at

*The Toll Road Company promises in 1895 to make a wagon road as far up as Henniger's Flat. 
Duarte-I895. In I 877 Rubio sold his claim to one Dr. Hall, who made it his home and died there in I879, In I88 I Mrs. Hall, the widow, sold her little farm and water rights to F. J. Woodbury, who in Dec., I883, joined his brother John in buying the land where Altadena now stands and tunneling and piping water from this canyon down through it, for irrigation and domestic purposes. After sundry changes and additional water developments, this canyon property was in I89I acquired by the present Mount Lowe Railway Company, who have further cleared and improved the farm, utilized the water, built the electric railroad into the canyon, built Rubio

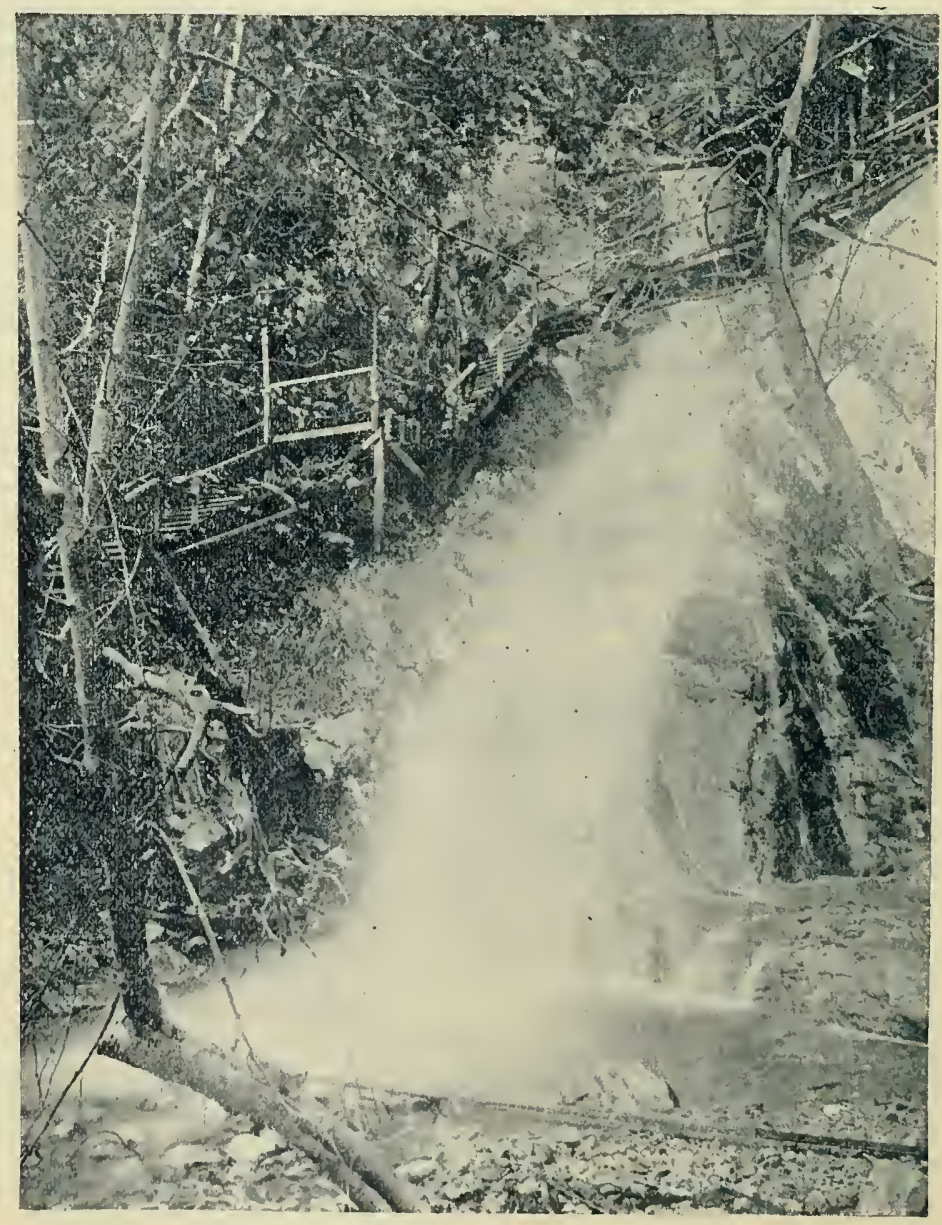

"Land of Sunshine," August, 1895.

MOSS GROTTO FALLS, IN RUBIO GLEN.

Pavilion, $*$ made nine waterfalls beyond this accessible by footways, built

* One day in 1893 a company of nuns visited Rubio pavilion, and among the many pictures there they were shown one of Father Gonzalez Rubio of the San Jose Mission, from 1833 to 1840 , and they were delighted in at once associating his name with this wonderful place. But he was never here. 
the great cable incline, etc., etc. The nine waterfalls referred to, above the pavilion, are as follows :

Maidenhair Falls, 17 feet high — named from the abundance of maidenhair ferns growing on its rocks.

Cavity Chute Falls, 9 feet high.

Bay Arbor Falls, 12 feet high. Named from a clump of bay trees near by, and through or under which the footway passes.

Ribbon Rock Falls, 36 feet high.

Moss Grotto Falls, $33 \% \mathrm{r} / 2$ feet high.

Grand Chasm Falls, a double-leaper of 33 and 15 feet, making the entire falls 48 feet high. This is at the outlet of a towering, narrow gorge called Grand Chasm; and at the crest of these falls there is a stone dam which forms a reservoir called "Mirror lake," from which water is piped down to the pavilion to run electric dynamos, printing presses, and for general uses. Heavy plank stairways lead up across the face of the falls, and a bridge leads over the lake up through the Grand Chasm.

Lodged Boulder Falls, I 2 feet high. Prof. Lowe stood on the "lodged boulder" from which this fall is named and made a speech to a large group of Pasadena visitors, gathered on the canyon stairway, July I, I893. 'This historic scene was photographed and has been widely published.

Roaring Rift Falls, 23 feet high - the noisiest one of the whole series.

Thalehaha Falls, I 2 feet high. The name is an Arizona Indian word, meaning "white water," and was given to it by Prof. G. Wharton James, editor of the Mount Lowe Echo.

[These measurements I made myself during the summer of 1893 , while studying the geology of the Mount Lowe system of mountain peaks, canyons, etc.-E. .]

Rubio canyon extends on up to the summit of the range, with Muir's peak looming up still higher and forming the east wall of this canyon's starting point. It is not accessible above Thalehaha falls except by winding footways down from Echo mountain; * and in this upper section are numerous picturesque falls and lovely dells, the chief of which are Rainbow dell and Leontine falls. Of the historic naming of this great fall I quote from the Mount Lowe Echo of March 29, I 894, the following account :

\section{LEONTINE FALIS.}

In a public address delivered in Rubio Music Hall by Dr. H. A. Reid, August 12, 1893, on "Field Geology of our Pasadena Mountains," the following notable passage occurred:

*The Mount Lowe literature now designates as "Glen canyon" that portion of Rubio canyou extending from above Thalehaha falls to foot of I.eontine falls. The first woman who ever clinbed into the fearful, rock-ribbed gorge at the crest of Thalehalıa falls was Mrs. Prof. Mcclatchie of Pasadena. Jume 30 , 1893. with her husband on a botanical excursion. Then on August 16 Mrs. Dr. Reid passed up the watercourse from this point to foot of Leontine falls, clambering over or around seven different falls in the perilous and seemingly foolhardy venture, which no mortal woman had ever attempted before. But on August 2I Mrs. Herve Friend of L,os Angeles did the same thing. 
"Then comes the great fall, 105 feet high in a single plunge, as seen from below, besides about too feet more above but flowing in a somewhat tortuous course and hence hidden from view by rock walls and growing shrubs. The portion seen from below is elegantly festooned with mosses of richest green; and at its foot there is a semicone of spray upon which a rainbow rests when the sun shines slantwise into it. Mrs. Reid and nyself saw this rainbow, vivid and bright, from 4 o'clock until 5:30 P.M. on July 29. This is really the grandest and finest all-the-year-round waterfall in all this range of mountains, and the only one known to produce a rainbow. And I have named it 'Leontine Falls,' in honor of Mrs. Prof. Lowe, who has earnestly sympathized with and sustained her husband in his most arduous and complex task of projecting. planning, superintending, pushing ahead, and paying for, the wonderful utilization and mastery of nature's resources which we here behold,-- the grandest enterprise which has been undertaken in Southern California since the transcontinental railroads were built. 'Leontine' is Mrs. Lowe's christened name; and by the same token I hereby christen this perennial queen of the mountain falls, and give you its Natalia or birthday legend :

\section{THE LEgEND OF L,ONTINE FAL, S.}

Saint Peter was holding a banquet In honor of souls who liad poured Their lives ont for human uplifting, And found their lives richly restored.

Bright angels in radiant garments Served forth the memorial feast With plates of seraphic devising, And pitchers like stars in the East.

The viands were those of the SpiritThe exquisite essence of Truth, Of Love and all Heavenly virtues For nurturing immortal youth.

The ditink was empyreal nectar Of rivers from life-source that flow ; God's bounty for beings celestialHis bounty for creatures below.

One angel by chance broke her pitcher, And its clear crystal sheen poured down

O'er the Falls of Rubio CanyonThe "Leontine Falls" of renown.

The angel's quick tears for lier pitcher, Falling down the aerial splere,

Were sprent into beanis iriclescent That form yet a bright rainbow here.

The first photographic view ever taken of this waterfall was by $W . H$. Hill of Pasadena, November 10, IS91. And the first woman who ever achieved the climb into its mountain-hidden dell was Dr. Rachel F. Reid, July 25, 1893. Still above Leontine Falls the water company has two tunnels. This canyon follows rapidly down from the summit to the foot of the front range in a line almost due sonth.

Eicho Canyon is a large branch of Rubio, coming in from the west, 


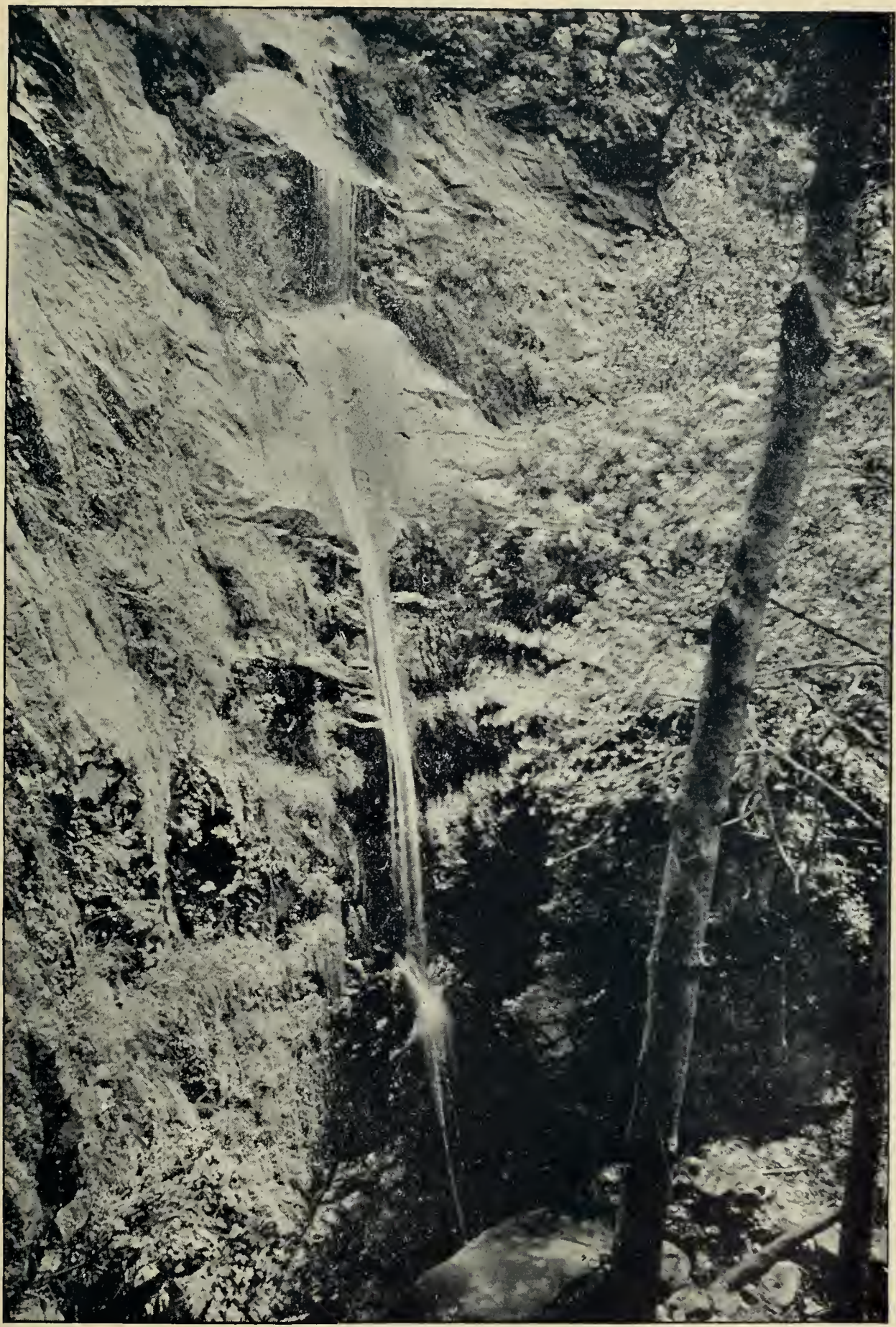

LEONTINE FALLS.

Photo by W. H. Hill of Pasadena, November Io, ISgI, assisted by Thaddeus L'wr. j 


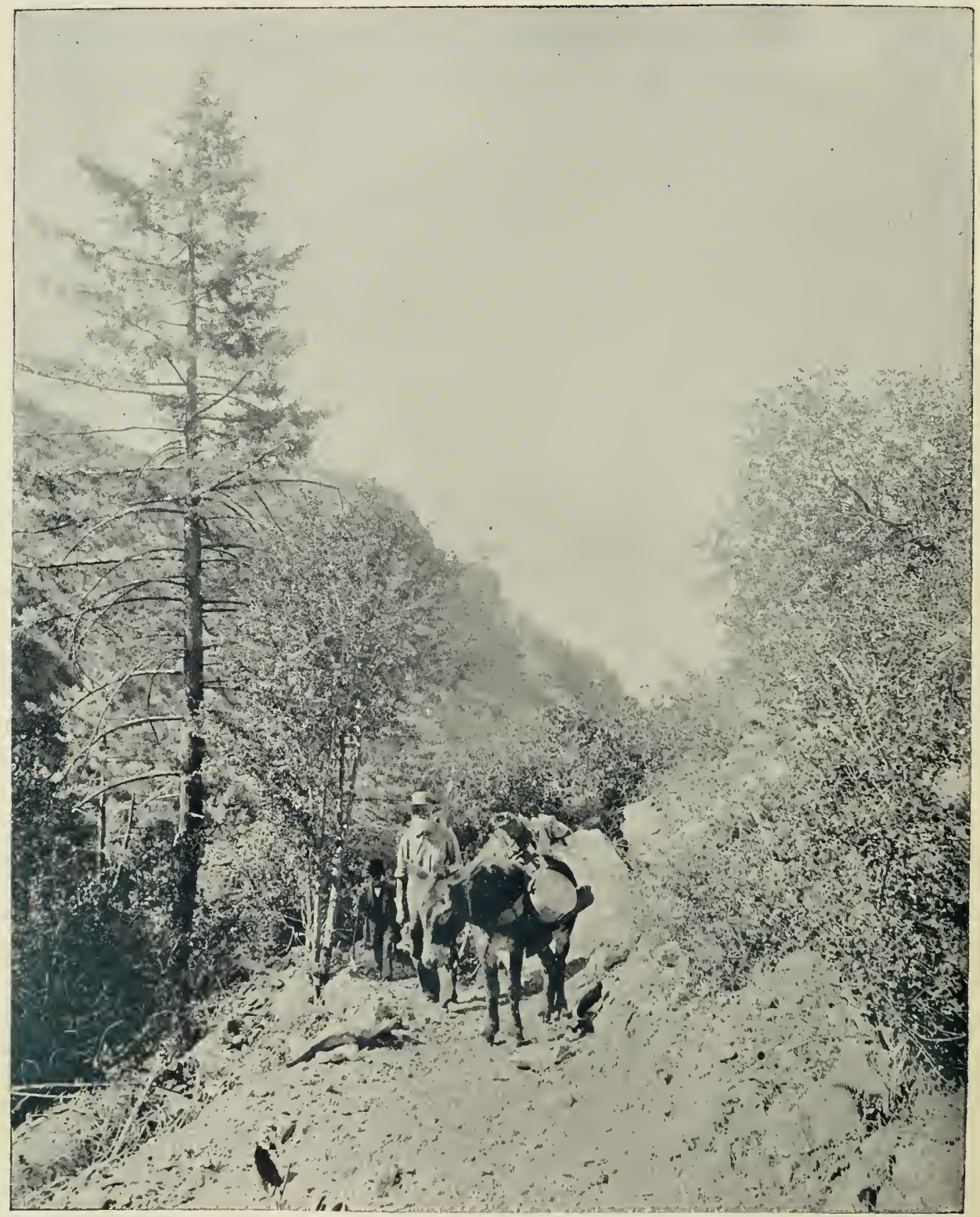

CASTLE CANYON.

Jason Brown and Dr. Reid making the ascent, August 28, 1893. Castle Rock, from which the Canyon takes its name: is seen in the midway distance. Photo and engraving by Herve Friend, Los Angeles. 
which segregates Echo Mountain from the main range, and used to be called West Rubio canyon and creek. It is named from a sharp echo which repeats itself in thunderous, rolling, reverberating cadences that gradually die away in the canyon's summit walls, when a gun is fired or a strong bugle blast is given on Echo Mountain. It has its heading in the great semicircle of summit-reaching white rocks called Echo Amphitheater, at the bottom focus of which there is a tunnel and water supply called "Sycamore Springs," from which water is piped for all uses to Echo Mountain House ; and the surplus is thence piped down r, 400 feet to Rubio Pavilion, where it is utilized on a water motor to run electric dynamos for operating the cable incline cars, electric lighting the Echo Mountain hotel, and other uses.

CASTIE CANYON.-This is a large branch of Echo canyon, coming down from the summit in a line nearly due south, and has some springs or water tunnels in its course. On its east wall is a conspicuous body of rocks which in perspective very strikingly resemble the ruins of some old Irish castle, with its round and square towers, etc.; and from this the canyon takes its name.

LAS Flores CANyon.- Of this name Judge Eaton writes: “'The high point of land running up toward 'Flower Canyon' was always known among the natives as the Mesa de las Flores-the bench or table of flowers-because its surface during the spring season is completely covered with poppies and may be seen far out on the Pacific ocean."

In 1885 , when the project of making a burro trail to the top of the mountains by way of Las Flores canyon was being talked up, a writer in the Valley Union of October 16, I885, said:

"Senator Arnold of Marshalltown, Iowa, told me that once when he was going by steamer from San Diego to San Francisco he noticed this tongue of land above all the rest along the mountain base and asked the captain of the vessel what point it was. He said it was Las Flores canyon (known also as Forsyth canyon), and was a land mark by which they could determine their relative position on the coast line, even when they were 80 miles out at sea. This was a most interesting piece of information to the Senator, and he told the captain about his intimate friends, Col. Banbury and the Woodburys," residing on that very slope of land. It was called Las Flores, or 'The Flowers,' because of the wonderful profusion of wild poppies which in their season tinged that whole canyon slope of a noticeable reddish color, even at so great a distance."

Gold mining operations were commenced in this canyon during the winter of $1892-3$ by Wm. Twaddell and associates. [For particulars of which see chapter on Geology.] Echo Mountain forms the east wall of the canyon; and the upper section of the Mount Lowe Electric Railway cross the upper portion of it and then passes around and up along the walls of Millard and Grand canyon.

Elmas's Canyon.-This is a small canyon in the face of the footmount- 
ains next west of Las Flores, and takes its name from Henry Elms, who opened and improved the land at its mouth in 1883 , and resides there yet, I 895 .

Chiguito Canyon, west from Elms's place.-Chiquito is Spanish for "snialler," and it was named by Mr. Elms. In April, i 895, a company consisting of P. W. Lloyd, Charles Copelin and J. T. Rood of Pasadena, and a Dr. Crandall of Los Angeles, were digging for water on a large scale in this canyon.

LEIGHTON'S Canyon.-West by south of Chiquito canyon is the farm of S. L. Leighton, whose house stands on the canyon ridge, up the crest of which runs his road over the footmountains into Millard canyon. His ridge road was worked and used by the North Pasadena Water Co. in I 892, while piping water out from some mountain springs above Millard Falls.

Millakd Canyon.-This was called by the Spanish-speaking native Mexicans Canyon el Blanco - white canyon-because of the whiteness of the rocks in some portions of its mountain walls. This is especially noticeable in its upper portion, now called Grand canyon. In I862, a man named Millard settled as a squatter at the mouth of this canyon, utilized its waters, and engaged in raising bees and hauling wood down to Los Angeles. Millard lived here ten years, or until 1872 , during which time his wife and one child died and were buried on what is now the Giddings farm; and he finally moved away to the Downey settlement in order to get where his children could attend school-but the canyon still retains his name. In I 874, Millard's abandoned claim was taken by Edwin Baker; he made some further improvements, and in 1877 sold his rights and holdings there to the Giddings family, who still occupy it, having bought adjoining lands and piped water out onto them. MILLARD FALLS is a fine cascade, 58 feet high, and was for some years a favorite picnic resort, the Giddings people having made a wagon road up to it, on which they charged a small tollage fee to help keep it in repair. These Giddingses were cousins of Joshua R. Giddings, the famous anti-slavery member of Congress for seventeen years from northeastern Ohio (Ashtabula county), who was a giant of pluck and moral power in his day. In his book entitled "All about Pasadena," Prof. C. F. Holder says:

"The writer was once detained for two days by the Millard canyon stream, that in midsummer almost disappears. A cloud-burst in the mountain filled it to overflowing, and the noise of the boulders, literally bowled from the upper range, was deafening and a continuous reverberating roar. Such occurrences are rare."

Punch Bown Canyon.-Half a mile or so above Millard Falls there opens into Millard canyon from the northeast a beautiful gap in which there are some fine falls, and two interesting potholes, which Eugene Giddings and Calvin Hartwell had dubbed "devil's saucer" and "devil's 


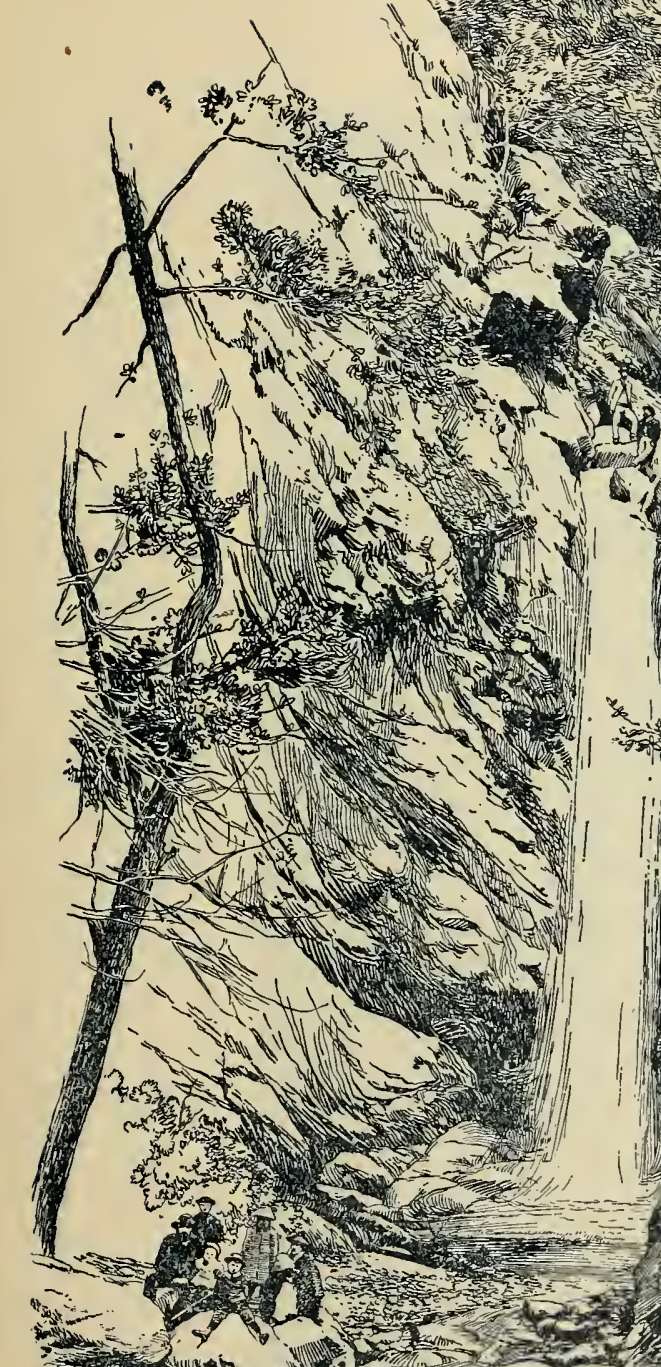
4 (3)

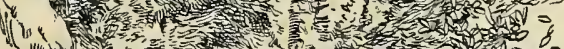

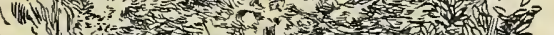

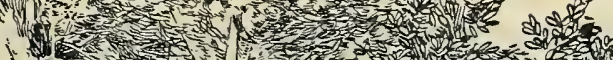
14 N

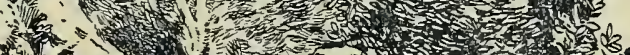

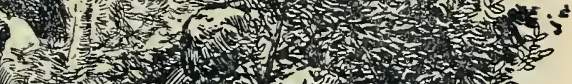
$141010 \%$ an 1) (An

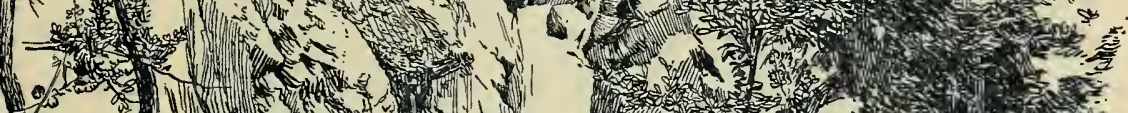
7.2. , 1 (1) (if is No 30 .

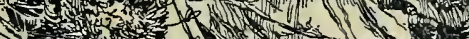

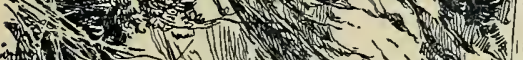
1.

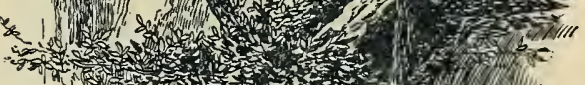

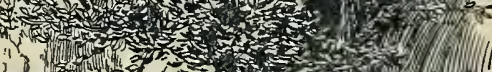
(1) Ning (4) (n) 4 , W. 40 ,

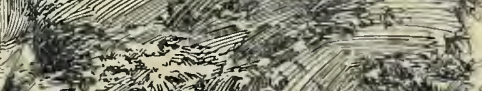
(1)

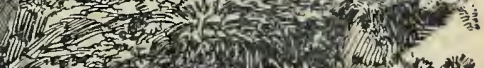

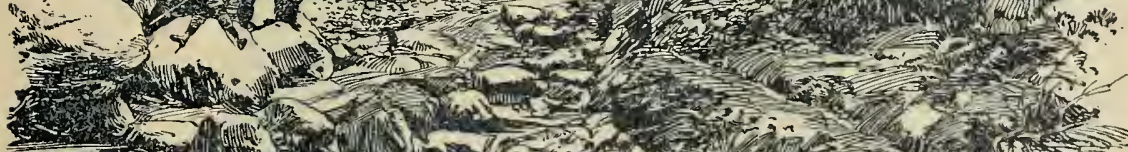

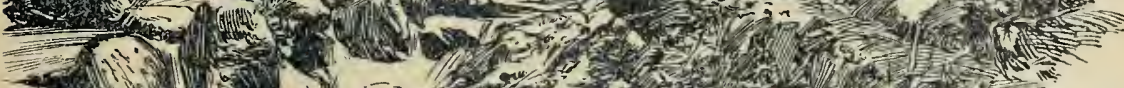

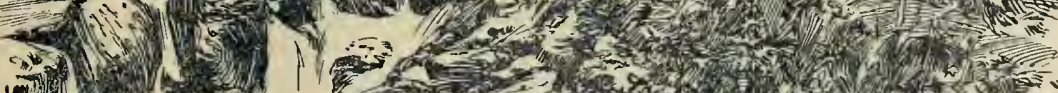

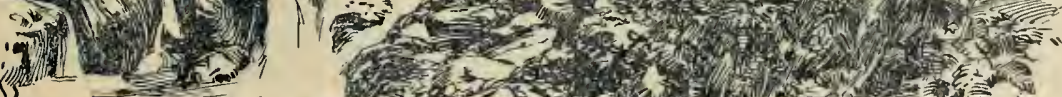

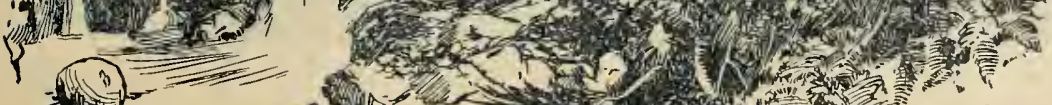

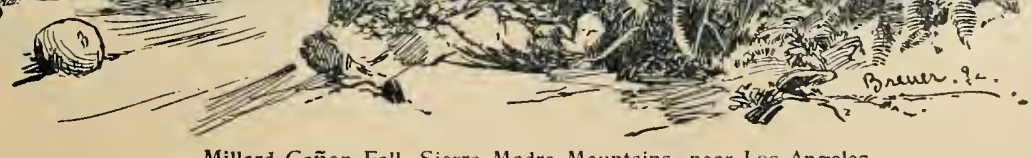

Millard Cañon Fall, Sierra Madre Mountains, near Los Angeles. 


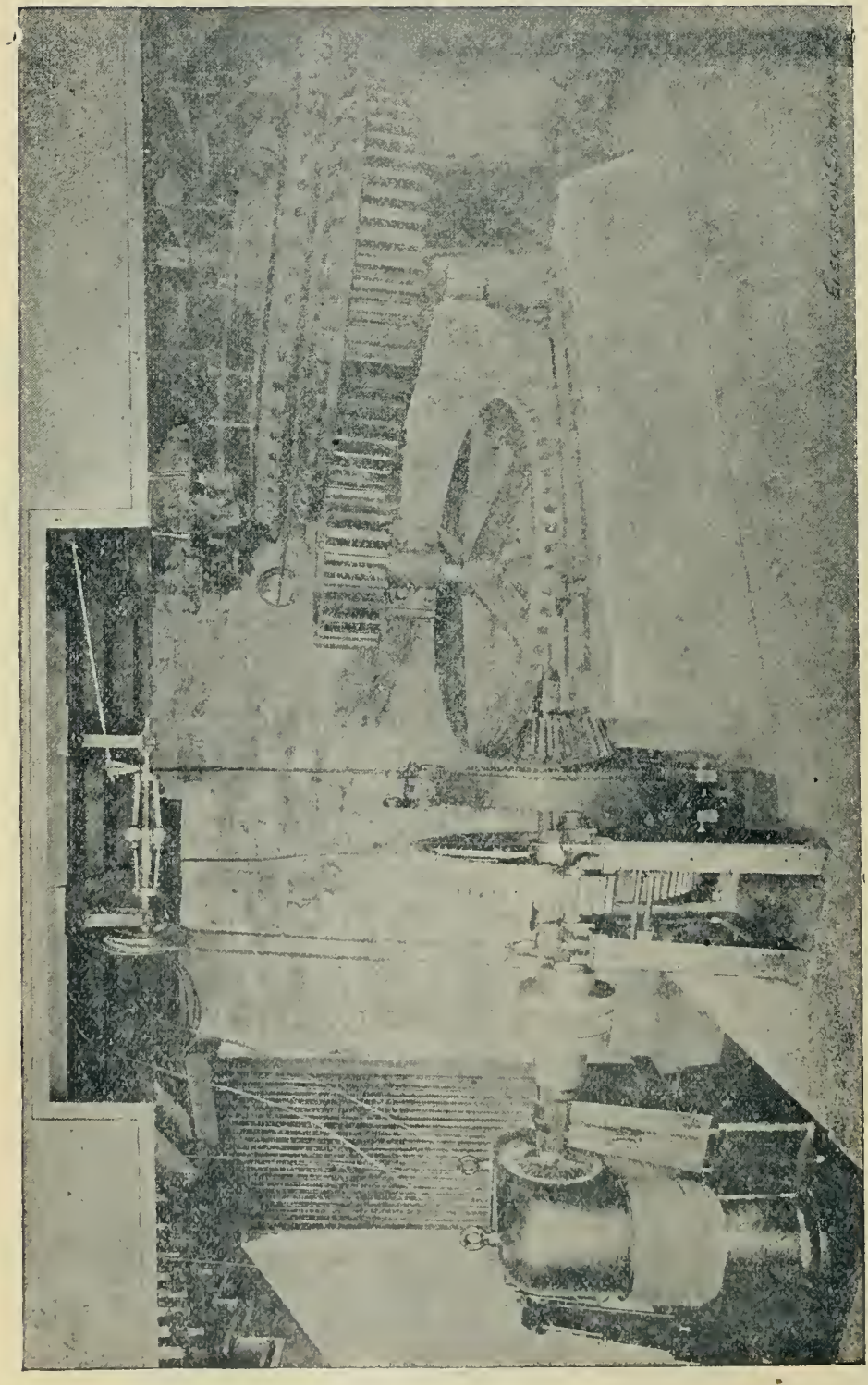

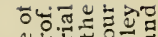

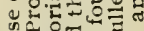

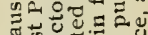
of $0=0$

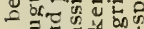
0ंदे हु tov

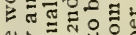

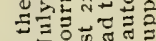
$z$ 年的 La

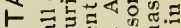
乙 ते च.

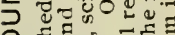

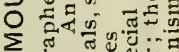

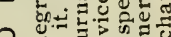

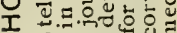
U

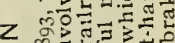
○ क.

于长岛

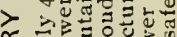

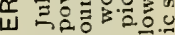

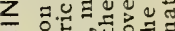

$\bar{I}$

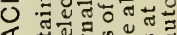

$\sum$

$\Sigma$ 㺃品

山 云可可

虫

\&

ठ 证

$\omega$ 过 w

Z

U

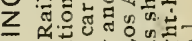

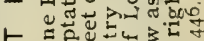

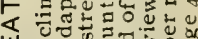

山 $\Xi$ क वे

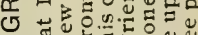

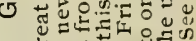

山

工

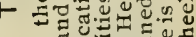
o 和言

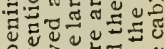
O을

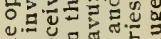

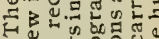
y

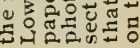


punchbowl." I failed to discover anything satanic about the place, or its great granite tureens of pure mountain water, and concluded to dehoof and dehorn it, and introduce it into good society without any "devilish" primogeniture attachment. The PUNChBOwL. FALIS are 70 feet high; and the bowl or "pothole" was so deep, smooth and steep-walled that I could not get down to measure it. The SAUCER FALLS, lower down, are 25 feet high ; and the saucer measured 2 feet, Io inches depth of water. Above this fall is a chute of 15 feet, and below it one of about 18 feet. These falls are about three-quarters of a mile up from the main Millard canyon, or Grand canyon as it is called above this point.

GRAND Canyon.-This comprises that portion of the great mountain gorge from above Millard Falls up to Crystal Springs, and the Alpine Club house station on the Mount Lowe Electric railroad. It is the portion which bore the old Spanish name of "Canyon el Blanco," from the white rocks that form its north wall. About half a mile below the club house is Grand CANYON FALLS, 92 feet high, deeply recessed by erosional wear in the great ledge of reddish syenite rock.

Alpine Falls.- - A few rods west, below the Grand Canyon Falls, a narrow, deep-gorged branch canyon enters from the worth with a very high fall, which I did not succeed in measuring, but thought it must be at least I 30 feet high in its front line of single leap; and I have not been able to learn of anybody ever attempting to measure either of these falls, or write any account of them, before. They are now (August, I895) very difficult of access; but the Alpine Club will make a footpath to reach them, both above and below, from their club house. When I first visited these falls in July, I 893, there was a little water passing over; in August, September and October they are usually dry precipices, but during the rainy season they are grand mountain cataracts.

Chapman's Glen, where the famous Yankee "pirate prisoner' got out pine timbers for the old church at the plaza in Los Angeles. [See pages 43 to 52.] Hon. Stephen C. Foster told me that he once went with some Spanish hunters up through La Canyada; and Tejunga canyon was pointed out as the place where timbers were cut for "building the old church." This was true, but they were for the old church at San Fernando Mission-not at Los Angeles. [See footnote, pages 46-47.] May 27, I 895, I stayed over night at E. W. Giddings's house. then the next day walked up the watercourse of Millard canyon from its mouth clear to Crystal Springs, in order to satisfy myself whether it was a preposterous supposition that Chapman had brought timbers down that way. And I had spent the whole day twice before on the same errand, December I and December 26, I894. Then, again, August 25, I 895 , Mrs. Reid made the hard and dangerous climb with me from Crystal Springs down around the Graud Canyon Falls, into the 
Glen, and saw the decayed old stumps and logs which still remain as relics of Joe Chapman's prisonership there, one of the stumps measuring 3 feet and 8 inches in diameter. She was the first woman who ever trod that wild historic spot, or viewed those lofty Grand Canyon and Alpine Falls.

Giddings Trail. Canyon.-This is the first branch or tributary of Millard canyon; and the Giddings trail follows up its southeast wall to the summit ridge, which was in 1886 flagged, staked, and claimed for name as "Giddings Peak." [See article "Giddings Trail."] This canyon starts at "Grizzly Point" of the Mount Lowe literature and drops rapidly down sonthwesterly into Millard canyon. The upper trolley section of the Mount Lowe Electric Railroad crosses the heading of Las Flores canyon first and this Giddings Trail canyon next. [See article, "Giddings Peak."']

Negro Canyon.- This is a comparatively small but bountiful waterbearing canyon, opening southwestward into the Arroyo Seco, and which took its name from a colored man named Robert Owen, who got out wood from there in the early sixties. The Centennial History of Los Angeles County, p. 44, says of him :

"'Robert Owen, familiarly called by Americans 'Uncle Bob,' came from Texas in December, I853, with 'Aunt Winnie,' his wife, two daughters, and son, Charley Owen. They survive him. He was a shrewd man of business, energetic and honorable in his dealings; made money by government contracts and general trade. He died, well esteemed by white and colored, August I8, I 865, aged fifty-nine years."

This canyon was government land, beyond the bounds of any land claimed by anybody else. Uncle Bob had secured a contract to supply fuel to the United States officers and soldiers at Los Angeles, and here is where he chopped down trees for that fire-wood supply. Instead of spending his money getting drunk and gambling, as others did, he saved it and bought up cheap vacant land at Los Angeles, which became highly valuable as the city spread over it, and made him the richest colored man ever known in the county. The first religious services ever held in Los Angeles county by colored people were at his house, in I 854 . His property was on San Pedro street and new Los Angeles street. "Uncle Bob" was a slave in Texas and hired his time, saved money, and bought his ow1 freedom; then kept on and sent money back to buy his wife and three children. ['Two grandsons of this man own the Owens block on Broadway near Third street, Los Angeles, and other valuable properties.] The water supply for the Las Casitas settlenent is piped down from Negro canyon. The mountain trail which two sons of the historic "old John Brown," who gave his life for the Negro race, commenced to build from Las Casitas to Brown's peak, ran partly in this same "Negro canyon."

Deadman's Canyon. - This is another small branch of the Arroyo Seco, next north of Negro canyon. In 1873 a very old Indian lived in a 
cabin alone here, getting out wood for Jesus Rubio (Marrone) after whom Rubio canyon is named. One day the old man was found dead, nobody knowing just when or how he died. And the canyon took its name from this circumstance. Old Mr. Brunk, who was one of the men who found the dead Indian there, always claimed that he had been murdered; but I don't believe it.

Brown's Canyon. - This is a small branch of the Arroyo Seco, next below Negro canyon, and is on the mountain homestead taken up by Owen and Jason Brown in $\mathrm{r} 886$, after Jason had sold his land where the Las Casitas Sanitarium now stands. It was on the east wall of this canyon that they started their trail to Brown's peak, but which never reached the summit.

The Arroyo Seco Canyon.-Arroyo Seco is Spanish for "dry creek," and this great branch of the Los Angeles river has been called by that name almost ever since Los Angeles was founded as a pueblo [town] in $\mathrm{I} 78 \mathrm{I}$. The reason was, that it was a running stream during the winter, but always went dry during the summer and autumn seasons. In the days of the Spanish rule it was their most famous hunting ground; and here were often captured wild cats, mountain lions, or bears, for the bloody sport-pens of Los Angeles; for bull fights, bear baiting, etc., were lawful sports, even on Sunday, up to 1855 - and on week days as late as October 26, 1872, when the last great public bull fight occurred there. The old accounts give two cases at least where bears were lassoed in the Arroyo Seco by one hind foot and one forefoot, and then dragged bodily over the ground down to Los Angeles (by the riatas being attached to the pommels of the horsemen's saddles) and there put into the bear pit to fight with dogs, or a bull, or wild cats. Pasadena lies on the east bank of the Arroyo, and extends across to its west hills, where extensive grading and improvements were made by $\mathrm{Mr}$. C. W. Scoville from 1887 to 1893 . The following item from the Valley Union of February 26, I 886 , gives some idea of the condition of things prior to 1886 , where all is now so changed by dams, bridges, retaining walls, county road, private winding drives, substantial dwellings, etc.:

"There has been more inquiry lately [February, 1886] for Arroyo lands, or wood lots, which extend from the Arroyo Drive across the great gulf and up the half mountainous hills on the west side of the stream. These hills are as full of local names as was old Judea. Jumbo Knob and Jumbo canyon belong to Charley Watts. There is undeveloped water in this canyon. The Fremont Trail and Wildcat canyon are on Mrs. Hood's lots. Buzzard Cliff and Gold-hunter's canyon are on Dr. Reid's lots. Near the head of this canyon are some old gold diggings. The gold dirt assayed only $\$ 4$ or $\$ 5$ per ton, and hence wouldn't pay for working. Fern canyon is on Johnson's land, but opens down on the west end of B. F. Ball's and J. F. Steen's wood lots. It is a sort of gap through the hill range, and would furnish the shortest and easiest route for a road from Pasadena to 
Eagle Rock. [Just where the county road now runs.-- En.] The vast Arroyo gorge from F. R. Harris's lot on the south, up to Mundell's chain of lots on the north, is called Giant's Glen, and is a weird, wild, romantic place to ramble in."

The above-named ownerships have all changed. Jumbo Knob remains in its place, looking like the famous big elephant's head lying at rest, with his trunk reaching down almost to the Arroyo in search of water, the same as before. But the buzzards have been driven from their ancient cliff; and Fremont's trail [although Fremont never rode within ten miles of it], and Wildcat canyon and Giant's Glen have all been obliterated by Mr. Scoville's extensive improvements. [See "Fremont's Trail," page 68.]

Along the banks of the Arroyo, from Lincoln Park far up into the mountains, there are numerous springs, from which Pasadena derives her water supply. These are all mentioned and described by name in another place. But the most notable point in the Arroyo Seco is

DEVIL's GATE, - which was so named by Judge B. S. Eaton in $185^{8}$; and the reason for it he writes me thus:

"From its resemblance to a point of that name on the Sweetwater creek, the last water that is seen running east and finding its way into the Gulf of Mexico, as seen from the old California trail by which I came to California with ox teams in $185^{\circ}$. This Arroyo Seco break throngh the spur of the Verdugo hills corresponds so perfectly with that of the Sweetwater, that when I first saw it I was carried back to my trip over the Rockies."

Cot'Tonwood Canyon.- On the west side of the Arroyo Seco, between Devil's Gate and Linda Vista, there is a small canyon where N. G. Yocum made two tunnels in 1887 , obtaining a small supply of water, and it was then called Yocum's canyon. In 1892 it was taken by the endorsers of a certain promissory note, through their trustee and attorney, W. S. Wright, who organized the "Cottonwood Canyon Water Co.," and gave the place this name because some cottonwood (?) trees [California poplar] were growing there. This company was incorporated October 29, 1892. [See "Water Companies."']

WildCAT CANYON.-This name was given by the early settlers to the canyon where the Scoville drive meanders up the west Arroyo hills to Scoville Heights; and the old Garfias trail (miscalled "Fremont's trail") was on the ridge that formed the north side of this canyon.

FERn Canyon.- The gap through the Arroyo west hills where the county road from Scoville's bridge leads through onto the Johnson farm, was given this name by Hon. Delos Arnold in the spring of 1881 , from his finding some rare ferns there; and the name remained.

San Rafaei, Canyon, or Crewk (Johnson's creek). -This descends from the west and enters the Arroyo Seco nearly opposite the foo of West 
Columbia street. It is the outlet of Johnson's lake (formerly called Beaudry's), and forms the principal drainage of the great Johnson farm on the hills west of Pasadena. The bed of this canyon for half a mile or so is a mortar-like puddingstone or conglomerate,-called also ".cement rock," the same as the notable Eagle Rock, about two miles northwest from this point; and the exposed conglomerate here at the mouth of the canyon is an eastward extension of the same ledge or stratum of this peculiar kind of rock from which the Eagle Rock is an outcropping or uplifted head; and this same conglomerate ledge has been traced and identified across the country as far eastward as Titus's artesian well, a mile or so south of Lamanda Park. In San Rafael canyon there is a small but pretty waterfall Puddingstone Falls - with a fine specimen of a pothole at their foot. In this connection it is proper to give an account of the Eagle Rock above referred to; and I here quote from the Valley Union of November 22, I884:

EAGLE Rock.- " About three miles over the hills westward from Pasadena stands a monster of a bald, rounded, weather-beaten rock which has been called by various names, but it is best known as Eagle Rock, and gives its name to Eagle Rock creek, Eagle Rock valley, Eagle Rock settlement. It is probable that very few of our readers know why this name was given it. although many Pasadenians have visited it as one of the natural curiosities of this region. The west side of the rock presents a face of perhaps I5O feet in height, and in this face are two recesses called the upper and lower cave. The lower cave can be reached by climbing along on slight protuberances of rock, although it is a somewhat difficult and dangerous passage; Mrs. Dr. Reid climbed there a few weeks ago, and says she wouldn't attempt it again for a corner lot; but the upper cave is inaccessible. Over a year ago some adventurers made a rude ladder and climbed up it from the lower to the upper cave, and left the ladder there as a testimony of their daring and prowess. It was a constant bait of temptation to other young fellows to risk their lives by attempting the perilous ascent, and finally it was pitched over the precipice and destroyed. The overhanging portion of the rock which forms the roof of the two caves, is so shaped that from some points of view it presents a well defined appearance like the outspread wings of an eagle, and that is what gave it the name of Eagle Rock. This peculiar appearance is well seen from the west hill-side, half a mile or more down the valley from the rock, and is also seen from Mr. Edwin Brown's place, about two miles distant."

The TUnneL. - Within a mile above Puddingstone Falls is the BEAUDRY TUNNel, r6o paces long, through the range of hills which form the south wall of this canyon. It was made by Prudence Beaudry, who formerly owned the Johnson ranch, and resided there. In making it he had three objects in view : Ist, To provide an easy and direct road from his farm to Los Angeles, instead of going a long way around, with heavy up-anddown-hill hauls. 2d, To pipe water down to Los Angeles or its northerly suburbs from a lake that he produced by using the material excavated from the tunnel to build a dam across the canyon, the dam serving also as road- 
way. 3 d, The chance, which was at that time deemed fairly good, of finding coal in these hills. Only the first object was ever realized. This tunnel is wide and high enough for a loaded hay wagon to pass through, or a covered carriage without lowering the top. I examined it, and paced its length, in 1885 - I60 paces, or about 480 feet.

Columbia Hir.L. - When the colony lands were first subdivided, a considerable body of hill-top land south of West Columbia street and west of Sylvan Drive or Avenue was reserved "for church, school and reservoir purposes." But all except a reservoir site was afterward sold to A. O. Porter and others. [See "Annals of the Schools," and "Sierra Madre College" for its later history.] It was called "Columbia Hill" from the fact that West Columbia street ran from Orange Grove Avenue on a winding grade down its north side to a junction with Arroyo Drive. The highest part of the hill is now occupied by the fine residence of Chas. D. Daggett, Esq. (the old school or college building made over), while other portions of it are occupied by residences of John Wadsworth, Chas. R. Foote, and others.

GRACE HiLl. - The body of land now known by this name was in one of the four fifteen-acre shares selected by Judge B. S. Eaton, when the original colony lands were allotted by. free choice, January 27, I874. Judge Faton sold it to a Mr. Chapman. In the winter of $1883-84$ Charles Legge bought from Chapman ten acres, which included the main hill or its highest part, and in five weeks after its purchase he sold it for One Thousand Dollars MORE than he paid for it. This was the first big gun of the "boom," and for a while Charley Legge wore the champion belt as a real estate operator. The purchaser of this splendid building site was a Mr. Himebaugh, who made some slight improvements in the way of landscape gardening, and named it "Grace Hill," after his daughter Gracie. He next sold it to Geo. W. Stimson, who made further and quite elaborate landscape improvements, and put it into the real estate market for sale at $\$ 25,000$. Here it hung untaken for three or four years, Mr. Stimson meanwhile keeping an expert gardener, Alfred Ellis, in charge of it; and it grew more beautiful every year. Finally Wm. Stanton, from Pittsburg, Pa., bought it, and built the noble dwelling which is now his family home on that eminence, from which there is such a superb and far-reaching outlook in every direction.

RAYMOND Hili.. - This foothill peak formerly belonged to what was known as the Marengo ranch, or Bacon's ranch. In 1883 Walter Raymond examinied sites for his contemplated great hotel project, at San Diego, San Bernardino, and Riverside, but finally settled upon this Bacon hill at Pasadena as coming the nearest to his ideal of anything he had seen; and he accordingly purchased it, with a tract comprising about fifty-five acres. The hill was then much higher than now, as it had to be cut down thirty-four 
feet to get a large enough area on top for the hotel buildings and grounds; and although it seems to loom up so loftily, the present top of the Raymond hill is just level with the sidewalk at corner of Fair Oaks Avenue and Colorado street.

\section{OAK KNOLL. - See page 344.}

ThE Old Mill.- In his work entitled "All About Pasadena," Prof. Holder says : "As to the age of El Molino [the Mill] no one knows, and there is no exact record of its builders; so in a way it is as mysterious as the mill in Newport, Rhode Island." This is all a mistake; but he was led into it by sundry errors about the Old Mill in the Farnsworth book, published in $\mathrm{r} 883$. This stone grist mill was built during the rigorous, energetic, work-driving administration of Father Jose Maria Zalvidea, while he served as official head of the San Gabriel Mission and brought it to its climax of industrial and commercial success, from i 806 to 1826 . The padre's "Old Mill " building was $24 \times 55$ feet, with walls of solid masonry from three feet to four feet nine inches thick, and was erected in I 8 Io to I 8 I2.* There were two great arches in the lower story (east front) where the water-wheel was placed; and in the upper story, or grinding room, there were two small windows protected by iron bars and heavy shutters. The original roof was of tiling. The Indians had been portioned off into about thirty classes of work people, with Claudio Lopez as major-domo over all, and a minor-domo or task-master, armed with rawhide whip, [see page 34.] over each class, whose business it was to see that every man and woman worked daily, according to rule. But the Indians so frequently revolted against their hard overseers, or escaped to the mountains as hostiles, that rigid guarding and severe punishments became necessary, as well as provision for a stronghold against attacks of the " unconverted " Indians. Therefore the San Gabriel Mission church as it now stands, as well as this mill building, seem to have been made with a view to their serving as castles in time of possible need. $\dagger$ And some parts of the mill, both above and below, were undoubtedly used also as a jail or house of correction for the more obdurate offenders.

In March, I829, a Boston gentleman, Mr. A. Robinson, spent two or three days at San Gabriel, having some trading business with Father Sanchez there-for his Boston trading ship was then lying at San Pedro harbor with a cargo of goods from Yankeeland. Mr. Robinson was a man of culture; spoke and read the Spanish language; and remained seventeen years engaged in ship trade and land travel up and down the coast. In

* Hugo Reid, in speaking of Father Zalvidea, says: "He it was who planted the huge vineyards, * * laid out the orange garden, fruit and olive orchards; buill the mill and dam; made fences of * * laid out the orange garden, fruit and olive orchards; buill the mill and dam; made fenc
lunas [broad-leaved cactus] round the fields; * * brought water from long distances;" etc.

†A spring flows out from beneath the heavy buttress at the northeast corner of the mill; and some writers, following the cue given by Miss Alice P. Adams in $183_{3}$, have made a great 11 ystery out of it. But the explanation is simple enough. In case the Spanish soldiers and priests should ever find it necessary to take refuge in the inill as a fort and withstand a siege by hostile Indians, this spring could be reached by excavation from within, for a water supply. It was a wise precaution, but never happened to be needed. 


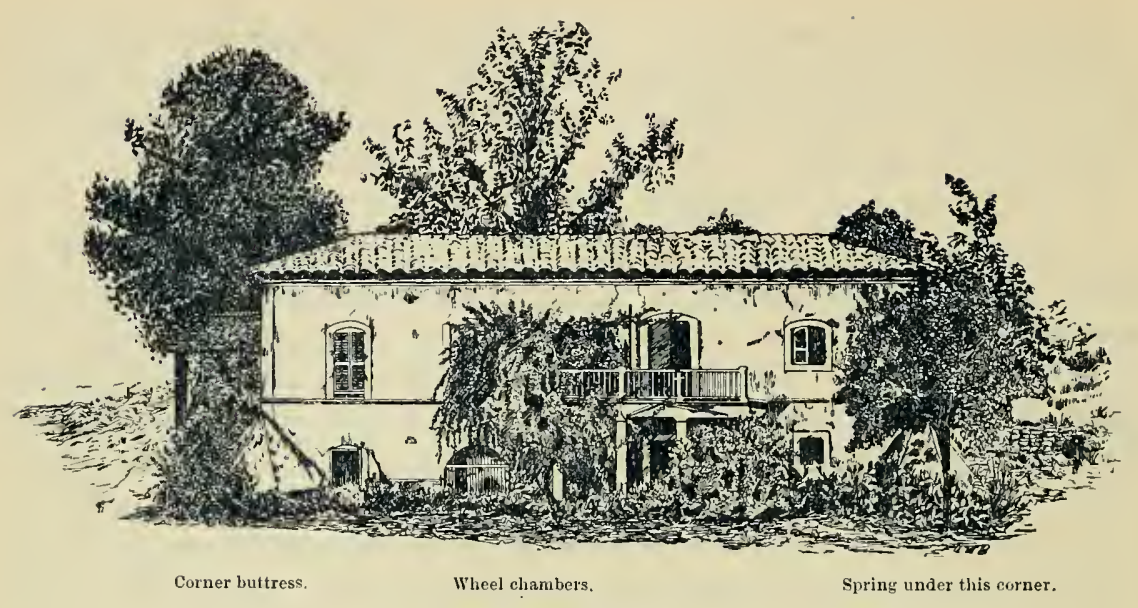

THE OLD STONE MILL.

As sketched in "Land of Sunshine," Ju1y, 1895.

I 846 he published at New York a book entitled "Life in California." On page 33, speaking of his first visit at San Gabriel, he says: "On the declivity of a hill is erected a molino, or grist-mill, surrounded with fruit trees and flowers. A beautiful lake lies calm and unruffled in front, and all around fresh streams are gushing from the earth, and scattering their waters in every direction. It would be a magnificent spot for a summer retreat, and much reminded me of many of the beautiful locations to be met with in the vicinity of Boston."

In the centennial "Historical Sketch of Los Angeles County," published in I876, there is a reference to the "Old Mill" which was written by Hon. J. T. Warner, a native of Connecticut who settled at Los Angeles in I 831, while the San Gabriel Mission was still flourishing in full vigor, under Padre Sanchez's prelatical rule. And Warner says :

"At an early period in the history of San Gabriel, a water-power mill for grinding wheat was constructed and put in operation in front of and near the Mission building. At a later period a new grist-mill was built by the Mission, and placed about two miles from the Mission proper.* This was also operated by water power. The building in which was placed this mill is now the property of E. I. Mayberry, and is used for a wine cellar. A water-power saw-mill was also built by this Mission, and was located near the last mentioned grist-mill. These were the only mills made or used in California, either for grinding or sawing, in which water was the motive power, or in which a wheel was used, for more than half a century after the founding of the first Mission in continental California. In these two gristmills the revolving mill-stone was upon the upper end of a vertical shaft,

* This is a mistake. The oid stone will was built first, under Padre Zalvidea, in 1810-12. The mill opposite the church was not built until 1 $251-32$. Joseply Chapman was the carpenter and millwright who buitt it, and Claudio I,opez was then major-domo. See pages 42 and 51 . 
and the water-wheel upon the lower end, so that the revolution of the stone was no more frequent than that of the water-wheel." *

The grinding stones from this old mill were laid up for a horse-block at the south front of Hon. J. DeBarth Shorb's residence, "San Marino," $\dagger$ and can be seen there yet $-\mathbf{I} 895$. They are $2 \frac{1 / 2}{2}$ feet in diameter and 7 to 8 inches thick. The kind of stone is volcanic tufa, said to be found some distance up the San Gabriel canyon. The water from L,os Robles canyon or creek (the same that has been called "Mill Spring creek," and "Willowdale creek,") was conveyed in a ditch along the side of the bluff on the Stoneman and Richardson farms to the upper side of the mill, where it flowed into a funnel-shaped cement cistern or fore-bay about i 2 feet deep. From the bottom of this cistern a narrow spout-flume extended through the thick stone wall into the brick-arched wheel chamber, and the water poured through the spout horizontally against the buckets of the water-wheel. A vertical shaft extended from the water-wheel up into the second story, where it bore the millstone on its upper end to do the grinding work. The water from Mill canyon was also brought by a ditch into the fore-bay of this mill. After the water had been used here it flowed by a cement ditch into the dam or lake, to serve the sawmill and other works below the dam. I visited this Old Mill, with Ex-Gov. Merrill and Hon. Delos Arnold of Iowa, in January, I884. But I went there again May 23 and July 25, and August 30 , I 894 , and other times, to re-examine and measure some parts. The curious fore-bay, with its adjunct reserve cistern and their inflow conduits are still to be seen at the up-hill side of the building; while in the lower story the wheel chamber is intact, with its recesses in the side walls for holding the heavy timbers to support the water-wheel on its vertical shaft; the hole in the arch for the shaft to pass up through; the inflow water flume, etc., are plainly to be seen. There are two arched wheel chambers, but only the south one was ever supplied with a working wheel, for the reason that the earthquake of $18 I_{2}$ cracked the north fore-bay before the wheel work was completed; and the crack has been widened a little by several "quakes" in later years.

In 1859 Col. E. J. C. Kewen, a soldier of the Mexican war and exattorney-general of California, purchased the old mill property, the building being then still just as the padres had left it, although a family had been living in it for several years. He made sundry additions and alterations to fit it for a genteel dwelling; and his family resided there until his death, November 25, I879.\$ Since that time it has only been used as a wine-cellar

\footnotetext{
* This was true of the first or stone mill, but not of the one built at the church. See page 52. War ner is also mistaken about these being "the only mills," etc., for Chapman had built one at Santa Ynez in 1820-2 T. See page $5 \pi$.

$\dagger$ 'The old mill stones in front of our home, now used as a horse-block, are the identical ones placed in the "Old Mill by the L,ake, by the Mission Fathers."-Letter of Hon. J. DeBarth Shorb to Dr. Reid, March 29, 1894 .

†The Hist. I.os A. Co. published by Thom pson \& West, 1850, at page 107, says: " 1858 . In Felruary, Col. Kewen of Walker filibustering fame; settled in I,os Angeles to practice law."
} 
below, and the up-stairs part as a storehouse for products of the ranch, and bunk-room for the workmen. The place is now owned by E. L. Mayberry, who has made extensive improvements, and built a fine new residence on a bluff above the mill.

WILSON LAKE. - This is marked on the official map of Pasadena as "Kewen Lake," and the maker of the map informs me that it has that name in the county records. But it had been known as "Wilson's Lake" for six or seven years before Kewen bought the old mill property, which embraced the lower end, the dam and the outlet of the lake. And before Wilson's time it was called the Mission lake. The dam was built in 18 Io to 1812. Father Zalvidea commenced his thrifty but iron rule in I806, and immediately went about establishing his system of taskwork for every one under his control, in order to increase the agricultural, vinicultural, livestock and manufactured products of the Mission; and a heavy stone dam was built to enlarge this lake. Then just below the dam he established a saw mill, a tannery, a wool-washery, etc., where the water could be conveyed by wooden troughs for the use of the work people, who were the neophytes or "converted" Indians. The water was also conveyed in ditches to irrigate additional vineyards and increase the wine and brandy products, these being prime articles of commerce at that time. For building the lake dam, heavy cobblestones or boulders were hauled in great clumsy ox-carts from Lincoln Park, this being the nearest point where large enough ones could be gathered in quantity; $*$ this I verified by special examination of the wall, and then of the wash channels near by. And cement for the work, a sort of water lime, was dug out of the hillside and burned where the Lincoln Park reservoir now stands in the old lime kiln pit. There had been a large bog or cienega at the lake place; and by building the dam the area of the lagoon or lake was more than doubled, and its water storage four or five times increased by depth. The mill stood on ground higher than the lake, and the mill stream flowed into the lake by a cement gutter after doing duty on the miller's wheel. The solid stone wall of the dam is from 6 to 7 feet thick, with reinforcing ledges and buttressed flume cheeks on lower side; Io to I 2 feet high at ontlet; and 70 paces or over 200 feet entire length at top of wall.

*" Old-tiners will remember that all along on the banks of the Arroyo about where the I,incoln Park depot now stands, were any quantity of small mounds, built of boulders, and these were said to be Indian graves. In 1858 I had the curiosity to examine some of them. I was soon satisfied that no bodies had ever been buried beneath them. It is probable that during the construction of the Mission San Gabriel, or some of their water dans that still exist in the neighborhood, Indians were sent there to gather them in piles to be hauled away for building purposes. This theory seens probable, since each pile would just about make a carreta load. These heaps were over and above what they needed, and were left."-Judge B.S Ealon's Reminiscences.

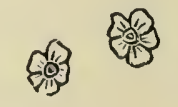




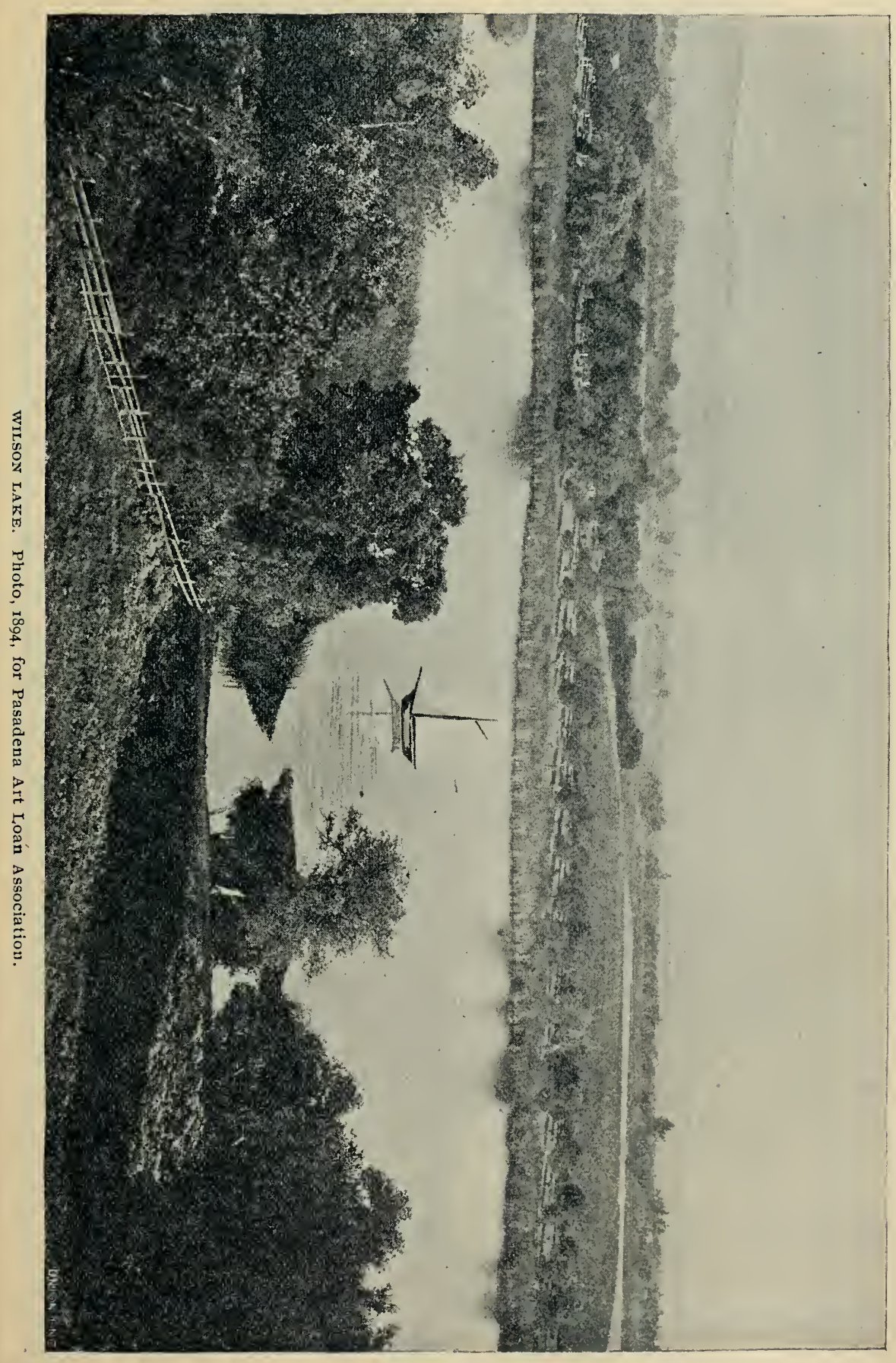




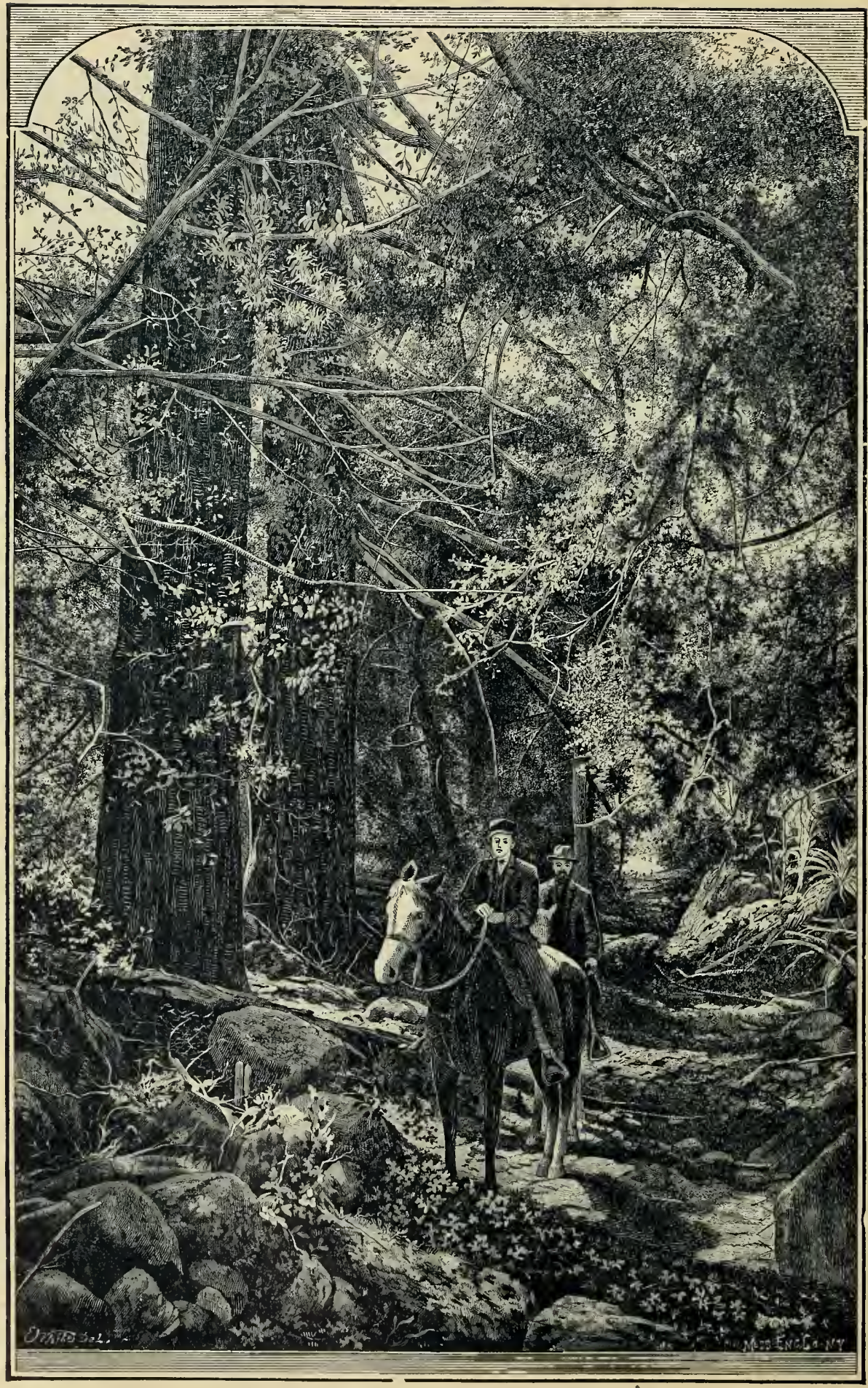




\section{CHAPTER XX.}

Mountain Trails, Roads, Etc.-The Wilson Trail.-The Telescope Episode.-John Muir's Mountain Climb in Pasadenaland.-The Mount Wilson Toll Road.

MOUNTAIN TRAILS, ROADS, ETC.

WiLSON's TraIL.-Many erroneous and more or less fanciful accounts have been put forth about this now famous and historic first travel-way ever made to the summit of the Sierra Madre mountains. I sought correct information from Mrs. Shorb and Mrs. Wilson, and they kindly furnished me a letter from Mr. Wm. McKee of San Francisco, written to Mrs. Wilson, August 28 , I 887 , in which he mentions the first trip ever made up that trail on horseback ; and I here quote his account of the matter. Mr. McKee says:

"Wilson's Trail up the mountains-when was it built? It was commenced early in r 864. In April of that year, Mr. Wilson invited me to go with him to see the trail, and to see the men at work on the road. I was living in town then.* On the day appointed we started for the mountains: took blankets with us, intending to stay there all night. About I o'clock we got to where the men were at work, near the place now called the HalfWay House.

"I was anxious to go on up to the top of the mountains. Mr. Wilson inquired of the men if they thought we could go to the top of the mountains with the horses. One of the men said he had been there, and that there was a spring of water on the very top of the mountains. At 2 o'clock we started, leading the horses; we soon got to the ridge of the mountains, and there found a well beaten bear trail leading to the spring. I thought then, and do still, that that water was the best I ever tasted in my life. We camped there that night. Oh, how beautiful! Next day we found the relics of the two houses. They were two parallelograms, well marked by a pile of what appeared to be ashes. Removing the ashes, we found the lower logs of the cabins not decayed. Americans must have built them. Mr. Wilson said so. Michael White, who came to San Gabriel in I825, knew nothing of them. $f$ We were the first who ever visited that Wilson Peak on horseback. In referring to this, I shall always remember it as one of the most pleasant trips I ever had with Mr. Wilson; and we had many. Yours very truly,

WILLIAM MCKEE.

Some writers have treated this story of the "old cabins" as imaginative; but Mr. McKee, and B. D. Wilson and his stepson, E. S. Hereford, all corroborated their existence. Mr. Hereford had charge of the first pack train that ever brought a load of shakes or pickets down that trail, in July or August, 1864. He is still living, and resides at San Gabriel - I895.

For ten or twelve years after Pasadena was settled it was reckoned a

*Mr. McKee resided in L,os Angeles at that time and had been employed by Mr. Wilson as private tutor to his children.

fof course not. Robbers and horse thieves wonld keep their own secrets. The historic records of this region of country show that from 1835 , or down to as late as 1874 . it was almost continually infested by gangs of white men outlaws, whose robberies were often cliarged to Indians. In December, 1840, Gov. Alvarado reported "that a party of adventurers from the Lnited States had stolen three thousand horses belonging to the Missions of San Luis Obispo and San Gabriel, and various private ranches." $-T$. $H$. Hitlell in Overland Monthly, November, 1885 , page 463. 
great adventure to go up the Wilson Trail, and stay on the summit over night. And on June $23^{-24-25}$, I 885, the largest party that had at that time ever made the ascent, spent three days on the trip, having a right jolly time of it. This historic company consisted of the following persons:

"Mrs. S. E. Merritt, Mrs S. P. Jewett, Mrs. Charles A. Gardner, Misses Olive Eaton, Carrie D. Hill, Maria B. Vischer, Helen Hill, Una Robinson, Flora Conger, Lucille Robinson, Dr. O. H. Conger, Prof. E. T. Pierce, George W. Howard, Charles L. Turner, Howard W. Conger, George Eaton, George Frost, Edward Mosher, William Watson, Hubert Winston, Roy Lanterman, Lester Lippincott, Frank Warner, Master Frank Ogden, Charles A. Gardner, seven hurros, and one Mexican. At dark they lighted the usual signal fire, and had the pleasure of seeing it responded to from Pasadena."

THE TELESCOPE EPISODE.

The most important historic event connected with this Trail in all the years was that of conveying the Harvard telescope up over its narrow line to the summit, in April, I889. The task was undertaken by the Pasadena Board of Trade, with Judge Eaton as manager-in-chief. [See page 326.] He found it necessary at some points to widen the trail, and at some points to change its line and make a totally new path. The entire material was over three tons weight, to be transported about eight miles from nearest railroad station, making in that distance an ascent of over 4,000 feet along a winding or zigzag donkey path mostly from six to twelve inches in width, on the steep mon11tain sides. Of course some of the stuff could be put into detached parcels and packed on the backs of mules or burros; but a large iron frame of nearly half a ton weight must go up solid. To meet this contingency, Judge Eaton devised a trundle-car that was made strictly on Scripture principles, for it was not a graven image, nor a "likeness of anything in heaven above, nor the earth beneath, nor the waters under the earth." It was a heavy-framed wooden platform two and one-half feet wide and three feet long, with a solid cast-iron roller seven inches in diameter and two feet one inch long serving as the front wheel, and being axeled a little forward of the middle of the platform; while at the rear there was a castor-wheel with a tail-bar or lever to steer the vehicle. Across the front was a stout iron bail, to which one or two mules could be attached in Indian file fashion for pulling ahead. On each side at the corners were heavy iron rings by which the freight was lashed with ropes or chains to the car platform, so that if the car should go off the track down a slope or over a precipice the load would still stay on it. At some points where there was a sharp angle in the trail, they had to pick and drill and blast out rock to widen it before they could make the turn safely; and at some places where there were a series of sharp angles constituting a zig-zag traverse, they had to drill into the mountain side for a secure anchorage at the upper lap of the traverse, and 
then with heavy ropes and pulleys hoist the car and its load bodily up the steep declivity till a new stretch of trail was reached, where the trundle-car could be rolled along again. Just think of a solid half-ton's weight of freightage being thus transported six miles in distance and 4,000 feet in elevation, and you get some idea of what a job it was at that time (for, remember, this was long before the toll road was built, but was really what led to it,) to get the Harvard telescope into place for its historic and famous astronomical work on Mount Wilson.

For further particulars about this telescope, and the special scientific work which it did here, see page 367- "Harvard Telescope Point." (In I 894 Dr. Reid took pains to secure this historic trundle-car for preservation in the Throop Polytechnic collection of relics pertaining to Pasadena history.)

At a public meeting, April 2, I889, for the purpose of raising $\$ 100,000$ to aid in establishing a 40 -inch telescope (biggest in the world) on Mt. Wilson, Judge Eaton gave the following points on distances and altitudes:

" Pasadena is just four miles south of Mt. Wilson, and four miles west. The distance from the foot of the mountain to the top is 8.7 miles, and he would make the grade not greater than one in ten. He estimated the altitude of Mt. Wilson to be 5,560 feet. Plenty of granite is available near the summit, and the Henniger flat $(2,200$ feet) afforded a splendid site for a hotel. He thought Pasadena was big enough and able enough to build a wagon road to the summit.

"As to the transportation of the 23 -inch telescope to the summit, the Judge said, 'It is all there!' (applause). The work had been laborious, but the people of Pasadena had redeemed their word, and put it on the monntain, at a cost of a little less than $\$ 1,000$, the greater part of which had been spent in improving the trail."

The Star of April 3, I889, said: "A big blaze on the summit of Mt. Wilson last night announced that Judge Eaton had succeeded in placing all the boxes containing the Harvard telescope on the spot where the observatory is to be built."

Star photographing was commenced here about May I, I889, and continued some eighteen months, in charge of Prof. King. Hence the local name thereof, "Harvard Telescope Point ;" but it had previously been known as Signal Peak or point; and the old telescope building has been converted into a mountain-top hotel annex called "The Casino." See page 367 .

THE MOUN'T WILSON TOLL ROAD.

For nearly twenty years after Pasadena was settled, it was deemed a great adventure to go up Wilson's trail and spend a night on the mountain; and this trip gradually became so popular that in 1885 and 1886 , various schemes were talked of for making some shorter, easier, safer and more direct travel-way to the mountain tops. One plan set forth early in I 885 , was for a hack line from Pasadena up into Las Flores canyon, where it was then expected a large sanitarium, or hotel, would soon be built; and from 
there a burro trail up the great dividing ridge between Las Flores and Millard canyons to the top of the range. There was a foot trail up this route, and Dr. B. A. Wright, who then owned the Las Flores house, followed it up on horseback to a point nearly or quite as high as Echo Mountain, just to test the feasibility of the plan. But the sanitarium scheme failed, and this mountain bridle road plan died with it. Another scheme was to make a bridle road up around Millard Falls and on into what is now called Grand canyon-thence up over the dividing ridge now called the "Mount Lowe saddle" - thence down across Grand Basin to the Eaton Canyon pass, and thence on to Wilson's peak. This would have made an intramontane trip excelling in picturesque beauty and grandeur the old Wilson Trail and the Switzer Trail; and it was designed to be worked as an adjunct to the Painter Hotel, for the benefit of its winter tourist guests. The parties interested in it were A. J. Painter, Calvin Hartwell, E. W. Giddings, L. W. Giddings. Byron O. Clark.* However, the project was never carried through; yet partly under its inspiration a good pack-trail was made clear up into Grand canyon, for the uses of water development work in the upper sources of Millard canyon. There was talk of making a wagon road clear to Wilson's peak by this route; but that was a preposterous idea, for it would have cost $\$ 100,000$ to make a road of passage there for four-wheeled vehicles.

It was in 1885 that C. P. Switzer, a carpenter from Los Angeles, constructed his trail up the Arroyo Seco canyon to a romantic place of cabins and tents, waterpools and falls, baths, etc., known to fame for a few years as "Switzer's Camp." But this was only a sort of half-way house to any part of the mountain top, and from here there were only difficult footpaths or burro trails to Mount Disappointment, Strawberry peak, and other lofty summits, and to Barley Flats.

In I 886 Owen and Jason Brown, sons of the famous "Old John Brown," commenced constructing a bridle road from their mountain homestead above Las Casitas to a point at the top of the front range, which they christened "Brown's peak." After building about two miles of their road they had to give it up for want of funds; and Owen's death in January, I889, totally ended the project.

Yet, in spite of all these different schemes, Wilson's Peak still had the call. + People mostly seemed to think and talk as if that was the only place

*As early as $188_{3}-84$, Byron O. Clark and his brother-in-law, H. C. Kellogg, a civil engineer, while prospecting and surveying for mountain springs to supply the Painter \& Bail tract, noticed the fine parks of oak timber on the west slopes of Oak Mountain (now called Mt. Lowe), and they applied to Washingtou for privilege to survey it at their own cost and buy a section of it as timber land. They got answer that it had been officially reported and recorded as "unsurveyable." "They tried further to get it. lut without success. Mr. Kellogg at that tine projected levels and grades and detours for a road to Wilson's Peak by the Millard canyon route; and Clark planned for a landscape paradise and half-way station in the same timber slopes where the Alpine Club house and Crystal Springs station of Mt. Lowe Railroad are now located. H. C. Kellogg is now [1894] connty surveyor of Orange county. Clark resides at Linda Vista, Pasadena.

f'"The Signal Peak Hotel Co. lias made arrangements witl Mr. Fox. Abbot Kinney and Col. Mayberry for right-of-way across their mountain side lands; and on Wednesday Clarence Martin and Mr. Rockwood located the ronte for their new lorseback road to the mountain top," etc.- Enion, June $11,1886$. 
where there was any mountain top worth going to, or at all accessible; and in I 886, a cog-wheel railroad similar to the one on Mount Washington, New Hampshire, was talked up-till finally R. Williams, Byron W. Bates and C. S. Martin formed a company, and took steps to secure rights for land, water, wood and stone on the unsurveyed government lands at the Mount Wilson summit.* Their idea was to make a good bridle-road first, and then enlist eastern capitalists to build a hotel up there, and build a cog-wheel railroad from the mouth of Eaton canyon up to it. They did secure some land claims, though from various causes their railroad and hotel project failed. But the locating of the Harvard photographing telescope on Mount Wilson in r889 gave a new measure of fame and interest centering at this mountain $; \dagger$ and the difficulties which Judge Eaton had to overcome in getting that telescope, besides the heavy timbers, irons, etc., necessary for its proper housing and mechanical control, up over the old trail, led him to think seriously of trying to build a better road right up from the mouth of Eaton canyon, $\ddagger$ and thus connect Pasadena with this mountain top in the shortest and most direct way, instead of having to go ten miles around, by way of Sierra Madre town and the Santa Anita canyon.

Accordingly, Judge Eaton called a meeting June i8, i889, at the President's room of the First National Bank, "to consider steps necessary to be taken to build a wagon road to Mount Wilson." The men who atttended this meeting were: J. A. Buchanan, P. M. Green, L. C. Winston, George A. Greeley, H. H. Rose, M. E. Wood, A. J. Painter, C. S. Martin, George F. Kernaghan, Charles Copelin, J. R. Riggins, W. U. Masters. P. M. Green was chosen for chairman of the meeting and Mr. Masters secretary. Judge Eaton fully explained the feasibility of the project, from a preliminary survey which he had made of the entire series of mountain slopes to be traversed; and ended by moving that they should proceed to organize a company to build such a road. The motion prevailed, and a preliminary organization was effected by electing Kernaghan for president, Martin vice-president, Wood secretary and First National Bank treasurer; and for directors, Martin, Kernaghan, Buchanan, Greeley and J. W. Hugus. The organization was incorporated as "The Pasadena and Mount Wilson Toll Road Company," July I 2, I889, with the following named shareholders:

P. M. Green, A. J. Painter, Charles Copelin, J. A. Buchanan, James R. Riggins, Benjamin S. Eaton, C. S. Martin, George F. Kernaghan, G. E.

* "Mr. J. M. Willard, the surveyor. with four assistants, has been at work the last week surveying for the new monntain-top company who have planned to make a good horseback road, with telephone line to the summit camp, starting up at the mouth of Precipicio canyon."-[Pasadena Valley Union, May" 14,1886 .

f"A good wagon road will bring it within ten miles of Pasadena, while the L,ick observatory is twenty three miles from San Jose. A mountain railroad will undoubtedly reduce the ten nilies to five, and bring the observatory within an hour of the Carlton." - C. T. Hopkins, public address on Library Interests.-Febrilary 18,1889

t"Four men are at work this week running barometric levels to test for a possible wagon road, rising one foot in ten, from the mouth of Faton canyon to the top of Mount Wilson direct."-[Pasadena Standard, February 23, 1889 . 
Prosser, George A. Greeley, W. E. Arthur, H. H. Rose, M. E. Wood. The capital stock was fixed at $\$ 50,000$, divided into 500 shares of $\$ 100$ each.

The company secured a right-of-way Ioo feet wide from the Precipicio Canyon Water Company (Eaton canyon) across their lands, and from the county board of supervisors for the rest of the distance-this latter including "Henniger's flat," which Capt. Henniger held at that time only by squatter's right, not by patent. Their first step was to determine just where their roadway should be located at the mouth of Eaton canyon, and its position relative to the tunnels, pipes, check valves, etc., of the water company; and Engineer J. E. Place was employed to survey this part of the roadway territory and prepare a detail map of the same. But no grading was done for more than a year; and the project seemed to have died before it was born. Debts had accumulated for various services and incidental expenses, and remained unpaid.

December IO, I890, a meeting was held to consider the situation, and decide what should be done further. At this meeting Mr. Kernaghan proposed a reorganization of the company, on condition of having assigned to him all the shares held by the various stockholders; and as the outstanding debts for which each stockholder was liable under the law about equalled the value of the stock held, the proposition was readily accepted, many of them being glad to thus let themselves down easy and get out of further responsibility in the matter. The reorganization was effected, and under it, George F. Kernaghan, C. S. Martin, J. W. Vandevort, R. T. Vandevort and George A. Greeley became the sole owners of the corporation and its franchises. And from this time on things began to move. Mr. Kernaghan as president and manager devoted most of his time to forwarding the enterprise. Engineer J. W. Sedwick was employed to survey the route from mouth of Eaton canyon to the summit, set the grade stakes and prepare estimates of all grading, filling, bridging and rock work to be done. The original wagon road theory had been boiled down to the more practical and feasible plan of a bridle-road; and a contract was let to Thomas Banbury to grade and construct such a road for the company. He pushed the work to completion as rapidly as possible; but the blasting and rock work around some of the granite spurs and crags proved a more difficult and costly job than had been anticipated.

The length of road constructed, four feet wide, is nine and one-eighth miles, extending from the mouth of Eaton canyon, about I, 575 feet above sea level, to the summit of Mount Wilson, where the Harvard telescope stood for a year and a half, 5,565 feet above the sea ;* and the grade nowhere

*Judge Eaton's aneroid barometer gave different altitude registers at foot of the road, varying from 1,500 to $T, 57,5$; and at the summit it varied more than 100 teet at different times, owing to wind currents of different degrees of moisture or dryness, or electrical tension; but an average of twenty observations gave 5.550 feet as the altitude. Engineer sedwick. who silveyed the Toll Road, gave 5,560 feet as the altitude. And Prof. Pickering of Harvard University, with his superior instruments and expert scientific tests, made it 5.565 feet elevation. So I take that as scientific authority. But it should ie noted that Judge Haton's resilt only varied fifteen feet from that of the great scientific expert; and Sedwick's actual survey only varied five feet. 
exceeded a rise of one foot in ten. The total cost of surveying, grading, building telephone line to foot of road, and incidental expenses, footed up about $\$ 5$, , oo.

This construction work was going on during the early months of I89I. Meanwhile Mr. Kernaghan was president of the Pasadena Packing Co., and also both president and manager of the Daily Star Publishing Co., and on the Ist of May he became postmaster of Pasadena. These varied cares and labors proved too heavy a strain upon him, and about the last of May he relinquished his interest in the toll road, being succeeded by $H$. W. Magee as president and manager. The grading work was then still in progress. On his retiring, the Company, as a souvenir of the past and a token of their kindly regard, presented Mr. Kernaghan with a "life pass" over the road-the only one ever issued.

The original land and water rights acquired in I 886 by Bates, Martin and Williams on Mount Wilson, besides some later claims, are now [1895] held by C. S. Martin, J. W. and R. T. Vandevort, J. H. Holmes of Hotel Green, Wm. Morgan and Wm. R. Staats, and comprise what are known as " Martin's camp," "Strain's camp," and "Observatory Casino." [See pages

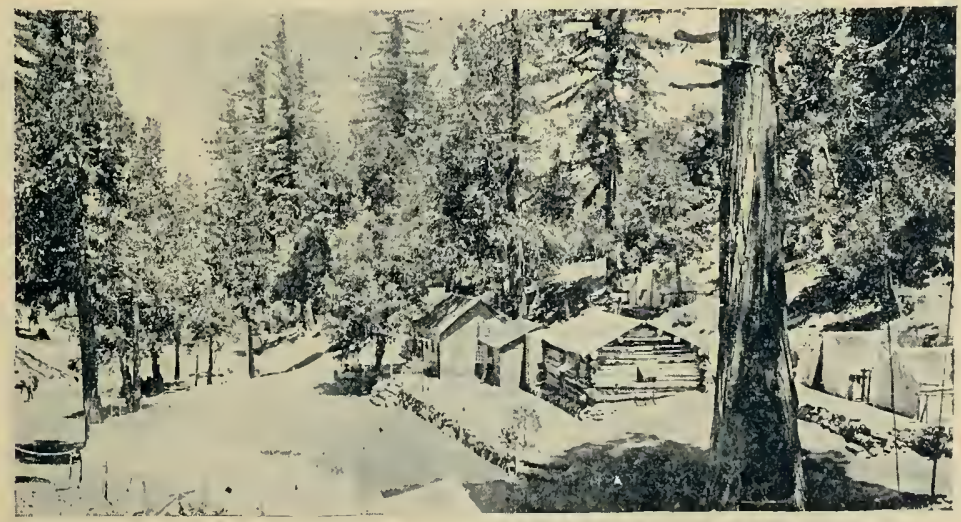

STRAIN'S CAMP-1894.

At the original Mount Wilson Spring. See article, "Wilson's Trail," page 395.

367-68.] And they have control of the old original Wilson Trail, as well as their own Toll Road.*

The Los Angeles Times of July 2I, I89I, contained the following account of the funniest historic incident connected with this Toll Road :

*The Weekly Star of July 8, 1891, reporting a trip of the county board of supervisors up the Toll Road in order to fix its toll rates, says: "It is over the same general route as that surveyed four years ago by Col. J. E. Place and Mr. Horne, for a cog-wheel railroad. That survey cost $\$ 1,000$, and was paid for by Col Markham, C.S. Martin and R Williams. That route was over a 25 per cent. grade, without any switchbacks, and went pretty straight up the mountain. * * The Toll Road survey was begun in November, 1890 , and took two months steady work. The cog-wheel road was estimated to cost $\$ 400,000$. The Toll Road is 8.7 miles in length, and its 10 per cent. grade gives a rise of about 5,000 feet. (?) It has numerous romantic points which have been named, such as Pasadena View, Saint's Rest, Halfway Turn, Mosquito Pass, Cape Horn, etc. Its top eud is at the observatory." 
"Decidedly the most novel feature to chronicle in connection with the mountain was the ascent made on Sunday by Joe Simons and Chas. Fishbeck, in carts of their own invention and manufacture, and designed especially for the trip. The journey was made thus for the reason that Joe's avoirdupois makes it well nigh impossible for him to make the ascent on foot or mounted. Hence he set his inventive genius to work, and the result was a two-wheeled cart, the wheels being but a trifle over two feet apart and the seat resting on the axle so that the driver could conveniently step to the ground along the narrow places of the trail. The odd-looking pair of vehicles left the foot of the new trail at five o'clock Sunday morning, and made the ascent without any mishap in a little over four hours. The day was spent at Martin \& Lynch's camp, where photographs were taken of the outfits and several attendants who went along to assist in case of emergency. The return trip was made the same day. Messrs. Simons \& Fishbeck enjoy the distinction of having first traversed the new trail on a wheeled vehicle."

The Star of Saturday, July I8, described the carts, which were made by Stephen Helen, who was to ride one of them, and it said: "They are very narrow-twenty-eight inches-and are provided with mowing machine seats. Joe's 270 pounds of constitution forbids him to either ride horseback or walk up the trail, so he tries the cart." 'The fact seems to be, that Messrs. Helen and Fishbeck took turns riding their queer thing.

The Pasadena Evening Neres of June 12, I895, said :

"At a recent meeting of the Mt. Wilson Toll Road Co., the following officers were elected: C. S. Martin, president; Wm. Morgan, vice-president ; W. R. Staats, secretary and treasurer ; R. T. Vandevort, manager.'

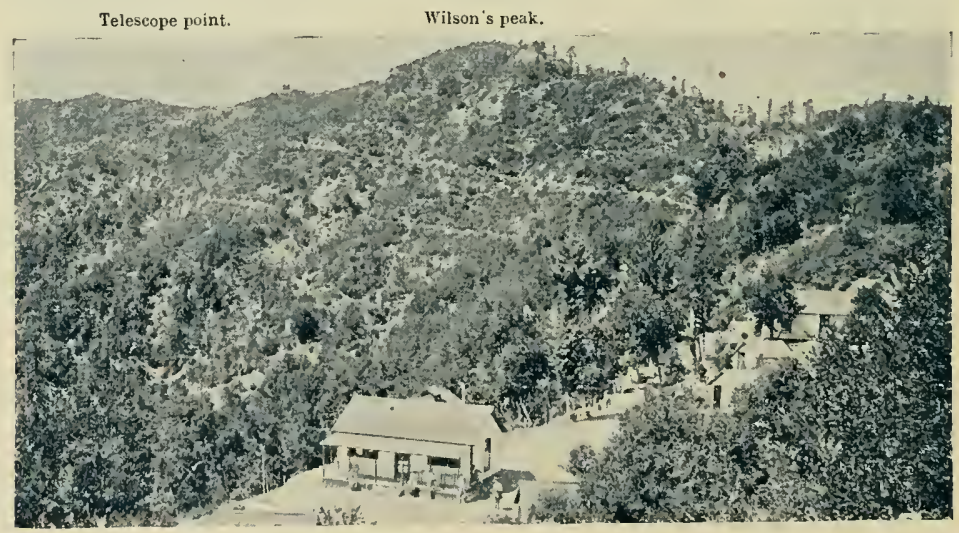

"Land of Sunshine," August, 1895.

MARTIN'S CAMP, AT MOUNT HARVARD NECK.

Then, in reply to my inquiries for latest data before printing this chapter, the secretary wrote me July I6, I 895 :

"The mountain wagon road will be twelve feet wide, and a length of nine miles to the summit. On the summit will be laid out ten to fifteen miles of bridle roads leading to different points of interest, and through the 
great pine forests; while on the way up there are many beautiful spots to which branch roads will be run. The Henniger Flats property, recently purchased by Harry C. Allen, consists of I 20 acres-the only mesa land on the mountain side. Here a park will be laid out and resort buildings constructed, in connection with the mountain road. This land, and the land owned by the company on the summit, is not included in the government forest reservation. The summit is now connected by telephone with Pasadena, Los Angeles, San Francisco, etc."'

\section{SWITZER's TRAIL. - The Valley Union of May 29, I885, said:}

“C. P. Switzer has filled a 'long-felt want' by making a direct trail up the mountains from Brunk's to the big fall of the Arroyo Seco. He has taken up a claim at the falls, and built accommodations for tourists, who are furnished with a good trail at a nominal price, and bed and meals for such as stay over. He is about half way to the summit, and tourists can make the trip up from this place and back in a day, and thus make a very comfortable trip of it."

The waterfall referred to was named VIRGinia FALLs. It is a beautiful mountain cascade, but not so high as those in Eaton, Rubio, or Millard canyons. Switzer's trail and mountain camp enjoyed much popularity for five or six years, until Mount Wilson and other points of loftiest outlook were made easily accessible. 'The following account of a trip up Switzer's trail, with some notable historic associations, was published in the Union of May 14, I 886 :

"At 7:30, May 4, a party of young folks left Orange Grove Avenue for a trip to the mountain top, via Switzer's trail. At Mr. Thompson's on the Las Casitas ranch, they expected to meet the guide with burros for the ascent, but he failed to put in an appearance; and so for that day they contented themselves climbing the beautiful hills around the ranch, from which (by the aid of the historic field glass formerly owned and used by John Brown at Harper's Ferry, in 1859 , ) they had a most charming view of the valley below, and of Pasadena.

"Mrs. Thompson (John Brown's daughter) kindly entertained them for the night; and in the morning Mr. Owen Brown, (the only survivor of Harper's Ferry) with his usual kindness, offered his services as guide. From a neighbor they obtained two horses. They thought it would be hard work to divide two horses between six people, but concluded to try it. Two young ladies and Mr. Thompson started at noon, on foot, for Mr. Brunk's, up the Arroyo; Mr. Thompson felled trees and helped them safely across the stream. At Mr. Brunk's they procured two more horses, but 110 saddles, and fortunately found Mr. S., a young man from Chicago, who was rusticating for a few days, and who joined the party. After a few minutes delay, the rest of the party came up. After leaving Mr. Brunk's they followed the valley up, crossing the Arroyo forty-six times during a five mile ride. With laughter and song they rode along, making the valley ring. The favorite song over this part of the road was, 'One more river to cross.' After riding for some time two of the ladies dismounted, letting their horses follow at will. All went well until they came to the last crossing; as the stones looked safe, the girls thought they could hop over; but alas! a little shriek, and in they went. If the gallant Chicagoan had not rushed to their 
rescue, they might have floated to the sea. One of the young ladies thought the ducking would not hurt her, as her grandfather was a Baptist. With their lovely bloomer suits somewhat the worse for the fall, they came to the foot of the mountain, and to climb the 'golden stair' was next in order. The 'golden stair' is a path just wide enough for a horse or burro, cut in zigzag shape up the mountain side. The party was glad to reach the top of the 'stairs' $(4,600$ feet above the sea), as it had been dark for some time, making the precipice along which they had been riding look deeper and more fearful than by daylight. Soon the lights of the camp fire were visible, and a glad shout went up, but although they were now on the down grade they could not go fast, and it was 8:40 when they reached Switzer's camp."

Prof. C. F. Holder's illustrated pamphlet entitled "The Highlands of Pasadena," published in 1889 , says:

"To thoronghly enjoy the beauties of the inner range, the services of the genial Switzer should be obtained. 'The 'Commodore,' as his friends term him, is the only dweller in the heart of the southern sierras, and has a camp about twelve [fourteen] miles from the valley, directly up the Arroyo. He penetrated these wilds originally in search of health himself, and having found it, is now engaged in enjoying it, and entertaining those who care to see something of Southern California scenery behind the big wall. * * * The 'Commodore's' squadron consists of a band of burros trained to climb the side of a house, trained to walk a tight-rope-like trail, and even to sing. These faithful animals very slowly and surely take you into Switzer's in five or six hours, making the trip twice a week." - p. 43-44.

Prof. Holder mentions in the same connection that a trail had been made from Switzer's to the top of Mount Disappointment, and also one to

BARLEY FLATS.-This is a table of land on a summit of the third range back from Pasadena, presenting a tolerably level surface of perhaps 160 acres which is covered with a dense, rich growth of wild barley in its season; this made it a regular deer pasture, and consequently a prowling place for mountain lions seeking prey - and these conditions together had given the place fame as a hunting ground for thirty years past, from Los Angeles. It could be reached by way of the old Wilson trail; but after Switzer's trail was made, that was the best and easiest route from Los Angeles or Pasadena to Barley Flats.

PINE FLATS. - This is another similar mountain-top area said to contain about 320 acres. It is in the same range with Barley Flats, is reached by a mountainous trail from Mount Wilson, and is a favorite summer resort for Pasadena hunters and campers. It is well covered with pine and cedar trees, some of which are 250 feet high and 7 feet in diameter. So say H. N. Farey, E. Groenendyke, and others.

Brown's Trail. - See article "Brown's Peak," page 373.

Giddings's Trail.-The Valley Union of June 18, i886, said :

"E. W. Giddings has planted an immense white flag on a mountain summit next east of Millard canyon which is hereafter to be known as Giddings's Peak, in honor of the famous old anti-slavery statesman of Ohio, 
Hon. Joshua R. Giddings. Mr. Giddings is building a double trail to this peak, so as to carry visitors up by way of Millard canyon and the falls."

In his "Highlands" pamphlet of I889, Prof. Holder said :

"The road to Millard canyon winds up by the Giddings ranch, then dips into the deep canyon. $* *$ A mile or more and the road ends, and a footpath leads to the falls, one of the most attractive in the range. * * To go beyond the fall the cliff must be climbed, the roots of great live-oaks forming supports. By keeping to the right the Giddings trail may be reached, from which one of the finest views of the city and the San Gabriel valley is obtained."

This Giddings trail was a burro path leading from Millard canyon uip to Giddings peak, which was the same point on the front range summit that is now called "Grizzly Point" in the Mount Lowe literature. And this Grizzly Point is the ledge of rock where a bear is said to have sat and laughed to see Gov. Markham, Charley Watts, David Townsend and E. G. Halleck of the "Pasadena rifle team," running from him pell-mell down the monntain side, in spring of i882. [See Gov. Markham's speech at the Mount Lowe celebration, August 23, I893, in Chapter 23.]

UnClE BOB's TraIL. - In going from Giddings Heights into Millard canyon, or in crossing Millard creek on the road to Las Casitas, there will be seen an old road in the west wall of Millard canyon that looks too steep to have ever been practicable for any wagon use; yet this is where Uncle Bob Owens, the colored man, hatiled wood out from Negro canyon to supply the U. S. headquarters and barracks at Los Angeles with fuel, in I862-3-4. It was better to haul it up over the mountain spur above Negro canyon and then down this fearful grade, rather than down the easier but far-around Arroyo Seco route, and then up the high, steep bluff at Devil's Gate. [See article, "Negro canyon," page 386.]

THE SOLEDAD TRAIL, or Grade.-Looking northwest from Pasadena, there is seen a line cut along in a north and south direction on the mountain side beyond and above Las Casitas. This is where the traders of Los Angeles set out in the year I868, before the Southern Pacific R. R. was built, to construct a wagon and stage road across the mountains to the Soledad mining region, which was then a booming center of development.* About six miles were completed as a wagon road, and six miles more worked sufficiently to be used as a pack trail; but the cost of the work greatly exceeded estimates, and the time required proved to be double and treble what was expected. Hence, as soon as it became settled that the S. P. R. R. would build to Los Angeles, this wagon road project was abandoned; but the gullied and ruined grade still remains to tell the story of a great enterprise of the mining days in South California. In 1887 the business men of Pasadena had a preliminary survey made over this same route

* Gold mining was going on at Soledad in 1868 ; but silver and copper mining was a success thert earlier; and in 1876 the place had a paper will. 
through the mountains, for the prospective Los Angeles and Salt Lake railroad, and claimed that the grade would be only about 87 feet to the mile.

Hodge's Trair.--See "Hodge's Peak," page 374.

LINDA VisTA TRAIL. - See Linda Vista peak, page 374.

Fremon'T's Trail. (?)-In one of Prof. Holder's books, and several of the Board of Trade pamphlets, "Fremont's trail" is mentioned as one of the objects of historic interest. Yet Fremont never "trailed" within ten miles of it. [See page 68 for points.]

Carson's Trail, or the Loris Gold Mine Trail.-During I893-94 Messrs. E. V. Carson and Jesse Dickey were engaged in developing their gold mining claims in Pine canyou, and made a pack trail up the west wall of the canyon for transporting the ore down from their mines on mules or burros, to the wagon road in the mouth of the canyon. See article on "Gold Mines," in Chapter 29.

Rubio Water Trail. - - The Rubio Canyon Water Company has a trail which starts at the foot of the east wall of the canyon, on Rubio farm, and extends up the crest of the main ridge between Rubio and Pine canyons to an elevation of over 3000 feet - then along the inner slope of the east wall to some tunnels which the company has made in the waterbearing gulches away in above the great Leontine Falls. For a romantic and interesting mountain tramp this is not excelled. The Pine canyon gold mines can also be reached by the same route. But the foot of this trail can only be reached by crossing the private enclosures of Rubio farm.

JOHN MUIR'S MOUNTAIN CLIMB IN PASADENALAND.

Well, who is John Muir? Why, he is the man who has climbed more mountains, walked more miles, lain out more nights, and discovered more glaciers than any other man known to history. Glaciers was his hobby. In Harper's Monthly for November, I875, he gives an account of the "Living Glaciers of California "; and says he has discovered no less than sixty-five of them in the Sierra Nevada mountains, between latitudes $36^{\circ} 30^{\prime}$ and $39^{\circ}$, his first discovery being in October, 187I. These living glaciers form the head fountains of the San Joaquin, the Tuolumne and the Owens rivers. He was also the first explorer of the great Muir glacier of Alaska, which rightly bears his name. He was the editor of a notable art-work published in I888, entitled "Picturesque California, and the region West of the Rocky Mountains from Mexico to Alaska." Also author of the "Mountains of California," published by the Century Co., New York, I894.

John Muir was a classmate with Dr. O. H. Conger in the State University at Madison, Wis., when Dr. Ezra S. Carr of Pasadena held the chair of Natural Science in that noble institution. Dr. Conger settled in Pasadena in 1874 ; and in the summer [August] of 1875 John Muir came to visit him and renew old acquaintanceship. At that time no man had ever gone from 
Pasadena directly to the top of the mountains, and Muir made the venture alone. Mrs. Conger baked three loaves of bread for him, and gave him half a pound of tea, which he usually steeped by putting a little into a bottle of cold water and laying the bottle on a rock in the warm sunshine. He carried no fire-arms, as he had conscientious scruples against taking animal life, and hence used no meat food. With provisions and blankets on his shoulder, he started, and was gone three days. When he got back he was extremely hungry; and Mrs. Conger writes :

"He said that in all his mountaineering he had never found any trip so laborious as that, on account of the very thick growth of underbrush; and he had never found a view so fine as that from the top of these mountains." In another note Mrs. Conger adds this interesting item: "He brought me some tiger lily bulbs from the mountains, and I planted them in my yard, where they have blossomed every year since [I9 years]; and I have always called them my 'John Muir lilies.',

He made his trip to the mountains by way of Eaton canyon; and in an article on "The Bee Pastures of California " published in the Century Magazine of July, I882, he gives some account of this mountain climb. It is the first report on record of any trip or exploration from Pasadena to our immediate mountain summits, and hence I quote a few paragraphs. He took one day in getting from Pasadena to the mouth of Eaton canyon-camped there over night with a native Mexican woodchopper, and in the morning walked np to the Falls - then hard climbing commenced. Of this Mr. Muir writes:

"From the base of the falls I followed the ridge that forms the western rim of the Fiaton basin to the summit of one of the principal peaks, which is about 5, ooo feet above the sea level.* Then, turning eastward, I crossed the middle of the basin, + forcing a way over its many subordinate ridges and across its eastern rim, having to contend almost everywhere with the floweriest and most impenetrable growth of honey bushes I have ever encountered since first my mountaineering began. Most of the Shasta chaparral is leafy nearly to the ground; here the main stems are naked for three or four feet, and interspiked with dead twigs, forming a stiff chevaux de frise through which even bears make their way with difficulty. I was compelled to creep for miles on all fours, and in following the bear-trails often found tufts of hair on the bushes where they had forced themselves through.

"For a hundred feet or so above tlie fall the ascent was made possible only by tough cushions of club-moss that clung to the rock. Above this, the ridge weathers away to a thin knife-blade for a few hundred yards, [Hence called “Muir's Knife-Blade Ridge."-ED.] and thence to the summit of the range it carries a bristly mane of chaparral. Here and there small openings occur in rocky places, commanding fine views across the cultivated valley to the ocean. These I found by the tracks were favorite outlooks and resting-places for the wild animals-bears, wolves, foxes, wildcats, etc. - which abound here, and would have to be taken into account in the

* This is the peak which ascends to a culminating summit from Pine canyon, Rubio canyon and Castle canyon -and forms part of the west wall of Eaton canyon and part of the south wall of Grand Basin. It is "Muir's peak." See page 369.

†This is the "Grand Basin" of the Mount Lowe literature. 
establishment of bee ranches. In the deepest thickets I found wood-rat villages-groups of huts four to six feet high, built of sticks and leaves in rough, tapering piles, like musk-rat cabins. I noticed a good many bees, too-most of them wild. The tame honey-bees seemed languid and wingweary, as if they had come all the way up from the flowerless plain.

"After reaching the summit I had time to make only a hasty survey of the basin, now glowing in the sunset gold, before hastening down into one of the tributary canyons in search of water. Emerging from a particularly tedious breadth of chaparral, I found myself free and erect in a beautiful parklike grove of live-oak, the ground planted with aspidiuns and brier-roses, while the glossy foliage made a close canopy overhead, leaving the gray dividing trunks bare to show the beauty of their plain, interlacing arches.* The bottom of the canyon was dry where I first reached it, but a bunch of scarlet minuulus indicated water at no great distance, and I soon discovered about a bucketful in the lollow of the rock. This, however, was full of dead bees, wasps, beetles and leaves, well steeped and simmered in the hot sunshine, and would, therefore, require boiling and filtering through fresh charcoal before it could be made available. Tracing the dry channel about a mile further down to its junction with a larger tributary canyon, [the one that flows from Mount Lowe down easterly through Grand Basin to a junction with Eaton canyon.- ED.] I at length discovered a lot of boulder pools, clear as crystal, brimming full, and linked together by glistening streamlets just strong enough to sing audibly. Flowers in full bloom adorned their margins, lilies ten feet high, larkspurs, columbiues and luxuriant ferns, leaning and overarching in lavish abundance, while a noble old live-oak spread its rugged arms over all. Here I camped, making ny bed on smooth cobble-stones.'

Judging from his account, and from what I know of the same mountain region and its present local designatious, I conclude that he went up across Grand Basin to Muir's Peak; then down across the basin northwestwardly to near where the head of Eaton canyon is lost in a pass or gap that leads through to West San Gabriel canyon ; and crossing here; he climbed up to Precipicio Peak, and thence along to Knife-Blade Ridge; but he evidently had to descend before he reached Mount Wilson, on account of nightfall, and came down somewhere in the trough of Henniger's Flat.

Dr. Carr had given college lectures on geology at Madison; I heard him myself on this theme in January, I862, while I was there at the state capital on some business connected with my army work as member for Wisconsin of the United States Sanitary Commission; and Mr. Muir, some time after his Pasadena trip, told the Doctor that these were "the worst tumbled up lot of mountains he had ever got into." This is accounted for by the fact that these mountains were elevated by the crushing, jamming, mashing-together process, from secular compression of the earth's crust, instead of from an internal center of upheaval which produces the long, gradual incline and anticline slopes of higher ranges farther inland.

In his book on "The Mountains of California," published by the Cen- 
tury Co., New York, in 1894, John Muir re-tells the story of his climb in Eaton canyon, but with some variations, and he now makes the grave mistake in geography of supposing this canyon to be in the fort-slopes of "Old Baldy." On page 376 he says :

"The fall, the flowers, the bees, the ferny rocks, and leafy shade forming a charming little poem of wildness, the last of a series extending down the flowery slopes of Mount San Antonio ['Old Baldy'] through the rugged, foam-beaten bosses of the main Eaton canyon."

Then again on page 380 , he says:

"Next day, in the channel of a tributary that heads on Mount San Antonio [?] I passed about fifteen or twenty gardens like the one in which I slept "; $\in$ tc.

As Mount San Antonio is about sixty miles away from Katon canyon, in another and entirely different range of mountains, this is a singular error; and I can only account for it by supposing that he mistook San Gabriel peak, which does furnish a tributary to Eaton canyon, for Mount San Antonio.

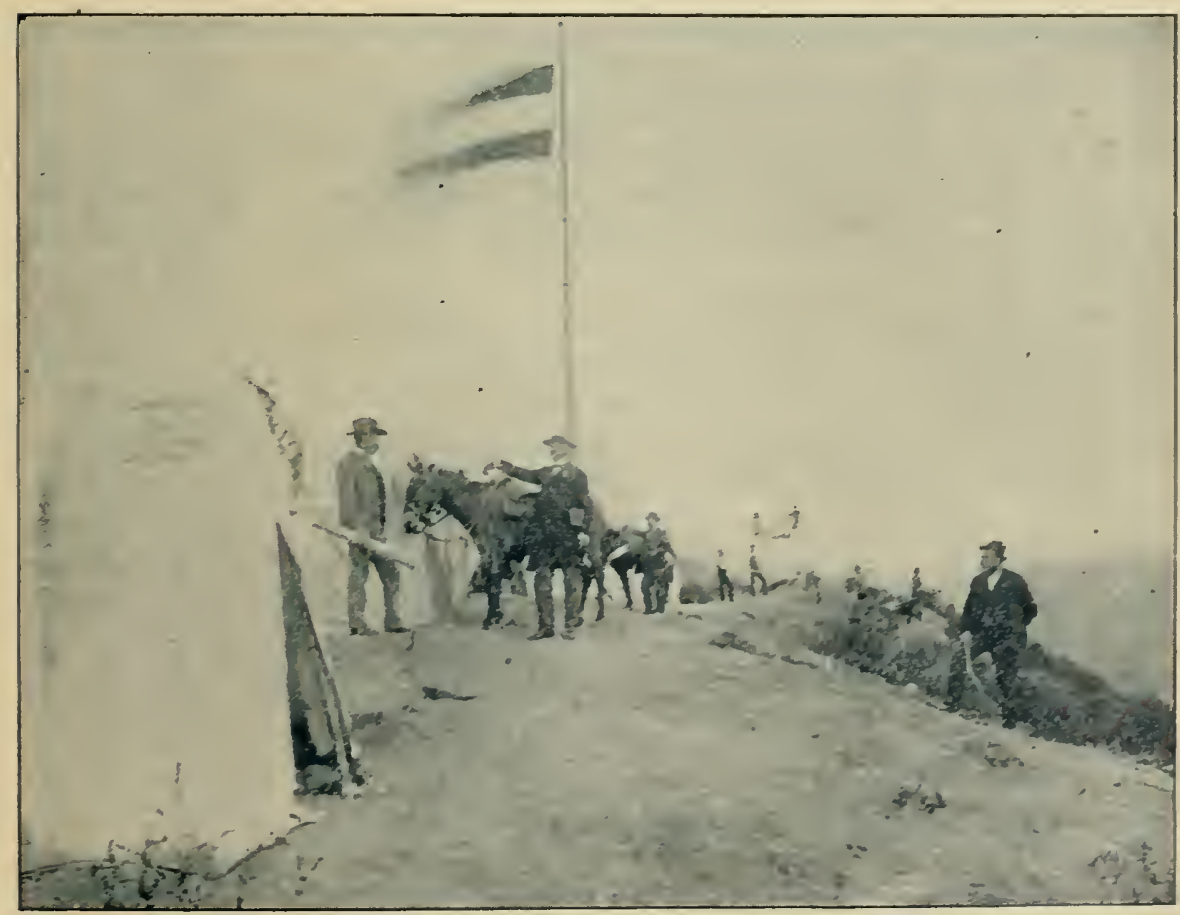

Enginner Macriberan. Prof. Lowe.

TOP OF ECHO MOUNTAIN, APRIL 12, 1892.

Breaking ground for the grade of the Great Incline, or Electric Cable Railroad 


\section{DIVISION SIX - BUSINESS.}

\section{CHAP'TER XXI.}

WATER COMPANIES. - The colony's water supply.- Ditches, pipes, and reservoirs.The water war.- Water measurements and adjustments. - Votes and equities.Sketch of ten different water companies.

THE SAN GABRIEL ORANGE GROVE ASSOCIATION.

The original colony association that settled Pasadena was in fact a mutual land and water company, and the water interests, plans and prospects claimed earnest attention from the beginning. When Calvin Fletcher, A. O. Porter and Judge Eaton were appointed as an executive board for the Association, they agreed that Fletcher should take special charge of the work of subdividing and platting the land; Eaton should take special charge of the water supply work; and Porter stood as coadjutor to both. The Association was formally organized November I3, 1873; but it took time to bring about all the requisite preliminaries for actual work, and it did not have existence as a corporation under the laws of California until December I3, I873, the date of its state certificate. Then on December 20, they voted to authorize their proper officers to purchase tracts One, Two, Three, Four, of Rancho San Pasqual, from John S. Grifinn. The Association office was then at No. 32 Main street, Los Angeles. [For particulars of the purchase, the incidental difficulties, etc., see pages 78 to $80,107-08$, I 24 , etc.]

The first transaction I found recorded in regard to the water business was January 17, 1874, when Miles \& Holbrook of Los Angeles offered the lowest bid to make and lay for the Association an i I-inch water pipe, from Devil's Gate to the reservoir on Orange Grove Avenue; and Eaton, Porter and Gibson were authorized to make the contract. Reservations had been made of reservoir sites at five different points, but this on Orange Grove Avenue was the main one. On February $4^{\text {th }}$ B. S. Easton was formally appointed as superintendent of construction of bed or ditch for the water pipe, and he went on with the work. Meanwhile the settlers themselves did some work toward excavating for the reservoir. On May $4^{\text {th }}$ a bill of $\$ 585.47$ " for work done on the reservoir and water pipe" was ordered paid. But the early records are very meager and incomplete with regard to the Association's business transactions. On May 23d I found this record: "The charge of the reservoir till further action of the board, was confided to the care of Judge Eaton."

On March 20 th A. O. Bristol and Calvin Fletcher had resigned from the board of directors, and Col. J. Banbury and N. R. Gibson were elected in their steads. Then on June 27 th Col. Banbury was appointed on the water 


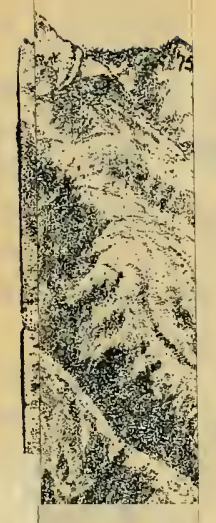




\section{DIVISION SIX - BUSINESS.}

\section{CHAP'T'ER XXI.}

WATER CoMpaniEs.- The colony's water supply.- Ditches, pipes, and reservoirs.The water war.- Water measurements and adjustments.- Votes and equities.Sketch of ten different water companies.

\section{THE SAN GABRIEL, ORANGE GROVE ASSOCIATYON.}

The original colony association that settled Pasadena was in fact a mutual land and water company, and the water interests, plans and prospects claimed earnest attention from the beginning. When Calvin Fletcher, A. O. Porter and Judge Eaton were appointed as an executive board for the Association, they agreed that Fletcher should take special charge of the work of subdividing and platting the land; Eaton should take special charge of the water supply work; and Porter stood as coadjutor to both. The Association was formally organized November 13, 1873; but it took time to bring about all the requisite preliminaries for actual work, and it did not have existence as a corporation under the laws of California until December 13, I873, the date of its state certificate. Then on December 20, they voted to authorize their proper officers to purchase tracts One, Two, Three, Four, of Rancho San Pasqual, from John S. Griinn. The Association office was then at No. 32 Main street, Los Angeles. [For particulars of the purchase, the incidental difficulties, etc., see pages 78 to $80,107^{-0} 8$, I 24 , etc.]

The first transaction I found recorded in regard to the water business was January I 7, I874, when Miles \& Holbrook of Los Angeles offered the lowest bid to make and lay for the Association an I I-inch water pipe, from Devil's Gate to the reservoir on Orange Grove Avenue; and Eaton, Porter and Gibson were authorized to make the contract. Reservations had been made of reservoir sites at five different points, but this on Orange Grove Avenue was the main one. On February $4^{\text {th }}$ B. S. Easton was formally appointed as superintendent of construction of bed or ditch for the water pipe, and he went on with the work. Meanwhile the settlers themselves did some work toward excavating for the reservoir. On May $4^{\text {th }}$ a bill of $\$ 585.47$ " for work done on the reservoir and water pipe" was ordered paid. But the early records are very meager and incomplete with regard to the Association's business transactions. On May 23d I found this record: "The charge of the reservoir till further action of the board, was confided to the care of Judge Eaton."

On March 2oth A. O. Bristol and Calvin Fletcher had resigned from the board of directors, and Col. J. Banbury and N. R. Gibson were elected in their steads. Then on June 27 th Col. Banbury was appointed on the water 


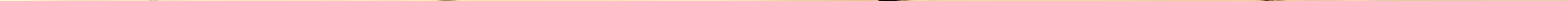




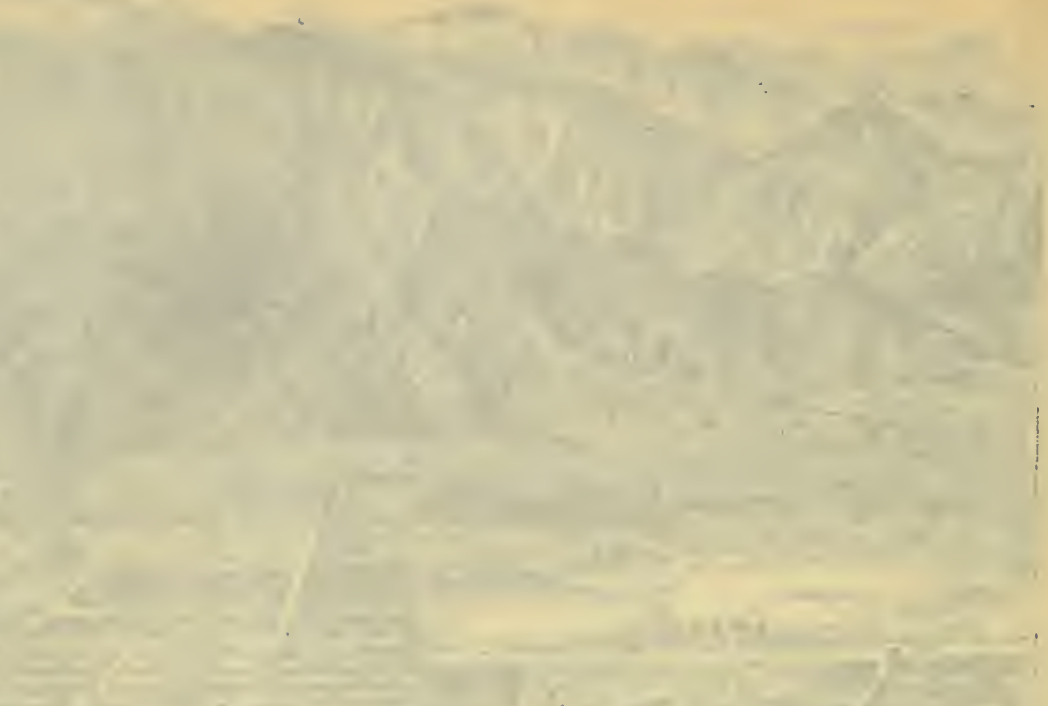

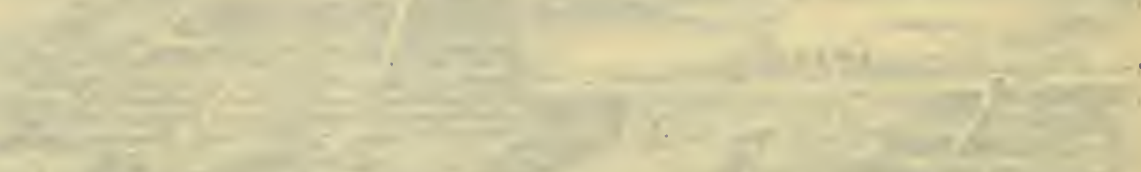

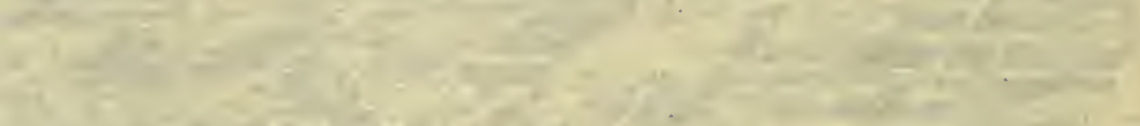

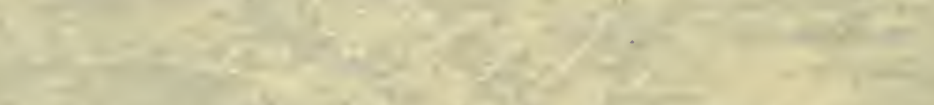

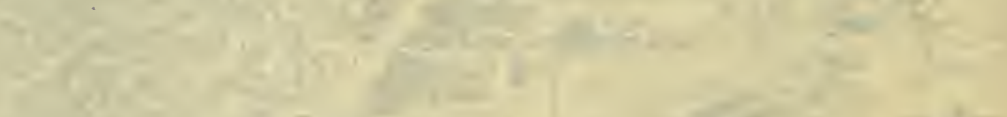

$$
\begin{aligned}
& \text { - }
\end{aligned}
$$

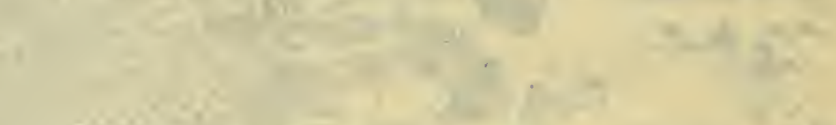

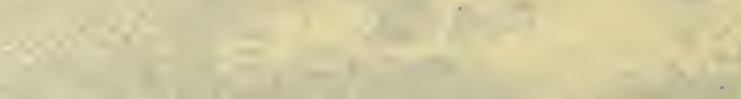

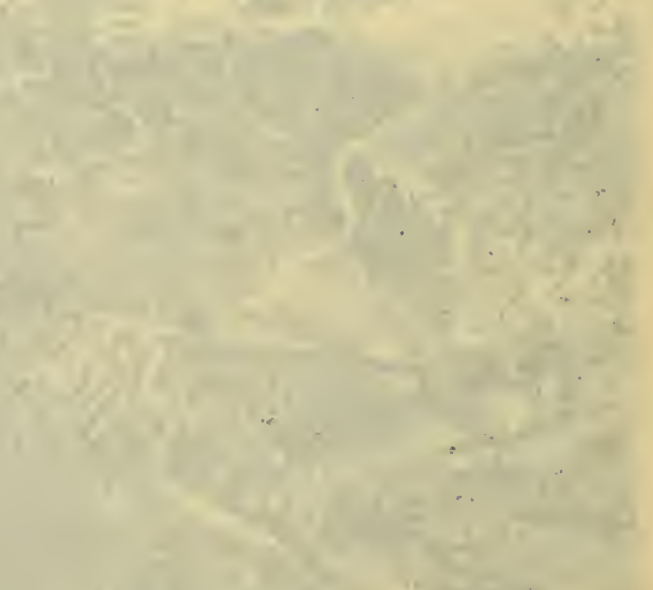


committee, vice Gibson, absent. On July $13^{\text {th }}$ the directors held a meeting at the sand-box [Devil's Gate]; and from this time onward their meetings were held in the colony [at the Secretary's house] instead of at Los Angeles. On August 8th Col. Banbury was appointed to take charge of water distribution and issue the permits. And he was thus the first Zanjero of Pasadena.

September I2, I874, mention is made of the lime kiln, and of Banbury and Croft as a committee to look after it ; but no further particulars. Then on October $3 \mathrm{~d}$ it is mentioned that Eaton and Clapp were authorized to employ a man to chop wood for burning two kilns of lime. [This lime kiln and lime quarry were right where the Lincoln Park reservoir is now, in South Pasadena ; and the lime was wanted for cementing the Orange Grove reservoir, and making cement pipe, etc.-ED.] On November 7 th occurs the first mention of Charles Morgan \& Co. [of Los Angeles] as the contractors for excavating the reservoir, although, as I learn from other sources, they had been at work on it from March; and water was let into one basin of the reservoir, not yet cemented, about the first of July.

On November 1 2, 1874, occurred the first annual meeting of the Association. The treasurer reported $\$ 2,862.63$ on hand. The Superintendent of water works reported the cost and capacity of the system; but no further particulars appear in the record. It is strangely deficient. The vote on board of directors for ensuing year is recorded thus: For Eaton, 152 shares voted ; Berry, I36 ; Croft, I50 ; Porter, I52 ; Banbury, I38 ; Gibson, 146 ; Dr. O. H. Conger, 78. The secretary reported having filed a claim to water in Millard canyon. [This was to supply their body of land now known as Altadena, which then had no water right. And this reported filing seems to have failed to stick, for they fually sold the land without any water right attached.-Eiv.]

The colony's water service went on without any particular difficulty from year to year, and was finally turned over to their first-born heir and successor, the Pasadena Land and Water Company.

The families that came here to live before the water pipe was laid to the reservoir had to haul water from the Arroyo, except Bristol; he got permission from B. D. Wilson to tap the old Wilson ditch where it came out on the mesa, and from there he made a plow-furrow ditch down to his place, to serve until the colony pipe was laid. This special advantage seems to have determined Bristol's choice of his colony lot.

\section{THE PASADENA LAND AND WATER CO.}

This company was the successor of the original San Gabriel Orange Grove Association; and the beginnings or forecast of it is indicated in a letter written by D. M. Graham to the Riverside Press July 13, 1880, thus :

"An association of fifteen of the land owners on the "Indiana" side 
of the settlement are making preparations to pump Sheep Corral spring water for their own use until the colony is ready to pay them for their works and take the water with the works. This will give the fifteen a superabundance of water, and give the rest of the colonists the water the fifteen now use, which is nearly half the present developed supply. This is hailed with delight as the solution of the problem of further water development which has frequently agitated us."

But the new company was not incorporated until March 18, I882, according to the county records. And the first record I found of a meeting was on April 21, 1882. The following names were then given as shareholders in the new company :

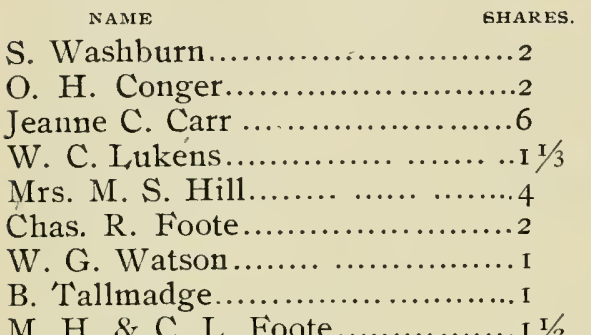

A. K. M'Quilling ................. $1 / 1 / 3$

C. H. Watts.................... 5

W. S. Hanaford...................

Josepl Wallace....................4

J. H. Baker ......................2

B. F. Ball ......................

B. S. Eaton ......................

P. M. Green ..................... $61 / 2$

A. O. Porter..................... 4

F. S. Clapp..................... 3

Thos. Nelmes.......................4

Mrs. E. A. Croft ...................4

S. B. Hunt ........................ 3

Elizabeth Whittier................. $2 / 3$

Edson Turner......................2

H. G. Bennett................... $31 / 2$

W. T. Holmes................... I

D. M. \& M. C. Graham............2

F. W. Greene ...................2

$\mathrm{J}$. Weingarth ..................... 3

Geo. Weingarth ...................2

SHARES.

E. F. Graves.................... I

E. F. Hurlbut ...................2

F. E. Chapman.................... 4

Mrs. M. A. Risley. .............. I

W. J. Bennett.................... $1 / 2$

H. N. Rust.....................4

E. H. Lockwood .................. I

John Ross ......................2

Geo. Lightfoot ................... 3

O. R. Dougherty. ................6 6

A. F. Mills ...................... I

W. T. Clapp $\ldots \ldots \ldots \ldots \ldots \ldots \ldots \ldots, \ldots$

F. A Clapp ..................... I

H. H. Markhan... ................ 3

Mrs. R. C. Locke .................. 4

H. L. Bryant .................... I

J. S. Mills ........................ I

A. O. Bristol......................2

James Smith....................... 7

H. J. Holmes......................

W. J. F. Barcus.................. I

Mrs. Mary S. Mosher.............2

Elisha Millard...................... I

E. A. Steele ..................... I

Alex. Edwards..................... I

J. H. Ellis.................... I

J. H. Lowell....................... I

W. H. Childs .................. $1 / 2$

James Cambell ..................... $4^{1 / 3}$

Mrs. L. Gilmore....................4

The first board of directors were O. R. Dougherty, P. M. Green, S. Washburn, H. G. Bennett, A. O. Porter, C. H. Watts, and E. Turner. The first officers were: Dougherty, pres't; Green, vice pres't; Bennett, sec'y ; Washburn, treas.; A. K. M'Quilling, zanjero [superintendent].

This water company being composed entirely of members of the colony association (and its officers the same), worked in harmony with it. The colony association had been incorporated November 13,1873 , for a term of 
ten years ; hence it was necessary to form this permanent company within the colony, to attend to the very important business of the water supply after the original incorporation should expire; and thus it came into its heritage and managed the water service some months before the property was formally conveyed to them. They fixed their capital stock at $\$ 50,000$, in 200 shares of $\$ 250$ each.

At a meeting of the San Gabriel Orange Grove Association, October 27 , I883, a resolution was adopted to convey for one dollar in gold coin, all its water interests to the Pasadena Land and Water Co. The items of property conveyed are described in full length of legal technicalities and details, from which I here summarize a few points of historic interest :

Arroyo lots 33 and 49. [Springy land.]

Reservation know11 as "Church Hill.", [Columbia Hill.]

Reservations located on the Holmes tract, the Lockhart tract, and the - Croft tract.

Undivided half of 'Thibbets' springs, etc.

The Sheep-Corral springs, and the reserved lands and waters in the Arroyo bed; also the pumping works, pipes, reservoirs, etc.

Its interest in the Elliott \& Richardson tract; and in lot No. 2 of $\mathrm{I}_{4}$ a Canyada; and an undivided three-tenths interest in sundry other lands and water rights.

All other rights, interests, properties and obligations of the San Gabriel Orange Grove Association.

O. R. Dougherty as president, and H. G. Bennett as secretary, were empowered and directed to execute this conveyance in due form of law. And thereupon the old colony association ceased to exist as a corporate body.

Mr. Dougherty served the new company as president continuously until April, I891, when he was succeeded by Mr. McQuilling, who had served five years as superintendent. Mr. Bennett had served as secretary of the colony association three years, and has been secretary of this water company continuously from its organization until now - I 895 .

As population increased it was found necessary to divide up the water shares into smaller values, in order to provide for a mere "domestic water service" to families owning only a village lot. And to meet this rapidly growing need, the company voted on November I6, I885, to increase their capital stock up to $\$ 75,000$, and make the shares number 3 , 000 instead of 200 , and at $\$ 25$ instead of $\$ 250$ each. This was preparing for the "boom." During i $885-86$ occurred the "water war," -but as it was chiefly confined to the Lake Vineyard side of the colony, I have given its chief historic points in my sketch of the Pasadena Lake Vineyard Land and Water Co. However, as an incident connected with the controversies of that time, I quote the following historic document :

WATER SUPPLY.

A. K. McQuilling, Eso.-My Dear Sir: After carefully going over the calculations from the measurements of the water supply of the Pasadena 
Water Company, taken yesterday by me, with your kind assistance, I find the results to be as follows : The total flow from Thibbets springs ............................... 56.6 Of which there passes into the Pasadena Water Company's pipe........ 34.0 Remainder flowing to the Pasadena Lake Vineyard Water Co.'s dam ....22.6 Including 2.2 seepage :

The flow of the Ivy springs, passing down to the P. L. V.'s dam..... 10.9 Total flow of the Flutterwheel springs .............................. 26.5

Recapitulating, the aggregate shows as follows:

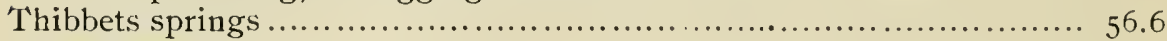

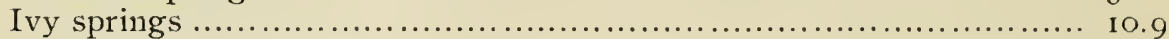

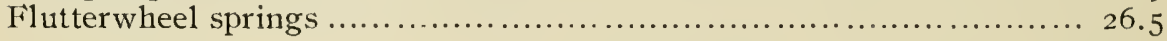

Total.

Of which the Pasadena Water Company receives 34 miner's inches, and the Pasadena Lake Vineyard Water Company 6o miner's inches. (A miner's inch equals $1-50$ cubic foot per second, or 1728 cubic feet, or I 3,000 gallons in 24 hours.)

As I understand the respective rights of the two companies to the various springs, the Pasadena Water Company is entitled to II-20 of the Thibbets springs, and I-IO of the Ivy and Flutterwheel springs. Applying these proportions to the above figures of volume now flowing, the Pasadena Water Company would be entitled to $34-89$ miner's inches. As we have seen, according to the present mode of division, this company is actually receiving 34 miner's inches, which may be considered very close to the mark, taking the many complications into consideration, and reflects much credit upon the zanjero who arranged the device for dividing the water so evenly.

I think a tunnel properly located will develop and concentrate all the water in the vicinity of the Devil's Gate, and I should be greatly deceived if it did not double the volume now flowing. The advantage it would possess over all other methods of diversion of water would be its permanence, and the fact that floods would not affect the quality nor interrupt the flow of the water, which wonld enter the pipes free from sand, leaves, insects, or any impurity.

\section{LOS ANGELES, November 4, I886.}

James D. Schuyler, Asst. State Engineer.

During i $887-88$, the two companies finally agreed-upon terms of ownership and division of the waters at Devil's Gate, and imade extensive improvements, including a large union delivery pipe from the Gate down to Reservoir No. I, in place of the old "Wilson ditch" which had before supplied the Lake Vineyard sicle, while the Orange Grove side had an I I-inch sheet iron pipe of their own from Thibbets springs to the Orange Grove reservoir. On November 9, 1888, water was first run through this union pipe to Reservoir No. I. Here it was divided in proportion of 7 -10 to the Orange Grove Company, and 3-10 to the Lake Vineyard Company, by a simple device arranged by the engineer, Col. J. E. Place. It was a brass double gate perforated with 4 -inch holes-seven in a row in one gate and 
three in a row in the other. The friction, the pressure, and the water level are equal, through each perforation, and thus the flowage through each is equal, and divides the waters in proper proportion to each company continuously, whatever the amount of the main supply may be.

January $22,189 \mathrm{I}$, the company voted to borrow $\$ 50,000$ to carry on some necessary improvements, and accordingly issued its bonds at 7 per cent. per annum, interest payable semi-annually. This money was used towards tunneling and piping at Devil's Gate ; enlarging and cementing the Orange Grove reservoir; laying a large new main down Orange Grove Avenue, and a new I I-inch steel pipe to the South Pasadena reservoir ; putting in a new pumping plant at Sheep Corral springs; building a submerged dam there; extending and improving their pipelines; etc. Concerning some of these matters I have gleaned a few points and dates. The Star of August 26, I891, said :

"City Engineer J. W. Sedwick has prepared drawings and specifications for the work proposed to be done near Devil's Gate by the two water companies for increasing the flow of water from the vicinity of Flutterwheel springs down to the sand-box. It involves the laying of about 500 feet of 22 -inch steel pipe, $35^{\circ}$ feet of which will be laid in a $4 \times 6$ tunnel under the hill. It is estimated that the work will cost about $\$ 2,500$."

The same paper of September 2 said:

"At a meeting of the executive committee of the Pasadena Land and Water Company, held yesterday, the contract for laying 2, IOo feet of I I-inch steel pipe, to replace the cement pipe to the South Pasadena reservoir, was let to E. White, Sons \& Co."

And September 44 it said:

"Contracts were signed today by the officers of the Lake Vineyard and the Pasadena Land and Water Companies and Carmichael, Reed \& Gillead, for the work of tunneling at Devil's Gate."

From a report of expenditures in 1893 I quote these items: Income: bonds sold, $\$ 27,000$; water dues, all classes, total, $\$ 13,553.93$. Expenditures-Orange Grove reservoir, $\$ 5, \mathrm{I} 32.35$; pump, boiler and oil plant, $\$ 7,35^{6.50}$; work at Devil's Gate, $\$$ I, 8 II.59; work at sheep corral springs, $\$ 5,2$ I 5.75; fuel, $\$$ I, 956.59 . These are the items of special historic interest. But the total income for this year was $\$ 4 \mathrm{r}, 774.07$; and total outlay, $\$ 38$, 482.53 .

It was in May, 1892, that an oil cistern was built under the Los Angeles Terminal railroad, a few rods north of the North Orange Grove Avenue crossing, and an oil pipe laid from there to the pumping works, so as to use crude

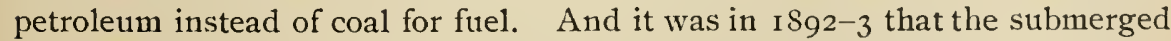
dam was built, 22 feet from its top down to bed rock at deepest point. [Find full account of this dam in Daily Star, December 19, I 892.]

In 1894 the pumps were started April I 8 , and run 13 hours per day, making 212 strokes per minute, and lifting 60,000 gallons of water per hour, 
with a dead pressure resistance on the up-pipe to the reservoir of about 65 pounds per square inch. The apparatus is Worthington's compound duplex condensing steam pump. These data I gathered from C. H. Hovey, the engineer in charge of these works in I $894-5$.

The Weekly Star of August 8, I 894 , gives an estimate by Thomas D. Allin, civil engineer of the two water companies, that the daily flowage at Devil's Gate was about 225 miner's inches, or about two and a half million gallons per day on April I, I 894. But the dry season, by July I 5, had reduced the flow to 179 inches; and there was no perceptible diminution after that date.

WATER RATES. - Secretary Bennett, in an article published March 4, I 895 , said :

"We have upon our books the names of 750 householders, and of this number 550 pay a monthly rate of \$I.25 to \$I.60 inclusive; IOO pay \$I.65 to $\$ 2$ inclusive, and Ioo pay over $\$ 2$. These are the rates for eight months of the year. During the four hot summer months, July, August, September and October, an additional charge is made for lawn sprinkling, as follows: All lawns $20 \times 30$ feet, or containing 600 square feet, are exempt ; lawns exceeding 600 square feet, and up to 5000 square feet, are charged 25 cents per 1000 square feet; 5000 , and above 5000 square feet, 15 cents per I000."

STATISTICAL EXHIBIT.

The following table was compiled expressly for this work by Secretary H. G. Bennett, at my request, to show the historic progress year by year of the business of this company, whose territory was entirely west of Fair Oaks and Lincoln Avenues, but included South Pasadena also:

\begin{tabular}{|c|c|c|c|c|c|}
\hline YEAR. & Income. & Expenditures. & VEAR. & Income. & Expenditures. \\
\hline I $882-3$. & $\$ 14,842 *$ & $\$ 14,557$ & I $889-90 \ldots$ & $\$ 1$ I , I 99 & $\$ 10,685$ \\
\hline I $883-4 \ldots \ldots$. & I 7,466 & I 6,655 & I $890-9$ I..... & IO, 742 & I 0,073 \\
\hline I $S_{4}-5 \ldots \ldots$ & $7,07 \mathrm{I}$ & 6,8 I 7 & I $89 \mathrm{I}-92 \ldots .$. & $32,5^{6} 3+$ & 32,014 \\
\hline I $885-6 \ldots$ & $5, \mathrm{I} 5 \mathrm{O}$ & 4,987 & I $892-93 \ldots \ldots \ldots$ & $4 I, 774$ & 38,483 \\
\hline I $886-7 \ldots \ldots \ldots \ldots$ & 20,902 & $\mathrm{I} 2,4 \mathrm{OI}$ & I $893-94 \ldots \ldots \ldots .$. & I 8,627 & I 2,706 \\
\hline I $887-8 \ldots \ldots \ldots \ldots$ & 29,588 & 27,355 & I $894-95 \ldots \ldots \ldots \ldots$ & I $7,5 \mathrm{I} 4 \mathrm{~S}$ & I 5,4 I 2 \\
\hline 1888-9........... & 26,565 & 26,368 & & & \\
\hline
\end{tabular}

The company now has ro miles of water pipe in use. The total value of its water rights, lands, tunnels, dams, pipes, pumping works, reservoirs, etc., is $\$ 250$, 000. Bonded debt, $\$ 50,000$. Up to April, I 895 , it had issued 825 water permits. The permanent employees are only three: Secretary at office; superintendent on pipelines; watchman at water sources. A steam engineer has to be employed to run the pumping works during the dry months.

PASADENA LAKE VINEYARD I,AND AND WATER CO.

See page II2, and following, for an account of the second subdivision of colony lands in Pasadena, which was made by B. D. Wilson in I886, under the name of "Iake Vineyard Land and Water Association."

* Assessmerts and water dues. ¥Bonds and water dues. Z Water dues only. 
In a few years it became desirable or necessary to put the management of the colony's water business into the hands of business men on the ground; and on July II, I883, a deed was made by the original Lake Vineyard Co. and the Orange Grove Co. to A. O. Porter and others as a syndicate. January 29, I884, the people on the Lake Vineyard side formed a new organization under the name of "Pasadena Lake Vineyard Land and Water Co.," with $\$ 75$, 00 subscribed, and on February 5 filed their articles of incorporation with the county clerk. Capital stock, $\$ 250,000$, in 5,000 shares of $\$ 50$ each. The incorporators and first board of directors were S. Townsend, C. C. Thompson, C. C. Brown, Samuel Stratton, G. T. Stamm, C. A. Clark, J. W. Wood. Towusend was elected president, Brown, treasurer, and $\mathrm{H}$. W. Magee, secretary. There were now three different water companies besides "the syndicate" doing business in Pasadena, and the "water question" became a strangely mixed muddle of confusion. The Union of March 15, 1884, said: "About 250 feet of the main ditch [cement] on the Lake Vineyard Co.'s lands were washed out by the late storm. A wooden flume is being put in ; and an assessment of 45 cents per share has been levied to repair damages."

April 26, I884, the Union mentioned that "over 3,000 shares of the P. L. V. L. and W. Co.'s stock had been subscribed, or about \$I50,000." Yet the same paper of September 6 said complainingly: "Six months have elapsed since the new company was chartered, yet only about half the old company stockholders have attended to changing their stock."

In the Union of September 27, I884, three members of the syndicate, H. W. Magee, Geo. E. Meharry, and James Clarke, offered to sell to the new company their holdings in the L. V. Association at a pro rata on $\$ 5$,000 for the entire property-springs, flumes, ditches, pipes, reservoirs, etc. And accordingly the Union of December 20, I884, contained an official notice that an election would be held by the new company on January Io, I 885 , to accept or reject this proposition from these men, and from any other holders of the old stock who might offer it on the same terms before the day of this election. The paper of same date contained also two other notices by the new company - one of an assessment of twelve cents per share to pay debts necessarily incurred, amounting to $\$ 351.75$; and one for an election of a new board of directors on January 26,1885 , to serve one year from February 4. The election of January Io, on the syndicate proposition, resulted in I 166 shares voted for accepting it, and I 35 shares against.

But this vote did not seem to settle anything; and for some months following there was warm discussion, sometimes even acrimonious, through the newspaper by a variety of water doctors, each making his own diagnosis of the colony's water ailments, and prescribing his own infallible cure-all. The two principal companies were designated as "west-side" and "eastside", they owned certain water-bearing lands or springs in common, with 
different proportions of water right. The titles and boundaries, and the methods of gathering and dividing the waters were all somewhat vague, giving rise to disputes, and at last to costly and fruitless lawsuits - in fact, a hot dispute once occurred near Devil's Gate, when shotguns were brandished, and threats of "ducking" in the ditch, etc., were indulged in. And these doughty belligerents still survive, as veterans of the "water war." The Union of July 17, 1885, contained a brief report of a mass meeting held in Williams hall on the $\mathrm{I} 3^{\text {th, }}$ at which Geo. E. Meharry presided, Chas. A. Gardner served as secretary, and C. C. Brown was the principal speaker-all on the "water question." The same date of paper also had a report of a general public picnic held at Devil's Gate on the I 5 th for speech making, questioning, discussion, and investigation of the "water question" under the auspices of this new company, of which C. C. Brown was then president.* And the same paper also contained the following announcement :

"A public meeting of the citizens of Pasadena in the interest of a peaceful settlement of the water question is called for Saturday evening, July I8, at Williams Hall. Let all who desire a peaceful settlement of our unfortunate difficulties be present and lend their influence to that laudable end. Signed
" J. BANBury.
S. TOWNSEND.
R. WILLIAMS.
H. W. MAGEE.
B. F. BRYANT.
Al BERT NINDE.
S. D. BRYANT.
M. M. PARKER.
J. İ. ClaAkKE.
A. A. Williamison.
RIDGWAY \& R
D. M. Graham.
Lyman Allen.
Chas. LEGGE.
H. H. MARKHAM.
P. M. GREEN."

These are historic waymarks on the road through the colony wilderness up to the goodly land of promise, as we now have it. The next issue of the paper reported that the "peace" meeting was held on Monday instead of Saturday; and it resulted in a formal request for a joint committee :

From the Pasadena L. V. Land and Water Co.................. 4

From the Lake V. Land and Water Association.................... I

From the Pasadena Land and Water Co........................ 3

To confer together, and devise and recommend some plan or terms of settlement of the existing difficulties.

This movement, however, produced no visible results, for the new company had a family skeleton in their own closet. Their vote on the syndicate proposition, January Ioth, was for some reason not satisfactory; and in October it was tried again on the same proposition, the names of $\mathrm{H}$. F. Goodwin and O.S. Picher being added to those of Magee, Meharry and Clarke. The result was reported in the Union of October 9, I885, thus :

"The election held Saturday [October 3, I885], by stockholders of the Pasadena Lake Vineyard Land and Water Company to decide upon buying

*I attended this picnic; and it was then that I first noticed and called attention of friends to the peculiarly marked rocks there, which I lave since identified and described as "slickensides," "glacial enamelings," and " water carvings." 
out the syndicate resulted in almost a unanimous vote for the measure I,677.1 2 shares being voted for it, and 291.78 against."

Yet even this did not end the trouble, for the controversy still went on by tongue, and through the press. And the Union of October 16 th contained official notice that on October IO, I 885, the directors had ordered an assessment of 45 cents per share on the stock, payable on or before November I 2 th, to purchase the interest of John Allin, O. S. Picher and H. F. Goodwin in the syndicate lands - the amount being $\$ 312.50$ for each interest; also to pay $\$ 337.65$ of debts legally incurred by the company. This was called "Assessment No. 3." I suppose the I 2 cents levy was No. I ; and I did not find No. 2.

On January 23, I886, another mass meeting was held in Williams Hall, of which the Union [29th] said: "The water meeting Saturday evening was a large and exciting one." Abbot Kinney presided. C. 'T. Hopkins and C. C. Brown locked horns on the matters in controversy, and were the principal speakers. But short speeches were also made by C. C. Thompson, Dr. Lyman Allen, S. Washburn, O. S. Picher, Samuel Stratton, H. W. Magee, Geo. E. Meharry, and some others - all boiling hot on the "water question." On the ensuing Monday another election took place ; and as to its points, purposes, and results, I quote from the Union of January 29, 1886, the following:

"'The water election Monday, January 25th, was the great event of the winter, and drew out an immense amount of interest on both sides. 'These sides may be designated as the old board of directors, and the opposition thereto, the latter indicating a difference of opinion with said old board as to management of the Company. The friends of the old board put in nomination C. C. Brown, M. H. Weight, A. V. Dunsmore and W. Freeman. 'The opposition thereto named S. Townsend, Justus Brockway, H. F. Goodwin, Thomas Banbury and R. Williams. Mr. Townsend however, withdrew early in the fight, leaving the ticket, like the other with only four, and these prevailed over the old board by a total vote of 7,138 shares to 4,830 shares. 'The amount of stock voted was 3 , OIO shares, indicating a most creditable interest in the affairs of the Company, for only about 3,300 shares have been issued. Each stockholder, of course, voted according to the number of his shares. These shares he might divide among different candidates, or concentrate all on a lesser number - even down to one. It thus follows that the vote is presented in two different ways - first as indicating the number of shares voted for each, and second, as showing the number of votes each received by this cumulative process. Taken on the first basis - that of shares, the vote was as follows:

\begin{tabular}{|c|c|}
\hline Brockway .................... & I, $6255-7$ \\
\hline Goodwin ................... & $1,742 \quad 2-7$ \\
\hline Banbury...... & $\mathrm{I}, 675 \mathrm{I}-$ \\
\hline Williams.... & $1,6313^{\prime \prime}$ \\
\hline Brown ......... & $2,0644^{-}$ \\
\hline Weight ..... & $952 \quad 4-7$ \\
\hline Dunsmore.. & 8862 \\
\hline Freeman ... & 926 \\
\hline
\end{tabular}

BY VOTES.

Brockway................... 2,845

Goodwin................... 3,049

Banbury ................... 2,932

Williams.................... 2,855

Brown....................... 3,6 $\mathrm{I}_{3}$

Weight ..................... 1,667

Dunsmore................... I, 55 I

Freeman..................... I, 622

Townsend................... 464 
"The elect therefore are Messrs. Justus Brockway, H. F. Goodwin, Thomas Banbury, R. Williams, C. C. Brown, M. H. Weight, and W. Freeman, the term of which new board is for one year from February 4 th. The proposed amendment to the By-Laws was defeated.

"The result of this, of course, is a change in the policy of the Company, the only point at issue in the election being a difference of opinion as to the wisdom of settling certain unsettled points between this and the old "Orange Grove" Company on terms proposed by the latter. The old board have held those terms to be unjust and have steadily declined a settlement on that basis. Many of the stock-holders differed with them in opinion, and it was on this difference of opinion that the opposition ticket was nominated and elected. A settlement of the long-vexed "water question" may therefore be expected at once, and to that end one of the first acts of the new board will be to submit the question to a vote of the stock holders."

The question was so submitted again on May 4 th, I886, and here is the Union's report :

\section{THE WATER QUESTION SE'T'TLED.}

"Tuesday's vote gave the following result :

No. of persons voting for the proposition............................. I 36

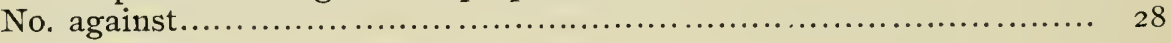

Majority by persons......................................... 168

Or nearly five to one.

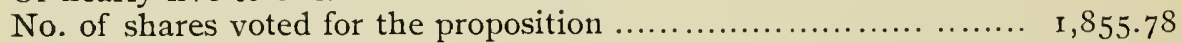

No. against ..................................................... $\quad 725 \cdot 3 \mathrm{I}$

Majority by shares................................... I, I30.47

Or about two and a half to one.

"It is a grand result for every future interest of the colony; and let it go abroad to all the world, with no uncertain sound, that Pasadena no longer has a "water question." That has been settled at once and forever, in the genuine American way, by the free and voluntary suffrages of those who were lawful voters in the case."

January I, I889, the lands, reservoirs, pipes, etc., of this company were valued at $\$ 154,403.26$; and during that year new pipes were laid to the amount of $\$ 9,577.88$.

During the year 1892 , the company expended $\$ 50,112.22$ in tunneling, reservoiring, pipelaying, etc. Two miles of 4 -inch pipe was laid from Reservoir No. I direct to the Raymond hotel, for special use of the hotel and its grounds. During this year and IS93, the old colony mudhole known as Reservoir No. 2 was deepened, its earth walls raised and strengthened, the entire inside cemented, and 5,000 feet of 16-inch steel pipe laid from Reservoir No. $I$ as the feed-pipe to No. 2. Its storage capacity is $2 \mathrm{I}, 000,000$ gallons-the largest cemented reservoir in South California at the time. And Villa street was opened straight across the lower end of the old reservoir site, instead of circling around it as before. It was during these years that the extensive tunneling operations were carried on at Devil's Gate to 
increase the quantity and improve the quality of the city's water supply. The secretary reported in 1893 , twenty-four official meetings of the directors ; 146 permits issued; and 288 transfers of stock.

During 1894, this company paid $\$ 4,550$ toward the purchase of water bearing lands known as the Elliott \& Richardson tract, to gain entire control of both the land and the water jointly with the other company, and put a stop to any further disputes or legal difficulties about it. The two companies joined in this purchase, and then worked together in tumneling for more water at these Richardson springs, and also at the Wilson springs about one-eighth mile farther south. Contracts were let to G. D. McGillard and D. F. Carmichael. And the secretary's annual report on these tunnelings presents a few points as to water-supply, water measurement, etc., which are of permanent historic interest, and I quote his language :

"Both tunnels are being prosecuted at the same time, with the result at the close of 1894 in a gain of 99 miners' inches, * which, with the former flow from the Flutterwheel springs tunnel, the Ivy and Thibbets springs, viz., I 78 miner's inches, makes a total of 277 miner's inches- 7 -Io of that amount as our proportion, being equal to $2,5 \mathrm{I} 2,944$ gallons per day, a sufficient amount to supply a population of 6,000 persons or $\mathrm{I}, 200$ families with $4 \mathrm{I} 8$ gallons per capita per day. Statistics from other cities show that in 1894 , Philadelphia used 160 gallons per capita per day, Chicago i 50, New York 95 and Boston 9o."

During 1894 the company's revenue from all sources was $\$ 8$, 000 more than in 1893 ; its sale of water alone amounted to $\$ 3,683.09$; and it reduced its indebtedness by $\$ 11,500$.

C. C. Brown has been a member of the board of directors of this company continuously from its first organization in 1884 -the only man enjoying this distinction, and he is thus the veteran survivor of "many wars." The successive secretaries of the company have been H. W. Magee, J. W. Wood, C. A. Sawtelle, R. Williams, E. E. Fordham-and lastly John Habbick continuously since July, 1887 . Albert $H$. Ninde has been inspector (or zanjero as the Spaniards called it) continuously from i 884 until i 895 .

On account of bickerings and strifes, differences of opinion, legal contests, charter rules and limitations not adapted to the practical necessities of the situation, and lack of funds to pay for proper clerical work, the books and records of the first four years are very incomplete. From the records as they are, and other sources, I have compiled the following table in chronological order :

*A miner's inch, Pasadena measure, is thus officially explained by the company: "An inch of water that is equal to 17,000 gallons of water every 24 hours, or about roo pounds per minute, is the water that is equal to 17,000 gallons of water every 24 hours, or about loo pounds per monsure or head of six inches above the center of theopening; the opening being two inches wide in the end of a box provided withes slide, and the number of square inches remaining open indicates the amount of water passing through in Miner's Inches." 


\begin{tabular}{|c|c|c|c|}
\hline YEAR. & Income. & Expenditures. & President. \\
\hline I $884 .$. & I $2 \mathrm{C}$ per share levy & 350.75 & Stephen Townsend. \\
\hline I $885 \ldots$ & $45^{\mathrm{C}}$ per share levy & I, 275.15 & C. C. Brown. \\
\hline I 886. & $*_{5}, 000.00$ & n........... & Justus Brockway. \\
\hline I $887 .$. & $\ldots \ldots \ldots \ldots \ldots$ & ........... & C. T. Hopkins. \\
\hline I $888 \ldots$. & $\$ 45,023,98$ & $43,168.19$ & R. Williams. \\
\hline I $889 \ldots \ldots$. & $23,502.69$ & $23,244 \cdot 47$ & Geo. E. Meharry. \\
\hline I $890 \ldots \ldots$. & I $4,887.47$ & I $4,957.68$ & John Allin. \\
\hline $189 \mathrm{r} . . . \ldots \ldots \ldots . . .$. & I $7,342.95$ & I $4,146.45$ & John Allin. \\
\hline $1892 \ldots \ldots \ldots \ldots \ldots$ & $52,742.43$ & 50, I 12.22 & Chas. M. Parker. \\
\hline r $893 \ldots \ldots \ldots \ldots$ & $29,033.4 \mathrm{I}$ & $28,788.18$ & Same. \\
\hline I $894 \ldots \ldots \ldots \ldots \ldots$ & $3^{6}, 64 \mathrm{I} \cdot 7 \mathrm{I}$ & 32,6 I 2.42 & Same. Also I 895. \\
\hline
\end{tabular}

NORTH PASADENA LAND AND WATER COMPANY.

This company was an outgrowth of the development of the "Painter \& Ball Tract," for which see page $34^{2-3}$. The origin of the present corporation was thus reported in the Valley Union at that time:

"A meeting of purchasers on the Painter \& Ball tract was held Saturday night [January 3, I 885] at the residence of J. H. Painter to take steps toward incorporating the water system of the tract. Present, B. F. Ball, J. H. Painter, Mrs. Edith Painter, Amos Wright, Henry Rank, C. Brenner, John Allin, Robert Hiatt, J. E. Doty, G. W. Hayes, M. D. Painter, and Byron O. Clark, who all favored the proposed step. B. F. Ball was elected chairman and B. O. Clark secretary. Amos Wright moved that a committee of five be appointed, with full power to act, to take steps toward the incorporation. Motion carried, and Messrs. B. F. Ball, John Allin, B. O. Clark, Amos Wright and M. D. Painter were appointed such committee."

The county record gives January I5, I885, as the date of incorporation. Capital, $\$ 90,000$, in $\mathrm{I}, 800$ shares of $\$ 50$ each. Corporation to exist fifty years. The first officers were B. F. Ball, president; M. D. Painter, secretary and treasurer; and Mr. Painter holds the same office yet. From the original enrollment of stock I quote this exhibit:

\begin{tabular}{|c|c|c|}
\hline B. F. Ball...... & 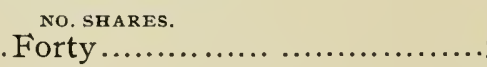 & $\begin{array}{l}\text { AMOUNT. } \\
\$ 2,000\end{array}$ \\
\hline John Allin...... & Four and one-half...................... & 225 \\
\hline J. H. Painter.... & 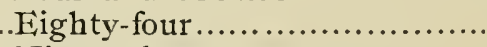 & 4,20 \\
\hline M. D. Painter.. & . Ninety-three............. & 4,65 \\
\hline Byron O. Clark & Forty-six and one-half.. & 2,32 \\
\hline
\end{tabular}

This statement was signed and sworn to on January 15, I885, before R. Williams, Notary Public at Pasadena.

The original beginnings of the water system now owned by this company were the open ditch made by Wilson \& Griffin's Frenchman, Dague, prior to $\mathrm{I} 868$, which led the waters of Millard canyon out to. a point just

*J. W. Wood resigued as secretary in October, 1886 , and gave in round numbers -700 new certificates issued $; \$ 2,000$ assessments and $\$ 3,000$ water dues collected during the year. 
north of Monks Hill ; and the ditch made by John W. Wilson in I878-79 from Negro canyon to the Las Casitas plateau. (But Painter \& Ball had done a large amount of developing and piping before the corporation was formed; in September, I884, they had bought some water rights of Mr. Brunk in the Arroyo Seco canyon and during the year laid two miles of iron pipe.) J. H. Painter and his sons M. D. and A. J., together with B. F. Ball, Byron O. Clark and engineer H. C. Kelsey, did all the prospecting for their additional springs in the Arroyo Seco above mouth of Millard canyon. And in 1885-86 the California Olive Company built a cement dam in Millard canyon far above Millard falls, besides some other developments, and piped the water out over the foot-mountain above Leighton's canyon and down to their 200-acre olive orchard, all as a part of the North Pasadena. system; and Byron O. Clark superintended this work.

In May, I889, the company levied an assessment of $\$ 5$ per share on its stock, there being then about $\mathrm{I} 700$ shares out. They had about two miles of cement pipe leading from the Arroyo to their upper reservoir; but this was leaky, and a new iron main was necessary. This was put in; and also some tunneling and other development work on their water-bearing lands. From the Pasadena Standard of October I2, I 889, I quote this interesting note:

"The North Pasadena Water Co. put in meters to test the supply by measure and prevent needless wastage. The results have been very satisfactory. The average amount used per family is given in gallons, thus :

During the month of July .............................. I 9,777

During the month of August.............................. 44,302

During the month of September.......................... 9,510

This 50 per cent. decrease per family shows that people were in July running out twice as much water as they really needed."

In response to my inquiries at the company's office in I894, the following particulars were furnished me :

"The company owns 160 acres of mountain land, covering springs in Negro canyon, a small branch of the Arroyo Seco; eighty acres of land covering springs in Brown's canyon; all the waters of the Arroyo Seco and Millard canyon at the head of our pipe line, in Section 5 , T. I N., R. I 2 W., besides the waters of numerous small springs in the mauntains to which our pipes are laid. Also, water rights at the head of the Wilson ditch, and 7.20 interest in the storage reservoir site in the east end of La Canyada valley. We have one reservoir roo feet square and ro feet deep, cemented, cost $\$ 4,000$; one reservoir $50 \times$ roo feet, I 2 feet deep, covered, cost $\$ 4,000$; seven miles of $1 / 2-$ to 6 -inch pipes in the mountains for collecting water from springs; $1 / 2 / 3$ miles of 16 - and 18 -inch vitrified water pipe, cost $\$ 6,000$; one mile I 3 -inch steel main, cost $\$ 5,000$; distributing pipes on Painter \& Ball tract from 2 to $\mathrm{I} 2$ inches. All the pipe system above named is probably worth in present condition $\$ 20,000$, and 300 meters, worth $\$ 4,000$. We have six tunnels, and various water-claims and developments yielding on the first day of September, I893, a flow of 30 miner's inches, besides a pumping plant capable of supplying I 2 miner's inches, measured when the 
water was lowest of any time in the year. We have a list of 360 consumers, on a tract of 1,800 acres of land, from whom we collected in water rents during the year of $\mathrm{r} 893, \$ 5$, $000 . "$

Total miles of water pipe, 20 ; two reservoirs with storage capacity of r, 200,000 gallons; total value of company's property, about $\$ 60,000$.

THE LAS FLORES WATER COMPANY.

The Urion of June I2, I885, says :

"At a meeting held on Wednesday [June Io] articles of incorporation were adopted, and the Las Flores Water Co. organized, with a capital stock of $\$ 96,000$, of which $\$ 73,000$ is subscribed. Directors : G. A. Swartwout, J. W. Hugus, D. Galbraith, L. A. Wright, P. Gano. On November 2 an assessment was made of \$1.25 per share, payable on or before December 24, i 885. R. Williams was then secretary of the company. Some tunneling, damming and piping was done by the company in Las Flores canyon."

HERMITAGE WATER COMPANY.

November I3, I886, the Union said :

"Articles of incorporation were filed Tuesday [November 9] by the Hermitage Water Co. to buy and sell water rights in and about Precipicio [Eaton's] canyon. Directors : James Craig of the Hermitage Tract, Ed. L. Farris, and T. P. Lukens of Pasadena, J. R. Scott and George Hanson of Los Angeles. Capital stock, \$100,000 - all subscribed.'

PRECIPICE CANYON WATER CO.

Incorporated March 30, I887. Capital stock, $\$ 625,000$, in 12,500 shares of $\$ 50$ each. Place of business, Lamanda Park. This company operates in Eaton canyon, the old Spanish name of which was Precipicio canyon - but they printed their certificates in plain English, Precipice Canyon. The stockholders in $\mathrm{r} 887$ were:

J. F. Crank........................................4,500 shares

Wm. Allen..........................................2, 000 shares

Albert Brigden.....................................2,000 shares

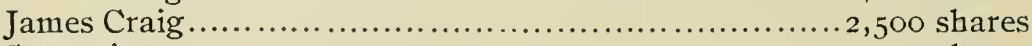

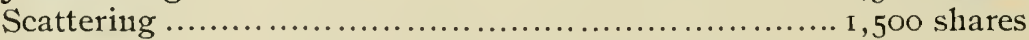

Total of 1,500 acres interested.

Officers: Crank, pres't; Craig, vice pres't ; Herman Blatz, sec'y.

The state engineer reported in 1887 that this company had a flow of 500 inches during the winter and spring, but rumning down to forty (?) inches in the dry time of a dry year. This report was before they had tunneled or developed their resources; but I think was a mistake even when made.

\section{OAK KNOLL, WATER COMPANY.}

January I, I887, the Union reported :

"Articles of incorporation were filed Tuesday [December 28, I886] for the Oak Knoll Water Co., to buy, sell, and deal in water rights, and to develop and increase water supply on the Oak Knoll Tract. Principal place of business, Los Angeles. Directors: S. D. Rosenbaum, New York City ; 
Morris Augustine, San Francisco; E. L. Stern, Leon Loeb, E. M. Adler, Los Angeles. Capital stock, \$100,000, in $\mathrm{r}, 000$ shares of $\$ 100$ each - all subscribed by the directors.

\section{RUBIO CANYON LAND AND WATER CO.}

Incorporated Februry 24, I886, by F. J. and John Woodbury, and others, to develop, utilize and control the waters of Rubio canyon. They did the first piping and tunneling ever done in this canyon, running a tunnel seventy-five feet into its west wall in December, I883. In I89 I their holdings were merged into the great enterprise now known as the Mount Lowe Electric Railway Co. The Daily Star of April I, I 895, said :

"At a meeting of the Rubio Canyon Land and Water Association today directors were elected for the ensuing year: F. J. Woodbury, J. H. Holmes, R. S. Barnhart, J. S. Torrance, and T. S. C. Lowe. Woodbury was elected president; Holmes, vice-president; A. B. Manahan, secretary ; and First National bank, treasurer."

\section{MILLARD CANYON WATER COMPANY.}

Incorporated April 14, I887, with J. P. Woodbury, E. C. Webster, Byron O. Clark, Calvin Hartwell and Levi W. Giddings as the first board of directors ; and E. W. Giddings and F. J. Woodbury were additional members of the company. I. W. Giddings was chosen president, and C. Hartwell secretary and treasurer. There are 7,200 shares of $\$ 5$ each. This company was formed to hold, develop, improve and concentrate the springs and water sources of Millard canyon and its tributaries; but it does not distribute the waters beyond or below the canyon. The Cemetery Association, the California Olive Company, and the Pasadena Improvement Co., each have reservoirs and pipelines of their own, served from this Canyon company's gathering pipes. In I 894-95 Hon. P. M. Green is president, and D. C. Porter, secretary and treasurer.

\section{PASADENA HIGHLANDS WATER COMPANY.}

The Weekly Star of May 27, I891, says:

"Messrs. G. D. and C. E. Patten, W. C. Besse, D. Galbraith and D. J. Macpherson, who own the Highland Tract, bounded by Washington street, Lake, New York and Hill Avenues, have formed the Pasadena Highland Water Company, with a capital stock of \$15,300, all of which is subscribed."

But according to the county records this company had been incorporated November I, I89o. No other particulars obtained.

\section{COTTONWOOD CANYON WATER COMPANY.}

Cottonwood canyon is a small gulch in the San Rafael hills [Dreyfuss's allotment] about half a mile up the Arroyo beyond the Linda Vista green house. The Pasadena Star of November 9, I892, said :

"The Cottonwood Canyon Water Company, composed of Pasadena men, has been organized. The company proposes to acquire water rights and dispose of water to inhabitants on block A of the San Pasqual tract, of the lands of the Lake Vineyard Land and Water Company, situated in the 
northwestern part of Pasadena. The principal place of business is Los Angeles. [?] The capital stock is $\$ 30,000$, all of which has been subscribed. The incorporators are W. S. Wright, trustee; Wm. R. Staats, John McDonald, W. S. Wright, C. E. Brooks, Joseph M. Campbell."'

N. G. Yocum had developed a small flow of water in this canyon in 1887 . The incorporators took it on a note of Yocum's, of which Wright was trustee; in 1894 they ran a new tunnel, and reported a stream of four miner's inches.

\section{CHAPTER XXII.}

RAII.ROADS.-The S. G. V. R. R. (Santa Fe).-The Dummy Road.-The Altadena Road and Los Angeles Terminal.-The Fair Oaks Line.-The Colorado Street Line.-The Painter Line.-The Highland Line.-The Linda Vista Line.-The Alhambra Line.The Pasadena and Los Angeles Electric Railway.-The Ramona and Pasadena Narrow Gauge (now Southern Pacific R. R.)

\section{SAN GABRIEL, VALIEY RAILROAD.}

This was the first undertaking to connect Pasadena with the rest of the world by railroad, and therefore has a very intimate and close historic connection with the development of the city and its adjacent settlements. The railroad was first projected and planned by Mr. S. P. Jewett, a young engineer who came to Pasadena from Chicago in 1879 , and with his widowed mother, Mrs. Belle M. Jewett, settled on Orange Grove Avenue.

The first meeting to talk over the project was held in Los Angeles in September, I882, when there were present: J. E. Hollenbeck, C. H. Simpkins, E. F. Spence, J. F. Crank, S. P. Jewett. The first three men feared that such a road could not be a financial success; there would not be traffic enough to sustain it, and they declined to join in forming a company to build the road. This delayed the matter nearly a year; but meanwhile Mr. Jewett stuck to his text, and went on perfecting his plans as to route, grades, curves, bridges, right-of-way, station points, terminus, etc.; and finally, through Mr. Crank's efforts, enough men were found who had faith in it to form a company. This was accordingly done at Los Angeles on August 3o, I $88_{3}$, by J. F. Crank, S. Washburn, W. R. Davis, A. Bridgen, W. P. Stanley and S. P. Jewett, who then became incorporated as the "Los Angeles and San Gabriel Valley Railroad Company," with capital stock fixed at $\$ 350,000$. The men named constituted the first board of directors, and they elected Crank, president; Jewett, vice-president, general manager and chief engineer ; Stanley, secretary; Washburn, treasurer.

The Valley Union of July 19, i 884, said: "A contract has been let to L. H. Carver of Boston, Mass., to build the whole road, the terms being that it is to be in running order by January I, I885, to Pasadena." And the same paper August 2 announced that the directors of the "Dummy Railroad" 
had ceased operations and left the field entirely to the San Gabriel Valley Company.

The grading work went on well for a while; then Mr. Carver failed. Money was not forthcoming to meet payments due for work and material. Work was stopped for several months; but the projectors stuck to it with good grit, and finally got in shape to go ahead again.

The first public mention that I find of special effort by Pasadena to aid this important work was in the Valley Union of June 5 , I 885, which says :

"The committee appointed to secure the right-of-way for the railroad has held two meetings and entered upon its work systematically. At the first meeting the work of canvassing for the right-of-way was divided between three committees, who are assigned to the following sections of the route: From Raymond Hill to Colorado street, J. H. Baker, M. W. McGee and W. H. Wiley ; Colorado street to eastern boundary of the Mutual Orange Orchard, C. C. Brown, S. Townsend, J. P. Woodbury ; from Mutual Orange Orchard to Rose's fence, James Craig, J. W. Hall and Abbot Kinney. It was voted to make $\mathrm{H}$. W. Magee and Abbot Kinney trustees to hold the right-of-way when secured until the railroad is completed and in operation. An agreement to this effect has been made between the railroad and trustees. This agreement requires that the right-of-way be secured before June i 5."

The same paper contained this item of railroad news :

"The first locomotive of the Los Angeles and San Gabriel Valley Railroad arrived from Cincinnati Tuesday. She is called a 30-ton engine, with 5 -foot driving wheels and an extension front, with Eastern style spark arrester. She was brought out dead by Mr. Homer, who will put her inshape for active service."

Pasadena interest was now fully awakened to the importance of this railroad project in its relation to Pasadena's growth and progress, and the Union from week to week took every opportunity to report any new step in its advancement. On July I $7 \mathrm{I}$ find this mention:

"Locomotive No. 2 of the Los Angeles and San Gabriel Valley Railroad was fired up for the first time yesterday and run a short distance. A construction train was also made up. About 3,500 feet of track was laid, up to last night."

And again, July $3 \mathbf{I}$, this appears :

"The Arroyo Seco bridge is completed, and track-laying has progressed to this point. A large cargo of ties arrived Wednesday and the track will be laid as fast as the grading can be completed.'

And on August I4 this:

"The first carload of freight went over the Los Angeles and San Gabriel Valley Railroad Wednesday. It was coal for the Pasadena Water Company."

Then came the opening day, which was the grandest affair in the history of the settlement up to that time. I quote from the Valley Union again:

"Wednesday, September I6, i 885, will always be an epoch in the history of Pasadena. The Los Angeles and San Gabriel Valley Railroad was formally opened to public traffic between Los Angeles and Pasadena. It was 
an occasion for rejoicing, and the people earnestly devoted themselves to the enjoyment of a grand jubilee.

At an early hour those having the arrangements in charge were actively engaged. Mr. Thomas Banbury had provided a street sprinkler that did a grateful service on the dusty streets and celebration grounds. The Central School Park had been selected as the place for the ceremouies, and between the Public Library and school buildings a large pavilion covering an area $80 \times 100$ feet, had been erected of rough lumber, open on all sides, but covered overhead with freshly clipped cypress boughs. At 9 a. m. a train left Pasadena for Los Angeles, carrying the reception committee, consisting of the following gentlemen, and the Pasadena band: J. Banbury, H. H. Markham, H. W. Magee, J. E. Clarke, G. W. Wilson, N. G. Carter, O. S. Picher; Bayard T. Smith, James Craig, O. H. Conger, P. M. Green, R. Williams. This was the first passenger train over the road, and the run was made in twenty-two minutes.

The Los Angeles guests were received at the Downey Aventue depot, and five carloads including about 300 ladies enjoyed a most delightful ride to Pasadena. All expressed themselves highly pleased with the road and its appointments. Arriving at Pasadena, the guests were conducted to the pavilion, where an abundant collation was served. The tables were splendidly decorated with fruits and flowers. On one of the tables was a locomotive and two cars ingeniously constructed of variously arranged flowers. These cars were loaded with varieties of fruits, and this very appropriate piece of floral work reflected much credit on Misses Matie and Ollie Stratton, who designed it. Mrs. M. Rosenbaum had four elegant floral pyramids; and many of the guests were supplied with neat button-hole bouquets. The floral engine was presented to General Manager Jewett.

After the repast, literary exercises were carried out in the following order, under the direction of Col. O. S. Picher, president of the day :

Address of welcome - Hon. H. H. Markham.

Response in behalf of Los Angeles - Mayor E. F. Spence.

The I. A. and S. G. V. R. R., response-Hon. J. F. Crank.

Original poem - Charles A. Gardner, editor Valley Union. The following is a portion of the poem :

As Troy, beleagured, in her hour of need Gave jovial welcome to the wooden steed, And poets lauded in heroic strain

The Centaur coursers of the Grecian plain So we, the people of another time Of happier nation, and a sunnier climeAre met with greeting for our modern horse, The tireless racer of the iron course.

But not like Trojan's shall our steed disclose The dread forerumner of a nation's woes The armed battalions and the waste of war That ravaged Troas in her peaceful shore; The shock of battle and the din of arms

That wrecked her happiness in war's alarms, The dreadful thunders of an angry Fate

That sealed the fortunes of a fallen state.

No! blessings rather, in her peaceful train Attend our courser of the smiling plain ;

The hum of Labor in her busy wheels;

The horn of Plenty in her bugle peals; 
The lengthened spirals of her smoky fleece

Are tranquil curlings of the pipe of peace.

And, 1o! her progress through a chosen land

Vakes smiling industry on every hand!

The voice of Labor and the arts of Peace

Bid homes accumulate and wealth increase;

And cities hasten in her path of fate

To swell the fortunes of a rising state.

The Los Angeles Board of Trade-Maj. G. H. Bonebrake.

The Influence of the Press in the Development of Los Angeles County - J. D. Lynch, Esq., editor Daily Herald.

The Produce Exchange - Eugene Germain.

The union of Pasadena and Los Angeles-Col. H. H. Boyce, editor Daily Express.

The regular program being completed, remarks were made by Hon. R. F. Del Valle; D. M. Berry, the father of the original colony from which Pasadena has grown up; Mrs. Jeanne C. Carr, and Gen. John Mansfield."

From this time on, there was regular train service between Pasadena and Los Angeles; and the construction work continued eastward. On November 7,1885 , the road was completed and train service commenced to Lamanda Park, where the first $\mathrm{Y}$ was built on which to reverse engines. Before this the engines had come up from Los Angeles head foremost and gone back with hind end foremost. At Lamanda the road took a rest for several months and boomed the town by running excursions there; and it was not until a year later-November 5, 1886--that it was completed to Duarte. Right-of-way difficulties and other matters had caused delay. But it was finally completed to San Dimas-or "Mud Springs," as it was then called and marked on the maps--a total trackage of twenty-eight miles.

Meanwhile another local company had been formed to build a road from Barstow on the Atlantic and Pacific line, down through the Cajon pass to San Bernardino, and thence westward to "Mud Springs," there joining the S. G. V. road, and thus making a continuous line to Los Angeles. It had long been an open secret that these two local enterprises were in the interest of the great Atchison, Topeka and Santa Fe R. R. Co., which was seeking a through connection of its own to the Pacific coast. Up to this time the Southern Pacific company had an autocratic monopoly of all transcontinental traffic with Southern California, and the Santa Fe company had to pay track-rent for its trains or cars from Deming to Los Angeles over the S. P. line. But now the Santa Fe company had finally gained control of the Atlantic and Pacific road from Albuquerque to Mohave ; and with these two local lines in possession, it would have an unbroken trackage of its own from Chicago to Los Angeles. In pursuance of this great scheme the S. G. V. road was sold to the Santa Fe company January I, I887, and Mr. Jewett remained in charge as manager for the new ownership until July I, I887, when he resigned-thus ending Pasadena's personal historic connection 
with the road. From the Valley Union of September 19, I885, I gather a few additional points :

"The charter provided that it should extend from Los Angeles to the eastern extremity of the San Gabriel Valley, a distance of about thirty miles. The route to the terminus, near what are known as "Mud Springs", * was selected with a view to open up one of the richest valleys in Southern California. The Southern Pacific passes through the southern part of the valley, but it is too far distant from some of the most fertile and promising sections situated upon or near the foot-hills of the Sierra Madre range. Such places as Pasadena, Sierra Madre, Duarte, and Azusa needed a close and convenient railroad connection with Los Angeles, the commercial center for all the southern counties of the State. Several surveys were made with the narrow gauge in view, and a part of the right-of-way had been secured and some grading done, when it was decided to abandon the narrow gauge scheme and build a standard gauge road. This was over a year ago, or some time in August, I 884 , when the capital was increased to $\$ 600,000$. The bridges are first-class in all respects. The first across the Los Angeles river is 3 I 2 feet long, contains IOO, O0O feet of lumber, I 2 tons of cast iron, and 22 tons of wrought iron, and will cost about \$IO,000. The Sycamore Grove trestle bridge is 450 long and 38 feet high. The bridge over the Arroyo Seco is 850 feet long, 38 feet high, and cost about \$15,000."

This Arroyo bridge was built both on a curve and an incline; and when the Santa Fe company took possession they found it unsafe for their heavy freight and Pullman passenger trains; they therefore made a new grade along the face of the Gibraltar cliff and crossed the Arroyo on a high, straight, level bridge, thus avoiding also the down and up haul of the old curve line. The old grade along the Garvanza bluff and the curved bridge were sold to the county and converted into a county wagon bridge and road at that point. And the Scoville bridge at Pasadena was also built of timbers from that old railroad bridge.

The Santa Fe company later extended their line to a tidewater connection at Redondo, and San Diego.

\section{THE “DUMMY RAILROAD” PROJECT.}

During the winter of $1883-84$ there began to be talk of connecting Pasadena directly with Los Angeles by some sort of rapid transit or streetcar service; and this talk resulted in the organization of the "Los Angeles and Pasadena Railway Company," which was incorporated June I2, I884, with the following board of directors: P. M. Green, B. F. Ball, W. Thomson, of Pasadena; A. Glasse11, A. H. Judson, G. W. Morgan, of Los Angeles; E. M. Hamilton. Glassell, Judson and Morgan all owned land along the proposed line between Los Angeles and Garvanza. Immediately after the incorporation the company issued a prospectus, from which I quote:

* "Mud Springs" was a great cienega or body of marsh land about half way between San Dimas and Lordsburg. And the towns of Lordsburg, San Dimas, Glendora, Monrovia, Sierra Madre and Lamanda Park did not then exist, 'They were born of the railroad. 
"It is the design of the projectors of this enterprise to construct a narrow-gauge railway from Los Angeles by way of the Arroyo Seco, Highland Park, Garvanza, Lincoln Park, Hermosa Vista, within a short distance of the proposed Raymond Hotel, and thence along a line midway betwren Orange Grove and Fair Oaks Avenues to a point as near as practicable to the intersection of Fair Oaks Avenue and Colorado street in Pasadena. Practically, it is the intention to extend the street railway system of Los Angeles to the center of the settlement of Pasadena, using as a motive power a noiseless steam motor known as a 'Dummy,' or such other power as may be required."

It will thus be seen that the project as laid out at that time was substantially the same as is now carried into effect by the Pasadena and Los Angeles Electric Railway Company ten years later. That original "Dummy line " stock was put at \$25 per share; and the prospectus further said : "It is desired to make this a people's road, built for the people, on a popular subscription by the people, without mortgaged or bonded indebtedness, and then run it in the interests of the people." It was a live project in its day. On June 5, I884, a meeting was held at Los Angeles to work it up. A. O. Porter was chairman, and Green, Ball, Eaton and Dr. Conger were also there from Pasadena, besides engineer Williel Thomson, who reported estimates of cost at $\$ 7,000$ per mile to build the road, and $\$$ Io per day for operating expenses thereafter, making five trips each way. Another meeting was held June 12, with Dr. Conger chairman, and articles of incorporation were adopted. Its preparatory work was pushed with zeal and energy. Right-of-way for its track was given along Pasadena avenue from Columbia to Colorado streets; I signed agreement for this, in common with other dwellers or owners of property on that avenue, although the avenue was then only open from California to Colorado. But it was found that this undertaking seemed to embarrass the San Gabriel Valley railroad [now Santa $\mathrm{Fe}]$ which was then making a tenacious struggle for existence, under the lead of S. P. Jewett, J. F. Crank and S. Washburn - all Pasadena men. And the Valley Union of August 2, 1884. contained this announcement:

"The directors of the Dummy Railroad and those of the S. G. V. Railroad came to a mutual understanding Thursday, in which the former agreed to cease operations, upon a positive guarantee that a road will be built and in operation by January 1,1885 ; and that not less than three trips per day will be made by their trains the first year, and four or more the second," etc.

So the "Dummy road" was never built. Yet the idea on which it was based, for a Pasadena-Los Angeles street car line owned by local holders and managers, still kept alive.* The rapid-transit road built by Capt. Cross

* An illustration of the many grand projects incident to the boom time is afforded by an article in the Pasadena Star of April 3,1889, on a new patent noiseless and smokeless street railroad motor, from which I quote this passage: "The fact that such a man as E. F. Spence and his associates are willing to invest money to build a railroad whose fra nchise will permit nothing but a noiseless, smokeless motor to be used, is a very practical way of showing their faith in this motor and that it is what it is clained to
be. This line is to go from the top of Mt. Wilson to the sea, through Pasadeng and Los Angeles, with trains every hour. It will give us what we have so long needed - frequent communication with Los Angeles, and bring every tourist that goes to $\mathrm{Mt}$. Wilson through Pasadena." 
in 1889 [now the Los Angeles Terminal] seemed to fulfill that idea for awhile - though in two or three years the need of some more direct. more frequent and more center-reaching line of street car service was felt, and plans for its accomplishment were talked up, resulting at last in the present electric line.

THE LOS ANGELES TERMINAL RAILROAD.

I wrote to the officers of this company, enclosing a suitable blank, asking for data that would enable me to write a historical sketch of the road. No answer was ever made, nor any facilities afforded me for getting any information from official sources. This explanation is due to myself because of the meagerness of details from which I was obliged to prepare this sketch. The "Terminal" as it now exists is a combination successor of the wrecks of several rapid transit, narrow-gauge and dummy lines that sprung up like mushrooms during our "boom" period. Of these, the Pasadena Improvement Company's standard-gauge road from Raymond station to Altadena, seven miles, comes first; and the first step which led to the building of this road was a "boom" land deal that is mentioned in the Pasadena Union of October 2, 1886, as follows :

"The purchase comprises the ranches of Woodbury Brothers, Col. J. Banbury and P. Gano, embracing in all nearly 1,300 acres of the most finely improved, best situated and best watered land in this valley. The purchasers are E. C. Webster \& Co., the Investment Bankers, Woodbury Bros. and other capitalists of this city, who form a syndicate of energy, foresight and enterprise. With the land bought are included the very valuable water right to 3,000 shares of the Rubio canyon water, 120 shares of the Las Flores water and one-third of the Millard canyon waters. The first step in the line of development will be the subdivision of this entire property into lots of five and ten acres. One very important enterprise already projected is the construction of a cable or electric railroad from some point near the Raymond to the base of the mountains at the head of the lands purchased."

The "lands purchased" were laid out as the town of Altadena, and was one of the high mark and very brilliant "boom" enterprises in its day. As lots were sold and buildings undertaken, the demand for better transportation facilities became imperative, and a regular standard-gauge steam motor line called the ALTADENA RAII.ROAD was built from Raymond station up through Pasadena to Devil's Gate, and thence eastward through Altadena to North Lake Avenue. Of course when the "boom" collapsed this was a losing enterprise, yet the company was obliged to keep trains rumning every day to hold their franchise.

The village of Garvanza was another " boom " enterprise or land speculation in I885-6; and a narrow-gauge dummy street-car railroad was built from Los Angeles to Garvanza, and thence to Eagle Rock valley. This project became bankrupt; and the railroad with all its property and franchises were bought by Capt Cross. He secured right-of-way through South 
Pasadena, after a long delay by litigation with certain landowners as to the amount of their damages, and built a "rapid transit" line from Los Angeles via Garvanza to Raymond station. Here he leased the Altadena railroad for three years and thus reached Pasadena's business center by running a switch down from the present Terminal depot site to a point between De Lacy street and Fair Oaks Avenue, and fronting on Colorado street. On March I I, I 890, the road was formally opened to the public, and Pasadena celebrated the event in great style. [See page 327.]

Within a year Capt. Cross sold out to the Los Angeles Terminal Railroad Company, T. B. Burnett, manager. And the Pasadena Star of August 26, I891, said :

"The Terminal Railway Company has filed in Los Angeles a trust deep to the St. Louis Trust Company in the sum of $\$ 1,500,000$ to secure payment of bonds to this amount. The Terminal is expending money in a conrageous way, showing that its owners have full faith in the future of Southern California."

When the three-year lease of the Altadena line expired, the Terminal bought that road and made it an integral part of their system; and they did the same thing with the narrow-gauge line from Los Angeles to Glendale. Also during I 89 I they built from Los Angeles to Long Beach, and to an ocean connection via Rattlesnake Island at East San Pedro; and the formal opening of this line was celebrated by an excursion under the management of the Pasadena Board of Trade, November I4, I891.

\section{THE PASADENA STREET RAILWAY CO.}

The first man who ever received a franchise for a street railroad in Pasadena was Stephen Townsend, on Saturday, October 10, 1885. This was before there was any city incorporation, and the grant was made by the county board of supervisors, The Valley Union of October 16, 1885, said:

"To Stephen Townsend was granted his franchise, the route being as follows: Commencing at a point on Fair Oaks Avenue, in San Gabriel township, opposite the center of the street leading to the Raymond station of the L. A. \& S. G. V. R. R., and running thence in a northerly direction along the center of said Fair Oaks Avenue, to a point about 300 feet south of Walnut street."

The enterprise seems to have made little progress for some months, and I find nothing more about it until February ${ }_{15}$, 1886, when a meeting was held in Williams Hall on the subject. Townsend's franchise had been granted on condition that the work of building the road should be commenced within three months, but this had not been done, so of course it had become void. At this meeting in Williams Hall C. C. Brown was chosen chairman, and Frank M. Ward, secretary; and S. Townsend explained the object of the meeting to be, to further the interests of Pasadena by the building of a street railroad. As a result of this meeting, the following document was put forth: 


\section{"PROPOSITION FOR A STREET RAILROAD.}

"It is proposed to incorporate a company with a capital stock of $\$ 50,000$, divided into 500 shares of the par value of $\$$ roo each, to be known as the 'Pasadena Street Railroad Company,' for the purpose of constructing and operating a street railroad on the following line. to-wit : commencing at the junction of Orange Grove Avenue and Columbia street, and running thence east to Fair Oaks Avenue, north on Fair Oaks to Chestnut street, east on Chestnut to Summit Avenue, and north on Summit Avenue to Illinois street; and such other lines as the corporation may deem desirable. Signed: S. Townsend, Williel Thomson, Ward Bros., R. Willians, H. F. Goodwin, J. S. Mills, P. G. Wooster, Samuel Merrill, 'T. P. Lukens, Chas. A. Gardner, J. H. Painter, N. G. Yocum, J. G. Miller, A. O. Porter, B. W. Bates, Geo. E. Meharry, M. J. McCall, E. C. Webster, D. R. Risley, M. W. McGee, G. Roscoe 'Thomas, J. Banbury, Byron O. Clark, H. W. Magee, L. H. Michener, P. M. Green, James Smith, John Allin.'

On February i 8 they met again and organized the company by electing Stephen Townsend president, and Frank M. Ward secretary. And the county records give February i 8 , I886, as the date of their incorporation. Then the Valley Union of February 19, said:

"The proposed street railroad from the college to Illinois street a'ia Fair Oaks Avenue is now assured, $\$ 22,000$ of the $\$ 50$, o0o capital stock being already subscribed. The directors for the first year are S. Townsend, Williel Thomson, Frank M. Ward, R. Williams, P. M. Green and P. G. Wooster. The iron is ordered, and two miles of the road will at once be built from the postoffice to Raymond station."

Yet, of all the twenty-eight names signed to the above "Proposition," and counted for stock subscribers in the Union's report, only seventeen ever actually took stock as proposed; and this being the first bona fide investment of capital for the construction of a street railroad in Pasadena, those seventeen form a historic roll of honor, as follows :

\begin{tabular}{|c|c|c|}
\hline $\begin{array}{l}\text { Name. } \\
\text { S. Townirend } \\
\text { Sh........... IO }\end{array}$ & $\begin{array}{l}\text { NAME. } \\
\text { G. Roscoe Thoms. }\end{array}$ & $\begin{array}{l}\text { SHARES. } \\
\text { Chane. A. Gardner..... I }\end{array}$ \\
\hline rank M. Ward........ I & P. M. Green.......... 5 & A. O. Porter.......... 5 \\
\hline I. F. Goodwin........ & John Allin............ I & M. W. McGee.. \\
\hline T. P. Lukens........... & Williel Thomson.....32 & H. W. Magee... \\
\hline N. G. Yocum...... & R. Williams.......... Io & James Smith... \\
\hline C. Webster .... ... 2 & P. G. Wooster....... 5 & \\
\hline
\end{tabular}

Total, I 00 shares subscribed, or $\$ 10$, ooo of the proposed stock; and with this the work went on. The first cost of construction of the ultimate entire line, including rolling stock, horses, barns, etc., was $\$ 20,300$; but \$1,ooo was afterward added; and stock was issued for the whole amount. The first section of the road was completed in September, and the Valley Union of October 2 gives the following account of the opening ceremonies :

"Thursday, the 3 oth of September, I\$86, will be referred to in after years as the day on which the first street car line in Pasadena was opened to the public. At twelve o'clock, over fifty invited guests of the projectors of the line assembled at the car stables to participate in celebrating this, the 
first street car ride in Pasadena. The cars, which are handsomely lettered "Pasadena and Raymond," were decorated with flags, and as they were drawn out of the stable made a fine appearance. All who could be comfortably seated took the cars, which run down to the South Pasadena end of the line, and then up to the present terminus, opposite the Grand Hotel. On arriving here the party and cars were photographed by E. S. Frost \& Son, after which all were served a dinner at the Grand Hotel. Following this, remarks were made by $\mathrm{H}$. J. Holmes, S. Townsend, P. M. Green, H. J. Vail, G. E. Meharry, Williel Thomson, M. M. Parker, J. E. Clarke, E. C. Webster, Dr. G. Roscoe Thomas, Mr. Muchmore, and A. O. Porter. The cars commenced regular trips on the day of the opening, and the rumbling of the wheels and sound of the bell adds to our already metropolitan airs. The officers of the line are Stephen Townsend, president; R. Williams, vice-president; P. G. Wooster, secretary; P. M. Green, treasurer ; and Williel Thomson, superintendent."

The company's business during the first year amounted to $\$ 2,470$; but its last year, I893, the amount was only about $\$ \mathbf{I}, 600$. In 1894 the property and franchises of the company were sold to the Pasadena and Los Angeles Electric Railway Company, for about \$I4,00o, and was incorporated with that system of electric lines as now in operation- 1895 .

THE COLORADO STREET R. R. LINE.

On October I 5, I885-five days after the date of S. Townsend's original street railroad franchise-the county board gave a grant to $H$. W. Magee and Geo. E. Meharry for their projected line; and the Union of October 23d said: "Messrs. Magee and Meharry of the Colorado street railway line inform us that the road will be commenced within the three months provided in the franchise." And it was ; for they bought a few rails and ties somewhere, and put down about 200 feet of track, then covered it up to hatch. And the first chicken that openly peeped from this particular street railroad incubator appeared in the Union of March 26, I886, which said:

"The stock-holders of the Colorado street Railroad company met at the office of T. P. Lukens, Monday, and elected a board of seven directors, as follows : Geo. E. Meharry, H. F. Goodwin, 'T. P. Lukens, C. C. Brown, S. O. McGrew, Samuel Stratton, and S. P. McLean. These organized Tuesday, by the election of Meharry, president; Lukens, secretary; and Stratton, treasurer.",

The county records give March $20[?-26]$ as the date when this company was incorporated. And the next mention I find is in the Union of June 25, from which I quote this paragraph:

" Civil engineer, J. M. Willard, has completed today his survey and profile of the grade line of the Colorado street railroad from Fair Oaks Avenue to Hill Avenue, east, a distance of 8,700 feet. 'The engineer has carefully ascertained the difference in street altitudes along the line, above sea level. [See page 363 ].

Track-laying proper was commenced July 28. And then in its issue of November I 3, I886, I find the following: 
"On Tuesday the second street car line opening occurred. At one o'clock about I 50 guests of the company assembled at the stables of Vore \& Hoag, where the cars were at once filled, and a very smooth and pleasant run was made to Olivewood. There two long tables were spread with a bountiful repast. C. T. Hopkins, the genial host of the occasion acted as president of the day. After the dinner was served, he opened the literary exercises with remarks that were sound and sensible, and then in pleasant language introduced Col. O. S. Picher, who made one of his characteristic speeches, pointed, vigorous, and hopeful. He was followed by $\mathrm{H}$. W. Magee, Esq., who spoke on behalf of the railway directors and officers. H. J. Holmes, president of the city trustees, closed the speaking."

The officers of the company at that time were Geo. E. Meharry, president; T. P. Lukens, secretary; Samuel Stratton, treasurer; C. C. Brown, supt. This line was ultimately extended to Hill Avenue, thence south to San Pasqual street. And another branch was built down Los Robles Avenue to California street thence to Wilson Avenue; and a branch up Lake Avenue to Illinois street. But in 1894 this railroad and all its belongings was sold to the Electric company and merged into its system of consolidated lines.

\section{CITY RAILWAY COMPANY OF PASADENA.}

The first public mention of this line as a coming project occurs in the Pasadena Union of August 27, I886, which said of it :

"The main line is to go up into the Arroyo Seco canyon, where it will connect with three different pack trails to the top of the mountains - the Switzer trail, which follows the same grand canyon; the Giddings trail, which is to go up through the Millard canyon and return on the outer face of the mountain; and the Owen Brown trail, which goes up west of Millard canyon." [See pages 403, 404 for account of these trails.]

The Union of November I 3 mentions that A. J. Painter had obtained the franchise for this road; the iron was bought and would be on the ground in a few days; and it was expected that cars would be running from the corner of Raymond Avenue and Colorado street to the Painter Hotel at North Pasadena in thirty days. The route described at this date was the same as where the line was afterward built, via Raymond Avenue, Chestnut street and Fair Oaks Avenue clear up to Mount View cemetery. The company was incorporated November I 7, 1886, with the following board of directors: A. J. Painter, C. W. Buchanan, Geo. D. Patten, John H. Painter, Delos Arnold, W. S. Holland. Capital stock, $\$ 50,000$; amount subscribed, $\$ 4,500$. A. J. Painter was chosen treasurer and general manager. A prelude to the building of this road was the opening, straightening and grading of Fair Oaks Avenue from Chestnut to Illinois street, which was done by a syndicate with M. D. and A. J. Painter at its head, in May and June, I 886. [See page 356.] The road was completed as far north as Washington street and opened for public travel the second week in February, I887. It was subsequently extended eastward on Washington street to Los Robles Avenue; northward on Fair Oaks Avenue to Mountain View 
cemetery ; and westward to Devil's Gate - this latter branch being operated by a steam dummy motor for some months, at a loss to the company, and was finally abandoned. The cemetery branch also never paid running expenses, although car service once a day, and twice on Sunday, was kept up until 1894, when the whole business was sold to the Pasadena and Los Angeles Electric Railway Co., and merged into their general combination.

THE HIGHLAND RAILROAD.

The Pasadena Union "Supplement" of date April 23, I886, refers to an article in their paper about eight months previously in regard to reaching the top of the mountains by way of Las Flores canyon, and says :

"We showed that the water coming down the canyon could be utilized to drive the machinery for a cable road. * * A vertical fall can be obtained of any amount from one hundred to three hundred feet; and it is not impossible that with this power a cable road or elevator may be carried to the top of the mountains* as well as for the down slope line. Our article was the first public suggestion that such a thing was within bounds of practical possibility, and most people laughed at it as a purely visionary scheme; but now measures are in progress to make it a reality."

Then nothing more appears in regard to this road until June II, when the Union says :

"On Wednesday George A. Swartwout secured the franchise for the cable railroad up Prospect Avenue (Lake Avenue) to Las Flores canyon. At Colorado street it will connect with the street railway, and at Olivewood with the San Gabriel Valley Railroad, and at Las Flores with a mountain pack train, or eventually with some kind of mechanical up-you-go to the top of the mountain."

The next mention occurs December I8, I886, when the same paper says :

"The right-of-way has been secured for a street car line from Colorado street along Euclid Avenue to Walnut street, thence along Los Robles Avenue to Villa street, along Villa to Lake Avenue, and up Lake Avenue to the Highlands."

The chief promoter of this enterprise was George A. Swartwout, who was then cashier and manager of the Pasadena National Bank. He owned and resided on a small fruit farm on the east side of North Lake Avenue ; through this he opened New York Avenue, running eastward from Lake Avenue, and built the railroad up to this point. The Highland Railroad Company was incorporated March 2, I888. Its line was extended down Broadway to Glenarm street near Raymond station ; and later it crossed from Broadway to the Grand Opera House on Palmetto street, thence up Raymond Avenue to Colorado street. But it was never a paying enterprise ; Mr. Swartwout lost all his property in the "boom," the road was taken by his creditors and kept running just enough to hold the franchise. It was

*As "coming events cast their shadows before," so the Mount Lowe "Great Incline " was here dimly previsioned six or seven years before its advent. Both this article and the one referred to were written by Dr. H. A. Red, who served as a sort of incoguito assistant editor of the Union for a year or two about that time. 
finally sold to the Pasadena and Los Angeles E!ectric Railway Company in I 894 .*

\section{WEST PASADENA RAII,WAY COMPANY.}

This was a horse car line which extended from Fair Oaks Avenue west on Colorado street to Vernon Avenue, thence north to Kensington Place, thence west to Millard Avenue, thence north to Walnut street, thence west to North Orange Grove Avenue, thence on Reservoir Terrace Drive around to head of Park Avenue, thence down the Park Avenue grade to the Linda Vista suspension bridge, thence across the Arroyo and following the same avenue to Linda Vista. The road was built by the Yocums themselves, in I887; but as other interests became involved with it the company was incorporated January 14, 1888. This railroad was one of the great "boom" enterprises, and was so intimately connected with the Linda Vista and Park Place land schemes of that time, that it is necessary to give some brief account of them, in order to explain how and why such a completely wipedout railroad was ever built at all.

In October, I886, J. D. Yocum subdivided his Linda Vista tract and sold the south half of it, about 600 acres, to a syndicate for $\$ 40,000$. 'They went on improving and subdividing their land, but soon found almost imperative necessity for some better way of reaching it than by the old hilly and stony wagon road across the Arroyo wash. Next, in November a syndicate composed of H. W. Ogden, I. N. Mundell, Thomas F. Flynn, and N. G. Yocum bought fifty-two acres of land on the reservoir terrace, named it "Park Place," and went on laying out streets and drives, with sightly residence lots for sale. And of this deal the Union of November 27, I886, said :

"It means improvements that will add greatly to the attractions of that part of the city. * * The street car line projected by the Messrs. Yocum and others to run to Linda Vista will pass through this tract, crossing the Arroyo near where the barn now stands.'"

This company, with Mundell as president and Flynil as secretary, opened business for sale of their lots January ist, I887, and advertised that this street car line was then being built. To make the Park Avenue grade down the bluff was a protracted and costly job for private enterprise ; and the combined wood and iron suspension bridge at its foot cost $\$ 8,000 .+$ But it was all done and the railroad built in connection with the speculative "booming" of the Park Place lands and the Linda Vista lands. The

\footnotetext{
*After the above article was written, I received the following additional data from J. B. Young: " The old Highland Railroad Conpany was organized March 6, 1888 , with a capital stock of $\$ 100,000$. Incorporators: George A. Swartwont. J. B. Young. C. C. Thompson, F. T. Swartwout and N. L. Young, George A. Swartwout, president; J. B. Young, secretary; Thompson, vice-president and general superintendent ; Pasadena National Bank, treasurer. This old company was abandoned; and a new Highland Railroad Company organized October 21, 1889. On March I8, 1890, all property and franchises of the company were sold to the Pasadena National Bank in settlement of all outstauding obligations of the company."

$\uparrow$ This is a Pratt truss bridge of two spans, 120 feet each, and one span 140 feet - total, 380 feet; roadway 18 feet wide, and 80 feet above the water bed.
} 
income of the road never paid running expenses, yet it was heroically kept in operation three or four years, but had to be given up at last; and in r 892 its iron rails were sold to Prof. Lowe and used by him on the lower trolly section of the Mount Lowe Electric Railway.

ALHAMBRA AND PASADENA STREET RAILWAY.

This line was built in January, February, 1887, by an Alhambra company, of which A. C. Weeks was president; F. O. Story, treasurer; C. T. Adams, secretary. The road extended from the Southern Pacific depot at Alhambra to the Raymond depot (Santa Fe route) in Pasadena, and was thus operated for some months; then trackage was secured on the Fair Oaks avenue line up to Colorado street, and the Alhambra cars stopped at and started from this central point for a period. But it was a losing enterprise from the first; and in 1893 the company's own track was torn up and sold, leaving no sign of its Pasadena history.

PASADFNA AND LOS ANGELES ELECTRIC RAILROAD.

Incorporated in April, I 894. Its first members or directors were : P. M. Green, L. P. Hansen, E. C. Webster, A. W. Roche, of Pasadena, and E. P. Clark and Wm. Lacey of Los Angeles. Its capital stock is $\$ 500,000$.

During 1894 this electric company bought up the four remaining horse car lines in Pasadena, and proceeded to reorganize their trackage, and running time, etc., into a consolidated system. They built an electric line in I 894-95 which gave street car service direct, every twenty minutes, from the Pasadena business center to the Los Angeles business center as far south as Fourth street. Also from Pasadena to Altadena for a direct connection with the Mount Lowe Electric Railway. The company's officers in r894-95 were: Webster, president; Hansen, vice president; M. E. Hammond, secretary and treasurer; E. P. Clark, general manager.

THE FIRST ELECTRIC CAR

Ever run in Pasadena was a trial trip made in the night of February 19, I895; and the Los Angeles Times correspondence of February 20, said: "At 7:30 o' clock this morning the car, propelled by electricity from the Los Angeles power house, began making regular trips on Fair Oaks Avenue between Columbia street and the Throop Institute." But it was over two months before the line was completed through between the two cities, and meanwhile the "Pasadena loop" car connected with a 'bus running between Columbia street and Garvanza, which met at the latter place the electric car from Los Angeles. Then in the night of April 20 the first electric car that passed over the whole line from Los Angeles to Pasadena was run through ; and of this event the Star said:

"Among citizens who had the privilege of making this first trip from Los Angeles were E. C. Webster, Hon. Jas. McLachlan, E. E. Jones and 
Frank J. Polley. Chief Engineer Larrabee and the bridge contractor were also passengers. Mr. Clark, the general manager, came up as far as Garvanza."

But the South Pasadena viaduct and trolley posts were not yet safe for passenger service; and the Pasadena power-house was not ready to steam up, even for trial, until April 26. On May I it was ready to pump lightning from Garvanza up around the "Pasadena loop"; and the line was on that day opened for complete electric rides between the two cities. This power house has two engines - one of 450 and one of $25^{\circ}$ horse power, with dynamos to match.

The same company, or an allied one, is building an electric road from Los Angeles to Santa Monica - so that in I 896 there will be a continuous line of electric railroad from the mountain tops to the sea shore, directly through Pasadena.

MOUNT LOWE ELECTRIC RAILWAY.

See Chapter 23.

\section{RAMONA AND PASADENA RAILROAD [Southem Pacific].}

In $1888-89$ a narrow-gauge rapid transit railroad was built from Los Angeles to Monrovia, passing through Ramona, and a branch of it was extended from Ramona up to the south city line of Pasadena near Raymond station. The track was laid, and an empty train run on it daily for a few months to hold the franchise, although no terminal station was ever reached or built. But it was "paying too dear for the whistle," and had to be given up at last. The track lay idle, rotting and rusting until 1894 , when the line was bought by the Southern Pacific company ; and the old rails being too light for their use, they were sold to the Pasadena and Los Angeles Electric Railway Co., and used by them on their track in Pasadena. The S. P. Co. built into Pasadena over this line, and up Broadway to Colorado street; and the Daily Star of June 15, I895, contained this item:

"The Southern Pacific line to Pasadena was dedicated to travel this morning by the departure of the Throop excursion to Santa Monica. About 200 passengers, largely students, went down. Six handsome cars were sent up for their accommodation."

\section{CHAPTER XXIII.}

The Mount L IOWE RaIlway.--Early Plans and Projects for Reaching the Mountain Tops.-Sundry Railroad Schemes.-Macpherson's the first bona fide Survey.-Prof. Lowe takes hold.- The Naming of Mount Lowe.-The Railroad's Corporate Name. -Pasadena's Mount Lowe Celebration.-Honors and Wealth Fairly Won.-Rubio Farm.-The McPherson 'Trestle.-Gov. Markham's Bear Story._Electric Power Generators.-Altitudes.-The Observatory.

THE MOUN'T LOWE RAILROAD.

I find no evidence that the Spanish occupants of this country ever made any attempt to reach the tops of the mountains for any æsthetic, scientific, 
or health-restoring objects-never for the glorious outlook or the exhilarating ozone. And even their hunting seems to have been limited to the mesas and canyons - never pushed to the mountain summits, for they were a race of horse-riders, "born in the saddle" as it were, and not sturdy, rugged climbers afoot, like the Yankees who supplanted them. The first attempt ever made to construct any sort of a roadway to the mountain top was by Hon. B. D. Wilson, early in 1864. [See page 395.] This was for business, not sentiment ; and the first recorded trip of "sentiment" up there was made by Wm. McKee (private tutor of Mr. Wilson's children) in April in that year. He says - "I was anxious to go to the top of the mountain:" The trail was only finished to the half-way house; but by clambering along and leading their horses they managed to reach the top, and here he exclaims, "Oh, how beautiful!" And thus the era of mountain-climbing sentiment dawned in Pasadenaland. Theirs were the first horses ever known to have made the ascent. They stayed there over night at the Mount Wilson spring, of which he wrote 23 years afterward: "I thought then and do still that that water was the best I ever tasted in my life." More sentiment, again. That same spring is still there, at the place known as "Strain's camp." This trail was the only means of reaching the mountain summit by horse or mule-back until the Toll Road was built, in I887-88.

The mountain-climbing sentiment did not develop to any great extent until after the settlement of Pasadena, and after the tourist business began to show inklings of the phenomenal growth and extent to which it has since attained. The old "Wilson trail," the foot or starting point of which was eight or nine miles from Pasadena, was the only route available for gratifying this sentiment; and in the Valley Union of October I6, I885, Dr. Reid strongly advocated a new route of ascent by way of Las Flores canyon, and said, "This would be the shortest and most direct route to the top of the mountains that can be miade from Los Angeles," etc.; and the route he then suggested was within a few hundred yards, or in fact partly the same, where the Mount Lowe railroad was ultimately built. In the same article Dr. Reid said :

"Within the next six months there will be a thousand people in Los Angeles who would willingly pay five dollars for a trip to the top of the mountains. Nine out of ten of the winter visitors to this coast have just as strong a desire to go to the top of the mountains as they have to go to the sea-shore."

From this time onward the air was full of projects for some more direct and easy way to ascend the mountains; and in his descriptive pamphlet, with eighteen beautiful full-page lithographic illustrations for Pasadena, published in I886, T. P. Lukens said :

"Several of our enterprising citizens, among whom is Mr. R. Williams, have secured 320 acres of land at Wilson's Peak, embracing some of the finest timber tracts in the mountains, and have made arrangements for build- 
ing thereto a four-foot wide horse trail. * * $*$ It is further proposed to put up a hotel in the park, and eventually to run a cog-wheel railroad to it from Pasadena."

Another mention of this scheme occurs in the Valley Union of May I6, which says :

"It is the plan of the company to make as soon as practicable a new trail by way of Eaton canyon, so as to start up directly from Pasadena, *

$*$ and they intend ultimately to have a cable railroad from bottom to top, operated by the water on their own lands above the clouds."

The Union of June I 8 contained another article on the subject by Dr: Reid, in which he said :

"There is a good deal of popular interest in Pasadena's mountain climbing railroad projects, and everybody wants to know how the thing can be done. There are at least five available plans for operating such roads. First, the cable road, the same as those on Second and Temple streets in Los Angeles. Second, a single cable to draw a car up by winding around a windlass at the mountain top. Third, a double track and double cable on windlass, so that one car or train will go down as the other goes up. All these imply stationary power of water or steam engine. Fourth, a central cog-rail in which a cog-wheel plays from the car-axle, driven by locomotive engine. This, of course, would require a lighter grade than any of the cable plans. Fifth, an ordinary railroad with zig-zag and tunnel-loop track to make the climb. This last could be operated without change of cars from Los Angeles to mountain top, but would be slow and tedious on the zig-zag part of the climb, and more costly to build. Either one of these five ways are practicable here.* It is only a question of money-or which plan will cost the least to build and operate it.'

[See article on the "Mount Wilson 'Toll Road"' for further particulars about this matter.] The original company never did any practical work towards either a bridle road, a wagon road, or a railroad. Its engineers were kept busy surveying the various claims taken by them (for it was unsurveyed government land) until the whole scheme failed for want of financial bottom. The field was, therefore, still open for a railroad to the mountain top, for no man had yet grasped the thing with the bull-dog grip of success. But now, in January, 1890, Mr. D. J. Macpherson of Pasadena went into the mountains with a few assistants and made the first bona fide survey that was ever made in California for a railroad to the mountain tops. However, he had been making previous preliminary observations and studying the problem alone during nearly a year before this, for the Pasadena Standard of March 2, I 889, said :

"D. J. Macpherson is prospecting a route by way of Las Filores and Rubio canyons. **** The cog-wheel railroad is the most feasible scheme yet broached, and from the present terminus of the Altadena railroad and the Highland horse-car line right up the face of the mountain where Sam Correll and his mule proposed to go, is the shortest, most direct, and best-for-Pasadena route for the cog-road."

*Electricity was not a proved success at this time, for ordinary street car service-and had not even been thought of for a mountain railroad. 
I must here explain about "Sam Correll." When in I 885 Dr. Reid advocated by articles in the Valley Union the Las Flores canyon route for a road to the mountain top, as a better thing for Pasadena than a road to Wilson's peak, the Las Flores ascent was objected to as being impracticable; but Samuel F. Correll, who had been up that way several times, made a challenge that "he could take a loaded burro and start from Las Flores in the morning, with only a hand-axe to cut his way, and by night he and the burro would be at the top." His proposed ronte for this test was up to the spur where Echo Mountain House now stands, and thence to the pine crest of Echo ampitheater. But before this, old Dr. B. A. Wright had ridden a horse up the west wall of Las Flores canyon to a point or ledge of rocks called "Jacob's ladder," which was just about as high as Echo Mountain. However, nothing ever came of these adventures.

Mr. Macpherson's actual first survey for any sort of mountain railroad was his own individual project, on a street car plan, with a grade of seven and a half to eight per cent., to be operated by traction motor cars, so constructed that all wheels should be drive-wheels.* He commenced his survey at Altadena and ran up into Rubio canyon on substantially the same line where the Mount Lowe Electric railroad is now in successful operation. But at that time [January, I 890] the name "Mount Lowe" had never been heard of, though now familiar around the world; and electricity for operating railroads was not then a well established success. At a point a little below where Rubio Pavilion now stands he crossed to the east side of the canyon and pursued a winding way eastward along the ins and outs of the face of the mountain to Eaton canyon, then up its west wall to a point far above Eaton Falls, into the northwest part of Grand Basin, and so on around, making a total distance of twelve miles to Wilson's Peak or "Harvard Telescope point," -- for no one had succeeded yet in breaking away from "Wilson's Peak" as the objective point for any sort of roadway to the mountain top. (This was partly due to the fact that there was here a bountiful spring nearer to the summit than anywhere else in the entire range.) He ran his lines, set his stakes, projected his curves, noted cuts and fills for earthwork and rockwork, made his estimates of cost, prepared his profile map, with plans and specifications, and so went into the capital market with something definite and tangible to show for his project. And this is the shape the matter was in when Prof. Lowe was first induced to give it any practical attention - I890-9r.

* Surveyor D. J. Macpherson with six assistants started last Monday to make survey, set stakes, record field notes, and prepare profile of route, statement of cuts, filts, bridges, culverts, tunnels if any be necessary, and all the facts and data for a detailed estimate of cost to build a narrow gauge railroad from the Altadena station on Lake Avenue to Wilson's Peak. It is believed that a route can be found with a grade of 8 per cent., or a rise of 424 feet per mile; and a car can be built to carry its boiler, engine, coal and water supply, and load of passengers all resting on the drive wheels, so that it can easily climb an 8 per cent grade by ordoad of passengers all resting on is in the field for business, and his project looks the most like "getting there" of anything that has yet been attempted.-Pasadena Standard, February $8,1890$. 
PROF. LOWE TAKES HOLD.

Prof. Lowe was born and raised amid the mountains of New Hampshire; he was a natural lover of mountains; and the more he investigated and thought about this mountain railroad project the more it grew upon him, until it became at last the crowning purpose of his life - for in connection with it as a mere business enterprise he also conceived a higher and grander purpose in the interests of science to which it.could be made eminently subservient, so that one feature could aid the other, and thus make a doubie success in a double service to mankind, above and beyond any other mountain railroad on the face of the earth. He soon discovered, however, that the terminal grounds on Mount Wilson were parceled and staked and held by various claimants who had only the narrowest cent-per-cent ideas of the project, and who imagined vain things as to the absolute necessity that any road which might be built must come to their grounds anyway. This would greatly embarrass and hinder the loftier objects he had in view, unless he should buy out all their claims at boom-bubble prices. Meanwhile he pushed investigations as to elevation, water supply, and possible accessibility of other mountain eminences nearer to Pasadena, and more conspicuously in view from its multitude of lovely homes. In regard to this period I quote here from a pamphlet by Prof. G. Wharton James, entitled "The Pasadena Mountain Railway," published in I893, page I2:

"In the latter part of 1890 he placed a corps of engineers in the field to make thorough surveys. The engineers were instructed to examine all desirable peaks. And with a persistency which to the skilled engineers seemed nothing less than stubborn obstinacy, Professor Lowe kept them engaged month after month, urging them to exercise their utmost endeavors to devise a method of scaling the (to them) unscalable mountain, whilst he himself bent his own trained energies and powers of observation to the work. And as the result of his personal labor and unwearied determination, he was at last able to point out a simple, effective and perfectly safe method of overcoming the chief difficulty in the way of reaching Mount Lowe, which, when seen, was immediately approved and endorsed by the highest engineering authorities. The new survey was undertaken and pushed to its completion with almost incredible speed; and to the astonishment of all concerned, it not only was found that the ascent to Mount Lowe could be made with ease, but that - with the exception of the one steep climb which the Echo Mountain Cable overcomes in six minutes - in no place would the grade exceed the slight rise of seven and a half per cent. This new route also revealed further possibilities not before contemplated. It allows the company to erect its stations and hotels at different altitudes to suit the many and varying health-conditions required. The Rubio canyon pavilion is the same height as the Catskill mountains hotels; Echo Mountain House is about the height of Mount Vesuvius; Mount Lowe is the same altitude as Colorado Springs and Mount Washington; whilst Observatory [San Gabriel] Peak compares in altitude with the Iron Springs hotel at Manitou, Colorado."

From this time forward the work progressed steadily in grading and 


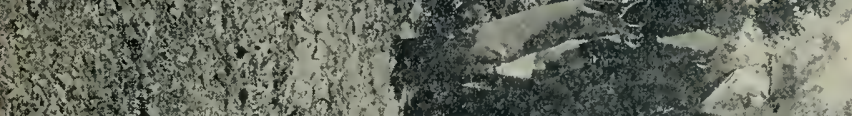

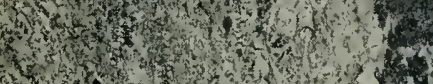

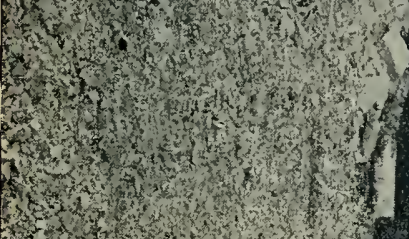

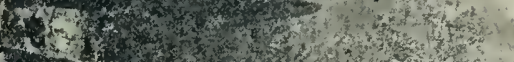

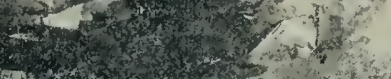

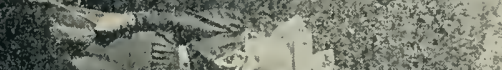

$\rightarrow x^{2}$

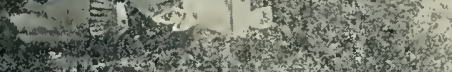

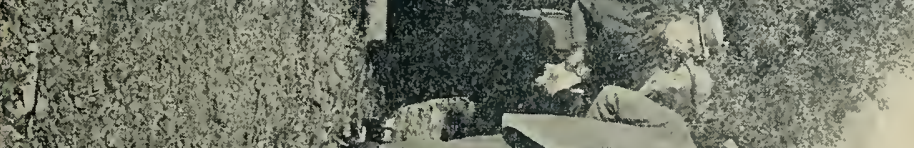

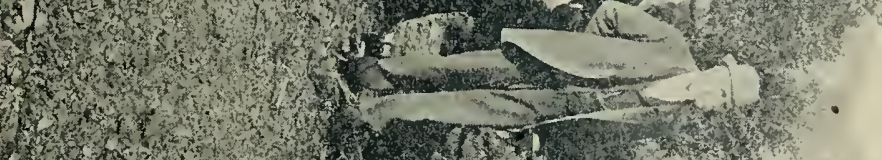

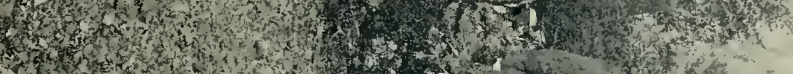

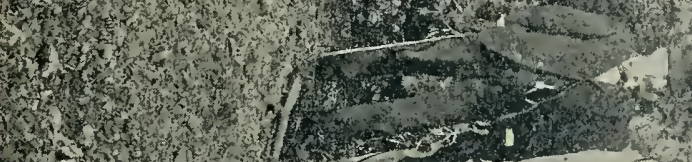

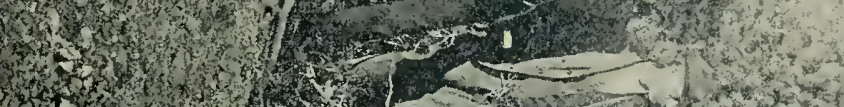

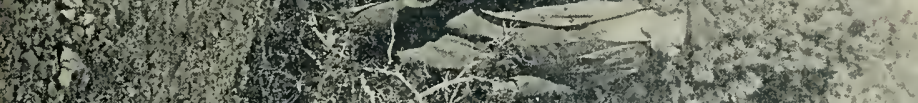

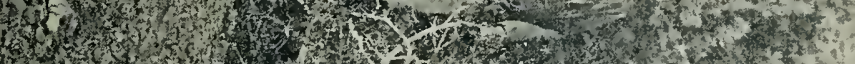

2
3

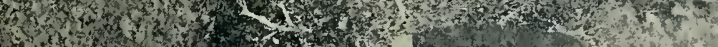

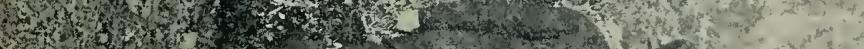

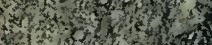

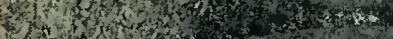

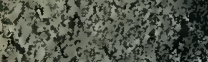

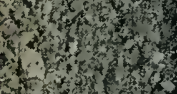

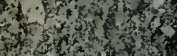

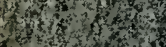

$-7201$

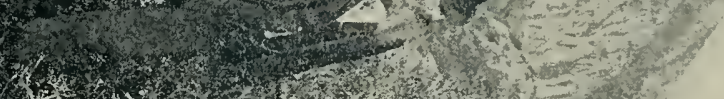

3
3

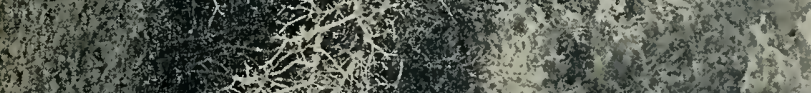

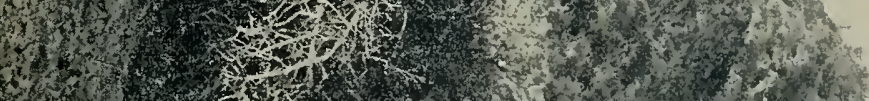

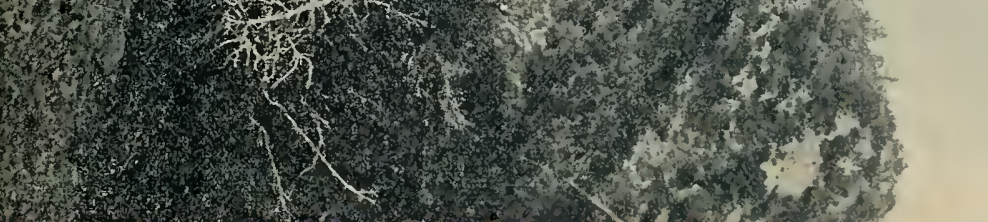




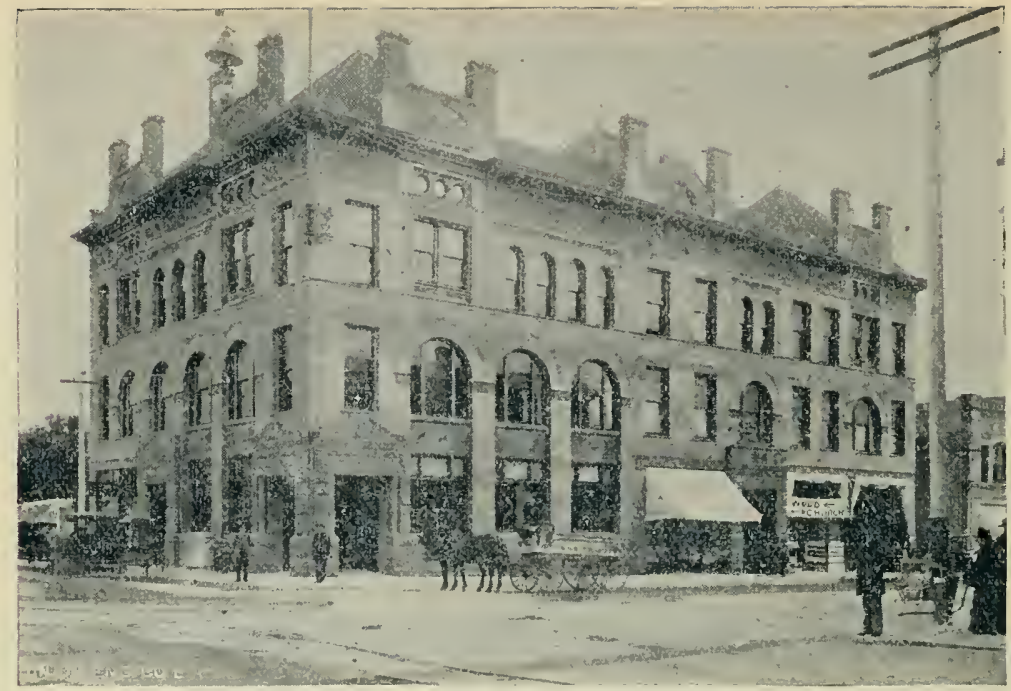

MASONIC TEMPLE-WEST-BY-NORTH VIEW.

[See page 507.]

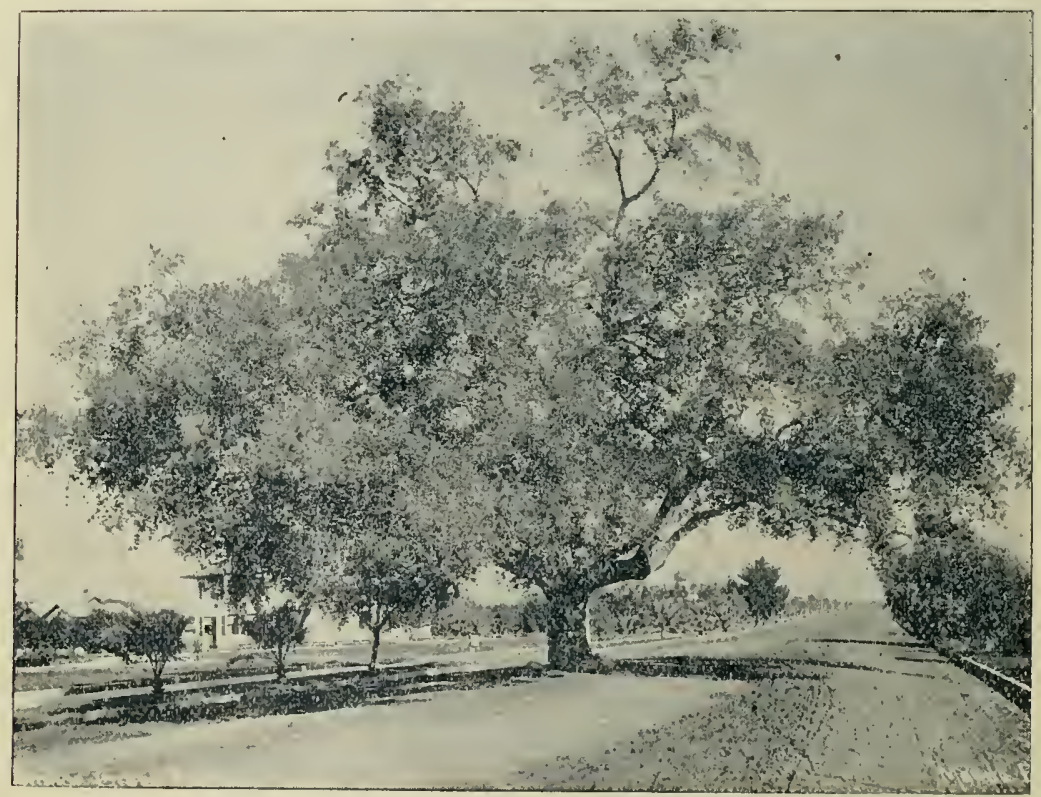

RED-OAK TREE. [Quercus Agrifolia.]

On Lower Orange Grove Avenue. This is one of the two trees which decided Calvin Fletcher in locating this Avenue so as to save them from being "cleared off." [See page $36 \mathrm{r}$-Orange Grove Avenue.] 
building the railroad, building the hotels, constructing bridle roads, designing and establishing novel features to attract visitors, and finally the great searchlight* at the zoological garden, the well-equipped observatory, the printing outfit where the Daily Mount Lowe Echo is printed in the highest style of typographic and photo-engraving art; and other details, a full account of all which would require a volume by itself. When Prof. Lowe had finally decided on the "Great Incline" project, and to build his road to the summit now called Mount Lowe [then known to old settlers as "Oak Mountain"] instead of to Wilson's Peak, a force of men was promptly put upon the grading work, both for the Rubio trolly section and the Echo Mountain cable section, this latter being definitely commenced April I2, I892, with D. J. Macpherson as engineer in charge of all surveys and construction work. Thus Macpherson's long dream of a mountain-climbing railroad went on to realization : not exactly after his own original plan, but as a direct outcome by genetic succession and "modification of species" from it - a clear case of struggle for existence and survival of the fittestan impressive rescript and geneagraph in the law of evolution. [See cut on page 409.]

THE NAMING OF MOUNT LOWE.

On September 24, I892, Prof. Lowe led a company of friends on the first ascent ever made on horseback to the summit of Oak Mountain - 6́, Ioo feet above sea-level, or 300 feet higher than Wilson's peak - and first raised the American flag there. The persons accompanying him were: Chas. A. Gardner, editor Pasadena Daily' Star; T. W. Brotherton, president Citizens Bank, Los Angeles; C. W. Brown, vice-president Pasadena National Bank; Dr. G. Roscoe Thomas of the Pasadena Improvement Co.; Mr. Randall of Los Angeles; T. W. Parkes, architect; Master Willard Brotherton; and Thaddetis Lowe, Jr. The guests understood that this great mountain, the highest of the Sierra Madres that can be seen from Pasadena, had never been named; and by spontaneous, unanimous and enthusiastic impulse they proceeded to christen it "Mount Lowe," the name by which in two years its fame encircled the globe, and will go down to remotest history. $\dagger$

* ' On Ficho Mountain is the World's Fair searchlight-a monster 3,000,000 candle power electric light, almost half as large again as any other searchlight in existence. The beam of light is so powerful light, almost half as large again as atuy other searchlight in existence. The beamd of light nightly its farreaching rays illuminate the streets of Pasadena and Los Angeles and light up broad stretches of the valley."-Pasadena Star, December 29, 1894 .

†The Auglaize, Ohio, Republican of December 1, 1892, contained a long letter from Los Angeles, written by some one who was a member of this historic christening party, and from it I preserve the following: "It was discovered that until this time this giant peak, the movarch of the Sierra Madres, was un named. One of the party suggested, that whereas Prof. T. S. C. Lowe, the great scientist, had first ridden to the top, had made the first trail to its lofty summit, was the first man to have planted the stars and siripes on its highest point, and was the first man to conceive the project of reaching its dizzy height with a railroad and with courage and means to put such a project into execution, as was now being done, no more fit and appropriate name could be given this mountain than the name of "Mount Lowe." no more fit and appropriate name could be given this mountain than the name of it was named, and will continue to be named when every one of the party present at the christening shall have been laid away in mother earth, and generations yet unborn will trace its rugged outlines on their physical geography and call it Mount Lowe. Andrew McNally, the greai Chicago map publisher, who owns a beautiful residence and grounds near its base, says the name given is so appropriate that "Mount Lowe" it shall be called on their next maps." 


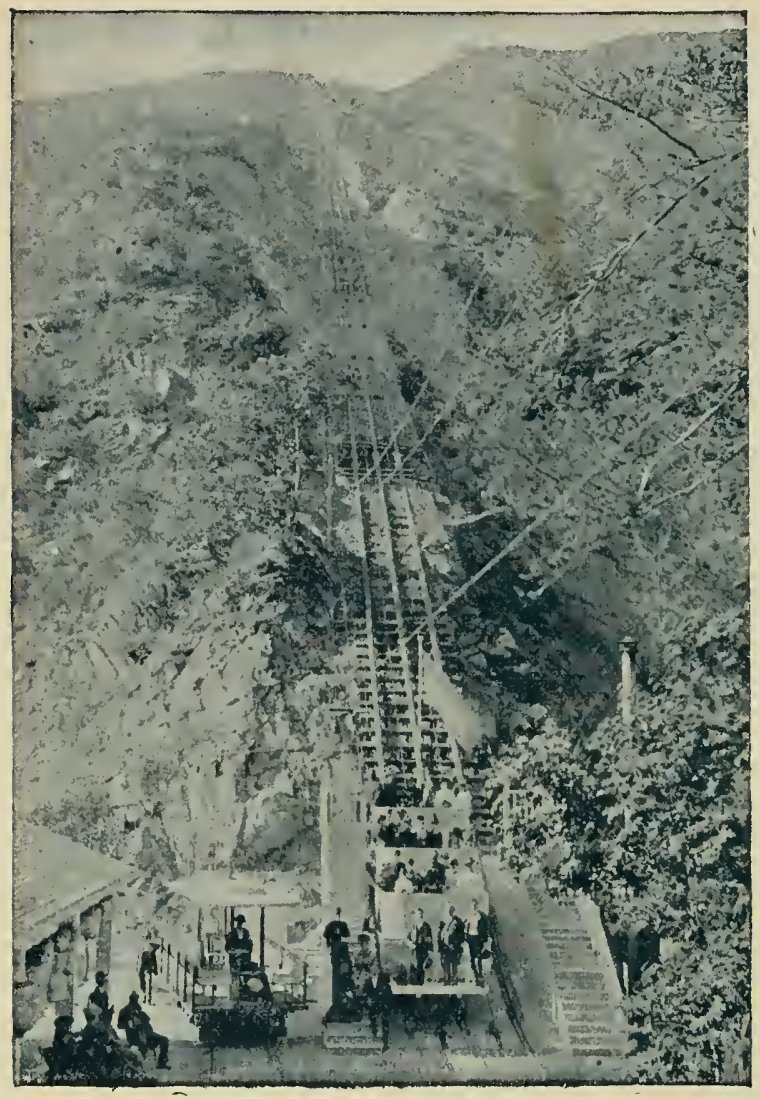

THE GREAT INCLINE.

In building the Rubio trolly section, there were some points so precipitous that workmen had to be let down and supported by ropes from above for several days, before they could excavate a standing place on the cliff or cut a path along its rocky face; and it required eight months of steady work, by all the men that could be put on it to advantage, to prepare the Great Incline grade ready for the ties. The first time the Great Incline cable was moved by electricity, being also the first event of its kind in the world, was on June 21,1893 . The first reg $11-$ lar passenger cars from Altadena to Rubio Pavilion were run on June 29opening day ; and the first passenger trips made on the Great Incline occurred

July 4, I893.* From this time forward the line was regularly open to Echo Mountain; and passage from there to summit of Mount Lowe was made by saddle animals.

November 10, 1893, the Eicho Mountain postoffice was authorized, with daily mail service. $\dagger$ Also a public telephone station, an express office and a Notary Public were added to the conveniences. And on Monday, March 12 th, the Daily Mount Lowe Echo commenced its regular daily issue; a weekly edition was issued on Saturdays, the first one being dated March 17 ,

- The Pasadena Daily Star said: "when the first passenger car ascended the great cable incline of the Mount. Lowe railway on Saturday the band rendered the music of "Nearer My God to Thee:" and Mrs. Jeanne C Carr, heing asked for a sentiment appropriate to the occasion, broke out into poetry as follows: Praise God from whom all blessings flow And also praise Professor Lowe."

The Monnt Lowe Echo credits Comrade John H. Stuntz with buying the first ticket ever sold to go "1p the Great Incline. He had been a soldier musician in the goth Pentusylvania Reserves and in the I9r Pennsylvania Veterans; and on this occasion he plaved some war-time tunes on the identical old fife which he was using in the army at the same time that Prof. Lowe was serving as clief aeronant to the U. S. Army.

+Postmaster George F. Kernaghan of Pasadena yesterday acted as official representative of the United States government in establishing a postoffice ou Echo mountain, with Prof. T.S. C. L,owe as postmaster, - Los Angeles Herald, Feb. 10, 1899. 
I 894. In September the great searchlight was put in place, and commenced its spookish peering into everybody's windows by night, for twenty or thirty miles around; and during the same month the temporary observatory was completed and opened to visitors, in charge of Prof. Lewis Swift, the famous comet discoverer from Rochester, N. Y. On November 24th occurred the formal opening of the newly completed Echo Mountain Hotel, with a grand banquet held there by the bankers of Southern California - a fraternity in which Prof. Lowe himself stands well to the front.

THE CORPORATE NAME.

The "Pasadena and Mount Wilson Railway Company" was incorporated June 3, i 89 I, with the following officers :

President, T. S. C. Lowe, Prest. Los Angeles Safe Deposit and Trust Co. Vice-President, Hon. P. M. Green, Prest. First National Bank, Pasadena. Secretary, A. P. West, Cashier Columbia Savings Bank, Los Angeles. Treasurer, T. W. Brotherton, Prest. Citizens Bank, Los Angeles.

\section{ADVISORY BOARD.}

Hon. H. H. Markham, Governor of California.

Hon. Joseph Medill, editor Chicago Tribune.

Hon. A. G. Throop, founder of Throop Polytechnic Institute, Pasadena. Andrew McNally, of the great Chicago map publishing house.

T. D. Stimson, President Columbia Savings Bank, Los Angeles.

G. G. Green, proprietor of Hotel Green, Pasadena.

J. W. Hugus, President National Bank of Rawlins, Wyoming.

C. W. Brown, Vice-President Pasadena National Bank.

A. C. Armstrong, capitalist, Altadena.

T. P. Lukens, President Pasadena National Bank.

Capital stock, 6,000 shares of $\$ 100$ each, or $\$ 600$,000.

As events developed, the corporate name soon became a misnomer-for, as before explained, Mount Wilson dropped entirely out of the reckoning; and in Prof. James's pamphlet of $\mathrm{I}_{993}$ it is, with full consent of the Company, called the "Pasadena Mountain Railway." But later it was re-incorporated as the "Mount Lowe Railway Co." - a more brief, convenient and correctly descriptive title, and by this fitter name it goes down to history.

\section{PASADENA'S MOUNTAIN RAILROAD CELEBRATION.}

'The first time the city council of Pasadena ever officially proclaimed and set apart a public holiday of their very own, was August 23, 1893and this was in honor of Prof. Lowe, and the opening to the public of his great Electric Mountain Railroad resort. The city had held "railroad opening" celebrations twice before, but none to compare in magnitude, enthusiasm and splendor with this one. It was like $4^{\text {th-of-July and }}$ National Thanksgiving day and Tournament of Roses all happily fused into one superlative demonstration. The streets were thronged to a jam with a great public parade, in which the city with one unanimous impulse outdid all its former efforts at festive jubilation. The arrangements were made by the Board of Trade, and carried out jointly with the city authorities. 
Prof. Lowe was accompanied by Gov. Markham, Mayor O. F. Weed, and A. R. Metcalfe, Esq., in a carriage; and in the grand escort procession the place of honor at the head was accorded to the old soldiers (G. A. R.) conmittee, consisting of Post Commander W. J. Barcus, R. H. Williams, A. L. Petrie, Benjamin Jarvis, A. M. Elson, and Hon. C. M. Simpson. The city marshal, John T. Buchanan, was grand marshal of the parade, with numerous aids. The speechmaking and indoor program was held in the Tabernacle, which had been elegantly and appropriately decorated by Dr. F. F. Rowland, C. H. Hovey of the Raymond nurseries, and others who lent a hand ; and the great building was thronged to the last inch of squeezing in that was possible. Hon. P. M. Green was president of the day; Rev. J. B. Stewart, D. D., chaplain; editor Charles A. Gardner, poet ; and Prof. O. W. Kyle, music director. And special committees had charge of various parts of the day's doings. (In the evening a grand banquet was given at Hotel Green.) From the many speeches at the Tabernacle I quote from the Eaily Star's report a few passages for historic preservation. Hon. P. M. Green said :

"The railroad, the opening of which we meet to celebrate today," added Mr. Green, " is so unique in its general character and design, so bold in its conception, and in itself such a triumph of engineering construction and skill, as to challenge our unbounded admiration. This celebration commemorates the most important event in the history of Pasadena. The Mount Lowe railway has the distinction of being one of three mountain railroads proper in the United States and the rare distinction of being the first and only one operated by electricity. It had been the good fortune of the speaker to know something of Prof. Lowe's enterprise from the start and to remember with what scorn and incredulity his proposition to build a road into the mountains was first received. They overlooked the fact that the projector of this enterprise was no ordinary railroad builder, but a scholar, engineer and scientist all combined, fully acquainted with the silent, powerful and occult forces of nature.

"After dwelling upon the toil and anxiety attendant upon carrying forward this great project, Mr. Green referred to the financial difficulties of the undertaking, in surmounting which Prof. Lowe had thrown his own private fortune into the scale and overcome every obstacle, bravely winning the right to be regarded as one of the ablest financiers in the land."

Gov. H. H. Markham said :

"Our honored guest has completed a railroad almost entirely with his own means ; certain it is, he has had to place himself responsible for every dollar it has cost. None of us can fully appreciate what Prof. Lowe has done and is still doing for Pasadena and Los Angeles county, nor can we appreciate the time, energy, patience, intelligence, and financial outlay incident to the successful completion of such a stupendous undertaking for a single individual. The idea of building a mountain road in Pasadena was not an original idea with Prof. Lowe. No, there were several of us here who had taken the subject up, had talked and talked about it, studied over it and worked it out all of one winter; and in the spring we talked it over again, and virtually at last gave it up. Prof. Lowe began to work and talk, and 
talk and wORK ; and without a hitch or a halt he has succeeded in grandly overcoming all obstacles, and today his work and his enterprise is crowned with success."

Of Hon. A. G. Throop's address the Star says :

"'The introduction of the venerable 'Father Throop' was the signal for a great outburst of applause, which continued for several seconds. He made a characteristic off-hand speech that evoked great laughter and much applause, the leading theme of which was that it is the duty of every man to do what he can for his fellow-men. He referred to Mrs. Lowe in highly complimentary terms as the power behind the throne of her gifted husband, * and made some humorous allusions to the blessings of the married state that aroused general merriment. To those who had become frightened over the financial stringency he proffered the advice that they take their money out of their old stockings and invest it in the bonds of the Mount Lowe railway. The building of a great observatory on the mountain summit will follow, if Prof. Lowe receives this sort of encouragement, and Pasadeda will lack nothing to make it a perfect place of residence."

From Prof. Lowe's response I quote a few passages :

"It is a great satisfaction to myself and fellow-workers to feel that our work has met with your approval. If anything will stimulate one to farther exertions, your presence here today to celebrate what we have accomplished will surely have the desired effect. * * When I first heard of Los Angeles, Pasadena, and the great San Gabriel valley, I got the impression that it was a vast plain with but few if any mountains near it ; but when in the summer of ' 87 I first landed in Los Angeles I was struck with the extent and beauty of the mountains, and my first ride was to Pasadena and the foot-hills of the Sierra Madres. I was then fully impressed that it required only the means of reaching the various interesting summits to enable one to enjoy all the atmospheric changes and temperatures that are usually sought after by thousands of miles of travel, extending even to Europe and the elevation of the Alps. It was with a full, open belief that the means of scaling these mountains would soon be provided, that decided myself and family to make our final home in this locality.

"The railway to the mountains was even then being talked of, and a small telescope, under the auspices of Harvard University, had proved the superiority of the atmosphere on these summits for astronomical purposes. I, at this time, had no idea of taking upon myself the whole labor and expense of building the road to the summit of these or any other mountains ; but always felt that when others would start such an enterprise, I would be one to aid by making a liberal investment in the same. Consequently the bulk of my fortune was invested in other enterprises before I fully decided to build the road, the opening of which you are today so generously and enthusiastically celebrating. Had I earlier decided to build this road entirely with my own means, if necessary, I should have deferred investments in other directions. Again I thank you for your aid and encouragement, and trust my future work will meet with the same hearty approval as my past efforts have by your demonstration today."

From an editorial in the Daily Star of same date I quote a few sentences that should go into this permanent historic record:

*See article on "I,eontine Falls," page 382 , for another mention of Mrs. Lowe's relation to the great enterprise. 
"Half a dozen years ago Prof. Lowe came to this city to seek rest and recuperation which its climate and inspiring surroundings promised. Feeling rejuvenated after some months residence, he began to explore the neighboring mountains, for he was born and spent his boyhood days on the flanks of the White mountains of New Hamphire and acquired an absorbing and legitimate passion for mountain scenery. * * At last he formed the determination to give his friends and neighbors an opportunity to share with him the magnificent new scenes visible from the summits of the Sierra Madre mountains. * * He placed surveyors in the field to locate a feasible route to the summit of a range higher than Mt. Wilson. They reported it insurmountable for railway purposes. Prof. Lowe had been accustomed to overcome what to others seemed insuperable obstacles. Nothing daunted by adverse reports, he studied the topography. of the mountain range himself, and ascertained that if he could scale the steep promontory now so well known as Echo Mountain, a practicable grade could be projected thence to the highest summit. By a bold stroke of genius he made the very impediment placed in his path by nature contribute to a brilliant success. He devised the electric cable incline, the only one in the world, by means of which five miles of grading was saved to the company and an hour's time to the traveler. Special machinery had to be planned for the enterprise; and numerous drawings were made, and altered, and revised, until at last the company secured just what was wanted."

Two days after this Pasadena celebration, the Los Angeles Chamber of Commerce testified its appreciation of the Mount Lowe Railway, as a magnificent project of lasting benefit to Los Angeles and all Southern California, by giving a grand banquet in Prof. Lowe's honor at Redondo.

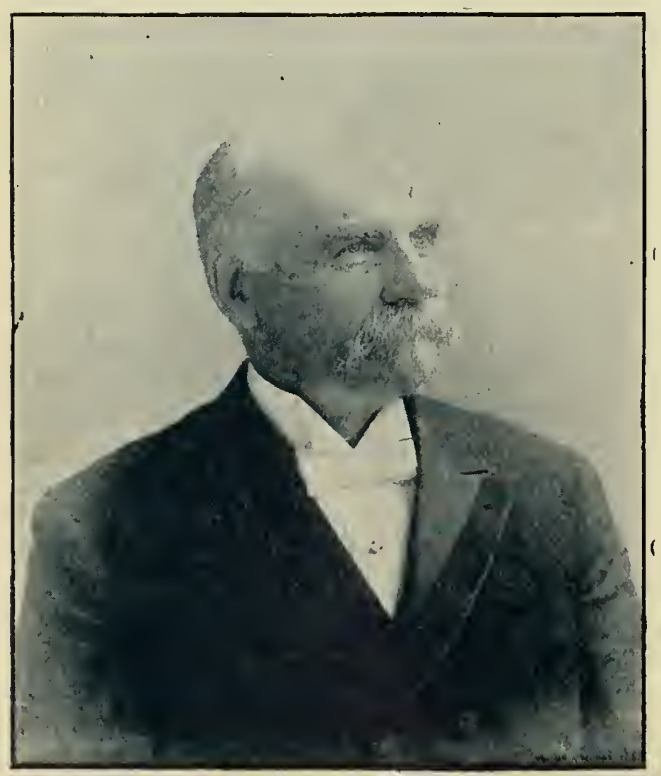

PROF. T. S. C. LOWE -1894.

\section{HONORS AND WEALTH ALI, FAIRLY WON.}

In an article on Prof. Lowe's career the San Diego News condensed into good form, the four great inventions upon which his well-earned fame securely rests, and I quote it here as a proper part of this historic narrative:

I. He originated and organized the balloon corps of the U. S. army, which did such efficient service during the war of the rebellion. By his method telegraphic communication between the balloon and the earth was established, so that the movements of the enemy were immediately known at headquarters, even during the progress of battle.

2. He is the inventor of the Compression System of artificially 
manufacturing ice-a system which has completely revolutionized the distribution of food supplies throughout the world. He was the first to demonstrate how fruits and meats could be preserved fresh and transported any distance; and all the present methods employed in the manufacture of ice, or artificial refrigeration, are but modifications of his patents, which originally covered the whole of the ground now occupied by these industries.

3. His invention of water gas for illumination, and the methods he employed for its manufacture and distribution, etc., have made his name familiar as household words, throughout the scientific world, for the "Lowe process and machinery" are in use in almost every city of any size in the United States.

4. His crowning achievement has been the originating, designing and building of the first electric mountain railway in the world. This last and greatest success marks an epoch in mountain railway building, for no company will ever be found foolish and improvident enough to go back to the old cumbersome, annoying and expensive method of a cog-wheeled locomotive engine climbing slowly and wearily up a toothed rail, blowing smoke, dust, ashes and grease fumes into the faces of passengers, when by the Lowe method of applying electricity and the cable, ease, comfort, safety and inexpensiveness are insured.

\section{RUBIO FARM.}

The Mount Lowe Railway Company owns a 300 -acre farm which it works as an adjunct to its hotels at Rubio Pavilion and on Echo Mountain. With its own cows it supplies all the fresh milk, cream and butter required; its poultry yards will supply all the eggs and chickens, etc.; whilst its orchards will give an abundant supply in season of oranges, pomegranates, figs, lemons, guavas, loquats, peaches, apricots, cherries, persimmons, apples, pears, plums, strawberries, blackberries, gooseberries, raspberries, etc. In the vineyard are table grapes of every variety, from the seedless sultana to the muscat, black Hamburg and rose of Peru. Tomatoes, peas, cucumbers, and all other table vegetables will be constantly growing and will deck the table at all seasons of the year.-Mount Lowe Echo.

\section{GREAT INCLINE BRIUGE.}

"This bridge, if placed on the level ground, would be one hundred feet higher at one end than the other ; elsewhere, a pefect monstrosity in appearance; here, appropriate to the road upon which we are climbing. It receives its name of "Macpherson Trestle" from D. J. Macpherson, Prof. Lowe's engineer, and is a worthy tribute to his skill and practical ability. It was planned and drawn by Mr. Macpherson, and the onerous and important work of building it was successfully executed by Messrs. Carson \& Son of Pasadena. Mr. Carson is a relative of the celebrated government scout, Kit Carson, whose monument at Santa Fe, N. M., is a worthy tribute to his valuable services to the United States government.-Prof. G. Wharton James.

\section{GOV. MARKHAM'S BEAR STORY.}

Among local points named in the Mount Lowe literature is one called "Grizzly point," the same that was flagged as Giddings peak, and a burro trail made to it from Millard canyon, in I887. But the name Grizzly point comes from an adventure of five members of the "Pasadena Rifle team" in 
I 882, viz : David Townsend, H. H. Markham, Chas. H. Watts, E. G. Halleck and Frank H. Heald. At Pasadena's great celebration of the Mount Lowe railroad to Echo mountain, Gov. Markham told the story thus:

"In the spring of $\mathrm{r} 882$, a small party of the bravest bear huters in Pasadena ( I was one of them) followed a grizzly bear from the base of the mountains right up over much of the ground where Professor Lowe's trails now lead from Echo mountain to Mount Lowe. We followed him clean over the ridge and down into the deep canyon on the other side. We were cautious hunters, and did not press the bear too closely; but away along in the afternoon he concluded to come back. As soon as we discovered this, we wanted to come back too: and we started on ahead of him on a run. In fact, we were not able to go half as fast as we thought we ought to ; and when we reached Echo Mountain we would have mortgaged all our earthly possessions for a trip down that Incline-indeed, I believe we were all sufficiently frightened to have begged the conductor to cut the cable and let the whole business slide, regardless of consequences. I tell you, this Incline will be a great comfort to bear hunters-of our makeup. . (Great laughter.)"

\section{ELECTRIC POWER GENERATORS.}

The Mount Lowe Echo gave the following particulars:

"There are several power generators on the system - one of i 50 horsepower capacity at Altadena Junction, one of 50 horse-power at Cabrillo Heights, one of i 50 horse-power, two of 50 horse-power and one of 30 horsepower capacity at Rubio Pavilion, one of 75 horse-power and one of 35 horse-power on Echo mountain.* The generator at Altadena is operated by two 60 horse-power Otto gas engines; that at Cabrillo Heights by a Pelton water wheel, which receives its impulsion by the flow of water from the Rubio Pavilion reservoir. This is filled by the flow from Echo mountain, I 400 feet above, which first operates the 150 horse-power generator of Rubio Pavilion, ere it goes on its further career of usefulness to Cabrillo Heights. The three small generators of Rubio Pavilion are all worked by water power through Pelton wheels, which is piped from Mirror lake in Rubio canyon. The motor of the Great Cable Incline is so arranged as to receive its power from either the gas engines at Altadena or the water wheel at Rubio Pavilion."

In August, 1895, the upper troller section from Echo mountain, four miles up to Crystal springs and the Alpine Club house, was opened for travel. This piece of road startles and amazes and charms the traveler with the astounding audacity of its engineering feats, and the consummate grandeur of scenic prospect revealed at each exploiture of salient recurves. [See " Alpine Falls," "Chapman's Glen," etc., page 385.]

*A later account says these engines are fired with gas piped up from Prof. Lowe's Pasadena city gas works, from which source also the Echo Mountain house is conpletely furnished with gas burners as well as electric lights. 


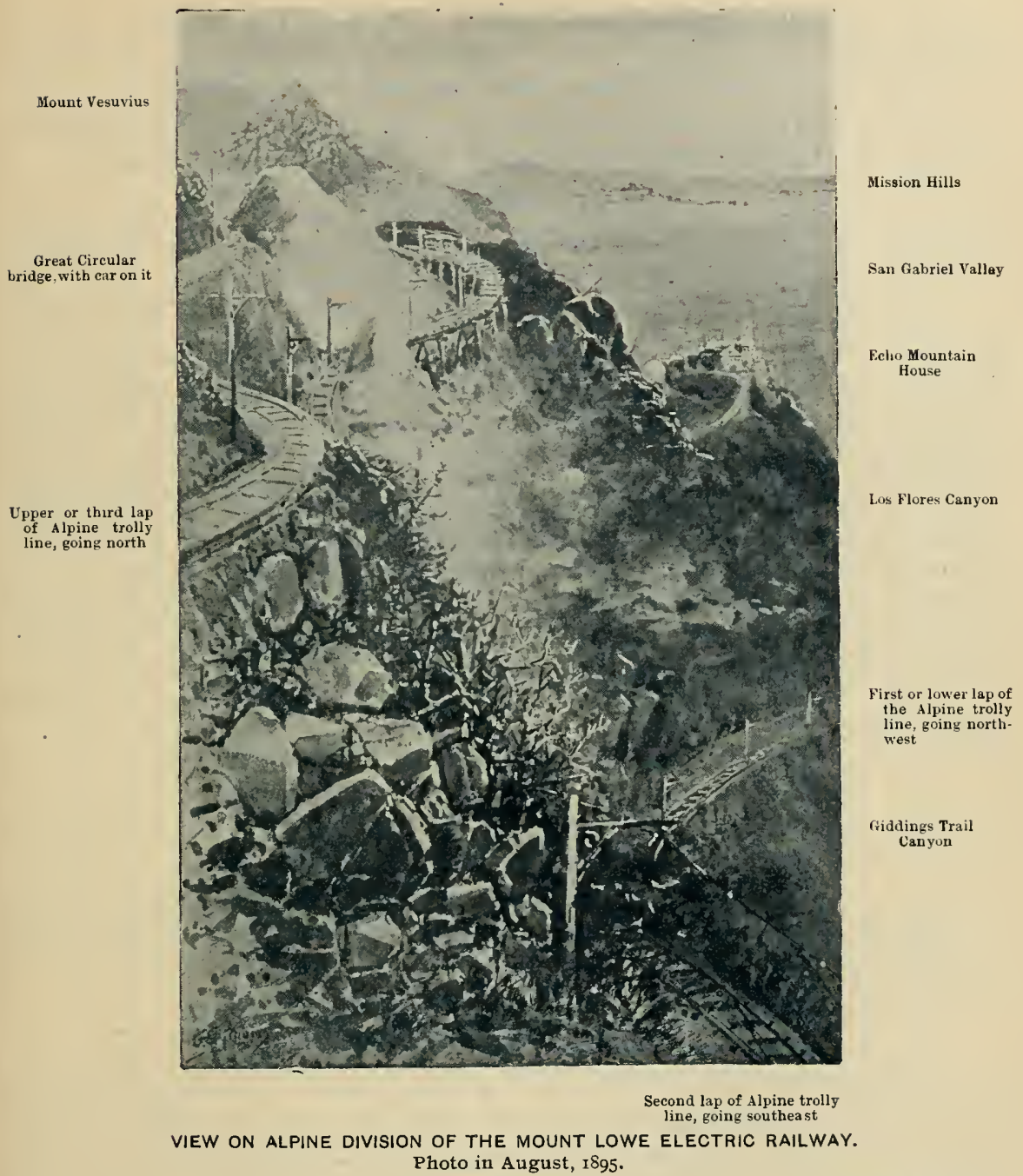
to in August, 1895 .

ALTITUDES.

Above Sea L,evel.

Los Angeles, at Terminal depot, First street................. 270

Pasadena ........................................................ 850

Altadena Junction ........................................... $55^{\circ}$

Rubio Pavilion...............................................2,200

Grand Rotunda p!atform at Thalehaha Falls................2,800

Echo Mountain House.................................... 3, 500

Crystal Springs..........................................

Summit of Mount Lowe......................................, 100

Summit of Observatory Peak [San Gabriel Peak] .............6,723

Mount Wilson, at "Harvard Telescope point" (Prof. Pickering's measurement) .......................................... 5,565

Henniger's flat...........................................2, 200 
The grade of the Great Incline is at first sixty per cent., then sixtytwo, then fifty-eight, then forty-eight per cent. It is practically a hotel elevator out of doors, and is the longest and highest one in the world.

During the first year that it was open this mountain railroad reported nearly 60,000 passengers carried between Altadena and Rubio Pavilion.

THE OBSERVATORY.

From the annual holiday number of the Pasadena Star, 1894-95, I quote this :

"The Mount Lowe observatory is in charge of Dr. Lewis Swift, late of the Warner Observatory at Rochester, N. Y., who is ably seconded in his astronomical work by his son Edward. Dr. Swift is the great comet finder of the world, and his son recently achieved fame for himself and the Mount Lowe Observatory by discovering another of these celestial wanderers. The observatory is equipped with a sixteen-inch telescope and several smaller ones, besides a full complement of other astronomical and scientific instruments. It is located on the mountain slope, about a quarter of a mile above Echo Mountain House. It is a handsome and convenient structure, having three other rooms besides the dome-crowned observing room. This observatory is to be erected ultimately on the highest of the three crests of Mount Lowe - the monarch of the Sierra Madres."

ECHO MOUNTAIN HO'TEL. - See chapter 24-article on "Pasadena's Historic Hotels.'"

\section{CHAPTER XXIV.}

INDUSTRIES.-Canneries and Drieries.-Manufactories.-Poultry and Ostrich Farms. -Electric Light and Gas Works.-Olive Company.-Orange Packeries.-Grand Opera House.-Oil Well.-Mountain View Cemetery.-Hospital.

The Five Historic Hotels.

\section{FRUIT INDUSTRIES.}

WALLACE'S CANNERY. - Joseph Wallace came to Pasadena from Canada in I 875, and bought thirty acres (one-half) of Ney Strickland's original colony lot, built a house, made improvements, put his land all into fruit, and resides there yet. In I88I Mr. Wallace started his cannery, under the name of the "Pasadena Packing Company," which was the first manufacturing enterprise established here, and used the first steam engine that ever puffed vapor in Pasadena. The first year Io, ooo cans of fruit were put up, which gave employment to twelve persons during the packing season. The Union of October 25, r884, reported that Mr. Wallace had put up 50,000 cans of fruit that season. On September 2, r 885, the cannery was burned down, [see page $\mathrm{I}^{2}$ ], yet notwithstanding his great loss above insurance, $\mathrm{Mr}$. Wallace rebuilt his works the next year and kept in the manufacturing field. In I89 I, Mr. Wallace took in associates to augment the working capital, and on May 7 th of that year the company was incorporated, with Geo. 
F. Kernaghan, president; Prof. T. S. C. Lowe, vice president; R. C. Commelin, secretary; First National Bank, treasurer; Joseph Wallace, superintendent. Capital stock, $\$ 75,000$. The Board of Trade pamphlet of 1892 made the following report:

"In the season of 1891 , the Pasadena Packing Company put up 250,ooo cans of peaches, apricots and pears; used three carloads of sugar; employed during the months of July, August, September and October, from seventy-five to one hundred girls, and paid for wages an average of $\$ 3.00$ per week. The establishment canned, in addition to the above, about I0,ooo pounds of strawberries, and dried large quantites of other fruits."

FRUIT DRIERIES.-Fruit-drying enterprises were carried on in a small way by some growers, to prepare their own fruit for market, ever since the colony had any fruit; but Joseph Wallace, in 1885 , was the first to operate a machine drier here-and it was destroyed by the burning down of his cannery that year. He has done some drying every year, to utilize surplus fruit that was not choice enough for canning.

J. R. Lloyd for five or six years did a somewhat extensive driery business, at the corner of Fair Oaks Avenue and Painter street, buying up fruit by the ton to prepare for market by the sunshine process. His was the pioneer commercial driery, others before having been only small, private works. [No figures furnished.]

C. C. Thompson has also run a driery for many years in his own extensive apricot orchards on North Lake Avenue, and has been one of our heaviest producers of dried fruit. His output was in 1890, four car loads; in 1891 , five cars; in 1892 , seven cars; in 1893 , five cars. Then in 1894 he went into the North Pasadena or Highland association.

There have been others engaged more or less in the same line whose names and places I did not get.

May I I, I894, the fruit-growers of North Pasadena organized the Pasadena Highland Fruit Association, whose objects were thus set forth :

"To receive, store, prepare for the market and sell the fruit or other food products of its stockholders, on a strictly co-operative basis; to take care of orchards of stockholders and gather and deliver the fruit of the same, etc. The principal place of business of the association is at Pasadena, and the term for which it is to exist is fixed at five years. The following board of directors was elected: C. C. Thompson, C. E. Tebbetts, L. S. Porter, Byron Lisk, A. R. Clark, H. Cooley and J. E. Smyth.

This association established a drying yard and procured a lot of patent cutting and pitting machines, and during the season of $1894-95$, they shipped 146 tons, or twelve and a half carloads of dried fruit.

Fruit CRYSTALLIZING Works.-The Union of November 27, I886, made this announcement :

"A company has been formed in this city for the purpose of engaging in crystallizing fruits. The members of the organization are P. M. Green, F. M. Hovey, Byron O. Clark, and James R. Riggins of Pasadena, and 
Frank M. Schamberger of Anaheim. The capital stock consists of $\$ 20,000$ in 200 shares, all of which has.been taken, and the company is thus enabled to start full handed. They propose to can fruits, and crystalize; and also manufacture jellies, syrups and unfermented wines, etc."

The county records give November 13,1886 , as the date of incorporation of this company. They bought land, erected buildings, and established their plant on Glenarm street and the Santa Fe railroad. Mr. Hovey superintended the factory work for a while, and produced some excellent goods; then he opened a store on Colorado street for their sale. But now the "boom" epidemic struck Pasadena; and all the members of this company caught the fever, and went to speculating in lands and lots; the factory business was not pushed by them, and it could not push itself - so it went down. The works lay idle for some months. Then in the winter of I888-89 Messrs. Philbrook and Stetson leased the plant, and started the business of canning baked beans, Boston brown bread, mince meat, etc. This firm was succeeded by F. F. Stetson \& Co., in the winter of I890-9I ; and in 1894-95 Mr. Stetson ran it himself. The articles manufactured are canned baked beans, Boston brown bread, Lima beans, mince meat, plum pudding, and tomatoes ; bottled catsup, and crystalized fruits. Amount of capital, $\$ 3,000$. Number of employes vary from three to twenty during the season. Amount of first year's business, $1889-\$ 2,000$; amount of last year's business, $1894, \$ 5,000$.

Olive INDUSTRY.- The Union of October i6, i886, said:

"The California Olive Co. has filed its articles of incorporation with the county clerk. [Incorporated May 15, I 885.] The principal place of business is Pasadena. The term of existence is fifty years. The directors are Fred J. Woodbury, John P. Woodbury, Byron O. Clark, James R. Riggins, and Charles H. Riggins, all of Pasadena. The capital stock is $\$ 120,000$, divided into 240 shares of the par value of $\$ 500$ each, and is all subscribed."

They planted 200 acres to olive trees, up toward the mountains west from the cemetery, intending to erect an oil mill when their trees came into bearing. But the members of the company all went monkeying with the "boom ;" some of them got bit; and their oil mill project went out with the general collapse.

CONDENSED VEGETABLES FACTORY.-Started in I $\$ 92$ by W. R. Baker in a small way, under his own patented process for evaporating potatoes, onions, cabbages, pumpkins, tomatoes, carrots, etc. The water is all eliminated without letting the natural flavor of the vegetable escape. Amount of capital, \$5,000. Number of employes in August, I 895 , were fifty. Amount of first year's business, $\$ 300$. Amount of last year's business, [ I 894-95] \$1 2,000. The company now consists of W. R. Baker and W. S. Hanaford. Factory at 552 Bradford street, where they own two and a half acres of land for growing vegetables, besides the buildings, machinery, and 
fixtures necessary to work up six tons of green vegetables per day. In July, I895, they had in hand orders for 100,000 one-pound cans, and ten tons of 25-pound cans, for shipment to Alaska, Siberia, China, Russia, and to supply whaling ships and other long-voyage vessels.

ORANGe PACKIng.-As early as I 885 the Earl Fruit Company of Los Angeles commenced buying orange crops on the trees, and packing the fruit in Pasadena - and has continued the business every year, up to 1895 . [The Germain Company also tried it two or three years, then dropped out.] The Earl Company operates in all Southern California, with a capital of $\$ 250,000$. I tried to get a table of its pack in successive years in Pasadena, but could only get a verbal estimate that they had shipped about i 50 car loads a year for three years past - a car load being 300 boxes. The average price to growers was about $\$$ I per box, on the trees, for navels, and about $75^{\mathrm{c}}$ for seedlings. About 30 men and women are employed here while the work is going on, which includes picking, hauling, washing, packing, box making, car loading, etc. Packery on Glenarm street and Santa Fe railroad in 1895 .

During the winter of $1885^{-86}$ the Southern California Orange Growers Protective Union was organized. F. H. Heydenreich became its representative in Pasadena; and early in ' 86 he and Byron O. Clark commenced orange packing here, in a building which then stood at the corner of Locust street and the railroad track; and that year they packed and shipped $35 \mathrm{car}$ loads. Mr. Clark says that growers were getting only $25 \mathrm{c}$ per box for their oranges on the trees, from the private packing companies; but those who went into the Union realized about $\$ 1.5^{\circ}$ per box.

During the season of $1886-7$ Brent Bro's packed and shipped about 100 car loads of oranges from here ; besides what were shipped by the Union, by the Earl Company, and by orchard owners themselves. I requested from the railroad company's books a table of the number of car loads of oranges and dried fruits shipped from Pasadena each year from 1885 to 1895 ; but, for prudential reasons, the agent was not permitted to furnish me the figures.

The Pasadena Fruit Growers Association was incorporated December I 4, I893, after several preliminary meetings. C. C. Thompson was the first president and manager; Dr. Lyman Allen, secretary. Capital stock $\$ 15,000$, in $I, 500$ shares of $\$ 10$ each. There are orange growing districts organized in this county at Alhambra, Downey, Fernando, Glendale, Pasadena, Rivera, Vernon, Whittier. These by delegates form the "Semi-Tropic Fruit Exchange" at Los Angeles; and delegates from that incorporation, together with those trom similar corporate bodies in other counties, form the "Exchanges of Southern California," a sort of mutual supreme council for the whole business. The Pasadena Association had 109 stockholders in 1894 , and 134 in 1895 . In '94, operating only a part of the season, they shipped 43 car loads of oranges, mostly east. In 1895, up to 
June 30 they shipped 60 car loads (about 18,000 boxes) to Chicago, Buffalo, West Virginia, Missouri, Texas, Montana. Their pay roll in I895 showed from 8 to 28 , with an average of 20 employees at work. They used the old Santa Fe freight depot below California street for a packing house. The officers in 1895 were: Geo. F. Kernaghan, president; B. F. Ball, vicepresident ; J. F. Jones, secretary ; First National Bank, treasurer.

NURSERIES. - There have been so many of these enterprises, both large and small, beginning with the first year of the colony, that I could not undertake to give an account of them.

\section{MANUFACTORIES.}

The Pasadena Manufacturing Company.-C. B. Ripley came to Pasadena from Maine in 1876 , and was one of the earliest contractors and builders here. Then in I 878 Harry Ridgway came here from Canada, and was the first man to open a regular architect business in Pasadena. Upon getting acquainted they formed a partnership and carried on business together; and in 1884 they built the first planing mill here. This was located nearly where the Union Ice Co.'s office and warehouse are now, on East Union street. This mill had the second steam engine ever run in Pasadena (Joseph Wallace's cannery having the first), and it startled the natives by steaming up and blowing its whistle vigorously for the first time on Tuesday evening, July 29, I884. The next day the mill started on its regular daily runs for business. The firm at this time had in hand a $\$ 3,000$ residence for $\mathrm{H}$. W. Magee; a $\$ 2,000$ residence for G. H. Tower; a $\$ 4,000$ business building for W. H. Wakeley; a dwelling for Geo. H. Little on upper Fair Oaks [now called Lincoln] Avenue; a new school house at Monks Hill, and another one on East Colorado street. These particulars I gather from the Valley' Union of August 2, I884. Mr. Ripley had projected the mill enterprise and was happy in it, for he was a mill man; but Ridgway preferred his own special work as an architect, and was very willing to unmill himself. Meanwhile a plan was formed to enlarge the mill business into a stock corporation for general manufacturing of all kinds of house finishings, trimmings, etc. A meeting to consider the matter was held in Williams Hall December Io, I 886. Another meeting was held December i6, when organization was effected, under the name of "Pasadena Manufacturing Co."- and on December 20 the company was incorporated, according to Oscar Freeman, the company's secretary; but the county records give December Io, the date of the first meeting, as date of incorporation. Nearly the same names occur at all these meetings, and hence I only give the names enrolled as first members of the corporation, as follows: C. B. Ripley, B. F. Ball, James Clarke, W. P. Forsyth, Oscar Freeman, O. M. Arnold, P. M. Green, G. W. Pillbeam, R. Williams, M. H. Weight, M. S. Overmire. The same men were named as board of directors; and the first officers were: Forsyth, president ; Ball, vice-president; Green, treasurer; 
Freeman, secretary ; Ripley, superintendent. Other officers have changed, but Oscar Freeman has been secretary continuously until now, I895. The amount of capital is $\$ 50,000$. Number of employes average about 40 . Works located between Broadway and the Santa Fe railroad, below Kansas street. Amount of first year's business, \$IOI,092.74. Amount of last year's business [I894], $\$ 68,75 \mathrm{I} \cdot 74$. The first year's business of the corporation, with its enlarged plant, was the opening year of the "boom," and was before the Mechanics Mill, and another one known as the Lindsay Bros.' Mill, which burned down and became extinct, had brought sharp competition into the field; hence that was the largest amount of business ever done by this company during any one year. The Board of Trade pamphlet of I 888 said of this mill :

"The firm paid out in the last year $\$ 72,000$ for labor alone. The lumber used per month is valued at $\$ 6,000$, while the glass, hardware and supplies amount to $\$ 25,000$ per year, making in all about $\$ 13,000$ per month distributed in Pasadena by a single firm."

MeChanics' Mil,L.-This is an establishment for the making of all manner of woodwork, both for inside and outside finish of any class of buildings. It was started in February, I 887 , by R. H. Brent, F. F. Crowell and G. C. Halsey. Building $50 \times 70$ feet, on Chestnut street at crossing of Santa Fe railroad. C. W. Mann bought a half interest in this mill in January, I888, then in the fall of same year he bought the other half; and about September I, I89o, he sold a half interest to G. A. Daniels, the firm being now, 1895, Mann \& Daniels. The plant consists of a complete outfit of woodworking machinery and apparatus, run by a 60 -horse power steam engine. Number of employes, sixteen in January, 1895. Amount of capital, $\$ 7,000$. Amount of business last year, 1894 , about $\$ 45,800$. Early in 1895 , this firm moved and reconstructed their old mill, and built an entire new one, $40 \times 106$ feet, two stories, with all modern improvements, at a cost of about $\$ 3,000$.

The LindSAy MILL.- - In I 885-86, three Lindsay brothers started a planing mill on Waverly Drive. In a few months the establishment burned down and was not rebuilt.

Holiand Blinds Factory.-Started in the spring of 1886 , as the Holland Manufacturing Co., by W. S. Holland, Chas. Swift, Fred. Swift, Geo. Durrell, with Holland president, Durrell secretary and W. S. Wright attorney. Amount of capital, $\$ 16,000$. Works located on Champlain street and an alley leading to Peoria street. Plant consists of grounds, buildings, all machinery for the manufacture of Hill's patent sliding blinds and Holland's screens, and both steam and gas engines for driving the machinery. Number of employes in the boom time, 30. First year's business, $\$ 25,000$ to $\$ 30,000$. Largest amount of business in any one year, $\$ 30,000$. [The business had been commenced in a small way at first by Mr. Holland, in a 
part of Ripley's planing mill near Locust street and railroad track, during the winter of $1885^{-86 .]}$

WAKELEy's NOVELTY Works.-W. H. Wakeley came to Pasadena in I $88 \mathrm{I}$, a mere youth, with his father, Capt. A. Wakeley, who had served as a soldier in the Mexican war and also in the war of the rebellion. The young man was an enthusiastic naturalist, especially in the study of birds ; and he at once commenced collecting, preserving, mounting, studying and classifying the native birds of this region. And these pursuits, at first merely for his own pleasure, gradually grew into a sort of taxidermy business-the first ever done in Pasadena. In I 883 he started a small hardware and tin store, with plumbing business attached under Robert Hentig's management, and mixed in some taxidermy work withal. In August, I886, he advertised for one thousand horned toads, for taxidermic mounting as California curios, and this set dozens of bright boys at work earning their own pocket money by catching pocketfulls of the curious little reptiles. In January, I 886, Mr. Wakeley started the Pasadena "Natural History Store," devoted entirely to the business of collecting, manufacturing and dealing in California curios, both by wholesale and retail. The business grew upon his hands so that in a few months he sold the store to Thomas W. Furlong, and devoted himself specially to the manufacture and wholesale trade in the same line, this amounting the first year to a business of $\$ 12,000$, and giving employment more or less to from ten to twenty persons. The Star of October II, I892, speaking of the District Fair at Los Angeles, said: "The Wakeley Novelty works of this city make a splendid display of articles in California woods, shells, etc., and Wm. H. Wakeley has two lathes in operation, with a force of three men in attendance. Last evening they gave away rooo pin-cushions turned out from yucca."

During I 893 he sold between 5,000 and 6,000 horned toads, roo dozen tarantulas, Ioo dozen scorpions, besides large numbers of centipedes, trapdoor spider nests, etc. And his goods were the only ones of their class from Southern California in the World's Columbian Exposition at Chicago. The factory and store are now located in a two-story brick block on North Fair Oaks Avenue. The machinery is run by a gas engine, and comprises machines for coarse and fine sawing, boring, turning, scroll work, carving, polishing, friction coloring and burnishing. A great variety of California woods are made into cups, vases, dishes, buckets, napkin rings, match safes, gavels, paper knives, canes, portierre and curtain rings, placques, and many souvenir forms.

BRICK MAKING.--The first brick building erected in Pasadena was B. F. Ball's original home place on North Fair Oaks Avenue; but these bricks were not made here - were all hauled by wagon up from Los Angeles 1878-9. The first business block built of brick, was by Craig \& Hubbard, grocers, on East Colorado street - the same now known as the Brunswick 
billiard hall. It was commenced in August, 1885, and they moved their grocery into it in October. The bricks were obtained from an old brickyard on Rose's ranch, east side of Santa Anita Avenue ; and the walls were laid up by Irvin Wilson. The second brick store was the Frost Block, built by E. S. Frost, about roo feet east of the other - commenced in September and completed in November, $\mathrm{x} 885$; these bricks were also hauled from the old yard on Rose's ranch.

The first brickyard ever started here was by Gass, Simons \& Hubbard of the City Brick Company at Los Angeles, in February and March, r884. They had the contract for brick foundation of the Raymond Hotel, and decided to make their bricks here instead of hauling them up from Los Angeles. Their yard and kilns for this job were just across the roadway east from the Raymond barn. Then after completing this job they moved their works to a site on Euclid Avenue just north of Maine street. In a year or two the clay gave out here, and they moved over onto Gen. Edwin Ward's land, on Madeline Drive west of Fair Oaks Avenue. They operated here until "the boom busted," and then retired from the Pasadena field. This first brick company furnished the bricks for four of our historic buildings : I - The Raymond hotel foundations, which took over half a million. 2The Ward Bro.'s block, just north of Williams Hall. 3-The first National Bank building. 4-The Carlton Hotel block. The Mr. Simons of this company was a cousin of the Simons Bros. who now own the steam brick works, but they never had any connection in the brick business.

A report published in the Pasadena Union said that the S. G. V. railroad in the first seven months of its operation had hauled 76 car loads or $7,000,000$ bricks up from Los Angeles to Pasadena. This was "boom" time.

During the winter of $1885^{-6}$ Joseph Simons, the head of the Simons Bros. Brick Co., came here from Hamburg, Iowa, and formed a business connection with John S. Mills and Dr. S. Rosenberger to start a brickyard, which he located and put in operation in the spring of 1886 , on Mills's land on Raymond Avenue below the Gas Works. This yard was run one season and then abandoned. Simons went hunting for more clay, and finally found the valuable deposit where the steam works now stand, on Glenarm street between Moline and Lake Avenues. Here he started a hand yard in the spring of 1888 and made a success of it, so that in the spring of 1894 , having been joined by his father and younger brothers, he put in a steam plant. The company now [1895] consists of Joseph Simons, manager ; E. O. Simons, secretary ; Walter R. Simons, ass't secretary. Their plant comprises a 40-horse power steam engine, and a Potts patent brick machine which is entirely automatic, from the raw unwet clay to moulded bricks ready for the dry-yard; and has a capacity of 45,000 bricks per day. The yard has 40,000 pallets or drying trays. They have about six acres of land; own the cottages for their workmen, and employ forty-five hands - no 
Chinamen. They also have a machine for making pressed brick, for smoothfinish work. This factory has furnished 90 per cent of all the brick used in Pasadena since $\mathrm{I} 889$. The company's entire property is estimated at $\$ 20,000$.

HoUl,aHAN \& GRIFFITH's brickyard was started in I894; but I have no data of it.

FERTILIZER Works. - The California Commercial Co. was incorporporated November I5, I888, by Belle M. Jewett, 'T. F. O'Riley, P. M. Jewett, J. D. Bicknell, Mrs. E. C. Bangs, S. P. Jewett. Prior to this Mrs. Jewett had erected a long brick building on Glenarm street and the Santa Fe railroad, having leased it in advance for a term of years to F. L. Rockwell, who engaged to carry on an ice factory and cold storage business there. The collapse of the "boom" froze out the zeal of the ice-maker, and his promised refrigerating plant was never put in. The Commercial Co. was then organized to utilize the building for storage, commission, forwarding, and other lines; and also as the business office for their fertilizer works at Chapman station on the Santa Fe railroad, east of Lamanda Park. These works manufacture bones and all kinds of slaughter-house refuse into fertilizing material, and have a capacity to manufacture 3,000 tons per year. S. P. Jewett, president; J. D. Bicknell, vice president; G. A. Herdeg, secretary ; First National Bank of Pasadena, treasurer; L. E. Jordan, superintendent.

I.IGHTING AND POWER WORKS.

Pasadena Gas and Elemctric Light Co.-Early in 1886 the project of establishing electric light works began to be discussed, and resulted in a list being made of persons who thought they would be willing to subscribe something for such an enterprise. These subscribers met in Williams hall March 25. Col. O. S. Picher, chairman; Frank M. Ward, secretary. It was voted to place the capital stock at $\$ 40,000$, in $\mathrm{I}, 600$ shares of $\$ 25$ each, and incorporate as the "Pasadena Gas and Electric Light Co." The Union reported $\$ 16,000$ subscribed in Pasadena, and that Dr. E. Mellis would place $\$ 8,000$ of the stock in San Francisco. April 9 there was another report of progress. Then on May io the Union says :

"The Pasadena Gas and Electric Co. held a stockholders' meeting at Williams hall yesterday afternoon, and elected the following officers: C. T. Hopkins, Emmons Raymond, P. M. Green, R. Williams, G. A. Swartwont, B. S. Eaton, and S. W. Bugbee, directors; president, Hopkins; vice president, Swartwout; treasurer, Green; secretary, Williams : 545 shares of stock were represented, Mr. Raymond having taken i6o shares.'

May 8 appears in the county records as the date of their incorporation. I found no further mention of their progress until October 2, I 886, when the Pasadena Union said: " M. G. Elmore, contractor for building the gas works, has 100 men at work on trenches, pipes, buildings, etc. The Carlton and the Raymond hotels are to be lighted with gas by November I." 
But meanwhile some change of organization was found necessary; for the same paper of December 4 made this report:

"The Pasadena Gas and Electric Light Co. was organized Thursday, December 2, with the following officers: O. H. Conger, president; E. C. Webster, vice president ; P. M. Green, treasurer ; Otto Froelich, secretary. Emmons Raymond and C. S. Martin were added to the board of directors."

This is the company which was finally bought out by Prof. Lowe, and is now operated by him, with A. W. Roche as secretary and treasurer. No statistics furnished. The gas is made from crude petroleum instead of coal.

ELECTRIC LIGHT AND POWER Co.-In March, 1888, the Pasadena Electric Light and Power Co. was organized by C. W. Abbott, J. M. Glass, A. R. Metcalfe, D. Galbraith, J. H. Fleming, and C. M. Skillen. But the articles of incorporation for this company were filed for record at Los Angeles January $3 \mathrm{I}$, I888. There were now two companies in the field, one, "Gas and Electric"; the other, "Electric Light and Power." December 9, $\mathrm{I} 890$, this company voted to increase its bonded indebtedness from $\$ 20$,000 to $\$ 25,000$. The power-house is located on Broadway below California street, and comprises, in 1894 , three boilers and two engines, with generators of I ro-arc light capacity, and I,200 incandescent capacity also. The company has a contract for three years from January I, I 894 , to supply the city with sixty-eight arc lights ; and it has thirty miles of wires throughout the city for its arc and incandescent light service. The power-house gives employment to five men; the number of line men employed varies from time to time. The company's capital stock is $\$ 50,000$. Its officers in I $894^{-}$ 95 were: L. C. Torrance, president and manager; L. P. Hansen, vice president; J. S. Torrance, secretary; San Gabriel Valley Bank, treasurer.

The Star of May 29, 1895, reported an addition $40 \times 50$ feet to the powerhouse, with a new engine of 250-horse power, and a new dynamo of 1,200light power, to increase the service.

The Grand Opera House.- In regard to this most ambitious undertaking of the "boom" period I found great difficulty in getting particulars. It seems to have been projected by E. C. Webster, with Frank M. Ward, Ben E. Ward, L. J. Rose, Dr. G. Roscoe Thomas, and others engaged in booming real estate on Raymond Avenue; and the "Pasadena Grand Opera House Co." was incorporated March 2 I, 1887. . The Board of Trade pamphlet of r 888 said: "Among the new buildings that attract attention is an opera house, which, now nearly completed, will cost \$25,000." And the Pasadena Standard of February 16, I889, said:

"The Grand Opera House was duly opened Wednesday evening [February 13,1889 ] with a great crowd in attendance. It is the finest and most complete mechanico-symposium of stage devices on the Pacific coast, outside of San Francisco. Mr. Wyatt, the lessee, says there is nothing equal to it in any other town of the same size in the United States. Cost \$roo,00o."

The company became bankrupt; and in May, r891, Prof. Lowe bought 
the building at bankrupt price, and made it headquarters for all his gas patents, gas works, and mountain railroad and hotel enterprises. It is a typical specimen of Moorish architecture. Its theater or opera house part is still continued (1894-95) with Thaddeus Lowe, jr., as manager.

SOUTHERn Oil, Company.-This enterprise was projected and worked up by Geo. H. Coffin, to prospect for oil, sink wells, manufacture or refine petroleum products, etc., and was organized at Pasadena on March I, I895. Incorporated March 29th, with the following as its first board of directors and officers: Geo. H. Coffin, president and general manager; A. H. Palmer, vice-president ; Edwin Stearns, treasurer; Chas. E. Getchell, secretary; Arthur H. Palmer, S. I. Stearns. Carital stock, $\$ 100,000$. The company by purchase and lease secured about r,200 acres of land on the hills south of South Pasadena and Lincoln Park, and have engine, derrick, purnps, and other machinery there, prosecuting their business. But up to time of this chapter going to press, oil had not yet been reached. July 8 their first prospect well was down and cased 400 feet.

POULTRY WORKS.

The OAk Lawn Poultro Farm.-This was commenced in September I 885 , by F. W. Machin, and was the largest and most heroic venture of the kind ever attempted in South California. The farm was a 20-acre tract on Allen Avenue south from Colorado street, and was a \$12,000 enterprise, based on the theory that the high price of poultry and eggs here would make the home production of them a profitable business, in competition with their shipment to Los Angeles from Kansas City, St. Louis, and all that region. I had tried the same business myself in I 884 and failed of successhence made visits of observation occasionally to this larger and later venture. This farm had or was planned for 100 houses for egg-layers - 50 hens to each house with its own yard. Also I, 000 breeders, with yards $25 \times 100$ feet, and 50 fowls to each yard. Four incubators, with total capacity of 2,000 eggs. Forty-eight artificial brooder yards for the baby chicks. Hospital yards and coops for sick or injured fowls. The owner was F. W. Machin, a business man of means, from Chicago; and its manager was C. VonCulin, a life-long worker and expert in this industry; hence the experiment had all that human interest and skill could furnish to make it a practical success. Yet, at the outset, Ed. C. Clapp, Pasadena's pioneer poultryman, said to me in his droll way, "I'11 give them just four months to bust up and go to smash with their whole business." Well, nature abhors a monopoly, as well as a vacuum, and would not tolerate so much chicken life in so small a space - at any rate not in Pasadenaland. In spite of all care, disease got among the fowls; young chicks by the hundred would be found dead in the morning; and, to shorten the story, in about six months this chicken "boom" bursted, went out entirely, and left no sign. 
OSTRICH FARM. - Early in I885 an ostrich farm was started on the banks of the Arroyo Seco at the end of Old Fair Oaks Avenue [now called Lincoln Avenue]. A fee of twenty-five cents was charged to see the birds; but on April 10, 1885, it was announced that the ostrich farm is closed except on Sunday, and the admission fee is then \$I. Stephen Townsend obtained a franchise and planned to build a street car line out to it, but finally gave it up. The Daily Star of May 18, I889, said :

"The nine ostriches at the Gardner ranch above town were disturbed by a dog early this morning, and six of them broke out and scattered on the run. Five of them were soon captured and returned to their quarters, and a sixth was corralled by some of Vore \& Hoag's men and run into their back yard. The manipulations of the owner to rope this captive were witnessed by a large crowd. The bird was finally led away in limbo."

Ten days later the same paper reported :

"The last of the escaped ostriches was captured the other day by Mr. Gardner. The bird was caught near the Brunk place, apparently on its way to Switzer's to see what could be found to eat in the way of tin cans, etc."

For some reason the business did not succeed well; and on September 2, I89I, I find this last mention of it:

"The Pasadena ostriches which had been under attachment and in charge of Officer Slater for some weeks, were yesterday released and taken to Los Angeles, their owner, Dennison, having given a bond as security for the payment of the amount claimed."

\section{CEMETERY AND HOSPITAL.}

Mountain View Cemetery.- When the Orange Grove colony settled here, and B. D. Wilson made them a free gift of the land now known as $\mathrm{Al}^{-}$ tadena, a man named J. W. Potts owned a considerable tract southwesterly from that, and he offered his also to them if they would pay the delinquent taxes on it. But they did not accept his offer ; and they would not have accepted Mr. Wilson's offer either, only that he assured them that the taxes were paid, and they thought in that case they would "risk it" - so little were these upper slope lands valued in I874. In i 875, however, Mr. Pott's land was bought by the Giddingses, Col. Banbury, and others, and it was a portion of this tract that was devoted to cemetery uses. The Pasadena Cemetery Association was incorporated December I3, I882, by E. H. Royce, C. A. Hartwell, J. L. Hartwell, E. W. Giddings, J. R. Giddings, G. L. Giddings, L. W. Giddings - the latter being elected president ; J. L. Hartwell, vice president; Calvin A. Hartwell, secretary and treasurer, which position he still holds - I 895 .

From the records of the company I have compiled this table of the number of burials during the successive years :

\begin{tabular}{|c|c|c|}
\hline & & \\
\hline & & I \\
\hline & I $889 \ldots$ & I 89 \\
\hline & $1890 \ldots \ldots \ldots \ldots \ldots \ldots$ & $1894 \cdots$ \\
\hline
\end{tabular}


Total to December 3I, I894-I,089. The first interment ever made in this cemetery was that of Mrs. Sophronia Johnson, aged forty-two, sister to Samuel and Wm. Pierce; she had died of consumption, and was buried here February 6, 1883. During that year the bodies of Laura C. Giddings, Bartlett Cobb, and C. Morton Banbury were removed from Col. Banbury's original home place on Orange Grove Avenue, and re-interred here; and eight other transfers were also made from private grounds to the new cemetery, or a total of eleven during the year, so that there were only thirteen deaths in Pasadenaland that year. During 1884 there were eight transfers, leaving the local death roll for that year twenty-two. The cemetery comprises twenty-three acres of land; gets its water supply from Rubio, Millard and Negro canyons; and its grounds, pipes, reservoirs, buildings, etc., are valued at about $\$ 30,000$.

CREMATORY, - In 1895 the undertaking firm of Reynolds \& Van Nuys built a complete cremation furnace, with all appointments complete, in the Mountain View Cemetery grounds.

HOSPITAL.-As early as $1886-87$ the question of having a hospital in Pasadena began to be agitated or talked about, and various plans to this end were from time to time promulgated; but they all came to naught. In I890-9 I the matter was again talked up with renewed interest, and some consideration was given it by the Board of Trade; and at one time it did seem as if something tangible would be done. James W. Scoville offered to give $\$ 10,000$ toward founding a hospital, if others would raise an equal amount for it ; and Mr. Scoville even bought some eligible lots for a hospital site. But the additional funds necessary were not raised; Mr. Scoville died; and the whole project dropped out of view.

Then, in January, I 895 , Dr. Jacob S. Hodge leased rooms Io, I I, I 2, I3, I4, in the Masonic Temple, and opened a Receiving Hospital, AND Surgical, Institute there. And this was the first thing in the way of a regular hospital service that ever came into Pasadena history, although there had been "Sanitariums" of many and varied sorts for a score of years before. The first patient put to bed in the "Receiving Hospital" was 'Ted Dobbins, a young man about i 8 years old with a broken leg, who was brought down from the Mountain View cemetery on a litter in a wagon. In August and September, I895, was built the Torrance \& McGilvray block, on northwest corner of Raymond Avenue and Green street, and its second and third stories were planned and built purposely for Dr. Hodge's Receiving Hospital, with every provision in the latest and best style for comfort, convenience, sanitary safeguard, etc., of patients-even to air and sun baths on the oriental roof-floor, reached by elevator.

\section{PASADENA'S HISTORIC HOTELS.}

THE LAKE VINEYARD House.- - This was the first building ever erected in Pasadena intended for use as a hotel, and was built by a Mr. Griswold 
during the winter of $1879-80$. In a letter written by D. M. Graham, February 23 , I880, to the horticultural paper then published at Riverside, he says: "Mr. Griswold had several applications for rooms in his new hotel before the plaster was dry." This was the only allusion to it that I found in any of the early documents. In 1882, this house with fifteen acres of land was bought by Isaac Banta, but he soon found that it was too far away from the village, or "The Corners," as the business center was then called, to make any success as a hotel-and it was also too small and inconvenient to serve the growing demand for such accommodations. He, therefore, in 1882-83, bought from Mrs. Jeanne C. Carr a 3-acre lot where the First National Bank, the Arcade Building, the City Hall, and other business blocks are now located, and built there the Los Angeles House, on the corner of Fair Oaks Avenue and Colorado street-the same house which now stands at the corner of Colorado and DeLacy streets. (This new hotel was opened in July, r883.) Mr. Banta's son-in-law, Wm. T. Pierce, then took the Lake Vineyard House; and he also soon learned that as a hotel for this enlightened country, its location, style of architecture, etc., foredoomed it to failure. The Union of March I, I884, said: "Mr. Butler has sold his interest in the Lake Vineyard House to a Mr. Granger, who will take possession at once." In I885 the property was sold to Milford Fish; he altered the house into a dwelling and now resides there, corner of Marengo Avenue and Florence street.

The Raymond Hotel. - In r883, Mr. Walter Raymond, who was then engaged in operating the "Raymond Excursions" from Boston to California and return, conceived the project of building a great hotel somewhere in South California especially to accommodate the tourist travel, and as a winter resort preferable to Florida, New Orleans, or Cuba. He examined eligible sites at San Diego, Riverside, San Bernardino, Ontario, Los Angeles and Pasadena ; and finally decided on what was then known as Bacon's hill, on the Marengo ranch at Pasadena, as offering on the whole the best prospect for success in such a great enterprise. And accordingly he bought the site, which comprised fifty-five acres of land, including some springs and portions of a brook. Mr. Raymond had no personal experience in the hotel business, but in his excursion business he had gained a pretty good knowledge of what tourists from the colder sections of our country wanted in the way of hotel comforts, and he associated with himself, Mr. Gluck of the International Hotel at Niagara Falls, and J. H. Littlefield, an experienced architect of San Francisco, as co-workers on structural details of the great hostelry building. Work was commenced in November, I 883 , toward cutting the hill down thirty-four feet lower than its original summit to make a level plateau large enough for the foundation and the necessary driveways and adjunct buildings, which would require a space of about five acres.

The grading contract was let at a given price per cubic yard for re- 
moving earth, and another price for removing rock. To external appearance at first the hill seemed mostly a body of earth that could be worked up with pick and shovel, plow and scraper, and so be done without very great expense. But as the work progressed it was soon found that the main bulk of the hill was composed of a sort of cement rock or conglomerate, and a peculiar formation of brecciable granite, or "bastard granite," as the workmen called it. These were new features in the case; and the more obdurate material was of such an unusual character that it very soon became an important financial question whether it was in a legal sense "earth" or "rock" material. This was submitted to a commission of experts at Los Angeles, and they decided that it was "rock." This result at once more than doubled the amount of money necessary beyond what was at first supposed would accomplish the leveling down of the hill. Drilling and blasting had to be resorted to on a large scale, and I,000 kegs of black powder and over a ton of giant powder were used up before the job was completed. Thomas Banbury of Pasadena had this contract. The number of men and teams employed varied at different times, but at one time as high as seventyfive teams and 250 men were on the pay-roll of this job. Of course there was then no railroad to Pasadena, and the lumber for the great building was delivered by the Southern Pacific R. R. Co. at San Gabriel station, and hauled up from there by teams, Mr. Banbury having this teaming work in hand also. The grading and lumber hauling occupied about four months of actual working time.

As a token and tender of their hearty good will toward Mr. Raymond's enterprise, and their willingness to aid it all they could, the people of Pasadena subscribed $\$ \mathrm{I}, 400$ to buy five shares of water, and pipe it to the hotel site. The Pasadena Union of March I, I884, said:

"Mr. Thomas Banbury, from the looks of things, will soon have the old landmark, Bacon Hill, reduced to the proper level for the foundation of the hotel. On Monday at high noon Mrs. Banbury lighted the three fuses that exploded 2,500 pounds of powder, the consequence of which was the complete disorganization of the last point of rock on the summit of the hill."

The fact that a woman had touched off this tremendous blast was a matter of local celebrity at the time, and makes one of the historic incidents connected with the erection of the Raymond hotel. That particular blast I heard myself, and it made a little earthquake for a mile or two around. On March 22 the Union said :

"Two vessels have arrived at San Pedro with 900,00o feet of lumber, and 500,000 shingles for the Raymond hotel. The contract for hauling all the lumber $(2,250,000$ feet $)$ has been let, and work is rapidly progressing; 500,000 bricks are now burned and being used on the foundation, the first brick of which was laid on Thursday."

On April 26 the same paper announced a suspension of work on the 
hotel ; and stated in explanation that instead of costing $\$ 200,000$, as first proposed, it would cost nearly double that amount - and consequently a revision of plans must be made. The fact was, the unforeseen granitic character of the hill formation had unexpectedly increased the cost of grading and foundation work two or three times beyond the first estimates. This suspension continued about six months, and Pasadena watched and waited the outcome with deep anxiety. Meanwhile the San Gabriel Valley railroad was completed from Los Angeles to Pasadena, and commenced running regular trains September I6, I885; and it was pretty well understood-in fact, a confidently trusted "open secret" even at that time - that this local line was ultimately to become a part of the Santa Fe's great transcontinental line; and this fact had much to do with determining the fate both of Pasadena and the Raymond hotel. And this suspension stage of the hotel work and its outcome are spoken of in the Union of June 4, I886, from which I quote this passage :

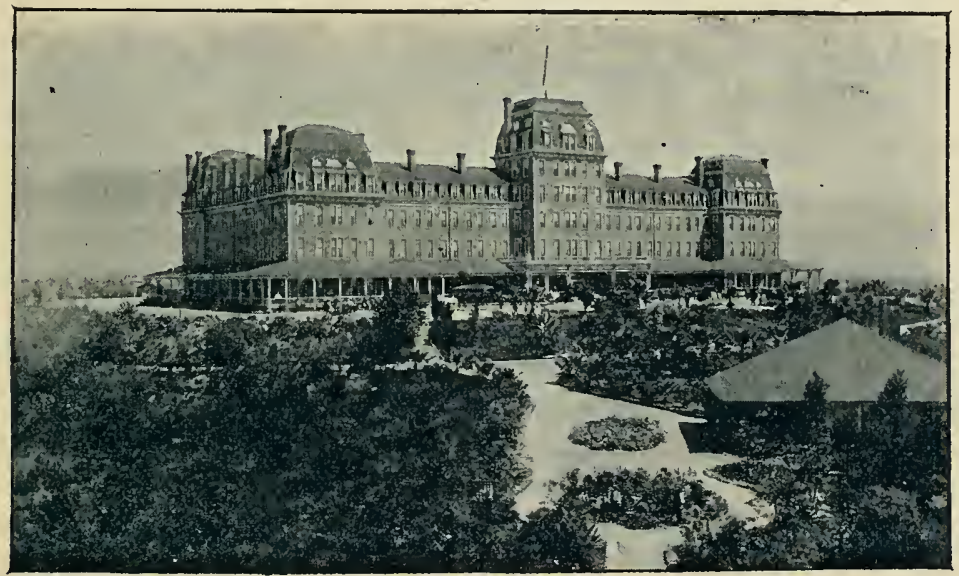

RAYMOND HOTEL - SOUTH-BY-WEST FRONT.

Photo. taken during its season of $1893-94$.

"April 23, I884, work on the hotel was stopped, owing to financial entanglements. Mr. Raymond had exhausted his means and knew not where to turn. At last he interested in the work his aged father, Emmons Raymond, long-time president of the Passumpsic River Railroad. The elder Raymond is 79 years old, but his days of usefulness are not ended, and when he came to realize the possibilities of the projected hotel, he lent vigorous aid with purse and head. Perched on its conspicuous eminence, the Raymond has been growing skyward since the 27 th of last September, when the elder Raymond, coming out from the east, devoted himself assiduously to the work. The great foundations had already been laid, 43,000 cubic yards of earth had been moved, and over a million bricks laid from the bed rock up. Since then the whole superstructure has risen, and today the vast building is very close upon completion. It is the most imposing sight in Southern California, and, perhaps, the greatest undertaking ever 
carried through here. The main building and the wings are four stories high, the dining room wing, two stories. The tower is 104 feet high, seven stories. There are forty-three bath rooms in the house, and forty water closets. The hotel grounds comprise fifty-five acres. The building cost $\$ 300,000 . "$

The bricks for the foundation walls, chimneys, etc., were made by Simons \& Hubbard from Los Angeles, at a yard which they then started on the Raymond grounds, east of where the great stable is now; and the Valley Union of November I3, I885, reported forty masons and carpenters then at work, and said, "the brick work will all be done this week except the kitchen"; also that " $1,300,000$ bricks will be used altogether." The brick laying for the ovens and chimneys was done by Robert W. Lacy of Pasadena, after whom DeLacy street was named by his son-in-law, A. F. Mills. Mr. O. J. Muchmore from Lebanon, New Hampshire, was general superintendent of the entire construction work, from the first foundation brick to the last roof shingle. He had previously built large hotels in Florida and the Bermuda Islands.

From the day that the elder Raymond took a hand in the enterprise, the construction work went on steadily and vigorously to completion, ${ }^{*}$ and opening day was set for November I7, i886. Of this historic event I copy the report of the Valley Union of November 20, 1886, which says :

"Wednesday evening, November I7, i886, will mark the date of the most notable and brilliant event that has yet occurred in Southern California. The occasion was the formal opening of the Raymond Hotel. At an early hour guests began to arrive in carriages, and at nine o'clock two heavily loaded trains had arrived from Los Angeles, and as the throng passed up the main avenue, lighted on either side with Chinese lanterns, the scene was

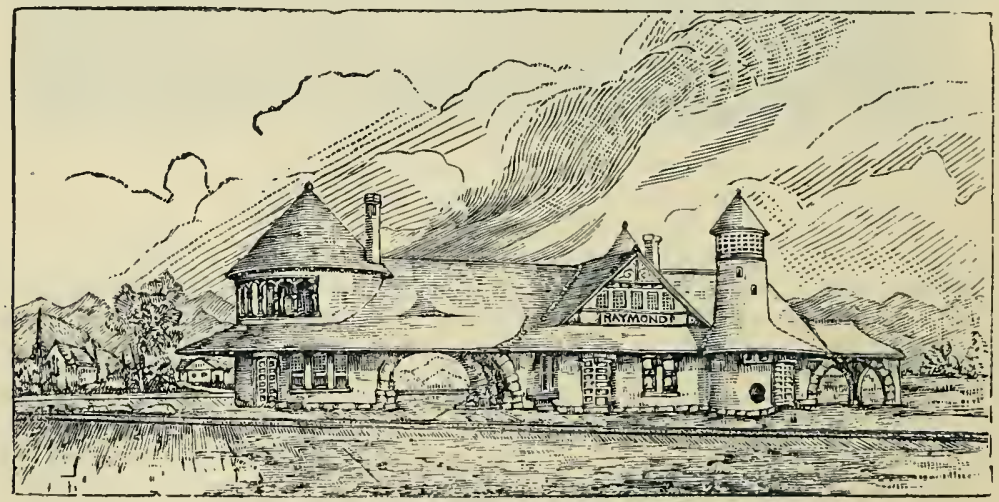

RAYMOND DEPOT, SANTA FE LINE.

Romanesque Architecture.

* The Raymond depot of the Santa Fe railroad has only a rear view of the great hotel. The elder Raymond objected to this, saying with emphasis, "I don't want my guests dumped down in my slopyard." And there was some talk of running the railroad around south and east of Raymond hill, with a depot on its east slope; but it was not done. There was also talk of a tunnel from the present depot in under the hotel, then ascend by elevator; but this it was found would be too costly a job to undertake. 
one long to be remembered. At ten o'clock the great company had nearly all assembled, embracing about $\mathrm{I}, 500$ guests."

The hotel had a successful season; and it has been regularly open from autumn to spring, or during the tourist season, every year since. Numerous additions and improvements were made in the building and the premises year by year.

\section{DESTROYED BY FIRE.}

On Easter Sunday, April 14, 1895, in the afternoon, this great hotel caught fire from some defective flue near the southwest corner on the upper floor. There was a stiff sea breeze blowing from the southwest at the time, which made the flames spread rapidly, and get such headway before discovered, that the fire hose on the different floors were utterly powerless to check the swift progress of the fire as it swept directly toward the remaining part of the immense structure, its annex and power-house, etc. In less than one hour everything was down in one vast heap of fiery ruin. The loss, as given by the manager, Gen. Wentworth, was $\$ 450,000$; insurance, $\$ 205,000$. There were 165 guests in the house Saturday night, besides about fifty employes in the annex. The buildings were all of wood, and the flames spread so rapidly that many lost all their clothing and personal effects; but no lives were lost, and nobody seriously injured. The hotel safe was dragged out the next day with grappling hooks and chains from the red-hot mass of fiery glowing embers, and its contents found unharmed.

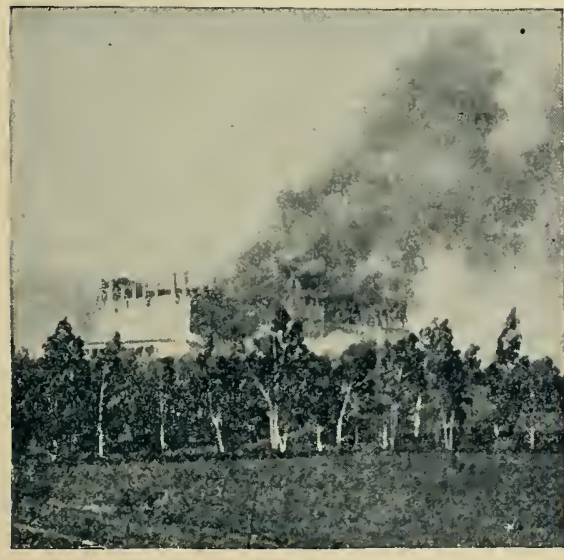

"Land"of Sunshine," May, 1895.

THE RAYMOND HOTEL ON FIRE.

It is a remarkable coincidence that Williel Thomson, who surveyed the hill for grading and set the stakes for the foundation walls - Thomas Banbury, who graded the hill down thirtyfour feet from its original summit O. J. Muchmore, who superintended the erection of the hotel-and Frank A. Haskell, who did the first job of painting on it-all happened to witness its flamy destruction ten years later. Mr. Vroman of Pasadena happened to be there taking a photo of a very fine rose bush in the yard, when the fire broke out - and then he took several views of the great structure while it was burning.

The Carlton Hotel. - This was the first attempt to establish at the Pasadena business center a hotel to be furnished and conducted in a style recognized as "first class." It was the first building in the city to have a passenger elevator. The base of the iron column at west side of its stairway 
entrance on Colorado street was the first bencli-mark or datum plane established by the city council, from which all official city grades or levels have since been reckoned. And a number of notable events transpired within its walls, which have given it a prominent place as one of our historic hotels. [See cut, page 284.]

After some weeks of talk about building a large business block, a syndicate was formed composed of Gen. Edwin Ward, then of Long Beach ; the Harper \& Reyvolds hardware company of Los Angeles ; Geo. A. Swartwout, A. Cruickshank and E. C. Webster of Pasadena. At a meeting in the first week of February, I 886, they adopted the name "Exchange Block" for their new building ; and on February 17,1886 , its corner-stone was laid by the architect, Harry Ridgway and assistants, enclosing a sealed casket of local newspapers, photographs, and other historic documents of Pasadena flavor; and speeches were made by C. T. Hopkins and Abbot Kinney. On June 2, 1886, the "Exchange Block Company" was incorporated. On August 17, 1886, occurred the visit of the National G. A. R. excursionists to Pasadena on their way back east from their National Encampment at San Francisco. The Exchange Block was not finished; but its large east rooms on first floor were cleared of rubbish, decorated, and used for the banquet reception to these war-record visitors. [See page 320.]

In February, 1887 , the city council meetings were being held in this building and on the igth of that month the famous prohibitory ordinance was enacted here. Then in August, I 888, the lessees of the Carlton Hotel were arrested for selling liquor there, contrary to the law, and the case had some historic celebrity. [See page 264.]

On December 19, 1888, the editors of South California assembled in the parlors of this hotel and here formed their State editorial association. [See page 322. ]

On January 28, 1889 , occurred in this hotel the Astronomical banquet [see page 326] which led to the placing of the Harvard photographing telescope on Mount Wilson.

The PaInTER Hotel-This was the third large hotel enterprise undertaken here, being built in 1887 by John $\mathrm{H}$. Painter and sons, and opened to the public in February, 1888 . It is the distinguishing landmark of North Pasadena, being situated on northeast corner of Fair Oaks Avenue and Washington street, I 200 feet above sea level. M. D. Painter and wife have been the managers of the hotel ever since it opened for business. It is a historic building, because of sundry other large enterprises incidentaliy associated with it. The Painter Bros. opened Fair Oaks Avenue from Chestnut to Illinois street [see page 356], and built the horse car line from Colorado street clear up past the hotel to Mountain View cemetery. They also built a steam dummy R. R. line from the hotel to Devil's Gate; projected Arroyo Park; built the first large covered reservoir ; etc., etc. But 
the father died in April, I89I; and then A. J. Painter died in November, I893, in the midst of his plans for further development, and they had to be abandoned. This hotel, with its adjunct grounds, livery barn, etc., represents an investment of about $\$ 80,000$.

Hotel GREEN. - The Hotel Green Co. was first projected in March, I 89I, by Col. G. G. Green of Woodbury, New Jersey. The first meeting to talk up and arrange for the organization of the company was held in the office of A. R. Metcalfe, Esq., Mr. Green's attorney in Pasadena; and the organization was finally made in Mr. Metcalfe's office on March 27, I891,

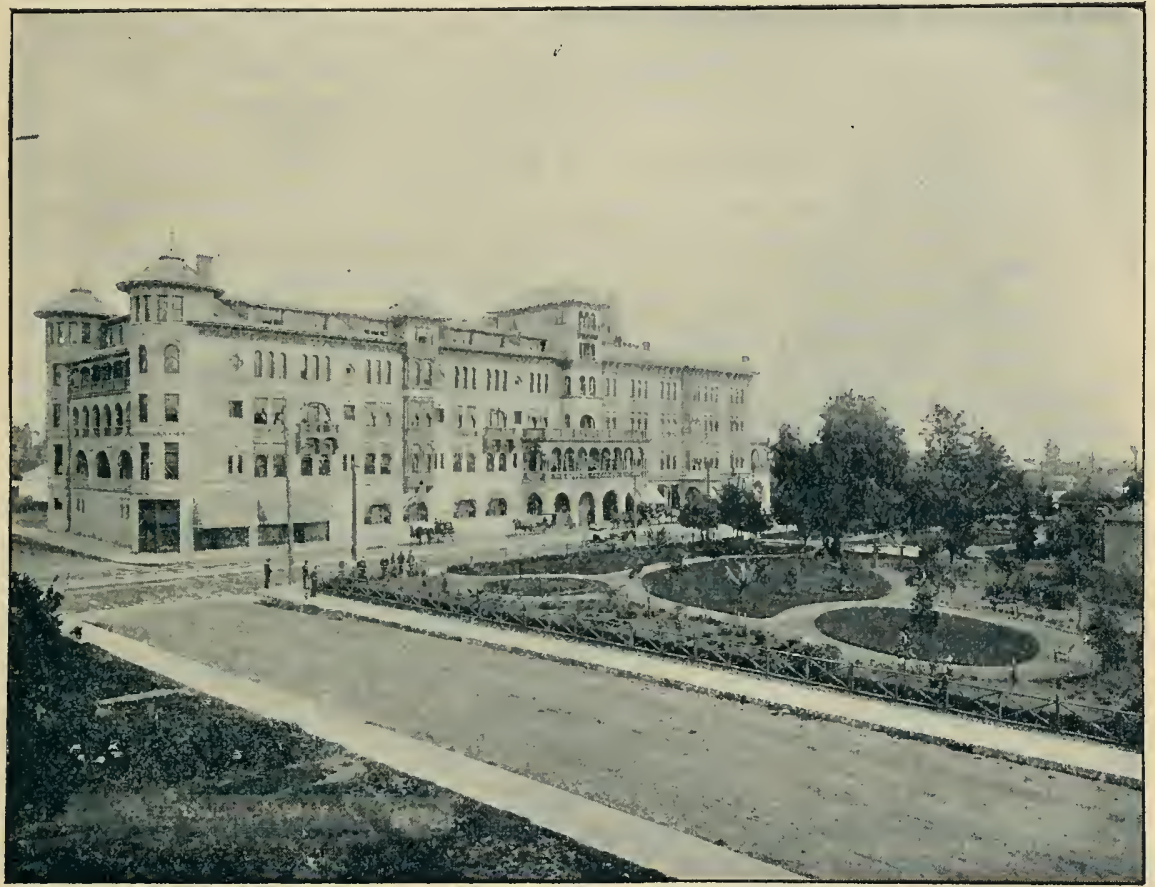

HOTEL GREEN.

Moresque Architecture. Photo. I89.

its members then being Col. G. G. Green, A. R. Metcalfe, H. W. Magee, J. H. Holmes, and J. G. Rossiter. Col. Green was made president, and J. H. Holmes secretary and treasurer. The hotel building was erected in I89r-92-93, with a frontage of $30 \mathrm{r}$ feet on Raymond Avenue by $9 \mathrm{r}$ on Kansas [now Green] street, and five stories high. Its frontages are in Moorish and Roman architecture, but the dining-room is a typical specimen of classic Greek style ; and the whole structure, both internal and external, has won fame as a grand symposium of the most imposing, elegant, chaste and æsthetic elements of architectural science, scarcely excelled in New 
York or London except by mere bulk. Connected with the hotel are a picturesque floral park; a lawn tennis court and croquet ground; a complete steam power and electric light plant; and a dormitory annex - all together representing an investment of about $\$ 450$,000. J. H. Holmes is the manager, with a corps of eighty-two employes. This hotel has the historic association of having been the scene of a banquet to President Harrison, Aptil 23, 24, r89r. [It was then a much smaller and very different looking structure called "The Webster," built with money borrowed from Col. Green.] Also, banquet to Prof. Lowe, in honor of the completion of his electric railroad to Echo Mountain - August 23, r893. Also, banquet to Hon. A. G. Throop, founder of Throop Polytechnic Institute, on Pasadena's first celebration of "Father Throop Day," December 21, I893. [For further account of these events, see pages I 95, 328, 33r.]

Echo Mountarn House.-This house is the latest addition to Pasadena's historic hotels, and it challenges the world for wonderfulness of

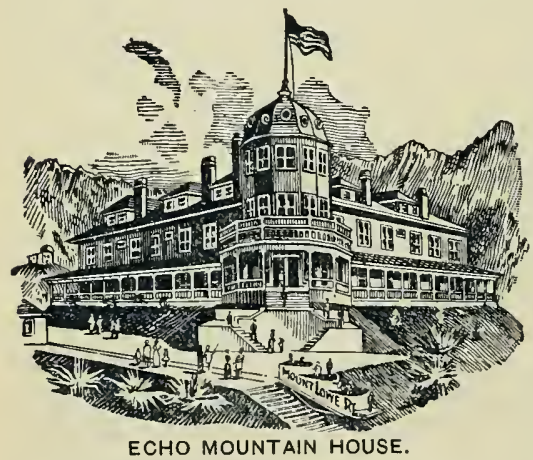

Colonial Architecture, with octagon rotunda and tower at the wings' vertex. position and adjunct attractions. Its projector and owner is the historic Prof. 'T. S. C. Lowe, of army balloon fame, original inventor of artificial icemaking machinery, and of water gas, and other valuable devices. Its builders were John V. Carson and his son Eugene, cousins of the famous and historic Kit Carson, whose name is inseparably associated with that of Col. John C. Fremont in his world-famed Rocky Mountain explorations, and initial conquest of California. Among the workmen employed on its foundations was Jason Brown, a son of the great anti-slavery leader, "Old John Brown" of Kansas and Harper's Ferry fame. It is built on the summit of Echo Mountain, where its south and east front verandas look down the mountain slope, and its rear projects over the declivity northward. It is reached from below by the famous "great cable incline," which is practically a hotel elevator half a mile long and making a vertical rise of 1,300 feet in six to eight minutes, by electrical power - the only structure of its kind now in the world (IS95). In front of it on the mountain brow stands the great electric searchlight, which was built for and used at the World's Columbian Exposition in Chicago in 1893 ; then at the sub-national Mid-Winter Fair in San Francisco in 1894 - and is the largest and most powerful instrument of its kind now in the world. A few rods up the mountain side above the hotel is the Mount Lowe Observatory (in its temporary location), in charge of Prof. Lewis Swift, a man of world-wide fame as a discoverer of comets, and who holds rank with the foremost 
astronomers of the world. Other adjuncts of this historic hotel are Rubio Gleu, with its half mile of stairways leading around or over nine mountain gorge waterfalls. The menagerie of native animals, and its playful bear which bit Jason Brown through the hand. The electric power house and cable machinery for operating the "great incline." The electric spray fountain. The electric trolly railroad to the summit of Mount Lowe, 6, I0o feet above sea level. About thirty miles of bridle roads and paths, leading to countless points of rarest mountain surprises, or grandeur of view, or deep historic interest. This hotel was formally opened to the public on November 26 , I 894 , the occasion being signalized by a banquet held there by the bankers of Southern California. Connected with this hotel's business is the Mount Lowe Echo, a daily newspaper. [See page 222.] The Pasadena Star stated that the receipts of the Echo Mountain House during one day in July, I 895 , a mounted to $\$ \mathrm{I}, 840$.

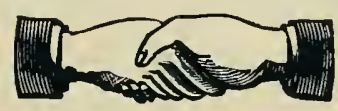

\section{DIVISION SEVEN — SOCIETARY.}

\section{CHAPTER XXV.}

RELIGION.-Brief historic sketches of every Church, or Religious or Missionary Society ever organized in Pasadena.

NoтE.-Instead of alphabetically they are given in chronological order, with the exception that those of one denominational name are grouped together as adjuncts after the first one of the kind in its proper date-place. Pictures of churches are only given as plates were furuished by their own people.

\section{FIRST PRESBYTERIAN CHURCH.}

The first public assemblage for religious services ever held in Pasadena was a prayer meeting called and led by Rev. W. C. Mosher, a Presbyterian clergyman, on August 30, I874, in Charles H. Watts's bachelor shanty, on what is now Live Oaks Avenue, in the Park Place tract. The people present were: Mr. Mosher and wife, August Blix and wife, Moritz Rosenbaum and wife, Wm. T. Clapp and his daughter Jennie [now Mrs. Rev. F. J. Culver]. About a month later, or as soon as Mr. Mosher could get his own house into usable condition, near Fair Oaks Avenue on Walnut street, these meetings were changed from Watts's to the Mosher house; and to the prayermeetings was added a Sunday school, under the lead of $\mathrm{Wm}$. 'T. Clapp and Daniel H. Pike, Mr. Clapp being a Congregationalist and Mr. Pike a Methodist. Then as soon as the first colony schoolhouse was ready for use, on Orange Grove Avenue below California street, the meetings were held there. 
And the first sermon ever preached in Pasadena was by Mr. Mosher, in this schoolhouse, on Sunday, February 7, 1875. On March 21, I875, the Presbyterian church of Pasadena was organized in this schoolhouse, with Rev. W. C. Mosher as pastor, and the following list of first members: Wm. T. Clapp, Mrs. O. E. Clapp, Miss Jennie Clapp, Mrs. H. F. Skinner, Mrs. Gen. Geo. Stoneman, Mrs. Mary S. Mosher, J. D.Vinnedge, August Blix, Mrs. Blix, Thos. F. Croft, N. C. Carter, Mrs. Carter, Wm. H. Henderson, Mrs. Judge Eaton, Mrs. Lavinia Stratton, Dr. H. G. Newton, Mrs. Newton, Josiah Locke, Dr. T. B. Elliott, Mrs. Elliott, Miss Helen J. Elliott. Out of these, Dr. New. ton and W. T. Clapp were elected elders. And later, Dr. Elliott, Thos. F. Croft and Daniel H. Pike were elected Trustees, with Mr. Clapp as treasurer and Henry G. Bennett as clerk of the society. Steps were at once taken toward the erection of a church building; money was raised, deposited in bank at Los Angeles, and the structure pushed forward in 1875-76. Meanwhile the bank failed, and $\$ 600$ of their church building fund was lost outright. Nevertheless, they struggled on, and completed the building in 1876 , at a cost of about $\$ 2,300$. Articles of incorporation were adopted July I8, I 876 , but were not recorded until November 20 th.

In July, '76, Mr. Mosher resigned the pastorate, and in August Rev. James A. Mitchell became the pastor, commencing his labors in the new edifice just completed, and which then stood on California street east of Orange Grove Avenue. A parsonage lot of $2 \frac{1}{2}$ acres was bought adjoining the church lot for $\$ 375$, and a parsonage built there at cost of $\$ 1,800$, in 1877 .

August 2I, I877, pastor Mitchell resigned; and October I a new pastor, Rev. W. F. P. Noble, took the place. In November I. B. Clapp was added to the board of ruling elders. Pastor Noble resigned January 23, I880. [Died October 26, I882.] The third Sunday in July following, Rev. Alvin Baker became the pastor. And November 20 Asahel Foote was chosen a ruling elder. [Died July I 5, I 882.] In July, I882, pastor Baker resigned; and on the first Sunday in October following, Rev. L. P. Crawford took charge as pastor; and in November John Ross was made a ruling elder. October 26, I884, pastor Crawford resigned; and on Sunday, October 25, I 885, Rev. M. N. Cornelius was installed in the pastorship, having served as "supply" since January 25. Early in September of this year the matter of removing the church to a more central location was agitated, and was finally referred to a committee, as follows: Rev. Cornelius, and elders W. T. Clapp, I. B. Clapp and John Ross; and trustees H. H. Markham, Geo. A. Swartwout, D. Galbraith, E. L. Farris, and W. B. McCormick; and members, Rev. Dr. Coyner, Rev. W. C. Mosher, H. G. Bennett, Rev. Williel Thomson, A. Cruickshank, Dr. Wm. Converse, Geo. A. Green, and J. H. Fleming. This committee made a divided report to a general meeting on Wednesday afternoon, September 30 . In the general meeting a majority voted for removal, and for taking all the church property or proceeds of its 
sale to the new location. [In consequence of this sweeping action, the ruling elders and many of the members withdrew from the church, and eventually united in establishing the First Congregational church in the same vicinity.] On November $8 \mathrm{Mr}$. Cornelius preached for the last time in the old location; and during the ensuing week the church edifice was removed to its new site on Worcester Avenue, where it was built-in as a part of the large new structure erected in 1886 on the corner of Colorado

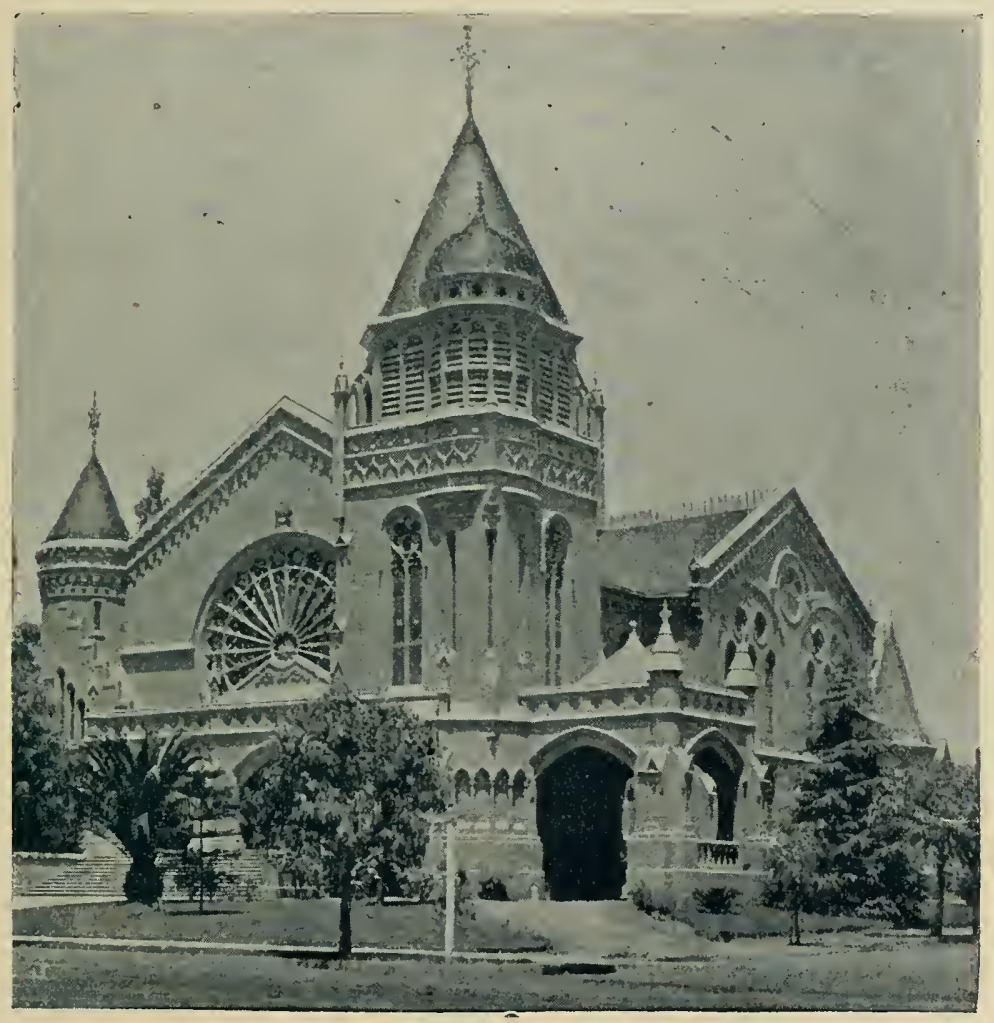

PRESBYTERIAN CHURCH.

English-Gothic Architecture. Photo. 1895.

street and Worcester Avenue. During the autumn of 1888 the first massive pipe organ ever brought to Pasadena was put into this church, at a cost of $\$ 6,000$.

In January, I889, pastor Cornelius resigned ; and Rev. Wm. Ormiston, D. D., LL D., preached as "supply" from July, r 889, till December, I89o. Rev. N. H. G. Fife was next called to the pastorate, being installed October 7, 1891, and is still in service - I895. In the night of December IO-I I, I89I, the lofty steeple of the church was blown down by a fierce wind storm, and fell over into Colorado street. [See page 165.$]$ 
In June, 1892 , the church published a little manual or directory of its membership, which showed a total of 345 names on the roll, but 39 of them were listed under "Residence unknown." In April, I 893, the membership was reported as $4 \mathrm{I} 2$. Contributions the previous year to the eight beneficences of the church, $\$ \mathrm{I}, \mathrm{I} 47$; to other benevolent objects, $\$ \mathrm{I}_{42}$; to current expenses, $\$ 6,704$. Total contributions, $\$ 7,993$.

Auxiliary Organizations within the church.- The first one formed, besides the Sunday school was the "Woman's Home and Foreign Missionary Society," organized March 24, I883, with Mrs. Mary S. Mosher as first president. Mrs. S. V. Maxfield president in $1893^{-94}$. Other bodies are : Ladies' Aid Society; Mrs. L. Ii. McCoy, president. King's Messengers Missionary Band; Miss Mary Mosher, president. Young People's Society of Christian Endeavor; John D. Habbick, president. Junior Endeavor Society ; Robt. M. Allen, president. Sabbath school ; Walter Graves, superintendent. Trustees; F. C. Bolt, president.

Calvary Presbyterian Church - was incorporated April 30, i 888 [county record gives Nov, 9, I888], and held its meetings in the old College building on Columbia Hill-now C. D. Daggett's residence. Its first members were: Rev. Williel Thomson and Rev. A. M. Merwin; J. R. Ells and wife; D. Gamble and wife; Geo. Young and wife; McLain and wife; T. F. Twinting and wife; Mrs. A. F. Thompson; and others. Their first minister was Rev. Merwin, as "supply." Then Prof. Albert McCalla, $\mathrm{Ph}$. D., served them some months as "supply." But in I89 I Rev. A. A. Dinsmore was installed as pastor, and still holds- 1895 .

During the winter of $1888-89$ they purchased a lot $138 \times 200$ feet (average) at corner of Columbia and Beacon street, and erected there a neat little church edifice; lot and building costing about $\$ 6,000$. The church was dedicated in April, I889. Its auxiliary societies, besides Sunday school, are Ladies' Missionary Society,-Y. P. S. Christian Endeavor. Church members in April, I 895, about 30.

First United Presbyterian Church of Pasadena. - The first meeting to consider the matter of organization was held in Williams hall. Those present were: Rev. H. W. Crabbe from Los Angeles; Rev. James Kelso and wife, A. W. McCormick and family, B. M. Kelso, and about twenty others. The church was organized March 8, I888, with the following members: T. B. Simpson and family, Alex. McCormick and family, Jared and Margaret Graham, Robt. Patterson, Jane Wallace, Rev. James Kelso and family, James and Mrs. Robb and family, W. H. Kelso and family, and B. M. Kelso. Services discontinued in April, I892.

METHODIST EPISCOPAL CHURCH.

The first Methodist sermon ever preached in Pasadena was by Rev. Solomon Dunton from Marshaltown, Iowa-father-in-law to Col. J. Banbury. This was on February I4, I875, in the original colony school-house 
on Orange Grove Avenue, south. Rev. W. C. Mosher, Presbyterian, had preached there just the Sunday previous the first sermon of any sort ever delivered in this vicinage. The church people of the colony thus maintained a union meeting for some months.

April I8, I875, a Methodist "class" was organized by Rev. J. M. Campbell of Los Angeles, with I. N. Mundell as leader, and the following first members: D. H. Pike, L tucinda Pike, A. O. Porter, Anna Porter, P. M. Green, Hettie Green, W. J. Barcus, Elmina P. Barcus, I. N. Mundell, Anna Mundell, and Elizabeth Edwards. This of course was the beginning of a distinctively Methodist church; and on July i 8, this year, Rev. F.oD. Bovard commenced preaching for them regularly every alternate Sunday. This continued until September, when the Conference made Pasadena a part of a circuit which included East Los Angeles, Florence and Vernon also, and Rev. C. W. Tarr was appointed over it. He preached at Pasadena once in two weeks until April 23, 1876, when he held his last service here in the then unfinished new Presbyterian church building on California street. Mr. Tarr returned east, and Rev. J. W. Stump of Los Angeles preached here until July. Then on July 2, I876, Rev. Charles Shelling commenced his labors here, with a notable centennial sermon for that day, and continued as the Methodist pastor of Pasadena until September, I878.

October I3, 1876, Rev. Shelling, A. O. Porter, D. H. Pike and P. M. Green were appointed a building committee to raise funds, buy a lot and let contract for a church building of their own. Times were extremely " hard" in California that year, and their numbers few ; yet by January 7,1877 , they had their new church dedicated, free of debt. It stood where now is the corner of Orange Grove Aventue and Palmetto drive. Mr. Shelling also procured a church to be built at Alhambra, which was in his circuit.

During the Conference year $1878-79$, Rev. F. S. Woodcock was pastor at Pasadena and Alhambra; and in September, '79, the Pasadena church reported 39 members. For the ensuing year Rev. E. S. Chase was pastor of the two places. Then in September, r880, Rev. R. W. C. Farnsworth was appointed; he served the two places two years, and the third year had Pasadena alone. [It was during this period that he prepared his book entitled "A California Paradise," which was published in 1883 . It took in Pasadena, Alhambra, San Gabriel, La Canyada, Sierra Madre and Duarte.] During Farnsworth's last year a parsonage was built.

In September, r883, Rev. J. B. Green became the pastor; and during his term the church was moved from its original site on Orange Grove Avenue to a lot on Colorado street next to Wiley \& Greeley's livery stable. In September, 1884, Rev. A. W. Bunker became the pastor and continued two years.

January 23, I886, it was decided to erect a new church and parsonage combined, after a design furnished by Ridgway \& Ripley, architects - to 
cost \$15,000. On Sunday, February 7 , Rev. Dr. J. G. Miller preached a sermon on the subject; and then $\$ 7,000$ was pledged, in addition to $\$ 600$ cash on hand, and the other property of the church valued at $\$ 3,000$. A building committee was appointed, as follows: C. B. Ripley, Geo. E. Meharry, P. M. Green, C. W. Roberts, C. W. Buchanan, and the pastor. Work was commenced on the foundation March 8, 1886; and on April 16 the corner stone was laid, with appropriate ceremonies. The stone itself was donated by A. F. Mills, and the box or sealing casket by F. D. Stevens. In the box were deposited twenty-eight different books, doctuments, papers, etc. At this time further subscriptions amounting to over $\$$ rooo were pledged for the building fund. The work went forward vigorously; and the Union of June 25, 1886, gave this summarized account of it:

"M. E. church and parsonage, corner Marengo Avenue and Colorado street; Gothic style of architecture. Ridgway and Ripley, architects ; John McCracken, superintending master workman. The combined building is $72 \times 122$ feet. The parsonage part contains eight rooms besides halls, closets, pantry, bath-rooms, etc.; the church area is $70 \times 78$ feet; auditorium $45 \times 45$ on floor and 34 feet high, with front gallery. Also, lecture room, 4 class rooms, pastor's study, church kitchen, church parlors; tower and steeple 140 feet from ground. Total cost, \$15,000."

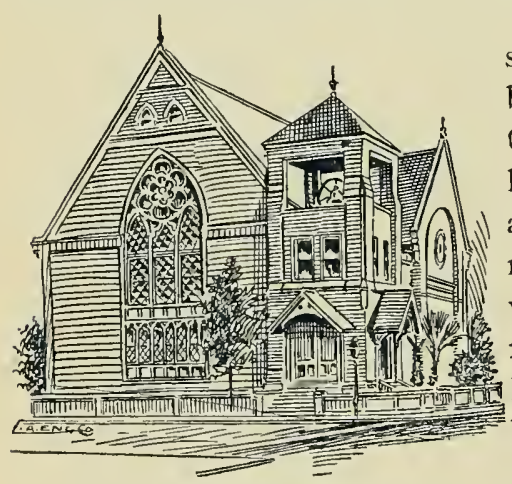

M. E. $\mathrm{CHURCH}$.

After the steeple was blown down.

A report made on corner-stone day showed that 268 persons had been full members of this church since its organization. On July gth this year they sold their church lot on Colorado street to Wiley \& Greeley and David Evey for $\$ 6,000$ cash. (These men afterward sold the building to the Universalist people.) On March 20, 1887, the new church was dedicated, free of debt. December II, I 890 , its great steeple was blown down. [See page i 65.]

In 1888 the people of this church erected the historic building known as "The Tabernacle," $80 \times 90$ feet, two stories, with seating capacity of 2,000 , at a cost of $\$ 10,700$.

In September, I886, Rev. P. F. Bresee, D. D., became pastor, and was continued four years, till 1890 ; then Rev. J. W. Phelps was appointed, and continued three years. On September 26, I893, Rev. Clark Crawford commenced his work as the pastor, and still fills the place in 1895 . In April, 1895, the roll of members in full connection was 973 ; prohationers about 40. Number of class meetings, I I. Members of Sunday school over 600 . The other auxiliary organizations are: Epworth League, Junior E. L., Boys' Brigade, Woman's Foreign Missionary Society, Young Women's F. M. S., Wesley Band (missionary), Women's Home Missionary Society. 
These various missionary societies maintain the Chinese Mission on North Marengo Avenue; and also mission Sunday services at Lamanda Park and La Canyada.

The pulpit stand of the Tabernacle has been occupied by many famous people, among whom I mention these: Rev. Sam Jones in I888. The next morning after speaking, Jones called on Dr. Bresee in his study and was smoking a cigar. The room being small was soon filled with smoke, which annoyed the Doctor, and he opened a window to get some unbefouled air. Jones remarked, "You Pasadena people don't favor smoking very much!" Dr. Bresee hesitated a moment, scratching his head for an idea, then replied, "No; we've repented of our sins."

On March I2, I889, the world-famed evangelist, D. L. Moody, preached here, and was given a collection of $\$ 80$. The attendance was reported at 2,000. August 5, I 890, the distinguished temperance orator of Kentucky, Col. Geo. W. Bain, spoke here. In I891 Rev. B. Fay Mills, of preeminent celebrity in evangelistic work, conducted meetings for a week in the Tabernacle. In September, I894, Gen. Lew Wallace, whose masterful Christian story of "Ben Hur" has been translated around the world, spoke here. June 21, I895, the world-famed Susan B. Anthony and Rev. Anna H. Shaw spoke here, on the Woman Suffrage question.

A printed report September 30, I89 I, showed that the church had raised and paid for current expenses the preceding year $\$ 7,432.15$.

German Methodist Eipiscopal, Church.-In i 882 Rev. G. H. Bollinger, presiding elder of the German district which included Pasadena, commenced holding cottage services for the German people here, who were few and widely scattered at that time. In the autumn they organized a German M. E. church at the house of C. H. Biedebach, on north Santa Anita Avenue near Lamanda Park, with fourteen members. Of this organization Mr. Biedebach was the class leader and local preacher; and Chas. Brenner was steward. December 23, I886, they incorporated under the name of "Emanuel Methodist Episcopal church," and bought a lot for a church and parsonage at corner of Worcester Avenue and Ramona street, where they erected buildings in the spring of 1887 , at a cost of $\$ 3,500$. Church can seat 225. The first board of trustees were: C. Brenner, A. Ruedy, and Henry, John and Conrad Biedebach. In April, I895, the church had about sixty-five members. Its successive pastors have been: Rev. Bollinger, I $882-83$; Rev. Wm. Schuldt, I883 to I886; Rev. L. E. Schneider, I886 to 1888 ; Rev. Schuldt again, 1888 to I89I; Rev. Bollinger again, I89I, and serving yet - I895.

North Pasadena M. E. Church.-- During the Conference year I888-89, Rev. W. A. Wright was appointed to preach at the mission stations of Olivewood and North Pasadena. The next year, I889-9o, Rev. T. C. Miller was put on the same circuit. And then Rev. A. W. Bunker 
filled this appointment for the two years, I 890 to 1892 . During these years the meetings had been held in a hired hall, but in 1892 this church bought the Free Methodist church building on Pepper street, and have since worshipped there. Rev. A. C. Manwell was the pastor in 1892-94. And Rev. J. A. Wachob in $1894-95$.

African Methodist Episcopal Church.-Rev. J. R. McClain held a meeting at the house of Silas Carnahan, who then lived at the west foot of Raymond Hill, about September I, 1889, at which only four or five persons were present. But the next Sunday, September 5, a meeting was held and the church organized in the old City Hall building on Raymond Avenue, with the following first members: C. G. Lee, S. Carnahan, Henderson Boone, A. Lumis, Alfred Summers, Mrs. Sadie Wright, Miss Mamie Wright, Mrs. Penelope Prince and her sons Wm. and Frank M. Prince, Mrs. James Coleman, Cora Cambell. The officers then were: Rev. McClain, pastor; Mr. Lee, superintendent Sunday school; Carnahan, Summers, Boone, and Albert Muse, trustees. After holding meetings in rented rooms at different points for several years, they finally secured a lot on North Fair Oaks Avenue near Villa street, and in 1892 built a church on it; then in I 895 they added a parsonage, the lot and buildings costing $\$ 1,700$. In April, I 895, there were thirty-two members. Besides the Sunday school, they have a Literary Society and a Woman's Mite Missionary Society. Their successive pastors after McClain have been Rev. - C Curran, Rev. Chas. Augustus, Rev. C. W. H. Nelson, Rev. W. R. Green, Rev. S. S. Freeman. In $1894^{-95}$ the Pasadena pastor preached also at Duarte and Pomona, where classes had been organized - these three places making the "Pasadena circuit."

FREE Methodist ChURCh.-During the month of May, i888, Rev. C. B. Eibey of the Illinois Conference of the Free Methodist church came to Pasadena. Assisted by Rev. C. E. McReynolds he conducted a series of meetings in a tent on grounds owned by Dr. Reid, corner of Pasadena Avenue and Kansas streets, and on Sunday, June 17, I888, Rev. Ebey organized the first Free Methodist church in Southern California. Names of first members: J. A. Bennett, Sarah W. Bennett, Maggie F. Bennett, E. E. Warren, Mrs. McReynolds, Mary McReynolds, C. M. Farr, Carrie Farr, E. C. Shipley, Eliza Shipley, Eunice Shipley, Mattie Ebey, Wm. H. Ball, Sadie Ball, Carrie Abbott. The first officers were: Rev. C. B. Ebey, pastor; J. A. Bennett, class leader; E. C. Shipley, local preacher ; C. M. Farr, J. H. Bennett, E. E. Warren, stewards. Later the tent was moved to North Pasadena, where a more extensive work was accomplished, - a lot purchased and a neat church built. In 1892 this property was sold to the North Pasadena M. E. church, and a lot purchased on Fair Oaks Avenue, near Chestnut street, on which a good church and parsonage were erected in 1892-93. The successive pastors after Eibey were : Rev. Chas. McReynolds, 
1889.--Rev. Josephine Cowgill, I890-[now, I 895, serving as a missionary in Jerusalem].--Rev. David McLeod, 189I-92-now postmaster at North Pasadena: and the new church on Fair Oaks Avenue was built under his pastorate.-Rev. James Seals, I894.-Rev. J. S. Phillips, I895.

M. E. Church South.-Organized in May, I889, with Rev. J. A. Harmon as pastor. It was kept up over a year, then abandoned, the members mostly uniting with other churches.

FRIENDS CHURCH.

In I88 I a Quaker minister named Adonijah Gragory and wife settled at Sierra Madre, and about August ist they commenced holding Sunday

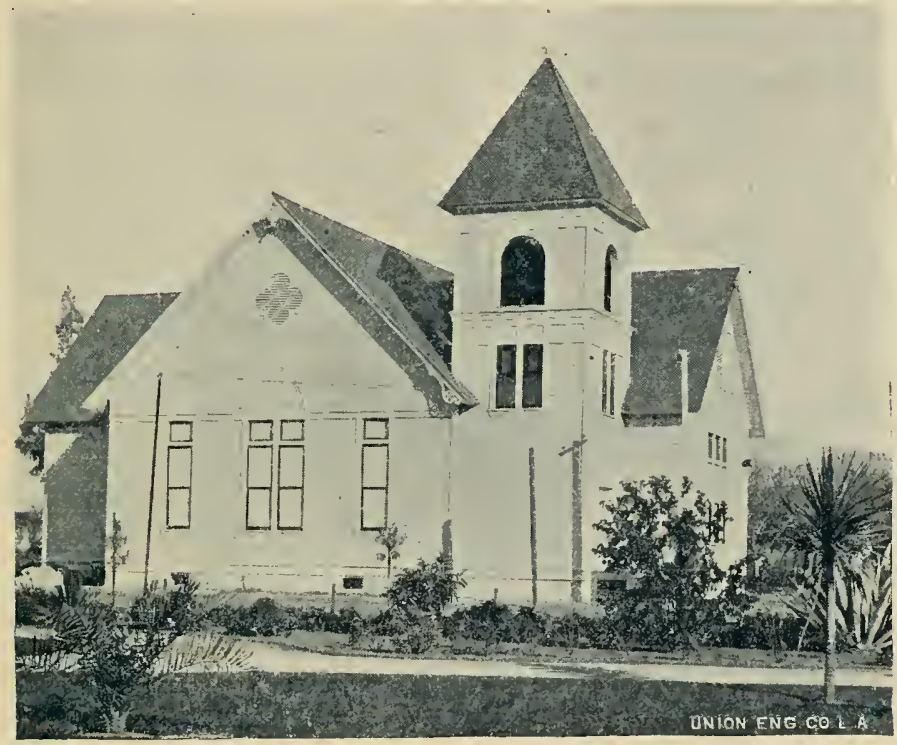

FRIENDS CHURCH. Photo. I895.

meetings of their own order at their house. To these meetings several Pasadena families of the same persuasion frequently went, until June, I882, when they held the first Quaker meeting in Pasadena, at the home of $\mathrm{Wm}$. Sharpless on north Los Robles Avenue. There were present: A. Gragory and wife, Wm. Sharpless and wife, Edith Painter, Samuel Bundy, Emmor Rood, Tacy Rood, Robt. C. Hiatt and wife, and perhaps others. From this time the meetings were held alternately at Mr. Gragory's in Sierra Madre and in Pasadena at various private houses, as John and Edith Painter's, Lawson Hollingsworth's, Samnel Bundr's, Smith James's, etc.

In July, I 883, John H. Painter gave lumber and leased a lot on North Marengo Avenue above Illinois street, and a small building was erected in which to hold the meetings. Then a church was regularly organized, and 
a Monthly Meeting also, with 67 original members. This first meeting occurred on the first Saturday of March, I884. A Sunday school was also organized, with T. K. Bufkin as superintendent.

In 1885 , Rev. Jeremiah A. Grinnell became pastor of the church-the first to fill this office; and he also served as a presiding elder, visiting, encouraging and aiding all the churches of this order in Southern California. The successive pastors after Father Grinnell have been: Reuben H. Hartley ; C. C. Reynolds; Dr. Wm. Nicholson; Ruth B. Ridges; Prof. C. E. Tebbetts-1895. In I888 a Christian Endeavor society was organized within the church, with C. C. Reynolds its first president. And before this a Woman's Foreign Mission society had been formed.

Early in I886, a new church edifice was erected at the corner of Marengo Avenue and Monntain street, at a cost of $\$ 3,500$, and seating over 300. It was dedicated November 28, 1886. In 1894 this church was moved to a more central location, corner of Raymond Avenue and Villa street, and considerably enlarged, at a cost of $\$ 2,800$. Rededicated first Sunday in March, I895.

In 1895 the Whittier Quarterly Meeting was divided, so as to establish a Pasadena Quarterly Meeting, composed of Monthly Meetings at Pasadena, Wildomar, Long Beach, San Jose and Berkeley. ('The original organization was incorporated May I6, I89r, under title of "Pasadena Quarterly Meeting Society of Friends, to assemble at Whittier.")

Pasadena Meeting, Societry of Friends, under Discipline of Ohio Yearly Meeting.-The first meeting of this order was held December 5, I886, at the house of Wm. Penn Evans, corner Walnut street and Los Robles Avenue - the place now called "Rosedale," and owned in I $894-95$ by R. M. Furlong. Those present at this meeting were: David Evans, Sarah T. House, Elisha Roberts and wife, Ann Sharpless, Mary Hanner, Josiah Stratton and family, Allen and Mary Lee, Caroline Cope, W. P. Evans and wife, Edward Sharpless, Wm. Shaw and family. Meetings were held at the same place for about a year; and afterward at Wm. Shaw's house at Monks Hill, and other private houses, until the spring of 1894 , when they built a goodly meeting house at the corner of Galena Avenue and Villa street. Mary Lee is a minister. Abram Cowgill is clerk of the society. There were about fifty-five members in April, 1895. The Eaily Star of January 8, 1895, said :

"A committee from the Hickory Grove (Iowa) Quarterly Meeting of Friends, composed of Zacheus Test and wife (parents of our townsman, L. L. Test), John Thomas and wife, Albert Emmons and wife, Anna Painter (sister of M. D. Painter), Nathan Satterthwaite and Joshua Smith arrived here Saturday night for the purpose of establishing a "Meeting of Discipline "in the Friends church on the corner of Villa and Galena. The visit will result in giving the society full power as the Pasadena Monthly Meeting, under the Iowa Quarterly and Yearly Meeting." 


\section{FIRST BAPTIST CHURCH.}

The first meeting to talk up organization was held November 7, I883, in Good Templars' hall in the old Library building. Those present were Rev. J. J. Woolsey, Rev. S. S. Fisk and wife, Henry Fisk, W. P. Jacobson, Miss Carrie Jacobson, D. Williams, O. S. Barber and wife, F. C. Quarles and wife, Mrs. Mary E. Case, Mrs. Martin Mullins. The next Sunday, November I4, they met again and completed the organization by electing Rev. Fisk as pastor; E. T. Pierce, clerk; S. Washburn, treasurer.

May I, I885, pastor Fisk resigned. The church had now secured Williams hall for its meetings, and preaching services were led by Rev. L. W. Hayhurst and others as "supply" until March, I886, when Rev. T. N. Lord became the pastor. On March 23 articles of incorporation were adopted, and the first board of directors chosen, to-wit: S. Washburn, A. J. Brown, Dr. Theron Nichols, L. F. Miller, Joseph Wallace. At same time a lot $75 \times 2$ Io feet was purchased from Charles Legge at corner of Fair Oaks Avenue and Locust street, for $\$ 1,800$, and steps taken to proceed at once with the erection of a church edifice. This work was pushed to completion so that they held their first Sunday services within its walls on September 26, I886. On February 27, I887, the church was dedicated, free of debt; and the treasurer's report (showing all bills paid) footed up the total cost as $\$ 7,777.77$-a most singular sextuple tally of the Scriptural "perfect number." In August, .I 887 , pastor Lord resigned. And January 22, 1888 , Rev.

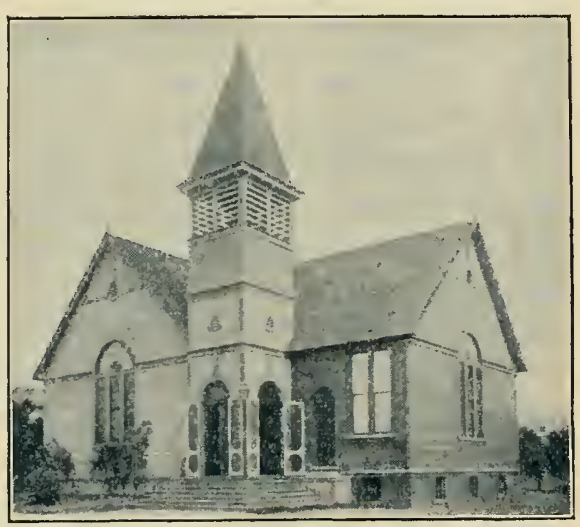

FIRST BAPTIST CHURCH. Photo. I894.

C. E. Harris became the pastor, in which office he continued until his death, September 25, 1894. During 1893-94 a considerable addition was built to the church. The membership in I894 was 2I2. Volumes in library, 305. The church auxiliaries, besides Sunday school, are: Ladies Aid Society, Ladies Missionary Society, Children's Mission Band, Baptist Young People's Union. Officers in I 894: Pastor, Rev. C. E. Harris. Trustees: Milford Fish, J. W. Camper, Ernest Canfield, A. A. Chubb, C. A. Whitman. Deacons: L. F. Miller, E. Canfield, M. Fish, A. J. Brown. Clerk, Geo. Taylor; treasurer, Milford Fish. Superintendent Sunday school, J. H. Merriam. Rev. C. T. Douglas entered upon the pastorate April 2I, I895.

A printed report of 1893 gives the value of the church property as $\$ 8,000$. Amount of church expenses for the preceding year, $\$ \mathrm{I}, 485.08$; and other contributions for various branches of church mission work, making the total of funds raised and paid out, $\$ I, 855.53$. 
German Baptist Church.--A Baptist Convention report of $\mathrm{I} 893$ has in its list of churches, "Pasadena German; Theodore Hansen, clerkorganized in I887." But no other data are given. The Pasadena Standard of November 23, I889, said: "The German Baptist or Dunkard society of Pasadena procured a lot and erected a church building, about two years ago, by borrowing money therefor and giving a mortgage of $\$ 3,300$ on the property. The members were poor, many of them have moved away, the mortgage had to be foreclosed, and now the holder, Wm. H. Wood, has the premises in lawful possession."

Rev. F. C. Koehler, a German Baptist preacher, resided here at that time; and his name was still in the list of Pasadena clergymen in 1893.

Friendship Baptist Church of Pasadena (Colored).- -The first meeting to talk up organization was held at the home of Mrs. Maria Hill on Vernon Avenue. A Sunday school was commenced on the fourth Sunday in June, I893, by Robert McDow; then a prayer meeting was formed, which grew into a church that was organized the third Sunday in September, I893. The names of the first members were: J. M. Fowler, R. Scott, Maria Hill, Mittie Scott, Rosa Fowler, Alice Griffin, Anna Fowler, Rowena Ballard, Henrietta Fowler. Rev. J. M. Fowler was the first pastor, and Reuben Scott the first deacon. The number of members in I 894 was 25 . Rev. Fowler still pastor; Scott, deacon, with Henry Griffin and James Coleman added; W. C. Dent, clerk; J. Coleman, treasurer. Superintendent of Sunday school, Y. M. Moulton; assistant superintendent, Mrs. Cora Strother.

\section{EPISCOPAL CHURCH.}

All through the month of February, 1884, the Pasadena Union contained this notice in its weekly list of churches: "EPIScopal.Services every Sunday, except first of month, at 3 o'clock. Sunday school at 2 P. M." No names mentioned nor place of meeting given. But in the paper of March 8th the notice was changed to read thus: "Episcopal.- - Services every Sunday, in Williams Hall at i I o'clock." Still no name given of who conducted the services. But the paper of April 5th announced that on and after April 6th these services would be held in Library Hall at 3 P. M., by Rev. A. W. Macnab, the newly appointed missionary; and on and after Easter Sunday the services would be held regularly at II A. M. (It appears that the services previously had been conducted by the Dean, N. G. L. Trew, of San Gabriel.) In the paper of May ro it was first designated as "All Saints Mission, Pasadena, Branch of San Gabriel Valley Associate Missions."

In February, I 885, Rev. Macnab engaged Ridgway \& Ripley to build a chapel for this mission. on East Colorado street, near where Euclid Avenue is now. In March Capt. D. R. Risley gave a Bible for the pulpit, and E. T. Hurlbut gave a communion service. The chapel was completed and first 
occupied for Easter services April 5, I885, Rev. Macnab and Rev. J. B. Britton officiating. The next day the annual meeting was held, with Dean Trew present, and the building committee reported debts all paid. The first parish officers were: Dr. J. M. Radebaugh, warden; C. Scharff, secretary; W. S. Arnold, treasurer; J. W. Hugus and Ben E. Ward delegates to diocesan convention. [This chapel was ultimately sold to the North Pasadena Congregational church, who moved it north, reconstructed and added to it, and have it now in use-I895.]

Succeeding Rev. Macnab, Rev. J. D. H. Browne was installed rector July II, I886. Early in I 888 the work was commenced for erection of their present fine Gothic stone church on North Euclid Avenue. In I889 Rev. G. A. Ottman succeeded Rev. Browne in the rectorship, and started a local parish paper called All Saints Record. [See page 219.] In I89I Rev. Wyllys Hall, D. D., succeeded Rev. Ottman as rector, and still fills the office- I 895 .

Auxiliary societies within the church are: Saint Andrew's Brotherhood; the Woman's Guild--divided into eight chapters for special branches of church work; the Choir Guild; Daughters of the King. The rector is exofficio president of each one. A report by the church treasurer, Dr. E. E. Gaylord, March 27, I894, showed total funds raised by the church during the preceding year, $\$ 4, \mathrm{I} 67.4 \mathrm{I}$. Expended, $\$ 4, \mathrm{I} 52.33$. Besides this, there had been received for the building fund $\$ 1,653$; and paid out from it \$I,540.50. April 7, I 893, the Woman's Guild gave in the Grand Opera House an exhibition called "Pageant of Roses," composed and arranged for them by Mrs. C. D. Daggett, which was the most elaborate and gorgeous entertainment ever given in Pasadena by any church. It was for the benefit of the church building fund, toward which this guild contributed during the year $\$ \mathrm{I}, 456$.

January 27 , I895, an aluminum pipe organ, just completed in the church at a cost of $\$ 3,500$, was first used and dedicated for Christian worship.

\section{FIRST CHRISTIAN CHURCH.}

(Also called "Disciples," or "Disciples of Christ.") The first meeting of this order in Pasadena was on May II, I884, at the home of L. H. Bixby on South Los Robles Avenue. Those present were: L. C. Foote and wife, L. H. Bixby and wife, C. M. Phillips and wife, Mrs. Sarah J. Allen, J. M. Craig and wife, L. A. Evans and wife, F. A. Foote, and Miss May Phillips. These people kept up "Cottage Meetings" for nearly two years, then rented Library Hall and engaged Ellder B. F. Coulter of 'Los Angeles to preach for them. May I 7, I 886, they became incorporated, and in this step there were added to the above names those of F. M. Randolph and wife, P. A. Riggins and wife, Martin Davis and wife, Mrs. Edith Robbins, Mrs. John B. Hill, Mrs. W. H. Wiley, Mrs. Geo. A. Greeley. Their first board of 


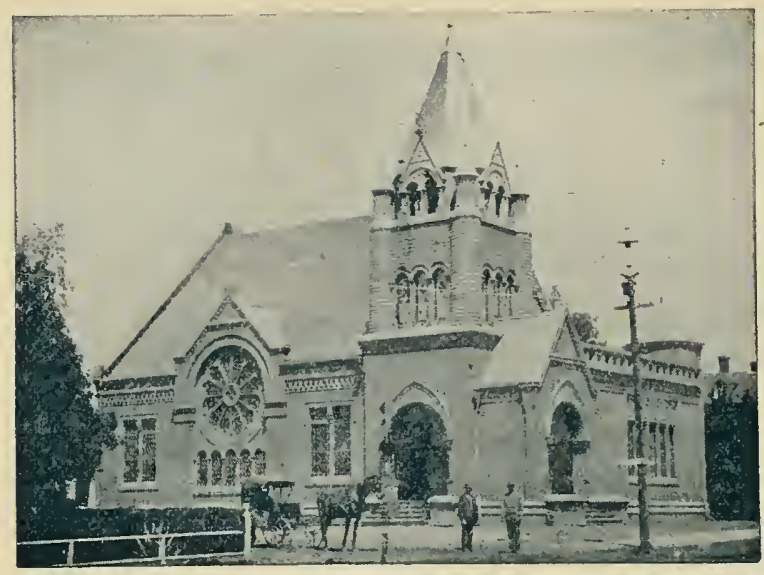

FIRST CHRISTIAN CHURCH. Photo. 1894 .

directors were Luther Foote, Evans, Randolph, Bixby, and Phillips. They bought from A. F. Mills a lot on DeLacy street for $\$ 45^{\circ}$, and proceeded at once to build a house of worship. December II, 1890, this building was blown down. [See page I65.] The society then secured a vacant store-room on North Fair Oaks Avenue and fitted it up for their use. But in $\mathrm{r} 892$, under the energetic pastorship of Elder T. D. Garvin, they bought the lot and built the handsome little church in Norman style of architecture, on the corner of Fair Oaks Avenue and Mary street, as it stands in I895. The successive pastors of this church have been: Elders B. F. Coulter, John A. Hedrick, F. W. Pattee, A. J. Wood, Wm. Bayard Craig, T. D. Garvin, H. Elliott Ward. The membership in April, 1895, was something over 300. Auxiliary organizations within the church are: Ladies' Aid Society, Ladies' Missionary Society, Young People's Society of Christian Endeavor, Junior Y. P.S. C.E., Bible School, Chinese Mission School.

HOI.INESS CHURCH. - In $\mathrm{r} 884$ the people of this order built a little church in the vicinity of North Moline Avenue and Ashtabula street, in O. K. Hines's subdivision. At that time that location was "away out in the country." Among its principal members were Isaac McCollum and family; Mrs. Eliza Jacobson and her daughter Carrie, and a few others. In I 888 they held a camp meeting on Dr. Reid's lots at corner of Pasadena Avenue and Kansas street; and then they rented the frame building next south of the Wooster block on Fair Oaks Avenue, occupying it as their church and parsonage. Rev. J. H. Clark, pastor till 1893 , when he and his wife joined the Salvation Army and went into its missionary work. In 1893 the society established their church on North Fair Oaks Avenue, near Peoria street.

\section{FIRST CONGREGATIONAL CHURCH.}

The first religious services of this order ever heid in Pasadena was in an unfinished upper room called Wakeley's hall, on Colorado street, on Sunday, May io, i 885. Rev. J. H. Warren, D. D., of San Francisco, state superintendent of Home Missions, had come here to view the field. That was the only room he could get. It 
had no seats, and he borrowed about two dozen chairs from the roller skating rink to serve his purpose. The only names I found of persons present at that first meeting were: Mrs. R. E. Burnham, Miss Etta Burnham, Dr. Rachel F. Reid, F. R. Harris, Mr. and Mrs. M. D. Painter, Mr. and Mrs. J. F. Steen, Mrs. C. P. Brown; though there were some others. There was some talk about organizing a church; some favored it, and some did not; and no definite steps were taken. In July arrangements were made for Rev. J. T. Ford, the Home Missionary of Southern California, to come, which he did, and preached on August 2, in the same room. At this meeting a few were ready (some ten or twelve at least) to organize and form a nucleus of a Congregational church. But now it was strongly urged that the Presbyterian church _ was struggling with difficulties, trying to secure and sustain a pastor; that many of its members were old-time Congregationalists; and if this new church were started it would tend to disintegrate, cripple and embarrass that one. Upon this view of the case it was finally "Resolved, That as a matter of Christian courtesy and good will toward the Presbyterian church, we defer the matter of oganization for the present." This was adopted, and no further action taken on that line. Then in October following occurred the split in the Presbyterian church over the question of removal [see page 476]. and many of its members withdrew. A conference was then held at Wm. T. Clapp's residence, and a committee consisting of Mrs. Dr. Reid, Mrs. R. E. Burnham, Mrs. I. M. Hill, Miss Annie Clapp, Miss Olive Eaton, Mrs. E. A. Nims, and Mrs. H. J. Holmes was appointed to ascertain who in the community would unite to organize a Congregational church. Another meeting was held at Mr. Clapp's house on November 7 , to hear the report of this committee, and they brought in forty-two names asking for such an organization. Rev. Dr. Warren was present by invitation and for counsel, and the following business committees were then appointed:

I. To procure a suitable place for holding church services temporarily-James Cambell, I. M. Hill, H. J. Holmes, M. D. Painter. 2. To procure site for a church edifice-Wm. T. Clapp, Thomas Green, I. B. Clapp, M. D. Painter, J. F. Steen. 3. To prepare a form of creed and covenant-Rev. J. B. Ford, Dr. H. A. Reid, Mrs. I. B. Clapp.. 4. On music-Miss Annie Clapp and Mrs. E. A. Nims.

The ensuing Sunday, Nov. 8, r885, services were held in the college building on Columbia hill [now Mr. Daggett's residence] by Dr. Warren and Rev. J. B. Ford. After the service a congregational meeting was held, The report of committee on creed was read and adopted. Then Rev. Ford. Dr. Reid, W. T. Clapp, John Ross, J. F. Steen, were appointed to issue letters missive inviting the other Congregational churches to send delegates to a council here, to examine the creed adopted, and other steps taken; and if approved, to give this new church their formal fellowship. At later 
business meetings the first officers of the church were elected, thus: Deacons-for four years, W. T. Clapp; for three years, John Ross ; for two years, A. A. Burrows; for one year, Geo. A. Green. Church clerk, I. B. Clapp; church treasurer, Dr. H. A. Reid. Superintendent of Sunday school, Geo. A. Green; S. S. secretary and treasurer, James A. Gates. The council and installation services occurred on December I and 2, I885; and the Valley Union of December 4, said in its report:

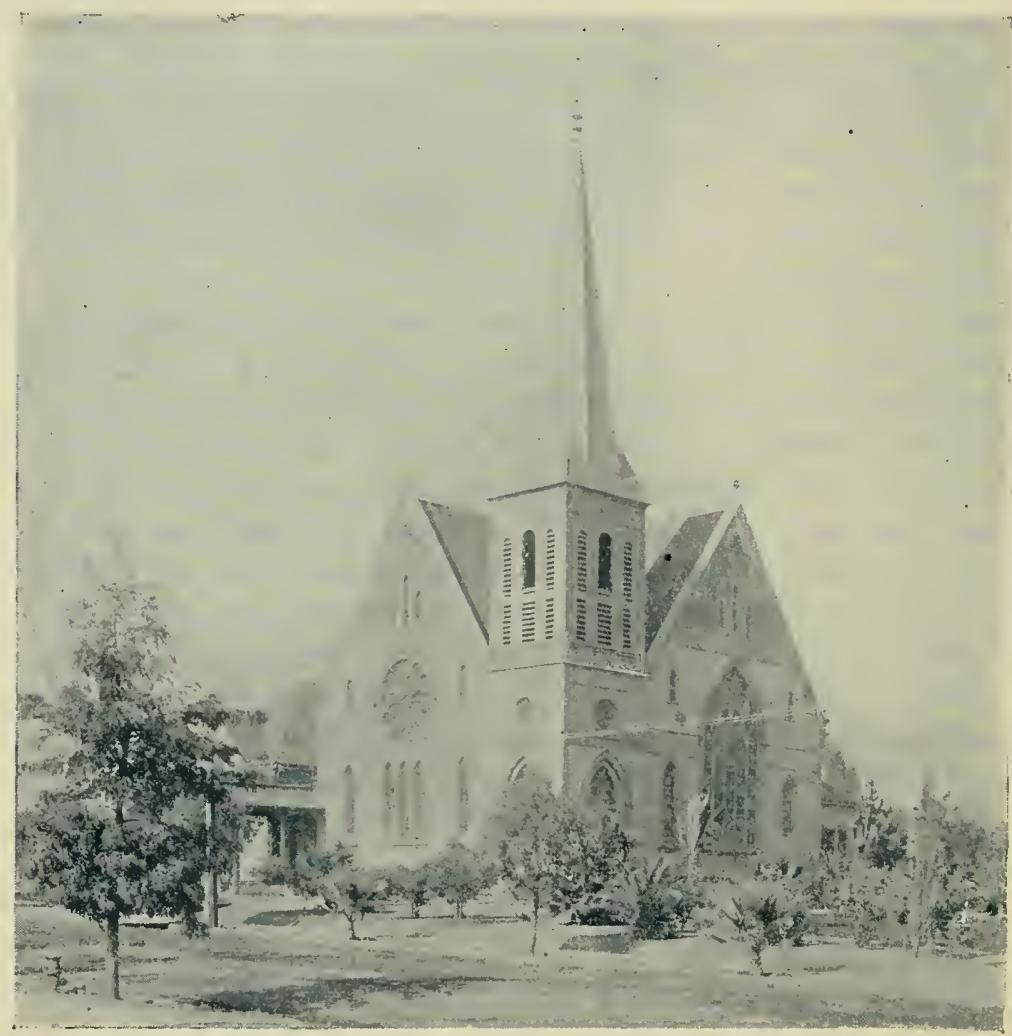

FIRST CONGREGATIONAL CHURCH. Photo. 1895 .

"Then came the ceremony of instituting the church, by the members all rising and giving their assent to the creed which they had themselves publicly prepared and adopted, not as a cast-iron jacket which all must wear alike, but for "substance of doctrine," as held in common, and with all reasonable christian liberty of conscience; then the solemn and affecting mutual covenant with each other in their new church brotherhood; then the ordination of four deacons previously chosen by the cliurch; then the warm, genial, and inspiring presentation of the fellowship, sympathy, and prayerful "God speed ye," of the sister churches; all concluding with the memorial service, or Sacrament of the Lord's supper." 
The list of first members was 42 by letter and 3 on profession of faith.

Preaching was maintained by "supply" for some weeks; then Rev. Arthur Smith, a returned missionary from China was engaged, and continued to fill the pulpit until March 28, 1886-when he was recalled to his missionary work. The services were held in the old college building. Meanwhile the committee on building site was at work. Several eligible points were found; and on June 2I, I886, final choice was made of the lot $160 \times 275$ feet, price $\$ 2,500$, where the church now stands, corner Pasadena Avenue and California street. In December, I886, Rev. D. D. Hill was engaged as pastor. The erection of a church building was pushed vigorously; and it was occupied as soon as built; but being considerably in debt, it was not dedicated until October 29, I891, when the debt had been cleared off, and a pipe organ had been furnished the church by Mr. and Mrs. C. W. Scoville. The building and grounds cost $\$ 35$, ooo.

October I, I894, pastor Hill resigned; and March 3I, I895, Rev. H. W. Lathe was called to the pastorate, and commenced his labors the first Sunday in May. Membership, 317.

Besides its Sunday school, this church has anxiliary organizations as follows : Ladies Aid Society.-Womans Missionary Society.-Y. P. S. C. E.; and Junior Y. P. S. C. E.-Chinese Mission ; and Chinese Sunday school.Children's Missionary Society.

North Congregational, Church.-On December i 8, I887, Rev. E. Bickford, a Congregational home missionary, preached in a barn west of the Painter hotel; and the next Sunday, December 25, a Sunday school was organized there, with Mr. and Mrs. M. D. Painter as the leading workers. It soon outgrew the barn, and Dr. G. Roscoe Thomas's hall was secured for its sessions. Mr. Bickford continued to preach for these people until July i 5 , 1888, when Rev. H. T. Staats took up the work. And on May 3, I889, a Congregational church was organized, with seventeen members. They bought from the Universalist parish the same building which had been the first Methodist church of Pasadena - first erected on lower Orange Grove Avenue; then moved to Colorado street; then moved to Chestnut street, and now moved up Raymond Avenue to Jefferson street. In December, I 89 I, this little church was demolished by a wind storm. [See page I65.] The society next bought the original Episcopal chapel on East Colorado street and moved it to their own lot and built some additions to it, making a much prettier and more commodious house of worship than they had before. Its total cost, besides some back debt, was $\$ 2,034$; and on March 27, 1892, it was dedicated - all clear of debt. Its membership in April, I 895, is about seventy. The auxiliary societies are - Ladies Missionary and Aid Society; and Young People's Christian Endeavor. 


\section{CATHOLIC CHURCH.}

The first Catholic religious services ever held in Pasadena was on Sunday, January 9, I886, when mass was celebrated in the Los Angeles house, by courtesy of Mr. Banta. After mass a business meeting was held to talk up the matter of building a church. The next meeting was at the residence of G. T. Stamm, on South Marengo Avenue, Sunday May 23, I886. In November and December, I887, their church was built, at the corner of Pasadena Avenue and Bellefontaine Avenue, and mass was celebrated there for the first time on December 18, i 887, by Rev. Father Hartnett. The Fasadena Star of March 30, 1892, said: "Jas. T. Smith, president of the Young Men's Catholic Institute, and Geo. Stanley, secretary, attended a meeting of the Institute in Knights of Pythias hall last night, and ten new members were received. J. A. MacIntyre is president of the society."

Rev. Cornelius Scannell became pastor in 1893 , and continues yet, 1895 .

\section{FIRST UNIVERSALIST CHURCH.}

The first preaching services of the Universalist persuasion ever held in Pasadena was in Williams hall, April 18 and 25, and May 1 and 7,1886 , by Rev. Miss Florence E. Kollock, then pastor of the Inglewood church at Chicago, and a graduate of the St. Lawrence Divinity School, New York. Arrangement for these meetings was made by Hon. A. G. Throop, "Father Throop" of honored memory. On May 7, after Miss Kollock's sermon, James A. Gates reported progress in the matter of securing names to organize a Universalist church. Father Throop submitted the Universalist creed, and the form of constitution in use at Riverside and other points; and they were adopted. Then Mr. Gates, Mrs. S. E. Merritt, and Byron O. Clark were appointed to canvass for members. The Star of June 4 reported thus :

"The Universalists completed their parish organization last Sunday, and elected as board of directors: Hon. A. G. Throop, moderator; Mrs. S. E. Merritt, secretary; Mrs. H. J. Vail, treasurer; J. A. Gates, Mrs. Filey Arnold, Prof. J. D. Yocum, J. D. Ripley. Mr. Gates, chorister. Williams hall was leased for holding regular preaching services."

Meetings were sustained and members added, under this parish organization, until April 21, I889, when a church organization was formed with 97 members, who elected Prof. Yocum moderator; Elisha Millard, treasurer; E. E. Spaulding, clerk. For deacons: Hon. A. G. Throop, M. W. Stimson, N. M. Johnson, J. B. Corson, Mrs. E. C. Bradley, Mrs. H. M. Conger. Meanwhile they had purchased the old colony church building of the Methodist people and moved it from Colorado street up to the corner of Fair Oaks Avenue and Chestnut street, where Machinery Hall of the Throop Institite now stands; and here was where the "parish" was advanced to a "church" organization on that Easter Sunday.

In $1888-89$ they built their present church edifice, on corner of Raymond Avenue and Chestnut street. March I9, I889, it was first opened to 
a public audience, when Mrs. Mary A. Livermore, of world-wide fame, delivered there her brilliant lecture entitled, "A Dream of To-morrow." At the annual meeting in May, I889, the building committee reported that the new church property had cost $\$ 56,000$, and was $\$ 20,000$ in debt. This debt was, within two years later, all removed, chiefly by the munificence of "Father Throop," who once told me himself that he had $\$ 40,000$ in it, although it was against his judgment, he said, to undertake so large and a costly structure.

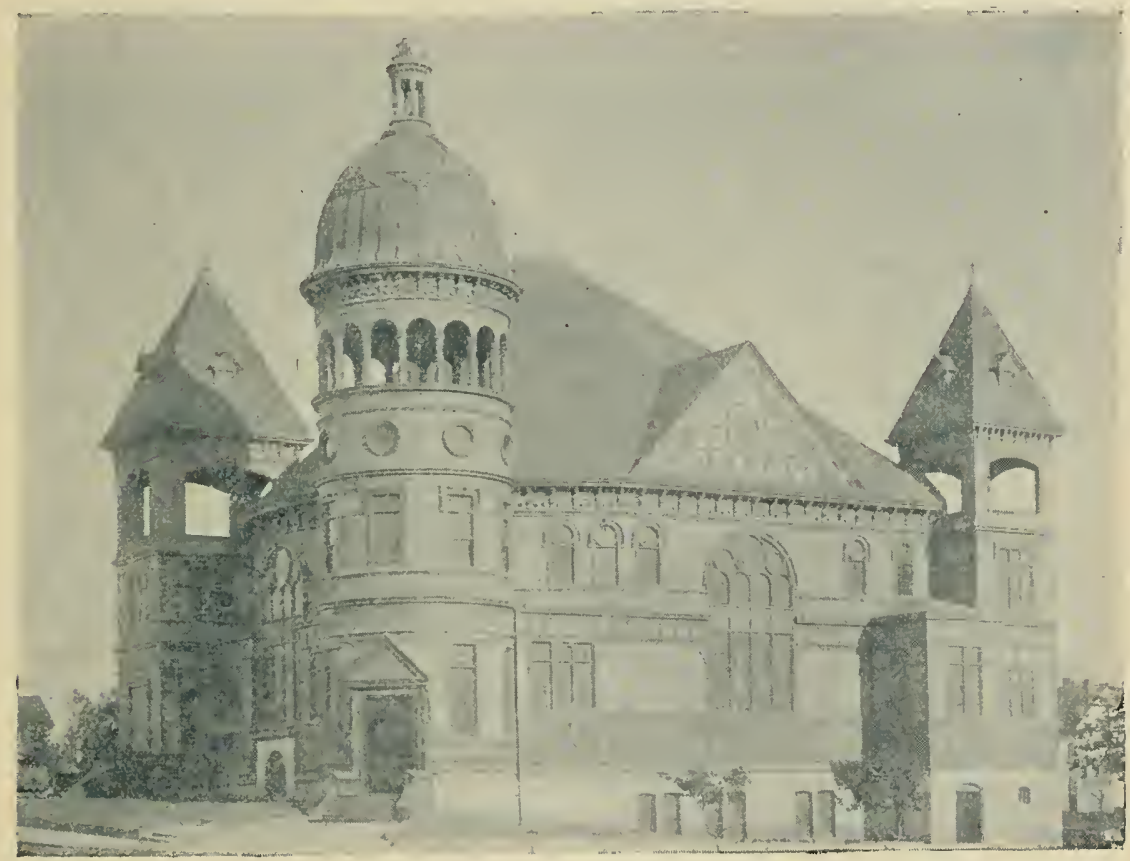

FIRST UNIVERSALIST CHURCH. Photo. I 895 .

Romanesque Architecture. West-by-north view.

A report in November, 1894 , gave $\$ 65,000$ as total cost of the grounds, church building and furnishings. And since that time a $\$ 5,000$ organ has been added. The library contained 300 volumes in 1894 ; and the roll of membership was 256. The successive pastors have been: Rev. — Briggs, in $1886-87$; Rev. E. L. Conger, D. D., 1888 to 1893 ; Rev. Florence E. Kollock, A. M., associate pastor in I892-93, and sole pastor in I893-94-95. In May, I895, Miss Kollock resigned; and in June Rev. W. M. Jones was elected to the pastorate, to commence September I, 1895. Its auxiliary societies are: Woman's League; Young People's Christian Union; Fortnightly Club.

\section{SEVENTH-DAY ADVENTIST CHURCH.}

This church was organized in June, I888, in a tent on Villa street, near Reservoir No. 2, by Elder E. A. Briggs. The first members were: J. T. 
Butler and wife; L. H. Buchanan and wife; L. D. Franklin and wife; I. H. Orr; Mrs. Dora Fisher; Miss Mary Larson; Miss Myrtle Griswold; Mrs. - Crosby, and others. In November and December of same year they built a small church on Waverly Drive. Then in I 893 they built a new and larger church at corner of Raymond Avenue and Mountain street the lot and building costing about $\$ 1,500$. It was dedicated in September, 1893. Auxiliaries within the church, besides Bible study class, are: Mothers Meeting Society; Missionary Society. Trustees in r895: L. D. Benton, J. T. Butler, - Scanlan. Number of members, 35. Elder George Bremner in charge.

First-Day Advent Christian Church.-In October, i894, Elder I. A. Wilkerson commenced preaching in a tent on North Fair Oaks Avenue; then he occupied G. A. R. Hall for some months, under name of "Church of the Blessed Hope"; but in April, I895, re-established their tent on Fair Oaks Avenue, opposite the end of Mary street. The church was formally organized April 19, 1895, the first members being Elder A. E. Vesper and wife; A. E. Pinkham and wife; Smith James and wife; E. F. Knox and wife; Jas. Mushrush and wife; B. T. Knight and wife; Misses Edith and Bertha Tipple; Daniel Kinkaid, Geo. Moore, and others.

GERMAN LUTHERAN ST. PAULUS CHURCH.

First meeting, to consider the matter of organization, was held in Opera House Block, hall No. II, November Io, I 893. Those present were C. Klein, A. Frank, A. Golderer, E. R. Strabendorf, A. Wolf, H. Ahrens, A. Lindner, A. Lau. The church was organized November 17, I883, in the Opera House Block. The first members were same as above, besides G. Borman, W. Tenhaef, W. Fachan, F. Weik, J. Schaufle, F. Mertz, - Bonowald. The first officers were: Frank, president; Wolf, treasurer: Klein, secretary ; these, with F. Weik and E. R. Strabendorf constituting the board of trustees. Pastor, Rev. Geo. Saager. A church was built in I 893-94 on the corner of Vernon Avenue and Walnut street, costing $\$ \mathrm{I}, 500$, Number of members in May, I894, were twenty-five. A Sunday school is also maintained.

\section{SWEDENBORGIAN.}

In I 892-93 Rev. Mr. Bartlett, a minister of the Swedenborgian or "New Jerusalem" denomination preached a few months at the Grand Opera House; but no church was organized, and the meetings ceased.

APPLIED CHRISTIANITY.

In August, I894, about I00 persons united in inviting Rev. R. M. Webster, a Congregationalist clergyman, to give a series of twelve discourses in Pasadena during the vacation weeks of the regular churches; and G. A. R. hall was secured as their place of meeting. Judge A. J. Utley, Prof. D. M. Harrison and Mrs. Katie M. Keese were the executive 
committee of this movement, and W. I. Keese, treasurer. After the twelveSundays engagement had been fulfilled, he was re-engaged for six months. Then in July, I895, a more formal organization was effected. [Data not furnished.]

\section{WOMAN'S CHRISTIAN TEMPERANCE UNION.}

In the spring of 1883 Miss Frances E. Willard, president of the National W. C. T. U., visited California, and organized a union at Los Angeles, among other places. At this time she visited Pasadena and gave a lecture in Williams hall. Later in the season Mrs. Mary Clement Leavitt, starting on her famous around-the-world-missionary tour, which took her seven years to accomplish, visited Pasadena and organized the W. C. T. U. here September 8,1883 . Ten women were present at the organization, but others joined soon, and up to January, I884, the list of members were: Mrs. L. A. Fisk, whose husband was then pastor of the Baptist church; Mrs. James Smith, Mrs. T. T. Rood, Mrs. George Bancroft, Mrs. E. R. Sheldon, wife of Dr. F. K. Sheldon, who started the first drug store here; Mrs. A. C. Townsend, Mrs. Mary E. Case, Mrs. S. Washburn, Mrs. Benj. Rice, Mrs. O. S. Barber, Mrs. Dr. Lord, Miss Ella Bryant, Mrs. A. O. Porter, Mrs. L. D. Hollingsworth, Mrs. M. Mullins, whose husband first opened Kansas street and laid out the first recorded village plat in Pasadena; Mrs. P. M. Green, Mrs. Louisa M. Woodin, M. D. The officers at this time were: Mrs. Rev. Fisk, president; Mrs. Dr. Sheldon, secretary and treasurer; Mrs. O. S. Barber, financial secretary. Of these first members, some have died, some have moved away, some have dropped out of the work, but Mrs. Smith, Mrs. Barber and Mrs. Lord are still working members of this Union - I 895 .

In April, I884, the famous Mrs. J. Elllen Foster of Iowa, visited this Union, and under its auspices gave a lecture in Williams hall, which resulted in the organization of the first Prohibition Club in Pasadena, April I4. [See page 229.] According to a report in the Valley Union newspaper of April 26, I884, Mrs. Foster and her husband were given free entertainment by Mrs. Banta at the Los Angeles House; and the rival stage companies then running (Vore's and Kilgore's) both offered them free transportation from and to Los Angeles. They were the "lions" of the hour.

In April, I886, this W. C. T. U. was visited by Mrs. Letitia Youmans, president of the Dominion W. C. T. U. of Canada, and leader of the temperance work in that province. During her stay in Pasadena Mrs. Youmans was the guest of Dr. Rachel F. Reid, and preached twice for the First Congregational church. She was a notably large woman-weighed $25^{\circ}$ pounds - and the Union newspaper of April 23 said: "She has a gospel power in proportion to her avoirdupois." The same paper of November I3, I 886, contained this historic item :

"At the last meeting of the W. C. T. U. of Pasadena, a little episode 
occurred which is worth printing. The name of Mrs. Ruth Thompson, daughter of 'Old John Brown - Ossawatomie Brown,' was proposed for membership, with the remark that she was a worthy daughter of the famous anti-slavery martyr. Instead of voting by the usual sign of uplifted hand, the members in this case all arose to their feet and sung with great unction and fervor the rousing song -

" 'John Brown's body lies mouldering in the grave,

But his soul goes marching on.'

"And so Mrs. Thompson was unanimously elected, with a 'hallelujah' thrown in."

The Union newspaper of January 29, I\$S87, published a furnished report, from which I quote these historic points :

"Mrs. Margaret Parker, from England, [Scotland] first president of the world's W. C. T. U., was present, and strengthened our hearts with her words of cheer. Mrs. S. V. Maxfield, one of Iowa's leading workers, told how much better prohibition succeeds there than some of the newspapers would have us think. Mrs. Gordon, missionary to Japan, gave us a most pleasing account of our temperance aronnd-the-world missionary, Mrs. Leavitt, who organized our Pasadena union ; and Mrs. Ruth Brown Thompson, whom we have all learned to love for her own as well as her father's sake, told us how John Brown smashed the whisky barrel."

Mrs. Parker was then a guest of 'Thomas Nelmes, a fellow countryman. In the autumn of 1887 , the Pasadena W. C. T. U. was visited by Mary 'T. Lathrop, the woman orator of Michigan, whose fame spans the continent, and who was also a member of the National Prohibition committee. She was entertained at the Carlton hotel, and gave a public lecture in the M. E. church to a large audience. In May, I889, this Union was visited by Mrs. Henrietta G. Moore of Ohio, a lecturer and organizer for the National IV. C. T. U.; and while here she was the guest of Mrs. Dr. O. H. Conger. A report in the Pasadena Standard of September 2 I, I889, gave a list of vicepresidents who represented the W. C. T. U. in the different churches of the city, thus: Baptist church, Mrs. Addie Camper; Presbyterian, Mrs. C. D. Case ; Efiscopal, Mrs. James Smith; Friends, Mrs. G. M. Keese ; Methodist, Mrs. E. Griffith; Universalist, Mrs. J. C. Hance; First Congregational, Mrs. H. N. Farey; North Congregational, Mrs. H. K. W. Bent; Christian, Mrs. Dr. Allen. Dr. Rachel F. Reid was then president.

A Young Woman's Christian Temperance Union was maintained about two years and then expired.

A Loyal Temperance LEGion has been maintained abont four years as a juvenile auxiliary order - practically the IV. C. T. U. Sunday school. Mrs. Mary C. Glass, superintendent, 1894-95.

\section{LADDIES' UNION PRAYER MEETING.}

In Jume, I 886, Mrs. F. H. Burdick and Mrs. M. Proudfit visited all the pastors of the city and secured their approval for a weekly prayer meeting to be held on Tuesday afternoons, for Bible study and prayer, by devout 
women from all the different churches. The first meeting was held in the Presbyterian chapel on Worcester Avenue; and I am informed that during the entire nine years of its career, this "Union Prayer Meeting" has not once failed to hold its hour of devotion on the appointed day. There are no officers, but a Leader is appointed for each meeting in advance. The attendance is usually about twenty, but often many more; and the meetings have been held alternately by seasons in the Presbyterian and Methodist churches. The "United Samaritan" organization was an outgrowth from this Prayer Meeting, in 1889, and the "Woman's Indian Association" in 189r. It also has an auxiliary band calied "Lovers of Zion," whose special bond of fellowship is a pledge to give one cent a day and make daily prayer for conversion of the Jews. Mrs. C. H. Durant is secretary of this praying band.

PASADENA BRANCH OF NATIONAL WOMAN'S INDIAN ASSOCIATION.

July 16 , I89I, the Pasadena W. C. T. U. held its usual bi-monthly meeting in the Baptist church. Mrs. Amelia S. Quinton of Philadelphia, president of the National Woman's Indian Association, was present and was granted a hearing on her specialty of missionary effort. Then at the close of the W. C. T. U. meeting an Indian Association was organized, with Mrs. Elizabeth R. Townsend, president; Dr. Rachel F. Reid, vice-president; Mrs. Hannah E. Taylor, secretary; Mrs. Mary C. Glass, treasurer. Its object is to promote school education among the Indian peoples of our country; but also therewith to instruct them in civilized cooking, sewing, housekeeping, and home making, besides agriculture, horticulture, and useful trades, to prepare them for self-sustaining citizenship. In 1895 this local society had about fifteen members; Mrs. S. V. Maxfield, president; Mrs. Dr. G. Roscoe Thomas, secretary; Mrs. - Stetson, treasurer. In October, 1892, the California State branch of this Indian Association was organized at a meeting in the Baptist church of Pasadena, Mrs. Hewitt of Riverside being elected State president, and Mrs. A. B. Giddings of Pasadena State corresponding secretary. The State society meets at different places by appointment.

\section{PASADENA WOMAN'S MISSIONARY UNION.}

Organized November 10, I894, at the M. E. church. The first officers were: Mrs. S. V. Maxfield, president; Mrs. Sarah J. Allen, secretary ; Mrs. Addie Camper, treasurer; and the following vice-presidents for the different churches represented in the organization: Mrs. R. E. Burnham, First Congregational; Mrs. H. K. W. Bent, North Congregational; Mrs. C. M. Parker, First Methodist Episcopal; Mrs. A. B. Giddings, North M. E.; Mrs. - Ingalls, Free Methodist; Mrs. — McClellan, Baptist; Mrs. Rev. N. H. G. Fife, First Presbyterian; Miss Annie Wilson, Friends church; Mrs. G. W. Pearl, Christian church. Thus nine churches of the city were united to co-operate in both home and foreign missionary work. At an all- 
day meeting April 25, I895, this society was addressed by Mrs. Amelia S. Quinton of Philadelphia, president of the National Woman's Indian Association.

\section{SAl,VATION ARMY.}

c

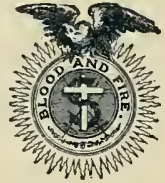

The first meeting of this church militant Order ever held in Pasadena was at Williams hall on Friday evening, April 25, I884, led by J. S. Ledford, gospel singer. It was announced by small handbills on the street and also in the Valley Union, that the meetings would be continued regularly, with a street service every evening. But this was not done; there was a drop for awhile; and just when the Army work was resumed here I could not learn. However, the city records show that in $1889-90$ a strong effort was made to put a stop to the drumming of the Army on the streets, because of the danger from frightened horses; and I here collate from the city police judge's reports as follows :

"January I, I890:" Salvation Army. Capt. Anna Beall, Lieut. I. Bingham, Wm. Ballard. Charged with violation of resolution of city trustees December 3, 1889.-January IO : defendants discharged.-March 3: Capt. Anna Beall arrested again for blocking the street.-March 4 : she demanded a jury.-March 5: case dismissed without trial.-March 5: Wm. Davey. Arrested for disturbing the peace with Salvation Army drum.-March 7: case dismissed without trial.'"

In this last case Mr. Davey was released, but the offending drum was still kept under arrest by the city marshal, D. R. McLean. When the time arrived for the Army's usual street prayer meeting parade Miss Beall went to the city marshal's office and in the sweetest, most smiling way of woman's gentle persuasion she said: “Mr. Marshal, aren't you going to let me have my church bell?" This was irresistible; and the marshal laughingly handed her the imprisoned drum. The Daily Star of September 2, I $89 \mathrm{I}$, reported some cases of narrow escapes from injury by people whose horses took fright at the Salvation Army drum on the street, and said further :

"During the meeting of the Salvationists in their hall some boys threw a handful of rotten eggs through the back door, striking one of the women and spreading a sickening odor throughout the room. That proceeding was disgraceful, but it appears to have had no connection with the events of the parade, as boys have been threatening for several nights to rotten egg the Army."

In April, I89I, occurred the visit of President Harrison and party to Pasadena. The distinguished guests were greeted on their arrival by an 
immense throng of people at the Santa Fe depot and Hotel Green. Postmaster General Wanamaker suddenly left the presidential group, and pushing his way through the crowd, went to a couple of women whom he had noticed in Salvation Army bonnets, shook hands with them heartily, giving some words of commendation, and then returned to his place.

\section{YOUNG MEN'S CHRISTIAN ASSOCIATION.}

On September 20, 1886, F. J. Culver, a Y. M. C. A. worker from the East, was passing along the street and was met by David Galbraith, then cashier of the Ist National Bank, who clasped his hand and said earnestly, "cannot something be done for our young men?" "Yes," was the reply, "if the time has come and the people are ready to act." "Satan is acting -and we must act," said Mr. G. "Very well; and when?" Culver answered. "To-morrow!" replied Galbraith with emphasis. Thereupon a meeting was called for the next day in an office on west Colorado street, and fifteen men were present. The question before the meeting was, "Shall we organize a Y. M. C. A. in Pasadena?" The answer was decisively, "If it be God's will, yes." And arrangements were made for a mass meeting in Williams hall the next day. This larger meeting was addressed by Rev. T. N. Lord, then pastor of the Baptist church, and by Mr. Culver, explaining the plan, working methods, etc., of the Association. Names were taken for membership, and a meeting to organize was appointed at the Methodist church on September 27. At this meeting 96 charter members were enrolled. The first officers and directors were : C. M. Parker, president ; O. S. Picher, Ist vice president; T. Nichols, 2nd vice president; T. J. Fleming, recording secretary ; M. D. Painter, treasurer ; F. J. Culver, general sectetary ; J. W. Hugus, G. E. Meharry, C. W. Abbott, D. Galbraith.

Prof. C. M. Parker, the first president, served until December, 1888, and was succeeded by A. F. M. Strong, who served until December, 1891, being then succeeded by Prof. Will S. Monroe, who resigned on March I, 1892 , on account of sickness. Then Dr. F. Grinnell was elected president, and holds the office yet- $x 95$.

Mr. M. M. Myers of San Francisco was elected general secretary in September, I 887; and resigned May I, I889. He was succeeded by Geo. Taylor, who has continued in that office since. He was the delegate from California to the World's Y. M. C. A. convention and half-century jubilee in London, in May and June, I894; and while abroad on this duty he visited the local Associations in all the great capitals of Europe, as their distinguished guest.

In $1886-87$, the Association caught the "boom fever," bought a lot, and secured pledges for a fund to erect a $\$ 40,000 \mathrm{Y}$. M. C. A. building at the corner of Fair Oaks Avenue and Valley street.* The cellar was exca-

*C. M. Skillen and Samuel Stratton offered to donate to the Association a 5o-foot lot next west of the Presbyterian church, on east Colorado street. if they would build there. This lot was then saleable at $\$ 150$ per front foot [boom], or $\$ 7.500$. But a majority of the directors thought that location was too far from the "loafing center" of the city to serve the special missionary objects of the Association's reading room, gymnasium, baths, games, etc. 
vated, the foundation walls built, the corner stone laid, and much material for the superstructure brought upon the ground. Then "the boom bursted;" thousands and thousands of dollars of pledges vanished into exceedingly thin air; and the unfinished walls still lie there as a reminder of our days of real estate bubblery - the late lamented "boom."

The Association has a Ladies Auxiliary committee; and Lyceum for youths. Also a free reading room, open every day and evening, well supplied with daily and weekly papers, etc.; and a library of i 50 volumes. In I 888 , Gen. O. O. Howard, of national fame, lectured under its auspices, at the Tabernacle. And also the same year they had Bob Burdette, the noted humorist, in their lecture course. In October, I892, this Association entertained the State.Y. M. C. A. convention, with 300 delegates, the largest number ever in attendance. Its sessions were held in the Presbyterian church.

During the year I893-4 there were made 395 visits to sick persons; and watchers were furnished 69 nights. Gospel meetings for men were held every Sunday, at which the total of attendance was 4,394. The registered visits to the reading room during the year were 7,300 . Present number of members, 105. Board of Directors in 1894: Dr. F. Grinnell, president; D. Galbraith, vice president ; P. M. Green, treasurer ; Geo. Taylor, general secretary ; A. J. Wallace; Milford Fish ; E. C. Griffith ; Dr. J. R. Townsend.

\section{PASADENA RAMABAI CIRCLE.}

Organized November I9, 1888, at the Ist Congregational church, where a church full of people had assembled to see and hear the high caste native Hindoo woman, Pundita Ramabai, whose fame as a child-widow missionary in India has since spread throughout the United States and England, as well as her own country. Rev. D. D. Hill was first president of the Circle, and Mrs. H. G. Bennett secretary and treasurer. In April, I 895, there were 37 members; with Mrs. Mattie Bent, president, and Mrs. Bennett still secretary and treasurer. The 7 th annual meeting of the National Ramabai Association was held in "Old South Church," Boston, March II, I895; and there were then IO3 local Circles or societies tributary to the Association. The Pasadena Circle had paid in on its annual pledges a total of $\$ 238.79$ during its seven years of existence, which showed something more each year than the amount it had pledged. It is a special missionary work to sustain Ramabai's school at Poonah, India, for childwidows, and thus help to break up the gross and cruel system of woman slavery in that heathen empire.

CHRISTIAN ENDEAVYR UNION.

Organized October I3, I889, by the Y. P. C. E. societies of the Friends, Congregational, Christian and Baptist churches. First officers: Prof. C. E. Tebbetts, president; deacon Geo. A. Green, vice president; Miss Clarice 
Hall, secretary and treasurer. Executive committee, Geo. W. Tuttle, Mrs. F. E. Tower, Miss Lillie Duncan, besides the officers. The Methodist church young people [Epworth League] joined awhile, then withdrew ; and the Baptist society withdrew to join the Baptist Union : but others came in ; and in April, 1895, the C. E. Union of Pasadena comprised the Young Peoples societies of the following churches: Ist Congregational; North Congregational; Ist Christian; Ist Presbyterian; Calvary Presbyterian; Friends church; Union Christian Endeavor society of Lamanda Park ; and Congregational church of Sierra Madre. On January 25, 1895, there were 345 active and 40 associate members. And the officers were: Rev. C. C. Reynolds, president; W. N. Campbell, vice president ; Miss Clarice Hall, secretary ; D. M. Mulford, treasurer. Each local society appoints its own member of the executive committee, to cooperate with the board of officers.

\section{PASADENA CHRISTIAN ALLIANCE.}

Organized April Ir, I89r. Members : Mrs. C. H. Durant, Rev. W. C. Stevens, Judge C. N. Terry and wife, Aaron Winder and wife, W. G. Strang and wife, Dr. J. R. Townsend and wife, Mrs. I. W. Rust, Mrs. S. V. Maxfield, Mrs. S. E. Bosley, Jesse Butler and wife, John Habbick, Miss Emma Allen, and others. This is a duly chartered branch of the National and International Evangelical Alliance which has its headquarters, publishing house, and missionary training school on Eighth Avenue, New York. The membership in April, I 895, was fifty-four. Officers: Rev. W. C. Stevens, president; Judge Terry and Mrs. Maxfield, vice presidents; W. G. Strang, secretary; Mrs. Durant; treasurer.

\section{PACIFIC GOSPEL UNION OF PASADENA.}

First meeting November 7 , 1892, held by A. L. Beer, J. C. S. Habbick, A. E. Baldwin, E. J. Mayo. Union formally organized in December, and meetings held for a year in a hall on North Fair Oaks Avenue; then in another hall on South Fair Oaks. Directors: C. N. Terry, president, J. C. S. Habbick, secretary ; John Habbick, treasurer ; Dr. J. R. Townsend; Tillman Hobson, J. W. Camper, Samuel Hahn, E. J. Mayo, A. K. Nash. Object: to reach the street-loafing and unchurched classes with religious i11fluences.

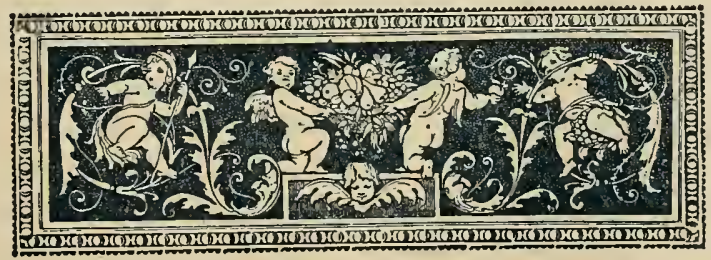




\section{CHAPTER XXVI.}

Fraternity.-Secret Orders - Patriotic, Fraternal, Reformatory, Beneficiary, Industrial.

\section{PATRIOTIC ORDERS.}

John F. Godfrey Post No. 93, Grand Army of the Republic; Department of California.

After several informal talks among old soldiers about forming an organization, a meeting was called for Tuesday evening, November 3, I 885, at Craig \& Hubbard's store, then in a frame building on west side of South Fair Oaks Avenue There were present at that meeting J. D. Gilchrist, E. S. Frost, W. T. Knight, Geo. A. Black, Geo. W. Barnhart, J. Ellis, R. B. Hubbard, W. H. Lordan, Wesley Bunnell, A. Wakeley, A. O. Bristol,W. J. Barcus, A. K. McQuilling, and Edson Turner; and the necessary steps were taken to go forward and organize a Post.

The next meeting was held and organization completed in Library hall, November 28,1885 . [The old original Library building then stood on south side of East Colorado street nearly where the Santa Fe railroad now runs, but was afterward moved to Dayton street where it still remains, being now changed into a dwelling house.] At this meeting the question of a name came up; and after sundry suggestions which did not seem to hit the mark; E. S. Frost moved the name of Col. John F. Godfrey, who had then recently died in Los Angeles, and it was adopted. Col. Godfrey was born at Bangor, Maine. He enlisted as a private in $\mathrm{I} 86 \mathrm{r}$, and was chosen second lieutenant in the Maine 2nd Battery; won promotion to Lieutenant-Colonel in the field. Resigned in I864 on account of broken health. Re-enlisted in I 865 and was sent in command of scouts with Gen. Sully's campaign against the Sioux Indians. In 1874 he settled in Los Angeles as a lawyer, soon rose to distinction, and was twice elected city attorney there. When the Pasadena colonists held their second anniversary picnic under the great oaks of Lincoln Park, January 27, I876, Col. Godfrey was one of the principal speakers [p. I I 2], being thus historically associated with Pasadena in its tender infancy; and now his name being adopted by the G. A. R. (and later by the Woman's Relief Corps) adds more enduring links to the chain of historic kinship. [He died at Los Angeles June 27, I 885.] After the name had been decided on, comrade Horace Bell of Los Angeles proceeded as mustering officer to muster in the following charter members: C. C. Brown, Alfred Wakeley, A. K. McQuilling, F. J. Woodbury, W. J. Barcus, W. H. Lordan, Wesley Bunnell, Milo J. Green, Geo. A. Black, E. S. Frost, Jehu Ellis, John B. Hill, J. D. Youngclaus, Lyman Allen, J. D. Gilchrist.

Although this was November 28, the Post charter bears date December 23, I 885 . The first officers installed were: Gilchrist, Post Commander; 
Frost, Senior Vice Commander; McQuilling, Junior Vice Commander; Barcus, Chaplain; Ellis, Quartermaster; Brown, Officer of the Day; Black, Officer of the Guard; Bunnell, Adjutant. The motto of the order is: "Fidelity, Charity, Loyalty." Its beneficiary plan is not by any fixed schedule, but by mutual aid according to circumstances in each case-and a relief fund is constantly maintained. The first time the old soldiers attended church in a body on Memorial Sunday was May 30, I886, at the Methodist Episcopal church, where a sermon appropriate to the occasion was preached by the pastor, Rev. A. W. Bunker, who had served in the First Maine Light Artillery.

In 1893 funds were raised by Comrade J. H. Stuntz, as a soliciting committee, and from other sources, to secure a hall for the Post and its allied orders. The second story of E. S. Frost's unfinished brick block on East Colorado street was leased for six years. Necessary alterations were made, both above and below, partitions put in, rooms finished and furnished, plumbing and gas-fitting done, a flag-pole erected, etc., at a total cost of about $\$ 1,600$ - thus providing two halls for sub-rental that can be opened together as one, for large assemblages. The number of members April I, 1894, was 130. [April I, I 895, I27.] One of its delegates to the State encampment in I894 was Gov. H. H. Markham. And in August, I895, Geo. T. Downing, a past commander of this post, was elected commander of the Department of California.

In I892-93 I spent several months collecting a complete list of all old Union soldiers then residing in Pasadena or its immediate vicinity, and it was printed in a small manual or "Directory of John F. Godfrey Post and its Allied Patriotic Orders." And from that roster, which was then complete up to February I, I893, I compile this table:

Old soldiers residing in Pasadena or its vicinity ................287

Army nurses............................................ 2

Soldier's' graves in Mountain View cemetery ..................... 35

Members of John F. Godfrey Post, G. A. R.................... I I 9

Members of John F. Godfrey Corps, W. R. C.................. I 4 I

Members of Phil Kearny Camp, S. of V....................... 48

Members Ladies' Aid Society ................................ 24

Since that time, and up to March, I895, I have thirty-four additions to the list of resident old soldiers ; five additions to the cemetery list ; and each of the four orders had increased their membership.

JoHN F. GODFRey W. R. C. No. 43.-The first meeting to consider the matter of organization was held in the latter part of June, I887, at Library hall on Dayton street. The Corps was organized July 6, 1887, with the following charter members: Cynthia B. Clapp, Avelina J. Crowell, Eliza M. Van Kirk, Clara A. Elsemore, Cynthia Ramsey, Margaret E. Lincoln, Maggie Williams, Emma A. McCoy, Virginia H. Rippey, Amelia G. Rice, Addie C. Conover, Minnie E. Wil- 
liams, Charlotte Smith, Margaret I. McQuilling, Catherine Meek, Mary L. Rippey, Helen A. Rippey. The first officers were: Cynthia B. Clapp, president; Avelina J. Crowell, senior vice president ; Eliza M. Van Kirk, junior vice president; Emma A. McCoy, secretary; Minnie E. Williams, treasurer; Amelia G. Rice, chaplain; Margaret E. Lincoln, conductor ; Nellie M. Conover, guard; Addie C. Conover, assistant conductor; Charlotte Smith, assistant guard.

This society, being auxiliary to the Grand Army of the Republic, has frequently held fairs, bazars, public dinners, musical, dramatic and other entertainments to raise money for the relief fund. And it bore a prominent part in securing, fitting, and furnishing the G. A. R. hall. They also own one-third of the G. A. R. lot in Mountain View cemetery. In December, I 894, there were 154 members.

\section{PHIL KEARNY CAMP NO. 7, SONS OF VETERANS.}

Instituted November 23, I886. It was duly chartered at the time, and its first members were: W. E. Darracott, who was also first captain of the camp; W. A. Dunbar, C. J. Williams, Geo. H. Frost, S. L. Wallis, L. E. Jarvis, H. H. Johnson, W. E. Johnson, C. U. Bunnell, Whit. Elliott, S. M. Cambell, Jas. H. Cambell.

During I 887 there was some revision or reconstruction of the order, the Division of California was established, and this camp received a new charter as "No. 7. Div. Cal.," dated April 2, r888 - the one under which it is now working. The only persons eligible to its membership are sons of union soldiers or sailors in the war of the rebellion; and sons of members of this order. Its objects are patriotic, fraternal, benevolent; and it is auxiliary to the G. A. R. and W. R. C.; also owns one-third of the G. A. R. lot in Mountain View cemetery.

Ladies' Aid Society No. I, auxiliary to Phil Kearny Camp No. 7 , S. of V. This organization was worked up by Captains Lacey and Bang. ham of the Sons of Veterans, and was instituted December I8, I892, in the old Library building on Dayton street. It was the first society of the order on the Pacific coast, and stands as No. $\mathrm{I}$ in the California Division S. of V. Its charter members were:

Barnhart, May

Brown, Lillian A.

Brown, Meda E.

Cambell, Mrs. Franc.

Crawford, Effie B.

Darlinton, Madge

Downing, Carrie M.

Dugger, Carrie P.
England, Fannie B. Fraser, Ida M. Janney, Mrs. Carrie Lacey, Mrs. Ida O. McClure, Mrs. M. F. McClure, Nina McMurty, Sadie [ret E. Williams, Minnie E. Mendenhall, Mrs. Marga-

Moore, Edith Rogers, Ceres B. Rodgers, Bonnie Rogers, Cressie V. Stevens, Claudine De F. Sutliff, Nettie M.

The first officers were: Mrs. W. S. Lacey, past president; Bonnie Rodgers, president; Ida M. Fraser, secretary; Ceres Rogers, treasurer. Motto: "Friendship, Charity, Loyalty." Objects: "To aid and assist the 
Sons of Veterans in all their objects, both financially and otherwise." Who may become members: "Mothers, wives or sisters of Union veterans of the war of I 86I-65. Also female lineal descendants of such veterans. Also wives of Sons of Veterans." Officers in 1895 : Minnie Williams, past president; Helen Darracott, president; Carrie Downing, secretary; Ida O. Lacey, treasurer. Number of members, 38 .

\section{AMERICAN PROTECTIVE ASSOCIATION.}

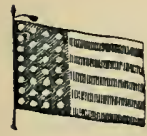

This order is better known by its initial title of the "A. P. A." The Pasadena council was instituted in Strong's hall July 6, I894. Motto: "America for Americans." Emblems, the American flag and little red schoolhouse. Its objects are, to cultivate, educate and concentrate public sentiment against alien ownership of land; against foreign dictum of church laws and penalties; against use of public funds or tax exemption for sectarian purposes; against any school, church, convent, monastery, reformatory or asylum that may not at any time be visited and inspected by the proper public officers; against any person being allowed to vote who cannot read in the American [English] language; etc., etc. Tilman Hobson is the president in 1895 . Membership about 450 on September I, I 895 .

MASONIC BODIES.
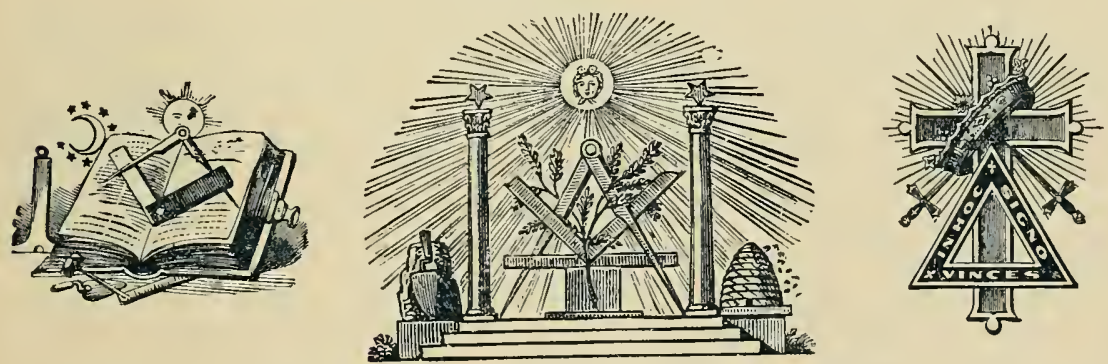

PASADENA Lodge, No. 272. F. AND A. M., was the first of the Masonic organizations, and was planned for at a meeting in Williams hall on February 20, I $88_{3}$, by C. M. Skillen, J. B. Springer, A. Wakeley, C. C. Brown, James Clarke, C. B. Ripley, R. Conkling, John Myrick, W. H. Wakeley, H. Ridgway, J. L. Cannon, J. Ripley, Isaac Heiss, H. McGee. The lodgé was instituted October 22, 1883 , in the old Public Library building, with these same men as the charter members. The first officers were: C. B. Ripley, Master; H. Ridgway, Senior Warden; M. Rockefeller, Junior Warden. In 1894 there were I I 9 members; and chief officers were: P. P. Bonham, Master; E. E. Griffith, Senior Warden ; W. L. Wotkyns, Junior Warden. .

Crown Chapter, No. 72, Royal Arch Masons.-The first meeting to talk up and arrange for this organization was held in the Masonic hall in 
Williams hall block, October 22, I888. Those present were: R. Williams, F. L. Jones, E. White, H. B. Sherman, J. Banbury, Chas. Swift, John Habbick, A. M. Collis, F. E. Biles, H. J. Slaughter, J. K. Vlier, C. H. Rhodes, D. S. Carnahan, T. J. Martin, Oscar Freeman, C. A. Smith, A. H. Conger. And the chapter was instituted on November 27, with these men as members; and as officers: R. Williams, High Priest; F. L. Jones, King; T. J. Martin, Scribe. In 1894 there are 79 members; and officers are: E. C. Griffith, H. P.; E. E. Gaylord, K.; J. R. Slater, Scribe.

Pasadena Commandery No. $3 \mathrm{I}$, Knights Templar. - The first preliminary meeting was held June I7, I89I, and the Commandery was instituted on July Ist in the Masonic lodge room in Williams block. Its first members were: F. L. Jones, E. L. Conger, L. W. Frary, W. T. Clapp, H. W. Magee, S. Washburn, A. Kemple, H. J. Slaughter, A. Wakeley, Wm. Shibley, J. Abraham, W. G. McGregory, Delos Arnold, T. E. Walker, J. Peaslee, G. E. Wright, J. A. Jacobs, P. Brown, D. O. Miltimore, A. M. Collier, S. H. Yocum, J. J. Gillie, C. H. Rhodes, T. Winter, J. B. Springer, S. W. Allen, G. M. Cole, L. S. Porter, W. L. McAllister, and W. P. Hammond.

Names and titles of first principal officers: Sir Florin Lester Jones, Eminent Commander; Sir Delos Arnold, Generalissimo; Sir Thomas Eaton Walker, Captain General; Sir Everett Lorentus Conger, Prelate; Sir Sherman Washburn, Treasurer; Sir Charles Hilliard Rhodes, Recorder. Motto: "In Hoc Signo Vinces." No. of members in I894-60. Chief officers in r894-Sir L. S. Porter, E. C.; Sir A. M. Collis, G.; Sir E. Griffith, C. G.; Sir Wyllys Hall, Prelate: Sir Romayne Williams, Recorder.

Pasadena Chapter No. io8, Order of Eastern Star..-This organization was first proposed and talked up at a picnic at Devil's Gate, in the spring of 1890 , some members of the Order in Los Angeles being there among the picnickers. And from this beginning the movement grew, until on August 7, I890, this Chapter was duly instituted, in the Masonic lodge room in IVilliams block. A list of its first officers and members was printed in the report of Grand Chapter sessions of October 20, 21, 22, 23, 1890. The principal officers then were: Carrie Louisa Peaslee, Worthy Matron; William Henry Wiley, Worthy Patron; Melissa Casandria Hester, Associate Matron; Isaac Newton Seares, Secretary ; Susie Etta Washburn, Treasurer; Avelina Juanita Crowell, Conductress.

In 1895 there are 130 members; and the chief officers are: Mrs. Ella A. Sears, Worthy Matron: Mr. Charles J. Willet, Worthy Patron; Mrs. Mary G. Wiley, Associate Matron; Mrs. Carrie B. Slater, Secretary; Mrs. Susie E. Washburn, Treasurer.

Corona Lodge (Under Dispensation) F. AND A. M.-Organized December 2I, I894. Its charter members were: Dr. L. W. Frary, E. C. 
Griffith, W. L. Wotkyns, J. A. Jacobs, E. E. Gaylord, C. H. Rhodes, W. D. McGilvray, A. H. Conger, Dr. R. J. Mohr, E. T. Howe, E. H. May, C. J. Willett, E. Groenendyke, C. H. Keyes, Dr. A. H. Palmer, J. E. Smyth. First principal officers : Dr. Frary, W. M.; E. H. May, secretary; Willett, treasurer; Rev. Dr. Wyllys Hall, chaplain. [Charter to be confirmed and number assigned by Grand Lodge in December, r 895.]

The Masonic lodge room was at first in the A. O. U. W. hall in the Public Library building. Then they leased and fitted up a room of their own in the Williams hall block. But on February 28, 1895, the five different bodies of the order took formal possession of their elegant rooms in the magnificent block now known as the

MASONIC TEMPLE,

corner of Raymond Avenue and Colorado street, they having taken a long lease on the entire upper floor-divided the space into rooms adapted to all their various needs, and finished, furnished and decorated them in a style of artistic taste and elegance not excelled even in San Francisco-some Masonic rooms there being larger, but none finer. The building cost $\$ 40,000$, and was erected by Col. L. P. Hansen, J. S. Torrance and M. E. Wood, in I $894-95$.

\section{TEMPERANCE ORDERS.}

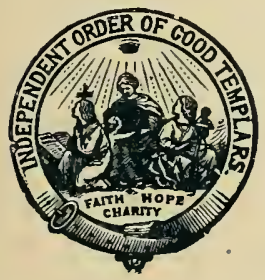

Pasadena Lodge, No. I73, INDEPendent Order of Good Templars.--The first meeting to talk up organization was held February 24, I879, at the little old schoolhouse which was moved from Orange Grove AvAvenue to the corner of Colorado street and Fair Oaks Avenue. Nearly all of the old settlers of the colony were present. The lodge was instituted on the same day, by Mr. Leland, Grand Lodge Lecturer, I. O. G. T. of California, assisted by members of the order from Merrill Lodge of Los Angeles, with the following as charter members: P. G. Wooster, C. C. Smith, F. S. Woodcock, I. N. Mundell, S. M. Cambell, Charles McAffrey, H. G. Bennett, S. D. Bryant, H. L. Bryant, Ella Bryant, A. S. Hollingsworth, Mrs. A. S. Hollingsworth, Della Washburn, Ward B. Swartzell, Nettie Millard, Elisha Millard, Iva Millard, Dell Millard, Ed. E. Millard, Esther Turner, Charles Turner, F. H. Heald, N. M. Townsend, John Lowe, Elisha Lowe, John Lowe, Jr., Frank Lowe, Alex. F. Mills, William G. Persing, W. H. Townsend, Dennis Prinz. The first officers were: Worthy Chief Templar, P. G. Wooster; Right Hand Supporter, Miss Iva Millard; Left Hand Supporter, Miss Jennie Masher; Vice-Templar, Mrs. Esther Turner; Secretary, Frank Lowe; Assistant Secretary, Miss Ella Bryant ; Financial Secretary, H. G. Bennett ; 'Treasurer, Mrs. Anna Mundell; Marshal, S. M. Cambell; Deputy Marshal, Miss Della Washburn ; Inside Guard, Mrs. C. C. Smith ; Outside Guard, Herbert 
L. Bryant; Chaplain, F. S. Woodcock; Past Worthy Chief Templar, Arthur Hollingsworth.

This was the first secret order fraternity organized in Pasadena. It was not incorporated until November 2I, I88I, when it joined with the A. O. U. $\mathrm{W}$. in putting a second story on the Library building for the use of the two lodges. [See page 204.] The lodge celebrated its fifteenth anniversary, February I 7, 1894, in Grand Army hall, when addresses were made by Rev. C. E. Harris, pastor of Baptist church; Rev. Florence Kollock, pastor of Universalist church; Rev. J. H. Stuntz, Dr. Wm. D. Turner, and others; and also by three of the original members, Mr. and Mrs. I. N. Mundell and Will H. Townsend.* The membership on May I, I895, was I I7.

For several years, about I888-89-90-9I, an order called BAND OF HOPE was maintained by the Good Templars - then it was merged into the W. C. T. U.'s "Loyal Legion." But in March, I895, an order of JUVENiLE TEMPLARS was organized, from which boys and girls may pass at proper age directly into the senior lodge, by right of inheritance. A. E. Baldwin, superintendent. Meetings Sunday afternoon, in G. A. R. hall.

Sons OF TEMPERANCE.-A Division of this order was instituted in r 884. Among its members were: A. F. Mills (who was its Worthy Patriarch), Benj. A. Rice, Robt. W. Lacy, H. L. Bryant, and others. But it did not long survive.

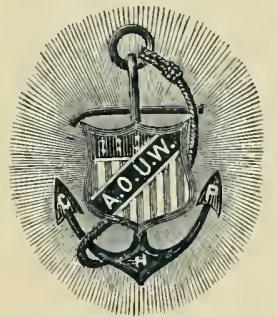

AnCient Order OF United Workmen. - Pasadena Lodge No. I5I, A. O. U. W., was instituted December I8, I879, in the old Central School building. The first members were Geo. E. Hall, B. F. Ball, Geo. Miller, Elisha Millard, Joseph. Nelson, A. V. Dunsmore, R. Williams, J. S. Mills, P. M. Green, F. D. Kellogg, S. Washburn, F. Heydenreich. The first officers were: Hall, past master; Ball, masterworkman; Miller, foreman; Millard, overseer; Williams, recorder ; Washburn, financier; Heydenreich, receiver; Mills, guide; Nelson, gatekeeper. The emblem of the order is an anchor and shield. Benefit $-\$ 2,000$ to family, at death of a member. This lodge joined with the Good Templars and built a second story on the colony's Public Library building, to use jointly for lodge rooms. Number of members in $1894-57$.

The data furnished from this lodge was very meager. It has a DEGREE OF Honor No. 47, a branch organization for ladies, but its date of organization, first members, etc., were not furnished, although I sent them a History blank, soliciting the information.

* Note - Dr. I. S. P. Lord, who has resided in Pasadena since 1879 , was a delegate in the convention at Cleveland, Ohio, in May, 1855, when the National Grand Lodge, I. O. G. T., was first organized; and was a member of the committee on ritual. 
Pasadena Lodge No. I32, Knights of Pythias, is thus mentioned as to its beginnings, by the Pasadena Union of September 25, I 885 :

"On Friday evening, the I8th inst., the first meeting was held at Masonic hall, for the purpose of instituting a lodge of the Knights of Pythias. The following candidates having signed a petition for a charter, were duly initiated to the rank of Knights: J. Banbury, R. Williams, W. O. Swan, Jr., L. A. Kreig, Emil Kayser, John C. Kerr, J. E. Clarke, Louis Heitman, and J. Ellis, while W. R. Davis, G. E. Meharry, J. D. Gilchrist, C. S. Howard, and Charles Swift united by card from other lodges. The second meeting was held on Wednesday, September 23, and the following candidates were regularly initiated: D. Galbraith, E. E. Fordham, Chas. W. Bell, Geo. A. Greeley, W. B. Loughery, and C. S. Barnet. After the initiatory services, Deputy Grand Chancellor M. G. McCoon proceeded to install the officers of the lodge, whose names and official rank are as follows: Jabez Banbury, past chancellor; J. E. Clarke, chancellor commander ; W. O. Swan, Jr., vice chancellor; John C. Kerr, prelate; E. E. Fordham, keeper of records and seal; D. Galbraith, master of exchequer; L. A. Craig, master of finance; Louis Heitman, master at arms; C. W. Bell, inner guard; R. Williams, outer guard. On October 20 they initiated eleven new members, and had a social supper at Pasadena hotel, with visiting brethren from Los Angeles, Alhambra, and San Diego. [No further data furnished.]

Fidelity TeMPLE No. 4, Rathbone Sisters, is an auxiliary order of women. But no data as to time of organization, first members, etc., were furnished, although the same request was made as of all the other orders. There is also a lodge of Uniform Rank Knights of Pythias. But no data furnished.

INDEPENDENT ORDER OF ODD FELLOWS.

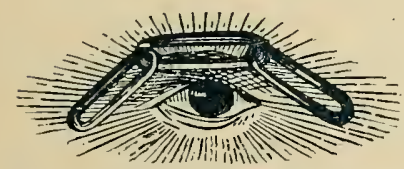

Pasadena Lodge No. 324 , I. O. O. F., was instituted December 30, I885; and the Union of January I, I 886 , said of it :

"The finishing work was done Wednesday evening, December $30,1885, *$ by the formal institution of the new lodge, and the work was crowned by a banquet and a good time at Nay \& Willard's Pasadena hotel. The initiatory steps for the new.lodge were taken in September by Frank M. Ward, E. S. Frost and others. Five or six meetings were held, and the charter was received with the names of Frank M. Ward, E. S. Frost, L. J. Newlan, H. Haskins, Joseph Laspada, A. D. Lockhart, J. E. Sullivan, Lewis H. Bixby, T. A. Smith, and Wn1. H. Darrow as charter members."

The first officers were: E. S. Frost, noble grand; T. A. Sinith, vice grand; Frank M. Ward, recording secretary; L. J. Newlan, treasurer. They met in the Masonic lodge room, Williams block. Motto: "Friend-

* The preliminary meetings had been held in a small private room in the historic old roller skating rink, corner Fair Oaks Avenue and Dayton street, where the Doty block now stands. 
ship, Love, and Truth." Objects - Fraternal, social, beneficiary. Number of members in r894- 71 . Officers in 1894 : A. G. Heiss, noble grand; A. S. Glidden, vice grand; Jas. B. McNeil, recording secretary; Jas. Zellhart, treasurer; J. S. Blick, financial secretary. Auxiliary orders : Encampment, and Rebekah lodge.

The Pasadena Weekly Star of January I3, I894, contained a report of a notable open installation held jointly in the Doty block by the Men's and Women's lodges of this order. Speeches were made by Rev. Dr. Conger, the chaplain elect, followed by Judge A. J. Utley and others. The Judge's speech has a historic interest and value. The Star's report said :

"Judge Utley spoke briefly and strongly in commendation of the recognition given to women in the work done by our Odd Fellow and Rebekah lodges. He thought the order a fit handmaid of the church, and that in both organizations men need the restraining influence of women. He cited as an instance of the presence of this restraint the late banquet to Father Throop, where there were ladies and no wine; and as an example of the lack of restraint, the banquet to President Harrison a couple of years ago, whereat there were no ladies, but so much wine that he had been informed a large proportion of the male guests and the waiters as well were as drunk as lords.

"Rev. Florence Kollock responded very happily to an invitation to speak. She accepted Judge Utley's estimate of the relative worth of men and women as correct; but she thought woman needs the broadening and intellectually stimulating influence of man, and that both were divinely ordered to work out the problem of life together."

Dr. Swearingen reported the following statistics of interest and historic value to Pasadena :

Sick benefits paid to members of lodge during i $893 \ldots \ldots \ldots 2,980$. 80

Sick benefits and funeral expenses for visiting brethren.... 6,54430

Total paid for relief..............................\$9,525 I0

On January 8, i 895, another open installation was held by these orders. And some statistics were then read by secretary Homer Blick (prepared by Dr. Swearingen) which show more distinctly than anything that has elsewhere been made public how heavily Pasadena is drawn upon year after year for the care and burial of sick people who come here without means. and generally too late for benefit by the climate. The table is one of special value for reference, and I quote it entire:

Lodge instituted December 3I, I885, and during the nine years we have paid to our own members 435 weeks sick benefits, amounting to....................\$3,05 I 50

Paid for nursing our own members.................... 5 I0 75

Paid for funeral expenses of four of our deceased members......................................... $25^{2} 55$

Total amount paid out for our own members...........\$3,814 80 
This lodge has relieved 78 visiting brothers, aggregating I 556 weeks' sickness, amounting to ...................

Paid for nursing visiting brothers...........................

Paid funeral expenses of I 5 visiting brothers.............

Donated an Odd Fellow's widow..........................

Donated a visiting brother.. .............................

Paid rent for a needy visiting brother.....................

Paid widows and orphans benefits.........................

5,91200

27050

I, I 5490

5000

2500

I0 40

36 I0

Total amount paid out for visitors....................\$7,458 90

Total amount paid for our own and visiting brothers.....\$ \$ I, 27370

PASADENa EnCAMPMent No. 84, I. O. O. F.- Several preliminary meetings were held in Dr. Swearingen's medical office during the winter of I887-88, by members of Encampments at Los Angeles, Cal.; Pittsburg, Pa.; North Adams, Mass.; Sterling, Ill.; Boston, Mass.; Detroit, Mich. And the order was finally instituted May 24, I888, in Odd Fellows hall in the Doty block. Its charter members were: W. A. Burdick, W. H. Darrow, A. C. Stevens, J. S. Blick, Geo. A. Durrell, Ernest Canfield. The first principal officers were: Darrow, Chief Patriarch; Burdick, S. W.; Stevens, H. P.; Blick, Scribe; Durrell, J. W.; Canfieid, Treasurer. Motto: "Faith, Hope and Charity." Sick benefits, \$4 per week. Number of members in I 894, 52. Officers: W. H. Korstian, C. P.; J. S. Blick, Scribe; A. G. Heiss, Treasurer.

Pasadena Rebekah Lodge No. 12 I, I. O. O. F., had its preliminary meeting in the Masonic lodge room, in Williams block, in July, I887, with thirteen persons present. And on August 3 it was duly instituted in the same room, with the following roll of first members: Clara D. Read, Addie E. Conover, Lona J. Ingalls, Bertha D. Denel, Carrie M. Willis, Helen Greene, Nellie M. Palmer, W. D. Read, J. F. Deuel, Dr. S. P. Swearingen, R. B. Conover, John Daly, Harry C. Mohn, A. C. Alexander, W. H. Darrow, O. W. Hooper, T. P. Larkin, S. M. Cook, J. M. Tuscher, Chas. Deuel, Devere Deuel, M. J. Green, I. A. Willis, B. F. Ingalls - 24 women and men. The first principal officers were: W. D. Read, N. G.; Bertha D. Deuel, Vice G.; Addie E. Conover, Secretary ; Helen Greene, Treasurer ; Carrie M. Willis, Warden ; Nellie M. Palmer, Conductor. Motto: "Friendship, Love and 'Truth." In 1894 there were 52 members. The only death in the order was that of Lona J. Ingalls, who died in October, I891, being at the time Noble Grand of the lodge.

\section{OTHER “BENEFIT ORDERS."}

Pasadena Council No. 199, Order of Chosen Friends. - Instituted February 5, 1889. The charter members were: A. A. Caswell, Mrs. Catharine Meek, Dr. J. C. Fraser, C. D. Middlekauf, F. E. Swift, Mrs. M. F. McClure, Mrs. H. M. Neitz, W. L. Clark, W. P. Young, Mrs. R. A. Biddle, Mrs. E. R. Biddle, W. B. Ladoux, M. C. Ladoux, J. Goodwin, C. R. Black, G. F. Mander, E. R. Biddle, R. A. Biddle. First officers : Cas- 
well, Chief Councilor; Mrs. Meek, Vice-C.; Dr. Fraser, Secretary ; Swift, Treasurer; Mrs. McClure, Prelate; and six minor offices. Medical examiners: Dr. J. C. Fraser and Dr. Kate S. Black. Motto: "Fraternity, Aid, Protection." Symbols of the order: Clasped hands, figure 7 , seven links, seven-pointed star, seven colors, the Ark, the rainborv, the triangle. Number of members in 1895 are: 16 social and 18 beneficiary-total, 34 .

Pasadena Council No. i7s, Fraternal Aid Association.-Instituted February 7, 1895, with 4 I charter members, and 23 beneficiaries who had already passed the medical examination. It is one of the Fraternity life insurance secret orders. Its first officers were: Past President, V. E. Carson ; President, A. L. Petrie ; Vice-President, Mrs. L. E. Mason; Secretary, Luther A. Brown; Treasurer, W M. Pennel; Medical examiner, Dr. F. Grinnell; Trustees, B. A. Sparks, W. Mason and A. Dougherty; Correspondent, Elizabeth Grinnell.

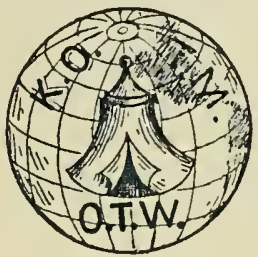

Pasadena Tent No. I, Knights of the MacCABEES. - Instituted February 26, I889, the first one in California. Among the first members were: J. K. Kelly, J. S. Glasscock, J. W. McEvers, Heman Dyer, J. F. Church. The officers in 1895 are: T. O. Prince, commander; W. H. Korstian, lieut. commander ; F. E. Burnham, record keefer ; J. W. Eyestone, finance keeper; W. S. Albaugh, chaplain; etc. [Very little data furnished.] Said to have 150 members.

Pasadena Hive No. 6, Ladies of the Maccabees. - Instituted February 26, 1894 , by Miss Bina West, official organizer for this State. It is auxiliary to the Knights of Tent No. I. The first officers were: Mary I. Furman, past lady commander; Luella Conrad, lady commander; Minnie J. McLachlan, lieut. lady commander; Kittie A. Prince, record keeper; Mary L. Pennis, finance keeper; Mary E. Shaw, chaplain; Effie J. Delbridge, sergeant; Lulu A. Clator, mistress at arms; Emma Shaw, sentinel; Ruth A. Smith, picket; Bertha L. Plant, Agnes Petrie, Ella L. Mark, banner bearers. Has about 60 members in 1895 .

Fraternal Mystic Cirche.-A secret Order bearing this name, and having a life insurance basis, was instituted September I4, IS9I, in the Knights of Pythias hall. There were 25 members, and the following were the first officers: C. A. Roberts, Worthy Ruler; S. R. Lippincott, Jr., W. Vice-Ruler; V. E. Carson, Past W. Ruler ; I. E. Barnhart, W. Chaplain ; W. N. Campbell, W. Recorder; Henry Newby, W. Treasurer; W. S. Windham, W. Collector; P. W. Walker, W. Marshal; Tilman Hobson, W. Warden; Fred. Wieck, Guard ; F. M. Plischke, Sentry ; R. A. Luckey, H. H. Hillier and J. J. Blick, Trustees. The working plan of this order did not prove satisfactory to its Pasadena members; and in time they disbanded, and all of them who could pass the rigid physical examination required by the "Royal Arcanum" joined it. 
PASAdena Councir, No. im i , Royal ARCAnum. - Was instituted April 9, I894, in Knights of Pythias hall. Its first officers were: S. R. Lippincott, Regent; Geo. A. Durrell, Vice-Regent ; F. H. Heydenreich, Secretary; W. I. Wotkyns, Treasurer; H. W. Hines, Collector. Motto. "Virtue, Mercy and Charity." It is a life insurance order, with assessments graduated according to age at time of becoming a member. Officers in 1895: Heydenreich, Regent; Lippincott, V. R.; J. J. Blick, Secy.; Wotkyns, Treas.; Calvin Hartwell, Collector.

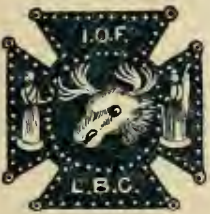

Court Pasadena No. 8365, Ancient Order ForestERS OF AMERICA.-The first meetings to talk up organization were held in the Balmoral hotel, August 28 and 3 I, I893. The order is fraternal, benevolent, beneficiary, and was founded in I745. The Pasadena Court was instituted on September 4, I893, by Deputy Grand Chief Ranger McGuinness, with 39 charter members; and the first officers were: C. W. Buchanan, Junior Past Chief Ranger; H.W. Hines, Chief Ranger; Henry Newby, Sub-Chief Ranger ; G. B. McLaughlin, Treasuer; A. F. Fuller, Financial Secretary; W. L. Lippincott, Recording Secretary; I. N. Todd, Senior Woodward; W. W. Leithead, Junior Woodward; W. S. Robinson, Senior Beadle; E. D. Tyler, Junior Beadle; Dr. H. H. Sherk, Physician ; Chas. E.Weck, T.J. De Huff, A. L. Hamilton, Trustees.

Alexandra Lodge No. 385, ORder Sons of ST. GeOrge, was instituted December I8, I894, in G. A. R. hall. The first members were: Geo. M. Boston, C. R. Balchin, F. W. Dawson, J. J. Ford, R. N. Malden, W. Stanger, J. Turner, R. Thomas, A. Wheldon, G. Wilson, H. J. Natcher, G. C. Sanderson, T. P. Adney. The first officers were: Boston, Worthy President; Wheldon, W. Vice President; Adney, Past President ; Ford, W. Secretary ; Natcher, Assistant Secretary ; Sanderson, W. Treasurer ; Thomas, W. Messenger; Balchin, Assistant Messenger. Number of members, 20. Motto : "Honi soit qui mal y pense." Benefits . \$7 per week in sickness, besides medical service; \$Ioo for member's funeral, or $\$ 50$ for wife's funeral.

\section{INDUSTRIAL ORDERS.}

CARPENTERS' UNION.- An article in the Valley Union of July 2, i 886 , says: "About roo carpenters and joiners of Pasadena and vicinity assembled at Williams hall Saturday night to consider the matter of organizing a Carpenters' Union. A delegation of nine from Union No. 56, Los Angeles, were present to explain the workings and objects of the organization. Twenty-four carpenters signed the roll as charter members, to organize a Pasadena Union next week." No names are given, and I found nothing more about it until the same paper of September 25, I886, published a series of resolutions by the contracting employers. The union had de- 
manded that after October I, I886, they should work only nine hours, and have the same wages per day as they were then getting for ten hours. In opposition to this, the contractors adopted a series of explanatory and declaratory resolves, the gist of which was that they did not object to nine hours as a day's work; but - " Resolved, 3d: That we most positively refuse to increase the present price per hour for labor, " etc.- the reasons for which are set forth at considerable length. And the document is signed by Buchanan Bros., C. B. Ripley, Seth Glidden, C. Ehrenfeld, H. H. Linville, Robt. Wetherill, C. W. Abbott, Swift Bros., A. Thorns, Lindsay Bros., Geo. D. Webster, Charles Crew, H. Wesley - all the carpenteremploying firms in Pasadena at that time. The result was that nine hours became a day's work in that trade, but only nine-hours pay was allowed. Some workmen quit and left town; some continued to work ten hours a day; some worked nine hours only. The building boom soon began to decline, and when it finally broke, the Carpenters' Union died out, for it came to that that men were glad to get work at almost any price. However, by 1891 business began to revive in this line, and

LOCAL UnION No. 645, of the Brotherhood of Carpenters and Joiners of America, was organized in the old Library building on Dayton street, January 3, 1892 , with fifteen charter members. The first officers were: J. S. Withiel, president; S. H. Porter, recording secretary; H. E. Shaw, financial secretary. The information is given me that in the spring of 1893 this Union succeeded in establishing eight hours as a day's work, instead of nine hours, for carpenters in Pasadena. Its officers in 1894 were: S. H. Porter, president; J. O. Burdick, vice president; H. H. Hillier, recording secretary; S. A. Rene, financial secretary; Christian Hanson, treasurer. Motto: "Labor Omnia Vincit." It is a beneficiary order, with fraternal, social, and industrial objects also in view.

KNIGHTS OF LABOR.- Pasadena Local Assembly No. I05I - founded April 7, 1888. Met in the Mills block. Motto: "An injury to one is the concern of all." Names of officers and charter members not furnished. But an official document is furnished, in which occurs this instruction :

"Above all things you are required to exercise the right of suffrage intelligently, and above partisan prejudice or bias. Do not vote for party before country. ** While the order is not a political party, it knows of no methods by which legislative reforms can be brought about except through a wise and intelligent use of the ballot. The aim of the order is to educate its members, and to mutually assist each other in every lawful and practicable manner."

Pasadena Union No. 92, Brotherhood of Painters and Decorators of America ; organized February 3, 1892. Motto: "Labor Omnia Vincit." Names of members and officers not furnished. Objects - Mutual aid, both socially, intellectually, and industrially to members of the craft. Benefits : Member's funeral, $\$ 50 ; \$ 100 ; \$ 150-$ according to period of membership. 
Permanent disability, same figures. Wife's funeral, $\$ 25 ; \$ 50$. Meetings Monday evening, in Arcade building.

Builders' Exchange. - Purely mutual and voluntary. Fifty members have boxes each for their own business, at office of Simons Bros. Brick Co. It is a place and facilities for conference on all matters as to cost of material, cost of labor, sub-letting of contracts, etc., on buildings, sewer work, street work, tunneling, excavating, cement work, brick laying, and all manner of trades work in these lines.

\section{NATIONALIST CLUB.}

The first record that I found of this society was dated August 9, I889, and said: "The third meeting for the consideration of Bellamy's book, and other social reforms, took place in the parlor of the Universalist church. Attendance, forty-eight. The subject of the evening was the 'Single Tax Sy'stem' of Henry George." At this meeting E. D. Neff was chairman, and Miss Laura B. Packard secretary; and the speakers mentioned were Walter Leavens, Dr. Lyman Allen, Mrs. Katie H. Keese, Mr. - Rhodes, Mrs. Sophia K. Durant, J. B. Corson. The weekly meetings are recorded as of "The Social Improvement Club," and seems to have had no regular officiary up to October 5, I889; but on this date the name "First Nationalist Club of Pasadena" was formally adopted, and a board of officers elected as follows: E. J. Durant, president; M. Larkin, vice president ; L. H. Bannister, secretary ; C. T. Dxss, treasurer ; Walter Leavens, W. H. Clark, J. Albertus, advisory committee. The meetings continued to be held weekly in the Universalist church basement until December 29; then they were held in Wooster hall until August 17, 1890, when they returned to the Universalist church again. And at this meeting the record says : "The secretary stated that the meetings seemed to be doing but little good, that many are losing interest, and they are at best but poorly attended." And this meeting ended the club's active existence, for no further record appears. At this time there were ninety-nine names on its roll of membership; yet more than half the names mentioned from time to time as taking part in the proceedings do not appear among the ninety-nine.

During the life of this organization it was a thing of note, and was always dubbed in press and common speech as "The Bellamy Club." Among the prominent people who gave lectures, addresses, sermons, topical papers, or the like under its auspices, were: Rev. E. L. Conger, D. D.; Mrs. Jeanne C. Carr ; Prof. James G. Clark, the eminent poet, music composer, and sweet singer; Rev. D. P. Bowen, author of "The Ideal Republic"; Rev. R. M. Webster, the apostle of "Applied Christianity"; Dr. O. H. Conger; Dr. Sivartha of Chicago, known as a "re-incarnationist"; Rev. Doremus Scudder, D. D., a Congregationalist minister of national famepublic lecture in Williams hall; Dr. Kate S. Black; Abbot Kinney, of the 
State forestry commission; Charlotte Perkins Stetson. Also many persons of lesser note spoke there.

June 8, I 890, was observed by this club as Woman's Day ; Mrs. Larkin acted as president and Mrs. D. W. Leavens as secretary; the proceedings were joined in by Mrs. Julia B. Sunderlin, Dr. Kate S. Black, Miss Marie A. Walsch of Los Angeles, Mrs. Sophia K. Durant, Mrs. Jeanne C. Carr, Miss Louise A. Off of Los Angeles.

\section{PEOPLE'S SOCIETY FOR ETHICAL CULTURE.}

This was assembled in the Conservatory of Opera hall, North Fair Oaks Avenue, October I I, I89r; and the records of the first meeting say : "Meeting composed chiefly of the elements of the old Nationalist organization." The formal organization was made October 18 , with 23 members, who elected for officers : M. Larkin, president ; C. F. Harris, vice-president; Mrs. D. W. Leavens, secretary and treasurer; L. H. Bannister, H. G. C. Gordon, Mrs. N. L. Ingham (besides the officers), executive committee. There was some difficulty in choosing a name; and the above rather lengthy name was finally adopted as a compromise. The declared object was: "The firiendly consideration and discussion of all questions affecting the social wellbeing of the human race." Meetings were kept up until June 5, I 892. No record appears after that date.

\section{SOCIOLOGICAL SOCIETY.}

Organized April 27, I895, in G. A. R. hall, with the following officers: Elias Smith, M. D., president ; Miss Emma C. Lentz, vice-president ; Frank Merritt, secretary and treasurer; Miss Carrie I. Smith and James Semple (with the officers), executive committee. Object: To discuss the live questions of the day. Motto: "Hear all sides." It is a successor to or re-incarnation of the old "Society for Ethical Culture." Names new, but plan and purpose substantially the same.

\section{- altruRIa ASSOCIATION - PASAdENA COUNCIL NO. 7.}

Organized August 22, 1894, in G. A. R. hall, with eleven active members. First officers: Geo. A. Swerdfiger, president; Mrs. E. A. Emerson, vice president ; Mrs. Katie H. Keese, secretary ; D. A. Harrison, chaplain; L. H. Bannister, supèrintendent; Mrs. Harrison, treasurer. Later the meetings were held bi-monthly, at Prof. Harrison's residence. This is one of eight councils connected with the co-operative colony called Altruria, in Sonoma county, Cal., the others being located at Altruria, Berkeley, Oakland, San Jose, San Francisco, and Los Angeles. In April, I895, W. I. Keese and family went from Pasadena to reside in the colony, and Mrs. Emma F. Gardner was elected secretary in Mrs. Keese's place. In May, r895, there were fourteen members. 


\section{CHAPTER XXVII.}

APTITUDES.-Literary, Charity, Nativity, and Sporting Organizations.

\section{LITERARY SOCIETIES.}

During the winter of $1875^{-76}$ the colony people organized a literary society, which covered the whole ground of essays, debates, recitations, a penand-ink local paper, dramatic performances, etc. For more particulars of this first and richly historic society, see pages $\mathrm{I} 37, \mathrm{I} 47$, and 169 .

Ponological, SocIETY. - The first fruit growers' organization in Southern California was organized in Pasadena in 1875 , and was in fact a literary society, to report, read, compare experiences, and discuss on all fruit-growing topics and interests. It met monthly in the colony schoolhouse; but I did not find any further details.

Chautaugua Literary and Scientific Circle of Pasaiena. - This was organized in October, I884; and the Valley Union of October I I said:

In pursuance of a notice in the Union of October 4, a meeting was held in the inner room of the Public Library building, Monday evening, for the purpose of forming a C. L. S. C. in Pasadena. A large Circle was organized, of which Prof. E. T. Pierce was elected president, and Mrs. S. E. Merritt, secretary. The following names were offered for membership: Prof. E. T. Pierce, George E. Meharry, Moritz Rosenbaum, Mrs. L. T. W. Conger, Mrs. H. W. Magee, Mrs. Caroline Ridgway, Mrs. N. M. Hisey, Mrs. E. T. Pierce, Mrs. G. E. Meharry, Mrs. M, Rosenbaum, Mrs. M. E. Gallmeyer, Mrs. C. C. Robinson, Mrs. S. E. Merritt, Miss Hannah Ball [now Mrs. F. R. Harris], Miss L. H. Hisey, Miss Elma Ball [now Mrs. H. I. Stuart], Miss Rhoda Dickey, Dr. John Cleaver, Prof. F. D. Bullard, Wm. B. Mosher, H. Bert Ellis [now Dr. Ellis of Los Angeles], Edward Mosher."

Others soon joined, but these were the only names enrolled at the first meeting. They kept up their meetings and readings for about six months, then gradually dropped out, and this first Circle died.

MARENGo Avenue Circle, C. L. S. C., was organized in November, I886, at Switzer's camp, away up in the mountains via Arroyo Seco canyon. Those who formed it there were: Mrs. C. A. Boynton, Frank S. Wallace, Miss Mary Wallace [now Mrs. F. S. Johnston], Mrs. H. E. Lucas, Miss Annie P. Boynton [now Mrs. Dr. Bleecker], Miss S. E. Sherburne, Mr. Lewis Carlisle. Mr. Wallace was chosen president, and Miss Boynton secretary and treasurer. This organization still continues, and its officers in I 895 are: H. N. Van Nuys, president; J. W. Sedwick, vice president; Miss Rosa Allin, secretary ; L. L. Test, treasurer. About twenty-five members.

Escholtschia Crrcle, C. L. S. C.-Limited to a membership of ladies only, and not more than twelve at one time, and day meetings only. This was organized September 27, I89o, with Miss Elma Ball, Mrs. T. C. Foster, 
Mrs. F. R. Harris, Mrs. August Meyer, Mrs. C. D. Sargent, Mrs. F. A. Stout, and a few others, as first members. They completed the four years course, and four of them-Madames Foster, Meyer, Sargent, and Stout, received diplomas; but others did not apply for them. In June, I 894, when the Chautauqua curriculum had been completed, they changed the name of their society to the "Monday Afternoon Club," and still continue their meetings and readings on lines of their own choice.

Delphi Circle, C. L. S. C.-This was organized October 2, I\&92, out of the Marengo Av. Circle, and is still in existence, 1895 ; but no data furnished.

Olivewood Circle, C. L. S. C.-Organized October 2, i892, out of the Marengo Av. Circle, to serve as a local for residents of Olivewood and vicinity. It was kept up for one Chautauqua year, then disbandedsome of its members going back into the parent circle and some into the Delphi circle.

The following is a list, as nearly complete as I could gather, of persons who have graduated from Pasadena circles and received the Chautauqua diploma: Mrs. O. H. Stanton, Mrs. Anna H. Johnston, Mrs. Annie P. Bleecker, Mrs. Frank S. Wallace, Mrs. Susie Holmes, Miss Maude Jacobs [now Mrs. Winter], Mrs. T. C. Foster, Mrs. August Meyer, Mrs. C. D. Sargent, Mrs. F. A. Stout, Mr. F. S. Wallace, Mr. A. B. Stevens.

Yucca Circle, C. L. S. C., South Pasadena.-Organized in October, I 887 , by Mrs. A. A. Burrows, Miss L. E. Whiting, Miss C. M. Bishop, Mrs. Gertrude Case [now Mrs. Bridges], Miss Rebecca Graham, Miss Belle Everett. [Mrs. Burrows was one of the first members and first graduates of the first Chautauqua class or circle ever formed in the world. That class was enrolled on the banks of Chautauqua lake, in i 878 , while Rev. Dr. Vincent was standing on a stump addressing them. She joined this Pasadena circle to review.] Its graduates have been : Miss Bishop, r891 ; Mrs. Leo Longley, I892; Harry W. Cunningham, 1893. In June, 1893, this circle died.

The Cynthia Bishop Cirche, C. L. S. C., South Pasadena,-Organized in October, I894. Miss — North, president; Miss Elva Swith, secretary.

The Shakspeare Club.-The beginning of this society was during a session of the Ladies Aid Society of the First Congregational church, in June, I888, when Miss Claribel Thompson and Mrs. Lydia Nash privately talked over the matter of having a ladies' literary society or club, and agreed to start one. Accordingly they appointed a meeting for the next week at Miss Thompson's home on Palmetto street. Other ladies had been invited, but only those two came. They, however, proceeded to formulate the plan for future meetings, and decided on Shakspeare as the first author to take up. At the next meeting there were three recruits - Miss Ellen F. 
Thompson, Mrs. Ella Allen and Mrs. Dr. Page. After this the attendance steadily increased; and on August 31, I888, a formal organization was made, under the name of "Women's Reading Club," with twelve members. Miss Ellen Thompson, president; Mrs. Lydia Nash, vice-president; Mrs. Henry G. Bennett, secretary and treasurer. It was soon found that the initials, W. R. C., of the name adopted being used in the newspapers, were always mistaken for the well known "Woman's Relief Corps" secret order; and therefore in March, I889, the name "Shakspeare Club of Pasadena" was substituted. The club has pursued a systematic study of the social and domestic life, architecture, literature, music and art works, industries, general history, etc., of different nations. The officers in 1894 were: Mrs. Prof. Keyes, president; Mrs. Frances A. Stout, vice-president; Mrs. Martha B. Pitkin, treasurer; Mrs. Ella B. Gabriel, secretary. The meetings were held at members' homes, by appointment, until ı 893 , when G. A. R. hall was secured.

The Fortnightly $\mathrm{Club}_{\text {b }}$ is a literary and public lecture association connected with the Universalist church. It was organized during the winter of 1892-93, and has continued since.

There are several local or neighborhood reading circles or clubs, in addition to the public ones above recorded.

Pasadena Medical Association was organized April 2, i889, by Drs. A. H. Davis, D. B. Van Slyck, N. A. Dalrymple, F. F. Rowland, Kelsey, - Pinckney. In I89i Dr. Van Slyck was their delegate to the State Medical Society. In 1895 the officers were: Van Slyck, president; Rowland, secretary. The objects are, to have reports and discussions on medical and sanitary matters, maintain a legitimate fee bill, promote fraternal relations, etc. In February, I895, they took strong ground in favor of police regulations to prevent the spread of consumption in Pasadena, and on other points of sanitary policeage.

\section{CHARITIES AND BENEVOLENCES.}

Charity Organization Societry. - The first meeting was held at M. E. Wood's real estate office on Colorado street, June 28, i889. Those present were: J. A. Buchanan, A. B. Manahan, W. U. Masters, D. Galbraith, W. E. Arthur, Dr. O. H. Conger, Rev. Dr. E. L. Conger, Dr. G. Roscoe Thomas, M. E. Wood, B. Marshal Wotkyns, Isaac Springer, Miss Anna L. Bartlett, Dr. Eliza Beach. A provisional organization was formed, and committees appointed to work up public interest. Then on August 20 a general public meeting was held in Williams hall, and officers elected, towit : Buchanan, president; A. F. M. Strong, vice president ; Isaac Springer, secretary; M. E. Wood, treasurer. And Buchanan, Strong, Masters, Rev. Conger, Dr. Eliza Beach, Miss Bartlett, and Miss J. C. McGuire, as an executive committee. The objects were stated to be: 
I. To see that all deserving cases of destitution are properly relieved.

2. To prevent indiscriminate almsgiving.

3. To secure the community from imposture.

4. To make employment the basis of relief.

The necessity for this organization was forced upon a committee engaged in soliciting aid for the sufferers by the terrible flood at Johnstown, $\mathrm{Pa}$., and great fire at Seattle, Washington, early in 1889 . At the Williams hall meeting, August 20, this committee reported nearly $\$ \mathrm{I}, 200$ collected; $\$ 500$ of it had been sent to each of the stricken cities, and the balance was turned over to this charity society. A published report of its transactions in I 891 showed a total of $\$ 6$ I 8.2 I received, and $\$ 359.35$ paid out. Of the amounts received from various sources there were: $\$ 33.50$ from donations; $\$ 62.9$ I from the President Harrison reception; $\$ 35$ from Los Angeles county; $\$ 284.97$ from the Chrysanthemum Fair.

The main purpose of this society is to secure mutual co-operation and oversight of all charity work in the city, so as to prevent imposture by professional beggars, chronic tramps, vagrants, etc.; to avoid overlapping of work : to aid promptly the worthy destitute who are not otherwise cared for; and to secure employment wherever possible for those in need. On this basis, there were in March, I89I, twenty-three churches and other organizations reported as thus co-operating under this society. In 1894 there were about fifty members, and the officers were: Buchanan, president; F. H. Vallette, vice president; Miss Bartlett, secretary; A. H. Conger, treasurer. Executive committee: President Buchanan, W. U. Masters, Mr. Vallette, Rev. C. E. Harris, Rev. Conger, Mrs. Judge Hester, Mrs. Glendora Kyle.

ORDER OF King's DAughtERS.- "Cheerful Workers" Circle No. I, was organized June 9, I888, by Miss Maude M. Marriner, with ten girls out of her class in the Methodist Sunday school; aud this was the beginning of the order in Pasadena. The first officers were: Miss Marriner, president; Nellie Austin, vice president; Helen Johnston, secretary; Jessie Buckius, treasurer. Motto: "In His Name." Object: Every sort of work and duty that will put the precepts of Christ into practice. Groups of "tens" select some special thing as their special work. This Circle gave its first public entertainment on September 25, I888, in the M. E. church, and cleared $\$ 65.80$ for their treasury. Miss Marriner died in I892, but her good work abides.

"The Whatsoever Circle," O. K. D., is connected with the First Presbyterian church; and its officers in 1894-95 were: Miss Ella Webb, president; Miss Pearl Van Doren, secretary; Miss Ethel Grey, treasurer.

UNited Samaritan Societr.-This was an outgrowth of the Ladies Union Prayer Meeting, and was organized June I8, I889, at the Presbyterian church, there being 55 first members. The name itself indicates its 
object. The first officers were: Mrs. Mary S. Mosher, president; Mrs. Elizabeth R. Townsend, vice-president; Mrs. H. Dyer, secretary ; Mrs. Hester J. Griffith, treasurer. And a board of managers composed of one from each church represented in the society. In 1890 , and each year since, the collection taken up at the Union Thanksgiving service has been given to this society; and the sum total, together with other freewill offerings, has been for the five years $\$ 793.35$. In the same time about 900 articles of clothing were received and given out. During I 894 about I50 visits were made to families needing aid and Christian sympathy, besides visits to prisons and hospitals. The Thankgiving collection this year was $\$ 59.32$; the individual offerings, $\$ 48.55 \mathrm{in}$ cash and $\$$ roo value in food supplies. With these means, 48 distressed families were aided; and 300 articles of clothing donated were placed where there was suffering need. On Thanksgiving day 23 families received dinners, groceries and clothing. It is a principle with this society not to get up any balls, fairs, suppers, bazars, concerts or public entertainments of any sort, to raise charity funds by indirect methods. All their resources are from freewill offerings, made directly and purposely for this Christlike work. Officers in 1885 : Mrs. S. E. Bosley, president; Mrs. A. F. Keyes, vice-president ; Mrs. Dyer, secretary: Miss E. E. Fish, treasurer.

MON'TClair ChildREN'S HOME.-About August I, I891, Dr. J. R. Townsend was appointed superintendent for Southern California of the National Children's Home Society (headquarters at Chicago), devoted to the work of getting homeless children into childless homes; and Mrs. Townsend was made assistant superintendent. They opened a temporary home to take in and care for homeless waifs until they could be placed in suitable familes either by guardianship or le-

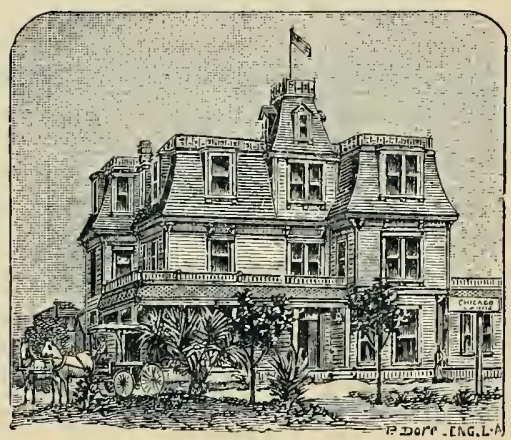

MONTCLAIR CHILDREN'S HOME-I895. gal adoption. In 1892 , a Rev. D. D. was sent here from the Chicago authorities as their general superintendent in California, whose manner was such that the whole business seemed to be a mere begging machine for raising money to pay his salary of $\$ 2,000$ a year and expenses; and our people didn't hanker for that sort of "charity."

The Montclair* Children's Home Association was organized December 20, I893, with Hon. P. M. Green, D. Galbraith, Rev. C. C. Reynolds, Mrs. S. V. Maxfield, Ernest Canfield, Henry Cooley, Dr. J. R. Townsend, as board of trustees ; and a State charter was granted them January I I,

* The name "Montclair" was given to this Home by Dr. Townsend and wife, as a memorial to their tittle son of this name, who died on the island of Jamaica, West Indies, while they were in service as missionaries there. 
I894. The same plan and objects was continued as before, with Dr. Townsend and wife as managers. Mrs. Townsend was also State superintendent for that department of work in the W. C. T. U. A report made to the State W. C. T. U. in May, I894, showed the parentage of children cared for at this home up to that date, thus: French, I ; Danish, I ; Spanish, I ; Swede, I; German, I; Negro, 3; white American, 49. There had been returned to friends, 4 children ; placed in homes, 23 ; secured iegal adoption, 3. A quarterly paper to represent this work was commenced in June, 1894 .

Freewill Children's Home. - In August, i893, Miss Olive L. Cleveland bought a property that had been built and fixed up for a saloon and beer garden in South Pasadena, and had been so used until the city authorities there drove out that nefarious business. She made suitable changes in the place, and opened it as a Home for destitute children, and for half-orphans, and for those needing temporary care till other provision can be made for them by parents or relatives. Those who can pay in whole or in part for cost of board, do so; but many children have to be kept purely as charity cases. Iu I895 the Universalist parish of Pasadena took a special interest in aiding this orphanage. Miss Cleveland was 70 years old April 4, I 895, and had then ro children in care.

PASAdena Humane Society, for prevention of cruelty to animals and children. Organized October I8, I894, auxiliary to the Los Angeles Humane society, and under sanction of the State law as re-enacted by the legislature of $1873^{-74}$. The charter members were: Dr. F. F. Rowland and wife, the meeting being at his office; Dr. Ward B. Rowland, Dr. G. Roscoe Thomas and wife, Mrs. Wm. Stanton, Dr. J. R. Townsend and wife, B. W. Hahn, Esq., Dr. Kate S. Black, Mrs. M. Dreer, E. E. Jones and wife. First officers were: Dr. F. Rowland, president ; Wm. Stanton, vicepresident; Dr. Townsend, secretary; Dr. Thomas, treasurer; W. B. Rowland, V. S., consulting veterinary surgeon; B. W. Hahn, attorney; Mrs. Wm. Stanton, Mrs. E. T. Howe, additional directors. August I, I 895, officers were the same; and there was an enrollment of 57 members. Mrs. E. R. Townsend and Miss Olive Cleveland stand as honorary members, in recognition of their faithful and devoted labors for orphan children.

NATIVITY ASSOCIATIONS.

The New England Societry.- Its formation was suggested by the incident of Geo. A. Durrell meeting Mrs. S. E. Merritt at the Pasadena Library rooms on Dayton street, both being from Massachusetts. Mrs. Merritt suggested the forming of a society of Massachusetts residents. Mr. Durrell amended this suggestion with another, the forming of a New England society; whereupon it was agreed to call a meeting of the sons and daughters of New England. Mr. Durrell hired the kitchen room of Williams hall, and advertised a meeting for March 16, 1887. There were present at 
that meeting the following, viz: Geo. A. Durrell, of Lawrence, Mass. (born in Sanbornton, N. H.); P. G. Wooster, Hancock, Maine (born in same place); Mrs. Mary A. Wooster, Edgartown, Mass. (born in same place); Thos. F. Flynn, Boston, Mass. (born in same place); O. J. Muchmore, Thetford, Vermont (born in Lebanon, N. H.); Mrs. O. J. Muchmore, Monmouth, Maine (born in same place); G. S. Elsmore, Calais, Maine (born at Cooper, Maine); Mrs. G. S. Elsmore, St. David, N. B. (born in Cooper, Maine); Mrs. E. J. McDermid, Skowhegan, Maine; Mrs. Alice M. Hildreth, Gardiner, Maine; S. L. Tuttle, Vergennes, Vermont (born in Monkton, Vt.); Mrs. S. L. Tuttle, Vergennes, Vermont; W. S. Holland, Pauton (born in Burlington, Vermont); his wife, Adeline, of Addison (born in Burlington, Vermünt); Albert P. Tower, Charlestown, Mass. (born in Somerville, Mass.); William T. Reid, Litchfield, New Hampshire; Joseph Smiley, Sydney, Maine (born in Skowhegan, Maine); Mary F. Smiley, Camden, Maine (born in Skowhegan, Maine); John C. Costello, Boston, Mass.; James E. Place, Portsmouth, New Hampshire (born in Cohoes, New York); James E. Clarke, Newcastle, Maine (born in Augusta, Maine); F. M. Hovey, St. Johnsbury, Vermont ; Jared Norton, Cottage City, Mass. (born at Edgartown, Mass.); Harry E. Lucas and wife. B. O. Kendall and wife, Theo. Harrington and wife.

This society was organized with constitution and by-laws, and had 197 members, all told. It held twenty-three meetings, beginning with March 16 , I887, and ending April 5, I889. P. G. Wooster was the first president; reelected January I9, I888. W. S. Wright was second president. Geo. A. Durrell was the first and only secretary. First treasurer, J. E. Farnum; second, W. S. Wright ; third, Mrs. Mary A. Wooster. First vice presidents representing the six New England states were: Mrs. E. S. Frost, Maine; Mrs. O. J. Muchmore, New Hampshire; Mrs. I. M. Hill, Vermont; Mrs. S. E. Merritt, Massachusetts; Mrs. I. B. Clapp, Connecticut; Mrs. Julia E. Briggs, Rhode Island. A big picnic was held at Lincoln Park, April 26, I887. Afterward meetings were held from house to house; the first at P. G. Wooster's, November IO, I 887, at 3 I I North Raymond Avenue ; and the last at Wooster block, April 5, I889. November 24, 1887, the sosiety had a large gathering and big Thanksgiving dinner at Williams hall; I 50 persons sat at the table. [This historical sketch furnished by Mr. Wooster.]

There have been also an Iowa Association, a Vermont Association, a Whiteside county (Illinois) Association, a Scottish Association, an Ohio Association, and perhaps others ; but they have not been kept up, and no data were furnished me.

SPORTING ORGANIZATIONS.

The Pasadena Rifle TEAM.-This was the first organization of the sort in Pasadena, and was formed during the winter of $1881-82$. I wrote to its secretary (C. H. Watts, now residing at Downey) for information, but 
received nothing; and from other sources I gathered the following list of names who were members of it: Col. Jabez Banbury, H. H. Markham, Chas. H. Watts, David Townsend, F. H. Heald, E. G. Halleck, E. F. Hurlbut, J. D. Gilchrist, J. H. Baker, Joseph Wallace, Seymour Locke. They had a practice ground on the Arroyo bottom about half a mile below where the Scoville bridge now stands. The ground was in 1884 turned into a Chinese market garden, and two or three years later was nearly all washed away. During the winter of $1884-85 \mathrm{Mr}$. Watts sold his Pasadena property and went into a livery stable business in Los Angeles; and the "Team" had a prize shoot there on April 28, I 885, for two cups given by Mr. Hurlbut. I found no tradition or record of any of their doings after this date. [See Gov. Markham's bear story, page 45I.] Mr. Townsend had died in 1883 ; Halleck went back to Wisconsin into some sort of railroad business: Heald went to Elsinore, became an editor, boomed a town, and busted; Markham was elected to Congress, then to the State governorship; Banbury started a lumber yard, then was elected to the legislature, and had no time for sporting any more; Wallace started a cannery, and had his hands full; Gilchrist started a great printing establishment in Los Angeles, and was tied up there; Baker built the Acme hotel; and so Pasadena's historic "Rifle Team " was scattered and broken up.

VAllay Hunt Cl,UB.-Organized November 3, I888, with the following persons as charter members :

F. F. Buell,
W. U. Masters,
H. H. Suesserott,
T. B. Barnum,
C. F. Holder,
R. Vandevort,
P. Martin,
Dr. H. N. Hall,
Dr. H. H. Sherk,
W. Browning,
Conway Campbell-Johnston,
Henry F. Pratt,

Ladies.
Mrs. Buell,
Mrs. Masters,
Mrs. B. M. Wotkyns,
Mrs. Barnum,
Miss J. Patten,
Miss M. Greenleaf,
Miss T. Greene,
Miss Fanny Cole,
Miss Mary Cole,
Miss E. S. Reid,
Miss - Peck,
Miss Fannie Shoemaker,
Miss Susan Carter.

Honorary members: J. DeBarth Shorb, Jr., Arturo Bandini, Count Von Schmidt. The first officers were: Barnum, president; Holder, vicepresident; Mrs. Wotkyns, secretary; Mr. Buell, treasurer. Masters of Hounds: Dr. Hall, Messrs. Browning, Vandevort and Campbell-Johnson. The club color is "Red." The objects set forth are: "The hunting of the jack rabbit, fox, and other wild game, with horse and hound; the e11couragement of horseback riding;' etc. This club made itself historic in a large sense by getting up and managing for several years a great New Year pageant and festival called the "Tournament of Roses," which has 
thereby become established as Pasadena's most characteristic annual festivity. The association owns its Club House property at the head of Colorado court, estimated worth $\$ 6,000$. Article I of Constitution limits the active membership to roo (admission fee \$IO); and in $1894-95$ the roll was full, besides applications awaiting vacancies.

At a meeting on November I8, I 892, articles of incorporation were adopted and the following board of directors chosen: F. C. Bolt, C. D. Daggett, W. L. Wotkyns, E. H. May, F. F. Rowland. And on the 23d they were sworn into office by Notary Public W. R. Staats. The principal officers in I 895 were: C. D. Daggett, president; L. C. Torrance, vicepresident ; N. W. Bell, secretary ; W. R. Staats, treasurer ; and these, with Wm. Stanton added, are the board of directors.

Company "B," of N. G. C.-The Pasadena Standard of December 28 , I889, said :

"The Pasadena company for the California National Guards was mustered in last Monday evening [December 23], with 66 members. The officers elected were: For Captain, Lawrence Buckley, I2 years lieutenant and drill master in the New York 7 th regiment; for Ist Lieutenant, A. I, Hamilton, principal of the Garfield school; for $2 \mathrm{~d}$ Lientenant, James $\mathrm{H}$. Cambell, city clerk. They will be known as Company $B$, 7 th regiment. The State allows them $\$$ r,200 a year for hall rent, and this ought to secure an Armory Hall in good style."

Capt. Buckley resigned October 30, I890, and on December I, I890, A. L. Hamilton was elected Captain ; Jas. H. Cambell, ist Lieut.; N. S. Bangham, 2d Lieut. In September, I 89I, Capt. Hamilton and ist Lieut. Cambell resigned, and on October 5, I89 I, N. S. Bangham was elected Captain; V. R. Sutliff, Ist Lieut.; and P. J. Cook, 2d Lieut. May 20, I893, Capt. Bangham resigned; and Lieut. Cook was elected Captain; Corporal Frank J. McGowan promoted ist Lieut.; and Corporal R. Collingwood, Jr., 2d Lient. - all to rank from December I I, I 893. January 24, I895, Capt. Cook and Lieut. McGowan resigned; and N. S. Bangham was again called to the captaincy; Collingwood was promoted to Ist Lieutenant, and Q. M. Sergeant Chas. H. Cole was made $2 \mathrm{~d}$ Lieutenant - all to date from February I 8,1895 .

The company celebrated its second anniversary, December 23, I89I, at the Painter hotel, in full dress uniform and accompanied by ladies. Capt. Bangham was in command, and had as guests Col. Schreiber of the 7 th regiment, and Lieut.-Col. Howland, from Los Angeles. Its third anniversary was held in its own Armory hall in the Morgan block, over postoffice, on Raymond Avenue, December 23, 1892. A report made at this time gave the public parades in which the company had taken part, as follows :

February I 2, I 890, at the laying of the corner stone for Whittier Reform School, with 50 men. 
March I 2, I 890, at Cross railway celebration, Pasadena, with 54 men.

May 30, I890, at Memorial Day parade as escort to the G. A. R. in both Pasadena and Los Angeles, with 48 men.

July 4, I890, at both Pasadena and Los Angeles, with 46 men. men.

September 9, I89o, at.Admission Day celebration, Pasadena, with 53

April 22, 1891, as escort to President Harrison, in Los Angeles, with 35 men.

July 4, I891, in Los Angeles, with 35 men.

July 4, I892, in Pasadena, with 45 men.

October 2I, I 892, at Columbian celebration in Pasadena, with 42 men.

At the company's fifth anniversary only four of its original members had been on the roll continuously from the first - to-wit : Ed. C. Clapp, C. H. Cole, Frank L. Heiss, and J. G. Rossiter. Two others, Collingwood and Willis, had been out awhile, then returned.

Pickwick Club.-This was designed for a social, literary, dramatic, and other pastime assemblage of a select circle, its original projectors being J. M. Shawhan, W. L. Vail, W. J. Craig, F. J. Polley, B. W. Bates, C. W. Bell, and others. The first meetings were held in the "kitchen" room connected with the three halls in Williams Hall block. But the club was finally organized in the old Central School building, on Raymond Avenue, in I 887, with about roo first members. Its first officers were: Byron W. Bates, president (he was then cashier of the S. G. V. Bank); J. M. Shawhan, secretary and treasurer. When the south half of Hotel Green was first built (then called the "Webster"), a suite of rooms were specially" planned there for this club, including a large dance hall and assembly room, with stage and dramatic fixtures, - all fitted and furnished in most elegant style - a regular society "boom," in keeping with the real estate boom. The club had its full share of ups and downs, ins and outs, trials and tribulations, but still continues to exist, the officers in $\mathrm{r} 895$ being: C. B. Thomas, president ; Hon. C. M. Simpson, vice-president ; L. J. Huff, secretary and treasurer. This club once entertained a son of Charles Dickens, the great English novelist, from whose "Pickwick Papers" the club took its name. They also entertained Thomas Nast, the famous cartoon artist of Harper's Weekly. These were, perhaps, the most notable historic incidents in the club's record thus far.

PASAdENA Athletic Club, was organized in August, I890, as an offshoot from the Pickwick Club, its chief promoters being H. R. Hertel, F. Martin Summers, C. W. Bell, F. J. Polley, and a few others. Mr. Summers was the first president; and at the end of his first term [he was reelected] he reported the receipts as nearly $\$ \mathrm{r}, 000$-all debts and expenses of the club paid-and a balance of $\$ 65$ in the treasury. The club had leased and fitted up a gymnasium and social rooms in the old Central school building on Raymond Avenue. Then in November, I89r, they leased ground 
between Fair Oaks and Raymond Avenues below Vineyard street, had an oval one-sixth of a mile track graded, tiers of seats erected, etc., to exhibit sporting events. And on December 24 following, they gave a great Field Day of athletic sports for which 48 entries were enrolled for the different events; and the following gentlemen served, according to printed program, as officers of the day: Starter, H. R. Hertel ; referee, F. Martin Summers; clerk of the course, C. W. Bell ; field judges, B. O. Kendall, H. E. Pratt and P. W. B. Walker ; timers, C. S. Martin, J. W. Wood and H. H. Rose ; finish judges, Cal. Hartwell, C. L. Miller and F. J. Polley ; official scorer, J. G. Rossiter ; official announcer, Geo. Frost ; marshal, Geo. Greeley. On August 23, 1893, occurred the great celebration on the completion of the Electrie railroad up Echo mountain, and known as "Prof. Lowe Day," this club gave a series of athletic events as part of the day's festivities.

In 1894 Thomas Banbury bought the old school building and moved it away. The club found no other quarters to suit their case; and now, in 1895, it is in a state of languishing desuetude.

Crown City CyCle Club.-Meetings to talk the matter over were held at Braley's Bicycle Emporium rooms on Raymond Avenue; and the club was organized there on July 25, I894, with the following roll of members : Chas. C. Glass, E. W. Flint ; E. R. Braley, J. S. Evans, S. E. Downey, R. V. Dey, W. H. Stewart, A. F. Canfield, A. L. Ryder, R. H. Hargreaves, L. Freeman, E. D. G. Campbell, R. H. Gaylord, C. A. Johnston, Ed. Gamble, W. B. Willis, A. G. Stevens, W. T. Stevens, W. Seamons, F. H. Smith, N. White, Harry Myers, C. H. Hillard, Wm. Crowell, Geo. Dell, Thomas Ralphs. The first officers were: Glass, president; Braley, vice-president; Flint, secretary; Gaylord, treasurer. The club colors are orange and green. This club's by-laws declare that no intoxicating liquors nor gambling of any sort shall be allowed in the club rooms; and no runs shall be made by or in the name of the club on Sundays. There were 45 members in March, I895. C. Hewitt, secretary. In July they leased 12 acres of land on Lincoln Avenue and Hammond street, and made a ouethird mile cycling track there; and at same time the Star said : "Pasadena has fourteen bicycle dealers, representing twenty-two different wheels." 


\section{DIVISION EIGHT-SCIENCE.}

\section{CHAPTER XXVIII.}

Prehistoric MAN in PASAdena.-The Glacial Period of Geology.-The ancient townsite on Reservoir Hill.-Human relics as ancient as those of Table Mountain in Calaveras county.-Descriptive list of stone implements found.-Prof. Holder's letter.

\section{PREHISTORIC MAN IN PASADENA.}

In order that the reader who is not specially versed in geology may have some fair idea of the real force and import of the facts which show that man dwelt in Pasadenaland many thousands of years ago, I must first present extracts from the latest and highest scientific authority on man's existence on the Pacific coast prior to or during the era known in geology as the Glacial period, which was the closing or breaking-up time of the Tertiary age. [See Geological Chart, Chapter 29.] The International Scientific Series, published by D. Appleton \& Co. of New York, is reckoned as first-rank authority in the scientific world. No. 69 of this series treated of "MAN AND THE Glacial Period," was published in I892, and was written by Geo. Frederick Wright, D. D., LL. D., F. G. S. A., professor in Oberliu Theological Seminary; Asst. on U. S. Geological Survey ; author of "'The Ice Age in North America," etc., etc., etc. He is therefore perfectly competent to give us the latest results of scientific research in his chosen field. And from his work on "Man," etc., published in I 892, I quote :

"Most interesting evidence concerning the antiquity of man in America, and his relation to the Glacial period, has come from the Pacific coast. * * These reports did not attract much scientific attention until they came to relate to the gravel deposits found deeply buried beneath a flow of lava locally known as the Sonora or Tuolumne Table Mountain. This lava issued from a vent near the summit of the mountain range, and flowed down the valley of the Stanislaus river for a distance of fifty or sixty miles, burying everything in the valley beneath it, and compelling the river to seek another channel. ** * $*$ It was under this mountain of lava that the numerous implements and remains of man occurred which were reported to Prof. J. D. Whitney when he.was conducting the geological survey of California, between I 860 and 1870 . *** Interest reached a still higher pitch when, in I866, an entire human skull, with some other human bones was reported to have been discovered under this same lava deposit, a few miles from Sonora, at Altaville, in Calaveras county, and hence known as the 'Calaveras sku1l.' * * * * The forms of animal and vegetable life with which the remains of man under Table Mountain are associated are indeed to a considerable extent species now extinct in California, and some of them no longer exist anywhere in the world. **** The connection of these lava-flows on the Pacific coast with the Glacial period is unquestionably close. For some reason which we do not fully understand, the vast accumulation of ice in North America during the Glacial period is correlated with enormous eruptions of lava west of the Rocky Mountains, and, 
in connection with these events, there took place on the Pacific coast an almost entire change in the plants and animals occupying the region.' '*

The above extracts are taken from pages 294 to $30 \mathrm{I}$, omitting everything but what seemed to have some bearing on our Pasadena case. For account of glacial marks on granite rocks at Devil's Gate, and other evidences of glacier work hereabouts, see chapter 29, on Geology.

\section{OUR ANCIENT TOWNSITE.}

The San Gabriel Orange Grove Association was organized December 23, 1873. One of their first necessities was to secure a water supply both for domestic use and for irrigation purposes. Their highest point of land was at the sorth end of the street they had laid out as Orange Grove Avenue, between it and the brow of the great Arroyo Seco chasm, and here they decided to build a colony reservoir. The site had long been used for a sheep corral, because of the land sloping away in every direction and thus giving the shepherds and their dogs an advantage in detecting the approach by day or night of bears, coyotes, mountain lions, foxes, wild cats, or other animals that prey upon sheep or lambs; and also because of the bountiful springs at the foot of the great bluff, where the pumping works are now located. The ground was covered several inches deep with sheep manure, which was scraped off and hauled away to fertilize young trees or growing crops. This left exposed the original unbroken surface of the ground which had never before felt the upturning stroke of plow or pick. This top was composed of mountain-debris soil just like the surface at lower points all around. The excavation was commenced, with no thought of anything unusual in the situation. However, when the work had progressed to a depth of about four feet below that unbroken surface the plows and picks began to turn up specimens of stones that had been wrought and fashioned by man for his own special uses. These relics were so abundant that they attracted a good deal of interest and curiosity at the time, and many persons carried away specimens to keep as curios. As nearly as I can learn, over a hundred specimens were carried away at that time, and quite as many more have been taken since. Yet in all this time, being now over twenty years, it has been regarded as simply an old Indian village site, such as are found in many places all over California, New Mexico, Arizona, etc.; and that the stone implements found here had no greater historic interest or significance than those found in hundreds of other places. But a very different and more far;reaching view of the matter was first publicly announced by Dr. Reid at a meeting of the Pasadena Fortnightly Club, February 27, I 894, Archæology and Geology being the topics of the evening, under auspices of

* See Geology of Cal., Vol. 1-J.D. Whitney, state geologist (published by the state. Printed at Phi'adelphia - 1805), pages 250 to 253 . The fossils were experted by such eminent authorities as Profs. S. Newberry and Joseph Leidy. 
the Science Section of the Club-Prof. A. J. McClatchie of Throop Institute, chairman of the section.

PRIME ELEMENTS OF THE ANCIENT TOWNSITE PROBLEM.

I. This site was on the highest point or body of land anywhere in the vicinity. The land sloped from it in every direction.

2. The surface was composed of materials conveved down from the mountains and canyons, just the same as the surface soil for miles around.

3. The surface had never before been plowed or dug up or filled in by man; it was just as nature had originally piled it there.

4. The stone-age relics were found mostly about four feet below the natural surface of the ground, or varying from three and one-half to five feet. The following witnesses to this fact are still living: A. O. Bristol, John W. Wilson, Henry G. Bennett, J. H. Baker, Chas. H. Watts, Col. J. Banbury, HLon. P. M. Green, Thomas Croft, W. T. Clapp, B. S. Eaton.

5. No fragments of pottery were found. These pre-Pasadenians had not yet acquired the art of making pottery.

6. No worked flint was found. They had not yet acquired the art of working flint, or using arrow heads or spear heads.

7. No grooved stone axes or hammers were found. These people had not yet discovered that method of attaching a stone weapon or tool to a wooden handle.

8. No specimens have been found with dish-depth sufficient to warrant their being called "mortars." These people had not yet reached that degree of stone-working skill. No real "pestles" were found-only "mealing stones."

9. No indications were found that they knew the use of fire : no bits of charcoal or burnt wood; no burnt clay or sand; no stones that showed the action of fire upon them - all of which are usually found at any ancient townsite within the historic period.

Io. The specimens found are true paleoliths, or early stone-age relics.

I I. How came they there, and when?

I now address myself to solving this deep and interesting problem.

The first four points noted above really belong together, as part of one general and controlling fact, which is, that the relics were buried four or more feet deep by natural causes, even though they were on the highest point of land in the vicinity. They must have been ariginally covered much deeper, for the hill had been subject to the natural washing down by rains for centuries, or ever since it was segregated from the west hills by the commencement of the present arroyo gulf. If they had lain anywhere on a slope, having higher land connected even in one direction, the washing down of soil over them would have been a commonplace affair; but the conditions in this case are so different as to have required some great and unusual turmoil of nature to produce them. And we must appeal to geology for the explanation.

The contour of the land, and the general conditions of bed-rock at cer- 
tain points, and transported deposits still in place hereabouts, besides the evidences of ancient deposits again washed away and leaving cobblestone walls of great height, all conspire to show that at the time our ancient townsite was occupied, the Linda Vista hills did not terminate with "Jumbo Knob" as they do now, but extended across the arroyo to Reservoir hill, that being its eastern end, and no great arroyo gulf there at all. The Linda Vista lands and the corresponding body of level land on the east side were then continuous clear across and formed the bottom of a terrace lake, with our stone-age village at its lower end; and its overflow waters swept out over and down the floodplain between the ridges of Orange Grove Avenue and Marengo Avenue, or at an earlier period, beyond Marengo Avenue southeastward, the land being higher than now all across from reservoir hill to Summit Avenue. At Devil's Gate there was another barrier ledge, the Verdugo hills extending across probably as far east as Monks Hill, and thus making another terrace lake in the Arroyo Seco and La Canyada above this great natural dam. The line of bluffs or barrier ledge from Columbia Hill eastward, taking in Grace Hill, Raymond Hill, Oak Knoll, etc., held another terrace lake where the lower part of Pasadena city is now situated. And the Lincoln Park Hills which now terminate with Gibraltar butte, where the Santa Fe R. R. crosses the Arroyo, was then joined continuously with the hills extending westward helow Highland Park, thus making another great lake where South Pasadena and Garvanza are now located.* This was prior to or during the glacial epoch of geology, or the great ice age of North America, which did not extend in its full rigor as far south as Pasadena, but yet the climatic conditions produced by it in the Sierra Nevada mountains and north and eastward therefrom did powerfully affect this region; and the four terrace lakes then existing within the bounds of Pasadenaland were destroyed by the violent meteorological disturbances connected with the closing of the ice age. These disturbances were also especially connected with the great lava flow which during that period covered the whole northern part of California $\rightarrow$ and large parts of Nevada, Oregon and Idaho with the molten products of intense and long continued volcanic eruptions. And now, it will be necessary to again quote some passages from our eminent scientific authority, Prof. Wright, and bring our pre-Pasadenians into nearer relation with contemporary events at points farther north. He is both a far-traveled explorer and a learned scientist. His great work on "The Ice Age of North America" was published in I889. But in April,

\footnotetext{
*The Sonth Pasadena plain and the Garvauza plain were continuous clear across, being the level buttom of the lake; and the great Arroyo gap, with its cobblestone walls or bluff: on each side, is a valley of erosion, washed ont since the lake waters found an outlet through the hills directly south.

$f$ "The extent of the outflows of lara west of the Rncky Mountains is a lmost bevoud comprehensinn. Literally, huudreds of thousal ds of square miles liave beeu covered by the m to a depih in many places of thousands of feet "-Man and the Glacial Period. p. 321, International Scientific series No. E9 1892. "In the Snake River Valley. Idaho, there are not far from twelve thousand square miles of territury covered with a continuous stratum of basaltic lava, extending nearly across the eutire diameter of the State from east to west." $-1 b$. p. 295.
} 
I891, he contributed to the Atlantic Monthly an able article on "Prehistoric Man on the Pacific Coast;" and from this I quote the following pertinent passages :

"The changes which have taken place since man became an inhabitant upon the Pacific coast appear enormous" and "are referred for their origin to the climatic conditions accompanying the great ice age of North America." * * "The ice age was one of great precipitation all over North America, in which the rainfall and snowfall were far larger than at the present time, and in which evaporation was far less than now."

"At last there came upon the inhabitants of that region, both man and beast, the added disturbances of the vast volcanic eruptions which have covered so much of the surface with indestructible basalt; though we are not compelled to suppose in California any great direct destruction of plants and animals by these volcanic outbursts. The extinction of species was due rather to the general disturbances of the conditions of life brought about by this new element in the problem. * * There can be no question that these enormous eruptions of basalt are correlated with the equally surprising facts connected with the glacial period, and, as we have seen, these two periods were doubtless closely contemporaneous in California."'

"The region from the Rocky Mountains to the Pacific coast belongs to the later geological eras, and has been subject to comparatively later elevation. The Rocky and Sierra Nevada mountains doubtless mark lines of present weakness in the earth's crust. It is by elevations along such lines of weakness that the gradually contracting sphere of the earth gets relief. Now, during the glacial period an area in North America of about 4,000,000 square miles, extending northward from a line connecting New York and St. Louis, was covered with ice to an average depth of probably three-quarters of a mile, making, we may suppose, 3,000,000 cubic miles of ice. This ice represents the excess of the snowfall above the melting power of the sun over that region, and it was all first lifted up in vapor from the ocean. To produce a glacial mass of such dimensions, water enough was taken from the ocean to lower its level, the world over, one hundred feet. Thus we have the ocean beds relieved from an enormous amount of pressure, and the same amount concentrated upon the northern and central portions of the continent. Thus we have a cause which would, by its local pressure alone, lay open immense fissures along the lines of weakness west of the Rocky Mountains, and force out of them the liquid streams of lava which have produced such significant changes upon the Pacific coast."

It was in connection with the great climatic disturbances above described by Prof. Wright that the sub-glacial floods poured down from Millard canyon, and the upper Arroyo Seco, and the La Canyada valley, bursting over or through the barrier ledges and previous deposits which held in place the four terrace lakes before mentioned, within Pasadenaland. Of course this did not all occurr at once, but the process went on both regularly and spasmodically for centuries, before the Arroyo Seco was cut down to its present condition, after some earthquake tremor had started a seam through the foothills where the lower Arroyo now takes its course. This Arroyo gorge from La Canyada down is in a geological sense comparatively recent, and was probably not formed at all until long after our ancient townsite 
had been buried under its covering of "glacial till" formation through which the Pasadena colonists were digging down for their reservoir basin, when they found this particular nest of stone relics. And that this Arroyo channel might easily have been started by an earthquake seam, is proved by what really did happen in this region in 1857 , an account of which I here quote from the Thompson \& West "History of Los Angeles county" [1880], page 53 :

"At about half-past eight o'clock, on the morning of January 9, I857, occurred one of the most memorable earthquakes ever experienced in the southern country. At Los Angeles the vibration lasted about two minutes, the motion being from north to south. The Los Angeles river leaped from its bed, and washed over the adjacent land. A new bed was opened to the San Gabriel river, which divided its waters, making two streams of what was before but one. At San Fernando two buildings were thrown down, and not far away a large stream flowed out from a mountain where hitherto no water had been; and a similar phenomenon was observed at Paredes, thirty-five miles southeast of Los Angeles. In the vicinity of San Fernando a large fissure ofened in the side of a high mountain, from which hot gas rushed forth, heating the neighboring rocks to such a degree that the hand could scarcely touch them. But it was in the vicinity of Fort Tejon that the full force of the shock exhausted itself. Here the ground opened for a distance of from thirty to forty miles a chasm ten to twenty feet wide, extending from northwest to southeast, in an almost straight line; then closed again, leaving a ridge of pulverized earth several feet high, and in many places quite impassable. Large trees were broken off like pipe-stems, and cattle grazing upon the hill-sides rolled down the declivity in helpless fright. Here the buildings were all injured to such an extent that officers and soldiers were obliged to live in tents."

The stone-age people who dwelt on our Reservoir Hill were, in my opinion, of as early date (possibly even earlier) as those whose remains were found by Prof. Whitney far under the lava beds of Table Mountain, in Calaveras county. Those Table Mountain proofs of man's existence in California prior to the lava flow have been under critical discussion in the scientific world for thirty years past, and their place in archæology is now pretty well settled. And from Prof. Wright's article in the Atlantic Monthly [April, I89I] I again quote, giving his statement as to the conditions of vegetable and animal life which then existed:

"Primeval man in California found shelter in forests very similar to those which on the discovery of America by Columbus, covered the whole eastern part of the continent. The elm, the birch, the willow, the poplar, the sycamore, the gum tree, the magnolia and the maple spread for him their protecting branches, while the beech tree, as well as the oak and the fig, added its fruit to his limited stock of vegetable food."

"The llama, an ally of the camel, and now confined to South America, was another companion of man in California at that time." [The rhinoceros, several species of horse, cow, and deer, and the inevitable wolf were also here.] "Whether the race of men whose remains are found under Table Mountain [and at Pasadena] became extinct with the horse, rhinoceros and 
mammoth, or whether it migrated south with the llama, we may never know."

\section{How long ago did these things occur?}

The same authority above quoted, and which is the latest presentation of facts and opinions commonly accepted in the scientific world with regard to these matters, sets forth conclusions from which I quote a few brief pasaages bearing upon the time problem. On page 3 I 3 ["Man and the Glacial Period"'] the author says :

"It is certainly not more than ten or fifteen thousand years ago that the ice finally melted off the Laurentian highlands; while on the Pacific coast the period of glaciation was still more recent."

Again, on page 353 , he says :

"The climax of the Glacial period represented a condition of things slowly attained by the changes of level which took place during the latter part of the Tertiary epoch. It is the theory of Mr. Prestwich and others that all the phenomena of the Glacial period can be brought within the limits of thirty or forty thousand years." **

And again, page 364: "One hundred thousand years, therefore, or even less, might easily include both the slow coming on of the Glacial period and its rapid close. * * After making all reasonable allowances, therefore, Prestwich's conclusion that 25,000 years is ample time to allow to the reign of the ice of the Glacial period cannot be regarded as by any means incredible."

And yet again, on page $32 \mathrm{I}$, speaking of the volcanic eruptions, which in the north and middle part of the state covered remains of man in the glacial gravels of Table Mountain, he says :

"These volcanic eruptions are mostly of late date, beginning in the middle of the Tertiary, and culminating probably about the time of the maximum extent of the Laurentide glacier."

Another eminent authority in this branch of Science is Prof. Warren Upham, who read a paper before the Geological Society of America, in December, 1893 [See American Naturalist for March, 1894, page 264], in which he says :

"The Glacial period, regarded as continuous, without inter-glacial epochs attending the culmination of the uplift, but terminating after the subsidence of the glaciated region, 20,000 to 30,000 years; and the postglacial or recent period, extending to the present time, 6,000 to 10,000 years. In total the Pleistocene era in North America, therefore, has comprised probably about 100,000 or I 50,000 years, its latest third or fourth part being the Ice Age and subsequent time." $\dagger$

* "All the evidence tends to prove that late Glacial, or post-glacial man, together with the extinct mammalia. came down approximately to within some 10,000 or 12,000 years of our own times. "-Prof. Joseph Prestwich, F. R. S., England. See American Naturalist, February. 1894, p. 162.

"From this wide range of concurrent but independent testimunies, we may accept it as practically demonstrated that the ice sheets disappeared trom North America and Europe some six to ten thousand years ago."-P,of. Warren Upham, in Popular Science Nonthly, December, 1893. p. 161.

$\dagger$ "It would beiter accord with truth to say that sixty thousand years ago the Glacial period was making ready to go out of business." After making c-rtain further explanatious, he add-- "The close of the Glacial period was o:ly thirty thousaud years ago." $-R$. W. McFarland, in Popular Science Moxthly of April, 1894, page 841 . 
It will be seen, therefore, that by the latest and highest scientific authority we are given a range of anywhere from ten thousand to one hundred thousand years for the period of man's existence on the Pacific coast; and I think our Pasadena "old settlers," who ground their food seeds in stone metates on Reservoir Hill, were about as ancient as any whose remains have yet been found under conditions to well authenticate their remote antiquity. And the great number of specimens found here, besides the much worn condition of many of them, show that the place was occupied as a village for a long period. Some Indians within the past fifty years have used metates and mealing stones very similar to those found here, and this has been cited as an argument against me in regard to the great antiquity of these remains. But this proves nothing; for I, myself, in October, I894, saw a Spanish woman in her own kitchen preparing food for her own family with a metate and mealing stone just like some that I have gathered from Reservoir Hill. It served the purpose alike in either case, to pulverize edible seeds, or bruise edible roots and herbs; but the Spanish woman could have had other and very different implements, while with the primitive woman, those rude, unfashioned stones were the only tools known in the world for doing such work, in her lifetime.

\section{DESCRIPTIVE LIST OF STONE IMPLEMENTS,}

Gathered from the Orange Grove Reservoir Hill, where they had been buried four to five fieet deep by watural causes, on the highest point of ground in the vicinity, with the land sloping from it in every direction.

A. K. McQuilling's collection: One small sized flat oblong metate. [Pronounced me-tah-ty; used as the bottom stone for making meal from dried acorns and various small seeds.] Material, grayish syenite; $91 / 4$ in. long, 7 in. wide, $21 / 2$ in. thick.

One typical mealing stone, for rubbing or grinding acorns, etc., into meal on a metate; oblong-flat, artistically shaped, coarse bluish-pinkish syenite-both flat sides well worn ; $4^{\mathrm{T} / 2}$ in. long, $3 \frac{\mathrm{T} / 4}{4}$ in. wide, $\mathrm{z} 3 / 8$ in. thick.

One convexoid mealing stone, of fine grained bluish syenite; both sides worn; 3 in. in diam., $13 / 4$ in. thick.

One oval-oblong rubbing stone, of bluish-pinkish syenite; $43 / 4$ in. long; two sides worn.

One oblong-triangular rubbing stone, two facets worn flat and one rounded; material, bluish syenite; 5 T/4 in. long.

One narrow oblong-roundish rubbing stone, of bluish-grayish syenite; two sides worn ; $4 \frac{1}{4}$ in. long.

One roller stone, of grayish syenite; worn smooth all around; $5 \frac{1}{2}$ in. long, 3 in. diam. [Used for mashing food substances by rolling over them on a flat wetate].

One I4-toothed cog-wheel stone, of brownish granite; sides flat; cogs uniform, and pretty well made, the creases or indentations being about 3-16 in. deep. The wheel is 3 in. in diam. and $I$ in. thick.*

*I have a stone of same size, shape and material, but with 12 cogs instead of I4, which was found in Purdingstune creek near San Dimas station on the Santa Fe railroad, 25 miles east of Pasadena. - [H. A. Reid. 
Another cog-wheel, of close-grained brown ferruginous grit rock; same size as the first, but having only 9 cogs, and they more irregular in size and imperfectly made. A segment with four cogs is broken away. The creases are small and shallow, and some of them run aslant. A rude, unskilled effort at wheel making. [The purpose of these peculiar wheels is not well established. They have been called by different names, as sun wheel, rose wheel, $\operatorname{cog}$ wheel, corrugated disc, radiate stone, gaming stone, etc. My own theory is this: The sun was the deity or day-god to all primitive tribes of mankind, and these radiate stones were a rude attempt to make an emblem or symbol of the sun. And after this they would readily fall into use for gaming purposes or "lucky stones" or "charms," and come to be greatly prized.]

Mr. McQuilling had also found there two irregular small fragments of unworked impure flint, but no flint chips, or arrowheads, or anything to indicate any use made of flint by these people. Besides this, he found about a half-ounce fragment of yellow ochre.

List of specimens found by J. W. Sedwick, city engineer, while re-excavating, embanking and cementing work was in progress there in $189 \mathrm{I}-92$ :

One flattened and two ovoid hand-stones for grinding on a metate. Material, syenite.

One double-surface rounded-sides mealing stone, of gray syenite; $43 / 4$ in. long, $23 / 4$ in. wide, and $75 / 8$ in. circumference. Weight about $1 \frac{1}{4} \mathrm{lbs}$., and much worn.

One ovo-oblong rubbing stone, of white feldspar, smooth polished; $33 / 4$ in. long, $55 / 8$ inches around midway, and $9^{1} / 8$ in. around lengthwise.

One spheroidal rubbing stone of bluish syenite, about one pound weight, and varying from $87 / 8$ to $91 / 2$ in. in circumference. Artificial wear only in one place. This was a naturally rounded pebble or small cobblestone which they had utilized.

Found by Master Clifford Wood (I892), a neatly-shaped, small, semioval, shallow-dished metate, of grayish syenite; $5 \frac{1}{2}$ in. diam. at bilge, $3^{\mathrm{T}} / 2$ in. diam. of dish rim, and $3^{\mathrm{T} / 2}$ in. thick from bottom of dish to base of the stone. This was probably used to grind ochre for face paint.

\section{The Throop Museum Collection.}

(Authenticated specimens procured by Dr. Reid specially for permanent deposit in the Throop Museum.)

One discoidal stone of coarse-grained syenite; $5 \frac{1}{2}$ in. diam., $23 / 8$ in. thick. The form is well wrought out, although no part of the disk is worn or polished - hence it was not used for a rubbing stone or a grinder. Its most probable use was for some kind of game or pastime by rolling it on the ground. This specimen was found in 1874 , and donated by Col. Jabez Banbury.

One six-toothed cog-wheel or sun-stone (?) of fine-grained greenish porphyritic clinkstone; 4 in. diam., $I / 2$ in. thick. Indentations $I 1 / 4$ in. across outer opening, and $1 / 4 \mathrm{in}$. deep. Found by Wm. Davy while repairing a leak in the reservoir in 1888 , and donated. [For further account of this class of wheels, see under "McQuilling collection," above.]

One large shallow-dished metate, of coarse-grained gray syenite - a fine specimen ; $2 \mathrm{I}$ in. long, I 4 in. wide, $36 \mathrm{in.} \mathrm{girth,} 49$ in. around lengthwise, and 50 or 60 pounds weight. Found and donated by John Showalter. [This specimen was plowed up several rods down the eastern slope of Reservoir Hill, two feet below the surface, while grading Vernon Avenue near 
Mary street in January, I894; and after due consideration of all the facts pertaining to it, I do not hesitate to place it as belonging with those of the hill top. But many other specimens of stone implements have been plowed or dug up in various parts of Pasadena which are of recent or doubtful date, and I have not included any such in this list of prehistoric palæoliths.]

One ovo-oblong metate of gray syenite, I 6 in. long, Io in. wide, 5 in. thick, with dish part worn $3 \frac{1}{8} 8$ in. deep. Found and donated by Thomas Banbury.

One heavy-weight ovoid slung-shot, of porphyritic syenite- $61 / 4$ in. long, $3^{\mathrm{T} / 4}$ in. wide, $3^{\mathrm{T} / 2}$ in. thick; I $23 / 4$ in. around the bilge. Found and donated by Thos. Banbury.

One fine-grained, flat metate, $9 \times 12$ in. area, and 3 in. thick. Found and donated by Dr. H. A. Reid.

One nearly triangular shaped, deep-dished metate, of coarse-grained, grayish syenite, medium size, and dish worn down to 3 in. depth at center. Found and donated by Thomas H. Wardlaw.

One well shaped, double-flat-surfaced, oval mealing stone-coarsegrained and well worn. Found and donated by Dr. Rachel F. Reid.

Fragment of child's metate, and two imperfectly ovoid, coarse-grained, heavy club-loaders or slung-skot stones. These, for use, were hung in a band of some tough sort of animal skin or vegetable fibre, * then drawn snug against the butt end of a club, the end parts of the band being laid along lengthwise on each side of the club or handle, and wrapped there with strong fibres. The ends of the stone would protrude beyond the edges of its bilge-band; and being securely fastened to the handle, it made a. powerful weapon with which to break the skull of man or beast at close quarters. $\dagger$ Found and donated by Mrs. Reid. [These reservoir-hill people were so primitive that they had not yet learned to use bow and arrows, spears or lances, for no flint or other stone heads for such weapons have been found among their remains. A few have been found in other parts of Pasadenaland, but they were on or near the surface, and of recent age.]

Two worn fragments of grit stone or schist, used as a scouring stone for smoothing club handles or any implements of wood; for this it served equal to both rasp and sand-paper. Found and donated by Dr. Reid.

One well worn, coarse-grained metate, of bluish syenite, $\mathrm{r}_{5}$ in. long, Io in. wide, 3 in. thick, with dish worn $2 \mathrm{~T} / 4$ in. deep. Found by W. T. Clapp while grading for the reservoir, in February, I874, and now, after twenty years, donated by him for this Throop collection.

One double-flat-faced ovo-oblong mealing stone, 4 in. long, $3^{\mathrm{T}} / 8 \mathrm{in}$. wide - of bluish syenite. Found by Chas. H. Cole and donated.

One face-paint dish, nearly round, $5^{1 / 2}$ in. in diameter, 2 in. thick, dished $3 / 4$ in. deep. Found by C. H. Cole while assisting City Engineer Sedwick during the re-excavation and cementing of east half of the reser-

* A shrubby plant called Indian hemp, or wild hemp [the Apocynum canabinum of botany], furnished from its bark strips of strong, tough, thong-like fibres or cords suitable for this and many other uses. It is found growing hereabouts yet.

+ Some modern savage tribes still use the club-loader or slung-shot weapon, some of them being skilled ennugh to make a crease around the middie of the stone for convenience of attachment, but our Pasad nian "ancients" had not reached that degree of skill yet. Of this class of weapons, the Standard Dictionary says: "Pogantoggan-A war club consisting essentially of a stone secured to the eud of an elastic wooden handle, ordinarily strengthened by a covering of twisted rawhide; a casse-tete; a skull-cracker; used by the Indians of the Plains." 
voir in $189 \mathrm{I}-92$, and donated by him. This specimen is of rare interest, being made from a reddish volcanic rock [volcanic tufa] such as I have not seen in situ anywhere nearer than the bed of the creek below Puddingstone Falls, near San Dimas station on the Santa Fe railroad, 25 miles east of Pasadena. But this kind of rock is said to be found up the San Gabriel canyon.

One small ovoid paint pulverizer, 2 in. long, $13 / 8$ in. wide, $11 / 8$ in. thick nearly the size and shape of a hen's egg. It is of white feldspar, with appearance of being indelibly tinted with yellow and red ochres, for the grinding of which it had been used - mayhap in the very dish found by Mr. Cole - to mix face paint. This interesting ovoid was found and donated by Dr. Reid.

One turtle-shaped mealing stone, worn nearly flat on its grinding face, but with a neat turtle-back upper surface, little worn. It is of bluish syenite, $4 \frac{1}{2}$ in. long, $3 \frac{3}{8}$ in. wide, $13 / 4$ in. thick. Found and donated by Dr. Reid.

Fragment of unshaped, unworked white flint, $\mathrm{I} 3 / 8$ in. long, $3 / 4$ in. wide, $3 / 8$ in. thick. Some of its fracture edges may have been used as a rude sort of knife, or scarifier. Found by Dr. Reid. [Not true flint.]

The foregoing lists are sufficient to show the type and character of these relics. Their great antiquity has been questioned, because implements that "look just like them" are found in many places in California, and are even in use by some Indian tribes yet. To this I answer broadly: No stone-age village site has been found elsewhere, buried under conditions which could only be explained by -

Ist. A consideration of the general facts known as to primitive man's existence on the Pacific coast prior to and during the glacial epoch of geology.

2d. A consideration of the topography and natural conditions of the place where these typical relics were first found, excluded from any admixture of specimens of later date.

3d. A consideration of the changes of ancient land and water areas, drainage, etc., traceable in this vicinity, which would account for these relics being buried on top of the highest point of land, as found.

4th. A consideration of the geological and meteorological transitions or changes of climate [and of the fauna and flora of the region] connected with the glacial epoch, which would naturally produce the local changes of land and water areas referred to.

My conclusions as to the geological period of Pasadena's ancient townsite on Reservoir Hill are based upon a careful study of the above four fundamental considerations, and their natural correlation with each other. The following portions of a letter from Prof. C. F. Holder, dated July I I, I894, present some points of interest and historic value. He says :

"I have located a number of camp sites, from South Pasadena all along up the Arroyo. There was a site at Johnson's ranch; one at Mr. Nelms's or below Locke's; another where the shooting club meets; one at the reservoir; one at Linda Vista; again, at the springs nearly opposite; again, at the mouth of the Arroyo Seco; and a very large camp at Giddings's 
ranch ; another was just east of the Raymond ; another a mile to the east. At all these places except one $I$ found specimens, and at all of them the mortars [metates] were from one to three or four feet down. [?] When they went on a journey these people buried their stone utensils; others were buried with their dead. It had not occurred to me that the reservoir site was different from the others. My finds there, as I remember them, resembled other finds; and my idea was, that while they might be many hundred years old, they were probably in use during the last one hundred and fifty or two hundred years. The granite out of which many of them were made disintegrates very rapidly. One found at Linda Vista fell in pieces when I picked it up. I am glad some scientist is investigating these things and collecting them, as they are passing away."

In regard to the Indian village sites, their burial customs, etc., see chapter I. For further particulars about glacier action within Pasadenaland, see parts of chapters 29 and 30 . About Indian graves, and how their stone implements happen to be buried, see page 3 I, 32 .

\section{CHAPTER XXIX.}

Geology.-What Geological Age?-Kinds of Rocks.-How these Mountains were made.-The Gold Vein.-Other Mineral Formations.-The Oil Question.-Glacier work in Pasadenaland.-Glacial enamelings at Devil's Gate._"Glacial till."Terminal moraines.-Lateral moraines.-Boulder clay.

\section{GEOLOGY.}

Prof. J. D. Whitney was State Geologist of California from I 860 to 1870 ; and in Geol. of Cal., Vol. I, preface, he states that up to June 30, I866, the legislature had appropriated a total of $\$ 95,600$ for his work. But the work had to be finally abandoned, less than half done, for want of funds. And of what was done, South California received only a few pitiful crumbs that fell from the north section's table.* And of these crumbs Pasadenaland got her little share; for Mrs. Shorb remembers that Prof. Whitney's party had their camp a few weeks early in I86r, only a few rods east from where Hon. J. DeBarth Shorb's fine residence, "San Marino," now stands, at the south end of Shorb Avenue. I have gleaned from Prof. Whitney's published report a few points which almost touch Pasadena. He says :

"The principal group of mountains included in the portion of the coast ranges now under consideration are, the Sierra Santa Monica, the San Gabriel, the Temescal, and the Santa Ana ranges. These will be taken up in this order, and the result of our very hasty examinations in this region given."

*" Scientifically considered Southern California is almost a terra incognita. Of the geological formation of our part of the State we know but little. There has been but little done towards classifying the rucks of onr hills and mountains, or analyzing the suil or our valleys. Its milueralogy, too, has been lieglected. althongh gold was discovered and succes fully miued in the canyous of the Sierra Madres forty years before Marshall found nuggets in the mill-race at Coloma." -Inaugural address of piesident of Sou. Cal. Hislorical Sociely, 1890. 
It wili be noticed that he ignored the old established name "Sierra Madre," and called our local range the San Gabriel Mountains, of which he says further :

"The San Gabriel range, as we denominate it, is a vast mass of mountains extending from the Cajon pass on the east, and joining with the Santa Monica and Santa Susanna ranges on the west. It is fully 60 miles long, and from 20 to 25 miles broad from north to south. ** San Gabriel is the designation of the principal canyon by which the chain is traversed, and of the only stream of any size which heads in it."

He gives some account of the range east of the San Gabriel river, but nothing west of it, except to mention incidentally that a little gold washing was carried on near the entrance of Santa Anita canyon or its outwash into the San Gabriel river. Further on he says again :

"In the vicinity of Los Angeles the rocks exposed are chiefly argillaceous, shaly sandstones, with dark colored shales interstratified; these rocks are highly bituminous, and have generally a southerly dip. In the Arroyo Seco, which comes into the Los Angeles river from the northeast, these strata are well displayed."

The above extracts show the nearest nips of geological investigation which Pasadena and her contiguous mountains have ever received from any official source, so far as I have been able to learn. But in $188_{3}$, by the kindness of Prof. Lowe, I was enabled to spend nearly three months in the Mount Lowe section of our local mountains; and two years before this I had spent six weeks in the Mount Wilson section and in traversing the West San Gabriel and the Arroyo Seco canyons. From data gathered in these and other previous researches in Pasadenaland, I prepared a Geological Report, and read it before the Science Association of Southern California in Los Angeles, at its meeting in January, I894; and from that report I here make some extracts :

\section{WHAT GEOLOGICAL AGE.}

"Our accredited authorities all agree that the Pacific coast mountains of California belong to the Tertiary Age, which means that in a geological sense they are of comparatively recent origin. The Tertiary Age was the first period in geological time, when the earth had become fitted to sustain such higher types of both vegetable and animal kind as hold place today. In the Zoic calendar of creation it is known also as the "Age of Mammals," evolved out of the "Age of Reptiles" next below, and in turn evolving the "Age of Man" next above, or the geological age in which we are now living, and in our turn evolving the "Age of Angels" or spiritual beings. [See chart, page 541.]*

*This full page plate is from the Review of Science, Vol. V., No. 3, 1881; Kansas City, Mo. There were three others, the "Mosaic Calendar," the "Psychic Calendar," and the "Synoptic Calendar of Creation," showing the steps and stages of creational progress on four different lines of inquiry, under the law of evolution-all prepared by Dr. Reid to illustrate topical addresses before the State Academy of scrences at Des Moines, Iowa, and public lectures thereafter at various places in Iowa, Minuesota, Nebraska and Missouri. 
G E O I, O G CA L, C I A RT;

Including the Rock Scale of Geological Perlods and the "Zoic Calendar of Creation." Compiled irom the works of Agassiz, Lyell, Huxley, Hæukel, Duma, LoConte, and other first rank authorities in Science at the present time. ByH, A.REID, A.M.,M.D, Secretary State Academy of Sciences at Des Moine , Iowa. [Published by permission of the Anthor.]

Explanation. - The side line at we left shows what portions of in the terms "eozoic," "paleozaic," etc. The first column shows the periods or "Ages" of genlogical time during wbich the different successive types of animal life predominated, or were the highest types then in existence. And these iwo divisions form the "Zoic Calendar of Creation."

The second column shows the great general groupings of rock strata, in which are found the fossil remains of the corresponding ani$\mathrm{mal}$ types named in the first column. Bnt. at the "Age of Rep. tiles" occurs a grand divergement, for it was during this age that animal life pushed out into its most wonderful developments; and there came into existence strange and marvelous forms of swimmivg reptiles, four-footed and two-footed walking reptiles, and two-footed and four-footed flying reptiles. Here also the true birds began to appear, thongh with reptilian peculiarities; and likewise the marsupial animals, which are a transitional type, between reptiles that produce their young by laying eggs und the true mammals, that briug forth their young well ma. tured and then suckle them.

The third column shows the les ser groupings of rock beds as clas. sified by our American geologists; but many minor snbdivisions and of space. At the top of this col. nore shown the geologlcal pe. riods of tirst appearance ol races of man, so lar as now an thenticated by competent scientific authorities.*

The fourth column shows the nnmber of feet in thickness of the different groups of rock layers as indicated by the hraces.

This Chart is the most comprehensive and thorough in its details, and yet the most systematithe eye, of anvthiug in its line Here is the whole story of gen]ogy and the ascent of lile condensed into the space of a few Inches, yet so plainly set forth as to readily fix itself in the memory like an outline map. scientific terms in newspapers and magagines often caich the reader at a disadvantage but a reference 10 this chart will at once show the relative place or period in creational progress to which the best anthorized geologlcal terns apply. It reaches, llke a Jacob's ladder, from the lowest inklings to the highest ideals of life on the earth. 28 tanght by modern ocience and the Christlan Bible. geological time are comprehended local groups are omitted for want cally and graphically presented to that has ever yet been published.

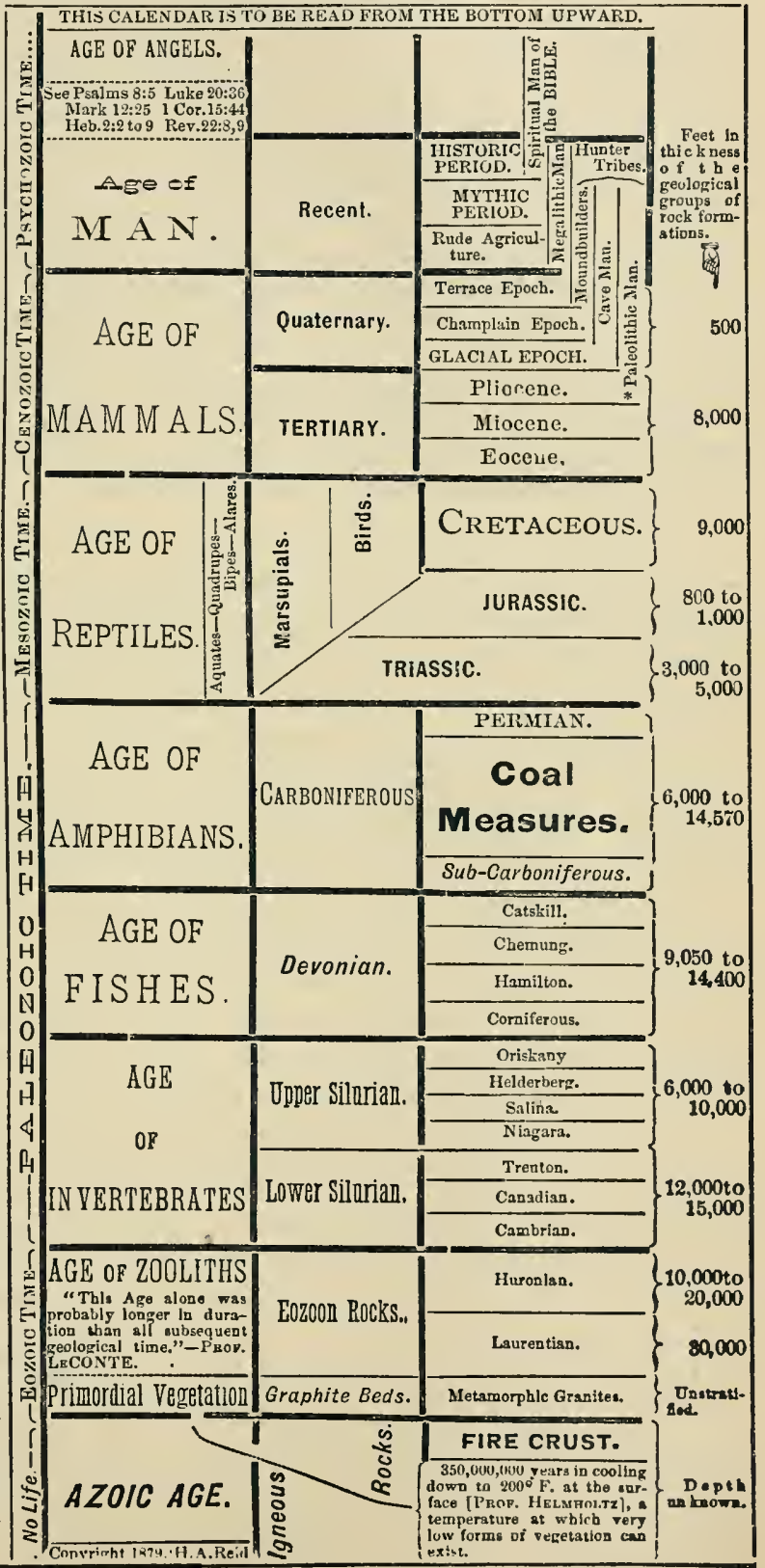

- A The exisence of Pl

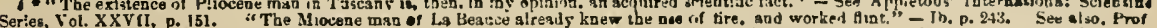
Series, Vol. XXVII, p. 151. "The Miocene man of La Beatece slreals knew the nat if tire. snd worked lint," - Ih, p. 243. See also. Prof

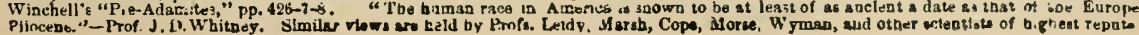


The matter of geological age is determined by the fossils found in these coast mountains, as compared with those of other mountains or plains that belong to lower or earlier geological ages. Official observers have reported such finds in kindred mountain sections both westward and eastward; and I have myself gathered specimens from Shell Rock creek, near Goleta in Santa Barbara county. Arthur B. Stevens of Pasadena, has gathered fossil shells from his father's plow-land at Chatsworth Park, twenty-five or thirty miles northwest from Pasadena. Prof. McClatchie of Throop Polytechnic Institute has found fossil shells in the Puente hills ; and Hon. Delos Arnold of Pasadena, during the winter of I880-8I, first discovered fossil fish in the chalklike hills about four miles sonth of the city. He has also gathered fossil shells of over two hundred extinct species of mollusks from the rocks of Deadman's Island and other points about San Pedro Bay, while there are not to exceed seventy-five species now living in the same vicinity.* Some of the species that are found here in the fossil state only, are found still living in the iceberg waters of Alaska, amid the rigors of a lingering glacial period. And this fact suggests a time when the climate of Los Angeles county was perhaps as frosty and frigid as that of Alaska is now. Such are the far-reaching lessons of geology."

Although no fossils have yet been found, distinctly within Pasadenaland, the reader will, nevertheless, wish to know what remains of extinct animals have been found in other sections, of same species as roamed here during the same geological periods. [See Prof. Holder's "Ancient Animals," etc., Chapter 3I.] In the annual address of the President of the Los Angeles County Historical Society, I $888-89$, he says :

"We have verified and recorded the discovery of a tusk of large proportions, the fragment found being six feet long and six inches in diameter, in a well at a depth of thirty feet, some twenty miles east of this city ; also of the skeleton of a whale on the summit of the Santa Monica mountains."

The Lewis "History Los Angeles County," I 889, says : "In asphaltum or tar springs west of Los Angeles [nine miles] a tooth of the saber-toothed tiger was found." And remains of the mastodon have been found at Tejunga, Los Angeles, Puente, and San Juan-by-the-Sea, at depths varying from five to twenty feet below the surface of the ground.

In Prof. Whitney's "Geology of California : Vol. I," there are many instances given of remains of extinct animals being found which existed in California at the same time with the primitive Man, whose remains were found and amply verified, under the great lava capping of Table Mountain. I hold that the primitive race of Man whose stone implements were found

*When Prof. E. T. Pierce, who served five years as principal of the schools of Pasadena, was priucipal of the State Normal School at Chiro, the Chico Daily Enterprise of Nov. 2I, r.991, coutained this item: "This morning Principal Pierce received the following letter from Senator Delos Arnold of Pasadena: 'I have this day shıpped to yourinstitution two boxes of specimeus. One box conta ning about eighty species and varieties of Quaternary fossils (Post pliocene), from San Pedro. They have all been identifi $=d$. and $I$ believe are nearly correct in their names. I thought this collection of recent fussils, starting as it does, at the top of the great and wonderful geological column, twenty miles or more in height, wculd stimulate the inquirer to dig down towards its base, quite as luuch as ove starting from the base and necessitating working up." "About Nov, 10 the same year Mr. Arunld presented the Throup Polytechnic Institute with 150 varieties of quaternarv and pliocene fossils found in I.os Augeles county. And this was a duplicate of a simlar collection which he had sent to the National Museum [Smithsonian Institute] at Washington. [See "Conchology Collection," page 212.] 
imbedded at Reservoir Hill, Pasadena, in February, 1874, was cotemporary in geological age with the "Man" of Table Mountain, and hence had the same animals as co-occupants of the land; and therefore I give here some of Prof. Whitney's instances, as pertinent to this History :

Page 102: Bones of mastodon and horse found in post-pliocene beds (gravel and boulders of gray sandstone) near Benicia on the Bay of San Francisco.

Page 232: Bones of mastodon and elephant found in Tertiary and postTertiary beds in Tuolumne county. At Gold Springs in that county, bones of mastodon, elephant and horse found in great abundance.

Page $25 \mathrm{I}$ : Under lava flow in same county, bones of rhinoceros, an extinct species of hippopotamus, extinct species of horse, extinct species of camel resembling Megalomery'x (Leidy), and remains of Man were found.

Page 252 : Again in same county (post-pliocene beds) along with mastodon, etc., were found bones of tapir and bison, and two species of horseone of these being identical with the living mustang or Indian pony. Remains of mastodon and elephant constantly spoken of as being very abundant; and rude stone implements of Man found in same formations.

KINDS OF ROCKS.

The rocks of these Pasadena mountains present nearly every variety of the granitic series; but no mass or stratum of any of the limestones, sandstones, shales, or carboniferous formation. In Rubio canyon there is a bed of peculiar silverglint rock which has the soap-like feel of steatite, and I have classed it as micaceous talc-a hydro-mica-schist formation. The layers of different kinds of granitic rocks are somewhat defined, and some approach to systemic stratification can be traced. I have identified massive bodies of porphyry, apparently consisting of a mass mixture of feldspar, hornblende, and augite or pyroxene, with disseminated crystals of white feldspar, and called by miners simply "black spar." Of this structure is the dark greenish rock wall on the east side of Rubio canyon, where the Pavilion platform rests on the abrupt mountain slope. Farther up this canyon there are layers of micaceous granite, quite friable, and steadily decomposing. Then a layer of syenite, which merges into a stratum of gneiss at the Hanging Cliffs. And beyond that again are lofty, towering masses comprising thousands of feet of syenite in various degrees of hardness, of texture, and of color - this being that form of granite which is composed of quartz and feldspar, combined with hornblende instead of mica : and these rocks are often interjected with seams, dykes or veins of quartz, or quartz and feldspar in fused or metamorphic combination. Above this again lies a bed some hundreds of feet in thickness, of a brown, ferruginous gneissic rock, with marked schistose peculiarities, (also called quartzite) and coming the nearest to a real sandstone of any massive body of rock that I found; but it seems to be both brecciable and solutive, and its mass readily decomposes or fractuates on exposure to air and moisture; hence it is of no value 
as a building stone. This brown sandstone layer is seen plainly imbedded around the walls of Echo ampitheater, next below the layer of white feldspar mottled syenite rocks which form the north rim or crest at summit of the ampitheater. And this marked contrast between the white syenite rocks and the brown gneissic layer is traceable all through these mountains. There are on Mount Wilson and Mount Lowe, and some other points, a limitless supply of beautiful, fine-grained, bluish syenite-a kind of granite most excellent for building stone, alike as to pressure resistance, weather resistance, good working quality, and susceptibility of a fine polish.

On Mount Lowe, and on the south-easterly facings of Mount Markham and San Gabriel Peak there are inexhaustible beds of decomposed feldspar or kaolin, from which the common table dishes or China ware of com $^{2}$ merce are manufactured: but all the specimens that I found showed such admixture of iron oxide or other impurities as to vitiate their commercial value. Some beds of a purer quality may possibly be discovered yet.

\section{HOW THESE MOUNTAINS WERE MADE.}

Some mountains are made by volcanic upheaval and outpour ; some by anticlinal or roof-like uplift of their whole series of stratified rocks; some by a great cataclysmal fracture and "fault," whereby the rocks on one side of the fracture are tilted up, and the other side depressed or pushed under, but the stratifications remaining more less intact; and some are formed by the crushing and mashing together of the rosks, which results from con. traction of the earth's crust in its steady process of cooling. Our Pasadena mountains partake of the last two methods. The mashing and crushing process, or its results, are specially illustrated at several points; but perhaps more plain to be seen in Granite Cut, on the Great Incline Cable Railroad up Echo Mountain, than elsewhere. I examined this point particularly on August 5, I893; and from field notes made at the time I quote this memorandum :

"Found some ferro-micaceous sand rock and gneiss, frequently interjected with dykes, seams, or pockets of pellucid quartz, white and pinkish feldspar, and raminated mica; also seams of metamorphic trap rock : and numerous fractures infiltrated with breccia and sandwash from above. Much of the formation is gneiss or gneissoid schist, passing into pulverulent sand rock - the nearly completed disintegration of what miners and water-tunnelers call "rotten granite." And there are gneiss laminations, micaceous seams, and porphyritic dykes lying at all degrees of inclination and all angles of intersestion. The rock colors here are gray, brown, drab, streaked, speckled, green, white, pinkish, tawney, slate, yellow. These colors appear mostly in separate bodies, or in distinct seams, veins, or dykes; but sometimes they all appear in a confused mass within a few square yards of space.

This mixed medley of formations is characteristic of the compression or crushing process of mountain making. And the same process or method is further illustrated and proven by the fact that the layers of different 
kinds of rock all through these mountains are not solid, but all checked and cracked and seamed and fractured at every possible angle, and in every size of blocks, from the fine breccia to the gigantic boulder. This condition, existing as it does here deep in the rock beds, is due in part also to rapid cooling after uplift, and to earthquake vibrations in connection with the enormous compression. And this cracked or seamed condition explains in part why these mountains form such a wonderful absorbent and store-house for the water of the winter rains and snows, holding it like a mighty sponge, and giving it out gradually during the dry season, by percolation down to the springs, ooze places and tunnels in the innumerable canyons of the range, or the lands below. It is furthermore the reason why large storage dams cannot be used successfully here, as the water will seep away through the cracks and crevices and fine seams in the rocks - and no large artificial water storage can be relied on unless the bottom and sides of dam or reservoir are solidly cemented.

The fracture and "fault" process of contiguous uplift and depression is illustrated by the fact that all along the south face of these mountains the layers of rock present a broken-off edge, and have a dip to the north, varying from 25 degrees of inclination up to a complete perpendicular. On the other hand, the Pasadena geological basin is, in my opinion, depressed toward the monntains, but having a sonth rim or lip along the line of the South Pasadena bluff, the Raymond hill, Oak Knoll, Col. Mayberry's bluff, the bluff north of the old B. D. Wilson ranch house, etc. From these and many other correlated facts, I conclude that the line of peripheral shrinkage-pressure was from the ocean side, with a line of resistance on the north caused by the previous uplift of the Sierra Nevada mountains, and of the great plateaus which now form the Mohave desert at an altitude higher than our Pasadena mountain tops. These older elevations had become a rigid continental mass, immovable, and the cretaceous or pre-tertiary ocean washed their foot-hills and beachy slopes. But the great round earth's peripheral shrinkage from cooling continued to produce outer wrinkles analogous to what we observe in a shriveling apple, and the California coast range began to bulge up out of the water by sheer necessity of crush-force displacement, till at last there was a mighty break, a crash, a slip, whereby Mount Wilson, Echo Mountain, and the rest, reared their heads up backward toward the north, with a fracture face looking south, while the layers of rock south of the line of fracture went under, making a depression or basin more than a thousand feet deep - yet with another fracture line and lesser uplift at Raymond Hill and its east and west range of co-ordinate bluffs. This great geological gulf extended from the Arroyo Seco eastward indefinitely; but the Pasadena portion of it probably had an eastern barrier reef or ridge on the east side of the present outwash of Eaton canyon, and the basin has been entirely filled up with boulders, breccia, sand, gravel, soil and vegetable debris from the mountains - of course, filling highest near the font of the mountains. And I think there was a lateral moraine or crowded up wall of boulders on the line of the Marengo Avenue ridge, from about where the Santa Fe railroad crosses it, down in almost a straight line southward to the adobe flat where the Raymond station is located. And a similar moraine in part formed the Orange Grove Avenue ridge. None of this work was done suddenly, except in spots ; it was rather the slow, steady process of unreckoned ages of time - for the pendulum of the geological 
clock beats centuries for seconds - and the uplift may not have averaged more than one inch in a hundred years. The good book says, "With God a thousand years are as one day ;" and here we discern the polytechnics of his world-making work.*

Earthquakes, and especially the California "tremblers," have an important place in the geological mechanism by which the Pasadena mountains were made. I presume all of you have at some time in your life heard the cracking sound of timbers or boards in a framed house when they were in process of contracting by cold during a frosty night. Or you have heard the snapping and cracking sound of a stove or stovepipe when cooling off. Well, that was a little earthquake - a phenomenon on a small scale precisely similar in principle to the earth tremblings which occur in California occasionally and are overdignified by the terrifying name of earthquake. The contractile pressure of the earth's crust in its cooling process has somewhere caused a crack, a fracture - and the earthquake is simply the jar produced by that tension click of the earth's rocky encasement - the fracture being generally, but not always, beneath the ocean or near a junction of land and sea. The extent of the earthquake, and its effects on land and sea in any given case, will of course depend upon the amount of rock displacement caused at the time; sometimes it is so little-perhaps only a hair's breadth - that there is only a faint sense of trembling; while at other times there will be one or more sharp shocks, and sometimes great and destructive commotion in the ocean's waters, as-occurred on the coast of South America a few years ago. And every time one of these shocks occurs it is a stroke of God's great hammer forging another link in the mighty mountain chain around the earth. $\dagger$

Our Pasadena mountain rocks were formed in layers beneath the ocean, from the disintegration and pulping of other and older rocks during an age when the ocean extended to the Sierra Nevada mountains and had the great Mohave desert for its sandy floor. Our rocks were formed by the joint action of heat and water, or in a bath of superheated steam under great pressure - thus giving them sometimes the appearance of aqueous and sometimes igneous rocks, but always marked as metamorphic rocks. It was the intensity of compression that gave the heat, and not the fire of combustion as in volcanic and primitive rocks; and this pressure heat was continued through centuries upon centuries of time. Hence these are jellied rocks - cooked rocks - or metamorphosed by the prolonged intense moist heat into a composite magma, in quality and relation of parts considerably different from their original condition when deposited as sediment on the ocean floor-and further changed in their crystallizing during the process of cooling, according as it went on slowly or rapidly in the different layers, either before or after their terrestrial uplift. Therefore all fossils, if they ever contained any, have been cooked into vapor and diffused undistinguishably through the common mass. Thus, too, the gold that is found was vaporized from older rocks below, and in part from the sea water itself,

\footnotetext{
*' 'The latter part of the Tertiary period has been the great mountain-building epoch in the earth's history. The principal part of the elevation of the Audes and the Rocky Mountains has taken place since the middle of the Tertiary period. *** A considerable portion of this elevation of the chiefest mountain systems of the world occurred in what would be called post-Tertiary time - that is, has been coincident with a portion of the Glacial period."-"Man and the Glacial Period," p. $32 \delta$ : International Scientific Series No. $69 ; 1892$.

$\dagger$ "The frequent earthquakes on the Pacific coast moke it not at all in probable that the process of elevation is still going on."-Prof. G. F. Wright, on "Prehistoric Man on the Pacific Coast," in Allantic Monthly, Api il, isol.
} 
and diffused through the mass of quartz and the mass of crude porphyry ["porphyritic dump" formation], both of which now hold it in molecular combination - with the result that it is not found as free gold, but only as flour gold, or verily "gold-dust," in small quantity after the ore has been ground to finest powder and the precious metal successfully separated.

THE, GOLD VEIN.

There is a vein of auriferous quartz extending easterly and westerly along the wall of the front range of these mountains, with a dip northward at an angle of 45 degrees, or more. In I 886 an outcrop of this vein was found on Mount Wilson; there was a flurry of excitement over it for a few weeks, and a number of claims were staked; a little gold was found but not enough to pay for working, and the claims were abandoned.*

An outcrop of the same vein occurs in the west wall of Pine canyon, which lies between Eaton and Rubio canyons; and the "Carrie Mine" was there being developed by its owners, E. V. Carson and Jesse Dickey, when I visited it September 30, and again December I, I 893. Their first tunnel starts into the face of the mountain some 50 or 60 feet below the mineral outcrop and extends inward roo feet on a level, running due north. At about 50 feet from the entrance it passes through the fissure vein, and at the inner end it strikes another vein less rich than the first, though still deemed worth working - but here a caving down occurred, and work at that point had to be stopped for the present. At the junction with the first vein sidedrifts or tunnels were worked both eastward and westward, the west one dipping downward and yielding "pay rock" of the kinds called in miners' parlance, "oxide," "sulphide," "honey-comb," and "sugar quartz." Besides the "Carrie" mine, the same parties had staked the "Pine Tree" mine, adjoining it on the east ; the "Edith" mine on the west; the "Summit," a deposit of lead carbonate gold-bearing rock near the top of this mineral ridge; and the "Surprise," a twelve-inch vein of gold-bearing feroxide quartz several hundred feet lower down, and in the east wall of Pine canyon, all the others being in the west wall. The following assays were made and duly certified by Wade \& Wade, assayers, of Los Angeles :

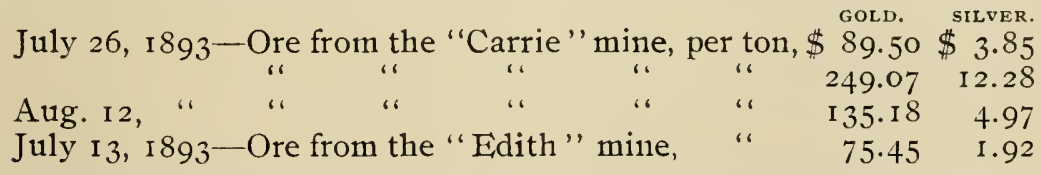

Besides these results from professional assayers, Mr. Dickey had made numerous tests for his own satisfaction, by the method which miners call "horning out" - that is, reducing the ore to a fine powder in an iron mortar, then separating the gold by using a horn spoon for a washer, and weighing it in delicate pocket scales that tip the beam even to grains and pennyweights, or "the small dust in the balance."

The "Carrie," the "Edith," and the "Pine Tree" mines lie about 3,000 feet above sea level.

* "Parties down from Wilson's Peak today report about 300 men there prospecting now, and that there are 38 men at work on the new trail."-Pasadena Union. A ugust 27, 1886.

The same paper of September 3 , speaking of W. H. Korstian and Frank Hearn of Pasadena, said: "After spending a week in diligent testing of their claim, they have just returned laden with son1e very rich specimens. The official assay makes a showing of \$i6g per ton of pure metal." The Los Angeles Herald at :ame time reported: "There is gold in the giavel of the Santa Anita, Forsyth [I.as Flores], San Gabriel and Precipicio [Eaton] canyons, which apprach each other very near in the mountans. Various ledges between these have been sampled and assayed, and yield gold from $\$ 50$ to $\$ 300$ per ton."-Los Angeles Herald, September- , 1886. 
June 22, I894, a corporation was formed called the "Loris Gold Mining Company," to operate these Pine Canyon mines under a patent process for reducing the ores and extracting the precious metal in some quicker and cheaper way than by the old stamp-mill process. The inventor of this patent was Geo. W. McGee of Chicago; and of the new company; the Star said :

"It is formed with Messrs. Ed. Kennedy, M. McCament, J. V. and Eugene Carson, J. H. Dickey (all of this city), A. W. Myers of Ishpeming, Mich.; Newell W. Bloss of New York City, and Geo. W. McGee of Chicago, as incorporators. All these gentlemen except Mr. McGee, are now here and have thoroughly examined the property in Pine canyon which they have bought for the purpose above set forth. They will order mill machinery and engine at once, and prosecute the development of the mines and the milling of the ore vigorously, having plenty of capital at their command."

The company was named "Loris," from Mr. Kennedy's little daughter, about six years' old, he being the largest stockholder, and was organized by electing Ed. Kennedy, president; N. W. Bloss, vice-president ; J. O. McCament, secretary, and San Gabriel Valley Bank, treasurer. A good pack trail was made from the mines down to the wagon road; a band of burros secured; a mill erected, with ample ore-deck at top; machinery put in; a fortyhorse-power oil-burning steam engine set in place to drive the mill; and M. G. Burns, a miner of twelve years' experience in the Black Hills, engaged to superintend the works. The capital by this time invested was said to be about $\$ 12,000$.

October 23,1894 , I visited this mill. It was then expected to steam up and commence regular work in two weeks. About roo assays had been made there at the mill camp, I was told, and had averaged $\$ 40$ per ton. There were fifty tons of ore ready for the hoppers. But the season had been unusually dry, and the water supply from the calyon, being small at best, was growing more scant day by day ; and up to December 15, I894, the mill was ready for work but lying idle because there was not water enough at command for the necessary uses of the miil and camp. [Later.-September, I 895 , I am informed that the Loris mining works have been abandoned and the 11111 moved away.]

After the foregoing digression, I quote again from my report of January, I 894:

"The same fissure vein of mineral-bearing quartz crops out also on Echo Mountain, only a few rods northward from the hotel reservoir; and the east bridle road to Mount Lowe crosses a slide of debris from this outcrop which I named "Temptation Slide," because for twenty years past it has semi-occassionally tempted some old miner or prospector to follow it up and dig awhile; and thus it has been "discovered," "staked," abandoned, and rediscovered several times orer. It is now staked and claimed by John E. Bennett of Los Angeles, and named the "Professor Lowe Mine ;' but no tunnel or shaft has been worked into it. From this cropping it dips both 
northward into the body of the mountain and southwest down into Las Flores Canyon. The vein varies from two and one-half to four feet thick.

"In LAS Flores Canyon, at an elevation of about 2,300 feet above sea level, is the most extensive opening that has ever been made into this Pasadena mineral vein. It has been traced here for about a mile, and claims staked at every available point, their recorded names being "Golden Star," "Jessie Marie," "Altadena," "Pasadena," "Monitor," and "Bald Eagle." At the "Golden Star" mine a shaft has been sunk, following the dip of the vein down 100 feet-at an angle of $45^{\circ}$ for 65 feet, then increasing to about $60^{\circ}$ of dip. This lower section became too dangerous by reason of foul air, called "fire damp," and it was boxed off for the present, and a tunnel run westward, which had been extended fifteen feet when I was there in September, I 893. The descending shaft was excavated four and one-half feet high and six feet wide; and the first sixty-five feet of it is timbered up solid enough for a railroad tunnel. To provide ventilation, a hot air furnace was kept burning at the mouth of the shaft and a draft-pipe run down to the workmen at the lower end of it, new joints being added as the tunnel progressed. A good wagon road extends up to within about $5_{50}$ feet of the mouth of the shaft and its dumpyard; and at this road-point the company has staked ground for a quartz mill of their own. Wm. Twaddell, the superintendent and chief owner of these mines, has bought the house and farm in the canyon, known to old settlers in Pasadena as the "Forsyth ranch." It has a priority water right in the canyon, which can be used to run the mill, and serve afterward for domestic and irrigation purposes just as well as it does now. Messrs. J. 'T'. Best, Samuel Wells, and Thomas Armstrong are members of this mining company ; and there are two others interested merely as capitalists or silent partners. I visited this mine September I 3 , and again on November 24, I893; there was then twenty to twenty-five tons of ore on the dump, and I gathered from it pocket samples of auriferous quartz, silver chloride, horn silver, iron pyrites, iron oxide rock, chloritic talcose shale-or, in plain English, green clay, sometimes miscalled "soap-stone"; gold sulphide, gold-bearing crude porphyry, and some red, pulverulent ore with flour of gold diffused. I estimated that probably one-fourth of the ore on this dump was "pay-rock," and the rest doubtful. The owners estimated its value to average \$IO per ton, claiming their assays to have yielded from $\$ 3$ to $\$$ I 4.29 per ton. The assays for Twaddell were made by Thos. Price of San Francisco, formerly State mineralogist, and an expert authority in such work. (The crude porphyry from one of the Las Flores water tunnels assayed $\$ 3.20$ of gold per ton.) The owners claim to be experienced miners, and seem to be well satisfied that they have a good property in these mines, which they intend to work as a regular, legitimate productive industry." *

[NoTE.-I visited Las Flores again October 23, I894. A new water tunnel had been worked into the east wall of the canyon about $1 / 3$ of a mile up from the claim staked for a mill site, to a depth of 125 feet, running east through a moist mineral vein, and a branch of 35 feet running north through a dry ore vein. It was the intention to continue the eastward tunnel 125

* M. E. Wood came to Pasadena in 1876 ; and in 1881 he and a miner from Arizona named Redway discovered mineral rock in Las Flores canyon. They staked a claim there, and had some of the ore assayed. It yielded a small amount of both gold and silver, but not enough to pay for working, and they abandoned it. 
feet farther, in search of more water. During the month of September Mr. Twaddell had procured four assays to be made for him at the Loris mining works. in Pine Canyon, and these yielded respectively $\$ 4, \$ 10, \$ 1$, and $\$ \mathrm{I}, 800$ per ton.]

Linda Vista Gold Mines.-In September, i886, W. L. Vail and Frank A. Kasson reported assays running from $\$ 40$ to $\$$ IOo per ton from gold ore found in the Linda Vista Hills. And in 1887 John W. Wilson and son worked a mineral vein from 14 to 18 inches thick, in the hills west of Linda Vista and about two miles from Pasadena. The vein yielded quartz oxide free milling ore, and six different assays gave from $\$ 4.60$ to $\$ 26.00$ per ton value in gold and silver, with gold predominating. But the right of all minerals of value ever to be found within this part of the old Spanish grant of the San Rafael Rancho was bought years ago from Benj. Dreyfuss by J. DeBarth Shorb; hence this mine could only be worked by Shorb's permission, and with a percentage to him, and thus it does not pay to work it.

In I 884 I owned some land on the Arroyo hills west of Pasadena, where the Scoville bridge and other improvements are now located; and near the top of the hill there was an abandoned gold-digging. Our late townsman, Dr. O. H. Conger, had assayed "the color," as miners term it, or yellow dirt which was found there, and it yielded a little gold, but not enough to pay for working. And the excavation has since been covered up by Mr. Scoville's grading operations.

In I883 there were still visible some abandoned gold-diggings in the semi-circular sandy flat below the county road as it winds up from the Garvanza bridge to Highland Park. The old Pasadena stage road crossed this flat within a few yards of the gold-digger's pits ; they were sand-wash diggings; but they are all now filled up, the land being used for a Chinese market garden. And the vegetable diggers are making more money out of it than the gold-diggers did.

In the old flood-plain of the Eaton canyon wash, above Lamanda Park, there is occasionally found a mysterious old pit in the sand and gravel, as if somebody had been digging for water. These are remains of gold-digging ventures-some of them made as long ago as I 852 . [See also page 53, and first footnote, page 73.]

\section{OTHER MINERAL FORMATIONS.}

On the west side of the Arroyo Seco, opposite the foot of Columbia street; there are shale beds of Tertiary age, and I have gathered from them specimens of selenite, a crystallized and pellncid variety of sulphate of lime, or gypsum; but it does not occur in commercial quantity. I also found there, as an exudate or efflorescence of the shale beds, some granular crusts of sulphate of magnesia or epsom salts, and in the same beds I found exudations of alkali - almost pure saleratus.

In 1876 Prudent Beaudry tunneled into the west bank of the Arroyo Seco opposite the foot of Columbia street for coal, and worked out altogether about a ton of a pretty good article, though it proved to be only a pocket deposit, and no more was found. The shaft or tunnel was carried in two hundred feet, but the moutl has cared in or filled up with debris, so that it 
cannot now be entered to obtain specimens.* This Beaudry coal shaft was excavated by Samuel Carson, a son of Gen. Fremont's famous Rocky Mountain scout, Kit Carson.

On the line of the abandoned old Santa Fe cut-off track from Raymond to Lamanda Park, at a point between Moline and Lake Avenue the grade or roadbed was cut through a deposit of bog iron ore, also called "ferriferous tufa," and "cellular limonite." It is a geological curiosity but of no commercial value.

In the South Pasadena hills, right where the Lincoln Park reservoir is now located, there is an extensive deposit of feldspathic shale, and mixed in it are boulders of water-lime rock which were dug out and burned and used for hydraulic cement when the Padres of San Gabriel built their Mission church, their mills and their dams. And the Pasadena colony people ordered lime burned there for their Orange Grove reservoir in I874; and Mr. Shorb procured it also for the original cement ditch from Devil's Gate to Reservoir No. I, in I876. But fuel is so high now that a better article of cement can be imported for less money than it will cost to quarry and burn the lime here.

Fossil Fish LEDGE-The body of hills extending from South Pasadena to East Los Angeles are commonly called " chalk hills," but there is little or no real chalk or lime in the feldspathic shale of which they are chiefly composed. It seems to be a sedimentry mixture of kaolin (decomposed feldspar) with silica and iron. Hon. Delos Arnold was spending the winter of $\mathbf{I} 880-8 \mathrm{I}$ in Pasadena, and boarding at Col. Banbury's. 'The Colonel was then working at carpentry, and was using a piece of this native chalk for his chalk-line. This attracted Mr. Arnold's attention, as a matter of geological interest; and one day while driving along the adobe road he picked up a piece of the chalky rock that had been washed down from the ledge, and on separating it into flakes discovered the fossil imprint of a small fish. He then followed up the wash-gully to the parent ledge, and there found more specimens. The exact place of this fossil bed was only known to five or six persons until July 9, r895, when a party of twenty-six Chautauquans spent several hours there, and succeeded in finding ten or twelve specimens of the fossil fish, varying from one-half inch to two inches long, besides fossil leaves and bud scales, and a beech nut, and wing cases of water beetles; also some specimens of dendrites. $t$

* Hon. J DeBarth Shorb tells me that he saw this stuff, and that it was not coal at all, in the common understanding of the term, but small erratic beds of asphalt, compressed to a hard, dry, britile condition almost like the best of true coal. And judging from all the conditions of the surrounding country, I thiuk Mr. Shorb is probably right about it.

†The Daily Star of July 10, 1895, said: "A geological fishing excursion, with a picnic attachment. * At half-past eight o'clock yesterday morniug the start was made from Fair Oaks avenue and Colorado street-seven buggies and two "bukes," with Dr. Reid as guide. The following persons constituted the party: Mrs. O. W. Stanton, presideut of the Delphi circle, and members, Prof. A. L. Hamilton, Mrs. M. A. Wakefield, Misses Cora and Nettie Underwood, Miss Aeta Udell, Miss Blanche Alin. W. N. Van Nuys, president of the Mareago circle; and nembers, Mrs. Van Nuys, J. W. Sedwick and wife, Prof. Charles M. Parker, A. B. Steveus, Miss Jennette Tower, Miss Rosa Allin, Mrs. Mary M. Smith, Mrs. Anna H. Johnson, Miss Blanche Johnion, Dr. A. B. Royal, Geo. W. Burman. Visitors, Mrs. A. M. Royal, the doctor's mother and his son Harry; Miss May. Allu, Roy Gray and Will Gray. Among their equipments for work were hammers, hatchets, a grubbing hoe, a railroad shovel, a putty knife, a cold chisel, a dirk knife, a case kuife, three jackknives, a framing chisel, a geological hammer, and several hair pins." 
The OrL Question.-In March, 1865, the Los Angeles Pioneer Oil Co., leased for a term of twenty-five years the exclusive right to operate oil works on the Rancho San Pasqual. The shale formation in the Arroyo banks at foot of Columbia street and thereabouts were then supposed to be of oil-bearing character. But the company never bored a well. See page 76 ; also 464, twhere the Southern Oil Co. is mentioned. This new Pasadena Company put up a derrick and went to work. I requested them to preserve a record of formations passed through, and let me have it for $\mathrm{my}$ chapter on Geology. They kindly did so, and here is the record of their second well, up to September 23, when this chapter went to press :

GEOLOGICAL, SECTION OF OIL BORINGS ON SOUTH PASADENA HILI. FT. DEEP.

Limestone and adobe.

Ioo At i 76 feet, water, about the level of old San Gabriel road.

Adobe.

200

Black shale.

Adobe.

300

At 350 feet, Iridium, or hornblende; 18 in., very hard; took 4 days to to drill through it.

Sand, very fine.

400

Shale, black.

At 450 feet, water again.

500

Shale, dark blue.

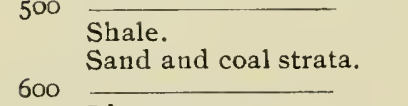

Limestone.

At $66_{5}$ feet, water again.

700

Close sand.

800

At 725 feet natural gas.

Sulphurous gas and water.

$900 \frac{\begin{array}{l}\text { Sand. } \\ \text { Natural gas. }\end{array}}{\begin{array}{l}\text { Carboniferous shale. } \\ \text { Sand. }\end{array}}$

1000

Edwin Baker and J. F. Barcus, two reputable old settlers, inform me that in $1887-88$ a Mr. Roberts had a spring in the Arroyo bank at junction of West Columbia street with Arroyo Drive, which at certain times of year tasted and smelled so strongly of oil that the family could not use it. But the spring is now abandoned and filled up, Mr. Roberts having removed to Los Angeles.

Geo. W. Glover, Jr., editor of the South Pasadenan, informs me that gas bubbles and a petroleous odor have sometimes been noticed at a point between Mr. Moody's house on the Arroyo bank and the site of the old adobe or Garfias ranch house. 
F. M. Underwood, a well-known mine prospecter of Pasadena, claims that he found outcrops of shale formation at sundry points west-by-north from Pasadena, which showed that the shale beds at Columbia Hill were part of a continuous stratum of oliferous shales extending from the oil wells of Newhall and Saugus in a line southeastward to those of Puente.

\section{GI,ACIER ACTION IN PASADENALAND.}

When I learned of the circumstances and conditions under which stone implements were found deeply buried in Reservoir Hill, in February, 1874, as described in the chapter on "Prehistoric Man in Pasadena," it became necessary to seek a geological explanation of the case ; and for this purpose there were two resources - earthquake phenomena and glacial phenomena. No writer to my knowledge had at that time supposed or suggested that the glacial epoch of geology had extended its Pacific coast ice mantle as far south as Los Angeles.* But when I began to study the Reservoir-Hill problem in that light, I soon discerned that Pasadenaland had been the scene of a series of terrace lakes, which were a feature of the glacial period; and thus our ancient stone relics came to be reckoned as cotemporary with glacial phenomena in this.valley, notwithstanding previous opinions that no glacier work had occurred so far south. My conclusion on this point was first publicly announced in an address before the Pasadena Fortnightly Club, February 27 , 1894. There was present in the audience Mr. J. B. French, who had formerly been a working member of the Western Reserve Historical Society at Cleveland, Ohio, and associated therein with Prof. Geo. Frederick Wright, who stands preeminent as an anthority on glaciology. Mr. French had himself done some field work on this line in Ohio, and was much interested in my discoveries here at Pasadena, for he had previously noticed what looked like "glacial till ;" but being under constraint of the common doctrine that glaciers did not reach so far down the coast, he had said nothing about it. He now mentioned the matter to me, and we thereafter took many trips together in search of glacier footprints, finding them numerous and well defined at many points within a radius of three to five miles from Pasadena's business center.

In connection with this matter I recalled that in I 885 [July I 5 , see footnote, p. 4I8] I had noticed at Devil's Gate some very singular markings on large rocks or boulders there-had pointed them out to friends at the time, and tried to explain them by some theory of an ancient waterfall, with sand, gravel and cobblestones washing over and wearing those peculiar marks on the rocks. Any suggestion of glacier marks would have been rank geological heresy at that time, and it did not occur to me; but now,

* "Prior to the autumn of $187 \mathrm{r}$, the glaciers of the sierra were unknown. In October of that year I discovered the Black Mountain glacier, between two peak of the Merced group, * * not expecting to find any active glaciers so far south in the land of sunshine." -Johu Muir, "Mountains of Califoruia," p. 28 . Mr. Muir reports 65 glaciers still existing in California that he has himself seen, at elevations from 9,500 feet to $\mathrm{r}_{1}, 000$ and 12,000 feet. 
I 894, I bethought me that there the glacier had left a memorial record in its own handwriting, indelible on the granitic syenite rocks, which could not be gainsaid; with Mr. French I went and reexamined them carefully ; and as all eventual historic outcome of this conclusion $I$ here quote an article from the Los Angeles Daily Journal of Sept. I3, 1894:

THE MARKINGS AT DEVIL'S GATE.

Pasadena, Cal., June 2, 1894.

By invitation of Dr. H. A. Reid we have examined what he claims are "'glacial scratches' on the rocks at Devil's Gate. They consist of some eight or nine examples of peculiarly polished marks on the surface of hard granite rocks-some of them being striations or little grooves in parallel lines, and others more like patches of polished chisel work, but all apparently made by a power moving from north to south, which it seems would have been the most natural line of motion of a glacier at this point. We are not expert geologists or glacialists, but have some knowledge of the subject in connection with other branches of natural science; and we do not know of any other natural cause which could have produced these particular marks in the place, and on the kind of rock surfaces, and in the relative positions of alignment, as we found them.

Signed :

A. J. MCClatchie, [Professor in charge of biology department in Throop Polytechnic Institute.]*

J. D. GAyLoRd, [Formerly principal of High School in Brooklyn, Conn., and of Academy at Ashford, Conn.; twenty-two years a teacher; constant reader of science periodicals, ete.]

J. B. FRENCH, [Formerly treasurer and librarian of the Western Reserve Historical Society at Cleveland, Ohio, co-member and worker with Dr. Geo. Frederick Wright, the foremost authority on glacial phenomena now living.]

GEO. ConANT, [For twelve years principal of incorporated academies in Western New York, and seventeen years principal of city schools in Ohio.]

Thomas Nelines, [Member of Science Association of Southern California.]

Defos ARNol,D, [Special student in paleontology; has gathered and classified the finest collection of fossil shells, crinoids, etc., in the State.]

Frank J. Polley, [Professor of history and accounts in Throop Polytechnic Institute; a zealous and working member of the Los Angeles County Historical Society.]

JOSEPH GRINNELL, [Special student in entomology and ornithology ; has made a large and valuable collection, especially of native birds.]

Chardes V. TeBbeTts, [Formerly professor in William Penn College, Oskaloosa, Iowa, and principal of Pasadena High School, r889-9o.]

Wr. H. Knight, [President of Southern California Science Association, 1894 ; honorary member Cincinnati Society of Natural History ; contributor to various scientific publications.]

For twelve months longer I pursued this investigation, and can now re-

*I have added in brackets after each name a statement of their relation to scientific studies or interests which explains why I nvited them to this particular investigation 
port more specifically upon it. There are three distinct varieties of geological waymarks among these exposed and weather-worn rocks on the northeast postern of the narrow gorge known as "Devil's Gate," to-wit : slickensides, glacial enamelings, * and water carving.

Slickensides.- "Polished and scratched or striated rock-surfaces, exhibited on the opposed faces of veins or faults, or occasionally between layers of stratified rocks where they have moved one upon another." - Standard Dictionary, 1895.

These marks were probably made when these rocks were first upheaved from their original bed at the bottom of the ocean, and pressed against each other so hard as to produce a glaze-film by the heat of friction; but they could possibly' have been made by earthquake movement at a later period; and these particular ones could also have been made by glacier movement, because they lie in a horizontal position and not vertical or at some angle of elevation, as slickensides usually do. This fact of their horizontal position, and of close association here with other marks certainly of glacial origin, and of their alignment with the most probable course of the glacial movement at this point, led me at first to class them as "glacial scratches" or striations, as spoken of in the above document. But Mr. Ossian Guthrie, an expert glacialist of Chicago, examined them with me early in February, I 895 , and pronounced them unquestionably "slickensides," notwithstanding their unorthodox position; and I concurred in that as perhaps the greater probability. $\dagger$

Glacial Enamelings.-These are the marks "like patches of polished chisel work" spoken of in the June 2 d document. They are not "scratches" in the ordinary sense, nor striations, but rather gougings, with a thin shell of glassy-like glazing on the surface, which were produced by a friction so great as to generate heat enough to melt or vitrify the surface of the rock at points of heaviest contact. The glaze-film or enamel would of course be harder than the body of the rock, and thus preserve their character-otherwise they would have been worn away by water or weather long ago; and in fact there are many spots discernible where flakes of the enamel have cracked and peeled off. These marks are on the surface of what is apparently an obtruding head of tilted and fractured bedrock that stands partly in contact with the slickensides rocks. It lies in the line of right-oblique movement which would naturally have been produced by a glacier moving

*'I noticed in many places, as we approached L,ake Tenaya, the polishings and scorings of ancient glaciers. ** It is wonderful that in granite so decomposable these old glacial surfaces should remain as fresh as the day they were left by the glacier. But if ever the polished surface scales off, then the dis. integration proceeds as usual. The destruction of these surfaces by scaling is in fact continually going on. '-Prof. Joseph LeConte, in Overland Monthly, Nov., 1885; page 50I.

What Prof. LeConte calls " polishings," I have called ". enamelings," because this latter term better expresses their distinctive character as glazed surfaces-entirely different from any water-worn or sandscoured smoothness.

TThree or four months later, Capt. D. M. Greene, late of U. S. Army, discovered there one series of slickenside striations which had another series crossing them diagonaliy. And this second grooving may have been produced either by glacier or by earthquake movement. 
down the Canyada valley, and meeting a lesser one from the Arroyo valley at their point of junction. And I have not seen, nor heard, nor read of, nor been able to suggest any other movements in nature which could have done this particular piece of work. Just why there is not more of it here I cannot say; but I believe a great deal more of it once existed, and was cracked, peeled, disintegrated, worn and washed away by the action of the elements in after time, these being only a few specimens which chanced to remain to tell the story ; for as Prof. LeConte says, "The destruction of these surfaces by scaling is in fact continually going on."

Water Carvings. - There are several smoothly worn troughs or chutes and other peculiar shapings which were produced by the scouring action of sand, gravel, cobble-stones, etc., carried along by rumning water. The most conspicuous and well-marked specimen of this class is the turban rock, in shape and position something like a small Moorish dome-and now so ruthlessly daubed over with advertisements that a good photo of it cannot be obtained without its being marred by the impertinence of paint. When this particular job of water-carving was done, the outlet of a mountain footlake in the Canyada and Arroyo above flowed here, at the elevation marked by these fluvial mementos on the rocks; but the stream has since worn its channel to a bed fifty or sixty feet deeper down. In my researches of months and years among our mountain canyons, I have observed scores of cases of the water carving work, for it is still going on every year; but I have not yet found examples of either slickensides or glacial enamelings except those at Devil's Gate. The geological indications are that there was a great pre-glacial river sweeping down from Tejunga, Canyada and the Arroyo southeasterly across Pasadenaland to the San Gabriel river, with Rubio, Eaton, Santa Anita, and many lesser canyons as feeders from the mountain slopes. During the period of the great lava flows in North California and beyond, there were intense meteorological disturbances, with torrential floods more powerful and destructive than anything known within man's historic period; and it was in this age of surface changes that our ancient river bed became filled up many hundreds of feet deep with boulders, cobblestones, coarse sand and gravel, swept down from the disintegrating mountain fractures by oft-repeated cloudbursts and terrific storms. But in the closing of the glacial period the action was of a more steady, gradual and gentle type. The yearly increase of ice and impacted snow was piled up in the shaded mountain gorges, with dust, breccia, boulders, sand, clay-everything that was shed by the mountain peaks, ridges, slopes, ledges and gorges, being incorporated promiscuously with the accumulating ice and yearly snow-pack. This vast body of congealed water, with its varied burden of solid materials within its bulk and on its surface, moved slowly down the outlets, it may have been an inch a day, or a foot in a 
year, or at some faster rate; $*$ but when it reached the open plain where the sun had longer and stronger power upon it, the process of melting away commenced, and the ice sheet thinned out to a fine edge till it disappeared entirely, but formed terminal and lateral moraines and made its own peculiar deposits - thus leaving a record in the rugged language of its own day, which by careful and diligent study we can read and translate into the milder language of our day.

NoTE.-After this chapter was written, I met.Capt. D. M. Greene, of Co. E, 6th U. S. Inf.- a graduate of West Point, and thirty years in the government service, most of the time in California and adjoining territories, and often making official reports to the government on the topography, geology, and other natural features of unexplored regions of mountain and desert. I asked him to investigate the geological problem of glacial phenomena in this region, and let me know his conclusion about it. He did so and here is his report :

Pasadena, Cal., June 2d, i 895.

DR. H. A. REID,-Dear Sir:- Referring to the topographical and geological aspect of the country along the west slope of the Pacific Coast Range of mountains, and particularly that portion of it in the immediate vicinity of Pasadena, there opens to the scientist a wide field of speculation. The persons who have sought to determine the causes which have disturbed the primitive geological formation of the earth's crust have found sufficient evidence of the intense glaciation of the Pacific Coast. There are abundant traces of glacial action along the foot-hills and valleys north and west of this city. The gorge known as "Devil's Gate" presents strong evidence of glacial action. The position of the immense boulders found at that place show conclusively that they came there by glacial transportation. They are water-worn, but their size precludes the possibility of water carriage. Some of the rocks are peculiarly marked by grooves and scratches such as could not be produced by the action of water. Portions of some of the boulders are highly polished, as if glazed with potter's enamel. The scratching and polishing must be the result of the boulders being pushed or dragged along under a moving mass of ice, and this theory seems to afford the only satisfactory explanation of the phenomena. There are many other similar evidences of glacial action to be found in Verdugo canyoul and along the south side of La Canyada.

Yours truly.

D. M. GREENE.

I am also informed by Harold S. Channing, our most proficient local metereologist, that he had noticed evidences of glacier work in Tejunga canyon and in La Canyada.

Glacial Till.-When deposits are made by running water they are subjected to an assorting process by which the coarser and heavier portions remain in place first, as large blocks or erratics ; then boulders, cobblestones, coarse gravel, fine gravel, coarse sand, fine sand, and last or farthest down the stream, will be the finer particles that eventually settle and cohere in beds of

* "I found its rate of motion to be little more than an inch a day in the middle, showing a great contrast to the Muir Glacier in Alaska, which near the front flows at a rate of from five to ten feet in twenty-four hours."-John .Muir's "Mountains of California," $p .34$. 
clay, mud,silt, or alluvium, according to their kind of mineral substance and amount of water in combination. But the materials brought down from mountains by the glacier or ice-sheet method are not thus assorted.* On the contrary, they are intermixed, so that a section or vertical cut in this kind of a deposit will show alluvium and sand and worn gravel and angular gravel [breccia], rounded stones and angular stones, all heterogeneously interblended. This is called "glacial till," and this is the sort of formation that we find all over the plain on which Pasadena is built ; yet there are frequent instances of assortation made by running streams in the melting edges or foot-line of the great ice-sheet, besides water washings of later and post-glacial time; and this accounts for the special cobblestone beds, gravel beds, clay beds, sand beds, etc., which are often encountered in digging for cellars, cesspools, sewer pipes, railrood cuts, wells, and other excavations - all which do not change the main fact that "glacial till" is the type of our general surface soil, and in some places for a hundred or more feet down, until the gravel and boulder filling of the ancient pre-glacial river beds are reached.

Terminal Moraines. - It is the habit of a glacial ice-sheet to slowly, steadily, continuously slide down to the place where its foot is melted away, dropping there its terminal load of stones and debris from the mountains; but here the rivulets formed from the melting ice will carry off to lower parts of the country the finer materials, leaving scarcely anything but a bed of stones ; and this sort of a deposit is called a "terminal moraine," the best example of which that I have yet noticed here is at the south front of Mr. J. E. Jardine's place, between Raymond creek and Los Robles creek, where the roadway winds around southeastward down the cobblestone bluff. $\dagger$ [The cobblestone walls forming the bluff banks of an arroyo or valley of erosion since the glacial period, are a different type of formation.]

Lateral Moraines. - These are formed by the moving ice-sheet forcing stones into a heaped-together mass, or sort of rude wall-line along the edges of its path in a canyon or valley. But torrential streams rushing down across a valley or floodplain will also do the same thing on a smaller scale; and while I have found plenty of these in the floodplains of the Arroyo Seco, and Eaton Canyon, and the San Gabriel river, I have not as yet noted any that seemed to be distinctively of glacial movement except worn boulders imbedded high up along the north slope of the Verdugo or La Canyada hills, and along the east contour of Pasadena's Arroyo hills.

Boulder Clay.-A glacial ice-sheet carries stones of all sorts, large and small, smooth and rough, frozen solid into its bottom and sides; and as it moves they grind and scour the rock surfaces along the bottom and sides of

* "Till.-An unassorted, commingled, and chiefly unstratified mass of clay, sand, pebbles and boulders, deposited directly by glacier-ice, not by glacier-waters."-Standard Dictionary.

$f$ "The compact ice appeared on all the lower portions of the glacier, though gray with dirt and cobblestones embedded in it. $* *_{*}$ I noticed boulders of every size on their journeys to the terminal moraine-journeys of more than a hundred years withcut a single stop, night or day, winter or summer."-Mountains of California, p. 32-33. 
the glacier's slow but powerful pathway. The particles thus rasped off are ground to finest powder between the upper and nether millstones and pulped with water to a paste, or are carried out as the impalpable coloring matter of muddy waters flowing from the sun-kissed foot of the glacier. This fine mud material is often deposited by gentle sedimentation in some part of a glacial lake, or a stream where there happens to be still water, or an eddy, and will thus ultimately form a bed of clay intermingled with boulders, cobblestones and other glacial products. And clay formations of this character are found along our glacial-terrace line of water-bearing bluffs. It was first discovered by Judge Eaton when he tunneled for water at his "Hillcrest" home place on Sylvan Aven11e, in I 882. It was later detected by J. De Barth Shorb in his numerous borings for artesian water, and he called it the "clay dyke." In 1894 it was cut into by Engineer Gervaise Purcell with the water tunnel which he made for Mrs. Gov. Stoneman in the foot of Oak Knoll canyon, and at other points. [See his letter in chapter on Hydrology.] But a surface deposit of boulder clay is also found near the foot of Lake Avenue, where the Simons Bros. are quarrying it for their steam brick factory at that location.

Pipeclay.-This term technically covers such clays as are suitable for the manufacture of common coarser grades of crockery, and earthenware pipes for drainage and other purposes; and should be nearly or quite free from iron. A small bed of this material outcrops as a grayish-white deposit in the escarpment of the Arroyo bluff where the graded roadway leads down to the Linda Vista bridge; but I think there is not enough of it to be of any commercial value. Lower down is a nother stratum of fine clay, but of ironrust color and quality. These are the clay formations which Harold S. Channing's well cut through in 1887 , at a depth of roo feet below the surface. [See chapter on Hydrology.]

Glacial Drift.-This is a general term, comprehending in some measure all the foregoing forms of glacial deposit s; but applied more technically to large areas of gravel and cobblestone deposits which were evidently of glacial or subglacial origin.

Glacial Meadows. - This term is applied by Prof. Le Conte and John Muir to filled-up and soil-covered glacial lakes which now form areas and stretches of treeless pasture lands. A considerable portion of Pasadena's area was of this character, and was utilized as pasture land by the old Spanish padres in the days when the San Gabriel Mission held possession here.

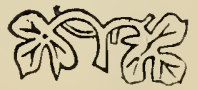




\section{CHAPTER XXX.}

Hydrology : Our Geological Basin.-Judge Eaton's Views.-Change of Climate.Wells of Pasadena.-Artesian Borings.-Mr. Shorb's Geological Section.-Dry Tunnels.-The Glacial Terrace.

\section{HYDROLOGY.}

This comprises all that has been learned from geological investigations, and from actual work done by hydraulic engineers, water tunnelers, well diggers, and artesian drills, in regard to Pasadena's natural sources of water supply; and this includes the mountain absorption of winter rains and snows, besides the great geological terrace basins - the filled-up ancient lakes over which the city of Pasadena is built. These lakes were filled at bottom with boulders, cobblestones, sand, gravel, and all sorts of debris from the mountains, and then a topping of tillable soil varying in thickness from one foot to over one hundred feet. The ancient gulf or lake basin under the city is over rooo feet deep in some places, and the lower 900 feet of this is simply a vast water bed, up to the level of its natural outlets by the springs in the Arroyo banks on the west, and those of the glacial terrace on the south extending from Columbia Hill eastward to San Marino (J. DeBarth Shorb's place) and Winston Heights. In I884 I had commenced my researches in regard to the geology and hydrology of Pasadenaland; but in I 893 I spent several months at Echo Mountain and Mount Lowe, by generous courtesy of Prof. T. S. C. Lowe, making a more close and careful investigation of our mountain formations and their water storage than I had been able to do before. Then in January, I 894 , I submitted a report before the Science Association of Southern California on the results and conclusions I had reached; and in this I spoke of Pasadena's great underlying water basin, with its lower lip at Raymond Hill and the canyon outlets in that east-and-west range of bluffs, giving numerous incidents of my own collecting to illustrate the case, and imagined that I " had a patent" on that geological basin or old filled-up lake theory. But when I set out to prepare a complete history of Pasadena I solicited some contributions for it from our veteran old settler, Judge B. S. Eaton, and he responded to my call with such a generous hand that in nearly half of my chapters I have something from him worth preserving. The water question had been one of his hobbies since his first settlement here abont twenty-five years ago ; and among. the matters which he wrote out for this volume is a very clear and distinct grasp of the doctrine of our underlying watter basins, which so far as I have learned, he was the first man to trace and define in their relations to Pasadena's fluvial interests. Thus my own "patent" on it is knocked out by the Judge's right of prior discovery, and here I present his narrative: 
JUIGE EATON ON PASADENA'S WATER SUPPLY.

About the year i 882 I ran a series of levels around that section of the San Pasqual ranch embraced between Columbia and Buena Vista streets in South Pasadena, extending the survey as far east as the waters supplying Marengo Rancho (Raymond creek). Half a dozen wells had been sunk over this territory; and taking their depth and comparing the height of the water in them with the levels of the natural outlets, the theory of there being a regular basin of water underlying the plain above was confirmed. A further survey demonstrated the fact that some four acres of my homeplace was below the level of the surface of the water in the basin ; but there was no natural outlet for it on my premises; so I determined to tap the hill with a tunnel. Before commencing this work, however, I sank a prospecting shaft at the top of the bench, on my extreme north line, in order to be sure and get on the inside of the supposed sandstone rim of the San Pasqual basin which our state geologist, Prof. J. D. Whitney, had mentioned to B. D. Wilson as his explanation of the peculiar conditions of water supply existing here, and in which I fully believed at that time. My surveys indicated the level of the water in the basin to be about forty feet below the surface of the ground at that point, and, sure enough, at that depth we encountered it. I felt satisfied then that the Professor's theory was correct; and running levels down the hill to a point corresponding with the bottom of the shaft, I commenced tunneling. I had driven the tunnel a distance of ninety-one feet under the hill, and as yet encountered no sandstone or ledge of any kind, but had observed that the floor of the tunnel was very moist, as if water were near-in fact, we were only four inches above the surface of the water in the basin. But where was the rim of sandstone? Following back, we found upon examination water at the same depth up to a point thirty-five feet from the mouth of the tunnel. Here then must be the point of interception. Upon a critical examination a stratum about twenty inches in thickness, of very compact clay, was found to have been pierced, and outside of this no water could be found. So that constituted the dam.* A dozen tunnels have been driven into this same bench east of this point since, and in every instance the moment this stratum was passed, water was found. Where Pasadena is there was at some period in the past an immense depression. In truth, I believe there must have been at least two, if not three, distinct basins lying parallel with the Sierra Madre range of mountains. The first had for its boundaries on the west the country lying along the Arroyo Seco, where the Canyada ranch is, and on the south by a line drawn in an easterly direction from the Devil's Gate. The second basin was bounded on the south by a line drawn from the Orange Grove Avenue reservoir, also in an easterly direction. The third probably comprised the section now embraced between Colorado and Columbia streets.

* Prof Whitney caught the idea of a great geological water basin north of MIr. Wilson's spring* bearing line ot bluffs. This was in 186 . No borings had at that time been made to detect the hidden local bed of boulder-clay, hence from surface indications he uaturally supposed the barrier rin to be a sandstone formation. And he did not recoguize the signs of glacial action, for at that time there was very little knowledge of glacier work in the United States; in fact. American glaciology has almost entirely been bult up since that time; and hence these two failures are no discredit to his proficiency as a geologist. The fact was, the state had sent him ont to find mineral wealth, rather than purely scientific knowledge, and he had to chase for gold-all other geological knowledge gained being ouly accidental or incidental, as tributary to that one main pursuit for precious metals. I make this explanation in justice to Prof. Whitney, who has been wrongfully criticized and censured for the incompleteness of his geological work in this part of the state. The Farisworth pamphlet of r883, page 5r, says: "The theory was advanced years ago by Prof. Whitney that this entire portion of the San Gabriel valley is underlaid by a vast subterranean body of water." 
At some time the waters poured down through Fair Oaks Avenue and found their way into the San Gabriel river.

[NOTE.-This corresponds almost perfectly with the three ancient terrace lakes which I had described in explaining the great antiquity of the stone implements found buried so deep on Reservoir Hill, which was before I knew anything about Judge Eaton's views on this matter. I give him credit for being the first to discern the true character and relative positions of these several water beds.-ED.]

Later on, and after they began to break away through and down the Arroyo, they were arrested by the bluff near Lincoln Park, which at that time probably extended to Garvanza and connected with the range of hills on the San Rafael ranch. [NOTE. - This is the same that I had described as a fourth terrace lake.-ED.] The waters turned through South Pasadena, and thence in a southeasterly direction to the bed of the San Gabriel river. But finally breaking through this last barrier they coursed on toward the Los Angeles river without meeting with further obstruction.

A phenomenon has occurred within the life of Pasadena with the water supply of the springs in the Arroyo Seco that goes far in my mind toward corroborating the theory of there being two or three distinct and separate basins. Ten or fifteen years ago my son Fred, civil engineer, and I were passing up the Arroyo, and noted the flow at the Sheep Corral springs. $\mathrm{He}$ estimated it at twenty-two inches - certainly not to exceed twenty-four. At a later period, Mr. Schuyler, the noted hydraulic engineer, was employed to measure the waters from the various springs in the Arroyo. Devil's Gate he gave as ninety-six inches, and two inches waste, making ninety-eight inches there. Under his direction, Mr. McQuilling, the zanjero of the Pasadena Water Co., measured the Sheep Corral springs, and from his data Schuyler gave as an approximate of the flow, fifty inches. In speaking of inches, miner's inches are meant, one of which equals about i 3 , ooo gallons per day of twenty-four hours. Last year I visited the springs with Mr. P. M. Green, and at that time, midsummer, there was not less than 150 inches of water there; and that after the water had been picked up and diverted into the pipes at Devil's Gate. Now comes the question, what had brought about this wonderful increase? My theory is that the water had been carried over the divide between the two basins in pipes and deposited in the lower basin for a term of years until the ground had become thoroughly saturated, thus augmenting the supply; consequently there was an increased flow through the natural drain at the Slieep Corral springs. What strengthened my belief is that the springs above have not shown a corresponding increase, though their average discharge has increased of late years. That I attribute to the fact that the waters of all the little streams from the mountains, which formerly were principally lost by evaporation, have been gathered and poured onto the lands covering the upper basin nntil it has become saturated, and now add their volume to the supply of that basin. This is the only theory that I can evolve from the circumstances, since the water shed has not been extended, and the average annual rainfall has shown no material increase during the past few years.

EXPLANATION-CHANGE OF CLIMATE.

This increased flow from the springs is a very interesting fact, yet very simple of explanation, and is connected with the change of climate which is 
going on here. From Devil's Gate eastward to Monks Hill and beyond there is a subterranean barrier ledge, or "divide," as Judge Eaton calls it, which serves as a submerged dam to hold the waters that are percolating down from the foothills and highland slopes, and compel them to find an outlet at the lowest point of the barrier, which in this case happens to be the Tibbetts springs and flutterwheel springs at Devil's Gate. Next, from Orange Grove Reservoir Hill eastward to Summit and Marengo Avenues at Chestnut street, or above the Santa Fe railroad crossing, there is another barrier ledge which compels the percolating waters to find outlet at the lowest point again, which in this case happens to be at Sheep Corral springs. And a similar underground topography is repeated at Columbia Hill, Raymond Hill, and the Glacial Terrace line of bluffs extending thence eastward.

Here, then, are our three principal underground basins or lakes. Now, twenty-five or thirty years ago Pasadenaland was a parched, arid, barren desert, all through the "dry season," and from its plains a dry, hot air was radiated or reflected with scorching effect. The mountains held no less water in store then than now, but it all ran to waste down the canyons until lost in their sandy outwashes, instead of being piped ont to moisten and fertilize the dried up plains. But since that time the piping has been done, and many thousands of acres that aforetime lay as a scorched plain during four to seven months of the year, are now supplied with moisture, and are covered with vines, fruit trees, flowers, shrubbery, grass lawns, hedges, and trees of stately growth. And thus by necessary consequence the local climate is changedhas become more moist, more humid, and in other ways modified both by increased evaporation from the soil and by the subtle chemistry of vigorous vegetation. The long stretches of railroad trackage and electric wires, the friction of moving trains, the diffusion of their volumes of steam and smoke into the atmosphere, etc., have also worked somewhat to change the electrical conditions prevailing, so that they, too, are different from what they were before this region was wrought upon by the art of man. These are points as to change of climate - both the fact of it and the factors of it. And now I will return to the matter of increased flowage from our springs, as mentioned by Judge Eaton. All the water piped out from the Arroyo Seco and Millard canyon and used either for irrigation or domestic purposes on any lands or lots south of Monks Hill, west of Los Robles Arenue and north of Villa street, is to this area a clear addition of that amount of water which would otherwise have gone to waste down the Arroyo bed, and never touched this land. This volume of water is not lost, except a little by evaporation, but after serving its special uses for man it sinks away into the ground, percolates down to the general water bed, and finds outlet again at Sheep Corral springs, thus increasing the flow there. Other areas and other springs are affected in a similar way and by the same processes; but waters that are used east of upper Los Robles or lower Marengo avenues do not return to 
the Arroyo Seco, but go to increase by so much the flowage in Mill canyon, Wilson canyon, Mission canyon, San Marino canyon, or the Craig Avenue swale which extends from foot of Craig Arenue down between the old Winston and Foord farms to the cienega or bog at connty road angle, where Foord's, artesian well flows apace, and from which bog Foord's creek arises. And water used south of Villa or IValnut streets, and west of Marengo Arenue go to increase the flowage in the Raymond Improvement Co.'s tunnel at Foothill street, and the flowage in Raymond creek. But this creek supply is now heavily tapped by the great well $S \times 12$, and twentyfive feet deep, in the Electric R. R. car house: and also by the Santa Fe R. R. well $S \times$ S, and sixteen feet deep at Raymond station.

In Pasadena's colony days much discussion was had and much experimenting done in regard to a water supply for each houselold by digging a well on their own premises. During the winter of is $4-85$. I made a careful research on this line and prepared a report which was printed in the Valley Union of March 20, ISS5. This report was the first collection of data ever made here on the well-water problem, and led to my conclusions about Pasadena being built over subterranean lakes of very ancient geological contonr. It is a matter of historic interest pertaining to the time before we were a city, and hence I quote the Union's article.

THE WELLS OF PASADENA.

Dr. Reid, while gathering up insurance business, has also gathered some statistics of the wells in Pasadena, which will be of curious interest as well as practical value to many of our readers. The list of locations, depth of digging and amount of water in these wells will throw much light on the problem of our permanent water resources, as well as on the geological character of this portion of the San Gabriel valley.

On the Pasadena Highlands, at the head of Lake Arenue, Mr. Melville Wood has a well which he dug in August, ISS2, only thirty feet deep, and the water stands in it steadily eight feet deep. This place is next east from Fred Woodbury's place. IIr. Wood has also an experimental well which he dug in December, ISSI, on the lowest or southeast corner of his place, which is only thirteen feet deep, and has one foot of water. In the same vicinity, and a little farther eastward, Mr. Hodgkins has a well thirtyfive feet deep. And on the Dr. Ellis place there is one twenty-five feet in depth. But on the Swartwout place, farther south, and probably more than roo feet lower down, a well was dug to the depth of 125 feet without getting water, and was abandoned and filled up: though later digging on other farms show that a good supply of water would probably have been obtained if the digging had been continued far enough.

[NoTE.-Some time prior to isSo, Mr. H. G. Monks dug a well a few rods north of Monks' Hill to a depth of I 33 feet, and obtained water. When Painter \& Ball, in זSSI, bought from Mr. Monks his 2,000 acres of land, they dug this well two feet deeper, and water stood in it usually about twelve feet deep: but in $1 S S_{5}$ it went dry. Mr. Monks had also run a tun- 
nel frorty or fifty feet intor the north side of Monks' Hill, and found a little moisture but no flow of water. Then in 1884 Painter \& Ball dug a well Ior, faet deep with three feet of water, on what is now the 'Tebbett's place, near the Washington schoolhrouse. - Eis.]

On Villa street, on land now owned by Mr. J. Blatenburg, there is a bored and piped well 490 feet deep, with 34 , feet of water standing in it. This well was sunk by Mr. Craig, after whrm Craig Avenue was named, in order tos test the probilem of artesian water in that vicinity. Further east, on Villa street, S. Bundy has a well i 74 feet deep. Alfred Hutchins, on the corner of Villa street and Hill Avenue, has a well ifor feet deep, with eight feet of water. A. Becker, corner of Villa street and Craig Avenue, has a well 170 feet deep, with nineteen to twenty feet of water. J. I). Korty has a well 148 feet detY, with frour feet of water. ('. D. Curtis' well on Santa Anita Avenue, the roarl that leads into Eaton Canyon, is 10,2 feet deep, with two feet of water. And P. B. Langworthy's well on Craig Avenue, is I 30 feet deep, with four feet of water. On the Allen ranch, north of $J$. F. Crank's place, and the one that gave name to Allen Avenue, a well was dug I 80 feet without finding water. On Cosloradn street, H. R. Case's well is 108 feet, with four or five feet of water. C. Maudlin's well is no feet, with seven to eight feet of water. Peter Sumstine's well, corner of Colorado street and Craig Avenue, is 93 feet deep, with twelve feet of water. I. McCollum's well, I 7 feet, with ten feet of water. J. R. Giddings' well, IIs feet, and six feet of water. A. M. Byram's well, i 3 feet, and ten feet of water. Dr. Aikens' well, go feet, with four to five feet of water. On Marengo Avenue, M. W. McGee has a well ninety-four feet deep, with ten feet of water ; and G. 'T. Stamm's well is eighty feet deep.

On Fair Oaks Avenue, M. Sandeman's well is twenty-six feet deep, with six to eight feet of water. John S. Mills's well, eighteen feet, with six feet of water. H. A. Wallis's well, fourteen feet, with five feet of water. These three wells are all in the adobe land, down near the Raymond Hill; and at the north-east fort of this hill is an outcrop of water formerly known as the Bacon spring which was the head of a forcolk flowing down across the old Bacon Ranch. [Paymond Creek.] On Columbia street, Mr. John Werner has a well ninety-six feet deep in which the water stands fifty-four feet, and is pure, soft water. It seems to come from a bed or stratum of clay almost entirely free from the lime and iron elements which make "hard water" of our water supply generally, whether it comes direct from mountain canyons, or the Arroyo, or from wells. In the same general ricinity around Mr. Werner's we find the Edwards wells, (recently bought by Mr. Raymond), sixty-five feet deep, with eight feet of water; Mrs. Riggins' well, seventy feet, with eight feet of water; D. Raab's well, fifty-eight feet, with eighteen feet of water; A. O. Porter and P. M. Green's well, seventy feet, with eight feet water; Judge Eatron's well, forty-six feet, with six feet water.

On the Arroyo Drive, aborte California street, Mr. Bruso has a well forty feet deep, with twenty feet of water. Below California stret, Mr. Baker and Mr. Barcus, and Miss Bishop each has a well twenty feet deep, with about five feet of water; and Mrs. Glover's well is twenty-nine feet, with five feet water. S. Washburn, corner of Fair Oaks Avenue and Valley street, had a well eighty-three feet deep, with ten feet of water, and a steam pump to lift it; but it caved in during the excessive rains and floodwash of February and March, 1884, and has not been reopened. 
The following additional wells were noted, without learning their street locations: G. N. Briggs, 83 feet, with I 2 feet water; E. H. Royce, 9 I feet, with 7 feet water; J. Butler, bored and iron-tubed well, 70 feet, with 30 feet water; D. W. Shellhamer, 83 feet; Mr. Biedebach, I 86 feet; Mr. Gripper, 83 feet; Messrs. E. A. Bonine, James Williams, Joseph Wallace and others also have wells, the figures of which were not obtained. John Werner, J. Butler, and Mr. Hammond expressed confidence that they can obtain artesian water by going down 500 to I, O00 feet.

Here are forty-six wells named within the neighborhood known as Pasadena, varying in depth from fourteen to 490 feet deep, and scattered about in all parts of the settlement; and there are probably ten or twelve more not noted. It is therefore pretty plain that Pasadena has resources to soak the heads of dry weather croakers, even should the clouds go farrow and the mountain streams dwindle all this year. [March, I 885.]

[NOTE. - Mr. John S. Mills, mentioned above, has since informed me that he dug his well in I882; that water was found at fifteen feet from the surface, and at twenty-one feet it came in so fast that it yielded twenty gallons per minute, and drove the workmen out. The John Werner well referred to was first dug by Hon. P. M. Green, a short time before Mills's well, and a moderate supply of water was obtained at a depth of forty-seven to fifty feet. Then after Mr. Werner bought the place he drilled this well about fifty feet deeper, and more than doubled the supply of water, having penetrated the bed of clay which Judge Eaton refers to as occurring in his tunnel and others along the Glacial Terrace. This clay formation is the "boulder clay" of geology, and was originally the fine mud that settled along the borders of a glacier - then it was covered by later material, and pressed into a tough, arenaceous clay (intermixed with boulders and cobblestones) by the weight of deposits above it.]

Since the above list of wells was published, in March, 1885, a great many other wells and tunnels have been dug in Pasadenaland, and I have obtained notes on a few of them. In I 887, when the Oak Knoll syndicate was engaged in subdividing and improving their picturesque tract they dug a well I 40 feet deep. Water was first found at twenty-two feet; and at fifty-six feet a water-bearing stratum was reached, which made the water rise six feet in the well, and it remained at that height-only sixteen feet from surface-but boring, was continued to a total of 140 feet from the surface. Then a steam pump was tried, and it could not perceptibly lower the water line. July 6,1895 , I investigated this well again; and found the steam pump at work lifting 4,420 gallons of water per hour for ten hours each day, without perceptibly lowering the supply. George Hyatt was the engineer in charge. The covered reservoir at ground level holds 250,000 gallons; and the tank, iwenty-one feet above ground, holds 60,000 gallons. A hout a fourth or third of a mile farther south on this tract there is a series of tunnel and trench surface springs which yield a good supply of water.

In I 887 , Harold S. Channing dug a well on his father's place on Orange 
Grove Avenue, across the street east from Reservoir hill. After passing through the surface soil or "glacial till" formation, fifteen or twenty feet, there was a continued alternation of water-wash layers of sand, gravel, cobblestones-each time in this consecutive order. Then at about roo feet below the surface he encountered a stratum of pipe-clay which was eighteen feet thick. As soon as this was passed through, a water-bearing bed of sand and gravel was met with and penetrated two feet, yielding an abundant supply of water. The total depth of the well was $\mathrm{I} 20$ feet. The bed of pipe-clay passed through in this case is the same that crops out in the bluff and in the roadway gully at foot of the hill road leading down to the Linda Vista bridge. [See page 559.]

In the spring of $\mathrm{I} 890$, Dr. R. H. Shoemaker, at corner of Craig Avenue and San Pasqual street, bored a well seventy-five feet deep, in which water stands twenty feet. A steam pump was tried on it at forty lifts per minute. This rapid rate succeeded in breaking the machinery but not in emptying the well. I visited this well on September I0, 1894, and found a gas engine steadily at work pumping I,, 00 gallons per hour, as stated by the pumpman in charge.

In 1890 Joseph Heslope sunk two wells 500 feet deep on his place between the Titus and Winston farms, and they flowed over the surface, but not strong enough to suit, so he tapped them with outflow pipes six feet below the surface, and got a stream of nine inches of water; and this water is now piped away to San Gabriel and Savannah.

In October, I89i, Mrs. Black, on south side of San Pasqual street opposite Dr. Shoemaker's, sunk a well roo feet deep, with a stand of sixty feet of water in the tube.

In I 891, L. H. Titus sunk a well on his peach farm on California street and Santa Anita Avenue to a depth of 500 feet, and water stands in it to within thirteen feet of the surface.

In I $892 \mathrm{~A}$. J. Painter sunk a well fifty-five feet deep, on Painter's Flat at the Arroyo Park grounds, near where his dummy railroad then ran from the Painter hotel down to Devil's Gate ; and from it was pumped a steady stream of seven miners' inches. Then a few rods southwest from this, J. Benj. Wilson had a well near the Arroyo bank, forty-five feet deep with three feet of water, which had stood true for five or six years. But in 1894 the water companies run a tunnel forty feet below the bottom of the well and drained it dry. This shows that there is a barrier ledge or dyke or waterproof rim of some sort between the underground basin and the Arroyo gorge. P. W. Lloyd owns this Wilson place now, and has a well shaft eighty-five feet deep to the bottom of the tunnel, from which he raises water by a windmill.

In the summer of 1893, C. S. Carpenter, at corner of California street and Shorb Avenue, sunk a well I 20 feet deep, and tested it with a steam 
pump that raised 2,400 gallons of water per hour, without perceptibly diminishing the supply. Mr. Carpenter informed me that the first fifty feet down seemed to be a soil formation just like the surface; then water was met with, and the boring was through sand, gravel, boulders, etc., all the rest of the way down. The water continually stands at fifty feet from the surface, but rises no higher, that being the normal water level in our submerged ancient lake-bed; and that fifty feet of soil represents the depth or thickness of the glacial till formation at that particular point.

In September-October, I894, Col. O. S. Picher and his son, sunk a well at their home place on Magnolia Avenue below California street. They bored to a depth of $\mathrm{I} 20$ feet and got seventy feet of water; then a steam pump was put in and run at its best endeavor for twenty-four hours without perceptibly lowering the water in the well.

In March and April, 1895, the Electric R. R. Co. sunk a well $8 \times$ I 2 feet in size; and 25 feet deep from surface, inside the northeast corner of their great truss-roof car house. For two weeks it was necessary to keep a rotary pump ruming at full speed night and day, to keep the water out so that the diggers could continue their work. I visited the place five times during the progress of this well. As to the amount of water being pumped out, the workmen gave me different statements; some I knew lied to me, and I distrusted all of them, but had no means of measuring it myself; yet I noted that the pump was throwing a steady 3 -inch stream with such force as to project it six feet from the outlet in a fall of about four feet. This is the largest well service yet developed in Pasadena's ancient underground lake.

April 18, I895, I inspected the Santa Fe R. R. Co.'s well at Raymond station. It is $8 \times 8$ feet in size and 16 feet deep, and usually fills from 7 to 8 feet during summer months; but the pump man thought the Electric Car Co.'s big new well had perceptibly lessened his supply, while it was being dug and its water-flow all pumped, out. With a $2 \frac{1}{2}$ inch outlet he could pump his well empty in $I \frac{1}{2}$ hours; then it would take about three hours for it to fill up again. The R. R. tank is 18 feet deep and holds 52 , 000 gallons. The $\mathrm{I} 1 / 2$ hours pumping would raise the water line about two feet, which would measure 5,778 gallons of water. He thought this well would have to be dug deeper eventually.

\section{ARTESIAN WELL BORINGS.}

The first historic effort in this line was made by James Craig, a native of England, who came here in 1869 , as agent for the Grogan tract of 5,000 acres, and took 150 acres of it for his own home, where he still resides, at the head of Craig Avenue. He calls his place "The Hermitage." The well in question was on the south side of Villa street near Wilson Avenue, and was drilled and piped to a depth of 490 feet; water stood in it 340 feet deep, but this was 150 feet short of coming to the surface for overflow, and 
hence was not an artesian well at all. It was a costly and sorry experiment for Mr. Craig, but was really the most heroic and valuable thing that had yet been done toward finding out what were the subterranean water resources of Pasadenaland. This was in 1880 or ' 81 .

About the same time the Foord Brothers had obtained a flowing well in a cienega or bog at foot of Santa Anita Avenue, this bog being a pocket in the Craig Avenue swale on the road between the original Ford and Winston farms, and out of it flowed Foord's creek. The Foord Bros.'s farm is the northwest part of lands of the East San Gabriel Land and Water Co., as shown on the official map of Pasadena, but is now owned by E. K. Alexander. The well was tubed, and flows there yet, close by the east side of the road.

The next notable effort on this line occurred early in I 886, and I copy here a report of it which I made in the Valley Union of May 28, 1886 :

"Mr. L. H. Titus has recently completed a remarkably successful artesian well. It is 290 feet deep from the surface, flowing out on higher ground than any other artesian well yet made in that region, and it flows freely to a height of eight feet and three inches above the surface. The water from this artesian well is as clear as crystal and gives no taste of mineral properties, but is warm, its temperature being 72 degrees Fahrenheit. It took them over three months to make this well. At seven feet from the surface they struck boulders and had to drill through them. At the depth of 218 feet they found a stratum of cement rock 21 feet thick, and in this they could drill about two feet per day. At 284 feet they struck the rounded side of a granite boulder which their tools conld not phase. In forcing the tubing down it was bent and partly iattened against this rock. Here was the point where 99 men out of roo would have given up,-but Mr. Titus stuck to it with iron grit-invented tools to rasp away the side of that flinty rock-kept up the unequal struggle at that abysmal depth for three weeksfinally forced the passage and then in a short time reached a bed of sand and gravel six feet lower, and here came the splendid flow of water above described."

The "stratum of cement rock 2 I feet thick," above mentioned as being met with at 2 I 8 feet below the surface, is the eastern dip of the conglomerate formation which crops out as "Eagle Rock," three or four miles west of Pasadena, and is again exposed by erosion at the mouth of San Rafael [or Johnson's] creek opposite foot of Columbia street, and is seen low down in east bank of the Arroyo Seco right across from the mouth of San Rafael creek.

The next important artesian venture was that of E. F. Hurlbut on South Orange Grove Avenue. In speaking of this the Pasadena Star of April ro, I889, said :

"A looser formation was struck yesterday than the drill had been passing through for some time, but nothing else. At a depth of 480 feet the first spring was struck since leaving the surface water at a depth of sixty-six feet. The water raised in the well twenty feet yesterday." 
The Pasadena Standard of September 2 I, I889, said:

"E. F. Hurlbut's well borers are down more than 900 feet, which is very nearly to sea level, but no artesian flow yet. This is the deepest boring ever made in this section of country.'

In my geological report before the Science Association of Southern California, in January, I894, I gave the following account of this well :

"The boring made on E. F. Hurlbut's place on Orange Grove Avenue in 1889-90 was a truly heroic struggle of hope against hope and faith against fate. It went down I 3 IO feet without striking bed-rock - nothing but boulders, sand, gravel, etc. Water stood in the tube at sixty feet from the surface, but rose no higher. The bore commenced ten inches in diameter, and a few hundred feet down was reduced to six inches. The massive steel drill, which with its necessary tackle, couplings, etc., was thirty feet long and one-and-a-quarter tons weight, finally dropped aslant in to a boulder cavity and became inextricably fastened in one or more of three possible ways: either by slant leverage against the walls of the cavity; or by a slip or crowding down of a large boulder upon it; or by its own expansion from the increased temperature at that depth. My own opinion is that both of the two last named causes operated in the case, and probably the first also. At any rate, five months were spent in vain efforts to extricate that drill. A two-inch hemp cable was broken; then a one and one-fourth inch wire cable was obtained, a hydraulic press lifter attached and worked up to a lifting strain of 100 tons, when this powerful wire cable broke also; and the well and tools had to be abandoned at last, with, of conrse, great loss to the contractor, Mr. Charles E. Mosher, of Pasadena, besides about \$10,000 loss to Mr. Hurlbut, who wanted to go down at least 2,000 feet, anyway, before giving up the project to get artesian water, or oil, or something."

In I89 I Mr. Geo. S. Patton bored for artesian water in Mission canyon. At a depth of fifty or sixty feet some water had been found; then a clay dyke twenty-five to thirty feet in thickness was passed through, and the water already in the well disappeared. The boring was continued to a depth of 200 feet, but no water obtained. In i $874-75$ a well had been bored on the east line of Mr. Shorb's place, below the bluff, with experience very similar to that I have given of the Patton well. And about the same time Mr. Mayberry had the same experience in boring for artesian water near the "old mill." Mr. Patton had bored too far south to strike the water bed for which the clay dyke served as a submerged dam, and the others were entirely below the dyke. This clay dyke was the same bed of "boulder clay" first discovered and recognized by Judge Eaton in his water tunnel, in I882, as heretofore mentioned. And in August, I 894, Gervaise Purcell cut through it by a tunnel which he run for Mrs. Gov. Stoneman, in the lower part of Oak Knoll canyon. Mr. Purcell ranks high as a hydraulic engineer; and I wrote him inquiring if he had met with this clay deposit at any other points where it would seem to be a part of the same original bed or stratum. Here is his reply :

Los ANgeless, Cal., January I9, I 895.

Dr. H. A. REID, - DEAR SIR: I have found the "boulder clay," as 
you classify it, in a tunnel recently run by me on the old Miguel White place, subsequently owned by James Foord, and now in the possession of $\mathrm{E}$. K. Alexander. This place lies immediately east of the Winston rancho. In this case it is largely mixed with boulders, but very little sand or gravel. When taken out it forms a glutinous, plastic mass, and is exceedingly fine, so much so that when mixed with water it will pass through any crevice that that liquid will. This deposit lies about forty-six feet below the surface, and is uptilted so as to render the ground back of it impervious ; in fact, we seem to be passing through the side of a bowl into a basin filled with a mixture of this clay and boulders. I found no fossils. The nature of this material here suggests very forcibly the truth of your theory that it is a clay formed by the grinding together of large stones. Very truly yours,

\section{GFRVAISE PURCeI.I.}

In I 892 Hon. J. De Barth Shorb bored an artesian well in the upper part of Mill canyon, at the foot of Lake Avenue. He kept a record of the number of feet passed through of each different kind of material and preserved a sample of the material each time, in a long case of little glass-covered boxes. 'This case is preserved at his great winery four miles south of Pasadena, where I spent the day, April IO, I894, examining its contents and giving name to each sample-for before this they had remained unnamed; the samples were there, with accompanying figures, but no explanation or description whatever. And this is the first and only complete geological section that I have learned of ever being preserved, out of all the scores of wells that have been bored or dug within Pasadenaland.* It is of much value and interest to geologists and hydraulic engineers, and also to any person who may contemplate sinking a well in that region - hence I give it here :

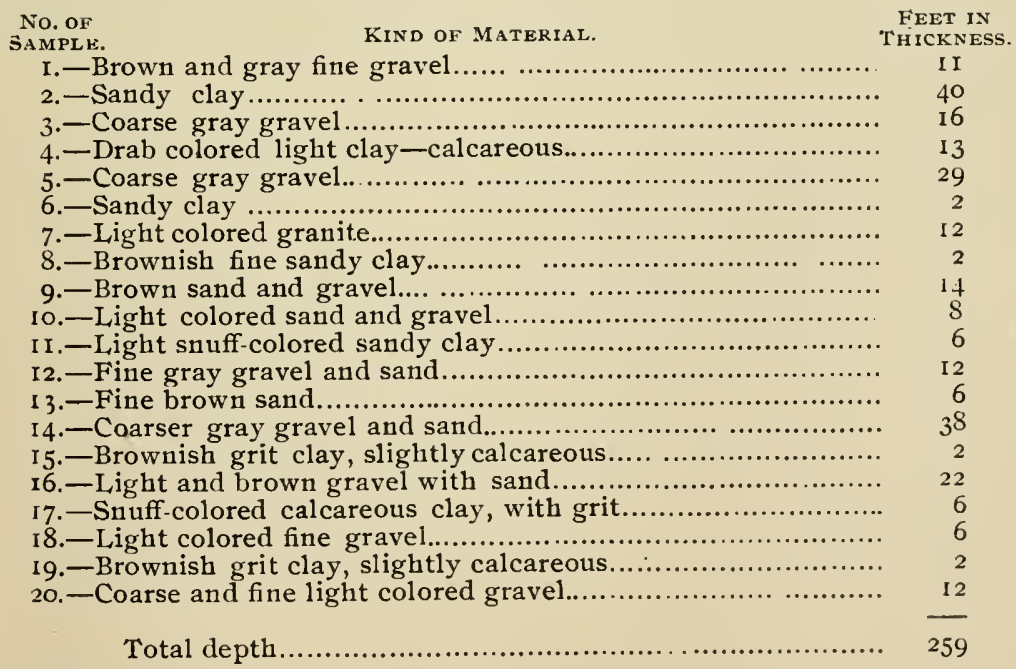

* The rooo-feet record giveu on page $55^{2}$ was made over three years after this one by Mr. Shorb. 
By former experience, Mr. Shorb had learned pretty nearly where the clay dyke or dam lay, and took pains to sink this well above it so as to test the permanent water level of the great underground basin. He then run a tunnel from lower down the canyon so as to tap the well at a point considerably below the permanent water level and thus obtain a liberal continuous flow. He informs me that he has tapped twelve wells in this way at points from ten to thirty-seven feet below their natural outflow, and in each case obtained from ten to twenty per cent. more water. The Winston farm, next east of Shorb's, has some wells tapped in the same way. Also the Heslope place next north of Winston's. But this is only practicable along the line of the glacial terrace and its clay dyke or submerged dam.

\section{WATER TUNNELS.}

From my geological report in January, I894, I quote this amusing bit of tunnel history :

"I11 I882 Judge B. S. Eaton tunneled into the basin rim at his place on the South Pasadena bluff and obtained a good flow of water. Then David Raab run a tunnel on his land farther east and lower down than Eaton's, and got a flow of water; but, lo! Eaton's tunnel went dry. Raab then sold this part of his land to Mr. Lightfoot and made another tunnel for himself farther east and a little lower down, with the result that he obtained water but Lightfoot's tunnel went dry. Next, H. D. Bacon made a tunnel on his land, farther east and lower down than Raab's, and got a good supply of water, but Raab's tunnel went dry. And the Bacon tunnel remains yet, being the one now owned by the Raymond Improvement Co. These four successive tunnels all tapped the basin rim, the last one, however, being lowest down and nearešt the flowage bed of this local basin's natural stormwash outlet - the depression or gully which rises west of Grace Hill, cuts across Columbia street, and debouches near Fair Oaks station on the Los Angeles Terminal railroad. For convenience I designate it as the "West Basin gully."

The Valley Union of June 4, I886, published a report which I made of a great tunnel undertaking then in progress at the foot of Dry canyon, and for its historic interest I here quote it:

"Pasadena has the longest water tunnel in Los Angeles county. This tunnel is in the wash that forms the outlet from three water-bearing canyons, Las Flores, Rubio, and Dry canyon, but there is no flowing water in the wash except occasionally during the rainy season. More than a year ago a prospecting shaft was dug by Dolben and Watkins, forty feet deep, which yielded five feet of water and kept to that depth all summer.' 'They then went about I950 feet down the wash and started the tunnel, in July, I 885, at a level I 20 feet lower than the bottom of their prospect shaft. The work has gone steadily forward since that time, and the tumnel is now in about 1050 feet from its mouth, in a line so straight that a man at the inner end with a good rifle could shoot a rabbit outside. The passage is three feet wide at base, and twenty inches at top, and five and a half feet high clear space inside of arch posts. Three air shafts have already been dug to connect with the tunnel from the surface; but the first one has been passed and closed; the second one is now in use both for ventilation and to hoist out 
debris; the third one has not been brought into use yet, but will be entered in a week or so by tunnelers, who will work from its bottom both ways, one gang excavating toward the prospect shaft, and the other gang toward a junction with the passage already made; and it is calculated that two more air-shafts will be necessary before they reach their water limit. The whole passage has been made through a bed of boulders, sand and gravel, with a little yellow clay mixed in, and many of the boulders are so large that they cannot be got out at all but must be drilled and blasted in order to clear a passage. The theory of this great enterprise is, that at or near their prospect shaft they will strike the sloping bed-rock of the mountain base, and thus undertap the percolation of the whole water-bearing stratum above the bed of the tunnel, which will be 160 feet below the surface at that point. The prospect shaft already penetrates five feet of the water-bearing stratum, and how much thicker that stratum is can only be determined by the philosophy of pick and drill. If they meet the bed-rock as anticipated, then they have right-of-way to cross-cut for sereral hundred feet both east and west, thus making lateral catch basins that will turn flowing streams into the outlet tunnel from both ways. The whole scheme is a gigantic experiment, based on a few known facts, and some unproved theories that look very plausible. But it costs a mint of money and a vast deal of pluck to make such a bold problemetical venture; and it is to be hoped that it will prove even a greater success than the projectors have reckoned on. The famous Bacon ranch tunnel, near where the S. G. V. railroad crosses Fair Oaks Avenue in South Pasadena, is 675 feet long, but this new one will be more than four times as long, counting its lateral feeders."

Sad to say, this great enterprise proved an entire failure; and the 3,000 feet tunnel lies there, dry and worthless, to rivet and clinch the name of "Dry canyon."

There are seven or eight tunnels connected with the Rubio canyon and Echo Mountain water supply. Two, I think, in Pine canyon, four in Las Flores canyon, and others in Eaton canyon, Millard canyon, and in banks of the Arroyo Seco and its tributaries; also at Linda Vista, and Henniger's flat, etc. - besides those in the Glacial Terrace - a total of about fifty water tunnels within Pasadenaland in IS94. Some of these are further mentioned in connection with history of the water companies to which they belong.

October Io, I89I, a Board of Trade committee consisting of J. A. Buchanan, J. W. Scoville, A. J. Painter and James Craig made a report on Pasadena's water supply, from which I quote this passage, as printed in the weekly Star of October I 4 :

"From the state engineer's report it is ascertained that the water available for use in this vicinity, estimated for the dry season of dry years, is as follows :

Sheep Corral springs...........................60 miner's inches

Ivy, 'Thibbets, and Flutterwheel springs. ......... I oo miner's inches

Painter's system ............................... Io miner's inches

Millard canyon ................................ 7 miner's inches

Las Flores canyon............................ ro miner's inches

Rubio canyon .............................. I5 miner's inches

Eaton canyon ................................ 40 miner's inches

Total.................... 244 miner's inches

A miner's inch of water is equal to a flow of nine gallons per minute. [See page 4I4; and foot note, page 42I.] 
GLACIAL TERRACE.

The following correspondence will briefly explain what local points and features are comprehended under this general term, and why:

OfFice Pasadena History Co.,

Pasadena, CaL., August 21, i 894.

\section{Prof. A. J. McClatchie, Botanist Throop Polytechnic Institute:}

DEAR SIR - Answering your inquiry as to local names of certain points rich in native flora, I respectfully submit the following: That peculiar and characteristic range of water-bearing bluffs from Raymond Hill eastward to San Marino, I have, for geological reasons, designated as the "Glacial Terrace" group of spring brooks and canyons. It comprises Raymond creek and canyon, [formerly called in Spanish, Arroyo San Pasqual]; Los Robles brook and canyon, bordering Mr. J. E. Jardine's place; Oak Knoll brook and canyon, which joins Los Robles brook at Willowdale and forms the "Mill Spring Creek" of the Mission Fathers; Mill Creek and canyon, which rises at the foot of Lake Avenue and runs directly down to Wilson lake, but its waters were also led by a ditch into their old stone mill by the Mission Fathers; Wilson's canyon, which rises at the foot of Wilson Avenue and runs down to B. D. Wilson's old original Iake Vineyard ranch barns and house, now known as the Patton place - this being the one where the Biology department of the Throop Polytechnic Institute has chiefly procured fresh frogs for dissection and microscopic study; Mission canyon, (also called "Wild Grape canyon") the longest and largest one of the series, famed for the abundance and fine quality of its wild grapes; and San Marino canyon, bordering San Marino ranch, Hon. J. De Barth Shorb's elegant residence grounds. Seven distinct water-way canyons, besides some unnamed tributary brooklets, all within a space of two miles; and I suppose the native flora of this entire series or group of spring streams is substantially the same. Yours very truly,

H. A. REID.

To Prof. McClatchie: The above having been submitted to me; If will say, that from my knowledge of glacial phenomena, and my observations in the region referred to, I consider "Glacial Terrace" an appropriate name to indicate the character of the geological formations found there, and also a fitting and convenient local designation for that peculiar range of bluffs taken as a whole.

Respectfully,

J. B. FRENCH.

I should here explain further, that the Glacial Terrace really commences at Columbia Hill, and extends eastward clear to the outwash of Eaton canyon, beyond Lamanda Park; and the "West Basin gully" from the Columbia street water-shed, and "Craig Avenue swale" on the eastern border of Pasadena territory, are both outlets of our geological basin, yet are not large enough to be rated as canyons - while the first named one does not produce a spring brook, and the last named produces its brook or creek beyond our Pasadena territory. These are the reasons why they were not named in the above document. Prof. McClatchie wished to know the historic names and associations of these densely-verdured water-bearing canyons - for sometimes botanical specimens were found in one canyon which did not occur in others. 


\section{CHAP'TER XXXI.}

ZooLogy.-Prof. Holder's Account and List of our Native Mammals; also of Extinct Animals. -Joseph Grinnell's Account and List of Birds. - Will H. Wakeley's Specimens.- The Editor's own account of Reptiles and Insects.

\section{NATIVE MAMMALS OF PASADENAI,AND.}

In I 886 Prof. C. F. Holder, LL. D., was engaged by the Board of Trade to furnish literary and scientific articles to eastern and northern newspapers, on such matters in and about Pasadena as he could utilize, and thus bring this city extensively before the reading public abroad.* The Union of October 30 published a list of his writings under this engagement, which numbered a total at that time of eighty-four articles furnished by him to the press of Boston, New York, Philadelphia, San Francisco, and various New England cities. He also made contributions to the local press of Pasadena and Los Angeles up to I889. Among these writings are his descriptions of the native animals here; and from these I make the following extracts :

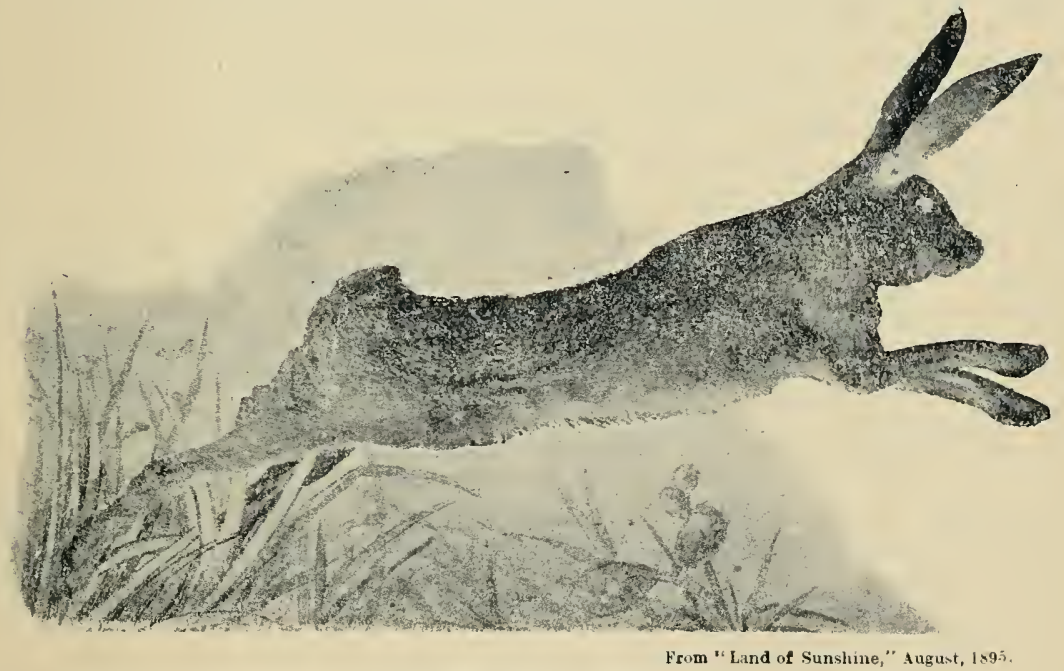

JACK RABBIT ON THE JUMP.

THE JACK RABBIT, which is properly a hare, and is known to science as Lepus Californicus. The hares never burrow, forming nests upon the surface in the grass and there rearing their young, while the cotton tail forms a deep burrow, after the fashion of all rabbits. The hare of New Mexico, Arizona and Texas, also called the "Jack Rabbit," is a different species, ( $L$. Callotis, ) though to the casual observer there is little difference.

KANGAROo RAT.-One evening at Las Casitas, near Pasadena, I saw in the dim light a curious object hopping along, which I found to be one of the queer jumping mice, so called, an animal known scientifically as Dipo-

* For list of Prof. Holder's published volumes, see page 224. 
domy's. It was a most attractive creature, almost as large as a small rat, of beautiful fawn color, with white beneath, a long tufted tail with a white stripe on the side, large expressive eyes, and long powerful legs for leaping. It looked like a miniature kangaroo, and my captive had a pouch, - two, in fact, one each side of the jaw. The little creature had been feeding and its pouches were filled with very small seeds which it was storing up to eat at leisure. It hopped along nearly like a kangaroo, sitting up when alarmed, then leaping a foot or more, using its short fore feet to aid in the motion, in its general appearance carrying out its popular name of kangaroo rat.* The form common about Pasadena is Dipodomys Phillipsi.

GOPHER.-Few in California but are familiar with the gopher (geomys) and have not watched with amazement gallons of valuable water disappear in the holes of these tyrants of the garden. The gopher tunnels in every direction, and the entire upper surface of the valley, especially the cultivated portion, is permeated with a maze of their making. Like the kangaroo rat, they have two pouches, one on each side of the mouth, and so large that two fingers can be pressed into them. The earth is pushed up out of the hole by the feet and breast of the animal, but the chief use of the pouch is to store up food, which is eaten at leisure in the burrow. The gopher is very sly and cunning, and rarely ventures out if any one is near. The nest of the gopher is in a room near the surface, and the young, queer little fellows, are often thrown out by the plow. The long burrows are made in excursions for choice roots, and perhaps for social and various purposes. [This creature is also called "pouched rat."-E,DR.]

TREE RAT.-The stroller in the canyons often sees bunches of leaves and twigs, bound together so tightly that it is sometimes difficult to tear them apart. Frequently they are in trees, again are in bushes near the ground. [Two different species. (?)] Coming suddenly upon one, you may see a little creature darting away, resembling a rat. It is possibly the duskyfooted wood rat (Neotoma fuscipes), and the bunch of leaves is its nest, which, being above the surface of the ground, gives rise to the saying that California rats live in trees. One opened by me in a branch of the Arroyo Seco, after considerable labor, showed much method in its structure. 'The nest was at least three feet high, resting between the limbs of a tree, touching the ground; the upper twelve inches was made up of leaves and refuse packed together so closely that it formed a perfectly water-tight roof ; the11 came a large room filled with at least an armful of plant fiber and other soft material, all of the consistence of cotton, as dry and warm as could be desired. This was the nest, the sleeping room and the nursery of the young. This rested on a flooring of leaves, and beneath was a store-room containing at least two quarts of large acorns, among which I noticed several corn cobs, evidently taken from a house some distance away. The entire nest was perineated by four or five passages, there being at least three exterior doors, while a lower or cellar door led into a burrow in the ground, which, in turn, had another opening fifteen feet away. This nest, I think, was unusual, as many more opened failed to show the system and good arrangement dis-

*Van Dyke calls this animal the "jumpiug mouse or jerboa, ofteu called kangaroo mouse." He also mentions four other varieties of mice found here, to wit: A loug-tailed ground mouse, a shorttailed ground mouse, a tree mouse, aud a desert mouse, somewhat squirrel-1ike iu appearauce and motion, as it runs witl great speed and occasional high juinps; it lives mostly in clumps or patches of the prickly pear cactus. These five varieties of mice he classifies entirely separate from the rats. 
played by this wood rat of the Arroyo Seco.* While they are extremely timid, they take the most remarkable liberties around human habitations at night. In one case they removed some seeds from a box and placed thern on a table, so that the owner began to grow superstitious about the singular changes that took place in the night. In another case a wood rat took corn frorn a bag and half filled the boot leg of a teamster before morning.

SquirREI,S. - Of the squirrels, we have the beautiful gray form with fox-like tail, of the upper range, found clinging to the sycamore and other trees, in the canyons; and the degenerate ground-squirrel of every vacant lot-nature's plow-man, upturning the earth, admitting air and water, so possibly doing some good. This creature, with its voice like the clink of a blaster's hammer, is found everywhere in the vicinity of man's habitation, and is a purely ground form, rarely ascending trees more than eight or ten feet. Some people esteem it a table delicacy, and it probably constituted a prominent feature of the Indian diet in olden times. $\uparrow$ There is also a small squirrel (Spermophilus spilosoma) occasionally seen, resembling the chipmunk of the East.

Speaking of the squirrels of Southeri Caijifornia, Van Dyke says :

"Above an elevation of 4,00o feet is a gray squirrel, apparently the same as the one found East, though its habits and bark are quite different from those of the latter. At five or six thousand feet is found a thick-set, bob-tailed, striped sided chip munk, about twice the size of the eastern chip munk. It climbs but little, living in the ground and in holes in the rocks and fallen trees. At about the same elevation is sometimes found a squirrel of about the same size, build, and activity as the red squirrel of the East, but of a dull gray color. But the most common squirrel is the groundsquirrel, found mainly in the lowlands, generally in open ground, and disappearing at five or six thousand feet, or in very heavy timber. It is about the size of the gray squirrel, but built a trifle heavier behind. Its color is a dirty gray, lightly mottled. Its tail is neither so long, nor so heavily clad with hair as that of the gray squirrel. * * These ground squirrels, with the whole rat, mouse, gopher and hare tribe, can live without water. A dry winter, however, stops their increase, as it does that of the bees, hares, and valley quails. They seem to know there will be a scarcity of food. In such years no young are seen, and in the latter part of the season even the old ones disappear, becoming dormant, and awaiting in their holes the rains of the next winter."

MoLE.-I have seen only one species of the mole here, but in all probability there are several. Their upturned ridges may often be seen after a rain, when they forage for the worms which constitute their chief food. The

* Van Dyke gives three species or varieties of native rat, to wit: The large wood rat, which builds both above and below ground at foot of tree or bush, as Prof. Holder has fully described; but also a smaller one which builds its nests well up in trees. Over eleven years ago I saw some of these in wilson canyon that were twenty-five feet or more above ground. A third variety that lives entirely underground, and makes no nest above.

tI with others, both ladies and gentlemen, tried ground-squirrel meat. both stewed and fried, while camping on Wilson's peak, and found it really more tender, juicy and palatable than the timber squirrel, of which latterwe had plenty. also. Yet I had always been told by the old settlers that these ground squ'rrels were not fit to eat-that they had a ratty quality and tasted of the ground, etc., -all of which was purely imaginary. Farly in 1893 a curious ground squirrel was caught at Eagle Rock valley and brought to W. H. Wakeley, the taxidermist of Pasacena, who secured and mounted the specimen as a rare lusus naturae. The right upper incisor had grown and curved inward until it formed a complete circle and came out at the top of the skull through the middle partition; while the left incisor made a similar curve, $2 \frac{1}{2}$ inches long, but veered sideways so that it turned up outside of the mouth. The tushes of the lower jaw were $3 / 4$ inch long. I saw the specimen and measured it myself at Wakeley's Novelty Works, in June, I $994-\mathrm{E}$.DR. 
eye of the mole has, from disuse, degenerated to some extent, but it is by no means useless, as is generally supposed. Moles should not be destroyed, as they annually kill vast numbers of insects injurious to vegetation. It has been estimated that a single mole will destroy 20,000 insects in a year.

Of the animals referred to above, the squirrels, rabbits, rats, kangaroo rat, and gopher belong to the order of Rodents, or gnawing animals. The Mole and its allies belong to another group, the Insectivora.

BATs.-We have about Pasadena several species, but perhaps the most interesting and conspicuous form is a long-eared bat, Macrotus Californicus, with an expanse of wing of nearly eighteen inches, a long head, and prominent almond-shaped ears. My first acquaintance with this little creature was in the mountains. I was awakened by what I thought was a draught blowing over my face. Again it came - a soft breeze lasting for a second, and I realized that a large bat was flying around the room. The bats here have the advantage of those farther north. The latter hibernate or go into winter quarters in November and lie dormant until the return of insect life in the spring. During this time they eat nothing, and nearly all the functions of life are at a standstill; the Pasadena bats, on the contrary, living in an exceptional climate, enjoy life at night all the year round.

A small bat (scotophilus hesperus) with an expanse of about seven inches, is common here, while vespertilo nitidus is another small form. All these are insect eaters, living on the nocturnal insects. During the daytime the bats creep into dark places-chimneys, holes in trees, old roofs, caves and crevices in the rocks.

CIVET CAT.-One of the most attractive of the carnivora about Pasadena is the little animal known as the civet cat, "Pacific cat," and other names, and to the Mexicans as "Caca-mixtli" or rush cat. 'To science it is Bassaris, the species being known as astuta and sumichra ti, and is the American representative of the Nasua, and closely allied to the coon. It looks not unlike a cat, but has large ears and a fine, long, many-ringed tail. The little animal is nocturnal in its habits and gives little or no evidence of its agility during the day, but at night is literally as playful as a kitten. It feeds upon birds and small animals, and has been a puzzle to systematists, who yet dispute as to its proper place in the scale of life.

No't'E.-This so-called "civet cat" is such an exceptional little animal, being 111 known in the Eastern States, that I will give more space to its consideration. The following article from the Los Angeles Times has a local historic interest, and at the same time illustrates what Prof. Holder says about the animal being "a puzzle to systematists :"

PASADENA, Aug. 3i, I893.--('To the editor of The Times.) There is a question of "civet-cat or coon" (?) at Hotel Rubio, the solution of which will be of interest to all lovers of beautiful wild animals. For a week or more some very cunning wild animal had been depredating the pantry, and especially feasting on fresh fruits kept in store. But on Monday night it was caught tuhurt in a box trap, and put into a large wire cage for exhibition. It is one of the prettiest wild animals known in California zoology. Dr. Reid of Pasadena pronounced it a California coon, but others present said 'Ihaddeus Lowe, Jr., liad told them it was a civet-cat. Thus the local doctors of zoology differed, and, as ustual, some sided with one and some with the otlier. 'The fact is, however, that both gentlemen were a little 
right, and both a little wrong. Prof. Tenney in his work on zoology calls it "civet-cat-Bassaris astuta," and remarks: "Animals somewhat raccoonlike in form. One species is found from Texas to California, and is about the size of the domestic cat, but more slender; its color above is brownish yellow mixed with gray beneath; the tail is white and has six or eight black rings. It is arboreal, easily tamed, and a favorite pet with the miners."

But now the Century Encyclopedia pictures the same animal and calls it "Ring-tailed Bassaris," with this remark in the descriptive text: "Resembling the raccoon in some respects, but slenderer. * * Most nearly related to the raccoons (Procyonidae), having some superficial resemblance to the civets and genets."

Thus it will be seen how easily Dr. Reid and Mr. Lowe might differ in naming the animal, and yet both be right. The pretty creature really seems to combine in itself characteristics of the fox, the raccoon, and the lemur, with feline qualities least of all. It has been called locally in California by such names as California coon, mountain coon, coon-cat, and civetcat, yet it is not a "cat" at all, either in face, skull, feet or preferred diet; and it is such a pretty and harmless creature that Prof. Lowe ought not to allow them to be killed within the bounds of his great mountain electric railway and bridle-road circuits.

ONE WhO HAS BEEN THERE.

Prof. Holder speaks of it as being "the American representative of the Nasua [Coati].* And Nicholson's Zoology says they "present a singularly close resemblance to the lemurs of the old world, and appear to be their representatives in the western hemisphere. ** They are in some respects intermediate between the raccoons and the civets."

RAcCOon.-The black-footed raccoon (Procyon hernandezii) is our neighbor, and that he is too neighborly sundry chicken owners can testify, while Mr. Rosenbaum tells me that they venture up to his pond or aquarium and have occasional nightly feasts upon his large carp. They hide during the day in the underbrush of the Arroyo, sallying out at night seeking whom they may devour. The Arroyo raccoons are famous fighters, and one that Mr. Bandini's hounds cornered seized one of the dogs by the claw, clinging like a bulldog, though beset by the entire pack, and only relinquished its hold when shot through the head by Mr. Bandini.

SkUNk.-One of the most attractive of Yasadena animals is the striped little skunk. We have two species: One as large as a cat (Mephitis occidentales), which I have occasionally met in the bush, and a smaller one about as large as a weasel though much stouter, the little striped skunk (Spilogale putorius). The latter is a most beautiful and attractive creature. A gentleman in this city told me that for a long time the family was astonished at singular noises in the house, as if some one was running about overhead, scampering, falling and sliding. A sudden rush would be made for the room and nothing found. Finally, one of the ladies crept up stairs one night and opening the door softly, found the culprit - a striped skunk. The little fellow had a rubber ball and was playing with it, chasing it about and rolling over and over like a cat. How it got in was a mystery. A friend of the writer, in Los Angeles, caught three of these creatures in his 
house in the heart of the city. They do no harm (if not disturbed) and undoubtedly drive out the rats and mice. Many farmers in the valley keep them in their barns for this purpose.

BADGER. - In strolling over the country one occasionally comes upon this curious flat animal, strongly marked with black and white. It is so very flat that it is easily overlooked, and might readily be taken for a rock. The American badger (Taxidea Americana) has a wide range, all over the middle and northern portion of the continent, and is particularly common here. It is terrestial and fassorial in its habits, a clumsy creature, with an enormous development of ciaws, enabling it to dig and burrow at an astonishing rate. The badger lives on small animals of various kinds, but is not averse to varying its diet when the former are scarce. It devours everything, from a wasp's nest to a snake, when pressed. The nest is the burrow, where from four to six young are brought out in the sfring. The badger has no enemies here except man, and as there is little or no demand for their skins, they are increasing rapidly. One of the oldest sports in Europe is badger baiting, the animal making a fierce fight. The Pasadena animal when cornered will make a good fight, and easily escape from an unarmed man.

WEASEL. - Often in riding or walking along in the low brush $I$ have startled a long, slender, snake-like little creature, which darts away with re ${ }^{-}$ markable velocity, filling the air with a pungent odor, disagreeable to the dogs. It is the weasel (Putorius), a reddish chestnut brown above, and lighter beneath. It preys upon small animals of various kinds, and is very pugnacious. Hawks sometimes pounce down upon it, realizing too late their mistake, the weasel fastening its sharp teeth in the throat, and finally becoming the victor though carried a long distance from home. The weasel burrows, forming a small inconspicuous hole. The ferret belongs to this group, and a number have been introduced on the San Rafael ranch to drive out the squirrels. Two, possibly three, species of weasels are found in this vicinity.

NOTE.-These weasels are called Mustela by our Spanish-speaking citizens. Mr. Arturo Bandini relates that in July, I889, he witnessed in Wilson canyon a fight between a weasel and a red racer. The weasel had seized the snake by the back of its neck, so that it could not bite him, and held his grip in spite of the snake's frantic endeavors to whip, or whisk or shake him off. Finally, it coiled itself around and around the weasel's body, and tried to squeeze it to death; meanwhile he could hear the gritting noise of the weasel's teeth in action, then presently there was a sort of click or snapping noise, and the snake, making one convulsive flop, fell over limp and dead. The weasel had gnawed away till he had completely bitten through and severed its backbone at the neck.-ED.

MOUNTAIN LION.- One of the finest animals, as regards general appearance and bearing, found in this vicinity, is the mountain lion. Its wide geographical range lends it an additional interest, it being found from the Straits of Magellan to Canada, and from the Atlantic to the Pacific on both continents. In the eastern states, especially New York, it is the pantherthe old Adirondack guides in telling me stories of its prowess, calling it the "painter." In New England it is the catamount; in Florida, the cougar; 
in South America, the puma, carcajou, or quinquajou. It varies but little in appearance in all these localities, when in good condition being a fine-looking cat, resembling to some extent the female Asiatic lion, and well deserving the name, Leon del Monte, that is given it in Southern California. It is the largest cat in North America proper, a formidable animal when cornered, and in many localities a menace to the farmer. Many stories are told of its ferocity in attacking man, but after much investigation I never could learn of but one instance where it had deliberately attacked a human being. A typical mountain lion stands about two feet at the shoulder, often more; is from five feet to five feet six from the snout to the root of the tail, and weighs one hundred and fifty pounds. Its color is like that of the lion, a reddish hue, light below ; its movements leonine, or cat-like. In comparing it to the cat tribe in general, the head is seen to be smaller in proportion to the body than others, except the leopard. The fact that this animal has such a wide geographical range has given rise to the belief that there are several species, but Felis concolor is the one found so extensively over North and South America. In Northern California it attains its greatest perfection, and the Indians believe that it makes a successful fight against the grizzly, and when pressed by hunger is known to be extremely savage. In this southern section of the state it is generally confined to the motnntains, and is sometimes met on the trails. One was killed near the sheep corral south of the Raymond last year, Mr. H. N. Rust securing the skin. At least two were killed on the Wilson trail; and one visited the town of San Gabriel this last winter [I888-I889] and was followed several days by the tracks.

LYNX.- Others of the cat tribe in this vicinity are at least two varieties of the lynx; one which we know as the wild cat, though properly a lynx (Lynx maculatus), and another larger form occasionally killed by $\mathrm{Mr}$. Bandini. The common lynx caught here in the wild-cat hunts is the former, the "Gato monte" of the Mexicans and Spaniards, the "No-me" of the Yuma Indians, and "Chimbi" of other Indians of this state. A typical specimen in the possession of the writer, obtained through the courtesy of Mr. Arturo Bandini, measures two feet seven inches from the tip of the tail to the nose; the tail being five inches in length. Bandini, who probably kills more of these animals in the course of the year than any one on the coast, has seen larger ones. The lynx varies so in color in different parts of the country that it is difficult to determine the species. Mivart includes all our species under one head, Lynx borealis, but any one who has seen our Pasadena lynx or wild cat and a Canada lynx side by side would notice a decided external difference. The lynx that attacked Mr. Bandini some months ago, was in all probability what is recognized by naturalists as the Red $\operatorname{lynx}$ (Felix mpa), while our ordinary wild cat is the spotted lynx (Lynx maculata). The lynx or wild cat is extremely common here, making its home in the greasewood brush and in the canyons. It preys upon small animals of all kinds, and does not hesitate to enter the hen-house, and when cornered will attack man or beast. The lynx encountered by Mr. Bandini sprang at his throat with great ferocity, ripping his clothes with its sharp claws, and ultimately escaping. When followed by hounds here, the cat takes to a tall tree, usually a sycamore, and will, when pushed, leap from fifty to sixty feet down, landing perhaps on its springy cushions, and dashing away from the hounds with remarkable speed, to be treed again, and ultimately die in a desperate encounter with the dogs. The 
spotted lynx about Pasadena has, if taken at the right time, a fine skin, making an attractive rug. Mr. Bandini has the finest collection of these skins probably in the country, all taken by his fox hounds, either in the Arroyo or Wilson's pasture near his home.*

Fox.- As I write I have a gray fox, from mountains back of Pasadena, by my side, growling an audible protest at the writing-up process. It is the California representative of the gray fox ; a creature about twenty-two inches long from the nose to the root of the tail, the latter being about fifteen inches in length - a fine brush with a distinct black line upon the upper surface. It is very timid, yet can be trained, and eats out of my hand. It is a remarkable climber, jumping into an orange tree and ascending to the top with all the ease of a cat, and then biting off the branches to make a comfortable place to rest. In hunting this fox in the Arroyo with the hounds, it often misleads the dogs by leaping into a tree and by jumping from limb to limb and passing over the masses of vines, making its escape. The fox in my possession is a most expert climber, and will balance himself upon a narrow plank-edge with all the skill of a cat, and is a most interesting little creature. Mr. Charles WVinston owns one that is so tame that it plays with the dog, and seems to be thoroughly domesticated. $\dagger$

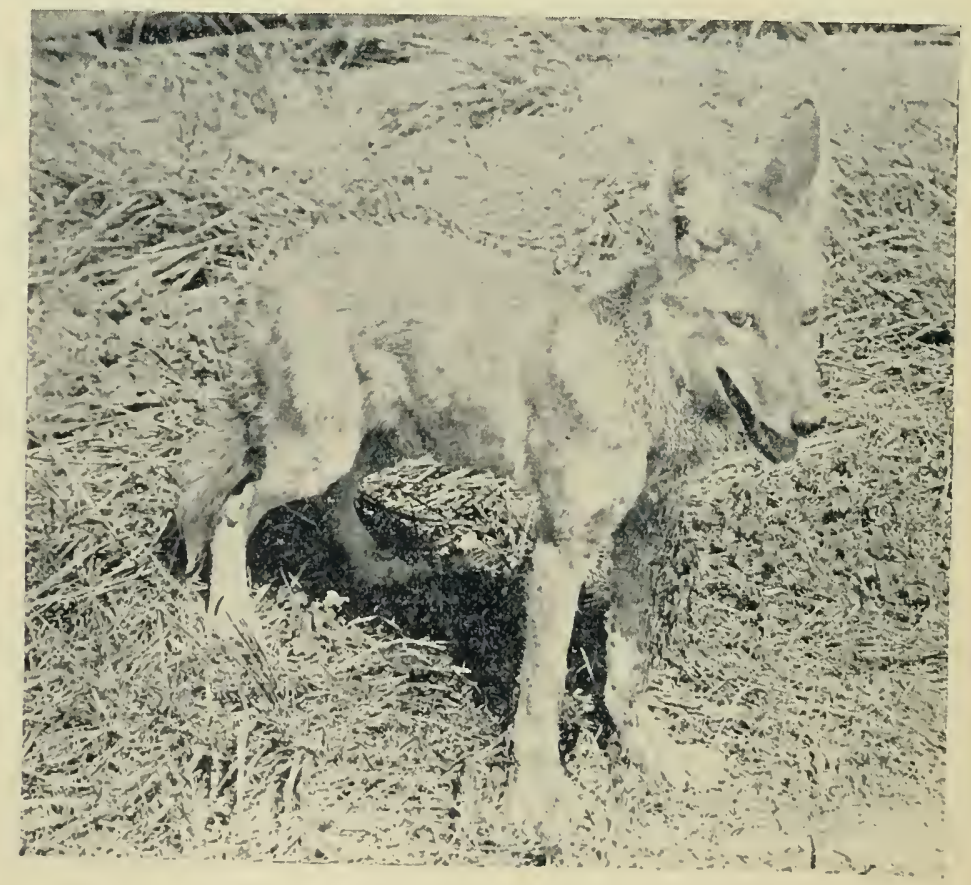

A YOUNG COYOTE-PHOTO FROM LIFE.

From "Land of Sunshine, October, 1895.

This is the most artistically successful and perfect portrait of our native coyote [pronounced co-yoh-ty] that has ever been obtained. The subtlety of character-expression in that sly, waggish
countenance is a study for Shakespeare or Dickens.

* This was in 1889. Since that, worms and insects got into Mr. Bandini's rare and valuable collection of lynx skins, and destroyed them.

† Van Dyke says: "The red fox is abuudant, though smallet than the red fox of the Atlantic states, aud has a grayer coat." I think there is but the one variety or species here, although it is called by such different names as monntain fox, coast fox, silver-gray fox, red fox, etc, all referring to the 
CoyotE.-The coyote (canis latrans) is to America what the jackal is to the old world, a sly, predatory, lowland wolf, hunting either singly or in bands, fleet of foot, hard to kill, the familiar of every portion of the western country. During the day the coyote remains in the canyons, in the Arroyo and the main range, but as soon as night sets in, their demoniac laughingbark can be heard, setting the dogs in the neighborhood wild. Knowing that it can outrun the average dog, the coyote strolls up into the town, trots down Orange Grove Avenue and through the orange groves, after plunder. They venture into the very heart of the town, being seen on Marengo Avenue and in various localities thickly settled. As morning approaches, they start for the Arroyo and the foot-hills. I have seen them lying on the slopes of the high hills south of Ramona during the day, and their wonderful speed has often tested the powers of Mr. Shorb's fine gray and stag hounds. In one run, the coyote was followed from the top of the range at least a mile and a half before it was caught, and then made a most savage fight, wounding every dog in the pack, and badly injuring the best dog. The coyote will rarely attack a larger animal than itself, but when caught or cornered it makes a valiant fight. The coyote burrows on the hill sides, forming a subterranean nest, where its young are produced. It preys upon various small animals, and is a veritable scavenger, eating anything it cau find or steal. The coyote belongs to the same genus as the common dog, and the difference between the skulls of the two is very slight.* They are readily tamed, and $\mathrm{Mr}$. Bandini informs me that he had one which ran with a pack of hounds unmolested.

MOUN'TAIN DEER. - In wandering in the low brush of our hill sides, or the deep, wellwooded canyons of the upper range, the stroller often sees for a fleeting moment a vision of long, pointed ears, bright, lustrous eyes, then a crash is heard, and the black-tailed deer is away, tinding its way through the seemingly impenetrable scrub with remarkable ease and celerity. This little creature (Cervus Columbianus) is very common among our hills and mountains. The blacktailed deer may be considered a purely mountain form, loving the thickly-wooded slopes, and the lofty ridges of the upper range. It equals the

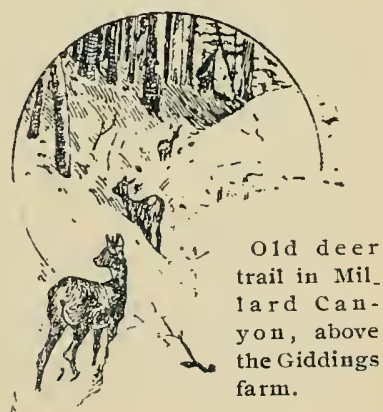
Virginia deer in size, often exceeding it, and has an entirely different antler arrangement, the horns being what is known as doubly dichotomous, or arranged in double pairs. It is stouter than the Virginia deer, and is not so fleet. The rutting season is usually in September, the horns being cast in March, and perfect again in August. The young number one or two, and are attractive little creatures, spotted like the young of many of the tribe. The black-tailed deer is easily distinguishable from the mule deer by its smaller size, its jet-black tail, and the dusky horse-shoe mark on the forehead.

MULE DEER. - The mule deer (Cariacus macrotis) undoubtedly ranges the whole Sierra series, and Judge Eaton has in recent years described a variety

* The coyote is almost identical with the wild dogs of Assyria and Palestine spoken of so frequently in the Bible, and with the Dingo or wild dog of Australia. The aborigines of our Santa Barhara islands had domesticated it. Chas. F. Lummis writes: "Coyote is one of the Aztec words adopted into Spanish. Its original form was coyotl." 
of this species from the Southern California mountains. The mule deer is more commonly found in the mountains of the north, and is, next to the $\mathrm{elk}$, the largest American deer. It is a particularly ungraceful creature; its stocky form and long ears calling to mind the animal from which it derives its name. Its color is ashy brown, assuming a grayish hue in winter; the legs are yellowish, while down the back there is a distinct black stripe. The ears are eight inches long and very conspicuous; the buttocks white and the glands of the hind legs large. As might be supposed, the animal is slower than the black-tailed deer. The rutting season is in October, the horns being cast in March. The young, generally one, is of a pale yellowish tint with white spots. Like the black-tailed deer, it is a mountain form, rarely being found in low country away from the locality of its choice.

ANTELOPE.-While the antelope and big-horn are not found in the San Gabriel valley, the big-horn sheep (ovis montana), one of the finest game animals in the world, has been shot in sight of Pasadena; two specimens were taken upon the slopes of Old Baldy last season [1888], Mr. Carr having the head of one. The big-horn is the ally of the wild sheep of Asia Minor. Several parties have been made up in Pasadena to follow the antelope or prong-horn, the last being organized by Dr. Rowland; the sport of chasing the nimble animals at full speed and shooting them on the dead run being described as very exciting. The prong-horn (antelocapra Americana) is the only antelope in America and is undoubtedly as swift as many of the African forms. In former years it was found iu this country in vast herds, but the advance of lot stakes has had the usual result, and they are becoming rarer every year. Their range may be said to be from Mexico to 53 degrees north latitude and east to the Missouri river. The prong-horn is a dainty little creature, about four feet six inches in length and two feet six at the withers. The general color is yellowish brown in the upper portion and white below - the buttocks pure white, the male and female being marked about the same. The eyes are large, lustrous, and expressive, and are placed immediately underneath the horns.

BEARS. - Nearly all the old hunters insist that there are four or five kinds of bears found in the western country - the grizzly, black, brown, and cinnamon. The differences are mainly in color, and systematists recognize but two kinds in the west (ursus horribilis), and the black bear (ursus Americanus), the others being considered mere varieties, and so judged from a careful comparison of skeletons. I believe the last grizzly shot in the vicinity of Pasadena was shot by Mr. E. W. Giddings, on his ranch at the mouth of Millard canyon. [See page 129.] The grizzly is one of the most formidable of all animals. It attains a length of nine feet and a weight of over 1800 pounds. Its long, gouge-shaped claws, its sharp, powerful tusks, and tremendous gripping power make it an adversary to be dreaded. The black bear is naturally a vegetarian, though they vary their diet according to the supply. In the fall they are usually fat, and in cold cliniates go into what is termed a state of hibernation. In this country the bears in all probability do not hibernate, though it is possible they pass through a partial hibernation on the ligh range where snow lies for several months.

In addition to the foregoing which I have collated from his published writings, Prof. Holder furnished me in Ju11e, r 894 , the following complete 
list of our native mammals which he kindly prepared specially for this volume :

PROF. HOLDER'S COMPLETE LIST OF OUR NATIVE MAMMALS.

[Notes in brackets by the editor.]

BADGER.-Taxidea Americana.

BATs. - Vespertilio lucifugus; Nitidus; Evotis; Plecotus macrotis; Autrozous pallidus; and several others.

BEARS.-Black: Ursus Americanus;-Grizzly: Ursus horribilis; cinnamon: Ursus cinnemoneus.

BIG-HORN.-Ovis montana. Found within a few years on Mount San Antonio. [Formerly also in the San Gabriel mountains.]

Coуоте.-Canis latrans. [Identical with the wild dogs of Assyria, Samaria and Judea.]

DEER.-Black-tailed : Cariacus Columbianus; mule deer (rare); Cariacus macrotis. [Abundant in all this region when Spaniards first came here.]

Fox.-Coast fox: Vulpes littoralis. [Also called silver-gray fox, and mountain fox. Plenty of them at Echo mountain and vicinity.]

GOPHER.-California variety: Thomomys bulbivonus (Baird).

MOLE.-Scalops aquatrius.

Puma.-Felis concolor. [Mountain lion.]

PORCUPINE. (?)--Erethizon dorsatum. [Extremely doubtful.]

RAccoon.-Black-footed : Procyon hernandezii.

RAcCoON-Fox.-Bassaris astuta. [Also called " civet-cat," ring-tailed bassaris, etc. [See "Civet cat," page - - .]

RABBI'Ts. - Jack rabbit (hare): Lepus Californicus; - cotton-tail: Lepus artemisia. I have seen two different species of cotton-tails, I am positive. [Van Dyke describes two species.]

RATs.-Pocket rat: Dipodomys phillipsii-observed at Las Casitas ;wood rat: Neotoma fuscipes.

SoUIRRELS.-Ground squirrel : Spermophilus Buchezii; 一 fox squirrel : Sciurus fossa;-chipmunk : Tamias Harrisii. [I think there is also a gray timber squirrel found high up in the mountains, but not given in this list.-ED.]

Skunks.-Big skunk: Mephitis occidentalis; - small spotted skunk: Spilogale putorius.

WeASEL. - Putorius. [The "Mustela" of the Spaniards.]

WiLd CAT.-Lynx rufus, variety maculatus. [Tenney's Zoology calls Lynx rufus the American wildcat, and this is the one that is called here the "California lynx," which is really a ferocious beast. But there is also another variety of wildcat here, which is much more pussy-like in its manners, though sometimes quite large.-ED.]

WolF-Gray: Canis occidentalis. [See Coyote above.]

The following I quote further from Prof. Holder's published writings :

ANCIENT ANIMALS OF PASADENALAND.

It will perhaps be a surprise to some readers to learn that not so long ago (geologically speaking) the elephant was included in the Southern Cali- 
fornia fauna - not the elephant of India or Africa, but a prodigious creature, vast in every sense, taller by several feet than existing forms, weighing a third more, and armed with gleaming ivory tusks from fourteen to sixteen feet in length. It browsed upon the herbage of the mountain sides, wandered into the well-wooded glens that led into the range, and roamed over the vast mesas and by the shores of the lakes, which then were a feature of California of the South. Picture an elephant a third taller than existing species, its trunk like the limb of a huge tree, its limbs enormous columns for support rather than for locomotion, its rough head covered sparsely with hairs, and protruding from the capacious mouth two massive columns of ivory, each weighing from three hundred to four hundred pounds, and some conception of this wonderful elephant may be obtained. In the different geological ages several elephants have inhabited this country-the mammoth, mastodon, and American elephant. Remains of the two latter have been found in Southern California, especially those of the mastodon. The mammoth was a hairy northern form, while the others ranged farther to the south. The geographical range of this animal has, from specimens found, been fairly well determined. It roamed over what are now the States of Texas, Georgia, Mexico, Oregon, Ohio and California, but probably did not venture north of the Canada line, being adapted for the warmer climate which existed in the south.

The Tertiary period of geological history is divided into three sections -Eocene, Miocene and Pliocene, the latter being the time just before the Age of Man, though some writers believe that human beings existed even earlier than this. [See Geological chart, page 54I.] The American elephant came upon the scene, as far as we know, in the Pliocene time, and, unaffected by the changes that resulted in the Quaternary, continued into it.

In the Pliocene time California was inhabited by many animals equally as strange as the elephant. With it, in droves, were camels, and a huge rhinoceros, as large if not larger than any found in Africa today. The tiger now found in India was represented by a huge form. Early man, did he exist, [see page 528.] could have hunted this tiger not only on the great elephant already described, but could have rode along the base of the Sierras on the back of a huge mastodon (Mastodon Mirificus). The ancestors of the present horse galloped over the plains, the curious Protohippus with three toes, fine specimens of which in its successive transitions down to the present horse, can be seen in the Museum at Yale University. The Pliocene period merged into the Quaternary, which was characterized by violent earthquakes and tippings, especially in high latitudes, and thereby marked changes of climate occurred, affecting animal life. In the Pliocene times, Pasadena and all the coast well down the Peninsula of California was under water, and the waves of the Pacific beat well up to what is now Altadena. The Puente hills and ranges about Santa Ana were beneath the wave, and huge sharks and whales fed over what are now Santa Ana, Orange, Tustin, San Juan, Ramona, etc. The vertebrae of whales are plowed up on mountain slopes all along this region; and in South Pasadena a deposit contains myriads of fossil fishes. (?) [See "Fossil Fish Ledge," page 55I.]

The Quaternary saw an elevation of the crust along the coast, and the Pliocene shell beds became dry land, some of the deposits being lifted high upon the tops of mountains. The lower animals, and many higher ones resembled those of today. This period saw the culmination of mammalian life and the beginning of its downfall. The American elephant, the mastodon, and the mammoth, lived then. 
OUR NATIVE BIRDS.

Young Joseph Grinnell, son of Dr. Fordyce Grinnell, has won the reputation of having captured, preserved, labeled and classified more specimens of our native birds than any other person. He seems to have a specimen of every species and variety of avian fauna ever found here, all nicely preserved, and neatly labeled with both its common and its scientific name. And he furnishes for this volume the following account of them.* [Emendations by the editor in brackets].

The Birds of Pasadena and Vicinity.-A great number of the birds inhabiting this State are entirely different from those found in any other section of the country. Examples of these are the California vulture [more commonly called Condor], California jay, California towhee. But also a large per cent. are either identical or very similar to the birds in the eastern or central parts. For instance, the mocking-bird, mourning dove, and turkey vulture are the same as found in the southern states east. The robins, blue-birds, wrens, pewees, and others show decided differences, while in general characteristics they are the same. Of course the climate and topography of California are the main factors in these differences. The geographical variations of our land are conducive to a wide variety of birds, thus producing a field for unlimited study.

QUAILS OR PARTRIDGES.-The most important game-birds are the partridges [quails] of which we have two widely-different species. The California partridges are the ones found in the vicinity of Pasadena and throughout all the valleys. They are slaty-olive on most of the body, but the lower part of the breast is mottled with black, yellow, white and chestuut. The throat is black, bordered with a broad white band. Also a white stripe passes over the eye and across the forehead. The head is adorned with a black plume composed of six feathers about an inch long. This description applies to the male only, the female having none of the high coloring of the male, and the crest is only about half as long. The call of the California partridge is very clear and musical, and is usually composed of three syllables, the accent being on the second, as "O-hi-o." This partridge [quail] remains in immense coveys during the fall and winter, but these disband in the spring and their members pair off to breed. They are exceedingly fond of grapes, and thousands are shot annually in the vineyards.

The mountain partridge is found in the higher mountain ranges, and is seldom seen below an elevation of three thousand feet. It is a much larger and finer-looking bird than the California partridge. It is of a dark olive color, except the breast and throat, which are bright chestnut. The breast and belly are also marbled with black and yellowish-white. The throat-

* Mr. Grunnell's grandfather was the first pastor of the Friends or Quaker church in Pasadena [see page 484$]$; and the young man is now a student in Throop Polytechnic Institute. 


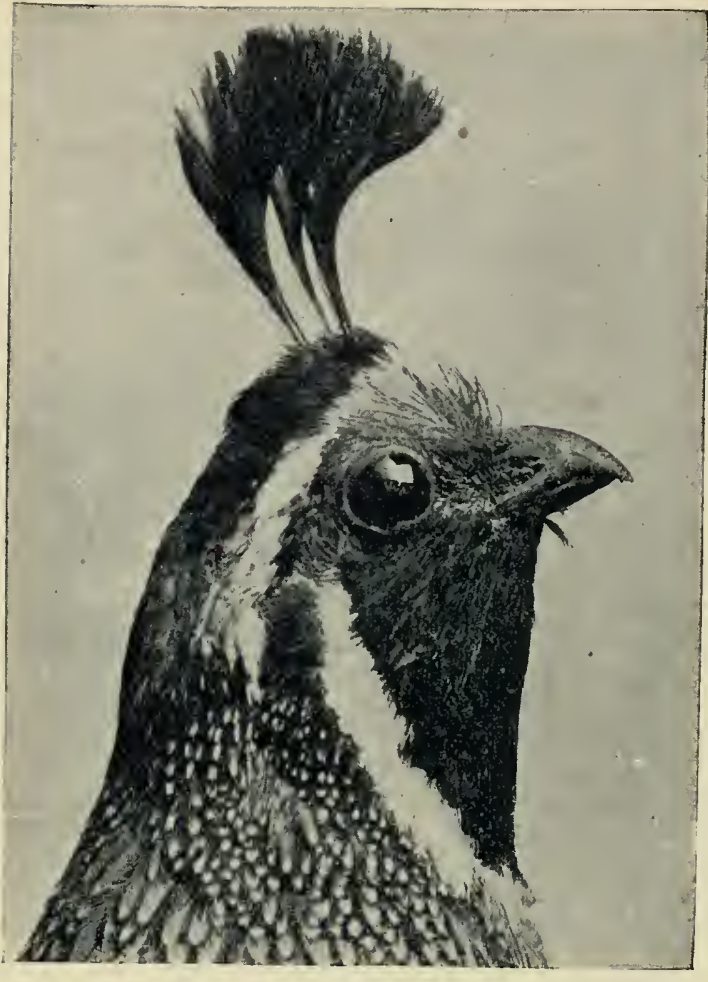

From "Land of Sunshine," Oct., 1894. CALIFORNIA QUAIL.

Photo, life size, from one the prize-winner birds at the World's Fair, Chicago, 1892-93. patch is bordered by a white band. The plume is black, and composed of two slender feathers from three to four inches long. The two sexes are very similar in coloration. The call of the mountain parttridge is very loud and resonant, but not as pleasing as that of the valley partridge. It is common on Mount Lowe and Wilson's peak, but is very hard to hunt on account of the high brush. The mountain partridges go in flocks, and their habits are similar to those of the "valley quail," as the California partridge is commonly called.

NoTE.-The quail holds such an important place among our native birds that I quote the following additional account of

it from Van Dyke's “Southern California."-Eì.

"The notes of the valley quail are quite varied; and even the same bird often varies within five minutes both the tone and accent of every note. The most common call of this quail is a clear, far-reaching $O$-hi-O, repeated four or five times in quick succession. Often the tone is changed so that it sounds more like ka-loi-o. Often the accent is shifted from the middle syllable to the first and last syllables, so that it sounds like tuck-a-hee. Again the stress is laid so heavily upon the second syllable that the other syllables are scarcely heard, and the whole sounds like $k$-woick- $\iota h$; and again the last syllable is omitted entirely, and the whole becomes a low $k$-woick. This is the call of the different members of the flock to each other when scattered, of the old hen to her chicks, and of the male and female to each other when separated. Should the winter rain-fall be insufficient to make an abundance of grass and seeds, this quail does not pair off and breed, but remains unmated in the large bands in which it has been all winter, - a curious case of instinct, shown also by the hares, squirrels, gophers and bees, all of which decline to increase. But after two or three good seasons in succession, the numbers of the valley quail in many parts of Southern California are incredibly great. When the seed of the alfileria 
and burr-clover is abundant, this bird is a strict vegetarian. It is a great ravager of gardens and vineyards; it will touch almost nothing but grapes, if it can get them ; and the amount of white grapes a quail can eat in a day is amazing."

Pigenon.-Of the pigeon family we have two species. The mourning dove, or, as it is commonly called, the "turtle dove," is the same as the eastern bird. They are hunted a great deal, and often congregate in flocks in weed-patches and stubble fields, where they obtain their food. The mourning dove breeds from January to September. The eggs are sometimes laid on the ground, but usually the frail nests are built in the bushes and trees.

The band-tailed pigeon, or as here called the "wild pigeon," is a large bird-even larger than a tame pigeon. It is most numerous in the winter, and subsists mainly on acorns, being most abundant where the largest supply of its food is situated. They usually remain in the mountains, but when the snow comes low down, or the acorn crop is short, they come to the oak groves in the valleys. Large numbers are sometimes shot around Santa Anita. The band-tailed pigeon retires to the farther ranges to breed, though a few have been observed to remain in the vicinity of Oak Knoll as late as June.

VULTURE.-- The turkey vulture is the same as the eastern "turkey buzzard." It is a notorious scavenger, being most common in cattle-raising regions. About here they are very common, and a landscape is hardly complete without two or three sailing slowly overhead. They breed in the hills to the west of Pasadena, and lay two spotted eggs on the ground under some rock or bush. [See "Buzzard Cliff," page 374.]

The California vulture [or condor] is one of the rarest birds, as it is seldom seen, and then only in the mountains. It bas the general appearance of the turkey vulture, but is very much larger, having a stretch of nine feet and even more, and a length of four and one-half feet.' It is thus fully as large as the condor of South America. It is said that fifty years ago the California condor was very common; but the cattle-men by poisoning carcasses in order to exterminate wild beasts, also killed great numbers of the vultures, and thus this species became very scarce.

NoTE.- This monarch of American birds is so rare a creature as to be worthy of some further notice. In 1888 there was an organization called the "Pasadena Academy of Sciences," of which Wm. L. Vail was secretary ; and in reply to some inquiries by him, Prof. C. F. Holder vrote:

"The bird you kindly allowed me to see is a rarity in this section, and is the largest North American bird. It is known commonly as the California vulture or condor, and to science as "Pseudogryphus Californianus." The bird takes the place in this country of the great condor of the Andes, and probably rivals it in size, attaining a breadth of wing of ten feet. It was unknown until the settlement of California, and is now known to range 
from the Colorado river to the Columbia west of the Rocky Mountains, and curiously enough, does not, as far as known, enter Mexico. The strength and power of the bird is almost beyond belief. Four adults have been seen to drag the body of a grizzly weighing over a thousand pounds, two hundred yards. The California condor possesses many of the characteristics of its ally of the Andes. It sights its prey from a vast height, and soars, especially before storms, to great altitudes. Its flight is regular and beauti$\mathrm{ful}$, the bird presenting a magnificent appearance when on the wing. The $n \in s t$ is composed of a few sticks thrown together carelessly. It rarely if ever attacks living animals. The bird is rare in the San Gabriel valley, and the present specimen is an unusually fine one, a young male in complete plumage, and perhaps three or four years old.'

In $1878 \mathrm{E}$. W. Giddings shot one of these birds, and it measured ten feet three inches from tip to tip of the wings. [See footnote, page 129.] It is almost identical with the lammergeyer of the Alps, in Europe.

HAwks.--We have seven species of hawks and probably more. All the larger species are commonly called chicken hawks, and are needlessly shot as enemies of the poultry yard, while in reality they do a vast amount of good in destroying mice and squirrels, and should be protected. The smallest and commonest one is the sparrow hawk. It is abundant everywhere except in town, and breeds in the arroyos. It subsists mainly on insects and mice, and is consequently very useful.

EAGLE.- The golden eagle is the only eagle found here; but down along the coast the bald eagle is sometimes seen. The golden eagle is common in the Pasadena mountains, and ofter comes down to the highlands and along the foot-hills.

OWI. - The owl family is represented by eight species. The best known of these is the barn owl, golden owl, or "monkey-faced owl," as it is variously termed. Its natural home is in the woods, where it lives in hollow trees; but in many instances it has taken up its abode in steeples and towers. Last year [1893] a pair raised a brood in the belfry of the Universalist church, and another pair took possession of the Wilson school tower. The barn owl is a very odd-appearing bird. It has a peculiar habit of wagging its head from side to side when closely watched. It is often caged, and makes a curious pet.* Our largest owl is the western horned owl. They do not stay in holes in trees, but roost in thick foliage or on the ground in shady places, coming ont towards evening. The burrowing owl is a queer little bird which lives out in the open fields, and which makes its home in holes in the ground. The dry, level poppy fields above Altadena are favorite resorts of this owl. There they may be seen stauding at the entrances to their burrows, or flying low over the ground. If disturbed, they usually run down the holes, and may then be dug out. They lay their eggs

* Mrs. A. P. Janney on Fast Union street kept a pet ow1 for four years. It was so tame that it stood cin a perch in the open room, like a parrot, and would make responsive motions and noises when slie talked to it. When the Wonnan's Relief Corps held a Fair in Williams hall, in 1892 , this pet ow1
was among the curiosities on exhibition. 
in a chamber hollowed at the end of their burrows. This chamber is usually close to the surface of the ground, or, anyway, higher than the gallery which leads to it. This is probably to protect it from being flooded during rain storms. The burrowing owl generally fits up a squirrel's hole for its use, but never lives "in the same hole with the squirrels or snakes," as is commonly believed; for, on the contrary, it is a great enemy of the squirrels, often following down their burrows and killing their young. It also eats Jerusalem crickets and small birds. The color of this owl as seen at a distance is a light brownish gray. The smallest and rarest of our owls is the California pygmy owl. [W. H. Wakeley says it is the smallest owl in the world.] Its home is in the higher mountains, but it is not uncommonly seen in winter lower down in the near canyons. The food of this owl appears to be entirely grasshoppers. The spotted owl is another rare bird occasionally found in the mountains.

THE ROAD RUNNeR is a bird peculiar to the southwest. It is very common here, where it haunts the dry mesas and Arroyo beds. It belongs to the cuckoo family, though it is a very much modified branch. On its foot two toes point forward and two backward; hence its tracks can easily be recognized from those of any other of our birds. The length of the road-runner is about two feet, of which the tail occupies nearly a foot. With the exception of a steel-blue crest which ornaments the head, the feathers on most of the body are bright green, bordered with white. This bird is noted for its swift running, as it is said to be able to baffle a hound. It eats snakes and lizards. In the stomach of one road-runner I found four lizards, each eight inches long. The bird batters the heads of its victims on the ground, and then swallows them whole.

NотЕ.-Of this rare creature, Van Dyke says ;

"About the only bird having no representative on the Atlantic coast is the "chapparal-cock," "road-runner," or paisano, as the native Californians call it. It looks much like a cross between a hawk and a hernshaw ; long-geared, long-tailed, and swift of foot, white, gray, and blue, with a bluish top knot, and a long bill. Though generally deemed unfit to eat, it is really one of the fattest and finest-flavored birds we have, in spite of its diet of centipedes, lizards, and scorpions. It is an interesting bird, easily tamed, and may be made a great pet. It is quite harmless, and is rarely shot, except by fool tourists who think it the proper thing to murder everything they see."

Mr. Will H. Wakeley, Pasadena's pioneer taxidermist, relates that once while driving up North Lake Avenue he saw a road-runner scampering up the street dragging a long gopher snake in its bill. After keeping ahead of him for a while, it turned off into an apricot orchard and commenced making violent and rapid up-and-down motions. He went to see what the creature was doing, and found it had threshed the snake upon the ground and beaten the life out of it. Mr. Road-runner was preparing his 
dinner of "jerked meat" - that was all. Prof. Holder in his volume entitled "All About Pasadena," page I24, says :

"It is of this bird that the rattlesnake corral story is told; the bird, it is said, building a corral of cactus leaves about the rattler, then awakening him to destruction on the spines. The story is generally considered a "fable"; though I have been told it by men who had watched the bird build the corral: and a well-known surveyor in this county states that he has found the corrals, with the skeleton of the snake in the center. There is possibly some mistake in the observations, though the story is not more wonderful than that of the gardener bird, and others, known to be true."

THE WOODPECKERS are well represented, there being seven species in this vicinity. The California woodpecker is a black-and-white variety, with a red head and yellow throat. It has a peculiar habit of digging small holes in the bark of oaks. These holes are exactly the size of an acorn. Into each hole the bird forces an acorn, leaving the acute end of the nut protruding. In course of time a small grub finds its way into each acorn, grows and fattens. Then the woodpecker revisits his hoard, pecks into the acorns and extracts the luscious grubs, leaving the empty shells of the nuts still sticking in the holes. The woodpecker often makes use of natural cavities in trees, and in these stuffs great quantities of acorns for the same purpose.

A little sap-sucker which is often seen in our pepper trees is in the habit of perforating the bark in circles around the tree, thus producing an odd appearance. This is probably for the purpose of extracting the sap on which it feeds.

NightriRds.-The Texas nighthawk is common in suitable localities about here. During the day they doze on the hot sand in the dry arroyos and "washes," but in the evening they may be seen seeking their insect food in the manner of bats and swallows. They have a peculiar trill or thwirr-r-r which is kept up a long time. The eggs are laid on the warm ground without any kind of a nest, and if the eggs are disturbed the birds carry them to another place in their mouths. The young are covered with a grayish-yellow down, which harmonizes well with the color of the surrounding earth. If they are endangered by any foe, human or otherwise, the mother tumbles all over herself in her endeavors to attract one's attention from her dear hawklets. The poor-wills are birds peculiar to the west. They are similar to the whip-poor-will of the east in a good many respects, but in a few details of external structure they are distinct. Their call consists of two syllables, "poor-will, poor-will, poor-will." The California poor-will frequents the foot-hills and canyon-sides. It is quite common in the hills back of Linda Vista, where they are often observed flitting along in the road or trail in the evening. It is also found on our highest mountains.

HUMMINGBIRDS. - They are abundant all the year, about every flower- 
garden in town and country. There are six species here, each distinct from any other. It is useless to try to describe their varied tints and metallic colors. A person must see them to appreciate and understand. Hummingbird's nests are wonderful examples of bird architecture,- so small, and yet so perfect in adaptation for their use. There is a general instinct that the nests must agree in color and shape with their surroundings. One that I found in an oak was placed on a horizontal branch to imitate a knot, and covered with .green lichens to correspond with the color of the bark and leaves. A nest built on an orange twig was composed of brownish substances and covered on the outside with black scale. Another situated on a cactus stem was made up of grayish vegetable down and small leaves of the wild sage. And yet another built in a sycamore, was attached at the base of a leaf, and made entirely of the yellow sycamore down found on the under side of the leaves. This provision is for protection against various marauders, especially blue jays, (both human and avain). Our six species of hummers are not all found here at the same season or in the same localities. The Anna hummingbird is the only resident species, being common all the year. They are quite hardy, usually being able to withstand the "Santa Ana" winds and the December frosts. This hummingbird breeds the earliest of any of our birds, the nest with eggs having been found in Pasadena as early as January 22. The Costa's hummingbird only stays here through the summer, and its nests are to be found on grease-wood, weeds, thistles and cactus, in the dry, open parts of the arroyos. The male Costa's hummer has a habit during the mating season of mounting high up in the air above the female, then descending like a shot down past her, then again mounting upwards to repeat this performance, till the female goes off to another perch. During each descending flight the male utters a shrill, swelling squeak, which is loudest as he passes the female. The blackchinned hummingbird is also a summer resident, building its nests on the sycamores and alders which line the streams in the canyons. The males are not often seen down in the canyons but remain high up on the mountain sides where the wild honeysuckle blooms. The males of none of the hummingbirds assist in nest-building or incubating. The Calliope, Allen's and Rufus hummers are spring and fall visitors, their summer homes being north of here. The two latter species are exceedingly abundant around the orange trees in March and April.

THE FLyCATCHERS are an interesting family of birds, and we have a good representation here. The black phoebe, or pewee, is common in town. It is usually seen on top of a hydrant or hitching-post in a garden. From this perch it makes sallies into the surrounding atmosphere, snapping up any insects which happen to pass that way. The black phoebe is of a slatyblack color, except the lower belly, which is white. It has a pleasing note and a graceful bearing. The pewee builds a cup-shaped nest, made of mud, 
and lined with grasses and feathers. It is stuck on the side of a barn or house under the eaves, like a swallow's nest, or it may be attached to rocks, or tree-trunks, or in tunnels, or under bridges. One of the rarer flycatchers is not uncommon in our mountains, especially in the Arroyo Seco canyon. It is a large, dark-looking bird called the olive-sided flycatcher. This bird is quite shy and hard to see, as it is usually perched on the tops of the naked dead pines high up on the mountain-side. It can easily be located, however, by the loud resonant call which it constantly utters during the early morning and in the evening.

The Kingbirds are familiar to the bee-ranches, as their food consists chiefly of bees. They have a very harsh note and the birds seem to be constantly quarreling with each other.

OUR ORIOLES have about the same habits as the Baltimore oriole of the East; they are just as highly colored, and sing fully as well. The orioles here often take possession of the banana trees and palms, in which they build their nests, the palm fibres forming favorite nesting material.

THE BUTCHER-BIRD [Shrike] is more ferocious and cruel in proportion to size than any other bird. It has the well-known habit of capturing and impaling small animals or insects on sharp thorns. A few of the anima's which I have found thus sticking on thorns are, wild canary (Arkansas goldfinch), western chipping sparrow, Gambel's sparrow, linnet (house finch), young chickens, mice, horned toads and other lizards, besides a large variety of insects. The butcher-bird seldom sneaks on its prey like a cat, but catches it in an open race. I have seen a butchie chase a goldfinch for fully two minutes. The goldfinch escaped through its superior ability to dodge, though the shrike could fly very much faster. I have seen a California shrike catch and carry off a Gambel's sparrow, which is a bird about seven inches long, the shrike being only eight and one-half inches in length. The butchie swooped down on the bird which was feeding in the grass, and proceeded to inflict a quick succession of blows with its beak on the back of the sparrow's head. This probably stunned the sparrow, and the butchie grasped it with its claws and flew laboriously off with it. I ran after him and succeeded in frightening him into dropping his victim. On examining the sparrow I found that it was not badly hurt, but nearly scared to death. Jerusalem crickets form the bread-of-life for the butchie, though he often indulges in linnets. On the whole, this shrike does a great deal of good in killing insects.

NотЕ.-For some reason Mr. Grinnell overlooked the mocking-bird, but it is too distinctive and characteristic a feature of Pasadena scenery to be left out of our bird sketch; and here is what Van Dyke says of it:

"The sweetest of all the song-birds is the mocking-bird. In size he is about the same as the Virginia mocking-bird, a little more trimly built, and with similar colors but a little differently arranged. The tone of his voice 
is about the same, but his repertoire is much more limited. Indeed, he scarcely deserves the name of mocking-bird because he mocks nothing that is found here. His song consists of only seven or eight changes, which are always the same. But he is pretty, graceful and harmless."

It is true that our mocking-bird is not so versatile and voluble a mimic as the eastern variety, yet I am informed of instances where it has distinctly imitated or "mocked" young chickens, and a person whistling, etc. In June, I888, I examined a nest in which a female mocking-bird was brooding two unfledged young ones: and found that the nest was made almost entirely of bits of old newspaper and writing paper. A State law prohibits the killing of these birds or robbing their nests.-ED.

\section{COMPIETE LIST OF PASADENA NATIVE BIRDS.}

BY JOSEPH GRINNELL, STUDENT AT THROOP INSTITUTE.

Plumed PARTRIDGe [mountain quail]-Oreortyx pictus plumiferas.

VALLEX PARTRIDGE [valley quail]-Callipepla californica vallicola.

BAND-TAILED PIGEON [wild pigeon] - Columba fasciata.

Mourning Dove [turtle dove] - Zenaidura macroura. nianus.

CAlifornia Vulture [California condor]-Pseudogryphus califor-

TURKEY VUlTuRE [turkey buzzard] Cathartes aura.

WHITE-TAILED KITE-Elanus leucurus.

MARSH HAWK - Circus hudsonius.

Sharp-Shinneid Hawk - Accipeter velox.

COOPER'S HAWK - Accipiter cooperi.

WESTERN RED TAIL [chicken hawk] - Buteo borealis calurus.

RED-BELLIED HAWK - Buteo lineatus elegans.

ZONE-TAILED HAWK - Buteo abreviatus.

SwaInSON's Hawk [chicken hawk] - Buteo swainsoni.

FERRUGINOUS ROUGH-LEG - Archibuteo ferrugineus.

GOLDEN EAGLE - Aquila chrysaetos.

BALD EAGLE-Haliaetus leucocephalus.

PIGEON HAWK - Falco columbarius.

DESERT SPARROW HAWK - Falco sparverius deserticolis.

AMERICAN BARN OWL - Strix pratincola.

AMERICAN Long-EARED OWL - Asio wilsonianus.

SHORT-EARED OWL-Asio accipitrinus.

SPOTTED OWL - Syrnium occidentale.

CAlifornia ScREECH OWh - Megascops asio bendirei.

WESTERN HORNED OWL-Bubo virginianus subarcticus.

Burrowing OwL [ground owl] - Speotyto cunicularia hypogaea.

CAlifornia Pygmy OWL-Glaucidium gnoma californicum.

ROAD RUNNER - Geococcyx californianus.

California CuckOo-Coccyzus americanus occidentalis.

BELTED KINGFISHER - Ceryle alcyon.

HARRIS's WOODPECKER - Dryobates villosus harrisii.

GAIRDNER'S WOODPECKER - Dryobates pubescens gairdnerii.

NUTTALL'S WOODPECKER - Dryobates nuttallii.

WHITE-HEADED WOODPECKER - Xenopicus albolarvatus.

RED-NAPED SAPSUCKER - Sphyrapicus varius nuchalis. 
RED-BREASTED SAPSUCKER - Sphyrapicus ruber.

WILLIAMSON'S SAPSUCKER - Sphyrapicus thyroideus.

CALIFORNIAN WOODPECKER - Melanerpes formicivorus bairdi.

LEWIS'S WOODPECKER - Melanerpes torquatus.

RED-SHAFTED FLICKER [yellow-hammer]-Colaptes cafer.

Dusky PooR-WILI [California whip-poor-will] - Phalaenoptilus nuttalli californicus.

TEXAN Night Hawk-Chordeiles texensis.

Brack SwIFT - Cypseloides niger.

VAUX's SWIF'T-Chaetura vauxii.

White-THRoATED SwiFtT- Micropus melanoleucus.

BlaCk-Chinned Humming BiRd - Trochilus alexandri.

CosTA's Humming BIRD-Trochilus costae.

ANNA's Humming Bird-Trochilus anna.

Rufous HumMing BIRD-Trochilus rufus.

AlLEN's HuMming BIRD - Trochilus alleni.

Calitope Humming Bird-Trochilus calliope.

ARKANSAS KINGBIRD - Tyrannus verticalis.

CASSIN's KINGBIRD - Tyrannus vociferans.

Ash-THROATED FlyCATCHER - Myiarchus cinerascens.

SAY'S PHOEBE-Sayornis saya.

BLACK PhOEBE [pewee] Sayornis nigricans.

OLIVE-SIDED FIYCATCHER - Contopus borealis.

WESTERN WOOD PEWEE-Contopus richardsonii.

WESTERN FIYCATCHER - Empidonax difficilis.

LITTLE FLYCATCHER - EmpidonaX pusillus.

HAMMOND'S FLXCATCHER - Empidonax hammondi.

WRIGHT'S FLYCATCHER - Empidonax wrightii.

MEXICAN HORNED LARK - Otocoris alpestris chrysolaema.

BLUE-FRONTED JAY - Cyanocitta stelleri frontalis.

CALIFORNIA JAY - Aphelocoma californica.

AMERICAN RAven - Corvus corax sinuatus.

CAlifornia CROW - Corvus americanus californicus.

ClARKE'S NUTCRACKER - Picicorvus columbianus.

YELLOW-HEADED BI.ACKBIRD - Xanthocephalus xanthocephalus.

RED-WINGED BLACKBIRD - Agelaius phoeniceus.

WESTERN MEADOWLARK - Sturnella magna neglecta.

Arizona HOODED ORIOLE - Icterus cucullatus nelsoni.

BULLOCK'S ORIOLE - Icterus bullocki.

BREWER'S BLACKBIRD (Common Blackbird) - Scolecophagus cyanocephalus.

WeStern Fivening Grosbeak - Coccothraustes vespertinus montanus.

CAlifornia PURPLE Finch - Carpodacus purpureus californicus.

Cassin's PURPLE Frnch - Carpodacus cassini.

Housf Finch (Linnet) - Carpodacus mexicanus frontalis.

WESTERN GOLDFINCH - Spinus tristis pallidus.

ARKansas Golnfinch (Wild Canary) - Spinus psaltria.

I,A WRENCE's GOI,DFINCH - Spinus lawrencei.

PINE SISKIN - Spinus pinus.

WHSTERN VHSPLR SPARROW - Poocaetes gramineus confinis.

OREgON VESPER SPARROW - Poocaetes gramineus affinis.

WeSTERN SAVANNA SPARROW-Ammodramus sandwichensis alaudinus. 
WhSTERn Grasshopper Sparrow - Ammodramus savannarum perpallidus.

WESTERN LARK SPARROW - Chondestes grammacus strigatus.

INTERMEDIATE SPARROW - Zonotrichia leucophrys intermedia.

GAMBEL's SPARROW - Zonotrichia leucophrys gambeli.

WHITE-THROATED SPARROW - Zonotrichia albicollis.

WeSTER ChIPPING SPARROW - Spizella socialis arizonae.

THURBER's JUNCO (Snowbird) - Junco hyemalis thurberi.

BeLL's SPARROW - Amphispiza belli.

RUfOUS-CROWNED SPARROW -- Peucaea ruficeps.

Hekrmann's Song Sparrow - Melospiza fasciata heermanni.

LinCOLn's SPARROW - Melospiza lincolni.

TOWNSEND'S SPARROW - Passerella iliaca unalaschcensis.

THICK-BILLED SPARROW - Passerella iliaca megarhyncha.

SPURRED TOWHEE - Pipilo maculatus megalonyx.

CALIFORNIA TOWHEE - Pipilo fuscus crissalis.

BLACK-HEAADED GROSBEAK - Habia melanocephala.

WESTERN BLUE GROSBEAK - Guiraca caerulea eurhyncha.

LAZULI BUNTING - Passerina amoena.

Louisiana TANAGER - Piranga ludoviciana.

WESTERN MARTIN - Progne subis hesperia.

ClifF Swallow -- Petrochelidon lunifrons.

BARN SWALLOW - Chelidon ery throgaster.

TREE SWALLOW--Tachycineta bicolor.

VIOLET-GREEN SWALLOW - Tachycineta thalassina.

BANK SWALLOW - Clivicola riparia.

Rough-WINGED SWAL,LOW - Stelgidopteryx serripennis.

CEDAR WAXWING - Ampelis cedrorum.

PhaINOPEPLA - Phainopepla nitens.

CALIFORNIA Shrike [butcher-bird]- Lanius ludovicianus gambeli.

WESTERN WARBLING VIREO-Vireo gilvus swainsoni.

CASSIN'S VIREO - Vireo solitarius cassinii.

HUTTON'S VIREO - Vireo huttoni.

LEAST VIREO-Vireo bellii pusillus.

CALAVERAS WARBLER - Helminthophila ruficapilla gutturalis.

ORANGE-CROWNED WARBLER - Helminthophila celata.

LUTESCENT WARBLER - Helminthophila celata lutescens.

WESTERN YEILLOW WARBLER - Dendroica aestiva morcomi.

Audubon's WARBLER - Dendroica auduboni.

Black-Throated Gray Warbler - Dendroica nigrescens.

TOWNSEND'S WARBLER - Dendroica townsendi.

HERMIT WARBLER - Dendroica occidentalis.

MACGILLIVRAY'S WARBLER - Geothlypis macgillivrayi.

WESTERN YELLOW THROAT - Geothlypis trichas occidentalis.

LONG-TAILED CHAT-Icteria virens longicauda.

PILEOLATED WARBLER - Sylvania pusilla pileolata.

AMERICAN PiPIT - Anthus pensilvanicus.

AMERICAN DIPPER [water ouzel] - Cinclus mexicanus.

MOCKING-BIRD - Mimus polyglottos.

CALIFORNIAN THRASHER [curved-billed thrush]-Harporhynchus redivivus.

CACTUS WREN - Campylorhynchus brunneicapillus. 
ROCK WREN - Salpinctes obsoletus.

CANYON WREN - Catherpes mexicanus conspersus.

VIGOR'S WREN - Thryothorus bewickii spilurus.

PARKMAN'S WREN - Troglodytes aedon parkmanii.

WLSTERN WINTER WREN - Troglodytes hiemalis pacificus.

TULE WREN - Cistothorus palustris paludicola.

CALIFORNIAN CREEPER - Certhia familiaris occidentalis.

SLENDER-BILLED NUTHATCH - Sita carolinensis aculeata.

Plain 'Titmouse-Parus inornatus.

Mountain ChickadeE-Parus gambeli.

WrEN TIT - Chamaea fasciata.

CALIFORNIAN BUSH-TIT - Psaltriparus minimus californicus.

WESTERN GOLDEN-CROWNED KINGLET-Regulus satrapa olivaceous.

RuBY-Crowned KingLE'T - Regulus calendula.

WESTERN GNATCATCHER - Polioptila caerulea obscura.

BlaCk-'TAILED GNATCATCHER - Polioptila californica.

TOWNSEND'S SOLETAIRE-Myiadestes townsendi.

RUSSET-BACKED THRUSH - Turdus ustulatus.

DWARF HERMIT ThrUSH - Turdus aonalaschkae.

WESTERN ROBIN-Merula migratoria propinqua.

VARIED 'THRUSH - Hesperocichla naevia.

WFSTERN BLUEBIRD - Sialia mexicana occidentalis.

MOUNTAIN BLUEBIRD - Sialia arctica.

This list contains no water birds, and only such land birds as have been positively identified within a radius of eight miles of Pasadena. There are between twenty and thirty species of water birds, such as ducks, geese, herons, sandpipers and rails, which have also been observed in the area; but these are almost without exception identical with those found in any American marsh. The total variety of birds found in Los Angeles county amounts to over 200 species.

NOTE.-The above is the first complete list or catalogue of our native Pasadena birds that was ever prepared for print, and I am much indebted to young Mr. Grinnell for his zeal and good work in preparing it specially for this volume.-EDR.

\section{WILL WAKELEY'S SPECIMENS.}

W. H. Wakeley came to Pasadena in I88 I and was the first taxidermist ever here. He was an enthusiastic student and collector of our native birds, and for ten years was looked to as authority on any question as to their species, habits, range, markings, etc. The authority which he followed in this branch of science was "North American Birds," by Baird, Brewer and Ridgway. Boston: Little, Brown \& Co., 1874:- a work of high standing. In January, I $887, \mathrm{Mr}$. Wakeley founded the Natural History Store, now owned by Frank A. Healy \& Co. [1894]; and later he founded "Wakeley's Novelty Works." [See page 460.] And since engaging so largely in this line of business he has been obliged to neglect his favorite study of birds, so that younger students have come forward and occupied the field, such as Masters Joseph Grinnell, Ralph Arnold and Horace Gaylord, who have each made excellent collections, exceeding Mr. Wakeley's 
in number and variety of native specimens. But we still quote Mr. Wakeley as good authority on Pasadena birds. He says the California mocking bird was not found north of Los Angeles county ten years ago, although it may be now ; and that the California pygmy owl is the smallest owl in the world; he has seven varieties of native owls in his collection. In February, I886, he found an albino finch - a specimen all white, and entirely new to science, hence its scientific name would be Fringilla Alba Wakeleyii. In I 890 old Mr. Giddings shot another albino linnet or finch (all pure white), at his home place, Giddings Heights.

\section{REPTILES.}

Our most celebrated and characteristic reptile is the "horned toad," so called, but which is not a toad at all but a species of lizard-Phrynosoma cornuta. It burrows in the dry sand and dust, and lies dormant during the winter season, coming out to run about and mate only in the warmest weather. It is as harmless as a pet kitten, and when laid upon your warm hand and gently stroked on its back with the other hand, it will blink its eyes in a lazy, dreamy, contented sort of way, as if it really enjoyed the warmth and the caressing. I have caught specimens from the size of my finger nail up to nearly as large as my hand. They abound all over Southern California, Arizona, New Mexico, Texas and old Mexico. It is a regular business in Pasadena to stuff and mount horned toads to sell as California curios. In August, I886, W. H. Wakeley advertised for 1000 horned toads for taxidermy purposes, and this set an army of boys scurrying about the dusty plains and barrens, filling their pockets with horned toads and earning many nickels for their own pocket money. In I893 Wakeley's Novelty Works mounted between 5,000 and 6,000 horned toads for the California tourist and eastern trade, besides roo dozen tarantulas, roo dozen scorpions, and a considerable number of trap-door spider nests and centipedes.

Rock LIZARD.- - In all canyons, mountain sides and rocky places the California rock lizard will be seen-three varieties of him, to-wit: black, gray, and iridescent or metallic luster lizard, but all of the same species. The long-tailed lizard, or "snake-lizard," as it is mostly called, is a different species-is more sluggish, more retiring, and not often seen.* I once caught one which was thirteen inches long, about three-fourths of this length being tail ; the body is more bulky and clumsy than the rock lizard, and as I held it up by the tail it made a hissing noise like a snake and thrust out a snake-like forked tongue. I have never caught but this one, and have had brief glimpses of only three others. They are not numerous and are

* "The Times correspondent at San Diego captured what is commonly known as "rattlesnake lizard " on Saturday. In form the creature resembles the Gila monster. Its general appearance is that of a rattlesnake with legs. The head is like that of the rattler. The markings of the reptile's back are like the markings of the suake. But the lizard's tail is devoid of rattles." -Los Angeles Times, March $18,1895$. 
very shy. Joseph Grinnell relates that once when he shot a delicate little cactus wren it fell down under the cactus bush and disappeared; and after searching some time for his prize he discovered a snake-lizard crawling away with the bird in its mouth. Then he captured the lizard also, which was eight inches long, and he has it in his collection. Our Pasadena lizards are all harmless, though the long-tailed, snaky fellow seems to have teeth for eating tougher meat than the flies and tiny worms on which the others feed.

In the pools that occur so often in the mountain canyons there will generally be found a pair or more of salamanders; called also "water puppies," "water lizards," etc. They are of a reddish-brown color, perfectly harmless, and live in or out of the water, being amphibian batrachians, amblystoma rubrum by name.

In Wilson lake is found a small species of mud turtle; also found in the tule pond or lagoon in upper part of San Marino canyon [see page 377], and in pools in the Arroyo Seco.

RATTLESNAKES were formerly common in all parts of Pasadenaland,* but they are now rarely found on the mesa, the advance of cultivation having nearly exterminated them; in the mountains, however, they still occur. There seems to be two varieties - a smaller one of dark slate color; and a larger, thicker-bodied, more sluggish one, of a reddish-brown color.

THE RED RACER is a snake peculiar to the country, and in some respects is similar to the black racer of the east - in fact, some observers say it is identical except in color. Mr. A. P. Janney, on East Union street, informs me that he kept a red racer snake two years at his place, in a box cage, and never knew it to eat or drink, although it shed its skin regularly; and once he chanced to see it in the very act of shuffling off its last year's overcoat. He finally sold it to a menagerie at Los Angeles. It is probably the swiftest-running snake of its size that we have any account of. In May, I 888, I saw one that measured five feet four and one-half inches : very slender; pinky on belly, dappled pinky on back, and a splotch of black on the neck. It was killed in a back door yard, where it was trying to catch some little chicks. In July the same year I saw another one; three feet eleven inches long, and with reddish, whitish and bluish colors. We called him the " 4 th-of-July snake."

The Gopher SNake is a large, long fellow that ought never to be killed, for it feeds almost entirely on young gophers, ground squirrels, etc., which it catches by crawling into their holes and nesting places, and is thus a true friend of the farmer.

In I884 I saw a long, lithe specimen of water snake in the Arroyo Seco stream nearly where the Scoville dam now stands, but have not seen any other of this kind except a small one in a pool in Rubio canyon.

* See Judge Eaton's statement, on page 123 ; and I. B. Clapp's on page IIg. It stands of record tbat Mrs. Dr. Reid killed a rattlesnake with a stick, in Castle canyon, in August, I893; a nd in August, 1894 . Mrs. Dr. Grimuell shot one in the Arroyo above Devil's Gate, which her sol Joseph skinned and preserved. 
In the mountain canyons is found the coral snake, which is marked with black and white, perhaps half an inch wide, around its body in regular alternation from head to tail. The first specimen I ever saw of this snake was in San Dimas canyon [twenty-five miles east of Pasadena] four or five miles up from its mouth, in I 888 ; then in 1893 I saw two specimens of it in Echo canyon, one of them being marked with red and black instead of white and black bands.

There are several varieties of smaller ophidian reptiles, such as striped or garter snakes, grass snakes, bush snakes, spotted snakes, etc. None of our snakes are venomous except the rattlers.

We have a large, warty garden toad, with some peculiarities that mark him as a California variety of the bufonidae. There is also a species of tree toad.

Of FRogs there are several varieties. The common pond frog abounds in the tule bogs, reservoir dams, springs and water ways of our Glacial Terrace canyons, where it can be found any time of the year. The mud frog lies dormant in the clayey beds of dried-up ponds during the dry season; but when the winter rains form poinds or puddles he emerges into life, and makes the evening air melodious with its song of tirr-r-r-r-r-r. The winter pond existing for many successive years at northwest corner of Colorado and De Lacy streets, furnished music of this sort for the whole city. But the place is now filled up. In the mountain canyons there are delicate rock frogs, of colors varying to suit the colors of the rocks in their particular stream, pot-hole, or pool.

The biological department of the Throop Polytechnic Institute has planned to make a special study of Pasadena reptiles during i895-96, which will doubtless result in their complete scientific classification, and special description of such as are new species. Nothing of the kind has been done heretofore.

\section{INSECTS.}

The scorpion is doubtless our most characteristic native insect. There seems to be two varieties of it. They are now rarely found in or about Pasadena ; their capture and mounting as curios seems to have almost exterminated them from this region. Wakeley's novelty works put up roo dozen of them in I893. The dread of their sting is largely imaginary. I have not heard of but one person here, Col. J. Banbury, ever being stung by one. This was in the colony days. He was loading wood and chips into a wagon; the scorpion stung his hand; he brushed it away, went on with his work, did nothing for the wound, forgot all about it, and it passed off as readily as the sting of a bee or a wasp would. And Judge Eaton says he never heard of any harm from them.

Of centipedes there seems to be two, or perhaps three varieties - one very large, of dull white or light straw color; and a smaller kind, sometimes 
white and sometimes of a streaky green color - possibly mere variations of sex or season. The largest kind have been found even eight inches in length. There is no evidence that their bite is poisonous, but they have forcep jaws and can inflict quite a severe wound - and the very thought of being bitten by such a disgusting looking creature is enough to make one feel poison-shivers all over him and grow sick at the stomach.

Another of our famous insects is the tarantula; and of this singular creature Miss Monks, who was at one time the foremost entomologist of Los Angeles county, said in the Historical Society's publications for I886:

"The Tarantula (Mygale Hentzii) is large - when extended it often covers the space of four or more inches; it is very hairy, black or dark brown in color, with sometimes an ashy tinge, and has long legs, which indicate a wanderer.

"The Trap-door spider (Cteniza Californica) is only half as large, is downy, pale brown, and has short legs. There is the greatest possible difference of opinion in regard to the tube-building habit of the two species. I have never found a tarantula in a nest with a trap-door, nor a trap-door spider in one with an open mouth. I have put Mygales of both sexes in jars of earth, and they would never attempt to build tubes. They pull bits of earth together and spin a little silk, then stop - seemingly satisfied with the result of their labor. On the other hand, Ctenizas invariably go to work the first night and dig a tube, and generally add the door the second night.'

The males of these two species will always fight till one or the other is killed, and most commonly both die in the struggle. As late as 1883 it was considered "sport" in Los Angeles to put some dirt in the bottom of an empty gold-fish jar, then put in a pair of these belligerent insects, and make bets as to which one would "whip." I witnessed this several times in store windows on Main street; and on one occasion I saw the larger one of the two spiders fighting away after its entrails were torn out and dragging under its feet. But I believe Pasadena never got quite so low down for "sport" as this. The Pasadena Star of October I9, I892, said:

" Two of our Lake Avenue citizens have just returned from a four days' tour in the country hunting for specimen tarantulas. They secured over 400 specimens, most of them large size, and all of them females."

Van Dyke says of these insects :

"The largest are nearly two and one-half inches long by one and onehalf wide, with long, thick, curved legs, and body low hung so that the curved part of the legs is above the back. It looks like an immense spider. The body is covered with short hairs. **** They have two black curved tusks in the upper jaw, long and sharp, which they can set [bite] through a green twig the size of a lead pencil."

The tarantula hawk, Pompilus formosus, is a large species of wasp that makes a business of stinging tarantulas whenever it can get a chance. It stings them in the back, striking down into the central ganglia of the Mygale's nervous system, thus thrusting its waspy virus into the very life center of the victim. This gives it a sort of paralysis or numb palsy so that it cannot 
fight nor crawl away, but it still lives. The wasp then digs a small pit for the tarantula to drop into, and lays its eggs there; and when the little wasp grubs come forth they burrow into the body of the paralytic which their provident mother had fixed there for them, and grow fat and sleek on its tarantulan juices.

A very large insect called "hawk moth" has a spread of wings four to five inches, and a very long proboscis or suction tube, which it has to wind up into three or four coils when it flies. It may be seen hovering over flowers in the evening, sucking honey through its long tube, and is often mistaken for some curious species of humming bird. Colors, gray, black and yellow. It is the tomato worm moth, or 5-spotted sphinx.

Another conspicious insect is the white-lined sphinx. It is olive green, white, black and rose colored, or a sort of pinkish tinge; it also hovers about the honey flowers in the evening, with a three-inch spread of wing: and is frequently mistaken for a species of humming bird. I have sometimes seen I suppose a thousand of these moths lying dead around on the ground under an argand electric light, into the fiery glare of which they and other species had plunged to their death during the night.

The Jerusalem cricket, or "Spanish cricket" as it is also called, is a peculiarly large California variety. It incubates deep in the ground during the dry season, and when the rains come to soften the earth, and the early spring warmth develops life generally, this creature bores its way to the surface and comes forth. It is a large, fat, clumsy cricket-I think the largest one known-and furnishes a rare feast for poultry and some of the larger native birds. It is a pest in the potato field and injures the crop by gnawing cavities in the potatoes when they are nearly or quite full grown.

In the early colony days Pasadena was ravaged with grasshoppers-a local variety, and not the migratory grasshopper or "locust" of the easterly Rocky mouritain slopes. But the plowing from year to year destroyed their eggs by exposure, and the Pasadena grasshoper is no longer known as a pest. [See page 144.]

In 1893 , at Echo Mountain I found specimens of the "praying Mantis," a species of the "walking leaf" insects. It is a small or medium sized variety, and most likely to be found on sycamore trees or willows. I have never seen it except in Echo canyon or glen, though I doubt not it occurs elsewhere; and it is one of the most singular of our native insects. Sobieski Lowe in 1893 , and Joseph Grinnell in 1894 , both informed me that they had found specimens of this rare insect at the same place, but not elsewhere.

In the little ponds of the mountain canyons there is found a very curious kind of water beetle-a real amphibian insect, for when the pool it happens to be in dries up, it will spread its wings and fly away to another. But ordinarily it looks like a small turtle creeping about at the bottom of a pool, and without necessity of coming to the surface for air ; yet it can live 
also in the air when necessary. This singular creature carries its eggs on the shell-like wingcases over its back, says Jason Brown, where they sometimes appear thickly massed together, but always in orderly arrangement. In this respect it is an approach toward the dorsological baby house style of incubation, heretofore known only in the Surinam toad.

Of a species of woolly spider I have seen both white and red varieties in the mountains.

Of course this is no place for a complete list of our native insects, for they run up into thousands of species or varieties. Van Dyke says there are at least ten different kinds of musquito here. I have only mentioned a few of the more notable insects, because of their singularity, or because as California curios they have become in some sense historic. The Pasadena field of Entomology is a very large one, entirely unworked, and lies open for some of our young naturalists to delve in and win fame. One of the queer things in this line is, that bedbugs and cockroaches cannot live here. Every season for the past twenty years bedbugs have been brought to Pasadena in clothing, in bedding, in carpets, or in furniture, yet they never live to propagate their species; the same is true of cockroaches. The reason for it still remains an unsolved problem for our young scientists to wrestle with.

As to books on California Entomology, a volume of 472 pages was published by H. S. Crocker \& Co., Sacramento, in 1883 , entitled "Injurious Insects of the Orchard, Vineyard," etc. It was prepared by Matthew Cook., State Entomologist, was liberally illustrated, and stills holds the field as the best California book of the kind yet produced.

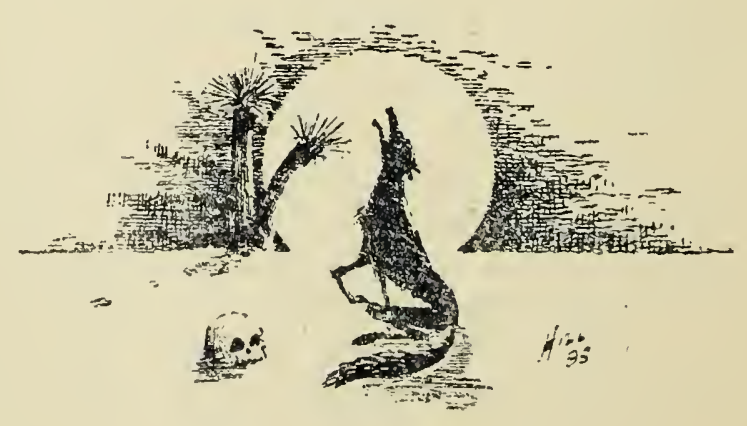




\section{CHAPTER XXXII.}

Botany.--Prof. McClatchie's Researches, Collections and Discovery of New Species of Plants, including Algæ, Fungi and Mosses, in Pasadenaland.-Complete List of all our Native Vegetable Growths, Scientifically Classified as to Branch of Vegetable Kingdom, Class, Order, Genera and Species.

FLORA OF PASADENA AND VICINITY.

By Alfred James McClatchie, A. M., Professor of Botany, Throop Polytechnic Institute.

The list of plants that follows was compiled, not because it was supposed that all of the plants growing about Pasadena were known, but because of the kind and urgent request made by Dr. Reid that I should undertake the task. Our flora is too varied for one person to become familiar with it during a three years' residence. The list simply includes all that have been collected and identified up to the time of going to press ; but each month adds several to the list, and will, undoubtedly, continue to do so for some time yet.

The region of which the plants are listed extends from the Lincoln Park hills on the south to the summit of the range north of Pasadena, designated by various names, but referred to in this list as the San Gabriel mountains. On the west the region is bounded by the sills across the Arroyo Seco and extends from there eastward to Sierra Madre and Santa Anita. Thus it is about ten miles in extent north and south, and about six miles east and west. The altitude at the southern limit is about 500 feet, while the summit of the mountains varies from 5,000 to 6,000 feet. The altitudes at the eastern and western boundaries are about the same. Hence the region might be thought of in a general way as a surface having a parabolic curve, one end resting against a range of low hills and the other resting upon a support ten miles away and a mile higher. The western edge of the region is traversed by the Arroyo Seco, whose precipitous banks average about fifty feet in height. At the bottom flows a swift stream, notwithstanding the fact that the name is the Spanish for "dry gorge." About a mile south of Pasadena is the lip of the geological basin that has been filled with soil for a site for our city. From this lip flow six nearly parallel streams, each about one-fourth to one-half mile from the next. Along these streams grow lixuriant forests of oak, sycamore, cottonwood, and alder, among which great numbers of higher fungi flourish during the wet season, and their waters abound in algæ and other water plants. To this region Dr. Reid and Mr. French have given the name Glacial Terrace. [See page 574.]

Between this lip and the foot of the mountains extends a sloping plain which bore, when in its natural state, principally herbaceous plants and small shrubs, some of which still remain scattered over the region. The mountain region is traversed by two large canyons that begin near the 
summit of Mount Lowe, besides several smaller ones that do not begin so far back in the mountains. It will readily be seen that a region so diversified - a region made up of mountain, canyon, plain, and moist woodlandmust have a varied flora. In the woods and canyons algæ, fungi, liverworts, mosses, ferns, and shade-loving seed-plants abound; on the plain, dwarfed shrubs, cacti, and other plants characteristic of an arid region; on the mountains, large shrubs, live-oaks, pines, spruces, cedars, and a great variety of smaller plants.

As an examination of the list will show, every month of the year brings forth some new plants, and during every month some of the higher plants are in bloom. The season of greatest growth is from January to June. It is during this period that the most of the lichens, the higher fungi, the liverworts, the mosses, the ferns, and the herbaceous seed-plants grow and reproduce. During the remainder of the year parasitic fungi flourish, a few mosses mature their spores, several Polygonaceæ, Euphorbiaceæ, Chenopodiaceæ, Compositæ, and some members of other families of seed-plants bloom and muture seeds. Algæ are to be found at all seasons of the year where there is sufficient water. Two beautiful species of Floridex grow in abundance throughout the year in the Arroyo Seco, and a great variety of brook-silk, green-felt, water-flannel, and other green algæ is always to be found there. The lover and student of plants can find an abundance of specimens to enjoy and study at all seasons of the year.

The plants of California, especially of the southern part, have not yet been so carefully listed and described as in many of the eastern and southern states. The literature accessible for their identification is still meager. The Botany of the Geological Survey, the works of Professor E. I. Greene of the State University, and some works descriptive of all the plants of certain groups found in North America, are the more useful books. The following are the principal works that list or describe plants of our region: Sternberg's Manual of Bacteriology, Wolle's Fresh-water Algæ, Wolle's Desmidiaceæ, Wolle's Diatomaceæ, Pound's Mucoreæ of N. A., Ellis and Everhart's Pyrenomycetes, Tuckermann's Lichens, Saccardo's Sylloge Fungorum, Kellerman \& Ellis's Journal of Mycology, Morgan's Gastromycetes, Farlow and Seymour's Host-Index, Harvey's Nereis Borealis, Hervey's Sea-mosses, Halsted's Characeæ of America, Allen's Characeæ of North America, Underwood's Hepaticæ of North America, Lesquerenx and James's Mosses of N. A., Eaton's Ferns of N. A., Underwood's Our Native Ferns and Their Allies, Jones's Ferns of the Pacific Coast, Vasey's Grasses of the Southwest, Bailey's Carices of N. A., Morong's Naiadacex of N. A., Watson's Liliaceæ of N. A., Greene's Oaks of the Pacific Coast, Wheelock's Polygala, Trealease's Rumex, Trealease's Eipilobium, Greene's Pittonia, Brewer, Watson and Gray's Botany of California, Gray's Synoptical Flora of N. A., Rattan's Popuiar Flora, Parish's Plants of Southern California, Davidson's Plants of Los Angeles county. 
Besides the above, several works describing plants of other regions are useful. Among them are Burrill \& Earle's Parasitic Fungi of Illinois, Rabenhorst's Cryptogamic Flora of Germany, Austria and Switzerland, Massee's British Fungus-Flora, Cooke's British Fungi, Berkeley's Outlines of Mycology, Phillip's Discomycetes, Farlow's Marine Algae of New England, Greene's Flora Franciscana, Greene's Manual of the Bay Region, Gray's Manual of Botany, Coulter's Rocky Mountain Botany, Chapman's Flora of the Southern States, Coulter's Flora of 'Texas, Wood's Class-book of Botany, and the Flora of Nebraska by the Botanical Seminar of the State University.

Several plant catalogues of other regions aid much in classification and nomenclature. Among these are Britton's Flora of New Jersey, Wheeler \& Smith's Flora of Michigan, Webber's Flora of Nebraska, McMillan's Metaspermæ of Minnesota. Millspaugh's Flora of West Virginia, and the Pteridophyta and Spermophyta of the Northeastern United States by the Botanical Club of the Am. Assoc. for Advct. of Sci.

All plants of doubtful identity have have been sent to specialists for determination, as follows: Perisporiaceæ and Pyrenomycetes to J. H. Ellis, Newfield, N. J. ; Discomycetes to A. P. Morgan, Preston, Ohio, J. B. Ellis and C. H. Peck, Albany, N. Y. ; Lichenes to T. A. Williams, Brooking. S. D. ; Uredinere to E. W. D. Holway, Decorah, Iowa; Imperfect Fungi to J. B. Ellis; Gastromycetes to A. P. Morgan and L. M. Underwood, Greencastle, Ind.; Agaricineæ to C. H. Peck and F. E. Clements, Lincoln, Neb.; the remaining Hymenomycetes to A. P. Morgan, L. M. Underwood, and J. B. Ellis ; Hepaticæ to L. M. Underwood; Musci to C. R. Barnes, Madison, Wis., Mrs. E. G. Britton, Columbia College, N. Y., and M. A. Howe, Berkeley, Cal. ; Pteridophyta to L. M. Underwood, and D. C. Eaton, New Haven, Conn.; Gramineæ to F. Lamson-Scribner, Washington, D C. ; Carices to L. H. Bailey, Ithaca, N. Y. ; the remaining Spermaphy ta to E. L. Greene, Berkeley, Cal., S. B. Parish, San Beruardino, Cal., and W. L. Jepson, Berkeley, Cal. To all I am greatly indebted for their aid, and wish to express to them my sincere thanks. I have also received much aid from several of my students, especially Miss Dian Haynes and Miss Margaret Morrison. To my wife, Anua Morrison McClatchie, I am especially indebted for continuous aid in collecting, identifying, drawing, and caring for herbarium specimens.

Unless impracticable, herbarium or microscopic specimens of each species listed have been preserved. Duplicates of a large number of them will also be found in the herbaria of those who have aided in their indentification. The aim has been to give the local place where all species not widely distributed have been collected.

The month or months given as the season of a plant cover the period of reproduction, or when reproductive organs may be found on the plant. 
When no period is given, it is to be understood that one or both the above conditions are present all of the year. The elevation of many of the plants is given, and for most of the others the elevation can be inferred from the place where found, by any one familiar with the region. I have also aimed to give the common name of each plant having a good one. When the specific name of a parasitic fungus is formed from the generic name of the host-plant, the initial letter has been used for the genus of the latter. All Agarics stated to be edible have been tested by myself, and several of them by some of my students.

Of most of the Bacteria listed, and many others not yet identified, pure cultures have been made in my laboratory. The pathogenic Bacteria are not listed. Little effort has been made to identify the Diatoms of the region, hence few of them are listed. Of the Agarics, about fifty collected species remain undetermined; of Lichens, about ten; and of Mosses, about the same number. The number of species and varieties listed is 1056, of which a large number were never before collected in the State. Sixty-two of them proved to be new to science. Most of these have been described, by group specialists and by myself, in the botanical journals and in the proceedings of scientific societies of America. The place of publication of each new species is cited in the list. Being opposed to the naming of new species after collectors, I have attempted to prevent any being given my name, and have succeeded in all cases except one that was published in spite of my protest.

I have attempted to follow the Rochester rules for nomenclature, but no doubt have failed to do so in many cases. The system of classification used is, in the main, that of Dr. Bessey. In the groups below the Spermaphyta, no smaller subdivision than Bessey's orders have been used above genera. In the Spermaphyta, family names are used, Bessey's ordinal names being omitted.

'THROop Biological LABORATORY, Pasadena, Cal., September 26, 1895.

\section{PROTOPHY'TA.}

\section{CLASS I. MYCETOZOA. Slime MouIds.}

RETICULARIA Bull.

R. UMBRINA Fries. On decaying wood. Firequent. March - May. HEMIARCYRIA Rost.

H. RUBIFORMIS (Pers.) Rost. On decaying wood. M. C.* Jautary - Mav.

TRICHIA Hall.

T. VARIA Pers. On decaying wood. M. C. January - Aprii.

STEMIONITIS Gled.

S. FUSCA Roth. On decaying wood. Frequent. March - September.

* Abrrivitations. - The following abbreviations have heen used to designate particular places by local name, where specimens have been fonnd: Lincoln Park L. P.; Arroyo Seco, A.S.; Los Robles Canyon, I. R. C : Oak Knoll, O.K ; Oak Knoll Canyon, O. K. C.: W'i]son Canyon, W. C.: Wild Grape Canyon [see page 377 . W. G. C.: San Cabriel Monntains, S. G. Mts.; Millard Canyon, M. C; Rubio Canyon, R. C.; Little Santa Anita Canyon, L. St. A. C.; Wilson's Peak, W. Pk.; Monnt Lowe, Mt. L. 
SPUMARIA Pers.

S. AIBA (Bull.) DC. On living willow stems. A. S. February-October.

DIACHEA Fries.

D. LEUCOPODA (Bul1.) Rost. On dead and living leaves. Com. January - April BADHAMIA Berk.

B. HYALINA Berk. On decaying wood in L. R. C. February-April. FULIGO Hall.

F. SEPTICA (Link.) Gmel. On decaying wood. Frequent. February - April. PHYSARUM Pers.

P. CINEREUM (Batsch.) Pers. On small living plants. January - March.

CLASS II. SCHIZOPHYCE\#. Fission-Plants.

Order Cystiphork. One celled blue-green Algae.

cHROÖCOCCUS Naeg.

C. COHCERENS (Breb.) Naeg. Common in stagnant water.

MERISMOPEDIA Mey.

M. GLAUCA (Ehrb.) Naeg. In watering-trough.

Order Nematogence. Filamentous blue-green Algae, Bacteria, etc.

NOSTOC. Vauch.

N. MUSCORUM Ag. Frequent among moss. January - April.

N. PRUFIFORME (Roth.) Ag. Common in running water.

N. RUPESTRE Kuetz. Among moss on moist banks.

N. SPHAERICUM Vauch. On wet soil. January - April.

ANABAENA Bory.

A. STAGNALIS Kuetz. In moist banks. June-October.

OSCILLARIA Bosc.

O. ANTLIARIA Juerg. In reservoir.

O. BREVIS Kuetz. On wet soil.

O. MAJOR Vauch. In pond at Oak Knoll, A. S.

O. TENERRIMA Kuetz. In stagnant water in Arroyo Seco.

O. TENUIS Ag. Common. In water and on wet soil.

LEPTOTHRIX Kuetz.

L. CAESPITOSA Kuetz. In watering-trough.

CLINDROSPERMUMI Kuetz.

C. Comatum Wood. In stagnant water in Arroyo Seco.

O. FLEXUOSUM (Ag.) Rab. Among moss on moist banks.

O. MACROSPERMUM Kuetz. In stagnant water in Arroyo Seco.

LYNGBYA Ag. \& Thur.

L. OCHRACEA (Dill) Thur. On a moist bank.

TOLYPOTHRIX Kuetz.

T. DISTORTA (Muell.) Kuetz. - Rubio Canyou - on rocks under running water.

MASTIGONEMA (Fisher) Kirch.

M. AERUGINEUM (Kuetz.) Kirch. Among damp moss.

M. FERTILE WOod. In reservoir.

HAPALOSIPHON Naeg.

H. BRAUNI Kuetz. In aquarium in laboratory.

BEGGIATOA Trevisan.

B. AL,BA (Vauch.) Trev. Frequent in stagnant water. MICROCOCCUS Cohn.

M. CREPUSCULum (Ehrb.) Cohn. In decaying fish. ASCOCOCCUS Zopf.

A. BILROTHII Stern. In putrid vegetable infusion.

BACILLUS Cohn.

B. ACETI (Kuetz) Cohn. In vinegar.

B. ACIOI LACTICI Hueppe. In sour milk. 
B. FLUORESCENS LIQUEFACIENS Fluegge. Common in water.

B. TERMO (Muell.) Cohn. Common in various decaying substances.

B. VUI,GARIS Haus. In decaying meat.

SPIRILLUMI Ehrb.

S. RUGUl, (Muell.) Ehr. Common in decaying substances.

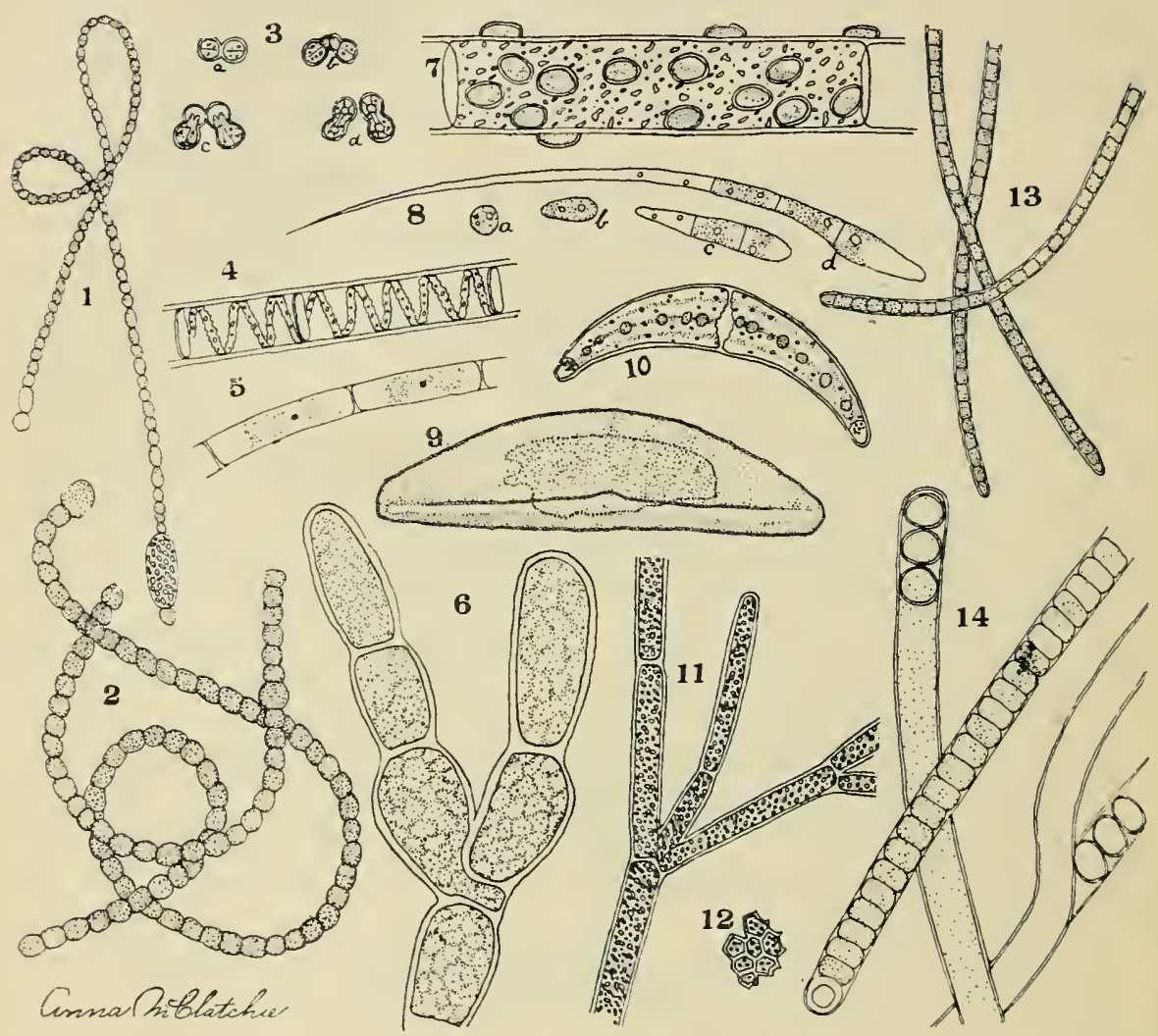

FRESH-WATER ALGE.

1. Cylindrospermum fexuosum. 2. Nostac nuscarum. 3. Cosmarium cordanum in process of division. 4. Spirogyra adnata. 5. Zygnema stellium. 6. Cladophora fracta. 7. Caconeis pediculus on Cladophora. 8. Spores of Stigeoclonium fastigiatum in various stages of division. 9. Cimbella gastroides. 10. Clasterium moniliferum. 1. Cladophora oligaclona. 12. Pediastoum bon 1anum. I3. Oscillaria antiliaria. 14. Tolypothra distorta. All magnified 250 diameters.

\section{PHYCOPHY'TA.}

\section{CLASS I. CHLOROPHYCEA}

PROTOCOCCUS Ag.

\section{Order Protococcoidece.}

P. VIRIDIS Ag. Very common in water and on wet surfaces.

SCENEDESMUS Meren.

S. DIMORPHUS Kuetz. Common in stagnant water.

S. OBTUSUs Mey. In aquariun in laboratory.

S. AcuTus Mey. Frequent in stagnant water. 
PEDIASTRUM MEYEN.

P. BORYANUM (Thurp.) Menegh. Frequent in stagnant water.

HYDRODICTYON Roth.

H. UTRICULATUM Roth. Common in streams.

PANDORINA Ehrb.

P. MORUM Bory. Common in stagnant water.

GONIUMI Muell.

G. PECTORALE Muell. In stagnant water in Arroyo Seco.

EUDORINA Ehrb.

E. STAGNALE Wolle. In stagnant water in Arroyo Seco.

EUGLENA Ehrb.

E. VIRIDIS (Schrank.) Ehrb. Frequent in stagnant water.

\section{Order. Conjugate. Desmids, Diatoms, etc.}

CI.OSTERIUM Nitsch.

C. MONILIFERUM (Bory.) Ehrb. Frequent in stagnant water.

C. ENSIS Delp. In stagnant water at Oak Knoll.

CALOCYLINDRUS D. By.

C. CONNATUS (Breb.) Kirch. var. MINOR Nord. Frequent in stagnaut water.

COSMARIUM Corda.

C. CORDANUM Breb. In stagnant water in Arroyo Seco.

CYMBELLA Agardh.

C. GASTROIDES Kuetz. Common in stagnant water.

COCCONEMA Ehrb.

C. MEXICANUM Ehrb. Common in stagnant water.

NAVICULA Bory.

N. SUBinflata Grun. In water in Arroyo Seco.

GOMPHONEMA Agardh.

G. ACUMinatuM Ehrb. In stagnant water in Arroyo Seco.

COCONEIS Ehrb.

C. PEDICULus Ehrb. On Cladophora in M. C.

C. CALIFORNICA Grun. In stagnant water in Arroyo Seco.

SYNEDRA Ehrb.

S. VALENS Ehrb. Common in stagnant water.

MERIDION Agardh.

M. CIRCULARE (Grev.) Ag. Common in stagnant water.

MELOSIRA Agardh.

M. VARIANS Ag. Common in stagnant water.

MESOCARPUS Hass.

M. RADICANS Kuetz. Stream in Arroyo Seco.

M. SCALARIS (Hass.) D. By. In stagnant water in Arroyo Seco.

ZYGNEMA Kuetz.

Z. STELLIUM Ag. On wet rocks in Rubio canyon.

SPYROGYRA Link. Pond-scum. "Frog-spittle." Brook-silk.

S. ALNATA Kuetz. Frequent in stagnant water.

S. FUSCO-ATRA Rab. In stagnant water in Arroyo Seco.

S. ORTHOSPIRA (Naeg.) Kuetz. Frequent in stagnant and ruuning water.

S, CRASSA Kuetz. Frequent in stagnant water.

S. QUiNinA (Ag.) Kuetz. Com. in stagnant water. Conjugates during April and May. ASCOPHORA Tode.

A. MUCEDO Tode. (Common black mould.) Common on decaying substances.

MUCOR Linn. Black mould.

M. MUCEDO Linn. Occasional on decaying substances.

M. RACEMOSUS Fres. On decaying cooked onion.

EMPUSA Cohn.

E MUSCAE (Fr.) Cohn. (Fly fungus) On flies. 
VAUCHERIA DC. Green-Felt.

\section{Order. Siphonice.}

V. HEMATA (Vauch.) Lyng. Common in running and stagnant water.

V. SESSILIS (Vauch.) DC. In pond in W. C.

V. TERRESTRIS Lyng. Frequent on moist soil.

SAPROLEGNIA Nees. Water-mould.

S. FERAX (Gruith.) Nees. On flies in aquarium in laboratory. BOTRYDIUM Wallr.

B. GRanulatum (L.) Grev. Common on moist soil. January - May. ALBUGO S. F. Gray. White rust.

A. CANDida (Pers.) OK. On Shepherd's Purse. February - May.

$$
\text { Order-Confervoidec. Water-flannel, etc. }
$$

CLADOPHORA Kuetz. IVater-flannel.

C. FRACTA (Dill) Kuetz. var. RIGIDULA Kuetz. Frequent in stagnant and running water.

C. OLIGOCLONA Kuetz. Common in stagnant and running water.

ULOTHRIX Kuetz.

U. ZONATA (W. \& M.) Ag. In watering-trough.

CONFERVA Link.

C. FLOCCOSA Ag. Common in stagnant and running water.

C. FUGACIssima Roth. Frequent in stagnant and running water.

STIGEOCLONIUM Kuetz.

S. FASTIGIATUM Kuetz. Common in stagnant and running water.

CYLINDROCAPSA Rein.

C. Geminelia Wolle. On shaded soil in Pasadena. February - April.

DRAPERNALDIA Agardh.

D. GLOMERATA (Vauch.) Ag. Frequent iu stream in Arroyo Seco. March - May. GEDGONIUM Link.

CE. AUTUMNALE Witt. Stagnant water at Oak Knoll.

\section{CARPOPHY'TA.}

CLASS I. ASCOMYCETES. Sac-Fungi.

Order, Perisporiacea. Simple Sac-Fungi.

SPHAROTHECA LEV.

S. PANnosa (Wallr.) Lev. On leaves of cultivated roses. December - June.

ERYSIPHE Hedw.

E. COMMUNIS (Wallr.) Fr. On cultivated peas.

CAPNODIUM Mont.

C. C.ESPitosum E. \& E. Proc. Phil. Ac. Nat. Sc. I894 p. 325. On loquat leaves.

C. CITRI B. \& D. On orange and lemon leaves.

EUROTIUM Link.

E. HERBARIORUM (Wigg.) Lk. On various decaying substances.

\section{Order Pyrenomycetece. Black Fungi.}

ROSELLINIA Ces. \& De Not.

R. AQUILA (Fr.) De Not. On oak bark and grape stems.

CUCURBITARIA Gray.

C. STENOCARPA E. \& E. (n. sp. in lit.) On dead stems of Rhus diversiloba. June September.

SPHARELLA Ces. \& De Not.

S. ARBUTICOLA Pk. On leaves of Umbellularia californica.

S. SIDACOLA E. \& E. Erythea I:198. On leaves of Sidalcea delphinifolia. MarchMay. 
STIGMATEA Fries.

S. GERANNII Fr. On leaves of $G$. carolinianum. February - April.

GNOMONIA Ces. \& De Not.

G. ALNI Plowr. On leaves of $A$. rhombifolia. June - October.

OPHIOBOLUS Riess.

O. Fulgidus ; C. \& P.) Sacc. On dead stems in Arroyo Seco. July.

CLYPEOSPHARIA Fckl.

C. HENDERSONIA (El1.) Sacc. On dead stems.

PHYLDACHORA Nitschke.

P. GRAminis (Pers.) Fck1. On Muhlenbergıa mexicana. August - October.

NUMMULARIA Tul.

N. RUMPENS Cke. On oak bark and on sycamore wood. January - April.

HYPOXYLON Bull.

H. CA LIFor nicum E. \& E. (n. sp. in lit.) On dead stems of Adenostoma fasciculatum. June - September.

H. Occidentale E11. \& Ev. Proc. Phil. Ac. Nat. Sc. 1894, p. 345. On dead limbs and trunks. L. R. C. and S. G. Mts.

GLONIUM Muhl.

G. IINEARE (Fr.) Sacc. On old decorticated trunks of Acer macrophyllum.

HYSTEROGRAPHIUM Corda.

H. PROMINENS (P. \& H.) B. \& G. On dead limbs.

ENDOCARPON (Hedw.) Fr.

E. MINIATUM Ach. On rocks.

\section{Order Discomycetece. Lichens. Cup-fungi.}

BUELLIA De Not., Tuck,

B. OIDALEA Tuck. On dead limbs.

CLADONIA Hoffm.

C. FIMBRIATA (L.) Fr. var. TUBAfFormis Fr. In soil in San Gabriel mountains.

C. FURCATA (Huds.) Fr. var. RACenosa Fl. Canyon sides.

C. PYXIDATA (L.) Fr. Canyon sides.

URCEOLARIA Tuck.

U. SCRUPOSA (L.) Nyl. On soil.

PERTUSARIA DC.

P. Multipuncta (Turn.) Nyl. On trees.

RINODINA Mass.

R. SOPHODES (Ach, ) Nyl. On trees.

LECANORA Ach. Tuck.

L. PALIESCENS (L.) Schaer. On trees.

L. PALLIDA (Schaer. var. CANCRIFORMIS Tuck. On trees.

L. PRIVIGNA (Ach.) Nyl. On rocks.

L. Subfusca (L.) Ach. On trees.

PLACODIUM (DC.) Naeg. \& Hepp.

P. AURANTIACUM 'Lightf.) Naeg. \& Hepp. On rocks and trees.

P. BOLACINUM Truck. On rocks.

P. Cerinum (Hedw.) Naeg. \& Hepp. var. PIRACEA Nyl. On trees.

P. FERRUGineUm (Huds.) Hepp. On trees.

P. MURORUM (Hoffm.) DC. On rocks.

LEPTOGIUM Fr. Nyl.

L. ALBociliatum Des. On trees and ground in A. S. and S. G. Mts.

L. Palmatum (Huds.) Mont. Among moss in San Gabriel mountains.

COLLEMA Hoffm. Fr.

C. NIGRESCENS (Huds.). Ach. On trees.

PANNARIA Delis.

P. LANuginosa (Ach.) Koerb. On rocks and soil in San Gabriel Mts.

PELTIGERA (Willd. Hoffm.) Fee.

P. CANINA (L.) Hoffm. On rocks and soil among moss.

STICTA (Schreb.) Fr.

S. PUlmonaRia (L.) Ach. On rocks and trees. 
UMBILICARIA Hoffm.

U. PHAEA Tuck. On rocks.

PHYCIA (DC., Fr.) Th. Fr.

P. HISPIDA (Schreb., Fr.) Tuck. On trees.

P. OBSCURA (Ehrh.) Nyl. On trees.

P. STELLARIS (Linn.) Tuck. On trees and rocks.

PARIELIA (Ach.) De Not.

P. CAPERATA (Linn.) Ach On trees and rocks.

P. CONSPERSA (Ehrh.) Ach. On rocks,

P. Orivacea (Linn.) Ach. On trees on Mount Lowe.

P. PERIATA (Linn.) Ach.

P. PHYSODES (Linn.) Ach. var. ENTEROMORPHA Tuck. On trees above 4000 feet.

P. TILIACEA Hoffm. Floerk. On trees.

THELOSCHISTES Norm. Emend.

T. Chrysophthalmus (Lynn.) Norm. var. A. Com. On shrubs and trees.

T. I,YCHNEUS (Nyl.) Tuck. On trees.

USNEA (Dill.) Ach.

U. BaRbata (Lynn.) Fr. var. ARTiculata Ach. On trees in S. G. Mits.

EVERNIA Ach., Mann.

E. VUr.PINA (Linn.) Ach. On coniferous trees above 3,500 feet.

CETRARIA (Ach.) Fr. Muell.

C. CALIFORNICA Tuck. On trees.

RAMALINA Ach., De Not.

R. CALCARIS (Linn.) Fr. var. FRAXINEA Fr. On trees.

R. LAEVIGata Fr. On trees.

R. MENZIESII Tuck. On trees.

R. RETICULATA (Noehd) Krem. On telephone poles.

RHYTISMA Fries.

R. PUNCTAtum Pers. On leaves of Acer macrophyllum. July - October.

TAPHRINA TUL.

T. DEFORMANS (Berk.) Tul. (Peach Curl.) On peach leaves. April-June.

CRYPTODISCUS Corda.

C. Atrovirens (Fr.) Corda. On dried shrub in S. G. Mts. August.

LACHNELIA Fries. Cup-fungus.

L. CONFUSA (Liun.) Fr. On decaying wood. January - April.

IACHNEA Fries. Cup-fungus.

J. SCUTEllata (Linu.) Fr. Com. On moist soil and decaying wood.

PSEUDOPEZIZA Fckel.

P. MEDICAGINis Sacc. On leaves of alfalfa.

P. TRIFOLII (Bernh.) Fckl. On leaves of white clover.

PEZIZA Dill. Cup-fungus.

P. CHRYsocoma (Bull.) C. \& E. On decaying wood. February - April.

P. SUBREPANDA C. \& P. Moist soil at Oak Knoll. January - April.

P. vrolacea (Gill.) Pers. Moist soil in Arroyo Seco. February - April

P. VESCICUlOSA Bull. Frequent in moist soil. December-April.

HELVELLA Fries.

H. CALIFORNiCA Phil. Common under trees at Oak Knoll. January - April.

H. CRISPA Fr. Under trees at Oak Knoll. April.

H. I.ACUNOSA Afz. Frequeut in shaded soil at Oak Knoll and A. S. Feb. - April.

MORCHELLA Dill. Morel.

M. Conica Pers. Occasional in shaded soil. February - May.

Order Uredinea. Rusts.

UROMYCES Link.

U. BETIF Kuehn. II. On cultivated beets.

U. CARYOPHYi.IInUS (Sclirk.) Schrt. On garden pink (Dianthus.)

U. CHORIZANTHIS E.11. \& Hark. III. On C. staticoides. June - August.

U. ERIOGONr (?) Ell. \& Hark. II. On E. elongatum and E. saxatile. May - Oct.

U. HuPIIOR131A: C. \& P. II, III. On E. serpyllifolia. Juue - September. 
U. Junci (Desm.) Tul. II, III. On J. balticus, J. robustus, and J. xiphioides. February - October.

U. LUPINI B. \& C. I, II \& III. On L. albifrons, L. formosus bridgesii, and L. cytisoides. March - July.

U. POLYGonI (Pers.) Fckl. II. On P.aviculare. June - August.

U. TEREBINTHI (DC.) Wint. II \& III. On Rhus diversiloba. August.

U. TRIFOLII (A. \& S.) Wint. I \& III. On T. gracilentum, T. macrei, T. microcephalum, T. ciliolatum and T. roscidum. April - June.

U. ZYGADENUS (?) Pk; II. On Z. fremonti. March - April.

PUCCINIA Pers.

P. ACHYRODIS Diet. \& Hol. (n. sp. in lit.) III. On $A$. aureum. June-August.

P. AMORPHA Curt. III. On $A$. Californica J.uly - September.

P. BACCHARIDIS Diet. \& Hol. Erythea I: 250 . II \& III. On $B$, viminea. JuneNovember.

P. CARICIS (Schum.) Rab. II \& III. C. barbarce and C. filiformis latifolia.

P. CLARKIA, Pk. I \& III. On Zauschneria californica; III. On Enothera bistorta and Godetia bottc. May - July.

P. convolvuri (Pers.) Cast. II \& III. On $G$. occidentalis. June - August.

P. CoRonata Corda. II \& III. On Holcus lanatus. May - September.

P. DIGITATA Ell. \& Hark. III. On Rhamnus crocea.

P. EULOBI Diet. \& Hol. Erythea I:249. I \& III. On E. californicus. April--Aug.

P. Flosculosorum (A. \& S.) Roeh1. III. On Carduus californicus and C. occidentalis. February - July.

P. GAIII [Pers.] Schw. II \& III. On $G$. californicum, $G$, cinereum, and $G$. nuttallii, May - September.

P. GILIA Hark. III. On G. attractyloides. June-August.

P. GRAMINelita (Speg.) Diet. \&. Hol. III. On Stipa eminens. March-June.

P. Graminis Pers. II \& III. On $A$. fatua, $A$. sativa. Elymus condensatus, $E$. triticoides, and cultivated barley.

P. HARKNESSI Vize. III. On Ptiloria cichoriacece, June-August.

P. Helianthil Schw. II \& III. On $H$. anmuns.

P. HiERACII (Schum.) Mart. III. On MTalacothrix tenuifolia. July.

P. INVESTITA Schw. I \& III. On Gnaphalium californicum. July.

P. JONESII Pk. III. On Velcea arguta. A pril -July.

P. MALVACEARUM Mont. III. On $M$. parviflora and hollyhock.

P. NODOSA Ell. \& Hark. III. On Brodicea capitata. April.

P. MCClatchiana Diet. \& Hol. Erythea II : 127. III. On Scirpus sylvaticus microcarpus.

P. MELLIFERA Diet. \& Hol. Erythea I:25I. I \& III. On Salvia mellifera. May - July.

P. MENTH A Pers. II \& III. On $M$. canadensis. June-September.

P. PALEFACIENS Diet. \& Hol. Erythea II : I2S, III. On arabais holbollii. Febrnary - April.

P. PIMPINELLE (Straus.)L k. III. On Osmorrhaza brachyopoda. April-May.

P. Polygoni-AMPhibil Pers. II. On P. acre.

P. PROCERA Diet. \& Hol. Erythea I:249. II \& III. On Elymus condensatus, E. triticocoides, and E. americanus.

P. PRUNI-SPINOSA Pers. II \& III. On leaves of cultivated plums, peaches and apricots. July - October.

P. PUlverulenta Grev. III. On Ephilobium paniculatum. September.

P. RECoNdiTA Diet. \&. Hol. Erythea I1: I28. III. On Artemisia vulgaris californica. September - April.

P. RUBIGo-verA (DC.) Wint. II \& III. On wheat Bromus hookerianus and Hordeum murinum. March - November.

P. TANACETI DC. II \& III. On Artemisia vulgariscalifornica. July - November.

P. XanTHII Schw. III. On X. strumarium. August - October.

PHRAGMIDIUM Liuk.

P. SUBCORTICIUM (Schr.) Wint. On leaves and stems of Rosa californica and cultivated roses.

P RUBI-IDAEI (?) (Pers.) Wint. II. On leaves, stems, and fruit of cultivated blackberries. July - October.

ECIDIUM Pers. Cluster Cups.

E. CLEMATIDIS DC. On C. ligusticifolia. March - July.

E. EUPHORBIA Gmel. On E. albomarginata and E. serpyllifolia. July - September. 
F. PHACELIA Pk. On P. ramossissima. February - April.

I. ROESTElIOIDES E. \& E. On Sidalcea delphinifotia. March - May.

E. URTICA Schum. On U. holosericea. February - April.

UREDO Pers.

U. FILICUN (Lk.) Chev. On Gymnogramme triangularis. January - April.

U. PTERIDIS Diet. \& Hol. Erythea II: I27. On P. aquilina. February.

MELAMIPSORA Cast.

M. SAlicis-CAPPE正 (Pers.) Wint. II. On S. lasiolepis. June - August.

PUCCINIASTRUM Otth.

P. EPILOBI (Chaill.) Otth. II. On E. adenocaulon occidentale.

USTILAGO Pers. Smit.

\section{Order Ustilaginea. Smuts.}

U. AUSTRO-AMericana Speg. On Polygunum nodosum. September - November.

U. AVENA (Pers.) Jens. On cultivated oats. April - June.

U. Brominora Fisch. de Wald. On B. hookerianus. April - June.

U. HORDEI (Pers.) K. \& S. On cultivated barley. April - June.

\section{IMPERFECT FUNGI.}

PHYLLOSTICTA Pers.

\section{Order Sphaeropsidece.}

P. FERAX Ell. \& Ev. Proc. Phil. Ac. Nat. Sc. I894, p. 355. On leaves of Lupinus formosus bridgesii. Sierra Madre. April.

DIPLODIA Fries.

D. UMBELLULARIA E. \& E. (n. sp. in lit.) On U. californica. July -October.

HENDERSONIA Mont.

H. UMBELIUlaRie E. \& E. (n. sp. in lit.) On U.californica. July - October. ASCOCHYTA Lib.

A. Graminicola Lib. On Poa Annua. December-March.

A. Menziesil Ell. \& Ev. (n. sp. in lit.) On leaves of Arbutus menziesii. S. G. Mts. February.

ACTINONEMA Fries.

A. ROSA (Lib.) Fr. On leaves of $R$. californica.

SEPTORIA Fries.

S. ALNIFOLIA E. \& E. On leaves of A. rhombifolia. April-November.

S. DUlCAMAR我 Desm. On leaves of Solanum douglasii. January-May.

S. Funiosa Pk. On leaves of Solidago californica. May-October.

S. IRREgularis Pers. On leaves of Rhus diversiloba. July-October.

S. Mimul, Ell \& Kell. On leaves of $M$. glutinosus. June-Angust.

S. ENOTHER 王 IVestd. On leaves of $E$. biennis. June-October.

S. Polygonorum Desm. On leaves of $P$. nodosum. June-November.

S. RHAMNI-CATHARTICA: Ces. On leaves of $R$. californica.

S. RUBI Westd. On leaves of $R$. ursipus.

S. SCROPHULARIXY Pk. On leaves of S. californica. January-May. SPHAEROPSIS I,ev.

S. ALNI C. \& E. On bark of $A$. rhombifolia.

ENTOMOSPORIUM LEV.

E. MACULATUM Lev. On leaves of Heteromeles arbutifolia.

AMEROSPORIUM Speg.

A. cinctum Ell. \& Ev. (n. sp. in lit.) On stems of Gladiolus. July.

\section{Order Melonconica.}

GLOEOSIORIUMI Desmi. \& MIOnt.

G. CERCOCARPI Ell. \& Ev. Erythea II:25. On leaves of $C$. parvifolius. JuneAugust.

G. PIY Ylachorordis Ell. \& Ev. Erythea I:20r. On leaves of Artemisea vulgaris californica. 
CYLINDROSPORIUM Unger.

C. CEANOTHI E11 \& Ev. On leaves of $C$. divaricatus. June - August.

C. TOXICODENDRI (Curt.) Ell \& Ev. Proc. Phil. Ac. Nat Sc. VII: 460. On leaves of Rhus diversiloba. July - October.

MELANCONIUM Link.

M. ACERinum Ell. \& Ev. Proc. Phil. Ac. Nat. Sc. I894, p. 373. On dead limbs of A. macrophyllum. February and April.

M. BICOLOR Nees. On bark of Alnus rhombifolia. July - October.

MARSONIA Fisch.

M. POTENTILIAE (Desm.) Fisch. On leaves of P. californica. March - July.

OIDIUM Link.

\section{Order Hyphomyceteae.}

O. ERYSIPHOIDES Fr. On Phacelia ramossissima, P. whitlavia, Stachys californica, Heterotheca grandiflora. Anthemis cotula, Galium aparine, Artemisia vulgaris californica, aud Helianthus annuus.

O. MONILIOIDES Lk. On Bromis americanus.

TRICHODERMA Pers.

T. LIGNORUM (Tode.) Hartz. On decaying wood. January - April.

BOTRYTIS Michx.

B. VULGARIS Fr. On withered rose petals.

PENICILLIUM Lk.

P. GLAUCUM Lk. On all kinds of decaying matter.

RAMILARIA Ung.

R. DECIPIENS Ell \& Ev. On leaves of Rumex crispus.

R. MELILOTI Eill. \& Ev. Erythea II :26. On $M$. indica. Oct.

R. URTICAE Ces. On U. holosericea.

CERSPORELLA Sacc.

C. PROLIFICANS E. \& E. On Sambucus glauca. April - November.

TORULA Pers.

T. SPORIDESMOIDES El1. \& Ev. Proc. Phil. Ac. Nat. Sc. I894, p. 377. On bark of dead limbs.

HORMISCIUM Kunze.

H. STILBospora (Corda) Sacc. On decaying wood.

BACTRIDIUM Kunze.

B. ELLISII Beck. On decaying wood. February - April.

DEMATIUM Pers.

D. vinosum Mass. On culture media in laboratory.

SCOLECOTRICHUM Kunze G Schm.

S. ASCLEPIAdIS El1. \& Ev. Erythea I : 203. On leaves of A. eriocarpa. JuneNovember.

S. GRAMINIS Fck1. On cultivated barley and oats.

FUSICLADIUM Bon.

F. DEPRESSUM B. \& Br. On Velaea arguta. June - August.

CLADOSPORIUM Link.

C. AROMATicum E. \& E. (n. sp. in lit.) On leaves of Rhus aromatica. July - Aug.

C. CARPOPHILUM Thm. On ripe apricots. July - August.

C. EPIPHyluUir Pers. On leaves of Eucalyptus globulus.

C. HERBARUM (Pers. ( Link. On various parts of decaying plants.

C. PAEONÆ. Sacc. On leaves of $P$. californica. May-August.

C. TYPHARUM Desm. On $T$. lalifolia.

CERCOSPORA Fries.

C. BETICOLA Sacc On beet leaves.

C. CIRCumcissa Sacc. On leaves of Prunus illicifolia.

C. Clavicarpa E. \& E. Erythea II:26. On Ptiloria virgata. July-September.

C. Crotonis E. \& E. On leaves of C. californicus. June-September.

C. EPILOBII Schn. On leaves of E. adenocanlon occidentale. July-September.

C. HETEROMELES Hk. On leaves of $H$. arbutifolia. June-November.

C. NASTURTII Pass. On leaves of $N$. officinale. July-September. 
C. ROSicola Pass. On leaves of cultivated roses and $R$. californica. JulySeptember.

C. SAURURI E. \& E. On leaves of Anemopsis californica. June-October.

C. SQUAlidDa Pk. On leaves of Clematis ligusticifolia. July-November.

C. VIOLE Sacc. On leaves of cultivated violets.

C. VITICOLA (Ces.) Sacc. On leaves of $V$. californica and cultivated grapes. June -October.

HETEROSPORIUM Klotzsch.

H. EUCAlypti E. \& E. Proc. Phil. Ac. Nat. Sc. I894, p. 381. On E. globulus leaves. November.

H. eUCAlypti E. \&. E. var. MACUlicolum (n. var. in lit.) On leaves of Eriodictyon californicum. June-August.

H. PHRAGMites (Opiz) Klot. On corn leaves. September-November.

CONOTHECIUM Corda.

C. UMBELIULARIA: E. \& E. (n. sp. in lit.) On stems of U.californica. June October.

MACROSPORIUM Fries.

M. Caudatum C. \& E. On dead leaves of Vitis californica. August.

M. MAYDIS C. \& E. On corn leaves.

M. Pela Rgonil Ell \& Ev. Proc. Phil. Ac. Nat. Sc. I894, p. 383 . On leaves of cultivated Geranium. February.

M. Solani Ell. \& Mart. On potato leaves.

STEMPHYLIUM Wall.

S. MACROSPOROIDEUM B. \& Br. On culture media in laboratory.

S. ALTERNARIA, Cke. On culture media in laboratory.

EPICOCCUM Lk.

E. NEGLECTUM Desm. On corn leaves. September-November.

PODOSPORIELLA Ell. \& Ev. Proc. Phil. Ac. Nat. Sc. I894, p. 385.

P. HuMilis E. \& E. Ibid. On leaves of Garrya veatchii. June-October.

CLASS III. BASIDIOMYCETES. Puff-Balls, Toadstools, Pore-Fungi.

\section{Order Gasteromycetec. Puff-balls.}

PHALLUS Mich. Stink-horn.

P. RAVENELII B. \& C. Frequent in rich soil and in lawns. October-March.

SECOTIUM Mont.

S. DECIPIENS Pk. (n. sp. in lit.) Common along gutters.

GEASTER Mich. Earth-star.

G. I.mpatus Fr. O. K.; A. S. under trees. February-April.

G. MINIMIS Schw. Oak Knoll. February-April.

G. SAcCatus Fr. Arroyo Seco. March.

ASTR.FUS Morg. Hygrometric Earth-star.

A. HYGROMETRICUS (Pers.) Morg. Com. under trees. Jannary-March.

TYLOSTOMA Pers. Stalked puff-ball.

T. CAMPESTRE Morg. Along Wilson Trail and in dry soil at Devil's Gate. January-July.

CALVATIA Fr. Puff-ball.

C. C五AATA Bull. In rich soil. February-April.

C. FRAGILIS Vitt. In lawn and along Wilson Trail, 4,ooo feet. January-October.

C. HESPERIA Morg. (n sp. in lit.) Along streets and in yards. November-Decelinber.

LYCOPERDON Tourn. Puff-ball.

I. CEPAISFORME Bull. Oak knoll. January-March.

L. MOL $L_{1}$ E Pers. Along street. December-March.

CATASTOMA Morg.

C. Circumcissum (B. \& C.) Morg. Along street. February-March.

BOVISTA Dill. Puff-ball.

B. AMMOPIILA Lev. Coll, below 2,00o feet. December-March.

SEI,ERODERMA PerS.

S. VULGaRE Fr, Frequent in rich soil. Septemluer-January. 
CYATHUS Hall.

C. VERNICOSUS (Bull.) DC. On decaying wood and in soil. March-May.

CRUCIBULUM Tul. Bird-nest fungus.

C. VULGaRE Tul. On decaying wood and in soil in and near the A. S. February -April.

\section{MANITA Fries.}

$$
\text { Order-Hymenomycetes, Toadstools, Pore-Fungi, etc. }
$$

A. PHaliordes Fr. Com. under oak trees. February-April. Poisonous.

AMANITOPSIS Roze.

A. VEIOSA Pk. (n. sp. in lit.) Com. under oaks. February-May. Edible.

\section{LEPIOTA Fries.}

L. ANGUSTANA Britz. Frequent under trees. December-February.

L. FUlvodisca Peck. . Tor. Bull. 22. 198. Among moist leaves in Arroyo Seco. January.

L. NAUCINoIDEs Pk. Abundant in lawns. August-November. Edible.

ARMILLARIA Fries.

A. MELLEA Vahl. Com. at base of trees and stumps. September-January. Edible.

A. MELLEA Vahl. Var: NIGR1PES Pk. (n. var. in lit.) On willow trunk in W. C. December.

TRICHOLOMA Fries. Pers.

T. EQUESTRE Linn. Among leaves under oaks. February.

T. MELALEUCUM Peri. Under oaks in W. C. January.

T. NUDUM Bull. Frequent under trees. January-March.

T. RUsSul. Schaef. Under oaks in O. K. C. February.

COLLYBIA Fries.

C. ALBOGRISEA Pk. Tor. Bull, 22:199. Frequent in W. C. January and February.

C. DRYOPHILA Bull. Frequent among leaves under trees. January and February.

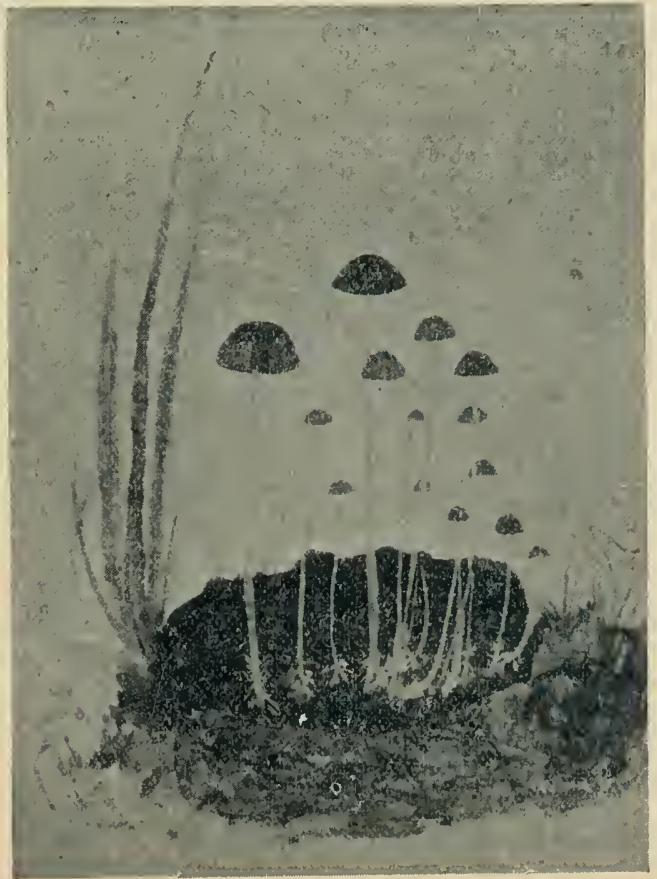

A. J. MeClatchie, del 
MYCENA Fries.

M. ACICUla Schaef. On decaying wood. February.

M. ATROALBOIDES Pk. Abundant among wet leaves. December-February.

M. ELHGANTULA Pk. Tor. Bull. 22:199. Abundant among wet leaves. December-February.

RUSSULA Fries.

R. EMETICA Fr. Com. under oaks. November-March. Poisonous.

LACTARIUS Fries.

L. CAMPHORATUS Fr. Com. under oaks. January-March.

L. INSUlsus Fr. Com. under oaks. Jauuary-March.

CLITOCYBE Fries.

C. PUSILLA Pk. Tor. Bull. 22:199. On manure. February.

C. TORTILIS Bolt. In moist soil in A. S. February.

OMPHALIA Fries.

O. Pyxidata Bull. On moist banks. December-February.

O. PYXIDATA Bull. var. FURCATA Pk. (n. var. in lit.) Com. in waste soil. January-March.

PLEUROTUS Fries.

P. OSTREATUS Jacq. (Oyster mushroom.) On decaying wood. January-March, Edible.

P. SAPIDUS Kalch. On decaying wood. January-March. Edible.

HYGROPHORUS Fries.

H. ERUBESCENS Fr. Com. under oaks. December-January.

LENZITES Fries.

L. Betulina Fr. On oak stumps in M. C. and in W. C. January-March.

SCHIZOPHYLLUM Fries.

S. COMMUNE Fr. Com. on decaying logs.

VOLVARIA Fries.

V. SPECIOSA Fr. Com. in grain fields and waste grouud. Jan.-March. Edible.

ENTOLOMA Fries.

E. FERUGiNANS Pk. Tor. Bull 22:200. Abundant under oaks. January-April. Edibles.

LEPTONIA Fries.

L. EDUlis Pk. Tor. BuIl. 22:20I. Frequent in grass and among weeds. December -February. Edible.

ECCILIA Fries.

E. NIGRICANS Pk. Tor. Bull. 22:202. Abundant in waste soil. December-March. Edible.

PHOLIOTA Firies.

P. ANOMALA Pk. Tor. Bull. 22:202. Among leaves in A. S. January-March.

P. PRAECOX Pers. In grass. March-June.

PLUTEOLUS Fries.

P. LUTEUS Pk. Tor. Bull. 22:203. Among leaves and grass under trees. February - March.

BOLBITIUS Fries.

B. FRAGILIS Fr. var. ALBIPES Pk. «n. var. in lit.) In grass. January.

B. TENER Berk. In lawns. April-June.

HEBELOMA Fries.

H. FOEDATUM Pk. Tor. Bull. 22:202. In grass along streets, January-Marcl.

H. Ischnostrium Cke. Among leaves in the A.S. January-March.

H. MESOPHOEUn Fr. Among moss in A. S. December-March.

NAUCORIA Firies.

N. MELINOIDES Fir. In grass. March-May.

N. Semiorbicularis Bull. Com. among grass and weeds. February-June.

GALERA Fries.

G. I,ATLRITIA Fr. In lawns. April-June.

G. OVAIIS Fir. In riclı soil. February-June.

G. THNI:RA Schaeff. In lawns. Very common.

TURARIA Snith.

T. PALLESCENS Pk. Tor. Bull. 22:202. On leaves and sticks under trees. January-March. 


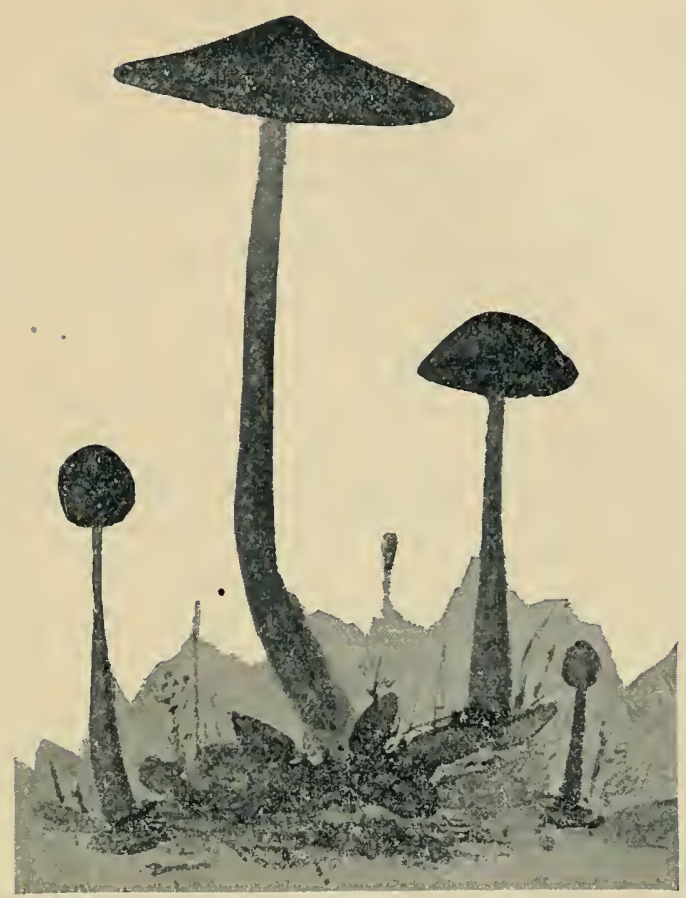

A. J. McClatchie, del.

PLUTEOLUS LUTEUS.

One-half natural size.

CREPIDOTUS Fries.

C. HEPATIZON Berk. On decaying stumps in A. S. December-March.

C. HERBARUM Pk. On leaves and sticks in A. S. January-March.

C. Subverantus Pk. (n. sp. in lit.) Com. on leaves and sticks. DecemberApril.

CORTINARIUS Fries.

C. vIRGatUs Pk. Tor. Bull, 22:203. Among leaves under trees at O. K. February. AGARICUS Linn.

A. CALIFORNICUS Pk. Tor. Bull. 22:203. Com. under oaks. December-February. Edible.

A. CAMPESTER L. (Common mushroom.) In forging shop and in gardens. Edible. STROPHARIA Fries.

S. BILAMELLATA Pk. Tor. Bull. 22:204. Along street. January. Edible.

S. SEMIGLOBATA Batsch. In lawns. April-June.

S. STERCORARIA Fr. On manure in woods. December-March.

HYPHOLOMA Fries.

H. A PPENDICUl,ATUM Bull. Ameng leaves in W. C. January-February.

H. FASCiCUlaRe Hud. At base of stumps, A. S., R. C. January-March.

H. INCERTUM Pk. In soil under trees. December-February.

H. LONGIPES Pk. Tor. Bull. 22:204. Among wet leaves in cañons. JanuaryMarch.

H. MADLODIscum Pk. Among leaves in in I. R. C. January-February.

H. PERPLEXUM Pk. On rotten wood in R. C. March.

PSATHYRELLA Fries.

P. Disseminata Pers. At the base of stumps, December-March.

PANAEOLUS Fries.

P. DIGRESSUS Pk. Tor. Bull. 22:205. On manure. July. 
P. INTERMEDIUS Pk. Tor. Bu11. 22:205. In sandy soil along streets and in washes. January-March.

P. RETIRUGIS Fr. In rich soil. April-June.

P. Sub-Balteatus B. \& Br. Common in lawns. April-June.

COPRINUS Pers. (Dissolving Toadstools.)

C. CALYPTRATUS Pk. In rich cultivated soil. March-May.

C. comatus Fr. (Shaggy-maned mushroom.) In rich soil. Edible.

C. CONGREGATUS Bull. In rich soil. March.

C. I.AGopUs Fr. In manure. January-March.

C. MICACEUS Fr. At base of trees and stumps. December-April.

C. PIICATILIS Fr. In rich soil. March.

C. PLUMBEUS Pk. In lawn. June-August.

C. Radiatus Fr. On manure. March.

BOLETUS Dill. Stalked Pore-fungus.

B. Subtomentosus L. Com. under trees. December-April.

POLYPORUS Mich. Pore-fungus.

P. ADUSTUS (Willd.) Fr. On decaying logs and stumps. December-March.

P. BUlbipes Fr. San Gabriel Mts. March-May.

P. DENDRITICUS Fr. On decaying boards. January-March.

P. Gilvus Schw. On decaying oak.

P. LEUCOMELAS Fr. San Gabriel Mts. March-May.

P. LEUSCUlum B. \& C. ' On decaying oak.

P. Roseus A. \& S. On decaying Pseudotsuga in San Gabriel Mts.

P. SCRUPIRUS Fr. On decaying wood.

P. SUlPhureus (Bull.) Fr. On decayed wood. February-April.

FOMES Fries.

F. APPLANatus (Pers.) Wallr. On decaying oaks. December-May.

F. IGNIARIUS (L.) Fr. On decaying oak.

F. LUCIDUS (Leys.) Fr. On decaying oak. January-April.

POLYSTICTUS Fries.

P. Hirsutus Fr. On decaying wood. January-June.

P. PERGAMENus Fr. On decaying Pseudotsuga in San Gabriel Mts.

P. VERSICOLOR (L.) Fr. On decaying wood. December-April.

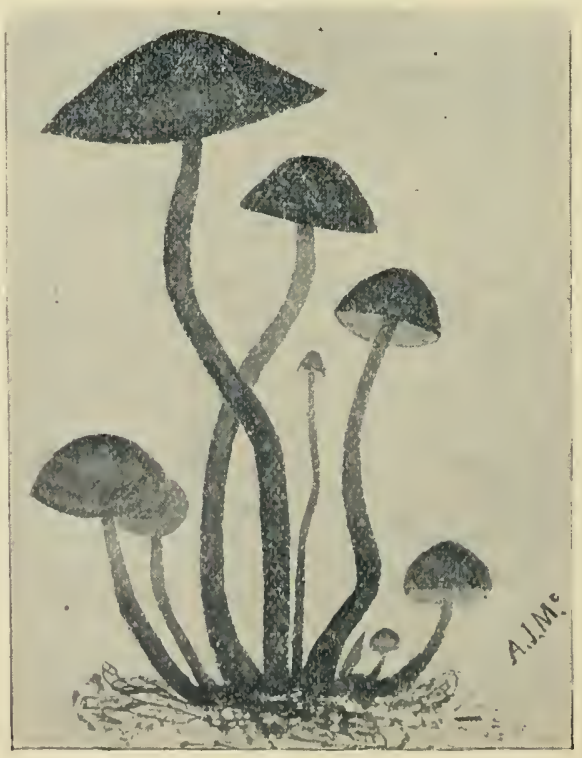

HYPHOLOMA FASCICULARE.

'Two-fifths natural size. 
TRAMETES Fries.

T. PECKII Kalch. On decaying wood.

FAVOLUS Fries.

E. PuRpurascens B. \& C. On decaying wood in San Gabriel Mts.

MERULIUS Hall.

M. CORIUM Fr. On decaying oak. December-May.

M. LACHRYMANS Fr. On moist soil and decaying wood. January-April.

PHLEBIA Fries.

P. MERISMOIDES Fr. On decaying bark. January-April.

RADULUM Fries.

R. ORBICULARE Fr. On decaying bark. January-April.

HYDNUM Linn.

H. OCHRACEUM Pers. On decaying oak bark. March-May.

STERUM Pers.

S. Albobadium Schw. On burnt and decaying wood and bark.

S. GALEATII Berk. On oak bark.

S. HiRsutum (Willd.) Fr. On oak bark. Common.

S. MOLLE Lev. On oak bark.

S. PURPUREUM Pers. On decaying wood and bark.

S. SPADICEUM Fr. On oak bark.

S. TRISTE B. \& C. On burnt wood.

S. VERSICOLOR (Schw.) Fr. Com, on oak bark.

CORTICIUM Fries.

C. CARNEUM B. \& C. On decaying wood.

C. Cinereum (Pers.) Fr. On stems of Adenostoma.

C. COMEDEUS (Nees.) Fr. On decaying oak branches.

C. LACTEUM Fr. On decaying sycamore. January-A pril.

C. SEBACEUM (Cke.) Mass. On moss. January.

HYMENOCHAETE LEV.

H. RUBIGINOSA (Schr.) Lev. On decaying roots and stumps.

PENIOPHORA Cooke.

P. MORICOIA Berk. On dry wood.

P. OCHRACEA (Fr.) Mass. On decaying sycamore.

P. QUERCINA (Fr.) Cke. On oak bark.

CONIOPHORA D. C.

C. Fumosa Pers. On sycamore bark.

CLAVARIA Vaill.

C. CORALLOIDES Linn. Among leaves at O. K. January-March.

C. GRISEA Pers. Among leaves at O. K. January-March.

C. InAEqUalis Berk. Among leaves at O. K. January-March.

C. LIGULA Fr. Under oaks at O. K. January-March.

TREMELLA Dill.

T. AURAntia Schw. On decaying wood. December-March.

T. INFLATA Fr. On rotton wood. March.

EXIDIA Fries.

E. Grandulosa Fr. On dead oak branches. December-March.

CLASS IV. RHODOPHYCE王.

Order Floridea.

BATRACHOPERMUM Roth.

B. Gelatinosum (L.) Woods. Stream in Arroyo Seco.

B. VAGUM Ag. Streams in A. S. and M. C. 


\section{BRYOPHYTA.}

\section{CLASS I. HEPATICA. Liverworts.}

RICCIA Linn.

\section{Order Ricciacea.}

R. AGGREGATA Und. Bot. Gaz. 19:275. Com. on bank and trodden soil. December-A pril.

R. ARVENSIS Aust. var. HIRTA Aust. Com. on banks and in gravelly soil below 3000 feet. December-April.

R. GLAUCA Linn. Shaded soil. January-April.

SPHAROCARPUS Mich.

S. TERRESTRIS Mich. var. CALIFORNicus Aust. Com. on moist compact soil. January-April.

MARCHANTIA Linn.

\section{Order Marchantiacea.}

M. POLYMORPHA Linn. Wet soil. O. K. ; A. S. ; Wilson Trail.

GRIMALDIA Raddi.

G. CALIFORNICA Gottsche. Shaded soil, Wilson Trail, 4000 feet. March-June.

CRYPTOMITRIUM Aust.

C. TENERUM Aust. Moist, shaded soil in canyons, below 3000 feet. March-June.

-ASTERELLA Pal. de Beauv.

A. CALIFORNica (Hampe.) Und. Com. on shaded soil below 5000 feet. November-April.

A. NUDATA (Howe) Und. Frequent in gravelly soil below 2,000 feet. FebruaryApril.

A YTONIA Forst.

A. ERythrosperma (Sulliv.; Und. Wet soil. R. C. Wilsou Trail, 5,ooo feet. March-May.

LUNULARIA Mich.

L. CRUCiAtia (Linn.) Dum. Com. in green-houses.

TARGIONIA Mich.

T. HYPOPHYLLA Linn. Com. on shaded banks below 4,000 feet. DecemberApril.

\section{Order Anthocerotacec.}

ANTHOCEROS Linn. Horned-liverwort.

A. FUSIFORMIS Aust. Moist soil. Not common. March-May.

A. LAEVIS L. Frequent on wet rocks along streains. January-September.

\section{Order Jungermaniacec. Scale-mosses.}

FOSSOMBRONIA Raddi.

F. LONGISETA Aust. Com. on shaded banks. December-April.

FRULLANIA Raddi. Scale-moss.

M. BOLANDERI Aust. Bark on trees in S. G. Mts. December-June.

MADOTHECA Dumort. Scale-moss.

M. BOLANDhRI Aust. Com. on rock in S. G. Mts. December-April.

\section{CLASS II. MUSCI.}

EUCLADIUM Br. \& Scli.

\section{Order Bryacec. True Mosses.}

E. VERTICIL_ATUM (Linn.) B. \& S. Sliaded soil in S. G. Mits. None bearing sporogonia collected.

DICRANOWEISIA Lindb.

D. crrrhata (Hedw.) I.indb. Shaded soil in S. G. Mts. March-May.

FISSIDENS Hedw.

F. GRANDIFRONS Brid. Under swiftly running water in canyons S. G. Mts.

F. Lrmbatus Sulliv. Com. in shaded soil. February-May. 
BARBULA Hedw.

B. MUELLERI B. \& S. Frequent on rocks. February-May.

B RURALIS (Linn.) Hedw. Com. on rocks and soil. February-May.

B. vinealis Brid. Frequent in S. G. Mts. and A. S. March-June.

GRIMMIA Ehrh.

G. CALIFORNICA Sulliv. On dry rocks in S. G. Mts. March-June.

G. LEUCOPH瓜A Grev. Com. on rocks and bark of trees. February-May.

G. TRICHOPHYLLA Grev. Com. on rocks and bark of trees. February-May HEDIVIrIA Ehrh.

H. Ciriata (Dicks.) Ehrh. Frequently on rocks in S. G. Mts. April-July. ORTHOTRICHUM Hedw.

O. LYELLII H. \& T. Con1. on bark of trees, especially in S. G. Mts. MarchMay.

FUNARIA Schreb.

F. HYGROMETRICA (Linn). Sibth. Com. below 3,ono feet. December-March.

BARTRAMIA Hedw.

B. MENZ1ESII Turn. Com. in S. G. Mts. February-April.

LEPTOBRYUM Schimp.

I. PYRIFORME (Linn.) Schimp. Com. in shaded soil below 3,00o feet. FebruaryApril.

IVEBERA Hedw.

W. NUTANS (Schreb.) Hedw. Shady canyon sides and decaying logs. Feb.-April. BRYUM Dill.

B. ARGENTEUM Dinn. Com. below 2,00o feet. February-May.

B ToRguescens B. \& S. Frequent below 4,ooo feet. March-June.

B. TURBinatum Schw. Foothills S. G. Mts. March-May.

AULACOMNIUM Schwaegr.

A. ANdrogynum (Linn.) Schw. Near Strain's Camp, Wilson's Peak. AprilMay.

POLYTRICHUM Linn.

P. PILIFERUM Schreb. Echo Mt. No specimens bearing sporogonia found.

ALSIA Sulliv. Feather moss.

A. A BIETINA Sull. Com. on rocks and trees in S. G. Mts. April-May.

A. LONGIPES S. \& L. Frequent on rocks in S. G. Mts. None bearing sporogonia collected.

PTEROGONIUM Swartz.

P. GRACILE (Linn.) Swartz. Rocks in canyons S, G. Mts. None bearing sporogonia collected.

ANTITRICHIA Brid.

A. CALIFORNICA Sull. Wet rocks in Rubio Canyon. None bearing sporogonia collected.

CLAOPODIUM Dill.

C. LEUCONEURUM S. \& L. Rubio Canyon. None bearing sporogonia collected.

CAMPTOTHECIUM Dill.

G. ARENARIUM (Lesq.) Ren. \& Card. On dry rocks and soil. February-May.

C. PINNATIFIDUi S. \&. L. Com. on rocks in A. S. and canyons of S. G. Mts.

BRACHYTHECIUM Schrimp.

B. RUTAbulum S. \& L. Canyons of S. G. Mts. March-May.

SCLEROPODIUM Schrimp.

S. CAESPITOSum (Wils.) Br. \& Sch. On dry rocks in A. S. and R. C. March-June.

S. ILLECEBRUM (L.) Br. \& Sch. Canyous of S. G. Mts. March-May. Common.

$\mathrm{S}$. OB'TUSIFOLIUM (Hook) Kindb. On rocks under running water in R. C. None bearing sporogonia collected.

EURYNCHIUM Schrimp.

E. STOKESII (Turn.) B. \& S. Rubio Canyon. None bearing sporogonia collected. RHYNCHOSTEGIUM Schrimp.

R. SERrulatum Hedw. Rubio Canyon. None bearing sporogonia collected. 
AMBLYSTEGIUM Schrimp.

A. IRRIGUM Hook. \& Wils. Moist soil in R. C. None bearing sporogonia collected.

A. SERPENS (Linn.) B. \& S. Com. along streams. February-May.

\section{P'TERIDOPHYTA.}

\section{CLASS I. FILICIN $£$. \\ Order Filices. Ferns.}

CYSTOPTERIS Bernh. Bladder-fern.

C. FRAGILIS Bernh. L. St. A. C., Rare. Jannary-July.

ASPIDIUM Swz. Shield-fern.

A. Munitum Kaulf, M. C., R. C., Eaton C., Mt. L., W. Pk.

A. RIGIDUM Swz. var. A RGUTUm Eat. A. S., S. G. Mts., Com.

ASPLENIUM Linn. Spleenwort.

A. TRIChomanes Linn. var. Incisum Moore. M. C., L. St. C. Not. common. IVOODWARDIA Smith. Chain-fern.

IV. Radicans Sm. O. K., A. S., M. C., R. C., Eaton C., L. St. A. C.

PELLAEA Link. Cliff brake.

P. ANDROMEDAFForia Fee. (Coffee-fern.) O. K., A. S., S. G. Mits. Com.

P. oRnithopus Hook. (Bird-foot-fern.) A. S., S. G. Mts. Com.

PTERIS Linn. Brake.

P. AQUilina Linn. (Common brake.) O. K., A.S., M. C., R. C. Com. January-October.

ADIANTUM Linn. Maidenhair.

A. CAPIllus-veneris. Linn. (Venus' Hair.) M. C., R. C., E. C. Abundant.

A. EMARGINatum Hook. O. K., A. S. Abundant, January-June.

A. Pedatum Linn. L. St. A. C. Rare.

CHEILANTHES Swz.

C. Californica Mett. (Lace-fern.) A. S., S. G. Mts. Com.

C. MYRiophylia Desv. Mt. L., W. Pk. Com. above 4,000 feet. December-July. NOTHOI, ENA R. Br.

N. NEWBERRYI Eat. (Cotton-fern.) Echo Mt. Rare.

GYMNOGRAMME Desf.

G. TRIANGULARIS Kaulf. (Golden-back fern.) O. K., A. S., S. G. Mts. Decen1ber-April.

POLYPODIUM Linn. Polypody.

P. CALIFORNICUM Kaulf. A.S., S. G. Mts. Com. December-June.

AZOLLA Lam.

\section{Order Salviniacea.}

A. FILICUloides Lam. O. K., A. S. Abundant. June-August.

CLASS II. EQUISITIN $Æ$.

Order Equisetacex. Horse-tails.

EQUISETUM Linn. Horse-tail. Scouring-rush.

E. MEXICANum Milde. A. S., M. C: January-March.

E. robustum A. Br. A. S., M. C., R. C., E. C.

E. TElmatera Ehrh. O. K., A. S. Abundant. January-October.

CLASS III. LYCOPODIN E. CLUB-MOSSES.

Order Selaginellacca.

SELAGINELLA Beauv. Little Club-ruoss.

S. RUPESTRIS (I.) Spring. A. S., S. G. Mts. Common. January-March. 


\section{SPERMAPHYTA.}

\section{CLASS I. GYMNOSPERM $Æ$.}

PINUS Tourn. Pine.

\section{Conifere. Conifers.}

P. AlbiCaulis Eing. W. Pk. April-June.

P. Monophylia T. \& F. (Nut Pine.) Mt. Lowe. A single specimen.*

P. MONTICOLA Dougl. W. Pk. April-June.

P. PONDEROSA Dugl. W. Pk. April June.

PSEUDOTSUGA Carr. False Hemlock.

P. MACRocarpa (Torr.) Lem. S. G. Mts. Com. April-June.

LIBOCEDRUS Endl. White Cedar.

L. DECURRENS Torr. IV. Pk. April-June.

JUNIPER Linu. Juniper.

J. CALIFORnica Carr. Near Sierra Madre. March-May.

\section{CLASS II. ANGIOSPERM $A$.}

\section{Sub-Class I. Monocotyledones.}

TYPHA Tourn. Cat Tail.

\section{Typhacea.}

T. Angustiforia Linn. O. K. March-June.

T. LATIFOLIA Linn. O. K., A. S. March-June.

\section{Naiadacea.}

POTAMOGETON Tourn. Pond-weed.

P. PECTINA'Us Linn. O. K. April-June.

P. PUSILlus Linn. O. K. April-June.

ZANNICHELLIA Presl.

Z. PAlustris Linn. O. K. April-June.

ANDROPOGON Linn.

\section{Graminea. Grasses.}

A. Macrourus Michx. R. C., E. C. August-October.

A. SORGHUM Brot. (Sorghum.) Occasionally escaped, and often persisting in old sorghum fields.

PASPULUM Linn.

P. DISTICHUM Linn. (Knot-grass.) Com. shaded soil. August-October.

PANICUM Linn.

P. CAPILLARE Linn. (Old witch grass.) Along streets and in waste soil. JulyOctober.

P. CRUS-GALLI Linn. (Barn grass.) Along streets and in waste soil. July-Sept.t

P. Sanguinale Linin. (Crab grass.) Along streets and in waste soil. July-Sep. SETARIA Beauv.

S. GLAUCA (Linn.) Beauv. (Fox-tail grass.) In cultivated soil. June-September. PHALARIS Linn.

P. INTER Media Bosc. (Canary grass.) Waste places in Pasadena. March-June.

* This is the only tree of the Indian nut pine known to exist on the front or middle ranges of our Pasadena mountains, and it has a history. On October 10, 1887 , Jason and Owen Brown built a cairu on this mountain top. (See page 369 , "Mit Iowe.") 'They noticed this rare tree, with its roots so much denuded by rain-wash and wind that it was ready to die; and they gathered and brought soil in their little tin dinner pall to pack around its exposed roots, thus saving its life at that time, and hence it has been called the "Osawatamie pine tree." Then on August 15, 1893, Dr. Reid and wife found it perishing again from the same canses; and Mrs. Reid gathered loose dirt and mulcin from between rocks and dragged it on an old barley sack which she had found, to the roots of the tree, while the Doctor laid up a wall of rocks on the lower side to hold the dirt in place; and so its life was saved again. They also broke off some of its dead branches, to give the live part a betler chance. The tree was then ten or twelve feet high. There are said to be some trees of the same species on San Gabriel peak, but this is not yet rerified by competent testimony.-ED. 
ARISTIDA Linn.

A. DIVARICATA HBK. A.ltadena. June-September.

STIPA Linn. Feather grass.

S. CORONATA Thurb. S. G. Mits. June-September.

S. EMinkns Cav. O. K., S. G. Mts. April-July.

S. SETIGERA Presl. O. K., S. G. Mts. A pril-June.

MUHLENBERGIA Trin.

M. DEBILIS Trin. Arroyo Seco. May-July.

M. Mexicana (Linn.) Trin. A. S., M. C., R. C., E. C. June-September.

PHLEUM Linn.

P. PRATENSE Linn. (Timothy.) Along streets and in lawns. June-September.

SPOROBOI,US R. Br.

S. AIROIDES (Steud.) Torr. Along streets. July-September.

EPICAMPES Presl.

E. RIGENS Benth. Arroyo Seco. June-August.

POLYPOGON Desf.

P. LIT'TORALIS Smith. Moist soil in Lincoln Park. May-July.

P. MONSPeliensis Desf. Moist soil about Pasadena. April-July.

AGROSTIS Linn. Bent grass.

A. Attenuata Vasey. R. C. June-August.

A. Exarata Trin. O. K., A. S. May-June.

A. Microphyli, Steud. Altadena, Sierra Madre. June-August.

A. verTICILLATA Vill. O. K., R. C. June-August.

GASTRIDIUM Beauv.

G. AUSTRALE Beauv. Altadena, Sierra Madre. June-August.

HOLCUS Linn.

H. LAnatus Linn. O. K., Santa Anita. June-August.

TRISETUM Beauv.

T. BARbatum Steud. Arroyo Seco. May-June.

AVENA Linn. Oats.

A. BARBATA Steud. (Wild oats.) Along streets. March-July.

A. Fatua Linn. (Wild oats.) Com. below 2,000 feet. February-June.

CYNODON Rich.

C. DACTYLON Pers. (Bermuda grass.) Along streets and in lawns. March-July.

ERAGROSTIS Beauv.

E. MEXICANA Trin. Along streets. August-October.

MELICA Linn.

M. IMPERFECTA Trin. Com, in unbroken soil below 3,000 feet. April -August.

DISTICHLIS Raf.

D. MARitima Raf. Moist soil south of Pasadena. April-July.

DACTYLIS Linu.

D. GLOMERATA Linn. Orchard Grass.) O. K., Santa Anita. June-August.

ACHYRODES Boehn.

A. Aureum (Linn.) O. Ktze. Com. below 2,00o feet. March-June.

POA Linn. Meadow grass.

P. ANNUA Linn. (Goose grass.) Along streets and in lawns.

P. PRATENSIS Linn. (Kentucky blue grass.) Along streets and in lawns. AprilSeptember.

P. TENUIFOLIA Thurb. Oak Knoll. April-June.

ATROPIS Rupr.

A. SCABRELla Thurb. O. K., San G. Mts. April-June. FESTUCA Linn.

F. ELATIOR Linn. var. PRATENSIS Linn. O. K. April-June.

F. Microstachy's Nutt. O. K., A. S. A pril-July.

F. Irvurus Linn. Com. below 3 , ooo feet. March-July.

F. TENELLA Willd. Oak Knoll. April-June.

BROMUS Linn. Brone grass.

B. Crifatus Linn. O. K., S. G. Mts. April-August.

B. HOOKkinianus Thrub. Com. below 2,00o feet. April-July. 
B. maximus Desf. Com. below 2,00o feet. April--July.

B. MoL,IS Linu. Along streets April-July.

B. RIGIDUs Roth. Devil's Gate. April-July.

LOLIUM Linn. Darnel.

L. PERENNE Linn. (Perennial rye grass) Com. in cultivateả soil. April-July.

L. TEMULENTUM Linn. (Bearded Darnel.) Com. in cultivated soil and along streets. April-July.

HORDEM Linn. Barley.

H. MURINUni Linn. (Wild Barley) Com. below I, Soo feet. March-July.

ELYMUS Linn. Wild Rye.

E. AMERICANus V. \& S. Oak Knoll. April-June.

E. Condensatus Presl. O. K.; A. S.; foothills of S. G. Mts. April-July.

E. SibIRICUS Linn. S. G. Mts. June-August.

E. SITANION Schult. O. K. Along streets. April-June.

E. TRITICOIDES Nutt. A. S.; foothills of S. G. MIts. June-September.

CYPERUS Linn.

\section{Cyperacea.}

C. DIANDRUS Torr. Var. CAPITATUS Brit. Oak Knoll.

C. ERYTHRORRHIZOS Muhl. O. K.; Baldwin's Ranch. July-October.

C. Laevigatus Linn. Arroyo Seco. August-November.

SCIRPUS Linn. Bullrush. Club-rush.

S. IACUSTRIS Linn. var. OcciDenTAlis Wats. Oak Knoll. April-June.

S. OlNEYI Gr. O. K.; A. S.

S. RIPARIUS Spreng. Oak Knoll. February-June.

S. Sylvaticus Linn. var. MICRocarpus (Presl.) McM. O. K.; A. S. MayAugust.

HELEOCHARIS R. Br. Spike-rush.

H. ACICULARIS (Linn.) R. Br. Oak Knoll.

H. ARENICOLA Torr. Oak Knoll; A. S. April-June.

H. PALUSTRIS (Linn.) R. Br.

CAREX Linn. Sedge.

C. BARbaraf Dewey. O K.; R. C. February-June.

C. FIliformis Linn. var. Lanuginosa (Michx.) B. P. S. O. K.; A. S. February-May.

C. Multicaulis Bailey. Mt. Lowe. April-June.

C. SPISSA Bailey. O. K.; R. C. February-May.

C. TERETIUSCUla Good. var. RAMOSA Boott. R. C.; L. St. A. C. JuneAugust.

C. TRIQUETRA Bott. Hills near Arroyo Seco. March-May.

LEMNA Linn. Duckweed.

\section{Lemnacea.}

L. GIBBA Linn. Johnson's Lake.

L. VAldiviana Phil. O. K.; A. S.

\section{Juncacea. Rush Family.}

JUNCUS Linn. Bog-Rush.

J. Balticus Deth. O. K; A. S. May-July.

J. Bufonius Liun. Com. in moist soil below rooo feet. March-June.

J. COMPRESSUS HBK. Oak Knoll. July-September.

J. Dubius Eng. Oak Knoll. July-September.

J. L.ONGISTYLIS Torr. O. K.; A. S. June-August.

J. Noposus Linn. O. K.;A. S.; M. C. June-August.

J. PHAEOCEPHALUS Eng. O. K.; A. S. June-August.

J. Robustus Wats. O.K., A.S., M. C. April-August. Used by the Indians for basket making.

J. XIPHIOIDEs Mey. O. K., A. S. May-July. 


\section{Liliacece. Lily Family.}

ZYGADENUS Michx.

Z. Fremonti Torr. Hills near Arroyo Seco. March-April.

CALOCHORTUS Pursh. Mariposa Lily.

C. Albus Dougl. A. S., San Gabriel Mts. May-June.

C. CATALINAE Wats. Hills southwest of Pasadena. February-May.

C. SPLENDENS Dougl. Hills near A. S., San Gabriel Mits. May-June.

C. WEEDII Wood var. PURPURASCENS Wats. L. P., Hills near Pasadena. JuneJuly.

MUILIAA Wats.

M. SERotina Greene. O. K., A. S, Echo Mt. April-June.

LILIUM Linn. Lily.

L. humboltdir R. \& L. (Wild Tiger Lily.) A. S., canyons of San Gabriel Mis. June-July.

BRODIAEA Smitl.

B. Capitata Benth. (Cluster Lily.) Conmon below 3000 feet. February-May.

B. MINOR Wats. South Los Robles Ave. April-May.

BLOOMERIA Keil.

B. AUREA (Hook.) Kell. (Golden Cluster Lily.) O. K., A. S. April-May.

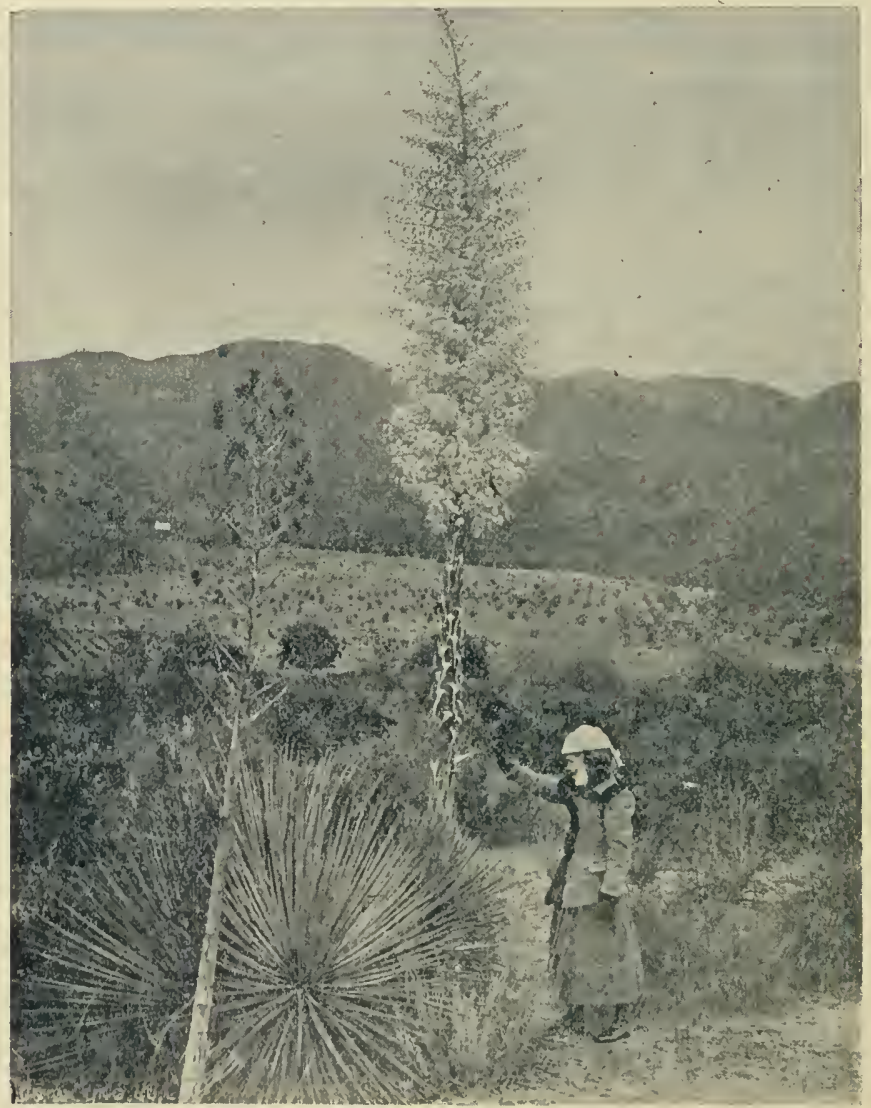

YUCCA WHIPPLEI. -SPANISH BAYONET.

Showing one plant in bloom, and an old stem still retaining some of its seed pods. 
CHLOROGALUM Kunth. Soap Plant.

C. POMERIDIANUM Kunth. O. K., A. S. and adjacent hills, S. G. Mts. May and Juue.

FRITILLARIA Linn.

F. BIFloRA Lindl. Arroy Seco. February-April.

YUCCA Linn. Spanish Bayonet.

Y. WHIPPLEI Torr. Common on hills and in S. G. Mts. May-July.

Iridacee. Iris Family.

SISYRINCHIUM Linn. Blue-eyed Grass.

S. BELLUM Wats, Common below I,500 feet. February--April.

EPIPACTIS Haller.

\section{Orchidacea. Orchids.}

E. GIGanteA Dougl. A. S., Eaton C. April and May.

HABENARIA Willd.

H. Leucostachys Wats. Eaton Canyon. April-June.

H. UNA LASchensis Wats. Hills near Pasadena, Echo Mit, IV. C. April--June.

SUB-CIASS II. DICOTYLEDONES.

Division 1. Choripetalæ. Separate-petaled Plants.

JUGLANS Linn. IValnut.

$$
\text { Juglandacea. }
$$

J. CALIFORNiCA Wats. (California Walnut). Hills near Arroyo Seco. April.

\section{Salicacea.}

POPUluS Tourn. Poplar. Cottonwood.

P. TRIChOCARPA Torr. \& Gr. (Cottonwood.) A. S., M. C. March and April.

SALIX Tourn. Willow.

S. LAevigata Bebb. (Black willow.) O. K., A. S. April.

S. LASIANDRA Benth. O. K., A. S. May.

S. LASIOLEPIS Benth. (White Willow.) O. K., A. S, M. C., R. C. DecemberFebruary.

S. Longifolia Muhl. Arroyo Seco. March and April.

ALNUS Tourn. Alder.

\section{Betulacec.}

A. RHomblfolia Nutt. A. S., Canyons of S. G. Mts. Jauuary and February.

QUERCUS Linn. Oak.

$$
\text { Fagacea. }
$$

Q. AGRIFoliA Nee. (Red Oak.) Com. from O. K. to Sierra Madre. April.

Q. CHRYSOLEPIS Liebn. (Live Oak.) S. G. Mits. April.

Q. Dumosa Nutt. (Scrub Oak.) Hills near A.S., foothills of S. G. Mits. March and April.

Q. ENGELMANNI Greene. (White Oak, Blue Oak.) Com. from O. K. to Sierra Madre.

\section{Loranthacee.}

PHORADENDRON Nutt. Mistletoe.

P. Flavescens (Pursh.) Nutt. On oaks, sycamore and alder at O. K. and in S. G. Mts. August.

ANEMOPSIS Hook.

\section{Piperacea.}

A. CALIFORNICA Hook. (Yerba Mansa.) Oak Kuoll. April-July. 


\section{Urticacece.}

PARIETARIA Tourn.

P. DEBILIS Forst. Canyons oî S. G. Mts. A pril and May.

URTICA Linn. Nettle.

U. HOLOSERICEA Nutt. Com. in shaded soil. March-May.

U. URENS Linn. Com. in waste soil. April-June.

PLATANUS Tourn. Sycamore.

\section{Platanacea.}

P. RACEMOSA Nutt. O. K., A. S., canyons of S. G. MIts. April.

RUMIEX Linn. Dock. Sorrel

\section{Polygonacea.}

R. ACETOSELLA Linn. (Sheep sorrel.) Along streets.

R. Conglomeratus Murr. (Green dock.) O. K., A. S. April-June.

R. CRISPUS Linn. (Curled dock.) Common in moist soil. February-June.

R. HYMenOSEPalus Torr. (Canaigre.) A. S., N. Pasadena. March and April.

R. SAlicifolius Wein, (White dock.) O. K., A. S. May and June.

POLYGONUM Linn. Knotweed.

P. ACRE HBK. (Water smartweed.) O. K., A. S. A pril-July.

P. AvICUlARE Linn. (Knot-grass.) Com. in yards and along streets. MayJuly.

P. Convolvulus Linn. Fields. May-July.

P. Nodosum Pers. O. K.. A. S., M. C., R. C. April-July.

ERIOGONUM Michx.

E. Elongatum Benth. A. S., foothills of S. G. Mts. June-October.

E. FASCICUlatum Benth. (Wild buckwheat.) Com. in dry ubbroken soil. MaySeptember.

E. GRACrLE Benth. Arroyo Seco. April-June.

E. SAXATILE Wats. Com. above 4,000 feet in S. G. Mts. June-August.

E. VIRGATUM Benth. Common below 3,00o feet. June-September.

CHORIZANTHE R. Brown.

C. PROCUMBENS Nutt. Lincoln Park. May-July.

C. STATrCordes Benth. Common below 3,000 feet. May-August.

PTEROSTEGIA Fisch. \& Mey.

P. DRYMARIOIDES F. \& M. Com, in unbroken soil below 4,000 feet. MarchJuue

\section{Chenopodiacece.}

CHENOPODIUM Tour. Lamb's quarter. Goosefoot.

C. ALBUM Linn. (Pigweed.) Common in cultivated soil. March-September.

C. AMBrosiordes Linn. (Mexican Tea.) Com. in waste soil. March-October.

C. MURALE Linn. Com, below I, Soo feet, especially in cultivated soil. FebruaryJune.

ATRIPLEX Tourn.

A. MICROCARPA Dietr. Along streets. July-October.

A. Patur.a Linn. Along streets. August-October.

AMARANTUS Tourn.

\section{Amarantacec.}

A. ALBUS Liun. (Tumbleweed.) Waste ground. May-September.

A. RETROFlexus Linn. Cultivated soil. May-September.

\section{Nyctaginacea.}

MIRABILIS Linn. Four o'clock.

M. CALIFORNICA Gr. Common on dry hills below 4,ooo feet. February-July.

CALYPTRIDIUM Nutt.

Portulacacea.

C. monandrum Mutt. Hills near Arroyo Seco. March-June. 
CLAYTONIA Linn.

C. PERFolitita Donn. (Indian lettuce.) Com. in shaded soil below 4,000 feet. February-May.

CALANDRINIA HBK.

C. MENZIESII Hook. Com. below 2,000 feet. January-April. PORTULACA Tourn.

P. OLERACEA Linn. (Purslane.) Com, in cultivated and waste ground. JuneSeptember.

SILENE Linn. Catchfly.

\section{Caryophyllacee.}

S. ANTIRRHina Linn. Frequent below 2,00o feet. April-June.

S. Galica Linn. Common below 2,00o feet.

S. LACINIATA Cav. (Indian pink.) Abundant on dry hills below 3,000 feet. May -July.

S. PALMERI Wats. S. G. Mts. above 4,500 feet. June-July.

S. PLATYOTA Wats. S. G. Mts. above 3,500 feet. June-July.

STELLARIA Linn.

S. MEDIA Linn. (Chickweed.) Com. in shaded soil below I,500 feet.

S. NITENS Nutt. O. K., A. S., Canyons of S. G. Mts. April-June.

CERASTIUM Linn. Mouse-ear.

C. VUl,GaTUM Linn. Com. in lawns and waste soil.

ARENARIA Linn.

A. DOUglasir (Fen.) T. \& G. Frequent in dry soil below 2,000 feet. April-May. SAGINA Linn.

S. occidentalis Wats. Moist and shaded soil about Pasadena. April.

SPERGULA Linn. Corn-spurrey.

S. ARVENSIS Linn. Frequent along streets and in yards. March-May.

POLYCARPON Linn.

P. DEPRESSUM Nutt. Altadena. April-June.

\section{Ceratophyllacea.}

CERATOPHYLLUM Linn. Hornwort.

C. DEMERSUM Linn. In ponds at Oak Knoll. June-August.

\section{Ranunculacea.}

AQUILEGIA Linn. Columbine.

A. TRUNCATA F. \& M. Oak Knoll. May-August.

DELPHINIUM Tourn. Larkspur.

D. CARDINALE Hook. (Scarlet larkspur.) Dry hillsides below 3,000 feet. JuneAugust.

D. DECORUM F. \& M. Hillsides. May-July.

D. PARRYi Gr. Foothills S. G Mts. April-June.

D. VARIEGatUM T. \& G. Hillsides. May-July.

PAEONIA Linn. Pæony.

P. CALIFornica Nutt. (California Pæony.) Com. in unbroken soil below 2,000 feet. March-May.

CLEMATIS Linn. Virgin's Bower.

C. Ligusticifolia Nutt. O. K., A. S., S. G. Mts. below 4,00o feet.

RANUNCULUS Linn. Buttercup.

R. CALIFORNICUS Benth. O. K., A. S. February-May.

R. HEBECARPUS H. \& A. Oak Knoll. March-May.

THALICTRUM Tourn. Meadow Rue.

T. POLYCARPuM Wats. O. K., A. S.. Canyons of S. G. Mts. May-July.

\section{Laurinea.}

UMBEILULARIA Nutt. Mountain Laurel. Spice-tree. Bay-tree.

U. CALIFORNICA (H. \& A.) Nutt. Canyons of S. G. Mts. February-April. 


\section{Papaveracea.}

PAPAVER Tourn. Poppy.

P. CALIFORNicum Gr. Hills near Pasadena. A pril-June.

ARGEMONE Linn.

A. HISPIDA Gr. Arroyo Seco. April-June.

PLATYSTEMON Benth.

P. CALIFORNICUS Benth. (Cream-cups.) Com. below 2,00o feet. March-May.

P. DEnTICUlatus Greene. A. S., Canyons of S. G. Mts. Apri-May.

DENDROMECON Benth.

D. RIGIDUM Benth. ('Tree poppy.) Hills near Arroy Seco. March-June.

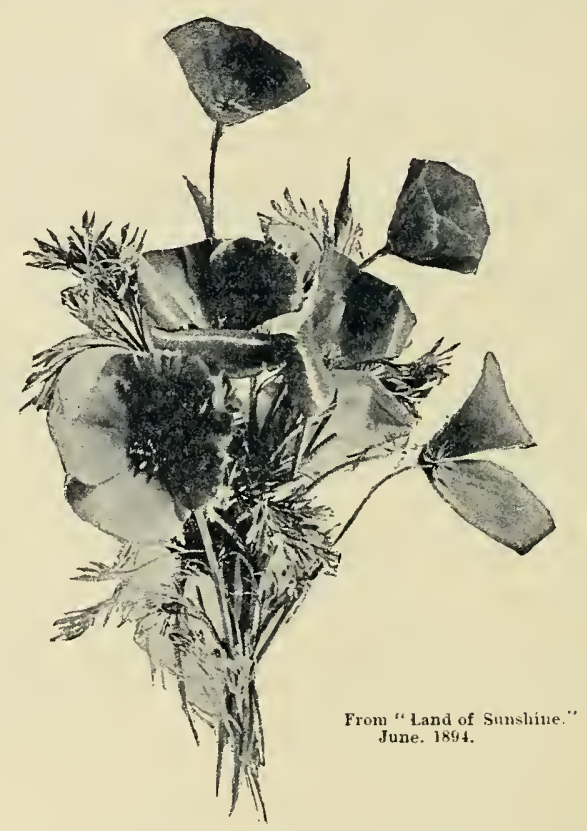

ESCHSCHOLTZIA CALIFORNICA.-CALIFORNIA POPPY.

One-third natural size.

ESCHSCHOLTZIA Cham.

E. CALIFORNICA Cham. (California poppy.) Com. below 2,000 feet. Most abuudant from January to May, but to be found at all times of the year.

DICENTRA Bork. Ear-drop.

\section{Fumariacea.}

D. CHRYSANTHA H. \& A. Frequent in dry soil, especially in S. G. Mts. MayJuly.

\section{TROPIDOCARPUM Hook.}

\section{Crucifera.}

T. GRACILE Hook. Oak Knoll. March-May.

\section{RAPHANUS Linn.}

R. SATivus Linn. (Radish.) Com. in fields. April-June.

THYSANOCARPUS Hook. Lace-pod.

T. CURVIPES Hook. O. K., A. S., Canyons of S. G. Mts. February-April.

T. LACiniatus Nutt. O. K., A. S., Canyons of S. G. Mts. February-April.

T. PUSILLUS Hook. O. K., A. S. February-April. 
LEPIDIUM Linn. Pepper-grass.

L. INTERMEDIUM Gr. Com. below I Soo feet. April-June.

L. NITIDUm Nutt. Com. below I 800 feet. February-A pril.

BURSA Sieg.

B. PASTORIS (Linn.) Wigg. Com. below I8oo feet. March-June.

SISYMBRIUM Linn.

S. CANESCENS Nutt. O. K., A. S., plains adjacent to S. G. Mts. February-A pril. BRASSICA Linn. Mustard.

B. CAMPESTRIS Linn. Com. below 1500 feet. February-April.

B NIGRA (Linn.) Kochz. Com. below 2000 feet. April-June.

ERYSIMUM Linn.

E. ASPERUM (Nutt.) DC. A. S., canyons of San Gabriel Mts. February-April. NASTURTIUM R. Br.

N. OFFICINALE R. Br. (Water-cress) Abundant in A. S. and at O. K.

CARDAMINE Linn.

C. GAMBELII Wats. Oak Knoll. May-July.

C. INTEGRIFOLIA (Nutt.) Greene. O. K., A. S., M. C. February-April.

STREPHANTHUS Nutt.

S. HETEROPHYLLUS Nutt. Hills near Arroyo Seco. March-April. ARABIS Linn.

A. GLABRA (Linn.) Wein. Hills near Arroyo Seco. March-April.

A. HOLbOELliI Hornem. Com. in San Gabriel Mts. April-June.

ALYSSUM Linn.

A. MaRitimum (Linn.) L. Am. Com, along streets.

VIOLA Linn. Violet.

\section{Violacea.}

V. PEDUnculata T. \& G. O. K., A. S., Las Casitas. February-April.

\section{Cistacea.}

HELIANTHEMUM Tourn. Rock-Rose.

H. SCOPARIUM Nutt. Common on dry hills below 4000 feet.-April-June.

LYTHRUM Linn.

\section{Lythracee.}

L. CALIFORNICUM Torr \& Gr. O. K., A. S. April-June.

MALVA Linn. Mallow.

\section{Malvacea.}

M. PARVIFloRA Linn. Common below 2000 feet. February-April.

SIDALCEA Gray.

S. DELPHINIFOLIA (Nutt.) Green. Oak Knoll. February-May.

GERANIUM Linn. Cranesbill.

\section{Geraniacea.}

G. CARolinianum Linn (Wild Geranium.) O. K., A. S. March-May.

ERODIUM L'Her. Storksbill.

E. CICUTARIUM (Linn.) L'Her. (Alfilaria) Common below 2000 feet. JanuaryJune.

E. moschatum (Linn.) L'Her. (Alfilaria) Com. below 2000 feet. January-June. OXALIS Linn. Wood-Sorrel.

O. CORNICULATA Linn. Frequent along streets.

RHUS Linn. Sumach.

\section{Anacardiacea.}

R. Diversiloba T. \& G. (Poison sumach. "Poison Oak") O. K., A. S., S. G. Mts. April-May.

R. INTEGRIFOLIA B. \& H. Com. in unbroken soil below 4000 feet. March-May. 
R. LAURINa Nutt. Com. in unbroken soil below 4000 feet. September-October. Berries used by the Indians for making an acid drink.

R. TRILobatA Nutt. O. K., A. S., canyons of S. G. Mts. February-April. Long, slender branches used by Indians for making baskets.

\section{Sapindacer.}

ACER Tourn. Maple.

A. Macrophylium Pursh. Canyons of S. G. Mts. March-April.

\section{Polygalacea.}

POLYGALA Tourn

P. CALIFORNICA Nutt. Near old Wilson trail. June-August.

\section{Ampilidacea.}

VITIS Tourn. Grape.

V. CAlIFORNICA Benth. O. K., A. S., canyons of S. G. Mts. May-July.

\section{Rhamnacea.}

RHAMNUS Linu. Buckthorn.

R. CALIFORNiCA Esch. O. K., A. S., canyons of S. G. Mts. February-April.

R. CROCEA Nutt. Arroyo Seco, S. G. Nits. below 5000 feet. February-March. Berries said to be used by the Indians for food.

CEANOTHUS Linn. California Lilac. Buckthorn.

C. CRASSIFOliUS Torr. A. S , canyons of S. G. IIts. February-April.

C. Cuneatus Nutt. Near Sierra Madre. March-May.

C. DIVARICATUs Nutt. Abundant in S. G. Mts. 2000 feet, 5000 feet. March April.

C. INTEGERRIMUS H. \& A. S. G. Mts. April-May.

C. OGLIGANThus Nutt. S. G. Mts. March-April.

CROTON Linn.

\section{Euphorbiacea.}

C. CALIFORNicus Muell. From center of Pasadena to foot of S. G. Mits. AprilJune.

C. SETIGERUS Hook. Com. below 2000 feet. August-November.

EUPHORBIA Linn.

E. Albomarginata T. \& G. Com. below 2000 feet. April-July.

E. POLYCARPA Benth. var. vestiTA Wats. Foothills S. G. MIts.

E. SERPYLLIFOLIA Pers. Frequent below 2000 feet. May-August.

\section{Umbelliferce.}

HYDROCOTYLE TOHIn.

H. RANUNCULOIDES Linu. Oak Knoll. May-July.

SANICUIA Tourn.

S. BIPINNATA H. \& A. O. K., A. S. March-May.

S. BIPINNATIFIDA Dongl. Com. in open ground below 2,00o feet. March-May.

S. MENZIESII H. \& A. Com. in shaded soil below 3,000 feet. March-May.

S. Nudicaulis H. \& A. Com. in open ground below 2,00o feet. March-May.

S. TUBERosa Torr. O. K., A. S. April and May.

VELAEA DC.

V. ARGUTA T. \& G. C. \& R. Hills near A. S., S. G. Mts. March-May.

V. PARISHII C. S R. Mount Lowe. June and July.

CONIUM Linn.

C. MACUIATUm Linn. Oak Knoll. March-June.

SIUM Linn.

S. CicutגiForium Gmel. Oak Knoll. June--August.

OSMORRHIZA Raf.

O. BRACIrYPODA Torr. O. K., A. S., canyons of S. G. Mts. March-May.

CENANTHE Linn.

Ci. CALIFORNICA Wats. Oak Knoll. June-August. 
APIUM Linı. Celery.
A. GRAVEOLENS Linn.
(Wild Celery.)
O. K., A. S. March-August.

APIASTRUM Autt.

A. Angustifolium Nutt. Common below 2,00o feet. April-June.

FOENICULUM Adans. Fennel.

F. VUu,gare Ger. O. K. Along streets. May-July.

PEUCEDANUM Linn.

P. CARUIFolium T. \& G. Hills near Arroyo Seco, April-June.

P. HASSEr C. \& R. Hills near Arroyo Seco. March-May.

P. UTRICUla TUM Nutt. Com. in unbroken soil below I,50o feet. March-May.

DAUCUS Tourn. Carrot.

D, PUSr, IS Michx. (Wild carrot) Com, below 1,800 feet. March-May.

CAUCALIS Linn.

C. MicrocarPa H. \& A. Oak Knoll. April and May.

C. Nodosa Hudson. Oak Knoll. April and May.

ARALIA Linn.

\section{Araliacece.}

A. CAI,IFORNICA Wats. (Spikenard.) Canyons of S. G. Mts. June-August.

\section{Cornacea.}

CORNUS Linn. Cornel. Dogwood.

C. Occidentalis (T. \& G.) Cov. Oak Knoll. April-September.

GARRYA Dougl.

(3. VEATCHII Kell. Echo Mt. May-July.

\section{Saxifragacea.}

SAXIFRAGA Linn. Saxifrage.

S. CALIFornica Greene. Arroyo Seco. April-June.

BOYKINIA Nutt.

B. ROTUNDIFOriA Parry. Canyons of S. G. Mts. June-August.

TELLIMA R. Br.

T. AfFinis (Gray) Bol. O. K., A. S., canyons of S. G. Mts. March and April.

HEUCHERA Linn.

H. RUBESCENS Torr. Frequent in S. G. Mts., above 5, ooo. June-August.

RIBES Linn. Currant. Gooseberry:

R. AMARUM McC. Erythea II, 79. Canyous of S. G. Mts. February-March.

R. Divaricatum Dougl. Oak Knoll. February-May.

R. GluTinosum Benth. S. G. Mts. 2,000-5,000 feet. January-March.

R. HESPERIUM MCC. Erythea. II, 79. Canyons of S. G. Mts. January and February.

R. SPECrOSUM Pursh. Hills near Arroyo Seco. January-March.

$R$, TENUIFLorum Lind1. Hills near Arroyo Seco. February and March.

TILLAEA Linn.

\section{Crassulacex.}

T. Mrnima Miers. Common below 3, ooo feet February-May.

COTYLEDON Linn.

C. LANCEOLATA Benth. Oak Knoll, foothills of S. G. Mts. June and July.

CEREUS Haw. Cactus.

\section{Cactacea.}

C. EMORYi Engelm. Arroy Seco. May and June. OPUNTIA TOurn.

O. ENGELMANNI Salm. (Prickly Pear.) Com. in dry unbroken soil. May and June. 


\section{Loasacea.}

MENTZELIA Linn.

M. A I BICAUl,IS Dougl. Near Sierra Madre. July-September.

M. Micrantha T. \& G. Foothills S. G. Mts. May-July.

\section{Datisacea.}

DATISCA Linn.

D. GLOMERATA (Presl.) Brew. \& Wat. O. K., A. S., canyons S. G. MIts. MayJuly.

\section{Onagracea.}

EPILOBIUM Linn.

E. ADENOCAUlon Haussk. var. OCCIDENTALE Trel. Com. in wet soil. AprilAugust.

E. Holosericeum Trel, Oak Knoll. May-August.

E. Panicuratum Nutt. Arroyo Seco. August and September.

ZAUSCHNERIA Presl. "Wild Fuchsia."

Z. CAIIFORNICA Presl. S. G. Mts. 3,000-5,000 feet.

Z. CAIIFORNICA Presl. var. MICROPHYi, A Gray. Com. on dry hills.

EULOBUS Nutt.

E. CALIFORNICUS Nutt. Frequent below 3,000 feet. May-July.

GNOTHERA Linn. Evening Primrose.

CE. ALYSSOIDES H. \& A. Hills near Pasadena, Echo Mit. May-July.

CE. BIENNIS L. Common in canyons. May-September.

CE. BISTORTA Nutt. Com. below 2,00o feet. February-June.

G. MICRANTHA Horn. Frequent below 2,000 feet. March-June.

C. STRIGUlos T. \& G. Frequent below 2,00o feet March-June.

GODETIA Spach.

G. BOTTA: Spach. Hills near Arroyo Seco, S. G. Mts. April-July.

G. EPILOBIOIDES (T.\& G.) Wats. Hills near Arroyo Seco. April-May.

G. QUADRIVUl,NeRA (Dougl.) Wats, Hills near A. S., foothills S. G. Mts. AprilJuly.

JUSSIAEA Linn.

J. DIFFUSA Forsk. Shorb's ranch. May-August.

\section{Rosacece.}

PRUNUS Tourn

P. ILICIFOLIA (Nutt.) Walp. (Wild cherry.) Foothills S. G. Mts. May.

HETEROMELES Roemer.

H. ARbutifolia (Ait.) Røemer. (California Holly.) Hills along Arroyo Seco, foothills S. G. Mts. June-August.

HOLODISCUS Maxim. Meadow-Sweet.

H. DISCOLOR (Pursh.) Max. S. G. Mts. May-August.

ADENOSTOMA Hook. \& Arm.

A. Fasciculatum H. \& A. Com. in dry soil below 4,00o feet. May-June. Sold by Mexicans for fuel, as "Grease-wood."

CERCOCARPUS HBK. Mountain Mahogany.

C. PARVIFolius Nutt. Foothills S. G. Mts. March-April.

POTENTILLA Linn. Five-finger.

P. CALIFORNICA (C. \& S.) Greene. Frequent below 2,500 feet. March-May.

P. GLANDULOSA Lindl. Frequent below 2,500 feet. A pril-Jine.

ALCHEMILLA Tourn.

A. ARVENSIS Scop. Oak Knoll. March-May.

RUBUS Lin11. Blackberry. Raspberry.

R. URSINUS C. \& S. (Wild blackberry.) Com. in shaded soil. March-May.

ROSA Toirn. Rose.

R. CALIFORNica C. \& S. O. K., A. S., Canyons S. G. Mts. 
VICIA Tourn. Vetch.

\section{Leguminose.}

V. AMERICANA Muhl. O. K., A. S. March-May.

V. ExiguA Nutt. Arroyo Seco. March-A pril.

V. Sativa Linn. O. K., Sierra Madre. March-April.

LATHYRUS I,inn.

L. VeSTITUS Nutt. (Wild Pea.) A. S., O. K., Canyons S. G. Mts. FebruaryMay.

ASTRAGALUS Tourn. Rattle-IVeed.

A. LEUCOPSIS Torr. Com. in open unbroken soil. March-May.

AMORPHA Linn.

A. CALIFOR Nica Nutt. S. G. Mits. 3,000 feet. May-June.

PSORALEA Linn.

P. MACROSTACHyS DC. A. S., Canyons south of Pasadena. May-June.

P. ORBICUlakis Lindl. Arroyo Seco. April-May.

P. PHXSODES Dougl. Arroyo Seco. June-July.

LOTUS Tourn.

L. AMERICANUS (Nutt.) Bisch. Frequent below I,500 feet. May-July.

L. ARgophyluUs (Gray) Greene. S. G. Mts. 3,000-5,000 feet. April-June.

L. GLABER (Torr.) Greene. Com. in unbroken soil below 3,000 feet.

L. Nevadensis (Wats.) Greene. A. S., Canyons of S. G. Mts. below 2,500 feet. April-July.

L. OBLONGIFolius (Benth) Greene. Arroye Seco. April-June.

L. SALSUGinosus Greene. Frequent in shaded soil below i,5oo feet. MarchApril.

L. STRIgosus (Nutt.) Greene. Com. below 2,000 feet. January-May.

TRIFOLIUM Linn. Clover.

T. ciliolatum Benth. Com. below 1,800 feet. April-May.

T. GRacilentum T. \& G. Com. below I, Soo feet. April-May.

T. InvorUCRatum Willd. Frequent below I, Soo feet April-May.

T. MACR A I H. \& A. var. A LBOPUR PUREUM (T. \& G.) Greene. Com. below I,Soo feet. April-May.

T. Microcephalum Pursh. Com. below I, 8oo feet. April-May.

T. Roscidum Greene. O. K., A. S., Canyons of S. G. Mts. below 2,500 feet. May August.

T. STENOPHYLLUM Nutt. Oak Knoll. March-April.

MELILOTUS Tourn. Sweet-clover.

M. AlBA Lam. Arroy Seco. May-August.

I. InDICA All. Com. in shaded soil below I,500 feet. April-July.

MEDICAGO Linn.

M. DENTICUlata Willd. (Burr-clover.) Com. below 2,00o feet. January-June.

M. SATIVA Linn. (Alfalfa.) Frequent along streets and roads whither it has escaped from fields.

LUPINUS Linn. Lupine.

L. AFFINIS Ag. Oak Knoll, March-May.

L. ALBIFRons Benth. Arroyo Seco. April-June.

L. CyTisotdes Ag. A. S., Canyons of S. G. Mts. below 3,00o feet. May-July.

L. FORMOSUS Greene. var. BRIDGESII (Wats.) Greene. Com. below 2,500.

L. HiRsutissimus Benth. O. K., A. S., foothills S. G. MIts. March-May.

L. MICRANTHUS Dougl. Com. below 2,000 feet. January-May.

L. SPARSIFrorus Benth. Frequent below 3,000 feet. March-iIay.

L. TRUncatus Nutt. Com. below 3,000 feet. March-May.

DIVISION II. SYMPATALA $Æ$ United-petaled Plants.

\section{Ericacee.}

ARBUTUS Tourn.

A. Menziesi Pursh. (Madroña.) S. G. Mts. Confined to a narrow belt at about 3,000 feet. March-April.

ARCTOSTAPHYLOS Adans. Manzanita.

A. PUNGENS HBK. S. G. Mts. 4,00o feet to near summit. February-March.

A. Tomentos A Dougl. S. G. Mts. 2,000-4,500 feet. March-A pril. 


\section{Primulacece.}

DODECATHEON Linn.

D. CLEVELANDI Greene. (Shooting Star.) Frequent below 2,000 feet. FebruaryApril.

ANAGALLIS Tourn. Pimpernel.

A. ARVENSIS Linn. Common below 1,800 feet.

SAMOLUS Linn.

S. VALERANDi Linn. var. AMERICANA Gr. O. K., A. S., canyons of San Gabriel Mts. June-November.

\section{Convolvulacer.}

CUSCUTA Tourn. Dodder.

C. SuBinclusa Dur. \& Hilg. Common on shrubs and other plants. May-July.

CONVOLVULUS Linn. Bindweed.

C. occidentalis Gray. (Wild morning-glory) Common below 2,500 feet. February-July.

\section{Polemoniacea.}

NAVERRETIA Ruiz \& Pav.

N. ATRACTYLoides (Benth.) H. \& A. Common in dry soil below 2,500 feet. MayJuly.

N. PRostrata (Gr.) Greene. Oak Knoll. April-May.

N. viscidula Benth. Common in dry soil below 2,500 feet. June-August.

LEPTODACTYLON H. \& A.

L. CAlifornicum H. \& A. Common on dry soil below 4,000 feet. April-June.

GILIA Ruiz \& Pav.

G. ACHILIEAFOLIA Benth. Frequent below 2,ooo feet. April-June.

G. GILIOIDES (Benth.) Greene. A. S. and adjacent hills. April-July.

G. INCONSPICUA Dougl. Frequent below 2,000 feet. April-June.

G. Multicaulis Benth. Common below 2,000 feet. A pril-June.

G. TENUIFLORA Benth. Frequent in S. G. Mts. June-August.

G. virgata Steud. Arroyo Seco. May-August.

LINANTHUS Benth.

I. ANDROSACEUS (Benth.) Greene. Frequent below 2,000 feet. April-June.

L. DIANTHIFlonUS (Benth.) Greene. Common below 2,ooo feet. February-May.

L. PHARNACEOIDES (Benth.) Greene. Common in dry soil below 2,000 feet. MayJuly.

PHLOX Linn.

P. GRACILIS (Dougl.) Greene. Arroyo Seco. February-April.

\section{Hy'drophyllacece.}

NEMOPHILA Nutt.

N. AURita Lind1. Arroyo Seco. April-June.

N. Insignis Doug1. Com. in shaded soil below 3,00o feet. February-May.

N. MENZIESII H. \& A. Com. in shaded soil below 3, ooo feet. February--May.

EUCR YPTA Nutt.

E. Chrysanthimifolia (Benth.) Greene. Com. in shaded soil below 3,00o feet. March-June.

PHACELIA Juss.

P. BRACHYLOBA Gray. S. G. IIts. 3,000-5,000 feet. June-August.

P. CIRCinata (Willd.) Jaq. Common below 2,50o feet. May-July.

P. HISPIDA Gr. Common below 2,500 feet. March-July.

P. LONGIPES Torr. A. S., S. G. Mts. May-July.

P. Ramosissima Hook. O. K., A. S., canyous of S. G. Mts. April-July.

P. TANACETIFolia Benth. Common below 2,500 feet. March-June.

P. Whi'travia Gray. Commou on dry hillsides below 3,000 feet. March-May.

EMIMENANTHE, Benth.

E. PENDULIFLORA Benth. Frequent below 2,500 feet. April-June. 
ERIODICTYON Benth.

E. CAliforNicum (H. \& A.) Greene. (Yerba Santa.) S. G. Mts, 2,000-4,000 feet. May-July. Leaves used by the Mexicans as a tonic.

E. Tomentosum Benth. S. G. Mts. 2,000-4,00o feet. May-July.

PECTOCARYA DC.

\section{Borraginacece.}

P. IINEARIS (R. \& P.) DC. O. K., A. S. March-May.

PLAGIOBOTHRYS Fisch. \& Mey.

P. NOTHOFUlvus Gr. Common below 2,00o feet. February-May.

CRYPTANTHE LEhm.

C. Ambigua (Gr.) Greene. Common below 2,000 feet. April-June.

C. microstachys Greene. Common below 2,00o feet. April-June.

AMSINCKIA L ehm.

A. SPECTABiLS F. \& M. Com. below 2,000 feet. March-May.

\section{Solanacea.}

SOLANUM Tourn.

S. DOUGIASII Dunal. Com. below 2,500 feet.

S. UMBELI,IFERUM Eisch. S. G. Mts. April-June.

S. XA.N I Gray. S. G. Mts. April-June.

PHYSALIS Linn.

P. AEQUATA Jacq. Com. in cultivated and waste ground. May-September.

DATURA Linn.

D. METELOIDES DC. In moist and shaded soil below I,ooo feet. May-October.

\section{Labiate.}

TRICHOSTEMA Linn. Blne Curls.

T. I.ANATUM Benth. Echo Mt. May-July.

T. LANCEoratum Benth. Com. below 2,ooo feet. August-October.

MENTHA Linn. Mint.

M. CANADENSIS Linn. Canyons south of Pasadena. May-September.

PYCNANTHEMUM Michx. Mountain Mint.

P. CAlifornicum Torr, O. K., A. S., canyons of S. G. Mts. June-September.

MONARDELLA Benth.

M. LANCEOLATA Gray. A. S., N. Pas., Las Casitas. . June-September.

SALVIA Linn. Sage.

S. CARDUACEA Benth. Occasional in dry soil. April-June.

S. COlumbariat Benth. (Chia.) Com. below 3,00o feet. March-May. Seeds nsed by Indians for food.

S. MELlifera Greene. (Black Sage.) Com. on dry hillsides. April-June.

S. SPATHACEA Greene. On banks of A. S. A pril-July.

RAMONA Greene.

R. Pol,ystachya (Benth.) Greene. (White Sage.) Com. on dry hillsides. April -June.

SCUTELLARIA Linn. Sknll-cap.

S. TUBEROSA Benth. Com. in nubroken soil below 1,50o feet. March-June.

MARRUBIUM Linn. Hoarhonnd.

M. VUlgare Linn. Com. below I,Soo feet. March-July.

STACHYS Linn.

S. Albens Gr. O. K., A. S., canyons of S. G. Mts. A pril-June.

S. CALIFORNica Benth. O. K., A. S., canyons of S. G. Mts. May-July.

\section{Scrophulariacece.}

CORDYLANTHUS Nutt.

C. FILIFolius Nutt. A. S., S. G. Mts. below 3,ooo feet. Jnne-september. 
CASTILIEIA Linn. Painted-cup.

C. Foliolosa H. \& A. Com. on dry hillsides below 3,000 feet. April-June.

C. Miniate Dougl. Com. on hillsides below 2,500 feet. April-June.

C. PARVIFlora Bong. Hills near Arroyo Seco, R, C. March-May.

C. Stenantha Gray. O. K., M. C. May-August.

ORTHOCARPUS Nutt.

O. PURPURASCENS Benth. ("Paint-brush.") Com. below 2,ooo feet. March-May. VERONICA Linı. Speedwell.

V. PEREGRINA Linn. Oak Knoll. May-June.

MIMULUS Linn. Monkey-flower.

M. BREVIPES Benth. Frequent below 3,000 feet. April-June.

M. CARDinalis Dougl. O. K., A. S., canyons of S. G. Mts. June-October.

M. FLORIBUNdUS Gray. Arroyo Seco, canyons of S. G. Mts. June-October.

M. FREMonti Gray. Echo Mt. April-June.

M. LUTEUS Linn. O. K., A. S.

M. Luteus Linn. var. Depauperatus Gr. S. G. Mts. 4,000-5,000. May-July.

DIPLACUS Nutt.

D. GLutinosus (Wendl,) Nutt. Hills along Arroyo Seco. April-July.

PENTSTEMON Mitch. Beard-tongue.

P. AzUreus Benth. Frequent on hillsides below 3,00o feet. May-July.

P. CEnTRANThifolius Benth. S. G. Mts. 2,000-5,000 feet. March-June.

P. Cordifolius Benth, Hills along A. S., S. G. Mts. below 3,00o feet. MayJuly.

P. PALMERI Gr. Mt. Lowe. June-August.

P. SPECTAB1Lis Thurb. Near Sierra Madre. April-June.

P. TeRnatus Torr. S. G. Mts. 4,000-5,000 feet. June-August.

COLLINSIA Nutt.

C. BICOLOR Benth. Com. below 3,ooo feet. April-June.

C. PARRyi Gray. Arroyo Seco. April-May.

SCROPHULARIA Tolirn. Figwort.

S. CALIFORNICA Cham. O. K.; A. S., canyons of S. G. Mits. May-August.

ANTIRRHINUM Tourn. Snapdragon.

A. Coulterianum Benth. Hills along A. S., foothills S. G. Mts. May-July.

A. GLandulosum Lindl. A. S., Altadena. April-Juue.

A. NUtTallianum Benth. Hills along A. S. May-June.

A. StRictum (H. \& A.) Gr. Hills along A. S., R. C. May-July.

LINARIA Tourn. Toad-flax.

L. Canadensis (Linn.) Dum. Common below 2,000 feet. April-September.

VERBASCUM Linn. Mullein.

V. virgatum With. Frequent below 2,00o feet, abuadant at Altadena. JuneAugust.

APHYLLON Mitch.

\section{Orobanchacea.}

A. Tuberosum Gr. Echo Mt. among shrubs. June-Angust.

VERBENA Linn.

\section{Verbenacce.}

V. POLYSTACHYA HBK. O. K., A. S. May-September.

V. PROSTRATA R. Br. Conı, below I,500 feet. April-September.

PLANTAGO I,inn.

\section{Plantaginacea.}

P. IHIRTELIA HBK. Oak Knoll. May-July.

P. IANCEOLATA Linn. Com. below I, 5 oo feet. April-July.

P. Major Linn. Frequent below I,500 feet. May-August.

P. I'ATAgonica Jacq. Coml. in dry soil below 2,500 feet. March-May.

ERYTHRAiA Rn. Canchalagua.

\section{Gentanacer.}

E. VEnUSTA Gr. Common in unbroken soil below 3,000 feet. April-July. In general use anong the Mexicans as a medicinal herb. 


\section{Apocynacea.}

APOCYNUM Tourn.

A. Cannabinum Linn. (Indian Hemp.) In A. S. April-June.

\section{Asclepiadcaece.}

ASCLEPIAS Linn. Milkweed.

A. ERIOCARPA Benth. Frequent below 2,00o feet. Com. at Las Casitas. JuneAugust.

A. FAScicularis Decsne. Frequent below 2.00o feet. June-August.

\section{Campanulacea.}

SPECULARIA Heist.

S. BIFLORA Gray. Occasional below I,500 feet. April-June.

NEMACLADUS Nutt.

\section{Lobeliacea.}

N. RA MOSissimus Nutt. var. PINNATIFidus. (Greene) Gray. Echo Mt. May-July. LOBELIA Linn.

L. SPI.ENDFNS Willd, Oak Knoll. Wild-grape canyon. July-October.

PALMERELLA Gray.

P. DEBILIS Gr. var. Serrata Gr. A. S., canyons S. G. Mts. July-October.

\section{Cucurbitacea.}

CUCURBITA Iinn. Cucumber. Squash. Pumpkin.

C. FOETIDISSIMA HBK. (Mock Orange.) Common in dry soil below 2,000 feet. April-June.

MICRAMPELIS Raf. Big-root.

M. FABACEA (Naud) Greene. April.

O. K., A. S., foothills S. G. Mts. February-

\section{Rubiacea.}

GALIUM, Linn. Bedstraw.

G. ANGUSTIFor.IUm Nut. Con1, below 3,00o feet. Marcl1-June.

G. APARINE, Linn. O. K., A. S., canyons S. G. Mts. March-May.

G. CAI,IFOR NICUM Hook \& Arn. O. K., A. S., foothills S. G. Mts. April-June,

G. GRANDE McC. Erythea II: I24. S. G. Mts. 2,500-4,00o feet. April-June.

G. NUTAI,II Gr. Foothills S. G. Mts. May and June.

G. occidentALIS MCC. Erythea II: I24. S. G. Mts. 3,00o-4,00o feet. May and June.

G.TRIFIDUm Linn. Baldwin's Ranch. June and July.

SAMBUCUS Tourn. Elder.

\section{Caprifoliacea.}

S. GLAUCA Nutt. Frequent below 2,500. April and May. SYMPHORICARPUS Dill.

S. Mor, IS Nutt. O. K., A. S., canyons S. G. Mts. April and May.

CAPRIFOLIUM DC.

C. SUBSPICATA (H. \& A.) Greene.

\section{Dipsacece.}

DIPSACUS Tourn. Teasel.

D. FUlronum Linn. (Fuller's Tease1.) O, K. June-August. SCABIOSA Linn.

S. STELLATA Linn, Along streets in Altadena. May-July. 
COLEOSANTHUS Cass.

\section{Compositur.}

C. CALIForNicus (T. \& G.) O. Ktze. Hills along Arroyo Seco, foothills S. G. Mts. July-September.

C. NeviniI (Gr.) O. Ktze. Foothills S. G. Mts. July-September.

GRINDELIA Willd.

G. ROBUSTA Nutt. Frequent below 2,00o feet. May-July.

HETEROTHECA Cass.

H. GRANDIF LOR A Nutt. Common below 2,00o feet.

CHRYSOPSIS Nutt.

C. SESSILIFl LoR A Nutt. O. K., A. S. June-August.

ERICAMERIA Nutt.

E. Cuneatus (Gr.) McC. Rubio Canyon. June-September.

E. MONACrIS (Gr.) McC. Hills along A. S., foothills S. G. Mts. June-Sept.

HAZARDIA Greene.

H. squarrosus (H. \& A.) Greene. Hills aloug A. S., foothills S. G. Mts. JuneSeptember.

BIGELOVIA DC.

B. VENETA Gr. A. S., foothills S. G. Mts. and adjacent plains. July-Sept.

SOLIDAGO Linn.

S. CALIFORNICA Nutt. O. K., A. S., canyons of S. G. Mts. to 5,000 feet (side of Mt. Lowe). August-October.

S. CONFinis Gr. Oak Knoll. August-October.

S. OCCIDENTALis Nutt. Arroyo Seco. August-October.

CORETHROGYNE DC.

C. Filaginifolia Nutt. Common below 5,000 feet. June-September. ASTER Linn.

A. ADSCENDENS Lindl. S. G. Mts. July-September.

A. EXILIS Eill. Along streets.

A. FREMonti Gr. var. PARISHi Gr. Canons S. G. Mts. August-October.

ERIGERON Linn.

E. CANADENSE Linn Common below 2,500 feet. June-September.

E. Foliosum Nutt. Frequent below 3,60o feet. May-August.

E. PHILADELPHICUM Linn. O. K, A, S. April-July.

CONYZA Linn,

C. COUITERI Gray. Oak Knoll. July--September.

BACCHARIS Linn.

B. VIMINEA DC. O. K., A. S., canyons S. G. Mts.

GNAPHALODES Tourn.

G. CALIFOR NICA (F. \& M.) Greene. Frequent in dry soil below 3,ooo feet. April -June.

FILAGO Linn.

F. CALIFORNICA Nutt. Common in dry soil below 3,ooo feet. April-June.

GNAPHALIUMI Linn. Everlasting.

G. CALIFORNICUM DC. Common below 3,00o feet. March--July.

G. CHILENSE Spreng. Common below 2,000 feet. A pril-June.

G. LEUCOCEPHALUM Gr. Frequent between I,00o-3,000 feet. July-September.

G. MicRocephalum Nutt. Frequent below 2,500 feet. July-September.

G. PALUSTRE Nutt. Oak Knoll. April-May.

G. Ramosissimum Nutt. Oak Knoll. August-October.

AMBROSIA Tourn. Ragweed.

A. PSirostachya DC. Com. below 2,000 feet. August-October.

XANTHIUM Tourn.

X. Spinosum Linn. Along streets. June-September.

X. STRUMARIUn Linn. In waste soil. June-Angust.

HELIANTHUS Linn. Sunflower.

H. ANNUUS Linn. Com. below 2,00o feet.

LEPTOSYNE DC.

L. DOUGLASII DC. A. S. and adjacent hills; foothills S. G. Mts. and adjacent plains. June-September. 
BIDENS Linn.

B. CHRYSANThHMOIDES Michx. O. K.; A. S.

B. PIrosa Linn. Along streets. July-October.

MADIA Molina. Tar-weed.

M. DISSITIFLORA (Nutt) T. \& G. Along street. July-September.

M. SATIVA Mol. Frequent below r, Soo feet. June-August.

HEMIZONIA DC. Tar-weed.

H. Fasciculata (DC.) T. \& G. var. Ramossima Gr. Com. Below I, Soo feet. May-July.

H. PUNGENS Torr. \& Gray. Frequent below 1,80o feet. May-August.

H. TENELLA Gray. O. K.; A. S. April-June.

LAYIA Hook. \& Arn.

L. GLANDULOSA (Hook.) H. \& A. O. K.; A. S. April-June.

L PLATYGlossa (F. \& M.) Gray. (Tidy-tips) Com. below 2,00o feet. April-June.

ACHYRACHAENA Schauer

A. MOLLIS Schauer. Near Oak Knoll. March-May.

BAERIA Fisch. \& Mey.

B. GRACILIS (DC.) Gr. Com, below 2,00o feet. March-May.

ERIOPHYLLUM Lag.

E. CONFERTIFLORUM (DC.) Gr. Com. in unbroken soil below 3,00o feet. AprilJune.

CHANACTIS DC. "Pin-cushion."

C. ARTEMISIAEFolis Gray. Frequent in dry unbroken soil below 3,00o feet. June-July.

C. GLABRIUSCULA DC. Frequent on dry hills. May-June.

C. LANOSA DC. Com. below 3,00o feet. April-June.

HELENIUM Linn. Sneeze-weed.

H. PUBERULUM DC. O. K.; A. S., canyons of S. G. Mts. June-October.

ACHILT,EA Linn. Yarrow.

A. MILIEFOLIUM Linn. Com, in foothills of S. G. Mts. and adjacent plains. May August.

ANTHEMIS Linn. Chamomile.

A. COTULA Linn. Com. below I,500 feet. April-July.

MATRICARIA Linn.

M. DISCOIDEA DC. Com. below I,50o feet. February-April.

ARTEMISIA Linn. Worm-wood. "Sage-brush."

A. CALIFORNICA Less. (California "Sage-brush.") Com. in dry unbroken soil below 4,00o feet. May-August.

A. DRACUNCUloides Pursh. Frequent below 2,00o feet. May-August.

A. Ludoviciana Nutt. Occasional below 2,00o feet. June-August.

A. Vulgaris Linn. var. CALIFORNICA Bess. Common below 2,500 feet. June August.

TETRADYMIA DC.

T. Comosa Gray. Near Devil's Gate. July-August.

LEPIDOSPARTUM Gr.

L. souanatum Gr. A. S., foothills S. G. Mts. July-September.

SENECIO Linn. Groundsel.

S. CALIFOR NICUS DC. Com. below 3,00o feet. March-May.

S. DOUGLASII DC. Hills along A. S., foothills S. G. Mts. July-September.

CARDUUS Tourn. Thistle.

C. CA LIFor nicus (Gr.) Greene. O. K., R. C. May-July.

C. occidentalis Nutt. Frequent below 2,00o feet. A pril-June.

SILYBUM Gaerth. Milk-Thistle.

S. MARIANUM (Linn.) Gaerth. Near Oak Knoll. May-July.

CENTAUREA Linn. Star-Thistle.

C. MELitensis Linn. Com. below 2,00o feet. May-August.

PEREZIA Lag.

P. MicRocephala Gr. O. K., A. S., foothills S. G. Mts. June-August.

MICROSERIS Don.

M. IINEARIFOlia Gr. Com. below 3,50n feet. February-May. 
P'TILORIA Raf.

P. CICHORIACEA (Gr.) Greene. Canyons S. G. Mits. July-September.

P. virgata (Benth.) Greene. Com. below 3,500 feet. June-October.

RAFINESQUIA Nuti.

R. CA I, IFOR NiCA Nutt. Hills along A. S. June-July.

MALACOTHRIX DC.

M. TENUIFOlia T. \& G. Com. below 2,500 feet. June-August.

HYPOCHARIS Linn.

H. RADICATA Linn. Along streets. May-July.

CREPIS Linn.

C. BIENNIS Linn. Along streets. April-June.

TARAXACUM Linn. Dandelion.

T. TARAXACUM (Linn.) Mac iT. Occasionalalong streets." April-October. LACTUCA Tourn.

L. SCARIOLA L. South of Pasadena. June-August.

SONCHUS Linn. Sow-Thistle.

S. ASPER Linn. Frequent below 1,500 feet.

S. OLERACEUS Linn. Common below I,500 feet.

HIERACIUM Tourn. Hawkweed.

H. PAkishil Gr. Canyons S. G. Mits. June-August.

\section{SUMMARY OF PLANTS LISTED.}

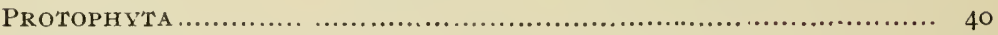

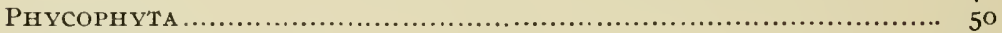

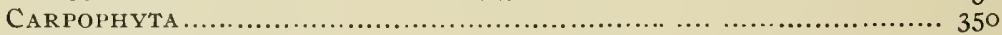

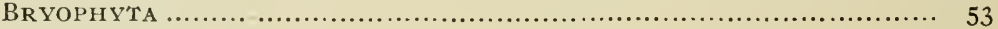

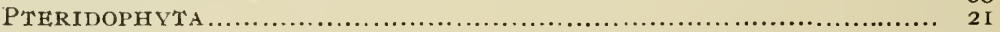

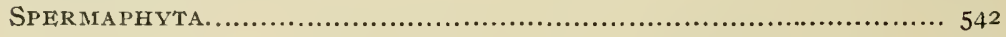

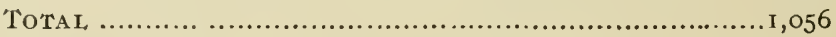


INDEX TO FLORA.

PAGE

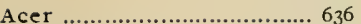

A chillea................................ 645

Achyrachaena.......................... 645

Actinonema....................... 616

Ecidium........................... 615

Adiantum................................. 626

Adenostoma....................... $63^{8}$

Agaricus ......................... 621

A grostis............................... 628

Albugo ................................ 612

Alchemilla........................... 638

Alder................................ 631

Alfalfa.................................... 639

Alfila ria................................... 635

Algæ, blue-green. ............... 609

Algæe, fresh-water............. 610

Alnus............................... 63 I

Alsia ....................................... 625

Alyssum.......................... 635

Amanita ............................. 619

A manitopsic ............................ 619

Amarantus......................... 631

A mblystegium .................... 626

Ambrosia .......................... 644

Amerosporium ...................... 616

Amorpha.......................... 639

A msinckia ........................ $64 \mathrm{r}$

Ascococcus........................... 609

Anabaena............................... 609

Anagallis.......................... 640

A udropogon ..................... 627

A nemopsis ........................... 631

Antirrhinum...................... 6:2

Antitrichia........................ 625

Anthoceros ...................... 62.4

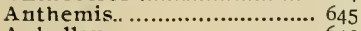

A phyllon ............................. 642

A piastrum......................... 637

A pium ............................ 637

A pocynum ........................... 643

Aquileg ia............................. 633

Arabis............................... 635

Aralia..................................... 637

Arbutus.................................. 639

Arctostaphylos .................... 639

A renaria ............................. $6: 3$

Argenone............................... $\sigma_{34}$

A ristida................................ 628

Armillaria .......................... 619

Artem isia.. ........................ 645

Asclepias .......................... 643

Ascochyta............................ 616

Ascophora......................... 6ri

Aspidium ............................ 626

Asplenium ............................ 626

Asterella........................... 624

Aster.................................. 644

Astræus ............................... 6 I 8

Ast ragalus ............................. 639

Atriplex............................ 632

Atropis............................. 628

Anlacomuium.......................... 625

A vena ................................ 628

A ytonia ............................. 624

Azolla................................. 626

Baccliaris.............................. 644

Bacillus ............................ 609

Bacteria.............................. 600

Bactridium........................... 6ig

Badhamia............................... 609

Baeria............................. 645

Barbula ................................ 625

Barley....................................... 629

Bartramia................................ 625

Batrachopermum............... 623

Bay Tree........................... 633

Beard Tongue......................... 642

Beggiatoa.............................. 609

Biden s.................................... 645

\begin{tabular}{|c|c|}
\hline PAGE & \\
\hline & Collinsia.. \\
\hline ...... 643 & Collybia. \\
\hline indweed ............................. 640 & ....... 633 \\
\hline lackberry ..........................6 638 & Conifers .............................. \\
\hline Bloomeria .................................. 630 & Conferva ........................... \\
\hline lue curls................................ 64 & Coniophora......................... 6 \\
\hline bitius ............................. 620 & Conium.................... \\
\hline 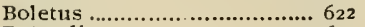 & Conothecium. \\
\hline rydium .............................. 6ra & Convolvulus... \\
\hline 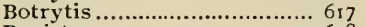 & Co11yza .................................... 64 \\
\hline 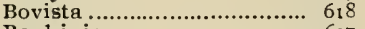 & \\
\hline oykinia ............................. $66_{37}$ & thus ................... 6 \\
\hline rachythecium..................... 625 & ne ...................... 644 \\
\hline Brassica .............................. 635 & Corrnel............................ 6 \\
\hline Brodlrea ............................... $66_{30}$ & Corn-spurrey ...................... 6 \\
\hline Bromus ................................ 628 & Cornus ................................ 6 \\
\hline 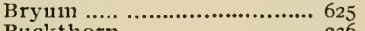 & \\
\hline Buckthorn ........................... 036 & 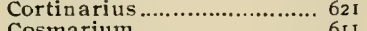 \\
\hline 613 & 6 \\
\hline h................................ 629 & \\
\hline er.......................... 639 & $\ldots \ldots \ldots \ldots \ldots \ldots, 6$ \\
\hline - & (....................... 621 \\
\hline 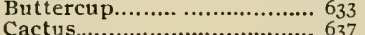 & 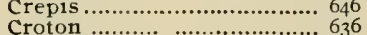 \\
\hline (a) & 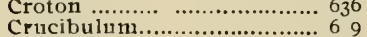 \\
\hline 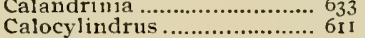 & (2) \\
\hline (15 & 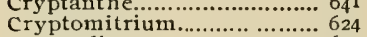 \\
\hline 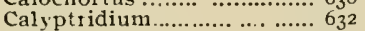 & ............6 654 \\
\hline um ................... 625 & \\
\hline$\ldots \ldots \ldots \ldots \ldots \ldots \ldots, 618$ & 643 \\
\hline ........................6 632 & \\
\hline gua ..................... 642 & ..................... 640 \\
\hline 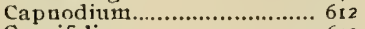 & \\
\hline (1)......................643 & $\mathrm{Cy}$ \\
\hline e ............................ 635 & m.. \\
\hline Carduus................................... 645 & (n.................. \\
\hline 629 & \\
\hline ot, wild....................... 637 & .................. \\
\hline ..........................642 642 & Cy \\
\hline ............................ 633 & (n.................. \\
\hline 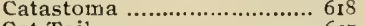 & $\mathrm{Da}$ \\
\hline 627 & ..................... 6 \\
\hline ....................... 637 & $\ldots \ldots \ldots \ldots \ldots 6$ \\
\hline 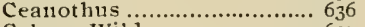 & ................... 6 \\
\hline 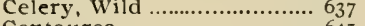 & ..... 6 \\
\hline 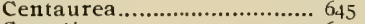 & \\
\hline ㅈ....................... 633 & econ..... \\
\hline $\operatorname{lum} \ldots \ldots \ldots \ldots \ldots \ldots 3^{3}$ & \\
\hline ….................. 617 & I \\
\hline 617 & \\
\hline carpus......................... 638 & ..... 634 \\
\hline (n) & 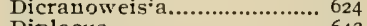 \\
\hline$\ldots \ldots \ldots \ldots \ldots \ldots \ldots, 61_{4}$ & ...... 6 \\
\hline 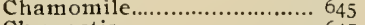 & ........... \\
\hline ....................... 645 & .043 \\
\hline 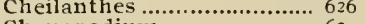 & .628 \\
\hline lium1.....................6 63 & 32 \\
\hline ild ......................... 638 & heon... \\
\hline ...................... 64 & \\
\hline 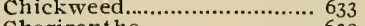 & \\
\hline (......................... 6 & \\
\hline 1.......... & \\
\hline (2.................... 60 & \\
\hline (........................ & ....... \\
\hline 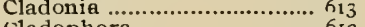 & ........ 6 \\
\hline ............... 612 & \\
\hline am.................... 617 & the. ..................... 6 \\
\hline m.......................... 625 & \\
\hline ……................... 62 & \\
\hline & \\
\hline …...... 6 & $\mathrm{~F}$ \\
\hline & \\
\hline ........ 6II & \\
\hline …........ 639 & $\mathrm{E}$ \\
\hline veet .......................... 639 & \\
\hline 626 & \\
\hline & \\
\hline ..... $6 \mathrm{II}$ & ….......... 644 \\
\hline Coleosanthus........................ 644 & \\
\hline
\end{tabular}


PAGE

Eriogonum ..................... 632

Eriophyllum ................... 645

Frodium .......................... 635

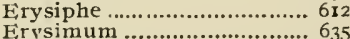

Frythræa ......................... 642

Eschscholtzia. .................. 634

Eucladium ........................... 624

Eucrypta............................... 640

Endorina............................ 6ri

Einglena............................ 6ir

Eulobus .......................... 638

Euphorbia............................. 636

Eurotium ........................... 612

Eurynchium ...................... 625

Everlasting .......................... 644

Evernia .............................6 614

Exidia................................. 623

Favolus ............................. 623

Feather-Moss ........................ 625

Fennel ........................... 637

Ferns.............................. 626

Festuca ............................... 628

Figwort............................ 642

Fissidens........................... 624

Fission Plants ................. 609

Five-Finger ......................... 638

Foeniculum....................... 637

Fomes............................. 622

Fossombronia................... 624

Four-o'clock ......................... 632

Fritillaria. ........................ 631

Frullania..........................6 624

Fuchsia, Wild.................... 638

Fuligo............................... 609

Funaria ............................. 625

Fungi, Black..................... 612

Fusicladium....................... 617

Galera................................... 620

Galium............................. 643

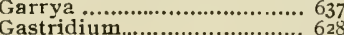

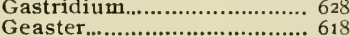

Geranium ............................ 635

Gllia .............................. 640

Gloeosporium........................ 616

Glonium ......................... 613

Gnaphalodes.......................... 644

Guaphalium ...................... 644

Gnomonia......................... 613

Godetia ................................. $63^{8}$

Gon1phoner11a................... 611

Goniun1...... 611

Gooseberry........................ 637

Goosefoot.............................. 632

Grape ............................... 636

Grass, Blue-eyed................ 63I

Grasses .................................. 627

Grease-wood .......................... $66_{3} \delta$

Grimaldia........................, 624

Griminia......................... 625

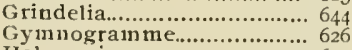

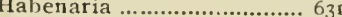

I Iapalosiphon....................... 609

I Iazardia............................. 644
Hebeloma.. ....................... 620

Hedwigia ........................... 625

Heleniun1.......................... 645

Heleocharis............................ 629

II elianthennm ..................... 635

11 eliant lus......................... 644

Helvella............................ 614

Henizonia ......................... 645

Hen11lock, False ................... 627

Hendersonia .......................... 616

Heteromeles ........................ 638

Heterosporium ........................ 618

Heterotheca......................... 644

Heucliera........................... 637

1Zieracium ......................... 646

Horehound............................. $6_{41}$

Holcus ................................. 628
PAGE

Holly, California ................6 $63^{8}$

Holodiscus ........................ $63^{8}$

Hordenm.............. 629

Hormiscium ..................... 6 6

Hornwort ............................ 633

Horse-tails ....................... 626

Hydnum .......................... 622

Hydrocotyle ..................... 636

Hydrdictyon ....................... 6 I I

Hygrophorus ..................... 620

Hymenochaete...................6 622

Hypholoma ....................... 62I

Hy pochæris...........................6.6.6. 646

Hypoxylon ........................ 613

Hysterographinm............ 6I3

Indian-pink ...................... 633

India 11 -lettuce..................... 633

Juglans............................ 631

Juncus ............................ 629

Juniper.................................. 627

Jussiæa............................. $63^{8}$

Knot-grass....................... 632

K notweed ........................... 632

I, ace-pod.............................. 634

Lachnea.............................. 614

Lachnella .......................... 6 6 4

Lactarius .............................6 620

I,actnca . ....................................646 646

L,amb's quarter................... 632

Larkspur......................... 633

I,athyrus........................ 639

I,aurel Mountaiu ................ 633

I,ay-ia.............................. 645

I,ecanora............................6 613

I.einna ................................ 629

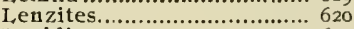

Lepidinm ............................. 635

L.epidospartum ................... 645

Lepiota............................. 6r9

Leptobryum ...................... 625

Leptodactylon...................6 640

Leptogium 613

Leptonia ............................. 620

Leptothrix......................... 609

Leptosyne......................... 644

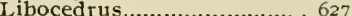

tichens ...............................6.6 $61_{3}$

Lilac, California..................... 636

Lilium....................... 630

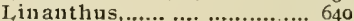

Linarla.......................... 642

I,ittle Club-moss................... $6_{26}$

Liverworts......................... 624

I,obelia.............................. 643

I,olium ................................. 629

I,otus ............................ 639

Lunularia....................... 624

I,ipinus............................... 639

Lyngbya........................... 609

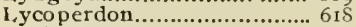

Lythrum........................6 635

Macrosporiuni ...................... 6 is

Madia ............................... 645

Madotheca........................... 1 $_{24}$

Madrona....................... 639

Maliogany, Morntain.......... 638

Malacothrix ....................... 646

Mallow.............................. 635

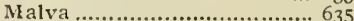

Manzanita .......................... 639

Maple............................ 636

Marchantia ....................... 624

Marrubin11........................... 641

Marsonia.............................6.6 617

Mastigowema ...................... 609

Metricaria....................... 645

Meadow Rue................ 633

Meadow-sweet ........................... $66_{3} 8$

Medicago................................ 639

Melampsora................ 616

Melanconiun...................... $6 r_{7}$

Melica ................................ 628

Melilotus............................. 6,39

Melosira ............................. 619
PAGE

Ientha..........................6 64

Mentzelia ........................... 638

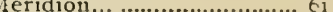

Merismopedia.................... 609

Merulius............................... 623

M esocatpns ......................... 611

Mexican Tea........................ 632

Micraunpelis ...................... 643

Micrococcus.....................6 609

Microseris............................ 649

Milkweed............................ 643

Iimulns

Mint.................................. $6_{41}$

Mirabilis........................... 632

Iistletoe 631

Mock-orange...................... 643

Monardella......................... $64 \mathrm{r}$

Monkey-flower.................... 642

Iorchella ....................... 6 I4

Morning-glory, wild............. 640

Mlosses ............................ 624

Mouse-ear.......................... 633

Vucor 6 II

Mublenbergia....................... 628

Muilla................................. 630

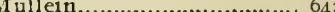

Mushroom, common.......... 621

Mustard.......................... 635

My cena............................ 620

Nasturtium ........................ 635

Naucoria

Naverretia ........................ 640

Navicula ............................... 6ri

Nemacladus....................... 643

Neinophila......................... 640

Nettle................................ 632

Nostoc ................................ 609

Notholrena.... 626

Nummnlar $19 . . . . . . . . . . . . . . . . . .6613$

Preonia.......................... 6.33

Paint-brush....................... $f_{42}$

Painted-cup ....................... 642

Palmerella ............................ 643

Panaeolis.............................. 621

Pandorina........................ 6ri

Panicuns ............................ 627

Pannaria.............................. 613

Papaver............................ 634

Parietaria........................... 632

Parmelia ............................... 6r4

Paspilum ............................. 627

pea, wild ............................. 639

Prickly Pear........................ 637

Pectocarya......................... $64^{1}$

Pediastrum,.......................... $6 \mathrm{n} \mathrm{t}$

Pellaea.................................. 626

Peltigera.......................... 613

Penicillinm ......................... 617

Peniophora ......................... 623

Pentstemon....................... 642

Pepper-grass.................... 635

Perezia................................ 645

Pertusaria........................... 613

Peucedanu111..................... 637

Peziza ............................... 614

Phacelia............................... 640

Phalaris............................... 627

Phallus........ 6Is

Plitebia.............................. 623

Phleum ............................. 628

Plilox.................................. 640

Pholiota........ 620

Phoradendron ....................6.635

Phragnidimm........................ 6i5

Phycia........................... 614

Phyllachora ...................... 613

Phyllosticta ......................... 6, 616

Pliysalis.............................. 641

Pliysari111......................... 609

Pigweed ........................... . 622

Pimpernel ............................ 640

Pincuslion .............................. 645

Pine............ 627

Placodium ......................... 621 


\begin{tabular}{|c|c|}
\hline & PAGE \\
\hline Plagiobothrys... & Salix.. \\
\hline Plantago ........................... 642 & Salvia.............. \\
\hline Platanus .......................... 632 & Sambucus........ \\
\hline Platystemon .............. & Samolns.......... \\
\hline Pleurotus................. & Sanicula.......... \\
\hline Pluteolis... & Saprolegnia.... \\
\hline Poa................ & Saxifraga........ \\
\hline Podosporiell & Scabiosa......... \\
\hline Poison Oak. & Scale-Mosses .. \\
\hline Polycarpon & Scenedesmus... \\
\hline Polygala.... & Schizophyllum. \\
\hline Polygonur & Scirpus............. \\
\hline ................. 626 & Scleroderma... \\
\hline Polypogon. & Scleropodium.. \\
\hline ................ 622 & Scolecotr \\
\hline . .............. 622 & Scrophularia... \\
\hline ................. 625 & Scutellaria ...... \\
\hline 627 & Secotium........ \\
\hline 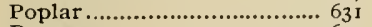 & ........... 629 \\
\hline 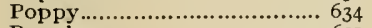 & Selaginella ..... \\
\hline 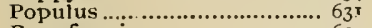 & Senecio............. \\
\hline ........... 621 & ....... 616 \\
\hline ............... 633 & .......... 627 \\
\hline ............... 627 & 640 \\
\hline .......... 638 & Sidalcea............ \\
\hline Primrose, Even ing............. 638 & Silene............. \\
\hline Protococcus...... & Silybum............ \\
\hline 638 & Sisymbriumı.... \\
\hline Psathyrella & Sisyrinchium... \\
\hline ..........6.6 $6 \mathrm{~J} 4$ & ........... 636 \\
\hline ......... 627 & Skull-Cap ........ \\
\hline .......... 639 & Smartweed...... \\
\hline ......... 625 & Sinuts.... \\
\hline ................... 625 & .............. 642 \\
\hline$\ldots \ldots \ldots \ldots \ldots \ldots \ldots, 632$ & Soap Plant...... \\
\hline Ptiloria...... & Sola num ......... \\
\hline 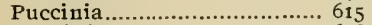 & Solidago.......... \\
\hline Pucciniastrum .................. 616 & Sonchus.......... \\
\hline Puff-Balls ........................... 6r9 & Sorghum......... \\
\hline$\ldots \ldots \ldots \ldots \ldots \ldots \ldots \ldots \ldots \ldots \ldots \ldots \ldots$ & 632 \\
\hline $1 \mathrm{~m} \ldots \ldots \ldots \ldots \ldots \ldots, 64 i$ & Sow-Thistle....................... 646 \\
\hline$\ldots \ldots \ldots \ldots \ldots \ldots \ldots, 63 \mathrm{~J}$ & anish Bayonet................. 631 \\
\hline .................... 623 & cularia........................ 643 \\
\hline .................... 646 & ................ 642 \\
\hline$\ldots \ldots \ldots \ldots \ldots \ldots \ldots, 64_{7}$ & .................. 633 \\
\hline$\ldots \ldots \ldots \ldots \ldots \ldots \ldots, 6 r_{4}$ & $\ldots \ldots \ldots \ldots \ldots \ldots 66_{12}$ \\
\hline ...................6.617 & ..............6 624 \\
\hline$\ldots \ldots \ldots \ldots \ldots \ldots, 64 \mathrm{I}$ & ............... $6 \mathrm{r} 6$ \\
\hline 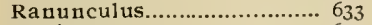 & ................ 612 \\
\hline$\ldots \ldots \ldots \ldots \ldots \ldots . . .634$ & .............6.630 \\
\hline Rattle-Weed....................... 630 & ............ 637 \\
\hline Rhamnus....................... 636 & Spirillım........ \\
\hline 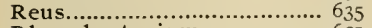 & Sporobolus..... \\
\hline gium................ 625 & ............. 610 \\
\hline ...................... 6I 4 & $\ldots \ldots \ldots \ldots \ldots 6,615$ \\
\hline ................. 637 & $\ldots \ldots \ldots \ldots 64 \mathrm{I}$ \\
\hline n................6 624 & Stellaria........... \\
\hline 612 & phylium. \\
\hline ........................ 635 & $\ldots \ldots \ldots \ldots \ldots \ldots, 623$ \\
\hline ....................... 638 & ............. 613 \\
\hline 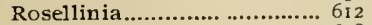 & Stigeoclonium .................... 6 I 2 \\
\hline ..................... $63_{3} 8$ & Strgmatea............................ 6r 6 \\
\hline ...................... 632 & Stipa ................................ 628 \\
\hline ....................620 & Strephanthus .................. 635 \\
\hline$\ldots \ldots \ldots \ldots \ldots \ldots \ldots \mathrm{I}_{4}$ & Stropharia ....................... 621 \\
\hline 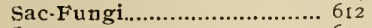 & w1111ach .......................... 635 \\
\hline$\ldots \ldots \ldots \ldots \ldots \ldots \ldots \ldots, 6 \ldots \ldots$ & Sunflower ......................... $6_{4}$ \\
\hline Sage, Black .............. & Sycamore... ......... \\
\hline Sage-Brush........................645 & Symphoricarpus................ 643 \\
\hline Sagina ............................... 633 & Synedra .............................. \\
\hline
\end{tabular}

Taphrina

Taraxacum...................... 614

Tar-Weed ......................... 645

Teasel................................ 643

Tellima ............................. 637

Tetradymia......................... 645

Thalictrum ........................... 633

Theloschistes ........................ 6 6

Thistle ............................... 645

Thysanocarpus ..................... 634

Tidy-Tips ........................... . 643

Tillaea ............................... 637

Toad-Flax........................ 642

Toadstools.......................618, 619

Toadstools, Dissolving......... 622

Toly pothrix..........................6 609

Torula................................. 617

Trametes ................................., 623

Tremella ............................... 623

Trichoderma......................... 611

Tricholoma ...................... 619

Trichostema ........................ $6_{41}$

Trifolium................................ $6_{39}$

Trisetum ......................... 628

Tropidocarpum................... 634

Tubaria ................................. 620

Tumbleweed........................... 632

Tylostoma .......................... $6_{18}$

Typha................................. 627

Ulothrix................................... 612

Umbellularia............................ 633

Umbilica ria.......................... 6I

Urceolaria ......................... 6I

Uredo....................................... 616

Uromyces............................ 6I4

Urtica. 632

Usnea................................. 614

Ustilago.................................... 616

Vaucheria............................ 6I

Velaea................................. 636

verbascum............................ 642

Verbena.................................. 642

Veronica .............................. 042

Vetch................................... 639

Vicia ......................................... 639

Viola ......................................... 635

Violet................................ 635

Vitis.................................. 636

Virgin's Bower..................... 633

Volvaria............................. 620

Walnut............................. 631

Water-Cress.......................... $6_{35}$

Webera.............................. 625

White Cedar ....................... 627

Wild Buckwheat................... 632

wild Rye.......................... 629

Willow ................................ $6_{31}$

Woodwardia ....................... 626

Wood-Sorrel ....................... 635

Wormwood............................ 645

Yarrow............................... 645

Yerba Mansa........................ 631

Yerba Santa........................ 641

Yucca ................................. 631

Zanuichellia ........................ 627

Zauschneria.......................... 638

Zygnema............................ 611

Zygadenus ............................... 630 


\section{DIVISION NINE - SOUTH PASADENA.}

\section{CHAPTER XXXIII:}

SOUTH PASADENA.- Its incorporation; and historic events of the municipality.-Its Schools, Newspapers, Library, Literary Societies, Post Office, Churches, Hotel, Opera House Block, Manufactures, etc., etc.

\section{THE CITY OF SOUTH PASADENA.}

The land comprised in this corporation was part of the original Rancho San Pasqual. See chapters I, 2, 3, 4, for important historic events which transpired within this city's boundaries, during the Indian, the Spanish, and the Mexican occupancies of the country.

The beginning of a town here was in the spring of 1885 , when O. R. Dougherty laid out ten acres of his land into town lots, and put up a neat little building marked "South Pasadena Land Office," at the junction of Sylvan Drive and Mission street, which was then on the daily stage route between Los Angeles and Pasadena. At the same time, or very soon after, subdivisions were made by Geo. Lightfoot and others in rapid succession, and the town of South Pasadena thus began to have a name and a place in the world of tangible things.

When the matter of incorporating the city of Pasadena was being agitated in $r 885$ and $r 886$, an effort was made to have this settlement join in the movement, but they declined. However, these people were strongly opposed to having liquor saloons in their midst; and within a few months it was found that they must either incorporate so as to have police control over their territory, or else be blotched and cursed at every eligible corner by the diabolical traffic. And thus they were compelled by sheer necessity for self-protection to incur the expense and trouble of forming a city corporation.

The city of South Pasadena was incorporated in February, i 888. The first meeting of city trustees, who had been named in the articles of incorporation, took place in the office of Smith \& Jacobs, March 8, I888; they were D. M. Graham, Geo. W. Wilson, A. A. Burrows, D. R. Risley, and W. P. Hammond. Graham was chosen president. C. C. Miles had been named for clerk, but was absent, and $\mathrm{Mr}$. Wilson served as clerk pro tem. Three ordinances were passed-No $I$, fixing time of trustee meetings at 9 a. m. every Monday; No. 2, place of meeting; No. 3, bonds of city clerk, treasurer, and marshal. And all were ordered to "be published once in the South Pasadena Bell, a newspaper published weekly in the city of South Pasadena."

The second meeting of the city trustees or council was on March r 2. At this meeting Captain D. R. Risley introduced and moved the adoption of 
the famous Pasadena prohibitory ordinance, just as it had been passed upon and sustained by the state supreme court ; and it was adopted without a dissenting vote - to take effect March I4, I 888. It remains in full force yet, $\mathrm{I} 895$, just as enacted at this meeting. However, it was ascertained later that these first four ordinances had not gone through all the forms of procedure laid down in the state law; hence they had to be formally rescinded, and then re-enacted step by step in accordance with the statute.

Under this first city council the following city officers were appointed: A. B. Cobb, marshal, with M. B. Sellman as deputy; attorney, W. S. Knott; recorder [police judge], J. A. Gates was elected, but declined to serve, and F. H. Smith was then chosen. Treasurer, J. H. Jacobs.

The first city election was held April 9, 1888, the officers having held their places by charter provision until this time. And all the same men were elected to the same places, except Capt. Risley, who had withdrawn, and E. Gardner was chosen in his stead. The trustees or councilmen drew lots for term, and Wilson, Graham and Hammond drew the two-year seats, while Gardner and Burrows drew the four-year seats. And the business of the city now went on efficiently and in good shape. July 2 E. Peters was appointed fruit-pest inspector.

At this time the city limits took in the whole of the Pasadena school district, which extended from Columbia street south to the north line of Los Angeles city, and from the Arroyo Seco east to the west line of the Stoneman ranch, or the Raymond brook and its ontwash, which are called also the "San Pasqual Arroyo" in the city records of April 29, I889, and other dates. Saloons had been started on Mission street, and Columbia street, and Fair Oaks Avenue, and the adobe road - some eight or nine in alland now the city had to wrestle with them. Some were closed without much trouble, but others staid to fight. And the city records of August I 3 , I 888, show that $\$ 23$ was paid to the Pasadena Detective Agency for services in this line. Again, April 22, I 889, \$20 was allowed to the city marshal, E. Peters, for payment of detectives. Thus all saloons north of the chalk hills were finally driven out; but those on the adobe road down toward Los Angeles could not be phased, and they continued to run wide open, although nominally in a prohibition city. To get rid of this offensive state of things it was necessary to have the city boundaries re-established, so as to exclude the incorrigible territory.

On July $3 \mathrm{I}, \mathrm{I} 889$, the city council voted to call an election, to take place September 7 , on a proposition to exclude from the city limits all the territory south of the Monterey road, etc. And it was ordered that notice of such election "be published four weeks in the South Pasadena Citizen, a weekly newspaper printed and published in the city of South Pasadena." On August 26 the council changed the date of this election to September 28, to cure some technical defects in their former action. The election was held at 
two polls - one in the territory not excluded, and another in the territory proposed to be excluded. The polling place for this latter section was at the Newton ranch house on the adobe road, near the bridge crossing the Arroyo del Castillo. And the sort of people forming that saloon-ridden settlement is pretty well indicated by the names of the officers for this election, which were : Daniel Kevane, inspector; Barton Qujaneck and Herman Schackow, judges; L. W. Kevane and Domingo Batz, clerks. The vote stood in the city, fifty-nine for exclusion, and seven against ; in the excluded territory, twenty-five for exclusion, and none against. The result was duly certified to the secretary of state, and the new boundaries then established continue to this time - 1895 .

February II, I889, M. B. Selman resigned as city marshal, and E. Peters was appointed. April 22, an official bench mark was established, being "the top of stone coping under windows at northeast corner of the Opera House [Graham \& Mohr's brick block] on south side of Center street - 657.86 feet above datum plane," or sea level. They had petitioned the county board of supervisors for a justice of the peace at South Pasadena, and accordingly F. H. Smith had been appointed for them; then they immediately made him also City Recorder [police judge]-May 27, IS89. The next regular city election took place early in April, I890; and the Pasadena Standard of April i 9, said:

"The South Pasadena city election was carried with a clean sweep by the whole ticket in favor of maintaining the anti-liquor ordinance. The new board consists of Ed. Gardner (holds over), Leo A. Longley, W. H. Mace, Charles Moore, S. J. Fleming; Clerk, A. F. M'Reynolds, re-elected ; Marshal, E. Peters, re-elected; Treasurer, J. H. Jacobs, re-elected. The total vote cast was I 26 ; and all but two of the candidates received every vote."

June 26, 1893, E. Gardner resigned as member and president of the city council, and J. P. Early was chosen in his stead. During this year also the city had a legal contest with the Los Angeles 'Terminal Railroad Company, which was charging a higher rate of fare to Los Angeles than that fixed in their right-of-way franchise through the city. About August I Judge Lucien Shaw of the Superior Court, Los Angeles, gave a decision in favor of the city. The railroad company appealed the case to the State Supreme Court, and this tribunal also decided against them. So they were obliged at last to either fulfill the terms which they had agreed to in their franchise, or else remove their trackage from the streets of the city.

The city officers in 1894-95 are as follows: Howard Longley, president of trustees; and P. M. Green, H. J. Cone, E. H. Rust, and Frank Stokes the other members. Isaac Peel, city marshal; A. F. M'Reyuolds, clerk; J. H. Jacobs, treasurer; Geo. Gleason, recorder; G. W. Wilson, street superintendent; W. E. Arthur, attorney, at call; T. D. Allin, engineer, at call. [The two latter reside in Pasadena.] 
THE PUBLIC SCHOOLS.

In chapter 9, entitled "Annals of the Schools," will be found a full account of how and when this south district became segregated from the original San Pasqual school district, down to the building of the fine schoolhouse on Columbia Hill, and its conversion into the "Sierra Madre College" - but later converted into a stately residence by C. D. Daggett, Esq. [See pages I 7I-72.]

The district was formed January $7, \mathbf{1} 878$, and originally extended from California street clear down to the north line of Los Angeles city, under the name of Pasadena School District; but its north line was later dropped down to Columbia street. Its first trustees were A. O. Porter, H. G. Bennett, I. B. Clapp, the latter being clerk. A small school-house was at once erected near the corner of West Columbia and Hermosa street. But on June 26 , I883, the contract was let to C. B. Ripley for the big school-house on Columbia Hill, to cost $\$ 3,925$. Then on June $\mathrm{r} 7, \mathrm{I} 884$, this building and its grounds, some five or six acres, were sold at public auction and bid in by P. M. Green for the Sierra Madre College, at \$2,000. Miss Mary Phelps was then the teacher. [For the history of this College project see page I88.]

Early in 1885 O. R. Dougherty and others commenced laying out the town of South Pasadena. A large lot at northwest corner of Center street and Oak Hill avenue was secured for school grounds; and on March 5, I885, a contract was let to Ridgway \& Ripley to erect a school-house thereon, for $\$ I, 550$. School was opened here the first Monday in October of that year, with Geo. W. Wilson as teacher. He taught one year, then caught the "boom fever" and went into the real estate business. September 20 , I886, S. Shaw took the school, and taught it until the holiday vacation. Then Miss Lottie E. Green taught it from January 3, I887, until the summer vacation. The school children increased so fast that for $1887-88$, two teachers, Miss Green and Miss Belle Townsend, were employed.

August 30, I 888, this school-house was moved down to the Lincoln Park portion of the district, and a new and much larger building was erected on the original school lot, with J. B. Soper as Superintendent of construction. It cost about $\$ 10,000$. For the school year I888-89, Miss Lily A. Martin was principal, with Miss Nellie M. White and Miss Lutie Martin as assistants. Year I889-90, same teachers. Year I890-9I, Miss Martin still principal, with Miss Lizzie A. McMillan and Miss Belle Townsend for assistants. Year I89I-92, Geo. W. Wilson, principal, with Miss E. M. Snyder and Miss Ara Riggins for assistants. Years 1892-93, and I 893-94, same teachers. Year I894-95, J. A. Goodrich, principal, with Miss Snyder, Miss Riggins and Miss Elva Smith as assistants. The school has primary, intermediate and grammar grades.

This school district now (1895) extends from Columbia street south to the Alhambra and Los Angeles road, and from the Arroyo Seco east to the 
San Pasqual Arroyo, which was the boundary between the old Bacon or Marengo ranch and the Stoneman ranch. The school census of April, I894, showed 183 children of school age, and I $5^{8}$ were enrolled in attendance during the year. The census of April, I895, showed I84 children, an increase of only one child-but during the year the southeast corner of the district had been set over into the Alhambra district, its school-house being a mile nearer to these people.

The school trustees in 1894-95 are Dr. F. A. Seymour, C. L. Neibel and J. B. Soper, the latter having been clerk of the board for three years past.

NEWSPAPERS.

The South Pasadena Bell seems to have been started some time in February, I 888 , but I failed to find the exact date, as no file of it was preserved. It was edited and published by John Sharp, who had the printing done at Los Angeles; so there was no printing office in the town. I found all city ordinances ordered to be published in this paper, up to December 24, I 888 ; but after that it seems to have died, for its name does not occur again.

The South Pasadena Citizen was started July 30, I 889, with W. D. Bridges, editor and publisher. Its typesetting was done in the Pasadena Standard office, then the type forms were carried to the city council room in Opera House block (Graham \& Mohr's brick building) in South Pasadena, where O. R. Dougherty, then a member of the council, had located a printing press, and here the sheets were printed and published. This was done to make a valid publication of the election notice for excluding certain territory from the original city limits, as explained before in my sketch of the city incorporation. The publication of the paper was continued weekly until Sept. 24-nine numbers in all-then discontinued. The heading said: "Published every 'Tuesday. Office in Graham \& Mohr block." The first page was generally made up of matter from the Pasadena Standard already in type, while the second, third and fourth pages were occupied with local items, articles and advertisements pertaining to South Pasadena.

The South Pasadenan was started June 8, I 893, by Geo. W. Glover, Jr., and now for the first time South Pasadena had a real printing office of its own. An outfit of types, press, paper cutter, etc., was procured; and Mr. Glover himself invented a successful label gumming machine; so that in I 895 he is issuing an excellent local paper, weekly, and is also competing with Los Angeles and Pasadena in some lines of job printing. From June I 2 to June 18,1894 , the paper was run as a daily, to make legal publication for a railroad franchise through the city; also again in January, $\mathbf{8 9 5}$, for a similar purpose. Capital in the plant, about \$I,ooo. Number of employes, three. Paper published every T'hursday, in six-page form.

PUBL,IC I,IBRARY AND READING ROOM.

This was opened in February, I889, in the Graham \& Mohr block, 
where a room was given for its use, free of rent. The South Pasadena Citizen of August 20, I889, published a list of 29 new books purchased for the Library. The officers then were : Leo A Longley, president ; J. J. Young, vice-president ; A. H. Nettleton, secretary, Mrs. Etta Longley, treasurer; Miss Jennie Collier, librarian. Open every evening from 7 to $9 \mathrm{o}^{\prime} \mathrm{clock}$, and on Tuesday, Thursday and Saturday afternoons from 2 to 5 o'clock. The South Pasadenan of December I4, I893, published a report of receipts and expenditures during the successive years I $889-90-9 I^{-} 92-93$, by $\mathrm{F}$. H. Longley. The total receipts had been $\$ 476.05$, and expenditures $\$ 475.55$; and it was announced that the library would be closed, for want of funds to meet the necessary expenses. But friends came to the rescue. It was not closed. And on April 19, I 894, the librarian reported a total of \$II6.45 received since December ; also that the rooms had been kept open, old debts had been paid, and some books and periodicals added on the shelves and tables. Another report on July 5, I894, showed visitors in April, 63; in May, 96 ; in June, 98 . To reduce running expenses, the room was now only opened on Tuesdays and Saturdays from 2:30 to 5 o'clock P. M.

In September, I 895 , the city council voted to make the Library a public institution of the municipality, and appropriated $\$ \mathrm{I}$, ooo of the city tax levy for new books and current expenses the first year. The library trustees appointed under this new system were: Rev. A. M. Merwin, F. H. Longley, Leo A. Longley, James Wadsworth and Merton Keith.

\section{LITERARY SOCIETIES.}

An account of the different Chautauqua Circles that have existed here will be found on pages 5 I 7-5 I8. The public school has a literary society of its own, whose officers June I, I895, were: Mabel Hauk, president ; Gussie Wood, vice-president; Ruby Fell, secretary ; Sidney Smith, treasurer.

There is a Literary Club, of whose membership I obtained the following names: Mrs. M. C. Graham, Miss Jennie Collier, Grace Longley, Mary Beery, Edna Smith, Ruth Dougherty, Alice Cone, Rena Neibel, Paul Dougherty, Charles Longley, Fred Crossly.

There is a South Pasadena branch of the Lyceum League of America, chartered as No. 1467 ; and from an article in the South Pasadenan I gatherd the names of some of its members, thus: M. E. Keith, president ; R. B. Stevens, Bert Brown, Paul Dougherty, J. F. Crossly, J. C. Goodrich, Miss Nellie North, J. A. Wassman, Miss Grace Longley, S. E. Hatfield. No further data obtained.

\section{THE POSTOFFICE.}

January 3, I 883, a postoffice named Hermosa, with Frank M. Glover as postmaster, was established at the Hermosa Vista house. The name "Hermosa" for their postoffice proved unsatisfactory to the people of that vicinity, because it lost to them the prestige of the name "Pasadena," which was now rising into high repute, and which they had secured for their school 
district. So the name of the office was soon changed to South Pasadena. Frank Glover was an invalid, and in a few months became unable to serve the office. He then procured the appointment as postmaster of Chas. H. Case who was teaching the district school in the diminutive first school-house near the corner of Columbia and Hermosa street. The office was moved from the Hermosa house over to a small building at the southwest corner of Columbia street and Sylvan Drive, where the daily stage between Pasadena and Los Angeles passed its door. This was the situation November 28, I883, when I first visited Pasadena. Frank Glover died March 29, I884. Mr. Case was also an invalid; and his wife Gertrude, a daughter of Hon. O. R. Dougherty, did most of the work, being herself deputy postmaster. In I 885 , when the S. G. V. railroad commenced to supplant the stage line in carrying the mails, this postoffice was moved down to a small building at the corner of Mission street and Prospect Avenue. Mr. Case died January I, I887; but a week or two before this he had appointed Geo. W. Glover, Jr., as deputy postmaster, to relieve his wife of the care of the office during his last days; and he also took measures to have her duly commissioned as his successor, so that the income of the office might be assured to her after he had passed away. She was accordingly appointed postmistress - and held the position until January, I890, when she resigned, and T. D. Keith became postmaster. Then on June 3, 1892 , Keith retired, and Mrs. Ida Stevens took the place, and holds it yet $-\mathrm{I} 895$.

\section{THE CHURCHES.}

About November I0, I885, the old original Presbyterian church building on California street was removed north to Worcester Avenue. This left South Pasadena without any religious assemblage ; and Mrs. O. R. Dougherty immediately took the matter in hand to organize a Union Sunday School. In this work she secured the assistance of Miss C. M. Bishop, Wm. Collier, Geo. A. Green, and others, Mr. Green being chosen superintendent. But early in December the First Congregational Church of Pasadena was organized, in the Coliege building on Columbia hill. Mr. Green united with this church, and was made one of its deacons, and superintendent of its Sunday school. [See page 490.] Nevertheless, the Union Sunday school was still maintained until it was finally merged into the Methodist church work, about a year later. Its sessions were held in the school house, and occasional preaching, topical talks, or lectures were had under its auspices.

THE SOUTH PASADENA M. F. CHURCH.

A class was organized November I0, I886, with four members-J. B. Soper and wife, and H. J. Cone and wife. Rev. C. W. Tarr was pastor in charge of Garvanza and South Pasadena, and thus regular preaching was established. April 25, 1887, this church society was incorporated, and they went on at once to put up a church building of their own, which was 
formally dedicated October 30, i887. Rev. A. W. Bunker wrote an excellent original hymn for this occasion. The exercises were conducted by the presiding elder of the district, Rev. Geo. F. Bovard, assisted by Rev. J. A. Wood, D. D., Rev. R. S. Cantine, D. D., Rev. P. F. Bresee, D. D., Rev. C. W. Tarr, Prof. W. P. Hammond.

In September, I 894, A. F. Mitchell donated a cottage for a parsonage, and it was moved onto the church lot. In 1895 , there are eighty members, and the church property is estimated at $\$ 3,600$. Besides the Sunday school and the class meetings, there is an Epworth League, a Ladies' Aid society, missionary society, etc., as auxiliaries in the church work. The successive pastors have been: Rev. C. W. Tarr, I 886 to I 888 ; Rev. A. W. Bunker, I 888 to I 890 ; Rev. F. S. Woodcock, I890-9I : Rev. J. D. Munroe, I89I-92; Rev. A. W. Bunker again, I892-94; Rev. H. J. Crist, I894-95. The church officers in I895 are : Trustees-J. B. Soper, W. P. Hammond, G. W. Wilson, O. R. Dougherty, J. H. Jacobs, M. B. Reed. Stewards-Soper, Reed, Mrs. Mary Soper, Mr. Jacobs, E. E. Barden, Martha E. Wood, A. L. Bennett, Mrs. G. W. Wilson. Supt. Sunday School-J. H. Jacobs.

MEMORIAL BAPTIST CHURCH OF SOUTH PASADENA.

Organized in September, I888, with about fourteen members, and joined for pastoral services with the Alhambra church, of which Rev. John Heritage was then pastor. He was succeeded in I890-9I, by Rev. T. L. Crandall, under whose administration this society was incorporated December 20, 1890. In I 892-93 Rev. W. Gregory, D. D., was pastor of these two charges; and from I 893 to ' 95 Rev. S. K. Dexter was pastor. A church building was erected in I89I, at a cost of about $\$ 1,000$. In I895 there are about forty members; and the church property is valued at $\$ I, 500$. It has a Young People's society of Christian Endeavor, and a Ladies' Aid society as auxiliaries. Trustees: A. J. Moody, T. D. Keith, C. L. Neibel, and--

\section{ST. JAMES' EPISCOPAI, MISSION.}

This was commenced in July, I893, at corner of Meridian Avenue and Mission street. (No further data furnished.)

NoTF.- The Calvary Presbyterian church, on Columbia street, stands about ten steps inside of South Pasadena limits. Its data was furnished me by Rev. Williel Thomson of Pasadena, one of its chief promoters; and its historic sketch will be found on page 478 .

HISTORIC WAYMARKS, INDUSTRIES, E'TC.

September 16, I885, regular passenger and freight service was commenced between Los Angeles and Pasadena by the S. G. V. railroad. [See Chapter 22.] But the first record in the matter which I found for South Pasadena was that A. F. McReynolds was station agent on and after February I0, I886. When the railroad commenced running, of course the two daily hack lines had to be given up. W. T. Vore's line had the contract for 
carrying the mail from Los Angeles to the South Pasadena and Pasadena offices, and he now arranged to bring it up on the railroad instead of by horse vehicle as before. And this change made the special occasion for moving the South Pasadena postoffice down from Columbia Hill to a building near the railroad station. But the railroad company itself does not appear of record as a mail contractor until March I5, i886, the previous arrangement having been all in Mr. Vore's name until his contract expired.

I1 March, I886, a telegraph office was first opened in South Pasadena, with Mrs. May McReynolds as operator--a position which she still holds, and also that of station agent in 1895 .

In I $886-87$ the South Pasadena hotel was built by George Lightfoot.

In 1887 , while the "boom" was still flush, D. M. Graham and Dr. J. H. Mohr let the contract for their great brick structure known as Opera House block, which was not completed until well on into i 888 , when the boom's green leaves had begun to wilt and look very sick.

In 1889 two invalid school teachers from New England came here for their health, and started a little business enterprise called "Women's Preserving Union." With a common cookstove and washboiler they preprepared pure fruit jellies, marmalades, etc., and put it up so nicely that it wo11 favor, became quite a success, and for several years gave South Pasadena some fame abroad. They had to enlarge their facilities and employ some help, as their trade increased. But in I89I Miss Thompson died, and Miss Ames sold the works to a Mrs. Woodruff and daughter who continued the business a few months, then gave it up; and the enterprise has never been revived.

GAS Engine Works.-In February, i894, a business was commenced by Robert S. Futhey and E. C. Steele, which developed into an establishment for the mantifacture of the Atlas Gas Engine, adapted to run by gas, gasoline, or distillate from crude oil, and to furnish power for well pumps, or for any other purpose of a stationary engine. The capital is about $\$ 1,200$, comprising buildings, tools, machinery, stock, etc. Employes, three. A general blacksmith shop, pipe fitting, machine repairing, etc., is combined with the engine factory.

BEER GARDEN.--In in86 a man 11amed Reinert bought a 2 I-5 acre lot at junction of Sylvan Drive and Mission street and erected a building on it for his family residence and a saloon. He also built an arbor, laid ont grounds, planted shrubbery, etc., for a regular Sunday beer garden business. But this offensive establishment was driven out in $\mathbf{x} 888$, after incorporation was obtained and the prohibitory ordinance put in force. Then in August, I893, Miss Olive Cleveland bought this ex-beer-garden property and converted it into an orpanage or children's home-a place to save homeless boys instead of to destroy them. [For more particulars about this "home," see page 522.] 
In 1895 the Pasadena and Los Angeles Electric Railroad was built through South Pasadena, from Garvanza northeastward; and also the Southern Pacific Railroad branch line to Pasadena was built up across the eastern part of this city. In the same year the Santa Fe R. R. Co. straightened and re-graded their track through the city, to avoid a double curve in the old line which had always been troublesome for heavy trains on the up haul; and the depot building was of course moved to the new short-cut track.

For account of the oil borings on South Pasadera hills, see pages 464 and $55^{2}$.

For early historic events which occurred on South Pasadena soil, see pages $58,65,67,71,72,98$, etc.

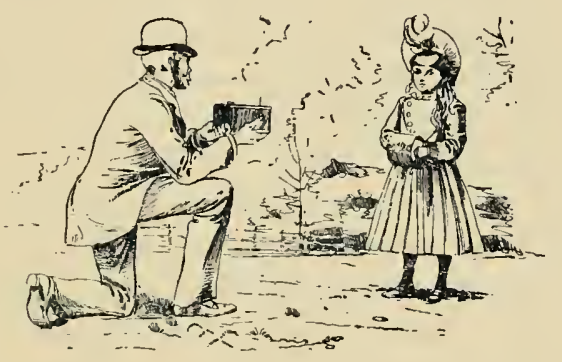

\section{DIVISION TEN - MISCELLANEOUS.}

CHAPTER XXXIV.

AN AFTERMATH OF FIRST THINGS.

It is an ancient saying that "First Things are always historic." This chapter is devoted to corralling a few untethered "first things" in Pasadena history, which did not happen to be caught and linked in at other points, or else here afford some new particulars not before given. This summary of "first things" by date shows in a striking manner how few years it has. taken to build up such a goodly city as Pasadena now is.

The first child born in the colony was that of Geo. Wentworth, who resided on what is now the Joseph Wallace place, with its cannery, etc. This was in 1874 . It was a girl baby, and the colonists made up a fund and bought a baby carriage for the little lady. The second birth was that of Lulu Bristol, December I, r875. The third, Lulu Conger, The first bcy baby born was Harvey, son of Chas. H. and Millie Watts, whose marriage was the first wedding in the colony.

The first school-house was built in January, 1875, on W. T. Clapp's land, where Mrs. Ware's cottage now stands; and Jennie Clapp reopened 
her school in this building on January 28, I875. It had been closed since October, for want of room, there being twenty pupils enrolled.

The first sermon ever preached in Pasadena was in this new schoolhouse, the very first Sunday that it was in condition to be used, February 7, I 875 , by Rev. W. C. Mosher, Presbyterian. The next Sunday, February I 4, Rev. Solomon Dunton, Methodist, preached there; and at this time a Union Sunday school was organized, with Daniel Pike as superintendent. Also a Union prayer meeting was established there, on this Sunday or the next, as a regular Sunday assemblage.

The first church organized in Pasadena was the First Presbyterian, on March 21, I875, with Rev. W. C. Mosher as pastor. The first administratration of the Lord's Supper was on April 4, conducted by Rev. A. F. White, D. D., of Ios Angeles, and Mr. Mosher; and at this time Dr. H. G. Newton and $\mathrm{Wm}$. T. Clapp were duly installed as the first ruling elders.

The first martiage in the colony was that of Charles $H$. Watts and Miss Miilie Locke, daughter of Major Erie Locke, March I2, I875. They now reside at or near Downey, Cal.

The first store in the colony was started in 1875 , by M. Rosenbaum, in a small rough-board building which he had erected on west side of Orange Grove Avenue below Colorado street, where Dr. John W. Wood's neat cottage now stands. But on account of liquor being sold here, against which the colonists most vigorously protested, the store was soon given $u p$, and the building rented for a Chinese wash-house; and so this and there was the first Chinese business started in Pasadena.

The first horticultural society in Southern California was organized by the Pasadena colonists, early in 1875 . It was called "Fruit Growers' Association," and met fortnightly in the school-house, to talk over experiences, compare notes, report progress, quote authorities, and discuss all matters pertaining to their new business; for they had started a fruit colony, although there was not an experienced horticulturist among them.

The first civil officer in Pasadena was I. N. Mundell, who was appointed road overseer in 1875. His jurisdiction extended from the Arroyo Seco eastward to Santa Anita canyon, and from the north line of Los Angeles to the mountains. He first opened or worked the "adobe road" to I,os Angeles, and several others within the district.

The first postmaster appointed was Josiah Locke, March I 5, I875; but he declined to serve, and 110 office was opened until Henry T. Hollingsworth was made postminster, September 21 , I876. [See page 234.]

The first barber chair in Pasadena was established during the winter of 1876-77, by Albert S. Hollingsworth. He was a great joker; and the colony wags made liis shop their loafing place, to spin yarns, play off jokes, or put ridiculous waggish stories in circulation "just for fun," which sometimes became a real grievance to innocent parties. It was said that Albert learned his trade practicing on his brother Henry, the young postmaster. 
The first death in the colony was that of $\mathrm{Wm}$. Green Porter, aged 8 years, June I3, I 876 - son of A. O. Porter. The next death was a 4 -year old son of James Blatenburg, January 20, $18 \% 7$. The third was the son of Col. Banbury, September 4, I877. [See page 234.] The first death of an adult was that of Bartlett Cobb, July I3, I878, step-brother-in-law to Mrs. Col. Banbury.

The first double wedding took place February I, I887, when J. H. Gifford and Samuel S. Page were married at the same time to daughters of John W. Wilson, by the Methodist pastor, Rev. Chas. Shelling. Gifford now lives at Los Angeles, and Page at Alhambra.

The first "house afire" was the burning down of Thomas Banbury's house, at Marengo Aventue and Glenarm corner, in I 878 .

The first regular real estate office and business was opened by 'T. P. Lukens, in I880; and during the first three years he sold upwards of $\$ 225$,ooo worth of Pasadena property. Now president Pasadena National Bank.

In February, I882, the first thoroughbred poultry yard in Pasadena was started by Ed. C. Clapp, with Light Bramahs. He still sticks to his original text in chickendoxy.

The first brass band was organized in $\mathrm{I} 882$, with 15 members, and was allowed the use of the central school house for evening practice, at first. In speaking of it the Union of May I, I885, says :

"The members now are as follows: Frank Newlan, (leader) solo cornet. Hancock Banning, ist cornet. George Woodbury, 2d cornet. Will Clapp, solo alto. A1. Howe, Ist alto. Carl Freese, 2nd tenor. George Eaton, bass. John Lowe, baritone. Lou. Winder, bass drum. Charles Clapp, snare drum. Prof. Scovill, Los Angeles, teacher. Three years ago it was undertaken, and of its then fifteen or sixteen members the majority have fallen by the way. During that time they had met in the school house, and in a blacksmith shop, and one winter in a tent. Some had walked three or four miles to rehearse; yet in the face of these difficulties their teacher complimented them with assurance that only one band in Los Angeles could take up a piece of new music and play it equal with them."

The first photograph artist here was George Weingarth, in $1882 . \mathrm{He}$ took the Pasadena views printed in the Farnsworth pamphlet of I883, including the one on page 167 in this volume. In I 884 Thomas G. Norton opened a photograph gallery, but he died in ' 85 .

The first telephone in Pasadena was put up in Williams's store in December, I882. Wesley Bunnell was the first person who ever talked by wire from this town-and the historic first words thus spoken were " $\mathrm{He}$ isn't here." The workman had just got the 'phone in and stepped out to fix something about the pole wires, when the bell was rung from Los Anggeles, and inquiry made for the said workman. Bunnell was clerk in the store, and he went to the 'phone and answered as above.

The first bicycle ever rode in Pasadena was in 1882 , by Will Hisey-- 
a 46-inch Otto wooden wheel. But later in the same year Geo. H. Frost run the streets on a 54-inch Expert Columbia wheel. And next came Geo. W. Glover with another one like Frost's. And the first bicycle race is thus reported by the Valley Union of December 18, 1885:

"Geo. W. Glover, Jun., made a good run on his bicycle Tuesday afternoon. Leaving Lamanda station at the same time as the train, he reached Pasadena station before the train crossed Colorado street on the way out. Distance $3 \frac{1}{2}$ miles ; time about fifteen minutes."

The first drug store was opened in 1883 by Dr. Frederick Sheldon, in a two-story frame building which he erected at the corner of Colorado and Mills streets, and which stands there yet.

The first dentistry office was opened by John White, from Marshalltown, Iowa, in 1883 . He now resides at Redlands.

Two "first things" of the year 1883 are thus reported in the Union of June I8, I 886 :

"Ben E. Ward commenced business in Pasadena in I88I. About the middle of February, $188_{3}$, he opened an office in R. Williams's building, then just completed, on the corner of Fair Oaks Avenue and Colorado street, and hung out the first business sign ever exhibited in Pasadena. It bore the legend-

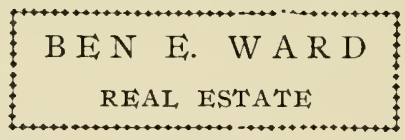

In August, I 893, he started the Pasadena Chronicle, with his brothers Frank and Walter as associate editors. The Valley Union is the direct continuation of that first newspaper ever published in Pasadena." [See page 2 I 4.]

The first lumber yard was started by Col. J. Banbury, October 20, $188_{3}$, on the north side of Colorado street, nearly where the Santa Fe Railroad runs now.

The first wagon built entirely in Pasadena was in January aud February, 1884. Woodwork by Charles Ryan; iron work by L. J. Newlan ; painting by Kline \& Zoubrodth; trimming by J. H. Fleming. It was a platform spring wagon.

The first bakery was opened in February, r $88_{4}$, by Fulford \& Crozier. The oven was twice soaked through and caved in by excessive rains before it could be firished and housed; and this delay and loss got the young men so swamped with debt that they soon had to sell out. It was the same bakery that has been run by Joseph Gantzer for about ten years past.

'The first billiard hall was opened on Saturday, March I, I 884 , by Jerome Beebe ; and in a few weeks he added a liquor saloon. [See page 24r.]

The first brick laid in the foundation of the Raymond Hotel was on March 20, r884. [See page 467.]

The first robbery in Pasadena was on Sunday night, April 6, r884, when the safe in R. Williams's store and the postoffice was broken open and robbed of $\$ 800$. No clue was ever found to the perpetrators. 
The first milk route was established in December, 1884 , by L. A. Carey.

The first bank was opened January I2, I885, as the Pasadena Bank, the same that is now the First National Bank of Pasadena.

The first express office (Wells-Fargo) was opened at Williams's store, April I, I885, with C. A. Sawtelle, agent.

The first public observance of Memorial Day in Pasadena was held on May 30, I 885, and was planned and gotten up by Mrs. S. E. Merritt, the librarian. From the Union's report I quote a few points :

"The business places of the town were generally closed, and the principal buildings ornamented with the national colors. In the evening memorial exercises were held at Williams' Hall under the auspices of the Library Asssociation. * * * The Pasadena Band contributed several selections, and a choir consisting of Messrs. A. F. Mills, F. B. Wetherby, Geo. Monfort, Dr. R. K. Janes, A. F. Clarke, Miss Byram, Miss Werner and Miss Clapp, with Mrs. Nimms as directress, rendered "Columbia, the Gem of the Ocean," "Tramp, Tramp, Tramp, the boys are marching," and "Tenting on the Old Camp Ground." There was no decoration of graves here, and we know of no soldiers buried here."

The Union of September 18, 1885, says: "The first freight brought over the San Gabriel Valley Railroad was a carload of seed barley to James Clarke, September r 5." But the same paper says in another place: "The first freight delivered in Pasadena by our new railroad was a cargo of lumber for the Pasadena Lumber Co." I think both of these shipments came by same train - hence the confusion as to "first."

The first regular railroad conductor of passenger train between Pasadena and Los Angeles was W. B. King, commencing about September 2 I, I 885. Morris Reeder was engineer and John D. Ripley was fireman on this historic train.

The first mention of mail arriving by cars is in the Union of September 25, I885-once a day. Mail closed at 9:24 A.M.; arrived at 6:36 P.M.

The first Pullman palace car ever hauled into Pasadena was the "Fitchburg," direct from Boston, 4,000 miles without change, via Los Angeles, October I 5,1885 ; it had twenty-four passengers, headed by Alonzo Tower, who afterward built the tourist home known as "Marengo Hall." Frank E. and Walter R. Ward were then a real estate firm here, and they had arranged a reception banquet for this party at the Los Angeles House, with plates for forty persons. Several leading citizens took part, making speeches, etc. Prof. George Conant came with this party, and still resides here.

The first gaslighting in Pasadena was of J. W. Wood's drug store, and the Masonic hall then over it, in Williams's block, October 22, I885. Mr. Williams had put a private gas machine in a vault under ground at the rear of the Williams Hall block, to serve the entire building; but when regular city gas works were started, this private generator was taken out. 
The first telescope observation ever made from the summit of Mount Iowe was an eclipse of the moon, March IO, I 895, by Prof. Edward Swift and L. G. Abbey.

\section{CHAPTER XXXV.}

MISCELLANEOUS.-The Orange Boom.-The Roller Skating Rink.-The Whitesiders.The Iowans.- The Prize Baby.-Local Poetry. - The Shorb Water Scare.-Williams Hall.-Eitc., etc.

Emendations, and sundry belated matters.

MISCELLANEOUS.

This chapter is devoted to such odds and ends of historic memoranda, incidents or statistics as seemed worth preserving for future reference, yet did not seem to exactly fit in anywhere else among the more systematized groupings of the many matters dealt with; and also some additional corrections, and belated matters for last chance of insertion.

THE ORANGE BOOM.

From a table of statistics gathered in i 879 for the whole San Gabriel Valley, I have compiled the following items of historic interest for Pasadena, from Hist. Los A. Co., p. 13 I :

NAME OF PLACE.

NAME OF OWNER.

NO. ORANGE NO. BOXES TREES. SHIPPED

Pasadena Colonists .

25,000

Mutuai Orchard....... Mutual Orchard Co........ I $3,65^{\circ}$

Oak Knoll..

B. D. Wilson \& Co.

I0, 498

San Marino

J. De Barth Shorb.

7,750

Lake Vineyard.

Mrs. B. D. Wilson.

$\mathrm{I}, 700$

Winston Height

W. H. Winston.

$\mathrm{I}, 100 \ldots \ldots \mathrm{I0}, 002$

E1 Molino.

E. J. C. Kewen.

2,500

3,323

Los Robles. Gen.

Fair Oaks J. F. Crank

$\mathrm{I}, 200 \ldots \ldots$ 803

Fair Oaks.

A. Brigden

$1,500 \ldots \ldots$

579

Marengo Ranch

F. P. Bacon.

3,000......

2 IO

Total number of orange trees

- 1,300

$\frac{1,400}{60,100}$

204

25,6 I 9

In culling from the mass of reports I took nothing east of Santa Anita Avenue or the Winston place, but only the orchards within Pasadenaland. The boxes of oranges reported were the shipments from San Gabriel station in I879. Another report for I893-94 said :

"I,ast season there were shipped from. Pasadena eighty carloads of oranges, or 24,000 boxes. In this city and vicinity it is estimated that there were dried last seaso11 4,00o tons of green fruit, principally apricots, peaches and prunes."

In the Pasadena Star of December 24, I89I, I found a table of orange shipments from Los Angeles county, from which I gathered this list from Pasadena and its near vicinity : 
STATION.

NO. BOXES ORANGES SHIPPED.

Alhambra.......................43,443

Azusa ......................... 3,469

Chapman ...................... 4, 168

Duarte $\ldots \ldots \ldots \ldots \ldots \ldots \ldots \ldots \ldots . \ldots \ldots, 267$

Lamanda Park.................16,500
STATION.

NO. BOXES ORANGES SHIPPED.

Monrovia ....................... I, 998

Pasadena ......................43,7 I 2

Raymond .................... I, 346

San Gabriel...................22,416

South Pasadena................. 2,708

Total for season of $1890-92-$ I 82,025 boxes. The shipments from Los Angeles city in same time were 22,826 boxes.

\section{ROLLER SKATING RINK.}

The Valley Union of October I I, I884, said :

"The Pasadena Skating Rink will provide us with a long-felt want in the way of a public building that will accomodate as large an audience as will turn out on any occasion for the next five years, probably. The two young men who enter into this enterprise, Messrs. Brinker and Lockhart, have displayed commendable enterprise, and deserve to make it pay. The building is $30 \times 90$ feet in dimensions, with a gallery over the entrance, while a large stage, with dressing rooms on either side fills up the other end. The seating capacity is about 600 . The opening took place last Saturday with a grand ball, which many young ladies and gentlemen attended.'

The roller skating fever was then running its course through the land, and Pasadena was well flushed with it. For several months the rumble of the rollers could be heard for five or six squares all around, every evening, as the devotees of that exhilarating pastime kept the skating floor in lively use. The building stood on the corner of Fair Oaks Avenue and Dayton street, where the Doty block is now. [See Second Citrus Fair, p. 319.]

In March, I885, Mrs. Helen Hunt Jackson, author of the famous Southern California story entitled "Ramona," was in Pasadena a few days, stopping at Marengo Hall, then kept by Mrs. Alonzo Tower.

In April, I 885, at the Flower Festival in Los Angeles, Mrs. Rosenbaum [since deceased] exhibited 150 different varieties of roses grown by her in Pasadena. At the same time Thomas Nelmes's two children, Tommy and Jeannie, exhibited 102 different varieties of wild flowers gathered by them hereabouts; and on this matter the Pasadena Union of May ist, said:

"The following record of the varieties of wild flowers gathered each month for the year r 884 by the children of Mr. Thomas Nelmes, is of interest as a matter of curiosity, as well as for its botanical value: In January, sixty-five varieties were gathered; in February, sixty-eight ; March, seventy; April, seventy-three; May, eighty-seven ; June, seventy ; July, sixty ; August, fifty-four ; September, fifty ; October, forty-five ; November, forty-eight ; December, fifty-six."

About the same time the same paper gave this arborial item:

"A. M. Byram has in his door-yard a white oak tree that measures seventy-six feet from edge to edge of the circle covered by its spreading branches. The tree is thirty-five feet high, and the trunk is four feet in diameter. He calls his place 'Nine Oaks.', 
THE WHITESTDERS.

The Pasadena Union of November 27, I886, contained this report:

"On Thanksgiving Day a company of our residents who came from Whiteside connty, Illinois, enjoyed a picnic at the Wilson Grove. After assembling at the grove $\mathrm{T}$. A. Smith called the meeting to order, and acted as temporary chairman on the temporary organization of an Association of the Whitesiders. T. P. Lukens was chosen chairman of a committee to effect such an organization, with C. G. Jones as secretary. Those present from Whiteside county were: Dr. Utley, John Snavely, T. P. Lukens and family, Frank Smith and wife, John Galt and daughter, Mr. Bressler and wife, George Jones, W. H. Griffin and wife, S. H. Kingery and wife, I. N. Van Horn and family, T. A. Smith and wife, C. W. Roberts and wife, Geo. Dunmore and family, C. C. Bunnell and wife, Wesley Bunnell and wife, Seraphina DeGroff and son, F. M. Smith and wife, Charles Worrell and wife, J. E. Church and wife, Mrs. Greer and son, A. E. Cochrane and wife, Mrs. Kate Brooks, James J. Daily and family, John Daily, James Daily, Jr., Wm. Burdick, Miss Carrie Roberts, Miss Aggie Smith, Clarence Bunnell, C. G. Jones, I. B. Worrell, Mrs. E. R. Worrell, Albert Phelps and wife, Mrs. Worth and Ed. Doty. From sixty to seventy-five in the group were photographed by E. S. Frost \& Son."

\section{PASADENIANS FROM IOWA.}

January I, I 887, the Iowans held a picnic at Live Oak Park [now called Lincoln Park] and formed a sort of organization by choosing Hon. Delos Arnold, president; B. F. Ball, vice-president, H. J. Vail, secretary ; C. C. Thompson, treasurer. A total of 408 Iowans were reported as now residents of Pasadena and immediate vicinity, being in numbers from different counties as follows :

\begin{tabular}{|c|c|c|c|}
\hline "، & Cedar & " & .4 \\
\hline "، & Hardin & “" & $\cdots \cdots \cdot 3 \mathrm{I}$ \\
\hline “" & Iowa & " & $\ldots \ldots \ldots$ I 2 \\
\hline ، & Jasper & “" & $\cdots \cdots \cdots 30$ \\
\hline “" & Johnson & " & ....... I 3 \\
\hline “" & Keokuk & " & …..... I 3 \\
\hline ") & Lin11 & "6 & $\ldots \ldots \ldots 7$ \\
\hline
\end{tabular}

\begin{tabular}{|c|c|c|c|}
\hline irom & Mahaska C & unty & ........ I 5 \\
\hline "، & Marshall & “ & $\ldots \ldots 6_{I}$ \\
\hline “ & Mills & “" & ........ 6 \\
\hline “" & Muscatine & “" & ........20 \\
\hline “ & Polk & “ & $\cdots \cdots \cdots \cdot 4^{6}$ \\
\hline “، & Powesheik & “ & .. 6 \\
\hline “" & Scott & “ & . 3 \\
\hline “" & 27 other ce & atie & .65 \\
\hline
\end{tabular}

Total, 408.

TRIPLETS BORN.

The Star of November 7, I892, reported: "A lady of Pasadena, Mrs. E. R. Braley, wife of the well-known fruit dealer of Raymond avenue, gave birth yesterday to two girls and a boy, and today she is reported to be doing well. Each of the children weighs about six pounds.'

BRIDGES AT DEVIL'S GATE.

November II, I89I, the Deputy County Surveyor, W. A. Burr, reported: "That at the Arroyo Seco is $148 \mathrm{x} / 2$ feet long and 83 feet high ; that over the Canyada ravine is 106.8 feet long and 59 feet high." 
PASADENA PRIZE BABY.

In June, I889, a photographer named Downing offered a prize for the finest baby born within a year; and he would take a picture, free, of all babies entered for the prize. When seventy-five different babies had been thus entered, their pictures were all put into one great partition frame. Then a committee was selected of three bachelors, who did not know whose baby a single one of the pictures represented. This committee never dared to permit their names to be made public; but they labored three days with the difficult task of deciding which one of the seventy-five should receive the prize, as the "prettiest and finest baby in Pasadena." The Pasadena Standard of July 26, I889, thus reports on the matter:

"This prize was awarded last Tuesday to FreDdie CLARENCE HAWLEY, baby son of Salma W. and Sarah S. Hawley. Baby Hawley was born in Pasadena, June 13, I888; was baptized in the Universalist church July 22, 1888; was photographed in competition for the prize, June 25, I889. The prize is a greatly enlarged picture of the child, finished in oil or crayon, as the parents may prefer, and handsomely framed. When baby's grandwother was informed of the award she wiped her spectacles and said complacently: "Well! well! well! I knew he was a nice baby-but I never expected that!" And her silver hairs took on a shinier shine. Mrs. Hawley is one of the devoted and faithful teachers in the Band of Hope; and her bright little boys, Milton and Frank, are often in demand to 'speak a piece' in the Band, or in Sunday School."

\section{LOCAL POETRY.}

From its earliest settlement Pasadena has been a paradise for poets, and I could fill a book with apothegms in verse, born of the land itself and its local environments; yet comparatively few of them are worth reprinting. The following excerpt was written by Charles A. Gardner, in I887-and was published some years later by the Art Loan Association as one of its choice souvenirs of Pasadena. It has thus gained a certain historic prestige, and hence I quote it, adding some footnotes of explanation which will better enable the reader to understand the subtle symbolism of its local allusions. The poet is coming up from Los Angeles to Pasadena on the Santa Fe railroad, and from that outlook and uplook he sings this song:

Steaming up from out the lowlands at the closing of the day,

When the sun has furled his banners by the trail of Santa Fe,

When the drowsy god has nestled in the bosom of the west, And the purple of his glory fills the valley of the blest,

G'eams the City of the Highlands in its beanty and its pride, With the laurel of the victor and the orange of the bride, Flasining out upon the vision like the bright and morning star That the pilgrims of the Orient have followed from afar.

Above the noise of battle, in its beauty and its peace, Its portals catch the earliest "Good Morning" from the east, 
And latest benedictions and the tenderest caress

Are pressed upon its temples by the purple of the west.

Ships sail by that Highland City* in the offing of the sky With the pennants and the orders of the Admiral on high, Bearing nightly courses westward in a heavenly patrol, While the thunders of their cannon by the Mother Mountains roll.

Steaming upwards from the lowlands at the closing of the day, By the ever-shining spirals of the trail of Santa Fe, Circling upward, ever upward, like an eagle in its flight, From the region of the shadow to the region of the light,

Gleam the portals of the city that can never more be hid, Flashing out upon the vision as the Roman mistress did - $\dagger$ Alba Longa of the moderns in its beauty and its pride, With the laurel of the victor and the orange of the bride.

THE SHORB WATER SCARE.

In 1890 there was a good deal of scare-talk in the Pasadena press about J. DeBarth Shorb's grand project for making an artificial lake in Sycamore canyon, a branch of the Eagle Rock Valley just over west of the Linda Vista hills, and storing it with the surplus waters of the Arroyo Seco, then piping it from the said reservoir lake down to Los Angeles. The plan was, to take water from the Arroyo at some point higher up than any of the Pasadena companies had filed their claims; and it was feared that under pretense of "surplus waters" this Shorb syndicate scheme would really tap and train off Pasadena's water supply. Among the curiosities to be seen in driving along the roadway of the upper Arroyo to the foot of Switzer's trail are some tunnels through rocky spurs of the canyon wall; and there are also tunnels in the Linda Vista hills leading through to Sycamore canyon. This was work done by the Shorb syndicate; and the Star of November 19, I89o, in deprecating this prospective raid on Pasadena's water resources, said :

"A series of tunnels are being run through projecting hills, $7 \times 8$ feet in dimensions, $* *$ to bring water to the flat below Las Casitas; thence by pipes down the east bank of the Arroyo to a point below Devil's Gate, where the Arroyo will again be crossed and the Linda Vista hills tunneled through to Eagle Rock Valley."

Attorney W. S. Wright, on behalf of Pasadena interests made an investigation of the legal status as to water claims above Devil's Gate, and the Star of October 7, 1891, thus reported his findings:

"He finds several filings on the surplus waters of the Arroyo Seco and Millard canyon, made by the Pasadena Land and Water Company, the Shorb Company, the Painter Company, the Highland Park Company, and

*Ior Pasadena's fame as a landmark at sea, see page $38_{3}$ - "Las Flores canyon."

†"Alba Longa" or long white city was one of the names of ancient Rome; and Pasadena looks that way as one approaclies it from I,os Angeles, up throngh the Arroyo Seco pass. 
by Gervaise Purcell. Work to hold them has been done by the Shorb Company and the two Pasadena companies mentioned. The Shorb filing Mr. Wright regards as fatally defective in several particulars."

This conclusion seemed to hold good, for the Shorb company stopped work, and their tunnels stand empty, to mystify the Arroyo traveler, or whisper in his ear the sad memorial word, "boom."

WILLIAMS HALL.

More historic public meetings have been held in Williams hall than any other place in Pasadena. The building was first erected during the winter of $1882-83$, and Williams's store and the post office and the telephone office was moved into the lower story. In 1885 , it was added to, and reconstructed, the following account of which I copy from the Valley' Union of November 6, 1885 :

"A new building was erected on Fair Oaks Avenue, in the lower story of which are C. L. Fisher \& Co.'s new store, the new post office, and the entrance to the hall above. In the upper story is the extension to the hall, the gallery, and a banqueting room to be used in connection with the theater, and the Masonic hall adjoining. The entire hall is $30 \times 90$ feet in size from the front of the stage to the rear of the gallery. The stage has a beautiful drop curtain representing an actual scene from life, the "Oberwesel," on the Rhine, a tower built by the Romans. It is a beautiful sketch, and presents a fine appearance, blending water, mountains and ruins with happy effect. It was painted by the Schroeder Brothers, of Los Angeles, artists of high reputation, who also have in hand the execution of the scenery, which will be sufficient for all ordinary purposes. The stage also contains all the accessories of prompter's box, gas machinery, etc., and is not behind in the dramatic conveniences of the theaters of larger cities. The main hall has a seating capacity for about 350 people, and is thoroughly lighted both by day and night. The gallery has i 70 stationary chairs. It is beautifully designed, with curved front, balcony and rail, and like the other portions of the hall is finished in natural woods."

\section{EMENDATIONS.}

On page 39: "August, I8I4, corner stone laid for a church in Los Angeles, but building never erected." Stephen Foster tells me this church was built, and used; but it was a poor, cheap adobe structure, a few rods north of the present church site at the plaza.

On footnote, page 73.-The Lewis Hist. Los A. Co., p. 97, says : "John G. Nichols, April I5, I85 I-first American child born in Los Angeles." Mr. and Mrs. Robinson tell me their child, Oscar, was born May ir, I 850 , in a building on New High street, north of Temple street, which was then in use as the county jail, Mr. Robinson being deputy sheriff and jailer from 1849 to $185^{2}$. But this baby boy died in February, 1852 , while they were living in the Garfias house, on Main street, near First.

M. E. Wood came to Pasadena in 1876 , yet his name is not given in 
list of "Old settlers" prior to I880, on pages 133 to 136 . Mr. Wood also gave three days work on the new Central School-house in 1878 , although his name is not in the list on pages $170,17 \mathrm{r}$.

On page 200: Before "Classical School for Boys," add Miss Collamer's school, established in April, I887, by Miss Emilie F. L. Collamer, on Camden street; limited to fifteen pupils. Primary and grammar grades, and college preparatory. Music and languages taught, besides all the common English branches.

On page 223: "James G. Clarke, author."-The Arena, one of the very front-rank American magazines, in its issue of September, I895, devotes fifteen pages to Mr. Clarke and his poetry, and rates him anong the greatest of our American prophet-poets. The Arena is competent authority in the literary world.

On page 224, Abbot Kinney, as an author should be credited with additional works : “Tasks by Twilight:" G. P. Putnam's Sons, New York ; I 893. "Conquest of Death," same publishers, I 893. "Eucalypti : " now in press. "Money," or the Silver Question.

And to the list of authors given on pages 223 to 226 , shonld be added : Norman Bridge; A. M., M. D. Contributor to medical and scientific journals ; 20 years professor in Rush Medical College, Chicago: author of a History of the College, now in press.

Addendum to Chapter XIII, pages 255 to 277 , on the "Whisky War."-On June ro, I 895, a meeting was held in the Carlton hotel parlors, to consider what should be done about the prevalent disregard of the "liberal" restrictive law as to liquor selling, for it was being daily violated with increasing boldness, and dramshops were being run under cover of restaurant, lunch counter, hotel, drug store, etc. Rev. W. H. McDougal, D. D., of Oaklaud, had been invited up from Los Angeles to explain the so-called "Oakland plan"; and after hearing him, steps were taken to organize the "PASAdena Council for SUPPREssion of THE Liguor TrafFic AND KINDRED EiviLS." Various meetings were held; and a special committee was appointed to employ detectives and secure such evidence as could not be bought, tricked, nor scared out of court. Attorney Benj. Hahn was employed to oversee the collection of evidence, and attorney George A. Gibbs to assist the city attorney in the prosecutions. September 20, six arrests were made; and the committee had in hand about fifty cases altogether, ready for prosecution. The organization is made up of representatives from different churches and other societies, as follows :

NAME OF CHURCH CHURCH DELEGATES YOUNG PEOILE'S DELEGATES Methodist . . . Rev. Clarke Crawford.

I. J. Reynolds, K. W. Wing A. B. Stevens.

Congregational......Rev. H. W. Lathe.... Dr. E. A. Briggs. A. K. Nash, Geo. A. Gibbs. .Prof. A. L. Hamilton. .Benj. Hahn. 
NAME OF CHURCH.

Baptist.

Rev. C. T. Douglass Eirnest Canfield.

B. F. Simcoe............................. Seo. Sroat.

Presbyterian Rev. N. H. G. Fife. Robert H. Fulton

Universalist Rev. W. M. Jones P. G. Wooster.

Rev. E. L. Conger, D.D., Mrs. Harriet K. Fay...Prof. W. Loree. Christian............Rev. H. Elliott Ward L. H. Turner. R. B. Colcord W. L. Jones.

Free Methodist......Rev. J. S. Phillips, M. C. Sperow.

Ind. Congregation..Rev. R. M. Webster, J. B. Corson.

Friends... Rev. Chas. F. Tebbetts. Wm. Cox, L. Brow11.

Friends, Orthodox..Prof. I. N. Vail, Tilman Hobson.

Salvation Army.....Henry N. Farey .

Y. M. C. A.........Dr. Fordyce Grinnell, C. C. Reynolds, Robt. H. Fulton, E. L. Stevenson.

Christian Allance. Dr. J. R. Townsend, Judge C. N. Terry.

Chr. Endv. Union.L. H. Turner, Mrs. A. M. Mulford.

$W . C . T$. U.......Dr. Ella Whipple-Marsh, Mrs. Hester Griffith, Mrs. Ellen Terpenning.

I. O. G. T........Albert Mercer, Miss Viola Weil.

Prohibition Club....James Cambell, T. Hobson.

Of this body of councilors, Tilman Hobson is president, Rev. H. Elliott Ward vice-president, Ernest Canfield secretary, Miss Viola Weil corresponding secretary, Dr. Ella Whipple-Marsh treasurer.

To raise funds, it was agreed that each church furnish ten cents per member. This made the apportionment for the M. E. Church about \$9o. A collection for it was taken up Sunday morning, September 22, and amounted to $\$ 119.50$. [Others not furnished, at closing of this report.]

On page 321 Maj. Horace Bell is reported as saying in a speech at Pasadena that Los Angeles, furnished only two Union soldiers in the war of the rebellion. The Lewis Hist. Los A. Co., p. Ioo, says: "A company of volunteers was raised in Los Angeles, to form a part of the 5,000 ordered from this State."

On page 353, footnote, I give Don Juan Bandini's grandfather as "Captain of Spauish battleship Riena at Trafalgar ;" it was his own father, Capt. Jose Bandini, who now lies buried at San Gabriel. [See page 55.]

On page 373: “Brown's Peak." - In July, I889, a party of young folks camping at Brown's cabin above Las Casitas started early one morning for a climb to the summit of Brown's peak. They were, Gordon, Mary and Nancy Baker, Carl Raab, Mary Thompson, and Jason Brown. The Baker youngsters were used to such trips, and they rushed on ahead, reaching the top half-a-mile ahead of the other three. Gordon set the lunch pail which he carried down beside a bush, just as Mary noticed some torn up earth and big cow-looking tracks, and exclaimed, "Who in the world is keeping 
cows up here?" Their dog "Grover" scented the tracks and went barking through the bushes where they led, but suddenly returned in skulking terror. A crash in the bushes was heard, and a terrific roar that was like an angry hog's grunt and an angry dog's growl mixed and enlarged. Gordon yelled, "A bear!" grasped his dinner pail and leaped down the steep trail like seven-leagued boots. Mary didn't wait for trail track, but went leaping and sailing over the grease-wood in a most wonderful manner, so that those who saw her from below said she beat the aerial flights on a circus poster all out of sight, and reached the rear party in an incredibly short time. Nancy got a few rods down the trail, but was so amused at Mary's marvelous feats that she had to stop, brace her hands on her hips and just laugh till she couldn't see. Meanwhile the bear, which was a she one with two cubs, hurried her little family away in the opposite direction. Jason Brown had a hatchet and butcher knife with him, but no gun, and he and his comrades pushed on to the summit; but the Bakers had seen enough, and took a rest. Jason identified the tracks of the mother bear, who had been digging up the ground for some sort of roots, and the tracks of two cubs; but they didn't get a sight of the animals. After returning to camp the girls wrote some humorous poetry entitled "A Trip, by one of the Triplets," in which this adventure was briefly related. All three of those girls have since graduated from the State Normal School, and have made a good record as teachers.

On page 403: "Henniger Flats."-In September the Toll Road Company bought this land from Mr. Allen, and will utilize it to raise vegetables. fruits, flowers, poultry, honey, pork and dairy products for their mountain camp hotels, besides its 11 se as a wildwood park and rural retiracy for guests who prefer it. [See page 365. ]

On page 408: "West San Gabriel canyon."-In I89I or '92 two or three hunters camped in the upper part of this canyon. One night a bear was caught by the hind foot in a heavy steel trap which they had set. $\mathrm{He}$ gnawed off his own leg and hobbled away on the bleeding stump, leaving his foot in the trap. The hunters soon discovered this in the morning, and following the bear's trail, shot him. 'They nailed the entrapped foot up on a tree at their camp, and I saw it there about two years later. From this incident that portion of the West San Gabriel has ever since been called "Bear Canyon." But there is another place north of Mount Lowe, a large branch of the Arroyo Seco, which is called "Great Bear Canyon," though for what reason I did not learn.

On page 453: Mt. Lowe Railway. - September 30, I 895, Prof. Lowe communicated his plans, aims and wishes to the city council, in regard to an electric railroad frauchise which he had petitioned for. His purpose was to extend the Rubio trolley section of his mountain railroad direct to Pasa- 
dena's business center, at once, so that passengers could make the trip between Los Angeles and the mountains inside of ninety minutes, late at night, or early morning, or any hour of day. It was found necessary to have a line of their own, clear down to Pasadena, in order to accommodate and handle satisfactorily the many and varied excursion parties, some of whom want to spend an evening with the telescope, the great search-light, the electric fountains, etc.; some waut to go at short notice for a frolic in the snow; some want to visit the great mountain cataracts of Thalehaha, Leontine, Grand Canyon and Alpine Falls, when they roar and plunge in all their glory after a rain storm; some want to witness the wierd scene of the valley and the electric-lighted cities by night, or the strange fog-sea with cities buried under it in early morning, without missing their business hours at Pasadena or Los Angeles. In fact, the various elements of popular interest at this great mountain resort could not be utilized to the public without a railroad line to Yasadena under the same management and control, for prompt service at short notice, at hours to suit, and with any number of cars needed to seat the company. It was also needful for prompt transportation of supplies, or of construction or repair materials, often required at short notice, or at untimely hours.

On page 466: "Crematory." -The first cremation at Mountain View cemetery occurred September 26, I895, with the body of George A. Cherry. Fire was maintained twenty-six hours, producing a 70o-degrees uniform white heat. Body incinerated in two hours and fifteen minutes. Ashes weighed 5 tbs. ro oz. The procedure was managed by W. N. Van Nuys, under inspection of Drs. Fordyce Grinnell, D. S. Green and A. W. Bickford.

On page 494: "Applied Christianity."--July --, I895, they organized as "The Independent Congregation of Pasadena," with Rev. R. M. Webster as pastor; and trustees-Dr. Elias Smith, chairman ; Geo. Swerdfiger, M. F. Merritt, treasurer, Mrs. Byron O. Clark, Mrs. Theresa Harrison, Mrs. S. E. Merritt, Miss Alma Stanford, secretary.

On page 495: W. C. T. U.-Some time in 1882 the Pasadena Union Temperance League was organized, with James Cambell, president ; C. B. Ripley, vice-president; Chas. H. Case, secretary. On December I6, I882, they gave a literary and musical entertainment in the Presbyterian church, then on California street, the program of which had been printed for them at Maj. J. D. Gilchrist's office in Los Angeles. And it was this society which procured and arranged for Frances Willard's lecture in Williams hall, and provided for her entertainment at Mrs. Bangs's Arroyo Vista house. After the lecture the chairman, Mr. Cambell, at Miss Willard's request, appointed a committee of ladies to meet the next Sunday afternoon in the Presbyterian church and organize a Women's Union. The committee named were: Mrs. Rev. Mosher, Mrs. A. O. Porter, Mrs. Dr. O. H. Con- 
ger, Mrs. James Smith, Mrs. O. S. Barber, Mrs. O. R. Dougherty, Mrs. Dr. Lord, Mrs. James Cambell, and perhaps others. Most of these women had young children to look after; and lived far from the church; and after attending Sunday school and morning services, did not feel like going again in the afternoon. But Mrs. Dr. Conger went, and had a delightful rest, all free from family cares, and all by herself, in Mrs. Gen. Stoneman's nicely cushioned pew. At the proper time she moved herself adjourned, sine die; and thus ended Miss Willard's projected W. C. T. U.

On page 499: "Y. M. C. A."'-Oct. I, I 895, new officers were elected as follows : C. C. Reynolds, president ; Dr. J. R. Townsend, vice-president ; Robert H. Fulton, secretary.

On page 519: "Fortnightly Club."-This society provided free public lectures, mostly by a high order of talent. The most eminent person who has lectured under its auspices was Prof. Joseph LeConte, the world-famed Professor of Geology in our State University, who spoke here in the spring of I893. Its successive presidents have been, Prof. C. H. Keyes, Theodore Coleman, Geo. H. Coffin. But Prof. George Conant has been the executive secretary, and chief manager of its affairs.

On page 543: "Micaceous talc." - This is the same kind of rock from which the Indians of the Santa Barbara Islands carved out pots, and other dish and cup utensils, many fine specimens of which may be seen in Dr. Palmer's very complete collection, on free exhibition at the Los Angeles Chamber of Commerce rooms. The material is commonly called "soapstone," although it is quite different from the soapstone of the eastern states.

On page 600: "Rattlesnakes." -On July 30, I893, old Jason Brown went as guide for a lone tourist lady from the east who wished to make the bridle trip from Echo Mountain to Mt. Lowe. When they reached Crystal Springs cabin, on their return route, the lady sat down at the workmen's camp mess-table to eat her lunch. A rattlesnake crawled out of a hole in the mountain side only six or eight feet from where she sat. As soon as she saw the reptile she jumped and screamed, which scared it, and it commenced turning to get back into its hole. Jason called to another man who was near to stop the hole quick and not let it get back; meanwhile he grasped a long-handled shovel, pushed it under the snake and commenced tossing him gently so he could neither coil himself to strike nor crawl to his hole. Jason then called to another man to bring an empty cracker box. This was brought, and he shoveled the snake into it, clapped on the cover, took the box under his arm and marched on down to Echo Mountain. I reached Crystal Springs from an exploring trip with Mr. Cameron just in time to see Jason start off with his rattlesnake under his arm. The lady was delighted with the adventure, and related with much enthusiasm how 
the snake was captured. She was assured that that was nothing for old Jason; that he would probably next time bring in a Mountain Lion. This rattlesnake was a fine specimen. It was kept in a cage at Echo Mountain for a month or two; then Thad. and Sobieski Lowe, and W. H. Brown the electrician at the cable power house, experimented in giving it trial doses of electricity, till they say it tied itself in a double bow-knot and went to rattlesnake heaven.

\section{Errata :}

Page 19I, bottom line: "Nov. 2, I 87 I" should be 1891 .

Page 251, 24th line from top : for "superior court," read supreme court.

Page $66,25^{\text {th }}$ line : $185^{2}$ should be 1853 .

Page 172 , 9th line: Chapter 35 should be 33 .

Page 255, 4th line: for "pages 243-44," read 248-49.

Page 368 , I 9 th line: for "Harvard," read Telescope point.

Page 53t, 3rd line from bottom; for " 50 or $60 \mathrm{lbs}$. ." read roo lbs.

Page 600, footnote, 2nd line: for "in August," read July 24. 
$x$

190179259 



